\title{
NESTS AND EGGS OF \\ NORTH AMERICAN BIRDS
}

BY OLIVER DAVIE

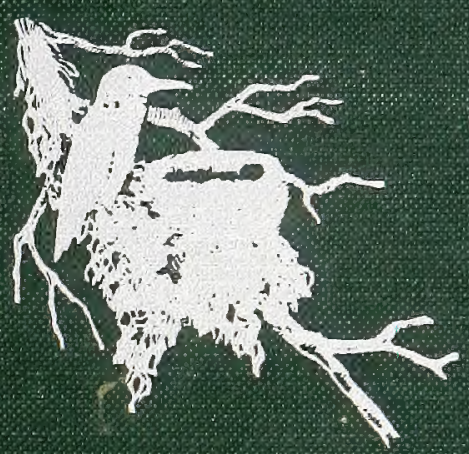

WITH 274. ILLUSTRATIONS 


\section{ALBERT R. MANN \\ LIBRARY \\ AT \\ CORNELL UNTVERSITY}

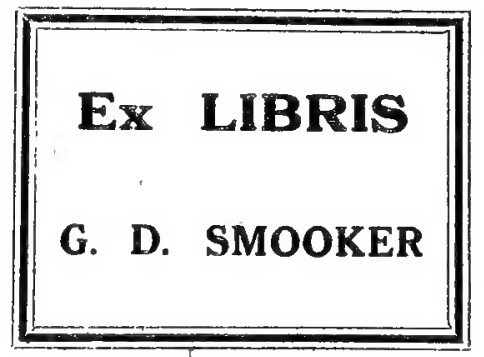




\section{Cornell University Library}

The original of this book is in the Cornell University Library.

There are no known copyright restrictions in the United States on the use of the text.

http://www.archive.org/details/cu31924000426472 

NESTS AND EGGS

-or-

NORTH AMERICAN BIRDS. 




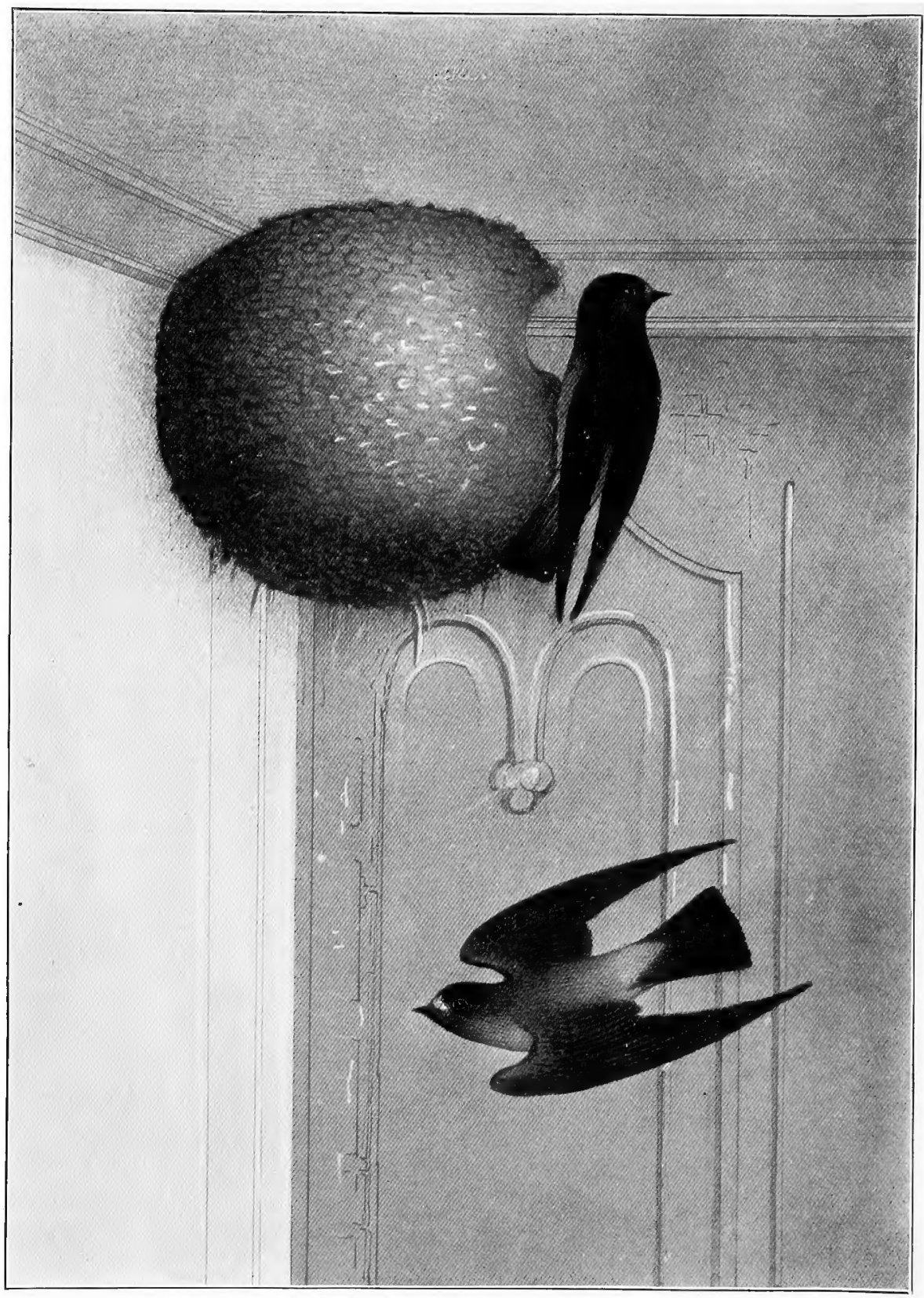

Cliff Swallows or Eave Swallows and Nest.

The nest in this picture is drawn from the actual specimen which was taken from the eaves of an old country church in Franklin Co., Ohio, by Dr. Theodore Jasper, the artist. 


\section{NESTS AND EGGS OF NORTH AMERICAN BIRDS, \\ BY OLIVER DAVIE,}

AUTHOR OF "METHODS IN THE ART OF TAXIDERMY."

WITH A CHAPTER ON ORNITHOLOGICAL AND OÖLOGICAL COLLECTING (THE PREPARATION OF SKINS, NESTS AND EGGS FOR THE CABINET).

THE FIFTH EDITION, REVISED AND ENLARGED, WITH TWO HUNDRED AND SEVENTY-FOUR ILLUSTRATIONS.

PHILADELPHIA

DAVID MCKAY, PUBLISHER 
Entered according to Act of Congress, in the year $r 898$, by OLIVER DAVIE,

In the office of the Librarian of Congress, at Washington.

Copyrighted, igoo, by DAVID McKAY 


\section{LUCIUS S. WILLSON}

One of nature's noblemen: My companion in many a woodland stroll, whose keen eye observed and gloried in the charms of varied pastoral scenes, whose listening ear heard and delighted in the caroling of feathered songsters and the cadence of murmuring streams. His ear caught the music of breezes as they wandered, through the boughs of forest trees, and, while striking the tenderest chords on their Alolian harps of russet-brown leaves, in the Autumn of 1882, they muttered to him their last farewell, and whispered something like-Eternity.

THE AUTHOR. 



\section{PREFACE TO FIFTH EDITION.}

The text of the present edition consists of the characteristic habits of North American birds, 'with particular reference to their nesting habits and eggs. Many of these will be found to be almost complete life histories of the species.

The geographical limits of the North American avifauna at the present time includes all the territory north of the Southern United States boundary, including Greenland and the peninsula of Lower California, with the islands naturally belonging thereto. The second edition of the A. O. U. Check-List, 1895, is the classification which I have followed, including the new species and subspecies enumerated in the Eighth Supplement.

All stragglers or accidental visitors have their respective numbers to the left in brackets. For an explanation of the authority of names, Canon L. (page 56) of the A. O. U. Code may be quoted: "The authority for a specific or subspecific name is the first describer of the species or subspecies. When the first describer of the species or subspecies is not also the authority, it is to be enclosed in parenthesis; e. g., Turdus migratorius L., or Merula migratoria (L)."

The species and subspecies which have been interpolated in this edition are indicated by the double asterisk $(* *)$.

No attempt has been made to describe the birds. For an analytical description of these the reader is referred to such works as "Key to North American Birds,"* by Dr. Elliott Coues, or "Manual of North American Birds," $\dagger$ by Robert Ridgway.

While I am indebted to books and periodical literature for a considerable amount of information gleaned from them, my acknowledgments are especially due a large number of active field ornithologists and oologists who have kindly placed at my disposal their notes containing original observations in the field on the nesting and eggs of various birds, many of these being the latest discoveries. others have furnished descriptions of nests and eggs from specimens in their private collections which, in many cases, were otherwise scarcely obtainable, thus bringing the work down to date as nearly as possible.

The illustrations are introduced simply to give the beginner an idea of the characteristic forms, etc., of the birds, together, often, with their environments.

Columbus, Ohio, Jannary \&, 1898.

OLIVER DAVIE.

* Published by Erstes \& Lauriat, Boston.

$\dagger$ Published by J. B. L.ppincott Company, Philadelphia. 



\section{NESTS AND EGGS}

\section{$\Longrightarrow \mathrm{OF}$ \\ North American Birds.}

NOTEs.-The nomenclature followed in the present edition of this work is that of the Amorican Ornithologists' Union Check-List.* The measurements of the eggs are given in inches and hundredths, except in cases where correspondents have furnished the measurements in millimeters. These will be found reduced to inches and hundredths in foot notes, as appears in the text of the Western Grebe.

1. WISTERN GREEE. A2chmophorus occidentalis (Lawr.) Geographic Distribution - Western North America, chiefly the interior, from Mexico and Lowe: Calíornia to Manitoba.

'I his is the largest of the Grebes in North America. Its distribution extends from Mexico and Lower California on the south, to the State of Washington and the Red River Region on the north, breeding nearly throughout this entire range. A common summer resident at Utah Lake and also at Lake Malheur, in Eastern Oregon, thence eastward to the extensive marshes of Shoal Lake, in Manitoba, where it breeds abundantly. Mr. Edward Stebbins found it breeding in an arm of Devils Lake, North Dakota, in the first part of June, at which time all the eggs were more or less inciubated. He estimates the number of nests observed to be about two hundrod in an area of an acre and a half. They were built in water three or four feet deep, and wire made of reeds and sedges matted together and fastened to the tall, rank grass, so as to float on the surface. It is a remarkable fact that the Grebes cover their nests with weeds and other vegetable matter before leaving them, so that incubation may continue during their absence. The Rev. P. B. Peabody observed the Western Grebe nesting among the flags of Heron Lake, Minnesota, on June 2d: Only a few of the nests observed by Mr. Stebbins were covered; the tall grass obstructed the view of the birds, so that when approached they would hurriedly slip of the nests, and leave the eggs exposed. The only birds seen were those in the

* Check-list of Nonth American Birds, prepared by a Committef of the American Ornithologistg' Union; second revised edition, 1895. New Zork, L. S. Foster, Publisher, 35 Pine street. 


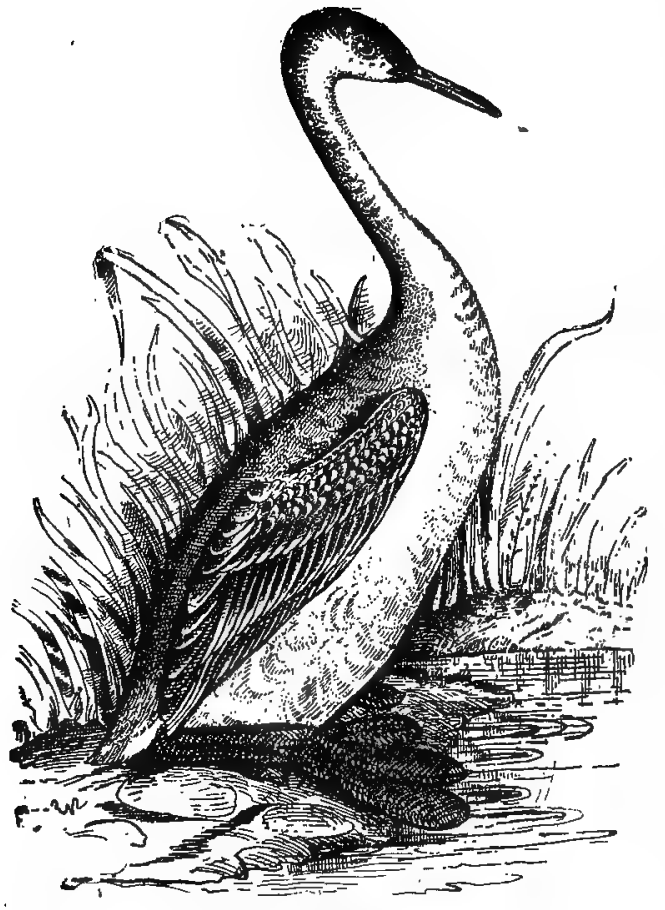

1. Western Grebe, vicinity of the nests, and they swam away with their heads and necks above water, making a kind of cackling noise. In their habits they resemble the Loon, diving or swimming under water with the greatest ease; and, when on the wing, they fly with wonderful rapidity for birds of their nature. The eggs of this specles are from $\overline{2}$ to 5 in number, elliptical oval in shape, very pale 'bluish green in color; and, like all Grebes' eggs, the surface is stained a light brown, or very much soiled by contact with the decomposed vegetable matter of the nests. Mr. Walter E. Bryant, of Oakland, Cala., has a set of 5 eggs in his collection, which were taken at Washoe Lake, Nevada, in the latter part of May. These measure as follows: $59 \times 39,63 \times 39$,

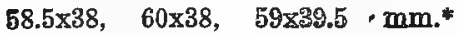
Three sets in my collection, two of five eggs and one of four, taken by $\mathrm{Mr}$. Stebbins, messure: $2.32 \mathrm{x}$ $1.58,2.40 \times 1.57,2.50 \times 1.53,2.46 \times 1.58$, $2.48 \times 1.60 ; 2.14 \times 1.48,2.27 \times 1.54,2.30$

$\times 1.63,2.29 \times 1.58,2.28 \times 1.53 ; 2.44 \times 1.52,2.37 \times 1.47,2.52 \times 1.44,2.45 \times 1.47$. The bird known as Clark's Grebet is probably the female of $A$. occidentalis.t, Its habitat is given as Western North America, chiefly along the Pacific coast. The bird and its eggs are recorded as averaging smaller than types of occidentalis.

2. FOLBCELI'S GREBE. Colymbus holbollii (Reinh.) Geog. Dist.-North America at large, including Greenland. Also Eastern Siberia, and southward to Japan. Breeds in high latitudes, migrating south in winter.

In the large bodies of water, the little bayous and sloughs, rivers and grassy pools from Northern Maine to Greenland; from the swamps of the Red River Valley of the North, and again, westerly and northward to the margins of the placid lakes that border the great Yukon River in Alaska, and beyond, this Grebe makes its summer home.\$ In the Fur Countries it breeds in lonely and retired places, such as in the tussocks of wiry grass that border the Waterhen River and Long Lake in Manitoba. It is said to breed abundantly at these places, and often where it is quite corrion during the breeding season, its presence may not be detected after many weeks' stay about its haunts. The nest is built similar to that of the common Dabchick, and like

- $2.32 \times 1.54,2.48 \times 1.50,2.36 \times 1.50,2.32 \times 1.56$ inches.

$\dagger$ Placed in the "Hypothetical List" c: ti:e A. O. U. Check-List.

₹Cf. Henshaw, Bull. Nutt. Orn. Club, $i$ i, 1881, pp. 214-218; B. B. and R., Water Birds N. Am., NI, p. 423; Bryant, Auk., II, pp. 313-314. in

\& The summer home of a bird is generally underztood to be its breeding plare. 
other Grebes this species covers its eggs before leaving them with grass and vegetable matter gathered from around the bottom of the nest. A set of three eggs, collected by $\mathrm{H}$. A. Wallace, in the marshes bordering Long Lake, in Manitoba, exhibit the following dimensions: $2.15 \times 1.20,2.15 \times 1.32,2.17 \times 1.14$. Their color is a dull white, with the usual soiled surface. Eggs in a large series vary from a whitish to a greenish white, and there is also a great variation in size, as they measure from 2.05 to 2.55 long by 1.20 to 1.50 broad. Mr. Wallace informs me that the number of eggs laid by this species ranges from two to five, and sometimes seven.

3. HORNED GREBE. Colymbus, auritus (Linn.) Geog. Dist.-Northern Hemisphere. Breeds from the Northern' United States northward.

The Horned Grebe is a generally diffused and an abundant species throughout North America. It is not uncommon in all suitable places, during the summer months, along the margins of the crystal lakes and rivers of Michigan, Wisconsin and Minnesota, and it is recorded as breeding sparingly, in Northwestern IIlinois. Mr. Frank W. I-angdon makes note of its supposed nesting in Ottawa county, Ohio.* It breeds commonly in the grassbordered lakes of the Fur Countries. Dr. Coues says: "I founditbreedingatvarious points in Northern Da-

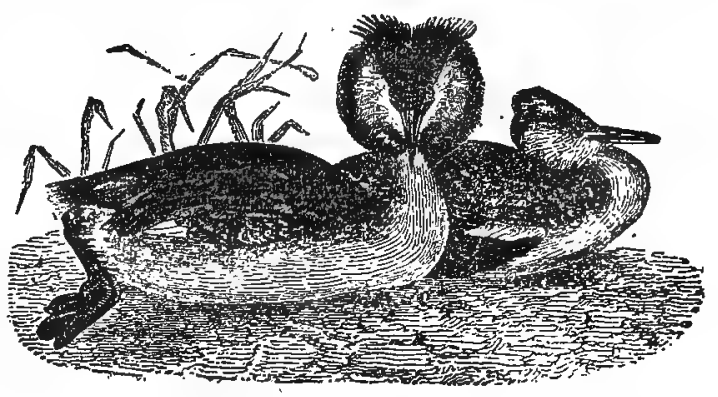

3. HoRr'ED GREBE.

kota, as along the Red River, in the prairie sloughs, with Coots, Phalaropes, and various Ducks, and in pools about the base of Turtle Mountain in company with $\boldsymbol{P}$. californicus and the Dabchick. $\dagger$ Mr. Thomas McIlwraith records it breeding in all suitable places throughout Untario, notably at St. Clair Flats." + Mr. McIlwraith says: "The nest is so completely isolated that the young when hatched may be said to tumble out of the shell into the water." A curious habit of this and other Grebes is that of quietly sinking beneath the surface of the water, or, as it were, like a snowflake, melt away with scarcely a ripple. The nest of the Horned Grebe, like all others of the family, is simply a floating mass of decayed vegetation fastened to the rushes and reeds in shallow water. The eggs are from two to seven in number, four being the usual nest complement; their shape is more of an oval form than is generally noticeable in the eggs of the Grebes; they are bluish-white in color, with the usual discolorations on the surface. They vary from 1.60 to 1.85 in length, and from 1.10 to 1.20 in breadth.

4. AMERICAN EARED GREBE. Colymbus nigricollis californicus (Heerm.) Geog. Dist.-Northern and Western North America, from the Mississippi Valley wंestward.

* Summer Birds of a Northern Ohio Marsh: Journal of the Cincinnati Soclety of Natural History, Vol. III, pp. 220-232.

$\div$ Birds of the Northwest, p. 732 .

¥ The Birds of Ontario, being a list of Birds observed in the Province of Ontario, with an Account of their Habits, Distribution, Nests, Eggs, etc. By Thomas McIlwraith, Superintendent of the Ontario District for the Migration Committee of the American Ornithologists' Union. Published by the Hamilton Assocation. Hamilton: A. Lawson \& Co., - Printers, 1886. See also new revised edition, 1894. William Briggs, Toronto, publisher. 
In most of the States and Territories west of the Mississippi River, this species breeds more or less abundantly in suitable localities, and its breeding range is almost as extensive as its habitat. It has been found nesting in the grassy lagoons of Texas, in the fresh water ponds of California, the pools and sloughs of Eastern Oregon, the alkali lakes of Colorado, Kansas, and the Territory of Wyoming, in the little inlets of the larger bodies of water in the Dakotas and in Minnesota, thence northward to the inland waters of British America. This Grebe, in common with the others, is justly noted for its expertness in diving and swimming, and, like all true divers, is awkward on land. From the posterior position of the legs these birds stand almost upright, so that they have more the air of a small kangaroo than of a bird. Its general breeding habits, are like others of the family, nesting, however, in more open situations, in fiags and rushes, or upon a floating foundation in shallow water: In the absence of the bird the eggs are covered with debris. The habit of covering the eggs among the Grebes is either for the purpose of concealing them from enemies, such as Hawks and Gulls, or that upon the artificial heat, produced by the decayed vegetation, they are more or less dependent for the hatching of their eggs. When thus covered, the birds are known to remain away from their nests during the entire daytime. The eggs of this species are four to eight in number, and in Minnesota, the Dakotas and Wyoming, they are deposited in the first part of June. They are elongated in shape, bluish white in color, but soon become soiled by the wet material of the nest. The measurement of eight eggs, collected in the marshes of Red Lake, Minnesota, on the 7 th of June, are as follows: $1.79 \times 1.21,1.75 \times$ $1.20,1.73 \times 1.25,1.70 \times 1.15,1.80 \times 1.23,1.79 \times 1.25,1.73 \times 1.20$, and $1.73 \times 1.18$. A set of four eggs from North Dakota has a decidedly buff ground color instead of the usual bluish white.

5. ST. DOMINGO GREBE. Colymbus dominicus Linn.' Geog. Dist.-Texas and Southern California, southward through Tropical America to Paraguay, including the West Indies.

Here is the smallest of our Grebes. It has a breeding range extending from the Valley of the Rio Grande southward into the tropical regions, nesting in the wild herbage of the lakes and ponds of Mexico and Central America, in many of the islands of the West Indies, and the sloughs of the immense level, tropical plains and pampas of South.America. Its entire life is spent in the water, and it possesses the same aquatic habits peculiar to all the Grebes. Dr. James C. Merrill was the first to establish the claim of this species as belonging to our North American fauna. He found it a rather common resident in Southwestern Texas., On May 16, 1877, he found several nests, undoubtedly belonging to this species, in a salt marsh a few miles from Fort Brown. 'They were made of water plants and pieces of reeds slightly fastened to one or two tule stalks, and forming a wet, floating mass. No eggs were obtained." "The eggs are described as a "pale, rhalky, greenish white," with the usual discolorations. They vary in size from 1.25 to 1.50 long by .85 to 1.00 broad.

6. PIED-BILLED GREBE. Podilymbus podiceps (Linn.) 'Geog. Dist.British Provinces southward to Brazil, Buenos Ayres, and Chili, including the West Indies and the Bermudas, breeding nearly throughout its range.

* Notes on the Ornithology of Southern Texas, being a list of Birds observed in the vicinity of Fort Brown, Texas, from February, 1876, to June, 1878. By James C. Merrill, Assistant Surgeon U. S. Army. Proceedings of the United States National Museum. Vol. I, pp. 118-173. 


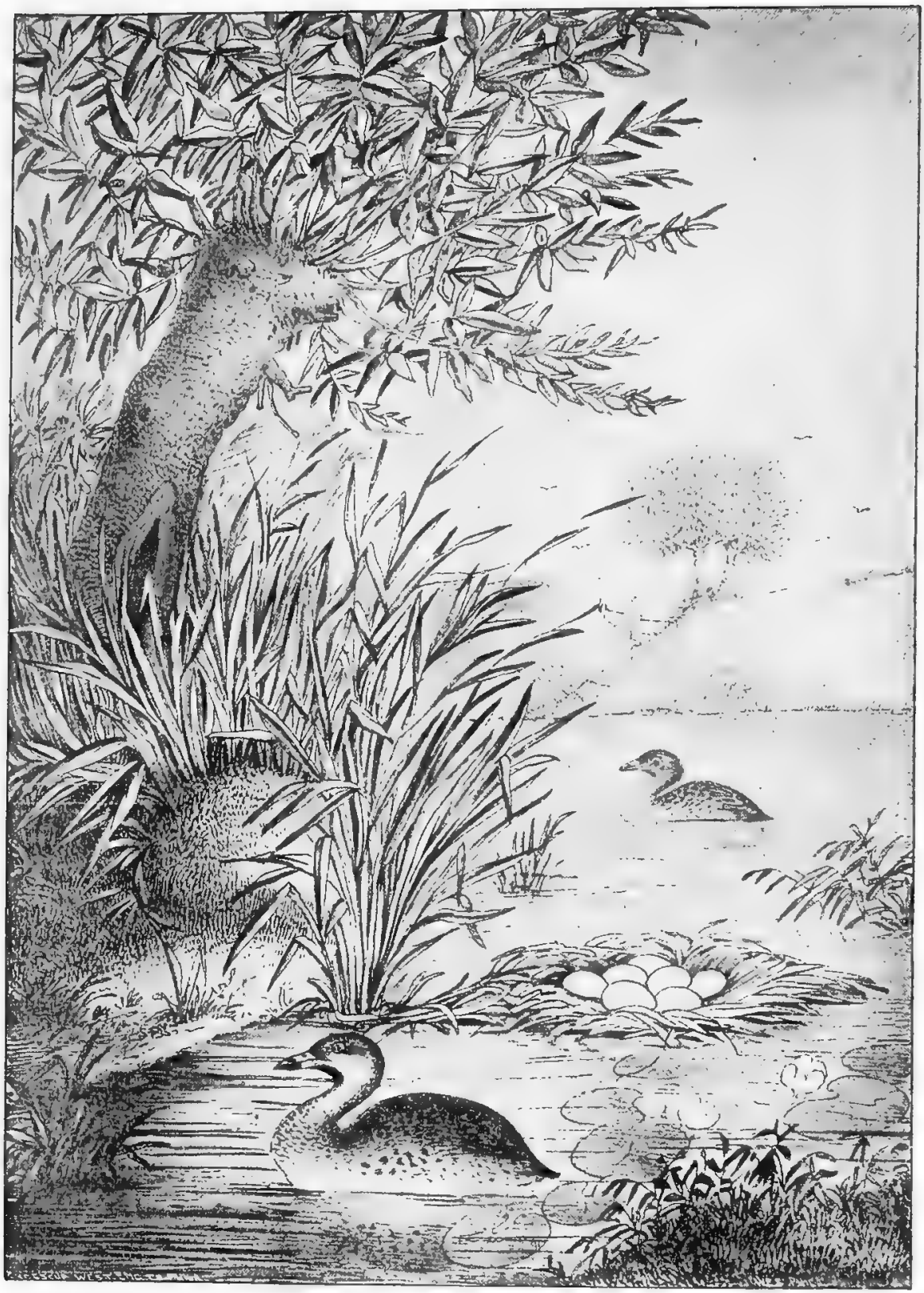

6. Pie-Billed Grebes and Nest. 
Thick-billed and Carolina Grebe, Pied-bill Dabchick, Dipper, Water-witch, "Devil-diver," and "Hell-diver" are some of the names applied to this Grebe. Most of these refer to its'wonderfuk powers of disappearance under water, and by one or more of these names it is known to every boy who has wandered with a gun along any of our creeks and rivers. It is a common bird throughout its range. The nest of the Dabchick is a little floating island of decaying rushes, reeds or grass, mixed with mud and debris brought up from the bottom of the slough or reedy pool in which it is built. The structure is fastened to the flags and aquatic plants; these are pulled down and piled upon each other till the nest rises two or three inches above the water. Mr. A. M. Shields informs me that in the neighborhood of Los Angeles, Cala., this species is very abundant-any lake or pond without the presence of two or three little Grebes seems very barren indeed. It nests about the middle of May. The number of eggs-laid by this species ranges from six to nine; the complement, however, is usually seven, and their average size is $1.72 \times 1.17$. Five specimens selected from five sets exhibit the following dimensions: $1.68 \times 1.19,1.70 \times 1.18,1.73 \times 1.18$, $1.74 \times 1.17,1.70 \times 1.17$. In Kansas, in the latter part of May, a number of nests were found containing from five to ten eggs each.* This species, like other Grekss, during the process of incubation, conceals its eggs with a covering of weeds and other vegetable material during the day, "and they are uncovered at dusk by the bird, "who incubates them until the morning sun relieves her of her task."

7. LOON. Urinator imber (Gunn.) Geog. Dist.-Northern part of Northern Hemisphere. In North America breeds from the Northern States northward; ranges in winter south to the Gulf of Mexico.

The Loons are large, heavy, birds, with flattened bodies and rather long necks; the legs are placed far back in the body, giving them great propelling power in the water. They are the most expert of all divers, disappearing beneath the water at the flash of a gun. The present species is known as the Great Northern Diver. In North America it is found from the Atlantic to the Pacific, breeding from about latitude $42^{\circ}$ northward to within the Arctic circle. Mr. Nelson states that this Loon is less common on the shores of Bering Sea than either the Red or the Black-throated species, but is far from rare at most places. $\dagger$ Mr. W. A. Davidson found the Loon nesting in the marshes of the Detroit River. Mr. Edson A. McMillan informs, me that they are quite common in the lakes of the Adirondack mountain region during the breeding zeason, which is about the first part of June. Here they breed on the islands occupied as breeding grounds by the American Herring Gull, Larus argentatus smithsonianus. He says that of nine different Loons' nest s which he examined, none of them contained material of any kind; they were simply hollows in the sand where the cggs were deposited. In Maine, Michigan'and Wisconsin and other localities the birds are known to build a roughly-formed hollow of sticks, weeds, sod and water grass. Mr. Andreas T. Hagerup in his "Birds of Grcenland," cays that he obtained from the Greenlanders eggs of this species in July and August. The Loon's egga are very dark-colored, of an olivaceous brown, sometimes olivaceous

* "Ornithologist and Oologist," a monthly magazine devoted to the study of Birds, their Nests and Eggs. Volume X, p. 165. Published by Frank B. Webster, Hyde Park, Mass.

† Report upon Natural History Collections made in Alaska between the years $\mathbf{1 8 7 7}$ and 1881 by Edward W. Nelson. Edited by Henry W. Henshaw. Prepared under the direction of the chlef signal officer. No. III, Arctic Serles of Publications issued in connection with the Signal Service, U. S. Army; with 21 Plates. Washington: Government Printing Office, 1887. 


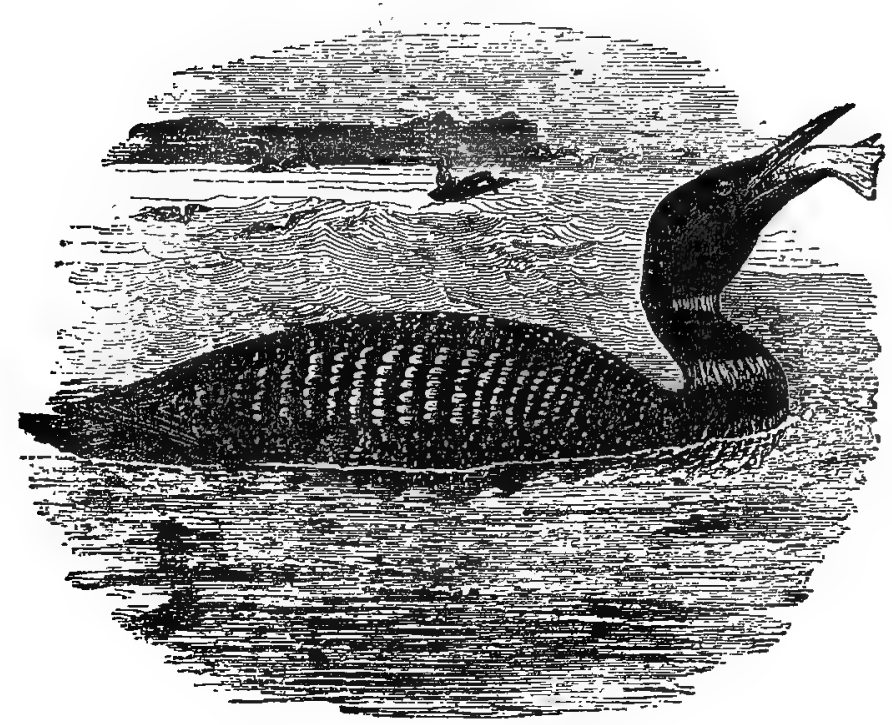

7. LOON,

drab, spotted and blotched with a very dark brown. In shape they are narrowly oval, occasionally very much lengthened. The number laid is two, sometimes three; in size they vary from 3.40 to 3.90 long by 2.10 to 2.38 broad. Two eggs in my possession collected by Mr. McMillan measure 3.63x2.26, 3.44x2.25.

8. YELLOW-BILLED LOON. Urinator adamsii (Gray.) Geog. Dist.-Western Aretic America and Northeastern Asia.

This species. is also known as the White-billed Loon. The bill is of a light yellowish color, and the general dimensions of the bird are greater than those of the last species. Less is known concerning the life history of this species than any of the Loons. The type specimen was secured on the Alaskan side of Bering Strait by Dr. Adams, of the British Navy, during the search for Sir John Franklin, and since that time, beyond the fact that the bird ranges over most of the circumpolar mainlands, little has been added to its history. It was first described in the Proceedings of the Zoological Society of London for 1859. Mr. John Murdoch (1885) records tinis Loon as a regular summer visitor at Point Barrow, and it probably breeds, though the eggs were never found. L. M. Turner (1886) says that it occurs sparingly at Saint Michael's. Mr. Nelson (1887) states that it is not a rare summer resident in certain localities about the head of Kotzebue Sound. The nesting habits and the eggs of this species are, in all probability, similar to those of the common Loon.

9. BLACK-THROATED LOON. Uvinator avticus (Linn.) Geog. Dist.-Northern part of the Northern Hemisphere. In North America migrating south in winter to the Northern States.

The Black-throated Diver is a bird which is more or less common in the northern regions of the globe. It breeds commonly throughout the interior of Norway and Sweden, and far up into Lapland. In most parts of the British Islands this Loon is 
considered of rare occurrence. On the little islands of the fresh water lochs, from the middle portion of Scotland northward to the islands beyond John O'Groat's House-the Orkney and Shetland-this species is known to breed as well as on the Hebrides on the west coast. In North America it occurs as far south as the United States. On the Pacific coast it is replaced by the next species, $U$. pacificus. According to Nelson this Loon is very common all along the American shore of the sea about Kotzebue Sound, and they are also numerous on the large streams and marshes of the interior, and the eggs have been taken at Fort Yukon. Like all the Loons, its home is on the water; it is awkward and almost helpless on land. Its progress under water haś been estimated to be not less than eight miles an hour. Mr. Nelson says that the eggs are usually placed on some small islet in a secluded pond. There is no attempt to make a nest, and frequently the eggs lie in a spot washed by water when the wind blows from the right quarter. In spite of this the young are duly hatched. Two eggs are deposited, of a dark olive, blotched with black spots which are generally confluent about the larger end, very frequently they are crowded into a black patch at the very apex of the larger end, elongated in shape, but occasionally somewhat oval. Extremes in size are $3.08 \times 1.95$ and $2.75 \times 1.76$. Twelve sets, selected from forty-six sets of this species' eggs are in Mr. Crandall's collection. They were collected in various parts of Sweden, Lapland and Finland. These show an average measurement of $3.32 \times 2.06$.

10. PACIFIC LOON. Urinator pacificus (Lawr.) Geog. Dist.-Pacific Coast of North America, south in winter to Cape St. Lucas and Guadalupe Island.

As its name implies, the Pacific Diver is confined to the West, and the above habitat clearly indicates its range. Mr. Murdoch mentions it as very common at Point Barrow. It breeds in the Arctic regions-on the islands in the lakes and bays of Alaska - in the marshes of the Yukon River, and it has been found breeding in considerable numbers at Fort Anderson. It breeds commonly in the innumerable lakes and ponds of the Near Islands, Alaska,* accoraing to Turner. The nest of this Loon is made in a decayed mass of vegetation similar to a Grebe's nest, and often it. is a mere hole in the turf in which the eggs are deposited. Sometimes the depression is found to be scantily lined with feathers. One hundred and five nests observed by Mr. MacFarlane, in the vicinity of Fort Anderson, contained no more than two eggs each. $\dagger$ The eggs are described as having a ground color, varying from a deep amber to a pale greenish-gray and in size measuring from 2.95 to 3.25 long by 1.85 to 2.00 in breadth.

11. RED-THROATED LOON. Urinator lumme (Gunn.) Geoc. Dist.-Northern part of Northern Hemisphere, migrating southward in winter nearly across the United States.

This beautiful little Loon breeds in high latitudes. It is also a bird of the old World, where its breeding range is about the same as that of the Black-throated Diver. It is not an uncommon summer resident of New Brunswick, and it breeds in company with the common Loon in the Province of Quebec, Canada, on the islands of the St. Lawrence River and Gulf.' In the large lakes and ponds of Manitoba it is a tolerably common summer resident, and particularly in the Red River valley. From these places northward to Alaska, and in the Arctic regions it breeds

* This group forms the westernmost portion of the Aleutian chain; they are co designated because they lie nearest the Aslatic Coast.

T Baird, Brewer and Ridgway's Water Birds, Vol. II, p. 457. 
more or less abundantly in all suitable places. It is common during the summer months in Greenland. In Labrador it bleeds in the first part of June; in Hudson Strait, eggs may be collected from the middle of June to the middle of July. Throughout Alaska, Mr. Nelson says, the present bird is by far the most abundant species of Loon. From the first of June until the first of July fresh eggs may be found. The nesting sites chosen are identical with those of the Black-throated species. Mr. M. Abbott Frazar says that on the islands and along the coast of Labrador this species nests on the edge of the smaller ponds, these often being mere pools of surface water. The birds make no nest, but deposit their eggs in a bare hollow space on the ground, usually not over a foot from the water's edge.* 'Two eggs are laid;' and the color varies from deep reddish-brown to grayish-green, sparsely spotted with brownish-black. In size they vary from 2.65 to 3.00 long by 1.70 to 1.85 broad. A set of two eggs collected by J. N. McFadden, on Resolution IsIand, Hudson Strait, June 18, measure $2.74 \times 1.78,2.72 \times 1.81$. Two sets of eggs collected by Mr. Pope near Anticosta Island, at the mouth of the St. Lawrence, measure as follows: $2.90^{\circ} \times 1.81,2.88 \times$ $1.75 ; 2.98 \times 1.76,2.90 \times 1.70$, respeatively. These are in the 'writer's collection.

12. TUFTED PUFFIN. Lunda cirrhata (Pall.) Geog. Dist.-Coasts and islands of the North Pacific, from California to Alaska, and from Japan to Bering Strait. Accidental on the coast of Maine.

A curious bird with a parrot-like bill, hence the name of Sea Parrot which is applied to all the Puffin. This species breeds on the islands along the Pacific coast, from the Farallons northward to the islands of Bering Sea. Its general color is black, with a conspicuous white face mask, long, floating yellow ear-tufts, bent like the horns of a ram; the legs are red, the beak is red and green, making altogether a grotesque looking creature. 'The birds deposit their single egg in crevices of rocks; a burrow is often dug in the guano, which has for ages accumulated on these islands; sometimes a few pieces of weeds are found in the bottom of the cavity, but often no material is used as a nest lining. Mr. C. Barlow, who has made a careful study of the birds on the Farallons, says that the nest of this species is usually at the end of natural burrows in the granite cliffs; the cavities vary in length from two to five feet. At one place they are found depositing their eggs in little depressions behind the rocks; the eggs being generally out of sight of the passer by $\uparrow, \mathrm{Mr}$. W. O. Emerson, who has collected extensively on the Farallon Islands, says that one of the birds may always be seen at the entrance of their nesting places on guard duty; they are among the most noisy of the sea birds, always screaming while out on the rocks, and constantly "growling" while in their burrows. Fresh eggs may be collected in the middle of June. Mr. Emerson informs me that he has taken fresh eggs and young birds in the latter part of July. One pair will rear two or three birds in a season. The eggs have a ground color varying from a pure white to a yellowish buff. Some have a circle of lilac markings about one or both ends. Eggs will be found in a large series having tan colored spots over the entire surface; others have lines and zigzag markings, while some seem to be immaculate, but upon close examination deep-lying shell markings are noticeable. Four eggs measure $2.87 \times 1.88,2.83 \times 1.86,2.84 \times 1.86$, 2.82x1.89. In a paper entitled "Birds and Eggs from the Farallon Islands," $\ddagger$ based principally upon Mr. Emerson's "matchless collection of birds and eggs, and his

* Ornithologist and Oologist, Vol. XII, p. 2.

$\dagger$ A few Notes on the Tufted Puffin in The Oologist, Vol. XI, p. 358.

₹ Read before the California Academy of Sciences, December 19, 1887 . 


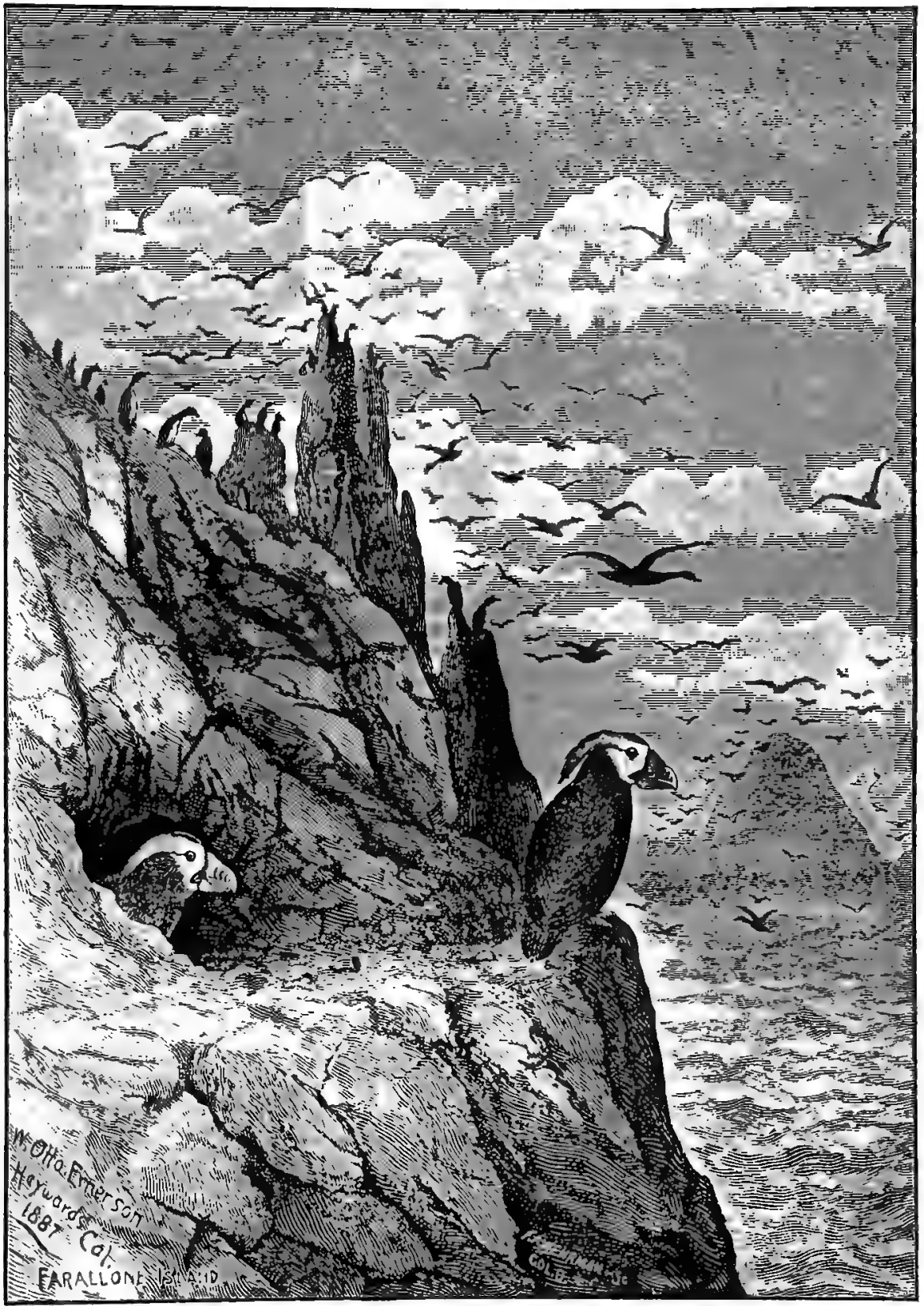

12. Tufred Puppins and Nastimo Borgow. 
notes regarding them," the author, Mr. Walter E. Bryant, says: "I have carefully measured fifty Puffin's eggs, which average $70.2 \times 48.4 \mathrm{~mm}$.* The individual proportions of eight eggs, showing the greatest and smallest extremes of both diameters, are $81 \times 50,77 \times 48,74 \times 50,71,5 \times 51,71 \times 46,65.5 \times 45,64 \times 50,63.5 \times 50 \mathrm{~mm} . " \dagger$

13. PUFFIN. Fratercula arctica (Linn.) Geog. Dist.-Coasts and islands of the North Atlantic. 'Breeding on the North American coast from the Bay of Fundy northward, south in winter to Long Island, and casually farther.

The Common Pufin is found exclusively in the waters of the Atlantic, breeding on the eastern coast of North America from Maine to Greenland. In Europe it breeds from Great Britain to the northern coast of Norway. The nest is made in a burrow in the earth, dug by the birds. Far north thousands breed in the fissures of rocky cliffs and in the sides of bluffs; tro birds are often found sitting, each on its egg, in the same burrow. The egos are deposited late in June and in July. Mr. Frazar found these birds abundant on the coast of Labrador. An island of two or three hundred acres in extent was covered wit? Puffin burrows; about a thousand nests examined contained one egg each, while in a dozen others there were but two eggs to a nest. The greater part of these were plain, dull white; others were more or less thickly spotted with obscure chocolate and reddish brown markings; a number had distinct brown spots, blotches and tracings, such as are seen in the Murre eggs. $\ddagger$ The sizes range from 2.25 to 2.85 in length by 1.45 to 1.85 in breadth.

13a. LARGE-BILLED PUFFIN. Fratercula arctica glacialis (Temm.) Geog. Dist.-Coasts and islands of the Arctic Ocean, from Spitzbergen to Baffin's Bay.

This bird, a subspecies, is like the last, but greater in size, the bill larger and differently shaped. It breeds in the far north, on the islands of Baffin's Bay and along the coast of Greenland-nesting in the same manner as arctica. The eggs are not distinguishable. Accopding to $\mathrm{Mr}$. Ridgway they average larger than $F$. arctica. $\$$

14. HORNED PUFFIN, Fratercula corniculata (Naum.) Geog. Dist.-Coasts and islands of the North Pacific, from Kurile Islands to Sitka.

The Horned Puffin breeds on the bleak rocky islands of the polar, seas. It is found along the coast of Alaska, is common in the Northern Pacific Ocean and on nearly all the islands of Bering Sea. Mr. Nelson states that this bird breeds abundantly on the Near Islands, but is not resident there. They are resident from the Aleutian chain south, but are summer residents thence north. They are equally abundant along both shores of Bering Sea, and south they are found on the coast of California and that of Japan. They also occur on the Commander Islands. Thousands of them breed on every rocky island, and whenever a vessel nears land in that region the clumsy. form of the Puffin soon becomes a familiar sight. It takes its name from the slender, upright horns on the upper eye-lids. . The term "horns," however, is regarded by some as misleading. In the living bird the horns are said to be only soft, flexible caruncles or wattles. The nest-holes of this species are in the deep, narrow interstices of rocks, seldom within the reach of a man's arm, and, except in the absence of the bird, it is hazardous to attempt to rob the nest. Like the Tufted Puffin, Lunda cirrhata, it often inflicts a severe wound with its powerful bill. The

- $2.76 \times 1.90$ inches.

$\div 3.19 \times 1.97,3.03 \times 1.89,2.91 \times 1.97,2.81 \times 2.01,2.79 \times 1.81,2.58 \times 1.77,2.66 \times 1.97,2.50 \times 1.97$ inches.

* Ornithologist and Oologist. Vol. XII, pp. 2-3.

\$ Manual North American Birds, p. 11. 


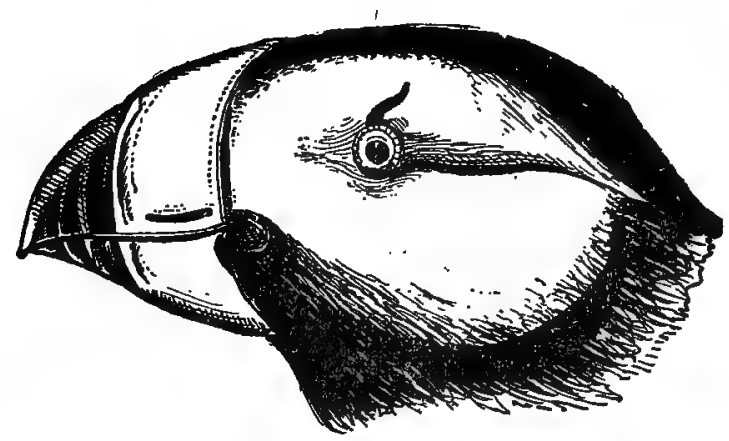

14. Horned PUthin, Male, Summer.

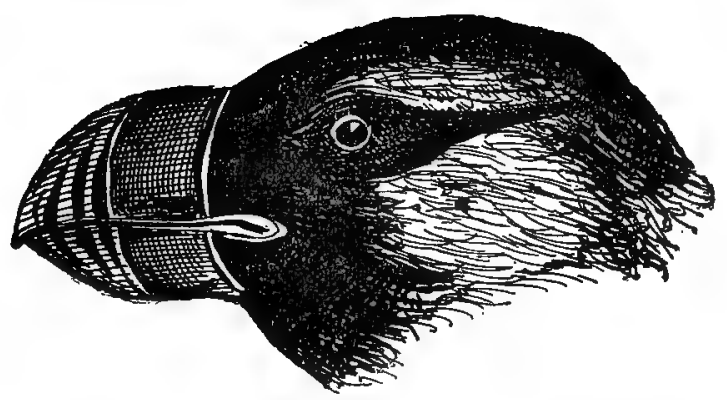

14. Horned Puffin, Adult, Winter Plumage.

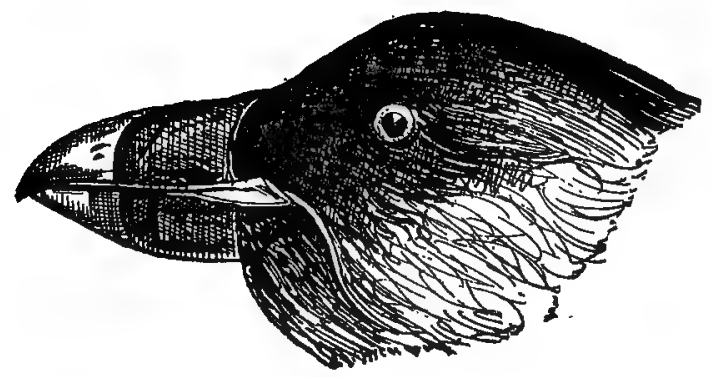

14 Horned Puffin, Young Male, Winter. 
nest cavities are lineu with grass, moss, etc. A single egg is laid, which is oblongoval in shape, pure white in color and the shell is rough, measuring $2.74 \times 1.84$.

\section{RHINOCEROS AUKLET. Cerrohinca monocerata (Pall.) Geog. Dist.-} Coasts and islands of the North Pacific, from Lower California (resident) to Japan.

On the islands of the Pacific coast, from Washington northward, the Hornedbilled Auk is said to breed, and was thought to breed on islands farther south. It is nocturnal in its habits, remaining throughout the daytime in crevices among the rocks and burrows in the ground, where it deposits its single egg. This is similar to the egg of the Horned Puffin-dull, chalky white, with discolorations and faint shell markings of obscure purplish-gray. Sizes range from 2.65 to 2.90 long and bJ 1.80 to 1.90 broad. Mr. Ridgway gives the size as $2.70 \times 1.82$.

16. CASSIN'S AUKLET. Ptychoramphus aleuticus (Pall.) Geog. Dist.-Pacific coast of North America, from the Aleutian Islands to San Diego, breeding southward to the Farallons.

Mr. Emerson found this species abundant on the Farallons. It is nocturnal in its habits, flying and roving about during foggy, stormy or mnonlight nights, but never at dusk. After dusk, however, they come out of their holes in the rocks all over the island, and can be heard calling to one another their peculiar notes, chee'rie-kee, chec-ric-kee. Mr. Taylor says: "Some observer has stated that Cassin's Auklet on the islands does not burrow. This is a mistake. Many of the Auklets lay their eggs in holes in soft earth in places where it can be found."* Mr. C. Barlow remarks that the Tufted Puffin and Cassin's Auklet are somewhat similar in their manner of nesting, and both species are usually found in the same locality, although the Auklet nests in all situations about the island. $\uparrow$ Any convenient crevice or hole in a pile of rocks which affords a hiding place suits this species for the purpose of depositing its single egg. . Mr. Bryant, in his paper, "Birds and Eggs from the Farallon Islands," says that this Auk arrives early in the year, coming in great numbers in the night of January 14, 1887. Two and three young are supposed to be reared in a season. Young birds in the down have been taken in September. Considering the size of this species, it lays a very large egg. The bird measures eight to nine and a half inches in length, or about the size of a full-grown Woodcock, while its egg averages $2.25 \times 1.47$. At first appearance the egg seems to be white, but upon holding it to the light it is a delicate shade of emerald green. The shell is finely granulated, and the general shape of the egg is ovate, some more pointed than others. Two extreme examples measure as follows: $1.97 \times 1.42,1.65 \times 1.22$. There is a series of ninety-four eggs in the oölogical collection of Mr. C. W. Crandall, all taken on South Farallon Island. The smallest of these measures $1.63 \times 1.27$, the largest $1.98 \times 1.32$, average size $1.81 \times 1.33$.

17. PAROQUET AUKLET. Cyclorrhynchus psittaculus (Pall.) Geog. Dist.Coasts and islands of the North Pacific, from the Aleutian and Kurile Islands northward.

" "A Trip to the Farallons," by H. R. Taylor, Vol. I, pp. 17-19, of The Nidologist, an Illustrated Monthly Magazine devoted to the study of Ornithology with special reference to the Nidfication of North American Birds, H. R. Taylor editor and publisher. Associated with Dr. R. W. Shufeldt. Office: Alameda, Cal.

t An Ornithological Paradise. Some observations gleaned from a sojourn in the famous Farallon Islands. By C. Barlow, Santa Clara, Cal, In The Museum, a journal devoted exclusively to research in Natural Sclence. Published by Walter F. Webb, Albion, N. Y., Vol. I, pp. 38-44. 


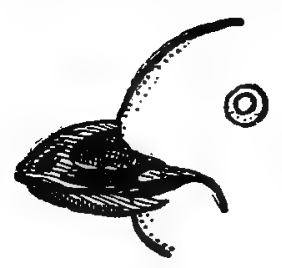

17. Paroquet Autlet, Female Adort, SUmmir.

Like a number of other species, the Paroquet Auklet has a strong preference for deep water and the islands situated in it. "It feeds at sea, flying out every morning, returning in the afternoon to its nest and mate." The bird is known also by the name of Pug-nosed Auk. It is distributed irregularly throughout the Northern Pacific Qcean and Bering Sea, being quite common on the Prybilof and Aleutian Islands in the breeding season, which begins about the middle of May. During the cruise of the Corwin in $1881 \mathrm{Mr}$. Nelson found the Paroquet Auklet breeding in extreme abundance on the islands in Bering Strait, and great bunches of them were brought on board by the Eskimo. Large numbers of eggs were easily secured. For its nesting place this Auk selects a deep crevice in the face of some cliff; the cavity is often winding, and it is sometimes exceedingly difficult to obtain the eggs. Even: on islands where hundreds of these birds are found breeding some of the cavities cannot be opened, except by the means of dynamite or blasting powder, which, if used, would destroy the eggs. A single egg is deposited on the bare surface of the cavities; it is generally an oblong-oval shape with rounded ends, chalk-white or bluish in color, and the shell rough. . The average size is $2.12 \times 1.46$. Eggs taken on the Seal Islands' by Elliott measured from $2.25 \times 1.50$ to $2.35 \times 1.45$.

18. CRESTED AUKLET. Symórhynchus cristatellus (Pall.) Goog. Dist.Coasts and islands of the North Pacific, from Kadiak and Japan northward.

The crested or Snub-nosed Auk, like the last, inhabits the coasts and islands of the north Pacific. On the islands of Bering Sea its breeding season extends from

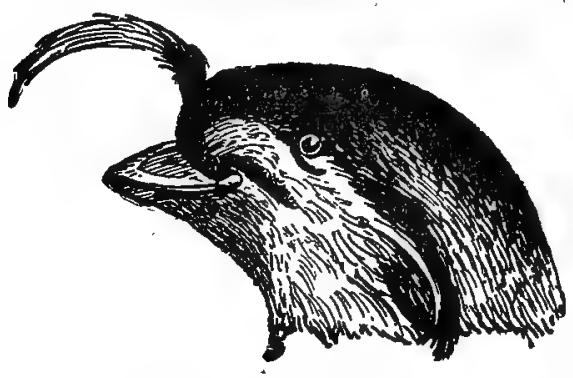

18. Crested Auklet, Summer. May to August. This little bird has a beautiful crest on the forehead of twelve to twenty feathers; it is about two inches long, and curls gracefully forward upon the bill. Its nesting habits are like those of the $C$. psittaculus. Mr. Nelson says: "This strangely ornamented bird has a range almost identical with that of the preceding species, -and I do not recall a single instance in which the Paroquet Auklet was seen in any numbers where the present species was not found. A few were observed in the passes near Unalaska in May, and the 13th of June a single pair were seen off the Seal Islands. This bird breeds plentifully on the Near Islands, but does not winter there. They also breed on the Commander Islands." He further records that in Bering Strait and about Saint Lawrence and Saint Matthew's Islands this species and $C$. psittaculus are found in equal abundance.' They choose the same 
nesting sites, and each lays a single white egg upon the bare rock or ground in crevices. On the Fur Seal Islands they also breed in great numbers, occupying the cliffs with the other auks. They arrive in May and deposit their eggs deep down in the crevices. The eggs taken on these islands are chalky white, and measure 2.31×1. 61 largest, and $2.06 \times 1.50$ smallest.

19. WHISKERED AUKLET, Symorlynchus Pygnaus (Gmel.) Geog. Dist.Coasts and islands of the North Pacific, from Unalaska through the Aleutian chain to Kamtschatka.

From what is known of this species it appears that its general habits are similar to those of the Least Auklet, but it is far from being as common. Another name by which it is known is Red-nosed Auk, the bill in adult birds being of a deep vermilion, tipped with bluish. A tuft of flamentous feathers on the head curves forward so that it hangs directly over the bill. According to Nelson the species is unknown from the Fur Seal Islands and we have no knowledge of its numbers and distribution in the Aleutian chain. It breeds abundantly on Near Islands, but it does not winter there. It also breeds on the Commander Islands.

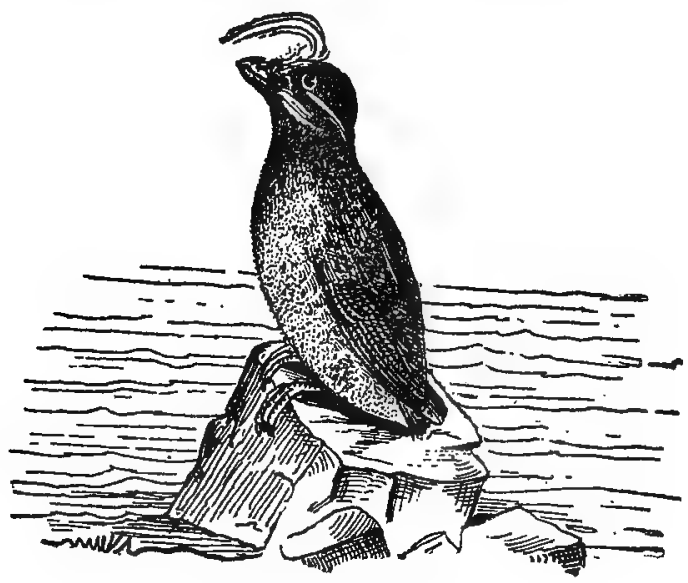

19. WHISKERED AUELET.

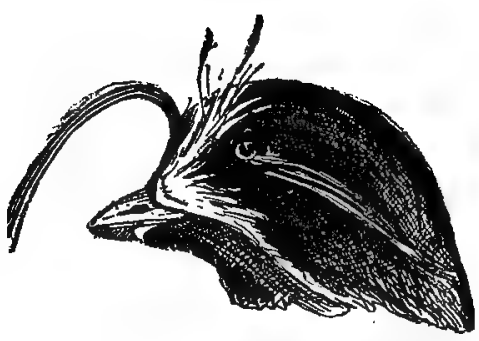

19. Whiskered AUKLET, ADULT MALE, WINTER.

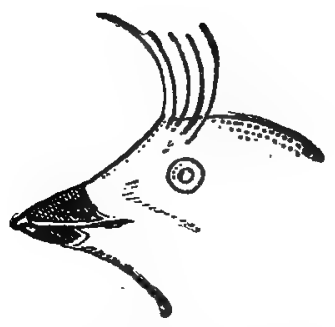

19. WHISKERED AURLET, Adult, FeMale, SUMMER. 
20. IEAST AUKLET. Symorhynchus pusillus (Pall.) Geog. Dist.-Coasts and Lslands of the North Pacific, from Sitka and Japan northward to Bering Strait.

Nelson says: "Of all the water fowl of Bering Sea this trim little bird is the most abundant." Like the Paroquet and Crested Auklets, this species has a great

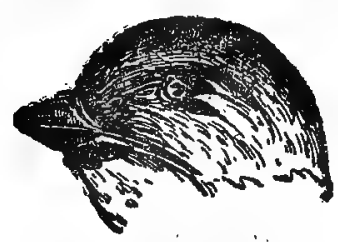

20. LeAst AuKLET, ADuLT, MaLe, SuMMER, preference for the deep western half of Bering Sea, except along the Aleutian chain. Mr. Nelson does not think they breed north of the strait, except on some of the cliffs on the Siberian shore. By the 1st to the 6th of June they arrive in great numbers on these islands, and begin to lay. It is said to be comically indifferent to the proximity of man, and can be approached almost within an arm's length before taking flight, sitting upright and eyeing one with great wisdom and profound astonishment. Dr. Coues says: "This curious little bird, the smallest of all the Auks, and one of the least of all water birds, inhabits the coasts and islands of the North Pacific, resorting to favorite breeding places by millions, with \$. psittaculus and $\$$. cristatellus. The nesting is similar, the single egg being laid in the recesses of rocky shingle over the water; size 1.55x1.12."* The bird is not known to come south so far as the United States.

\section{ANCIENT MURRELET. Synthliboramphus antiquns (Gmel.) Geog.} Dist.-Coasts and islands of the North Pacific, from Sitka and Japan northward. Accidental in Wisconsin.

The Black-throated Guillemot, or Murrelet, is found in the North Pacific Ocean, breeding on the islands and along the coasts from Sitka northward. It breeds in abundance on Near Islands, where a few are resident. On the Commander Islands they also breed. Nests that have been found of this species were in holes in banks, or in burrows in the ground, similar to those used by the Fork-tailed Petrel. On some of the islands of Bering Sea, however, the birds are known to deposit their eggs in the crevices of cliffs. A single egg is laid, pale buff in color, with small longitudinal markings, somewhat subdued, of lavendergray and light brown. Sizes range from 2.15 to 2.50 long by 1.40 to 1.55 broad.

22. TEMMICK'S MURRELET. Synthliboramplus wumizusume (Temm.) Geog. Dist.-Coasts and islands of the North Pacific, from Japan and (Washington ?) northward.

The Japanese Murrelet, according to the best evidence at hand, is not entitled to a place in the avifauna of North America. Mr. Ridgway remarks that it is "very doubtfully American." Mr. Nelson in his "Birds of Alaska" says: "The present species has been credited to the northwestern coast of America, and I mention it here merely to call attention to the fact that no explorer has found it in the region covered by this paper." It has since been eliminated from the A. O. U. Check List.f

23. MARBLED MURRELET. Brachyramphus marmoratus (Gmel.) Geog. Dist.-Coast and islands of the North Pacific; on the American coast from San Diego northward, and breeding as far south as Vancouver Island.

This is another of the diminutive Murres confined to the Pacifle Ocean. There seems to be little known concerning its nidification, but its nesting habits ard eggs

* Key to North American Birds, p. 809.

$\uparrow$ Cf. Stejneger, Proc. U. S. Nat. Mus. IX, 1886, p. 524. 
are said to resemble those of the Ancient Murrelet, $S$. antiquus. They are ovate in shape, ground color buffy, marked with various shades of brown. Size, $2.14 \times 1.42$.

24. KITTLITZ'S MURRELET. Brachyramphus kittitzii (Brandt.) Geog. Dist.-Kamtschatka and Aleutian Islands, east to Unalaska.

Mr. Nelson took the first specimen of this bird in Unalaska Harbor the last of May, 1877. The birds were in company with $S$. antiquus and $B$. marmoratus. Their habits appeared to be the same. In "Contributions to the Natural History of Alaska" page 121, Turner says: “A single specimen of Kittlitz's Guillemot was obtained April 24, 1879, at Iliuliuk village on Unalaska Island. It was the only one seen in that locality. The native who brought it to me asserted that this species is abundant throughout the year at Sannakh Island. They breed there, laying a single, pure white egg. The nest is placed among the roots of the large tussocks of grass on the edges of bluffs and cliff ledges. I observed several of these birds to the westward of Unalaska Island. They are not rare on Amchitka Island and in the neighborhood of the Old Harbor, on Atkha Island."

25. XANTUS'S MURRELET. Brachyramphus hypoleucus Xantus. Geog. Dist.-Coasts of Southern California to Cape Saint Lucas.

There appears to be no literature describing the nesting habits and eggs of this Murrelet. The bird is stated to breed on the coast of Southern California, from San Diego southward.

26. CRAVERI'S IMURRELET. Brachyramphus craveri (Salvad.) Geog, Dist. Island of Natividad, Gulf of California.

Craveri's Murrelet, of plain dark, slaty plumage above, and entirely pure $w$ hite beneath, breeds on the islands at the southern portion of Lower California, in the vicinity of Cape St. Lucas. 'It nests in burrows in the ground, and its general habits in all respects are said to be the same as those of $S$. antiquus. It deposits a single egg, which is ovate in shape, of a yellowish or buff ground color, thickly dotted, sprinkled and marked with blackish-brown. Average size $2.03 \times 1.40$.

27. BLACK GUILLEMOT. Cepphus grylle (Linn.) Geog. Dist.-Coasts of Northern Europe, south to Dénmark and British Islands; coast of Maine, south in winter to Philadelphia; Newfoundland. (?)

In Europe this species breeds from the northern coasts of the British Islands to the Arctic Ocean. In Greenland, according to Hagerup, it breeds incolonies of from two to thirty pairs, among the precipitous cliffs along the sea shore.* It is resident on the north coast of Ireland. Breeds commoniy on the Hebrides, Orkneys and other islands on the coast of Scotland. A very common species along the entire coast of Norway. In North America it breeds on the islands off the coast of Maine; on Grand Manan and other smaller islands it is found in countless numbers about the middle of June, depositing its eggs in the nooks and crevices of rocks, and in all sorts of places which offer shelter above high water mark. The eggs are laid on the bare surface of the rock, with no attempt at nest building. So skillful is the bird in hiding away its eggs that they are sometimes found hidden away in subterranean caves. $\uparrow$ Two, and rarely three eggs are laid, and they are indistinguishable from those of the following species, but average larger.

* The Birds of Greenland. By Andreas T. Hagertp.' Translated from the Danish by Frimann B. Arngrimson. Edited by Montague Chamberlain. Boston: Little, Brown \& Co., 1891.

+See "Notes on Some of the Birds of Grand Manan," by C. H. Andros, Ornithologist and Oologist, Vol. XII, pp. 179-180. 
28. MANDT'S GUILLEMOȚ. Cepphus mandtii (Licht.) Geog. Dist.-Arctic regions of both continents; south on the Atlantic coast of North America in winter to New Jersey, breeding to Hudson's Bay and Labrador; Alaskan coast, south in winter to Norton Sound.

The Sea Pigeon, as it is called, breeds abundantly on the coast and islands of the North Atlantic. It is very abundant from Labrador and Hudson's Bay northward, nesting in the holes and crevices of rocks, often in the most inaccessible places. The eggs are laid in June and July. The usual complement is two, often three. These vary from white to a pale greenish-white, light drab, yellow or buff, marked irregularly with spots and blotches of different shades of brown and black, thickest at the great end, where they are usually almost a confluent ring; they are oval or elliptical in form; size about $2.30 \times 1.55$, but, like nearly all eggs in a large series, there is a great variation in the size, shape, and also in the style of markings, etc.

29. PIGEON GUILLEMOT. Cepphus columba (Pall.) Geog. Dist.-Coasts and islands of the North Pacific, southward from Bering Strait to Northern Japan and Southern California.

On the Pacific coast of North America this species is found breeding from San Nicholas Island northward to the islands of Bering Sea. Dr. Leonhard Stejneger says that it is a very common bird on Bering and Copper Islands; its eggs were collected at the latter place June 16th.* Mr. Taylor says: "The Pigeon Guillemot (so like a Guillemot and so like a Pigeon) is found in rather limited numbers [on the Farallons.] Most interesting are these pretty, graceful birds looking so petite and modest among an army of clamoring Gulls. I believe the questioned statement that they gather smali stones for a nest is true, in most instances. I noted the flat stones and pebbles about their eggs often and they did not appear to be accidental." $t \mathrm{Mr}$. Emerson says egg-laying on the Farallons begins about the first of Mayp or shortly after, and continues into July. Two eggs is the number laid, and they. are deposited in the crevices of rocks or in dark nooks under boulders, often near the water's edge. If the eggs are taken the foolish bird will lay again in the same place. The favorite resting place of these birds is on the rock just above the foaming surf, where they sit in pairs and "converse" with one another in low whistling notes. In a large series of eggs the ground color varies from light pearl gray to greenish-blue; their general shape is like that of the Gulls' eggs, rounded oval at the large end and pointed at the smaller. The markings are of two shades of lilac; in some they are thickly spread over the entire surface; in others they form a circle about the larger end. Mr. Bryant gives the average measurment of twenty-five sets of two eggs each in Mr. Emerson's collection as, 61.6 by $41.4 \mathrm{~mm}$. $\neq$ Extremes in size, 66.5 by $41.5,58.5$ by 41 millimeters. $\$$

30. MURRE. Uria troile (Linn.) Geog. Dist.-Coast and islands of the North Atlantic, southward on the coast of North America in winter to Southern New England; breeding from Nova Scotia northward.

- Bulletin of the United States National Museum. No. 29. Fesults of Ornithological Explorations in the Commander Islands and Kamtschatka. By Leonhard Stejneger,

$\uparrow$ In Nidologist, Vol. I, p. 19.

$\$ 2.43 \times 1.62$ :

$\$ 2.62 \times 1.63,2.30 \times 1.61$. 
Like all of the Auks, Murres and Puffins, this species is eminently gregarious, particularly in the breeding season. It is found in great numbers throughout the Arctic Ocean and on nearly all the islands north of Asia, Europe and America. On this side of the Atlantic it breeds from Nova Scotia northward. Tens of thousands of these birds congregate to breed on the rocky islands, depositing and incubating their single egg close to one another on the shelves of the cliffs. The birds sit side by side, and although crowded together, never make the least attempt to quarrel. Clouds of birds may be seen circling in the air over some huge, rugged bastion, forming a picture which woúld seem to belong to the imagination rather than the realistic. They utter a syllable which sounds exactly like murre. The eggs are so numerous as to have commercial value, and they are noted for their variation in ground color and markings. They vary from white to bluish or dark emerald-green in ground color; occasionally unmarked specimens are found, but they are usually handsomely spotted, blotched, lined in various patterns of lilac, brown and black over the surface. In some the markings are confused zigzag lines that look like hieroglyphics. The eggs are large for the size of the bird, measuring from 3. to 3.50 long by 1.95 to 2.10 broad; pyri-form in shape.

30 $a$. CALIFORNIA MURRE. Uria troile californica (Bryant.) Geog. Dist.Coasts and islands of the North Pacific, breeding from California north to the Prybilof Islands.

Mr. Emerson says that the California Murre is the most common sea fow 1 on the Farallon Islands, and they do not seem to diminish in number, notwithstanding

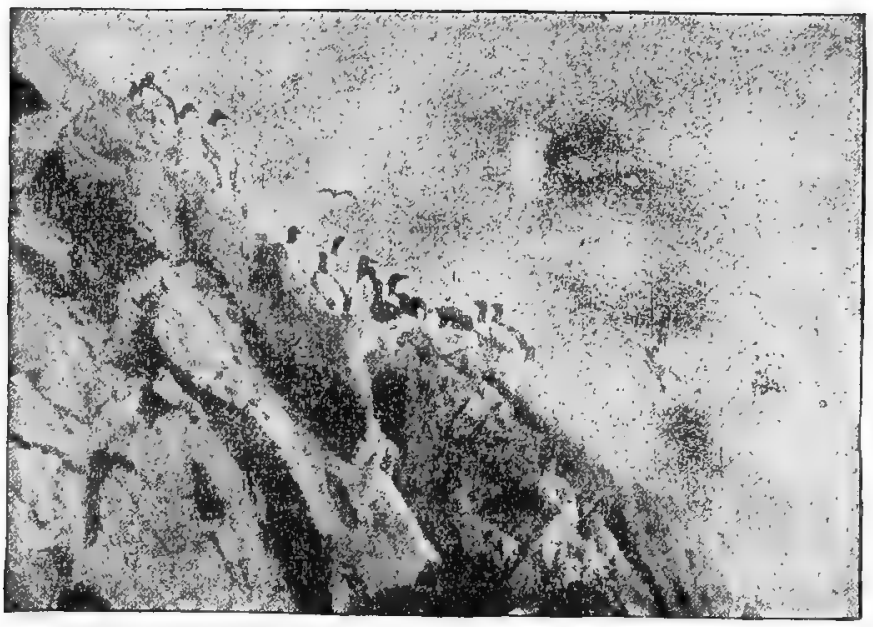

30a. California Murkes on the Farallons, (From The Nidologist.)

the wholesale destruction of their eggs for commercial purposes. The birds begin to lay by the middle or latter part of May. Fresh eggs can be found as late as August. This is due, more or less to the many robberies to which the birds are subjected, and they are compelled to lay several times before they are left undisturbed hv the pogpers. Sn telling is the effert die to constant laying'that the eggs deposited 
in the latter part of the season are perceptibly smaller. Mr. C. Barlow also states that this species greatly exceeds in numbers any of the birds inhabiting the Farallon; they nest on the cliffs in rookeries, usually near the summits of the peaks. For years their eggs have been collected for the San. Francisco markets where they are used by bakeries in the manufacture of all kinds of pastry.* According to Mr. Bryant the number of eggs marketed for the last few years has averaged from one hundred and eighty thousand to two hundred and twenty-eight thousand. In 1886 two men who were left on Sugar Loaf, collected one hundred and eight thousand eggs. The Western Gull, Larus occidentalis, is another enemy of this Murre; it sarries off and devours both eggs and young. So it would seem that the chances for the Murre to rear its young and launch them into the deep, blue sea, where they can take care of themselves, are not very favorable, yet these birds are found in countless numbers on the islands of the Pacific coast. Mr. Bryant, in his excellent paper, $\dagger$ says: "The gulls pick a Murre's egg up bodily and carry it away in their capacious mouth, but do not stick their bill into it to get hold, as is stated by some writers, whose observations must have referred to the eggs already broken by the gulls or eggers." This species lays a single pear-shaped egg on the bare rock, often on the narrow shelves of cliffs, where the bird has just room enough to sit, and if unmolested will rear two or three young in a season. Like the eggs of the last species, they show a wonderful diversity of color and markings; the ground color is white, buff, greenish of several shades, yellowish, and cinnamon. They are either unspotted or blotched or streaked with zigzag markings of brown and black. They measure from 3.50 to 354 long by 1.90 to 2.05 broad; occasionally as small as 2.05 in length by 1.45 in breadth. Mr. H. A. Taylor says: "The California Murre, the representative birds of the islands, lay their colored, pear-shaped eggs on bare rock on the steepest crags, in caves and almost everywhere, save on the few low flats near the shore, where many Western Gulls choose to build their nests of coarse Farallon weeds, and in the hollow spaces under certain boulders the Pigeon Guillemot lays her two eggs." $\ddagger$

31. BRUNNICH'S MURRE. Uria lomvia (Linn.) Geog. Dist.-Coasts and islands of the North Atlantic and Eastern Arctic Ocean, south on the Atlantic coast of North America to New Jersey. Breeding from the Gulf of St. Lawrence northward.

This species has the same general habits and characteristics as the common Murre, Uria troile. Its distribution in the breeding season is about the same, and the eggs are indistinguishable. It is an abundant bird on the islands of the North Atlantic. We can now, for the first time, add this bird to the avifauna of Ohio. A mounted specimen before me, was captured alive by Mr. R. T. Stewart in a field near Fair Haven, Preble county, Ohio, December 19th, 1896. The bird was kindly identitified for me by Mr. Charles W. Richmond, Assistant Curator of Birds in the National Museum. He states that a wave of these birds was scattered, by a storm which occurred about the above date and Prof. I. L. Moseley reports two specimens being shot at Put-in-Bay and two at Sandusky on December 19 th.

31a. PALLAS'S MURRE. Dvia lomvia arra (Pall.) Geog. Dist.-Coast and islands of the North Pacific and Western Arctic Ocean.

The great "egg bird" of the North Pacific, swarming at its breeding places on the rocky islands and shores in myriads. Its habits and nesting are the same as those of the foregoing, the eggs averaging larger, 3.21 x2.01.

* The Museum, I, p. 38.

$\dagger$ Birds and Eggs from the Farallon Islallds.

‡ "A Trip to the Farallons" in The Nidologist. Vol. I. Dp. 17-19. 
32. RAZOR-BILIED AUK. Alca torda Linn. Geog. Dist.-Coasts and islands of the North Atlantic, south in winter on the North American coast to Southern New England.

The Razor-billed Auk is abundant on the coasts and islands of the North Atlantic and some parts of the Polar seas. The Razor-billed Auk is about eighteen inches long, with a pointed tail and flatly compressed bill; the plumage is brownishblack aboveand white beneath, the black bill having a white curved lineand the back part of the wing is edged with white. It breeds from the northeastern coast of Maine northward. Mr. Frazar found it common everywhere in Labrador, more so even than the Murre, Uria troile, owing to its habit of breeding in less irrequented places-concealing its eggs in the cracks and crevices among the rocks, where it was not apt to be disturbed. It frequents the rock shores, and deposits its eggs in June and July, often in deep fissures of the rocks and in caverns. It very frequently lays its eggs at the entrance of inhabited puffin's burrows. Generally one egg is laid, but in about twenty instances Mr. Frazar found two. These are white with a creamy or bluish tint, spotted and blotched with dark brown or black, the spots often becoming confluent and generally forming a circle toward the large end; pyriform to oval in shape; size about $3.00 \times 2.00$. The eggs exhibit a great variety in the distribution and style of markings. In shape they are not distinguishable from some types of the common Guillemot, but are generally more or less ovate or elongated pearshape. The Razor-billed Auk breeds sparingly on the outlying rocky islands of Nova Scotia, as on Devil's Limb and Gannet rock. The bird is about eighteen* inches long. In life it is said to have a particularly trim and elegant form, and its feathers are always kept perfectly clean, smooth and glossy. This Auk is said to be of quarrelsome disposition, seldom allowing a puffin or murre to alight near it without opening its bill at the intruder and disclosing a bright orange mouth. The Razor-bill rides lightly on the water and dives well.

33. GREAT AUK. Plautus impennis (Linn.) Geog. Dist.-Formerly the coasts and islands of the North Atlantic, from Massachusetts and Ireland northward nearly to the Arctic Circle. Now extinct.

Ornithologists generally agree that the Great Auk has disappeared from the face of the earth. Within the present generation it is one of the birds that has become extinct doubtless through the agency of man. Like the penguin, which it much resembles in general form, it did not possess wings suitable for flight, those members being of very small size and only useful as fins in the water. The specific name, inıpennis, or wingless, is not really a correct term. An excellent and thorough paper* on this bird has been written by Frederick A. Lucas, of the United States National Museum. I quote the article entire: "The Great Auk, or Garefowl (Alca impennis), was the largest member of the Auk family, distinguished not only by its size, but by its flightlessness, enjoying the proud distinction of being the sole bird in the northern hemisphere incapable of flight. The name by which the Great Auk was originally and commonly known in America was Penguin, and like southern birds, now known by that title, did not receive this appellation until many years after. Garefowl is of Scandinavian origin, and comes to us by way of western Scotland. In color we Great Auk much resembled its lesser relative, the Razorbill, the head, neck, and back being black, and the under parts white. A peculiar mark of the bird was a large white spot in front of the eye, one old writer with a greater love of the

* Animals recently extinct or threatened with extermination. as represented in the collections of the U. S. National Museum. Smlthsonfan Report, 1889, pp. 638-641. 
marvelous than of truthfulness stating that this spot was found on the right side only. The wings, although far too small to sustain the bird in the air, formed an admirable pair of oars, the Great Auk being a most expert swimmer and diver, and performing even longer migrations than many of its relatives that were endowed with the power of flight. (Plate CIII.) Many, possibly all, of the Auk family use their wings quite as much as their feet for propulsion under water, and they may literally be said to $L y$ beneath the sea as well as over it. It has been noted that the inability of the Great Auk to fly was due to lack of development of the bones of the foream and hand, the humerus being proportionately as long as in other Auks. This modification of structure was directly correlated with the aquatic habits of the Garefowl, for the resistance of water being vastly greater than that of air, a wing especially adapted for subaquatic flight would demand less surface and more power than a wing formed for aerial locomotion. In the case of the Great Auk this demand was met by shortening the outer portion of the wing, while other birds that use their wings in diving obtain as far as possible the same result by only partially opening their wings. The Great Áuk was confined to the North Atlantic, ranging on the European side from Iceland to the Bay of Biscay, and on the American from Greenland to Virginia, these localities marking the extreme limits of the bird's migrations. Greenland was the habitat of the Garefowl to a very limited extent, and the same may be said of the coast of Norway, while the southern limits given above were reached only during the winter migrations of the bird. The positively

- known breeding-places were few in number, those where the bird bred abindantly, being the Garefowl Series off the coast of Iceland and Funk Island on the Newfoundland coast. These islands, or more properly islets, were very similar in their general character, being isolated rocks, lying at some distance from shore and difficult of access. Of course the reason for this similarity is apparent. 'The Great Auk and its eqgs formed desirable articles of food, and since the bird was helpless on land, it was easily captured, whence it came to pass at an early date that the bird was exterminated at all localities easy of access. Another and more important factor in the extermination of the Auk, especially in America, is to be found in the gregarious habits of the bird and its predilection for certain breeding-places. This habit of the Garefowl is shown by other birds which are restricted in their breeding habitat without any apparent reason, although there may be some unknown cause in the nature of food supply that might account for it. A good example of this is found in the Gannet, which, although a bird of powerful flight, breeds at only three localities on the eastern coast of America, and in Europe crosses the North Sea to nest in Scotland, when localities seemingly quite as favorable exist along the shores of Norway. There were apparently plenty of suitable breeding-grounds for the Great Auk in Maine and Labrador, but had the bird bred in small colonies at localities scattered along this wide expanse of territory, it would have been in existence to-day. The most important European breeding place of the Garefowl was an islet 25 miles off Reykjanes, Iceland, where, for many years, it led a somewhat precarious existence, several times seeming to have been so reduced in numbers that expeditions in search of birds and eggs were not worth the risk. Still the bird would have existed in this locality many years longer than it did, but for volcanic disturbances in March, 1830, during which the Geirfuglasker sank beneath the sea compelling the existing Garefowl to seek new breeding places. Most of them appear to have moved to an islet by the name of Eldey, and this being near the coast and moro accessible, the few remaining Great Auks were in the course of fourteen years 
all killed, the last pair being taken about the $3 d$ of June, 1844, this being the last authentic record of the Great Auk in Turope. It was from this locality that most of the skins now extant were obtained, only one mounted specimen being recorded from American localities, although zearly all akeletons have come from Newfoundland. The history of the Great Auls in America may be said to date from 1534, when, on May 21, two boat's crews from Cartier's vessels landed on Funk Island, ard, as we are told, "In lesse than halfe an hour we filled two boats full of them, as if they had bene stones. So that besides them which we did eat fresh, every ship did powder and salt five or sixe barrels of them." The Great Auk having thus been apprised of the advent of civilization in the régular manner. continnor to be ritilized by all subsequent visitors. The French fishermen depended very largely on the Great Auks to supply them with provisions; passing ships touched at Funk Island for supplies; the early colonists barreled them up for winter use, and the great abundance of the birds was' set forth among the other inducements to encourage emigration to Newfoundland. Theimmense numbers of the Auks may be inferred from the fact that they withstood these drains for more than two centuries, although laying but a single egg, and consequently increasing but slowly under the most favorable circumstances. Finally some one conceived the idea of killing the Garefowl for its feathers, and this sealed its fate. When and where the scheme originated, and how long the slaughter lasted, we know not, for the matter is rather one of general report than of recorded fact, although in this instance circumstantial evidence bears witness to the truth of Cartwright's statement that it was customary for several crews of men to pass the summer on Funk Island solely to slay the Great Auks for their feathers. That the birds were slain by millions; that their bodies were left to molder. where they were killed; that stone pens were erected; and that for some purpose frequent and long continued fires were built on Funk Island, is indisputable. This locality has been but thrice visited by naturalists, the last time in the summer of 1887 , by a party from the U. S. National Museum, who, by the aid of the U. S. Fish Commission, were enabled to obtain much information in regard to this interesting spot, and to make very exten'sive collections of remains of the Great Auk. Just when the Great Auk ceased to exist in America is unknown, for there were few naturalists on this side of the water wher the Garefowl was being done to the death; but the extinction took place not far from' 1840, almost coincidently with the extermination of the bird in Europe. Few birds have received more attention than has the Great Auk since it became extinct, and it has been the subject of numerous papers, both popular and scientific, while its remains bring extravagant prices whenever chance brings them into the market. The last skeleton sold brought $\$ 600$, the last skin $\$ 650$, while an egg brought $\$ 1,250$, and then was resold for the round sum of $\$ 1,500$." The following is from the Naturalists' Journal, of London, for June, 1895, p. 129: "A specimen of this extinct bird was recently offered for sale at Steven's Great Sale Rooms, Convent Garden. The specimen belonged to Sir F. Milner, M. P., to whose father-Sir W. Milner-it was sold by Graham, of York, who stated it had been obtained in the Orkneys. For some years it has been in the Leeds Museum, but since its removal has been re-stuffed. The bidding went up to 350 guineas, and the bird was then bought in, but has since been sold to the Edinburgh Museum for $£ 350$. Of the 24 skins of the Great Auk now in Britain, 11 are safely lodged in public museums. An egg of this bird was offered for sale at the same time, and knocked down for 180 guineas to an hotel keeper." The egg is like that of the Razor-billed Auk, but of course much larger, measuring $4.69 \times 2.92$ inches. 


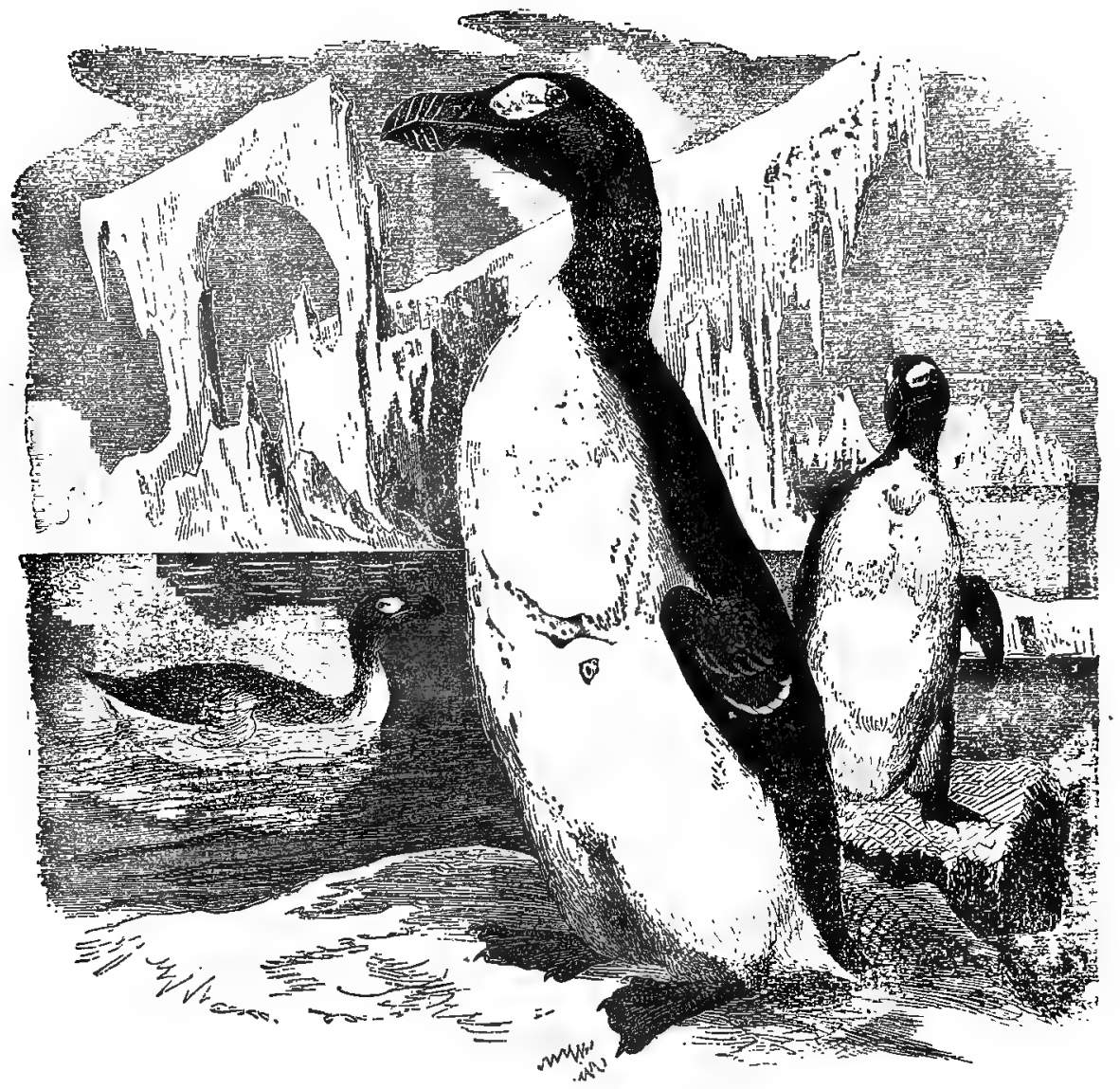

33. Great Auk (From Brehm.

34. DOVEKIE. Alle alle (Linn.) Geog. Dist.-Coasts and islands of the North Atlantic and Eastern Aretic Occan; in North America, south in winter to New Jersey; breeds in high northern latitudes.

The little Ice-bird of the fishermen and the Sea Dove of ornithologists. Its entire lifc is spent on the open sea, rarely visiting land except during the breeding season $\mathrm{o}:$ when driven thence by severe storms. It breeds in the Arctic regions of America anc Europe, the islands of the Arctic Ocean, and in the northwestern portion of Asia. $=: 2$ head and bill of this bird are formed almost exactly like that of a quail. It is rery abundant at its breeding grounds in the far north, and is one of the most boreal o: birds; nesting chiefly on islands, or always in places near the sea, depositing its single pale, greenish-blue egg in the crevices of rocky cliffs. The eggs measure from 1.80 to 1.90 in length by 1.25 to 1.30 in breadth.

35. SKUA. Megalestris skua (Brunn.) Geog. Dist.-Coasts and islands of the North Atlantic. South to Spain and Massachusetts. Rare on the coast of North America. 
The Skua Gull may well be called the feathered pirate of the seas. It does not congregate in flocks; two or more pairs are seldom seen together. It is noted for its courage and daring, attacking and harassing gulls, forcing them to disgorge the fish which they have swallowed. In the Island of Unst, and also Foula, the most northern ones of the Shetland group, it is found breeding. The bird was given a place in the fauna of North America on the ground of its occasional occurrence along the southern coast of Greenland, where its eggs are said to have been taken. In Iceland this species builds its nest on the hillsides in the latter part of June. The nest is simply a shallow cavity in the long grass, lined with grass stems and moss. The eggs are two in number, with an olive-green or drab ground-color, marked by irregular dark olive-brown and chocolate-colored blotches; they measure from 2.75 to 3.00 in length, by 1.50 to 2.00 in breadth.

36. POMARINE JAEGER. Stercorarius pomarinus (Temm.) Geog. Dist.Seas and inland waters of northern portions of Northern Hemisphere, south to Africa and Australia, and probably South America, Not known to occur in winter on the Atlantic coast of North America north of Long Island.

Another of the faicon-like sea fowls, commonly called Gull.Hunter by the fishermen. Resident throughout the summer in high northern regions, chiefly within the Arctic Circle. Mr. Nelson states that they are abundant off the Yukon mouth in spring, but at all seasons they are rare near Saint Michael's. During the cruise of the Corwin he found them abundant about Saint Lawrence Island and everywhere in Bering Strait. In winter it is a great wanderer, and is known to occur on the Great Lakes, and as far as the above habitat indicates. The bird is said to live chiefly by plundering the Kittiwake Gull; but will attack other species, even the largest.

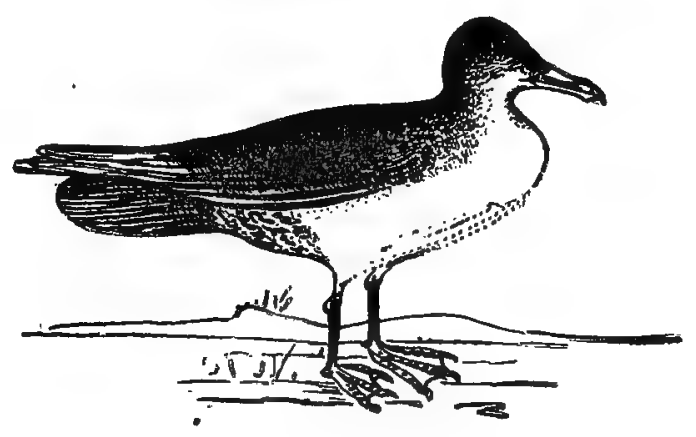

36. Pomakine Jaeger

Nelson says the birds are clumsy and cowardly as compared with their smaller relatives. When one of this species chances to cross the path of the smaller species, the latter almost invariably gives chase and beats its clumsy antagonist off the field by repeatedly darting down from above. Comparatively little is known of its nesting habits. It breeds in remote places, and is said to form a rude nest of grass and moss, situated on dry elevated spots in marshes. The eggs of all the Skuas are very similar in appearance-pale olive-green or yellowish-gray in ground color-irregularly blotched and spotted with two shades of brown; those of the present species are said to be thinner in form and more pointed than those of the others. Dr. Brewer describes an egg procured in Greeniand as rounded-ovoid; its ground-color, deep olive-drab, sparingly spotted with slate-color and two shades of umber, chiefly at the larger end, where they become confluent. There are also a very few scattered dots of black. Size, 2.25 by 1.70 .

37. PARASTTIC JAEGER. Stercorarius parasiticus (Linn.) Geog. Dist.Nortiern part of Northern Hemisphere, southward in winter to South Africa and 
South America. Breeds in high northern districts, and winters from the Middle States and California southward to Brazil and Chili.

The Parasitic Jaeger, like the others of this family, is eminently rapacious, and it is known as the "Man-of-War," from its habits of pursuing and robbing the terns and smaller gulls. It breeds in the interior of Arctic America, and is especially abundant in the Anderson River region. Mr. Nelson records the following: "This tyrannical bird occurs about the entire coast line of Bering Sea, but is most numerous along the low, marshy coast of Norton Sound, and thence south to the Kuskoquin River. Its breeding range covers the entire region from the Aleutian Islands north to the extreme northern part of the mainland. Upon the Aleutian Islands Dall found them in summer and winter. They were taken during the breeding season on Kyska and Amchitka, near the western end of the chain. They have been taken at Kadiak. and are plentiful from the Yukon mouth up to Nulato and probably above. Elliott found them, occurring as stray visitors on the Fur Seal group, and the writer noted them in Bering Strait vicinity during the summer of 1881." A common bird in the more northern portion of Asia and Europe. So far as known, its general habits do not differ from those of the Pomarine. It is given as the most common of the Skuas off the coast of Norway, but does not go far inland to breed. The nest of this species is made on islands or on the margins of lakes; it is a mere depression in the ground, lined with a few grasses and withered leaves. In Greenland it is said to be a resident species, and it breeds in Iceland on the moors far inland. In the Shetland Islands this bird breeds in communities, fifty or more pairs congregating at the same place. The eggs are usually two in number, sometimes three, and are as variable in ground color and markings as those of the Eskimo Curlew. They vary from olive drab to green, gray and brown, marked with several shades of chocolate, brown and an obscure stone gray, distributed over the entire egg. Size from 2.00 to $2.40 \mathrm{long}$, and from 1.50 to 1.70 broad. Nelson says that the eggs are laid upon the mossy knolls or uplands in their haunts about the 5th of June. The nest is merely a depression in the moss containing two eggs, indistinguishable from those of the next species, and measuring from $2.40 \times 1.70$ to $2.00 \times 1.50$.

38. LONG-TAIIED JAEGER. Stercorarius longicaudus Vieill. Geog. Dist.-Northern part of Northern Hemisphere, south in winter to the Gulf of Mexico.

The same plundering habits mark the character of this' bird as are peculiar to any of the Jaegers or Skuas. It is distributed in the breeding season throughout all parts of the region near the Arctic Circle, in Siberia, Northern Asia, Europe and America, and on the islands of the Arctic Ocean. It breeds in Greenland and Iceland, is abundant throughout the barren grounds of the Arctic coast, and is said to be very numerous in the vicinity of Fort Anderson, also on the shores of FrankIin Bay. It is also found breeding on several of the Orkney and Shetland Islands. According to Nelson this graceful and handsome bird is the most common of the Jaegers on the Alaskan coast and vicinity, and especially about Saint Michael's. They arrive there about May 12 or 15, but are not numerous until ten days or more later. He states that all the Jaegers are very destructive to the eggs of other birds, and in spring nests of various water fowl are often destroyed by them. Nests found in the Arctic regions are mere depressions in the soil, scantily lined with dry grass and leaves. Some are placed far inland near small lakes, and often there is really no nest, the eggs being laid on the bare ground. The eggs are said to be not always distinguishable from those of the Parasitic Jaeger, but average smaller; exceptionally large specimens of $S$. longicaudus are sometimes as large as exceptionally small 


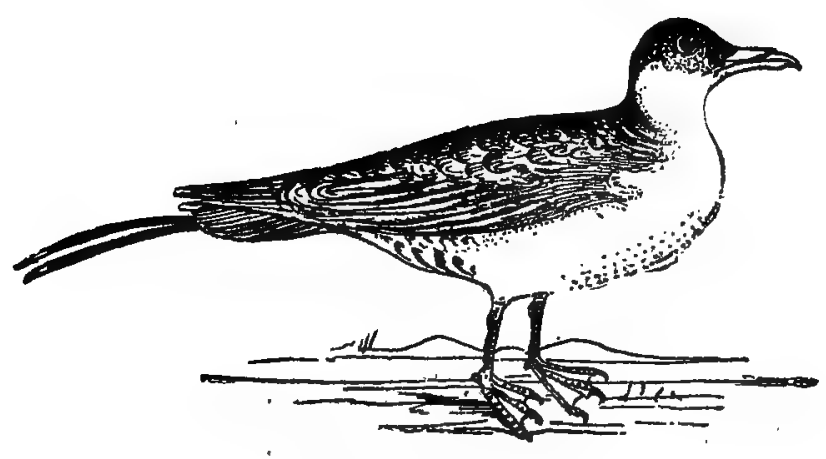

38. Long-Tailed JaEger.

ones of $S$. parasiticus. They range from 1.95 to 2.18 long, and from 1.45 to 1.55 broad. Mr. Nelson describes a nest of this species which was in a cup-shaped depression in a mossy knoll where lay two dark greenish eggs with an abundance of spots.

39. IVORY GULL. Gavia alba (Gunn.) Geog. Dist.-Arctic Seas, south in winter on the Atlantic coast of North America to Labrador and New Foundland, casually to New Brunswick, and on the Pacific side to Bering Sea.

A bird that is resident in the Arctic regions of both hemispheres, only occasionally visiting the more temperate zones. It is said to breed the farthest north of all the gulls. Specimens of this species were seen on several occasions by the naturalist of the Jeannette, Mr. R. L. Newcomb, during his long imprisonment in the icy sea to the west of our northern coast. It was noted as a rare visitor-at Point Barrow by Murdoch, and also by various expeditions among the network of channels north of Lritish America. Noted for its ravenous appetite, gorging itself with the flesh of the seal and the blubber of the whale. They have the habit of watching about sealholes in the ice, waiting for the seal, whose excrement the gull devours. On the islands and along the coasts of Spitzbergen it breeds sparingly; in like places on the coast of Northern. Siberia it is abundant. The bird is a resident of Greenland, and the breeding scason there begins about the middle of June. The nest is built on some inaccessible rock or cliff; it is made of dry grass and lined with moss and a few feathers, forming quite a hollow. An egg is described as oblong-oval in shape, with a ground color of light yellowish-olive with small blotches of dark brown scattered over the surface. These are intermingled with more obscure brown and cloudings of lilac. Size 2.45 long by 1.70 broad.

40. KITTIWAKE. Rissa tridactyla (Linn.) Geog. Dist.-Arctic region, south in Eastern North America in winter to the Great Lakes and Middle States.

The Kittiwake Gull is a northern species, found in the Atlantic waters of Europe and America. On the Pacific coast it is represented by the next form, pollicaris. It is one of the commonest resident species of Greenland, and according to observers it inhabits nearly all parts of the Arctic regions. Breeds on the islands of the Atlantic coast of North America, from New England northward; an abundant species, nesting not always on the ground like most gulls, but on rocky cliffs overhanging water. On Gannet Rocks of the St. Lawrence this noisy Gull is especially numerous, where its nests are found on narrow ledges; they are composed of grass 
and seaweed. Some of the nests are quite flat, while others are several inches in thiclines and, deep'y hollowed, new material being added each year, and they are somctimcs so numcrous that the breeding rlaces become very filthy and emit an intolerablo cdor. The cggs are two and sometimes three in number, and have a grcund-color of yellowish buff, brownish-gray or pale greenish-gray, marked with irregular spots of varying shades of brown and lilac. The average size is $2.26 \times 1.61$.

40 . PACIFIC KITTIWAKE. Rissa tridactyla polliraris Ridgw. Geog. Dist.-Coasts of North Pacific and Bering Sea.

This form of the Kittiwake is abundant on the islands of the North Pacific. It is abundant along the entire coast line of Alaska and on all the numerous islands. The bird is resident upon the Aleutian Islands and breeds in great abundance upon ,all the islands of Bering Sea, the Straits, and along the Arctic coast to Cape Lisburne. Dr. Leonhard Stejneger records it as a common breeding bird, both on the islands and along the Kamtschatkan coast, and in all places suitable for rookeries they are found in astonishing numbers. For the purpose of nesting they select the shelves and projections of cliffs, the tops of walls that rise perpendicularly out of the deep sea, and especially on the high pinnacles standing lonely amidst the foaming breakers. The nest is composed of matted fragments of moss and grass, and frequently the eggs are deposited in mere hollows in the loose dirt. The nesting is precisely the same as that of $R$. tridactyla, and the eggs are indistinguishable, except that in a large series they are said to be more uniform in their markings.

41. RED-LEGGED KITTIWAKE. Rissa brevirostris (Bruch) Geog. Dist.Coasts and islands of Bering Sea.

The living bird of this species has coral-red legs and feet, which contrast richly with the snowy white plumage of the head, neck and under parts. An abundant. species on the islands of Bering Sea. On the Prybilof group it swarms by tens of thousands to breed in the first part of May. It is especially abundant on St. George's and St. Paul's Islands. The nesis, like those of the Pacific Kittiwake, are placed on almost inaccessible shelves and projections, so that seldom is a nest reached unless a person is lowered down to it on a rope passed over the cliff. Dry grass and moss cemented with mud are the materials which constitute the nests. The Red-legged Kittiwake is common on the islands along the Kamtschatkan coast, notably on Copper Island, where it breeds in company with pollicaris. The eggs have a ground-color of brownish white, varying to light drab and buff, marked with blotches, sepia-brown and umber; these are underlain by subdued shades and cloudings of lilac-gray. The average size of the egg is $2.28 \times 1.66$.

42. GLAUCUS GULL. Larns glaucus Brunn. Geog. Dist.-Arctic regions, south in North America to the Great Lakes and Long Island. North Pacific.

One of the largest of the Gulls, equal, in fact, to the Creat Black-backed Gull, L. marinus. It is a bird of high northern range during the breeding season-inhabiting the Arctic regions of Europe and. Asia and the more northern portions of North America. In Spitzbergen it is said to breed in immense numbers, placing the nests on the shores or low rocks and even on masses of ice. They are large structures, made of sea weed and moss. The Burgomaster Gull, as it is called, feeds on crabs and fishes; it attacks smaller birds and also robs them of their eggs and young. It attends fishing boats for the purpose of devouring the offal which may be thrown overboard. The bird is recorded as a constant resident of Greenland. In Hudson Bay region it builds its nests on the islands in lakes and rivers, and the young are hatched 
in June. The nests are built of sea ferns and dry grass, placed among the grassy tussccks in the center of the island. The eggs are two, sometimes three in number; their general shape is spherically oval, and the ground color dark grayish-brown, pale ash, pale clay or a pearly white. The markings are small patches of light brown and brownish black. The sizes range from 2.95 to 3.15 long by 2.18 to 2.25 broad.

42. 1. POIITT BARROW GULL. Larus barrovianus Ridgw. Geog. Dist.Bering Sea and adjacent waters, northeastward to Point Barrow, southwest in winter to Japan.

This new species of Gull, whose plumage is described as resembling that of the Glaucous and Iceland Gulls, and whose size is intermediate between these two species, is found on the islands of Bering Sea, and its range extends as indicated in the geographical distribution. It has proved to be distinct from the Atlantic coast species. Specimens that served for description were from the Island of St. Michaels and Point Barrow.* Nelson says: "The solitary islands of Bering Sea and all its dreary coast line are familiar to this great gull." On June 4 their first nest was found. It was placed on a small islet, a fer feet across, in the center of a broad, shallow pond. The structure was formed of a mass of moss and grass piled up a foot or more high, with a base three feet across, and with a deep central depression lined with dry grass. There was a single egg. The female as she sat on the nest was visible a mile away and not the slightest opportunity was afforded for concealment on the broad surrounding flat. An equally conspicuous structure was found near St. Michaels on June 15. The majority of the nests found were situated on a small islet in a pond. The nest found on June 15 was a bulky structure made up of tufts of moss and grass rooted up by the birds' beaks. The ground near the nest looked" as though it had been rooted up by pigs. Mr. Ridgway gives the measurement of the eggs as $3.05 \times 2.03$. One of the eggs taken by Mr. Nelson was white, without a trace of the usual color marks.

43. ICELAND GULL. Larus leucopterus (Faber.) Geog. Dist.-Arctic Regions, south in winter in North America to Massachusetts, and farther.

This Gull is precisely like the last, but smaller, and it is difficult to distinguish the two at a distance. Another common name for it is White-winged Gull. It is an Arctic species, and its distribution during the breeding season is nearly identical with that of the Burgomaster, being found in the northern parts of Europe, Asia and North America. Mr. Hagerup states that on Arsuk fjord in South Greenland about a thousand pairs nest on what is known as "bird cliff," above the Kittiwake Gulls. The lowest nests are built at a height of about two hundred feet; the highest about five hundred feet above the sea level. The two species are often found nesting in the same places, and the nests are of the same construction. The eggs, however, are smaller, measuring $2.79 \times 1.85$. The Iceland Gull is, according to Mr. Nelson, the most abundant species along the coasts and about the islands of Bering Sea, thence along the adjoining Arctic coasts. It was found abundant on the Yukon, from Anvik to the sea by Mr. Dall, who secured its eggs there from the 5th to 10th of June. The eggs were laid in small depressions in the sandy beaches of the islands in the river.

44. GLAUCOUS-WINGED GULL. Larus glaucescens Naum. Geog. Dist.Pacific coast of North America, from Alaska south to California on the Asiatic side south to Japan.

- For detalls see Auk, III, p. 330, or Ridgway's Manual N. Ar.. Birds, p. 26. 
Almost as large a species as the Glaucous Gull or Burgomaster. It breeds on the islands of the Pacific coast from Washington Territory northward. The nests are not always built on the shelving rocks of high cliffs. On the Aleutian Islands they are found among the tall grass on the highest parts of the islands, while others are built on projections of rocks. Sometimes there is little or no attempt at nestmaking, the eggs being laid in a slight depression of the. ground. On Bering Sea and Copper Islands, on the Kamtschatkan coast, this species breeds all around the shores. Eggs have been found as early as the middle of May. These are said to be of a more greenish tinge and the spots more numerous and better defined than in those of glaucus. Size $2.88 \times 2.03$. According to $\mathrm{Mr}$. Dall this is a very abundant species throughout the Aleutian chain, but more numerous in the eastern half of the group. Young birds nearly fledged were secured at Kyska in July. He states that the habit of this and other species breeding on isolated rocks and small islands, is accounted for by the immunity thus gained from the ravages of foxes on the eggs and young. Rarely more than three eggs were found together, and were laid on alrost any little depression of the ground, with little or no attempt at a lining.

45 KUMLIEN'S GULL. Larus limmlieni Brewst. Geog. Dist.-North Atlantic coast of North America; south in winter to the coast of the Middle States.

This new species of Gull, first described by Mr. William Brewster,* is like glancescens, but somewhat smaller. It is recorded as being quite common in the upper Cumberland water, where it breeds, placing the nests on shelving rocks of high cliffs. The eggs are said to be the same as those of glaucescens.

46. NELSON'S GULL. Larus nelsoni Hensh. Geog. Dist.-Coast of Norton Sound, Alaska.

In a series of gulls collected by Mr. E. W. Nelson in Alaska Mr. H. W. Henshaw found a specimen which differed decidedly, not only from any other taken by Mr. Nelson, but from any in the National Museum. In recognition of Nelson's valuable services to Alaskan ornithology the bird has been dedicated to his honor by the authority above stated. Ir. Henshaw states that its resemblance to several of the larger gulls is likely to keep us in ignorance until it is made an object of special attention by naturalists visiting Aláska. There is no reason to believe that its general habits and eggs differ from those of the Glaucous-winged Gull.

47. GREAT BLACK-BACKED GULL. Larus marinus (Linn.) Geog. Dist.'Coasts of the North Atlantic; south in winter to Long Island and Italy.

The large and powerfuI Black-backed Gull, or Saddle-back, inhabits the Atlantic waters of Europe and North America. Breeds in great numbers on the coast of Norway as far as North Cape. In various parts of the British Islands it is found throughout the year, especially on the islands around the coasts of Scotland, where it breeds in abundance. On the American coast it breeds from the Bay of Fundy northward to Greenland. Years ago it was known to breed quite commonly on the islands off the coast of Nova Scotia. In Labrador it is common everywhere. Mr. M. Abbott Frazar found it breedins on the small islands, placing its nests generally on some elevated spot. He seldom found more than a half dozen pairs breeding on a single island. The nests were built of dry grasses, were very bulky and deeply hollowed. He found no nest containing more than three eggs. During the breeding season the birds feed largely upon the eggs of other birds, especially upon those of

* Bull. Nutt. Club, Vol. VIII, p. 216. 
the Murre and upon young Eidēr ducks,* 'The eggs of this Gull vary from a bluishwhite or olive-gray to a deep yellowish brown, and are irregularly spotted and blotched with reddish-brown and lilac of different shades. The sizes vary from $2.70+33.02$ long by 2.05 to 2.25 broad.

48. SLATY-BACKED GULL. Larus schistisagus (Stejn.) Geog. Dist.-North Pacific, chiefiy on the Asiatic side; Herald Island, Arctic Ocean, and Alaskan coast of Bering Sea.

Dr. Stejneger says: "Among the specimens of gull collected by me on the Jommander Islands is a very dark-mantled large species, somewhat intermediate between $I$. marinus and $L$. cachinnans, although in general aspect much nearer to the former, and when on the wing indistinguishable from it. The occurence of this new species in the Kamtschatkan waters easily explains the abnormality in the alleged distribution of Larus marinus, as it is almost certain that all North Pacific references to the latter species really belong to the present form." $\uparrow$

49. WESTERN GULL. Larus occidentalis Aud. Geog. Dist.-Pacific coast of North America, breeds from Southern California northward.

The most abundant species of gull on the California coast, breeding on all suitable islands. It is the only gull which breeds on the Farallons. Mr. Emerson states that on these islands the nest is built either on high ridges or low places near the shore. The material used is a dry, rank weed; with this they construct their rather bulky nest and repair or rebuild it each year. Mr. Barlow remarks that this gull nests chiefly in colonies on the Farallons, on level portions, although a few pairs may be found almost anywhere. The nests are loose affairs of Farallon weed and measure a foot across. Usually they are very shallow and are given shape by the hollows in which they are constructed.* Of their general habits Mr. Bryant says: "The gulls are indiscriminate feeders; in addition to their usual articles of diet, they subsist largely upon eggs during the ummer. They do not eat the eggs of their own species, nor do thəy trouble the cormorants after the murres have commenced laying. Sea urchins, crabs, young murres and rabbits, and fish stolen from the cormorants' nests are eaten. Not being quick enough to swoop upon the rabbits, they catch them by patient watching at their burrows, and will persevere for fifteen minutes to swallow a squealing young rabbit, and finally fly away with the hind feet protruding. The dead bodies of murres are also eaten; they detach pieces of flesh by backing away and dragging the body, meanwhile shaking their head, till a piece breaks off." The eggs are deposited as early as the first part of May on the Farallons, and laying is sometimes continued into $J$ uly. The usual complement is three; but from constant robberies by the eggers, who collect eggs for the San. Francisco market, often only two are laid. The same variation of ground-color and markings are to be found in these eggs as is common to all those of the gulls; light grayish olive, clay color, bluish-white and deep yellowish-brown, spotted and blotched with umber-brown, blackish and lilac of varying shades. The average size of fifty specimens is, $2.76 \times 1.94$; the largest $2.99 \times 2.01$; the smallest $2.56 \times 1.89$.

50. SIBERIAN GULL. Larus affinis Reinh. Geog. Dist.-Greenland; Asia: Europe, southward in winter to North Africa.

* Ornithologist and Oologist, Vol. XII., p. 17.

t The Auk.; T., 231.

+ Tho Mucoirm T $n$ 2a 
The Siberian Gull is a rare or occasional visitor in Greenland, whereupon it claims a place in the fauna of Nortn America. It breeds in the extreme north of Europe, notably on the shores and in the lagoons of the Petchora River in the northern part of European Russia. The eggs are said not to differ from those of the Herring Gull.

51. HERRING GUIL. Larus argentatus (Brunn.) Geog. Dist.-Old World, south to the Azores; Cumberland Sound; occasional on the eastern coast of the United States.

The European Herring Gull is known as an occasional visitor to the coast of Eastern North America. On the Azores, a cluster of nine islands in the Atlantic, eight hundred miles due west of Portugal, this Gull is very common, breeding on

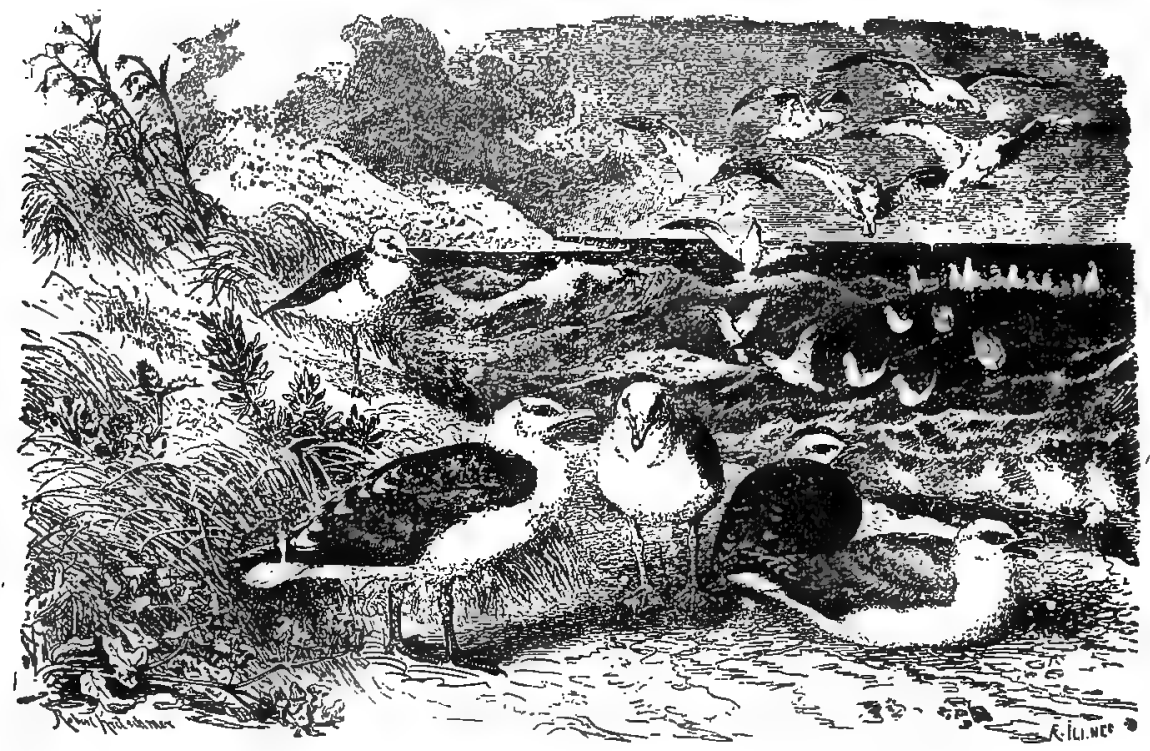

51. Hzaring Guzls (From Brehm).

some of the islands in immense numbers. In Great Britain it is a familiar bira everywhere. Mr. H. K. Swann, in The Birds of London, states that it is of not uncommon occurrence in winter on the eastern side, and frequently straying up the Thames. It breeds in the islands on the coast of Scotland, especially the Hebrides, Shetland, Orkney and the Faroe Islands; thence northward to Iceland. One of the most common gulls along the coast of Norway, as far as North Cape, where they breed by thousands. Its nesting habits and its eggs are the same as those of the American bird, smithsonianus. Eggs 2.91×1.98.

51a. AMERICAN EERRING GULL. Larus argentatus smithsonianus Coues Geog. Dist.-North America generally. Breeds on the Atlantic coast from Maine northward.

"The Blrds of London, by H. K. Swann. London: Swan, Bonnenscheln \& Co., Pater noster Square, 1893, pp. 118-119. 
In North America this gull is a common bird throughout its range, particularly coast-wise. It is also more or less abundant on the inland lakes and rivers during its periods of migration, and in many of these places it is found breeding. At Moosehead Lake, Me., where a few pairs breed, the eggs are laid in the latter part of May, or in the first week of June. In the interior it is found breeding on the lakes and larger bodies of water, as far north as the Mackenzie and Anderson River regions. On many of the large prairle lakes of Manitoba it breeds in great numbers. Mr. Frazar mentions this species as the most common of all the gulls inhabiting Labrador, breeding in colonies and placing their nests on the ground.* $\mathrm{Mr}$ WaIter Raine found this gull breeding abundantly at Shoal Lake, Manitoba, June 18, 1895. In many places where the Herring Gull has suffered persecution, it has been known to depart from its usual habit of nesting on the open seashore, and place its nest on trees sixty and seventy-five feet from the ground. At Grand Manan and in Labrador, in some of the old breeding grounds, its human foes have brought about this change in its habits. Some of the nests built on the ground are merely a shallow depression with a slight lining. Others are large and elaborately made of grass and moss. Those built in trees are said to be strongly interwoven and very compact. Mr. Dall records this gull as abundant on the Upper Yukon, Alaska. It was found breeding on the islands in the river, laying its eggs in small depressions on the bare ground. The complement of eggs is normally three; they vary from bluish-white to deep yellowish-brown, irregularly spotted and blotched with brown of different shades; in a large series a great diversity of ground-color and markings exists. Mr. Elwin A. Capen in his superb work $\dagger$ figures three prevailing types of coloration. The gizes range from 2.73 to 2.91 long by 1.64 to 1.94 broad.

52. VEGA GULL. Larus vegae (Palmen.) Geog. Dist.-Bering Sea and adjacent waters, south in winter to California and Japan.

This form of the Herring Gull is "characterized by a particularly dark gull-gray mantle and flesh-colored legs" and is found in the countries bordering Bering Sea and adjacent waters. It is said to breed on the islands of the Upper Yukon River, in the first part of May, depositing its eggs in slight depressions of the bare ground. The eggs are not likely to be distinguishable from those of the Herring Gull, $L$. argentatus.

53. CALIFORNIA GULL. Larus californicus Lawr. Geog. Dist.-Western North America.

The California Gull is found along the Pacific coast in winter, but retires to its breeding places in the summer months. Its breeding grounds seem to be inland, on the lakes and large bodies of water. It breeds abundantly on Great Salt Lake and Pyramid Lake, Utah, and on Lake Malheur, in Eastern Oregon. It has been found nesting as far north as Great Slave Lake, Fort Resolution, Fort Simpson and the Lower Anderson River. The nests of this species are made on the ground, or built on rocks and, sometimes where the birds are breeding in vast colonies, the nests are placed on stunted sage or greasewood bushes. They are built of sticks, grass and a few feathers. The eggs are usually three or four in number, occasionally five. Prof. Marcus E. Jones informs me that at Great Salt Lake this gull generally lays five eggs. These are deposited in a little bare spot surrounded by a few twigs, the hollow

- Ornithologist and Oologist, Vol. XII, p. 18.

† Oology of New England: a description of the eggs, nests and breeding habits of the birds known to breed in New England, with colored lllustrations of their eggs. By Elwin A. Capen. Boston, 1886. 
Just deep enough to keep the eggs from rolling out. The nests are made on the sand or any other bare spot on islands far out in the lake. The eggs are laid about the middle of May. They vary from a bluish-white to a deep brownish-clay color, spotted and blotched with dark brown, slate and blackish zigzag markings. Sizes range from 2.50 to $2.70 \mathrm{long}$ by 1.65 to 1.95 broad.

54. RING-BILLED GULL. Larus delawarensis Ord. Geog. Dist.-North America at large; south in winter to Cuba and Mexico.

This Gull inhabits the entire Continent of North America, and is on the whole, the commonest species poth coastwise and in the interior. It breeds in the United States and far north, placing its nests on the ground or on cliffs. Mr. Walter Raine found this gull breeding abundantly on the islands of Shoal Lake, Manitoba, in the latter part of June. Mr. Stebbins found this species and the Common Tern occupying an island of about an acre in extent in Devil's Lake, North Dakota, in the first week of June. The entire island was covered with eggs of the gulls and terns. Mr. Stebbins says: "I don't suppose you could lay down a two-foot rule anywhere-without each end of it striking a nest. It was common to find the terns and gulls breeding side by side. Most of the gulls' nests were in the grass, while those of the terns were in the sand. I did not find a gull's nest with more than three eggs, and a very few with two; whereas, several hollows were found with as many as eighteen terns' eggs in them, which had rolled together." Mr. Frazar observed a few colonies of this species breeding in Labrador, nesting like other gulls, and the nests never contained more than three eggs. These have the usual variations in color to be found in eggs of the terns-bluish-white to dark brown, spotted and blotched with brown and lilac of various shades. Sizes from 2.75 to 2.80 long by 1.60 to 1.75 broad.

55. SHORT-BILLED GULL. Larus brachyrhynchus Rich. Geog. DistArctic America and Pacific coast to Southern California.

In the breeding season the Short-billed Gull occurs in the northern regions of North America. It has been found nesting on the ground in the small lakes in the vicinity of Fort Anderson, and in the Mackenzie River Valley. Breeds in great abundance at the mouth of the Yukon, where Mr. Dall obtained large numbers of its eggs. It has also been observed nesting along the streams in the Barren Grounds of the Arctic regions. Its nest is made of hay or wiry grass, and is sometimes placed on stumps and in trees. The eggs are usually three in number; greenish or olive brown, with various markings, but chiefly small spots of reddish-umber. Sizes vary from 2.00 to 2.35 long by 1.45 to 1.70 broad.

56. MEW GULL. Larus canus Linn. Geog. Dist.-Europe and Asia; accidental in Labrador.

This is the Sea-mew or Sea-mall of Europe. In Great Britain it breeds more or less abundantly along the entire coast, and is especially common on some of the smaller islands in the Hebrides; on the north coast of Scotland it is found on the Orkney and Shetland Islands. It breeds on inland lakes as well as on the sea-coast, building its nest on the grassy summits of precipitous rocks near the sea or on moorland locks far inland, and even on high mountain ranges. It is abundant on the coast and on the fresh-water lakes of Norway. A common species and breeds in nearly all parts of Central and Northern Russia. Abundant on the Prussian coast and on the northern coast of France. The nests are made of grass and vegetable substances. The usual number of eggs is three; yellowish-brown, olive-brown, and wiitish to greenish-gray, irregularly marked with dark brown and purplish gray. The size varies from 2.08 to 2.25 long by 1.40 to 1.58 broad. 
57. HEERMAN'S GULL. Larus heermanni Cass.

Geog. Dist.-Pacific coast of North America, from British Columbia to Panama.

This is said to be one of the handsomest birds of the family to which it belongs, and is commonly called the White-headed Gull. It is a common species along the California coast and is most abundant in winter. At the Farallon Islands it is occasionally seen, but does not breed there. It probably breeds on the Santa Cruz and Santa Rosa Islands, as it does on others farther south. The general habits of this species are the same as those of other gulls. One particular trait, however, marks this species-that of following flocks of pelicans and robbing them of a portion of the fish which these birds carry in their pouches, seizing upon the fishes which fall out or hang outside. The food of this gull is almost exclusively fish, which it also procures by diving. It also feeds on small crustacea and mollusca. The eggs of this species are described as having a yellowish-drab ground-color, over which is scattered spots and markings of lilac and different shades of brown. The average size is 2.45 by 1.50 .

58. LAUGHING GULL. Larus atricalla Linn. Geog. Dist.-Eastern tropical and warm temperate America, chiefly along the sea coast, from Maine to Drazil; Pacific coast and Middle America.

The Laughing or Black-headed Gull is more of a southern species, particularly one of the Gulf and South Atlantic States, but is found breeding as far north as the coasts of New England. It is an abundant and a resident species on the coast of Florida, along the whole extent of the Gulf of Mexico; and also on the Pacific an Atlantic coasts of Central America. Mr. Maynard says: "The notes of gulls a. loud and startling, but those of the Laughing are the most singular of them all, for their cries, especially when the bird is excited, sound like loud peals of prolonged and derisive laughter."* Mr. Theodore W. Richards states that this gull is aburdant on all the marshes along the Virginia coast. For a nest they collect an immense amount of rubbish and build in the wettest portion of a marsh; many nests were found actually afloat. $\dagger$ Mr. R. C. Stuart, of Tampa, Fla., writes me that this species nests in large communities, on grassy islands along the Gulf coast in May and June, placing the nests in tussocks of grass; the cavity is nicely lined with fine, dry grasses. The eggs are from three to five in number. In color they vary from bluish-white to greenish-ash, spotted and blotehed with brown, umber and lilac of varying shades; the usual variations in size, ground color and markings are to be found in a large series of these eggs; sizes from 2.00 to 2.28 long by 1.50 to 1.65 broad.

59. FRANKIIN'S GULL. Larus franklinii Sw. \& Rich. Geog. Dist.-Interior of North America, breeding from the northern border of the United States northward; south in winter to Central and South America.

In North America this gull is confined to the interior, chiefly west of the Mississippi, breeding from the northern border of the United States northward. Mr. J. W. Preston found it nesting in the marshes of western Minnesota, about the middle of May $\ddagger$ I am informed by Mr. H. J. Wallace that it breeds abundantly in the marshes 'of the Red River Valley of Western Manitoba. He found this beautiful gull breeding in large communities, in marshes and wooded swamps, making its nest of wet grasse and sedges on the tops of broken down stalks. The eggs are described as closely resembling those of the Eskimo Curlew in size, shape and color, though the dark

* Birds of Eastern North America.

† The Oologist, IX, 79.

Ornithologist and Oologist, Vol. XI, pp. 54-55. 
- splashes are more evenly distributed over the surface. The ground-color varies from dirty white to olive-drab and light brown, with all the shades of the lighter tints of green and ashy. They are usually marked with numerous and bold splashes and zigzag lines of umber-brown and different depths of chocolate, particularly at the larger end. The eggs average about $2.12 \times 1.40$; they are three in number. Three eggs in my possession, collected at Heron Lake, Minnesota, on the 9th of May, measure as follows: $2.06 \times 1.41,1.98 \times 1.45,2.03 \times 1.47$. These are olive-drab with bold spots and blotches of light and dark brown; there are no zigzag lines.

60. BONAPARTE'S GULL. Larus philadelphia (Ord.) Geog. Dist.-E'ntire North America, breeding chiefly north of the United States; south in Finter to Mexico and Central America.

This handsome little'gull is a common species throughout North America, from the Atlantic to the Pacific coasts. It is especially abundant along the Atlantic coast 'during its period of migration. Breeds northward nearly to the Arctic Ocean. Its flight is described as being light, airy and very graceful, resembling that of the Terns. Its principal food is small fish. On many of the large lakes and marshes in the prairie regions of Manitoba it breeds in great numbers, from thence northward and throughout all parts of the Fur Countries it is found breeding in suitable places. In the marshes of the wooded regions bordering the Mackenzie River it breeds in the latter part of June. The usual number of eggs laid is three, rarely four. The nests are always placed in elevated situations, in bushes, trees, or on high stumps; the materials used are sticks and grasses, with a lining of vegetable substances. The eggs vary from greenish to brown, spotted and blotched with brown, umber and lilac of various shades; these markings are chiefly clustered around the larger end. Size, $1.95 \times 1.34$.

60. 1. IITTLE GULL. Larus minutus Pall. Geog. Dist.-Europe and parts of Asia and Africa: accidental in the Bermudas and on Long Island.

We can now positively include this bird in the North American avifauna. It has long been more or less doubtfully recognized by ornithologists as accidently American upon the strength of a specimen said to have been taken on the first Franklin expedition. Its place in our fauna has aiways been questionable. Mr. William Dutcher records the capture of an immature specimen of this gull which was shot at Fire Island, Suffolk county, New York (Long Island), about September 15, 1887. It was mounted by the late John Wallace, taxidermist, New York City, who presented it to the American Museum of Natural History, Central Park. Mr. H. K. Swann in his "Birds of London" mentions this gull as of rare occurrence in the vicinity of London, although it occurs from time to time, during the winter, on the east coast of England. It is stated by Prof. Nillson that this gull is known to breed in the marshes in the vicinity of the Baltic, placing the nests on the grassy knolls near the sea. Three eggs constitute the complement, and their color varies from yellowish-brown, olive-brown to greenish-gray marked with spots of dark brown and purplish-gray. Size $1.80 \times 1.32$.

61. RosS'S GULI. Rhodostethia rosea Maggil. Geog. Dist.-Arctic regions; Point Barrow, Alaska; Melville Peninsula; Englana, Faroes, Heligoland, etc.

This species was first discovered north of British America. A specimen was taken by Mr. Nelson near St. Michaels, Norton Sound, on October 10, 1879. Three specimens were brought home by the naturalist of the ill-fated Jeannette. During Perry's adventurous journey over the ice north of Spitzbergen, it was seen several 


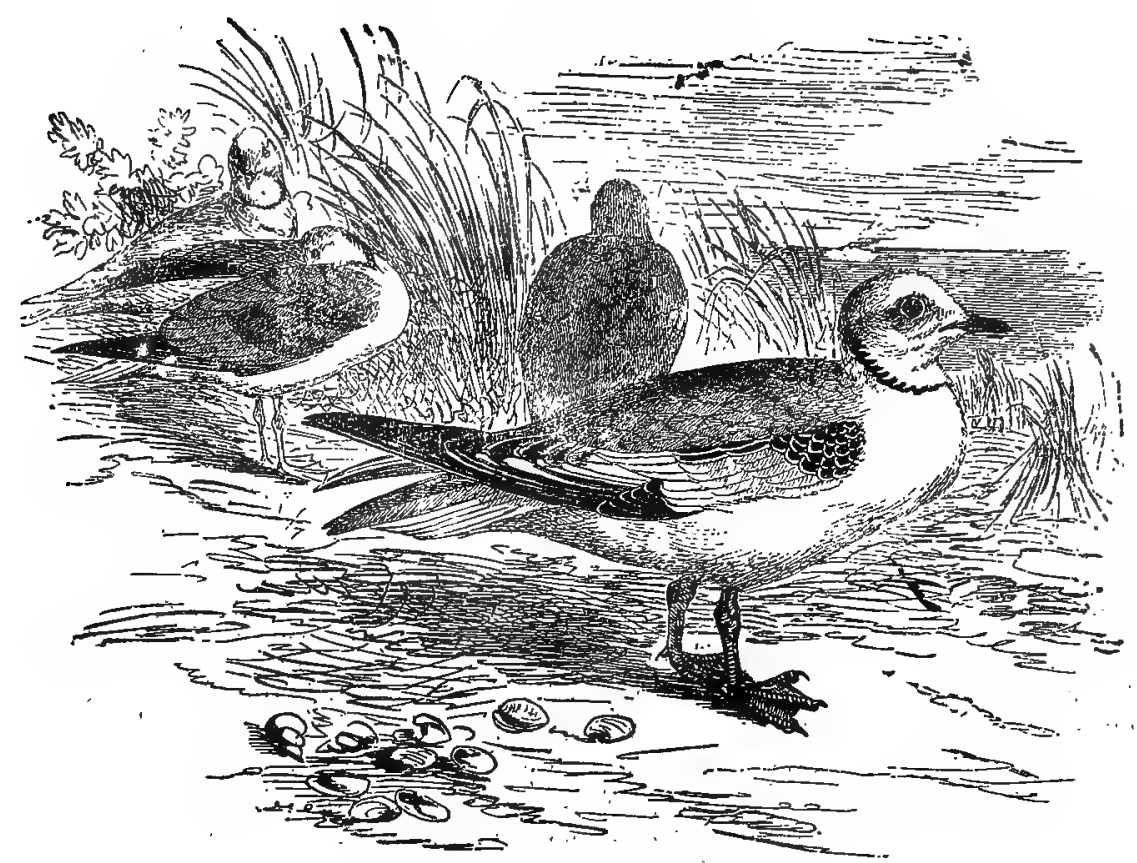

61. Ross's Guz? (From Brehm).

times. A large series of this rare and beautiful gull was obtained by Mr. John Murdoch at Point Barrow in the latter part of September and in October, 1881, and a larger series might have been secured had the weather and other conditions been favorable. In a letter published in the London Daily Chronicle last' November, Dr. Nansen, the most recent Arctic explorer, states that he found flocks of the Rosy or Ross's Wedged-tailed Gull on August 6 th in lattitude $81^{\circ} 38^{\prime}$ and longitude $63^{\circ}$ east. The birds were seen near four small islands called "Hirtenland" by Nansen, a little northeast of Franz Josef Land. He did not actually find the nests, but the birds were so abundant that he concluded that their nests were near by. There seems to be no reason to question the correctness of Nansen's determination or his surmise that the birds were breeding not far away, as the presence of the gulls in such numbers in that high latitude renders it very probable that they were breeding.*

62. SABINE'S GULL. Xema sabinii Sab. Geog. Dist.-Aretic regions; in North America south to New York, the Great Lakes and Great Salt Lake.

The Forked-tailed Gull breeds in the extreme northern portion of North America and Asia, especially on the islands of the Arctic Ocean, depositing its eggs in a depression of the sand, which is generally lined with bits of fine, dry grass; the nest is also often made in beds of moss, with similar lining. This gull is recorded as abundant in the marshes in the neighborhood of St. Michael's, Alaska, where it breeds. Its food consists of worms and insects, which it obtains in mud lakes. 'On the northwestern coast of Greenland, above Alison Bay, this species has been found

* From T. S. Palmer's article: 'Nansen's Discovery of the Breeding Grounds of the Rosy Gull." Science, January 29, 1897. 
breeding, but not in large colonies. The eggs are two to three in number. They are of a deep greenish-brown, obscurely spotted and blotched with darker shades of the same; they very closely resemble those of the Willet or Curlew. The average size is $1.75 \times 1.25$.

63. GULL-BILLED TERN. Gelochelidon nilotica Hasselq. Geog. Dist.Nearly cosmopolitan. In North America chiefly along the Atlantic and Gulf coasts of the Unitcd States.

In North America the Marsh Tern, as it is commonly called, breeds from New Jersey southward. On Cobb's Island, Va., it nests sparingly in the latter part of June. Dr. James C. Merrill and George B. Sennett found a colony of this species in company with Sterna forsteri, breeding on, a grassy island; among lagoons and marshes, near Fort Brown, Texas, May 16, 1877. 'The nests were slight depressions among the short grass, and the eggs were frequently' wet.* This Tern breeds abundantly on Pelican Island, in the Gulf of Mexico, in the latter part of May, laying its eggs on the bare sand. Farther south, on the islands along the coast of Mexico and in the Bahamas, it is known to nest in great numbers. The eggs are usually three in number, sometimes four. They vary from yellowish-buff to greenish, spotted and blotched with yellowish-brown and lilac, especially about the larger end, but, like the eggs of all terns, are extremely variable. The average size is $1.75 \times 1.30$. This is the only species of tern having the bill shaped in noticeable degree like that of a gull-hence its common name. Marsh Tern is another name by which it is known, but this is not regarded as exactly correct. According to the best authorities the Gull-billed Tern is a species of wide distribution and is characteristic of no particular region, breeding alike in the islands of the Indian Ocean and in those of the Gulf of MExico, the islands and the coasts of Jutland in Denmark and along the coast and the interior in the marshes ind lagoons of southern South America. A few specimens have been taken on the coasts of France and Germany, and it is recorded as being common in Hungary, Greece and Asia Minor, where it breeds. It is known to breed in various other portions of Southern Europe, and also in the northern parts of Africa. Its flight is spoken of as easy and graceful, partaking of the elegance which is characteristic of these birds when on the wing.

64. CASPIAN TERN. Sterna tschegrava Lepech. Geog. Dist.Nearly cosmopolitan; in North America breeding southward to Virginia, Lake Michigan, Texas, Nevada and California.

This is the largest of these elegant and graceful birds, the Terns; it measures from twenty to twenty-three inches in length. The bill of this bird in life is of dark vermilion-red, growing lighter towards the tip; the pileum and occipital crest is glossy, greenish-black, extending to the lower line of the eyes. The back and upper parts of wings are pearl-blue, the whole underparts are white. The legs and feet are black. The extent of wings in the adult bird is from fifty to fifty-five inches. It is nearly cosmopolitan in its distribution, being found in greater or less abundance in various portions of the globe. At a distance it is often mistaken for the Royal Tern, but may be distinguished from the latter by its more robust form and less deeply forked tail. The bird is also known as the Imperial Tern; irregularly distributed throughout North America, but chiefly in the Arctic regions, where it breeds, and along the entire Atlantic coast. Eggs and young have been taken on Cobb's Island, Va., in July. Dr. Merrill observed it breeding on Padre Island, near Fort Brown.

* Nates on the Ornithology of Southern Texas. 


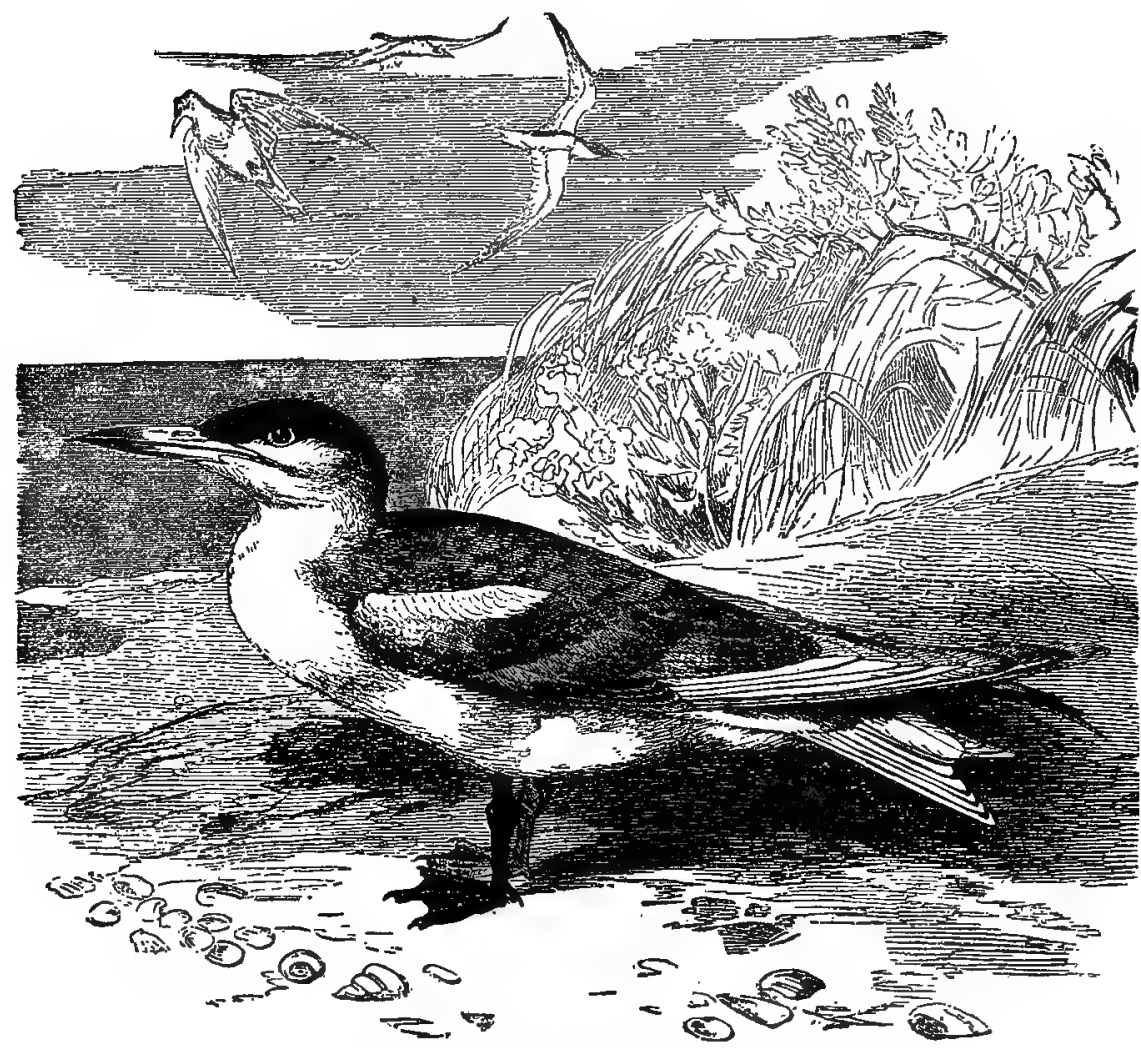

61. Caspian Tekn (From Brehm).

Texas, in May. The late Mr. B. F. Goss found it nesting on the islands of Lake Michigan. Large numbers of this species are said to breed on Pelican Island in the Gulf of Mexico. The nests are mere hollows scooped in the dry sand, in which the birds deposit two or three eggs. These vary from white to greenish-buff, spotted and blotched with brown and lilac of different shades; broader and more elliptical than those of the next species; size $2.66 \times 1.77$.

65. ROYAL TERN. Sterna maxima Bodd. Geog. Dist.-Tropical America and warmer parts of North America, northward to Massachusetts, the Great Lakes and California. West coast of Africa north to Tangiers.

This handsome tern, next in size to the Caspian, breeds in large colonies along the Atlantic coast, from New Jersey southward, depositing from one to three or four eggs on the bare sand. 'It breeds abundantly along the coasts and on the marshes of Florida. On some of the islands in the Gulf of Mexico it nests in immense numbers. Very abundant on many of the lagoons and marshes of Southern Texas. Prof. Robert Ridgway records the Royal Tern breeding on Cobb's Island, Va., in the first part of July. In an area of about an eighth of an acre the eggs were so numerous that it was almost impossible to walk through the nesting site without crushing a greater 
or less number; many of the eggs were covered by the drifting sand.* The eggs are described as being narrower, and especially more pointed and rougher. than those of the Caspian Tern. They are yellowish-drab, irregularly blotched with dark umber and lilac of various shades; sizes range from 2.67 to 2.75 long by 1.70 to 1.75 broad.

66. ELEGANT TERN. Sterna elegans Gamb. Geog. Dist.-Pacific coast of America from California to Chili.

Dr. Coues describes this tern as a "truly elegant species, resembling the Royal Tern, but easily distinguished." It is a Mexican and Central American species, rarely occurring on the California coast. An egg is described as having a groundcolor of pinkish-white, with bold and distinct markings of deep black and burnt sienna and subdued shell-markings of lavender-gray; size 2.20 by 1.45 .

67. CABOT'S TERN. S'terna sandvicensis acufavida (Cabot.) Geog. Dist.Tropical America northward along the Atlantic coast, irregularly; to Southern New England.

The beautiful Sandwich Tern has an extensive distribution. In North America it has bccn observed as far north as Southern New England, and is known by the name of Ducal Tern. Breeds in large colonies, like most of the terns, depositing the eggs in the dry sand. It nests on the small sandy islands off the coast of Cape Sable in the lätter part of June. Breeds commonly on the coasts of Central America, and on some of the larger West India islands. The eggs vary from white to buff; irregularly spotted and blotch $2 d$ with brown, umber, bluish and reddish; rather pointed; two or three in number; size about 2.10 by 1.40 :

68. TRUDEAU'S TERN. Sterna trudeau Aud. Geog. Dist.-Southern South America; casual or accidental on the Atlantic coast of the United States (New Jersey, Long Isländ).

This bird; has'been accidentally found in New Jersey and Long Island. It breeds in southern South America, but I believe its eggs have not yet been described.

69. FORSTER'S TERN. Sterna forsteri Nutt. Geog. Dist.-North America generally, breeding from Manitoba southward to Virginia, Illinois, Texas and California; in winter southward to Brazil.

Like all the terns, this one is noted for its graceful flight and, with them, it shares the name of Sea Swallow-a name which velongs more particularly to the next species. Forster's Tern was once thought to breed only in the interior of North America. The above habitat, however, indicates clearly the range throughout which this species is found breeding in all suitable places. It nests on the grassy islands among the lagoons and marshes of Southern Texas, thence northward irregularly to British America. In Manitoba, on the islands and marshes of the lakes and rivers, it nests abundantly. Here on the islands of Shoal Lake Mr. Arnold and Mr. Raine found them breeding by thousands. Breeds in colonies, often in company with the .Common "and Gull-billed Terns, the Laughing and Bonaparte's Gulls." When its nesting places are disturbed it is said to be very noisy, uttering a grating, monotonous note, and at the same time attacking the intruder on al! sides, often darting close to his head. In some localities this species constructs its nest in a turf of dry grass, upon the sand, or among stones. It breeds chiefly in grassy marshes, building its nest of flags, water-plants, lining them with finer reeds. The eggs are two or three in number, with an average size of $1.85 \times 1.35$. In color they vary from nearly

"Buil. Nutt. Club, Vol. V, pp. 221-223. In article on the eggs of "Sterna caspla." 
pure white and pale green to warm brownish-drab, irregularly spotted and blotched with brown, umber and lilac.

70. COMMON TERN. Sterna hirundo Linn. Geog. Dist.-Greater part of the Northern Hemisphere and Africa. In North America chiefly confined to the Eastern Province, breeding variously throughout its range.

Sea Swallow, Wilson's Tern, Red-shank. "Mackerel Gull" and "Summer Gull" are the names by which this beautiful species is known in various localities. It is an abundant bird throughout its North American range, breeding on many of the inland lakes and marshes as well as along the coasts. In various places on the Atlantic coast it breeds in company with other apecies, such as Forster's, Arctic, and Roseate Terns, the Laughing Gull and others. Mr. W. W. Worthington, of Shelter Island, New York, writes me the following: "Although a few Wilson"s Terns breed on nearly every sandy point near here, Gull Island, situated a mile or so east of Plum Island, is their chief breeding ground in this section. Here they breed by thousands, fairly filling the air when you land and disturb them. Their nests are always placed on the ground or rocks, and are usually composed of a few pieces of grass and seaweed. They place their nests all over the island above high water line, on the beach, on the sides of the bluffs, all around, $a=1$ in the garden cultivated by the light-iouse keeper. Fresh eggs can be obtained there from the 10th of June to the middle of. July, as egging parties keep them cleaned off about as fast as they are laid. I collected a set of four eggs of this species on Gull Island last spring (1881), which is the only set I ever saw containing more than three eggs, which is the usual number laid." Mr. Worthington and Mr. M. C. Howe found two sets each containing five eggs on Gull Island in the season of 1894. This is an unusual number to a set. The eggs vary from greenish to deep brown, spotted and blotched with brown, blackish and lilac; they vary in length from 1.49 to 1.75 by 1.18 to 1.30 broad.

71. ARCTIC TERN. Sterna paradisaea Brunn. Geog. Dist.-Northern Hemisphere; in North America breeding from Massachusetts to the Arctic regions and wintering southward to Virginia and California.

Throughout all Northern Alaska, both on the coast and in the interior, the Arctic Tern is an abundant summer resident, breeding wherever found. In its general appearance and habits, its mode of nesting, flight, and other characteristics, this species closely resembles the Common Tern. Its distribution is, however, more northern, breeding in the most northern latitude, where $S$. hirundo is found only in limited numbers. The eggs of both are indistinguishable.

72. ROSEATE TERN. Sterna dougalli Montag. Geog. Dist.-Temperate and tropical regions; north on the Atlantic coast of North America to Massachusetts, and casually to Maine.

On the Atlantic coast of North America this beautiful species is found breeding from Maine southward to Florida. It is known also by the name of Paradise Tern. On some of the islands of the New England coast this species breeds in abundance, notably on Muskegat, Nantucket, Martha's Vineyard and Elizabeth Islands. In many places it breeds in colonies with the Common and Arctic Tern's and the Laughing Gull. On a small island, called Goose Island, about three-quarters of an acre in extent, situated in Long Island Sound; and a short distance from Faulkner's Island, Mr. M. B. Griffing found this species nesting in abundance. The high land is from two to six feet above the beach, and is covered with a thick growth of weeds 
and grass; in this some of the nests were concealed; others were in plain sight; they were so numerous as to fairly cover the ground. They were nothing more than slight hollows lined with dry grass, and contained usually two eggs. Mr. Griffing says he is satisfied that this is the usual number laid by this species, as there were but two sets containing three eggs in the hundreds of nests observed; incubation had begun in nearly every set, and many were almost hatched. Some of the eggs were laid on the shore just above high water mark. Mr. Griffing says that the eggs differ from those of the Common Tern, being less pointed at the small end; the markings are usually much finer and more numerous. By placing a tray of the eggs of each species side by side the difference is very marked. They vary in size from 1.55 to 1.75 in length by 1.10 to 1.25 in breadth. Mr. Griffing states the birds are very noisy when their nests are being disturbed; hovering overhead they utter a harsh gutteral cry, peculiar to the species. They also have a note which sounds like the syllable tip, tip, tip.

73. ALEUTIAN TERN. Sterna aleutica Baird. Geog. Dist.-Coast of Africa, from the Island of Kadiak to Norton Sound.

This tern has been found nesting in various parts of Alaska; on the Island of Kadiak, and on some of the Eastern Aleutian Islands. On several islands in the vicinity of St. Michael's, Alaska, this tern, according to Nelson, breeds, laying its eggs directly upon the moss, with no attempt at nest lining, which would be entirely unnecessary there. Its habits do not differ essentially from those of other terns. The eggs measure from 1.65 to 1.85 long by 1.10 to 1.15 broad. They have a ground color, varying from brownish-white to greenish-olive, with bold markings of light reddish and chestnut brown.

74. LEAST TERN. Sterna antillarum (Less.) Geog. Dist.-Nortlern South America, north to California and New England, and casually to Labrador, breeding nearly throughout its range.

This pretty little Sea Swallow breeds on the Island of Cuba, and other islands uf the West Indies, along the coasts of Central America and Mexico. Mr. Stuart says it breeds abundantly on the white sand beaches of the Gulf coast, and on the jalands of the Atlantic coast of Florida. Mr. Theodore W. Richards in the seasons of 1888-'90 found this tern comparatively rare on the Virginia coast. A few pairs were observed breeding on the shelly beaches where once they swarmed by hundreds.* The eggs are laid on the bare sand in May and June. The "Little Striker," as it is called, is found nesting on the Atlantic coast as far north as Massachusetts; a few, zowever, breed a little farther north. The eggs are difficult to observe on the breeding grounds, their color being very similar to the sand and broken shells in which they are laid. They are two or three, and seldom four in number. They vary from pale greenish to drab or buff, spotted and blotched pretty evenly with brown, umber and lilac of various shades, with an occasional tinge of yellowish; in some the markings tend to form a wreath about the larger half. The average size is 1.25x.95.

75. SOOTY TERN. Sterna fuliginosa Gmel. Geog. Dist.-Tropical and subtropical coasts of the Globe. In America from Chili to Western Mexico and the Carolinas; casually to New England.

The Sooty Tern is found both in temperate and tropical regions almost everywhere throughout the world. It breeds abundantly on the rocky islets off the coast

- The Oologist, IX, p. 79. 
of the Island of St. Helena, and on Ascension Island, which is farther north and west; in favorite srots at the latter place it is said to breed in countless numbers. The eggs are regarded. by some as a great delicacy, and are so numerous that they are an important article of commerce. This species is said to be semi-nocturnal in its habits, being able to fly by night as well as by day, going out to sea to feed long before daylight. It is "the egg bird" of Jamaica. Breeds on the islands in the Gulf of Mexico, about the middle of May, and on the small islands south of Key West, Fla., early in May. In some places the eggs are deposited on the bare ground or on rocks; in others a nest is made in the long grass under bushes. This species lays but a single egg. Audubon states that the Sooty Tern always lays three eggs, but more recent observers say that in thousands of nests examined there were only two instances of two eggs being found together. It is a handsome egg, pinkish or creamy white, spotted and blotched with a rich reddish-brown, tinged with lilac. Sizes vary from 1.95 to 2.12 long by 1.45 to 1.50 broad.

76. BRIDLED TERN. Sterna ancethetus Scop. Geog. Dist.-Tropical regions; casual in Florida.

The Bridled Tern is especially abundant in the West India Islands, where it is the "egg-bird" par excellence, and is often confounded with the Sooty Tern. The bird occurs casually in Florida, but does not breed there. It is noted for its social peculiarities, always nesting in company with the Roseate, Sooty and Noddy Terns. The single egg of this species is deposited on ledges of rocks or in the cavities among loose boulders along the sea shore. The egg has a ground-color of a rich cream, with large blotches and smaller spots of reddish-brown, with confluent shell-markings of dull lilac. The blotches are usually confluent at the large end, while others are scattered over the entire surface. Five selected specimens in Mr. Crandall's collection offer the following measurements: $1.83 \times 1.30,1.84 \times 1.26,1.85 \times 1.27,1.86 \times 1.29$, $1.87 \times 1.31$, the average being about $1.84 \times 1.31$.

77. BLACK TERN. Hydrochelidon nigra surinamensis (Gmel.) Geog. Dist.Temperate and tropical America, from Alaska and fur countries into South America; preeding from the Middle United States northward.

The Black or Short-tailed Tern is distributed throughout North America at large, both along the coast and in the interior; breeding anywhere in colonies, in marshes and reedy sloughs, where it deposits the eggs on dead reeds, which are often floating. It is known to breed abundantly in various marshes of Michigan, Wisconsin, Minnesota, Dakota, Oregon and California. It has exceedingly long wings, and in its pursuit of insects in the air its flight and evolutions resemble those of a swallow. .Mr. Frank W. Langdon observed this species to be a very common summer resident of a marsh in Northern

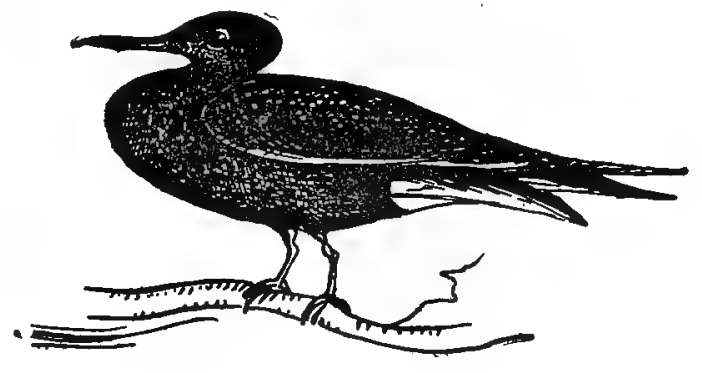

77. BLACK TERN. 
Ohio." He found it "nesting, or rather laying its eggs, on the little islands of decaying vegetation and mud formed by sunken muskrat houses. Three eggs constitute a full set, and they are apparently rolled about in the mud purposely until well coated, so as to hide the markings, and thereby make them less conspicuous." Mr. Langdon says that in two or three instances an attempt at nest building was noticeable, consisting merely of a few fragments of grasses, so disposed as to prevent the eggs from rolling. Two broods are reared in a season, as eggs were taken in May, and Mr. Langdon collected fresh eggs in July. They vary from brown to greenish; thickly spotted and blotched with brown and lilac of various sizes, but mostly bold, large and of light and blackish brown, thickest around the larger end. They resemble some of the sandpipers' eggs in size, shape and color. Average size 1.35x.98.

78. WHITE-WINGED BLACK TERN. Hydrochelidon leucoptera (Meisn \& Schinz.) Geog. Dist.-Eastern Hemisphere; accidental in North America.

A single example of this European species was taken on Lake Koshkonong, Wisconsin, in the first week of July, 1873. The ovaries of this specimen contained small eggs. It occurs occasionally in Great Britain, and is accidental in Sweden. On the lakes, rivers and marshes of the countries of the Alps it is said to be very common, and also in the bays, and inlets of the Mediterranean Sea. Its nesting and general habits are said to be like those of $H$. nigra surinamensis. The eggs, however, as a general rulc, have a lighter. ground color, and average slightly larger than those of the American bird.

79. NODDY. Anos stolidus (Linn.) Geog. Dist.-Tropical and sub-tropical regions; in America, from Brazil and.Chili north to the Gulf and South Atlantic States.

Dr. Brewer says: "The common Noddy Tern appears to be an inter-tropical species, and to be found round the entire surface of the globe, both north and south of the equator, at a distance from it of rarely exceeding thirty degrees north or south." On the Island of St. Helena it is a common species, and it also breeds on Ascension Island. It breeds in profusion on several of the West Indies. On the Bahamas the nests are built of sticks, leaves and grass, and they are placed in the branches of trees. In some of the islands of the tropics this species places its nest on the top branches of cocoanut trees and the outer branches of mangroves. It lays but a single egg; this will vary from ashy-yellow to buff or cream color. The spots are small and scattered, dark chestnut, with subdued shell-markings of lavender gray; average size $2.00 \times 1.35$.

80. BLACK SKIMMER. Rynchops nigra Linn. Geog. Dist.-Warmer parts of America, north on the Atlantic coast to New Jersey, and casually to the Bay of Fundy.

In summer the Black Skimmer is abundantly distributed from New Jersey gouthward, and is strictly maritime. It may be known by its singularly shaped bill,

* Summer Birds of a Northern Ohlo Marsh. 
the under mandible of which is much longer than the upper, and compressed like a knife blade, the end being obtuse. The bird seems to feed as it skims low over the water, the under mandible grazing the surface. Like the terns, the Skimmers breed in communities.' On the coast of Virginia Mr. T. W. Richards found them breeding in immense colonies in the month of June. The eggs were deposited in hollows of the sand bars and, when the

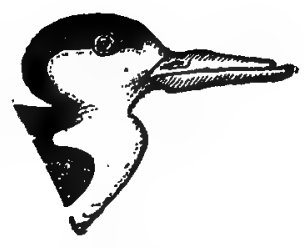

80. Brack Sximmer. birds are not molested, four eggs are laid, at least as often as three. This species is known by several names, such as "Razor-bill," "Cut-water," "Shear-water," "Sea Crow" and "Sea Dog;" the latter name it receives from its cries, which resemble somewhat the barking of a dog. It breeds on Cobb's Island, Va., in the last of June. Mr. I. C. Stuart“informs me that this species nests along the Gulf coast of Florida i: Viny and June, depositing in hollows of the sand from three to five eggs. He says I10 . ㄱ. J., Tritca zno that he has taken cggs as early as May 26, on the Nèw Jersey coast. His czperienco is that four eggs are oftener laid than three, which is generally stated to be tho usual number. The cggs arc among the most beautiful of all eggs; they are white and palc buff, rather coarsely spotted and blotched with brown, blackishumber and lilac of varying shades, with neutral tint shell blotches; sizes range from 1.65 to 1.98 in Iength by 1.31 to 1.40 in breadth.

* * WA.NDERING ALBATROSS. Diomedea exulans Linn. Gèog. Dist.Southern seas, north very irregularly to Florida (Tampa Bay ?) and coast of Washington. (?)

The Wandering Albatross is now assigned to the Hypothetical List of the A. 0 . U. Check List. It is said to have occurred in Tampa Bay, Florida, and also off the coast of the State of Washington. Both of these records are unsatisfactory. This albatross wanders over the vast waters of southern seas ranging as far north on the Atlantic coast of Africa as the Canary Islands, on that of South America to Trinidad Island and beyond. The bird has been taken in Europe and was admitted to the North American fauna on the grounds of its occurrence as above stated. It has been found breeding on various islands of the South Atlantic and Indian Oceans, on Prince Edward's, Crozete, and Kerguelen Islands lying southeast of Africa, and on the Island of Tristan d'Acunda to the southwest. At the latter place it breeds in January, nesting on the highest ledges of the cliffs. Dr. J. H. Kidder met with a number of these birds nesting on Kerguelen Island on the 2d of January. The nests were upon tall mounds, built up of grass to the height of two or more feet from the ground, and, being of different heights, seemed to have been used again and added to year after year. Dr. Kidder counted twenty-three birds in sight at one time, each perched upon its nest. Driven from the nests and compelled to walk, the birds looked not unlike overgrown geese.* Three eggs of this species are in the collection of Mr. C. W. Crandall, of Woodside, N. Y. They were taken January 22, 1886, on South Georgia Island, east of Cape Horn. The birds were captured. The nests were built up from the ground of mud and coarse tussock grass. In shape the eggs are almost equal-ended and measure respectively as follows: $5.43 \times 3.08,5.36 \times 3.21,4.94 \times 3.21$. On the first the coloration is dull white for the surface, beautifully ringed about the

* Bulletin No. 2, United States National Museum, p. 20. 


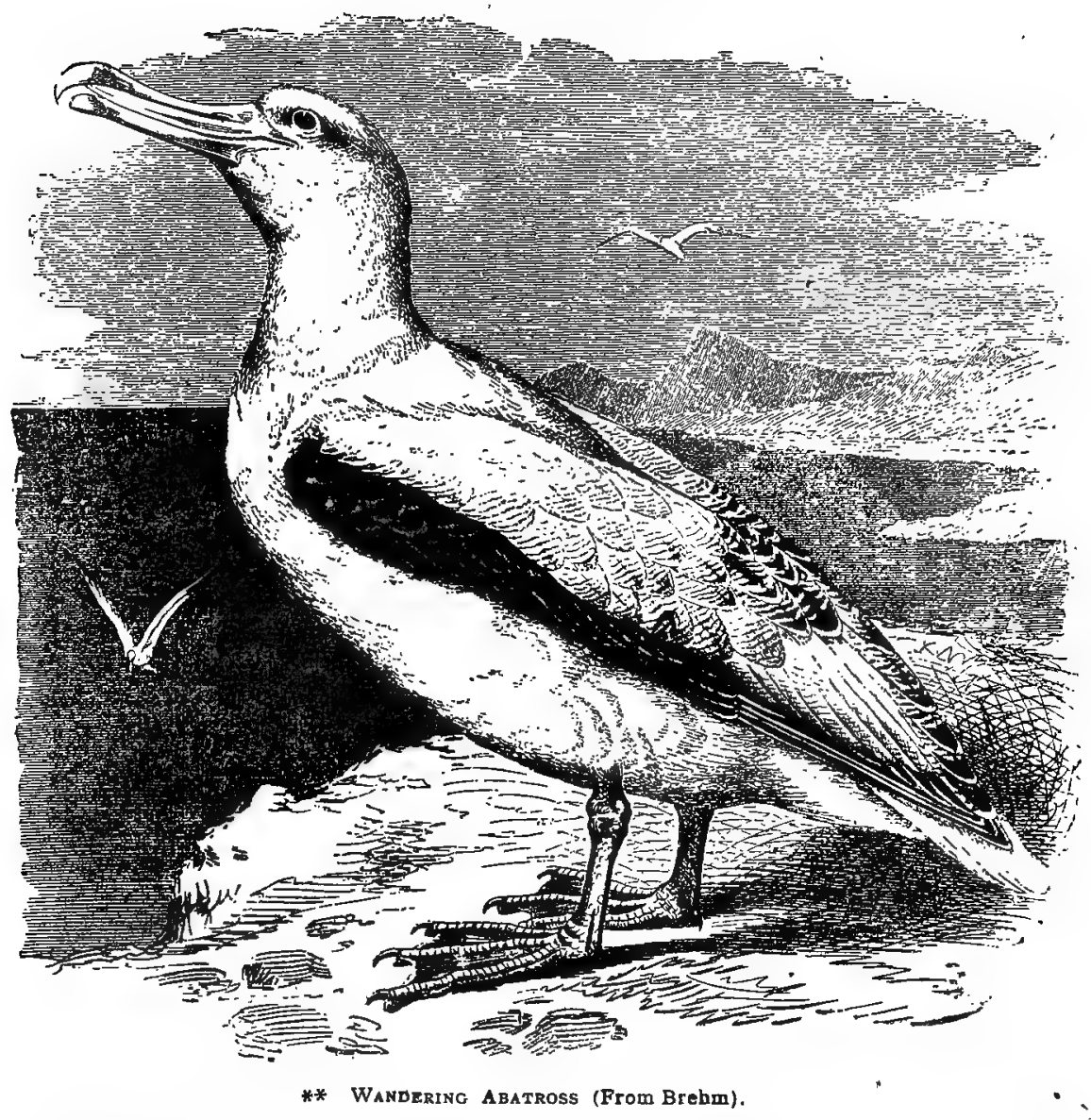

larger end with reddish specks and spots, the spots running together. The second has the lairge end sprinkled with minute specks of dull reddish and the small end is also similarly marked. In the last specimen above measured the large end is sprinkled with small specks of chestnut brown. An average size of ten specimens is as follows: Largest, $5.43 \times 3.08$; smallest, $4.87 \times 3.00$; the broadest specimen being 3.14 .

81. BLACK-FOOTED ALBATROSS. Diomedea nigripes Aud. Geog. Dist.North Pacific, including west coast of North America.

The Black-footed Albatross is an abundant bird of the North Pacific Ocean. Like others of this family, it is noted for its protracted powers of flight, following vessels for hundreds of miles and subsisting on the refuse thrown overboard, which, with crabs, etc., is its main food. Very little is known concerning the nesting habits of this species. It is said to breed on the small guano islands southwest of the Sandwich group in the North Pacific, depositing a singlc white egg in a depression of the soil, surrounded with a little sea-weed. Mr. Dall learned from Capt. George 
Holder, who was in search of new guano islands, that these birds nest during the winter months on the coral island of Gaspar Rico near the equator.

82. SHORT-TAILED ALBATROSS. Diomedea albatrus Pall. Geog. Dist.Pacific Ocean, including western coast of Africa, northward to Bering Sea.

This Albatross inhabits the Pacific Ocean at large. It breeds on the lonely islands west of the Sandwich group. It is also supposed to breed on some of the islands off the coast of China and Japan and on some of the Aleutian Islands. This species requires many years before it attains perfect plumage, but the young are aaid to be easily distinguished from nigripes. It is a constant attendant of whaling vessels, feeding on the scraps of blubber or refuse thrown from the ships. It is easily eaught with hook and line, and when taken on board is said to be unable to rise from the deck, as it requires a long range of surface on which to flap its wings. The single egg which this species deposits is white, equal-ended, and measures $4.20 \times 2.60$. It is laid on the bare ground.

83. YELLOW-NOSED ALBATROSS. Thalassogeron culminatus (Gould.) Geog. Dist.--Indian and South Pacific Oceans; casual off the coast of Oregon.

Supposed to be a rare visitant on the Pacific coast north of the equator. A dead specimen answering the description of this species was washed up on the beach near the Golden Gate, and an example is said to have been taken as far north as the mouth of the Columbia River, Oregon. It breeds on the islands of the Southern Indian and South Pacific Oceans. A single egg is laid. A specimen of the egg of this species, which was collected by Captain Thomas B. Lynch, at Diego Ramirey Islands, near Cape Horn, February 8, 1886, measures 4.30x2.72, and is dull white, faintly speckled with lavender and purplish. The specks form an indistinct wreath at the larger end; in the same manner that the eggs of Leach's Petrel are often marked. In fact, Mr. Norris says that this specimen looks like an egg of the latter seen through a powerful magnifying glass. Incubation in this case was slightly advanced. The nest consisted of mud scraped together in a heap on the ground. Mr. Emerson has an egg of this albatross which measures $4.68 \times 2.68$; it was taken by Captain Lynch at Diegos Kavnen's rocks, S. by E. fifty-two miles from Cape Horn, Janüary 12, 1880. The egg was fresh. The nest was composed of grass and mud on the outside, and lined with fine grass and feathers. The diameter outside at the top 12 inches, and at the base 18 . Iniside it was 10 inches broad by 5 deep. It was built on the top of rocks on a loamy plain. The data accompanying Mr. Emerson's specimen states that the nests are placed close together, and they are very nicely and solidly built, laisting two or three seasons even in that hot climate.* Ridgway gives the size of the egg as 4.18x2.63. Mr. Crandall has an egg collected by Capt. Lynch which measures 4.11x 2.73. This was on the same island as recorded above -52 miles from Cape Horn.

84. SOOTY ALBATRoss. Phobetria fuliginosa (Gm.) Geog. Dist.-Oceans of the Southern Hemisphere, northward to the coast of Oregon.

A great ocean wanderer, more common in the South than in the North Pacific regions. A rare visitor to the coasts of North America. This dusky species breeds on the islands off the coast of China and southward. It nests commonly on the Islands that lie southeast of Africa, namely: Prince Edwards, Crozete, Kerguelen Islands and others. Here they breed in October and November, placing the nest in the cavity of some high, perpendicular rock. The nest is a conical mound, 7 or 8 iuches high, hollowed at the top and rudely lined with grass. The single egg which this species

* Ornithologist and Oologist, Vol. XI, pp. 21-22. 


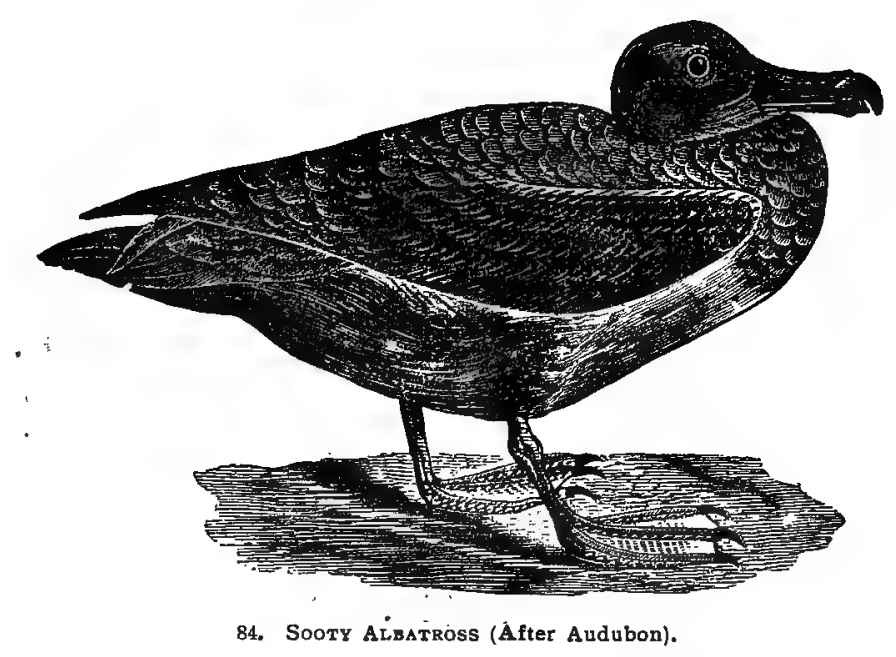

lays is described as white, very long in proportion to its thickness; sometimes it is marked with spots about the larger end; size 3.95x2.63. The cries of this Albatross are said to be very loud, and not unlike the calls of a cat. In November, 1885, Capt. Thomas B. Lynch collected eggs of this species at Diego, Ramirey Islands, fifty-two miles off Cape Horn. One of these eggs is in the collection of Mr. Crandall. The nest was built up from the ground about two feet and was constructed of mud. The egg is dull white in color, very long and narrow, the large end sprinkled with purplish red. Size, $4.53 \times 2.45$.

85. GIANT FULMAR. Ossifraga gigantea (Gm.) Geog. Dist.-Southern oceans; casual off the coast of Oregon.

The largest of the Petrels, known as "Mother Cary's Goose," "Giant Petrel" and "Bone-breaker." In size it equal's many of the Albatrosses, measuring about three feet in length, with a spread of wings seven feet. The Albatrosses and Petrels are noted birds, of gull-like form, variegated with black and white or uniformly sooty color. They are birds of the ocean, rarely landing except to breed. Among the seamen and whalers this large species is known as "Molly-hawk," "Gong," "Glutton Bird," "Nelly." It breeds on the islands of the South Seas-Bouvets, Prince Edwards, Crozete and Kerguelen Islands are some of its breeding places. Said to breed late in December, making the nest on elevated ground some distance from the sea. The Giant Fulmar Petrel also nests on the Falkland Islands, which lie east of the entrance of the Strait of Magellar in Southern South America. Dr. J. H. Kidder found this species in considerable numbers in the vicinity of Kerguelen Island, feeding on the carcass of the sea elephant. Its voracity and filthy habits reminded him strongly of the vultures. Like vultures, the birds so crammed themselves that they were unable to rise from the ground.* The egg is described as dirty white in color, rough to the touch, and its shape like that of a common goose; size 4.25 2.66 .

86. FULMAR. Fulmarus glacialis (Linn.) Geog. Dist.-North Atlantic, south on the American coast to Massachusetts.

* Bulletin of the National Museum No. 2; p. 24. 


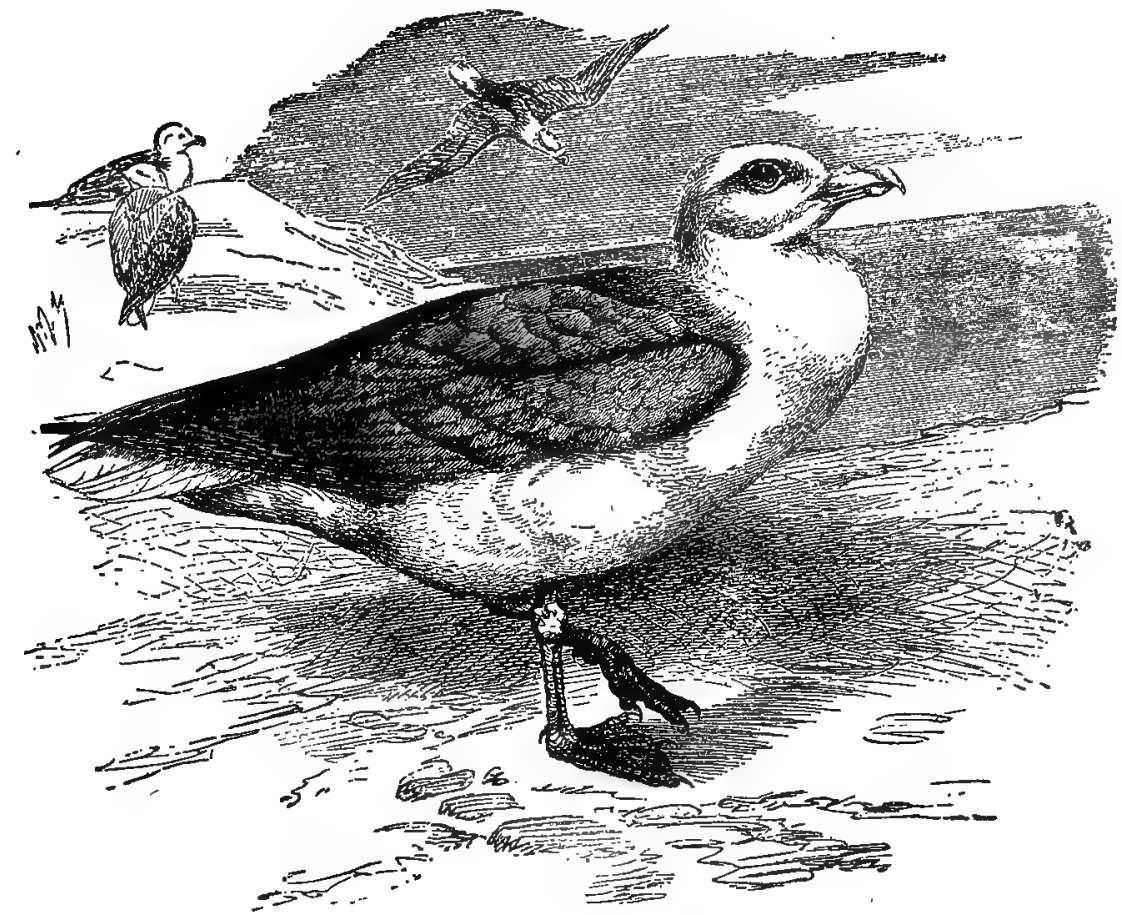

86. Fulmar (From Brehm).

This species is commonly called Fulmar Petrel. It is found in light and dark phases of dress. Abundant in the North Atlantic and in the Arctic Oceans of America, Europe and Asia. The Fulmars constantly attend whaling ships out at sea and feed on the blubber of the whale, which they devour with voracity. This species 'is exceedingly numerous in the North Atlantic, congregating in thousands at St. Kilda, the most western of the Hebrides, on the west coast of Scotland. Others of its favorite breeding places are the Faroes, which are farther north; Iceland, Spitzbergen and Greenland. On some of the rocky islands off the coast of Spitzbergen Lhousands of Fulmars breed in company with Brunnich's Guillemot, Black Guillemot, and the Kittiwake Gull. The abundance of the Fulmar at some of its breeding places in Greenland is something astonishing, nesting as they do in myriads on the inaczessible cliffs in mountainous places, depositing the single white egg in the crevices or on the ledges of rocks facing the sea. The young are at first fed by regurgitation, upon oil which is of a clear, amber color. This the birds, old and young, vomit upon the slightest provocation, imparting to them, their nests, and even their breeding grounds a disagreeable odor. The ail is one of the important commercial productions of St. Krilda. The single egg is pure white; in shape resembling a hen's; shell brittle. Four eggs from Iceland measure 2.96 by $2.04,2.74$ by $1.91,2.99$ by $2.02,2.97$ by 2.01 .

86a. LESSER FULMAR. Fulmarus glacialls minor Kjærbœlling. Geog. Dist.--North Atlantic. 


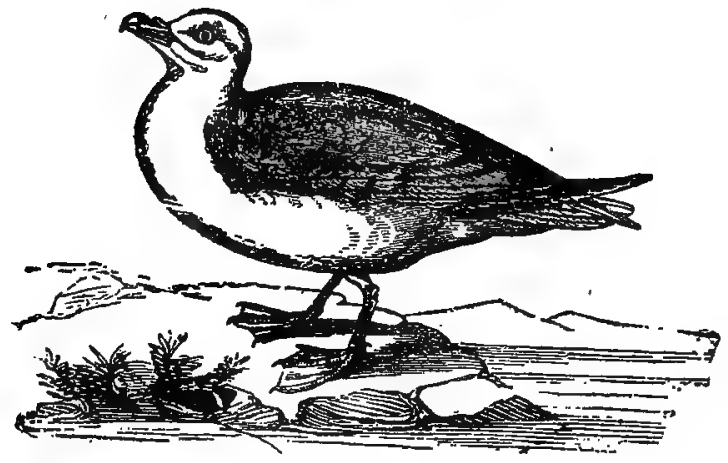

86a. Lesser Fulmar.

This subspecies occurs as far north on the American side as the coast of New England. It is a smaller race than the typical F. glacialis.

86b. PACIFIC FULMAR. Fulmarus glacialis glupischa (Stejn.) Geog. Dist.North Pacific, south on the American coast to Mexico.

This race is also known in light and dark phases of plumage. Dr. Leonhard Stejneger found it breeding in enormous numbers in suitable places on the islands in Bering Sea off the coast of Kamtschatka. Their rookeries were in high and steep rocky bluff's and promontories, rising out of the sea 300 to 800 feet. Dr. Stejńeger says: "I have spent hours under their rookeries listening to their whining voice and watching their high and elegant flight in sailing out and in and around the cracked rocks, like bees at an immense bee-hive." The egg is single and pure white. Five eggs collected on Copper Island, July 12th and 13th, exhibit the following dimen-

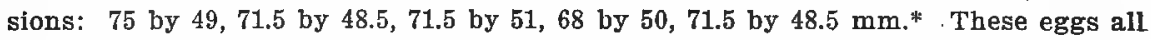
belonged to the dark phase of birds.

86c. RODGER'S FULMAR. Fulmarus glacialis rodgersii (Cass.) Geog. Dist.Bering Sea.

Rodger's Fulmar is similar to the preceding, but there is no dark phase known. Mr. Nelson says: "All of the Bering Sea islands situated off shore and north of the Aleutian ,chain are frequented by these Fulmars during the breeding season." Mr. Elliott found them breeding upon the Fur Seal Islands and says that they are the only species of the petrel kind found about this group. They reach these islands very early in the season and repair to the cliffs, especially on the south and east shores of St. George's Island, where, selecting some rocky shelf on the face of the cliff, safe from all enemies except man, they deposit a single egg upon the bare rock and proceed at once with the incubation. They are very civoted to their eggs, and Mr. Elliott states that they may even be pelted to death with stones before they will desert their chargie. The eggs are laid by the 1st to the 5 th of June, and measure about $2.90 \times 1.90$. The color is soiled white; the shell is rather rough and tive egg is scarcely more pointed at one end than the other.

2*2.95 by $1.99,2.85$ by $1.90,2.85$ by $2.00,2.67$ by $1.96,2.85$ by 1.90 . 
87. SLENDER-BILLED FULIMAR. Fulmarus glactaloides (Smith.) Geog. Dist.-Seas of the Southern Hemisphere, and northward along Pacific coast of North America.

The nesting habits and the eggs of bird are, so far as I can ascertain, unknown.

88. CORX'S SHEARWATER. Puffinus borealis Cory. Geog. Dist.-Off the coast of Massachusetts.

This species was described by the late Charles B. Cory in the Bulletin of the Nuttal Ornithological Club, Vol. VI, April, 1881, p. 84. A number of specimens of this bird were taken near Chatham Island, Cape Cod, Mass., on the 11th of October. We have no knowledge of its nesting habits or eggs.

89. GREATER SHEARWATER. Pufinus major 'Faber. Geog. Dist.-Atlantic Ocean.

A wanderer over the entire Atlantic Ocean, and sometimes seen in immense flocks skimming the billows in its light and graceful manner, similar to the smaller Petrels. Its flight is described as most beautiful, gliding as it does through the air without visible motion of its wings. It also swims and dives with ease. Common Atlantic and Wandering Shearwater are other names by which it is known. There appears to be very little knowledge in the regard to nesting habits of the Greater Shearwater. It is known, however, to breed in the islands of the North Atlantic and is often confounded with other species of Shearwaters. Dr. Brewer describes an egg of this bird, collected on an island of South Greenland, as being nearly oval in shape, with a ground color, originally white, but soiled by the peaty black earth from which it was excavated; size $2.88 \times 2.00$. Another from the same locality is of smaller size, and yellowish-white, which measures $2.75 \times 1.85$.

90. MANX SHEARWATER. Puffinus puffinus (Brunn.) Geog. Dist.-North. Atlantic, chiefly the eastern side; rare or casual off the North American coast (?).

In many places in the regions of the Mediterranean and Adriatic Seas and the Grecian Archipelago this is a common species. It is said to wander to Greenland. Breeds on the islands of Pantellaria, Gozo, Malta, and other smaller islands of the Mediterranean, depositing a single pure white egg on the bare ground, in crevices, or under fragments of rocks. This species also breeds on the islands off the southern coast of France, where it nests in, cavities under rocks, laying upon the ground. The eggs are described as pure white, sometimes tinted with sray, measuring $2.36 \mathrm{x}$ 1.62. The principal food of this bird is fish, mollusks and crustaceans, which it collects from the surface of the water.

91. PINK-FOOTED SHEARWATER. Puffinus creatopus Coues. Geog. Dist.-Pacific Ocean; on the American coast from Lower California to Juan Fernandez Islánds.

Little is known concerning this Shearwater and nothing whatever concerning its eggs.

92. AUDUBON'S SHEARWATER. Pufinus auduboni Finch. Geog. Dist.Atlantic Ocean, from New Jersey southward.

Audubon's Dusky Shearwater is found on the Atlantic coast of the United States frcm New Jersey to Florida. It wanders to the coast of Africa, where it is said to breed on the islands lying on the west coast. It breeds in the Bermudas and the Bahamas, and nests especially in abundance on most of the uninhabited Keys of the 
latter group; here they breed in March, depositing the single white egg in holes in rocks. A nest is made consisting of a few dry twigs. 'Both' sexes inculate and when caught on the nest the birds do not offer any resistance. The egg of this species is of a clear chalky white color, oval in shape and measures from 1.90 to 2.32 long by 1.30 to 1.45 broad.

93. BLACK-VENTED SHEARWATER. Puffinus gavia (Forst.) Geog. Dist.Pacific Ocean, chiefly southwarã.

This species is supposed to occur along the whole Pacific coast as far north at least as Oregon. Little seems to be known regarding its general habits; the eggs are said to resemble those of other members of this family.

94. SOOTY SHEARWATER. Puffinus stricklandi Ridgw. Geog. Dist.North Atlantic, on the American coast south to-the Carolinas.

Here is a Petrel that escaped the observations of the earlier ornithologists, Wilson, Audubon and Nuttall. Recent explorers, however, have discovered that it is a common bird off our Atlantic coast, and that far north it breeds in immense colonies on the islands ' of the sea. It burrows in the ground to the extent of several feet and deposits a single white egg. The average size of the egg is $2.58 \times 1.78$.

95. DARK-BODIED SHEARWATER. Pufinus griseus (Gmel.) Geog. Dist.South Pacific, north to Lower California.

The Dark-bodied Shearwater is known to breed on Cornwallis and Chatham Islands, east of New Zealand, in the South Pacific Ocean, and also on other islands lying farther south. The bird burrows in the peaty ground a horizontal hole three or four feet deep and turning slightly to the right or left. At the end of this burrow a rude nest is formed of twigs and dry leaves, where one white egg is laid; size 2.25 $\mathbf{x 1 . 4 5}$. It is stated that the old birds of this species roost along the shores. of the islands during the night and the noise they make is said to be "something absolutely irightful."

96. SLENDER-BILIED SHEARWATER. Puffinus tenuirostris (Temm.) Geog. Dist.-North Pacific; from Sitka to Kotzebue Sound on the American coast.

According to Dr. Stejneger the Slender-billed Shearwater is rather scarce on the Commander Islands, but he says: "I feel convinced that a few breed there." I saw a flock on the $22 \mathrm{~d}$ of August, 1882, at the entrance of Lissonkovaja Buchta, southern part of Bering Island, leaving the whale carcass, upon which they were sitting at our approach." A specimen was obtained on Copper Island in June, 1883. A siri of this Shearwater was secured by Mr. Dall from an Eskimo. The bird was killed in Kotzebue Sound, thus extending the range of the species through Bering Strait to the Arctic Circle. The eggs are at the present time unknown.

97, BLACK-TAIIED SHEARWATER. Pufinus cinereus (Gmel.). Geog. Dist.-South Pacific; accidental off the coast of Californla.

This peculiar species, approaching the fulmars in many characters, is accidental off the coast of California. Its home is on the islands of the South Pacific. Nothing is known of its eggs.

* * CINEREOUs SHEARWATER. Pufinus knhlii (Boie.) Geog. Dist.-Eastern Atlantic. 
This is an Eastern Atlantic species of which no American specimens are known to exist in collections at the present time. A series of four sets of one egg éch are in Mr. Crandall's collection. The nirst was taken June 21st, 1890, on Porto Santo Island, one of the Maderia group. The egg measures 3.02x1.95. The second was taken in one of the islands of the same group July 5 th, 1891; the specimen measures 2.87x2.01; another, collected June 21st, 1893, on Porto Santo Island, measures $2.90 \mathrm{x}$ 1.90. The fourth was taken July 18th, 1893, on Desertas Island, of the Maderia group, and its size is $2.90 \times 1.80$. Three of the specimens are quite pointed, but the fourth is of a well-rounded type like those of the albatrosses. The Chnereous Shearwater's eggs are of exceedingly brilliant whiteness, and although little pits appear regularly over the shell, the texture is very fine. They are by far the handsomest white sea birds' eggs, and for this reason can easily be differentiated from those of the Fulmars. This species nests in the holes and crannies of cliffs.

98. BLACK-CAPPED PETREL. Astrelata hasitata (Kuhl.) Geog. Dist.Warmer parts of the Atlantic Ocean; accidental in Florida, Long Island, England and France.

We know nothing concerning the nesting and eggs of this species, which is of casual occurrence on the Atlantic coast of the United States.

99. SCALED PETREL. AEstrelata scalaris (Brewst.) Geog. Dist.-Unknown; accidental in Western New York.

A specimen of this species was caught in New York State, Livingston county, April, 1880. Its geographical range, habits, eggs and nesting are unknown.

100. FISHER'S PETREL. Fistrelata fisheri (Ridgw.) Geog. Dist.-Coast of Alaska.

This species was described by Mr. Ridgway from a specimen taken on Kadiak Island by Mr. Fisher. (See Proc. U. S. National Museum, 1882, pp. 656-658.) Nothing distinctive is known of its habits.

101. BULWER'S PETREL. Bulweria bulweri (Jard $\varepsilon$ Selby.) Geog. Dist.Eastern Atlantic, including coasts of Europe and Africa.

This petrel is known to breed on the Canary and Madeira Islands and others on the northwestern coast of Africa. It is said to be an occasional visitor to the Bermudas and accidental in Greenland. It nests in burrows in the soft earth under overlying boulder-rocks and in deep crevices in cliffs. The bird is stated to be nocturnal in its habits, never flying about in the daytime. The single egg which this species lays is oval in shape, equal-ended, and pure white in color; sizes range from 1.59 to 1.76 long, by 1.17 to 1.23 broad.

102. PINTADO PETREL. Daption capensis (Linn.) Geog. Dist.-Oceans of the Southern Hemisphere, north to about latitude $25^{\circ}$. Accidental on the coasts of California and England.

This petrel inhabits the Southern seas generally. It is known as the Cape Pigeon and Damier. Its eggs are at present unknown. The shape of the bird very much resembles that of a pigeon, as will be seen by the illustration. 


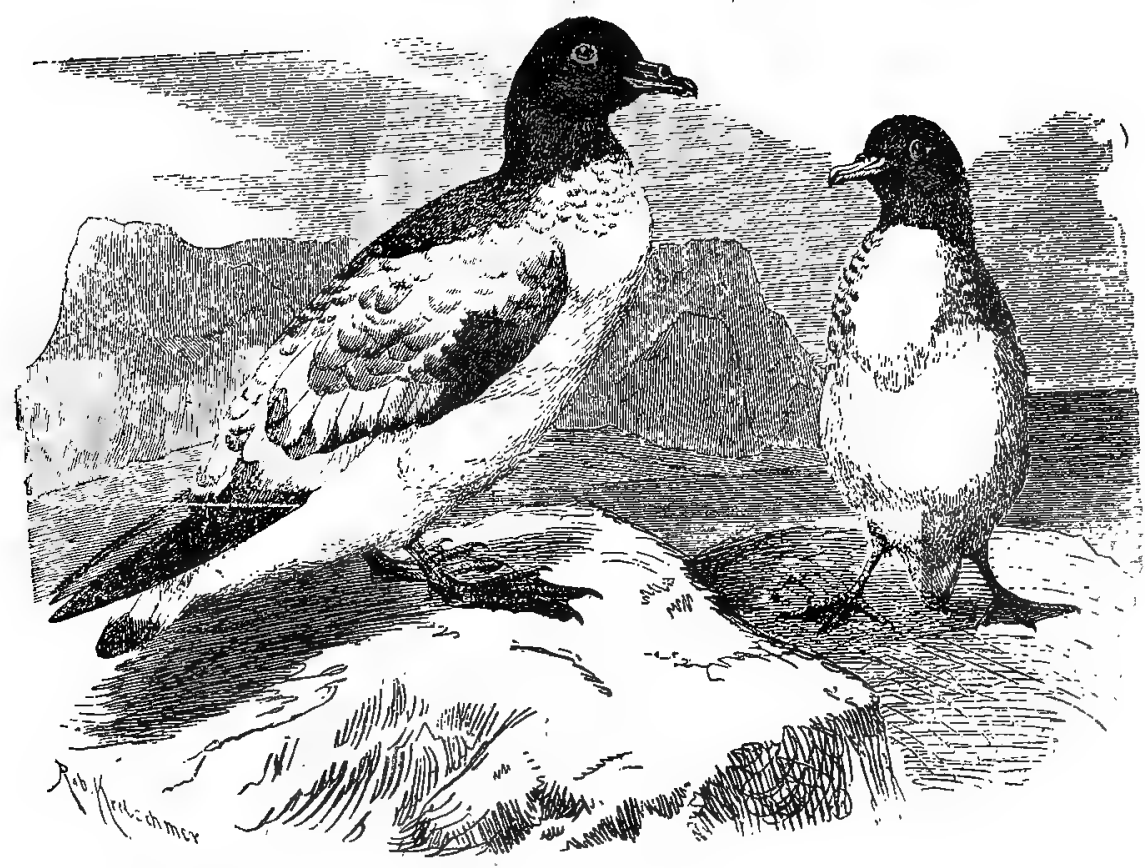

102. Cape Pigeon (From Brehm.)

103. IEAST PETREL. Halocyptona microsoma Coues: Geog. Dist.-Coast of Lower California.

A set of one egg of this queer little petrel is in Mr. Crandall's collection; it is pure white in ground color, with a ring of minute black specks around one end and a few scattered over the other; it is short elliptical oval in form, and measures 1.00x.72. It was collected by Mr. A. W. Anthony on San Benito Island, Lower California, July 26th, 1896. The egg was laid on bare rock under a loose slab of stone.

104. STORMY PETREL. Procellaria pelagica Tinn. Geog. Dist.-Atlantic Ocean; on the American side from the Newfoundland Banks northward. West coast of Africa and coast of Europe.

The "Mother Carey's Chicken" of the sailors. Common in various portions of the' Northern Atlantic; rarely found near land except when breeding or during-severe storms. It is not known to breed on the American coast, but it does in various porticns of the Atlantic coast of Europe. In the Mediterranean it breeds in abundance. $\therefore$ Csts commonly on nearly all the islands on the coast of Scotland-the Hebrides, Whotland; Orkneys and Faroes; laying is begun in the latter part of June. Dr. Coves says: "This is the rarest of the three little black white-rumped "Mother Carey's chickens' of our Atlantic Coast, easily distinguished by its short legs and square tail; Leach's, the most numerous, is also short-legged, but larger and fo 'ztailed; Wilson's is intermediate, with square tail, but very long, stilt-like legs, flat claws, and a yellow spot on the webs." The single egg is deposited in holes in high cliffs or in burrows made by the birds under boulders lying on the ground. The 


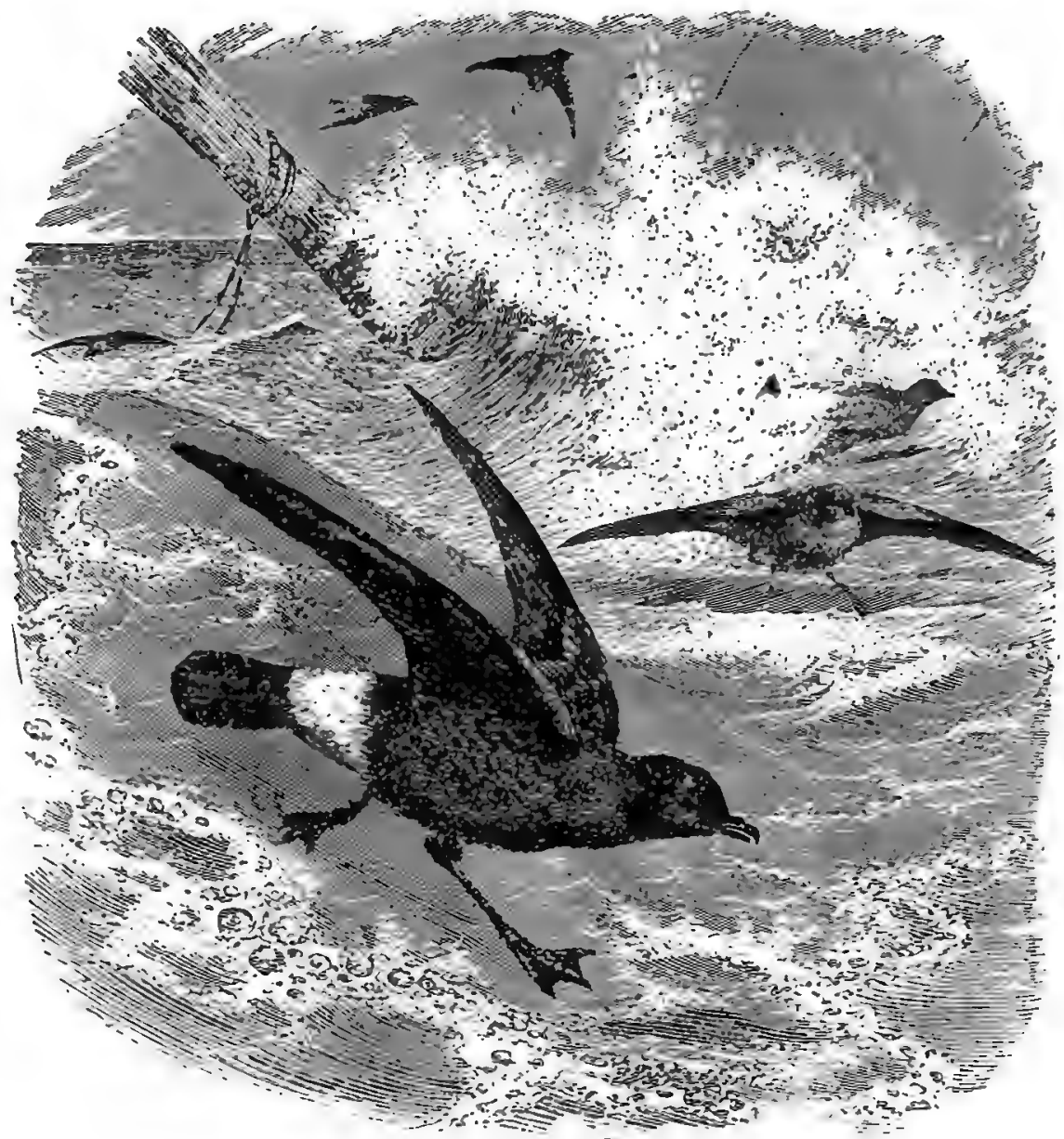

101. STosury PEtrel (From Brehuj.

cavity is lined witn twigs and leaves. The cgg is white, obscurely dotted with reddish brown on the larger end; slzcs rango from 1.09 to 1.12 long by .78 to .83 broad.

105. FORK-TAILED PETREL. Oceanodroma furcata (Gmel.) Geog. Dist.Pacific Ocean, on the American coast south to Oregon.

On all of the less populated islands of the Aleutian group as far east as Unalaska this species is found breeding in the month of June. The nests are made in burrows or holes about a foot deep in steep banks: the termination of the cavity being thinly lined with fine roots and dry grass. This specles, like Leach's Petrel, when caught has the habit of ejecting a reddish oily fluid which has a strong, disagreeable smell: the nest, eggs, and even the old dry skins of the birds arc forever infected with it. 
A small colony of these graceful petrels were found breeding on Copper Island, in Bering Sea, by Dr. Stejneger. The eggs were taken July 12th, a single one in each nest, were deposited in deep holes in the steep basaltic rocks, three feet or more deep, and it was only with great difficulty that a few could be secured. Some males and some females were taken in the nests. The eggs were in different stages of incubation, white without gloss, with minute dark specks evenly dusted over the blunt end; in one the specks were a little larger, purplish-black, forming a circle around the blunt end. Three eggs measure $34 \times 26,32.5 \times 25,34 \times 26.5 \mathrm{~mm}$.*

106. IEACH'S PETREL. Oceanodroma leucorhoa (Vieili.) Geog. Dist.-North Atlantic and North Pacific Oceans.

Leach's Fork-tailed Petrel at various seasons of the year wanders over a large portion of the watery expanse of the globe. It breeds in the months of March, April, May, June, July and August, according to locality, in the northern latitudes of Europe, Eastern and Western North America. On the Atlantic coast of North America from Maine northward it nests generally in June and July. . Thousands breed on come of the isilands on the northern New England coast, especially those in the vicinity of Grand Manan and the small islands of Casco Bay. The offensive reddish, oily fluid with this species almost invariably ejects when handled or irritated probably serves as food for the young. The male and female assist in the duties of incubation and often both sexes may be found sitting side by side in their burrow. Eggs collected on the Atlantic coast are chalky-white, finely dotted on the larger end, often in a circle, with purplish-red and lilac. Twenty specimens average in size 1.34x1.00. On approaching the breeding ground of the petrels, not one of them is to be seen. Many of the birds are far out at sea, and as night comes on those in their burrows come forth and those out at sea return, and the air seems alive with them flitting about like bats and uttering their peculiar elattering notes.

106. 1. GUADALUPE PETREL. Oceanodroma macrodactyla (Bryant.) Geog. Dist.-Guadalupe Island, Lower California.

Mr. Bryant describes this species as being similar to 0 . leucorhna, but larger and darker. White of upper tail coverts more restricted, and the ends of coverts broadly tipped with black. Pileum darker than back, lighter anteriorly. Bill broader and deeper at base than that of leucorhoa. He records this petrel as nesting in March on Guadalupe Island, which is situated two hundred and twenty miles southward and westward of San Diego California. Here he found the birds breeding in burrows under boulders and fallen branches; these places were from one to three feet in length, at the extremity of which were enlarged chambers where the single egg was laid upon a few pine needles. The egg, Mr. Bryant describes as shaped much like that of a pigeon's, white in color, one end being wreathed with a fine spattering of minute dots of reddish-brown and pale lavender: $\dagger$ The average size of fifty eggs taken March 4th and 5th, is 35.7 by $27 \mathrm{~mm}$. or $1.40 \times 1.06$ inches.

107. BLACK PETREL. Oceanodroma melania (Bonap.) Geog. Dist.-South Pacific, northward to Lower California.

Specimens of this species have been taken at Cape St. Lucas and other islands of Lower California, and its eggs as noted below. Mr. Chauncey W. Crandall has in his

* $1.34 \times 1.02,1.28 \times .98,1.34 \times 1.04$ inches.

† Additions to the Ornithology of Guadalupe Island. By Walter E. Bryant. Bulletin 6, Callfornia Academy of Sclence. 
collection a set of one egg of this rare and little known species. The eeg Is pure white in color with no marks of any kind, elliptical oval in shape and measures 1.44x1.08. It was taken by Mr. Anthony on San Benito Joland, Lower Jalifornia, July 25th, 1896. The egg was deposited on bare ground at the end of a burrow about three peet long.

108. ASHY PETREL. Oceanodroma homochroa (Coues.) Geog. Dist.-Coast of California.

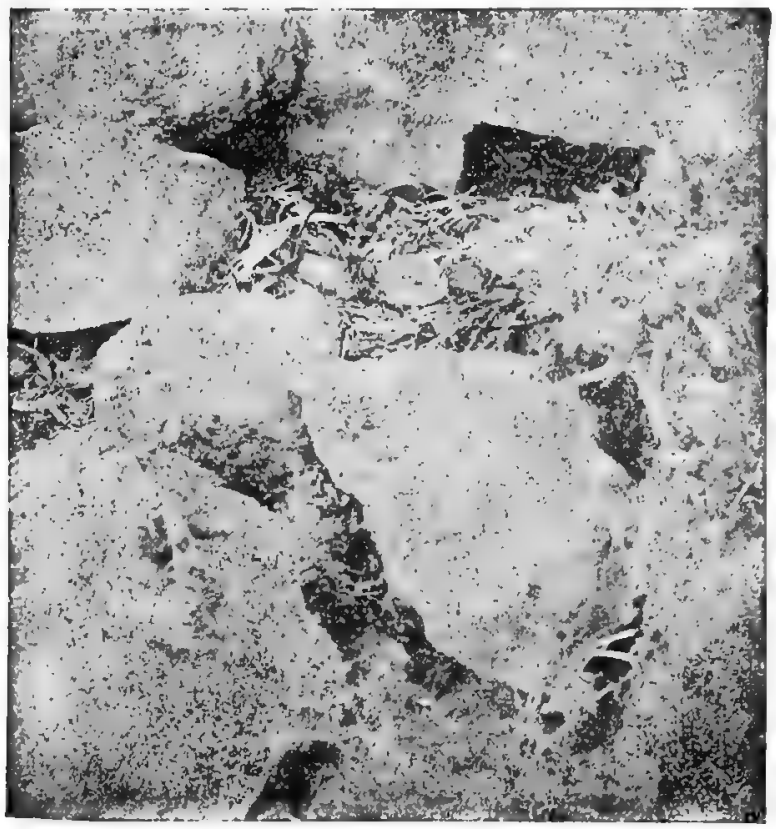

106. Nest and EgG of the Ashy Petrel on the Farallone Islakds. (From The Nidolaglses)

Mr. A. M. Ingersoll first found the egg of this species on South Farallon in June, 1885. He described the egg as dull creamy-white, with a circle of reddish spots around the large end, so fine as to be almost indistinct. The large end is somewhat flattened, like the large end of an acorn. It measures 1.18x.94." This, Mr. Emerson informs me, is the rarest of the birds that breed on the Farallons; nesting anywhere In cavities under boulders, laying a single egg. Two eggs collected June 15, 1885, and June 8th, 1886, measure respectively $30 \times 23,31 \times 23.5 \mathrm{~mm}$. $\dagger$ The following on the Ashy Petrel is by Mr. C. Barlow in The Museum for December, 1894: "They nest throughout the island preferably beneath stone piles on the ground. They fly about only at night. One egg is laid which is of a creamy white color both before and after

- Ornithologist and Oologiat, Vol. XI, p. 21.

$+1.18 \times .91,1.22 \times .93$ inches.

$\$$ Mr. Barlow has also contributed a lengthy article on the nesting of the Ashy Petrel In The Nidologist for August, 1894. 
being blown. It is usually but very faintly spotted about the large end and often wholly unmarked. I have but one egg which is well marked and it has a wreath about the large end composed of irregular dots of light reddish-brown. The eggs of this Petrel average considerably smaller than those of Leache's. The measurements of seven eggs are as follows, the extreme sizes being given first: $1.26 \times .89,1.22 \times .89$, $1.20 \mathrm{x} .89,1.20 \mathrm{x} .87,1.19 \mathrm{x} .86,1.13 \times .89$ and $1.11 \mathrm{x} .87$ inches."

108. 1. SOCORRO PETREL. Occallodroma socorroensis Townsend. Geog. Dist.-Coasts and Islands of Lower California.

This is a new species of petrel just added to the avifauna' of North America. A specimen of the egg of this bird is in the extensive collection of Mr. Crandall. It was collected by Mr. Anthony, the well-known ornithologist. Mr. Crandall says: "My set of this species is pure white with a ring of pale lavender or pinkish specks around the large end, elliptical ovate in shape, and measures $1.22 \times .85$. It was collected by Mr. A. W. Arithony on Coronado Island, Lower California, July 10th, 1896, and was laid on the bare ground at the end of a burrow about three feet long.'

109. WILSON'S PETREL. Oceanites oceani rus (Kuhl.) Geog.' Dist.-Atlantic ard Southern Oceans.

Wilson's Stormy Petrel is one of the best known and commonest of the smaller petrels. It is to be met with nearly everywhere over the entire watery surface of

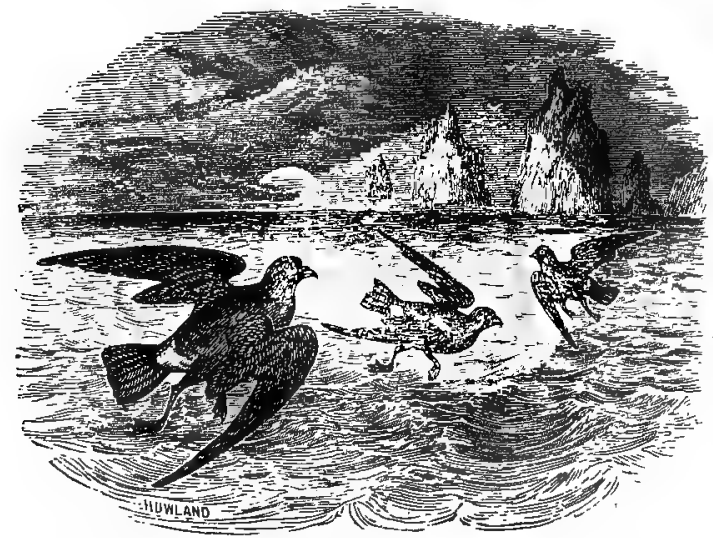

109. WiLson's Stormy Petreil. the world-far north in the icy regions 'of the Arctic seas and south to the sunny isles of Southern cceans. Its general habits are the same as those of Leach's Petrel. Dr. J. H. Kidder found it on Kerguelen Island, southeast of Africa. He had previously seen them at the sea coast off the Cape of Good Hope, and, on December 14, saw them out by day feeding on the oily matter floating away from the carcass of a sea-elephant. The birds, he says, frequent the rocky parts of hillsides, and, flitting about, like swallows;

they catch very minute insects, Dr. Kidder remarks that he never succeeded in finding the egg, but learned from Rev. Mr. Eaton, who found one on Thumb Mountain December 8, that this species nested under large rocks not far from the beach. The egg found was white. The species was supposed to nest among and under the rocks, habitually, at considerable elevation above the sea.

110. WHITE-BELIIED PETREL. Cymodroma grallaria (Viell,) Geog. Dist. -Tropical oceans; accidental on the coast of Florida.

A single instance of this petrel having been taken on the coast of Florida entitles it to a place in the North American avifauna. We know nothing regarding its nidification. 
111. WHITE-rACED PETREL. Pelagodroma marina (Lath.) Geog. Dist.South Atlantic and Southern Seas; casual off the coast of Massachusetts.

This petrel with a renarkably long, slender bill and very long legs, has been once taken off the coast of Massachusetts. As far as I can learn this species has the same habits which are common to other petrels. Its nesting habits are the samedepositing as it does a single egg in burrows in the ground. Mr. Crandall has an authentic egg of this species which was taken at Otago, on the southeast side of South Island, New Zealand. The egg, in shape, is the same as that of Leach's Petrel and measures $1.37 \times 1.02$. It is well and rather heavily marked for a petrel's cgg, with brownish and purplish red in a ring about the larger end, and a few apecks and spots over the rest of the egg, except at the small end.

112. YELLOW-BILLED TROPIC BIRD. Phaethon flavirostris Brandt. Geog. Dist.-Tropical and sub-tropical coast of America north to Florida.

In appearance this bird resembles a large tern; the principal external peculiarity is its long middle tail-feathers; the general color of the plumage is wits, inged with salmon. Its habits are similar to those of the terns. It is inter-tropical in its distribution, of a wandering disposition, breeding on the islands of inid-ocean thousands of miles apart. The bird is noted for its elegant, airy and long-pret:acted flight. On St. Bourdon, Mauritius and other islands east and south of ". Iadagascar, this species breeds in the crevices of the rocks of inaccessible cliffs, and $11.70110 \mathrm{w}$ trees. In the Bermuda Islands it nests about the first of May in holes in iigh places along the shores. Here its favorite resorts are the small islands of Creat Sound, Castle Harbor and Harrington Sound. According to Mr. Buckenham* Trunk Island, Harrington Sound, seems to be a favorite resort of this species. I- $I_{-y}$ ys: "On the shore of this island are a great many crevices among the rocks, which form the nesting places of this bird. I found two nests not more than a foot apart, and each nest had its bird sitting on an egg. The eggs are laid on the bare ground unless anything is handy with which to line the nest. The bird never lays more than one egg at a setting and has several settings each season. The eggs are chalky white, thickly spotted with chocolate-brown becoming more dense at the larger end and often presenting a smeared appearance. In some specimens the color varies from a reddish brown to purplish chocolate, but the predominating color is chocolatebrown. The average measurement is about $2.23 \times 1.53$ in. The measurements of three specimens are as follows: $2.24 \times 1.50,2.19 \times 1.54,2.26 \times 1.53 \mathrm{in}$. respectively. The first was found at the entrance of Shark's Hole, along the shores of Harrington Sound, in a hole in the rocks about five feet from the water. The second, on Trunk Island, Harrington. Sound, in a crevice in the rocks. There was nothing in the nest for lining except a few feathers of the old birds. The third was also found on Trunk Island under a pile of large racks which had fallen down and formed a place for a nest. This was lined with some weeds and a few feathers." The Phaeton, as this bird is called, breeds in the Bahamas in holes in the perpendicular faces of cliffs, and also on the flat surfaces of rocks. A single egg is laid, which has a ground-color of purplish brownish white, covered in some specimens almost over the entire surface. with fine reddish chocolate-colored spots; in some specimens this coloring appropaches blackness: The average sizé of the egg's is 2.21x1.54.

113. RED-BILLED TROPIC BIRD. Phaethon athereus Linn. 'Geog. Dist.Coast of tropical America, nonth on the Pacific coast to Lower California.

* In The Museum, November, 1894, pp. 15-16. 


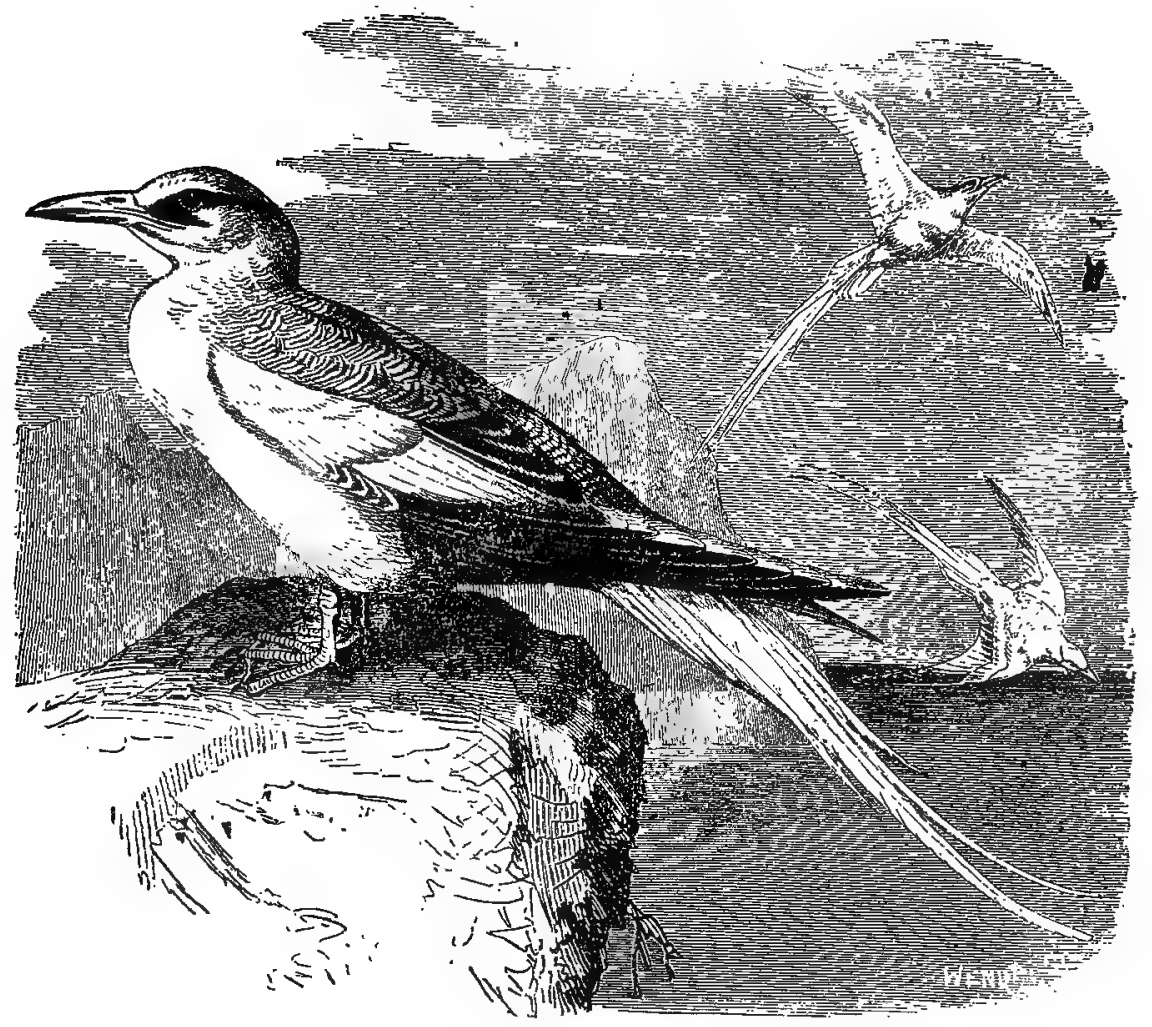

113. Red-BILled Tropic BiRd (From Brehm).

The Red-billed Tropic Bird occurs along the Pacific coast of South America, in the West Indies, and as far north as Cape St. Lucas. In one instance it is said to have straggled to Newfoundland. Breeds on the various islands off the coast of Mexico. Its breeding habits are said to be like those of the Yellow-billed species. The eggs are creamy-white with a purplish tinge, marked with fine dots of chestnutbrown. The sizes vary from 2.20 to 2.37 in length by 1.55 to 1.70 in breadth.

114. BLUE-FACED BOOBY. Sula cyanops Sund. Geog. Dist.-South Pacific, West Indies and Southern Florida.

The Gannets are birds that resemble very closely the cormorants, and, again, they may be said to look like geese-a name often applied to them. They are large, heavy sea-birds, noted for their vigorous protracted flight. They procure their food by plunging into the water from a height, completely submerging themselves, often for several minutes. The Blue-faced Gannet inhabits the. Southern Pacific Ocean as far southwest as Australia. In some of the islands of the Paumotu Group this species deposits its eggs on the dry sandy beaches of lagoons. Both sexes incubate: When a colony of these birds is disturbed none of them leave their nests, but remain gravely at their stations, and hiss at the intruder like a domestic goose. On the Bahamas this species nests in the latter part of March, laying always 
two eggs. These are white, covered with a calcareous deposit; sizes range from 2.45 to 2.60 long by 1.67 to 1.75 broad.

114. 1. BLUE-FOOTED BOOBY. Sula gossi Ridgw. Geog. Dist.- Islands in the Gulf of California, south to the Galapagos.

Between the 15th and $28^{2} \mathrm{~h}$ of March, 1888, the late Col. N. S. Goss found this new species breeding on the San Pedro Martir Isle, situated in the Gulf of California about midway between the shores. It is a rock about one and a half miles long, nearly as broad, and about 1045 feet in height, a little north of latitude $28^{\circ}$ Colonel Goss states that the birds make no nests and lay but one egg; this they drop upon the smooth rock, often in exposed situations, preferring the places where the guano has been removed and, in many cases, close beside the winding paths that were hourly trodden. No young birds were found, and from the condition of the many eggs examined, he was of the opinion that the birds do not commence laying before the first of March. The average measurement of twenty-one eggs is given as $2.42 \times 1.60$. The ground color is greenish-blue, coated with a dull white chalky substance, but generally more or less stained with guano that generally gives them a dirty buff wuite look; in form elliptical ovate.* A specimen of the egg of this species in the collection of the late Capt. B. F. Goss measures $2.34 \times 1.60$.

115. ВоOBY. Sula sula (Linn.) Geog. Dist.-Tropical and sub-tropical coasts and islands of America, north to Georgia.

The Boóby Gannet is said to breed on some of the islands about the extreme southern coast of Florida. In the Bermuda Islands, anu in some $0_{1}$ the Bahamas, and many of those along the coast of Central and South America, this Gannet congregates by thousands at its breeding places, where it deposits its eggs on the sand of the beaches, or on the bare rock; no nest whatever is made. The food of this species consists chiefiy of flying-fish and small mullets, which they disgorge in a half macerated state into the open mouths of their young. Audubon found mullets weighing more than a half a pound in the bodies of the gannets he examined. In various islands of the southern oceans the Boohy. constructs its nest of sticks and weeds on bushes and low trees. Here it is said to lay but one egg. Observations of those who have collected in the West Indies disclose the fact that the complete nest complement is two eggs. These are of a uniform dull, challky white in color, with great variations in sizes, measuring from 2.16 to 2.64 long by 1.50 to 1.57 broad.

115. 1. BREWSTER'S BOOBY. Sula brewsteri Goss. Geog. Dist.-Islands of the Eastern South Pacific Ocean, northward to Lower California.

This is another new species of Booby which was found breeding by Colonel Goss on San Pedro Martir Isle in the Gulf of California. The birds were not wild, but their nesting places, as a whole, were not in as exposed situations as those of the Blue-footed, they seemed to prefer the shelves and niches on the sides of the rocks. They lay two eggs, and in all cases collect a few sticks, sea-weed, and often old wing and tail feathers; these are generally placed in a circle to fit the body, with a view, it was thought, to keep the eggs that lie upon the rock from rolling out. There is but little material on or apout the isle out of which a nest can be made. Colonel Goss says the birds must commence laying as early as the 10th of February, as young were found in many cases from half to two-thirds growr. The average measurement of seventeen eggs is given as $2.44 \times 1.60$. In color and form, as well as size, they are

* The Auk, V, p. 242. 
similar to the eggs of the Blue-footed, in fact so nearly alike that when placed together théy cannot be separated with certainty. A set of two is in Captain Goss". cabinet. These measure $2.40 \times 1.70,2.30 \times 1.62$ respectively.

116. RED-FOOTED IOOBY. Sula piscator (Linn.) Geog. Dist.-Coast and islands of tropical and sub-tropical seas, north to Western Mexico and Florida.

The Red-footed Booby is characterized by the same general habits as others of its family. Its nesting is essentially the same as that of the Blue-faced Gannet. Two eggs are laid, white in color, elongate-ovate in shape, with a calcareous deposit on the surface; size, $2.57 \times 1.80$.

117. GANNET. Sula bassana (Linn.) Geog. Dist.-North Atlantic; south in winter to the Gulf of Mexico and Africa. Breeds from Nova Scotia and British islands northward.

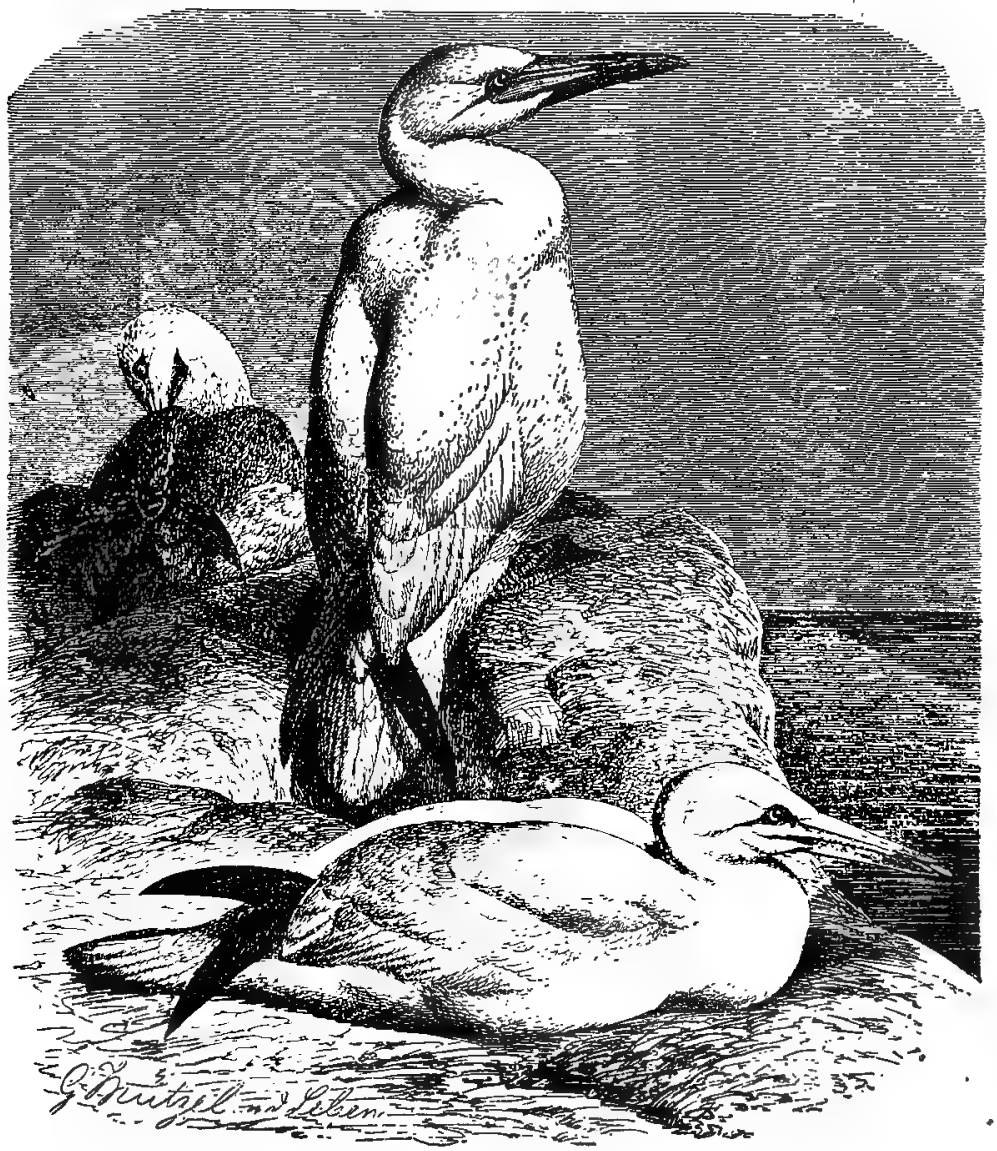

117. Gannets (from Brehm). 


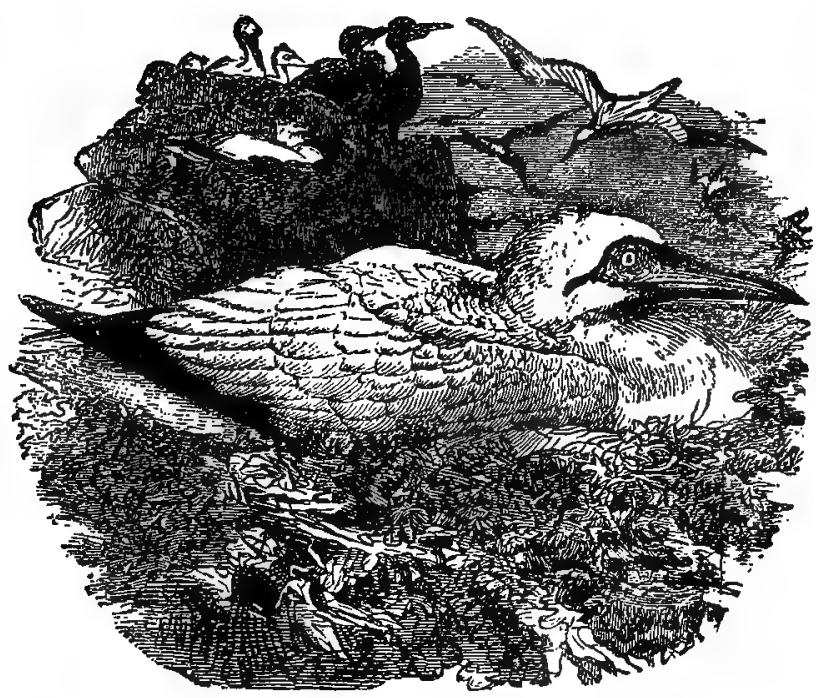

117. Gannets and Nests.

The White Gannet, or Solan Goose, is widely distributed throughout the Northern Atlantic Ocean, and is more or less a resident wherever found. Some of the most noted breeding places of this bird are on the islands about the coasts of Scotland, notably the great Bass Rock at the mouth of the Firth of Forth. Here it breeds in tens of thousands, with the Gulls, Cormorants and Puffins that inhabit the rock. Another of its breeding stations is St. Kilda. The precipitous cliffs at this place rise to the height of 1400 feet. Here the Gannet breeds in countless numbers. This bird also nests on the Faroe Islands and upon islands on the coast of Iceland. Small colonies are to be found breeding in Labrador. One of its well-known breeding places on the coast of North America is "Bird Rocks," in the Gulf of St. Lawrence. The nests are built on the summits and ledges of the rocks. They are made of sea-weed, mud and small stones, raised to about ten inches in height and eighteen in diameter. In some cases the nest is made of, straw and other available material. A single egg is laid. It resembles very much the average Brown Pelican egg, with, however, these differences: Its general shape is more elongated, and the calcareous deposit on it is thicker; the color is chalky-white; sizes range from 3.25 to 3.50 long by 1.65 to 2.05 broad.

118. ANHINGA. Anlinga anhinga (Linn.) Geog. Dist.-Tropical and subtropical America, north to the Carolinas and Southern Illinois.

Known as the Water Turkey, Darter and Snake Bird.' It often swims with the body submerged, its head and long neck in sight like some kind of water serpenthence the latter name. This singular-looking bird is very common in summer in the South Atlantic and Gulf States to North Carolina, frequenting the almost impenetrable swamps. It is a constant resident of Florida. The bird dives with amazing ease, and when alarmed will drop from its perch with scarcely a ripple on the surface of the water, and will swim beneath the surface to a safe distance before reap- 


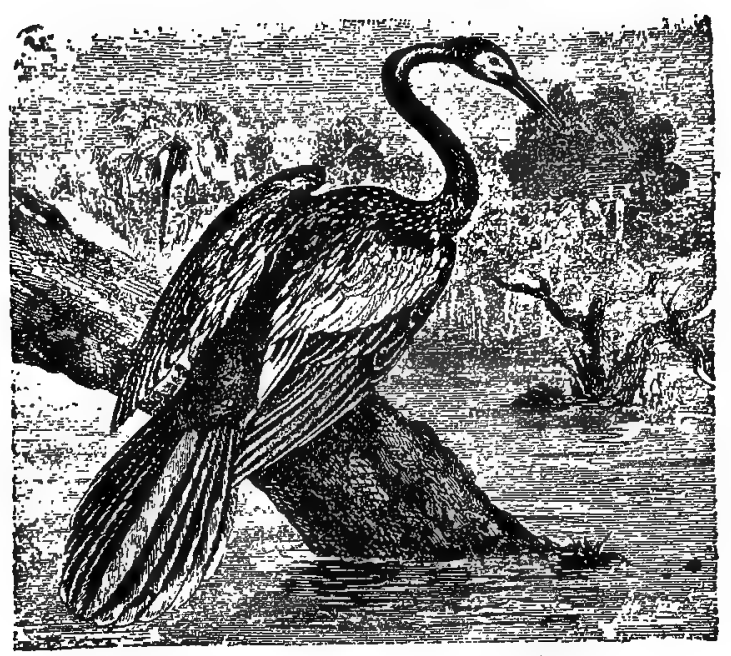

118. Anhiwga.

pearing. It has also the curious habit of quietly sinking like a grebe. The nests of the Anhinga are variously placed-sometimes in low bushes at an elevation of only a few feet, or in the upper branches of a high tree, but always over water. Sometimes this bird breeds in large colonies with various species of Herons. The eggs are from three to five in number, bluish or dark greenish-white, with a white chalky incrustation; they are narrow and elongated in shape; the sizes range from 8.00 to 2.30 long by 1.30 to 1.40 broad. In Florida the Water Turkey deposits its eggs In April; many eggs are collecte 1 in March, and a writer in The Oologist (May, 1893, p. 149), states he has seen nests occupied in February. Mr. I. W. Williams, jr., informs me than the Anhinga will occupy the same nest ycar after year with little repairs. In a small swamp near Tallahassee the nests are fiequently found in close proximity to those of Ward's Herons. He states the $\Delta$ nz:בga may be robbed of its eggs constantly and yet they will continue to nest in the same swamp.

119. CORMORANT. Phalacrocorax carbo (Linn.) Geog. Dist.-Atlantic coasts of Europe and America, south in winter on the coast of the United States, casually to the Carolinas.

The Common Cormorant is very generally distributed throughout nearly the entire northern hemisphere. It breeds in the northern parts of Europe and Asia, and in North America from the Bay of Fundy to Greenland. The Cormorants are curious birds of strange figure; the outer surface of the plumage in most species normally is of a dark lustrous greenish-black, but subject to great changes, making their study very difficult. The eyes as a rule are green, a color rarely seen in birds. They feed principally upon fish and their voracity is proverbial. This species breeds in vast numbers on the rocky shores of Labrador and Newfoundland; making the nest upon the tops of ledges or on projections and in the crevices of precipitous rocks, which are covered with the excrement of the birds. It is composed of sticks, kelp and sea weed. Like all the Cormorants this species is gregarious and breeds in communities. They are all known under the common name of Shag. Mr. Frazer 


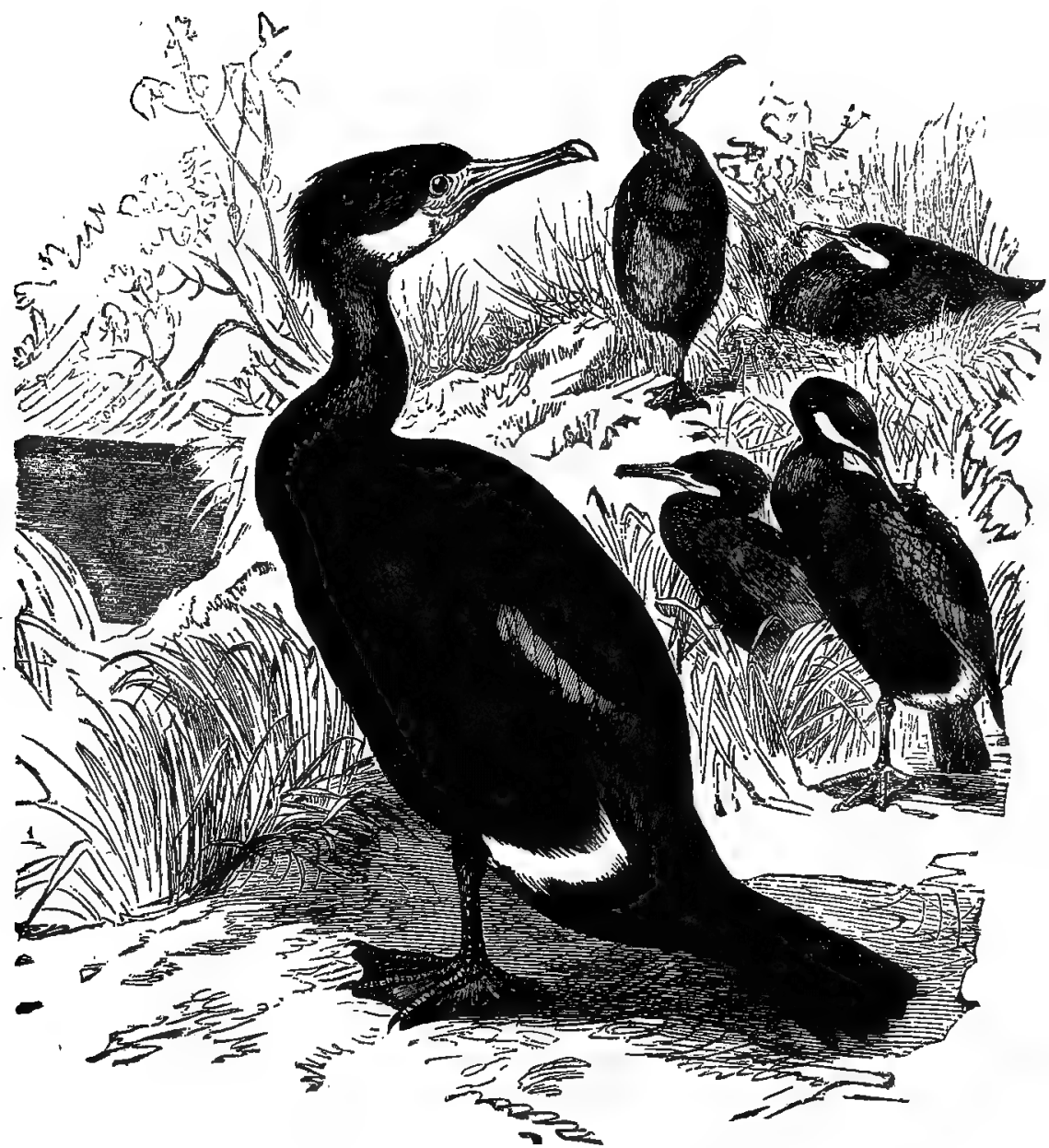

19. Cormorant. Phalaerocorax carbo. (From Brehm.)

met with a colony of this Cormorant in company with the Double-crested species on the coast of Labrador. Many of the nests contained large young June 19. Nests of the Double-crested Cormorant were placed wherever the ledges would hold them, While those of the common species were built close to the top. The nests of the Common Cormorant usually contained four or five eggs, and several sets were taken of six. The eggs average larger than those of the Double-crested; the sizes vary from 2.38 to 2.65 long by 1.29 to 1.60 broad. Color, pale greenish; form, elliptical.

120. DOUBLE-CRESTED CORMORANT. Phalacrocorax dilophus (Sw. \& Rich.) Geog. Dist.-Atlantic coast of North America; southward in the interior to the Great Lakes and Wisconsin. 
In Eastern North America the - ouble-crested Cormorant or "Crow Duck" is a common species, breeding on the coast from the Bay of Fundy northward and in many of the inland lakes, reservoirs and marshes. It is said to have nested years ago in Ohio, at the Licking County Reservoir, and otner similar places in the northern part of the State. Mr. Walter Raine found nests of the Double-crested Cormorant, built on the ground, on a small island of Shoal Lake, Manitoba, in the second week of June. The ground was dotted all over with the eggs of White Pelican, Herring Gull and of this Cormorant. He states that the Cormorants' nests were made of twigs and weeds.* On some of the rocky islands of the lakes and large, isolated bodies of water in Iowa and Wisconsin, this Cormorant breeds in great numbers. Mr. Frazer met with colonies of it breeding on the islands and cliffs along the coast of Labrador. The nests were placed on ledges of the rocks; they were composed of sea weed and kelp, freshly pulled from the bottom of the ocean. None of . the nests confained more than four eggs. On the islands of inland waters tris Cormorant often constructs its nest on low spreading trees. The eggs in number range from two to four; bluish-green in color, with the usual chalky substance over their surface; sizes vary from 2.09 to 2.27 long by 1.35 to 1.50 broad. The eggs are of a more regular oval than those of $P$. carbo.

120a. FLORIDA CORMORANT. Phalacrocorax dilophus floridanus (Aud.) Geog. Dist.-Coasts of the South Atlantic and Gulf States, northward in the interior to Southern Illinois.

A smaller and. more southern variety of the Double-crested species; resident in Florida and along the Gulf coast, where it nests in communities on the mangrove islands. The nests are always placed in mangrove bushes and are composed of the twigs and very often lined with the leaves of this plant. Mr. Stuart has often observed nests made entirely of the branches of the mangrove, with the green leaves still on them. In the vicinity of Tampa and Charlotte Harbor the birds nest in May asd June, and below Cape Sable in the months of October and November. The eggs are three or four in number. Six selected specimens measure $2.30 \times 1.43,2.28 \mathrm{x}$ $1.38,2.36 \times 1: 45,2: 25 \times 1.40,2.51 \times 1.50,2.42 \times 1.40$.

120b. WHITE-CRESTED CORMORANT. Phalacorcorax dilophus cincinatus (Brandt.) Geog. Dist.-West coast of North America, south to California.

The late Maj. Charles E. Bendire met with this variety of the Double-crested Cormorant breeding in large numbers on several low, narrow islands of Lake Malheur, in the southwestern portion of Oregon. 'The birds began to lay about the 20th of April. The islands were also occupied by White Pelicans and Great Blue Herons as breeding places. About two-thirds of the Cormorants' nests were made on the ground, and they were composed of pieces of drift, small sticks, etc. The balance were placed on low greasewood bushes. They were lined with pieces of bark and tule and coarse grasses, and placed very close to the water's edge, so that when the lake was rough the water must have splashed into many of them. The eggs, four or five in number, are described as being of an elongated oval, pale green, covered more or less with chalky coatings. They average $2.42 \times 1.48$. Major Bendire states that the largest set in a number exhibits the following measurements: $2.86 \times 1.60,2.70 \times$ $1.65,2.66 \times 1.64,2.70 \times 1.60$. A single egg was found measuring $1.80 \times 1.20$, $\uparrow$

* The Oologist, XII, pp. 3-6.

† Ornithologist and Oologist, VII, p. 138. 
120c. FARALIONE CORMORANT. Phalacrocorax dilophus albociliatus Ridgw. Geog. Dist. - Coast of California, south to Cape St. Lucas and islands of the coast of Mexico.

'This bird is as common on the Farallones as Balrd's Cormorant, and it nests on the rough ridges or points of rocks overlooking the islands. About the first of May they may be seen carrying weeds and dry sea kelp to thelr nesting sites where they construct a flat, loose and bulky platform, which is, on the whole, quite a shallow structure. Their nesting is similar to that of other Cormorants, and they may be observed sitting on their empty nests for hours at a time, probably, as Mr. Emerson suggest., for the purpose of working out the hollow of their nests with

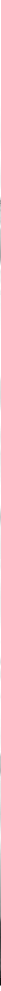

1206. A Gormorant Rooicony on th8 Farallone Islands. (From The Nidologist)

their large feet, for which purpose they are so well suited. By the middle of the month they have begun to deposit their lime covered eggs. These compare well with those of Brandt's Cormorant, and are a little larger than the eggs of Baird's.

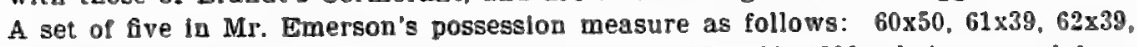
f0x40, 62x39 $\mathrm{mm}$. respectively; these were taken May 20, 1886; their general form is rather ovate oval, and quite round at the greater end. Their color and general characteristics are the same as those peculiar to other Cormorants' eggs-light

* $8.36 \times 1.57,2.40 \times 1.54,2.44 \times 1.54,2.36 \times 1.57,2.44 \times 1.54$ inches. 
greenish in color and coated with a chalky substance. Four eggs seem to be the number commonly laid; both male and female assist in the process of incubation, one remaining on the nest or beside it while the other is off on a short fishing excursion.*

121. MEXICAN CORMORANT. Phalacrocorax mexicanus (Brandt.) Geog. Dist.-Southern United States, north to the interior of Kansas and Southern Illinois.

The Mexican Cormorant is a tropical species found on the coasts and inland marshes of Mexico, Yucatan, and Central and South America, where it breeds. It is mentioned by Dr. Merrill as being a common summer resident in Southwestern Texas, in the vicinity of Fort Brown, where it doubtless nests in the dense growth of trees and bushes that border most of the lagoons. The breeding habits of this species are similar to those of $P$. $d$. floridanus-congregating in large communities and nesting in trees or bushes. In some places along the South American seacoast the bird nests on rocks as well as on shrubbery. The eggs are three or four in number, greenish-white in color, with the usual chalky substance on their surface; sizes range from 2.10 to 2.35 long by 1.30 to 1.40 broad.

122. BRANDT'S CORMORANT. Phalacrocorax penicillatus (Brandt.) Geog. Dist.-Pacific coast of North America, from extremity of Lower California to Washington Territory.

T'he most common of the Cormorants breeding on the Farallones. Its habits are the same as those of the other species, but it is of a more sociable disposition, congregating in large communities to breed on the shelving rocks and ridges. It does not always choose the most inaccessible places for nesting. Like the others, it has great difficulty in constructing its nest, for as fast as it gathers the weeds together, the thieving Western Gulls make away with them. So often are the Cormorants molested in this manner that they frequently change their place of nesting. An interesting article entitled "A Cormorant Rookery," in The Nidologist for JuneJuly, 1894, is by H. R. Taylor. I quote it almost entire: "A Cormorant rookery furnishes the observer with some queer sights. The great, ungainly birds crane their necks this way and that, uneasily and helplessly, fearing to scramble away into flight lest they be robbed of their eggs or young. The latter, however, are not fascinating objects, being entirely naked and black as a kid glove. The parent bird will allow the intruder to approach sometimes within five feet before flýing, at least such was my experience with the Brants' and the Farallone Cormorant on the Farollone 1slands. It would seem that the innate ugliness of the young Cormorant were sufficient guarantee against invasion, but to make their peculiar sort of defence more effective, I have seen Farallon Cormorants, when I came quite near, go into contortions and disgorge the contents of their gullets. Whether this disgusting performance were a method of defence, as I have suggested, or the result of pure fright, I am not prepared to say. Our illustrations, showing both old and young birds, is taken from a photograph of a rookery on an islet near Monterey, and is a characteristic picture of the summer home of Brants' and the Farallone Cormorant. Bairds' Cormorant does not seem to breed so much in colonies, but fashions Its compact nest on some slight ledge under a crag, where it is often inaccessible. The nests become cemented with guano, and do service for more than one year. This Cormorant, on the Farallones, seems to fear that its claim will be "jumped" by some other bird, as it is often found in the nest when no eggs are laid; and if its eggs

\footnotetext{
+ From my article on the eggs of this Cormorant in Forest and Stream, Vol. XXVII,
} p. 158 . 
are taken it returns to sit on the nest as if nothing had happened. While one Cormorant is sitting, its mate brings it small fish to eat. This applies to the three species. I have seen in a rookery of Brandt's Cormorant many little fish scattered about the nest, which the Western Gulls were endeavoring, with some success, to make away with. While watching the Gulls the Cormorants must keep an eye on each other, for sometimes one bird will steal the nesting material of another. The nests are coarsely constructed. In the rookery here referred to they were of Farallone weed, alycle and sea moss. Some varieties of the moss were pulled up, I believe, by the birds from under the water, and it occurred to me at the time that a collector of sea moss could not do better than visit a Cormorant rookery." The eggs are three, usually four, sometimes five in number, light greenish-blue, with a chalky deposit on the surface. They measure as small as $56 \times 38 \mathrm{~mm}$., and as large as $66.5 \times 38 \mathrm{~mm} . *$

123. PELAGIC CORMORANT. Phalacrocorax pelagicus Pall, Geog. Dist.Aleutian and Kurile Islands, and Kamtschatka, south to Japan.

This beautiful Cormorant is abundant in the Aleutian and Kurile Islands and those along the coast of Kamtschatka, where it breeds. Dr. Leonhard Stejneger says it is a very abundant resident of Copper and Bering Islands, breeding on all the most rugged and steep promontories which rise immediately from the sea, as well as on the outlying islets and stones. Eggs, three or four in number. Three eggs collected at Bering Island, June 8, exhibit the following dimensions: 56 by $37.5,53$ by $37,5 \supset$ by $35 \mathrm{~mm} . \dagger$ Two from Copper Island, taken July 14, measure 59 by $34.75,58$ by $35, \mathrm{~mm}$. The color and general characteristics of the eggs do not differ from those of other cormorants.

123a. VIOLET-GREEN CORMORANT. Phalacrocorax pelagicus robustus Ridgw. Geog. Dist.-Coast of Alaska.

On the rocky coasts and islands of Alaska the Violet-green Cormorant is very abundant. Here it nests on the ledges and projections of high cliffs, making the nests of sea-weed, grasses and aquatic plants, which are cemented together with the excrement of the bird. In all respects its general habits, nesting and eggs, are similar to those of the Pelagic Cormorant. The average size of the eggs is 2.25 by 1.45 .

123b. BAIRD'S CORMORANT. Phalacrocorax pelagicus resplendens (Aud.) Geog. Dist.-Pacific coast of North America, from Cape St. Lucas north to Washington Territory.

On the Farallones this species is less common than Phalacrocnrax dilophus albociliatus or $P$. penicillatus. The nests are built more frequently on inaccessible places. The same rookeries are used each season, the birds repairing the nests by adding a few pieces of weed or sea kelp. Colonies of eight or ten pairs nest on the shelves of perpendicular or overhanging rocks. The birds will occupy the same nest after being robbed, and setting commences after the first egg is laid, in order to protect it from the gulls. Mr. Emerson says that by June the birds have begun to deposit their eggs, which are three or four in number, pale greenish-blue in color, with the usual chalky coating. Mr. Bryant states that the eggs of Baird's Cor-

* $2.20 \times 1.50,2.62 \times 1.50$ inches.

$\dagger 2.20 \times 1.48,2.09 \times 1.45,2.32 \times 1.46$ inches.

$\$ 2.33 \times 1.37,2.28 \times 1.38$ inches. 
morant may usually be known by their small size, the average dimensiong of thirtysix specimens (nine sets of four) are $55.5 \times 36.5 \mathrm{~mm} .{ }^{*}$ the largest $59 \times 36$, and the smallest $52 \times 35 \mathrm{~mm} . \dagger$

\section{RED-FACED CORMORANT. Phalacrocorax urile (Gmel.) Geog. Dist.-} Islands of Bering Sea and eoast of Kamtschatka.

The Red-faced Cormorant is a common species on the islands of Bering Sea, especially on St. George and St. Paul Islands of the Prybilof Group. Breeds commonly on some of the Aleutian Islands. Dr. Stejneger mentions it as being less common on Bering and Copper Islands than $P$. pelagicus. He states that the eggs of the two species cannot be confounded; those of the Red-faced being considerably larger than those of the pelagicus, and the green color of the eggs when looked at through the shell is totally different,-much more bluish in the former, against yellow in the latter. The nests are built on the projections of the narrow shelves or ledges along the face of a cliff, the material used being seaweed, ferns, grasses, etc., which are matted together largely with the excrements of the bird itself. The young are fed on small fish, crabs and shrimps, and in a short time the nesting places become very filthy, as a large portion of the food brought by the old birds is strewn over and around the nests. The eggs vary in size from 2.30 to 2.55 long by 1.50 to 1.55 broad. Three eggs collected by Dr. Stejneger on Copper Island, July 14, measure 61x40, $635 \times 39,66 \times 37 \mathrm{~mm}$.

125. AMERICAN WHITE PELICAN. Pelecanus erythrorhynchos Gmel. Geog. Dist. - Temperate North America, north in the interior to about latitude $61^{\circ}$, south to Central America; rare or accidental in the Northeastern States; abundant in the Middle Province and along the Gulf coast; common on the coast of California and Western Mexico.

The White Pelican is generally common west of the Mississippi, breeding from Utah northward. It was formerly known to breed in various parts of Florida. The late Major Charles E. Bendire found it nesting in large numbers on several small islands of Lake Malheur, in southeastern Oregon. It is common on various lakes in the Red River Valley, in British America. In Ohio this bird must be considered a comparatively rare spring and fall migrant, occurring most frequently in the fall. In 1838 Dr. Kirtland records it as an occasional visitor. A specimen in spring plumage was taken in the State about fifteen years ago. In the fall of 1861 quite a large flock made their appearance in the vicinity of Columbus, one specimen of which is still preserved in the museum of the Starling Medical College. At this. time Dr. Wheaton observed three of these birds on the Scioto river. In 1875 a specimen was taken at Licking Reservoir and preserved by Dr. Jasper. Dr. Langdon in "Summer Birds" says: One or two instances of the occurrence of this species in. summer in northern Ohio are noted by Mr. Porter. Mr. H. E. Chubb, a Cleveland taxidermist, had one alive which was wounded and captured in Sandusky Bay February 7, 1881. The latest records I have concerning this bird in Ohio are as. follows: One taken by Elliot Gilfillon on Big Walnut Creek September 15, 1892, ten miles south of Columbus, now in Dr. Jasper's collection; another is reported to me by G. Sutter, taxidermist, Hamilton, Ohio, taken in'September, 1892, at St. Mary's Reservoir. Our illustration represents the portion of an island in Shoal Lake, Manitoba, phoțographed by Mr. Walter Raine, who found it to be a very popular breeding

* $2.19 \times 1.44$ inches.

$\dagger 2.32 \times 1.42,2.05 \times 1.38$ inches.

$\$ 2.40 \times 1.57,2.50 \times 1.64,2.60 \times 1.46$ inches. 
ground of the White Pelican, Double-crested Cormorant, American Herring Gull and other species of water birds. As will be seen in the picture, the ground is dotted a)l over with the nests and eggs of these birds. It was about the middle of June, and the eggs proved to be fresh. I am Informed by Prof. Marcus E. Jones that several thousand of White Pelicans are permanent residents of Great Salt Lake, Utah, breeding on the islands twenty miles out in the lake. They begin. to lay about the first of May or two weeks earlier, according to the season, and fresh eggs are frequently found as late as July. The usúal number of eggs, he says, is two, rarely three or four. The birds make their nests on the ground between the clumps of white sage (Atriplex confertifalia) that grow on the islands. They scrape the sandy soil into a heap about six. inches on the outside of the nests and arrange dry twigs without system; the nests are about a foot in diameter with a slight depression at the top. Prof. Jones says the birds travel sixty miles to catch fish for

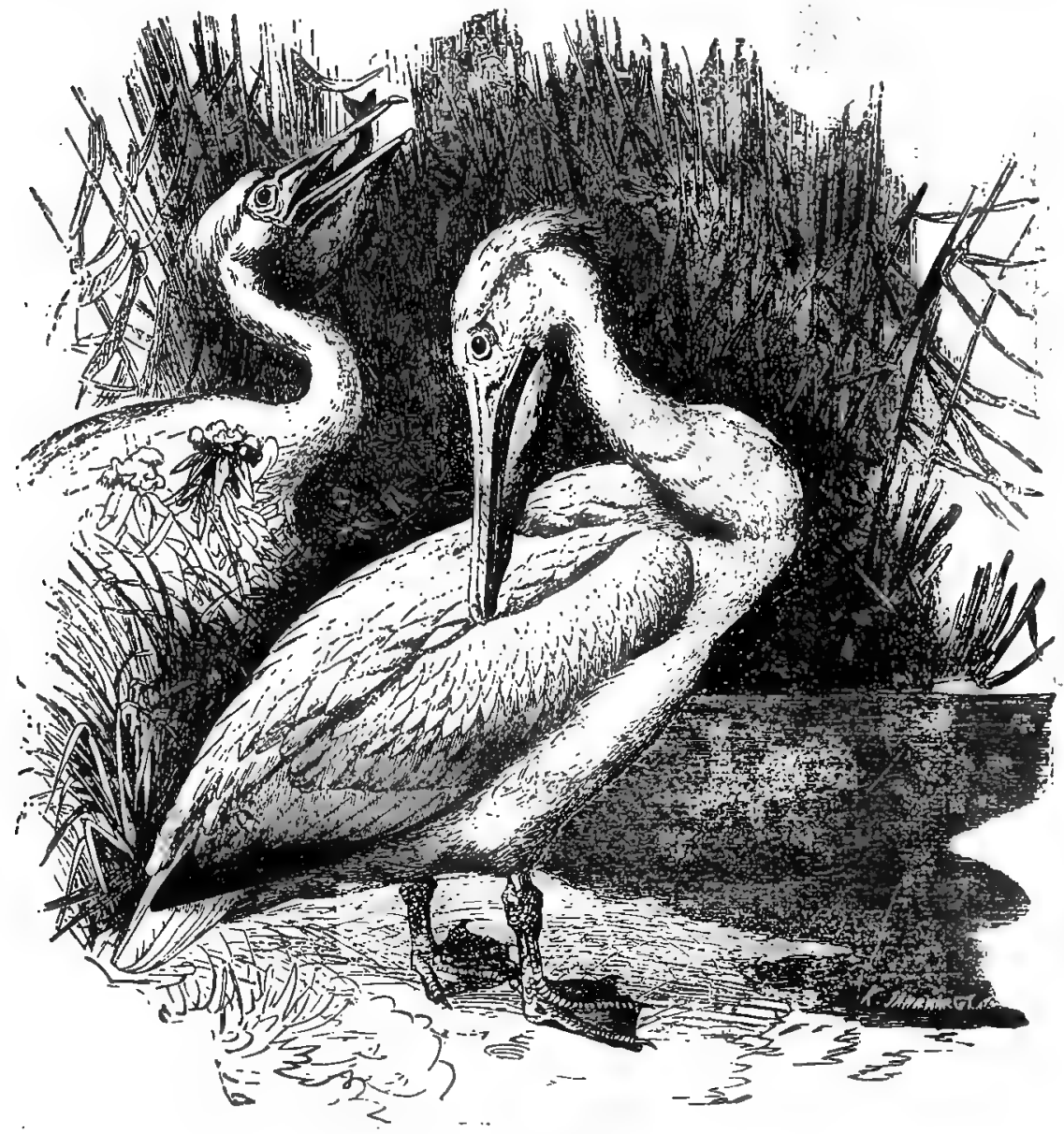

125. White Pelican (From Brehm). 


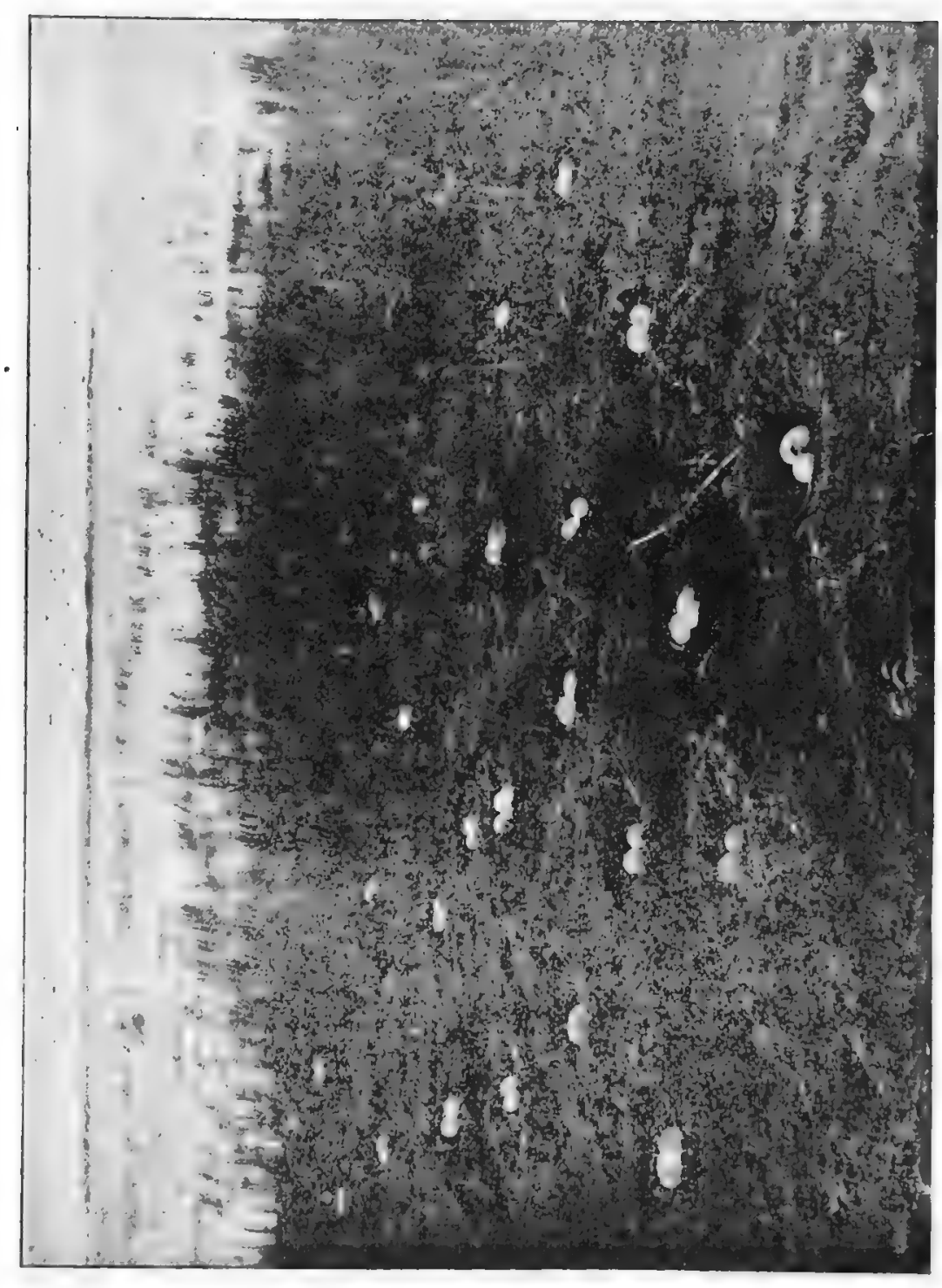


themselves and young, and they often vomit up the contents of their stomach on the ground, which, with the great heat on the islands at the nesting time, soon decay. The stench of the rookeries and the noise of the birds are almost intolerable. Major Bendire found two to be the usual number of eggs laid, although three and four to a nest was by no means rare, and occasionally as many as five were found. The eggs áre dull, chalky white in color, with a calcareous deposit on them, and always more or less blood stained. Major Bendire gives the average size to be about 3.45 x2.30, and measurements of a few selected specimens out of several thousand are as follows: $4.08 \times 2.15,4.04 \times 2.20,4.01 \times 2.19,3.99 \times 2.20,3.72 \times 2.40,3.86 \times 2.55,3.87 \times 2.32$, $3.62 \times 2.40,3.60 \times 2.40,3.57 \times 2.35,3.20 \times 2.51,3.17 \times 2.23,3.20 \times 2.21$; two runt eggs, $2.69 \times 1.88$, $2.46 \times 1.73$.*

126. BROWN PELICAN. Pelecanus fuscus Linn. Geog. Dist.-Atlantic coast of tropical and subtropical America, north to North Carolina; accidental in Illinois.

This Pelican is an abundant bird and constant resident of Florida and southward into the tropical regions. It is said, when feeding, to plunge for its prey like a gannet, and does not scoop them while swimming, like the White Pelican. Like the white species, however, it selects particular localities for breeding, and will return to them from year to year. Pelican Island, in the Indian River, Florida, is a noted breeding ground, where thousands congregate for this purpose. Here they breed in March and April. I take the following from an excellent article on the "Nesting Habits of the Brown Pelican in Florida," which appeared in the March number (1894) of The Oologist. It is from pen of Dr. Morris Gibbs, the naturalist and ornithological writer: A visit was made to Pelican Island. He says that the Pelicans, which had been studied for some time as they flew. back and forth, were the constant target at which all visitors shot, and it is a surprise that the birds do not leave the section. The Brown Pelicans, Dr. Gibbs states, have a love for a nesting spotiand they adhere to a chosen site even when persecuted year after year. This rookery has been known to exist-for over twenty years and the birds have been shot and robbed of their eggs and young annually for over a decade, and yet they persist in nesting in the same situation each spring. Nearly all the nests were built on the ground, although a few dozen were in the branches of the black mangrove trees which grew scantily on the north shore of the island. The xests in the trees were more substantial structures than those on the sand, but were of much the same materials, sticks, coarse grass and rank weed stalks. Mr. Stuart says they breed in large communities on the islands along the GuIf coast, most always placing the bulky nests in mangrove trees: often as many as a dozen nests are built in a single tree; They are made of sticks and weeds, lined with grasses. Many nests are also placed on the ground. Along the gulf coast fresh eggs may be found in May and June. From two to five eggs are laid, three being the most common number. Six selected specimens measure: $2.85 \times 1.95,3.02 \times 2.04$, $3.03 \times 1.87,3.08 \times 1.89,3.00 \times 2.01,3.12 \times 1.87$. They are chalky white, and in every respect, except size, resemble those of the White Pelican.

127. CALIFORNIA BROWN PELICAN. Pelecanus californicus Ridgw. Geog. Dist.-Paicific cowist, from Burrad Islet, British Columbia, to the Gale pagos.

The general habits, nesting and eggs of the Brown Pelican found on the Pacific coast are exactly the same as those of $P$. fuscus. It is a larger bird and has a red

* Ornithologist and Oologist. Vol. VII, p. 130. 
pouch during the pairing season. It is said to breed on islands on the western coast of Mexico, and inland marshes. Breeds abundantly in Honduras, along the coasts and in the interior.

128. MAN-0'-WAR BIRD. Fregata aquila (Linn.) Geog. Dist.-Tropical and subtropical coasts generally; in America, north to Florida, Texas, Ohio, Wisconsin, Kansas, casually to Nova Scotia and California.

This great bird is known by several names, such as Frigate bird, Frigate Pelican, Man-o'-War's bird; and "Hurricane bird." The latter name comes from the West Indies, where its appearance is said to be prognostic of bad weather, always flying low just before a gale. It is a maritime bird inhabiting tropical and subtropical coasts of the globe, but often wanders far from its home in the tropics. A specimen, which is now in the possession of Dr. Renshaw, of Sugar Grove, Ohio, was taken by Mr. Emmet Adcock in Fairfield county, Ohio, in the spring of 1880. The Frigate bird is occasionally met with on the southern coasts of Europe and on those of Africa-on Ascension Island and the Island of St. Helena. In the Atlantic it visits the Bermudas. On the Pacific coast it wanders as far north as San Francisco, and breeds on islands off the coast of Western Mexico. It is said to breed-anywhere on the Gulf coast except at two points at Key West. This bird is noted for its majestic flight and graceful ærial motions, often soaring to sublime elevations. It may be

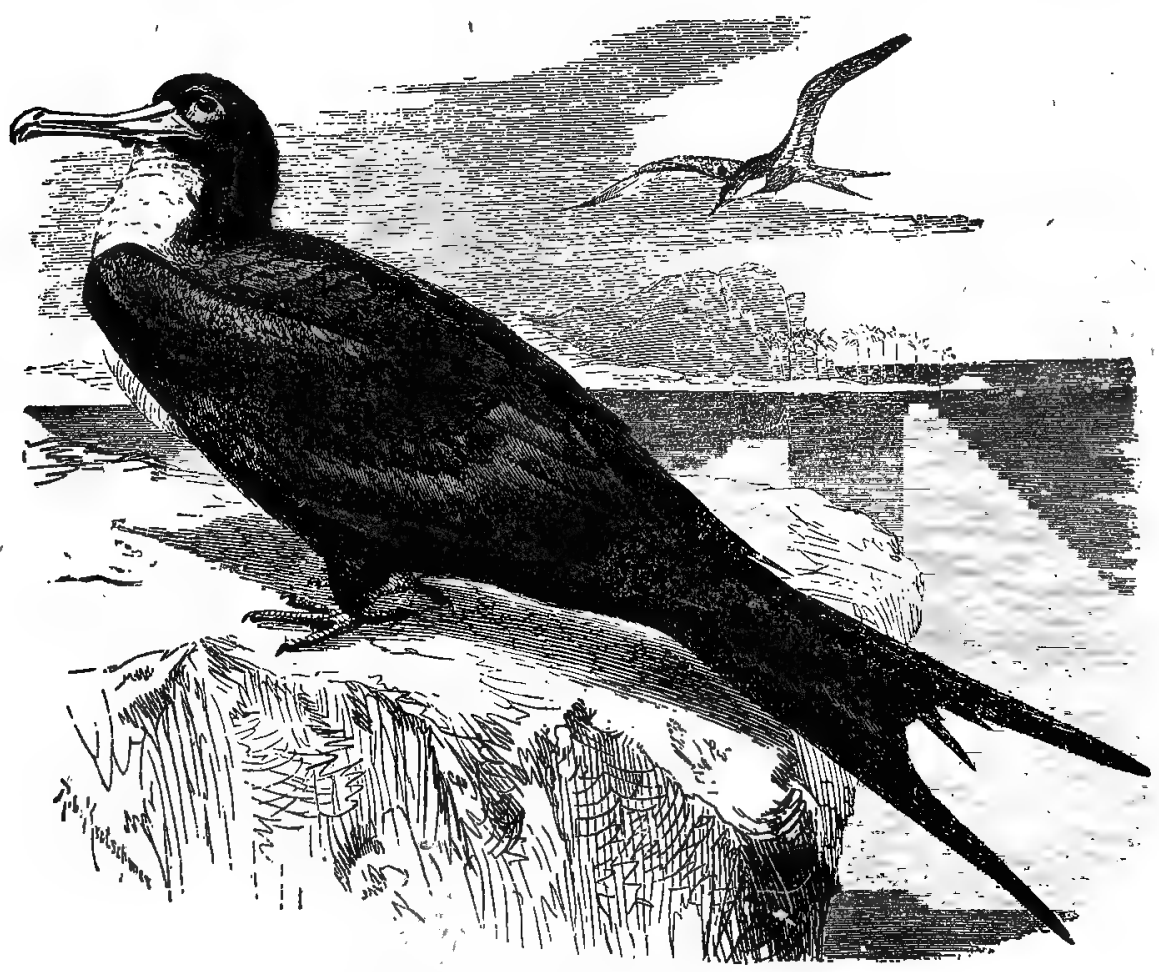

128. MAN-O'-WAR Bird (From Brehm). 


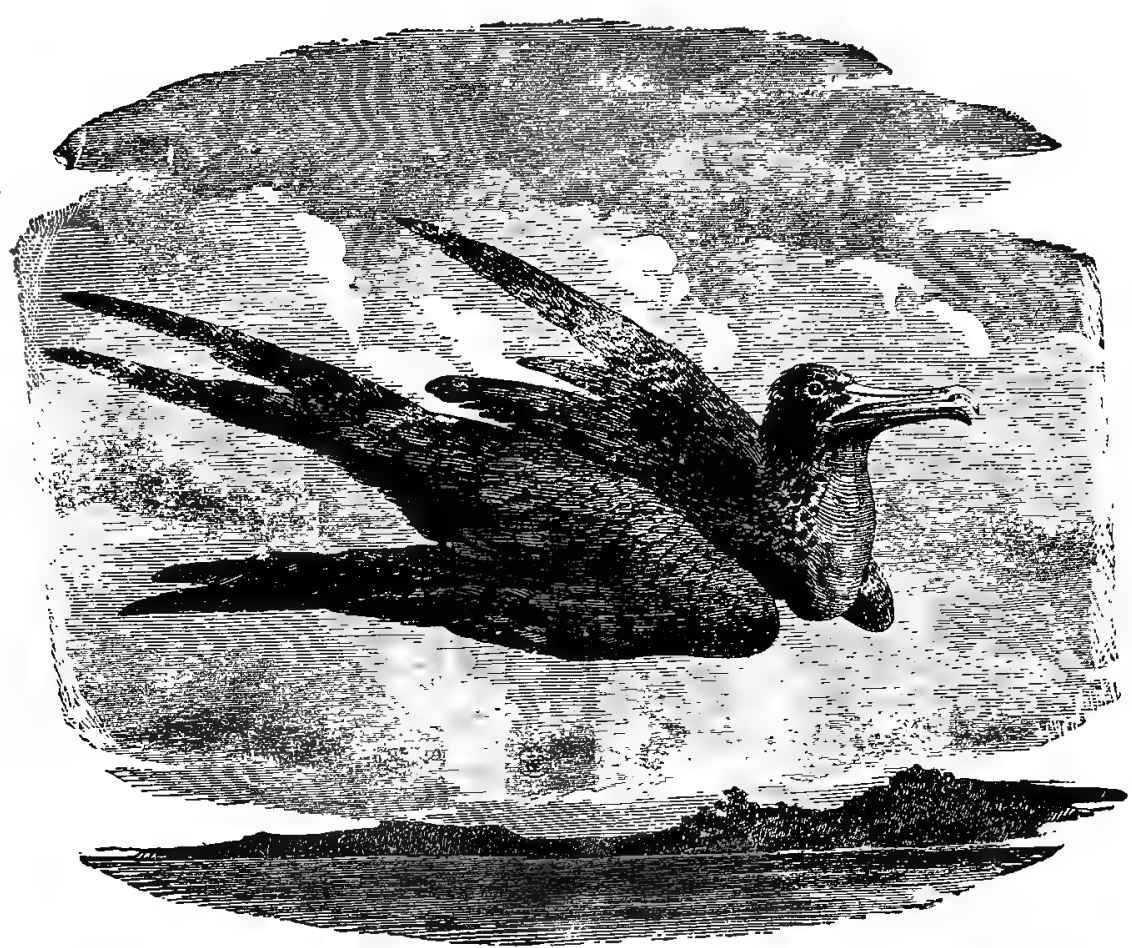

128. MAN-o'-WAR BIRD, in downward tlight

known by its immense wings and deeply forked tail, and colors of brownish-black, glossed with green. It is a constant resident of the Bahamas, breeding on some of the Keys in March. One of the best descriptions ever written concerning the nesting and general habits of this species is that by Walter E. Bryant, entitled: "Rookery" of Man-o'-War Biras," in The Nidologist, September, 1893. From this article I take the following interesting facts: Upon the mangroves bordering a small lagoon on the eastern side of Santa Margarita Island, one of the islands forming the spacious harbor of Magdalena Bay, Baja, California, he found an extensive nesuing colony of this species in 1888-9. If the imagination can picture twice and three times the number of birds which appear in the illustration it will form but a partial conception of the number of individuals congregated about the lagoon-a tidal body of water a few hundred yards in length and not more than eighty wide. The illustration was taken from the most populous portion of the rookery. The eggs are laid in January, only a single one to each nest. Both parents take part in the incubation. The eggs are dull immaculate white, shaped somewhat like' a Gull's egg and averaging $68.7 \mathrm{x}$ 46.9 millimetres. Upon the slight platform of dry twigs composing the nest and not larger in size than a dinner plate, it is surprising that the egg will remain, but most of the nests have more or less projecting bits of twigs which keep the egg in place. The nest shown in the illustration had probably been used once or twice, as il is heavily incrusted with guano of young birds and is of more than average thick- 


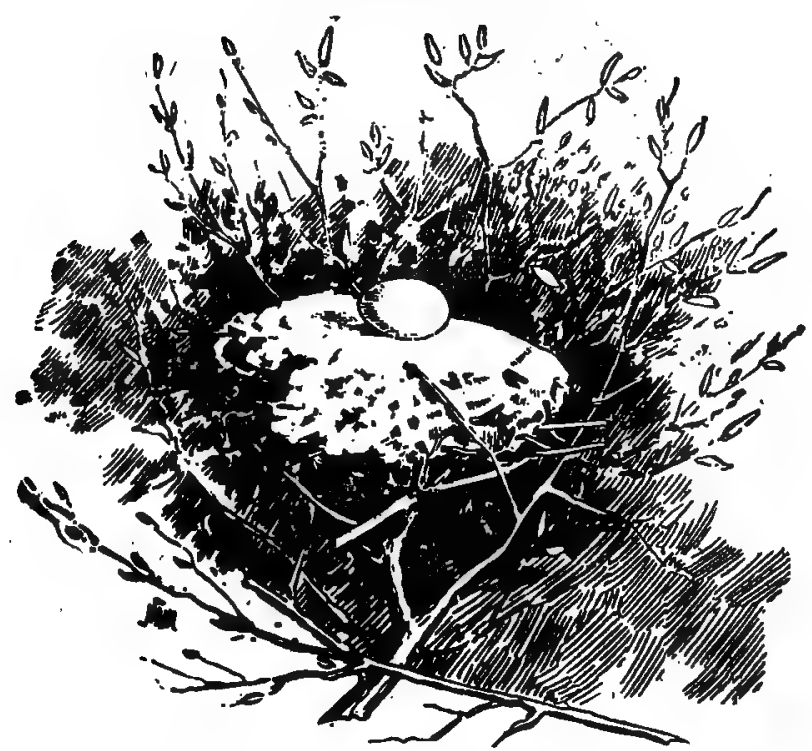

128. Nest and Egg of Man-o'.War Bird (From The Nidologist).

ness, from nesting material added each time it was used. Smooth as it appears Mr. Bryant obtained an egg from it on February 13, 1888. The principal feeding ground was out at sea, but an opportunity was never lost to rob the Cormorants, both of fish and materials brought for their nests. The Cormorants' rookery was in the same locality. An unmistakable odor of guano pervaded the rookeries and was noticeable a hundred yards away to leeward.

229. AMERICAN MERGANSER. Merganser americanus (Ćass.) Geog. Dist.-North Ámerica generally.

The Sheldrake, Goosander or Merganser, as it is variously called, is a common bird throughout North America, breeding from the Northern States northward. It has lately been found breeding in New Mexico; Mr. N. S. Goss having seen a female with four little ones July 2, on the Pecos River.* Is very abundant on fresh as well as salt waters in spring and fall. The three species of Mergansers or Sheldrakes with the "saw-bill" are commonly called "Fish Ducks." Their flesh is rank and unpalatable. The male may be recognized by his larco sice, white breast and green gloss on the head and neck, the latter scarcely crested; the female, which is much smaller than the male, has a deep red head and neck, with the crest better developed; under parts salmon-tinted. The nest is made in hollow trees, after the manner of the Wood Duck, and is composed of moss, leaves and grasses, warmly lined with down from the bird. In Northern Maine eggs are deposited in the latter part of May or the first of June. The eggs are 6 or 8 and sometimes 10 in number; of yellowish or buff color, and measure from 2.50 to 2.80 by 1.70 to 1.80 . Mr. A. B. Call found a nest of this species on West River, a few miles below Newfane, Vt. It was in a hollow tree about 35 feet above the river and 6 or 8 feet below the top of the entrance. This was on May 14, and the nest contained sixteen well incubated eggs. $\dagger$

" Auk, Vol. IV, p. 344.

† The Nidologist, March, 1894. 


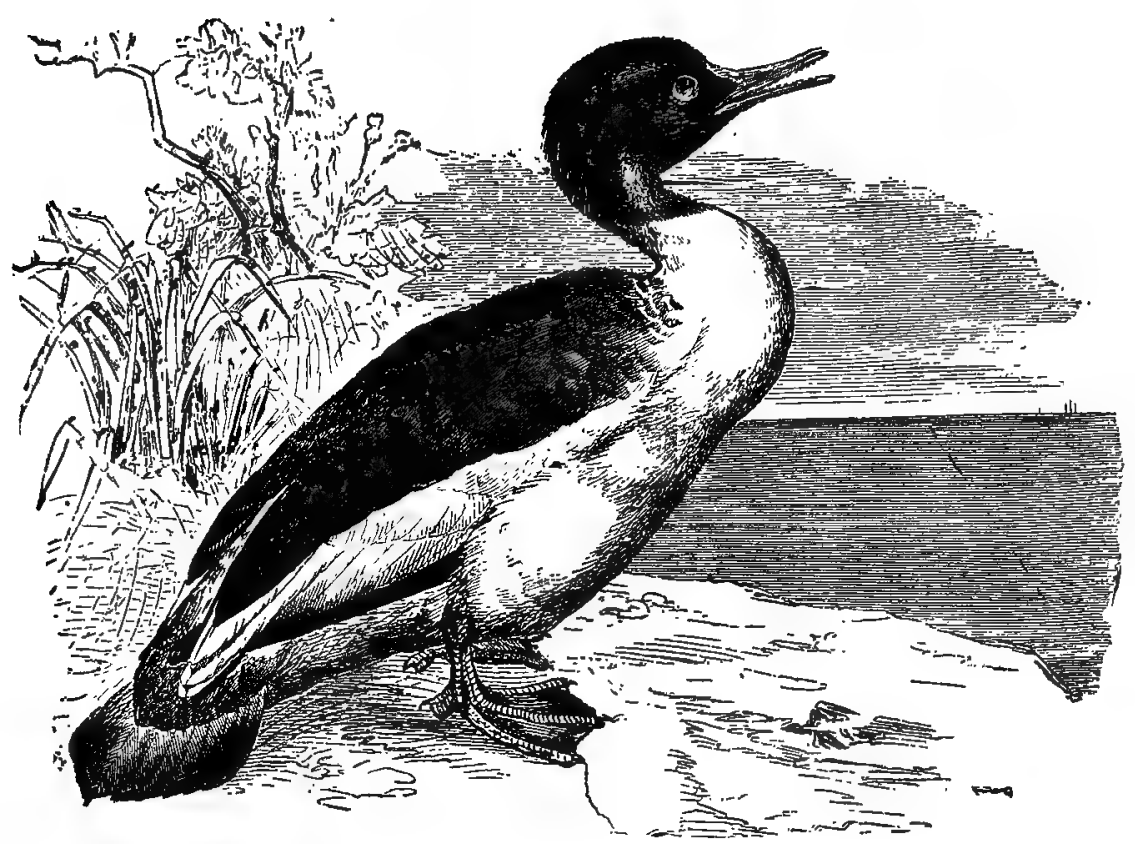

129. Merganserer (From Brehm).

130. RED-BREASTED MERGANSER. Merganser serrator (Linn.) Geog. Dist.-Northern portion of Northern Hemisphere; south, in winter, throughout the United States.

An inhabitant of the more northern portions of the Northern Hemisphere, being common to Europe, Asia and North America. In the latter continent it is more abundant than the $M$. americanus. Very common in the United States in winter, where it is found breeding in suitable localities in the months of May and June. The Red-breasted Merganser breeds abundantly in Newfoundland, Labrador, the fur countries of British America and Alaska. It is a resident of Greenland and Iceland. It nests usually on the ground among brushwood, surrounded with tall grasses and at a short distance from water; most generally it is concealed by a projecting rock or other object. The nest is made of leaves and mosses, lined with feathers and down, which are plucked from the breast of the bird. The number of eggs in a set varies from six to twelve, usually about nine or ten; oval or elliptical in shape, and vary in size from 2.48 to 2.65 long by 1.65 to 1.82 broad. The color is a yellowish or reddish-drab, sometimes a dull buffy-green.

131. HOODED MERGANSER. Lophadytes cucullatus (Linn.) Geog. Dist.North America generally, south to Mexico and Cuba.

This handsome Merganser is an exclusively North American species. In suitable places throughout its range, in wooded districts near water almost wherever it oceurs. it may be found breeding. It nests in hollows of trees or stumps, lining the 


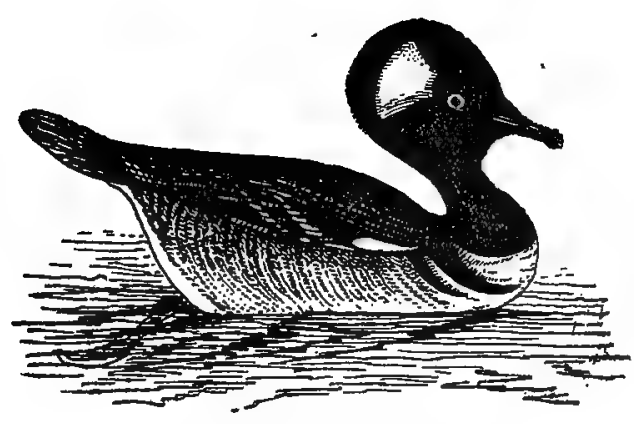

131. Hooded Merganser, Male. cavities with fine grasses, leaves, feathers and down. In some localities the bird is called "Water Pheasant" and "Hairy-head." Anyone can recognize the male of this species by its striking black and white colors and its magnificent, erect, compressed, semi-circular black and white crest. The general color of the head, neck, sides and upper portions of the female are grayishbrown; white beneath, and the crest is not so prominent. As many as 18 eggs have been found in a single nest; ten or twelve, however, appear to be the most common numbers, and often as few as six are laid. They are of a delicate pearly-white, rounded oval and measure from 2.05 to 2.25 long by 1.70 to 1.75 broad.

[131. 1.] SMEW. 'Mergus albellus Linn. Geog.'Dist.-In summer, Northern Europe and Asia; in winter, south to the Mediteranian, Northern India, China and Japan. Accidental in Northern North America.

This is the Nun or the White-headed Merganser of British authors. It is found during the summer months in Northern Europe and Northeastern Asia. In Great Britain it is occasionally met with during the winter. It is admitted to our American fauna upon its accidental occurrence in Greenland.*

132. MALLARD. Anas boschas Linn. Geog. Dist.-Northern parts of Northern Hemisphere; in America south to Panama and Cuba, breeding southward to the Northern United States.

The Green-head, or Mallard, is one of the most highly esteemed ducks, its habitat being nearly cosmopolitan, and almost everywhere domesticated. It is the criginal of our barn-yard duck. A common bird in North America at large, breeding sparingly throughout the United States. In the sloughs and meadow marshes of the northern tier of the states this duck breeds more or less abundantly in the month of June. Rare in New England, scarcely found beyond Massachusetts, and is replaced farther northeast by the Black Mallard, or Dusky Duck. Mr. C. Barlow states that it is one of the most abundant species in California. He found it very numerous about the marshes in the neighborhood of San Jose, eggs being taken May 1. In Greenland, Mr. Hagerup states that the Mallard is common the whole year round. Nests with eggs were found in May and June. The eggs of the Greenland Mallard, he adds, are considerably larger than those of the Danish bird; the former measure $2.36 \times 1.73$, the latter $2.20 \times 1.61$ inches. Mr. A. M. Shields writes me that this is, perhaps, the most common of the ducks in the vicinity of Los Angeles, Cala., breeding from the first of April to the last of June, selecting for its nesting place the tall grass in fields not far from a lake or river. The eggs are six to ten in number, pale, yellowish drab, or olivaceous-green, but most generally the latter color when fresh; elliptical; average size, $2.25 \times 1.25$.

*Cf. Allen, Auk XIII, 1896, 164, 243. 
133. BIACK DUCK. Anas obscura Gmel. Geog. Dist.-Eastern North America, west to Utah, Texas, north to Labrador, breeding from the Northern United States northward.

The Dusky Duck, or Black Mallard, is much less common in the interior than along the Atlantic coast. The characteristic and one of the commonest ducks of New England, where it breeds at large, and from thence northeastward, but is most numerous during the migrations. The eggs are from six to twelve in number, usually seven or eight; are elliptical, or nearly so in shape; measure about $2.30 \times 1.70$, and vary from pale buff to pale greenish-buff. Incubation period is from the last of April to the early part of June. The nest is placed on the ground, in grass or rushes in the neighborhood of ponds, pools, and streams, in meadows and sometimes in swamps. It is a large and neatly arranged structure of weeds and grass, nicely hollowed and lined with down and feathers from the breast of the bird.* In rare instances it has been known to nest in the hollow of a tree, or a "stub" projecting from the water of a swamp. Mr. Frazar found the nest of this Duck in Labrador usually placed upon the "outreaching branches of stunted spruces," which are seldom higher than four feet. The bird may be known by its resembling the female of the Mallard, A. boscllas, but darker in color.

134. FLORIDA DUCK. Anas fulvigula Ridgw. Geog. Dist.-Florida, Kansas.

This is a local, lighter colored species, which is resident in Florida. They are smaller than the northern birds. The eggs are deposited during the first and second weeks in April. They are similar to those of the Black Mallard, but smaller, averaging $2.15 \times 1.61$.

134a. MOTTLED DUCK. Anas fulvigula maculosa (Senn.) Geog. Dist.-Eastern Texas and north to Kansas.

The types of this subspecies were taken by Mr. J. A. Singley in the latter part of March and the first part of April, 1889, in the marshes between the Nueces river and Nueces bay. A male and female were shot and in the oviduct of the female a fully developed egg was found. Mr. Singley informs me that the egg could not be differentiated from those in a set of Florida Duck's eggs, A. fulvigula. Mr. C.: W. Crandall has a set of seven eggs of the Mottled duck, taken in a large marsh near Iberia, La. The nest consisted of a foundation of rushes lined with down, and was placed on top of an old muskrat nest. The eggs are nearly elliptical in shape, of a pale greenish buff color and measure as follows: $2.14 \times 1.57,2.15 \times 1.58,2.23 \times 1.53$, $2.18 \times 1.55,2.25 \times 1.60,2.17 \times 1.60,2.19 \times 1.58$ inches.

135. GADWALL. Anas strèpera Linn. Geog. Dist.-Nearly cosmopolitán. In North America breeding chiefly within the United States.

The Gadwall, or Gray Duck, is a widely diffused species in most parts' of the world: In North America, during the breeding season, it may be found inesting anywhere, especially south of the British Provinces. Common in meadows; and in grain fields near marshes and lakes in Minnesota, nesting in the 'middle of June and depositing from eight to twelve eggs in a cavity of the ground. Mr. A. M. Shields states that this Duck is a resident in the vicinity of Los Angeles, Cal:, but is not met with in great numbers. He found a nest contáining elèvèn eggs on ApriI 16, these were apparently about two weeks incubated.' The nést' was a slight hollow, amongst a thick bunch of weeds, six feet from loé water's edgè; it was com-

* Oology of New England, p. 96. 
posed of fine grass, and feathers from the breast of the bird. The eggs are clay color or creamy buff, elliptical in shape, and measure 2.09 by 1.57 .

136. WIDGEON. Anas penelope Linn. Geog. Dist.-Northern part of the Old World. In North America breeds in the Aleutian Islands. Occurs occasionally in the Eastern United States.

The European Widgeon, in its size and general character, resembles the American Widgeon or Baldpate. In the south of Scotland and throughout England it is an abundant winter visitant; a few remain to breed on the islands of the lochs in the northern portions of Scotland. It breeds in Norway and Swieden, and is the most abundant of the ducks that breed in Lapland, nesting in the grassy swamps and lakes midst tall rushes, the material for the nest being reeds and grasses, with a warm lining of down and feathers from the bird's body. The eggs are five to eight in number, and their color is pale buff; their average size is $2.23 \times 1.53$.

137. BALDPATE. Anas americana Gmel. Geog. Dist.-North America, from the Arctic Ocean south to Guatemala and Cuba.

The American Widgeon or Baldpate inhabits North America at large, breeding anywhere in suitable localities. This is one of the neatest of our ducks, and may be known by the spotted neck and head. The latter is white on top; the speculum green and black; the lower neck, scapulars, sides and upper breast chestnut-red, tinged with ashy, finely banded, all but the breast, with dark brown. The greater upper wing coverts are white, tipped with black, and the under parts are pure white; the bill and feet are grayish-blue. The female is similar, but lacks the.white crown anc iridescence on the head. There is a great variation in the normal coloration of the plumage, aside from age or sex, but as Dr. Coues says: "The bird cannot be mistaken undèr any condition; the extensive white of the' under parts and wings is recognizable at gun-range." The nest of this species is made on the ground and in marshes, composed of grass and weeds, neatly arranged and nicely hollowed; it is usually lined with the down and feathers from the breast of the bird. The eggs are pale buff, eight to twelve in number, measuring 2.00 by 1.50 , with slight variations.

138. EUROPEAN TEAL. Anas crecca Linn. Geog. Dist.-Northern part of the Old World. Casual in Eastern North America and the Aleutian Islands.

This duck, which resembles very closely our American Green-winged Teal, is of Irregular occurrence in Eastern North America. In the northern portions of Europe It is very common, especially throughout Norway and Sweden. Breeds in abundance all over Lapland and in Northern Russia. Mr. Mathew Clugston informs me that this duck is quite common in Scotland, where it nests in the grassy herbage about the edges of lochs. A few breed in various places in Great Britain-as far south as Suffolk, England, and also in Wales. It is known to breed on some of the islands on the west coast of Spain and those on the northwestern coast of Africa. The nest is formed of grasses and reeds, warmly lined with feathers. In scme places this duck's favorite breeding resorts are the bogs and marshes in grassy fields. The eggs are commonly eight to ten in number; and sometimes as many as fifteen are laid. They are yellowish-white, oval in shape, and measure 1.75 in length by 1.30 in breadth. 
139. GREEN-WINGED TEAL. Anas carolinensis Gmel. Geog. Dist.-North America, migrating south to Honduras and Cuba.

This handsome little Duck is exceedingly abundant throughout North America. It breeds from the northern borders of the United States northward to Greenland and Alaska. During the spring and fall migrations it is one of the most abundant of water fowl, frequenting the small brooks and ponds as well as the larger waters. It may be recognized by its small size; the primaries of the wing-covets are of leaden-gray; speculum velvety purplish-black on the outer half, the inner half rich green; bordered in front with chestnut, fawn or whitish tips of the greater coverts, behind by white tips of the secondaries, interiorly with purplish-black stripes on the outer webs of the lengthened secondaries. The head and upper neck of the male are rich chestnut, blackening on the chin, with a glossy green patch behind each eye. There is a white crescent in front of the wing. The female differs in the head markings, but those of the wing are the same. It is a well-known and highly esteemed game bird. The nest is placed on the ground, in a thick growth of grass, and is essentially the same as that of the Blue-winged Teal. The eggs are from five to eight in number, greenish-buff in color, usually ovoidal in shape, sometimes nearly oval, and vary in size from 1.73 to 1.90 long by 1.22 to 1.32 broad.

140. BLUE-WINGED TEAL. Anas discors Linn. Geog. Dist.-North America, but chiefly the Eastern Province; north to Alaska and south to the West Indies and Northern South America.

A beautiful little duck, inhabiting North America in general, but chiefly the eastern portions. During the breeding seasons it is found in the same localities as the Green-wing, but is more abundant in the northern tier of States at that season than the latter. This duck feeds chiefly upon vegetable matter, and its flesh is tender and luscious. It may be known by its small size, blue wings and narrow bill. The feet are yellowish. The male has a white, crescent-shaped spot in front of the eye. The female is brown throughout, with the feathers edged with whitish which becomes prominent below. The nest is made on the ground, in a thick patch or tussock of grass, usually in meadows, the border of ponds or streams and swampy places. It is composed of soft pieces of grass and weeds, lined with down and feathers from the breast of the bird. The eggs are greenish or buff, lighter in color than those of the Green-winged Teal; they vary from ovate to ovoidal, and are sometimes nearly oval in shape; six to ten and twelve in number, and vary in size from 1.30 to 1.35 broad by 1.90 to 1.95 long.

141. CINNAMON TEAL. Anas cyanoptera Vieill. Geog. Dist.-Wastern America, from the Columbia River south to Chili, Patagonia and Falkland Islands; east in North America to the Rocky Mountains; casual in the Mississippi Valley; accidental in Ohio-Davie.

This pretty South American Teal is abundant in the United States west of the Rocky Mountains, and breeds anywhere in this range; Colorado, Utah, Nevada, California, Idaho, Oregon, etc. In the adult male the head, neck and under parts are rich chestnut, the wing coverts are sky-blue, as in the Blue-winged Teal. The speculum is green and is set between the white tips of the greater coverts and the secondaries. Its habits on the whole do not differ from those of its well-known ally, the Blue-wing. Mr. A. M. Shields regards it as common in the vicinity of Los Angeles, where it breeds in great numbers; nesting in the first week of May. Its favorite breeding places are in fields of tall grass or clover, in close proximity to 
water. He says the complement of eggs ranges from nine to thirteen, and that the nest is so compactly woven of grass, feathers and down that the entire structure may be picked up without its coming apart. It gives me pleasure to be able to add this beautiful duck to the avifauna of Ohio as an accidental visitor. On the 4 th of April, 1895, a fine male of this species was killed, together with a number of ducks, at the Licking County Reservoir, by William Harlow. On the 6th I skinned and mounted this specimen and it is now one of the rare Ohio birds in my collection. It proved to be good eating. This, I believe, is the first record of the Cinnamon Teal ever having been taken in the state. The eggs of this species are creamy-white or pale buff; six to twelve; one end smaller than the other. In my cabinet there is a set of ten eggs collected by Dr. James C. Merrill, near Fort Klamath, Oregon, June 14, 1887; they exhibit the.following dimensions: $1.90 \times 1.38,1.82 \times 1.37,1.88 \times 1.39,1.90 \times 1.38,1.92 \times$ $1.39,1.88 \times 1.38,1.85 \times 1.40,1.94 \times 1.38,1.89 \times 1.36,1.83 \times 1.34$; the average size is $1.88 \times 1.38$. The nest was built at the edge of a marsh; it was made of grass blades and stems, warmly lined with down.

141. 1. RUDDY SHELDRAKE. Casarca casarca Linn. Geog. Dist.-Southern Europe and Southern Asia, south to northern Africa. Accidental in Greenland, Iceland and the Scandinavian Penisula.

Called also Casarka Sheldrake. It is found in Southern Europe, Asia and Russia; accidental in Greenland. Mr. C. W. Crandall has a set of eight eggs of this species in his oölogical collection which was taken June 2, 1893, in Southern Russia. Their measurements are $2.60 \times 1.89,2.55 \times 1.90,2.48 \times 1.87,2.42 \times 1.82,2.48 \times 1.83,2.55 \times 1.87,2.51 \times$ $1.86,2.53 \times 1.86$, respectively They are of an exact ovate in shape of a pale cream shade, almost of the same tint as that found in the Wood Duck's eggs

142. SHOVELLER. Spatula clypeata (Linn.) Geog. Dist.- Northern Hemisphere. In North America. Breeding from Alaska to Texas. Not abundant on the Atlantic coast.

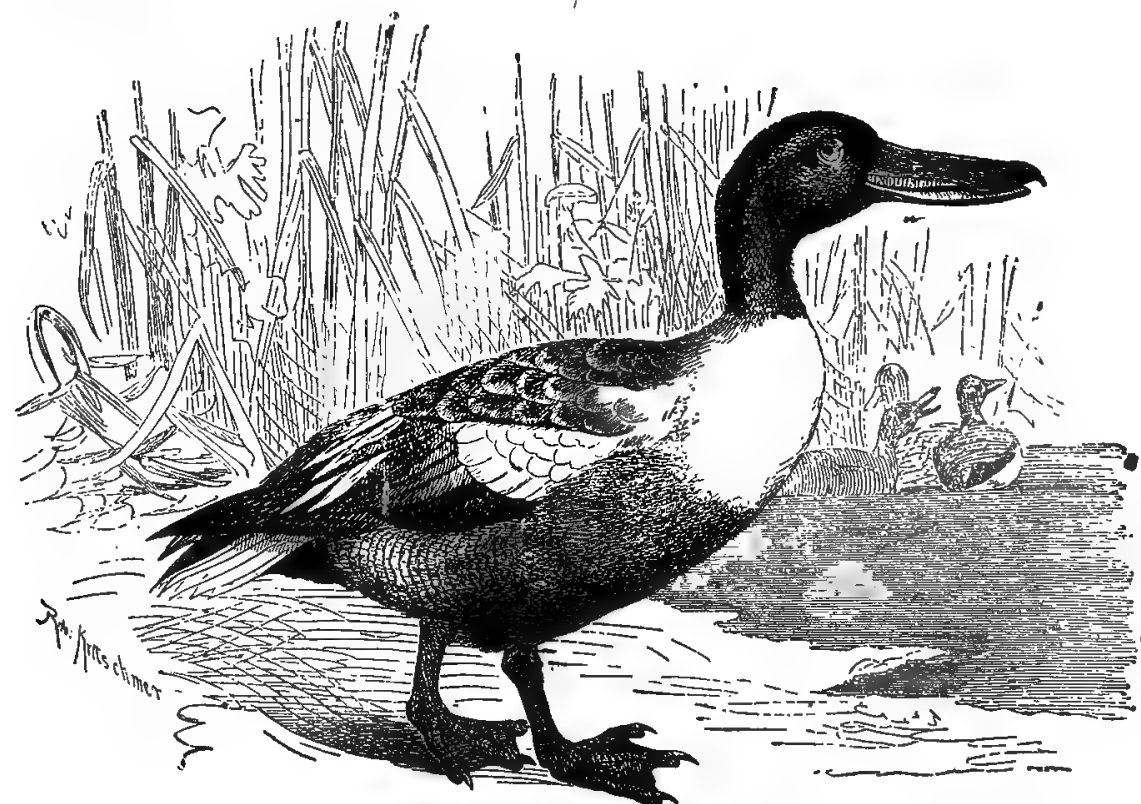

142. Shoveleer (From Brehm). 
The Shoveller, or Spoonbill Duck, is common in the noruern portions of the globe. Said to have the most extended distribution of any species of the duck tribe, being more or less common in every portion of Europe and Asia, except in the extreme north; is found in Northern and Central Africa, and other portions of the tropical world. It is not common in England, where it breeds sparingly, but is more abundant in Scotland. In North America this peculiar-looking duck breeds tnroughout its range in all suitable places; it winters chiefly in the south. It may easily be recognized by its broad bill, blue wing coverts and green speculum. The iris is yellow and the feet bright orange. The spoonbill makes his nest on the ground in boggy places which are difficult of access. It is composed of grass and weeds. The eggs are greenish-gray, or faintly bluish; elliptical; s1x to ten in number; averaging in size about 2.10 by 1.50 .

143. PINTAIL. Dafila acuta (Linn.) Geog. Dist.-Northern Hemisphere. In America migrates south to Panama and Cuba.

In North America the Pintail, or Sprig-tail, is a common species everywhere, being found as far north as Greenland and the Arctic coast, and south to the Isthmus of Panama and to Cuba, breeding from the Northern States northward tnroughout

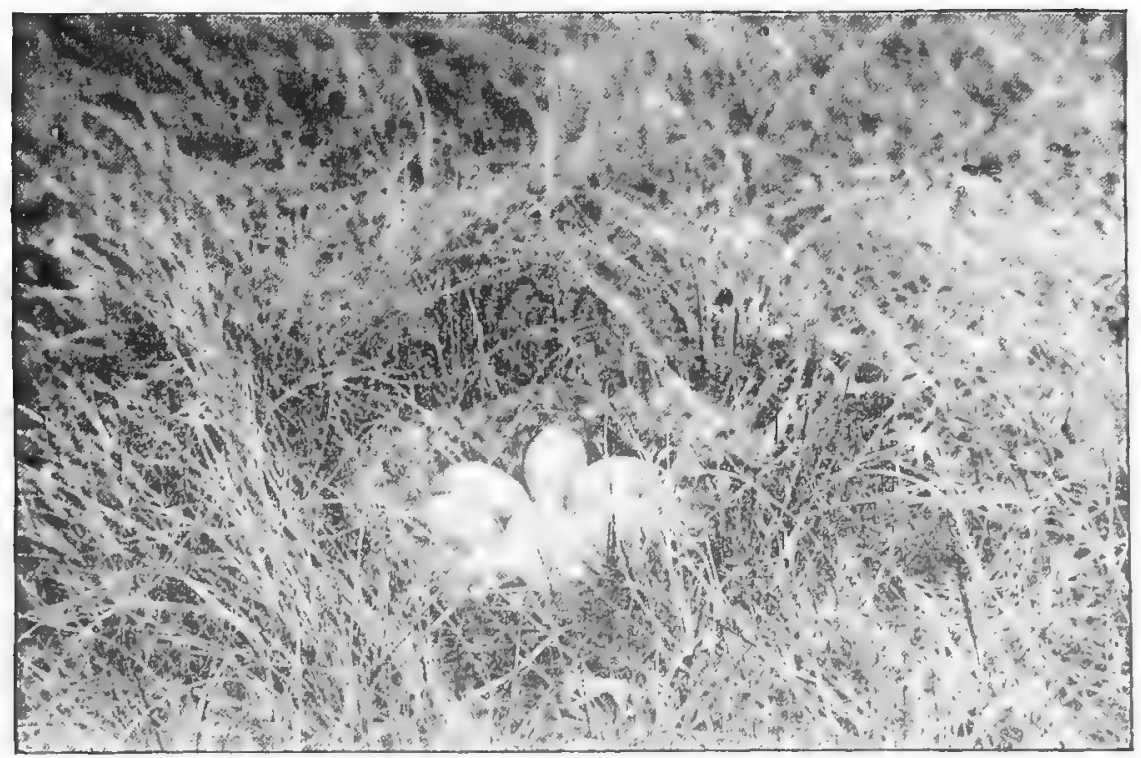

Nest and Eggs of the Pintall Duck. (Photo. by W. Raine.)

the Fur Countries to Alaska, and in Greenland. It is abundant in the United States during the spring and fall migrations. In the vicinity of Los Angeles, California, Mr. Shields says it is very abundant during the entire winter, and a few remain to breed. The place usually selected for the nest is in tall buncues of prairie grass, seldom far from water. The number of eggs laid is commonly eight or nine; these are deposited about the middle of May. If the eggs are taken the bird will immediately deposit a second set, which is seldom more than five or six in number. 
The male bird, inclusive of the long central tail-feathers, is about twenty-nine inches long; the general color of the upper parts is grayish, delicately penciled with white; either sex may be known by the very long and slender neck, but the female is shorter, being about twenty-two inches long, the central tail feathers making a difference of seven inches. In the far north this species deposits as many as twelve eggs in a single nest. These are of a dull grayish olive; elongate ellipsoidal in shape and measure from 2.10 to 2.30 long by about 1.52 broad.

144. WOOD DUCK. Aix sponsa (Linn.) Geog. Dist.-Temperate North America, breeding throughout its range.

An exquisite bird, the most beautiful of all our ducks; in fact, no description can give a sufficient conception of the variety and lustre of its plumage. It is crested, the head iridescent green and purple, with parailel curved white superciliary and post-ocular stripes and a broad white throat patch. The iris and edges of eyelids are red. In the female the head is mostly gray. A freshly-killed specimen has all the variegated tints to be seen in the rainbow. It is well-named Bridal Duck. It inhabits North America at large and is especially abundant in the United States, breeding almost wherever found. Frequents the wooded portions of the country

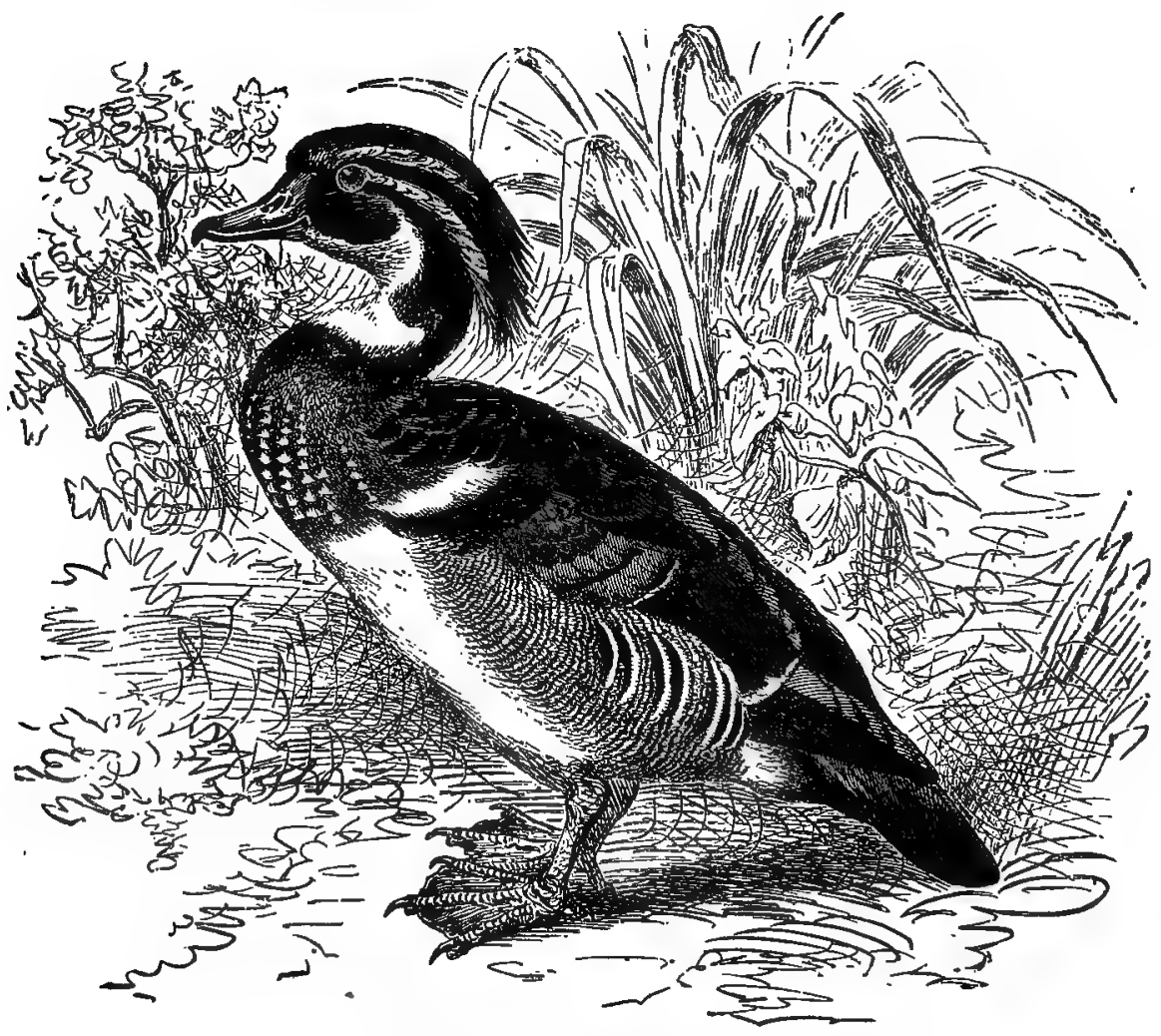

14. Wood Duck (From Brehm). 


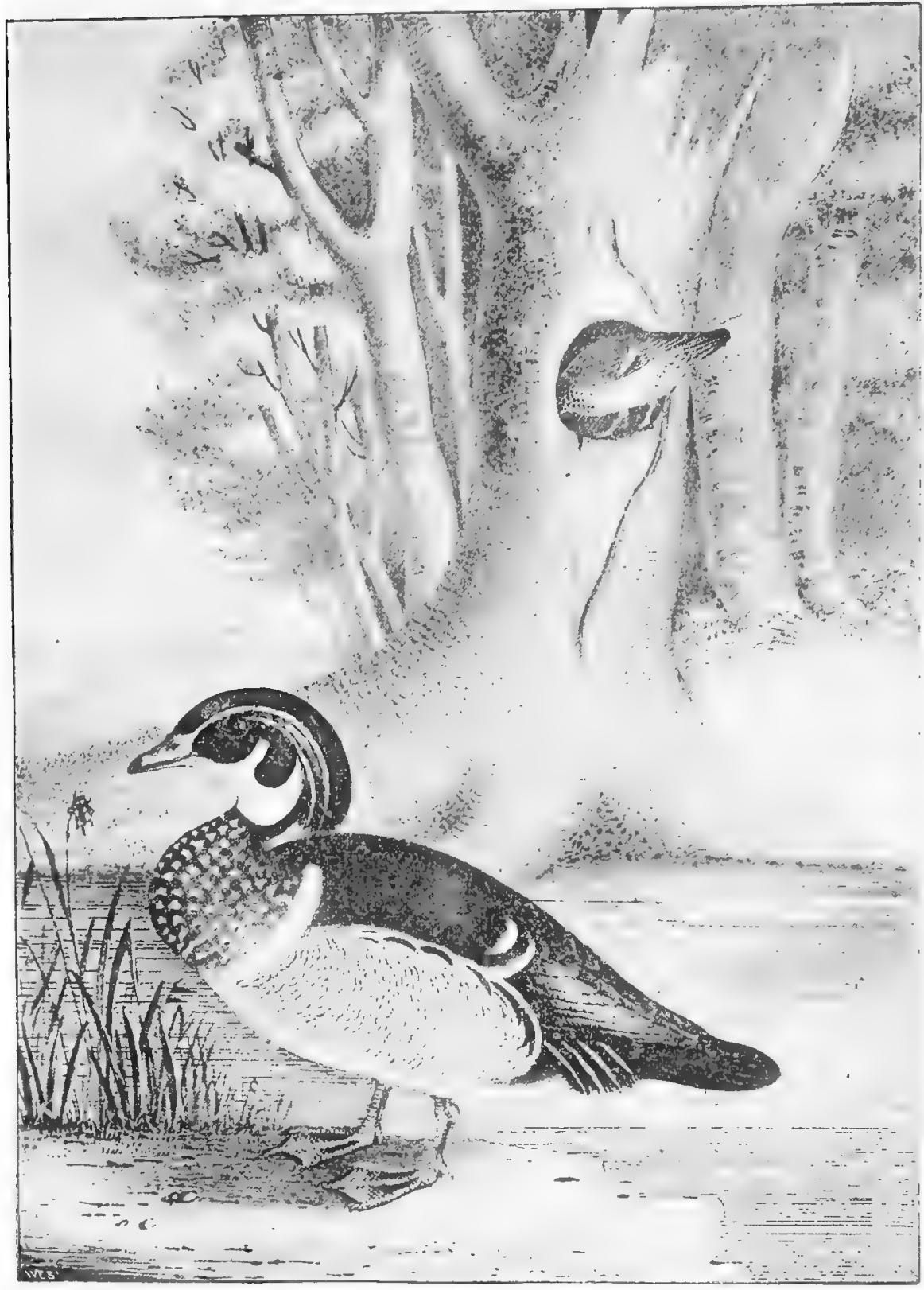

144. Wood Ducks and Nestikg Place. 
near water. The nest is made in the hollow of decayed trees, often at the depth of four to six feet. It is composed of twigs, weeds or grass, warmly lined with the down from breast of the bird. What is remarkable about the entrance to the nest is, that it is often so small that it would seem almost impossible for the bird to pass in and out. The tree in which the nest is made is frequently situated a considerable distance from water in some retired place. The young are carried to water in the bill of the parent bird. The eggs number from eight to twelve, and I have seen several sets of fourteen; they are of a pale buff color, averaging in size about 2.00 by 1.50 , but there is a great variation in this respect when a large series of specimens from different parts of the country are examined. When robbed of its eggs the bird will often lay a second set.

145. RUFOUS-CRESTED DUCK. Netta Rufina (Pall.) Geog. Dist.-Eastern Hemisphere; accidental in the United States.

The claim of this species to a place in the North American fauna rests on a single specimen obtained in Fulton Market, New York City, February 2d, 1872. It is supposed to have been shot on Long Island Sound. The bird- is found in Southern and Fastern Europe, and in portions of Africa and Asia. The eggs are described as being of a pale olive-buff and measure 2.32×1.68; not distinguishable from those of the next species.

146. REDHEAD. Aythya americana (Eyt.) Geog. Dist.-North America, breeding from California and Maine northward.

The Redhead or Poachard, so frequently confounded with

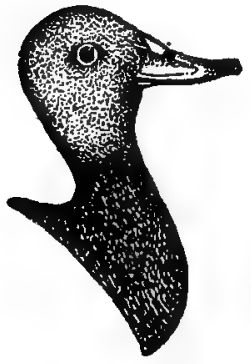

146. REDHEAD. the Canvas-back, is a common duck throughout North America. It breeds in all parts of the Fur countries and is very abundant in the marshes of Manitoba throughout the summer months. It nests in suitable localities of various northern states, Maine, Michigan, Wisconsin, Minnesota and Dakota. The Redhead also breeds in the marshes of California. Mr. Shields mentions it nesting in a swamp near Los Angeles about the middle of June.* The nest is built on the ground in thick grass or weeds and is composed of aquatic plant stems and grasses, lined with the down and feathers from the breast of the bird. The nest is often constructed in a mass of reeds over water after the manner of a Coot's. Mr. Shields found the nests to contain from seven to fourteen eggs. Eight or ten are more commonly laid further north. They are creamy-white, elliptical, and average 2.40 by 1.70 , with slight variation.

147. CANVAS-BACK. Aythya vallisneria (Wils.) Geog. Dist.-Nearly aIl of North America.

The celebrated Canvas-back Duck is an exclusively North American species, found in the interior and on both coasts as far north as the Arctic Ocean and southward to Central America. Breeds on the interior marshes, rivers and lakes frcm

- Young Oologist, a magazine devoted to the study of birds, their nests znd eggs, published by Frank H. Lattin, Albion, N. Y., Vol. I, p. 90. 
the Northwestern States to Alaska. Nests commonly in many of the lakes and ponds of Manitoba. On the marshes and lakes in the mountain valleys of Oregon the Canvas-back constructs its nest at the edge of the water or near it in tall rushes or grass. The Canvas-back is the highly esteemed table duck. When feeding on wild celery the flesh is said to acquire a peculiarly fine flavor, but under other circumstances not one person in ten thousand can tell it from any other duck, on the table. It is often confounded with the Redhead, but there is no occasion for this, even when the different sexes come to hand in any state of plumage. Although both species are similar in. plumage, their heads alone will' differentiate them. The Redhead has a high forehead, while the Canvas-back's head slopes gradually down to the bill and the bill rises high on the forehead. In the male Redhead the entire head is clear chestnut

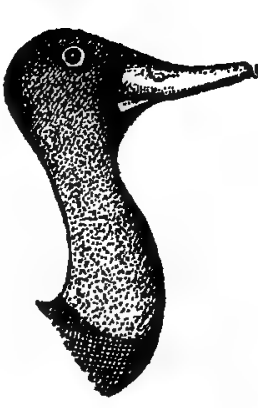

147. Canvas-Back. red, with a coppery tint, and the bill pale grayish-blue, with a dark tip. In the Canvas-back nearly the whole head is blackish-brown, and the bill blackish. The general color of the females of both is brownish throughout. The nest of the Canvas-back is generally made on the ground in marshy places; tall, rank grass is usually selected. It is composed of grass and weeds, less thickly lined with feathers than the nests of other ducks are. The eggs are from six to ten in number, pale grayish-drab or greenish-buff, elliptical, and measure from 2.25 to 2.50 long by 1.70 to 1.75 broad.

148. AMERICAN SCAUP DUCK. Aythya marila nearctica Stejn. Geog. Dist.-North America, breeding far north.

This and the next species are closely allied, and are variously known as Bluebills, Raft Duck, Floating Fowl and Shufflers. This one is called Big Blackhead or Greater Scaup Duck, on account of its size. It inhabits the whole of North America, and breeds far north. It is not so abundant in the United States as the next species. In many of the river valleys and in the lakes of Manitoba it is a common summer resident, where it nests on the ground in swampy places. The nest material is grass and weeds, and the lining is down from the breast of the bird. In the male the head, neck and the front part of the body are black, the former with a green gloss; the back and sides whitish, finely waved in zig-zag with black; underneath and speculum of wing is white. The bill is blue, with black nail; iris yellow. In the female the head and anterior parts brown; face pure white. The eggs of the American Scaup Duck are of a pale, buffy olive-gray, or ashy-green, elliptical, six to ten in number, size $2.54 \times 1.71$.

149. IESSER SCAUP DUCK. Aythya affinis (Eyt.) Geog. Dist.-North America in general, migrating south to Guatemala and the West Indies.

As its name indicates, this species is smaller than the last, to which it is very similar. Breeds chiefly north of the United States. It is a common summer resident in the lakes, marshes, ponds, and rivers of Western Manitoba and throughout other portions of the fur countries northward. Its nesting habits and its eggs are the same as $A$. marila nearctica. The average size of the eggs is about $2.25 \times 1.58$.

150. RING-NECKED DUCK. Aythya collaris (Donov,) Geog. Dist.-North America, migrates south to Guatemala and the West Indies. 
Ring-billed Blackhead, Marsh Blue-bill and Ring-necked Scaup Duck are names by which this species is commonly known. In the United States it is a common spring and fall migrant, and breeds from Maine, Minnesota, Wisconsin, and other northern States northward. In some parts of Manitoba it is very abundant, especially in the Red River Valley, where it breeds in the marshes of the lakes and ponds, among the reeds and thick grasses. The nest is made of fine grasses, and slightly lined with feathers. In its general appearance, the bird is similar to the foregoing, but the adult male has an orange-brown ring around the neck; the female has no collar, and the head and neck are brown. This bird may be known in all stages of plumage by the broad bill and gray speculum. The Ring-neck lays from six to twelve eggs, varying from grayish to buff color; they are elliptical in shape, and measure from 2.25 to 2.30 by 1.60 to 1.65 .

151. AMERICAN GOLDEN-EYE. Glaucionetta clangula americana (Bonap.) Geog. Dist.-North America, breeding from Maine and the British Provincrs northward; migrates south to Cuba.

The American Golden-eye, Whistler, Garrot, or "Great-Head," is very similar to the next species. It has a large round white spot before the eye, not touching the base of the bill throughout. It is given the name of Whistler from the peculiar noise of the wings while flying, and Great Head from its large and beautifully created head. It is an abundant species throughout the fur countries, where it frequents the rivers and fresh-water lakes in great numbers. Breeds as far north as Alaska, where, on the Yukon, it nests about the middle of June. Like the Wood Duck, it constructs its nests in hollow trees and decayed trunks. It is made of grass, leaves, and moss, lined with down from the bird's. breast. The eggs are from six to ten in number, ashy green in color, rounded-oval in shape, and measure from 2.30 to 2.55 long by 1.70 to 1.78 broad.

152. BARROW'S GOLDEN-EYE. Glaucionetta islandica (Gmel.) Geog. Dist.-Northern North America, south in winter to New York, Illinois and Utah. Greenland; Iceland.

The Rocky Mountain Garrot, or Golden-eye, is almost exclusively a North American species, breeding, from the Gulf of St. Lawrence in the east and the

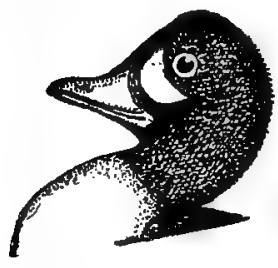

152. Barrow's Golden-eye. mountains of Colorado in the west to high northern regions. It is a resident of Greenland and Iceland. It may be known by the large triangular white spot before the eye running up to a point, applied against the entire base of the bill and the division bf the white area on the wing. The head is moderately puffy, with an occipital crest, and the color of the gloss is chiefly purple and violet. The bill is black or greenish-dusky and the iris golden-yellow. In the female the head is snuff-brown and no white patch in front of the eye. This bird, like the last, makes its nest in hollow trees, of grass, sticks and weeds, lined with feathers. Mr. Edwin Carter was the first to find the nest and eggs of this species in the mountains of Colorado in 1876. From six to ten eggs are laid, these are usually elliptical in shape, and measure from 2.25 to 2.30 long by 1.60 to 1.65 broad.

153. BUFFLE-HEAD. Charitonetta albeola (Linn.) Geog. Dist.-North America; south to Cuba and Mexico. Breeds from Maine northward, through the Fur Countries and Alaska. 
This duck is variously named, as Butter-ball, "Dipper," “Butter-box," "Spirit Duck" and "Hell-diver." It dives with the greatest of ease, slipping under the water almost as quickly as a grebe. Its expertness in diving enables it to obtain food in very deep water. The Buffle-head is peculiarly an American species, but of accidental occurrence in Europe. In Manitoba and throughout all the fur countries it is a common summer resident, breeding as far north as Alaska. The nests are concealed in hollows of trees or stumps, near the banks of streams. They are lined with down and feathers. The Butter-ball breeds occasionally in Northern Maine. In the United States it is an abundant spring and fall migrant, and in many places al winter resident. The male is one of the handsomest of our small ducks. The head is particularly puffy, of varied rich iridescence, with a large showy white patch on each side behind the eye. The broad black and white pattern of his upper coat stands out in strong contrast against a glossy white breast. The female is smaller and a very insignificant looking duck; the head is scarcely puffy, dark gray, with traces of the white auricular patch. The eggs of this duck vary from buff to a creamy-white or grayish-olive; ellipsoidal in form and range from six to fourteen in number; sizes from 1.95 to 2.05 long by 1.35 to 1.50 broad.

154. OLD-SQUAW. Clangnla hyemalis (Linn.) Geog. Dist.-Northern hemisphere; in North America south to the Potomac and the Ohio. Breeds far northward.

The Long-tailed Duck, Old Wife or South-southerly, as it is variously called, is distributed throughout the northern portions of the globe, making its summer home in Arctic regions. A resident in Greenland and breeds in various places in

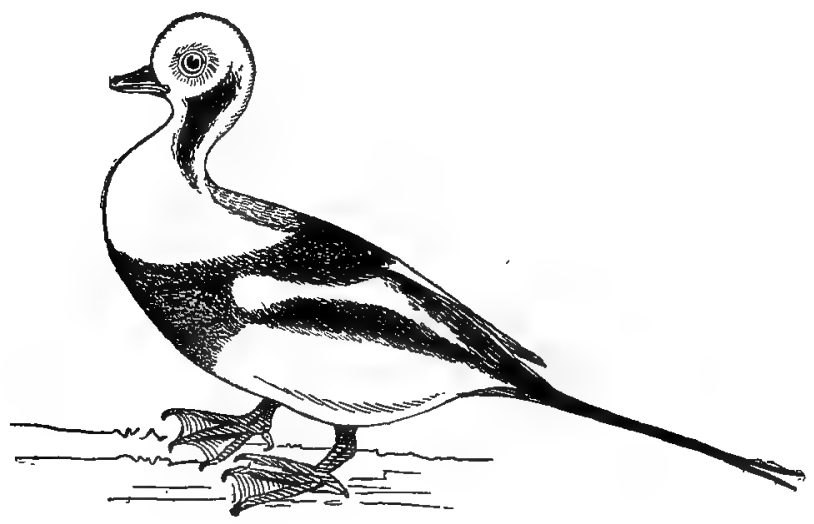

134. Old Sguaw or Long-tailed Duck, Male,

lceland. The nests are made on the margins of lakes or ponds, among low bushes or tall grass; they are constructed of grasses and generally, but not always, warmly lined with down and feathers. The eggs are from six to twelve in number. The Long-tailed Duck inhabits the more northern countries of Europe-a winter visitant to Great Britain, and it is found occasionally in Germany and France. Abundant on the sea coast of Alaska, is resident on the Prybilof and Aleutian Islands. In the United States it is found only in winter. The male of the Old-squaw is a handsome. duck, and may be recognized by its long tail and peculiar reddish-brown and brownish-black and white markings. The female lacks the lengthened tail-feathers. 
and is, on the whole, a very inferior looking bird. The eggs of this species average 2.05 by 1.49; they are pale, dull grayish pea-green, varying to dull light olive-buff.

155. HARLEQUIN DUCK. Histrionicus histrionicus (Linn.) Geog. Dist.Northern North America.

The beautiful and singularly marked Harlequin "is an inhabitant of the southern part of the circumpolar zone." It is not common wherever found. In many parts of the old World it is only a rare or an occasional visitor; this is the case in Great Britain, France and Germany. It breeds in several places in Southern Greenland, according to Mr. Hagerup. At the commencement of the breeding season it leaves the sea coast and retires to the lakes and rivers of the interior regions. A summary of this bird's breeding range is given by C. Hart Merriam, as follows: "In Siberia it is known to breed about Lake Baikal and in the Bureja Mountains

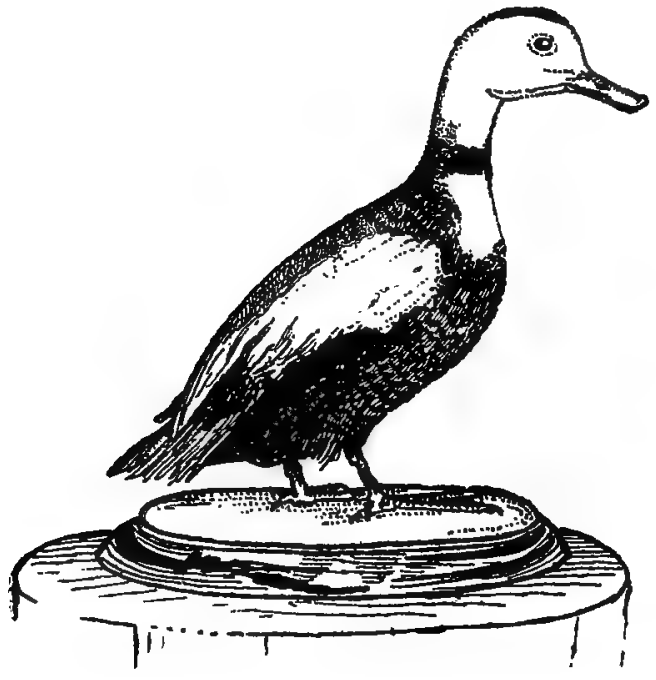

156. LABRADOR DUCK.

(Radde); in Mantchuria and at various points in the great Stanowi Range (Von Middendorff); about the Upper Amoor (Von Schrenck), and in Kamtschatka. On the American continent it has been found breeding along the tributaries of the Yukon in Alaska (Dall); in the interior of the fur countries and about Hudson Bay (Richardson); on the fresh water ponds of Labrador (Audubon), and in the Rocky Mountains within the limits of the United States (in Montana, Coues). It also nests in Newfoundland, Greenland, and Iceland (Kruper)."* Dr. Merriam says that all accounts agree that this duck nests on the ground in close proximity to swiftly running water, and states that he is also informed that in Newfoundland the nests are built in hollow trees. In some of its breeding grounds it is said to lead a solitary life, being found alone or in pairs in the most retired places on small streams. The nest is composed of weeds, grass, etc., warmly lined with down and feathers from the breast of the bird. When the female leaves the eggs she carefully covers them up

* Büll. Nutt. CIub, VII, 220. 
with down. In some places the Harlequins are called "Lord and Lady Ducks." The male is second only to the Wood Duck in beauty, and the female will bear no comparison to the same sex of that species. The eggs are six to eight in number, rounded oval, yellowish-buff or greenish-yellow, and measure $2.30 \times 1.62$.

156. LABRADOR DUCK. Camptolaimus labradorius Gmel. Geog. Dist.Formerly Northern Atlantic coast, from New Jersey (in winter) northward, breeding from Labrador northward. Now extinct.

The nest and eggs of this bird are unknown and the bird is extinct. The last example taken was shot near Elmira, New York, in 1878. There are only thirty-six specimens known to be preserved in the museums of the world. The specimen represented in our illustration is one which was collected by no less a person than Daniel Webster, and is figured by Audubon." This duck was shy and difficult of approach, a strong swimmer and of rapid flight. Its extinction seems strange and unaccountable.

157. STELLER'S DUCK. Eniconetta Stelleri (Pall.) Geog. Dist.-Aretic and sub-Arctic coasts of Northern Hemisphere.

The summer home of Steller's Duck is in very high Arctic latitudes. It breeds in Northern Russia, in Europe and in Siberia, nesting in the latter part of June, depositing from seven to nine eggs. It is said to breed on the inaccessible rocks of Kamtschatka, on the islands of Bering Sea, and sparingly on some of the Aleutian Islands. In its habits it resembles the Common Eider. The nest is placed on the ground and is made of grass, thickly lined with down and feathers from the breast of the bird. Dr. Coues says the bird is not yet common in collections, though abounding and sometimes gathering in enormous flocks on the islands and both shores of Bering Sea and the Arctic coast of Northeastern Siberia. It winters mainly on the Aleutian Islands, and iș usually found in company with the Pacific, Spectacled and King Eiders. The eggs vary from pale olive-buff to pale olive or pale green and measure 2.30 by 1.62 .

158. SPECTACLED EIDER. Arctonetta fischeri (Brandt.) Geog. Dist.Coast of Alaska, north to Point Barrow.

This Eider with a peculiarly dense and puffy patch of velvet feathers about the eye, suggesting spectacles, has nesting habits similar to the American Eider, $S:$ dresseri. The eggs are also similar. It inhabits the islands and coasts from Norton Sound northward to Point Barrow. On St. Michael's Island, Alaska, it breeds in company with the Pacific Eider S. v-nigra. The eggs measure from 2.35 to 2.57 long by 1.55 to 1.85 broad.

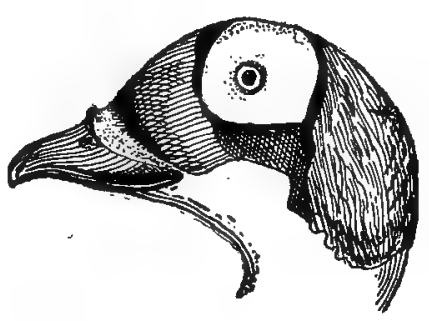

158. Spectacled Eider.

159. NORTHERN EIDER. Somateria mollissima borealis (A. E. Brehm.) Geog. Dist.-Northern Europe and, Northeastern North America, including Greenland and Northern Labrador, south in winter on the Atlantic Coast to Maine.

The Eider, so famous for its down, which has become an article of commerce and luxury, is common along the Northern Atlantic coasts of Europe and America. The great demand for its down has caused the inhabitants of Iceland, Norway and

* From U. S. National Museum Report, 1889. 
other parts of Europe to protect it during the breeding season. In these places the Eider becomes very tame. It is a resident of Greenland, where it nests in the latter part of June or the first week of July. On some of the small islands on the coast of Iceland it has become almost domesticated, breeding in vast numbers, nesting on the grassy banks, between large stones, on rocks, and in every available hollow which will hold the nest. The nest is made of sea weed, lined with the down plucked from the breast of the bird. This is augmented as incubation proceeds and the quantity of down often becomes so great that the eggs are concealed from view. The eggs range from six to ten in number, greenish drab, and measure 2.97 by 2.01 .

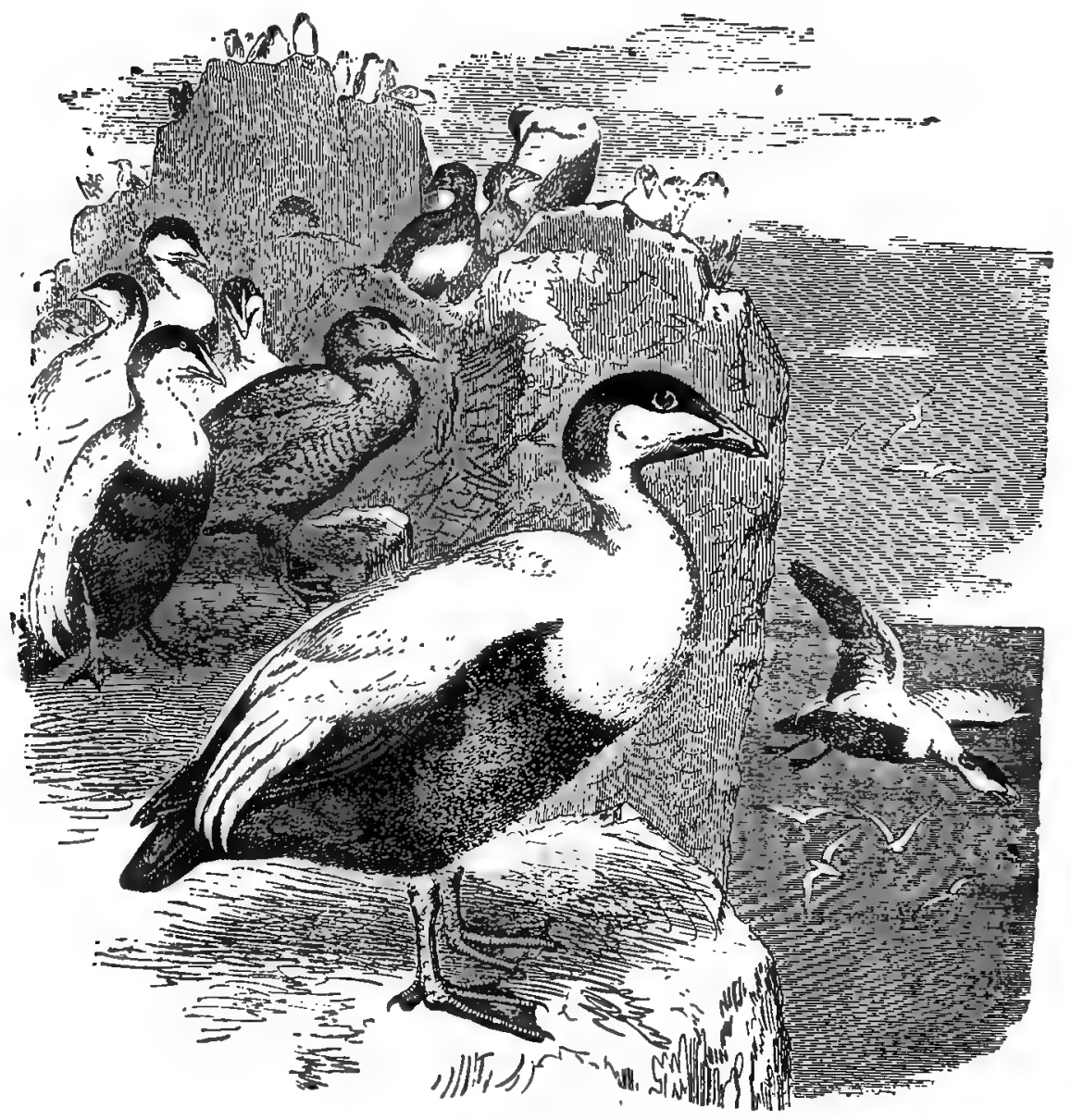

100. ErbIn Ducks (From Brebm).

160. AMERICAN EIDER. Somateria dresser Sharpe. Geog. Dist.-Atlantie coast of North America, from Malne to Labrador; south in winter to the Delaware and west to the Great Lakes. 
The American Eider breeds along the Atlantic coast of North America from Maine to Northern Labrador. On Grand Manan and some of the smaller islands

- In that vicinity this duck formerly nested in great numbers, but from constant persecution its numbers have been greatly diminished. A female specimen of this speciesin my collection was taken November 11, 1895, at the Licking County Reservoir (Ohio) by William Harlow. It is one of the most characteristic summer ducks of Labrador and Newfoundland. Mr. Frazar found this Eider breeding commonly on small islands on the coast of Labrador, making the nest in the short, soft grass. The favorite nesting place was at the foot of some large rock, or in the nooks between rocks, where the birds found shelter from the wind. They were always made of the slate-colored down from the breasts of the birds. Most of the nests contained four or five eggs; a large number of six, two seven and one eight.* The eggs are from four to ten in number, but often fewer; they are plain dull-greenish-drat; measuring about $3 \times 2$.

161. PACIFIC EIDER. Somateria v-nigra Gray. Geog. Dist.-Coasts of the North Pacific; in the interior to the Great Slave Lake, and Eastern Siberia.

The Pacific Eider is common in suitable places on both coasts and islands of Bering Sea and the polar coasts of Siberia; replacing the Common Eider, S. molissima, Spectacled and Steller's Eiders. Dr. Stejneger says it is now rather scarce on the Commander Island. On Copper Island it breeds only in a few places, and in limited numbers. It breeds on the Aleutian Islands, the Island of St. Michael's, and in great numbers on the Arctic coast, near the mouth of the Anderson River. Its nesting habits are the 'same as those of $S$. dresseri, and the eggs measure

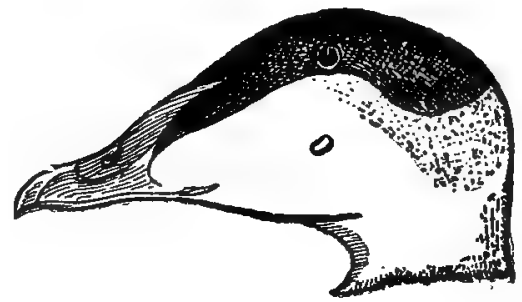

161. Paciric Eider. from 2.95 to 3.20 long by 1.95 to 2.10 broad.

162. KING EIDER. Somateria spectabilis (Linn.) Geog. Dist.-Northern part of Northern Hemisphere, breeding in the Arctic regions; in North America south casually in winter to New Jersey and the Great Lakes.

A beautiful Arctic species, very closely resembling the three last. It is a resident of Greenland, and is found on the Atlantic coasts of Europe and America, and on the Pacific coasts of America and Asia. Abundant in various places along the shores of the Arctic Ocean, thence southward in winter on the Pacific side in great numbers to the Aleutian Islands and beyond. Rare on the Alaskan coast of Bering Sea. The nests of this Eider, found in the islands of the Arctic seas, are placed in depressions of the ground, and composed wholly of down. In Greenland the King Eider breeds in the latter part of June or in the first part of July, nesting in the vicinity of ponds and marshes. Six eggs are the usual number laid, but as many as ten are said to be deposited. They vary from light-olive gray to grayish-green, and measure from 3.10 to 3.15 long by 1.75 to 2.10 broad.

163. AMERICAN SCOTER. Oidemia americana Sw. \& Rich. Geog. Dist.Coasts and larger lakes of Northern North America; breeds in Labrador and the northern interior; south in winter to New Jersey, the Great Lakes and California.

* See Mr. Frazar's article: Ornithologist and Oologist, Vol. XII, pp. 19-20. 
A few of this species are said to breed in Labrador as they do in the neighborhood of marshes and ponds in the interior, northward. In the Hudson Bay region the American Scoter nests in June and July. It has been found on islands along the

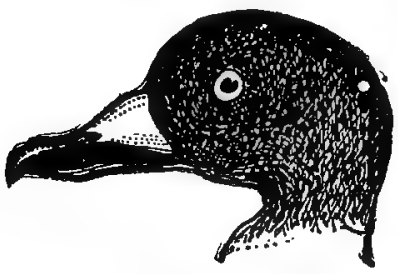

163. American Scoter. coast of Alaska and at the mouth of the Yukon in June. The Scoter nests similar to the Eider, on the ground, near water; the material used being coarse grass, feathers and down. The nests are often well secreted in the cliffs and hollows about steep banks. This duck is called Sea Coot, Butter-billed and Hollow-billed Coot. The plumage of the adult male is entirely black, and the top of the bill orange; the color of the female is sooty-brown, becoming paler below. It is much smaller than the male. This duck, like many others in winter, is sometimes found in great numbers along the entire Atlantic coast. Its food is principally small bivalves, which it secures by diving. A female of this duck was killed December 3, 1895, on Alum Creek, a small stream, which is at present the eastern boundary line of Columbus, Ohio. The specimen is now in my collection. The eggs are said to range from six to ten in number. They are of a pale dull buff, or pale brownish-buff, and measure $2.55 \times 1.80$.

[164.] VELVET SCOTER. Oidemia fusca (Jinn.) Geog. Dist.-Northern Old World; accidental in Alaska and Greenland.

This fine sea duck belongs to the old World. It is a winter visitant on the coasts of England; a few specimens have been obtained at different times in the London markets. It is recorded as having been taken as far south as Italy. On the Orkney and Shetlañd Islands it is said to be common. Found in Norway, Sweden and Scandinavia. Said to be abundant everywhere in Lapland, where it nests on hummocks, among the willow swamps, in long grass near water, or by the edges of large lakes in mountain districts. The eggs are of a pale cream color, and measure $2.87 x$ 1.92 .

165. WHITE-WINGED SCOTER. Oidemia deglandi Bonap. Geog. Dist.Northern America, breeding in Labrador and the Fur Countries; south to the Middle states, Southern Illinois and Southern California.

Like the Velvet Scoter, O. fusca of the Old World, the American bird is eminently a sea duck, resorting, however, mainly to inland waters during the breeding season. Its summer home is in the Arctic regions. Found along the Atlantic and Pacific coasts, and as far south as the Middle States in the spring, fall and winter. It breeds on many of the lakes, rivers and larger bodies of water in Manitoba. The "White-winged Coot," "Sea Coot," "Black Surf Duck," or Velvet Duck, as it is "variously called, has been found breeding quite abundantly on the Lower Anderson river, constructing the nest on the ground near fresh water. The nests contain a Nining of down and feathers. Audubon found it breeding in Labrador from the 1st to the 10th of June. The nests were built by the side of small lakes, two or three miles distant from the sea, and usually placed under low bushes; they were formed of twigs, mosses and various plants matted together. The nests were large and almost flat, several inches thick, lined with some feathers of the female, but without down. The eggs are usually six in number, measuring $2.68 \times 1.83$. They are of a pale buff, varying to green. 
166. SURF SCOTER. Oidemia perspicillata (Linn.) Geog. Dist.-Coasts and larger inland waters of Northern North America; south to the Carolinas, the Ohio river and Lower California.

The Surf Duck and the three preceding species are called Coots by the gunners; their habits, appearance and general characteristics being similar. It is peculiarly an American species, and is only an occasional or accidental visitor in Europe. The plumage of the male of this species is glossy black, no white on the wings, but a triangular white patch' on the forehead pointing forward. The female is a sooty-brown, below silvery-gray; side of the head much whitish. It breeds in the far north along the coast and in the interior of the fur countries. Audubon found this species to be the least numerous of the ducks inhabiting Labrador. He discovered a nest in a fresh-water marsh placed among the tall grass and weeds. It was entirely made of withered, rotten weeds, lined with the down of the bird. The nest contained five eggs; they were pale yellowish or cream color, and measured 2.31 by 1.63 . The general average is $2.47 \times 1.70$; pale buff to creamy-buff.

167. RUDDY DUCK. Erismatura rubida (Wils.) Geog. Dist.-North America in general, south to Cuba, Guatemala, and Northern South America.

The Ruddy Duck is an American species, and is found breeding throughout most of its range, but more especially from the northern borders of the United States northward. In spring and fall it is an abundant duck on the large bodies of water, as well as rivers, small streams and ponds. It is exceedingly difficult to kill, being very tenacious of life, and, when wounded, dives with the greatest of ease, remaining under the water for a long time-in fact, no duck excels this one in diving. Mr. Shields writes that the Ruddy Duck breeds quite commonly in the vicinity of Los Angeles, Cala, depositing from five to eleven eggs about the last of May, and fresh eggs may be taken as late as June 25. He says the-e is positive proof that this duck prefers the abandoned nests of Coots fcr nesting purposes to those constructed by itself, and cites several instances in which he took eggs of this species from what appeared to be Coots' nests reconstructed. Seven Ruddy Ducks' eggs were found in a Coot's nest, from which, a few weeks previous, a set of the Coot's eggs were obtained. The locality usually selected for a breeding place is some deep, sluggish stream, lake or pond, and the nests are always built close to the water's edge; they are composed of reeds, dry rushes and grass. The structure is often made so that it ri.l float, similar to a grebe's nest. The male is a handsome bird; its general color is glossy chestnut, and the lower parts silvery white; the chin and sides of the head are white, the crown and nape glossy black. The female is brown above, finely dotted, and waved with dusky; below paler and duller. From its peculiar stiff tail feathers, I have often heard hunters call it the "Sprigtail," a name, however, applied to the Pin-tail Duck. It is also called Dipper Duck. The eggs are grayish-white, ovoid or oval in shape, with a finely granulated surface; sizes range from 2.35 to 2.50 long by 1.70 to 1.80 broad. They, appear large for the size of the bird.

[168.] MASKED DUCK. Nomonyo dominious (Linn.) Geog. Dist.-Tropical America in general, including West Indies, north on the Gulf coast to the Lower 
Rio Granae; accidental in Eastern North America (Wisconsin; Lake Champlain; Massachusetts).

This tropical American species is purely accidental in Eastern North America as above stated in its geographical range. Nothing is known regarding its nesting or eggs.

169. LESSER SNOW GOOSE. Chen hyperborea (Pall.) Geog. Dist.-Pacific coast to the Mississippi Valley, breeding in Alaska; south in winter to Southern Illinois and Southern California.

There are several forms of the Snow Goose which exist in North America; two are designated by their respective sizes, namely, Lesser and Greater. The Lesser species breeds in Alaska, and occurs throughout the northwestern portions of the continent, and in winter migrates over the whole of the country, from the Pacific coast to the Mississippi Valley. The Greater' Snow Goose, Chen hyperborea nivalis (Forst.), according to Prof. Ridgway, occurs in Eastern North America; its breeding grounds are unknown, but they are probably in the Arctic regions east of the Mackenzie river. In winter it is found in the United States from the Mississippi Valley to the Atlantic coast.* These birds seek a nesting ground along the course of the Lower Anderson river, and the neighboring region along the Arctic coast Nelson).

169a. GREATER SNOW GOOSE. Chen hyperborea nivalis (Forst.) Geog. Dist.-North America, breeding far north (east of the Mackenzie basin) and migrating south in winter, chiefly along the Atlantic coast, reaching Cuba.

Mr. Frank M. Chapman in his "Handbook of Birds of Eastern North America"* says: "The Snow Goose does not appear to be a common bird on any part of the Atlantic coast. It migrates both by night and day, and when on the wing its white plumage and black-tipped primaries render it identifiable. It is a noisier bird than the Canada Goose, and its voice is higher and more cackling." $\dagger$ Mr. Chapman states that its nest and eggs are unknown.

169. 1. BLUE GOOSE. Chen carulescens (Linn.) Geog. Dist.-Interior of North America, breeding on eastern shores of Hudson Bay and migrating south, in winter, through the Mississippi valley to Gulf coast; occasional on the Atlantic coast.

Apparently it is nowhere common in North America, and it is even less common on the Atlantic coast than in the interior. At one time it was supposed by many ornithologists to be the young of the Snow Goose. The Blue Goose was first recorded as an Ohio bird by the late Dr. J. M. Wheaton in 1875. Two specimens were identified; one of these, which was captured alive four miles south of Columbus; was . kept in the City Park for a year, where it associated with the swans. Another was wounded and captured on the Scioto river; it was placed in the park with the other specimen, but died in a few days. I believe there is nothing authentic known concerning its nest and eggs.

* Manual of N. A. Birds, p. 115.

$\dagger$ Handbook of Birds of Eastern N. America, with keys to the species and descriptions of their plumages, nests and eggs, their distribution and migration and a brief account of their haunts and habits, with introductory chapter on the study of ornithology, how to identify birds and how to collect and preserve birds, their nests and eggs. By Frank M. Chapman, Assistant Curator of the Department of Mammalogy and Ornithology in the American Museum of Natural History, New York City; member of the American Ornithologists' Union, etc. Second edition. New York: D. Appleton \& Co., 1895. 
170. ROSS'S SNOW GOOSE. Chen rossii (Cassin.) Geog. Dist.-In summer Arctic America, migrating south in winter to southern California and eastward to Montana.

There is nothing known of the habits, nests and eggs of this boreal species.

[171.] WHITE-FRONTED GOOSE. Anser albifrons (Gm.) Geog. Dist.Northern parts of Eastern Hemisphere and Greenland.

The White-fronted Goose of the Old World, which very closely resembles the A'merican species, is distributed in its migrations throughout various sections of Europe, but is more abundant in the eastern than in the western portions. Said to extend its migrations into Central Africa, almost to the equator. It breeds near the coast line of the Arctic Ocean in Europe and Asia, and also on the lakes, larger rivers, bays and inlets. There is no difference between the general habits of this species and those of the American bird. It nests on the ground, in the immediate vicinity of water, making a large structure of sticks and hay which is lined with down. The eggs are from four to six in number, yellowish-white in color, and measure about $3.10 \times 2.05$.

[171.1.] BEAN GOOSE. Anser fabalis (Lath.) Geog. Dist.-Northern Asia, eastward into Northern Europe and Northern Africa. Accidental in Greenland.

The Bean Goose is an inhabitant of Northern Asia and Northern Europe. It is. the Allsel segetum of Pennant. A winter visitant to Great Britain, and is said to breed on some of the Hebrides. It breeds in Northern Europe, and was found nesting by Hewitson on islands of the Norwegian sea, near the Arctic circle. The nests were simply hollows in the ground, usually in elevated portions of the islands; they were lined with rank grasses and sedges. The eggs are from five to eight in number, of a dull greenish color and their average size is $3.27 \times 2.27$ inches. This Goose is successfully bred in confinement and the description and size of the eggs here given are from specimens from that source.

171a. AMERICAN WHITE-FRONTED GOOSE. Anser albifrons gambeli (Hartl.) Geog. Dist.-North America, breeding far northward; in winter, south to Mexico and Cuba.

Often called "Laughing Goose." It is of large size and robust form, may be known by its --hite forehead and spotted breast. A very handsome bird and a favorite with sportsmen. Large numbers are often killed on the lakes and reservoirs in spring and fall. The Whitefronted Goose is common throughout the whole of North America, but is more abundant on the Pacific coast than in the interior or along the Atlantic. It flies in V-shaped flocks, frequently uttering a loud, harsh cry, which may be heard at a considerable distance. This species breeds in high latitudes and is particularly abundant in Alaska, nesting in large numbers along the Yukon river, laying its eggs in depressions in the sand. Said to breed also on Stuart's Island and other islands along the coast. Its favorite resorts are in the vicinity of freshwater lakes. Along the Lower Anderson river, on the Arctic coast and on the islands of the Arctic Sea this species breeds in abundance in June and July. The nests are made in a depression of the ground, and made of hay, feathers and down. Dr.

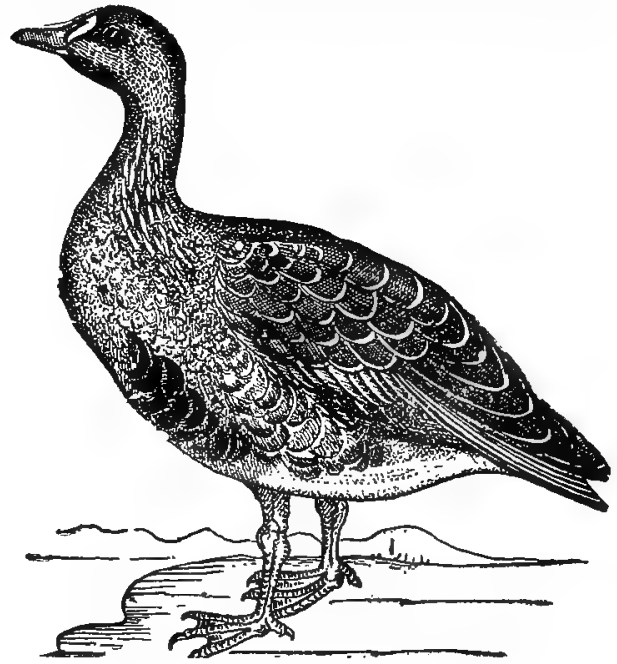

17la. AMERICAN WHite-FroN TED Goose. 
Brewer states that nests found by Mr. MacFarlane were generally found in wooded districts. Murdoch says that the eggs are always laid in the black, muddy tundra, often on top of a slight knoll. The nest is lined with tundra moss and down. The number of eggs in a clutch appears subject to considerable variation, as sets of four, six and seven were well advanced in incubation. The last laid egg is generally in the middle of the nest, and may be recognized by its white shell, unless incubation is far advanced, the other eggs 'being stained and soiled by the birds coming on and off the nest. The eggs are six or seven in number, and measure from 2.90 to 3.30 long by 2.05 to 2.10 broad. They are elliptical in shape, dull greenish-yellow with obscure darker tints. Nelson records the measurements of a very large series of eggs taken at St. Michael's, Alaska. They are as follows: Maximum 3.45x2.28; minimum, $2.98 \times 2.10$. Within these limits he says there are innumerable gradations.

172. CANADA GOOSE. Branta canidensis (Linn.) Geog. Dist.-Temperate North America, breeding in the Northern United States and British Provinces; south in winter to Mexico.

The Common Wild Goose of North America, in its various forms and great extremes of size, is generally distributed throughout the continent at large, $B$. canidensis proper, breeding, as indicated in the above habitat. It is the most abundant of our geese. Large numbers may be seen during the spring and fall migrations flying overhead in wedge-shaped flocks, with an old gander always in the lead at the apex of the triangle, frequently uttering the sonorous honk, honk, which is often heard at a great height. In many places they breed in captivity with the common domestic goose, producing a hybrid bird much esteemed for the table. It has been learned from birds in confinement that none of them lay until three years old; the first season four eggs are laid, five the second season, and when older six and seven.* Dr. Coues alludes to the breeding of the Canada Goose in trees in various parts of the Upper Missouri and Yellowstone regions. $\dagger$ Breeding grounds, inundated along the banks of streams, have at times caused the birds to resort to trees for the purpose of nesting, some making use of Herons' and Ravens' nests.t Nests of the Canada Goose in Dakota are usually situated far away from water on the prairies. The most interesting information I can offer on the breeding habits, migration, etc., of this goose in a semi-domestic state, is as follows: In March, 1886, Mr. George Sackett, of Delaware, Ohio, shot three specimens while they were passing over his farm. Upon examination they were found to have only been "winged." The wounds were dressed and the birds allowed their freedom on the farm for two successive summers, but from the lack of sufficient water and the annoyance of cattle they did not prosper in their domestic affairs. On two occasions the cattle destroyed their nests and young. The wild, timid creatures were finally transfefred to Mr. F. P. Vergon, proprietor of an artificial lake which has a surface of about thirty acres. It is used as a pleasure resort and is interspersed with many little islands. Here the two that were mated made their nest in the rank grass and rubbish at the most secluded end of the lake; the young were hatched and from some unknown cause were again destroyed. The next season they took up their quarters on one of the islands, made a nest of sticks and straw, and commenced laying in the latter part of March, incubating until May, bringing forth eight young. During the ten years on the lake only two eggs failed to hatch. The young were not taken into the water until

* Wm, Dutcher, in The Auk. Vol. II, p. 111.

$\dagger$ Birds of the Northwest, pp. 554-555.

$\ddagger$ Maj. Chas. E. Bendire: Bull. Nutt. Club. Vol. I, p. 50 . 


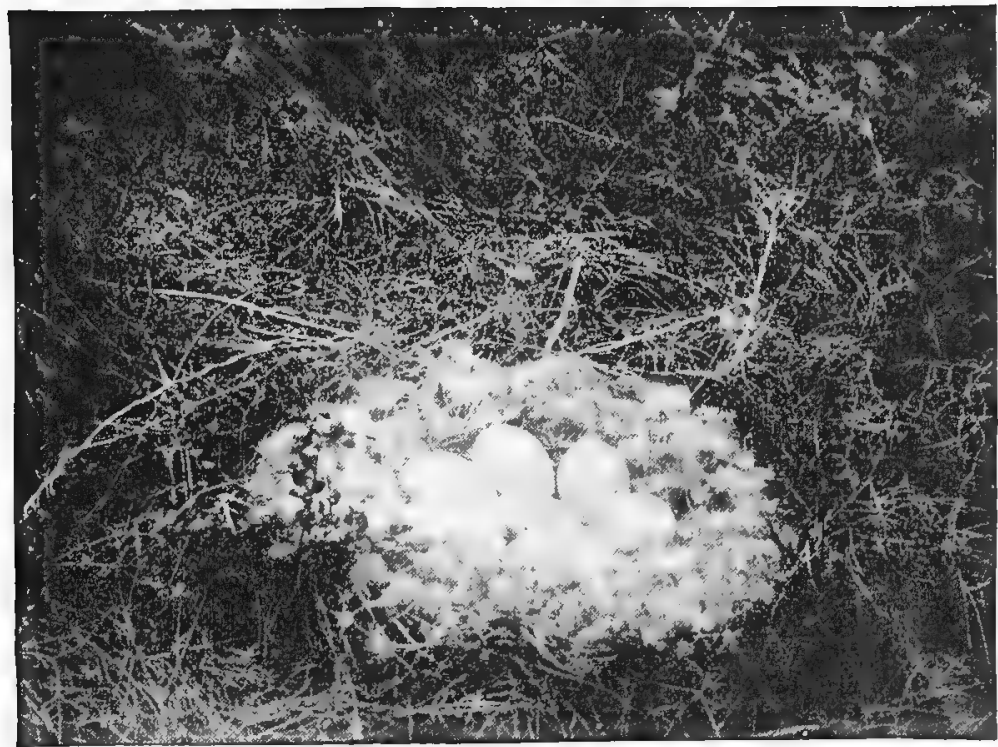

172. Nest and Eggs of the Canada Goose. (Photo. by W. Raine.)

they were six days old, and this was in early morning and evening, at which times the old birds would float off from their island with their well-known honk, the young following single file behind them, feeding at the extreme end of the lake. This was kept up until August, when the young could fly and take care of themselves. The eggs were always seven and never more than eight in number. What is most. remarkable about these birds is that they would go south every fall and return every spring; their number always being diminished by the time they returned; some probably being killed by sportsmen. Mr. Vergon says the geese often strayed away from "home" as far as ten and fifteen miles on the Olentangy River and other waters in the neighborhood. He fed them on a high ridge near the lake and on this ridge they were always first seen in spring when they returned. Mr. Vernon says he thinks they always came at night and is very sure they always departed in autumn at night. While the flocks that departed in the fall and returned in the spring had often been diminished in numbers, yet as many as twenty-two new ones came with them and stayed at the lake. Out of thirty that departed the fall of 1886 only three returned in the spring. The birds were very much afraid of strangers, but with Mr. Vergon they were very familiar, allowing him to handle and caress them at pleasure. Dr. Merrill found this species breeding on the Upper Missouri, Yellowstone, and Big Horn Rivers, where their favorite nesting sites were on the numerous low sandy islands in these rivers, covered in the higher parts with a growth of young willows. Their nests were simply a hollow in the sand, around which was placed a few sticks and twigs, and the eggs lay on a layer of gray down. Nests were found on the tops of broken trunks of trees; one on a rocky ledge three hundred yards from the river; another was made on a pile of brush that had collected in the top of a fallen tree that had floated down and lodged near the middle of the river; some nests 
were placed on the high banks among high grass, or on piles of drift wood. By the first of May the nests contained the full complement of eggs, generally five in number. Dr. Merrill says: "When these geese nest among the branches of a tree I do not think they ever construct the nest entirely themselves, but take possession of a deserted nest of the Fish Hawk, and repair it wite twigs and a lining of down. They have been seen to carry small sticks to the nest for this purpose." The color of the eggs is a pale dull greenish, and their size is about $3.50 \times 2.50$.

172a. HUTCHINS'S GO0SE. Branta canadensis hutchinsii, (Sw. \& Rich.) Geog. Dist.-North America, breeding in the Arctic regions, migrating south in winter, chiefly through the Western United States and Mississippi Valley; Eastern Asia.

This bird, which is like canadensis in color, but of a smaller size, breeds in boreal regions. It's length is about 24 to 34 inches. Its general habits are the same as those of the common Canada Goose. Breeds abundantly along the Yukon River and on the islands on the coast of Alaska. Nests have been found on the Islands of the Anderson River and on the Aretic coast. In these regions eggs of this species have been taken from Hawks' and Crows' nests built in trees. It nests usually on sandbeaches, depositing, from four to six eggs in hollows in which there are more or less leaves, grasses, feathers and down. In his paper on "The Birds of the Western Aleutian Islands," Mr. Dall states that it does not breed east of Amchita Island, but some nest on Amchitka, Kyska and other islands there. Its nesting habits, notes, and general mode of life are identical with those of the Cackling Goose. The eggs are white, and measure $3.18 \times 2.10$. In the Arctic regions the eggs are laid in June and July. Eggs of this vird taken at the mouth of the Yukon in June measure $3.02 \times 2.10,3.08 \times 2.11,3.04 \times 2.00,3.00 \times 2.11,2.90 \times 2.07$. There is a great variation in the size of the eggs of this bird and those of minima.

.1720. WHITE-CHEEKED GOOSE. Branta canadensis occidentalis (Baird.) Geog. Dist.-Pacific coast region, from Sitka south, in winter to California.

A larger sub-species than Hutchins's Goose, length about 35 inches. Mr. Nelson states that during his residence on the coast of Bering Sea this bird was not seen, as hundreds of the two other related forms were examined both at St. Michael's and at the Yukon mouth it appeared evident that either the White-cheeked Goose proper never reached those localities; if at all, merely as a straggler. Mr. Dall recorcs specimens having been taken at Sitka during the Western Union Telegraph expedition. The nesting habits and the eggs are more than likely like those of the Canada Goose.

172c. CACKLING GOOSE. Branta canadensis minima Ridgw. Geog. Dist.Coast of Alaska, migrating southward into Western United States east to Wisconsin.

The length of the Cackling Goose is about 24 inches. Nelson states that this is the most common and generally distributed goose found breeding along the Alaskan coast of Bering Sea. From the sea shore its breeding ground extends along the courses of the great rivers far into the interior. While descending the Yukon, Dall 'found their eggs laid upon the bare sand banks, as were those of the White-fronted species. The last week of May finds many of these birds already depositing their eggs. Upon the grassy borders of ponds, in the midst of a bunch of grass, or on a small knoll these birds find a spot where they make a slight depression and line it with a scanty layer of grasses, after which the eggs are laid, numbering from five to eight. These eggs, like the birds, average smaller than those of the other geese. 
The following measurements, taken from a large series of eggs, show about the average sizes: $3.00 \times 1.90,2.90 \times 1.90,2.80 \times 2.00,2.75 \times 2.00,2.70 \times 1.92$. As the eggs are deposited the female gradually lines the nest with feathers plucked from her breast until they rest in a bed of down. When first laid the eggs are white, but by the time incubation begins all are soiled and dingy.

173. BRANT. Branta bernicla (Linn.) Geog. Dist.-Northern portions of the Northern Hemisphere; in North America chiefly on the Atlantic ccast, rare in the interior or away from salt water.

The Brant Goose is almost cosmopolitan in its distribution. It is found on the sea coasts of Europe and eastern North America, breeding only within the Arctic circle. Hagerup records this bird to be common as a migratory species along the southern shores of Greenland, and says it breeds possibly in the northern part of Danish Greenland. While being more maritime than United States geese generally are, it is also found inland occasionally on lakes and rivers. During the migrations it is abundant, and seems to prefer the coast to the interior, seldom passing over large tracts of land, following the windings of the shore, and nearly always keeping over water. The Brant is a particular favorite with sportsmen, and many are shot from points of land which project out into the sea. The common Brant Goose is said to breed in immense numbers in Spitzbergen and on the islands about the coast. The nest is constructed on the sandy beaches, of grasses, moss, feathers and down, the birds depositing from four to six eggs. In some parts of Greenland where this species is known to breed, some of the birds make their nests on cliffs. The eggs are grayish or dirty-white, and average in size 2.70 by 1.80 , according to Saunders.

174. BLACR BRANT. Branta nigricans (Lawr.) Geog. Dist.-Arctic and Western North America; rare in the Atlantic States.

The Black Brant is very closely allied to the common Brant Goose; it is found on the Pacific coast, where the latter does not occur. Its summer home is in high latitudes, and in Alaska, the mouth of the Yukon, is said probably to form the extreme southern limit of this bird's occurrence in the breeding season. At Point Barrow, according to Murdoch, a few remain to breed in June. The nest is placed in rather marshy ground and is a simple depression lined with down, with which the eggs are completely covered when the birds leave the nest. Breeds in abundance on islands northeast of the mouth of Anderson River, in Liverpool Bay on the Arctic coast, on the shores of Franklin Bay, and on various other parts of the coast, especially in regions west of Anderson River. In these regions, according to Dr. Brewer, nests were founa by Mr. MacFarlane on small islets in fresh water ponds: others on islands in the Anderson near its mouth; many were made on the shore or: on islands in Franklin Bay, and in various parts of the Arctic Sea. Some of the; nests were nothing but mere depressions lined with down, while in others the quantity of down was quite large. The number of eggs in a nest was gererally five:' but in one case as many as seven were seen, and, in six or seven instances six. The eggs are grayish-white, and range from 2.75 to 2.90 long by 1.80 to $1: 85$ broad:

[175.] BARNACLE GOOSE. Branta leucopsis (Bechst.) Geog. Dist.-Northern parts of the Old World; casual in Eastern North America.

The Barnacle Goose inhabits the northern portions of Europe and is occasionally found on the Atlantic coast of North America. But many of the specimens taken on this side of the Atlantic are birds that are supposed to have escaped from con- 
finement. In Great Britain it is a winter visitant. During the migrations it is said to be found in great numbers along the coast of Norway, and at these seasons it is stated to be abundant in. Holland, France and Germany. It is said to occur during the breeding season in Northern Siberia. The shores of the White Sea to the eastward are supposed to be the great breeding places of this bird.* The eggs are grayish-white and measure $3.71 \times 2.38$.

176. . EMPEROR GOOSE. Philacte cana'irica (Sevast.) Geog. Dist.-Coast and islands of Alaska north of the Peninsula; chiefly about Norton Sound and Valley of the Lower Yukon; Commander Islands, Kamtchatka; casually southward to Hum bolt Bay, California.

Among the various species of birds more or less peculiar to Alaska, says Mr. Nelson, this goose is perhaps the most noteworthy. This author and naturalist lay camped on a lonely islet in the middle of the Yukon delta for the purpose of gaining some knowledge of the habits of these geese and other water fowl during the last of May and first of June. The birds arrive about those periods. Early in June the

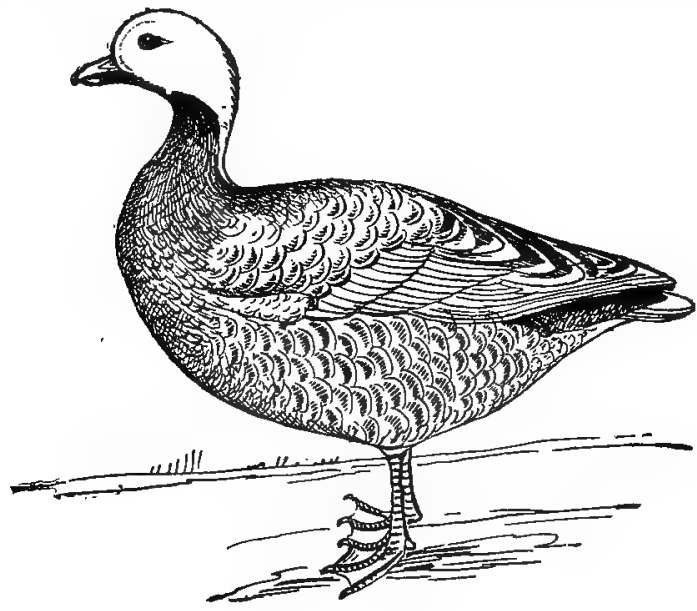

176. EMPERor Goose.

Emperor Goose begins to deposit eggs on the flat, marshy islands bordering the sea. On June 5 a female was found setting upon her eggs on a little knoll, near by a small fragment of bleached driftwood. The nest contained three eggs. They rested in a depression with no sign of a lining. Other nests were found and the birds each. time betrayed them by flying off with a startled cry. The majority of the nests contained from three to five eggs, the full complement usually ranging from five to eight. The eggs are absolutely indistinguishable from those of the White-fronted Goose, and in form and measurements present a wide range of variation; some are much elongated, while others are slightly pyriform. As usually taken from the nests they are of a dirty brownish-white, but when fresh are nearly pure white. As the complement of eggs approaches completion the parent makes a bed of leaves, fine grass and feathers plucked from her own breast. The eggs vary in size from $3.28 \times 2.22$ to $3.03 \times 2.00$. 
177. BLACK-BELIIED. TREE-DUCK. Dendrocytna autumnalis (Linn.) Geog. Dist.-Southwestern border of the United States and southward (Mexico, West Indies, etc.)

The Autumnal Tree-duck is a species of variegated plumage and long legs. It inhabits the southwestern border of the United States and southward to Mexico, West Indies, Central and South America. It is commonly called "Long-legged Treeduck." Along the Rio Grande in Mexico and Texas it is abundant from April to October and later. Dr. Merrill found it common in Southern Texas. He says: "This large and handsome bird arrives from the South in April, and is soon found in abundance on the river banks and lagoons: Migrating at night it continually utters a peculiar chattering whistle, which at once indicates its presence. Called by the Mexicans patos maizal, or Corn-field Duck, from its habit of frequenting those localities. It is by no means shy, and large numbers are offered for sale in the Brownsville market. Easily domesticated, it becomes very tame, roosting at night in trees with chickens and turkeys. When the females begin to lay, the males leave them and gather in large flocks on sand-bars in the river. My knowledge of the breeding habits is derived from Dr. S. M. Finley, U. S. A., who had ample opportunity of observing these birds at Hidalgo. The eggs are deposited in hollow trees and branches, often at a considerable distance from water (two miles), and from eight to thirty feet or more from the ground. The eggs are placed on the bare wood, and are from twelve to sixteen in number. Two broods are raised, and the parent carries the young to the water in her bill. Twelve eggs received from. Dr. Finley average $2.11 \times 1.53$, with but little variation in size; they are of the usual duck shape, and in color are a rather clear yellowish-white. The birds leave in September, but a few late broods are seen as late as November. The soft parts in a full plumaged living male were as follows: iris, brown; bill, coral-red, orange above; nail of bill, bluish; legs and feet, pinkish white."*

178. FULVOUS TREE-DUCK. Dendrocygna fulva (Gmel.) Geog. Dist.Southern border of the United States; Louisiana, Texas, Nevada, California, southward.

Resembles the last in its general appearance, habits, etc. Its geographical range is chiefly within the tropics, extending as far South as the Argentine Republic. Dr. Merrell states that this species is about as common as the Corn-field Duck in Southern Texas, both species frequenting the same places. He learned nothing definite in regard to its breeding habits, but they probably do not differ much from those of the other bird. The Fulvous Tree-duck is said to lay from ten to fifteen pure white eggs.

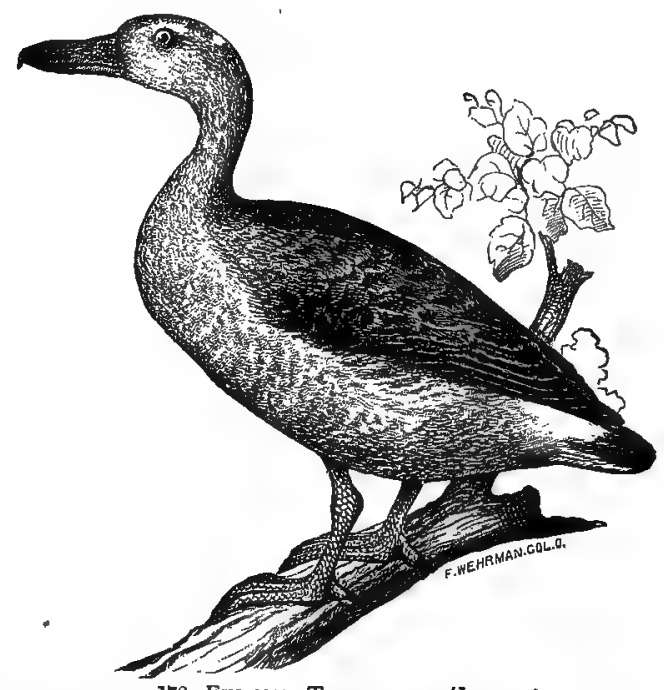

178. Fulvous Tree-Duck. (Jasper,)

* Notes on the Ornithology of Southern Texas: Proceedings U. S. National Museum, Vol. I., page 169 . 
[179.] WHOOPING SWAN. Olor cygmus (Linn.) Geog. Dist.-Europe and Asia; Greenland.

In Europe this bird is called "Hopper," "Elk," and "Whistling Swan." It is a winter visitant to the more southern portions of Great Britain, and is found throughout the year in the Orkneys and other islands north of Scotland. Known to visit Holland, France, Spain and Italy, and a few are said to penetrate as far south as Barbary and even Egypt. Hagerup says that it formerly nested in South Green-

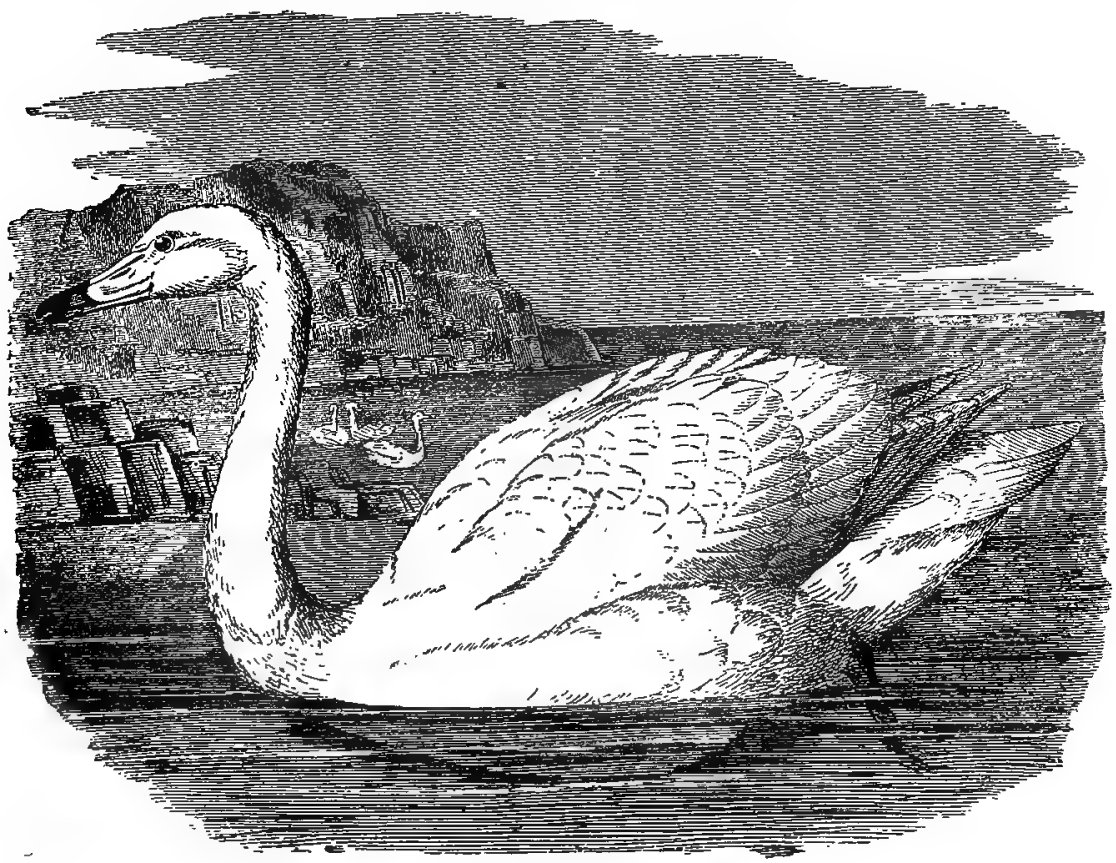

179. WhOoping Swan (From Brehm).

land, but it is now only a rare visitor. Breeds in the secluded swamps and lakes up in Lapland, nesting on the ground in marshy places. It also breeds in Iceland. The nest is large and composed of rushes, coarse grass, and almost any material near at hand. As many as seven eggs are laid by this species; they are of a dull brownish white, or dark ivory color, and measure $4.28 \times 2.88$.

180. WHISTLING SWAN. Olor colimbianus (Ord.) Geog. Dist.-Entire of North America, breeding far north.

The common American Whistling Swan is the smaller of the North American species, measuring under five feet in length. There is a small yellow spot on the bill in front of the eyes, and it is sometimes wanting. The tail feathers are normally twenty. This bird is found in the United States in winter, and during the migrations. It is not a common spring and fall migrant in Ohio. The Whistling Swan breeds in the Arctic regions on the small lakes of the coast and islands of the Arctic Sea, nesting in June and July. A few are said to breed in the interior of the ur countries. All along the Yukon River, and especially near its mouth this species 
is said to breed in the large marshes. Here the eggs are usually laid on a tussock entirely surrounded by water, and so near it that the female sometimes sits with her feet in the water. On the islands of Franklin Bay and on those of the Arctic Ocean, the Whistling Swan constructs a large nest of moss, grass and herbage of various kinds. According to Nelson this fine bird arrives on the shore of Bering Sea in the vicinity of St. Michael's early in May, and in some seasons by the 27th of April. At Nulato, Dall found them laying eggs by May 21, but on the sea coast the earliest date Nelson records is May 30. The ordinary number to a nest is three to six. The nest is usually upon a small island in some secluded lakelet, or on a rounded bank close to the border of a pond. The eggs are deposited in a depression made in a heap of rubbish gathered by the birds from the immeditite vicinity of the nest, grass, leaves and moss, forming a bulky affair in many cases, There is some variation in the eggs of this swan; the following meesurements show the average, the specimens being taken near St. Michael's in June: 4.15x2.85, 4.05x2.74, 3.96x2.66. They are of a dull white with more or less of a brownish or reddish discoloration. The surface of the shell is usually rough.

181. TRUMPETER SWAN. Olor buccinator (Rich.) Geog. Dist.-Chiefly the interior of North America, from the Gulf Coast to the Fur Countries, breeding from Iowa and Dakota northward; west to the Pacific coast, but rare or casual on the Atlantic.

During the breeding season the Trumpeter Swan is found almost exclusively in the interior of the northern regions. A few breed in Central and Northern Iowa and in Dakota; from thence northward. Dr. Brewer states that the nests found by $\mathrm{Mr}$. MacFarlane on the barrens of the Arctic coast were usually placed on elevated ground, and they were composed of hay, down and feathers intermingled. One nest containing six eggs was found near the beach on rising ground; others were observed. near the banks of the Lower Anderson River. On the islands in the fresh-water lakes and ponds bordering the north branch of the Saskatchewan River, in British America, a few pairs of the Trumpeter Swan are to be seen throughout the summer. This species is also known to breed in Alaska, as a specimen is noted by Mr. Dall as having been secured, with its eggs, at Fort Yukon by Mr. Lockhart. In Ohio it is a rare migrant and winter visitor. The full grown bird is five feet or more in length, and may be distinguished from the Whistling Swan by its entirely black bill and having normally twenty-four tail-feathers. The eggs range from two to six in number; chalky-white with a rough surface; sizes from 4.03 to 4.50 long by 2.50 to 2.76 broad.

182. AMLRICAN FLAMINGo. Phœnicopterus ruber Linn. Geog. Dist.-Atlantic coasts of sub-tropical and tropical America; Florida Keys.

This magnificent bird of scarlet plumage is a constant resident of Cuba, the Bahamas and southward; rare at Cape Sable and on the Florida Keys. It is a remarkable bird and of striking appearance, having long legs and neck, the former of a lake-red color. The bill is unique in shape, being abruptly bent in the middle, so that when feeding the upper surface faces the ground. The plumage is scarlet throughout, except the primaries and secondaries, which are black. The stature of the bird is nearly five feet, and it weighs in flesh six or eight pounds. The nest of the Flamingo is described as a mass of earth, sticks and other material scooped up from the immediate vicinity to the height of several feet and hollow at the top. On this the birds sit with their legs doubled under them. Mr. D. P. Ingraham, who has collected a large number of these handsome birds in the West Indies and spent more or less of his time for four seasons among them, has given me the following 


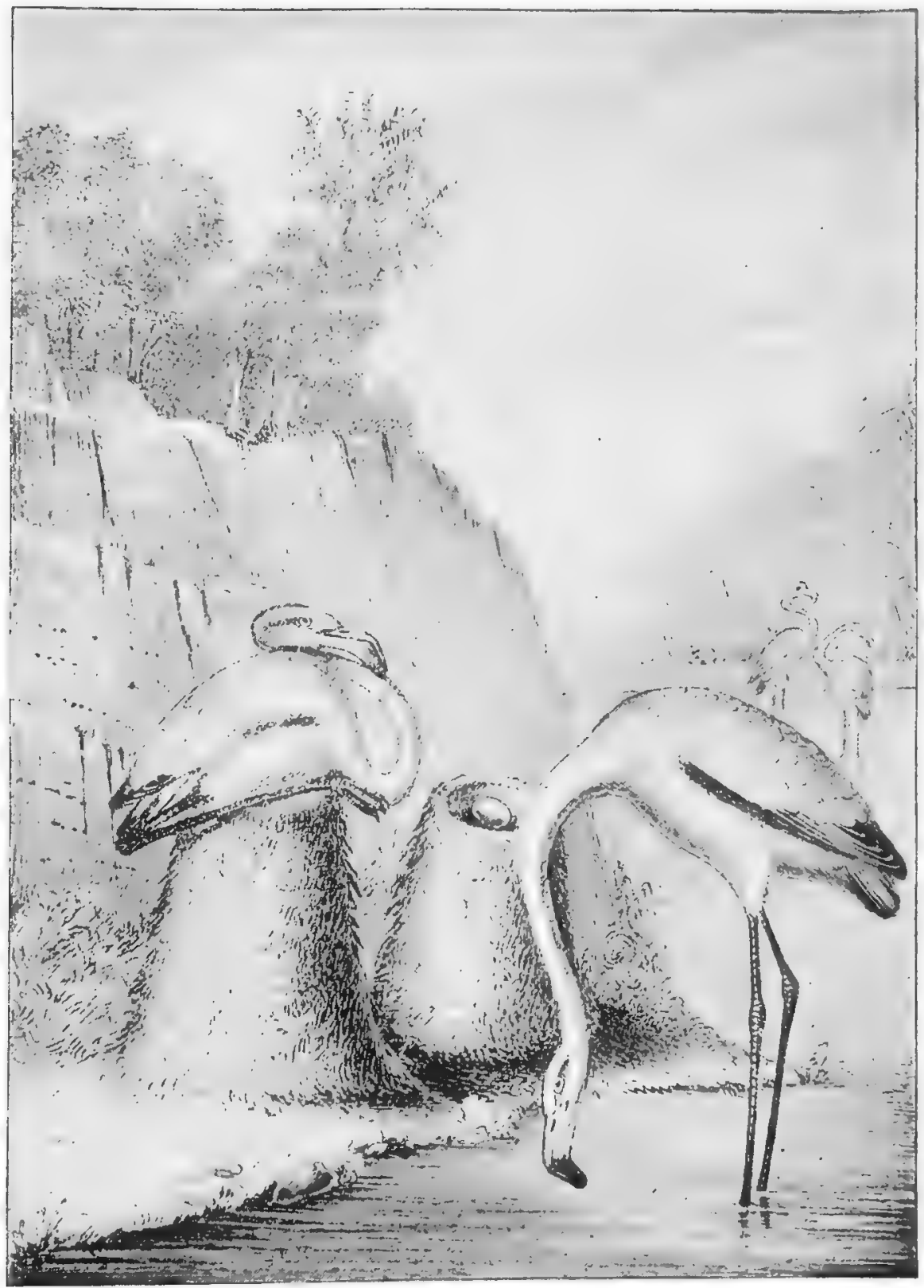

182. Flamingos and Nests. 
interesting notes concerning their, nesting: He states that the birds inhabit the shallow lagoons and bays having soft clayey bottoms. On the border of these the nest is made by working the clay up into a mound which, in the first season is perhaps not more than a foot high and about eight inches in diameter at the top and fifteen inches at the base. If the birds'are unmolested they. will return to the same nesting place from year to year, each season augmenting the nest by the addition of mud on the top, leaving a slight depression for the eggs. Mr. Ingraham speaks of visiting the breeding grounds where the birds had nested the previous year and their mound-like nests were still standing. The birds nest in June. The number of eggs to a clutch is usually two, sometimes only one and very rarely three. When three are found in a nest it is generally believed that the third has been laid by another female. According to Mr. Ingraham's observations the nests in our illustration must be considered correct except in height. They are simply small mounds. The old story of the Flamingo bestriding its nest in an ungainly attitude while incubating is absurd fiction. The eggs are one or two in number, elongate-ovate in shape, with a thick shell, roughened, with a white flakey substance, but bluish when this is scraped off. It requires thirty-two days for the eggs to hatch. Size $3.57 \times 2.20$, with considerable variation.

183. ROSEATE SPOONBILL.' Ajaja ajaja (Linn.) Geog. Dist.-Southern United States and southward into Southern America. Formerly north to Southern Illinois.

The Rosy Spoonbill, of so handsome plumage and singular form, is distributed throughout South and Central America, Mexico, and in all favorable localities of the Gulf region of the United States. In Florida it was formerly abundant, but its numbers have greatly diminished by the constant. persecution of the "plume huinters." Rare as far north as the Carolinas. viarshy or muddy borders of estuaries, the mouths of rivers, shrubby islands of tropical seas, or some dense marsh, are the favorite breeding resorts. Mr. R. E. Rachford visited a small colony of these birds in Southwestern Louisiana, June 2, 1886. The birds were found nesting in a clump of cypress trees in a low marshy place fully twenty miles from habitation. Here also nested the Snow, Louisiana and Little Blue Herons, and the Snake Bird. 'The nests of the Spoonbills were placed from eight to eighteen feet from the ground, and the usual number of eggs found in the nests was three or four; although from one nest seven eggs were taken, and five or six from several others. The nests were platforms of sticks, and for the most part were built close to the trunks of the trees; they were usually more massive than the Herons' nests. The general shape of the eggs is ovate; and their color is white, or buffy-white, blotched, spotted and stained with various shades of brown; sometimes a pure white egg is found in a nest with spotted or marked examples. They measure from $2.50 \times 1.70$ to $2.60 \times 1.77$.

184. WHITE IBIS. Guara alba (Linn.) Geog. Dist.-South Atlantic and Gulf States southward to the West Indies and Northern South America; casually on the Atlantic coast to. Long Island; in the interior to the Lower Ohio Valley and Great Salt Lake.

The White Ibis or Spanish Curlew is distributed in summer throughout the South A.tlantic and Gulf States from the Carolinas southward, throughout Mexico, Central America, and portions of Northern South America: It breeds in communities by thousands in the tangled marshes of the southern coast; fastening the nest to broken down or upright living reeds; it is composed of reeds, compactly woven 


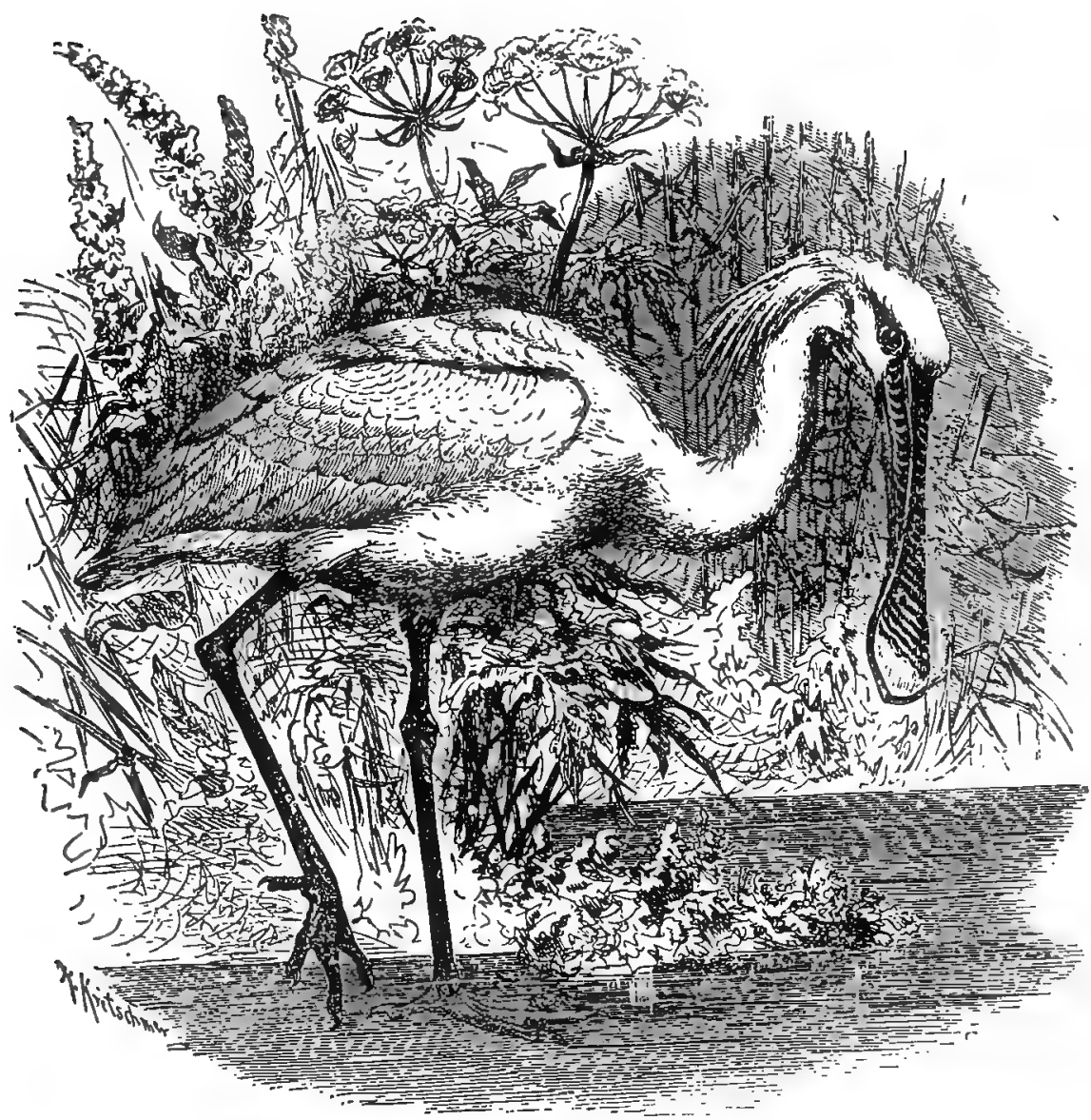

Europan SPOONBILl (grom Brehm).

together, is deep and much hollowed, which is unlike the frail platform nests of the herons. Mr. Scuart says the White Ibis breeds abundantly on the low mangrove bushes on the islands of the Gulf coast. There is a large rookery in Charlotte Harbor. The nests are usually made of the green twigs of the mangrove. The eggs are laid in June. At Cape Sable eggs are deposited after the 10th of April; these are from three to five in number, ashy-blue, spotted and blotched irregularly with yellowish, reddish and umber-brown of varying shades; two or three in number, and measure about 2.25 by 1.50 .

[185.] SCARIET IBIS. Guara rubra (Linn.) Geog. Dist.-Eastern coasts of tropical America, north casually to Florida, Louisiana and Texas; southward to the West Indies.

An exquisite bird of the richest scarlet plumage. There is probably no well authenticated instance of its having been taken within the United States. Wilson was not correctly informed concerning its abundance in the Southern Scates, and Au- 
dubon only saw a flock of three in Louisiana. The bird is said not to be an uncommon visitant to Jamaica and Cuba, and very common on the Island of Trinidad, where it formerly nested. Mr. Warren observed the Scarlet Ibis breeding in immense colonies on the banks of the Amazon, in dense, impenetrable thickets of bamboo canes, several kinds of thorny cactus and Spanish bayonets, besides numbers of small mangroves and palmettos, all interlaced and tangled with huge vines. In one place every bush and tree had on it from five to twenty nests; they were about a foot and a half in diameter and perfectly flat; the materials used in their construction were twigs, fibrous roots and leaves. Mr. Warren states that the Ibises, being disturbed, rose in. immense numbers, and a more striking spectacle than a

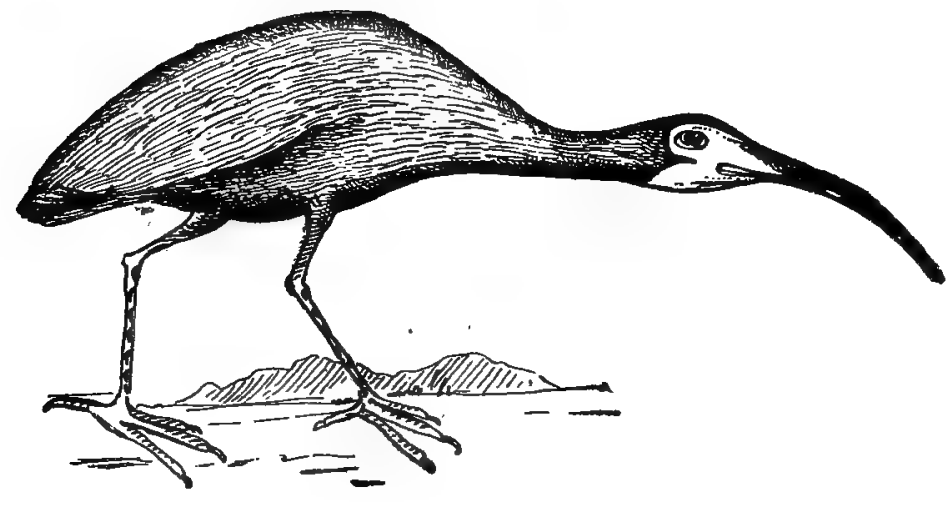

185. SCARLET IBIS.

large flock of these splendid birds floating through the air, like a crimson cloud, cannot possibly be conceived. The rookeries are only tenanted during the dry season. The eggs are two or three in number, grayish-white in color, marked with spots and blotches of brown of varying shades, and distributed variously over the surface, but generally more profusely at the larger end. The average size is $2.15 \times 1.46$.

186. GLOSSY IBIS. Plegadis autumnalis (Hasselq.) Geog. Dist.-Old World, West Indies, and Eastern United States.

This species occurs irregularly in the eastern portions of the United States, and has been known to breed in Florida. It has also been found breeding in Neyada. In Europe the course of its migrations for the summer is said to be chiefly in a line from Egypt, to Turkey, Hungary and Poland, and to the southern parts of Russia. In its passage from Africa it is occasionally seen in the Grecian Archipelago, in Sicily, Sardinia, Genoa, Switzerland, France, Holland and Great Britain. The nesting of the Glossy Ibis is like that of the next species. The eggs are of a deep greenish-blue and average $2.01 \times 1.47$.

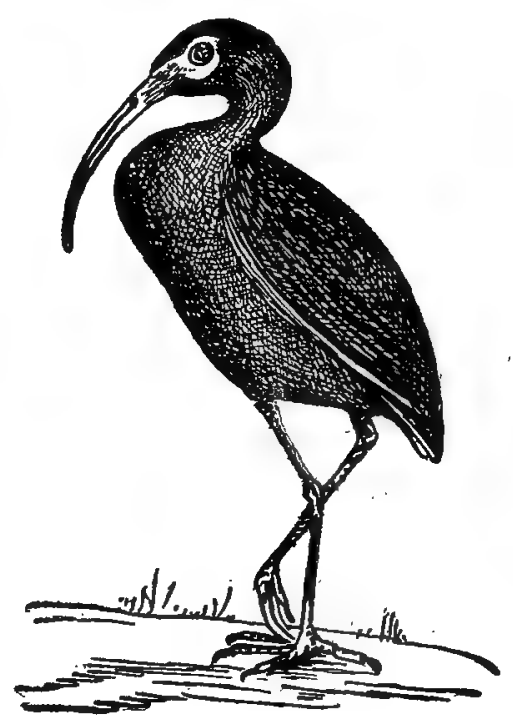

186. Glossy IBIS. 
187. WHITE-FACED GIOSSY IBIS. Plegadis guarauna (Linn.) Geog. Dist.-Western United States (Texas, Utah, Nevada, Oregon, California, etc.), southward to Mexico, West Indies, Central and South America.

This beautiful, lustrous Ibis inhabits southwestern United States and south into tropical America. It is found as far north as Kansas, west through New Mexico and Arizona to California. It is especially abundant in southern Texas, and in some localities along the banks of the Rio Grande swarms by thousands. At this place Dr. James C. Merrill, in company with Mr. G. B. Sennett, on the 16th of May, 1877, visited a large patch of tule reeds, growing in a shallow lagoon about ten miles from Fort Brown, in which large numbers of this Ibis and several kinds of Herons were breeding. The reeds covered an area of perhaps seventy-five acres or less. Besides the Ibises, the Great and Little White Egrets, Louisiana and Night Herons, and several other birds were breeding here. The reeds grew about six feet above the surface of the water, and were either beaten down to form a support for the nests, or dead and partly floating stalks of the previous year were used for that purpose. Dr. Merrill states that it was impossible to estimate the number of the Ibises and different Herons nesting here. "Both nests and eggs of the Ibises were quite unlike those of any of the Herons, and could be distinguished at a glance. The nests were made of broken bits of dead tules, supported by and attached to broken and upright stalks of living ones. They were rather well and compactly built, and were usually well cupped, quite unlike the clumsy platforms of the Herons. The eggs were nearly always three in number, and at this date were far advanced in incubation; many of the nests contained young of all sizes. Fifty eggs now before me average $1.95 \times 1.35$, the extremes being $2.20 \times 1.49$ and $1.73 \times 1.29$; they are decidedly pointed at the smaller end, and are of a deep bluish-green color."

188. WOOD IBIS. Tantalus loculator Linn. Geog. Dist.-Southern United States from Ohio Valley, Colorado, Utah, California, etc., south to Buenos Ayres; casually northward to Pennsylvania and New York.

The American Wood Stork, as it is called, is distributed over a large portion of South and Central America, Mexico and Southern North America. It is found in all the Gulf States, and is most abundant in Florida, where, Mr. Stuart informs me, it nests in the intericl in dense cypress swamps, on the tallest trees, which are often more than one hundred feet in height. In these rookeries are also found nesting the American Egret, Ardea egretta; Great Blue Heron, A. herodias; the Anhinga and others. The nests, like those of the Herons, are platforms of sticks loosely arranged, with a lining of long moss. The same rookery is occupied each year, and the nests are repaired and augmented until they often become of immense size. The eggs are chalky-white, sometimes spotted with pale reddish-brown; somewhat elliptical. The shell is rough, with a flaky substance. Two or three is the number laid, but almost invariably three. Size from 2.70 to 2.75 lorig by 1.70 to 1.75 broad.

[189.] JABIRU. Mycteria americana Linn. Geog. Dist.-Tropical America, north casually to Southern Texas.

This singular bird is known as the American Stork. It is found in portions of Central America and throughout most of South America, but occurs rarely farther north. One specimen is said to have been taken within the limits of the United States, and that near Galveston, Texas. The bird is said to have the same general habits peculiar to the White Stork of Europe. The nest is a large platform of sticks built in the highest trees. An egg is described by Dr. Brewer as rounded-oval in shape, and of an olive-green color; size $3.33 \times 2.20$. 


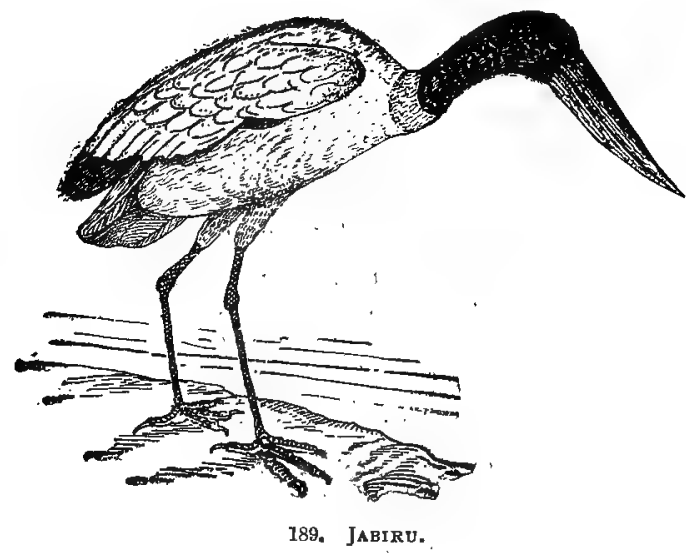

190. AMLERCAN BITTERN. Botaurus lentiginosus (Montag.) Geog. Dist.Temperate North America, south to Guatemala and the West Indies.

This noted bird is known by various names, such as Indian Hen, Stake Driver, Bog-bull, and Thunder Pump. It inhabits the entire temperate North America, north

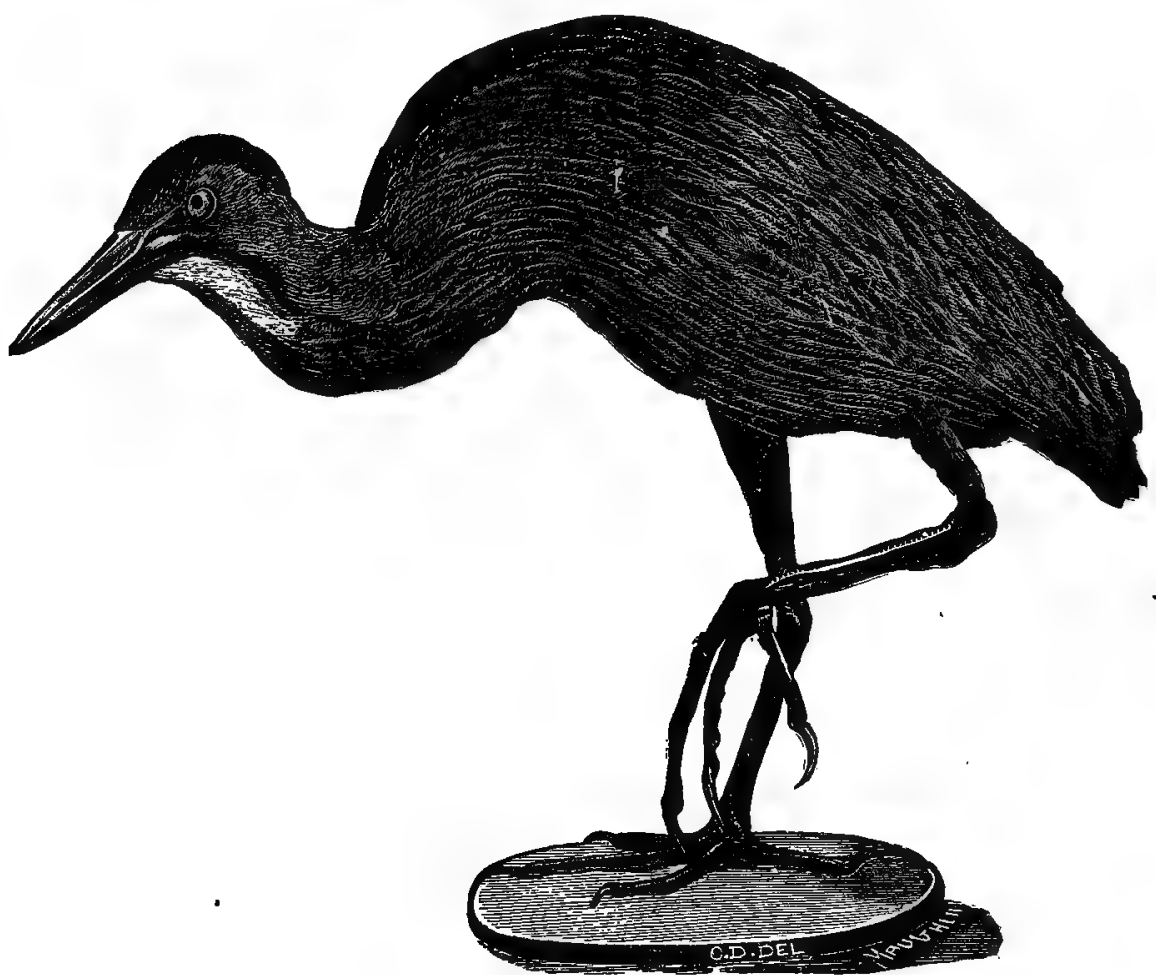

190. AMERICAI BITTERN. (From a mounted specimen.) 
to $58^{\circ}$ or $60^{\circ}$, and breeds chiefly from the middle districts northward, wintering thence southward. The name last mentioned is occasioned by its hoarse, gurgling cry of alarm. The bird is often spoken of by the poets as the "booming bittern." In the breeding season it has a "love note" that resembles the stroke of a mallet on a stake, chunk-a-kunk-chunk, quank-chunk-a-lunk-chunk. Few ornithologists have actually seen a Bittern "pump." One of the best accounts ever written of the Bittern's "pumping" is that by Frank H. Nutter, a civil engıneer who observed the performance in a marsh in Minnesota. It appears in the "Öllogist's Exchange" for April, 1888 (Vol. I, No. 4), which was among the prize essays on bird life, and the writer was appointed judge.' ' It has been quoted frequently since its first appearance. So many new and original observations were advanced by Mr. Nutter that I was compelled to award him the prize without previously knowing from whom the MS. came. This is one of the observations: "By the way, did you ever see a Bittern while engaged in its serenade? It is a ludicrous performance. One favored me with it within easy range of my telescope. After standing in a meditative position for some time it would slowly raise its head and stretch up its neck till its bill pointed nearly straight upwards, when it commenced by several times opening and shutting its big beak with a snap that was plainly heard, though five or six hundred feet distant; it then uttered the characteristic notes from which it takes its common name of 'Stake Driver' or 'Thunder Pumper'; and truly it seems much like pumping, for each syllable seems to originate deep in the interior of the bird and to be ejected only with the greatest muscular exertion, puffing out its feathers and working its long neck up and down, as if choking to death. After a short season of meditation to recuperate its strength, the performance is again repeated, and doubtless to its mate, engaged in her maternal duties, is the sweetest of music." The American Bittern never associates with other species of Heron and is not even fond of the society of its own kind. It does not breed in colonies and the nest is difficult to discover. It inhabits almost impenetrable swampy places: the bog, the reedy marsh, and the tangled brake, where its nest is placed on the ground. The eggs are brownish-drab or isabella color, unspotted, elliptical in shape, three to five in number, but generally only three; size from 1.90 to 2.00 long by about 1.50 broad.

191. LEAST BITTERN. Ardetta exilis (Gmel.) Geog. Dist.-Temperate North America, from the British Provinces to the West Indies and South America.

An extremely interesting little bird," of quiet, retiring habits. Breeds throughout its range. In some places as many as a dozen or twenty pairs breed along the

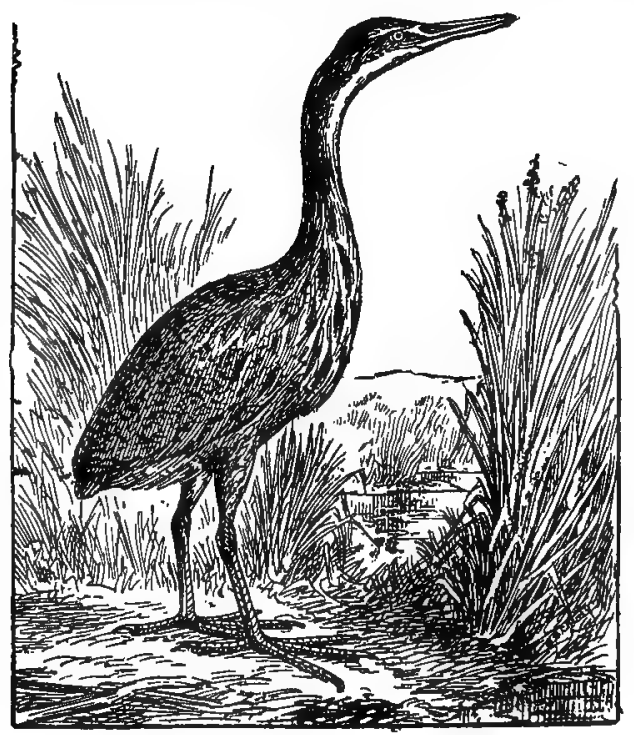

191. LeAst Bittgrịn. grassy shores of a small lake or pond. Like the last it inhabits reedy swamps and marshes where the quagmire abounds with a luxuriant growth of rushes, which is also the home of the Rails. The nest is placed on the ground or in the midst of the rankest grass, or in a bush. It is often placed on floating bog, and is simply a platform of dead rushes. The bird has many odd habits. When standing on the edge of a stream, with its neck drawn in, it is often taken for a woodcock, the long bill giving it this appearance. It appears so stupid at times that it may be caught with the hand. The bird is mostly seen just before or after sunset. In many of the Southern States this species rears two broods in a season, fresh eggs having been obtained in May and in August. In Texas, Mr Rachford says, it nests along the 
edges of the water counses in May bending down the tops of the water grass and platting it into a snug little nest, about two or three feet above the water. Mr. Perry informs me that the Least Bittern in Beaufort county, South Carolina, makes its home in the fresh water ponds and commences to build about the 10th of May, fixing the nest in the thick rushes. The eggs of the Least Bittern are from three to five, usually four, in number, pale bluish or greenish-white, elliptical in shape. Six eggs measure as follows: $1.15 \times 90,1.16 \times 93,1.22 \times .95,1.23 \times .92,1.24 \times .93,1.23 \times .93$. l'he average size is $1.20 \mathrm{x} .93$.

191. 1. COREY'S LEAST BITTERN. Ardetta neoxena (C.ry.) Geog. Dist.Southern Florida (Caloosauatchie river, near Lake Okeechobee); Ontario; Michigan.

This is recorded as being without doubt perfectly distinct from any known species. It was described from a specimen taken in the Everglades of Florida. In the same region to which the species was supposed to be confined a half dozen other specimens have been taken. Examples have been shot in the marshes near Toronto, Canada, where A. exilis is common. One is recorded from Michigan. It is more than likely, according to authorities who have examined specimens, that it will prove a color phase of $A$. exilis.

192. GREAT WHITE HERON. Ardea occidentalis Aud. Geog. Dist.-Florida, Cuba, Jamaica; accidental in Mississippi Valley.

This beautiful, majestic bird, known as the Florida Heron, is an abundant resident of Florida, the Keys and southward to Cuba and Jamaica. In Florida, however, it is said not to be so abundant as in former years. Whole rookeries have been destroyed by the "plume hunters," who collect feathers for hats and other decorative purposes. The birds are killed and the plumes are taken from their back, head and breast, and the carcasses thrown to the buzzards." This Heron nests usually in large colonies, and in company with the Great Blue Heron. Most of the nests are built low down, not more than five or ten feet from the ground, but where tne birds are disturbed the nests are placed in the highest mangroves. They are simply platforms of sticks. The eggs are plain bluish-green, of varying shades; sizes from 2.00 to 2.45 long by 1.80 to 1.85 broad. The bird known as $A$. vouerdemanni (Baird) $\dagger$ is believed to be either a colored phase of $A$. occidentalis, or an abnormal specimen of A. wardi Ridgw.

193. WARD'S HERON. Ardea wardi Ridgw. Geog. Dist.-Florida.

This large Heron in its white phase is described as indistinguishable from the Great White Heron; in the colored phase like occidentalis, but with the head colorei as in the Great Blue Heron. It is restricted to Florida; common in the southwestern portion, and may frequently be found nesting along the coast. It breeds in communities with other herons, egrets and snake birds, constructing the same kind of nest as does the Great Blue Heron. The eggs are four, often only three, in number. Prof. Ridgway gives the average measurement as about $2.65 \times 1.85$. Their color is bluish-green.

* See W. E. D. Scott's article on the Present Condition of the Bird Rookeries of the Gulf Soast of Florida in The Auk, Vol. IV, pp. 135-144, 213-222, 273-284.

$\dagger$ Placed in the Hypothetical List of the A. O. U. Check List. 
194. GREAT BLUE HERON. Ardea herodias Linn, Geog. Dist.--North America, from the Arctic regions southward to the West Indies and South America.

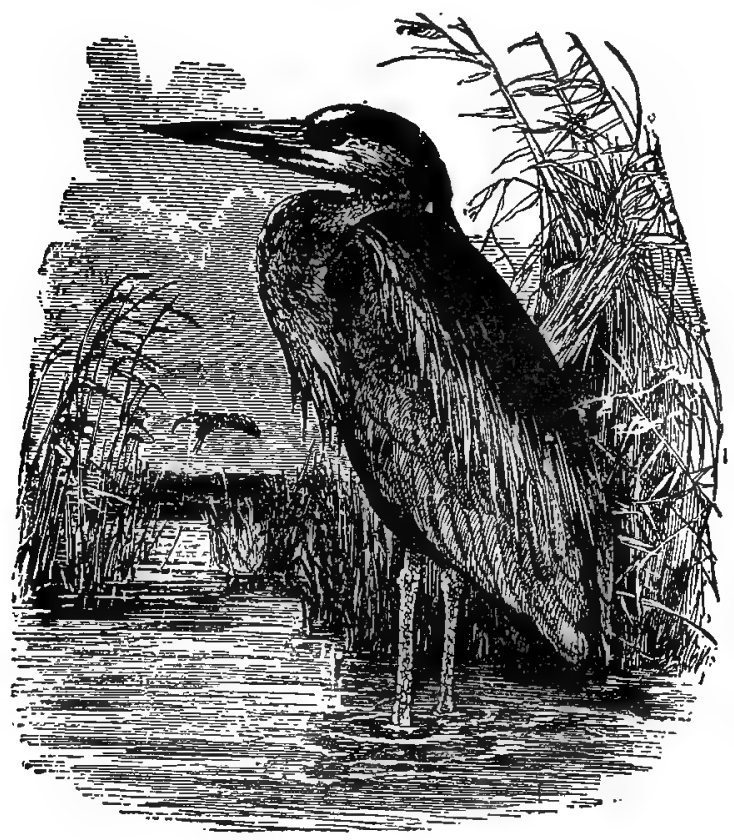

194. Great BLue herron.

The Great Blue Heron is often erroneously called "Sand-hill Crane" or "Blue Crane"-in fact it is better known by either of these names than it is by its proper vernacular name. One of the most characteristic birds of North America, breeding singly and in colonies in suitable places throughout its range. In the warmer parts of the country it breeds in vast heronies in company with other species of herons, to which places they resort year after year. In Florida it is very abundant, but its numbers are rapidly decreasing by the constant persecution of the "plume hunters." Its rookeries are so frequently broken up, and the remaining birds compelled to retire to other resorts, that the breeding season may be said to extend over a period of live or six months, and no doubt two broods are reared in a season. The nest is placed in high trees along rivers, or in the depths of retired swamps; in localities destitute of trees it is built on rocks. Sycamore trees seem to be favorite resorts of these birds, the light color of the limbs and the peculiar tint of the foliage harmonizing so well with their plumage as to render their presence difficult of detection. The eggs are plain greenish-blue; varying from elliptical to oval in shape; three to six in number, commonly three or four; average size $2.50 \times 1.50$.

[195.] EUROPEAN BLUE HERON. Ardea cinerea Linn. Geog. Dist.Europe; accidental in Southern Greenland. 
This is a familiar Heron in Europe, and is very abundant in places where it is protected by law. In England most of its breeding places are guarded by land owners. In the middle ages when falconry was a favorite sport the bird was held as royal game, and penal enactments preserved it for the pleasure of royalty. Hagerup mentions this Heron as an occasional visitor in South Greenland. A skin which was from Gadthaab is in Benson's collection. It was taken in 1877. This Heron builds its nest according to circumstances, either on the ground, in trees, or on high rocks. It breeds in colonies, and its favorite nesting places are on the tops of trees, on the outer branches. The nest is large and flat, composed of sticks and lined with grass. Each year the nests are repaired and augmented until they become very massive. The eggs are four or five in number, of a pale green color, and measure 2.42×1.72. Four eggs from England in my collection measure $2.48 \times 1.67,2.49 \times 1.61,2.52 \times 1.64,2.40 \times 1.65$.

196. AMERICAN EGRET. Ardea egretta Gmel. Geog. Dist.-Temperate and cropical America, from New Jersey, Minnesota and Oregon, south to Patagonia; casually on the Atlantic coast to Nova Scotia.

This beautiful species, the Great White Egret of America, has an extended distribution, breeding as far north on the Atlantic coast as New Jersey, on the Pacific coast to Oregon, and in the interior as far north as Southern Illinois. It breeds throughout South America to Patagonia, and is a resident on the Island of Trinidad. In the enormous rookeries of Florida this bird was formerly abundant, but of late years the "plume hunters" have wrought great destruction in their numbers. It is a bird of purest white, and during the breeding season has a magnificent train of silky plumes flowing from the back over the wings and drooping far beyond the tail. Our illustration of the European Great White Egret, $H$. alba, will give a fair idea of the appearance of the American Egret. Our bird measures from 36 to 42 inches in length, not including the dorsal train, which is sometimes more than 12 inches longer. The nests of the Great White Egret are built in deep cypress swamps, often on the tops of the tallest trees; others are found on low bushes or on mangroves, a short distance above water. The eggs are plain bluish-green, varying from elliptical to oval, two to four in number and measure from 2.20 to 2.35 long by 1.40 to 1.65 broad.

197. SNOWY HERON. Ardea randidissina Gmel. Temperate and tropical America, from Long Island and Oregon, south to Buenos Ayres; casual on the Atlantic coast of Nova Scotia.

The breeding range of this species is almost the same as that of the last. A few are supposed to be summer residents as far north as Long Island, from thence southward it is found along the entire Gulf coast and the shores of both oceans. It occurs in the interior as, far north as Oregon. Very abundant throughout a large portion 


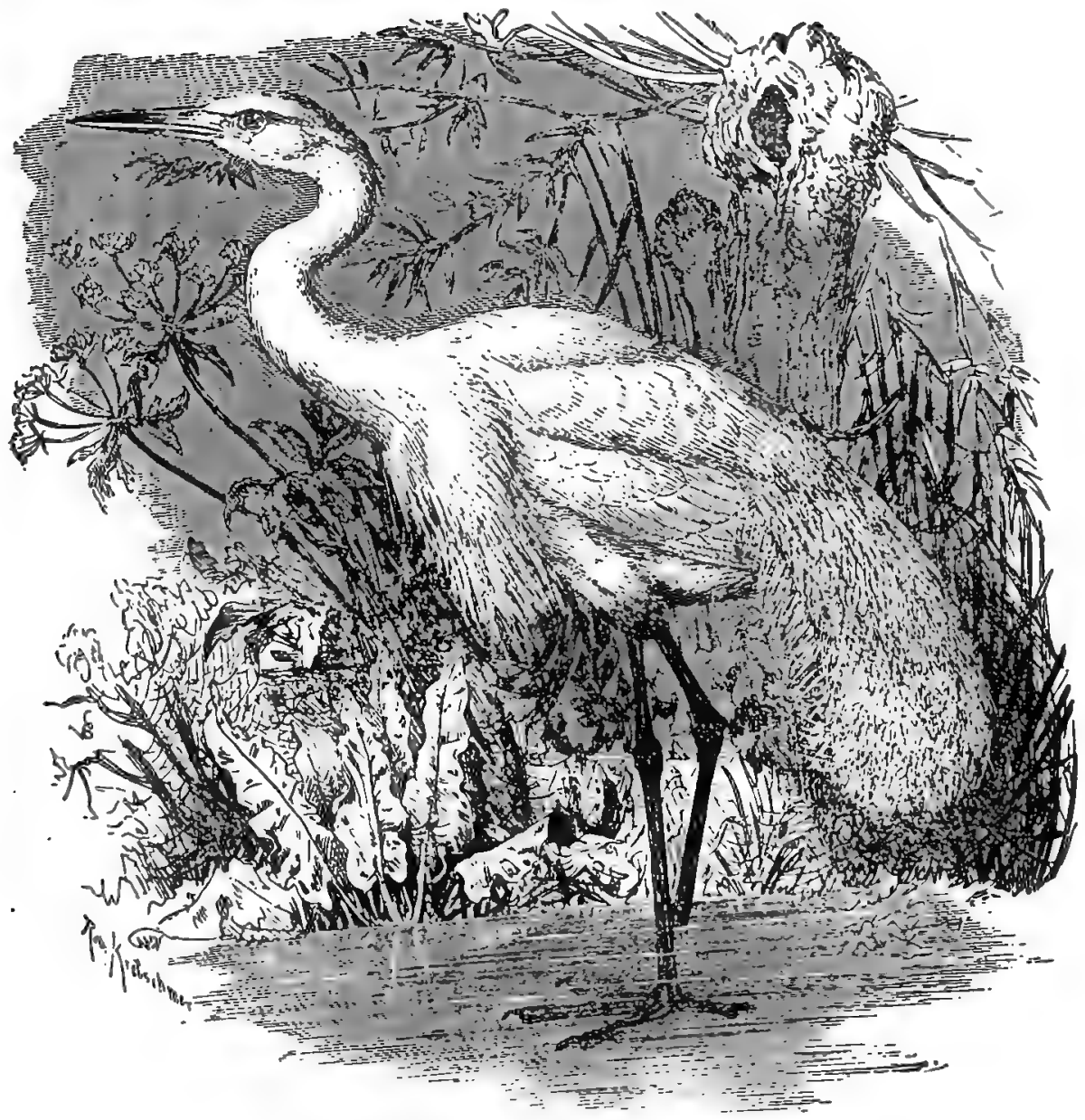

- Europen Great White Egret, Heredias albe, (From Brohm.)

of South America, the West Indies, Mexico and Central America. It is called Little White Egret, and is doubtless the handsomest bird of this tribe. Pure white, with crest composed of numerous elongated, halr-like fcuthers; similar plume on the lower neck; the same on the back which extends beyond the tail and are recurved when perfect. See fig. of the European Little White Egret, $G$. nivea. In Texas, Mr. Rachford says, this specles nests in colonies, usually prefering willow bushes in the marshes for this purpose. The breeding season is from the latter part of April to the middle of June. Mr. Stuart mentions it as abundant along the Gulf coast of Florida, where it breeds on the mangrove islands, and in the interior in the willow ponds and swamps generally in company with the Louisiana and Little Blue Herons. The nest is simply a platform of sticks. The eggs 
are from two to five in number, usually four, varying from elliptical to oval in form; sizes trom 1.80 to 1.85 long by 1.20 to 1.25 broad.

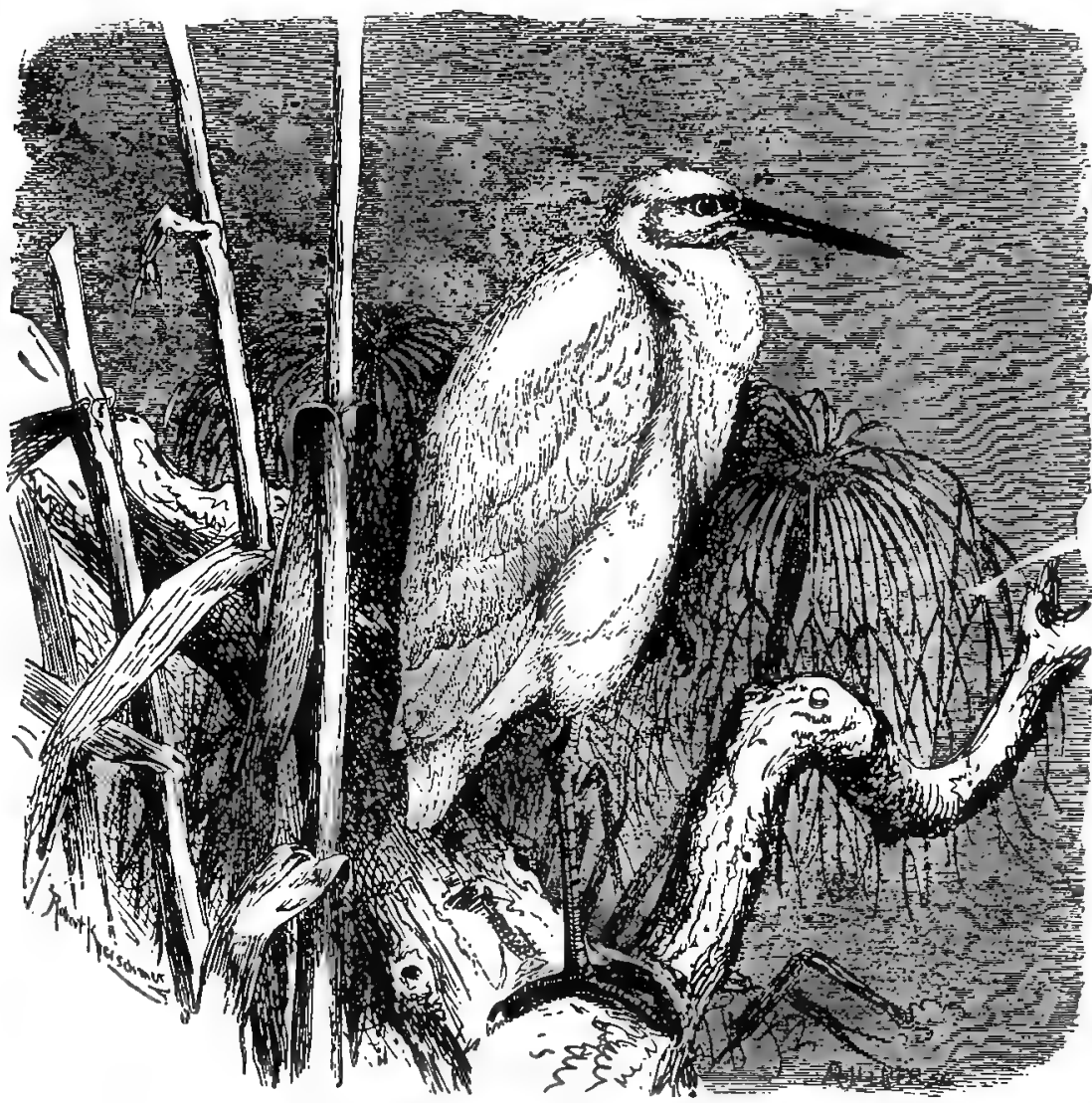

+ European Little White Egnit, Garzetta mivea. (From Brehm.)

198. REDDISH IGRET. Ardea rufescens Gmel. Geog. Dist.-Gulf Stateg and Mexico, south to Guatemala, Jamaica and Cuba.

The Reddish Egret is an abundant resident of the Gulf States. It is common in Florida and in Mexico, southward to the West Indies and Central America. The bird called Peale's Egret* is supposed to be the white phase of A. rufa. The nesting habits of the Reddish Egret are essentially the same as those of the Louisiana and Snowy Herons. Mr. Stuart informs me that he has never found them very plentiful along the Gulf coast of Florida, where they breed on the islands, placing the nest on the mangrove bushes. The eggs are light bluish-green, elliptical in form; two to lour in number, and measure from 1.85 to 2.00 long by 1.40 to 1.50 broad.

* Hypothetical List of the A. O. U. Check List. 
199. LOUISIANA HERON. Ardea tricolor ruficollis (Gosse.) Geog. Dist.Gulf States, Mexico, Central America and West Indies; casually northward to New Jersey.

In summer the Louisiana Heron is distributed from the Carolinas southward. It is very abundant all along the Gulf States, into Mexico and Central America, and is found in the West Indies. Known as "Lady of the Waters." It has an occipital crest of several long feathers and a splendid train of decomposed, fringe-like feathers extending beyond the tail. Mr. Stuart states that it is very abundant on the mangrove islands along the gulf coast of Florida, where it breeds in communities, placing the nests on the mangrove bushes; in the interior it is found nesting in the willow swamps, and usually in company with the Little Blue and Snowy Herons. Four or five eggs are deposited. Fresh eggs may be found in May and June. In Texas, Mr. Rachford says, this species nests similarly to the Snowy Heron, but its breeding Eeason commences a little earlier than that of the latter-about the first of April. The eggs are from two to four, sometimes five, in number, bluish-green, and measure from 1.75 to 1.80 long by 1.30 to 1.40 broad.

200. LITTLE BLUE HERON. Ardea ccrulea Linn. Geog. Dist.-New Jersey, Illinois and Kansas, southward through Central America, West Indies, Guiana and New Grenada; casually north on the Atlantic coast to Massachusetts and Maine.

This beautiful little Heron is abundant in the South Atlantic and Gulf States. It has been found breeding in all favorable localities intermediate between Florida and New Jersey, on the coast, and specimens have wandered into the interior. It is found throughout Mexico, Central America and the northern portion of Soutn America. The breeding habits are like those of the Snowy and Louisiana Herons, nesting with them in trees and bushes, often in large communities in deep swamps. The eggs are bluish-green, two to four in number, generally more oval than other Herons' eggs are. The sizes vary from 1.60 to 1.82 in length by 1.25 to 1.35 in breadth. The young of this Heron are pure white, and should not be confounded with immature specimens of $A$. candidissima, Snowy Heron, which is of the same size and similar form.

201. GREEN HERON. Ardea virescens Linn. Geog. Dist.-Canada and

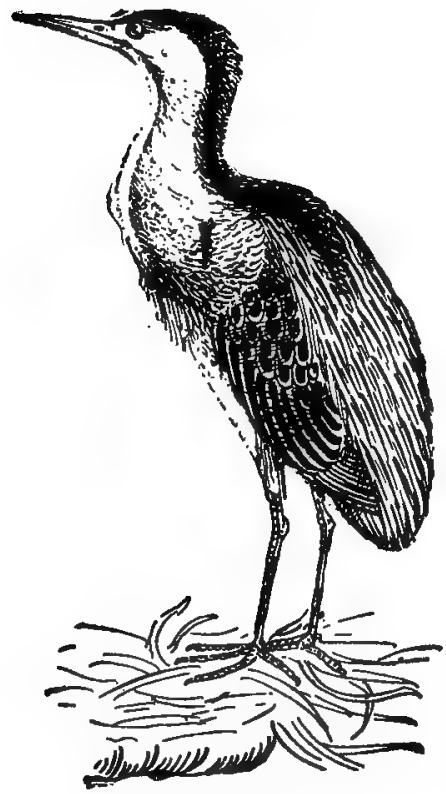

201. GreEN Heron. Oregon, southward to northern South America and the West Indies.

Throughout the United States in all favorable localities this is a well-known and an abundant bird, breeding in suitable places anywhere in its range. It has a number of common names, among which "Fly-up-theCreek" is probably the most refined. It is resident in the West Indies and in Central America, and is found in the northern regions of South America. The bird frequents the borders of ponds and swamps, or it may be found along running streams whose banks are fringed with trees or thick shrubbery. While on the wing it frequently utters its familiar guttural cry or squawk. Its food consists of insects and aquatic larvæ, crustacea and small fishes, for which it usually searches in the twilight. During the day it is sluggish, and may be found quietly resting. The nest of this Heron is made of twigs, very loosely put together; it is placed in the branches of trees or bushes on the border of a stream or swamp; sometimes in an orchard tree at considerable distance from water. The eggs are light greenish-blue, elliptical in shape and are from three to six in number, four being the usual nest complement. Average measurement is 1.60x1.14. 
201a. FRAZAR'S GREEN HERON. Ardea virescens frazari Brewst. Geog. Dist.-Lower California (vicinity of La Paz).

This subspecies is dedicated to M. Abbott Frazar, the naturalist and taxidermist who took the first specimens near La Paz, Lower California, in 1887. Mr. Brewster says: "Although the points of difference between this bird and true $A$. virescens are not easily expressed, they are, nevertheless, apparent on the most casual comparisons, or, indeed without any comparison whatever. The deeper, more purplish maroon of the neck, with its decided glaucous tinge, is perhaps the best character of the new form. None of the specimens in the National Museum from the west coast of Mexico show any approach to frazari, all being apparently true virescens."* Its nesting habits and eggs are unkuown, but more than likely are identical with $A$. virescens.

201c. ANTHONY'S GREEN HERON. Ardea virescens anthonyi Mearns. Geog. Dist.-Arid region of Southwestern United States, and southward into Mexico.

This subspecies, named in honor of A. W. Anthony, belongs to the arid portions of Southwestern United States and southward. I have nothing positive regarding its nesting and eggs, but they will probably not differ from those of A. virescens.

202. BLACK-CROWNED NIGHT HERON. Nycticorax nycticorax navius (Bodd.) Geog. Dist.-America, from the British Possessions southward to the FalkIand Islands.

A handsome bird, whose neck and legs are not so long as those of other Herons. It has a stout body, and its total length is about two feet. It has two or three very long white, filamentous plumes springing from the occiput. The Black-crowned Night Heron, Qua-bird or Squawk, as it is variously called, is found throughout the entire continent of America, except the Arctic regions. It breeds in several of the West Indies, and is resident throughout Central America, breeding in all suitable localities. It is found throughout the greater portion of South America, and has been observed breeding on the Falkland Islands. Throughout the United States, in various sections, large colonies may be found during the breeding season. Hundreds, and even thousands, colonize and form extensive heronies. Mr. M. B. Griffing, of Shelter Island, N. Y., says that in the herony on Gardiner's Island as many as four nests were found in a single tree, all containing eggs. Tall trees are usually selected for the nesting sites, and they are not always easy of access. The nests are bulky platforms of sticks, considerably hollowed. Mr. Rachford says that in the vicinity of Beaumont, Texas, this Heron nests in cypress trees along the banks of streams, and that the breeding season begins about the first of April. The greatest number of eggs found in any nest is four, which is the usual number. In all the sets that Mr. Griffing and Mr. Worthington had collected for three years there were but four sets containing more than

- Auk, V, Jan., 1888, 83.

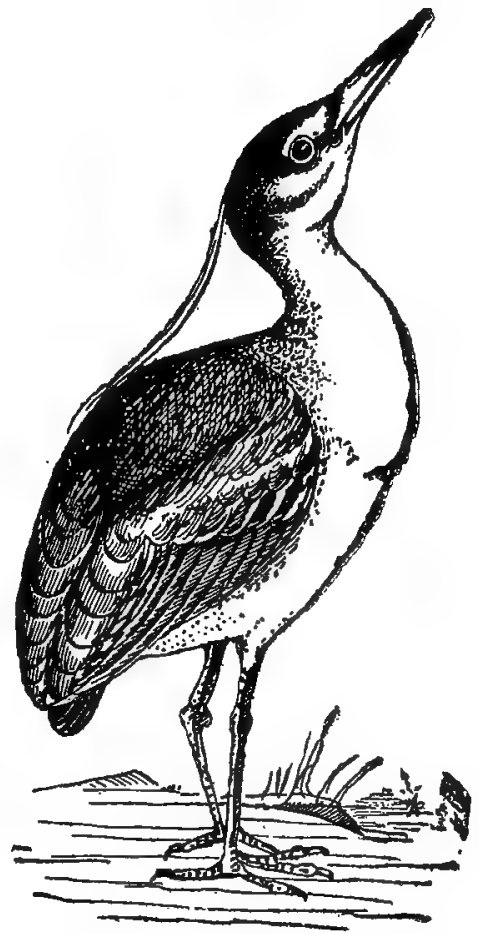

202. Black-Growned Night Hzron. 
four eggs; these were three of five and one of six. The eggs are pale, bluish-green, varying from elliptical to oval; size from 1.90 to 2.15 lang, by 1.35 to 1.55 broad. In some localities the nest of this Heron is built on the ground in marshes.

203. YELLOW-CROWNED NIGHT HERON. Nycticorax violaceus (Linn.) Geog. Dist.-Warm-temperate Eastern North America, from the Carolinas and the Lower Ohio Valley south to Brazil; casually north to Massachusetts and west to Colorado.

The Yellow-crowned Night Heron is a southern species, known to breed on the Atlantic coast as far north as the Carolinas, and in the interior as far north as Southern Indiana, Illinois and Missouri. It is found along the entire Gulf coast of Mexico, throughout the West Indies, Central America and in Northern South America. The bird is very similar to the Black-crowned Night Heron, but is a little smaller. The back and head are furnished with long, elegant, lanceolate plumes. The general color is pale, ashy-blue. Its nest is a slight platform of sticks. In some parts of the Southern States this Heron is said to be quite abundant, while in others it is rarely met with. In portions of Florida it breeds in great numbers, generally in company with other species, forming large heronies, especially in the interior in large cypress swamps. In the southern portion of South Carolina it nests in swamps or in tall trees which are surrounded by water. In various regions of Texas the nest of this Heron is built on the lower branches of a cypress tree, near some stream. Mr. Rachford says he never found more than two or three nests in close proximity to one another, but frequently found the birds breeding in company with the Snowy and Louisiana Herons. The nesting season is during April and May. He has taken as many as six eggs from a nest; the usual number, however, is four. They vary in shape from elliptical to oval; sizes 1.90 to 2.00 long by 1.40 to 1.50 broad.

204. WHOOPING CRANE. Grus americana (Linn.) Geog. Dist.-Interior of North America, from the Fur Countries to Florida, Texas and Mexico, and from Ohio to Colorado.

The Great White or Whooping Crane is confined to the interior of North America, and breeds from Illinois, Iowa, Minnesota and the Dakotas northward, passing the winter in the swamps of Florida and Texas. Its chief line of migration seems to be the Mississippi Valley at large. It is said to be common in the fur countries. In Ohio it is considered a rare spring and fall migrant. Breeds in various places throughout Manitoba, building its nest on the ground in the midst of rank grass near marshes, or in wet meadows. Mr. J. W. Preston mentions the finding of a number of nests in Northern Iowa. One found in the marshes near Eagle Lake, was about eighteen inches in height, well built of tough, fine marsh grass and placed on firm sod; it was neatly cupped and contained two heavily marked, drab-colored eggs.* Mr. R. M. Anderson found a nest containing two eggs in a marsh of Hancock county, Iowa, May 26. The nest was composed of a mass of grass and reeds and was about twenty-four inches in diameter and was placed eight or ten inches above the water. The two eggs measured $4.06 \times 2.38,4.03 \times 2.50$, respectively. The eggs of the Whooping Crane are large and coarse looking; in color, light brownish-drab, sparsely marked, with large irregular spots of a pale dull chocolate-brown and obscure shell-markings; elliptical; the shell is very rough, covered with numerous elevations like little warts; Dr. Coues says two (or three?) in number; size about

* The Oologist, Vol. IV, p. 43. 
3.75 by 2.65 . Some eggs are blotched irregularly over the surface, while others are marked at the smaller or greater end. Two eggs in my collection from Northern Iowa measure $3.89 \times 2.52,4.03 \times 2.55$, respectively.

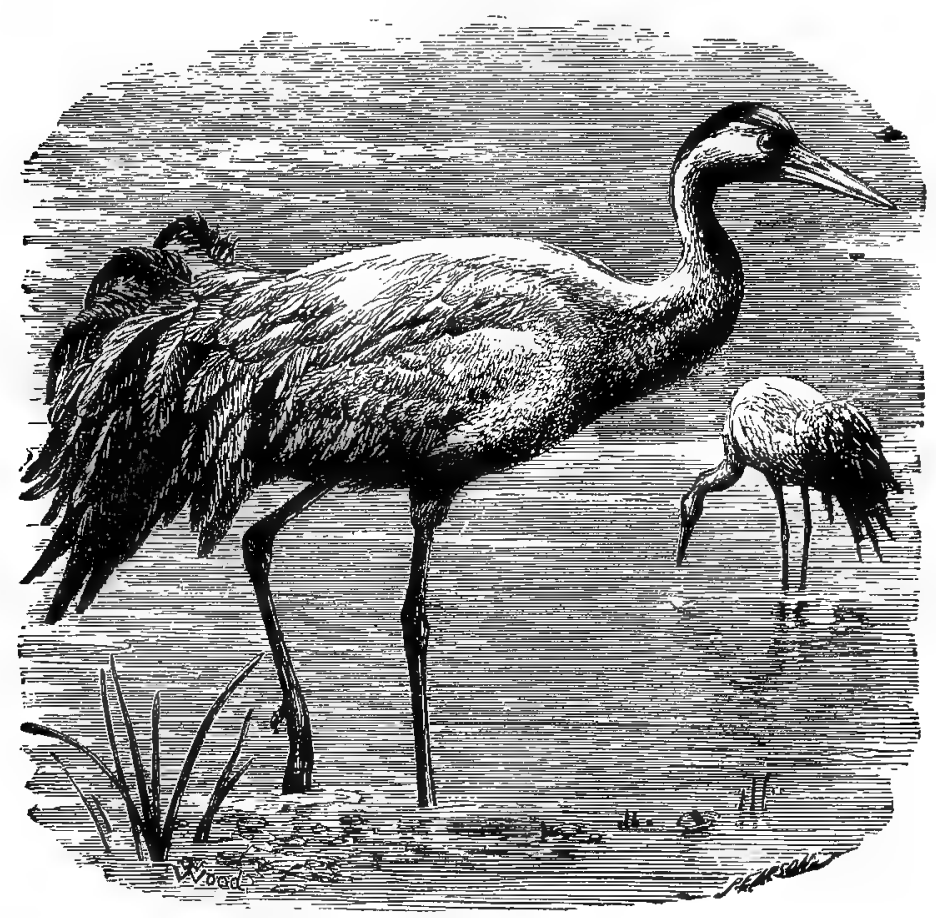

204. Whooping Crane.

205. LITTLE BROWN CRANE. Grus canadensis (Linn.) Geog. Dist.-Arctic and subarctic America, breeding from the Fur Countries and Alaska to the Arctic coast, migrating south in winter into the Western United States.

The Little Brown Crane, which is almost exactly like the next species, but Emaller, is abundant in Arctic America. I mounted a specimen of this bird which was taken in the spring of 1884 from a flock of seven birds near Springfield, Ohio. It is a rare migrant in the state. Specimens of the bird and its eggs have been taken in various parts of Alaska. Common on the Island of St. Michael's and at the mouth of the Yukon. Eggs were obtained by Mr. Dall, on the Yukon river, June 17th. They were laid in a depression of the sandy beach. This species is common in the marshes of Norton Sound, where their nests are built on the dry knolls, and the eggs are laid before the end of May. Throughout most parts of Manitoba, the Little Brown Crane is a common summer resident. Eggs have been obtained on the Lower Anderson river, in Franklin Bay, and if Liverpool Bay on the Arctic coast. Nelson states that the Little Brown Crane is a summer resident upon St. Mathew's and St. Lawrence Islands, and were found nesting by Nordenskjold in considerable numbers at Seniavine Strait, south of Bering Strait on the Siberian coast, July 28. Eggs containing small embryos were secured May 27, but they are generally deposited 
the last few days of May or first of June. The site for the nest which is to contain the two eggs which this bird always lays is usually on the grassy flats, where the dryer portions or the slight knolls afford them suitable places. The nest is frequently a mere hollow in the ground, and is commonly lined with more or less coarse grass stems and straws. In one instance a nest was found on a bare flat, and was lined with a layer of straws an inch deep, all of which must have been brought for some yards; this is unusual, however. The eggs vary in ground color from pale greenish clay to buffy brown or warm brownish, and the entire surface is irregularly marked with spots and blotches of chocolate-brown, rather sparsely distributed chiefly at the apex. The size varies from $3.70 \times 2.40,3.72 \times 2.40,3.71 \times 2.41$, representing the maximum; $3.26 \times 2.28,3.40 \times 2.35,3.33 \times 2.21$ representing the minimum in a series of twenty-five specimens.

206. SANDHILL CRANE. Grus mexicana (Mull.) Geog. Dist.-Southern half of North America; now rare near the Atlantic coast, except in Georgia and Florida.

The Southern Sandhill Urane, Common Brown or Sandhill Crane, as it is variously called, is found in the United States chiefly in the Mississippi Valley west to the Pacific coast and south into Mexico and eastward along the Gulf coast to Florida and Georgia. It is irregularly distributed and apparently breeds in sufficiently mild regions throughout its range. It has been found nesting in Michigan, is reported breeding in Northern Ohio, and is known to breed on the table-lands of Colorado. Mr. Stuart says that in various regions of Florida, this species nests during the months of February, March and April. The nests are usually built in shallow, grassy ponds, which are common in the pine woods and prairies of that State. They are flat and composed of a mass of grass, weeds, roots, etc., slightly elevated above the water, oftentimes not more than two or three inches. On this structure two eggs are deposited. Mr. Stuart remarks that the young birds are able to follow the parents soon after being hatched. The eggs are ashy-yellow, with a buffy tinge, spotted and blotched with brown, reddish-brown and various shades of gray. The average size is $3.98 \times 2.44$. Two eggs in my cabinet from Florida measure $3.85 \times 2.35,3.82 \times 2.36$.

207. LIMPKIN. Aramus giganteus (Bonap.) Geog. Dist.-Florida; coast of Gulf of Mexico: Greater Antilles, south to Costa Rica.

The Courlans are large, Rail-like birds and are in fact very closely allied to the true Rails, with but a slight difference in their external structure. There is one genus with two species, inhabiting the warmer parts of America. The Brazilian Courlan, A. scolopaceus (Gmel.), occurs in Eastern South America, while the Limpkin, which holds a place in the North American fauna, is found in the Greater Antilles, portions of Central America, with only a restricted distribution in Florida. It is called Crying Bird from its loud and startling note which is said to be not unlike the cry of a child in distress. Mr. Thomas H. Jackson met with this species breeding in the subtropical wilds of the Ocklawaha river in Florida. He states that this bird chooses for a nesting place a secluded spot on the banks of a river or slough. Several pairs often nest close together in the manner of Herons, though isolated nests are frequently observed. The nest is made of pieces of dead vines, dry leaves and old vegetation of various kinds loosely constructed and generally bedded on a mass of vines, from five to eight feet from the ground. The usual complement of eggs laid is five or six; four and seven are not uncommon numbers. Fourteen sets in $\mathrm{Mr}$. Jackson's cabinet consist of eight sets of six, one of five, two of seven, two of four and one of three eggs. In size, shape and texture of shell they resemble those of the 
domestic fowl, while in color and markings they are similar to those of the Sandhill Crane-varying from almost pure white to creamy, buff, and grayish-white. The eggs are variously spotted, daubed and stained with brown and gray. A set of six eggs containing the largest specimens in the series, exhibit the following dimensions: $2.57 \times 1.80,2.44 \times 1.75,2.40 \times 1.77,2.28 \times 1.75,2.39 \times 1.80,2.41 \times 1.83$; the set showing the smallest sizes are given as follows: $2.21 \times 1.72,2.21 \times 1.70,2.22 \times 1.622 .23 \times 1.63,2.45 \times 1.63$, $2.23 \times 1.65$.*

208. KING RAIL. Rallus eleyans Aud. Geog. Dist.-Fresh-water marshos of Eastern United States from the Middle States, Northern Illinois, Wisconsin and Kansas southward. Casually north to Massachusetts and Maine, and Ontario.

The King Rail, Fresh-water Marsh Hen, or Red-breasted Rail, is distributed in summer from New York southward, breeding throughout the inland marshes. It is a summer resident in Ohio. I collected eggs of this species in a marsh a few miles from Columbus in May, 1887. It is frequently confounded with the Clapper Rail; the latter, however, is confined to the vicinity of salt water, and is a bird of duller

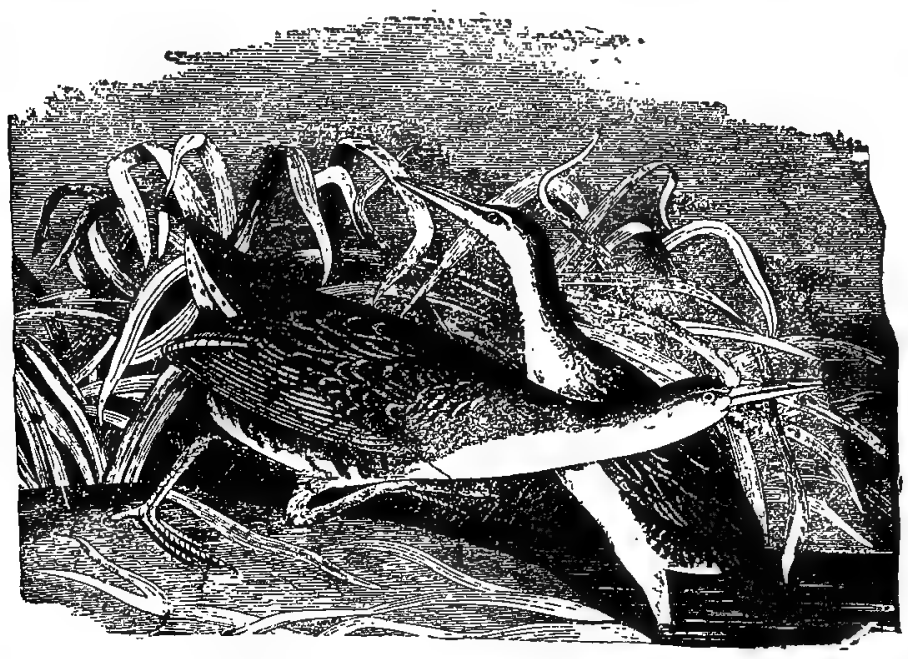

208. King Rail. (After Audubon.)

plumage. The nest of this Rail is placed on the ground in a marsh, often fastened in a tussock of grass. It is composed of grass and weeds. The eggs vary from a dull white to cream or pale buff, sparsely dotted and spotted with reddish-brown and lilac; six to twelve in number; size from 1.55 to 1.72 long by 1.15 to 1.25 broad, averaging 1.67 by 1.12 .

209. BELDING'S RAIL. Rallus beldingi Ridgw. Geog. Dist.-Lower California (Espiritus Santo Island and vicinity of La Paz).

Under the ruling of the A. O. U. Code to admit the islands pertaining to Lower California, this species comes within the North American avifauna. It is very much like $R$. elegans, but is darker and richer colored throughout, the white bars of the

* Ornithologist and Oologist, XII, pp. 159-160. 
flanks much narrower and the blackish bars very distinct. Length, according to Mr. Ridgway, about 15.00-16.00; wing 5.70-6.40; depth of bill .29-.35 (.31); tarsus 1.88-2.10 (1.93). I can find no information regarding this bird's nidification, but in all probability it is similar to that of $R$. elegans.

210. CALIFORNIA CLAPPER RAII. Rallus obsoletus Ridgw. Geog. Dist.Salt marshes of the Pacific coast from Lower California to Oregon.

Mr. Bryant regards this Rail as abundant, at all seasons of the year, on the salt marshes of Oakland, San Mateo, and other marshes that are partially covered by the high tides, at which times the birds are remarkably tame. They swim well, and when wounded and closely pursued they dive and hold on to the marsh grass beneath the water to keep from rising. They commence breeding in April, selecting a high piece of marsh ground, usually on the bank of a slough. The nest is composed wholly of dry marsh grass, loosely laid together. The bird deposits eight or nine eggs, of a light, creamy buff, spotted, often blotched, with reddish-brown and lavender markings, the latter color appearing as if teneath the shell. Of some thirtysix specimens examined, all have markings more numerous at the larger ends; on some the lavender predominates. A set of eight, taken at San Mateo, April 24th, contained small embryos. They measure respectively $1.70 \times 1.25,1.73 \times 1.23,1.75 \times 1.23$, $1.77 \times 1.23,1.68 \times 1.23,1.70 \times 1.22,1.63 \times 1.26,1.69 \times 1.24$. The average size of thirteen eggs is 1.71x1.24.* In the marshes of San Francisco Bay Mr. Emerson took eggs of this Rail in April, May and June, one set containing seven eggs.

211. CLAPPER RAIL. Rallus crepitans (Gmel.) Geog. Dist.-Salt marshes of the Atlantic coast of the United States, from New Jersey southward; resident from the Potomac southward. Coast of Louisiana.

The Clapper Rail, or Salt-water Marsh Hen, is an abundant bird in the salt marshes of the Atlantic coast from New Jersey southward. Breeds in profusion and is the most abundant aquatic bird in the marshes from the Carolinas to Florida. It has lately been found breeding on the coast of Louisiana, in the Gulf of Mexico, Dr. A. K. Fisher having taken an old bird and two young at Grand Isle, in $1886 . \mathrm{Mr}$. S. C. Shick, of Sea Isle City, states that the Clapper Rail arrives on the-southeastern coast of New Jersey about the last of April; their presence is made known by harsh cries at early dawn and at sunset. Nest building is commenced in the latter part of May, and by the first of June the full complement of eggs is laid, ranging from six to nine or ten in number, thirteen being the largest set he ever obtaincd from any nest. Farther south this bird is known to lay as many as fifteen, this number, however, being uncommon. On Cobb's Island, Va., the Clapper Rail breeds in great numbers, carefully concealing the nest in high grass; the full complement of eggs is laid by the first of May. Their color is pale buffy-yellow, dotted and spotted with reddish-brown and pale lilac, with an average size of $1.72 \times 1.20$, but there is a great variation in this respect in a large series.

211a. LOUISIANA CLAPPER RAIL. Rallus crepitans saturatus Ridgw. Geog. Dist.-Coast of Louisiana.

This subspecies was discovered by Henshaw, who described it in 1880 . It is smaller than the type-length about thirteen inches-is of brighter-colored plumage, the brown of the upper parts is of a richer tint and more deeply tinged with olive, while the breast is of a richer shade of brown. It has been found only on the coasts

* Bull. Nutt. Club, V, p. 124. 
of Louisiana. I know nothing reliable concerning its nesting or eggs, but they are said to be similar to $R$. crepitans, which in all probability are identical.

211. 1. FLORIDA CLAPPER RAIL. Rallus scottii (Senn.) Geog. Dist.Salt marshes of Western Florida.

The Florida Clapper Rail differs from crepitans proper in being black, fucous, or olive-brown above, with olive-gray margins to the feathers; in having tne neck and breast cinnamon-rufus washed with brownish, and in having the belly and flanks black instead of gray. In fact, the general color of scottii suggests a King Rail, but the latter may always be known by its rufous wing-coverets and clear cinnamon-rufus neck and breast.-Chapman.

211. 2. CARIBEAN CLAPPER RAIL. Rallus longirostris caribans Ridgw. Geog. Dist.-West Indies and Gulf of Mexico; north to Texas (Corpus Christi and Galveston).

A subspecies inhabiting the West Indies, its colors being similar to $R$. crepitans. Its nidification is more than likely similar or identical to that species.

212. VIRGINIA RAIL. Rallus viryinianus Linn. Geog. Dist.-North America, from the British Provinces south to Guatemala and Cuba.

The Virginia Rail is an exact miniature of $R$. elegans, the coloration being exactly the same; the legs, iris and bill brown-the latter reddish-orange at the base of the lower mandible. In summer it is distributed from Canada to Florida; frequenting marshes and boggy swamps. The nest is built in a tuft of reeds or grasses close to the water; it is compact and slightly hollowed. The eggs are cream or buff, sparsely spotted with reddish-brown and obscure lilac; they are like those of the King or Clapper Rail, but of course, like the bird, much smaller; sizes range from 1.20 to 1.28 long by .90 to .93 broad. The number in a set varies from six to twelve. The Virginia Rail and the Sora have habits that are very similar; when on the wing they will fly in a straight line for a short distance with dangling legs, and suddenly drop into the grass. The Virginia Rail is almost exclusively a fresh water bird.

[213.] SPOTTED CRAKE. Porzana porzana (Linn.) Geog. Dist.-Europe; occasional occurrence in Greenland.

The European Spotted Crake is found in most parts of Europe, Asia and Africa. Common in Italy, Sicily and in the Southern portions of Russia. Hagerup mentions this species as a "rare visitor in South Greenland." Breeds abundantly in Southern France and in various parts of England. It frequents the banks of streams, ponds and lakes, and the thick grasses and vegetation of marshy grounds. The nest is usually built in these places, being loosely woven of aquatic plants, and lined with finer material of the same; it is often placed near the water's edge, and so arranged as to be capable of floating on the water. Spotted Rail, Spotted Water-hen, Spotted Gallinule, Water-crake, and Water Rail are names common to it in England. The eggs of this bird are from seven to twelve in number; pale buff or cream color, or of a yellowish-gray, spotted and speckled with a dark reddish-brown and tints of lavender. Six eggs, collected in Southern France, in my cabinet measure 1.34x.96, $1.36 \times .94,1.32 \times .93,1.34 \times .94,1.33 \times .96$ and $1.32 \times .95$.

214. SORA. Porzana carolina (Linn.) Geog. Dist.-Temperate North America. South to the West Indies and Northern South America. 


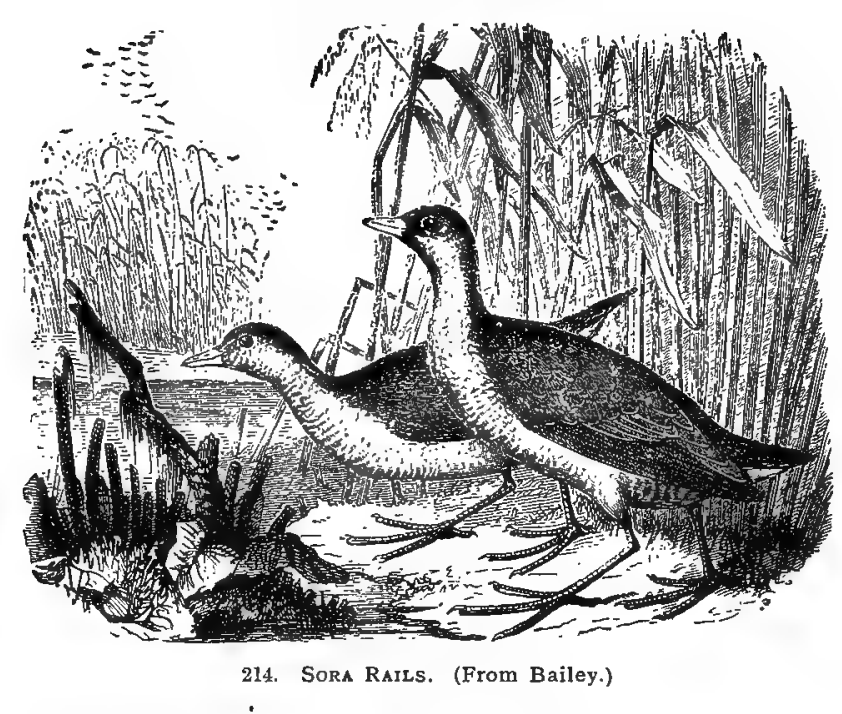

The little slate-colored Carolina Rail breeds from the Middle States northward. In the reedy swamps of the Atlantic States great numbers of this Rail are killed every year. It is a highly esteemed game bird, and is usually abundant during the migrations. More common in the Eastern Province of the United States, breeding chiefly northward. Mr. Shields states that the Sora Rail is quite common in the swamps about Los Angeles, Cala., where he obtained six sets of its eggs in the season of 1886; the largest set contained fourteen and smallest seven eggs. In Ohio the Carolina Crake, Common Rail, Sora or Ortolan, as it is variously called, is a common summer resident, breeding in the extensive swamps and wet meadows throughout the State. The Carolina Rails are equally abundant on both salt and fresh water marshes, but the latter places are preferable to them as breeding grounds. The nest is a rude affair made of grass and weeds, placed on the ground in a tussock of grass in a boggy tract of land, where there is a growth of briers, etc. The eggs of Sora are ovoidal in shape, tapering gradually to the smaller end but not sharply pointed. They have a ground color of dark cream or drab, darker than those of the Virginia Rail; the spots are reddish-brown with purple shell spots scattered over the surface, but more numerous at the large end. Twenty eggs in my collection have an average size of $1.26 \times$. 90 .

215. YELLOW RAIL. Porzana noveboracensis (Gmel.) Geog. Dist.-Eastern North America from Nova Scotia and Hudson Bay west to Utah and Nevada.

The small Yellow Crake appears to be quite rare everywhere in Eastern North America or wherever found. It is known to breed in Northern Illinois, where its eggs have been taken. Dr. Howard Jones has frequently taken it in the vicinity of Circleville, Ohio, and considers it nearly as common as other species, and believes it breeds there, which is probably the case throughout the State. The Little Yellow Rail has the same general traits common to others of this family, frequenting marshy places, skulking and hiding in the wet grass to elude observation. The eggs are said to be about six in number, rich buffy-brown, marked at the larger end with a cluster of reddish-brown dots; sizes range from 1.05 to 1.12 long by .80 to .85 broad. 
216. BLACK RAII. Porzana jamaicensis (Gmel.) Geog. Dist.-Temperate North America, north to Massachusetts, Northern Illinois and Oregon; south to West Indies and South America.

Smallest of our North American Rails; not often found in the United States and one of the rarest of our birds. Its small size and secretive habits are doubtless one of the causes of its apparent scarcity. A nest containing ten eggs was found near Saybrook, Conn. Ten fresh eggs were taken from a nest in Illinois, June 19, 1875, near Calumet River. The nest was placed in a deep, cup-shaped depression; in shape and situation resembled that of the Meadow Lark, but the Rail's nest was much deeper in proportion to the diameter. It was elaborately made of grass-stems and blades. The eggs were clear white, thinly sprinkled with reddish-brown dots, more numerous about the large end.* Mr. Harry Menke found a nest containing nine eggs in a marsh near Garden City, Kan., June 6, 1889. The nest was placed on a low ridge near the center of a pond, a neat, compact structure, composed entirely of blades of a kind of water grass. Dr. Coues says: "Eggs from New Jersey are altogether different from those of the Sora, or Yellow Crake, being creamy-white, sprinkled all over with fine dots of rich, bright reddish-brown, and with a few spots of some little size at the great end; most like the more finely speckled examples of the egg of the large Ralli; dimensions, $1.05 \times 180 . "$

216. 1. FARALLONE RAIL. Porzana coturniculus (Ridgw.) Geog. Dist.Farallone Islands.

This species is like the last, but rather smaller, more uniform in color, without the white specks on the back. It is known only from the type specimen taken on the Farallones.

[217.] CORN CRAKE. Crex crex (Linn.) Geog. Dist.-Europe and Northern Asia; casual visitor in Greenland, Bermuda and Eastern North America.

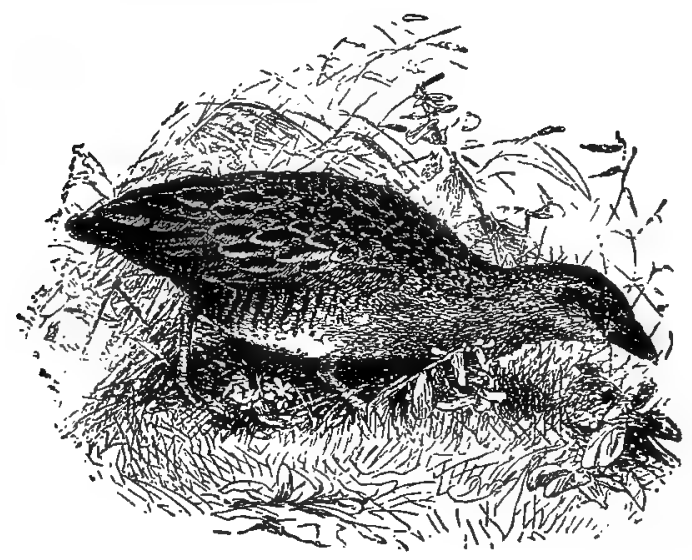

217. Corn Crake.

The Land Rail, Corn Crake, or Corn Creak, is an abundant species over the entire continent of Europe. In England and Scotland it is a familiar bird, where it breeds in abundance. Very common in the Orkney and Shetland Islands. It frequents the

* L. W. Nelson: Bull. Nutt. Orn. Club. Vol, I, p. 43. 
long grass of wet meadows, near rivers and marshes, and in fields of grain. Its presence is indicated by the creaking note from which it takes its name. The nest is placed on the ground, generally in a field of grain, grass or clover; it is made of dry plants and grasses. In England this bird nests about the first or middle part of June. The eggs are from seven to ten in number; these, when fresh, are of a pale reddish-white; when blown, the ground color is light buff, with a reddish cast; they are spotted and sprinkled with pale reddish-brown, chiefly at the larger end. The measurements of a set of five eggs in Mr. Crandall's collection taken near Mersburg, Germany, July 7, are as follows: 1.40x1.02, 1.43x1.05, 1.40x1.00, 1.42x1.03, 1.45x 1.05 , respectively.

218. PURPLE GALIINULE. Ionornis martinica (Linn.) Geog. Dist,--South Atlantic and Gulf States; casually northward to Maine, New York, Wisconsin, Ohio, etc.; south through the West Indies, Mexico, Central America and Northern South America to Brazil.

This beautiful Gallinule inhabits the South Atlantic and Gulf States and strays occasionally northward as far as Maine, New York, Ohio, Wisconsin and other Northern States. It has been taken several times in Central Uнio in June and July. The bird is resident in the South. From its bright purplish-blue colors it may quite readily be distinguished from the Florida Gallinule, even at a long distance. In Florida it breeds in the latter part of May. Mr. Rachford writes me that in Texas the Purple Gallinule nests in the tall grass along the edges of water courses, bending the grass down and weaving it together. Besides its true nest, the bird makes several "shams," often as many as five or six. The nesting season is in May or June. Mr. Arthur T. Wayne informs me that in South Carolina the nest is invariably built in rushes over water. The usual number of eggs laid is eight or nine, but frequently more are deposited. The eggs are cream color, ficely and rather sparsely dotted with chestnut-brown and umber; rather elliptics l, ard measure from 1.70 to 1.75 long by 1.15 to 1.20 broad.

219. FLORIDA GALLINULE. Gallinula galeata (Licht.) Geog. Dist.-Temperate and tropical America; north to British Provinces.

Known as the Common Galliuule and Rod-billed Mud Hen. Its center of abundance is in the South Atlantic and Gulf States, and it breecs as far north as Massachusetts. Not an uncommon summer resident in Ohio, brecding in the extensive swamps and marshes throughout the State. The nest is usually fastened in the sedges and marsh grass above shallow water, or among the flags. The foundation is often made by breaking down the flags, so as to form a little platform, which will, to a certain degree, rise and fall with the water. On this the nest proper is built of the last year's flags. In Florida, wherc the bird is remarkably abundant, the nest is placed in the dyer portions of the marshes, among thick reeds and rushes. A set of eight eggs, collected by Dr. Jones near Circleville, Ohio, measure $1.70 \times 1.20,1.81 \times 1.18,1.81 \times 1.17,1.78 \times 1.23,1.84 \times 1.25,1.84 \times 1.22,1.77 \times 1.24$, and $1.83 \times 1.16$. The number of eggs laid ranges from seven to thirtcen. They are creamy or brownish-buff rather thickly spotted and blotched with brown and umber; some of the spots are as small as pin.heads; sizes vary from 1.75 to $2.00 \mathrm{long}$ by 1.20 to 1.30 broad; shaped like an average hen's egg.

[220.] EUROPEAN COOT. Fulica atra Linn. Geog. Dist.-Northern parts of the Eastern Hemisphere in general; accidental in Greenland. 
This bird closely resembles our American Coot, but its average size is slightly larger. It is a common resident south of middle England, and in the summer is found breeding in the numerous lochs throughout Scotland. Its habits in all respects are like those of the American bird. The nest is built in close proximity to water, on islands, borders of lakes, ponds and rivers. It is generally placed among and attached to flags, reeds or rushes. It is large and roughly made of plants and vegetable matter. The eggs are from six or seven to ten or even fourteen in number, pale, dull buff, or stone-color, spotted with rust-colored brownish-black and purplish-gray. The average size of a large series is $2.15 \times 1.50$.

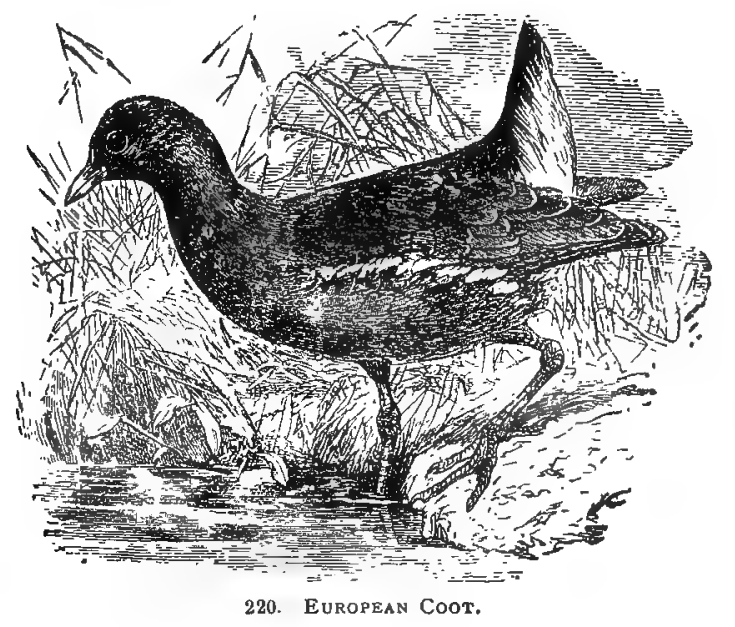

221. AMERICAN COOT. Fulica americana Gmel. Geog. Dist.-Whole of North America; south to Mexico, Central and South America and West Indies; north to Alaska, occasionally to Greenland.

Well known as the Mud Hen, and in some sections the Crow Duck. This is the water fowl that young sportsmen persist in shooting as a game bird, but at a riper age he does not "hanker" after its flesh. It is easily known by its slate-colored plumage, white or flesh-colored bill, marked with reddish-black near the end and at the base of frontal plate, greenish legs and carmine iris. The Coot is a good swimmer and diver, having lobate feet like the phalaropes and grebes. It can also move swiftly through tangled grass and aquatic plants. On almost any large or small body of water sufficiently secluded and whose margins are overgrown with reeds and rushes, or on sluggish streams, swamps, pools or reedy sloughs, there you will find the Coot during the breeding season. The nest is made of dead reeds and grasses, placed on the ground, just out of the water or on floating vegetation; the flags on which it rests being broken down, rises and falls with the water. Some times immense numbers of these birds breed together. Mr. Shields records taking five hundred Coot eggs, together with large numbers of those of ducks and grebes in Southern California.* The eggs are clay or creamy-white, uniformly and finely dotted all over with specks of dark brown and blackish; six to twelve and fifteen eggs are often found in a single nest; in shape and general style of color and markings resemble those of the Florida Gallinule; sizes range from 1.77 to 2.00 long by 1.40 to 1.45 broad.

* Egging in a California Swamp. Young Oologist, Vol. I, p. 90. 


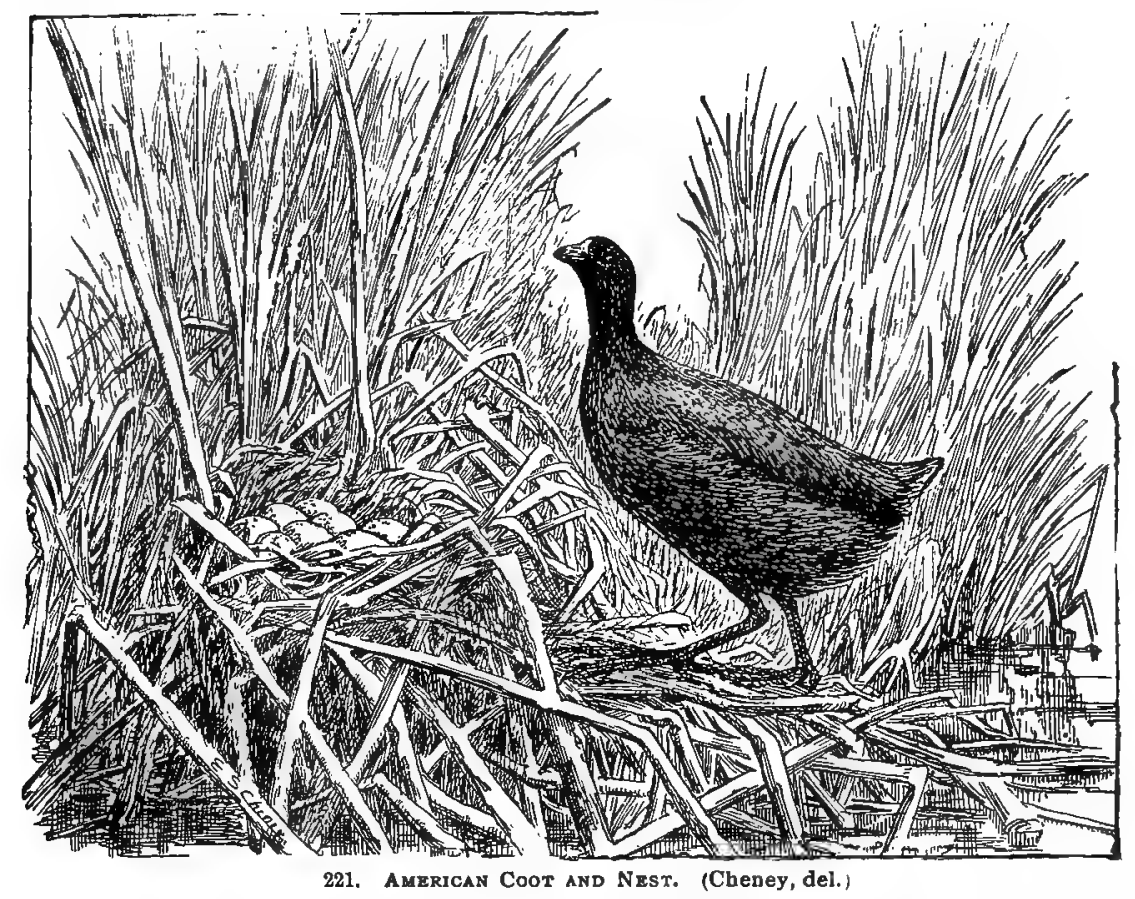

222. RED PHALAROPE. Crymophilus fulicarius (Linn.) Geog. Dist.-Northern portion Hemisphere, breeding in Arctic regions, migrating south in winter; in North America south to Middle United States, Ohio Valley and Lower California.

The Coot-footed Tringa, Red or Gray Phalarope, as it is differently called, is distributed in summer throughout the Arctic regions, wandering far south in winter. Breeds in various portions of Norway, Sweden, Finland and up into Lapland; in Siberia, Spitzbergen, Iceland, Greenland and the Arctic coast of North America. Hagerup, in his "Birds of Greenland," states that it is common, but not often seen in the breeding season south of the 68th parallel. Eggs were found from June 3 to June 28. The Phalaropes are curious birds, partaking of the nature of a wader and a swimmer. The three species of this family resemble Sandpipers, but are at once distinguished by the lckate feet like those of the Coot and Grebes. The body is depressed and the under-plumage thick like that of a duck. They ride the waves lightly along the coast, and when on the margin of a stream or pool often surprise their associates, the Sandpipers, by swimming out into deep water. The Red Phalarope appears to be more exclusive maritime than other species of the family. The nest is a slight hollow in the ground, sparsely lined with moss and dry grass. Mr. Capen quotes a letter from Mr. Boardman in which he says: "Twice I have found the Red Phalarope breeding in Maine." The eggs, Mr. Capen says, are laid the first part of June.* They are greenish or yellowish-ash, blotched and spotted with brown of various shades. The eggs of this species cannot, with certainty, be distinguished from those of the following species; in fact, the range of coloration is so varied that they are difficult to describe satisfactorily in a brief manner. They are three or

- Oology of New England. 
four in number. Five sets of four eggs each of this species are in Mr. Crandall's collection. They were taken in Iceland and each set gives the following average measurement: First, 1.12x.81; second, 1.17x.81; third, 1.18x.84; fourth, 1.20x.82; fifth, 1.21x.83.

223. NORTHERN PHALAROPE. Phalaropus lobatus (Linn.) Geog. Dist.North parts of North Hemisphere, breeding in Arctic regions; south in winter to tropical regions.

The general habits, movements and distribution of the Northern Phalarope are nearly identical with those of the Red Phalarope; common to both continents, and breeding in the Arctic regions of Asia, Europe and America. The nesting habits are substantially the same and the eggs are laid in June. Hagerup records it as breeding quite generally along the coast of South Greenland. The bird is also known as the Red-necked Phalarope. The eggs are greenish or yellowish-ash, thickly blotched with varying shades of brown; three or four; sizes range from 1.10 to 1.30 long by .75 to .82 broad, averaging 1.20 by .80 ; like the last, there is a great variation in size, shape and color. A set of four eggs from Greenland exhibit the following average measurements: $1.19 x .83$; another set of four from the same region shows an average size of 1.19x.82. These are in' Mr. Crandall's collection.

224. WILSON'S PHALAROPE. Phalaropus tricolor (Vieill.) Geog. Dist.Chiefly interior of temperate North America; south in winter to Brazil and Patagonia.

Exclusively an American bird, more common in the interior than along the sea coast. Little information regarding its habits was obtained by the older ornithologists. Known now to breed in Northern Illinois, Iowa, Wisconsin, Minnesota, Dakota, Utah and Oregon. May be found nesting in suitable places from these regions northward to the Red River of the North and the Saskatchewan country. It is recorded as a summer resident in Northern Indiana and very likely breeds in Northwestern Ohio. Mr. N. S. Goss states that he is quite confident the biru occasionally breeds in Western Kansas.* The nesting habits of Wilson's Phalarope have been carefully observed by Mr. E. W. Nelson in Northern Illinois, and his observations form a veryc omplete and interesting biography of the species. $\dagger \mathrm{Mr}$. Nelson states that it is the most common species in Northern Illinois, frequenting grassy marshes and low prairies, and is not exceeded in numbers even by the ever-present spotted Sandpiper. "The nesting site is usually in some thin tuft of grass on a level spot, but often in an open place concealed by only a few straggling blades of small carices. The male scratches a shallow depression in the soft earth, which is usually lined with a thin layer of fragments of old grass blades, upon which the eggs, numbering from three to four, are deposited about the last of May or first of June. Owing to the low situations in which the nests are placed, the first set of eggs is often destroyed by a heavy fall of rain, causing the water to rise so as to submerge the nest. In this case, the second set, numbering two or three, is often deposited in a depression scratched in the ground, as at first, but with no sign of any lining, Accidents of this kind cause the second set of eggs to be sometimes deposited as late as the last of June." The male alone undertakes the duties of incubation. The eggs are ashy-yellow, usually coarsely spotted and blotched with brown of varying shades, with numerous specks and scratches; three or four in number; sizes vary from 1.20 to 1.35 in length by 1.60 in breadth, making them elongate pyriform in shape.

* A Revised Catalogue of the Birds of Kansas, with descriptive notes of the nests and eggs of the birds known to breed in the State. By N. S. Goss. Published under the direction of the Executive Council, May, 1886. Topeka: T. D. Thacher, State Printer. P. 14.

† Bull. Nutt. Club. Vol. TI, pp. 38-43. 
225 AMERICAN AVOCET. Recurvirostra amerieana Gm. Geog. Dist.-Temperate portions of North America, from the Saskatchewan country and Great Slave Lake southward: in winter to Guatemala and the West Indies.

A bird of striking appearance, of odd coloration, having extraordinarily long legs; feet webbed like those of a swimming bird; body flattened underneath, and duck-like plumage to resist the water. The most striking characteristic of the bird, however, is its long, decidedly up.urned bill, anu from its blue legs it receives the

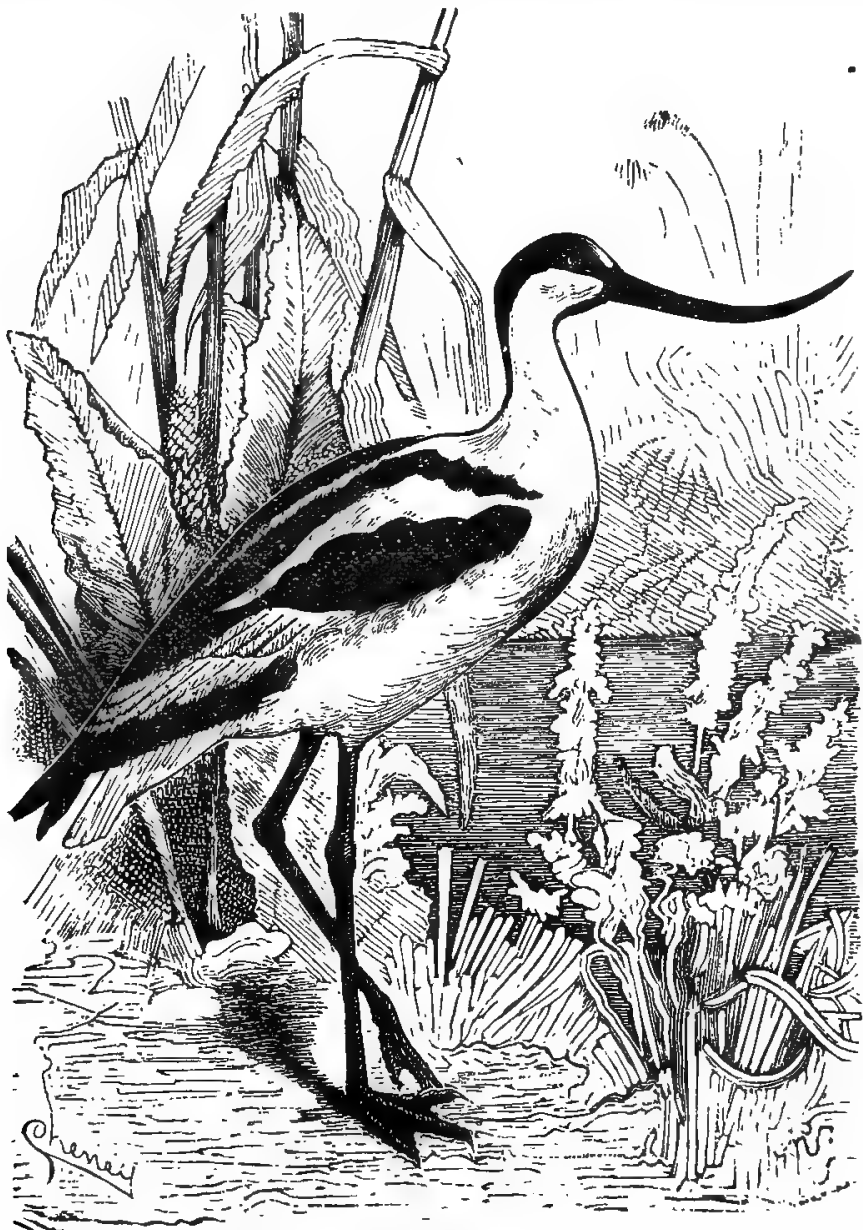

225. European A vocet. Not distinguishable in cut from our American species (From Brehm).

name of Blue-stocking. It is very abundant in the West, on the plains of the Dakotas, Montana, Wyoming, Colorado and Utah. In these regions it breeds in June, nesting in the tall grass in marshy or wet places. The eggs vary from a dark olive to buff, pretty uniformly and profusely spotted with chocolate-brown - of various shades; they vary in size, shape and markings like the birds themselves; three or four in number; sizes from 1.80 to 2.10 in length by 1.25 to 1.45 in breadth.

226. BLACK-NECKED STILT. Himantopus nexicanus (Mull.) Geog. Dist.Temperate North America from Northern United States southward to West Indies, Brazil, and Peru. 
This exceedingly long-legged bird is distributed throughout the United States, and like the Avocet, is rare in the eastern portions. It is abundant in the West, but its range is rather more southerly than that of the Avocet. In Ohio it is a rare summer visitor. Perhaps breeds. The nest of the Stilt is often only a slight depression in the ground, lined with dry grasses, situated along some stream or ditch, or near water; some collectors have found the nest at the water's edge, or on a heaped mass of vegetation just above the surface of shallow water. A. M. Shields says that the Stilt arrives in the vicinity of Los Angeles, Cala., about May 1st, and the eggs may be found fresh until the middle of June. He states that the birds usually congregate in large flocks in some suitable locality, and build their nests close together, a score or more are often found within a few yards of each other; the nests being composed of small sticks and roots, closely laid together and placed among the grass on the margin of a lake or river.* This record refers to the abundance of the Strlt in the season of

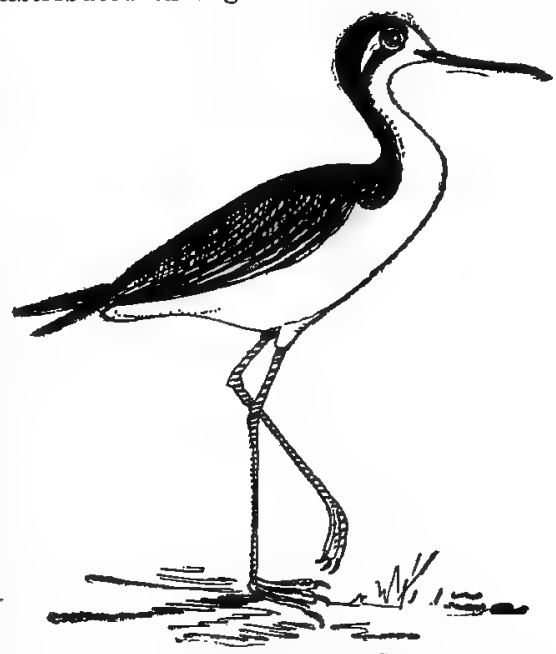

226. BLACK-NECKED STILT. 1883, and those previous; but I am informed by Mr. Shields that the bird is not so abundant as formerly, only a few pair breeding in the neighborhood of Los Angeles each year. The eggs are of a greenish-yellow, thickly spotted, blotched and lined irregularly with brownish-black of varying shades; pyriform in shape; three or four in number; sizes from 1.60 to $1: 85$ long by 1.15 to 1.25 broad.

[227.] EUROPEAN WOODCOCK. Scolopas rusticola Linn. Geog. Dist.-Òld World; occasional in Eastern North America.

The European Woodcock is widely distributed over the northern parts of the

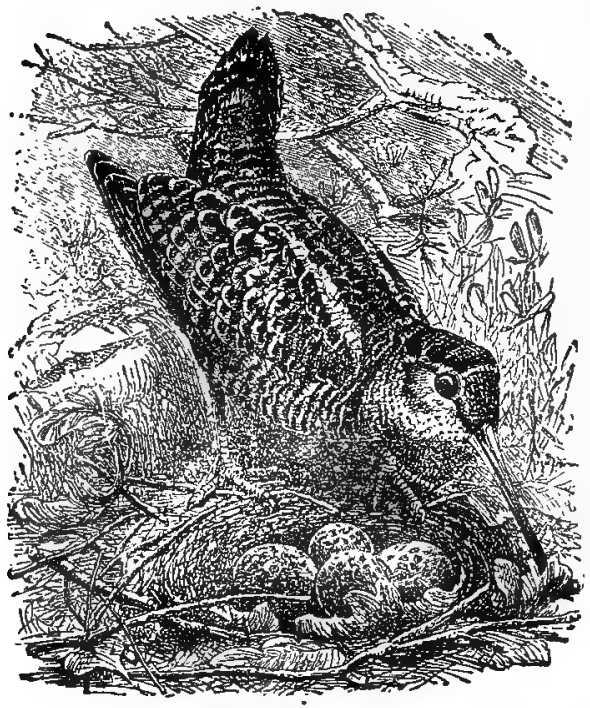

2.7. EUKOPEAN WOODCOCK. old World. It is of larger size than the American bird. Many instances are on record of its breeding in various parts of Great Britain, but the greater portion of the birds are considered migratory. Breeds abundantly in Norway, Sweden, Lapland and in Northern Russia. Nocturnal in its habits, reposing in the daytime in grassy bottoms in woods, and at twilight it regains. activity, resorting to open glades and marshy bottoms, where it feeds. These tracts are known as "cock-shoots," or "cock-roads." The food of the birds is. the common earth-worm, which they procure by boring, or thrusting their bills into the soft mud. The nest consists of a few leaves loosely laid together, and without lining. The eggs are usually four in number; of a pale yellowish-white, blotched and spotted with various shades, ashy-gray and reddish or yellowish-brown; most numerous about the larger end. Four eggs: measure $1.75 \times 1.27,1.74 \times 1.27,1.73 \times 1.23$, 1.77x1.28.

- Young Oologist, Vol. I, p. 41. 
228. AMERICAN WOODCOCK. Philohela minor (Gmel.) Geog. Dist.—Eastern Province of North America, north to British Province, west to Dakota, Nebraska, Kansas, etc. Breeds throughout its range.

This noted game bird frequents the bogs, swampy fields and wet woodlands of Eastern United States and Canada, and breeds throughout its range. The nests are mere depressions in some dry spot in swampy land, generally under the cover of a clump of briers or other wild shrubbery, often in more open places. The eggs of the Woodcock are laid early in April, and in some localities not until some time in May. In Ohio, I have found eggs as early as April 3, and young have been seen as early as April 9, near Cleveland, Ohio. There are records of eggs of this species averaging in size $1.80 \times 1.25$, but $I$ have never seen any so large, although they exhibit considerable variations. These sizes doubtless refer to the eggs of the European species. Although known to the majority of people by its name of Woodcock, it nevertheless has many aliases in different parts of the country which it visits, and is called Big

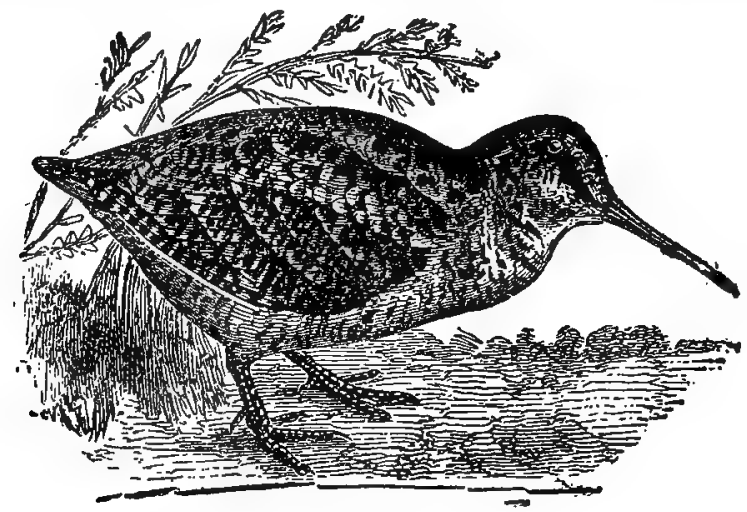

228. AMERICAN WOODCOCK

Mud, Big-headed, Blind and Wood and Whistling Snipe; * * * Timber Doodle, Bog Bird, Night Partridge, Night Peck, Hookum Pake, Pewee, Labrador Twister, Whistler, and probably many others. Being a migrating species, the length of its stay in any particular locality depends greatly upon the weather, for though perhaps very abundant on one day, yet if during the night from sudden cold their feeding ground becomes frozen, by the next morning not a bird would be found, all having departed to a milder clime. It migrates always at night, when indeed, it is most active, for it is a nocturnal bird, its sight being much better after the sun has departed than when the eye is exposed to the full light of day.* As a taxidermist I have prepared more specimens of this species killed within the last twenty years by telegraph wires, moving railroad trains, etc., than I have those brought in by

* North American Shore Birds; a history of the Snipes, Sandpipers, Plovers and their allies inhabiting the beaches and marshes of the Atlantic and Pacific coasts of the North American continent; their popular and scientific names, together with a full description of their mode of life, nesting, migration and descriptions of the summer. and winteplumages of adult and young, so that each species may be readily identified. A reference book for the naturalist, sportsman and lover of birds. By Daniel Giraud Elliot, F. R. S. E., etc.; ex-President American Ornithologists' Union, Curator of Zoology in the Field Columbian Museum, Chicago; author of "Birds of North Amerlca"; lllustrated monographs of Auk, Thrushes, Grouse, Pheasants, Birds of Paradise, Hornbills, Cats, etc., with seventyfour piates: New York: Francls P. Harper, Publisher, 1895. pp. 39-40. 
sportsmen who depend upon the gun. This is, I believe, principally from the fact that the bird is of nocturnal habits, but is often forced to fly from the ground in daytime. The Woodcock is often called Bog-sucker, from its habits of boring in the mud for worms and animalculæ, of which its food consists. The eggs are creamy or buff, irregularly and thickly spotted with pale, reddish-brown of varying shades; pyriform, but more rotund than those of most of the small waders, and some are quite broad, varying from 1.40 to 1.55 long by 1.15 to 1.20 broad. The usual number of eggs is four. Four selected specimens measure $1.58 \times 1.21,1.53 \times 1.14,1.57 \times 1.17$, and $1.53 \times 1.20$.

[229.] EUROPEAN SNIPE. Gallinago Wallinago (Linn.) Geog. Dist.-Northern portions of the Old World; frequent occurrence in Greenland. Accidental in the Bermudas.

A species of general distribution over Europe. In the breeding season it is found in the more northern portions and in the winter months it inhabits the southern regions. A common game bird on the British Islands, breeding in greater or less abundance in all parts of England and Scotland, especially to the north on the Orkney and Shetland Islanus. In summer it is found on the Faroes, Iceland and in Greenland. Breeds in the northern portions of Russia and Siberia and as far south as France, Germany, Holland and Hungary. The nests of this Snipe are placed on the ground in tall grass by the side of some pond or shallow water, or amids the long heather which grows upon the hill side. Nests have been found at an elevation of a thousand feet above the plain. The full complement of eggs is four; they have a ground-color varying from yellowish-white to greenish-yellow. The markings are of several shades of reddish or chestnut-brown, scattered chiefly about the larger end. The eggs are pyriform in shape and quite pointed at the smaller end. Four eggs collected near Lancaster, England, measure 1.54x1.14, 1.53x1.08, 1.59x1.15, $1.51 \times 1.10$.

230. WILSON'S SNIPE. Gallinago delicata (Ord.) Geog. Dist.-Whole of North and Middle America, breeding from Northern United States northward; south in winter to West Indies and Northern South America.

The American Snipe is a favorite game bird, well known by the name of Jack Snipe. It is also known as the English Snipe. Throughout the greater part of the United States it occurs only during the migrations. Breeds from about latitude $45^{\circ}$ northward to Hudson Bay region on the east and as far west and north as Sitka, Alaska, and Fort Anderson. The birds frequent low open places, such as wet meadows and marshes, and muddy banks of streams. They are found in small companies of from three to twelve, technıcally called "wisps." Solitary birds are not unfrequently met with. No other game birds are more erratic and eccentric than these. They are extremely fickle in the choice of their feeding ground; one day they may swarm in a certain locality, and the next none are to be discovered. Their flight is strong, but, especially at the beginning, erratic. They almost invariably fly against the wind, and lie closest on still, clear days. Occasionally they alight on trees or fences. Their note, uttered as they rise, resembles the word "escape." The nest is only a slight depression in the grass or moss of a bog. The eggs vary from a grayish-olive to greenish-brown and yellowish-ash, spotted and blotched with reddish-brown, umber, and sometimes with lines of black; the markings are bold and numerous, particularly on the larger end, usually also sharp scratchy lines of blackish and shell-spots, hardly noticeable. The shape of the eggs is pyriform; three or four in number; sizes range from 1.50 to $1.60 \mathrm{long}$ by 1.05 to 1.10 broad. 
231. DOWITCHER. Macrorhamphus griseus (Gmel.) Geog. Dist.-Eastern North America. Breeding far northward.

Known by several names, such as Red-breasted Snipe, Gray Snipe, Brown-back, and Gray-back; these are also applied to the Long-billed Dowitcher. This bird, which greatly resembles the Common Snipe in structure and general appearance, differs from it in habits. It is described as migrating in flocks, often of large size, and as being so unsuspicious as to allow a near approach. Breeds in high Arctic regions, in various places in Alaska, and is spoken of by Dr. Richardson as having an extensive breeding range throughout the fur country, from the borders of Lake Superior to the Arctic Ocean. In the Arctic Regions nests have been taken between the middle of June and the first part of July. They were placed on the marshy borders of small lakes and ponds, and were made of a few dry leaves and grasses. The eggs were usually four in number. These cannot, wito certainty, be distinguished from those of Wilson's Snipe. They are generally long, narrow, and pointed in shape; sizes from 1.62 to 1.75 long by 1.10 to 1.15 broad.

232. LONG-BILLED DOWITCHER. Macrorhamphus scolopaceus (Say.) Geog. Dist.-Mississippi Valley and Western North America from Mexico to Alaska.

This bird, whose size is larger and bill longer than that of the last, inhabits North America at large, but is supposed to be rare on the Atlantic coast. It is called Greater Long-beak, Greater Gray-beak and Rew-bellied Snipe. Breeds in the far north; is said to be common about the mouth of the Yukon and islands along the coast of Alaska. In the West the birds gather in dense flocks, and they being of a gentle and confiding disposition, and so closely huddled together, that great slaughter may be effected by the gunner if so a.sposed. Eggs larger and nesting. same as the last.

233. STILT SANDPIPER. Micropalama himantopus (Bonap.) Geog. Dist.Dastern Province of North America, breeding north of the United States; migrating south in winter to tropical regions.

The Long-legged Sandpiper, of slender form and very long legs, breeds north of the United States, and visits Southern localities in winter; Bermudas, West Indies, Central and South America. MacFarlane found this species breeding at Rendezvous Lake, in the Arctic regions, June 27. The nests were similar to all others of this family, a mere depression in the ground, with a lining of a few leaves and grasses. The eggs are three or four in number, pyriform in shape, with a ground color of light drab or grayish-white, with bold spots and markings of chestnut-brown and purplish-gray, more numerous about the larger end; in some quite confluent. Sizes vary from 1.43 to 1.46 long by 1.40 to 1.1 .0 broad.

234. KNOT. Tringa canutus Linn. Geog. Dist.-Nearly cosmopolitan; breeding in high northern latitudes. Migrates far southward.

This handsome species, so remarkable for its seasonable differences of plumage, is the largest of the North American Sandpipers. It inhabits most parts of the globe; in America chiefly coastwise, and breeds in high latitudes. It is migratory, and is also found in the interior about large bodies of water and rivers. Red-breasted and Ash-colored Sandpiper and Gray-back are other names for it. Elliot in his "North American Shore Birds" gives other names by which this bird is known: Red Sandpiper, Gray Back, May Bird, Robin Snipe, White Robin Snipe, White-bellied Snipe, Silver Back, Red-breast Flover, Buff-breast Plover, Buff-breast, Blue Plover, Beach Robin, Robin-breast and Horse-foot Snipe. At Point Barrow, Alaska, it was rather 
rare, but Murdoch was of the opinion that it bred there, for a female was killed with full-sized eggs in her ovaries; but he never round the nest. At the Yukon mouth Dall found the Knot rare and obtained a young bird at St. Michael's. This species seems to be more numerous about Hudson Bay and on Melville Peninsula. Hagerup states that the Knot is a common summer resident of Greenland, in the northern portion of which it breeds. An authentic egg of the Knot has for many years been the object of special and diligent search by eminent naturalists and explorers traveling in Arctic regions where this bird is known to live during the season of production. Lieut. A. W. Greely, U. S. A., commander of the late expedition to Lady Franklin Sound, succeeded in obtaining the long-sought-for egg of the Knot. C. H. Merriam publishes the first account of it, written by Lieut. Greely, as follows: "The specimen of bird and egg were obtained in the vicinity of Fort Conger, latitude of $81^{\circ} 44^{\prime} \mathrm{N}$. The egg was $1.10 \mathrm{inch}$ [28 mm.] in the longer axis, and $1 \mathrm{inch}$ [25.40 $\mathrm{mm}$.] in the shorter. Color, light pea green, closely spotted with brown in small specks about the size of a pin-head." **

235. PURPLE SANDPIPER. Tringa maritima Brunn. Geog. Dist.- Northern portions of Northern Hemisphere; in North America, chiefly the northeastern portions, migrating south in winter to Eastern and Miđdle States. Mississippi Valley.

The Purple Sandpiper is found in the high Arctic regions of America and Europe. Said to be a resident of the Aleutian Islands. Breeds in the Faroe Islands, Iceland, and in GreenIand, where some remain in the fiords of the southern portion all winter. Dr. Richardson states that it breeds abundantly on Melville Peninsula and on the shores of Hudson Bay. The nest is a mere depression in the soil with a scant lining of dry grass. The eggs are clay color, shaded with olivaceous, with large and distinct markings of rich umber-brown of different depths of intensity all over the shell, but most numerous as well as largest on the greater half; pyriform; the eggs are usually four in number, and measure about 1.40 by 1.00 .

236. ALEUTIAN SANDPIPER. Tringa conesi (Ridgw.) Geog. Dist.-Coasts धnd islands of Bering Sea, north to St. Michael's.

Closely allied to the last species, and the birds are hardly distinguishable in their respective winter plumages. It is common in the Aleutian and other islands, and also along the coast of Bering Sea as far west as the Commander Islands. Dr. Stejneger records it as a resident of the latter group, found there during both summer and winter. The first eggs are laid about the middle of May. These are described a pale olive-buff, varying to light brownish-buff, spotted and blotched with vandyke-brown or deep umber; size $1.46 \times 1.00$.

237. PRYBILOF SANDPIPER. Triwgl ptiluncmis Coues. Geog. Dist.Prybilof Islands, Bering Sea.

The Black-breasted Sandpiper, as it is called, is confined to the Prybilof group and several other islands of Bering Sea; but does not visit the Commander Islands. It is said to be the only wader that breeds on the Prybilof Islands. In May it nests on the dry uplands and mossy hummocks, placing its nest in bunches of moss, in which four pyriform eggs are laid. The eggs are described as light brownish-buff, heavily spotted with rich chestnut-brown, clouded with purplish-gray. Average size $1.50 \times 1.07$.

*Auk, Vol. II, p. 313. 
238. SHARP-TAIIED SANDPIPER. Tringa acuminata (Horsf.) Geog. Dist.-Eastern Asia and coast of Alaska, migrating south to Java and Australia.

The Sharp-tailed Sandpiper was first introduced to the North American avafauna by E. W. Nelson, who secured a female at St. Michael's in September, 1877. Later in the season others were sean and during each of the succeeding autumns they were found to be one of tae most common species of snipe in that region, frequenting the brackish pools and tide-creeks in company with the Pectorial Sandpiper, Red-breasted Snipe and several other species. The Sharp-talled Sandpiper resembles the Pectorial Sandpiper in appearance.

239. PECTORAL SANDPIPER. Tringa maculata Viei:l. Geog. Dist.-North, Central and South America; breeding in the Arctic regions. Of frequent occurrence in Europe.

During the migrations the Pectoral Sandpiper is very abundant, both on the sea coast and in the interior. It frequents the borders of ponds, the shores of lakes and rivers, and is found commonly in the vicinity of wet cornfields and meadows. It is only of recent date that we have obtained any positive information regarding this bird's breeding places. Hagerup states that it is a rare guest in South Greenland. Nelson found it to be extremely common at the mouth of the Yukon River, where the low grassy flats afford it a much frequented breeding ground. Arriving on the

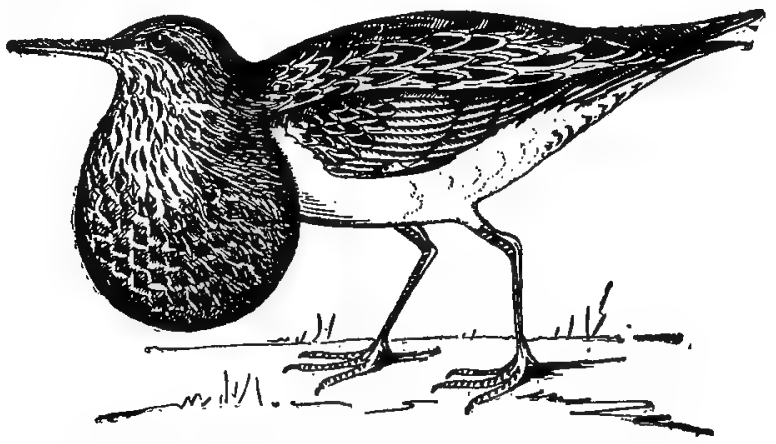

239. Pectoral Sandpiper, Adult male, in summer, with crop inflated. (From Nelson.)

shores of Bering Sea, near St. Michael's, from the 15th to the 25th of May, the birds linger about a short time; they then pair and seek nesting places, which are usually in tufts of grass. Murdoch records that the Pectorial Sandpiper breeds abundantly at Point Barrow, Alaska, in June and July, moving south in September. Nelson states that during the breeding season they have an unique habit, not to be found among waders, but is common among members of the Grouse family; this is of inflating the throat until it becomes as large as the body before the bird utters the deep, hollow, resonant sounds which may be represented by the syllables, too-u, too- $u$, too- $u$, too- $u$, it fills its æsophagus with air as above described. The skin of the throat becomes very flabby and loose at this season, and by dissection it was found that the inner surface of the sack is covered with small globular masses of fat. The accompanying engraving, taken from Nelson's Report, will give an idea of the character and extent of this inflation. Nelson says that the male at times rises 20 or 30 yards in the air and inflating its throat glides down to the ground with its sac hanging below. Nests found by Mr. Murdoch contained four eggs each, of the 
usual pyriform shape. They vary in size as follows: $1.58 \times 1.06,1.44 \times 1.11,1.42 \times 1.08$, $1.54 \times 1.02$ inches. They have a drab ground color, with a greenish shade in some cases, and are spotted and blotched with umber-brown, varying in distribution on different specimens, as is usual among waders' eggs. The average is $1.45 \times 1.04$.

240. WHITE-RUMPED SANDPIPER. Tringa fuscicollis Vieill. Geog. Dist.-Eastern North America; breeds far north. In winter migrating through the United States, the West Indies, Central and South America and Falkland Islands. Occasional in Europe.

Bonaparte's Sandpiper during the breeding season is found in the Arctic regions. It is a species of wide distribution in the migrations, wandering into tropical regions. The bird is said to breed in suitable places on the shores of Cumberland Sound. MacFarlane met with its nests and eggs on or near the Arctic coast; one taken July 3 contained four eggs with large embryos; another found the day following contained three eggs. A third, obtained June 29 on the Barren Lands, was a mere depression in the ground, lined with a few decayed leaves and contained four eggs with very large embryos. A fourth found on the banks of a small river, of similar construction, held 4 eggs. Theggsare pyriform in shape, of light olive or olive-brown, spotted with bold and sometimes rather fine markings of deep chestnut-brown, almost into blackness, chiefly about the larger end in confluent groups. Average size, $1.37 \times .94$.

241. BAIRD'S SANDPIPER. Tringa bairdii (Coues.) Geog. Dist.-North America, chiefly the interior. Rare on the Atlantic coast; wintering in Mexico, Central and South America.

Baird's Sandpiper is distributed throughout North America generally, but is - said not yet to have been observed west of the Rocky Mountains. It is found chiefly in the interior. Known to breed in the Arctic regions; winters south of United States. This bird was entirely unknown to ornithologists until within the last thirty-five years; when discovered and for sometime after was confounded with other species. Dr. Coves first gave it rank and name in 1861. It breeds in the Arctic regions-on the Barren Lands; nests in the latter part of June, usually within the vicinity of lakes and small ponds. The nest is made of a few dry leaves and grasses in a small depression, shaded by a tuft of grass. The eggs are usually four in number; buff or clay colored, spotted and blotched with varying shades of chestnut-brown; in most instances the markings are fine and innumerable, of definite size, irregular in shape and thickness at the greater end, where they are occasionally massed in blotches; size about $1.30 \times .90$. .

242. LEAST SANDPIPER. Tringa minutilla Vieill. Geog. Dist.-Whule of North America; breeding north of the United States.

The smallest of the Sandpipers, measuring five and a half or six inches in length. It has the same habits as characterize its Semipalmated cousins, frequenting the same localities, and flocks of birds are often composed of both species. When this is the case the Semipalmated Sandpipers even if largely in the minority, take the lead, as they are of somewhat larger size, stronger in flight and they have a louder note. When not in company with other species none of our shore birds are more confiding and unsuspecting than these, large flocks continuing their search for food almost under the feet of the observer. The Least Sandpiper breeds from Canada, Newfoundland and Labrador northward into Arctic regions, and in Alaska. June 5,1875 , one was found building its nest in the vicinity of Chicago, Ill. Nests in 
the Arctic regions are usually mere depressions, lined with leaves and grasses, on the ground, in the vicinity of lakes or ponds. The eggs are usually four in number, and may be found between the latter part of May and June. The eggs are pyriform in shape, the ground color is light drab, thickly spi:_xled with reddish-brown spots and purplish-gray. The average size is $1.15 \mathrm{x} .85$.

[242. 1.] LONG-TOED STINT. Tringa damacensis (Horsf.) Geog. Dist.Asia, breeding toward the Arctic coast; accidental in Alaska (Otter Island, Bering Sea).

From Daniel Giraud Elliot's "North American Shore Birds" I take the following: "This species is a miniature Sharp-tailed Sandpiper, without the lengthened tail and proportionately much longer toes. It also resembles the Least Sandpiper on the back, but exhibits very much more chestnut on the margin of the feathers of the back and head. The breast band is differently colored also. It is taken into the North American fauna from the fact that a specimen was procured on Otter Island, Alaska, June 8, 1885, as stated by Mr. Ridgway in The Auk for 1886. It is an Asiatic species going as far east as Japan, and also found in the Indian Archipelago. It can only be regarded as an accidental straggler to our shores. On Bering Island, Stejneger observed it in large flocks in May, when it frequented the beach, and was very active engaged in picking up small crustaceous from the floating weeds which the surf had cast ashore. A few remained to breed, but the majority passed farther north. He was unable to find the nest."

[243.] DUNLIN. Tringa alpina Linn. Geog. Dist.-Europe; accidental in North America.

The Purre or Dunlin has a wide distribution in the northern parts of the Old World. By far the most abundant of the British Sandpipers, being equally distributed in the marshes, on the borders of inland lakes, and along all the seashores from the most northern island to the southern coast of England. The birds usually feed in great numbers after the retiring tide, or on the oozy flats of soft sand or mud, which cover the low-lying shores of the islands. In the spring they separate into pairs, retiring to the marshes and shores of inland lakes and muirs to breed. Their nests are made at the foot of a small bush or tuft of grass, often so concealed as to be very difficult to find. A few bits of grass or moss form the lining of the slight cavity, in which usually four eggs are deposited. They vary in ground color from greenish-white, yellow, gray and often inclining to light blue; they are spotted and blotched irregularly with reddish-brown; the spots becoming more numerous

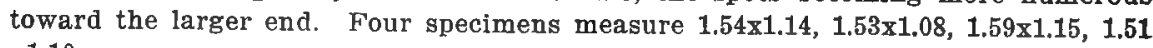
$\mathrm{x} 1.10$.

243a. RED-BACKED SANDPIPER. Tringa alpina pacifica (Coues.) Geog. Dist.-North America in general, breeding in high latitudes. Eastern Asia.

This is the American Dunlin, Black-bellied Sandpiper, or Ox bird; it is larger and brighter colored than T. alpina. Distributed throughout the whole of North America, and breeds in the Arctic regions, migrating in winter in the United States, especially coastwise. Breeds in various places on the Alaskan coast-at the mouth of the Yukon and in the salt marshes of Norton Sound. It has also been found breeding on the Aretic coast of North America, on Melville Peninsula, the shores of Davis Strait and in Southern Greenland. The nest is built in the vicinity of lakes and ponds or in marshes; it is a slight hollow with merely a few dry grasses and leaves 
scraped into it. The eggs, four in number, of a dull brownish-buff or clay color, spotted, blotched and stained with chestnut, principally about the larger end; their average size is $1.43 \times 1.01$.

244. CURLEW SANDPIPER. Tringa ferruginea Brunn. Geog. Dist.-Old World in general, occasional in Eastern North America and in Alaska.

A bird with a bill resembling that of the Curlews-long, slender, compressed and considerably decurved. The length of the bird is about eight and a half inches. It is said to be one of the rarest of the Sandpipers which visit North America. A common species in Siberia, where it breeds. Said to breed in Holland, Denmark and northward into Norway, Sweden, and in Finland. In England it is nowhere abundant and does not assemble in large flocks like the Dunlin or Purre. A few pairs are believed to breed in Great Britain. Known to breed in various portions of Greenland-nesting near the margins of lakes and rivers where the eggs are deposited in a slight hollow of the ground, lined with bits of grass. The eggs are four in number, pyriform in shape, pale grayish or greenish-buff, spotted and blotched with chestnut-brown. They are hardly distinguishable from those of the Pectoral or Red-backed Sandpiper's eggs, the average size being $1.50 \times 1.04$.

[245.] SPOON-BILL SANDPIPER. Eurynorhynchus pyymous (Linn.) Geog. Dist.-Asia; in-summer along the Arctic coast, in winter Southern and Southeastern Asia; agcidental on the coast of Alaska (Choris Peninsula).

This is a curiously unique representative of the Sandpipers. Its bill is about as long as its head, straight, spatulate long. Nelson secured a specimen in summer plumage in 1881 at Plover Bay on Choris Peninsula, and Dr. Bean obtained one in 1880. In summer it is found from Plover Bay to Cape Waukarum, and in this part of the Siberian coast, according to Elliot, its breeding grounds are situated. Dr. Coues states that it is one of the rarest birds in collections, only some 25 or 30 specimens being known, mostly from India. It breeds north of Bering Strait, but the locality is unknown.

246. SEMIPALMATED SANDPIPER. Ereunetes pusillus (Linn.) Geog. Dist.-Northern and Eastern North America; west during the migrations to Rocky Mountains.

This little "Peep" is found everywhere in North America. In the summer it is distributed from Labrador and western shores of Hudson Bay northward, this being its breeding grounds. In spring and fall it is an abundant migrant in United States, thronging the beaches, the gravelly and sandy shores of streams and muddy banks of ponds, in company with the Spotted Sandpiper and others, with which it is usually confounded. It winters from the Carolinas southward. It has the same 'tweet, 'tueet as the Spotted Sandpiper, and utters it frequently, both on the shore and when flying. The Semipalmated Sandpiper arrives in the Saskatchewan River country about the middle of May, where it deposits its eggs early in June on a few pieces of withered grass in a slight hollow in the ground. These are three or four in number, and measure from 1.20 to 1.25 long by .82 to .85 broad. In a large series the usual variations in color are noticeable; the ground color varying from clay to grayish or greenish-drab or positive olive tint; usually boldly spotted and splashed with umber or chestnut-brown; thickest about the largest end; and again, in some, very fine dots are distributed over the entire surface. 
247. WESTERN SANDPIPER. Ereunetes occidentalis Lawr. Geog. Dist.Western North America; occasionally eastward to the Atlantic coast; breeding far north. Migrating in winter to Central and South America.

Very much like the last species and there is essentially no difference in its general habits, nesting, eggs and other peculiarities. Abundant in Alaska, breeding along the Yukon and the shores and islands of Norton Sound. Nests commonly'on the Island of St. Michael's, depositing four eggs in nests, which are mere hollows in the ground with a few blades of grass for lining. In June and July it breeds abundantly on the islands in the bays along the Arctic coast and also in the Barren Lands. The eggs exhibit as great variation as those of $E$. pusillus. Nelson describes their ground color as pale clay, shading toward pale brownish-clay. In many instances, usually among the larger eggs, the ground color is nearly or quite concealed by fine, light reddish-brown spots or specks. The other extreme has the spots gathered mainly about the large end in irregular spots of rich chocolate and umberbrown in small spots, a little more dense at the larger end. Sizes vary from $1.30 \times .92$ to $1.11 \times .82$.

248. SANDERIING. ralidris arenaria (Linn.) Geog. Dist.-Nearly cosmopolitan, breeding in high Arctic regions.

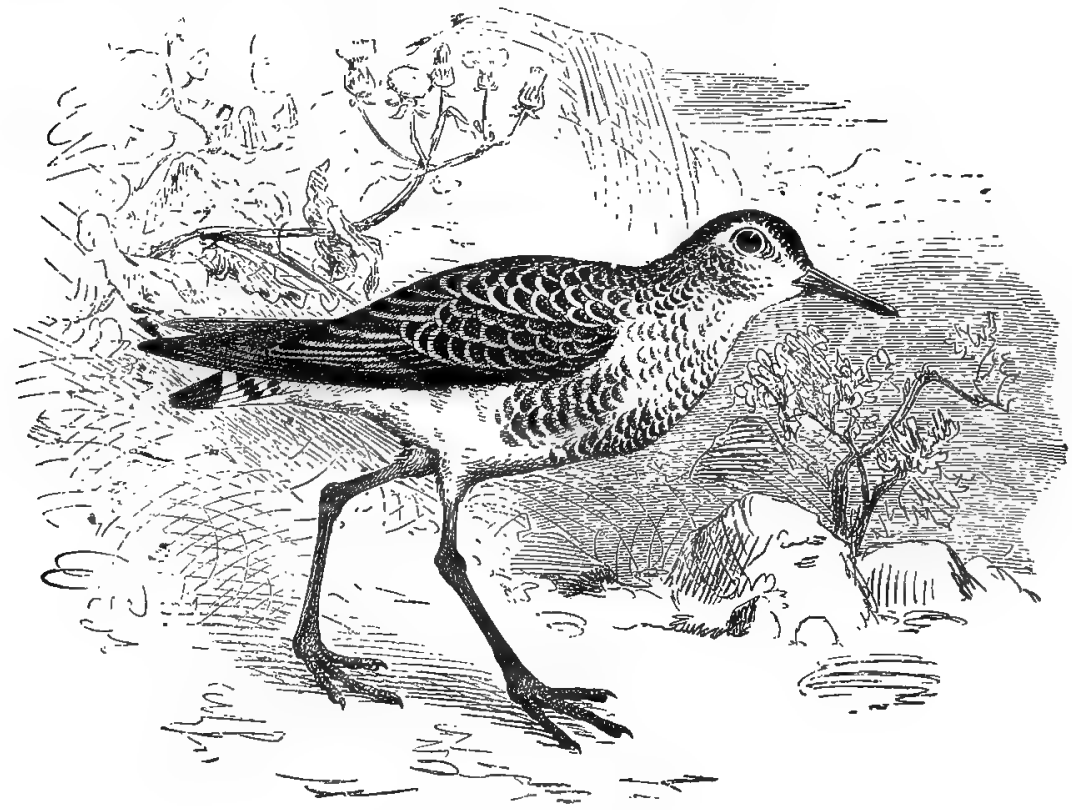

248. Sandekling (From Brelmi).

The Sanderling, Ruddy "Plover" or "Beach Bird," is a species of wide distribution. "During the breeding season it. is distributed through the northern regions of Europe, Asia and North America. It inhabits, hovever, the entire continent of North America, wandering in its migrations through the United States, and in winter to the West Indies, Mexico, Central and South America. Its nests and eggs 
have been taken in Grinnell Land, and it is said to breed on islands about the coast of Greenland and on the shores and islands of Hudson Bay. Dr. Brewer states that Mr. MacFarlane, on June 29, discovered a nest with four eggs on the Barren Lands, near the Arctic coast. The eggs at this date were quite fresh. The nest is said to have been made of hay and decayed leaves. The eggs are ashy or greenish-brown, spotted and blotched with brown of different shades, pyriform in shape; two to four in number, and measure 1.41 by .91 .

249. MARBLED GODWIT. Limosa fedoa (Linn.) Geog. Dist.-North America in general. Breeds in the Missouri and Upper Mississippi regions, thence to the Saskatchewan. Winters in the Southern States and southward.

The 'Great Marbled Godwit, or Marlin, inhabits the entire temperate North America, and it is a common bird during the migrations and in winter. It breeds chiefly in the Mississippi and Eastern Missouri regions, in Iowa, Minnesota and the Dakotas, thence to the Saskatchewan; known to breed in Northern Ohio, in Wisconsin, Iowa, Minnesota, Kansas and Nebraska. This is the largest of the "Bay birds," except the Long-billed Curlew, and can readily be distinguished, its bill being either straight or bent a little upward, and not decurved, like the Curlew's. It frequents muddy pools, sandy shores and marshes, usually in flocks of greater or less extent. The bird is held in high esteem for the table, and they are eagerly hunted by the gunners when flocks of ten or a dozen birds appear on the marshes. The sportsmen call them "Dough" or "Doe" birds. The eggs are creamy-buff or light oliveaceousdrab spotted and blotched, rather sparsely, with yellowish and umber-brown of varying shades, long oval; size about 2.27 by 1.60 ; three or four in number, and they are deposited in a slight depression of the ground, lined with a few bits of grasses. The nests are placed in the vicinity of a pool or river, but not always near the water's edge.

250. PACIFIC GODWIT. Limosa lapponica baueri (Naum.) Geog. Dist.Coasts of Eastern Asia and across to Alaska, south in winter to New Zealand and Australia; casual to Lower California.

In the winter months the Pacific Godwit is found in many of the islands of the Pacific Ocean-the Polynesian Islands and Australia. At this season it is also found on the Eastern and Southern coasts of Asia and Japan. Cn the American coast it is a summer resident in Alaska, and south of this point it is recorded only from Lower California. An abundant species at the mouth of the Yukon and on the marshes of Pastolik, which are farther north. The nests are built in tussocks of grass, lined with the same material. The eggs are said to be only two in number, of light olive drab, spotted with irregularly formed spots of umber of varying shades, similar to those of the Godwit; size, $2.25 \times 1.45$.

251. HUDSONIAN GODWIT. Limosa hæmastica (Linn.) Geog. Dist.-North. ern North America. Not recorded west of Rocky Mountains, only in Alaska.

The Hudsonian Godwit, though not common anywhere in the United States, is distributed throughot North America generally, but has not been observed west of the Rocky Mountains. It passes the winter south of the United States, and breeds in the most northern sections of the country. Breeds abundantly on the Barren Lands of the Arctic Ocean. In the Lower Anderson river region it nests in the first part of June, depositing its eggs in a slight depression of the ground lined with a few leaves and grasses. It associates with $L$. f $f d a$, and has the same habits and characteristics. Called by the gunners the "Smaller Doe-bird." American Black- 
tailed Godwit and Ring-tailed Marlin are its other names. The eggs of this species are heavily shaded olive-drab or "hair brown" almost as dark as a Loon's egg, sometimes lighter; obscurely spotted and blotched with dark brown; usually four in number; size $2.20 \times 1.42$.

[252.] BLAC 1 -TAILED GODWIT. Limosa limosa (Linn.) Geog. Dist.Northern portion of the Old World; accidental in Greenland.

At different seasons of the year the Black-tailed Godwit has been observed in nearly every portion of Europe, Asia and Africa. It is only an occasional visitant of Greenland which gives it a place in the fauna of North America. Considered migratory in Great Britain, and a few are known to breed there in the various marshes. In the summer months, however, this Godwit is found in various parts of Denmark and throughout Scandinavia, especially in Finland and up into Lapland. Known to nest in France, and is supposed to breed sparingly in Switzerland. In Scotland and other portions of the British Islands this species deposits its eggs yearly in May. This bird is known as Common Gowit, Godwyn, Yarwhelp, or Yarwhit, Jadreka Snipe, and Shrieker. The nesting is like that of all the Waders so far as knownsimply a hollow in wet meadows or in dry parts of swamps, midst grass or weeds. The eggs are usually four in number; they are of a deep grayish-olive or even a deep green, faintly spotted with olive-brown of different shades. Size 2.17x1.50.

[253.] GREEN-SHANK. Totanus nebularius (Gunn). Geog. Dist.-Old World; accidental in Florida.

Audubon took three specimens of the Green-shank on Sand Key, Florida, near Cape Sable, May 28, 1832. This is the only record of its appearance in North America. An abundant bird in the British Islands, many remain to breed, especially In Scotland, and on the islands about the coast. Breeds in Nolway and Sweden, in Finland and in Lapland as far north as the Arctic Circle. The nest is often placed some distance from water, usually in a tuft of grass with a slight lining. The eggs are four in number and vary from yellowish to brownish-buff, sprinkled and spotted all over, with irregular spots of dark brown, varying in intensity of shade. The eggs are generally pear-shaped. The average size of ten specimens is $1.98 \times 1.40$.

254. GREATER YELLOW-LEGS. Totanus melanoleucus (Gmel.) Geog. Dist.-Nearly all of North America; breeding in the more northern portions.

The Greater Yellow-legs, or Tell-tale, is found in North America at large. It is said to breed in the large marshes of Wisconsin, in Iowa, and in Northern Illinois; doubtless a few breed in suitable places in California. The Greater Tell-tale winters from the Carolinas southward; is abundant during the migrations, and is well known to the gunners. In the Eastern States it appears to be much more wary than in Ohio, and is said to give warning to ducks and other game birds on the approach of the gunner. About four rapidly repeated, loud and shrill whistling notes are uttered, which is a signal to the rest of his feathered neighbors, when the whole take wing, often to the disappointment of the fowler. From this habit it derives the name of Tell-tale, and it is also known as Stone "Snipe," Greater Yellowshanks, and Long-legged Tattler. The stately form of this bird may be seen moving along the gravelly banks of streams, wading in pools or the shallow margins of rivers and lagoons, feeding upon small fishes, crustaceans, etc. It is generally found in pairs, less often in small flocks, and its association with other Sandpipers is merely accidental. The eggs are grayish-white, marked with spots of dark brown, varying 
In Iatengity of shade, together with obscure shell-markings of lilac. The markings are over the entire surface, but more numerous at the larger end; three or four ia number; size $1.43 \times 1.20$.

255. YELLOW-LEGS. Totanus Aavipes (Gmel.) Geog. Dist.-North America. The Common Yellow-legs,or Lesser Tell-tale, is found throughout North America. It breeds from Northern United States northward, extending its migrations to the Artic regions. It winters in the Southern States and southward. In some localities during the migrations it is more abundant than the Greater Fattler, and its general habits and characteristics are the same; its cries are clearer and not so loud. It is fond of wading about in pools of water seeking food, which consists of larvæ of insects and small crustaceans. The Lesser Yellow-shanks is known to breed in Alaska, at the mouth of the Porcupine River, which empties into the Yukon. It doubtless breeds in all the region between Fort Selkirk and Fort Lake, and abundantly in the MacFarlane and Anderson River regions. The nests were mere depressions in the ground, without any lining; sometimes they were placed at the foot of a bush, with a scanty lining of withered leaves. The eggs were usually four. The bird is reported as doubtless breeding in Illinois and other regions farther south than those just mentioned. There is no doubt that a few of the Lesser Yellowlegs breed in Central Ohio. In referring to my notes I find that a sportsman brought me a male bird on the 28 th of June, 1886. This season (June 14, 1888) Mr. Robert Hedden shot a specimen, which proved to be a female, the skin of which is now in my cabinet. From this bird I took a well-formed egg, and the ovaries contained several others in different stages of development. The breast of this specimen was quite bare of feathers, indicating that it was engaged in the duties of incubation. The bird was sitting on the top rail of a fence when killed, and no others were noticed in the vicinity. The eggs of the Yellow-legs are of a light drab, or even vary to clay, buffy or cream color, sometimes light brown; the markings are bold and heavy, with great diversity of heavily splashed blotches of chocolate, umber-brown and blackish, these being chiefly at the larger end, and sometimes confluent. Paler shell-markings are also numerous and noticeable; pointedly pyriform in shape; three or four in number; sizes range from 1.58 to 1.78 long by about 1.16 broad.

256. SOLITARY SANDPIPER. Totanus solitarius (Wils.) Geog. Dist.--North America, breeding in Northern United States, northward; migrating southward to Northern South America.

The Solitary Tattler, or the American Green Sandpiper, is found throughout the entire North America; breeds in Northern United States and northward, and probably throughout most of its United States range. Winters chiefly in Mexico, Central and South America and in the West Indies. It has the same characteristic habits of the Green Sandpirer of Europe-always seen near water, during the migrations, on the borders of lakes, ponds and rivers, or seeking its food, which consists chiefly of worms in the soft loamy soil of marshes. The Solitary Sandpiper is well named, when its personal habits or the localities which It frequents are considered. It is found, except during and shortly after the breeding season. about small ponds in woods, remote shaded ditehes or small brooks, just such localities as are frequented by the Water Thrush, and its alarm note is very similar to that species, but is shriller and louder and is sounded while on the wing in its rapid flight. Although common, the

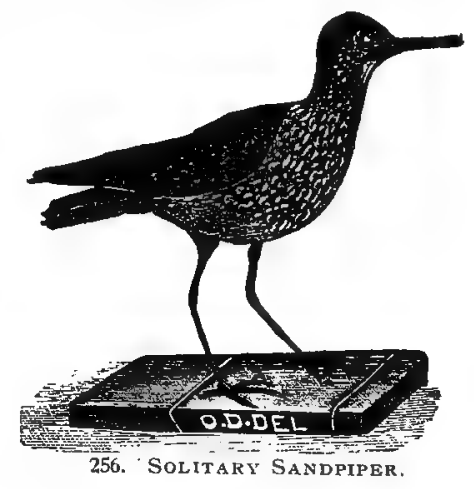


eggs of this species have been until a comparatively recent date of special desideratum, and only a few specimens are as yet to be found in the numerous collections. In the last edition of this work I mentioned an egg supposed to belong to this species, which I took in an open field bordering the Scioto River, near Columbus, Ohio, in the latter part of May, 1877. This specimen was first described by the late Dr. J. M. Wheaton.* The egg was of a pointed oval shape, and not nearly so pyriform as are the eggs of most of this family, size 1.25 by .88 , smaller than the eggs of the Spotted Sandpiper. The ground was clay-color with a reddish tinge, thickly marked with reddish and blackish-brown. The nest was on the ground in as exposed a locality as is ever frequented by this bird. It contained two eggs, both far advanced in incubation, only one of which was preserved. In Jones's magnificent work $\dagger$ this egg is accurately figured. From comparisons made at the time this specimen could not be referred to any other species than that of the Solitary Sandpiper. Dr. Brewer describes an egg, taken May 28, 1878, by Mr. Jenness Richardson, near Lake Bombazine, Vermont. It measures $1.32 \times .90$. The ground color is of a light drab, similar to that of Afyialitis meloda; over the surface are scattered small rounded markings of brown, some of these are quite dark, nowhere confluent, and not large enough to be called blotches. Its shape was elongated pyriform. Mr. Capen, in his finely illustrated work, $¥$ gives a faithful colored illustration of this specimen. The female parent of this eeg was shot as she left the nest.

256a. WESTERN SOLITARY SANDPIPER. Totanus solitarius cillnamoneus Brewst. Geog. Dist.-Pacific coast region, eastward to the Plains.

The Cinnamon Solitary Sandpiper of the Pacific coast region and the plains is a race not always distinguishable from the eastern species, $T$. solitarius. According to descriptions given by Mr. Brewster (Auk, VIII, p. 377), from specimens collected by Mr. Frazar in Lower California, the bird is larger, wing grayer, the light spots on the back, scapulars, and wing-coverets brownish-cinnamon, instead of white or buffy whitish; the sides of the head more whitish, especially on the lores; no welldefined loral stripes.

[257.] GREEN SANDPIPER. Totanus ochropus (Linn.) Geog. Dist.-Northern Portions of the Old World. Accidental in Nova Scotia.

If we may regard the authority of the older ornithologists, Richardson and Nuttall, this bird obtained from them recognition as a straggler to North America. Its claim to our fauna, however, has been restored by the capture of a single specimen, said to have been taken in Nova Scotia, which was in the possession of J. Edmund Harting, Esq. The bird is very similar to our Solitary Tattler and averages slightly larger. It is very generally distributed through Europe and in some places esteemed a great delicacy for the table. Said to breed in all the northern portions of Asia. In England it is considered an abundant bird in spring and fall and a number of pairs remain to breed. Known also as the Whistling Sandpiper. It frequents the shores of the sea and inland lakes, the banks of shallow streams and the borders of ponds and marshes. Breeds in various parts of Northwestern Germany and is known to nest in Southeastern France. The Green Sandpiper is said to be very peculiar in its mode of nesting-depositing its eggs in old nests

- In his Report on the Birds of Ohlo. Vol IV, Ohio Geological Survey, entitled Zoology and Botany, p. 486.

t Illustrations of the Nests and Eggs of Birds of Ohio. Illustrations by Mrs. N. E. Jones: Text by Howard Jones, A. M., M. D., Circleville, Ohio, 1886.

$\$$ Oology of New Engiand: Plate XIX. Fig. 6. 
situated in trees and is not known ever to nest on the ground. The nests usually occupied are those of pigeons, jays, shrikes and other birds, but most commonly those of the Thrushes. These are said to be situated from three to six feet and as high. as thirty-five feet from the ground. The eggs are four in number; greenish-white or delicate grayish sea-green, sparsely marked with spots, blotches, and markings of dark-brown, chiefly at the larger end; average size 1.52x1.12.

258. WILLET. Symphemia semipalmata (Gmel.) Geog. Dist.-Eastern temperate North America, south to the West Indies and Brazil. Breeds from Florida to New Jersey and locally, and rarely to Maine. Accidental in Bermuda and Europe.

The Willet is the largest of the American family Scolopacidæ, except the genera Limosa and Numenius. One of the most extensively distributed of all of our. North American birds, being found in the marshy regions of the interior; along the Atlantic coast from Nova Scotia to Florida; throughout Central America and into a large portion of South America. It is also abundant along the Pacific coast. Breeds throughout its United States range and wherever found in Southern districts. Nests commonly on Cobb's Island, Va., effectually concealing the eggs in the tall grass on the higher parts of the Island. The marshes at this place are also favorite breeding localities, where the nests are built up from the ground, which is wet at high tide. At Long Beach, N. J., it breeds rarely and is said to have been formerly one of the most abundant breeding species. Mr. Perry writes that the Willet finds favorite breeding grounds in the salt marshes of Georgia and South Carolina. He mentions a large tract of "salt grass" in Beaufort Co., S. C., where it breeds in great numbers. A hundred pairs or more are commonly observed breeding in this locality and at the same time, the eggs are very difficult to discover. Crows feed on them and the empty shells are strewn plentifully over the field. The nest is a mere depression of the ground, lined with a few pieces of dry grass. Sometimes it is placed in a tussock of grass. Mr. Perry states that the eggs are deposited early in May. Mr. Stuart reports the Willet as breeding abundantly along the Gulf coast or Florida in May and June. The eggs are four in number, and there seems to be two distinct types of coloration in the ground color-either a greenish-white or a dark brownish-olive, marked with bold spots of various shades of umber-brown and markings of subdued purple. The eggs are very large for the size of the bird, rangIng from 1.98 to 2.12 in length by 1.46 to 1.58 broad. Four eggs measure $1.95 \times 1.50$, $1.98 \times 1.49,2.05 \times 1.53,2.04 \times 1.53$.

258a. WESTERN WILLET. Symphemia semipalmata inornata Brewst. Geog. Dist.-Western North America, east to Mississippi Valley and Gulf States; in winter, south to Mexico, and, during migrations, sparingly along coast of southern Atlantic States. Breeds from coast of Texas to Manitoba.

Mr. Brewster first described this race in The Auk, Vol. IV, April, 1887, pp. 145146. It is somewhat larger and grayer than the eastern species, and according to Elliot the two forms in winter cannot be distinguished from each other, save possibly by the longer bill of the present species, though this is not always reliable. The present variety is very common in the western part of the United States and in Texas. The nesting habits and eggs are identical with those of S. semipalmata; the eggs, however, averaging a trifle larger.

259. WANDERING TATTLER. Heteractititis incanus (Gmel.) Geog. Dist.Pacific coast of America, from Norton Sound, Alaska, to Galapagos, and west to Kamtchatka and the Hawaiian Islands: also more eastern groups of Polynesia. 
This plainly colored bird is well termed "wandering." No gpecies of this family traverse so much sea and coast during the changing seasons as this one. Elliot says: Along the vast extent of the Pacific coast it goes from the Equator onward to the Aleutian Islands in the far north, and to the interior of Alaska, where it probably breeds along the banks of the mighty Yukon. He states that the places where this bird breeds may be well within the Arctic circle.

[260.] RUFF. Pavoncella pugnax (Linn.) Geog. Dist.-Northern portions of the Old World; occasionally straying to Eastern North America.

The male of this species is known as the Ruff and the female as Reeve. It is a bird of .wide distribution; found at various seasons of the year throughout Europe, the northern parts of Africa, and in western Asia. Examples of this bird have been taken in Eastern United States, as well as on Long Island and in various places in New England. Dr. Jasper took a specimen November 10, 1872, at the Licking

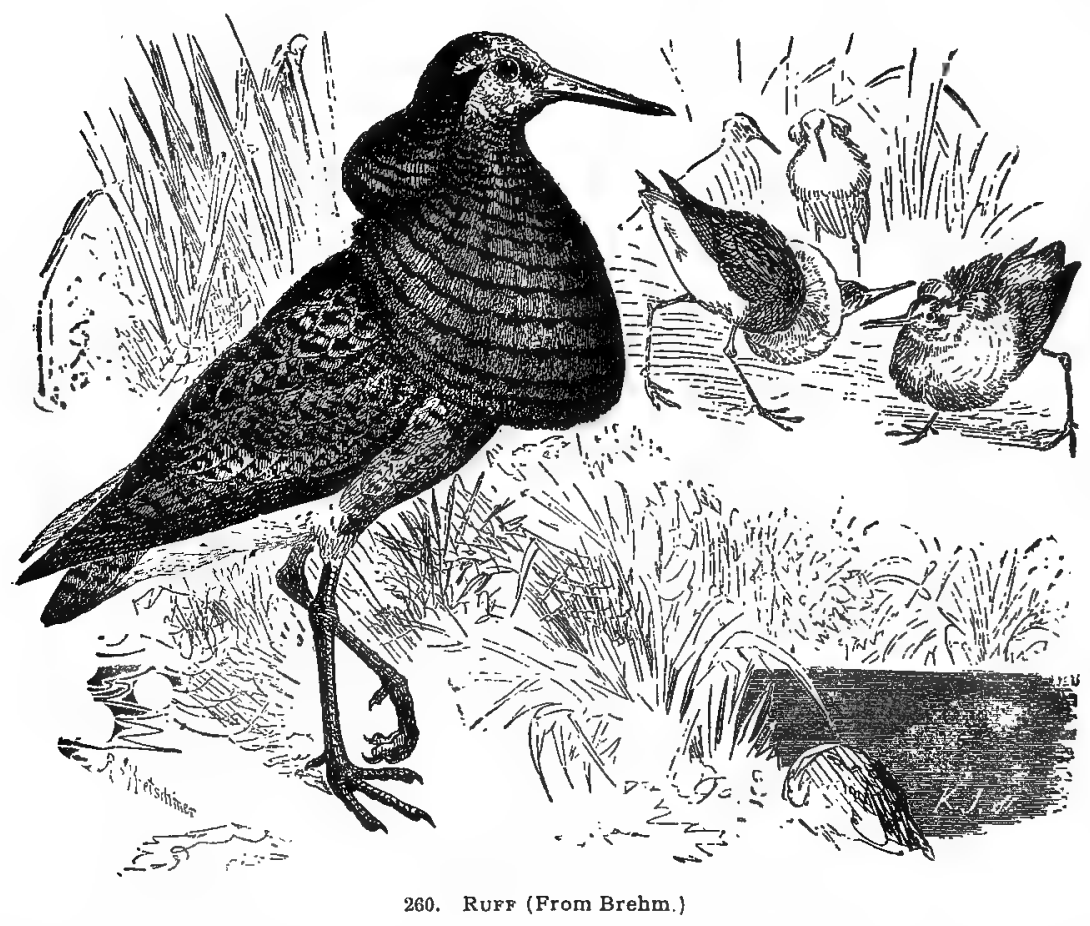

County Reservoir, Ohio. It breeds more or less commonly, in England and Scotland, where the eggs are deposited during the first or second week in May. The Ruff is about the size of the Bartramian Sandpiper, and it also resembles this bird in color. But the most marked peculiarity of the species is the ruff-like growth of feathers about the neck, from which it takes its name. There is an endless variety of plumage in the birds, the males and females differing widely in this respect. As its specific name, pugnax, implies the bird is of a pugnacious disposition, the males engaging in aggressive combats during the breeding season. Their movements in 
nghting are said to be something like a game cock. Breeds throughout the greater portion of Scandinavia and in Denmark. In Lapland it arrives in the last week of May where it is found along the margin of lakes and rivers; later in the season it may be found hiding in the tall grass of the marshes. The nest is usually placed on a slight elevation in swampy places surrounded by coarse grass of which material it is composed. The eggs are four in number and average 1.60x1.09. Four eggs in my

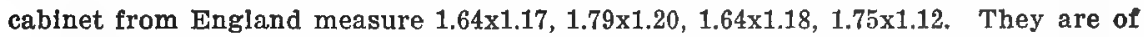
an oblong pyriform shape; the ground color is of an olive or grayish-green; the markings are the same as those of the Americán Jack Snipe-eggs but are heavier and more profuse-with spots and blotches of umber and blackish-brown.

261. BARTRAMIAN SANDPIPER. Bartramia lonjicauda (Bechst.) Geog. Dist.-Eastern North America, north to Nova Scotia and Alaska. Breeds throughout its range. South in winter as far as Southern South America.

Bartram's Tattler is distributed more or less abundantly throughout the United States, but is rare west of the Rocky Mountains. Breeds commonly from the middle districts-Ohio, Indiana, Illinois, Iowa, Minnesota and the Dakotas northward, into the Fur Country, and in Alaska. It is very numerous on the prairies of the interior and is also common eastward. It is known as Field "Plover," Upland "Plover," Grass "Plover," Prairie "Pigeon," and Prairie "Snipe." In Ohio and Pennsylvania the eggs are hatched by the first or second week in June. One of the most familiar birds on the dry, open prairies of Manitoba, where it breeds, and is known as the "Quaily," from its soft, mellow note. Mr. L. Jones, of Grinnell, Iowa, informs me that it nests in that region about the 20th of May. Known to breed in various portions of Michigan, but its eggs are not often taken. The bird is less aquatic than most of the other Sandpipers, and is seldom seen along the banks of streams. Its favorite resorts are old pastures, upland, stubble fields and meadows, where its nests may be found in a slight depression of the ground, and they are not always well concealed. It frequently alights on trees or on fences, like a Meadow Lark. The eggs of Bartram's Sandpiper are of a pale clay or buff, thickly spotted with umber and yellowish-brown, especially about the larger end; commonly four in number; sizes range from 1.70 to 1.90 long by about 1.28 broad.

262. BUFF-BREASTED SANDPIPER. Tryngites subruficollis (Vieill.) Geog. Dist.-North America, especially the interior. Breeds in the interior of British America and in Alaska. Occasional occurrence in Europe.

This interesting little Sandpiper is of general distribution in North America, but apparently nowhere very common. It is migratory in the United States, and breeds in the Arctic regions. Winters south of United States. It is often found in company with the Semipalmated Plovers and Semipalmated "Sandpipers on the gravelly banks of rivers. This bird is said to resemble Bartram's Sandpiper in frequenting upland flelds and meadows. Breeds in the MacFarlane and Anderson River regions and in the Barren Lands of the Arctic coast. The nesting season in these regions is the latter part of June, extending to the middle of July. The bird also breeds in the Yukon River district. The nests are slight depressions in the soil, scantily lined with a few grasses or withered leaves. The eggs are clay color of various shades, sharply spotted and blotched with rich umber-brown; there is a great diversity in the shades of the ground color in a large series of specimens, and there is also the same variations in the markings; the eggs are pointedly pyriform in shape; commonly four in number, and measure from 1.40 to 1.50 long by 1.02 to 1.10 broad. 
263. SPOTTED SANDPIPER. Actitis macularia (Linn.) Geog. Dist.-North and South America and West Indies. Winters chiefly south of the United States.

The familiar little Spotted Sandpiper is an extremely abundant bird throughout North America, breeding everywhere. It winters in the Southern States and beyond. Every lazy fisherman and idle school boy, who has whiled away many a , balmy and hot summer day along the banks of streams, knows this bird well by the bobbing and tilting movements of its body and tail, and its peculiar note, peet-weet, peet-weet, as it flies up and down and across the streams. It is known by many a curious nickname: "Teeter-tail," "Tip-up," "Sandlark," "Peet-weet" and others which generally refer to some eccentricity of the bird. The eggs are creamy, buff or clay color, blotched, spotted and dotted with blackish-brown; usually four in number, and measure about 1.34 by .92 . The nest of this Sandpiper is made on the ground, generally in the shelter of high weeds or grass on a sandy island or border of a cultivated meadow, near water and often at a considerable ustance from any water. It is simply a depression in the soil, sometimes constructed with hay and moss. The eggs like all those of the waders lay in the nests with the small ends together.

264. LONG-BILLED CURLEW. Numenius longirostris Wils. Geog. Dist.Temperate North America, migrates south to Guatemala and tho West Indies.

The large Sickle-bill is of irregular distribution in temperate North America,

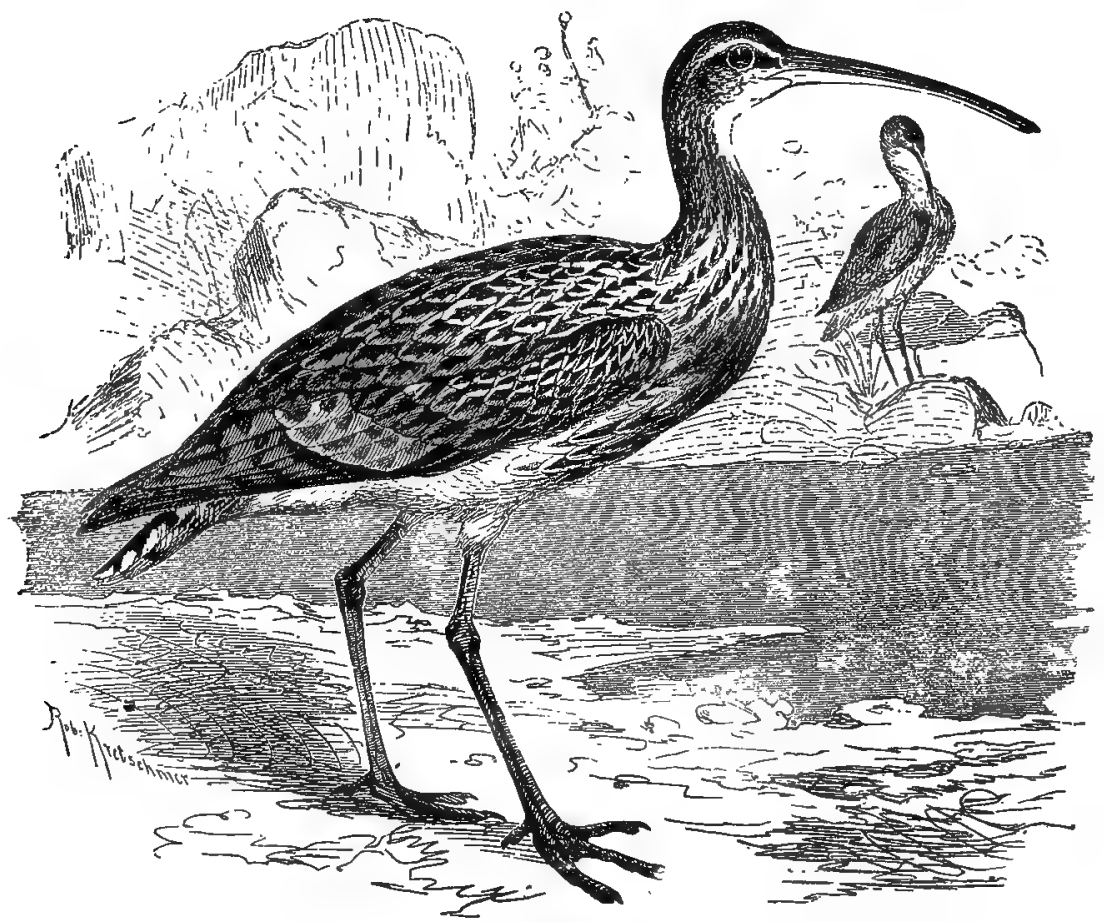

- Edropean Curdew, Numenius argustus. Similar in cut to the Long-biller Curlew. (From Brehm). 
breeding nearly throughout its range. It is migratory northward and is resident from the Carolinas south to Mexico. It nests very abundantly on the South Atlantic coast, and on the prairies of the interior and the Northwest. Unlike others of its genus it is not a bird of high latitude. The eggs of the Long-billed Curlew are three or four in number; and almost exactly resemble those of the Willet, but are larger, measuring from 2.45 to 2.80 in length by 1.80 to 1.90 in breadth; they are, however, more of a pyriform shape than the eggs of the Willet. In common with other waders the eggs are deposited on the ground in a slight hollow lined with a few grasses. This Curlew may be known from all others by its large size and very long, curved bill, measuring from four to six or eight inches. It may sometimes breed at St. Mary's Reservoir, in Mercer county, and other localities of Northwestern Ohio, as it is known to breed in Northern Illinois.

265. HUDSONIAN CURLEW. Numenius hudsonicus Lath. Geog. Dist.North and South America and West Indies. Breeds in the far north; winters chiefly south of the United States.

The American Whimbrel, Short-billed, or Jack Curlew, as this bird is variously called, is not so abundant as the Long-billed or Eskimo Curlews. It is generally distributed throughout North America, breeding in the far north-in vicinity of ponds and lakes on the Barren Lands of the Arctic regions, the regions of the Anderson River and in various parts of Alaska. Nests like those of the last species. In the United States it is a spring and fall migrant and is often found in company with Godwits, Snipe and others of its tribe. The eggs are ashy-yellow, the markings are large and bold, of different shades of chocolate and umber-brown. The eggs of this species can only be distinguished from those of the following species by their larger size; from 2.12 to 2.30 in length by about 1.60 broad; generally four in number; of the usual pear-shape.

266. ESKIMO CURLEW. Numenius borealis (Forst). Geog. Dist.-Eastern Province of North America, breeding in the Arctic regions; south in winter to Southern South America.

The Dougn-bird, or Eskimo Curlew, is found in North America at large and breeds within the Arctic circle. It migrates through the United States, where it is rarely known to winter, and never to summer; wintering in Central and South America. Abundant in certain places during the migrations. In Labrador it is said to fairly swarm in August. Of this bird's nest and eggs Dr. Coues says: "This species breeds in great numbers in the Anderson River region, usually making up its nest complement of four eggs by the third week in June. The nest is generally in an open plain, and is a mere depression of the ground, lined with a few dried leaves or grasses. The eggs vary to the great extent usually witnessed among waders. The ground is olive-drab, tending either to green, gray or brown in different instances. The markings, always large, numerous and bold, are of different depths of dark chocolate, bistre and sepia-brown, with ordinary stone-gray shell spots. They always tend to aggregate at the large end, or at least, are more numerous on the major half of the eggs; though in a few instances the distribution is nearly uniform. Occasionally the butt end of the egg is almost completely occupied by confluence of very dark markings. Eggs vary from $1.90 \times 1.40$ to $2.12 \times 1.33$, averaging about $2.00 \times 1.45$."

* Birds of the Northwest, D. 512 . 
[267.] WHIMBREL. Numenius phaopus (Linn.) Geog. Dlst.-Old World; eecasional in Greenland.

In England and Scotland this bird is known as Whimbrel Curlew, "Half-Curlew," or Jack Curlew. It breeds throughout Northern. Europe and Asia. Thongh pretty generally diffused in Great Britain, it is only found breeding in the extreme north of Scotland, on the Orkney and Shetland Islands, where the eggs are hatched by the first part of June. In these places the nests are made on elevated portions of the heath. During the breeding season the Whimbrel is found on the Faroe Islands and in Iceland. It is distributed throughout Denmark, Scandinavia and Russia; a few are known to breed in Lapland, as far north as latitude $65^{\circ}$. It is said by the best authorities that this bird is the most widely diffused of all the waders. Its extra-limital range includes Siberia, India, China, Australia and Africa. On the Faroe Islands it is recorded as breeding from the 25th of May to the 17th of June. The nest being simply a depression in the soil on some slight elevation in dry spots. in marshes. The eggs are four in number, pear-shaped, and vary in color from light olive-brown to dark greenish-brown, clouded with spots and blotches of dark umber; average size $2.34 \times 1.67$.

[268.] BRISTLE-THIGHED CURLEW. Numenins tahitiensis (Gmel.) Geog. Dist.-Islands of the Pacific Ocean; occasional on the coast of Alaska and Lower California.

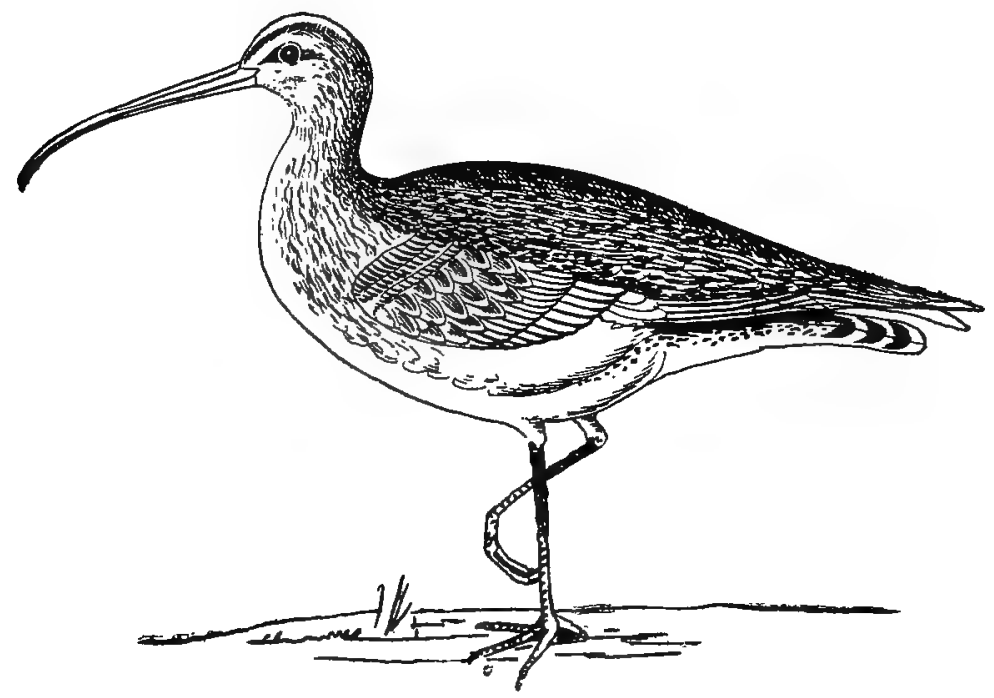

268. Bristle-thighed Corlew. (From Nelson.)

This Curlew, which is a native of various islands in the Pacific Ocean is given a place in our avifauna on the ground that two examples were taken on our western coast, one at St. Michael's Island and the other on Kadiak Island, Alaska.

[269.] LAPWING. Tanellus vanellus (Linn.) Geog. Zist.-Northern portion of Eastern Hemisphere; occasional in Arctic America, Greenland and the Islande of Norton Sound, Alaska. 
The Lapwing or Peewit is one of the most familiar birds of Europe. A rare visitant in Greenland and other parts of North America. Abundant in all suitable localities in Great Britain and in all the adjacent smaller islands. Found as far north as the Faroes, and in Iceland. Common in Denmark, Norway, Sweden and throughout Russia. It is not so abundant in various portions of Continental Europe, as in France, Spain and Italy. The Lapwing is a handsome plover; in the

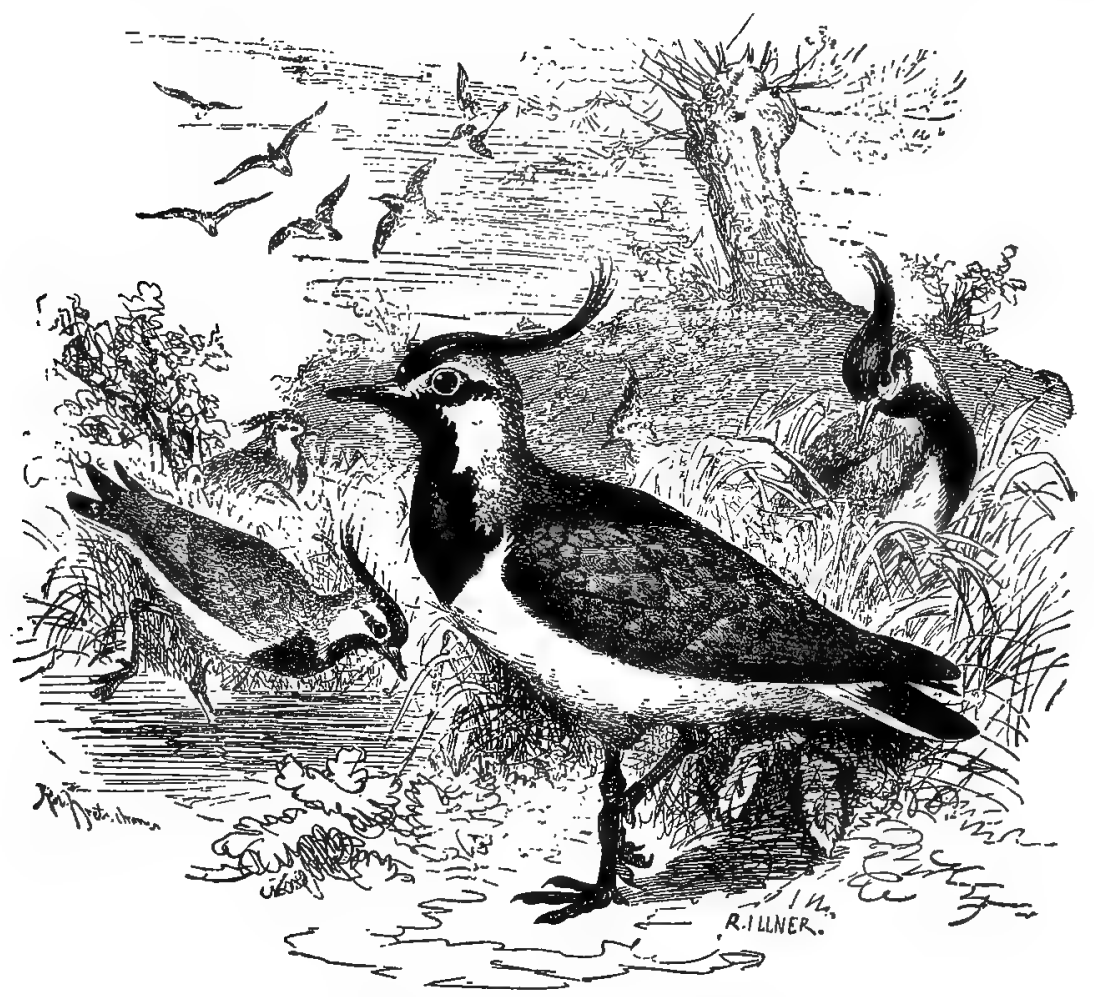

269. Lapwing (From Erehm).

adult in summer dress the fore part and top of the head, chin, throat and breast is uniform blue-black; side of head and neck white, grayish behind the neck; upper parts chiefly metallic bottle green, changing to a coppery purple. From the occiput springs a long crest of narrow bluish-black feathers which curve upwards. It is commonly called Te-wit, Crested Lapwing, Green Lapwing and Green Plover. The nests of this bird are like those of all the Plovers-slight depressions in the soil with a few grasses for a lining. The eggs are four in number; they vary from a dull, light, grayish-buff to deep olive buff, more or less heavily marked with spots and blotches of brownish-black; they are pyriform in shape. Four eggs in my cabinet, collected in Staffordshire, England, April 18, measure 1.88x1.30, 1.89x1.32, 1.84x1.36, 1.82x1.32. The average size is $1.85 \times 1.33$. The eggs are regarded as a delicacy and are much sought after in all districts where the bird is common. 
270. BLACK-BELIIED PLOVER. Charadrius 8quatarola (Linn.) Geog. Dist.-Northern portions of Northern Hemisphere, breeding far north; migrating south in winter; in America to Brazil, New Grenada and the West Indies.

This handsome bird is known by several different names: Beetle-head, Ox-eye, Whistling Field Plcver, Bull-head Plover and Swiss Plover. It is a species of wide distribution, being nearly cosmopolitan during its migrations, wandering through Southern Asia, Northern and Southern Africa, Australia, the West Indies, Central and South America to Brazil. The eggs have only been taken in the extreme Arctic regions-on both sides of the Ural Mountains in Northern Russia-the banks of the Taimyr in the East and the tundras of the Petchora River in the West. In North America it has been found breeding in various places in the Arctic regions, as on the islands of Franklin Bay on the Arctic coast, in the first part of July and on the Barren Lands. It is also known to breed in Greenland. All the nests found are mere depressions in the ground with a slight lining of grasses and leaves. The eggs are described as being very similar to those of the Golden Plover, C. apricarius, or those of the Lapwing; pyriform in shape, varying from light buffy-olive to deep olive-buff, thickly and heavily marked with brownish-black or deep black; average size, $2.04 \times 1.43$.

[271.] GOLDEN PLOVER. Charadrius apricarius Linn. Geog. Dist.-Europe; in winter south into Africa. Greenland.

The European Golden Plover is like the American bird, but the linings of the wings are white. In Great Britain during the winter months it is one of the most abundant species; in summer returning to the moorlands of Scotland and Ireland, and northward to the Orkney and Shetland Islands, where is breeds. It is found in Norway, Sweden and in Lapland. Breeds also in the Faroes, in Iceland and in Eastern Greenland. The nest is simply a hollow in the ground, lined with a few grasses. The full complement of eggs is four and seem exceeding large for the size of the bird. The ground color in a large series of these eggs varies considerablycreamy-white, others with a much darker shade of the same, and again of a dark chocolate-brown. On these different ground colors the large, bold spots and confluent blotches of brownish-black present quite a varied appearance. Eight eggs in my cabinet from Renfrew, Scotland, measure, $2.02 \times 1.42,2.08 \times 1.37,2.10 \times 1.38 ; 2.11 \times 1.45$, $1.96 \times 1.40,2.01 \times 1.37,2.08 \times 1.40,2.12 \times 1.43$. Average, $2.08 \times 1.42$.

272. AMERICAN GOLDEN PLOVER. Charadrius dominicus Mull. Geog. Dist.-North America at large, breeding in the Arctic regions.

The Golden or Green Plover breeds in Arctic America east of the coast of Bering Sea and Strait, migrating south in winter nearly throughout the entire America as far south as Patagonia. MacFarlane found it breeding at Franklin's Bay. In spring and fall it is an abundant bird in the United States, and is generally esteemed for the table on account of its large size and the flavor of its flesh. Breeds abundantly on the coasts and islands of the Arctic Sea, and on the Barren Lands, depositing four eggs in a depression of the soil, which is usually slightly lined with bits of dry grass. Out of one hundred and fourteen nests recorded by Mr. MacFarlane in the Arctic regions, ninety-two contained four eggs each. They vary from pale buffy-brown to dark grayish-buff, spotted and blotched with brownish-black, chiefly at the larger end. The spots are often confluent. The average size is $1.98 \times 1.37$. In the collection of the late Capt. B. F. Goss there is a set of four eggs collected by Mr. MacFarlane on the Barren Grounds near the Anderson River. These are buffy-drab, spotted and 
splashed with dark brown, almost black; they are pyriform in shape, quite pointed the small end, and blunt at the larger portion of the egg.

272a. PACIFIC GOLDEN PLOVER. ('haradrius domilicus fulvus (Gmel.) Geog. Dist.-Asia, and islands of the Pacific. In North America, the islands and coasts of Alaska. In winter, south through India, China, etc., to Australia and Polynesia.

The Asiatic Golden Plover is similar to C. dominicus, but is slightly smaller and of a more golden color. It breeds in Northern Asia, the Alaskan coasts of Bering Sea and Strait. Nesting and eggs similar to those of the last. Average size of the eggs, $2.02 \times 1.30$.

273. KIILDEER. Agialitis vocifera (Linn.) Geog. Dist.--Temperate North America, south in winter to the West Indies, Central and Northern South America.

This familiar bird whose notes, kil-deer, kil-deer, are heard in the daytime, and often in moonlight nights, more frequently during the breeding season than at any other time, is very abundant in North America at large, breeding nearly anywhere in its range. The nest is placed on the ground, usually in the vicinity of a stream, or pond, and often on an elevated spot in the grass or in a furrowed field. It is merely a slight depression of the ground. The bird frequents both high and low grounds, pastures and fallow fields, as well as borders of streams. The eggs are drab or claycolor, thickly spotted and blotched with blackish-brown and umber; small end quite pointed, as is usually the case with all eggs of birds of this order; the eggs are generally four in number, measuring from 1.50 to 1.60 long by about 1.10 broad.

274. SEMIPALMATED PLOVER. Egialitis semipalmata Bonap. Geog. Dist.-North America in general; breeding in Arctic and sub-Arctic districts; south in winter throughout tropical America as far as Brazil and Peru.

The Semipalmated Ring Plover is abundant and generally diffused throughout the whole of North America. In the United States it occurs only in the migrations, but it probably breeds occasionally in some of the Northern States. Both eggs and young have been taken near Chicago, Ill., in July. 'It has been found in the summer' months in the Saskatchewan and Mackenzie River regions, and in those of Hudson Bay, in Greenland and throughout various portions of Arctic America. It has been found breeding in the latter part of June on the Arctic coast, and in the Anderson River regions. Breeds on the islands of the Alaskan coast, and at the mouth of the Yukon. Audubon found it nesting in Labrador. The nest is a mere depression in the ground, with a lining of dry grasses or leaves. The bird's general habits are like those of the Killdeer. The eggs vary from greenish to yellowish-ash, spotted, blotched and dotted with varying shades of brown; pyriform; scarcely distinguishable from those of the Killdeer, excepting in size; length 1.20 to 1.40 by .90 to .95 in breadth; two to four in number.

275. RING PLOVER. AEgialitis hiaticula (Linn.) Geog. Dist.-Northern portion of Eastern Hemisphere; and eastern portion of Arctic America.

The well known Ringed Dotterel, or Ringed Plover of Europe, holds its place as a North American species on the grounds of its breeding abundantly throughout Greenland and on the shores of Cumberland Gulf. It is particularly common in Great Britain, where it frequents the banks of rivers, inlets and bays, and the shores 
of the sea. Common in Norway, and it has been met with in Lapland. The eggs of this species are deposited in a slight depression in the sand, broken shells or shingles above high-water mark. Four eggs are laid and their ground color is of a pale buff or cream color; they are beautifully spotted with dark reddish-brown, approaching black, here and there are obscure shell markings. Average size 1.41x1.00. Four eggs from England, collected May 6, are in my cabinet and measure $1.36 \times 1.00,1.40 \times 1.02$, $1.43 \times .99,1.42 \times 1.00$.

[276.] LITTLE RING PLOVER. Agialitis dubia (Scop.) Geog. Dist.-Northern portion of Eastern Hemisphere. Accidental on the coast of California and in Alaska.

The Little Ringed Dotterel or Little Ringed Plover breeds in the northern portions of the Old World. This European species has less grounds for being included in the North American fauna than the previous ones. Its general habits, nesting and eggs resemble those of the Semipalmated Plover, but the eggs, like the bird, are much smaller. The average size of ten eggs in my collection is $1.19 \times .85$. They are short ovate in form, of a pinkish-buff ground color, finely speckled all over with brown.

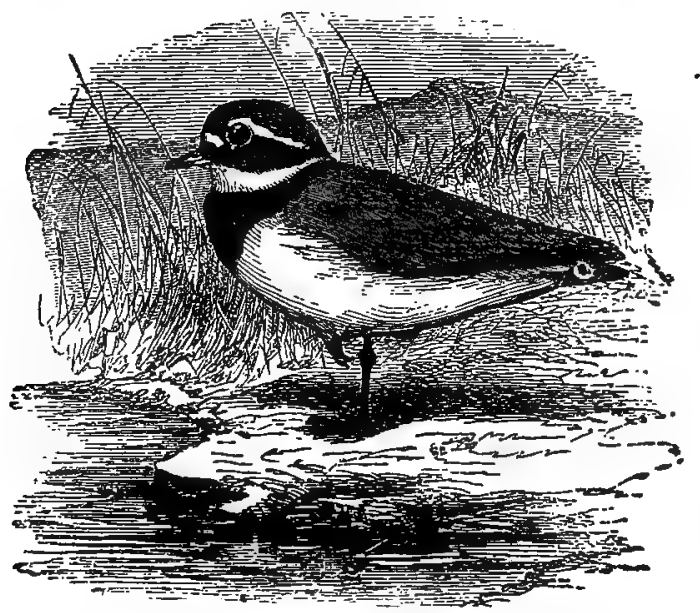

276. Little Ring Plover.

277. PIPING PLOVER. Aljialitis meloda (Ord.) Geog. Dist.-Chiefly the Atlantlc coast of the United States, north to southern Labrador. In winter, West Indies.

The Piping Plover is an abundant species in the summer months along the eastern coast of the United States, breeding from the Carolinas northward as far as the Gulf of St. Lawrence. It is a graceful and attractive little species, possessing a remarkably musical voice which can be heard as the bird moves gracefully over the sandy beaches. Its food is small marine worms, crustacea, etc. During incubation it is said that the parents rarely sit upon their eggs, except at night and in damp weather, but always remain in the vicinity and watch over their treasures with solicitude. The eggs are four in number, pale buff, speckled with black and purplish gray. In some the markings are very much more profuse than in others. The average size of a large series (fifty in number) is $1.29 x .95$. Four specimens measure $1.28 \times 1.01,1.31 \times 1.01,1.25 \times 1.03,1: 28 \times 1.00$. 
277a. BELTED PIPING PLOVER. Egialitis meloda circumcincta RIdgW. Geog. Dist.-Missouri River region; occasionally eastward to the Atlantic coast.

This variety of the Piping Plover is found between the Missouri River and the Rocky Mountains and as far eastward as Lake Koskonong, in southern Wisconsir. and occasionally along the Atlantic coast. Its habits are the same as those of meloda. The eggs measure $1.27 \times .93$.

278. SNOWY PLOVER. Wgialitis nivosa Cass. Geog. Dist.-Festern North America, south to Mexico in winter, botk coasts of Central America and in Western South America to Chili.

The Snowy Ring Plover inhabits the United States chlefly west of the Rocky Mountains. It is a constant resident along the California coast, and a specimen has been taken on the coast of Texas in the latter part of June. Mr. Emerson, of Haywards, California, informs me that it nests along the sandy beaches of the ocean coast, and says he has no doubt that it breeds along the bay beach, as he shot the young there in June. Mr. Shields states that it is abundant along the sandy beaches in the vicinity of Los Angeles, nesting in the first week of April; fresh eggs often being found as late as May 15. Mr. N. S. Goss found the Snowy Plover breeding on the salt plains along the Cimarrion River, in the Indian Territory, the northern limits of which extend into southwestern Comanche County, Kansas; he also took two specimens within the State limits. The birds are described as being very much lighter in color than the California specimens.* The eggs are three in number, in ground color, pale buff or clay color, and the marl-ings very much resemble Wilson's Plover, but are more numerous and scratchy; about the size of the eggs of the Piping Plover, meloda, 1.20x.90.

[279.] MONGOLIAN PLOVER. Egialitis mongola (Pall,) Geog. Dist.Northern Asia, south in winter to Malay Archipeliago and Australia, Choris Peninsula, Alaska, accidental.

A bird of wide distribution. Found throughout Northern Asia in general, west to St. Petersburg, Palestine and Northeastern Africa. In winter it is found throughout Southern Asia and as far south as the Philippines, Malay Archipeliago, etc., to Australia. Breeds commonly in Northern portions of Asia, nesting on the ground like others of its tribe. The eggs are four in number; pale dull olive or buff sparsely marked with brownish-black; size, $1.43 \times 1.05$.

280. WILSON'S PIOVER. Egialitis uilsonia (Ord.) Geog. Dist.-Atlantic and Gulf coastș of North America, north to Long Island. Casually to Nova Scotia. South in winter to Brazil and Peru and West Indies.

Wilson's Plover, named in honor of the immortal Wilson, is common along the sea coast of the South Atlantic and Gulf States. It is found along the Eastern coast, but rarely north beyond New Jersey. One of the "beach birds," and may be found in company with others of the genus Evtalitis. On some of the islands on the coast of Georgia Mr. Perry found them breeuing in great numbers in company with the Least Tern, nesting very much in the same manner. The eggs are deposited in a cavity of the loose pebbles or shells of the beach; they are usually three in number. The ground color is a pale olive-drab or clay-colored, some having a greenish tint, marked all over with blackish-brown, well defined spots, small splashes and fine 
dots. Sizes from 1.30 to 1.45 long by 1.00 to 1.05 broad. A set in Mr. Perry's cabinet measures as follows: $1.37 \times .99,1.82 \times .98,1.40 \times 1.00$.

281. MOUNTAIN PLOVER. Agialitis montana (Towns.) Geog. Dist.-Western North America, east to the Great Plains; accidental in Florida.

More properly called Prairie Plover, but it seems to have been badly named, for it certainly is a prairie bird, inhabiting the most barren prairies, as well as the watered regions of the United States, from the plains to the Pacific. It can readily be recognized by its large size, the lack of rings on the breast, with the uniform pale, yellowish-brown above. It is quite independent of water, and is said to be not the least aquatic, even on the Pacific coast; it frequents the plain, never the marsh or beach. Nests anywhere on the open prairie in June and July. The eggs are usually three in number, olive-drab, with a brown shade, finely and thickly dotted with very dark brown and black, the markings not larger than a pin's head; sizes from 1.40 to 1.50 long by 1.10 to 1.12 broad.

282. SURF BIRD. Iphriza virgata. (Gmel.) Geog. Dist.-Pacific coast of America, from Alaska to Chili.

Known as the Plover-billed Turnstone. It is rare on our shores, although it is found almost along the entire western coast of the two Americas. Little is known concerning its breeding place and the eggs have not been discovered. Nelson secured specimens of the bird in the vicinity of St. Michael's, Alaska, and the natives claimed that it bred on the bare mountains of the interior, some 20 or 30 miles from the coast. At the present time, however, its breeding place is unknown.

283. TURNSTONE. Arenaria interpres (Linn.) Geog. Dist.-Entirely cosmopolitan, chiefly along the sea coasts. Breeds in high northern latitudes.

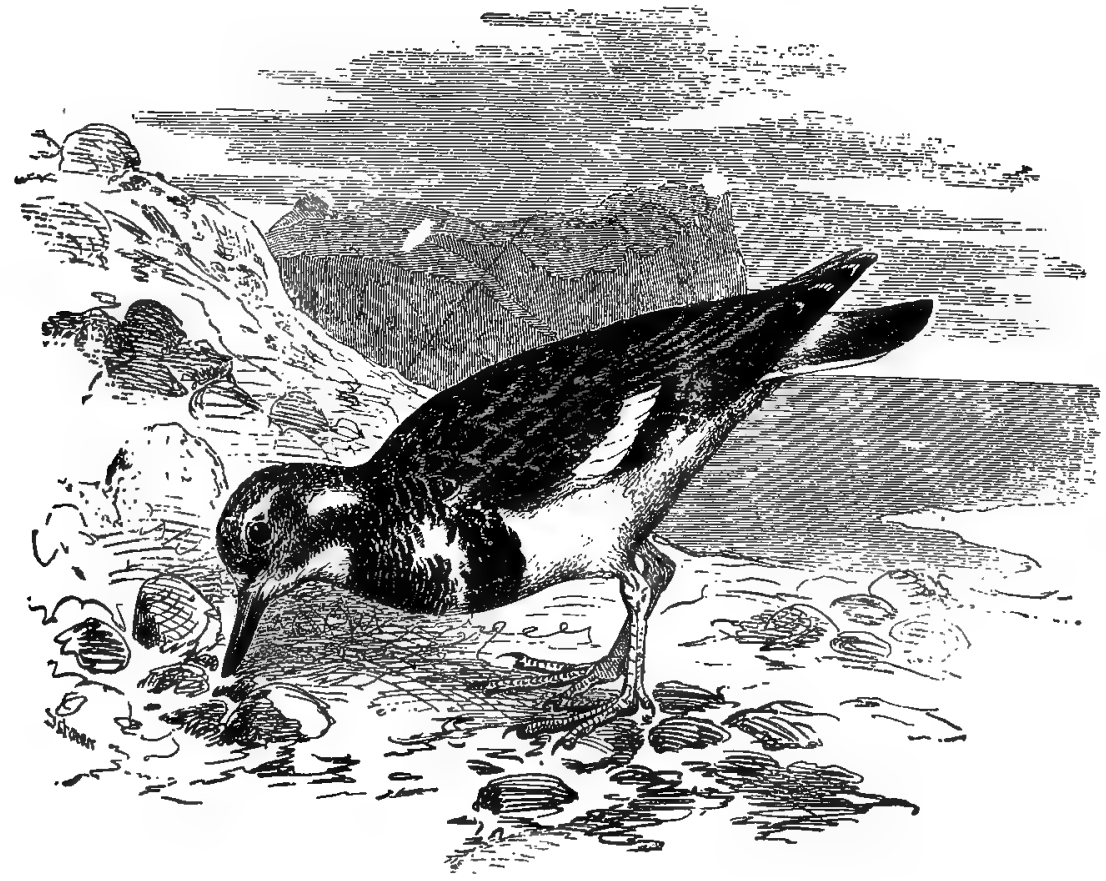

283. TURNSTONE 
The common Turnstone is widely distributed in the breeding season throughout the northern portions of both continents, and wanders southward along the sea coasts of all countries. In America it breeds commonly in the Barren Lands of the Arctic coasts and the Anderson River districts, on the islands of Franklin and Liverpool Bays, nesting in July. In the Hudson Bay country the eggs are laid in June; the nest is nothing but a hollow scratched in the earth, lined with bits of grass. It is known by various names, "Brant Bird," "Bead Bird," "Horse-foot Snipe," and from its varigated colors, "Calico-back." The eggs are greenish-ash, spotted, blotched and dotted irregularly and thickly with yellowish and umber brown; two to four; abruptly pyriform in shape, and average 1.58 1.15 . A set of four eggs of this species is in the cabinet of Captain B. F. Goss. These were taken on the Yukon River, in Alaska. The nest was a slight depression on the ground. The eggs are

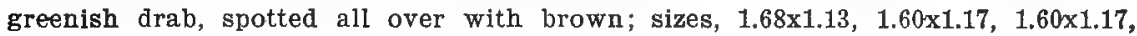
$1.68 \times 1.13$.

284. BLACK TURNSTONE. A renaria melanöcephala (Vig.) Geog. Dișt.Pacific coast of North America, from Alaska to Santa Cruz and San Minguel Island.

The Black-headed Turnstone is common along the Pacific coast of North America. It has been found nesting in Alaska at the mouth of the Yukon. In all respects its habits, nesting, eggs, etc., are said to be similar to those of $A$. interpres. The eggs average $1.62 \times 1.12$.

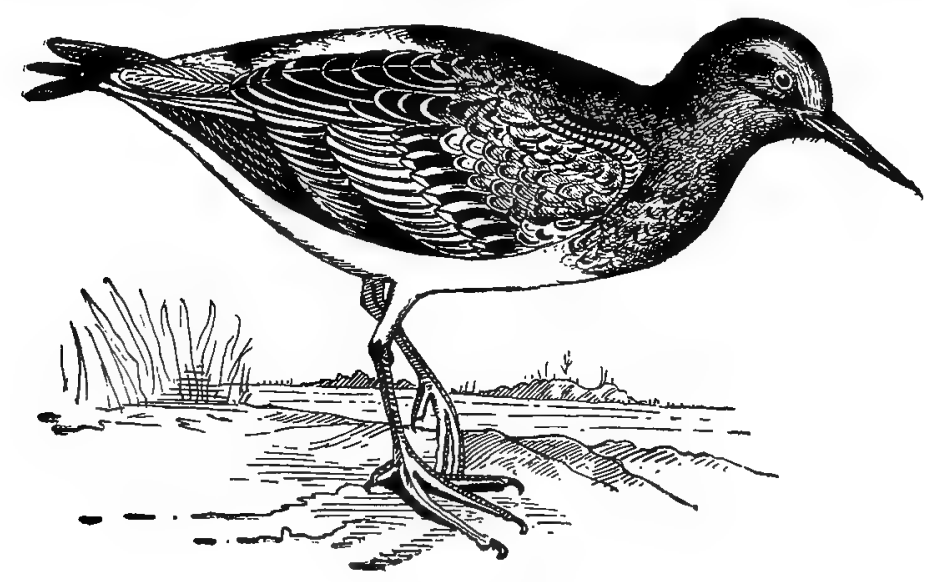

284. BLAcK TURNSTONE.

[285.] OYSTER-CATCHER. Homatopus ostralegus Linn. Geog Dist.-Sea coasts of Europe, portions of Asia and Africa; occasional in Greenland.

The Oyster-catcher of Europe claims a place in the North American fauna from its occasional occurrence in Greenland. It appears to be common in all suitable places on the coasts and islands of Europe, extending northward to the northern shores of Russia and Siberia, where it breeds on the great Arctic flats. Common throughout the summer months in Denmark, Sweden and on the west shores of Norway. In Great Britain the Oyster-catcher is a well known species, nesting on the shores and islands as far north as Orkney and Shetland. The bird breeds gen- 
erally in pairs, but in some instances a large number are found nesting in one place. Four eggs are usually laid in some cavity in the sand or shingle. Nests hare been found on the top of rocks, ten to fifteen feet above the ground. The eggs aro of a dull creamy buff, spotted and blotched with brownish-black, generally over the ontire egg. Six eggs in my cabinet from England measure 2.15×1.57, 2.35x1.53, 2.16x $1.56,2.17 \times 1.54,2.32 \times 1.50,2.19 \times 1.56$.

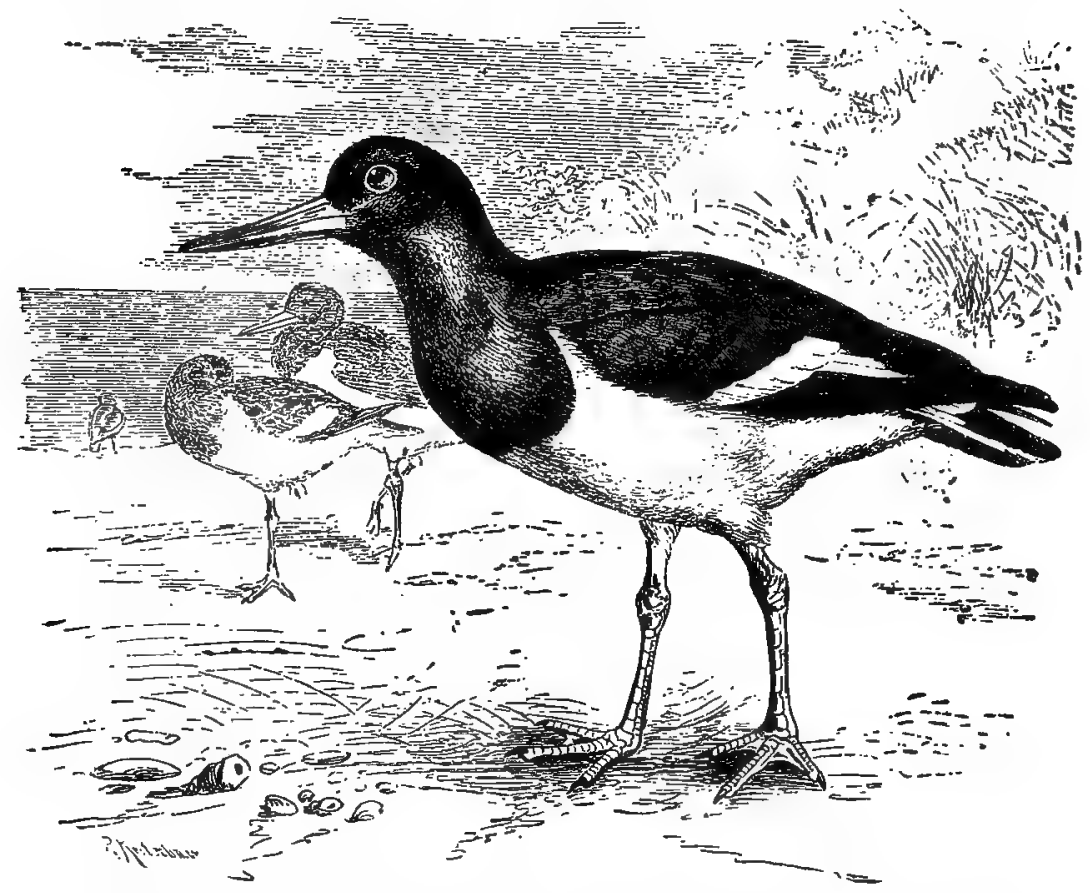

- Europein Oyster-catcher, similar to the American Oyster-catcher. (From Brehm.)

286. AMERICAN OYSTER-CATCHER. Homatopus palliatus Temm. Geog. Dist.-Sea coasts America from Nova Scotia and Southern California, south to Patagonia.

The brownish-backed Oyster-catcher breeds along the Atlantic coast from New Jersey southward, where it becomes more common. It breeds abundantly, but irregularly, in different localities. There are extensive breeding resorts along the coast of Virginia. On Cobb's Island it was formerly quite common during the breeding season, where now only a few pairs are said to be found nesting. It is common along the coast of Florida, nesting on the beaches and depositing three, sometimes only two, eggs. The American Oyster-catcher is an abundant resident throughout the Bahamas, nesting wherever there are sandy beaches. It has been found breeding in Galveston Bay, Texas, in June, and on islands at the mouth of the Rio Grande. The eggs are creamy or white, spotted and blotched irregularly with varying shades of brown; rather oval in shape; sizes range from 2.12 to 2.30 in length by 1.50 to 1.62 in breadth. Six eggs from the coast of Virginia measure $2.22 x$ $1.57,2.23 \times 1.58,2.19 \times 1.52,2.15 \times 1.52,2.25 \times 1.60,2.21 \times 1.57$. Mr. Walter Hoxie, in the 
"Ornithologist and Oölogist" for August, 1887, gives us an interesting account of a pair of these birds moving their eggs when their nest was discovered. While Mr. Hoxie was watching the parents they carried the eggs about one hundred yards from the old nest, and deposited them safely in a new nest which he saw the birds prepare. The female lifted the eggs between her legs and successfully carried them away.

286. 1. FRAZAR'S OYSTER-CATCHER. Hamatopus fra $a r i$ Brewst. Geog. Dist.-Lower California (both coasts), north to Los Coronados Islands.

Mr. William Brewster has dedicated this new species to M. Abbott Frazar, who secured three specimens north of La Paz, on the Gulf of California. It was said to be common in the locality and evidently preparing to breed on the sandy islands and shores of the gulf. It has been seen on Los Corronados Islands, San Quentin Bay, Cerros Island; also at Magdalena Bay, where it was common, and on Santa Margarita Island." Here they mated in January. They feed upon small bivalves. Mr. Brewster describes this species as differing from $H$. palliatus in having a stouter, more depressed bill, little or no white on the eyelids, the back, scapulars and wing-coverets richer and deeper brown.* I have no description concerning the nesting and eggs of this new species.

287. BLACK OYSTER-CATCHER. Hrematopus bachmani Aud. Geog. Dist.Pacific coast of North America from Lower California north to the Aleutian Islands and across to the Kurilas.

Bachman's Oyster-catcher, as it is called, is a characteristic bird of the Pacific coast, being more common to the north than to the south. It is said to be partial to rocky coasts and islands and not always net with on sand beaches. It is common in Alaska, where it is one of the characteristic birds of the seashore, and it is also a summer resident of the entire Aleutian chain of islands. Dall found it breeding the latter part of June on Range Island, one of the Shumagin group. Here he found two nests. In both cases the eggs were placed directly upon the gravel on the beach; one contained two eggs, the other one. They were all partly incubated. The eggs of this species are two

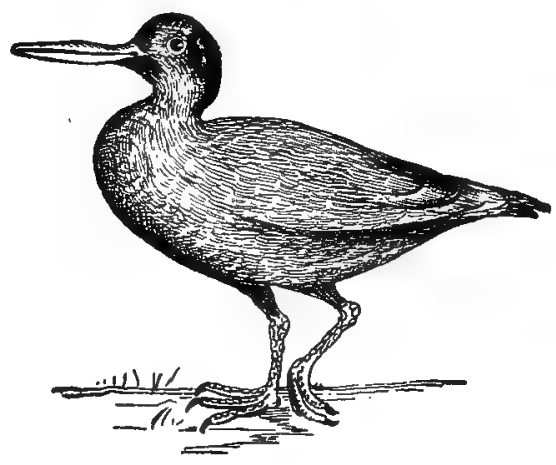

287. BLACK Oyster-Catcher. or three in number, light olive-buff, speckled or spotted with brownish-black and purplish-gray. Their average size is $2.20 \times 1.52$ inches.

[288.] MEXICAN JACANA. Jacana spinosa (Linn.) Geog. Dist.-Valley of the Lower Rio Grande, Texas, south into Central America, Panama, Cuba, Hayti.

A bird which combines the characters of the Plover and the Rail, but out. wardly distinguished from either by the excessive development of the toes and particularly the claws. These are slender, compressed, nearly or quite straight, that of

* For a complete description see The Auk, V, pp. 84-85. 
the hallux much longer than its digit. The spread of feet thus acquired enables the bird to run quite easily over floating vegetation in the marshes. Dr. James C. Merrill met with the present species near Fort Brown, in Southwestern Texas, in the early part of August, 1876. The bird is common throughout the whole of Middle America, Mexico and Central America to Panama, inhabiting the dense marshes of these regions, nesting like the Rails. The eggs are of a rounded-oval shape, ground color, bright drab or tawny olive, marked over the surface with a confused net-

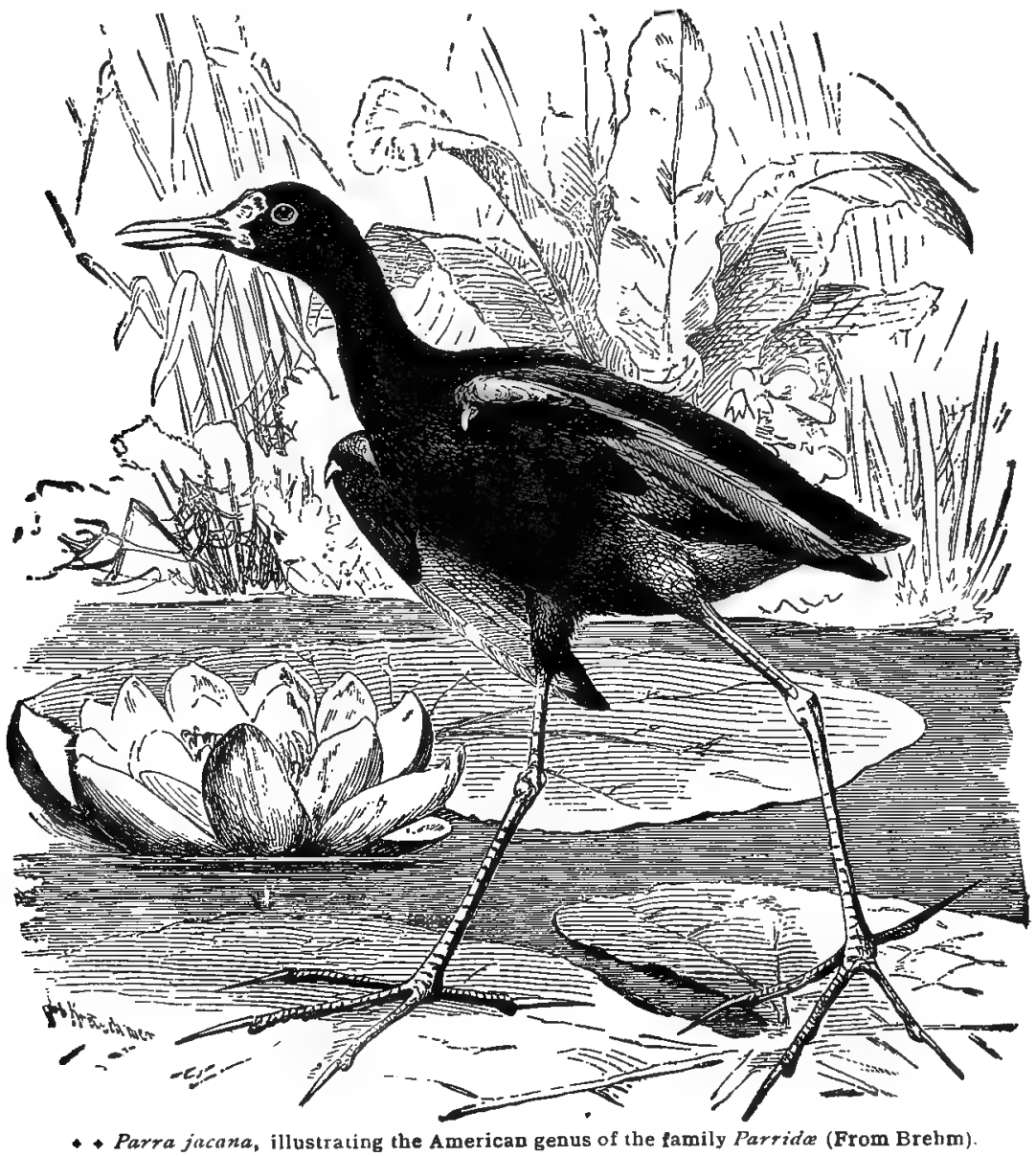

work of black, or dark brown wavy stripes, blotches and lines. Average size, 1.22 x.94. $\mathrm{Mr}_{\text {: }}$ Crandall has two sets of the eggs of this bird collected by Frank B. Armstrong in Tamaulipas county, Mexico, respectively on May 13 and July 18, 1895. The nests in both cases were composed of water weeds and trash of any kind. They were constructed so as to float among the lilly leaves growing on a pond, similar to a grebe's nest. One set contains five eggs, and they measure as follows: 1.19x.89, $1.16 \times .90,1.18 \times .89,1.21 \times .90,1.23 \times .91$. The second set of four eggs, taken in July, ex- 
hibit the folowing dimensions: $1.20 \times .91,1.22 \times .90,1.19 x .93,1.18 \times .92$. The average size of the nine eggs is $1.19 \times .90$ inches. In a larger series the average size is larger, as above cited.

* EUROPEAN QUAIL. Coturnix coturnix (Linn.) Geog. Dist.-Northern portions of Northern Hemisphere; introduced into the United States.

The Common Quail of Europe has been imported by the hundreds in various parts of this country during the last eighteen years. This has especially been the case in the Eastern States, north to New Prunswick. Either the climate or the food was unsuited to them and their naturalization is considered a failure.

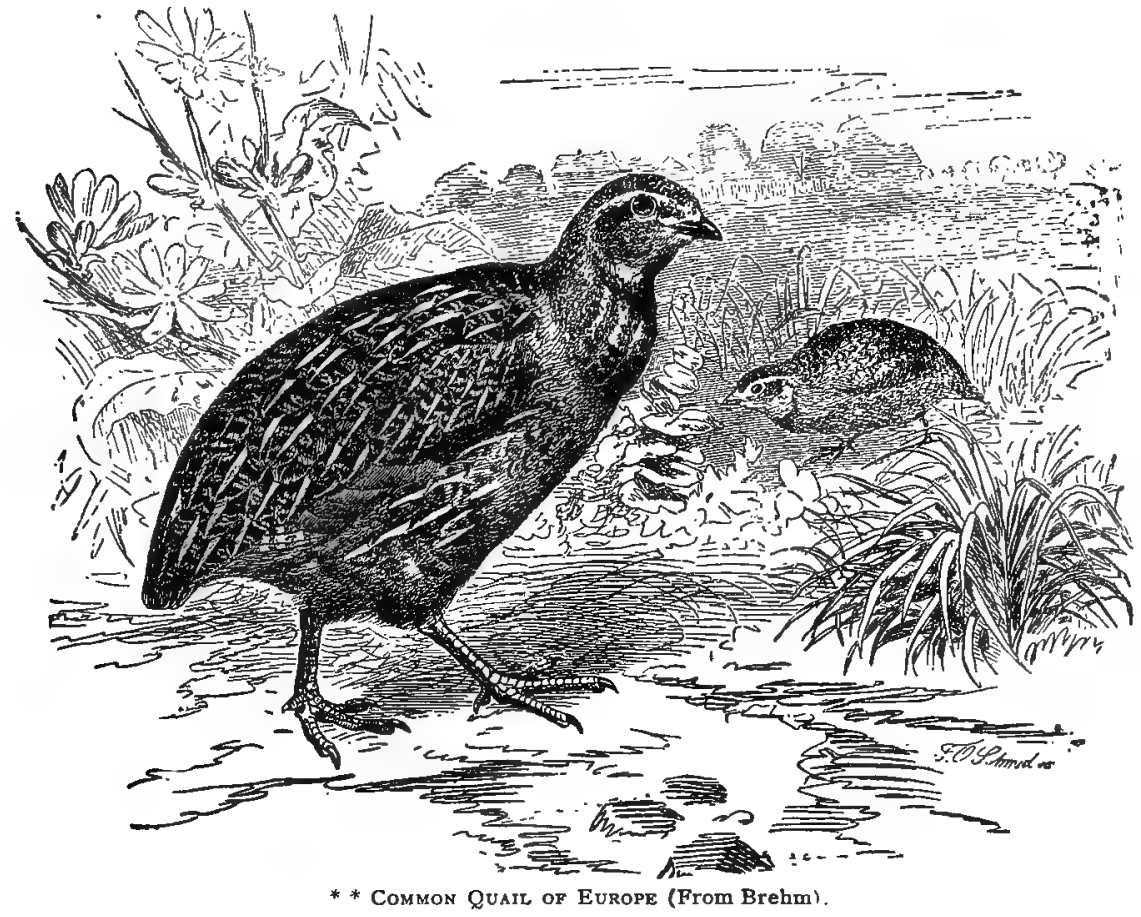

289. вов-WHITE. Colinus virginianus (Linn.) Geog. Dist.-Eastern United States; west to Dakota, Kansas, Indian Territory and Eastern Texas. North to Southern Maine and Southern Canada, south to the Atlantic and Gulf States.

The celebrated game bird of Eastern United States. It has now extended its range westward into nearly all the Western States and Territories. In the two southern extremes of its habitat it is found in two light and dark climatic varieties, as below. Found throughout the greater portion of the year in coveys; in the early spring pairing, each pair selccting a particular locality, where they remain during the summer months. Where mating has taken place the male's well-known mellow notes,-Bob-uhite,Bob-white, may be heard at short intervals echoing throughout the woodland. The favorite nesting places of this bird are on the ground in corners of rail fences, at the foot of stumps surrounded by a thick growth of vegetation, in gardens or cultivated fields where there are bunches of tall grass or weeds. 
Two and sometimes three broods are reared in a season and nesting begins as early as May 1st. The nest is often made in close proximity to the farm house. It is rarely built in thick woods. Dr. Jones mentions a nest which he found alongside a railroad track. It is usually constructed of dry grasses, straws, leaves or weeds. The complement of eggs is from fifteen to twenty-five, often only twelve, but usually about eighteen. They are pure white unless stained by the bed of grass upon which they lie. At one end they are quite pointed, at the other obtusely rounded; size $1.20 \times .95$.

289a. FLORIDA BOB-WHITE. Colinus virginianus floridanus (Coues.) Geog. Dist.-Florida.

A darker colored bird than $C$. virginianus. General habits, nesting and eggs the same. Eggs, 119x.92.

289b. TEXAN BOB-WHITE. Colinus virginianus texanus (Lawr.) Geog. Dist.-Texas and Northern Mexico, north to Western Kansas.

A bird of paler color than the C. v. floridanus. Eggs smaller than C. virginianus, 1.17x.91.

* * CUBAN BOB-WHITE. Colinus virginianus cubanensis (Gould.) Geog. Dist.-Cuba and Southwestern Florida.

The late Maj. Bendire in his great work: "Life Histories of North American Birds," says: "This slightly smaller and darker colored bird than Colinus virginianus floridanus, is found in limited numbers in Southwestern Florida, south of Lake Okeechobee and Tampay Bay." Quoting Dr. Juan Viaró, professor of natural history, University of Havana, Cuba: "The Cuban Bob-White lays from ten to eighteen eggs; these are usually deposited, between the months of April and July, in a slight cavity of the ground, sheltered by vegetation." The average size of nine eggs in the U. S. National Museum collection is $1.20 \times .94$.

291. MASKED BOB-WHITE. Colinus ridguayi (Brewst.) Geog. Dist.-Sonora to Southern Arizona.

The handsome Masked or Arizona Bob-white is a comparatively recent addition to the avifauna of North America, it having been described and named by Mr. William Brewster in The Auk (Vol. II, 1885, p. 199), from a specimen taken by Mr. F. Stephens, August 11, 1884, about eighteen miles southwest of the town of Sasabe, in Sonora, Mexico. It appears that this species is confined to a narrow strip of country along our southwestern border, and is nowhere as common as the Gambel's and Scaled Partridges, which are found in the same regions. The eggs appear to be indistinguishable from those of the eastern Bob-white. An egg obtained by the late Maj. Bendire measures 1.22x.94.

292. MOUNTAIN PARTRIDGE. Oreortyæ pictus (Dougl.) Geog. Dist.-Pacific coast from San Francisco north to Washington.

The beautiful Mountain or Plumed Partridge is a much larger and handsomer bird than the Bob-white. The head is adorned with two arrow-like plumes three or four inches in length; these are noticeable in the chick just from the egg, in the form of a little tuft of down. The general slate and olive color of the adult is beautifully marked with white along the sides, inner secondaries of the wings, sides of the neck, etc. The bird is found breeding along the Pacific coast region from California north 
into the State of Washington. Mr. Emerson informs me that it breeds in the higher mountain ranges, not below 4,000 feet. In some portions of Oregon it is very abundant. The eggs are deposited on the ground, on a bed of dead leaves, under a bush or tuft of grass or weeds. Six to twelve are usually laid, of a cream color with a reddish tint. Dr. Coues describes the eggs as miniatures of the Ruffed Grouse's, only distinguishable by their smaller size, $1.36 \times 1.02$.

292a. PLUMED PARTRIDGE. Oreortyx pictus piumiferus (Gould.) Geog. Dist.-Sierra Nevada ranges from Oregon southward; coast ranges of California to Cape St. Lucas.

This subspecies, which very much resembles 0 . pictus, inhabits both sides of the Sierra Nevada Mountains from Eastern Oregon southward, through the coast ranges of California. Its general habits, nesting, eggs, etc., are the same as those of the Mountain Partridge. The eggs are creamy-buff, of varying shades, and their average size is $1.40 \times 1.02$.

292b. SAN PEDRo PARTRIDGE. Oreortyx pictus cofinis Anthony. Geog. Dist.-San Pedro Mountains, Lower California.

This is a comparatively recent subspecies, having been first described by $\mathrm{Mr}$. A. W. Anthony in 1889. It differs from the last-named species, in that the upper parts are grayer and the bill thicker. Mr. Anthony informed Maj. Bendire that the breeding range of this race extends from the foothills along the base of the San Pedro Mountains, Lower California, to the tops of the highest peaks, estimated at about 12,500 feet. Mr. Anthony found a nest on Valladares Creek, March 29, 1889. The nest was placed in the midst of thick manzanita chaparral, high up on a hillside. The nest was a mere hollow under a manzanita bush, lined or rather filled, with dry leaves of the lilac and manzanita, and contained but a single egg. Mr. Anthony shot the female and secured from her another egg just ready to be deposited. He states that they resemble those of the Plumed Partridge in shape and color, being creamy white and unspotted. The two specimens measure $1.42 \times 1.10$ and $1.46 \times 1.06$ respectively.

293. SCALED PARTRIDGE. Callipepla squamata (Vig.) Geog. Dist.-Northwestern Mexico and border of the United States, from Western Texas to New Mexico and Southern Arizona.

This handsome Partridge, called Blue Quail, is distributed throughout Northwestern Mexico, Western Texas, New Mexico and Arizona, but is said to be less numerous than the crested Partridges or Quails. In Arizona they are found in flocks of from six to ten, sometimes more in the most barren places, miles away from any water. Mr. W. E. D. Scott found this Quail as abundant on the dry mesas of the San Pedro slope of the Santa Catalina Mountains, up to an altitude of 3,500 feet, as its congener $C$. 'yambeli. At this altitude Mr. Scott found a nest, May 20, containing eleven eggs.* It inhabits a more open country than pambeli and in other localities large flocks of both species were often seen together. A slight depression under a bush serves as a nest, it is generally lined with a few coarse grasses. In Western Texas complete sets of eggs may be found as early as Apiil 25. The eggs are extremely thickshelled; the number laid ranges from eight to sixteen, twelve being the more common number. Their color is buffy-white or of a cream color, irregularly dotted with specks of light brown; size, 1.24x.94.

- Auk. III, pp. 387-388. 
293a. CHESTNUT-BELIIED SCALED PARTRIDGE. Callipepla squamata eastanogastris (Brewst.) Geog. Dist.-Eastern Mexico and Lower Rio Grande of Texas.

This bird is like the last, but the general coloring is deeper and richer. The bird appears to inhabit the low lands along the lower Rio Grande Valley, while C. squamata inhabits the table lands of Northwestern Mexico, Western Texas, New Mexico and Arizona. Mr. George H. Ragsdale, of Gainesville, Texas, kindly sent me four eggs of this bird for inspection; these have a ground color varying from white to a buff with the surface marked with minute specks of reddish brown. In a specimen having a white ground the markings have a purplish tint. The shape of the eggs is characteristic of all eggs of the Partridge. The sizes of the four specimens are, 1.17x.94, 1.13x.92, 1.15x.94, 1.16x93. In the collection of the late Capt. B. F. Goss there is a set of ten eggs of this Partridge taken May 14, 1886, in Western Texas. They are dull white, speckled all over with fine dots of different shades of brown. Some of the eggs have a few small brown spots on them more than a sixteenth of an inch in diameter; they resemble the eggs of the Scaled Partridge, but are more thinly speckled and much lighter in color. Sizes, $1.25 \times .99,1.17 \times 1.00,1.24 \times$ $1.06,1.26 \times 1.05,1.26 \times .99,1.24 \times 1.05,1.25 \times .99,1.27 \times 1.00,1.27 \times .99,1.28 \times 1.00$. The nest from which these eggs were taken was on the ground and made of leaves and dry grass

294. CALIFORNIA PARTRIDGE. Callipepla californica (Shaw.) Geog. Dist.-Coast region of California south to Monterey. Introduced in Oregon, Washington and British Columbia.

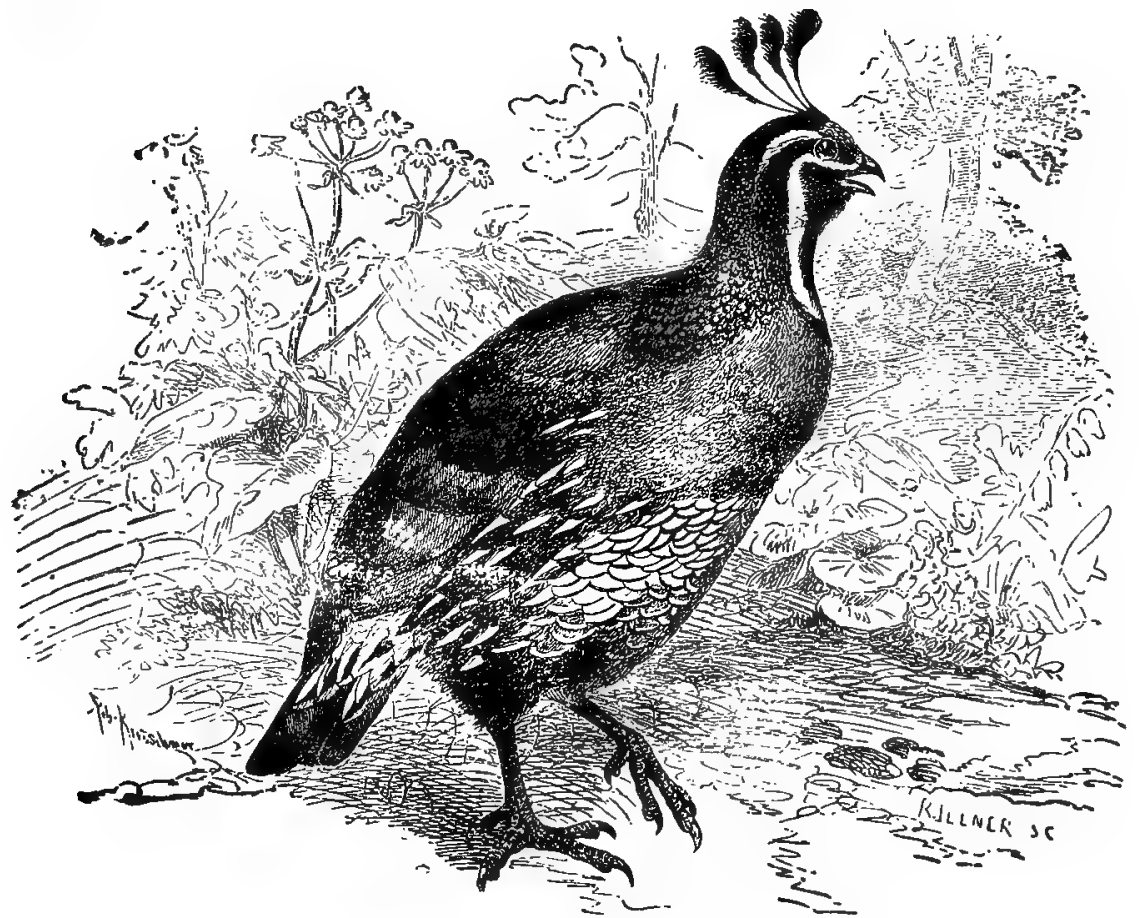

194. Uacifornia Partridge or Helmet Quall (From Brehm). 
The handsome California Partridge or Valley Quail inhabits the lower portions of California and Oregon, where it is very abundant, and also eastward nearly to the Colorado River. It is known also by the name of Helmet Quail. The nest is made on the ground, and is often found in curious places. Mr. Emerson says it is sometimes placed in the garden, within twenty feet of the doorway; he saw eggs of this Quail laid in the nest of chickens that had hidden their nests in the barn-yard, and it is commonly found under hedges, bushes, brush-heaps; even in the grass by the wayside. Mr. Bryant mentions several cases of this bird's nesting in trees upon the end of a broken or decayed limb, or at the intersection of two large branches. One case he cites of a brood being hatched in a vine-covered trellis at the front door of a popular seminary.* Mr. H. R. Taylor, of Alameda, California, records a nest of the Spurred Towhee on the ground in which were 4 eggs of the Towhee and 2 of the California Quail. $\dagger$ The eggs of this species are most beautifully marked on a creamy-white ground with scattered spots and blotches of old gold, and sometimes light $\mathrm{drab}$ and chestnut-red. In a large series of specimens sent me by Mr. Arnold Boyle, collected in the vicinity of Banning, California, there is a striking variation in this respect. In some specimens the gold coloring is so pronounced that it strongly suggests to the imagination that this Quail feeds upon the grains of the precious metal which characterizes its home, and that the pigment thereof is imparted to the eggs. The number laid ranges from eight to twenty-four. In shape they are like those of the Bob-white. Ten selected eggs measure $1.13 \times .90,1.18 \times .93$, $1.19 \times .93,1.19 \times .94,1.23 \times .90,1.27 \times .96,1.30 \times .95,1.32 \times .95,1.33 \times .97,1.35 \times .94$. The average size is $1.23 \times .94$.

294a. VALLEY PARTRIDGE. Callipepla rrlifornica tallicola (Ridgw.) Geog. Dist.-Interior Regions of California and Oregon, south to Cape St. Lucas.

This variety, which is very similar to the last species, is common to the interior valleys and foot-hills of the Pacific Province. There is essentially no difference between the eggs of this bird and those of $C$. californica.

295. CAMPBELL'S PARTRIDGE. Callipepla fambelii (Nutt.) Geog. Dist.Northwestern Mexico, Arizona, New Mexico, Southern Utah and Western Texas.

A characteristic game bird of Arizona and New Mexico; abundant on mountains and in valleys. It is found as far east as Western Texas, west to the Colorado River, north to Southern Utah. In Texas it is replaced by the Massena Quail. Mr. W. E. D. Scott found it distributed throughout the entire Catalina region in Arizona below an altitude of 5,000 feet. Ey the middle of April, on the San Pedro slope of the Catalina mountains most of the birds are paired, and breeding has fairly begun. About Tucson the breeding season begins from three weeks to one month earlier. $\frac{f}{5}$ This bird is also known as the Arizona Quail. The nest is like that of any other partridge, placed on the ground, sometimes without any lining. The eggs are from eight to sixteen in number and they do not differ from those of the C. californica. The average size of thirty specimens is $1.27 \mathrm{x} .98$.

296. MASSENA PARTRIDGE. Cyrtony. montezuma (Vig.) Geog. Dist.Tablelands of Mexico from the City of Mexico north to Western Texas, New Mexico and Arizona.

In Arizona this bird is known as "Fool Quail" or "Fool Hen." Mr. Scott mentions finding it common in the evergreen oak region of the Pinal Mountains, near

* Unusual Nesting Sites, I. Bull. Cal. Acad. Scl. II, 451.

$\dagger$ Ornithologist and Oologist, Vol. X, p. 142.

$\ddagger$ Auk. Vol. III, D. 388-389. 
the head of Mineral Creek in Arizona and about as abundant in the same localities on the San Pedro slope of the Catalina Mountains, ranging up as high as 5,700 feet and as low as 4,000 feet throughout the year. It was generally met with in coveys of six to a dozen birds. Mr. Otho C. Poling found this Partridge to se fairly common in parts of the Wetstone, the Santa Rita, Patagonia, and Huachuca Mountains of Southern Arizona. On July 15, 1890, he found a nest containing eight eggs; it was situated under a dead limb of a pine tree on a hillside; sunken in the ground and composed of grass stems, arched over, and the bird could only enter it by a long tunnel leading to it from under the limb with the grass growing around it. Mr. G. W. Todd found a nest of the Massena Partridge containing ten eggs in Kinney county, Texas, June 20, 1890. These are now in Mr. Thomas H. Jackson's collection, West Chester, Pa. The eggs are white and similar to those of the Bob-white, the majority being more elongated. The average measurement of the eight eggs collected by Mr. Poling, 1.26x.94 inches.

297. DUSKY GROUSE. Dendragrapus obscurus (Say.) Geog. Dist.-Rocky Mountains, west to Wahsatch, north to Central Montana, south to New Mexico and Arizona.

The Dusky Grouse in its several geographical garbs is distributed chiefly throughout the wooded and especially the evergreen regions of the United States, from the Rocky Mountains to the Pacific and northward in British America. In the mountains of Colorado this species is found on the border of timber line throughout the year, going above in the fall for their principal food-grasshoppers. In summer its flesh is said to be excellent, but when frost has cut short their diet of insects and berries, they feed on spruce needles and their flesh acquires a strong flavor. In its habits it resembles the Ruffed Grouse. It nests on the ground, often under shelter of a hollow log or projecting rock, with merely a few pine needles scratched together on which the eggs are laid. The eggs are buff or cream color, marked all over with small round spots of umber-brown, but generally more numerous toward the greater end; eight to fifteen are laid; average size $1.98 \times 1.42$.

297a. SOOTY GROUSE. Dendrag'apus obscurus fuliginosus Ridgw. Geog. Dist.-Mountains near the Pacific coast from Sitka, south to California.

A darker colored bird than D. obscurus. Mr. A. W. Anthony records this Grouse as abundant in Washington county, in the northern part of Oregon.* He states that in the winter the bird remains high up in the firs and is very seldom seen. At the first indication of spring the males begin to "hoot." This is not dissimilar to the "booming" of the Prairie Hen, and when uttering these love notes the bird may usually be seen about fifty or seventy-five feet from the ground in a thick fir. The note is repeated from five to seven times. Mr. Anthony says: "This Grouse is an accomplished ventriloquist; I have often looked for an hour for one supposed to be fifty yards in front of me to find it as far in the rear." Nests found in May contained from five to seven eggs. A set of seven eggs of this bird in the collection of the late Captain B. F. Goss was taken June 1st, 1887, at Oakland, Oregon. The nest was placed on the ground. The eggs are creamy buff, spotted and speckled with reddish brown; the spots are small and scattered, most of them sharply defined; the measurements of the seven eggs are as follows: $1.87 \times 1.38,1.81 \times 1.33,1.78 \times 1.33, \pm .86 \times 1.37,1.88$ x1.36, $1.80 \times 1.34,1.83 \times 1.35$.

* Auk, Vol. III, p. 164. Field notes on the Birds of Washington County, Oregon. 
297. RICHARDSON'S GROUSE. Dendragapus obscurus richardsonii (Dougl.) Geog. Dist.-Northern Rocky Mountains of the United States-Central Montaza northward into British America.

This race is more or less common in the various mountain ranges of Montana. Its general habits do not appear to be different from those of $D$. obscurus. The birds prefer rough and rocky ledges with only a moderate growth of fir to the denser forests. Occasionally they are found away from the mountains in scattered clumps of fir growing on the high bluffs or growing on some of the streams. Their "tooting" is a low, muffled sort of cooing, uttered without vigor or any apparent effort on the bird's part, which may be squatting on some rock at the time. The eggs are cream color, marked with small dots of reddish-brown; average size $1.84 \times 1.30$. 1 hey are not distinguishable from those of $D$. obscurus, and the nesting habits are the same.

298. CANADA GROUSE. Dendragapus cunadensis (Linn.) Geog. Dist.Northern North America, east of Rocky Mountains, from the Northern portions of New England, New York, Michigan and Minnesota to Alaska.

Known as the Spruce or Wood Partridge, Canada, Black or Spotted Grouse, and found in all favorable localities, especially the spruce forests and swamp regions from Northern. United States northward, as far as the woods extend in the Arctic regions, and it has been found breeding in Northern Alaska. Audubon found it breeding in the vicinity of Eastport, Maine, in the interior recesses of almost impenetrable woods of hackmatack or larches. He was informed that the birds breed in the neighborhood about the middle of May, which is a month earlier than they do in Labrador. In the nesting season the males produce the same well-known and peculiar drumming as does the Ruffed Grouse. The female constructs a nest of a bed of dry twigs, leaves and mosses, and is usually carefully hidden, on the ground, under low horizontal branches of fir trees; it is generally placed in quiet and swampy localities. The eggs are of a buffy or reddish brown color, irregularly splashed, dotted and spotted with different tints of brown; eight to fourteen in number; average size of ten eggs is $1.70 \times 1.20$. The shape is characteristic, being like those of the Ptarmigan in form.

299. FRANKLIN'S GROUSE. Dendrayapus franklinii (Dougl.) Geog. Dist.Northern Rocky Mountains, west to the Pacific coast; chiefly north to the United States.

This bird is held by some authorities as a mere variety of $D$. canadensis. It is confined to the territory between the Rocky Mountains and the Pacific coast, chiefly in British America. Its habits in all respects are identical with those of canadensis. The nest is made on the ground, of dry leaves and grass, often at the foot of decayed stumps, or by the side of fallen timber in dense mountain woods. The eggs average in size $1.68 \times 1.24$.

300. RUFFED GROUSE. Bonasa umbellus (Linn.) Geog. Dist.-Eastern United States, south to North Carolina, Georgia, Mississippi and Arkansas.

The Ruffed Grouse, "Pheasant" or "Partridge," is a noted game bird distributed in wooded districts throughout Eastern United States. At the limits of its habitat it is found in several geographical races as is shown by the following sub-species. Its habits in many respects differ from those of the Prairie Hen; the latter is found on open plains, while the Grouse is rarely met with there. The food of the two apecies is very similar, making the difference in their respective abodes quite striking. The well-known drumming of the male birds is made during the love season, 
which commences in March. The sound is produced by the bird while standing on a fallen log or elevated rock in the most retired portion of the woods; the wings are lowered, tail expanded, the neck contracted, and the entire body seems inflated. The tufts of neck feathers are elevated, the bird all the while strutting about in the most pompous manner possible to imagine, striking the sides of his body with rapid strokes of his wings. These become so rapid that the sound thus produced resembles the rumblings of remote thunder, and the sounds always seem nearer than they really are. Under favorable circums.ances this Grouse not infrequently rears two broods between the first of April and the middle of October. The nest is usually situated at the border of a large woods in the midst of dense undergrowth, often in a thicket, not far from the roadside, and very frequently the birds venture to construct it in a small woods adjoining a farm house. The position of the nest is on the ground beside a log or stump, or in a brush heap, or under the branches of a fallen tree. It is constructed of decayed leaves, a few feathers, roots, etc. From six to fifteen eggs are deposited, usually ten or twelve; theyare of acreamcolor of various shades, some times so dark as to be nearly brownish, and in others the surface is almost milk-white. They are often stained in wet weather by the leaves upon which they lie, and are sometimes faintly blotched or speckled with shades of brown. $\mathrm{Mr}$. L. Jones, writing from Iowa, says that the eggs in that vicinity are deposited about May first. Ten eggs measure $1.54 \times 1.10,1.51 \times 1.13,1.54 \times 1.13,1.54 \times 1.14,1.51 \times 1.12,1.56 x$ $1.13,1.55 \times 1.14,1.53 \times 1.12,1.57 \times 1.14$.

300a. CANADIAN RUFFED GROUSE. Bonasa umbellus to'jata (Linn.) Geog. Dist.-Eastern Oregon and Washington Territory, east to Moose Factory, Nova Scotia, Maine, etc.

Eggs supposed to belong to this darker colored variety of Ruffed Grouse in my collection from Northern Maine do not differ from those of $B$. umbellus.

3000. GRAY IUUFED GROUSE. Bonasa umbellus umbelloides (Dougl.) Geog. Dist.-Rocky Mountain Region north to Alaska, east to Manitoba.

The upper parts of this bird are mostly or entirely grayish, and the tail is always of a gray color. It is found in the wooded districts of the Rocky Mountain region of the United States, and as far north as the Yukon valley in Alaska, in British America, east to Manitoba. In the late Capt. Goss's collection there is a set of five eggs of this bird taken at Estes Park, Colorado, May 28, 1884. They are creamy buff; some of the specimens are almost or quite immaculate, others are faintly and sparingly spotted with lilac brown. The eggs in this set are smaller in size and less spotted than the usual spotted examples of $B$. umbellus, and unless closely examined the marking would scarcely be noticed. These eggs were taken from a nest on the ground; the sizes are as follows: $1.47 \times 1.11,1.45 \times 1.12,1.44 \times 1.12,1.42 \times 1.15$.

300c. OREGON RUFFED GROUSE. Bonasa umbellus sabini (Dougl.) Geog. Dist.-Northwest coast from Northern California to British Columbia.

This subspecies resembles $B$. umbellus, but the upper parts are darker rustybrown; the tail is also usually deep rusty color, rarely grayish.

Red Ruffed Grouse. The nesting habits and eggs of this subspecies are essentially the same as those of $B$. umbelius of the Eastern States. It breeds in Oregon, Washington into British Columbia. The nest is placed in a sunken hollow of the ground, under a bush or branches of a fallen tree, the cavity of the nest being lined with dry leaves, spruce needles and a few feathers. The eggs range from seven to fourteen in number, creamy white in color and average in size $1.56 \times 1.16$ inches. 
301. WILLOW PTARMIGAN. Laypus lagopus (Linn.) Geog. Dist.-Northern portions of Northern Hemisphere; in North America south in winter to Sitka, northern New York, etc.

This Ptarmigan is distributed in summer throughout Arctic America. It breeds abundantly in the valleys of the Rocky Mountains on the Barren Grounds and along the Arctic coasts. The winter dress of the bird is snow white, with the central tail feathers black, tipped with white. In summer, the head and neck are yellowish-red, back black, barred rather finely with yellowish-brown and chestnut; most of the wings and under parts remain white as in winter. Large numbers of the Willow Ptarmigan are said in the winter to shelter in willow thickets and dwarf birches on the banks of lakes and rivers, where they feed on the buds of the smaller shrubs which form their principal food at that season. Their favorite resorts in daytime are barren, sandy tracts of land, but they pass the nights in holes in the snow. When pursued by sportsmen or birds of prey they are said to often dive in the loose snow and work their way beneath its surface. Mr. MacFarlane found nests of this species in the Anderson River region early in June,
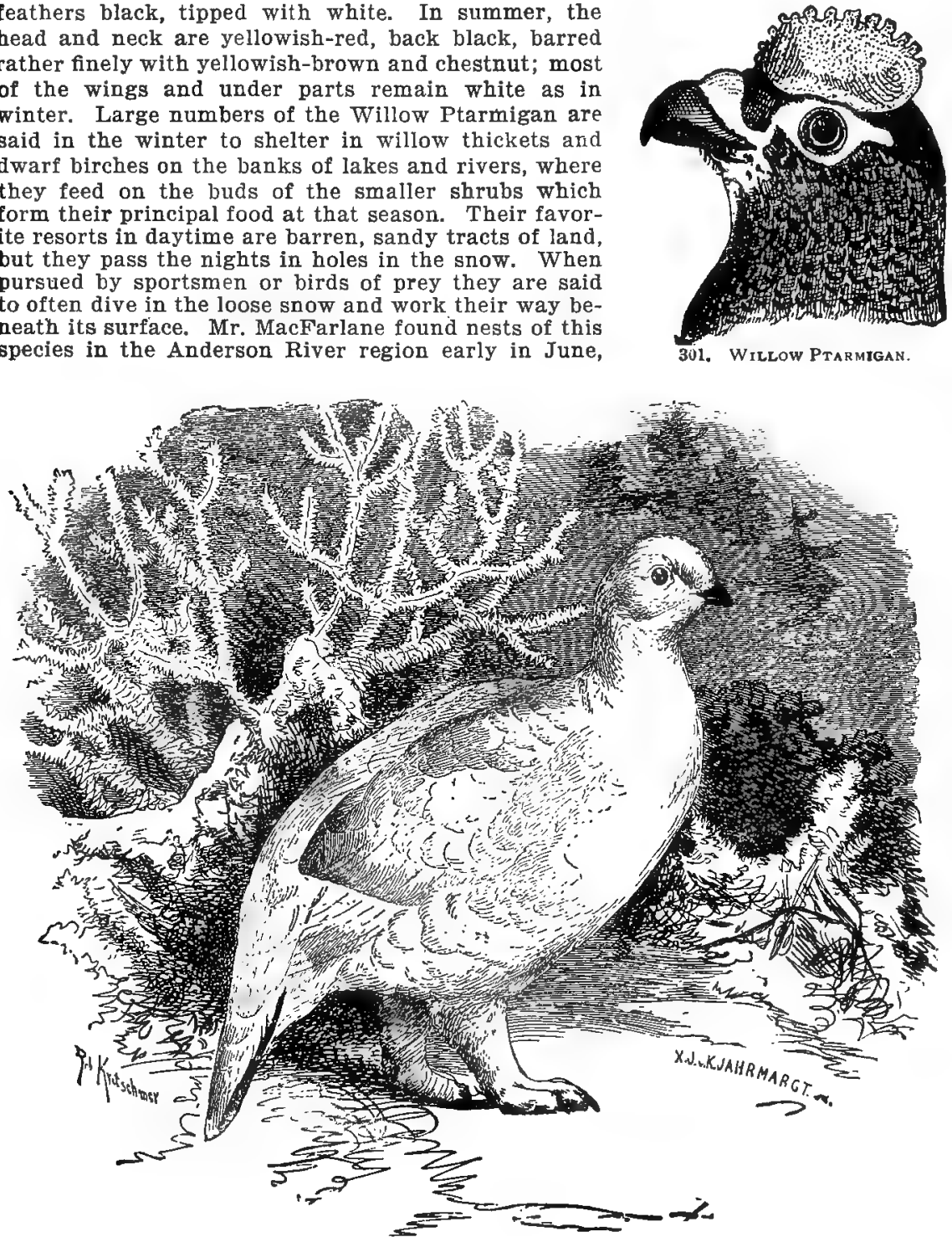

301. Wilzow Ptarmigan, winter plumage (From Brehm). 
and as late as June 24th. Otbers were found on the banks of the Swan River as late as June 27th, containing large embryos. A nest observed July 10th contained ten perfectly fresh eggs, and another set of eggs was examined July 22, the contents of which were slightly developed. The nests made on the ground were mere depressions, generally lined with leaves, hay, and a few feathers from the birds themselves. The same nest is often occupied in successive seasons. The largest number of eggs taken by Mr. MacFarlane was ten, but the female is said to lay as many as sixteen. A few of this species breed in various parts of Alaska. Mr. Dall took eggs near the mouth of the Yukon in the latter part of June. The eggs have a ground color varying from pale yellowish-buff to deep chestnut-brown, more or less sprinkled, speckled, spotted or marbled with rich brown or black. Average size 1.78x1.25.

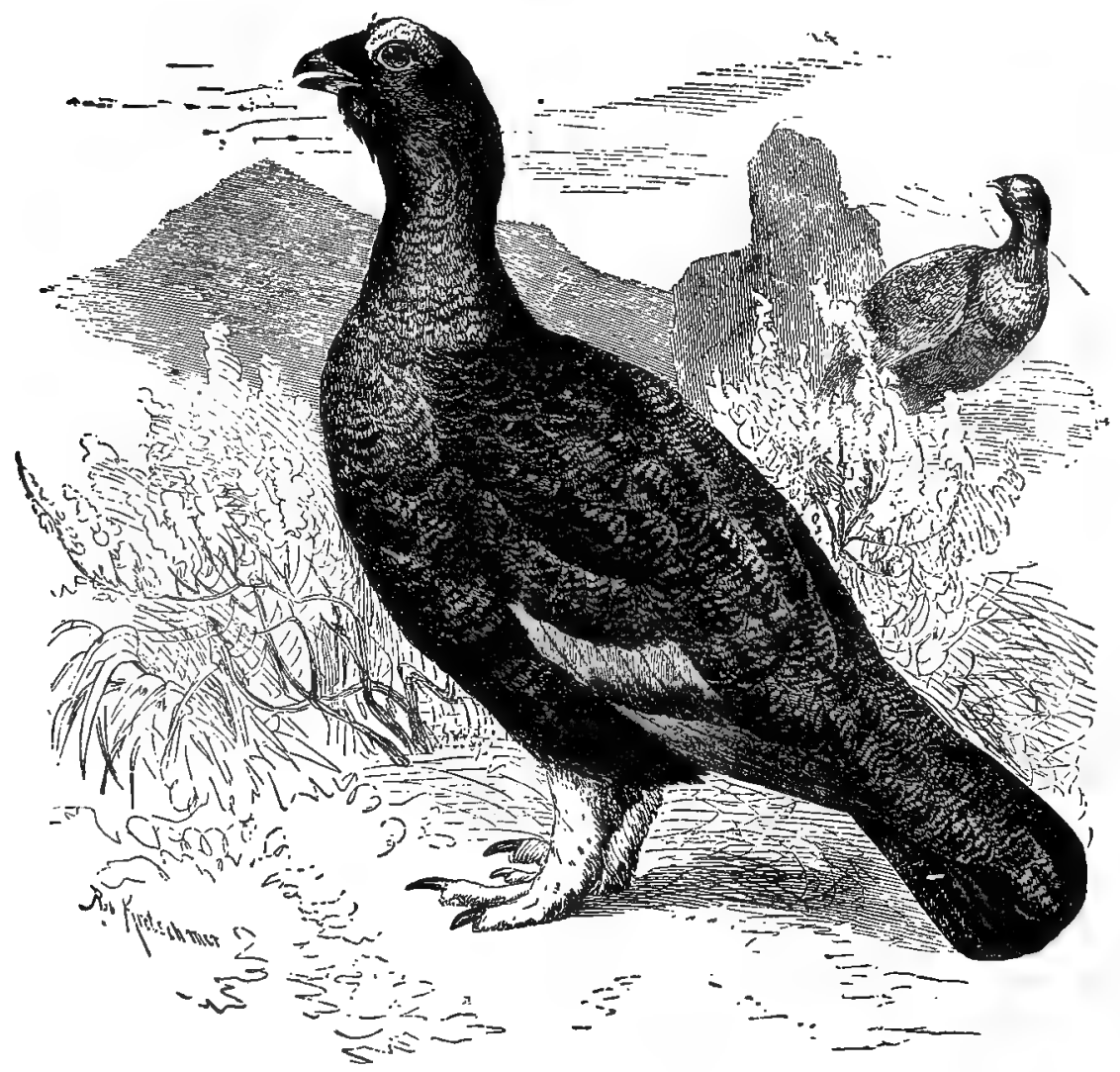

301. Wrllow Ptarmigan, summer plumage (From Brehm).

301a. ALLEN'S PTARuIGAN. Lagopus lapopus alleni Stejn. Geog. Dist.Newfoundlard.

According to Dr. Stejneger this newly described subspecies is similar to $L$. lagopus, but distinguishable by having the shafts of both primaries and secondaries Hack, the wing feathers and even some of the coverets marked and mottled with the 
same color. It is an abundant resident in Newfoundland. It frequents beds of alder and dwarf birch in swampy places, especially the borders of lakes and rivers. On the drier portions of these places its nest is found. The breeding range of this wellmarkcd race seems to be confined to Newfoundland where it is resident. I have no description concerning its eggs, which are undoubtedly indistinguishable from those of the Willow Ptarmigan.

302. ROCK PTARMIGAN. La'opus rupestris (Gmel.) Geog. Dist.-Arctic America in general, except northern extremity of Peninsula of Labrador and region thence northward, Greenland and Aleutian Islands; southeastward to Gulf of St. Lawrence, Island of Anticosti.

The Rock Ptarmigan is somewhat smaller than the foregoing and the summer and winter dress is similar. The general mode of living is said to be the same, but it does not retire very far into wooded districts in winter, frequenting the more open woodland on the border of lakes, especially on the skirts of the Barren Lands. Mr. MacFarlane founa this species breeding in the vicinity of Fort Anderson, incubating in June, and young birds of goodly size were observed June 30 . The rests were placed on the ground and were of the same composition as those of $L$. lagopus. The eggs with certainty cannot be distinguished from those of the Willow Ptarmigan, but are described as usually less heavily spotted or less densely marked-averaging lighter in color and less in size, 1.70x1.18.

302a. REINHARDT'S PTARMIGAN. Lagopus rupestris reinhardi (Brehm.) Geog. Dist.-Greenland and western shores of Cumberland Gulf, and northern extremity of Labrador.

The general appearance, summer dress, etc., of the Greenland Ptarmigan is similar to that of the foregoing. It is found in Greenland and the islands on the western side of Cumberland Gulf and Northern Labrador. The eggs are indistinguishable from those of $L$. rupestris, averaging $1.65 \times 1.17$.

302b. NELSON'S PTARMIGAN. Lagopus rupestris nelsoni Stejn. Geog. Dist.-Unalaska and some ajacent Aleutian Islands.

The first specimens of this new race were taken by Mr. Nelson, at Unalaska, one of the Aleutian Islands. He reports it as common at that place, frequenting the mountain tops and slopes, and breeding in June. Turner says: 'On some of the islands it is extremely abundant, among those may be mentoned Unalaska, Akutan and Akun. It is resident wherever found. At Unalaska they seem to prefer the high, rocky ledges, but everywhere come down to the low narrow valleys to roost and rear their young." The nest is composed of a few stalks of grass and feathers that may call from the mother's breast and is described altogether as being a very careless affair. The site for the nest is chosen usually amidst the tall open tundra among the moss and scanty grass. The number of eggs varies from nine to seventeen, eleven being the usual number. There appears, at the present writing, that there are no eggs of this subspecies in the extensive oölogical collections of this country, but it is safe to infer that there is little or no difference between the eggs of this bird and those of the Rock Ptarmigan. 
302c. TURNER'S PTARMIGAN. Lagopus rupestris atkhensis (Turner.) Geog.

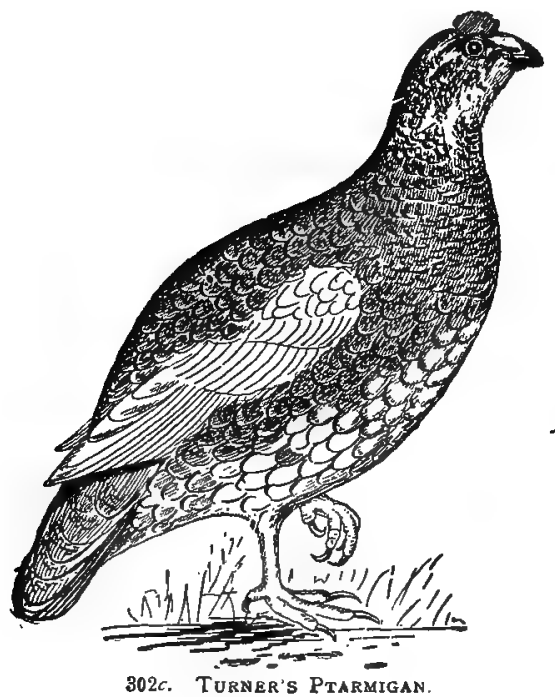

Dist.-Atka, one of the Aleutian Islands.

This proves to be another well-marked geographical race of L. rupestris. Turner secured specimens May 29 and June 7, upon Atka Island, the extreme western end of the Aleutian chain. According to Turner they were abundant at this place and also on Amchitka and Attu Islands. The nest is built amongst the rank grasses at the bases of the hills and the lowlands near the beach. It is carelessly arranged on the ground with a few dried grass stalks and other trash that may be near. The eggs vary from eleven to seventeen and are darker in color than those of $L$. rupestris, and slightly smaller than those of L. lagopus. A number of eggs of this bird were secured, but were broken in transportation. So far as I am aware nothing farther is known concerning this bird's eggs.

302d. TOWNSEND'S PTARMIGAN. Layopus rupestris townsendi Elliott. Geog. Dist.-Kyska and Adak Islands, Aleutian Chain.

I can find nothing regarding the nidification of this subspecies which, very likely, is identical with that of L. rupestris.

302. 1. EVERMANN'S PTARMIGAN. Lagopus evermanni Elliot. Geog. Dist.-Attu, one of the Aleutian Islands, Alaska.

Dedicated to Prof. Barton W. Evermann, the distinguished naturalist of the United States Fish Commission. (Cf. Elliott, Auk, XIII, p. 25.)

303. WELCH'S PTARMIGAN. Latopus welchi Brewst. Geog. Dist.-Newfoundland.

A new species, described by the ornithologist, William Brewster, who named it in honor of Mr. George O. Welch. It is an inhabitant of Newfoundland. Mr. Brewster says: (Auk, II, p. 194.) "The colors in the male of this Ptarmigan are confused and blended to such a degree that a detailed description, however carefully drawn, fails to do them justice." According to Mr. Welch these Ptarmigan are numerous in Newfoundland, where they are strictly confined to the bleak interior. Unlike the Willow Ptarmigan of that island, which in winter wander long distances, and frequently cross the Gulf of Labrador, the Rock Ptarmigan are very local, and for the most part spend their lives on or near the hills where they were reared. The nest and eggs of this species have not yet, as far as I am aware, been described, but more than likely they are similar to L. rupestris.

304. WHITE-TAIIED PTARIIGAN. Lagopus leucurus Swains. Geog. Dist.-Alpine summits of the Rocky Mountains, south to New Mexico, north into British Provinces; west to the higher ranges of Oregon, Washington Territory, and British Columbia. 
The Rocky Mountain Snow Grouse inhabits the Alpine regions of Western North America from British America south to New Mexico. In summer it is found on the mountain ranges from the timber line to the highest peaks; at this season, the upper parts of the plumage of this species are minutely marked with black, white, grayish-brown and tawny, with the tail wing and lower parts white. In winter the plumage is entirely white. Mr. Dille informs me that it breeds commonly in Lamar county, Colorado, making the nest in some cavity among rocks above high timber line. The nest is scantily made of a few grasses. The eggs are from eight to fifteen in number, generally eight or nine, creamy-ground color, marked very finely over the entire surface with umber-brown. The surface is often almost entirely hidden by the heavy markings. Average size 1.68x1.15. Mr. Dille states that the eggs are deposited early in June.

305. PRAIRIE HEN. Tympanuchus americanus (Reich.) Geog. Dist.-Prairies of the Mississippi Valley, south to Louisiana and Texas, west to Middle Kansas, Nebraska and North Dakota; north to Wisconsin, east to Indiana, Ohio and Kentucky.

The Prairie Hen or Pinnated Grouse is a well known game bird, once dispersed throughout the United States; at present it is found especially common in Indiana, Illinois, Iowa, Missouri, Arkansas, Texas and Louisiana, Middle and Eastern Kansas and Nebraska. It is a rare resident in Northwestern Ohio, and probably breeds. In Kansas the birds begin laying the last of April. The nest is placed on the ground in the thick prairie grass, and at the foot of bushes on the barren ground; a hollow is scratched in the soil and sparingly lined with grasses and a few feathers. The eggs are usually eight to twelve in number, but frequently more are laid. Mr. L. Jones states that in Iowa high or low lands are resorted to for breeding grounds, and little or no attempt is made at concealing the nest. The eggs are deposited by May 1st. In Nebraska the eggs are laid in the latter part of April. These are light drab or dull buffy, sometimes with an olive hue, and occasionally sprinkled with brown; their form is rather oval; average size $1.68 \times 1.25$.

305a. ATWATER'S PRAIRIE \#EN. Tympanuchus americanus attwateri (Bendire.) Geog. Dist.-Coast region of Louisiana and Texas.

This geographical race of the prairie chicken was first described by the late Major Charles E. Bendire in "Forest and Stream" (Vol. XI, No. 20, May 18, 1893).

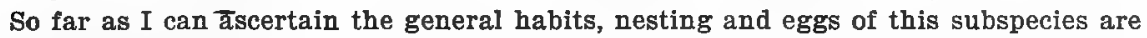
indistinguishable from those of the common Prairie Hen of the prairies of the Mississippi Valley.

306. HEATH HEN. Tympanuchus cupido (Linn.) Geog. Dist.-Island of Martha's Vineyard, Mass.

The light colored Prairie Hen of the Western prairies formerly had a smaller, darker, and redder eastern representative, which was originally distributed throughout Long Island, New Jersey, Eastern Pennsylvania and Virginia. Perhaps the last of this race still linger at Martha's Vineyard, Mass., and a wide range of territory now separates it from its Western cousins. Mr. Brewster states that it is common on Martha's Vineyard, where it is confined to the woods, haunting oak scrub by preference, feeding largely on acorns. Being strictly protected by law, there is, according to the best evidence at hand, no present danger of the colony being ex- 


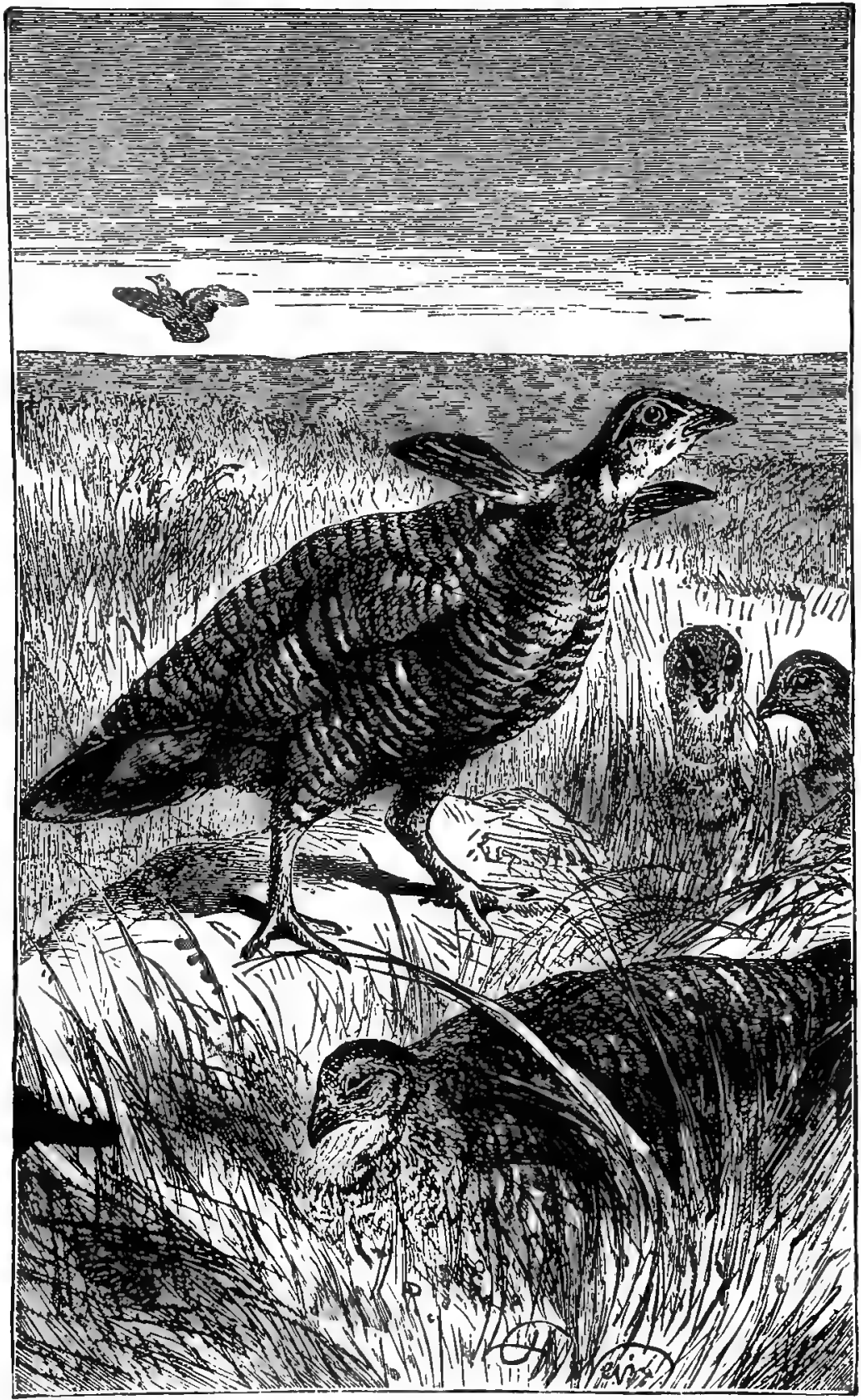


terminated.* The eggs are described by $\mathbf{M r}$. Capen from a manuscript by $\mathrm{Mr}$. Maynard: "They are regularly oval in form, all the specimens being quite uniform in this respect. The color is a yellowish-green of a peculiar shade, quite different from the more decided greenish-brown seen in the Western species, from which the eggs now at hand also differ in being unspotted. There is little variation in the dimensions of all six, the average measurements being 1.72 by 1.27 inches." Mr. Capen, in his beautiful work, also figures an egg from this set. $\dagger$ This set of six in Mr. Brewster's collection is the only one known of the Heath Hen so far as I am aware.

307. LESSER PRAIRIE HEN. Tympanuchus pallidicinctus Ridgw. Geog. Dist.-Eastern edge of Great Plains from Western and probably Southern Texas, northward through Indian Territory to Kansas.

The late Maj. Bendire says in his great work that the breeding range of the Lesser Prairie Hen, a smaller, paler-colored species than $T$. americanus, is not as well known as could be desired, and as far as our present knowledge goes includes Southwestern Kansas and western parts of Indian Territory. Its general habits, its nesting and eggs are similar to those of the common Prairíe Hen, except that the eggs are of a somewhat lighter color. The number laid is the same and, like the bird, average a trifle smaller.

308. SHARP-TAILED GROUSE. Pediocrtes phasianellus (Linn.) Geog. Dist.-Interior of British America, from Lake Superior and Hudson Bay to Fort Simpson.

The Sharp-tailed Grouse, in its various forms, inhabits the western and northwestern plains of the United States and the northern portions of North America, frequenting the grassy prairies and the wooded districts. It is commonly called Pintail Grouse. The present species is said to be especially abundant in the territory between Great Bear Lake, Fort Simpson, and the country bordering Great Slave Lake. It is found in the open glades or low thickets on the borders of streams and large bodies of water, this being the case where the forests are partially cleared. At all seasons it is found in small flocks, in the winter perching on trees, but keeping to the ground in the summer. In winter it often hides in the deep snow, and works its way under the surface with ease, feeding as it progresses on the buds of the willows, larches, aspens, etc. Its food in the summer and autumn is principally berries. The eggs are deposited in the first part of June in a nest on the ground, made of coarse grasses and lined with feathers. The eggs are of a dark, tawny, minutely dotted or speckled with darker spots of brown. The number laid ranges from six to fourteen, usually twelve. The average size is $1.75 \times 1.25$.

308a. COLUMBIAN SHARP-TAILED GROUSE. Pediocates phasianellus coInmbianus (Ord.) Geog. Dist.-Plains of the Northwestern United States and British Columbia to central portions of Alaska; northward chiefly west of the main Rocky Mountains; eastward in Montana and Northeastern California.

Dr. Coues says: The Pin-tailed Chicken inhabits the western portions of Minnesota, a small part of Iowa, all of Dakota, thence díagonally across Nebraska and Kansas to Colorado in the Laramine and Upper Platte regions; from thence westward in suitable localities to the Sierra Nevada and Cascade ranges; northern limit

* See William Brewster's article on The Heath Hen in Massachusetts: Auk, II, 80-84. † Oology of New England: Page 82, Plate XXIV, Fig. 4. 
to be conventionally established along the northern border of the United States, beyond which it shades into true platsianellus. In fine, this is the prairie chicken of the whole Northwest; usually occuring where C. cupido does not, the two overlap to some extent.* In some portions of Manitoba it is said to be very abundant, living exclusively on the open prairie in summer, and exclusively in the wooded istricts in winter. The nest is placed on the ground, composed of a few dry grasses arranged in a circular form. The bird is esteemed as highly for the table as the Prairie Hen. The eggs are light clay to a dark rusty-brown, uniformly speckled with fine dottings of darker brown; from six to twelve in number; average size 1.70x1.25.

308b. PRAIRIE SHARP-TAILED GROUSE. Pediocates phasianellus campestris Ridgw. Geog. Dist.-Plains and prairies of the United States east of the Rocky Mountains, south to eastern New Mexico.

Another variety of the Sharp-tailed Grouse, inhabiting the great plains of the United States east to Wisconsin and Northern Illinois, west to Eastern Colorado and south to Eastern New Mexico. The ground color of the plumage in this bird is more rusty, or ochraceous, than in $P$. p. columbianus, that of the latter species being buffy-grayish or pale grayish-clay color above, with little or no rusty tinge.

Ridgway gives the average measurements of the eggs as $1.66 \times 1.23$.

309. SAGE GROUSE. Centrocercus urophasianus (Bonap.) Geog. Dist.-Sagebush plains of the Rocky Mountain plateau, north into British America, south to New Mexico, Nerada, Eastern California and Washington Territory.

The Sage Cock, Sage Grouse, Sage Hen, or Cock of the Plains, as it is variously called in the West, is principally found in what are known as the sage-bush regions of Montana, Wyoming, Colorado, Utah, Nevada, Oregon, Idaho, Arizona, Eastern California and other Western States and Territories, where the march of civilization has not exterminated their favorite food, the leaves of the wild sage-bush, which cover large tracts of Western country. This is the natural home of the bird. It is the largest of American grouse. The color of the bird is so nearly like that of the ground and sage-bush that it is difficult to detect its presence. In summer their food is sage leaves, berries and insects, but their sole food in winter seems to be sage leaves. The male is a little larger than the female; their weight is about ten pounds, and that of the female seven, live weight. They roam everywhere in winter in lairge flocks, the snow quenching their thirst instead of the water of the streams which supply them in the summer, and along which they scatter in small bands at this season. The males flock together during the season of incubation; the females always remaining by themselves to rear their young. Mr. G. G. Mead states that the eggs in Wyoming are deposited about the 15th of May. W. S. Rougis reports them in the same Territory as being laid as early as the latter part of April or in May, and that the nests are mere hollows scratched in the ground under sage-bushes. $\mathrm{Mr}$. Rougis found the nest complement to vary from ten to fourteen eggs, and varying in shape from oval to that of the usual shape of hen's eggs, and some specimens taper to a smaller point at the smaller end than do those of the domestic fowl. They are of a light greenish-drab or pale olive-buff or a drab shaded with buff, thickly freckled with small rounded spots of reddish-brown and dark chestnut, occasionally with large' blotches and spots. The average size of one hundred and nine specimens in the National Museum is $2.17 \times 1.50$. - Mr. Rougis gives the measurements of six specimens as follows: $1.75 \times 1.33,1.63 \times 1.17,1.69 \times 1.18,1.63 \times 1.17,2.25 \times 1.51,2.23 \times$

- Key to North American Birds, Dp. 582-583. 
1.48.* According to Major Bendire's observations he considers the number of eggs laid by this species as usually varying from seven to nine, and he considers elght a fair average number.

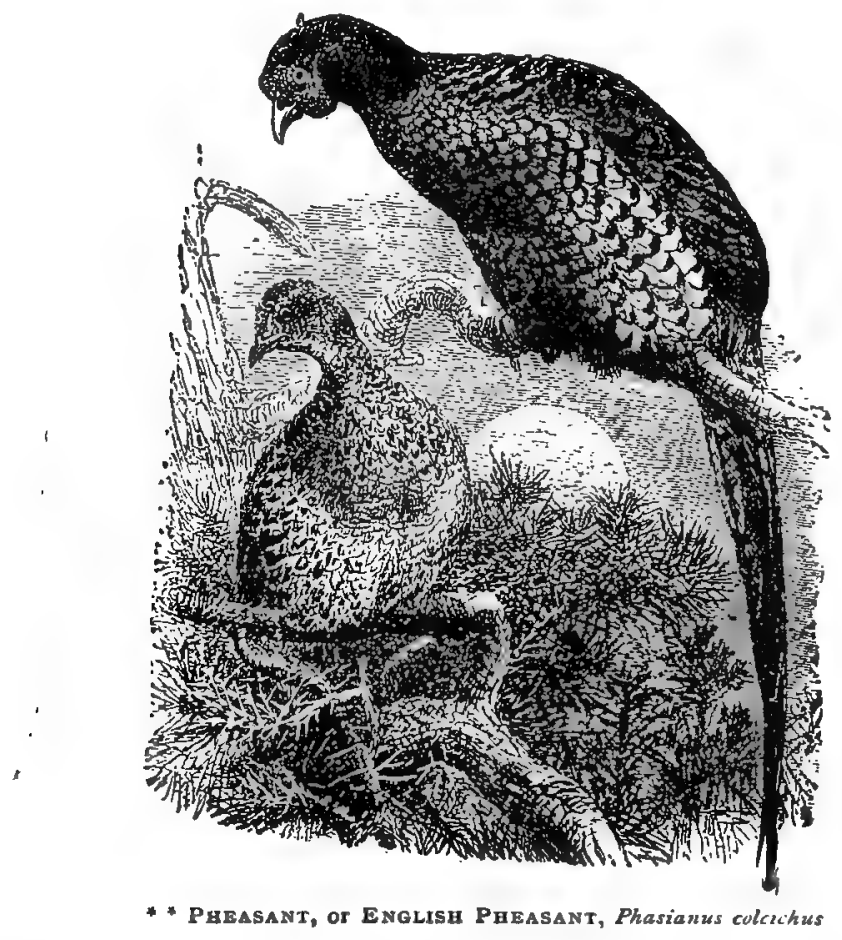

* PHeasant. Phasinnus col(hir.us Linn. Geog. Dist.-Europe in general; introduced into and naturalized in (?) Eastern United States.

This species resembles very much the Ring-necked Pheasant. The male has no white ring about the neck, which is one of the chief differences. It is generally called English Pheasant, for it is very common in England and throughout Europe in general, except the colder portions. It was introduced into Europe from Western Asia. Its general habits are similar to those of the Ring-necked Pheasant, and with regard to the nesting and eggs they are substantially the same. Mr. Adams in his "Nests and Eggs of Familiar Birds" states that in England the eggs are laid in April or May and the number of eggs deposited varies from six to fourteen; but as many as twenty have been found in a nest. A set of seventeen eggs collected May 12, 1893, in Herefordshire, England, in size has an average measurement of $1.80 \times 1.40$.

* RING-NECKED PHEAsanT. Phasianus torquatus Gmel. Geog. Dist. China Introduced into the United States. Common in Oregon; southward into California; eastward into Idaho. Introduced in other sections.

- Young Oologist, Vol. I, v1). T6-77. 
This is certainly a welcome foreigner to our shores. As an introduced species this pheasant of magnificent plumage is now common in various localities of the United States, especially in Oregon and southward into California. It is common in portions of Idaho, where it has been found breeding in numbers. The whole plumage of the male of this species is of such gorgeous, changeable hues as not to permit a full description here. The female is much smaller than the male and of a uniform pale yellow, with light shades and spots of brown, black and gray. It is known by two other names: Chinese and Mongolian Pheasant The male measures from 34 to 40 inches; the tail being from 15 to 24 inches. It is a very hardy bird and from the evidence $I$ have at hand it will propogate in any temperate latitude. A number of pairs of this splendid bird have been liberated in several localities in Ohio, and are protected by law until they become established sufficiently to make their ultimate extermination by the gun impossible. As a table bird its flesh is among the finest and for beauty of plumage it has few equals. Both of these qualities will be great agents in its protection fiom total extermination. Dr. A. G. Prill, of Sodaville, Oregon, writes me that the legislature of Oregon in the winter of 1894-95 passed an act changing the name of this pheasant, calling it Denny's Pheasant in honor of Judge O. N. Denny, of Portland, Oregon, who, about twelve years ago imported six pairs, which were liberated and protected by law, and they have since multiplied to the extent as above stated. The males crow and fight similar to the domestic cock. Dr. Prill states that the nest is made upon the ground in open fields; it is made of leaves and dry grass, built in a tussock of grass or perhaps under some small bush. Three broods are generally raised in a season and from seven to fifteen eggs are laid, and the first complement of eggs is deposited by April 15, or by May 1st. A set of thirteen of this bird's eggs are in my collection, collected by Dr. Prill near Sodaville, Oregon, April 8, 1895; they are a buff color with a cast of bluish over the surface; three of the specimens, however, are of a yellowish buff throughout. Their average size is $1.61 \times 1.31$. Dr. Prill says that the birds nest and breed in captivity and do well. In order to show the value of this excellent bird I quote the following from a letter to the editor of the "Oregon Naturalist." It is from Mr. F. S. Matteson, of Turner, Oregon. He says: "Noting your article, "The Denny Pheasant,' please allow me to say: The food which he dearly loves is grasshoppers, cutworms, crickets, etc., and the chicks especially are very fond of aphids, flea beetles, etc. Turn a domestic hen with a brood of pheasant chicks into your cabbage lot and you will have no cabbage aphid, or flea-Leetle. We have tried it. We used to think they would prove a nuisance, when they first became numerous, but our further acquaintance has changed our views. They pay for all they eat, and more. It may be that they will crowd out some native birds, but if these latter are supplanted by a better, why should we mourn? They are fully as useful insect destroyers as our quail, or native pheasants, and they are hardier, and better calculated to take care of themselves from skunks, hawks, crows, trappers, pot-hunters, etc. Our hens, in confinement, laid over 100 eggs each last summer, and we now have a pheasant hen sitting. We have now the third generation from the wild state, and the birds are notably gentler to us. When strangers come around they appear wild. You say 'this bird will hybridize with the domestic hen.' Please permit me to doubt! Our experience does not point that way yet. But he is the game bird par excellence, and we are that much ahead of our eastern brothers. He is a beauty, a fighter; and is useful as well as ornamental.

310. WILD TURKEY. Meleagris gallopavo Linn. Geog. Dist.-Eastern United States, north to Southern Canada, south to Florida and Eastern Texas, west to the Great Plains. 


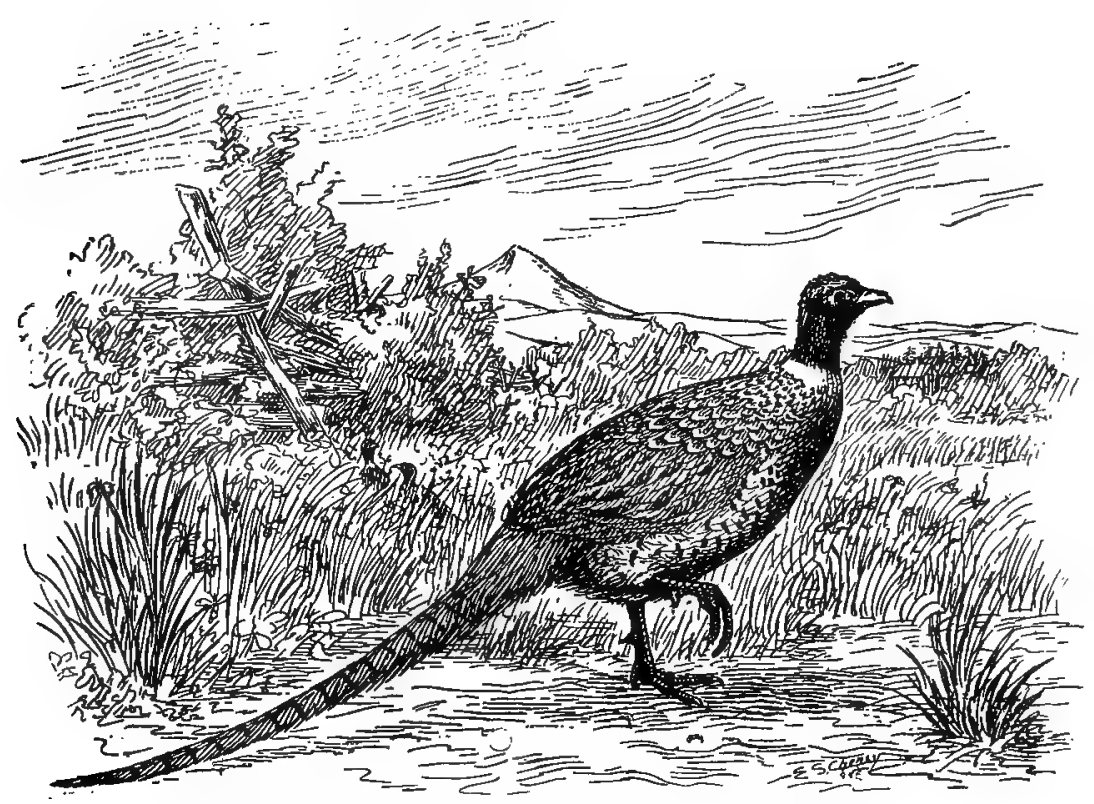

* * Ring-neckid Pheasayt, Phasianustorquatus, (Cheney del.)

This is the bird which so very much resembles the domestic turkey, but is more brilliant in color. It is a constant resident in suitable localities throughout Eastern United States. It occurs as far north as Canada; is probably extinct in New England, and is found as far northwest as the Missouri river, and southwest as Texas. But this grand bird is rapidly becoming exterminated, not only as it is in New England, but in other sections of the country. In Ohio it was formerly an abundant resident, breeding throughout the State; now quite unknown in the more thickly settled portions, but still common in some of the northwestern counties. Dr. Kirtland (1850) mentions the time when Wild Turkeys were more common than tame ones are now. Mr. Thomas McIlwraith, in his admirable work on the Birds of Ontario, says that within the recollection of people still living, Wild Turkeys were comparatively common along the southwestern border of Ontario, and that the day is not far distant when this bird will be sought for in vain in the provinces.* Mr. Edwin C. Davis reports the Wild Turkey to be very common in the vicinity of Gainesville, Texas, hundreds being brought to market and sold during the winter months. The nests of this bird, he says, are very difficult to discover, as they are made on the ground, midst tall, thick weeds or tangled briers. The female will not leave the nest until almost trodden upon. Mr. Davis states that when the eggs are once touched the female will abandon her nest. The eggs are rich, dark cream color, thickly sprinkled with rounded spots of rusty-brown or umber. The number laid varies from nine to eighteen, commonly nine to twelve. Some writers say ten to twenty and twenty-four, but I have never seen this number in a set. Four typical

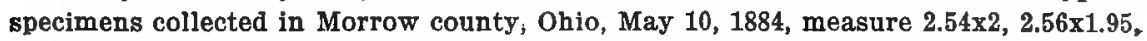
$2.56 \times 1.97,2.69 \times 1.94$. The average size of a large series, $2.55 \times 1.80$.

- The Birds of Ontario, Do. 130-131. 


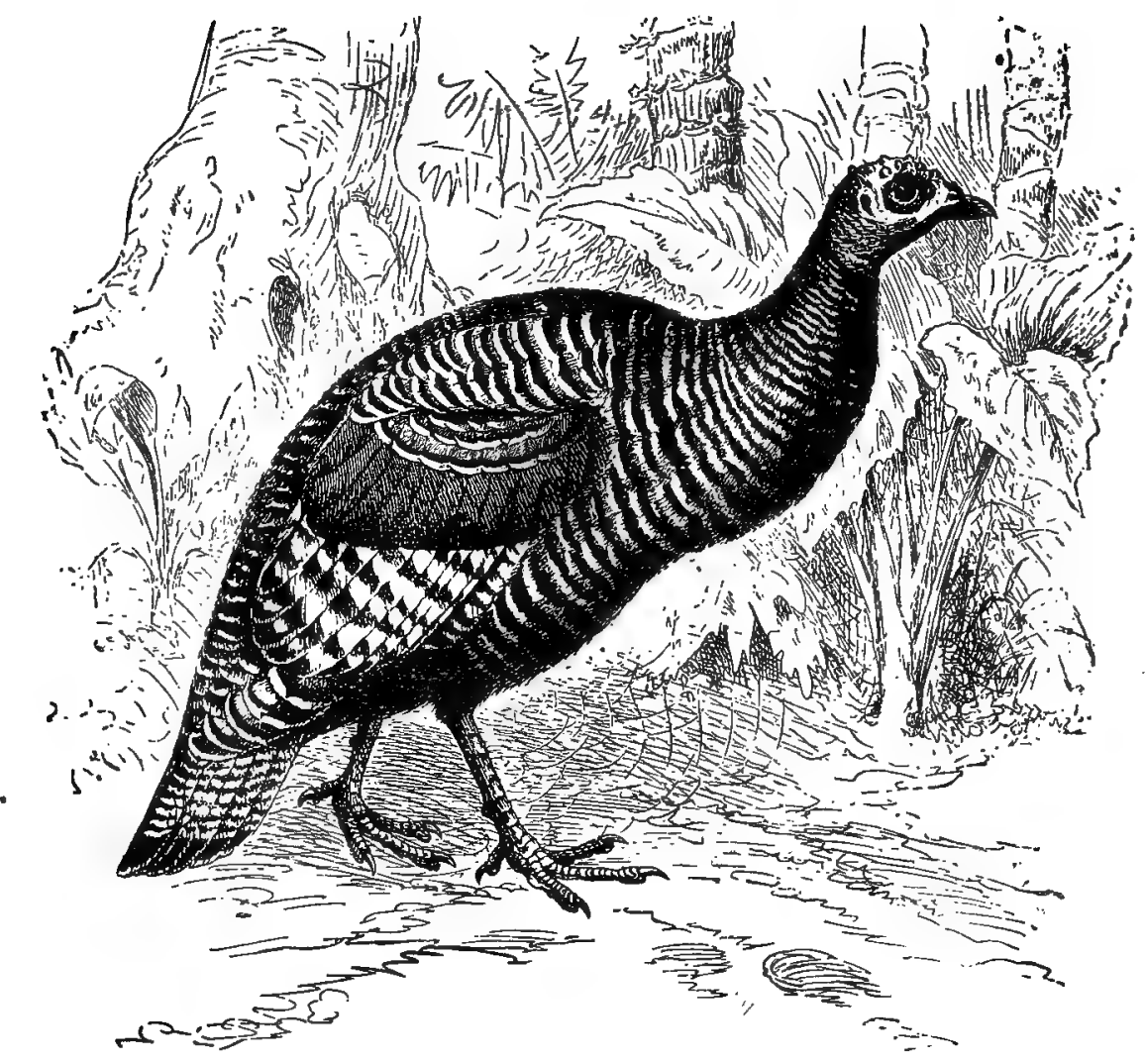

* * Wird Turkey of Central America, Meleagris ocellata (From Brehm).

310a. MEXICAN TURREY. Meleagris gallopavo mexicana (Gould.) Geog. Dist.-Table-land of Mexico, north to the southern border of the United States; Western Texas to Arizona.

This Turkey is found in Western Texas, New Mexico, Arizona and southward; in suitable localities it is abundant. In various mountain ranges throughout $\mathrm{New}$ Mexico it is very common. On the approach of winter they leave their summer haunts and travel down the foot hills and the mesas, where they remain until the snow disappears, when, like the deer, they return. Mr. Scott states that in the pine woods of the Catalina mountains of Arizona this Turkey was very common late in November, 1885, though snow covered the ground. The bird, however, from what he could learn, has already decreased in number in most localities, and to have become exterminated in others where it was formerly abundant.* Mr. George B. Sennett found this Turkey common on the Lower Rio Grande of Texas, nesting in the dense woods. The first set of eggs, twelve in number, were taken April 24, contained young chicks peeping in the shell. A set of fifteen obtained April 26 were

* Auk, Vol. III, p. 389. 
fresh.* The nesting habits are the same as the common wild turkey. The eggs are described as resembling those of the domestic turkey in ground color and markings; dark buff or creamy-white, more or less thickly sprinkled with spots of light and dark umber-brown; they measure $2.40 \times 1.80$. The average size of twenty-eight eggs, as given by Mr. Sennett, is $2.43 \times 1.86$; the largest, $2.50 \times 1.90$; the smallest 2.33 $\mathbf{x} 1.72$.

310b. FLORIDA WILD TURKEY. Meleagris gallopavo osceola Scott. Geog. Dist.-Southern Florida.

This is a new race of the Wild Turkey described by W. E. D. Scott in "The Auk" for October, 1890. I have sets of what I presume to be this bird's eggs and have at present considerable correspondence concerning its habits, and in all respects they do not differ from those which are characteristic of the Wild Turkey of the North.

310c. RIO GRANDE TURKEY. Meleagris gallopavo ellinti Sennett. Geog. Dist.-Lowlands of Southern Texas and Northern Mexico.

The general habits, nesting and eggs of this geographical race are the same as those of the preceding subspecies. This bird was first described by George B. Sennett in "The Auk" for April, 1892, page 167.

311. CHACHALACA. Ortalis vetula maccalli Baird. Geog. Dist.-Valley of the Rio Grande, southward into Mexico.

The Texas Guan, or Chachalaca, is a remarkable bird, inhabiting the warm tropical regions of America. It measures from twenty-two to twenty-four inches in length, of which the tail measures from nine to eleven. Dr. Merrill states that this is one of the most characteristic birds of the Lower Rio Grande region. "Rarely seen at any distance from woods or dense chaparral, they are abundant in those places, and their hoarse cries are the first thing heard by the traveler on awaking in the morning. During the day, unless rainy or cloudy, the birds are rarely seen or heard; but shortly before sunrise and sunset, they mount the topmost branch of a dead tree and make the woods ring with their discordant notes. Contrary to almost every description of their cry I have seen, it consists of three syllables, though occasionally a fourth is adced. When one bird begins to cry, the nearest bird joins in at a second note, and in this way the fourth syllable is made; but they keep such good time that it is often very difficult to satisfy one's self that this is the fact." $†$ The Mexican name, Chachalac, meaning a noisy person or kird, is derived from the discordant cries of this species. The quality of these notes may be imitated by putting the most stress upon the last two syllables. The compass and harshness of the cries are said to be almost equal to that of the guinea fowl. The birds are said to be easily tamed, and to cross with the domestic fowl. Dr. Merrill remarks that they are much hunted for the Brownswille market, but the flesh is not particularly good, and when domesticated the birds become troublesomely familiar, and are decided nuisances when kept about the house. Mr. Sennett states that this bird does not breed in communities, but in isolated pairs, and from all accounts, raises but one brood in a season, unless the nest is despoiled, when the female will lay another clutch, which almost invariably consists of three, rarely less. Mr. Norris has a set

* Further notes on the Ornithology of the Lower Rio Grande of Texas, from observations made during the spring of 1878 . By George B. Sennett. Edited, with annotations, by Dr. Elliott Coues, U. S. A.; pp. 247-248. Extracted from the Bulletin of the Geographicat Survey, Vol. V, No. 3; Washington, November 30, 1879. Author's edition.

$\dagger$ Notes on the Ornithology of Southern Texas 
of four eggs, and reports that Mr. Thos. H. Jackson has received several sets of the same number from southern Texas. Mr. Sennett obtained fresh eggs on the Rio Frande, April 10th, and on the 20th sets were generally full and fresh, after which time they contained embryos. The nests are shallow structures, often made entirely of Spanish moss, and are placed on horizontal limbs, a few feet from the ground. The eggs are of a buffy-white, thick-shelled and roughly granulated; they are large for the bird; sizes range from 2.18 to 2.35 long by 1.55 to 1.60 broad.

312. BAND-TAILED PIGEON. Columba fasciata Say. Geog. Dist.-Western United States, from the Rocky Mountains to the Pacific coast, from Washington Territory and New Mexico south, through Mexico to the highlands of Guatemala.

The Band-tailed, or White-collared Pigeon, is found from the Rocky Mountains westward to the Pacific. It is common, but irregular in distribution. In Washington county, Oregon, Mr. Anthony records this Pigeon as a common summer resident, and that south of Beaverton is a large spring, whose waters contain some mineral which has a great attraction for these birds, and here they are always to be found in large numbers. Mr. Scott states that this species is common in the Santa Catalina mountains in Arizona, breeding in July. He met with it commonly in May and June, as low down as 3,500 feet, feeding on wild mulberries. It was not uncommon in the pine region about the middle of April.* This is an attractive bird. about the size and possessing many habits of the domestic pigeon. It sometimes congregates together in flocks, even while breeding, and nests in trees and bushes along the banks of streams, or in the thick forests near water. The nest is a mere platform of sticks, and the eggs are also placed on the ground without any nest, which is sometimes the case with the Mourning Dove ( $Z$. macroura). The eggs are one or two in number, equal-ended, glistening-white, with an average size of 1.50x1.20. The average size of thirteen eggs in the U. S. National Museum, as given

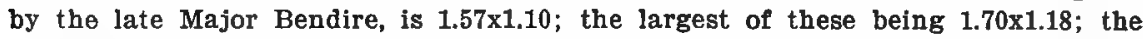
smallest $1.50 \times 1.06$ inches.

312a. VIOsCA'S PIGEON. Columba fasciata viosca Brewst. Geog. Dist.Lower California.

Mr. William Brewster first described this new subspecies from a large series of specimens taken by Mr. Frazar at La Laguna, Lower California. The bird as described differs from the Band-tailed Pigeon in being a trifle smaller; the tail band is wanting, or only faintly indicated; the ground color lighter and more uniform, etc. $\dagger$ Mr. Frazar, while collecting near Pearco's Ranch in Lower California, secured two nests, each containing a single egg. One egg which the late Maj. Bendire describes was found in a nest composed of a few sticks, placed on a broken upright branch in the center of a giant cactus, about 18 feet from the ground. It is pure white, slightly glossy, elliptical ovate in shape, and not quite as notably pointed at the small end as the eggs of Columba fasciata. It measures $1.50 \mathrm{x}$ 1.04 inches.

313. RED-BILLED PIGEON. Columba favirostris Wagl. Geog. Dlst.-Southern border of the United States from the Rio Grande Valley, Arizona, Mexico and Lower California south to Costa Rica.

This large and handsome Plgeon is common in the valley of the Rio Grande and southward. In some localities on the Rio Grande in Texas it is abundant during

* Auk, Vol. III, p. 421.

†f. Brewster, Auk, V, 86. 
the summer months. Dr. Merrill found it not uncommon about Fort Brown, but more plentiful higher up the river. It loves the deep, dense woods, where it can dwell in quiet and retirement. The nests are frail platforms of twigs and grasses, such as are usually built by other pigeons, placed in trees and bushes. Mr. George B. Sennett describes a nest which he found April 9th, near Hidalgo, on the Rio Grande. It was placed in a thicket, about eight feet from the ground, made of twigs, $w$ as frail and saucer shaped and contained a single young, nearly fledged. He states that this bird lays several times in a season. Nests were found containing eggs and young in all stages of development, but in no case did a nest contain more than one egg or young. Mr. Sennett gives the average size, taken from a large series, as $1.55 \times 1.10$, the length varying from 1.60 to 1.45 , and the breadth from 1.18 to $1.10 .^{*}$ The eggs are pearly white.

314. WHITE-CROWNED PIGEON. Columba leucocephala Linn. Geog. Dist.-Greater Antilles, Bahamas and Florida Keys.

The White-crowned Pigeon occurs in summer on the Florida Keys, and it breeds abundantly on some of the smaller islands; it is an abundant resident species in the Bahamas and West Indies. This Pigeon, according to Audubon, arrives on the southern Florida Keys about April 20th, or not until May first. The birds were shy and wary on account of the war waged against them, their flesh being esteemed for its fine flavor. Their shyness only partially abated during the breeding season and they would silently slide from their nest when sitting, and retreat to the dark shades of the mangroves. The nest is built in low trees and bushes, composed of twigs carefully arranged, with little or no lining of grasses. It is, on the whole, a bulky structure for a pigeon, These birds often breed in numbers, nesting in trees, some at high elevations, others in low mangrove bushes, and the nests resemble that of the Passenger Pigeon, but are said to be more compact and better lined. The eggs are two in number, oval in form, and opaque-white with a very smooth surface; the average size is $1.41 \times 1.02$.

315. PASSENGER PIGEON. Ectopistes migratorius (Linn.) Geog. Dist.Eastern North America, from Hudson Bay southward, and west to the Great Plains, straggling thence to Nevada and Washington. Breeding range now mainly restricted to portions of the Canadas and the northern borders of the United States, as far west as Manitoba and the Dakotas.

The Wild Pigeon once wandered in immense numbers in search of food throughout all parts of North America. In early times it was extremely abundant in particular localities. At the present writing (1897) it seems to be on the same parallel with the American Buffalo of the Western plains, almost, or very nearly exterminated. Both were seen in countless housands, and today it is not easy to procure examples of either. The late Maj. Bendire, writing in 1892, says that it looks now that the total extermination of the Wild Pigeon might be accomplished within the present century. The only thing which retards the complete extinction of the Passenger Pigeon is the fact that the birds are so few in numbers that it does not pay to net them. The breeding range of this famous pigeon today is principally in the thinly settled and wooded regions along our northern border, from northern Maine westward to Northern Minnesota; in the Dakotas, as well as in similar localities in the eastern and middle portions of the Dominion of Canada, and northward to Hudson Bay. According to an informant of Mr. Brewster's, the last nesting in

- Further notes on the Ornithology of the Rlo Grande of Texas. 
Michigan of any importance was in 1881. Wlison's and Audubon's graphic accounts of the "congregated millions" which they saw in Ohio, Indiana and Kentucky seem hardly credible to those who have not seen them. The extensive forests which once served as breeding and feeding grounds have been partially or wholly destroyed, and we are no longer favored with the sublime sights of immense, unbroken, and apparently llmitless flocks. Until about 1855 , these Pigeons were extremely abundant in central Ohio, having at that time a roost and breeding place near Kirkersville,

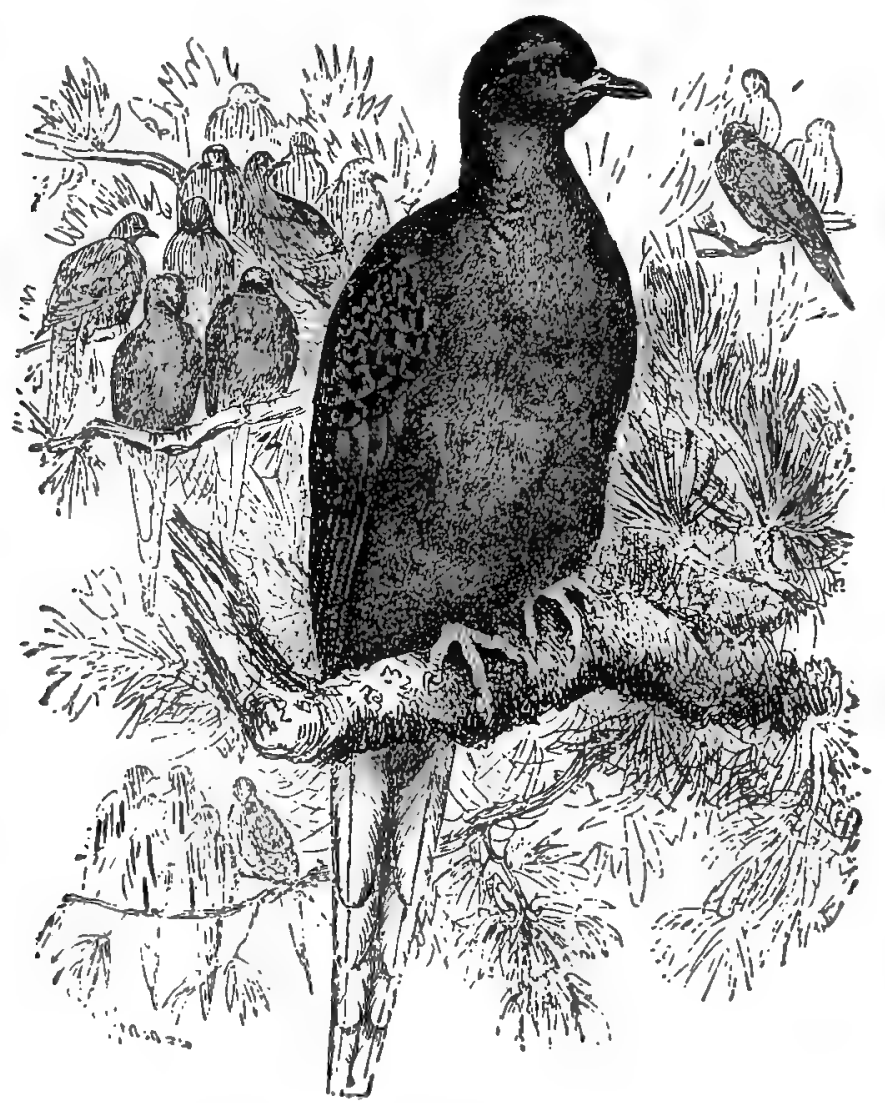

316. Passenger Pigeon (From Brehm).

Licking county, and large numbers were to be seen from sunrise till nine o'clock and after, flying westward from the roost, and in the afternoon about four o'clock till sundown returning. At these hours they were never out of sight, and often dozens of flocks were in sight at once. Dr. Kirtland states that near Circleville, in 1850, one thousand two hundred and eighty-five were caught in a single net in one day, and the average price for the birds in Columbus was fve or six cents per dozen. The Wild Pigeon congregates in vast communities for the purpose of breeding, nesting in trees and bushes, frequently at a considerable height from the ground, and often 
as many as fifty and a bundred nests have been observed in a single tree. The nest is a mere platform of sticks, carelessly thrown together. The eggs are usually one, never more than two in number, pure white, and broadly elliptical in shape; average size, 1.50x1.03. A nest found in Oak Park, Minneapolis, Minnesota, June 21st, 1895, is the latest record of which $I$ am aware. The nest contained one egg and the female bird was taken. The late Maj. Bendire gives the average measurements of twenty specimens in the U. S. National Museum as 1.48x1.04.

316. MOURNING DOVE. Zenaidura macroura (Linn.) Geog. Dist.-Whole of temperate North America from Southern Maine, Canada and Oregon, south to Panama and the West Indies.

The Carolina Dove, also called Turtle Dove, is one of our best known and familiar birds. Its gentle disposition, its sweet but mournful cooing, have made it the typical sad-toned singer in poetry and song. The Turtle Dove is distributed throughout temperate North America; it is to be met with everywhere, both in woodland and in open places. It is particularly fond of feeding in country roadways. During the breeding season they are found in pairs, but at other times are highly

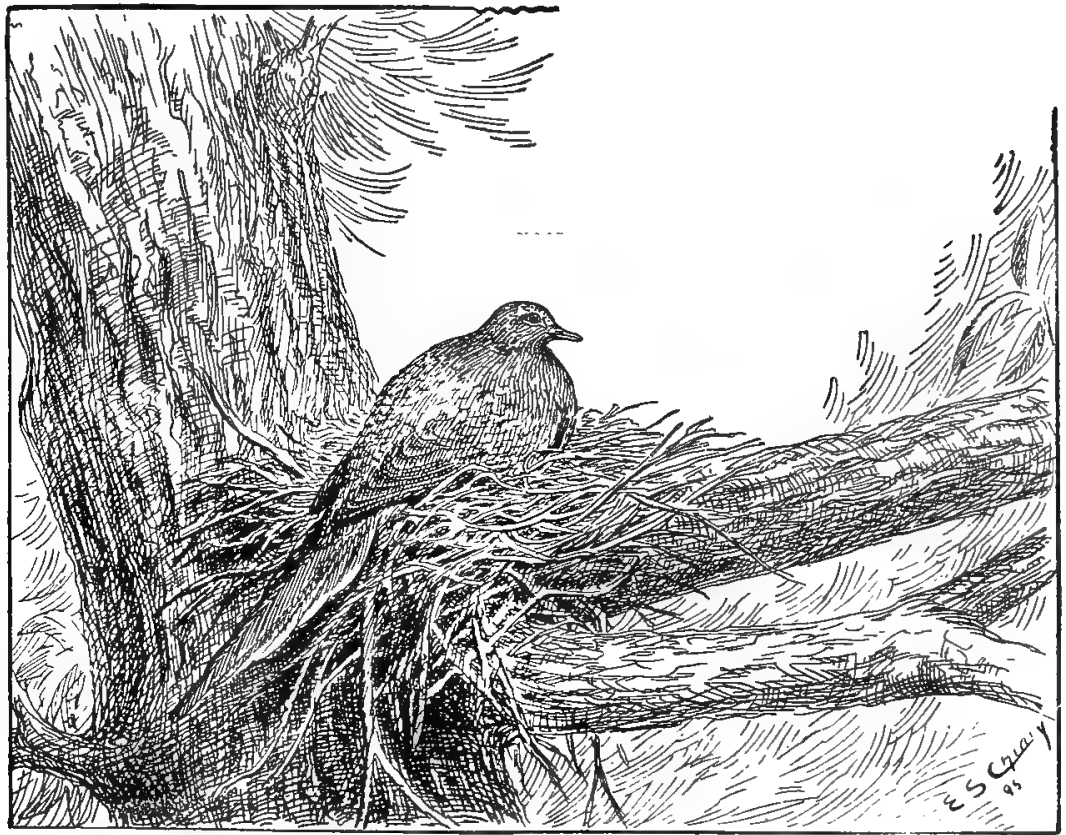

316. Mourning Dove awd Nest. (Cheney del.)

gregarious, though flocks of them never attain the size of those of the Wild Pigeon. The nest is placed on the horizontal branches of trees, on stumps, on the top rail of old snake fences, on rocks, in bushes, and in treeless regions the nest is placed on the ground. It varies in construction with its location. When found in small branches of trees it is made of a few sticks, somewhat after the style of the Cuckoo's nest, but if on a large limb or stump, it is often but a rim of twigs sufficient to retain the 
eggs; when on the ground, a few straws and twigs are used to indicate the nest. The Carolina Dove rears two, sometimes three broods in a season. It begins to nest early. I have taken eggs April 10th; the late Dr. Wheaton found the nest with young as early as the middle of April. Breeding usually continues until September. Dr. Jones states that he had seen Doves sitting on fresh eggs in every month except December and January, and he has no doubt that they occasionally build nests and lay eggs in these months in mild winters.* Two white eggs are laid; there are exceptional cases, however, where more are deposited. Mr. Norris has a set of three; Mr. L. Jones, of Grinnell, Iowa, writes that he has in his collection a set of four. Mr. P. W. Smith, of Greenville, Ill., records several sets of three and four; two sets taken from old robbins' nests. He also found a Brown Thrasher's nest containing one egg of the Thrasher and two of the Dove's. $\dagger$ The eggs are elliptical in shape and average 1.12x.82.

317. ZENAIDA DOVE. Zenaida zenaida (Bonap.) Geog. Dist.-Florida Keys, Bahamas, Cuba, Jamaica, Porto Rico, Santa Cruz, Sombero and coast of Yucatan.

According to Audubon's observations, this species makes its appearance on the islands around Indian Key, Fla., about April 15, increasing in numbers until October, when they all departed for the West Indies, where they are the most numerous. Egg laying is begun about the first of May. In Jamaica this species is known as the Pea Dove and in Santa Cruz as Mountain Dove. Its general habits are similar to those of the Mourning or the Ground Dova, and like the latter species it is more terrestrial in its habits. It nests indiscriminately on the ground, in trees or in low bushes. In trees or bushes the nest is a slight platform of twigs. Audubon states that this species breeds in various keys east of Florida, which are covered with grass and low shrubs, placing the nest between tufts of grass or on the ground with little concealment. It is built of dry leaves and grass imbedded in a hollow scooped in the sand. It is said to be more compact than the nest of any other pigeon. The eggs are one or two in number, white, with a very smooth surface; size, 1.19x.94.

318. WHITE-FRONTED DOVE. Leptotila fulviventris brachyptera (Salviadori. Geog. Dist.-Valley of the Lower Rio Grande in Texas, southward through Mexico to Guatemala.

Mr. George B. Sennett added this Dove as a new species to the fauna of the United States in 1877; the first speclmens being taken in the vicinity of Hidalgo, on the Rio Grande in Texas. Dr. Merrill notes it as not rare in the vicinity of Fort Brown, being shy and not very often seen. Mr. Sennett states that in its general habits this bird is quiet and not easily alarmed; it frequents the high branches of tall trees, associating with the White-winged Dove and is less numerous than the red-billed pigeon. By its peculiar note-a low, short cooing-it is easily distinguished from all other species. A nest was found situated in the forks of bushes, about five feet from the ground, was flat and quite large for a pigeon's nest, and composed of the dead branches, twigs and bark of pithy weeds. Dr. Merrill found a nest on Junc 8, 1878, which was about seven feet from the ground, supported by the dense interlacing tendrils of a hanging vine, growing on the edge of a thicket. This nest contained two eggs which were quite fresh; sizes $1.16 \times .86$ and $1.19 \times 8.8$, re-

* Illustrations of the Nests and Eggs of Blrds of Ohlo, D. 9 .

† Ornithologist and Oologist, XI, p. 28. 
spectively. These are described as a strong olive-buff color. Mr. Seznett describes them as of a light drab, or light olive drab, and gives the measurements of four specimens as follows: $1.14 \mathrm{x} .89,1.12 \mathrm{x} .88,1.16 \mathrm{x} .83,1.15 \mathrm{x} .85$; averaging $1.14 \mathrm{x} .86$.

319. WHITE-WINGED DOVE. Melopelia lewcoptera (Linn.) Geog. Dist.Southern border of the United States (Texas to Arizona) and Lower California, southward to Costa Rica and the West Indies.

Dr. James C. Merrill mentions this as a very common species during the summer months in the vicinity of Fort Brown, Texas. The nests, he states, are, "as a rule, smaller and more frail than those of the Carolina Dove, and the eggs have a decided creamy tinge, which is rarely lost after blowing, at least not for months. Thirtyfour eggs average 1.17x.88; extremes $1.30 \times .95$ and $1.05 \times .80$. The note is a deep sonorous coo, frequently repeated and heard at a great distance." At Lomita Ranch on the Rio Grande, in Texas, Mr. Sennett found this species to be more abundant than all the other pigeons combined, and when they have begun breeding, all day long the air is filled with the music of their cooing, drowning out the notes of most other birds. They are the last of the doves to come in the spring and leave about November. By the first of May eggs were found. Their color, Mr. Sennett describes, as varying from white to cream, the latter prevalling, and two is the number laid. From a large series the size averages $1.14 \times .88$; the largest, $1.22 \times .93$, the smallest, 1.05x.88. Two sets of the eggs of this Dove are in the cabinet of $J$. Parker Norris. One of two sets of eggs taken May 1, 1884, in Neuces county, Texas, measure 1.10x $.82,1.10 \times .81$. The second set collected near Catulla, Texas, May 11, 1887, measure $1.05 \times .78,1.08 \times .79$, respectively.

320. GROUND DOVE. Columbigallina passerina terrestris Chapm. Geog. Dist.-South Atlantic and Gulf States; Texas, New Mexico, Arizona and California, south to the West Indies and the northern portion of South America.

A diminutive Dove, measuring only six or seven inches in length. Abundant in Mexico, Yucatan, Central America and the West Indies. In the South Atlantic and Gulf States it is a common and familiar species, nesting indiscriminately on the ground, on stumps, on vines, bushes and young saplings. The nest is elevated sometimes as high as twenty feet, but usually from two to six feet above the ground, and is simply a frail structure of twigs, often containing pine needles. The breeding season in Georgia begins early in April, and fresh eggs may be found in May, June and sometimes in July. Mr. Perry informs me that in the vicinity of Savannah he has taken fresh eggs as late as July 9th. Mr. Arthur T. Wayne took a set of two eggs near Charleston, S. C., October 19th, 1886; these contained small embryos and the parent bird was incubating.* This date, however, is exceptional. Mr. Walter Hoxie, of Frogmore, S. C., states that this species is called Mourning Dove by the natives, who used to have a superstition that any one who molested their nest would be "mourned to death" by the grief-stricken owners. The eggs are two in number, white or creamy in color; a large series averages $.85 x .65$.

320a. MEXICAN GROUND DOVE. Columbitrallina passerina pallescens (Baird.) Geog. Dist.-Mexico and contiguous territory of United States, from Texas to Lower California; south on both Mexican coasts to Central America.

According to the late Major Bendire in his "Life Histories of North American Birds," the breeding range of the Mexican Ground Dove within our borders is con-

* Ornithologist and Oologist: Vol. X1I, p. 7. 
fined to Southwestern Texas and Southern Arizona, and prowably to Southern New Mexico, although there are as yet no records of its breeciing in the latter Territory, so far as he was aware. A few stragglers breed probably in Southern California, where it has been taken on several occasions. It is quite common in Lower California, where Mr. J. Xantus took its eggs near Cape St. Lucas, and Mr. L. Belding at San Jose del Carbo. Mr. Xantus says: "The small and rather compact nests are placed on the horizontal branch of a stout bush or tree, and are lined with a lew straws. On one occasion I found the eggs in a roughly-made nest on the ground on the edge of a prairie." Dr. James C. Merrill found this subspecies abundant in the vicinity of Fort Brown, Texas, where he secured the eggs. Mr. Herbert Drown says it is common about Tucson, Arizona. From April to June is the nesting season of this Ground Dove. The eggs are two in number, pure white, elliptical oval in shape, a few slightly pointed, and some may be called oval. The average measurement of fifty-four specimens in the National Museum collection is .85x.65; the largest $.91 \times .69$, the smallest $.79 \times .63$.

321. INCA DOVE. Srrerdafella inca (Less.) Geog. Dist.-Southern border of the United States (Texas to Southern Arizona) south to Mexico and Guatemala.

This species is known as the Scaled Dove; nearly all the plumage is marked with black crescentic-edged feathers, producing a scaly appearance. In various places in Southern Arizona, New Mexico, and along the Rio Grande valley in Texas, this species is quite common during the summer months. Throughout Mexico and Yucatan it is very aburdant, and is known as the Long-tailed Ground Dove. It is very tame and familiar, frequenting cultivated gardens about houses, and is said to live more on the ground than the so-called Ground Dove. Its cooing is coarse and tolerably loud. The nest of this species is built in busher, vines and small trees similar to that of Columbigallina passerina; it is a mere platform of twigs. The eggs are invariably two in number, white, oval in shape, both ends being nearly equal; average size, $.82 \times .65$.

\section{[322.] KEY WEST QUAIL-DOVE. Geutrygon martinica (Linn.) Geog.} Dist.--Key West, Florida, Hayti, Cuba, Bahamas.

A constant resident of the Bahamas, Cuba and Hayti. Audubon met with a few of this species on the island of Key West, Florida, but it is said not to have been observed there lately. Within the United States, however, its breeding range is confined to the island of Key West and the extreme Florida Keys. According to Audubon, the movements and general habits of this species are similar to those of the Carolina Dove. The nest is described as formed of light, dry twigs; it is built in the branches of trees or in bushes, occasionally it is placed on the ground. According to Audubon the eggs are two in number, pure white, and about the size of those of the White-crowned Pigeon.

[322. 1.] RUDDY QUAIL-DOVE. Geotrygon montana Linn. Geog. Dist.Tropical America in generål, including West Indies; north to Cuba and Eastern Mexico; accidental at Key West, Florida.

The Ruddy Quail was first given a place in the avifauna of North America by Mr. W. E. Scott from a specimen taken at Key West, Dec. 10, 1888. Maj. Bendire states that it is very doubtful if it breeds within our limits. Two eggs are laid. The average size of seven eggs in the U. S. National Museum collection, all taken in the West Indies, is $1.06 \times$. 83 . They are oval in shape and in color vary from pale green to salmon-buff. Its general habits and nidification resemble those of the Key West Dove. 
[323.] BLUE-HEADED QUAIL-DOVE. Stamœnas cyanocephala (Linn.) Geog. Dist.-Cuba and Florida Keys.

It appears that the Blue-headed Quail-dove has been found only by Audubon on the Florida Keys; it is resident in the Island of Cuba, where it nests in April and

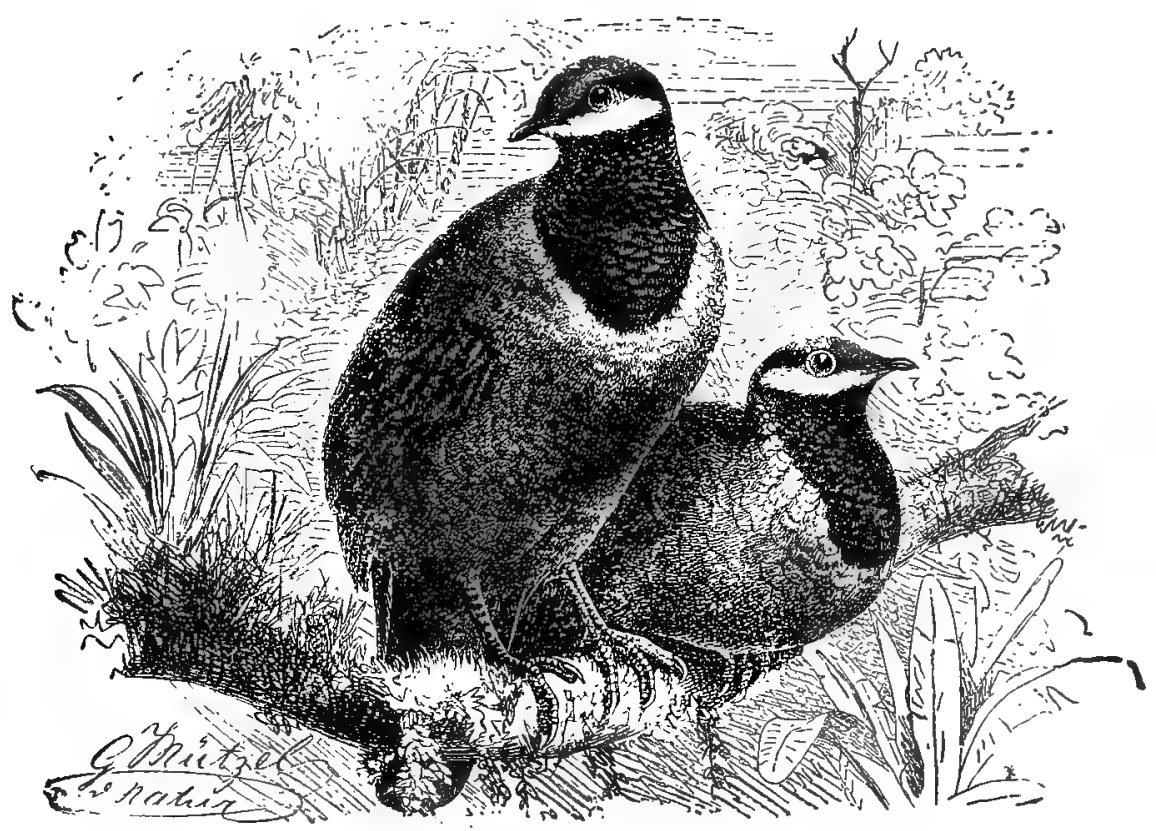

323. Bujg-headed Quail-dove (From Brelim),

May. It is a singular Dove, with the crown rich blue, bounded by black; a white stripe under the eye, extending under the chin; the throat is black, bordered with white. Length of bird about eleven inches. - The nest is placed on trees and bushes, and composed of sticks carelessly arranged. The eggs are two in number, pure white. The average size is $1.38 \times 1.01$.

324. CALIFORNIA VULTURE. Pscudyyryplus californianus (Shaw.) Geog. Dist.-Coast ranges of Southern California from Monterey Bay southward into Lower California; formerly north to Frazer River.

Concerning the California Condor or Vulture, Dr. Brewer remarks as follows: "The single species composing this very distinct genus belongs to Western North America, and so far as known, has the most restricted distribution of any large raptorial bird in the world. It is remarkable for its very large size, all its dimensions nearly, if not quite, equaling those of the famed Condor of the Andes (Saremrhamphus gryphus)." This great bird has already become very much reduced in numbers and extinct in localities where it was formerly abundant; this is doubtless due to the indiscriminate use of poison which is placed on carcasses for the purpose of killing wolves, bears, lynx, cougars and other noxious animals which played havoc with 
sheep, calves, and other cattle of the stockmen. Upon these poisoned remains the birds feed and perish. It is at present restricted to the area of the Pacific coast ranges as above stated. It is more common in the warm valleys of California, among the almost inaccessible cliffs of the rough mountain ranges running parallel with the Sierra Nevadas for a hundred miles south of Monterey. They may he found in those places, where the foot of man has never trodden. For years this bird has been thought to be on the verge of extermination chiefly for reasons stated above, but by the indefatigable labor of several ornithologists within the last ten years, we are led to believe that the bird will still be able to hold its own. $\Lambda$ ccording to the late Maj. Bendire it does not seem to be decreasing in the barren mountain ranges in the vicinity of Santa Barbara. The writer has a mounted specimen taken in Monterey county, May 10, 1890, and a number of specimens have been taken within the past few years in the mountainous regions which this bird inhabits. A

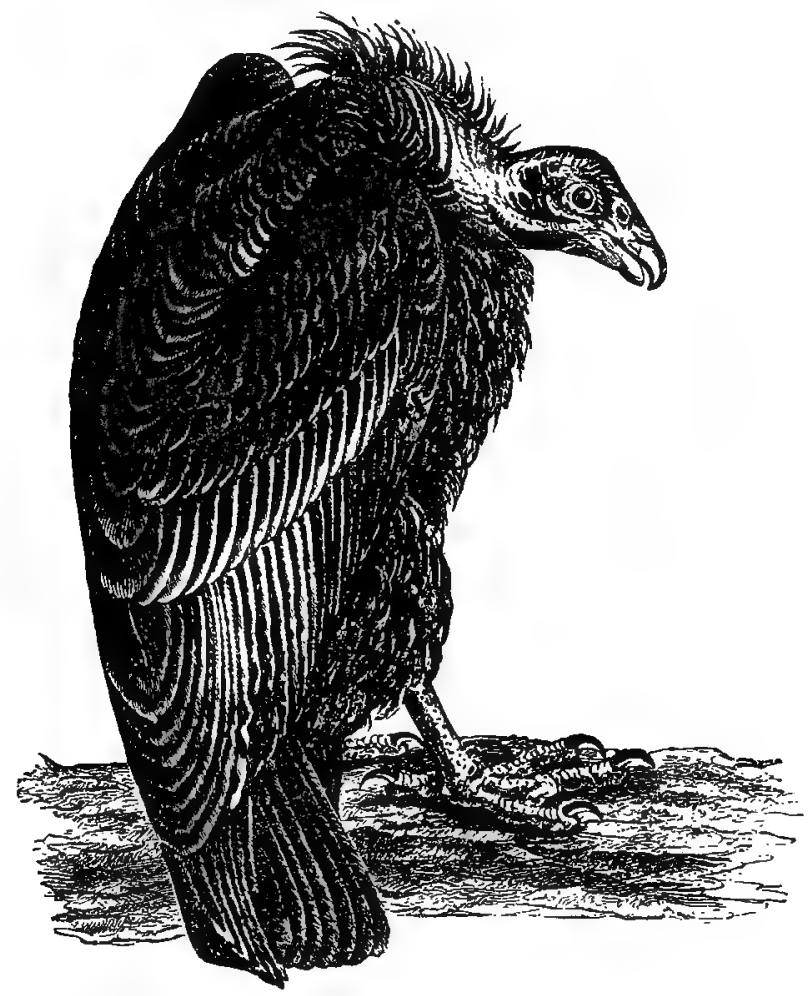

324. California Condor (From Tenny, after Audubon).

young bird was taken July 7, 1896, from a nest which was simply the bare floor of a cave high up in the cliffs in Monterey county, overlooking a dark canyon with the stream about 300 feet below. It is in the possession of Mr. Frank H. Holmes, of Berryessa, California. This specimen is well illustrated from life at about eight months old in The Nidologist for February, 1897, page 58, with a full text regarding his peculiar habits in confinement. It associates with the Turkey Buzzard, 
and the habits of both species are alike, often feeding together on the same carcass. Wke the Turkey Vulture its flight is easy and graceful, sailing majestically with almost motionless wings, in wide circles at great heights, over a large space of terrilory, in search of food. The weight of this bird varies from twenty to twenty-fivo pounds; extent of wing from eight and a half to eleven feet. Previous to the egg recorded by Mr. H. R. Taylor it is doubtful that a specimen had been taken in twelve years. With the discovery of this egg and the nesting place of this species we have, with further accessions in an oölogical way, a reasonably full knowledge of the b)e's nidification.* Mr. Taylor says: "There are probably but three or four eggs

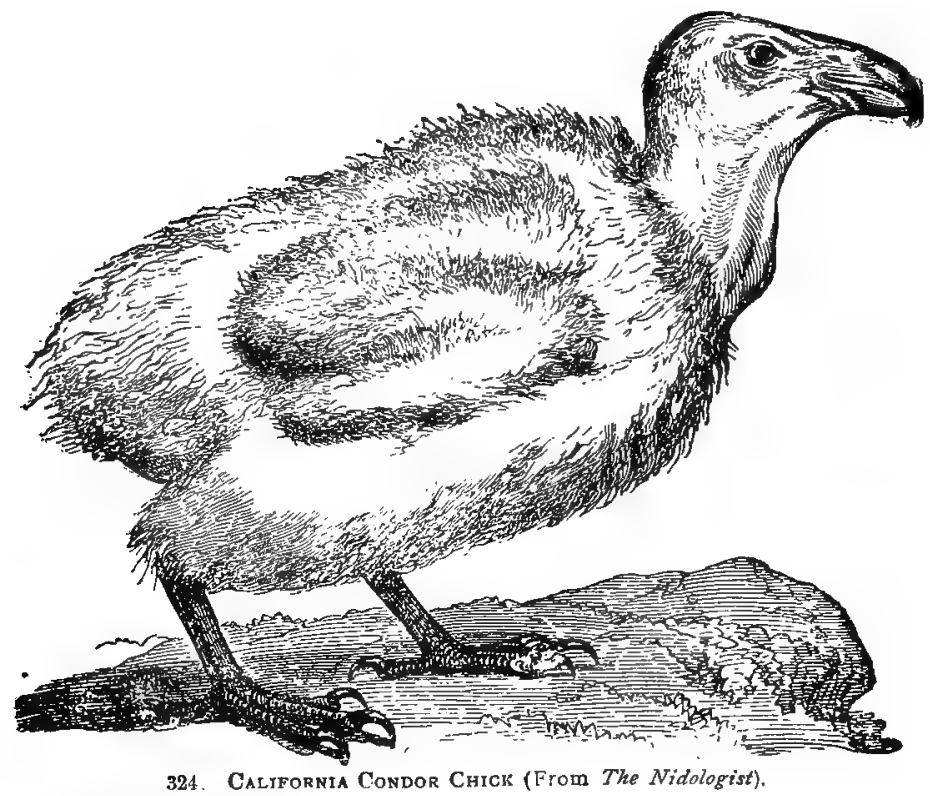

of the California Condor in existence, and one of these I have the honor to claim as my property, having purchased it a month ago at a good round figure from the oollector, who took it in 1889, and had since been keeping it as a curiosity (!) The discovery of this egg gives positive information as to the nesting time, heretofore unknown, and is in every way a considerable bit of ornithological news. In appearance the egg is almost a facsimile of the one figured by Capt. [the late Maj.] Bendire, although I would describe the color as ashy-green. As an unspotted egg is bound to appear flat in a lithograph (see figure of egg in 'Life Histories') I have not attempted to illustrate this one. My egg was taken in May, 1889, in the Santa Lucia Mountains, San Luis Obispo county, Cal., at an altitude of 3,480 feet. The egg was deposited in a large cave in the side of a perpendicular bluff, which the collector entered by means of a long rope from above. The bird was on the nest, which was in a low place in the rock, and was, the collector says, 'lined with

* For an exhaustive treatise on the habits of the California Condor see Taylor's article in The Nidologist for February, 1895, pp. 74-79; also March, 1895, concerning the partheulars of the taking of the egg. 
feathers picked from her own body.' This latter assertion may be an unwarranted conclusion. There was but the one egg, incubation, 'about one week.'" The specimen figured in Maj. Bendire's work measures $114 \times 65 \mathrm{~mm}$., or $4.49 \times 2.56$ inches. The color is described as a light grayish-green, unspotted. Another egg of this Condor was taken in the same region described by Mr. Taylor. It was secured by the wellknown collector, Mr. O. W. Howard, and an assistant for Mr. A. M. Shields, of Los Angeles. It was found in a cave of a lofty precipice. Rope and tackle were used to reach the entrance. The egg was laid on the bare ground in a saucer-shaped depression. It was taken April 25, 1895, and is now in the cabinet of G. Freen Morcom, of Chicago. It measures $4.42 \times 2.65$ inches. Another egg was taken from a cave in the same region about the same time. From the facts at hand, it appears that the California Condor lays but a single egg.

325. TURKEY VULTURE. Cathartes aura (Linn.) Geog. Dist.-Temperate America from New Jersey, Ohio Valley, Washington and Saskatchewan region. southward to Patagonia, and the Falkland Islands.

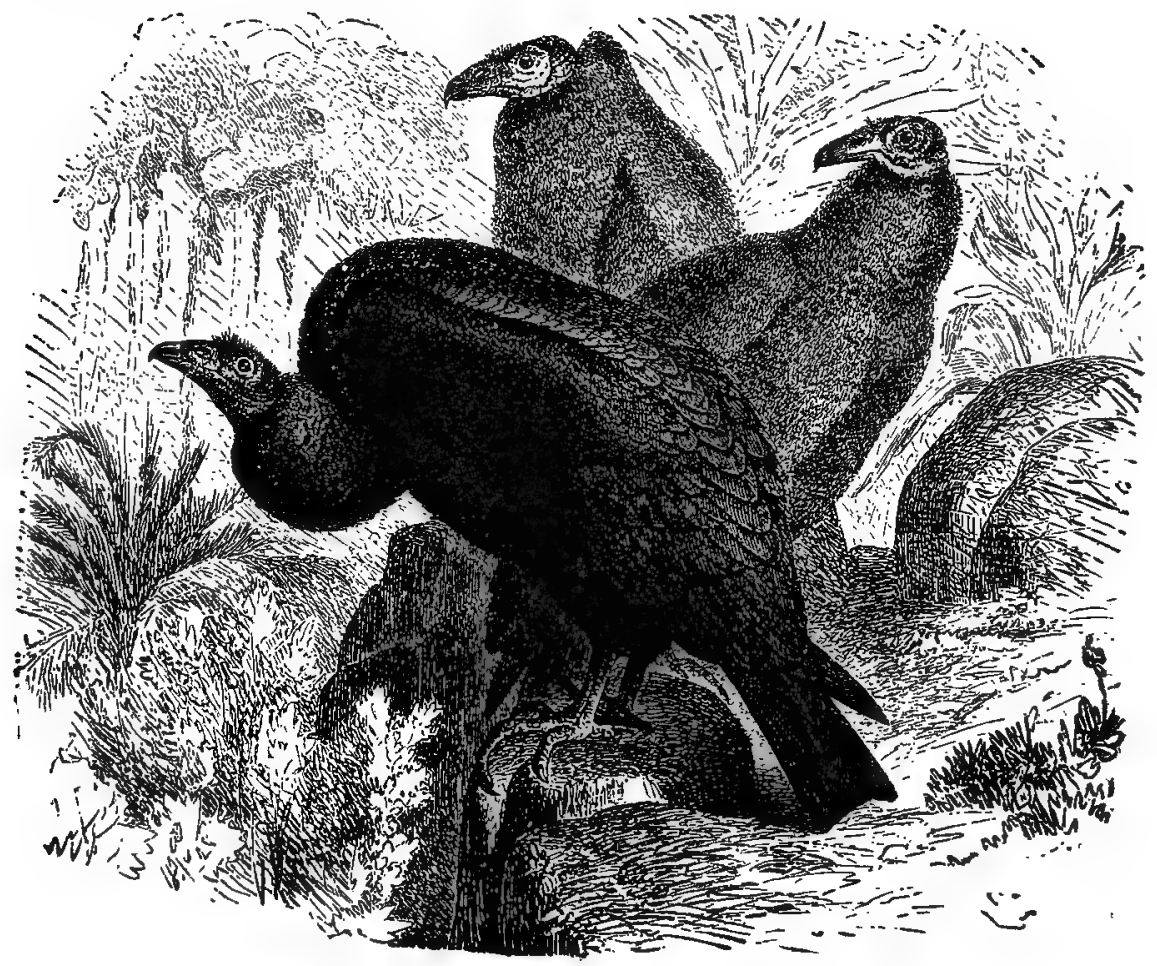

325. TUREey Vulture (From Brenm).

The common Turkey Buzzard inhabits the United States and adjoinlng British" Provinces from the Atlantic to the Pacific, south through Central and most of South America, and is resident north to about $40^{\circ}$. Every farmer knows it to be an in- 
dustrious scavenger, devouring at all times the putrid decomposing flesh of carcasses. It is essentially gregarious, not only flying and feeding in company, but resorting to the same spot to roost; breeding also in communities and sometimes by single pairs; depositing its eggs on the ground, on rocks, or in hollow logs and stumps, usually in thick woods or in a sycamore grove, in the bend or fork of a stream. The nest is frequently built in a tree or in the cavity of a sycamore stump. In the vicinity of Tampa, Florida, Mr. Stuart says, the eggs of this bird are laid in February and March; in Indian Territory they are deposited in March; April and May. In Arizona and Colorado it nests in the latter part of April and in May. Mr. Shields states that in the region of Los Angeles, Cal., this bird begins laying about April 15. He observes that although the usual nesting sites are chosen, the favorite place for depositing the eggs is a little depression under a small bush or overhanging rock on a steep hillside. In Ohio and other Eastern States fresh eggs may be found in April and May. Notwithstanding the arguments set forth by renowned naturalists that this bird is not possessed of an extraordinary power of smell, it has been proven recently by the most satisfactory experiments that the Turkey Buzzard dves possess a keen sense of smell by which it can distinguish the odor of flesh at an immense distance. The flight of this Vulture is truly beautiful, and no landscape w:th its patches of green woods and grassy fields, is perfect without its dignified figure, high in the air, moving in great circles; so steady, graceful and easy, and apparently without any effort. It is a very silent bird, only uttering a hiss of defiance. or warning to its neighbors when feeding, or a low gutteral croak of alarm when flying low overhead. The eggs are creamy or yellowish-white, variously blotched and splashed with different shades of brown and usually showing other spots of lavender and purplish-drab; two in number, sometimes only one; average size abour 2.73×1.87. Six specimens measure $2.80 \times 1.89,2.73 \times 1.89,2.79 \times 1.98,2.80 \times 1.91,2.84 \times 1.88$, 2.87×1.90. Mr. H. R. Taylor, of Almeda, Cala., records finding early in April a set of immaculate eggs of this species.* The average size of nineteen sets, thirty-eight eggs, taken between April 3, and June 13, is 1.90x2.75 inches. This series is from Texas, California, Kansas, Mississippi, North Carolina and New Jersey. These are in the collection of Mr. C. W. Crandall, Woodside, N. Y. Mr. Raymond C. Osburn reports to me a curious nesting place of the Turkey Vulture which he found in Licking county, 0. , May 15, 1894. It was in a hollow tree twelve feet below the opening, and the parent bird would not leave the nest until a hole was chopped in the tree on a level with the nest.

326. BLACK VULTURE. Catharista atrata (Bartr.) Geog. Dist.-Whole of tropical and warm-temperate America, south to Argentine Republic and Chili, north regularly to the Carolinas and Lower Mississippi Valley, irregularly or casually to Maine, New York, Ohio, Indiana, Illinois, etc.

This Vulture, called Carrion Crow, is very common along our South Atlantic and Gulf States, and is resident from South Carolina southward; in many places if is more numerous than the Turkey Buzzard, and its general traits, nesting habits, etc., are the same, breeding in hollow logs, decayed trunks of trees, stumps, and on the ground. In the Southern Atlantic cities the Black Vulture is said to be a semidomestic bird, and even protected by law. Their services as scavengers in removing offal render them valuable and almost a necessity in Southern cities. A specimen of this Vulture, which I mounted and now in my collection, was killed February 6, 1895, fcur miles north of Reynoldsburg, Ohio. On an island near Beaufort, South Caro-

* Ornithologist and Oologist, Vol. XIII, p. 102. 
"Yna, Mr. Walter Hoxie found the Black Vulture nesting under a dense growth of yucca. No attempt was made at forming a nest, or even excavating a hollow. The eggs are laid far in under the intertwining stems of the yucca and in the semishadows were quite hard to be seen. Mr. Hoxie states that the parent birds have the habit of always following the same path in leaving and approaching the nesting place. By these paths, which were often winding, he was able to discover the eggs. Both sexes assist in incubation and two eggs constitute the nest complement. Mr. Hoxie never observed a bird sitting on a single egg, and so far as he was able to determine the period of incubation is nearly thirty days; eggs were taken from May 2 to May 26. He states that Mr. Alfred Cuthbert took a set of three eggs in 1884.

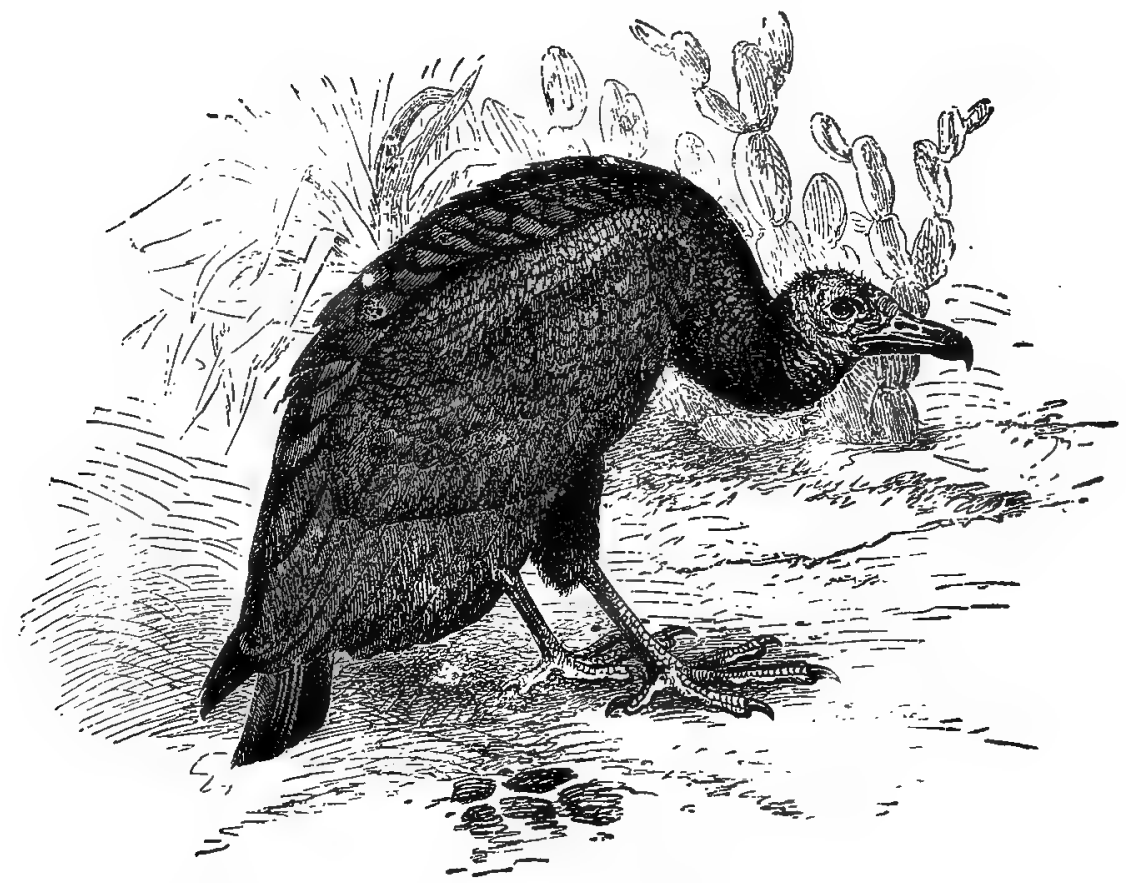

326 BLack Vultire (From Brehu).

The eggs are generally 'jroadly elliptical-ovate in shape and similar in color to thase of the Turkey Vulture-bluish-white, blotched and spotted with very dark brown and umber-not so densely marked as those of Cathartes aura; avorage size 3.10x2.04. Mr. Crandall's series of this bird's eggs consists of twenty-four sets, forty-eight eggs, mostly taken in Texas, some in Mexico, between February 28 and June 5 . The verage size of this series is $2.99 \times 1.99$ inches.

327. SWALLOW-TAILED KITE. Elanoides forficatus (Linn.) Geog. Dist.Tropical and warm-temperate parts of continental America, north regularly up the Mississippi Valley to Illinois, Iowa, Minnesota, etc. Casually east to Pennsylvania. and Southern New England. 


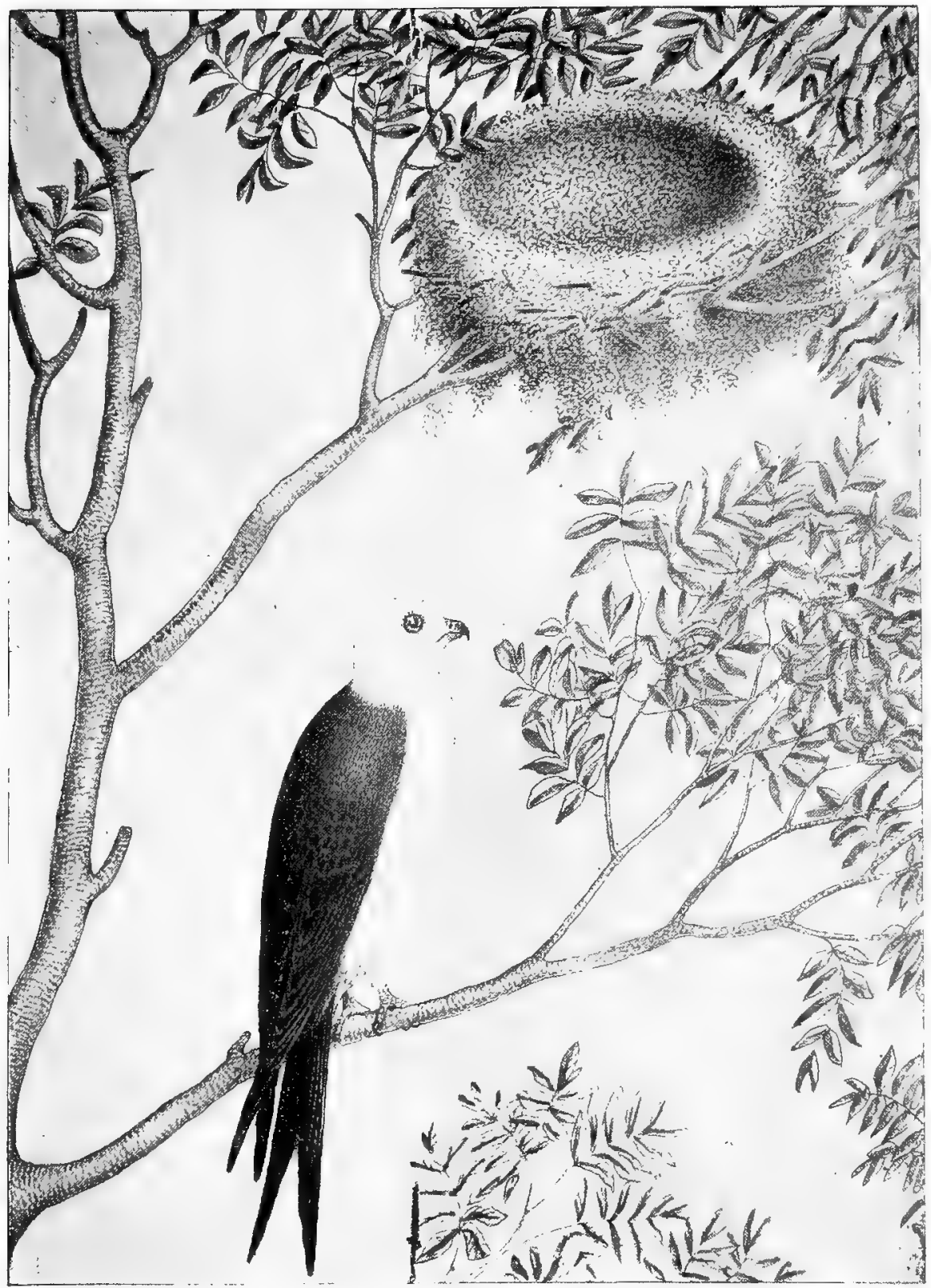

327. Swallow-tailed Kite aNd Nest. 
This beautiful species, noted for its graceful and elegant tight, is an abundant summer resident of the Southen $n$ United States as far north as Virginia, occasionally straying to the Middle States, and regularly far up the Mississippi Valley. Skins of this Kite are in my collection which were taken in Ohio, August 22, 1878, and July 10, 1883. Previous to these records it has not been heard of in the State since 1858. The favorite resorts of this bird are bottom woodlands near prairies or fields. Its food consists of small reptiles and insects; it is particularly fond of small snakes and lizards, grasshoppers, crickets, and various beetles. The nest of this Kite is built at the extremity of small branches near the tops of the tallest trees. The one represented in our illustration is taken from a sketch made on the spot by Mr. J. A. Singley, of Giddings, Lee county, Texas. This nest, as represented, is placed in the top branches of a pecan tree; it is composed of sticks and pieces of green moss, some of the moss hanging over the sides, giving it a beautiful appearance when seen from the ground. Outwardly it measures eighteen inches in diameter; depth twelve inches. Two eggs from this nest measure 1.77x1.43, 1.81x1.45. In other localities the materials for the nest differ, no moss being used. Mr. Singley states that the birds are very vicious while nesting; he has seen them attack and drive off Owls, Turkey Buzzards, Florida Redshouldered Hawls, Buteo lincatns alleni, Black Vultures and Crows. On April 25, 18s5, while his collector, Mr. Theodore Thassler, was climbing to the nest represented in the engraving, he was almost knocked our of the tree by the birds; and before he could secure the eggs was compelled to kill the most pugnacious one, which proved to be the male. Unlike the White-tailed Kite, when the nest is disturbed, the birds will desert it. The eggs of this species are from two to four in number, occasionally but onc, and rarely three or four. This is the statement by the late Maj. Charles E. Cendire in his matchless work, "Life Histories of North American Birds." According to his measurements of twenty specimens from different parts of the United States the average size is $1.85 \times 1.46$ inches. Mr. Singley took seven sets in the season of 1887, and was fortunate enough to find one containing three eggs, and a nest with three young. The color of the eggs is white, greenish or yellowish-white, spotted and blotched with brown and umber of varying shades; some are sparingly marked with specks of dark brown, in others the spots are clustered about the large end. The markings are often large and of a rich chestnut and mahogany color. During a trip to Texas, in 1888, Mr. G. B. Benners and Mr. Thos. Gillin collected six sets of eggs of this bird in that State. One set contained three eggs, another only one, while the other four nests had two eggs each. Under date of August 2d, 1895, Mr. Singley writes me that the Swallow-tailed Kite is almost exterminated here (Lee county)" "and I doubt if there were two sets of eggs taken in Texas this season." They must now be considered expensive eggs to procure. Two sets of two eggs each collected by Mr. Singley measure $1.87 \times 1.50,1.78 \times 1.49$; the second $2.03 \times 1.40,1.90 \times 1.50$ respectively. These are in Mr.C. W. Crandall's collection, Woodside, New York.

328. WHITE-TAILED KITE. Elanus leucurus (Vieill.) Geog. Dist.-Southern portion of the United States, from South Carolina, Southern Illinois, and California, southward into South America.

The late Maj. Bendire states in his "Life Histories ö North American Birds" that the breeding range of this species so far as actually known by the taking of their nests and eggs, seems to be confined to South Carolina (where Mr. Ward, Audubon's assistant, found it nesting on the Santee River early in March), Florida, the Indian Territory, Texas and the middle portions of California. The Black-shouldered or 
White-tailed Kite is distributed throughout Southern. United States from the Atlantic to Pacific, and southward into tropical America. In the East it is found as far north as Southern Illinois; in the West as far north as Indian Territory and Middle California. The flight of this bird is said to be easy and graceful, but not rapid. Sometimes it stops for a few moments, descends with great velocity to the ground to capture a lizard or snake. T ne nest of this species, like that of the Swallow-tailed Kite, is always placed just as high in the tree as possible. Prof. B. W. Evermann informs me that of all the nests he examined he did not notice an exception in this respect. It is not a very substantial structure, compased of sticks, forming scarcely more than a mere platform, the cavity being quite shallow; it is very sparingly lined with the inner bark of the cottonwood, sometimes with straw. When róbbed of a first set of eggs another is likely to be laid. Prof. Evermann states that the usual time of nesting in the Santa Clara Valley is from April 1 to May 1. Nests of this Kite have been found in Southern Texas which were placed in bushes, only seven or eight feet from the ground. Mr. Samuel C. Evans took six sets of the eggs of this species in San Jose Valley between May 1 and 22, 1886; one of two eggs on the 1st was far advanced in incubation; one of four on the 8th was fresh; another of two on the 19th was fresh; two sets of two each, taken on the 20 th, in which incubation had begun, and on the $22 \mathrm{~d}$ a set of five fresh eggs was taken. The nests were placed in sycamores, oaks and maple trees; one was situated forty feet from the ground, and the heights of the others ranged about fifteen feet. Mr. Evans, in several cases, placed small painted hen eggs in the Kites' nests, and the birds did not detect the difference, but continued laying. The eggs are of a dull, creamy-white, thickly blotched, dotted and tinged with deep chestnut, in some almost completely covering the whole ground; nearly spherical; four to six; this is the number usually stated, but four is almost invariably the number of eggs lain. A set of four eggs collected by Prof. Evermann in the Santa Clara Valley, California, measure $1.64 \times 1.27,1.62 \times 1.27,1.69 \times 1.27,1.62 \times 1.27$. The average measurement of fourteen eggs in Mr. Crandall's collection is $1.72 \times 1.30$.

329. MISSISSIPPI KITE. Ictinia mississippiensis (Wils.) Geog. Dist.Southern United States, east of the Rocky Mountains, southward from South Carolina on the coast, and casually or irregularly to Kansas, Iowa, Wisconsin on the interior; south to Mexico.

The Mississippi Kite is a summer resident in the southern portion of the United States. It is irregular in its distribution, and its occurrence in particular localities is uncertain, often being found common in regions where it was formerly rare. It is generally found in the same localities with the Swallow-tailed Kite, and, like the latter species, its extremely beautiful fight is one of the bird's characteristics. It often soars so high in the air as to be almost invisible. Like the Swallow-tail species, its food consists of insects, small snakes and lizards. The nests of the Misisissippi Kite are built in the tops of gigantic pines, pin oaks, sycamores, cottonwood, elm, and lofty cypress trees. Mr. J. A. Singley has a nest which he took in Lee county, Texas, which was placeu in the forks of a live oak twenty-two feet from the ground. The foundation and sides of the nest is built entirely of small sticks, the interior portion of small, green oak twigs in leaf, and leaves of the mesquite treé; the lining is of green moss, on top of which are placed green leaves of the pecan tree. The outer diameter from the ends of the longest twigs is seventeen inches, the most compact portion eleven inches; interior diameter five inches; outer depth seven inches, inside one and a half inches. Mr. Singley states that the 
measurements of two eggs taken May 22, 1886, is $1.65 \times 1.40,1.63 \times 1.34$; they are bluiahwhite, unmarked, one of them having light brown stains on it. They were taken from a nest placed in the slender forks of a small post oak about thirty feet from the ground; it was made of sticks and weed stems, lined with willow twigs in leaf. Mr. Singley has given me the sizes of the eggs of four sets which he collected in the

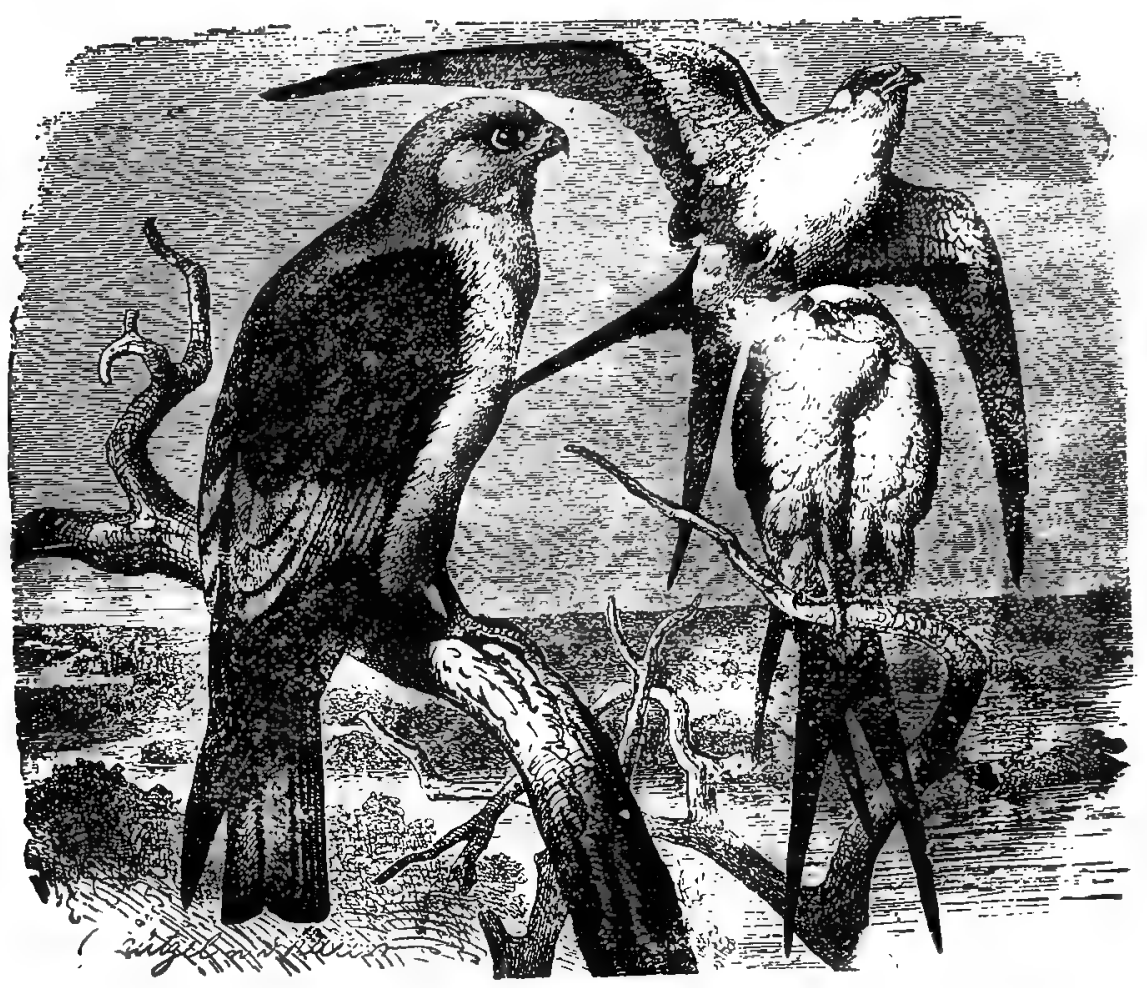

329. Left, Mississiprı Kite, right, Swallow-tailed Kıtk (From Brehm).

ceason of 1887. Three of these sets were of two eggs each and one of three; their color was invariably bluish-white, unmarked, and their sizes are as follows: 1.68x $1.34,1.64 \times 1.36,1.71 \times 1.32,1.63 \times 1.34,1.60 \times 1.35,1.67 \times 1.32,1.65 \times 1.34,1.59 \times 1.35,1.62 \times 1.38$. Considerable variation will be noticed in the length of these specimens, while their diameter is very uniform. Col. N. S. Goss found this species breeding in company with the Swallow-tailed Kite in the vicinity of Neosho Falls, Kansas, An egg was taken July 5, from an old crow's nest, fitted up with a few extra sticks and green twigs in leat for lining. It was placed in a medium-sized oak about forty feet from the ground. The egg, which was advanced in incubation, he describes a pure white, size 1.70x1.35.* Col. Goss also observed the Mississippl Kite nesting in the timber lands bordering Medicine Rlver, near Sun City, Barber county, Kansas, and found 
seven nests on the $22 \mathrm{~d}$ of May; on the 31 st he collected four sets of eggs containing two each and one nest contained a single egg. June 10th, two more sets of two eggs each were taken Col. Goss describes the eggs as "white or bluish-white;" the last two sets were stained by the wet leaves in the nests. The eggs measure by sets as follows: First, $1.55 \times 1.33,1.52 \times 1.36$; second, $1.76 \times 1.48,1.65 \times 1.35$; third, $1.70 \times 1.39$, $1.56 \times 1.35$; fourth, $1.70 \times 1.37,1.68 \times 1.30$; fifth, $1.75 \times 1.30$; sixth, $1.54 \times 1.31,1.45 \times 1.24$; seventh, $1.70 \times 1.38,1.68 \times 1.43$. The nests were all built either in the forks from the main body, or in the forks of the larger limbs of the cottonwood and elm trees, and when old would be taken for the nests of the common crow. Their height from the ground ranged from twenty-five to fifty feet.* Mr. R. E. Rachford informs me that he took two sets of the eggs of this species in Texas from nests situated about thirty feet from the ground in oak trees. The color of the eggs he describes as white, with a slight greenish tinge. The average measurement of ten specimens is $1.64 \times 1.28$.

330. EVERGLADE KITE. Rusthamus sociabilis.(Vieill.) Geog. Dist.-Florida, Atlantic coast of Mexico, part of West Indies, Central America, Eastern portion of South America to the Argentine Republic.

This slate-colored Kite is a resident of the Everglades of Florida, and also occurs in the fresh water marshes and lakes of the middle and southern portions of the State. Mr. W. E. D. Scott found it abundant at Panasofkee Lake, about February first, where it was feeding on a kind of fresh-water snail, which was very abundant, and the local name given the bird is "Snail Hawk." The birds fish over shallow water, after the manner of gulls; securing a snail by diving, they carry it to the most available perch, when the animal is dexterously taken from the shell without injury to the latter. At many places where a particularly convenient tree or stub rises out of the saw-grass, the ground is literally heaped with the empty shells of the snails. $\dagger$ The nesting season of this species in the Everglades of Florida is in March, some pairs breeding later than others, and two or three eggs are deposited. The nests are built in tall, rank grass and bushes; especially in the saw-grasses, about a foot below the tops, just so as to be out of sight, and the nests are usually composed of the same material; they measure about a foot in diameter, with a cavity three inches deep. Mr. H. B. Bailey describes a set of three eggs, taken in the Everglades, March 16, by E. W. Montreuil; their sizes are 1.91x1.50, 1.80x1.51, 1.80x1.45; the color of one is light brown, nearly obscured by large blotches of dark and reddishbrown; another has a dirty-white ground color, with spots and blotches of various shades of brown, which become smaller and fewer at the smaller end. It resembles the common varieties of eggs of the European Sparrow Hawk, Accipiter uisus. The third is of a greenish-white, over the smaller end are scrawls, lines and a few spots of light and dark brown.

331. MARSH HAWK. Circus hudsonius (Linn.) Geog. Dist.-Whole of North America, south in winter to Panama, the Bahamas and Cuba.

The Marsh Hawk, Blue Hawk, or Harrier, is distributed thronghout the whole of North America. It is one of the most abundant and widely diffused of our birds, and breeds from the fur country of Hudson Bay to Texas, and from Nova Scotia to Oregon and California. It is found especially in regions covered by bushes, small trees, rank grass, swamp prairies or marshy places. Here the nest may be found,

* Auk, Vol IV, pp. 344-345.

$\uparrow$ Bu*I Nutt. Club, Vol. VI, p. 16.

† Auk, I, p. 95 . 
placed on the ground, which is only a collection of twigs and hay, but from three to seven inches in height and a foot or more in diameter. Sometimes the nests are of large proportions, which is the result of nesting in the same spot for a number of years. The eggs are frequently laid on a bed of green moss, with the material arranged in a circular form. The bird may often be seen during the spring and summer months sweeping slowly over meadows and bottom lands in pursuit of gophers, mice, birds, grasshoppers and large insects. It can readily be recognized by the entirely pure white upper tail coverts; the male above bluish-ash, whitening below; the female above dark umber-brown. Mr. S. F. Rathbun records a set of seven eggs taken June 14, at Dunnville, Ontario. Marsh Hawks frequently begin to incubate with the first egg and the young are hatched at intervals, after the manner of the cuckoos. Fresh eggs may be found from the first of May to the 15th or 20th of June, according to locality. The eggs are greenish-white, either immaculate or faintly spotted with pale brown or lilac, rather oval in shape; three to six in number, often four or five, and measure from 1.80 to 1.90 in length by 1.38 to 1.45 in breadth.

332. SHARP-SHINNED HAWK. Accipiter velox (Wils.) Geog. Dist.Whole of North America, south to Panama.

This spirited little Hawk is distributed at large throughout North America and it is considered an abundant species, although in some localities it is quite rare. Known as Pigeon Hawk, but it should not be confounded with Falco columbarims.

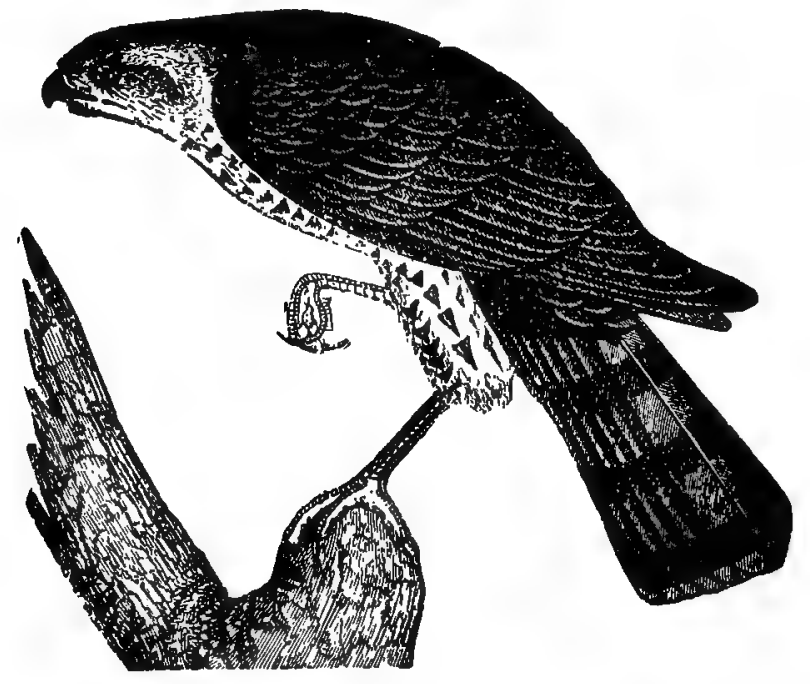

332. Sharp-shinned HaWK (After Audubon);

The Sharp-shinned Hawk is swift, irregular and nervous in its flight; is one of the most daring of the family, often successfully attacking birds of its own weight; failing sometimes to do so either from over-confidence in its own abilities, or underestimation of the powers of its victim. The smaller birds and quadrupeds, young chickens, pigeons, small reptiles and various insects constitute this bird's food. The nests of this species are built in trees in dense woods, preferably pine groves; 


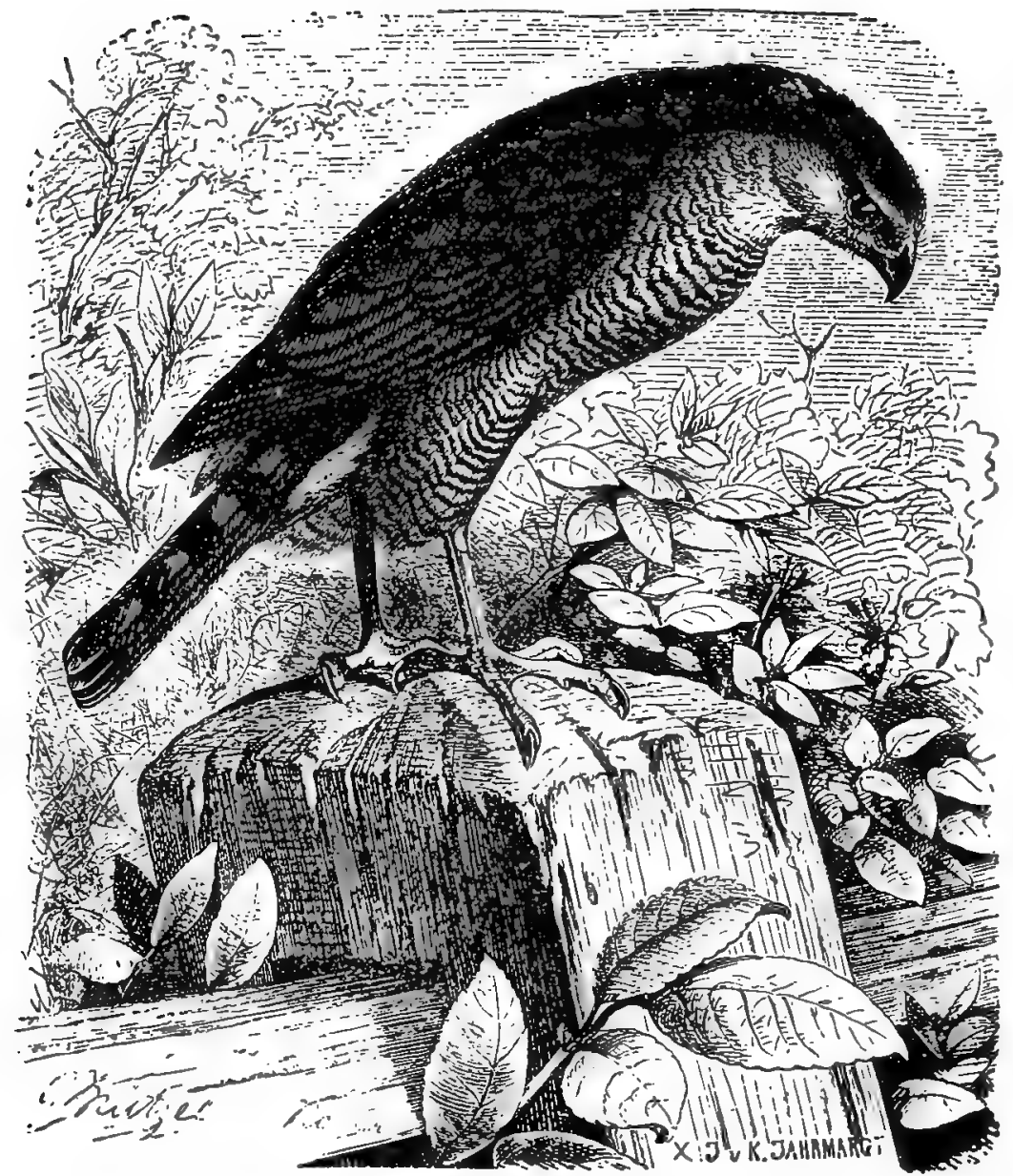

* Accipter nisw of Europe. The cut well represents our Sbarp-shinned, Cooper's or Goshawk.

rrequently a scrubby oak or a birch offers a favorite site, and the height from the ground may range from ten to sixty feet; the nests generally rest against the trunk of the tree at the base of a limb. The composition of the nests are small sticks forming a platform with a slight hollow, usually without lining. Occasionally nests are placed in cavities similar to those of the Sparrow Hawk, or upon a ledge of rock overhanging a lake or river. Mr. O. C. Poling informs me that in Western Illinois this Hawk selects for che s..e of its nest the top branches of an almost limbless tree, usually an oak, which is situated in dense woods; it is generally composed of oak twigs and leaves. Mr. Poling states that nesting begins by the middle of April; all the nests he has observed contained five eggs, although others were found in that region containing three and four. M: Charles F. Morrison, of Fort Lewis, Colorado, 
took a set of three eggs June 22 from a dilapidated Magpie's nest, the arched roof of which had fallen in, and formed a hollow, which was lined with a few feathers upon some dead leaves. „he Marsh Hawk and the present species deposit their egge when other Hawks are nearly through breeding. The Sharp-shinned Hawk's eggs may be found in the first week of April and as late as the last week of Junc; the hirds seldom occupy a nest tue second time. Mr. Crandall's oölogical collection consists of thirty-eight eggs, two sets of five and seven secs of four, and have an average measurement of $1.47 \times 1.20$ inches. Mr. J. Parker Norris has a large series of these eggs in his collection, consisting of seventeen sets, ranging in number from three to five, and onecontaining the unusual number of seven eggs; the dates on which they were taken are from April 11 to June 26. Most of these eggs were collected by the experienced oölogist, "J. M. W.," Mr. C. L. Rawson, of Norwich, Conn. Mr. Norris also describes seventeen eggs which were laid in succession by a single bird between May 23 and June 25. The eggs of the Sharp-shinned Hawk, Mr. Norris states, are subject to great variation in markings, and yet, as a rule, they can be identified at a glance. With the exception of the Sparrow Hawk, Tinnunculus sparverius, they are the smallest laid by any of the hawks found in North America, and among the most beautiful eggs of any of the Raptores. Their ground color varies from bluishwhite to grayish-white, spotted, blotched, speckled, streaked and clouded with light fawn color, burnt umber, chestnut, lavender-gray, chocolate, russet-brown and cinnamon, exhibiting an endless variety of bold and indistinct patterns of coloration and design. The usual form of the egg is spherical, of nearly equal size at both ends. The average size is $1.50 \times 1.16$.

333. COOPER'S HAWK. Accipiter coopcrii (Bonap.) Geog. Dist.-North America at large; greater portion of Mexico.

Distributed throughout temperate North America at large as a summer resident, and well known to the farmers by the name of Chicken Hawk. Its flight is easy and usually slow, but the bird is quick, in its movements, its long tail serving the purpose of a rudder as it suddenly pounces upon the object of its pursuit or quickly ascends into the air. This and the last species are perhaps the boldest depredators of the family. They are shy and difficult of approach, yet their imprudence often proves fatal to them. They do not hesitate to attack chickens in the presence of their owners; they also feed largely upon small quadrupeds, weasles, squirrels and young rabbits; snakes and reptiles are among their victims. A specimen of this bird is in my collection which was killed by a weasel in mid air, the weasel sucking the blood of the hawk, while the bird was struggling with its intended victim, which escaped unharmed. The nests of Cooper's Hawk are usually placed in tall trees, from ten to fifty feet from the ground; frequently an old crow's or some other hawk's nest is fitted up for the purpose, which is occupied for a succession of years, and the nests are often so augmented by the continuous adding of brush and rubbish that they become huge structures. May 15, 1880, a collector brought me a set of four eggs taken from an old squirrel's nest. Mr. L. Jones, of Grinnell, Iowa, writes that this Hawk deposits its eggs in that region about the first of May. The number of eggs laid ranges from four to six, rarely the latter number, and they may be found in various sections between April 1 and May 20. The eggs are of a pale-bluish or greenish-white, usually spotted with pale reddish-brown. The average size is $1.97 \mathrm{x}$ 1.42 inches. A set of four eggs from Southern Arizona, taken May 15. measure $1.90 \times 1.40,1.95 \times 1.42,192 \times 1.40,1.90 \times 1.42$; another set of four collected in Central Ohio, April 9. measure $1.89 \times 1.40,1.92 \times 1.45,1.93 \times 1.40,1.90 \times 1.42$. 
334. AMERICAN GOSHAWK. Actipiter atrirapillus (Wils.) Geog. Dist.Northern and Eastern North America; the northern half of United States, a winter resident in some parts.

A large and handsome hawk-one of the most symmetrical in outline of the family; known to breed mostly north of the United States. Its breeding places are usually in thick evergreen woods, the nest being placed in tall hemlock trees; it is bulky and composed of sticks, twigs and weeds, lined with bark strips and grass. The number of eggs laid by the Goshawk varies from two to five. The average size is $2.32 \times 1.75$ inches; they are bluish-white in color, sometimes faintly spotted with yellowish-brown.

334a. WESTERN GOSHAWK. Itripiter atrirapillus striatulus Ridgw. Geog. Dist.-Western North America.

A darker colored race than the foregoing, inhabiting the Pacific coast region, north to Sitka, breeding in the Sierra Nevadas probably as far south as $39^{\circ}$. General

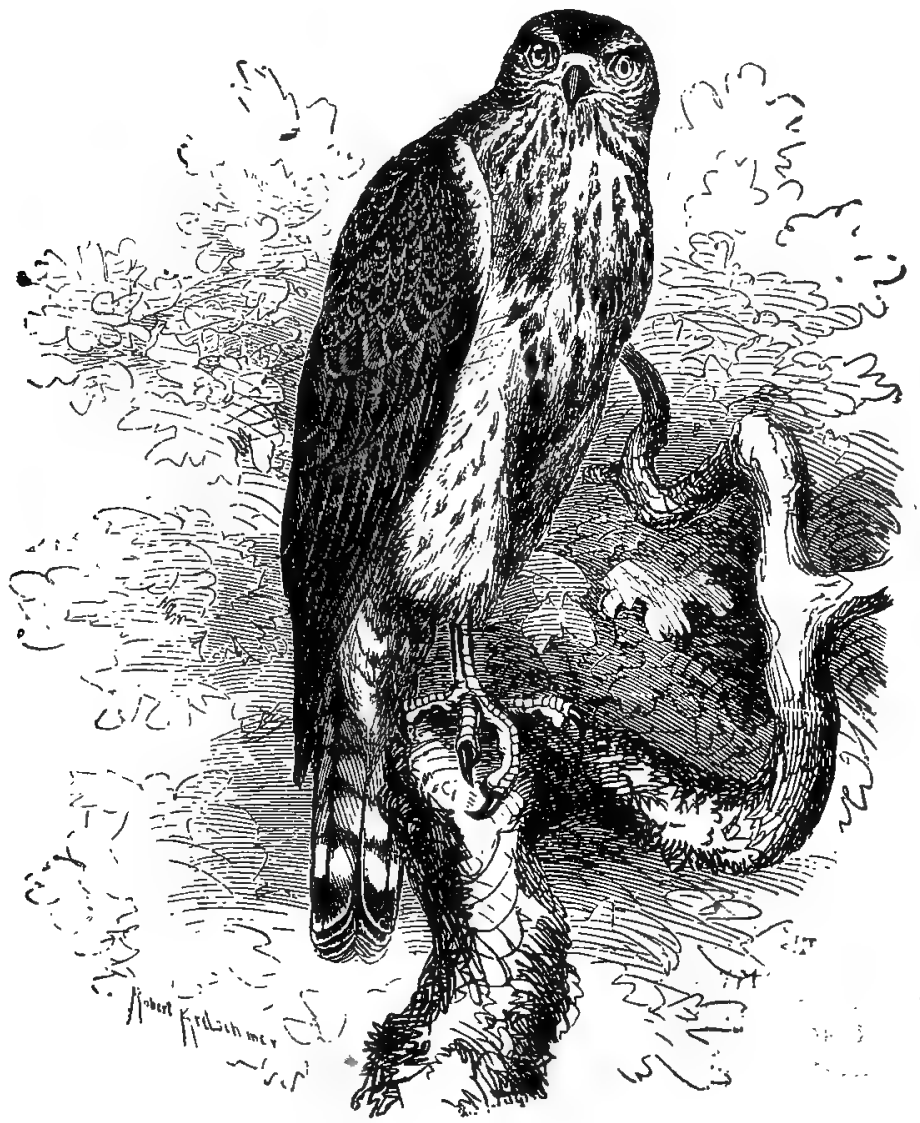

334. European Goshawk. The cut well represents the American Goshawk (From Brehm), 
habits, nesting, eggs, etc., the same as those of atricapillus. Average size of eggs $2.36 \times 1.75$.

335. HARRIS'S HAWK. Parabuteo unicinctus harrisi (Aud.) Geog. Dist.Southern border of the United States; Mississippi, Texas, Arizona, southward to Panama.

This bird is an inhabitant of the warmer parts of America, extending its range over our Mexican border. In Texas it is common, especially about the mouth of the Rio Grande. Its habits resemble those of the Caracara Eagle, but it is not so active, and the nests are hardly distinguishable in situation and construction. It is said, by some observers, to subsist entirely on carrion, and may be seen in company with the Turkey Buzzard, Black Vulture and Caracara Eagle. Mr. Sennett found this species to be the most abundant of any other of the family on the Lower Rio Grande in Texas. In their crops he found mice, lizards, birds and often the Mexican striped gopher, indicating that they were active hunters instead of sluggish birds. The eggs are white, with a yellowish tinge, sometimes marked with light dashes of yellowish-brown and dottings of purplish drab; commonly two or three in number, rarely four. Four sets of these eggs are in the cabinet of Mr. J. Parker Norris, and show considerable variation in size and shape. One set of three taken near Corpus Christi, Texas, May 10, 1886, is entirely dull white; sizes, $2.19 \times 1.61,2.13 \times 1.63,2.14 \times$ 1.58; another of two eggs taken in Cameron county, Texas, May 25, 1886, measure $2.08 \times 1.65,2.19 \times 1.71$; a set of three eggs from the same place, collected April 25, measure $2.00 \times 1.65,2.06 \times 1.65,2.13 \times 1.69$; one of the eggs of this set has a few faint cinnamon spots; the fourth set taken in Cameron county, Texas, May 3, 1886; two of these are faintly marked with lavender, but the third is distinctly spotted at the large end with cinnamon; sizes, $2.14 \times 1.65,1.94 \times 1.61,1.99 \times 1.57$.

[336.] EUROPEAN BUZZARD. Buteo buteo (Linn.) Geog. Dist.-Northern portions of the Eastern. Hemisphere. Accidental in Michigan.

The older ornithologists were doubtless mistaken in the identification of the specimens obtained in this country, which they described and figured as Buteo vulparis of Europe. This Hawk has been entirely excluded from our fauna by more recent authorities, and it is admitted only on the grounds of a single specimen taken near Paw Paw, Michigan, by J. D. Allen, and received in the skin by Mr. C. J. Maynard in the autumn of 1873 . The bird is quite common in England, frequenting the more cultivated portions, as well as the very wildest parts of Scotland and tracts of Alpine forests, where its favorite breeding place is on the edges of ravines. The nest is placed in some large tree or on a ledge "of rock, and is built of sticks with a scanty lining of wool and hair. The eggs are two or four in number, generally three, of ap oval form, bluish-white, with pale brown blotches and spots of yellowishbrown, chiefly at the larger end. A set of three eggs in my cabinet, from England, measure $2.30 \times 1.75,2.28 \times 1.72,2.30 \times 1.68$.

337. RED-TAILED HAWK. Buteo borealis (Gmel.) Geog. Dist.-Eastern portions of North America, west to the Great Plains.

The Red-tailed Buzzard, in its light and dark geographical races, is distributed throughout the whole of North America. This species is abundant in the eastern portion. A large Hawk and a notorious visitor to barn-yards, though lacking much of the pluck and dash of the members of some of the preceding genera it has the equally successful quality of perseverance. The food of this species is chiefly smali 


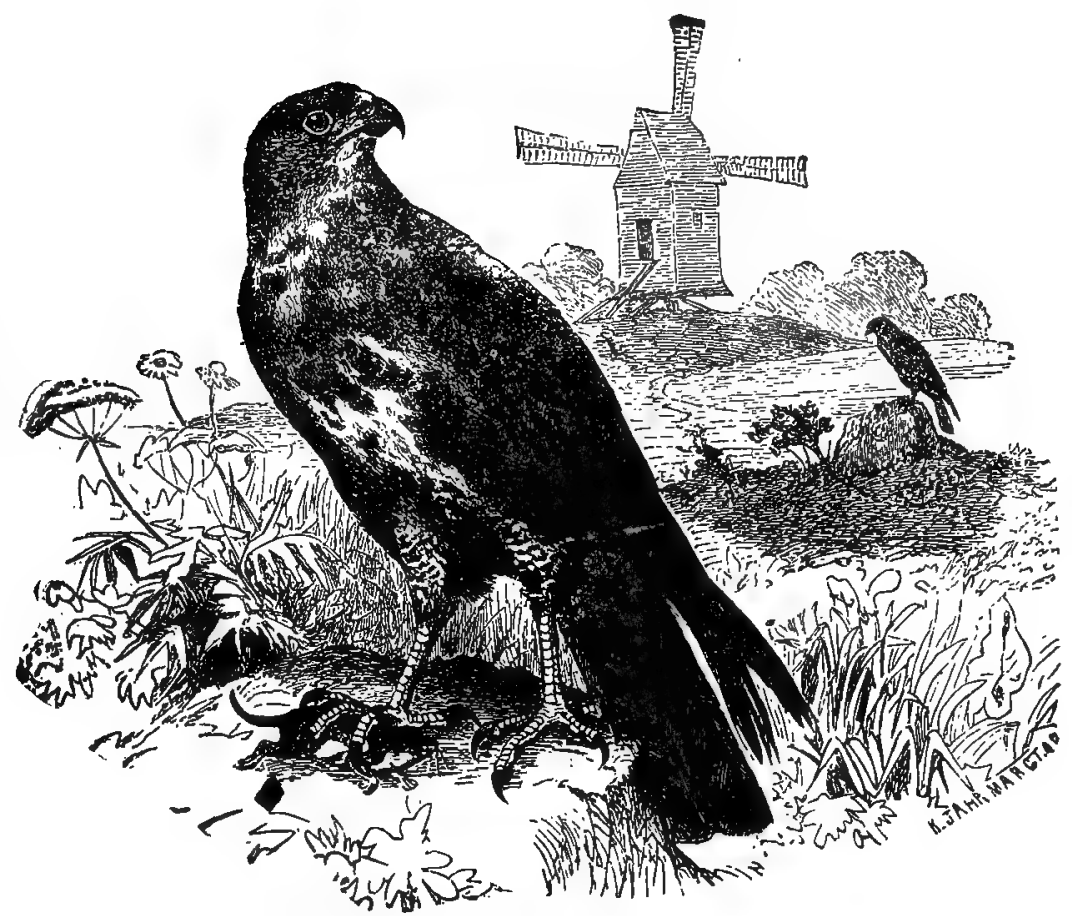

336. European Buzzard (From Brehm).

quadrupeds, red squirrels, gophers and ground moles, and the remains of these rodents may always be found in this bird's nest containing young. The Hawk will always be found common where these small animals are most abundant. The nest is placed in high trees in deep woods; it is large and bulky, though comparatively shallow; made of -sticks and twigs, mixed together with corn-husks, grass, moss, and on the inside may be found a few feathers. Sometimes the deserted nest of a crow or that of another hawk is fitted up and used. Mr. J. Parker Norris records a nest occupied first by the Great Horned Owl and afterwards by the Red-tailed Hawk, each year; the young owls leave the nest before the hawk is ready to occupy it. The number of eggs laid by this species is two or three, rarely four. Mr. Norris has a series of twenty-seven sets collected in Connecticut, Pennsylvania, Iowa, Mississippi, and Texas; nineteen of these sets are of two eggs, six of three, and two of four.* The time of depositing the eggs in the United States varies according to locality and circumstances, but they are generally laid in March or April. Eggs are found in different stages of incubation as late as the middle or latter part of May. A large ceries of eggs present amazing differences in size and markings; their ground color is white or bluish-white; some are entirely unmarked, while others are very heavily blotched and splashed with many shades of red and brown; some are faintly marked here and there with a light purplish tint, and again the colorings may form an

* For a detalled description of this serles see Ornithologist and Oologist, Vol. XI, pp. 67-69. Since the above was written Mr. Norris has Increased his series to thirty-six sets. 
almost confluent wreath at either end. The largest eggs in $\mathrm{Mr}$. Norris' cullection measure $2.41 \times 1.84,2.37 \times 2.00$; the smallest, $2.17 \times 1.80,2.20 \times 1.78$. The average size is $236 \times 1.80$.

337a. KRIDER'S HAWK. Buteo borealis kriderii Hoopes. Geog. Dist.-Great Plains of the United States, from Minnesota to Texas.

This lighter colored variety of the Red-tailed Hawk occurs in the Great Plains, from Minnesota to Texas; east irregularly or casually to Iowa and Northern Illinois. Mr. F. M. Dille writes that this bird nests in remote places on the plains and among the large cliffs of Colorado. He was unable to detect any difference between the nest and eggs of this bird and those of the Western Red-tail. He took a set of the

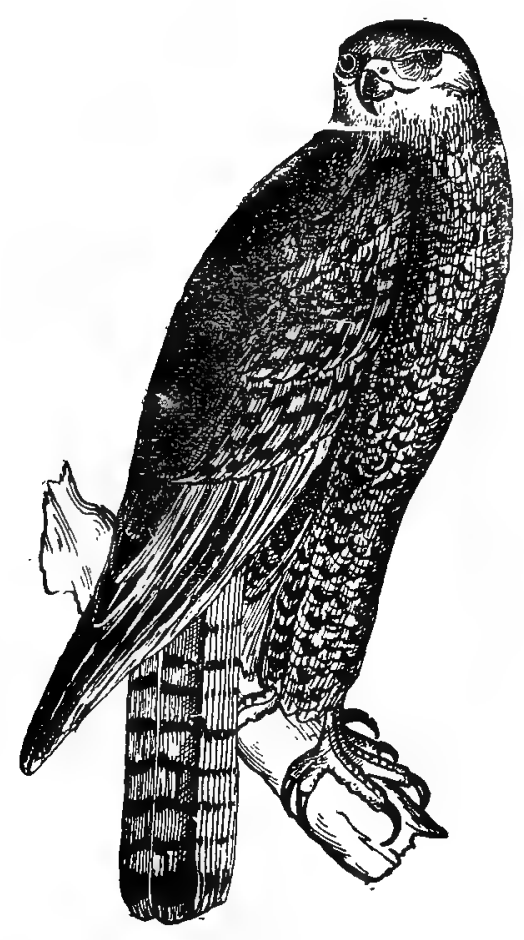

3376. WESTERN RED-TAIL. eggs, three in number, in Weld county, May 24, 1886, from a nest in a cottonwood tree. Two of these specimens are slightly spotted with Vandyke brown, but the third is quite heavily splashed and blotched at the smaller end with chestnut and cinnamon; their sizes are $2.34 \times 1.82$, $2.30 \times 1.84,2.28 \times 1.83$. A set of three colected by $\mathrm{Mr}$. Dille is in my collection and offer the following measurements: $2.40 \times 1.90$, $2.38 \times 1.85,2.30 \times 1.89$ inches. Mr. Dille states that the nest contained cotton balls, from the tree in which it was placed; these had burst and made excellent soft lining for the nest.

337\%. WESTERN RED-TAIL. Butco borcalis calurus (Cass.) Geog. Dist.--Western North America, especially in the United States, from Rocky Mountains to the Pacific, south into Mexico.

A blackish or sometimes an almost entirely sooty variety inhabiting Western North America. In all respects its breeding habits are the same as those of the Eastern representative, nesting in the branches of lofty oaks, pines, sycamores, etc. In mountainous regions the nests are often placed on the narrow ledges of cliffs. The eggs cannot be distinguished from those of B. borealis.

337". ST. LUCUS RED-TAIL. Buteo borcalis lurusumus Ridgw. Geog. Dist.Peninsula of Lower California.

This subspecies is confined to the Peninsula of Lower California. Its nesting and eggs are identical with the above variety.

337d. HARLAN'S HAWK. Butea borealis harlani Aud. Geog. Dist.-Gulf States and Lower Mississippi Valley, north to Pennsylvania, Iowa and Kansas; south to Central America. 
Mr. Crandall has a set of the eggs of this subspecies taken at Avery's Island, Louisiana, March 17, 1895. The nest was large and bulky, composed of sticks, twigs, lined with green leaves and moss. The nest was placed in a large white oak tree on the edge of a swamp. The eggs, two in number, measure $2.40 \times 1.81,2.45 \times 1.83$ respectively. Their ground color is bluish-white, blotched with brown; in one somewhat sparingly over the small end, and in the other specimen sprinkled over the entire surface.

\section{RED-SHOULDERED HAWK.} Buteo lineutus (Gmel.) Geog. Dist.-Eastern North America, north to Nova Scotia; west to the edge of the Great Plains.

This large species is one of the commonest hawks in the United States, and it is especially abundant in winter, from which it receives the name of Winter Falcon, but it is not more hardy than the Red-tail. It also shares the name of Chicken Hawk, commonly applied to all the larger hawks. Only occasionally it visits the barnyard, its diet is of a more humble hind, such as frcgs, rats, mice and small

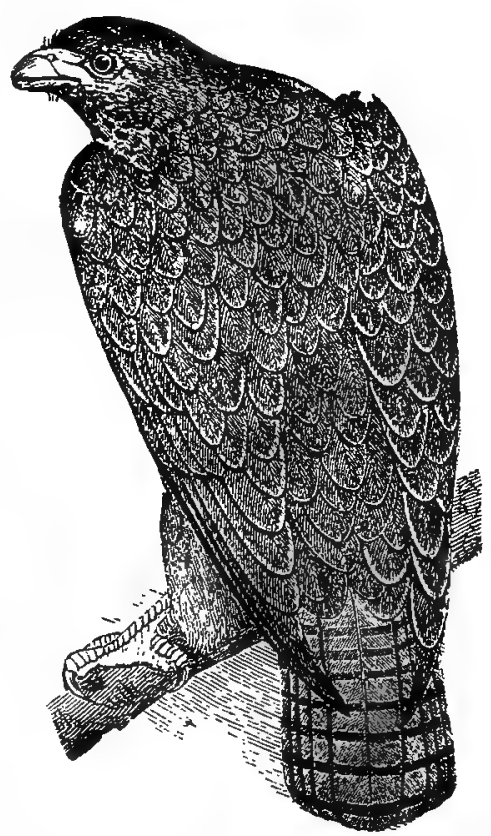

337d. HARLAN's Hawk (After Audubon). snakes. The nesting of the $\Gamma c d$-shouldered Hawk is very much the same as that of the Red-tail, but in many sections it seems to have a preference for lower woods, in bottom lands. The nest is said not to be so long re-occupied by the birds. The eggs are usually deposited in April or May. The number of eggs is three or four, sometimes only two. The ground color is bluish, yellowish-white, or brownish, spotted, blotched and dotted irregularly with many shades of reddish-brown; they are usually more highly colored than the eggs of the Red-tail. Some of them are exceedingly handsome. A series of sixty-one sets are in Mr. Norris' cabinet, nearly all of which were collected by the celebrated oölogist, "J. M. W." (C. L. Rawson); they" show a wonderful variation in size and markings, ranging from almost unmarked to very heavily spotted and blotched specimens. To describe all the shades of reds and browns, which comprise the variation, would be an almost endless task, and a large series like this must be seen in order to appreciate how much the eggs of this species vary. The sizes range from 2.00 to 2.30 long by 1.65 to 1.75 broad. For a thorough treatise on the food of the Raptores we refer the reader to Dr. A. K. Fisher's "Hawks and Owls of trie United States."* Hundreds of stomachs of these birds have been examined and their contents recorded in this work, which proves conclusively that they are of great benefit to agriculturalists and should by. all means be protected by law everywhere in this country.

* U. S. Department of Agriculture Division of Ornithology and Mammalogy, Bulletin No. 3. The Hawks and Owls of the United States in their relation to Agriculture. Propared under the direction of Dr. C. Hart Merriam, Ornithologist, by A. K. Fisher, M. D., Assistant Ornithologist. Published by authority of the Secretary of Agriculture. Wash. ington: Government Printing Office, 1893. 
339a. FLORIDA RED-SHOULDERED HAWK. Buten lineatus alleni RidgW. Geog. Dist.-Florida, Texas.

In Texas Mr. Singley found this bird breeding in the densely wooded bottom lands, in tall pin oaks that border the streams. He states that the nest is placed on the large limbs of the trees, and is constructed of large and small sticks, weeds and moss; sometimes it is beautifully decorated with Spanish moss. A few of the birds prefer the uplands for a breeding place, and select pin oaks and hickory trees in the neighborhood of streams. Mr. Singley says this Hawk has the peculiar habit of placing green leaves in the nest. Sometimes the leaves are bruised and often stain the eggs, and by the time incubation is well advanced the nest is half full of the leaves. Nest building commences about the middle of March, and fresh sets of eggs may be found until the middle of April. Two or three eggs are laid. Mr. Norris has seven sets collected by Mr. Singley in Lee county, Texas. Their ground-color is dull white or bluish-white and they vary from almost entirely unmarked to heavily blotched, spotted and speckled with red, lilac and rich reddish-brown. They vary in size from 1.96 to 2.19 long by 1.67 to 1.73 broad.

339b. RED-BELIIED HAWK. Buteo lineatus elegans (Cass.) Geog. Dist.Pacific coast of the United States, south into Mexico.

This western race, whose whole under plumage is of a rich dark reddish color, is distributed from the Rocky Mountains to the Pacific. Nesting and eggs similar to those of B. 1. alleni. Average size of the eggs is $2.19 \times 1.71$. A set of two eggs in Mr. Norris' collection, taken May 2, 1887, in Los Angeles county, California, measure $2.12 \times 1.75,2.04 \times 1.77$. They are grayish-white spotted with russet.

340. ZONE-TAILED HAWK. Buteo abbreriatus Caban. Geog. Dist-Texas, Arizona and Southern California, south into the northern portion of South America.

The Zone-tailed Hawk is a peculiar species, unlike any other of the United States. It is slenderly built with long wings and tail and in its various plumages is not yet well known. The bird is a Mexican and Guatemalian species and is of quite general distribution in Texas and Arizona, where it frequents the wooded districts in the vicinity of streams. Its food is small birds, quadrupeds, beetles, locusts and grasshoppers. In Texas and Arizona this Hawk has been found nesting in May, fresh eggs being taken by the middle of the month. The nests are built on tall trees, such as cottonwood, ash, box-elders, sycamore and cypress that fringe the streams. It is placed from fifteen to forty feet from the ground, in the horizontal branches; is large and bulky, made of coarse sticks, lined with cottonwood leaves or Spanish moss. When disturbed while incubating the bird is said to fly off, uttering a loud whistling cry. The eggs are two to four in number; dull white, usually opotted, splashed or speckled, with rich chestnut or umber-brown, chiefly at the larger end; their average size is $2.15 \times 1.70$.

341. SENNETT'S WHITE-TAILED HAWK. Buteo albicaudatus sennetti Allen. Geog. Dist.-Lower Rio Grande Valley of Texas, southward through Mexico, Central and most of South America.

This fine Hawk is a rather common resident on the Rio Grande of Southern Texas and southward. Dr. Merrill mentions two nests which he found May 2, 1878, placed in the top of a yucca growing in Palo Alto prairie, about seven miles from Fort Brown. The nests were not more than eight feet from the ground, and wer good-sized platforms of twigs, with scarcely any lining. While examining these 
nests, the parents saile 3 in circles overhead, constantly uttering a cry resembling the bleating of a goat. Each nest contained on $\Theta$ egg. The first was fresh; size 2.35 x1.91; dirty-white, with a few reddish blotches at the smaller end. The second, partly incubated, was like the first, but the blotches were rather sparsely distributed over the entire egg; size, $2.35 \times 1.85$. Mr. Edwin C. Davis found a nest of this Hawk seven miles south of Fort Grifin, Texas, containing two slightly incubated eggs, on the $2 \mathrm{~d}$ of June, 1886; it was in a mesquite bush, eight feet from the ground. This is doubtless late nesting, as all other nests found were empty. Three sots of two eggs each are in Mr. Norris' collection; one taken May 2, 1884, near Corpus Christi, measures $2.20 \times 1.80,2.19 \times 1.80$; their color is light grayish, faintly and sparingly spotted with light drab; another collected in the same locality March 24, 1886, one egg of which is unmarked, and the other faintly spotted with fawn color at the large end; sizes, $2.17 \times 1.77,2.25 \times 1.78$; the third set was taken on the Arkansas river, Texas, April 2, 1888; they are dull grayish-white, faintly and sparingly marked with light fawn color; sizes, $2.33 \times 1.65,2.30 \times 1.73$.

342. SWAINSON'S HAWR. Buteo skainsoni Bonap. Geog. Dist.-Western North America from the Mississippi Valley to the Pacific; north to the Arctie regions and south to Buenos Ayres. Casual in New England.

One of the commonest and most characteristic of the large Hawks in various places of the West. Many are killed, as they commit great depredations in the poultry yards; their food, however, consists largely of birds and the smaller quadrupeds-squirrels, gophers, rats, mice, etc. The flight of Swainson's Hawk is usually slow, but in pursuit of its prey its swiftness is said to remind one of the dash of Accipiter velox, Sharp-shinned Hawk. The sites which are chosen for'nesting places by this Hawk are extremely variable; in some localities the nest is built on the ground, on bushes, small saplings and on the ledges of rocky cliffs. Old nests of hawks and crows are fitted up for the pccasion; but usually it is built in the tallest trees and in an almost inaccessible position in the outer branches. $\mathrm{Mr}$. L. Jones states that in Iowa this bird, while breeding, is found principally in moderately timbered tracts, selecting less inaccessible places for its nests than Buteo borealis, but of the same position and composition. The eggs are deposited as late as May 15, usually May 1. Mr. A. M. Shields took a set of two eggs of this Hawk, May 21, 1886, in the vicinity of Los Angeles, California, from a nest situated in the extremity of the branches of an oak tree, fully fifty feet from the ground; these are in $\mathrm{my}$ cabinet and measure $2.20 \times 1.61,2.20$

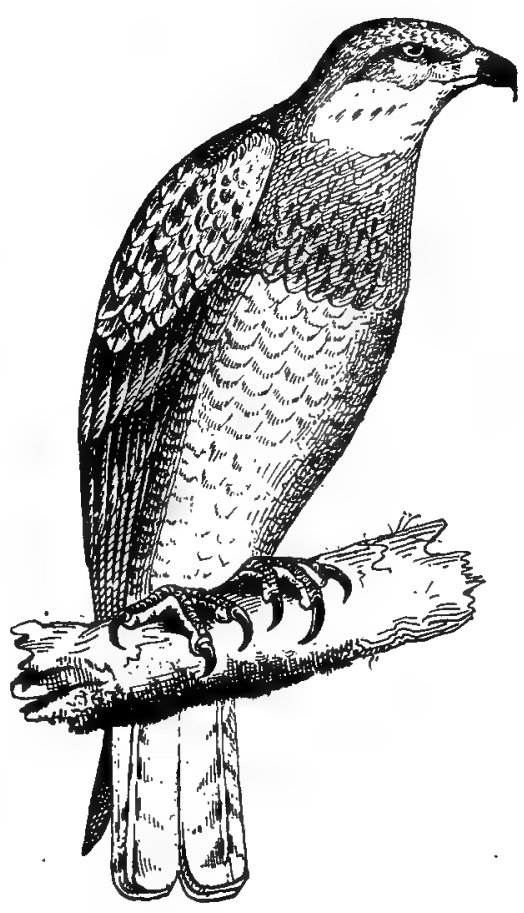

342. Swainson's Hawk. 
x1.67. The eggs of this Hawk are two to four in number, greenish-white, buffywhite or colorless, sometimes unmarked, but usually spotted, stained or blotched with reddish or rusty-brown. Their average size is $2.21 \times 1.70$.

343. BROAD-WINGED HAWK. Buteo latissimus (Wils.) Geog. Dist.Eastern North America, from New Brunswick and the Saskatchewan country south to Texas, Mexico, Central America, northern portion of South America and West Indies.

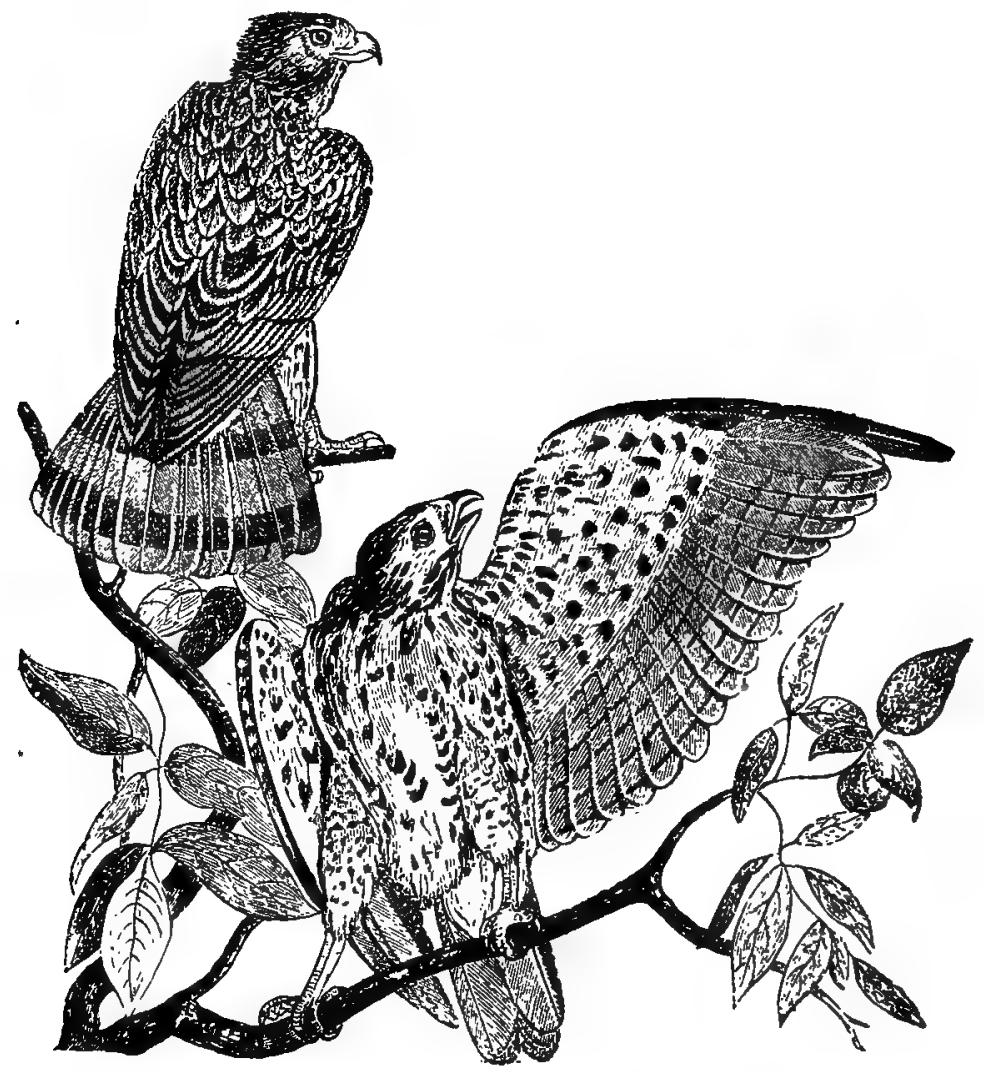

343. Broad-winged Hawk (After Audubon).

The Broad-winged Hawk is of general distribution in Eastern North America. It makes its summer home in the solitudes of dense woodlands, usually in the vi-inity of a marsh, lake or river. The bird is of an unsuspicious and spiritless character, frequently permitting the intruder to approach within a few yards of it without exhibiting the least alarm. When the nest is approached this Hawk is said to utter a piercing cry of a arm. Its food consists of squirrels, weasels, frogs, mice 
and small birds. Not always are the highest trees selected as nesting sites; in some sections the crotches and branches of trees, ten to forty feet from the ground, are usually chosen, while in other regions the tallest oak and hickory trees, sixty to eighty feet from the ground, are preferred. Abandoned crows' nests are likewise made use of by this spezies.* The nests are coarsely constructed of sticks, lined with fibrous roots, bark strips, moss or feathers. The eggs of the Broad-winged Hawk are usually deposited in May. In the forests of the Red River of the North in Minnesota, Mr. J. W. Preston found the eggs in the latter half of May; they have been taken near St. John, New Brunswick, as late as June 23; in Monroe county, Pennsylvania, June 6; and Northampton county, Pennsylvania, May 17 and 18; near Framingham, Massachusetts, May 25; in Lafayette county, Mississippi, April 9, May 17 and 18. Mr. O. C. Poling took sets of this Hawk's eggs near Quincy, Ill.,. in May. A set of two eggs were brought to me which were taken in Knox county, Ohio, May 26, 1886. The eggs are of a grayish, lavender-gray or yellowish-white ground color, variously marked with spots and blotches of fawn color and umberbrown and chestnut. Two or three are the usual number laid, and four are exceptional. The average size is $1.90 \times 1.54 \dagger$

344. SHORT-TAILED HAWK. Buteo brachyurus Vieill, Geog. Dist.-Mexico, Central America and most of South America, north to Eastern Mexico and Florida.

This tropical species comes as far north as Florida, where it is said to breed regularly, where it places its nest in the tall trees of the cypress swamps. An egg is described by the late Major Bendire as dull white, showing blue when held against a strong light. It is marked on the larger end with reddish-brown spots and blotches over about one-fourth of the surface. Size, $2.17 \times 1.61$ inches.

345. MEXICAN BLACK HAWK. Urubitinga anthracina (Licht.) Geog. Dist.-Arizona, southward to northern portions of South America.

A beautiful Hawk, known as the Mexican or Anthracite Buzzard, and found throughout tropical America, and north to Southern Arizona. The general color

* Many nests of the Raptores described by writers as resembling those of the Crow may safely be attributed to the latter as their architects, and wherever Crows breed abundantly it is almost an assurance that some species of Hawk or Owl may be found nesting in the immediate vicinity.

$\dagger$ This is the average size given by Mr. Norris, taken from a serles of seventeen sets in his cabinet, nine of which came from Minnesota, three from Mississippi, one from Massachusetts, and four from Pennsylvania; forty-two eggs in all. Mr. Norris states that there are two types of coloration in the series; twenty-four of the eggs have markings of very subdued tints of pearl-gray, lavender-gray, lilac-gray and ecru-drab, on a faint yellowish or bluish-white ground; the tints in many instances have the appearance of being under the shell, and are present in specks, spots and blotches. The remaining eighteen eggs are marked with spots and blotches of fawn color, russet, walnut-brown, burnt umber and chestnut. Some of the sizes from this series are as follows: $1.74 \times 1.52,1.76 \times 1.50,1.85 \times 1.46$, $1.87 \times 1.53,1.90 \times 1.54,1.99 \times 1.53,2.01 \times 1.62,2.06 \times 1.52$. See Ornithologist and Oologist, Vol. XII, pp. 9-11 and Vol. XIII. p. 21. 
of the adult bird is coal-black; tail-coverts narrowly tipped with white; tail black, the tip and base white, and crossed at about the middle by a broad band of white. Dr. Edgar A. Mearns met with this Hawk in the valley, of the Rio Verde, Arizona, in 1884-5. The birds were present throughout the summer months, but departed in autumn; they were extremely shy and were usually found hidden in the dense foliage of cottonwoods near water, in some low situation. Their flight he describes as swift and powerful. Occasionally one was seen eating a fish upon the sandy margin of the river. Their loudly whistled cry was rendered with great power, and different from that of any bird of prey with which he was acquainted. A nest was found built in a cottonwood tree June 19. This had evidently been the birthplace of many generations of these Hawks, for it measured four feet in depth by two feet in width. It was lined with a layer of cottonwood leaves, several inches deep, was very slightly concave, and composed of large sticks, much decayed below, showing that they had been in position for a number of years. The nest was about thirty feet from the ground and contained a half-grown nestling. Upon approaching the nest the Hawk exhibited much uneasiness and screamed lustily. A fully identified egg of this species, taken by Dr. Mearns on May 20, 1887, as described by the late Major Bendire, is oval in shape, dull white in color, and irregularly blotcheu, principally about the larger end, with small markings of different shades of brown. It measures 2.22x1.81 inches. This egg is figured on Plate 8, Fig. 8, of Maj. Bendire's great work, Vol. I.

346. MEXICAN GOSHAWK. Asturina plagiata Schlegel. Geog. Dist.Southern border of the United States, southward to Panama; accidental in Southern Illinois.

The late Maj. Charles E. Bendire states that this, one of the handsomest of our Raptor's, is not an uncommon summer resident of the southern portions of Arizona. The bird's peculiar call-notes he describes as resembling the piping of the Longbilled Curlew; their flight exceedingly graceful and swift, resembling in many respects that of the American Goshawk. They seem to prefer more open country than the latter species. In the timber bordering Rillitto creek, near Tucson, Maj. Bendire found this Hawk breeding in 1872; on the dates May 17, June 6 and 19, and June 20, nests were found containing two and three eggs each. The nests were placed in cottonwood trees, fifty and seventy-five feet from the ground; one found May 17, located in the topmost branches of a cottonwood was not a very substantial structure; a shallow platform composed principally of small cottonwood twigs, a number of them broken off green by the birds themselves. The birds were seen, while flying, to grasp at a suitable twig with the talons, usually succeeding in breaking it off at the first trial. The nest was lined with dry cottonwood leaves and the tops of the willows, the latter taken while yet green. Major Bendire describes the eggs as white or pale bluish-white, unspotted, but always more or less stained with yellowish matter hard to clean off; size $2.00 \times 1.60$.* A set of two eggs, taken in Arizona, May 23, 1884, by Mr. F. Stephens, is in the collection of the late Captain B. F. Goss. The nest from which these were taken was in a cottonwood tree, seventy-five feet from the ground; it was made of cottonwood and willow twigs, mostly green, lined

* Ornithologist and Oologist. Vol. VI, pp. 87-88. 
with small twigs and green leaves. The eggs are white, with a lew indistinct buffybrown spots, s1zes $1.96 \times 1.54,1.96 \times 1.58$.

[347.] ROUGF-IEGGED HAWK. Archibuteo lagopus (Brunn.) Geog DLtNorthern portions of the old world; Alaska.

The European Rough-legged Buzzard very much resembles our American bird, suncti-johannis. In Europe it is said to be sparingly distributed over the northern parts, appearing occasionally in Northern Britain, and with regularity in the more southern portions. It is known to breed in the rugged mountain regions of Switzerland and various parts of France and Italy, placing the bulky nest of sticks in lofty trees or on precipitous rocks. The eggs, two to four in number, varv fron dirty-

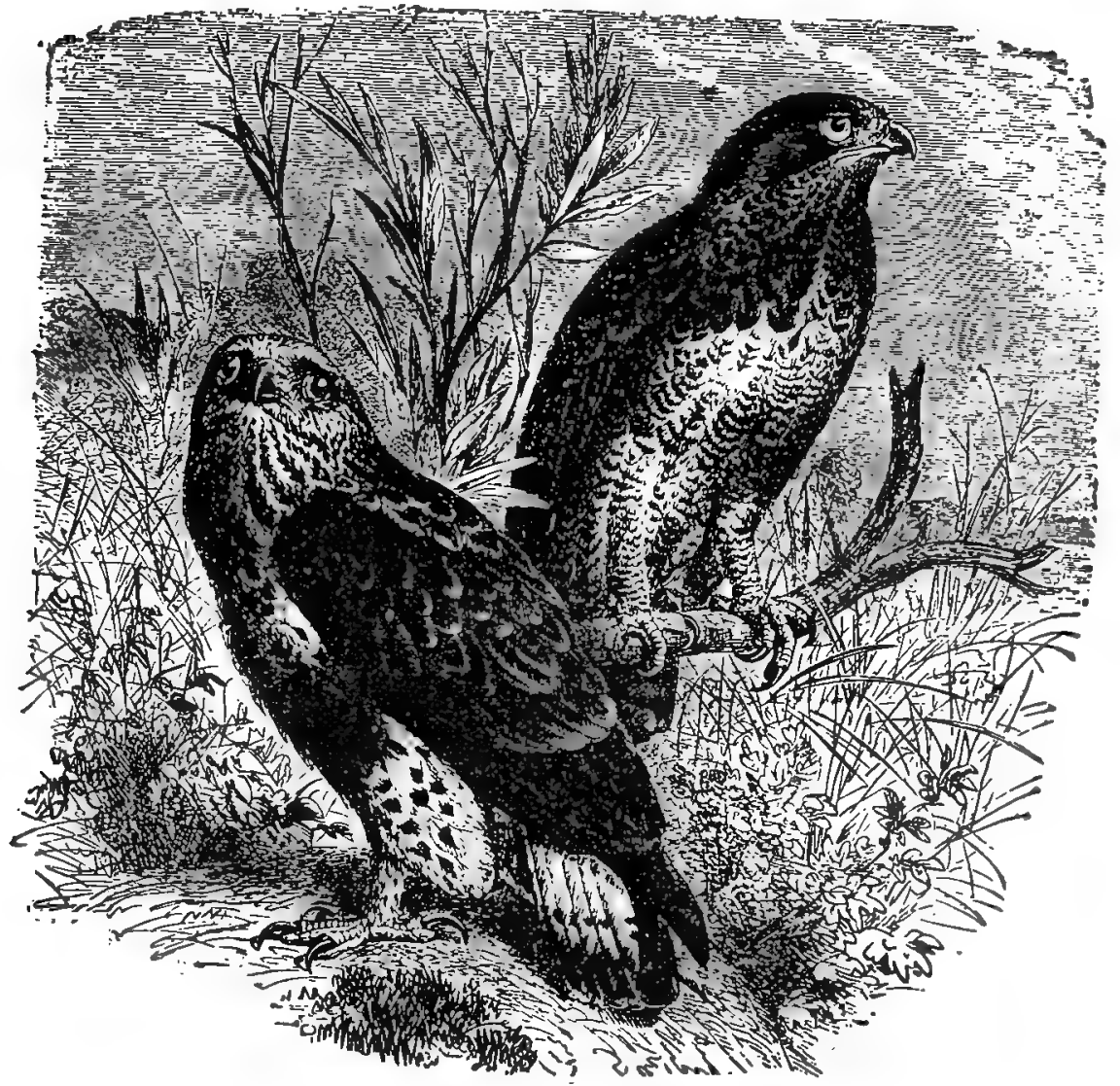

347. Rovgr-Legged Hawk (From Brehm)

white to grayish or cream-color, usually marked with numerous spots and blotches of umber and sepia-brown, and sometimes entirely unmarked; average slze $2.20 \times 1.80$. 
347a. AMERICAN ROUGH-IEGGED HAWK. Archibuteo layopus sanctijohannis (Gmel.) Geog. Dist.-Whole of North America, north of Mexican boundary breeding chiefly north of the United States.

The plumage of the "Black Hawh," as it is called, is subject to great variations. In general, the whole plumage is dark brown or blackish and light brown, gray or whitish. From these variegated stages the bird varies to more or less uniform blackish; but in either plumage it is easily recognized by the feathered shank. The Rough-legged Buzzard frequents swamps, marshes and the vicinity of lakes and rivers. It appears to be more numerous near the coast than in the interior east of the Mississippi. It is less active than most Hawks, and approaches the ow is in the habit of hunting by twilight. Its food consists chiefly of mice and frogs. The nest of this species is placed on large trees, frequently on ledges of rocks; it is a bulky structure, composed of sticks, grasses, weeds and various other materials which are soft and easily matted together. The eggs are two or three in number; they are white or buffy, sprinkled, spotted or blotched with brown; the average size given is 2.27x1.76. Mr. Norris has a set of two eggs taken June 9, 1864, on the Anderson River, in Arctic America, by R. R. MacFarlane. These are of an ivory white, spotted, splashed and blotched with cinnamon; they measure, $2.20 \times 1.76,2.22 \times 1.81$.

348. FERRUGINOUS ROUGH-LEG. Archiluteo ferrmineus (Licht.) Geog. Dist.-Western United States, across the great plains, north to the Saskatchewan region; south to Mexico. Occasionally to Illinois.

Known as the Ferruginous Rough-legged Buzzard or California Squirrel Hawk. A common species on the plains of the west, and one of the largest and handsomest of our American Hawks. In some localities this species builds its large and bulky nests on trees, ranging from ten to fifty feet from the ground; it is composed of large sticks and lined with leaves, tufts of grass and roots. Mr. F. M. Dille, of Greeley, Colorado, states the birds are not shy, and made no demonstration when he approached the nest. He describes a nest as measuring three feet in diameter and two in depth. The eggs are two or three, rarely four, in number. The late Capt. B. F. Goss informed me that he found this Hawk in Northern Dakota nesting on the ground, on rocky, precipitous hillsides; this, too, being the case seemingly from choice, for heavy timber was only a few miles away, and patches of brush and low trees were often in the immediate vicinity of the nest. May 4, 1884, the late Capt. Goss found a nest at the foot of a rock, on a steep bluff; it was composed of sticks, buffalo ribs, weed stalks and small pieces of turf, lined with dry grass. Four eggs vary greatly in color, from finely spotted to heavily splashed with different shades of brown; sizes, $2.44 \times 1.96,2.55 \times 1.96,2.45 \times 2.00,2.40 \times 1.92$. Mr. Dille states that the usual date for depositing the eggs on the plains of Colorado is about May 20, but he has taken fresh eggs as early as April 20. A set of two in Mr. Norris' collection, taken in Comal county, Texas, March 30,1873, are spotted, splashed with brown and burnt umber. They measure $2.33 \times 1.88,2.33 \times 1.88,2.34 \times 1.86$. Mr. Crandall has a series of the eggs of this species consisiting of nine sets of four eggs each, the thirtysix eggs show an average measurement of $2.43 \times 1.91$ inches.

349. GOLDEN EAGLE. Aquila rirysaetos (Linn.) Geog. Dist.-Northern portions of the Northern Hemisphere, chiefly in mountainous regions.

The Golden Eagle inhabits North America at large, and also the northern parts of the Old World. It may be recognized by the tarsus being wholly feathered to the toes; the general color of its plumage is dark-brown throughout, and the tone of the 
color, in certain lights, is of a golden-brown. It is known to breed in mountainous portions of Northern New England and New York. In the Anderson River region Mr. MacFarlane found the Golden Eagle nesting as early as the last of April, and eggs containing large embryos were taken May 27. The bird is quite common in the mountainous regions of California. The nests are built usually on inaccessible rocks, and sometimes in trees, and two or three eggs are laid, generally two. Throughout California the Golden Eagle seems to nest in trees by preference. Mr. Samuel C. Evans found it breeding in March, in the wild, rugged mountains of Santa Clara county, in the vicinity of Mt. Day; the nests were placed in sycamores, pinos and oaks-one in a large pine tree which overhung a deep and rocky canon. Mr. Norris has a set of two eggs which was taken February 26, 1886, near Tres Pinos, California, from a nest built in a solitary live oak standing in a wheat field, on the side of a gulch. This nest was very large, nearly four feet in depth and five feet in diameter; it was composed of sticks and lined with straw stubble, green grass and twigs in leaf. The eggs are whitish, heavily blotched with chestnut, and pale lavender under-shell markings; sizes, $2.86 \times 2.21,2.89 \mathrm{x}$

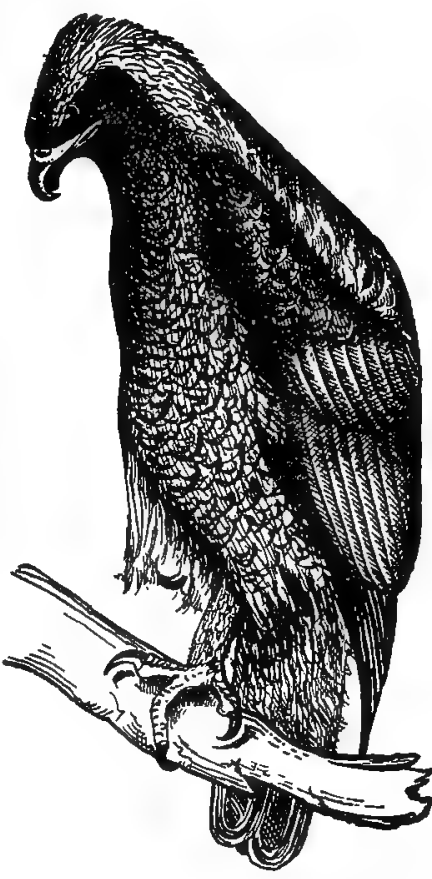

349. Golden Eagle (After Fisher).

\subsection{Mr. J. R. Chalker, in the seasons}

of 1886-7-8, collected ten sets of the eggs of this bird in San Benito county, California, nearly all of which were taken from nests placed in trees. The first set was found February 26, and the others at various dates in the month of March. Two eggs was the usual number laid, and one set of three was taken. A nest in a lofty red-wood tree, ninety-four feet from the ground, is described as being made of large sticks, lined with red-wood twigs and straw-stubble. Nests were also found placed on almost inaccessible cliffs. The eggs in colors varied from white, unmarked, to faintly and heavily marked specimens. One set was found which was densely blotched with reddish-brown all over. Maj. Bendire gives the average measurements of twentyeight specimens taken in California as $2.95 \times 2.28$. Mr. C. W. Crandall's oölogical collection contains no less than a series of over sixty eggs of the Golden Eagle. Many of these were taken by Mr. Chalker and among these is a set containing the number of three. These are beautifully marked over a whitish ground with heavy blotches, - spots and specks of chestnut, lavender, grayish and purplish brown and sienna varying in degrees of intensity in each egg, but these are always more abundant and heaviest at the large ends. Their sizes are $2.97 \times 2.37,2.96 \times 2.27,2.95 \times 2.40$ inches. They were collected March 4, 1889, in San Benito county, Cal. The nest was situated on a cliff and had been used for years, this year being lined with a little straw. Mr. Crandall states that all of his Golden Eagle eggs are heavily marked, which we believe is not generally the rule with this species. He gives the measurement of thirty-seven eggs as $2.91 \times 2.32$ inches. 
[350.] HARPY EAGLE. Thrasatos harpyia Linn. Geog. Dist.-Lower Rlo Grande Valley, casual; south to Paraguay. Louisiana (?).

The late Maj. Bendire says in his "Life Histories of North American Birds": "The Harpy Eagle, if not the largest, is certainly the most powerful of all the birds of prey found on the American continent, and can only be considered as a straggler, having been noticed in the Lower Rio Grande Valley in Texas. No specimens have as yet been taken within our borders. It breeds in Southern Mexico and thence southward as far as Bolivia and Southern Brazil." According to the authority of Dr. Felix Oswald, this bird attacks and kills large turkeys, young fawns, sloths, fullgrown foxes and badgers, middle-sized pigs and even the black Sapayou monkey (Ateles paniscus), whose size and weight exceed its own more than three times. The Harpy Eagle's nesting place is amongst the highest branches of the tallest forest trees and the more inaccessible rocks of the foothills. The nest is composed of dry sticks and moss, lichens, etc. The eggs, four or five in number, but according to Dr. Oswald the birds never hatch more than two. They are white, with yellowish-brown dots and washes; about as long, but not quite as heavy as a hen's egg. Maj. Bendire says: "Judging from the size of several specimens of the Harpy Eaglo in the U. S. National Museum collection, the egg of this species should at least be as large as that of the Golden Eagle (Aquila chryscetus), and in fact considerably larger. I have been unable to find a correct description of the egg of this species."

[351.] GRAY SEA EAGLE. Halicetus albicilla (Linn.) Geog. Dist.-Northern portions of Europe and Asia; Greenland.

A large dusky brown species known as the White-tailed or Gray Sea Eagle. Included in our North American fauna upon its occurrence in the south and southeastern coasts of Greenland, where it is common, nesting in all suitable places. It is common to the sea coasts of Europe and is rarely found inland. Breeds on the coasts of Great Britain; its most favorite haunts being the shores and islands of the northern and western coasts of Scotland; the Hebrides, Orkney and Shetland Islands, where it nests on the rocky cliffs projecting out over the water. The nests are made of sticks or seaweed. Trees are also resorted to, though much less frequently. This Eagle also breeds on the coasts of Denmark, Norway and Sweden, and those of Russia. The eggs are two or three in number, plain white, but occasionally with small faint spots of light brown, rounded ovate in shape. The average size of twenty-four eggs in Mr. Crandall's collection (of one to three eggs to a set respectively) is $2.92 \times 2.29$. These were all taken in Southern Russia and on the coast of Sweden between February 28 and April 20. There are seven sets of three eggs, one of two and one of one. The largest egg measures $3.10 \times 2.32$, the smallest $2.64 x$ 2.19. Mr. Crandall states that some of the eggs are considerably pointed.

352. BALD EAGLE. Halioetus leucocephalus (Linn.) Geog. Dist.-Whole of North America, south to México.

This great bird is common everywhere in North America. It passes through three stages of plumage; the first year the young are very dark-colored and are erroneously called "Black Eagles," the second they are "Gray Eagles," and are usually larger than the old birds. The residence of the White-headed Eagle is greatly influenced by the abundance of food, especially that of fish. It is found as far north as the Arctic Circle, and south as far as Florida and Texas. Breeds in the interior Arctic regions on the borders of lakes and rivers. Not an uncommon summer resident in Labrador, and breeds from thence southward along the Átlantic cosst to 


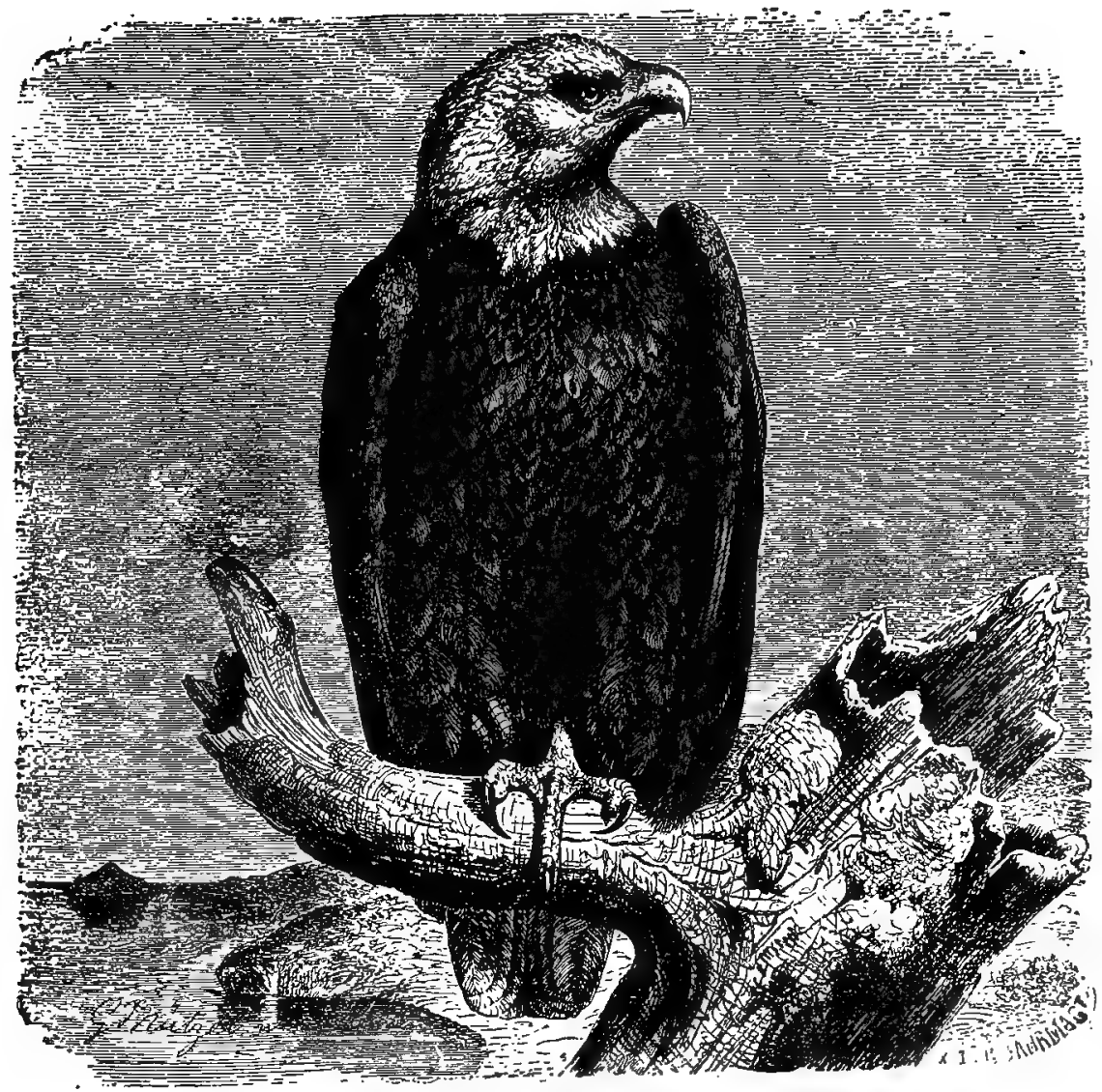

352. BaLd Eagle (From Brehm).

Florida. Common resident of Oregon and Washington Territory. It is particularly common along the Columbian River, where the supply of fish is abundant. The eggs are deposited from December to April, according to locality. The Bald Eagle is not the sluggish, fish-eating bird that some writers state it to be, devoid of energy, obtaining its living by robbing ihe industrious Osprey. "It has been known to swoop down upon flocks of Geese, Brant, Duck and Coot, select a particular bird, when the flocks scattered, and successfully carry off its victim to the nearest sand-bar. If it is a goose, and too heavy, both birds fall into the water, when the Eagle literally tows the prize along the surface until the shore is reached.* This bird also captures wounded ducks and other birds, and feeds on putrid fish and flesh. Florida seems to be a favorite breeding ground of the Bald Eagle, where they nest usually in January, but in the extreme southern portions-Cape Sable and the Keys in that region-

* Wm. Brewster: Bull. Nutt. Club, Vol. V, pp. 57-58. 
they breed in December. The nests are massive structures, made of sticks, lined with roots or grass; they are placed in trees, and their distance from the ground ranges from twenty to ninety feet. On rocky coasts, destitute of suitable trees, this Eagle resorts to the cliff for nesting places, and the same eyrie is occupied for many years. The eggs are two, rarely three in number, and are white, or ivory-white, unmarked, usually with a granulated surface and nest-stained. Three sets of two eggs each are in Mr. Norris' collection; one from Merritt's Island, Florida, taken

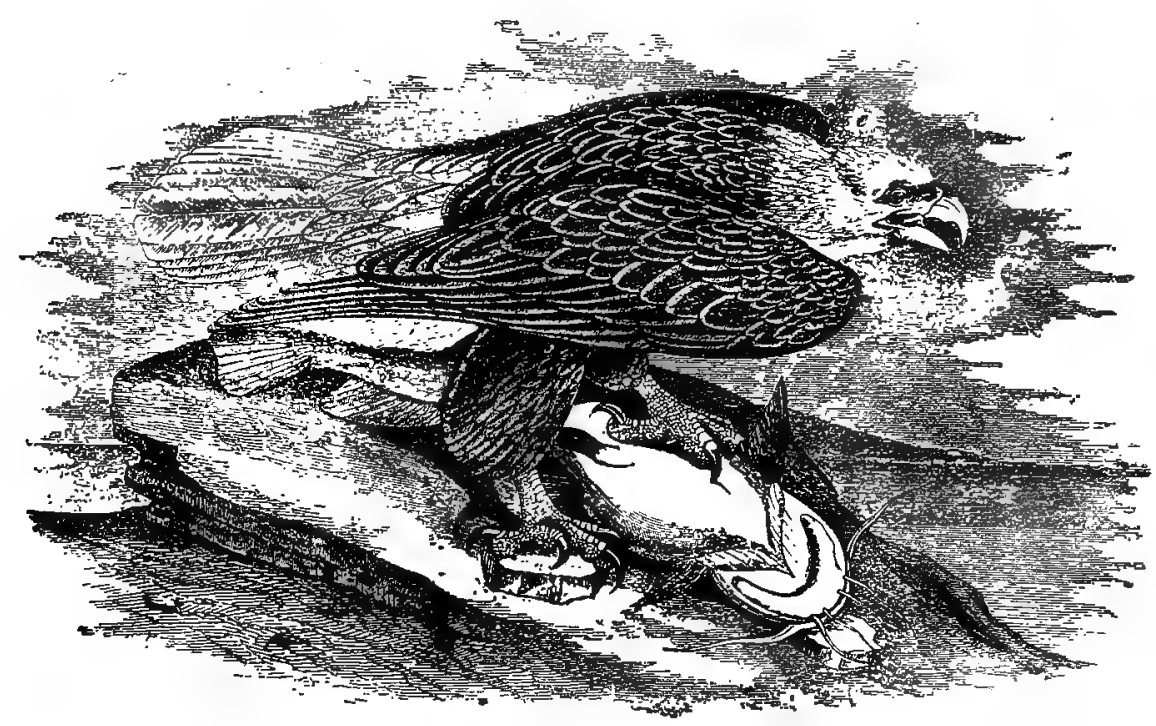

352. Bald Eagle (After Audubon).

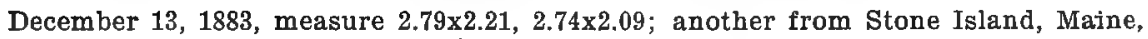
collected April 21, 1887, measure $2.88 \times 2.15,2.94 \times 2.13$; the third from Tampa, Florida, taken December 3, 1884, give the following dimensions: 2.70x2.12, 2.70x2.10. Four sets in my cabinet, collected by Mr. R. C. Stuart at Cape Sable, December 1, 4. and 16, exhibit the following sizes by sets: First, $2.57 \times 2.12,2.98 \times 2.22$; second, $2.89 \times 2.15$, $2.91 \times 2.17$; third, $2.73 \times 2.09,2.63 \times 2.02$; fourth, $2.51 \times 1.94,2.51 \times 2.00$. These eggs were taken from huge nests, placed in mangrove trees, twenty to thirty-five feet from the ground.

353. WHITE GYRFALCON. Falco islandus Brunn. Geog. Dist.-Arctic regions, including Arctic America and Greenland.

The Gyrfalcons are large handsome birds and are found in various phases of plumage, being white, more or less barred and spotted with brownish and black. They are birds of boreal regions, and nest in trees or cliffs, preying upon the smaller quadrupeds, grouse, ducks, auks, etc. The adult of the present species averages as white as the Snowy Owl. It is called Greenland Gyrfalcon and breeds in Greenland and other portions of Arctic America. Dr. Stejneger states that this species breeds on Bering Island. A pair had their nest in a steep and inaccessible rock, a couple of miles from the main village. The eggs are two to four in number. Mr. Crandall has two sets of four eggs each of this species taken at Umanack, Greenland, May 26 
and 28th, 1894. Both nests were placed upon ledges of cliffs and the structures were composed of sticks and rubbish. The eggs, Mr. Crandall informs me, have a reddish-white ground color, profusely marked with a rich dark red of varying shades, but exceedingly bright in intensity. In some these markings blend with the ground color. All the eggs show little elevations like warts on the shell. The first set mentioned measures: $2.32 \times 1.83,2.35 \times 1.83,2.38 \times 1.84,2.39 \times 1.79$ inches respectively; the second, $2.40 \times 1.82,2.38 \times 1.85,2.41 \times 1.74,2.43 \times 1.83$ inches.

354. GRAY GYRFALCON. Falco rusticulus Linn. Geog. Dist.-Extreme Northern portions of Europe, Asia and North America; Iceland, Southern Greenland; south in winter to the northern border of the United States.

The Gray Gyrfalcon is not uncommon in Iceland and Southern Greenland, and strays in winter jnto Northeastern United States. Mr. Norris has a set of two eggs of this bird, collected by Mr. Proctor in Southern Greenland, on the 30th of May, 1884. Incubation was just begun, and the parent bird was shot. The nest was placed on a shelving rock. One of the eggs is marked, over a whitish ground, with small light reddish-brown spots sparingly sprinkled over the surface, confluent at the small end, where they almost obscure the ground color. The rest of the egg has a whitish appearance. The other specimen is heavily marked over the entire surface. Sizes, $2.26 \times 1.82,2.25 \times 1.86$,

354a. GYRFALCON. Fulco rusticolus jyrfalco (Linn.) Geog. Dist.=-Northern Europe; interior or Arctic america, from Hudson's Bay to Alaska.

MacFarlane's Gyrfalcon breeds abundantly in the interior regions of Arctic America, where numerous skins and eggs are annually taken. It not infrequently visits the Northern United States in winter, and it is recorded as even reaching the Middle States. The number of eggs laid by this variety of Gyrfalcon ranges from two to four, more commonly three to four. In Mr. Crandall's collection there are two sets of four eggs each, taken April 20, 1892, and April 25, 1893; the former near Kantokino, the latter near Finnmarken, Lapland. Both nests were placed on ledges of cliffs and were composed of sticks, small twigs, feathers, etc. The first set of eggs are very light colored and may be described as appearing an almost uniform dull yellowish red; the sizes are $2.18 \times 1.68,2.28 \times 1.70,2.28 \times 1.71$, $2.20 \times 1.70$. The second is of a very dark type of coloration, the ground showing but little of the yellowish-red; the markings being of a deep burnt-umber, resembling the markings of the typical Merlin's eggs. They measure $2.34 \times 1.79,2.30 \times 1.79,2.35 x$ 1.78, 2.32x1.82 inches. These two sets are selected to show the wide contrast in coloration from a series of forty-one eggs of this species. A single egg in the cabinet of the late Capt. B. F. Goss, taken at Fort Yukon, Arctic America, in June, 1865, is flnely and evenly speckled with reddish-brown over the entire shell; the spots are partly confluent, giving the egg a reddish appearance; size $2.34 \times 1.75$, which is unusually large.

354b. BLACK GYRFALCON. Falco rusticolus obsoletus (Gmel.) Geog. Dist.Labrador; south in winter to Canada, Maine and New York.

This dusky form of the Gyrfalcon makes its home on the clifis of the rugged coasts of Labrador. Its habits are said to be the same as those of any of the foregoing belonging to the genus, and the eggs are similar. All the eggs of the several forms of Gyrfalcons present common characteristics, and do not differ from each other more than eggs known to belong to the same species of hawk are found to vary. The average size of the Black Gyrfalcon's eggs is 2.26x1.77. 
355. PRAIRIE FALCON. falco mexicanus Schleg. Geog. Dist.-Western United States, from the Eastern border of the Plains to the Pacific Ocean. Sonth into Mexico. Casual to Illinois.

The American Lanner or Prairie Falcon is an abundant species throughout the open country of Western United States. It is the representative of the two Lanners of the Old World. This Falcon is said to possess great strength and daring; It attacks and overpowers the great hares of the prairies, and other animals even larger and heavier than itself. It is very common in Wyoming and Washington Territories, Oregon and California. The Prairie Falcon nests usually on cliffs and ledges of rocks, sometimes in carities in trees. The composition of the nests is sticks with

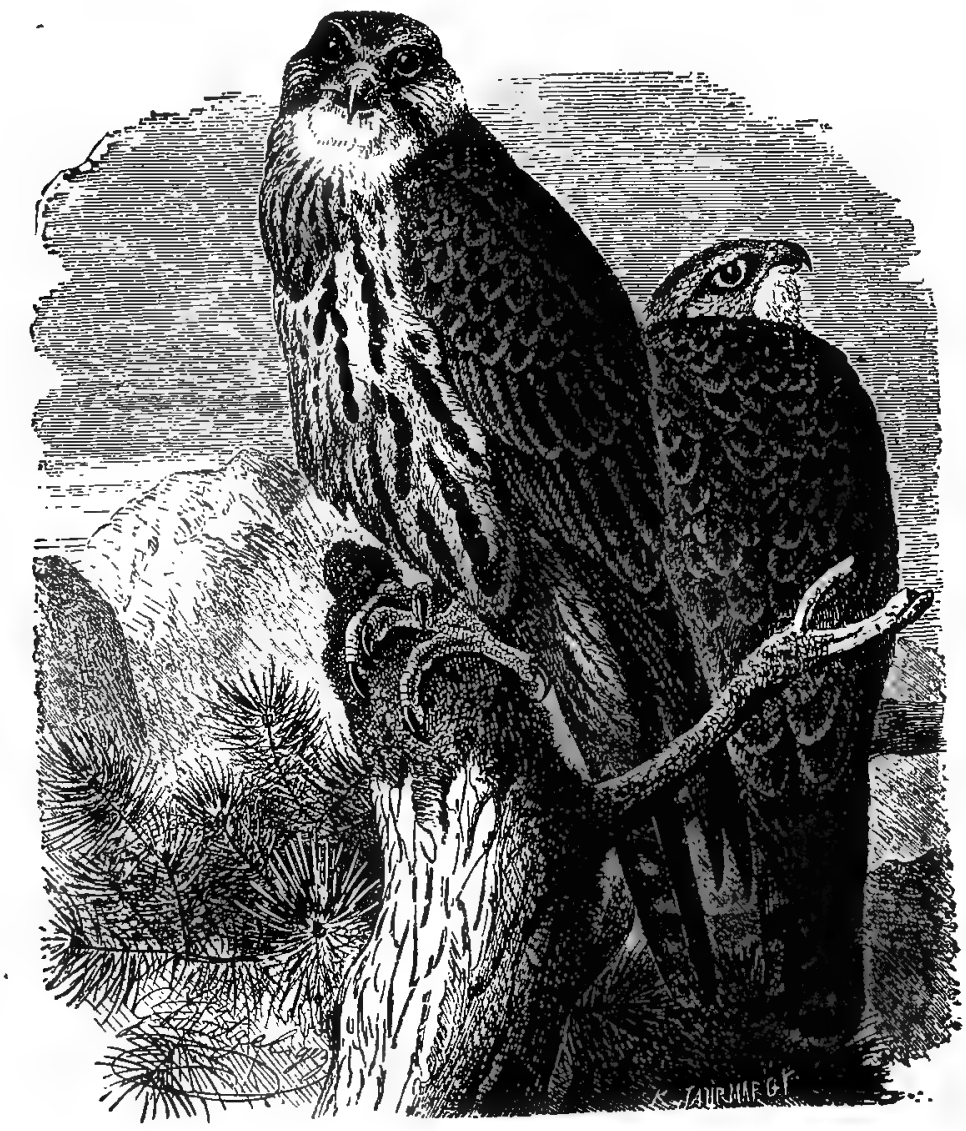

- + Lanner Falcon, not distinguishable in cut $f_{1}$ om our Prairie Falcun (From Brehm).

a lining of grasses. In some of the rocky canons of Colorado nests of this hawk have been found on the tops of those massive sandstone columns that stand solitary and alone like huge chimneys. The eggs are two to five in number. Three sets of the eggs of this species are in the cabinet of J. Parker Norris. One of five eggs, 
collected by Walter E. Bryant, near Mt. Diablo, California, exhibit the following dimensions: $2.00 \times 1.56,1.99 \times 1.56,1.98 \times 1.59,2.11 \times 1.57,1.93 \times 1.56$. These were laid upon the sand in a cavity in a large boulder. They are handsome eggs, creamy ground color, almost wholly obscured with specks, spots and cloudings of clnnamon and vinaceous-cinnamon. The second set is of two eggs, taken in Sweetwater county, Wyoming, May 1, 1887; the nest was on a rocky mound, along the Big Sandy River. The eggs are quite different from each other in appearance; in one the ground color is cinnamon, sprinkled all over with Mars brown; size, 2.13x1.66. The other has a ground color of russet, sprinkled all over with burnt umber; s1ze, 2.14x1.68. The third set consists of three eggs. They were collected May 6, 1888, in Sweetwater county, Wyoming. The nest was on a rock on the bank of the Big Sandy River. The ground color varies from a deep cream to a hazel, and it is almost wholly obscured with cinnamon, rufous and light chestnut. They measure $2.28 \mathrm{x}$ $1.68 ; 2.10 \times 1.64 ; 2.40 \times 1.67$.

356. DUCK HAWK. Falco peregrinus anatum (Bonap.) Geog. Dist.-Whole of North America.

The Peregrine Falcon, Great-footed Hawk, or Wandering Falcon, as this species Is variously called, is distributed throughout North America at large, but it can hardly be considered common anywhere. The Duck Hawk breeds as far south as latitude $36^{\circ}$, and usually in mountainous regions, or in the vicinity where water fowl are abundant. The nests are placed in natural cavities in trees, and on the sides of rocky cliffs. Colonel N. S. Goss states that this Hawk is not an uncommon resident of Kansas, and that it begins laying early in March. It is known to breed in many of the rocky regions and along the coasts of the New England States; in Pennsylvania, New York and in Michigan. It has been found nesting in the Anderson River regions in Arctic America, in Alaska and on the coast of Labrador: This species is often called Bullet Hawk, being the terror of ducks and other water fowl, pursuing and striking them down while on the wing, often seizing the bird which the hunter has killed, carrying it off when almost within his reach. The eggs of the Duck Hawk are three or four in number, and measure $2.15 \times 1.62$. They vary from creamy-white to reddish-brown, spotted, blotched and dotted with reddish-brown and chocolate of varying shades. Mr. Crandall writes me as follows concerning a series of this bird's eggs in his cabinet: "A set of four of this species in my collection, taken by R. H. Beck, in Alameda county, California, April 21, 1896, was taken from a nest on a narrow ledge of a cliff twenty feet below the top; no regular nest was made, only a few small sticks on either side of the eggs. The bird was flushed and incubation was begun. These eggs are of the dark, heavily marked type, and show the following measurements: $2.11 \times 1.64,2.28 \times 1.66,2.15 \times 1.67$ and $2.10 \times 1.68$ inches. Another set of three eggs from Greenland measure $1.99 \times 1.55,2.02 \times 1.58$ and 1.96x1.61. These are also heavily marked. Thinking perhaps it would be interesting, I herewith give the average size of my series of the European Duck Hawk. Seven sets of four, twenty-eight eggs, average 2.08x1.63. These were carefully selected from a number of sets."

356a. PEALE'S FALCON. Falco peregrinus pealei Ridgw. Geog. Dist.Aleutian and Commander Islands, south along the Pacific Coasts to Oregon.

Dr. Leonard Stejneger states that the "Black Hawk," as it is called, is a common resident of Cooper and Bering Islands, breeding in high and inaccessible cliffs. The eggs are not described, but are doubtless similar to those of F.peregrinus. 


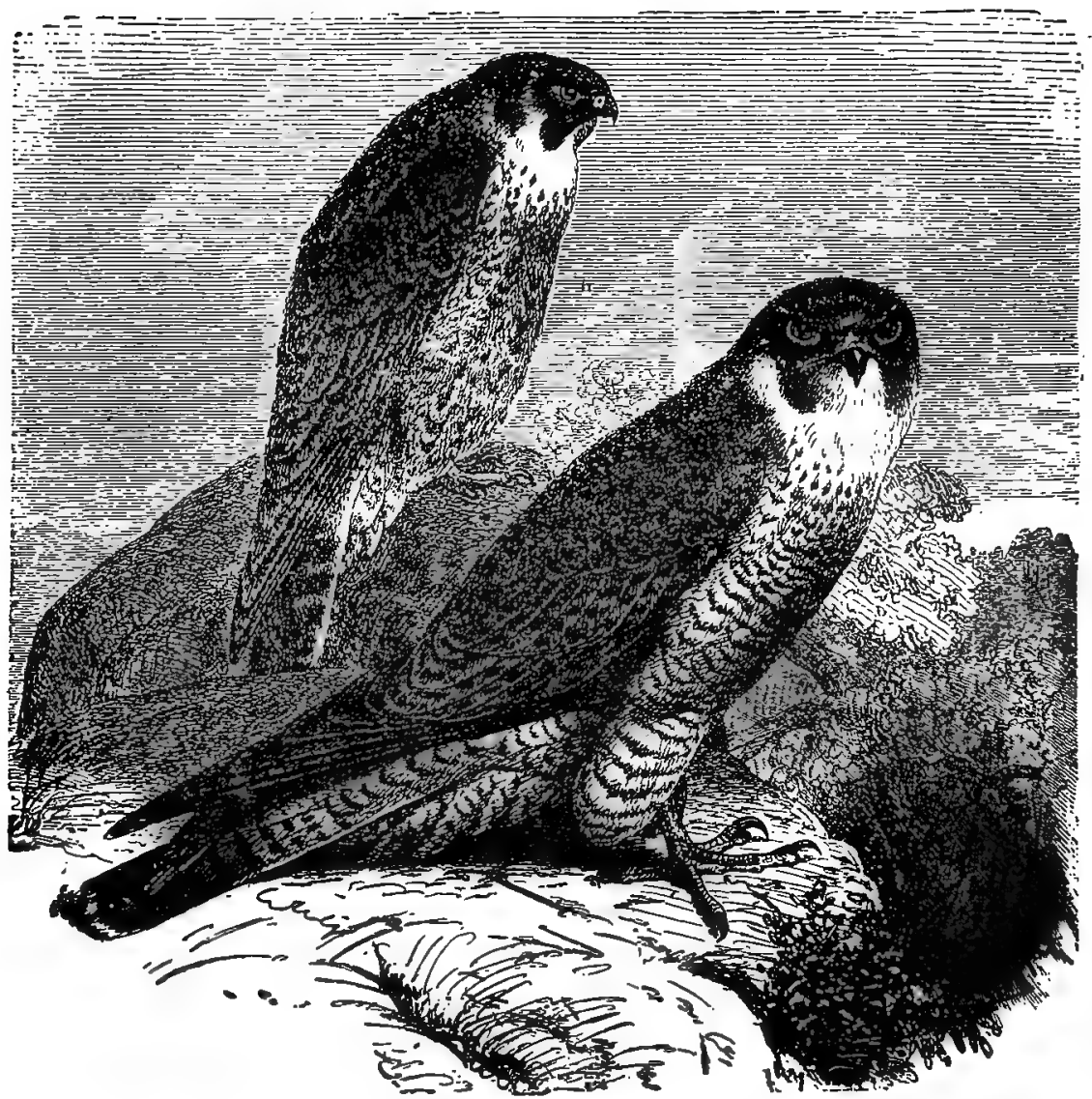

356. Duck Hawk (From Brehm).

357. PIGEON HAWK. Falco columbarius Linn. Geog. Dist.-North America in general, south in winter to West Indies and northern South America.

A handsome little Falcon, generally distributed throughout North America, and known to breed in various sections from latitude $40^{\circ}$ northward, but the maJority breed north of the United States. It subsists mostly on smaller birds, together with an occasional mouse or small squirrel, capturing them on the wing. When in pursuit of its prey the speed of its flight is something astonishing. Known to breed as far north as the Anderson and McKenzie River regions in Arctic America, and it is common in Alaska. During the breeding season it is found as far south as New Brunswick and Nova Scotla, in various New England States, New York, Delaware, otc. It formerly bred in Ohio, but not of recent date. In the West it has been found breeding in Washington Territory, Oregon, Idaho and Utah. Mr. Norris' cabinet contains two sets of four eggs each; one collected in the Wasatch Mountains, Utah, May 29, 1868. They have a cinnamon ground color, heavlly spotted and blotched 
with burnt umber; sizes, $1.56 \times 1.25,1.59 \times 1.25,1.56 \times 1.21,1.59 \times 1.23$. Another set from Bingham county, Idaho, taken May 13, 1885, have a creamy-white ground color, sprinkled, spotted and blotched with chestnut; sizes, $1.44 \times 1.22,1.56 \times 1.24,1.52 \times 1.25$, 1.47x1.22. The nests of this Hawk are variously situated; in the cavity of a cliff, in the hollow of a tree, on the branches of trees, and sometimes under the roofs or between the rafters of ruined or deserted buildings.

357ィ. BLACK MERLIN, Fulco columuarius sukleyi Ridgw. Geog. Dist.Northwest coast region of North America, from California to Sitka; eastward in Oregon and Washington.

Little is known concerning the breeding habits of this, the darkest colored of our Merlins. Major Bendire states that its range probably includes the mountain regions from Northern California to Alaska, along the coast; and in the interior it is found in Southern Oregon (Fort Klamath) and Eastern Washington (Fort Walla Walla), in both of which places he obtained specimens of the bird, but was not aware that its eggs have ever been taken. He states, however, that he is quite positive that an occasional pair breeds in the vicinity of Fort Klamath. I have no authentic information at hand which describes the nests and eggs of this Merlin, but it is reasonable to believe that they do not differ from those of Falco perfirimus pealei.

358. RICHARDSON'S MERLIN. Falco richardsonii Ridgw. Geog. Dist.Interior of North America, northward to the Arctic regions, south in winter to Texas and Arizona; straggles west to the Pacific coast.

Richardson's Merlin is said to breed in the Rocky Mountains of Colorado, and from thence northward. Its habits in general are identical with those of $F$. columburius. Little has been known respecting the nesting, eggs and breeding range of Richardson's Merlin, and no absolutely authentic eggs have been described. I now take pleasure in describing, so far as I am aware, the first genuine set of this bird's eggs in the cabinet of Mr. Crandall, of Woodside, New York. The eggs, a set of four, were taken, the female bird shot and carefully identified. The late Maj. Bendire and other oollogical "students of eminence have pronounced them genuine and the set remains unique in collections at the present time. The region in which they were taken was Calgary, Alberta, Northwest Territory, May 12, 1894, by Mr. J. E. Houseman. The ground color of the eggs is a creamy or buffy-white, shaded in places over the surface with spots, blotches, splashes and cloudings of rich reddishbrown, chestnut and rufus of various tints, interspersed with very blackish-brown blotches, like some types of coloration in the eggs of the White-tailed Kite. The measurements of the four eggs are as follows: $1.59 \times 1.25,1.60 \times 1.24,1.66 \times 1.24,1.61 \times$ 1.23 inches. In general appearance Mr. Crandall writes me that they seem to differ from any falcons which he has seen, either American or European.

[358. 1.] MERLIN. Falco regulus Pall. Geog. Dist.-Europe, etc., accidental in Greenland.

Mr. Ludvig Kumlien, of the Public Museum, Milwaukee, Wisconsin, received from Dr. C. F. Wiepken, of Oldenburg, Germany, a fine specimen of this bird, which was shot at Cape Farewell, Greenland, May 3, 1875, making an additional species to the avifauna of North America. It is a common bird in Europe, especially in the more northern portions. In Fngland it is considered migratory, while in Scotland. it resides permanently. It breeds commonly in the Orkney and Shetland Islands, placing its nest among precipitous rocks. It was formerly trained to the chase, and 
used to hawk for qualls, snipes and larks. The rugged mountain ranges on the Scottish border furnish many breeding places for the Merlin. The site generally gelected is the slde of some ravine, a projecting rock, bank, or tuft of heath. The nest consists of a scanty supply of sticks, heather, grass or moss, loosely arranged.

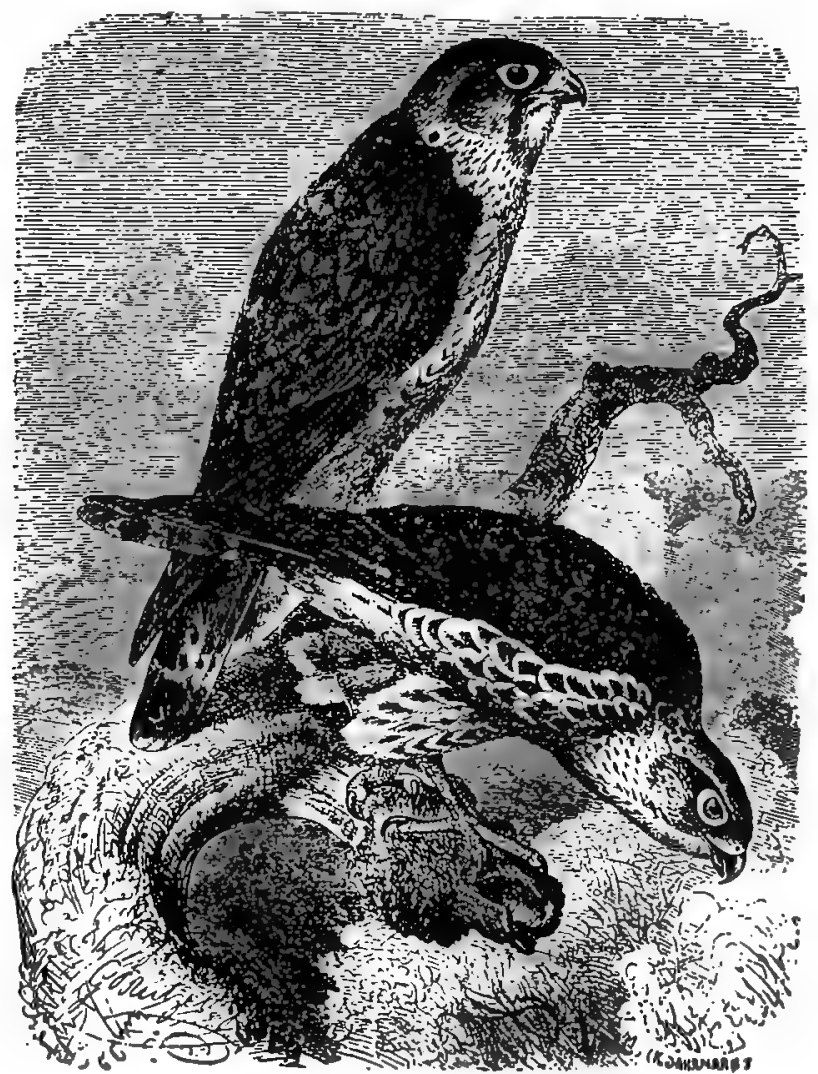

359. 1. MerLim (From Brebu)).

The eggs are three, four or five in number; Bewick says six; Temminck, five or gix. They are bluish-white, spotted and blotched, generally more thickly at the larger end, with deep reddish-brown. Average size, 1.49x1.20. Eleven sets of five eggr each are in Mr. Crandall's extensive collection. These viere taken in Lapland and various localities in Iceland, all in June between the dates ranging from the $3 d$ to the 14th. The average size of the fifty-five eggs is $1.68 \times 1.23$ inches; the longest being $1.65 \times 1.26$, the shortest $1.60 \times 1.24$.

359. APLOMADO FALCON. Falco fusco-corulescens Vieill. Geog. Dist.Southern Texas, New Mexico and Arizona, south to Patagonia. 
This beautiful bird, known as the Femoral Falcon, is common, and has a wide range in South and Central America; and specimens of the bird, its nests and eggs have been taken in Southern Texas, along the banks of the Rio Grande, and in Arizona. Dr. James C. Merrill found nests of this species on June 16, 1877, and May 7, 1878, near Fort Brown, Texas; they were placed on the tops of the low Spanish bayonet, and were simply slight platforms of twigs with deprossions, lined with

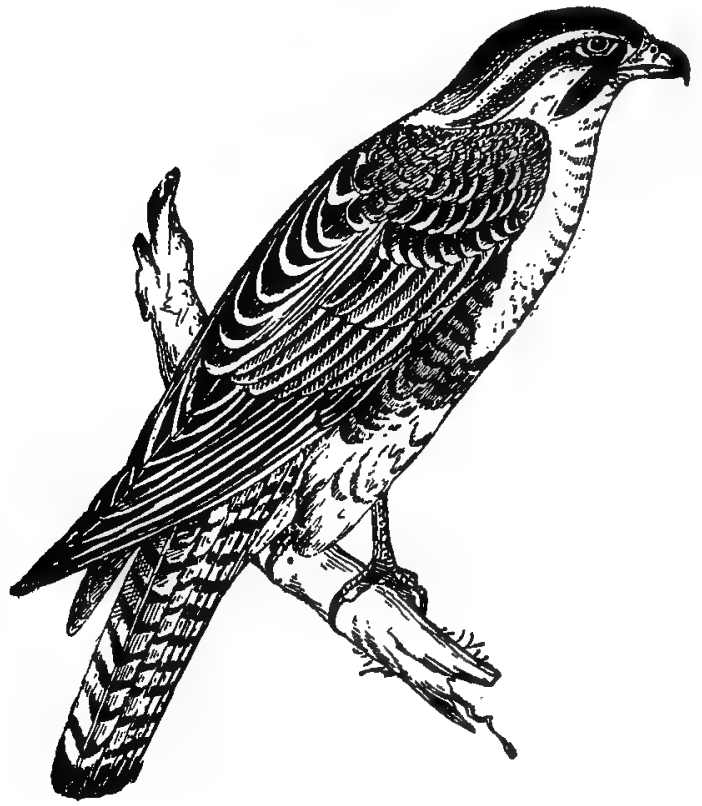

359. APLOMADO Falcon.

a little grass. Two nests contained three eggs each. The eggs measure 1.78x1.34, $1.84 \times 1.29,1.73 \times 1.32$. Their ground color is white, but so thickly dotted with reddish as to appear of that color; over these are somewhat heavier markings of deeper shades of brown. The three others measure $1.80 \times 1.29,1.77 \times 1.33,1.88 \times 1.33$.

[359. 1.] KESTREL. Falco tinnunculus Linn. Geog. Dist.-Europe, etc., accidental in Massachusetts.

Mr. Charles B. Cory, of Boston, Massachusetts, makes record of the first occurrence of this bird in North America. A female specimen was shot by a hunter at Strawberry Hill, Nantasket Beach, Massachusetts, on September 29, 1887, the skin of which is now in Mr. Cory's cabinet.* The European Kestrel thus finds a place in the avifauna of North America. It is a common species in Europe, and one of the most abundant of its tribe in Great Britain. It resembles the American Sparrow Hawk in size and general appearance, and, like that bird, it has the curious habit of poising in midair over a mouse, lizard, frog, or some other object of food before attacking them. In Great Britain it is one of the commonest Falcons, and may be found in all parts of the country. The nest is built in rocky cliffs by the sea coast,

* Auk, V. 110 and 205. 
in natural cavities of trees, in ancient ruins, in towers of churches, both in the country and cities, even in.London. The material used consists of sticks, twigs, hay, wool and feathers, all arranged in a slovenly manner. When the nest is placed in rocks, it is said that no material is used. The eggs, which are rounded-oval in form, ire four or five in number, sometimes six. They vary from a redđish to yellowish, speckled, spotted or blotched with orange-brown and reddish-brown. A great varia-

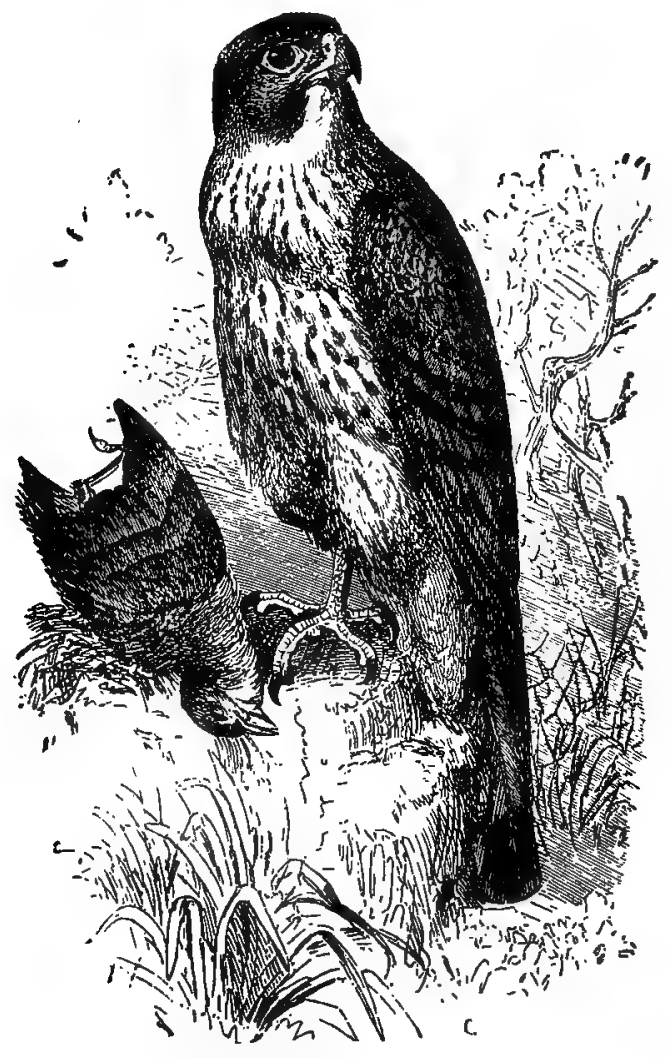

359. 1, Kestrel (From Brehm).

tion exists in the style and amount of markings in a large series of eggs. Four eggs collected in Staffordshire, England, May 12, 1884, measure 1.42x1.20, 1.48x1.24, $1.50 \times 1.30,1.53 \times 1.24$. A set of five eggs taken from an old church spire in County Antrum, Ireland, May 25, 1883, gives the following measurements: $1.58 \times 1.30,1.56 \mathrm{x}$ $1.26,1.54 \times 1.28,1.56 \times 1.26,1.54 \times 1.24$.

360. AMERICAN SPARROW HAWK. Faleo spurverius Linn. Geog. Dist.North America, east of the Rocky Mountains, south to Northern South America.

This beautiful little Hawk is abundant everywhere in North America in its several geographical races, and is familiar to every boy who has been in the fields. 
Here it may be seen hovering almost motionless in mid air, then suddenly swooping down to the ground, arises again with perhaps a field mouse in its talons. From this habit it receives the name of Mouse Hawk, aituough it also preys upon sparrows and other small birds. It is found almost everywhere, though most abundant along streams where the high sycamores whose natural cavities furnish suitable nesting places, but meadows and fields are its retreats when in search of food. It builds no nest, but deposits its eggs in the natural cavities of high trees, often in the deserted holes of woodpeckers, or in crevices in rocks, in holes in banks along rivers, or nooks about buildings. In the West it frequently occupies a deserted Magpie's nest. I have eggs of this Hawk taken from a crevice in a stone quarry on the Scioto River, where the birds have nested for years. Boxes on farm barns, provided for domestic pigeons, are often appropriated by the Sparrow Hawk, and it always proves to

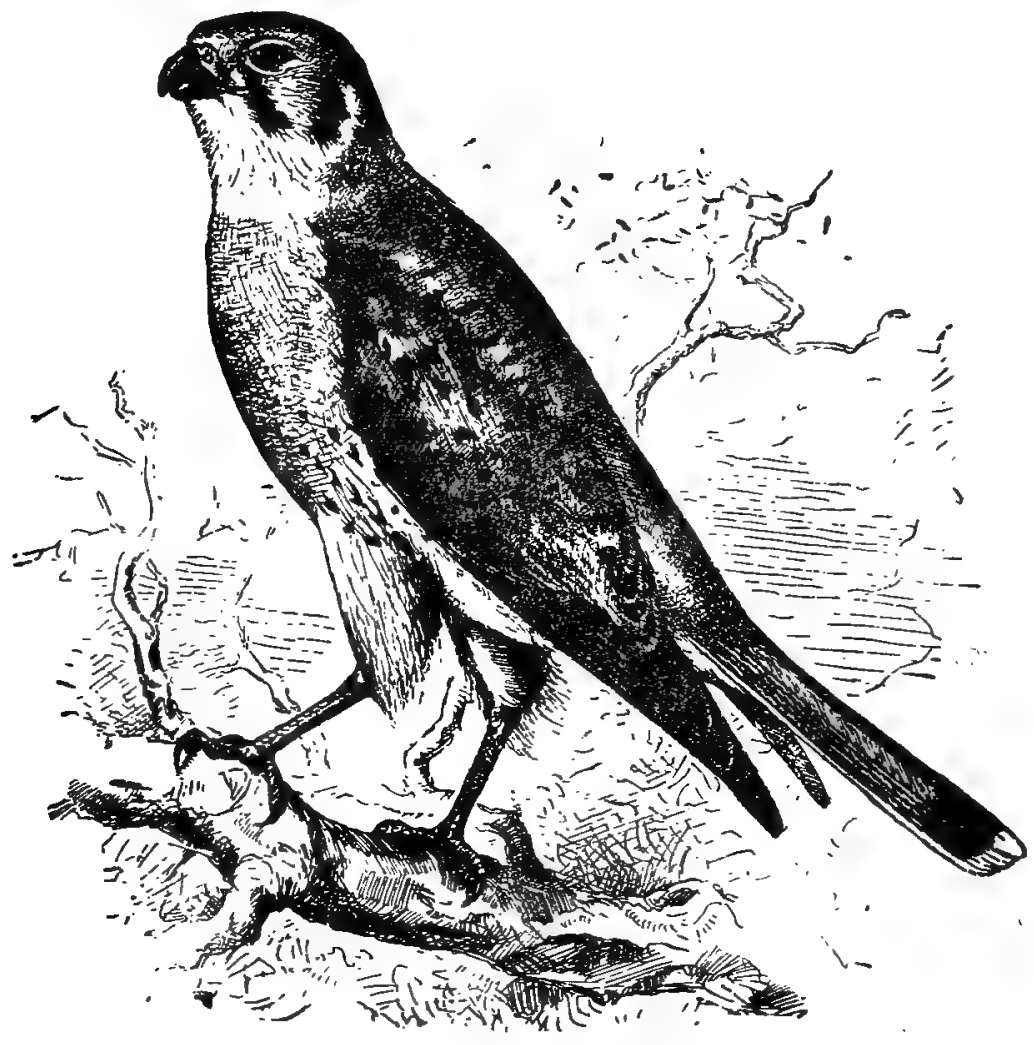

360. American Spakiow Hawk.

be a peaceable neighbor. The cavities where the eggs are deposited generally' contain no lining. The eggs of the Sparrow Hawk are four or five; rarely six in number. A series of lorty eggs before me exhibit the usual wide diversity of coloration that is to be found in eggs with- spotted shells. Most of my eggs are from Ohio, Indiana and Kentucky, while two sets are from California. The ground color varies 
from a yellowish or creamy-white to reddish or pinkish-buff; the surface is sprinkled, splashed, blotched, spotted and clouded with shades of chestnut and cinnamonbrown, and the markings may be more numerous and heavier at either end, and they may be so confluent as to conceal the ground color. The largest eggs I have are from Ohio, taken by Robert Linton, April 20, four in number. Sizes, 1.37x1:15, 1.40x $1.13,1.38 \times 1.12,1.44 \times 1.16$. The average size of the Sparrow Hawk's eggs is 1.36x1.12. They are usually deposited in April or in the first half of May.

360a. DESERT SPARROW HAWK. Falco sparterius deserticolus Mearns. Geog. Dist.-Western United States, north to British Columbia and Western Montana.

The nidification and general habits of this subspecies are in most cases identical with those of its Eastern representatives. Mr. L. P. Williams, of Redlands, California, writes me that he found this hawk nesting in holes in the bank of a creek in that vicinity. He states that the holes were dug on an average of about fifteen feet above the stream and were about twelve inches deep. A set of five and one of four eggs were taken from a hole from which he had previously obtained a set of Redshafted Flicker's eggs. The Hawks, he states, dug the holes themselves, and the nest lining was nothing but the dust from the walls.

360u. ST. LUCAS SPARROW HAWK. Falco sparverius peninsularis Mearns. Geog. Dist.-Lower California.

This geographical race, confined to Lower California, has the same habits which characterize the American Sparrow Hawk of the Eastern States.

[361.] CUBAN SPARROW HAWK, Falco dominicensis Gmel. Geog. Dist.Cuba; casual in Florida.

A darker colored bird than $F$. sparterius is a common resident of the Islands of Cuba and Haiti, and it secures a place in the North American avifauna on the strength of stragglers having been taken in Florida. The general habits of the Cuban Sparrow Hawk are counterparts of those of the species of Eastern United States. The eggs are from three to five in number and average a trifle smaller than those of $S$. sparterius.

362. AUDUBON'S CARACARA. Polyburus rheriucuy (Jacq.) Geog. Dist.Northern South America (Ecuador and Guiana) north to the southern border of the United States, Florida, Texas and Arizona.

Common to the Southern border of the United States, and known as the Mexican Fagle or Buzzard-intermediate between the Eagles and Buzzards, and resembling woth in its habits. It catches some of its prey living, but feeds readily upon dead animals. Although sluggish at times, it is said to fly well, moving in a direct line, resembling the Black Vulture somewhat, flapping and sailing alternately, but when high in air, circles like a Hawk or Eagle. Dr. Merrill records this bird as a common resident, but more abundant in winter than summer in the vicinity of Fort Brown, Texas, and Mr. George B. Sennett also mentions it as not uncommon in the region of Brownswille. It has been found breeding as far, north as Comal, Hays and Lee counties, Texas, in the months of March and April, and in Jefferson county as late as March 30. Mr. Stuart informs me that he has always met with this bird breeding on the large prairies of Southern Florida in March and April. Eggs were taken April 4. The tops of the cabbage palmetto trees are their favorite nesting places in that region. The nests in Texas and Mexico are bullt in trees or bushes, and sometimes in cliffs; they are bulky platforms of branches, with a slight depression, lined with twigs, roots and grasses, and frequently altogether without lining. Both sexes 


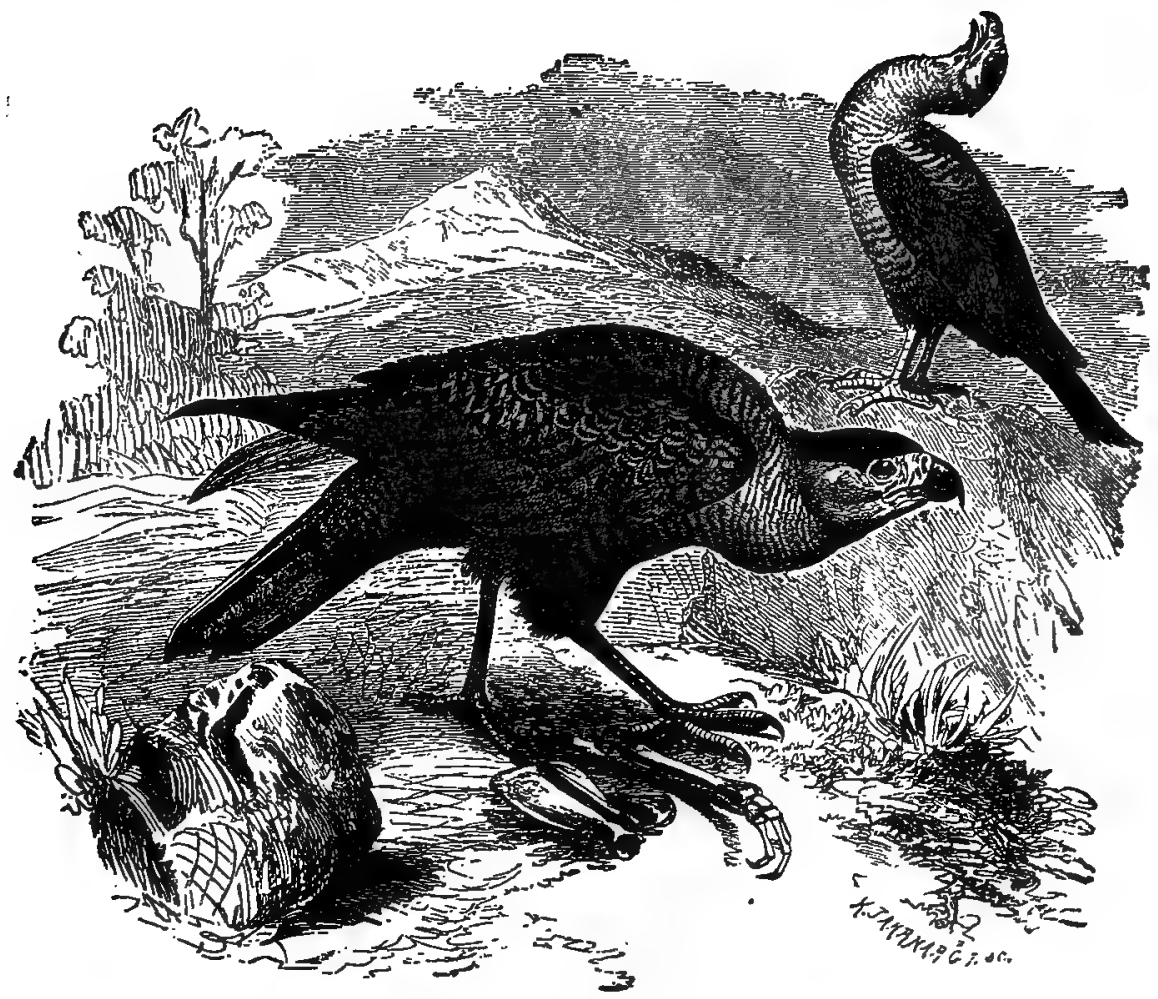

362. The Caracara (Fium Brehm).

incubate. Two or three eggs are laid, and they are noted for the beauty of their coloration. On a ground color varying from light and dark cinnamon to reddish and umber-brown, are specks, spots, blotches and cloudings of yellowish or reddish-, brown, bright chestnut, umber or claret-brown. The markings are variously distributed over the surface; in some specimens they are dispersed over the entire egg, while in othersscattering or more abundant at the smaller or greater half; occasional specimens are found almost entirely unmarked. The sizes vary from 2.10 to 2.92 in length by 1.37 to 1.90 in breadth.

363. GUadalupe Caracara. Polyborus intosus Ridgw.-Geog. Dist.Guadalupe Island, Lower California.

This is a much paler and browner colored species than the preceding. It was and possibly is a resident of Guadalupe Island.From all accounts its general habits are the same as those of Audubon's Caracara, and there is probably little difference in its nesting and eggs.

364. AMERICAN OSPREY. Pandion haliatus carolinensis (Gmel.) Geog Dist.-Nearly cosmopolitan. In America from Alaska and Hudson Bay south t, Wert Indies and Northern South America. 
This winged fisher Inhabits the entire temperate North America, breeding anywhere in suitable places throughout its range. Found about inland waters, and particularly along the sea coast. Mr. W. W. Worthington, of Shelter Island, N. Y., says they are exceedingly variable in the choice of a nesting place. On Gardiner's Island they all bulld in trees at distances varying from ten to seventy-five feet from the ground; on Plum Island, where a great many of them breed, a large number place their nests on the yround, some being built up to the height of four or five feet, while others are simply a few sticks arranged in a circle, and the eggs laid on bare sand. On Shelter Island they build on the chimneys of houses, and a pair has a nest on the cross-bar of a telegraph pole. Another pair has a nest on a large rock in Gardiner's Bay, near Gardiner's Island. "They are made chiefly of coarse sticks and sea weed and anything that is handy, such as pieces of dry cow dung, bones, old shoes, straw, etc. A curious nest of the Fish Hawk was found by Mr. S. C. Shick in May, 1888, on the coast of New Jersey. A set of three eggs was taken, and upon de-

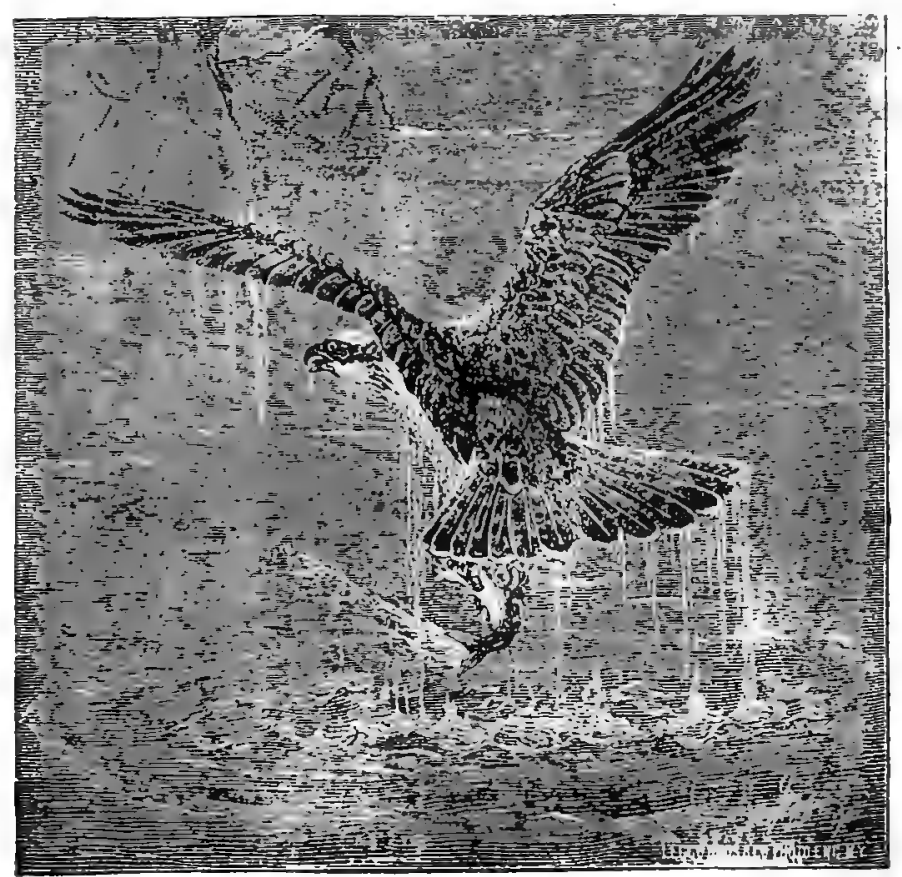

i64. Fish Hawr, or Osprey.

gcending the tree, Mr. Shick observed a nest of the purple Grackle, Quisculus quiscula, securely imbedded in the loose material of the Osprey's nest; from this he took five eggs. At the bottom of the Osprey's nest was a thick, rotten limb, in whlch there was a Tree Swallow's nest containing seven eggs. Mr. Worthington, who has collected hundreds of the eggs of this species. and to whom I am indebted for a large series, says the largest. set of eggs he has ever taken or seen is four; the usual number, however, is three, though sets of two are common. They are subject to great variation; the ground color is of yellowtsh or creamy-whtte, spotted, streaked and 
blotched with reddish-brown and umber, so thickly at the larger end as to completely obscure the ground, some are marked chiefly at the smaller end; in a series of two hundred eggs before me, thcre is a wonderful diversity of coloring; some are almost entirely unmarked. The shapes and sizes also exhibit great variations. Four gelected specimens measure $2.05 \times 1.65,2.21 \times 1.76,2.42 \times 1.76,2.54 \times 1.87$. The average bize is $2.40 \times 1.75$.

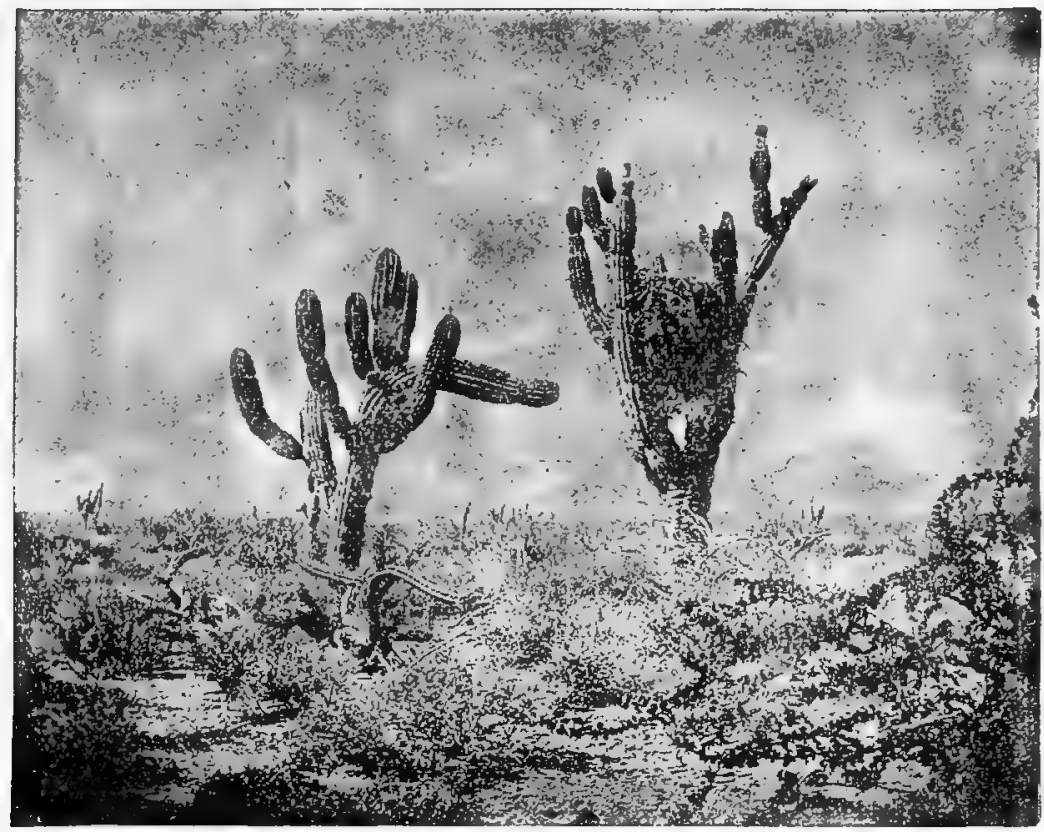

864. Osprey's Nest in Grant Cactus. (From The Nidologist.)

365. AMERICAN BARN OWL. Strix pratincola Bonap. Geog. Dist.United Sțates in general, south into Mexico.

A beautiful ochraceous-yellow or amber-colored owl; sometimes called the "Monkey-faced Owl." A constant resident of the southern portions of the United States. Mr. Stuart says that in Florida the Barn Owl breeds most generally in March, usually in hollow trees, sometimes in deserted buildings or in the wrecks of boats left along the coast. I am informed by Mr. Shiclds that in the region of Los Angeles, California, this Owl nests almost anywhere; in church towers, hollow trees, holes in banks, In barns, pigeon houses, old crows' nests, and even in holes in the pround. He took a set of five eggs from a nest in a burrow far out upon the plains. The breeding season he states begins about the first of April, and continues until the last of June. Natural cavities of trees are this bird's usual nesting places. Mr. Samuel C. Evans writes ths. 2long the Santa Anna River are high banks, perforated with holes, in which these owls nest. The eggs are often found in various stages of incubation in the same nest-some fresh and others nearly hatched. The nests are scantily supplied with a few sticks, straw, bones and other refuse of food. The number of eggs deposited by the Barn Owl ranges from flve to eleven, rarely the latter 
number; some writers say three to ten. I know of several authentic sets of eleven. Their color is plain, dead white; their shape ovate. Six specimens measure 1.75x1.35, $1.67 \times 1.30,1.79 \times 1.33,1.67 \times 1.34,1.72 \times 1.35,1.68 \times 1.29$. Twenty-eight specimens have an average size of $1.74 \times 1.30$. The largest egg of the Owl of which I have any record is in the collection of Joseph M. Wade, of Boston, Massachusetts; it measures $1.97 \times 1.40$.

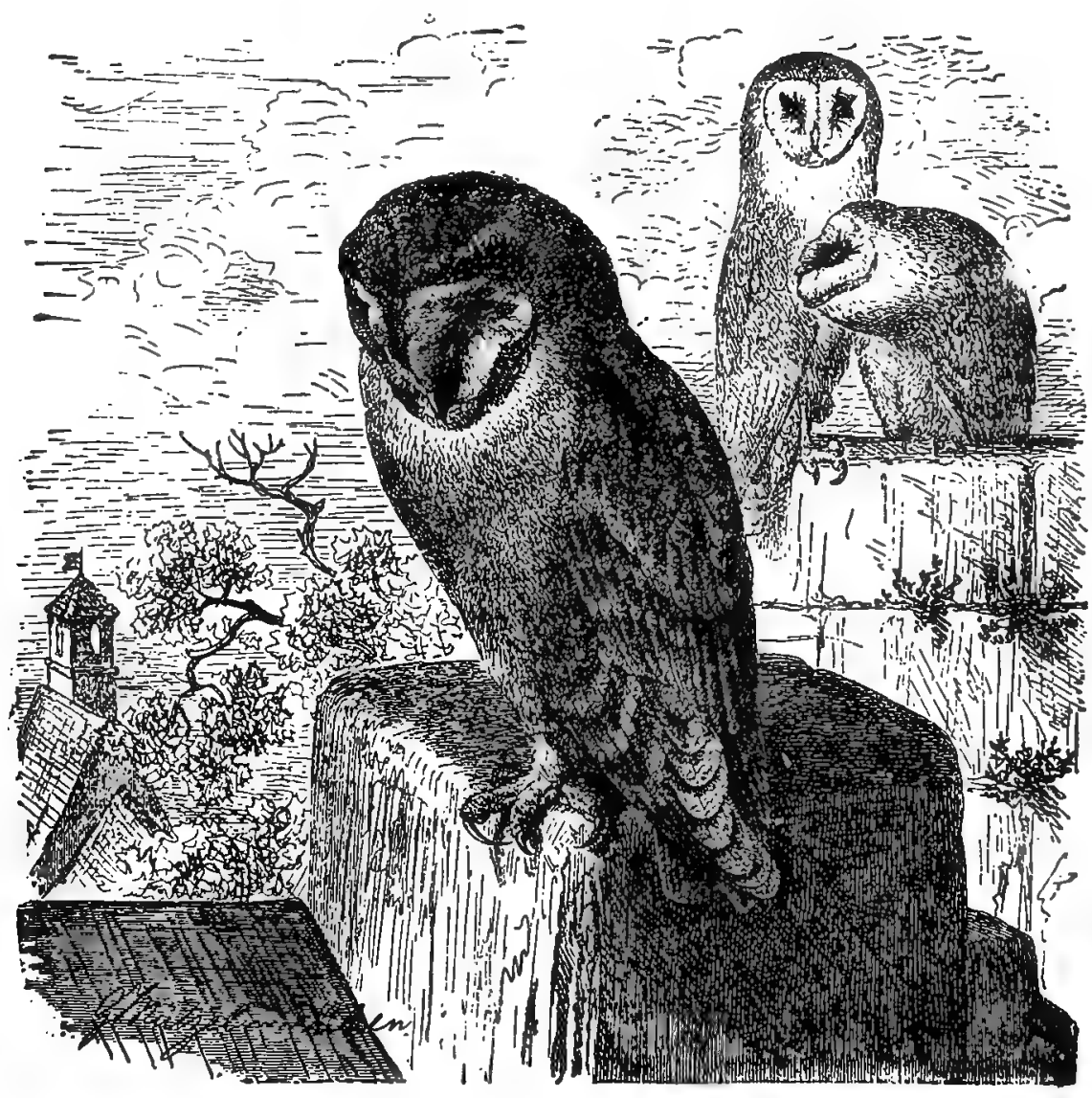

+ Baxn Owis (From Brehm)

366. AMERICAN IONG-EARED OWL. Isin Tilsonianus (Less.) Geog. Dist.- Temperate North America, south into Mexico.

The Long-eared Owl is a common resident and generally distributed throughout North America at large. It is of nocturnal habits, thus escaping observation, even where it is very common. Itg food consists chiefly of mice and other small rodents. Breeds in suitable places wherever tound. Forests of evergreens are favorite re- 
sorts of this species for breeding purposes. The nest is constructed with very little art; composed of a few sticks with a more or less complete lining of feathers. Various nesting places are selected; such as a hollow tree or stump, rift of rock, an old crow's or hawk's nest, which is repaired with a few sticks. In some localities the nest is made on the ground or on low bushes, and the same nest is occupied for several years. In the West where this Owl is very abundant it frequently deposits its eggs in old Magpie's nests. In California it begins nesting as early as the middle of February; in Kansas the eggs are deposited early in April. The eggs are from three to six, and sometimes seven in number; they are white and oval in shape. Three eggs of this Owl are in my collection, taken from an old hawk's nest in Knox county, Ohio, April 20,1884; they were so far advanced in incubation that they could hardly be preserved; these measure $1.62 \times 1.32,1.57 \times 1.28,1.59 \times 1.35$. Three eggs from a set of five collected in Marion county, Ohio, April 9, 1884, measure 1.65x1.27, 1.59x $1.33,1.75 \times 1.28$. A set of six eggs from an old Magpie's nest, collected in Douglas

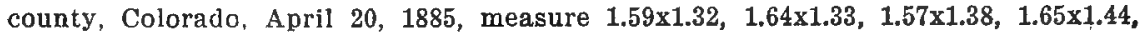
$1.60 \times 1.35,1.60 \times 1.40$.

367. SHORT-EARED OWL. Asio accipitrinus (Pall.) Geog. Dist.-Entiro North America; nearly cosmopolitan.

The Marsh Owl, or Short-eared Owl, is found throughout North America at large, but is more abundant in the Arctic regions during the breeding season than it is in the United States. It frequents the marshes, the thickets of bottom lands, and it seems to be particularly common in the tall weeds and grass of fields and meadows. In the West it is found on the vast prairies, along sloughs, hiding in the daytime among the sage bushes and tall grass. This Owl is the species commonly shot by sportsmen, as it rises from a seld, marsh or thicket. It is nocturnal, but often hunts its food on dark days; this consists of field mice, moles, shrews and other small rodents. The nest is made on the ground in the matted grass of marsh land; it may be found in a derression, at the foot of a bush, beside a $\log$, or in a burrow made by a rabbit or a muskrat; a few sticks, soft grasses and a few of its own feathers usually comprise the nest proper; sometimes the eggs are laid on the bare ground. The complement of eggs ranges from four to seven. In Ohio they are deposited in the month of April, sometimes as early as the latter part of March, or as late as the middle of May. Within these dates it doubtless may be found breeding throughout the United States. 'A set of six eggs in my cabinet, with the parent bird, collected by A. Corwin, in Morrow county, Chio, May 8, 1884, measure $1.60 \mathrm{x}$ $1.20,1.56 \times 1.19,1.50 \times 1.21,1.52 \times 1.20,1.64 \times 1.18,1.56 \times 1.22$. They are white and oval in shape. The nest was on the ground, between logs, at the edge of a blackberry patch. The average size of the eggs is $1.55 \times 1.25$.

368. BARRED OWL. Syrnium nebulosum (Forst.) Geog. Dist.-Eastern United States, north to southern British Provinces; south to Georgia and Northern Texas 
Called the American Hoot Owl or Wood Owl, and Round-headed Owl. A large

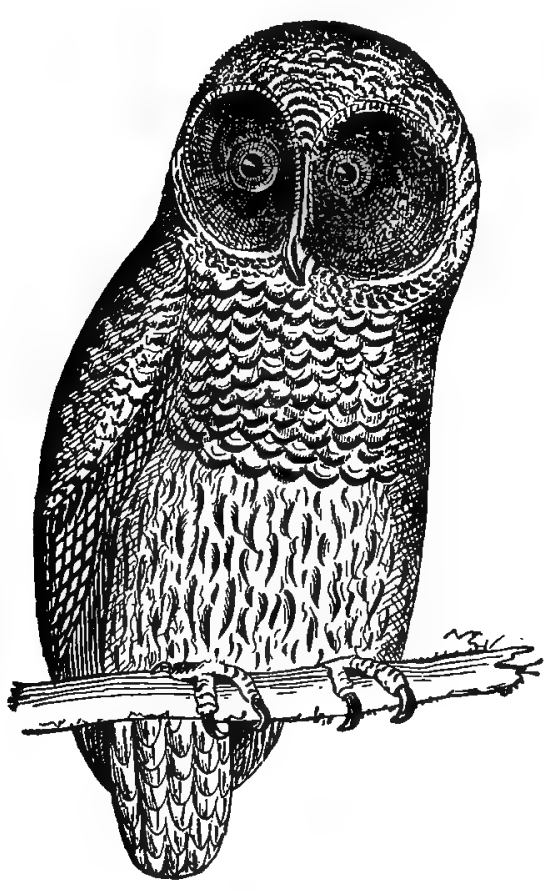

368. Barred OWL (After Jasper). dark-eyed species, common to wooded lands of Eastern United States, especially bottom woods; those of swamps, along ravines and rivers where there is a heavy growth of tall timber. The loud, laughing notes of this $O w 1$, heard in the night, are something terrible, and if heard about the farm-house or camp-fire will not soon be forgotten. Its flight is soft, as if on wings of down, noiseless, quick and easy. Nests in hollows of trees, in old nests of hawks and crows. In Ohio it is sald to breed as early as the last of February, but I have always found it nesting in April and the first half of May. In New London county, Connecticut, Mr. C. L. Rawson has taken eggs of this Owl in February, which were deposited on a solid cake of ice in a cavity or in the open nest; he states that of late years full clutches of eggs are deposited by the last of March. The usual time of nesting in Iowa is March and April. The same nesting place is occupied by the birds for years, even after being robbed many times. The eggs are two or three in number, very rarely four; globular, white. Between the eggs of this species and those of the Great Horned OwI there is commonly considerab!e difference in dimensions in favor of the former, but sometimes they approach each other so closely that to identify them by size alone is impossible. The Barred Owls' eggs measure in long diameter from 1.87 to 2.20 , and in short diameter from 1.50 to 1.75 .

368a. FLORIDA BARRED OWL. Syrnium nebulosum alleni Ridgw. Geog. Dist.-Florida, Texas, Louisiana and adjoining regions.

A darker colored race found in Florida, Texas, etc. Mr. Singley states this is the commonest owl in Lee county, Texas, where it frequents almost exclusively the thick wooded bottom lands. He found seventeen nests in hollows of trees with eggs or young, and the number in each was invariably two. The sizes of a set of two eggs taken March 20, 1885, now in Mr. Norris' collection, are 1.89x1.58, 1.86x1.61; six other specimens measure $1.97 \times 1.78,1.90 \times 1.61,1.88 \times 1.67,1.89 \times 1.60,1.81 \times 154,1.87 \times 1.63$. The eggs are subspherical, pure white, smooth, without granulations

369. SPOTTED OWL. Syrnium occidentale Xantus. Geog. Dist.-Southwestern United States, California, Arizona, New Mexico, Lower California and Mexico.

By no means a common bird and comparatively little is known concerning its life history. The Western Barred Owl was first described in 1859 from a specimen which remained unique in collections until Major Bendire rediscovered it in Arizona 
in the spring of 1872. A nest was found April 17, which appeared to have been built by the birds themselves, and was placed about thirty feet from the ground; composed bf small sticks and twigs, lined with grasses, bark and a few feathers. It contained one white globular egg. Mr. Ridgway gives the size of an egg as $2.05 \times 1.80$. Mr. Norris has a set of two eggs collected by E. M. Haight, near Riverside, California, May 19, 1885. They measure $2.11 \times 1.67,2.12 \times 1.68$; they were laid on the bare ground at the base of a large rock.

370. GREAT GRAY OWL. Scutipter cincra (Gmel.) Geog. Dist.-Arctic America, south in winter to the northern border of the United States.

An immense owl-one of the largest in North America,-round-headed and very much resembling the Barred Owl in appearance. It breeds far northward. Dr. Richardson met with this species in the fur regions and found it common on the borders of Great Bear Lake, keeping constantly in the woods, hunting hares and other smaller quadrupeds. May 23 a nest was found built on the top of a lofty balsam-poplar, composed of sticks with a lining of feathers. Mr. MacFarlane found this Owl abundant in the Anderson River region, and on July 19 discovered a nest built in the top of a pine tree, twenty feet from the ground; it was composed of sticks, mosses and thinly lined with down. The eggs are white, two or three in number, and the average size given is $2.16 \times 1.71$.

[370a.] LAPP OWL. Scotiaptex cinerea lapponica (Retz.) Geog. Dist.Arctic portions of the Old World; accidental in Alaska (Norton Sounu).

A lighter colored bird than the Great Gray Owl, and is given a place in our avifauna on the grounds of a single specimen brought to Mr. L. M. Turner from the Yukon Delta April 15, 1876. According to Dresser this Owl is considered one of the rarest inhabiting the Polar Arctic region, and is almost entirely confined to the more boreal districts, where it is a resident in the upper portions of the forest belt, but rarely straggling lower into the northern parts of Central Europe. It has not been met with in Great Britain, Greenland or Iceland, but is found throughout the northern portions of the Scandinavian Peninsula. The nests of the Lapp Owl are built chiefly in fir trees, often at considerable heights. They are composed of sticks, small twigs, heather, and sometimes are made of any kind of rubbish near at hand. The eggs are from two to six in number, pure white, but have a finer shell texture than those of the Great Horned Owl. Two sets of this bird's eggs are in the collection of Mr. C. W. Crandall, of Woodside, New York. One is of six eggs, taken near Kittila. Lapland, April 8, 1891. The measurements of the eggs are as follows: $2.16 \times 1.67,2.17 \times$ $1.68,2.31 \times 1.71,2.25 \times 1.66,2.12 \times 1.70,2.09 \times 1.61$ inches. The nest was placed high up in a

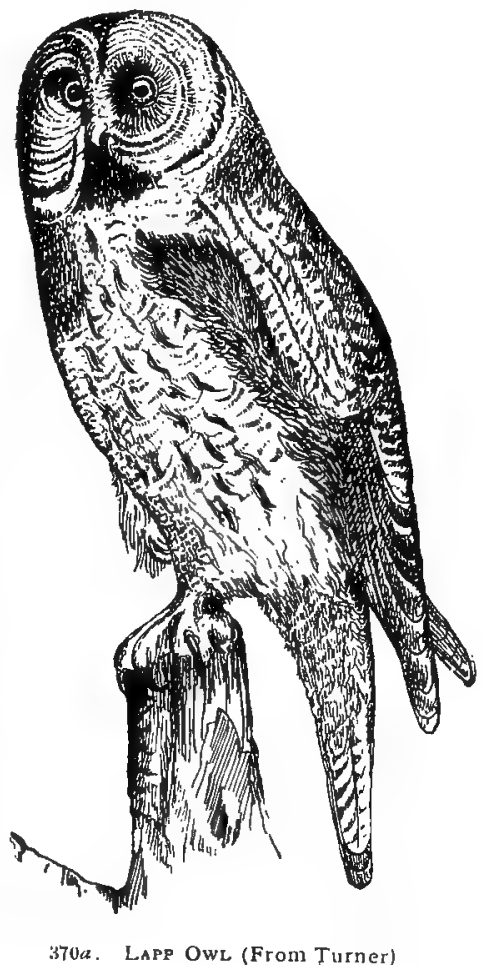


fir tree. The second set was collected ncar Muonio, Lapland, June 7, 1892, from a nest eighteen feet up in a fir tree; these measure $2.08 \times 1.72,2.05 \times 1.67,2.11 \times 1.71$ inches.

371. RICHARDSON'S OWL. Nyrtala tenymalmi richardsoni (Bonap.) Geog. Dist.-Northern North America, south in winter to northern border of the United States.

The American Sparrow Owl, or Richardson's Owl, so far as known, breeds in northern latitudes and is supposed to nest as far south as Nova Scotia. In Western Manitoba, in the Red River region, it is quite common in the wooded districts. Specimens of this Owl have been taken in various parts of the Arctic regions. as at.

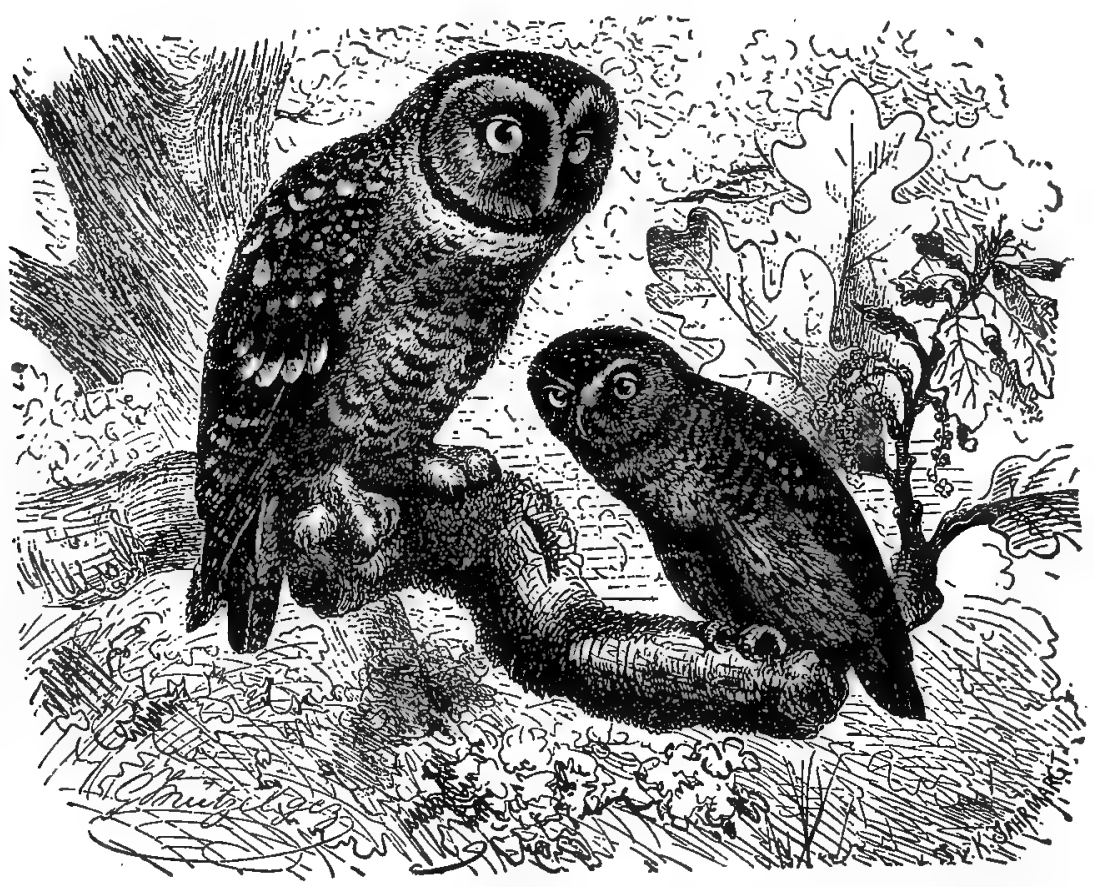

371. Larger figure-Tengmalm's European Saw-Whet Owh, similar in cut to our Richardson's Ow' No. 371. Smaller figure, resembles the Californla Pigmy Owl No. 379a.

Fort. Simpson, Fort Resolution, etc., and in Alaska. Dr. Richardson states that it inhabits all the wooded country from Great Slave Lake to the United States. The nest is described as built in trees, composed of grass and leaves; the eggs two to four in number and their average size $1.35 \times 1.14$. They are globular in shape and white in color.

372. SAW-WHET OWL. Nyctala acadica (Gmel.) Geog. Dist.-Whole of North America; breeding fror Middle United States northward.

The Acadian Owl is the smallest member of the family found in Eastern North America, and it inhabits the United States from the Atlantic to the Pacific, ranging 
north into British America; southward in wooded, mountainous regions, into Mexico. Its shrill, harsh notes, resembling the filing of a saw, have occasioned its name. The tird has been found breeding in Massachusetts, Maine, New York, etc., nesting in holes of trees, artificial nests, and in the old nests of herons. Mr. William Brewster records a set of four eggs taken April 5, near Tyngsboro, Massachusetts, by $\mathrm{Mr}$. W. Perham; they were deposited in artificial nests made from sections of hollow trunks, nailed to trees in woods. The sizes of four eggs are given as follows: $1.12 \times .95,1.21 \times .98,1.25 \times .96,1.25 \times .97$. Other eggs were taken from similar nests by Mr. Perham. Near Utica, New York, Mr. Egbert Bagg, on the dates of April 7, 21 and 30,1886 , found four sets of eggs of this species; two sets of five and two of seven eggs each. They were taken from deserted woodpeckers' excavations in tree stubs, ranging from twenty-two to fifty feet from the ground. The eggs were laid on the rotten chips in the cavities, and a few feathers of the Owl were present. The eggs are white, nearly elliptical; the average size is $1.20 \times 1.02$. The number ranges from four to seven. On May 28, 1889, my friend, J. E. Gould, shot two young birds of this species in a woods near Worthington, Ohio,-about five miles north of Columbus. These had just left the sest. About a mile and a half distant, in an entirely different strip of woods, another specimen was observed the same day. On June 2, returning to the place where he had taken the two young, three more were observed, sitting in the branches of the same sapling from which the two were shot on May 28. One of these was secured with a stick, the other 2 were allowed to remain. These were doubtless a brood of five, and the one observed in another woods making six in all. There is little doubt that the three young observed on June 2 were not strong enough to leave the nest when Mr. Gould visited the place on May 28. A dead mouse was observed hanging in a crotch of the sapling where the Owls were perched, which was doubtless placed there by one of the parent birds. Two of these specimens, kindly presented to me by Mr. Gould, are in my collection; the third is in his possession. That the Acadian Owl breeds in Central Ohio there is now no longer any doubt, and the securing of its eggs is only a question of time.

373. SCREECH OWL. Megascops asio (Linn.) Geog. Dist.-Eastern United states, north to British Provinces; west to the Great Plains, south to Georgia.

The Mottled Owl is resident throughout Eastern United States and Canada; west to the Rocky Mountains; on the limits of its range shades into several varieties. The eggs of the different varieties of Hcgascops are not distinguishable. The nest of the Little Horned or Red Owl, as it is often called, is made in a hollow tree or stump, sometimes in the topmost corner inside of an old barn or shed. I have found several nests between the oroken siding of ice-houses, along streams. The materials used are i few sticks. leaves, feathers, etc., on which the eggs are laid. In the month of April, 1885, a farmer brought me nine young, with the parent birds, which he had taken from a hollow tree. This number of young is, of course, extraordinary for this species. One of the old birds was

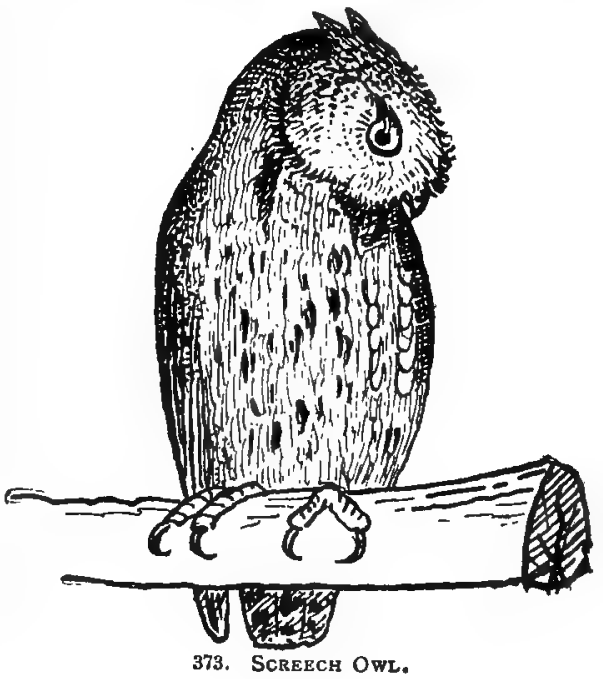


gray, the other red, and some of the young were of red, and some of the gray type of coloration, this being a common occurrence. The eggs of this bird range usually from four to six, frequently eight; they are white, nearly round and average $1.40 \times 1.20$.

373a. FLORIDA SCREECH OWL. Megascops asio floridanus (Ridgw.) Geog. Dist.-Florida, Southern Georgia, occasional in Lousiana.

A smaller and much darker form in the red and gray phases of plumage inhabiting Florida and adjoining regions. Its habit's are the same as those of $M$. asio, and eggs in my collection are not distinguishable except, perhaps, by their smaller size, $1.32 \times 1.15$.

373\%. TEXAS SCREECH OWL. Meyascops asio trichopsis (Wagl.) Geog. Dist. -Rio Grande Valley of Texas, south to Guatemala.

This is a slightly darker bird than asio, of the same size as floridanus, and found in the red and gray plumage. Three eggs in my cabinet, collected near Corpus Christi, March 20, 1885, measure 1.36x1.17, 1.33x1.18, 1.36x1.15.

373r, CALIFORNIA SCREECH OWL. Meyascops asio bendirei (Brewst.) Geog. Dist.-California.

No red phase of plumage is known in this bird; it is grayish-brown or brownishgray, and very much like $U$. asio, being of the same size. Eggs in my collection from Petaluma and Riverside, California, do not differ from those of the Eastern representative.. Four specimens measure $1.38 \times 1.18,1.40 \times 1.18,1.47 \times 1.19,1.47 \times 1.20$. The average of ten eggs is $1.40 \times 1.17$.

373d. KENNICOTT'S SCREECH OWL. Meyascops asio kennicottii (Elliot.) Geog. Dist.-Region of the Northwest coast, from Sitka to Oregon, east to Montana.

Kennicott's Screech Owl, in the red and gray phase of plumage, averages considerably larger than asio and mccallii. Length about eleven inches. Its general habits are essentially the same as those of $\boldsymbol{M}$. asio. Major Bendire gives the sizes of a set of four eggs taken from a hole in a cottonwood in Washington Territory, April 7, as $1.47 \times 1.28,1.43 \times 1.29,1.45 \times 1.30,1.46 \times 1.30$. The cavity from which these eggs were taken was sixteen inches deep and twenty-five feet from the ground.

373". ROCEY MOUNTAIN SCREECH OWL. Megascops asio maruellia (Ridgw.) Geog. Dist.-Rocky Mountain region, from Colorado north to Montana.

This form of the Screech Owl has been named in honor of Mrs. M. A. Maxwell, of Boulder, Colorado, a noted huntress and taxidermist. No gray phase is observed in this form, but the whole plumage is very light colored. Mr. Norris has a set of four eggs, taken near Loveland, Colorado, April 20, 1888; they measure 1.49x1.19, $1.46 \times 1.20,1.46 \times 1.21,1.54 \times 1.26$.

373\%. MEXICAN SCREECH OWL. Megnscops asio cineraeceus (RIdgw.) Geog. Dist.-New Mexico, Arizona, Lower California and Western Mexico. 
The plumage of this form is described as nearly ashy-gray above, with broad blackish streaks in strong contrast, blackish bars on lower parts numerous, biack border on the face and black spots on the breast. Its general habits do not differ from those of its Northern and Eastern relatives. Average size of the eggs, $1.30 \times 1.10$.

373\%. AIKEN'S SCREECH OWL. Meyascops asio akeni Brewst. Geog. Dist.-Plains El Paso County, Colorado, south probably to Central New Mexico anu Northern Arizona.

I have no knowledge concerning the nesting habits of this bird. There is no reason to believe that they differ materially from those of the Flammulated Screech Owl.

373h. MACFARLANE'S SCREECH OWL. Megascops asio macfarlanei. Geog. Dist.-East of the Cascades in Washington, interior of British Columbia; southward to Central Oregon and eastward into Montana.

So far as I know there are no published records concerning the nidification of this new subspecies.

374. FLAMMULATED SCREECH OWL. Hejascops fummeola (Kaup.) Geog. Dist.-Highlands of Guatemala and Central Mexico, north to Colorado and Northern California.

A small species whose general appearance is that of a young or rather an ungrown Mottled Owl, $M$. asio-the toes are entirely naked to the extreme base. A nest of this Owl was found in Fremont county, Colorado, June 15, 1875, by Charles E. Aiken; it was in a dead pine tree, and contained one egg, which was taken with the female bird. In color and shape the egg resembles those of other species of the genus, and measures $1.12 \times .95$.

374a. DWARF SCREECH OWL. Merascops famneola idahoensis Merriam. Geog. Dist.-Mountains of Central Idaho.

The type specimen of this new subspecies, and so far as known the smallest of our Screech Owls, was obtained in the Big Wood River Mountains, near Ketchum, Alturus county, Idaho, September 22, 1890. Nothing so far as I am aware is known concerning its general habits, nests or eggs, but it is reasonable to believe that they do not differ from the preceding species.

375. GREAT HORNED OWL, bubo virginianus (Gmel.) Geog. Dist.-Eastern North America, westward as far as the Mississippi Valley, and from Labrador south to Costa Rica.

Literature abounds with the observations of naturalists on the habits of the Great Horned Owl, and the pages of prose, poetry and song graphically depict its many characteristics. It is known as the Hoot or Cat Owl, or "Hooter," and is the targest of all the,owls with ear-tufts. A common bird throughout North' America at large in its several geographical varieties, the present species being restricted to the region east of the Mississippi Valley. Barn-yards are its favorite hunuug grounds, 
and its depredations done there among the poultry are well known. Rabbits. raccoons, weasels. miuk and other quadrupeds, with an occasional quail or grouse, make up a large portion of this bird's food. The bones, fur and feathers of these animals. and other refuse of lood may be found in their nests in greater or less abundance, and the nesting places are also frequently impregnated with the odor

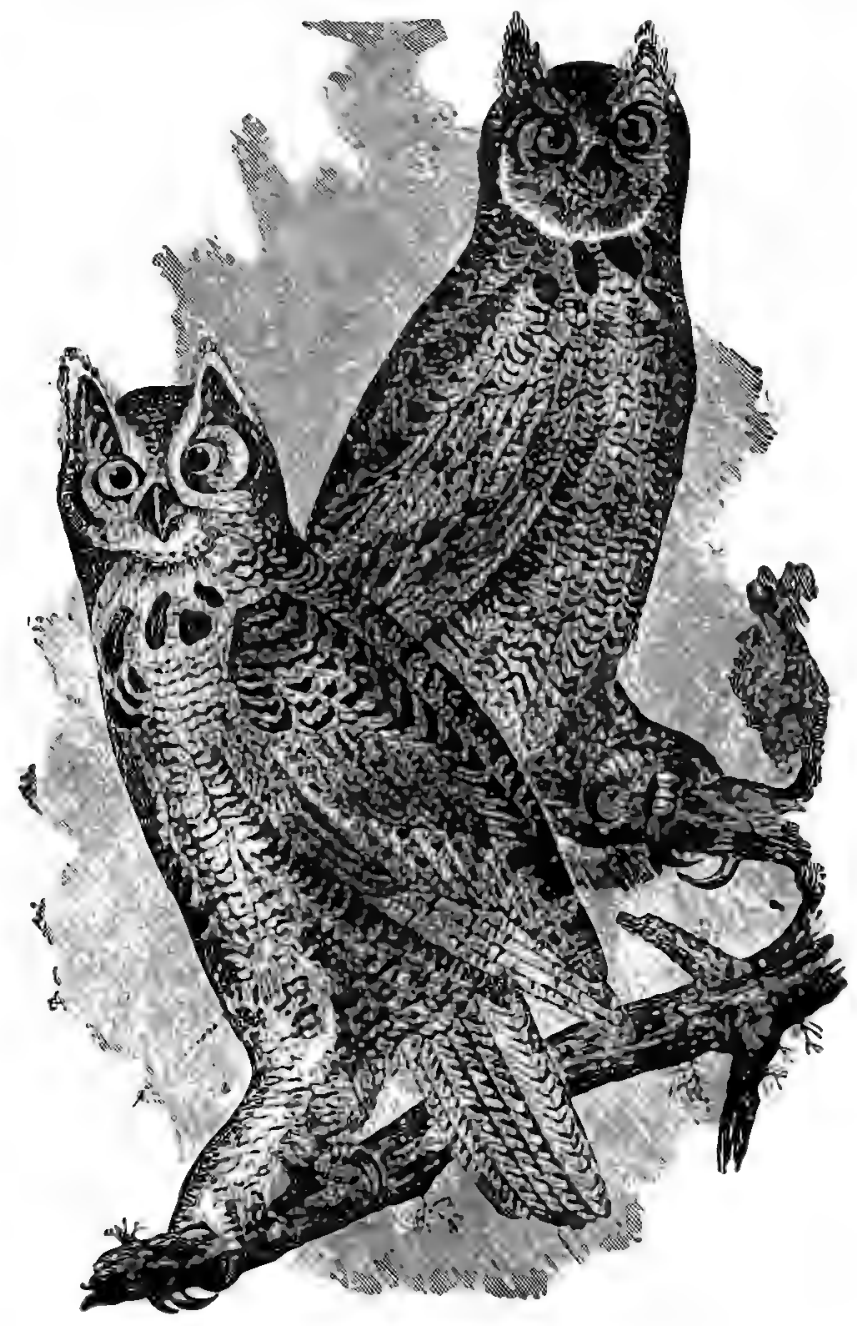

375. Great Horneo OWL (After Audubon).

the skunk. This bird does not migrate, but is resident wherever found. It generally breeds earlier than the Barred Owl. The time of nesting is usually in February and March, and I know of eggs comparatively tresh taken April 15. but through extensive research and information furnisbed by correspondents regarding the nest- 
ing, the greater portion of the eggs are deposited in the latter part of February or the first part of March; at least more eggs hare been collected at that time than at.any. other period; and these dates will apply to the nesting of all other forms of this Owl. Deep woods are its favorite haunts while breeding, where its bulky nests of sticks, bark, leaves, etc., may be found in the branches of trees ranging from twenty to one hundred feet from the ground, or the eggs may be deposited in a natural cavity of a tree. The deserted nests of crows or those of hawks are appropriatedthe nests of the Red-tail, Red-shouldered and Cooper's Hawks being common receptacles. In Florida and some other sections the nests of the Bald Eagle, Osprey and Caracara Eagle are frequently taken possession of by this Owl, and the same pair of birds will occupy a nest for successive years, even after being annually molested and robbed. A rap on the trunk of the tree will generally cause the birds to leave the nest. Besides the material already mentioned, the cavities will often contain weed-stems, corn stalks, corn-silk and feathers from the breasts of the mother bird, and again the eggs will be found laid upon the bare ground or decayed wood of the cavity in the presence of a few bones and skulls of animals. This Owl deposits two or three white, globular eggs.* Five sets of two eggs each are in my cabinet from Florida, Indiana, Iowa and Ohio; the ten specimens measure, $2.18 \times 1.72,2.20 \times 1.78$, $2.24 \times 1.80,2.26 \times 1.88,2.26 \times 1.79,2.29 \times 1.82,2.31 \times 1.88,2.30 \times 1.89,2.28 \times 1.74,2.32 \times 1.80$. The average measurements of thirty eggs in Mr. Crandall's collection is $2.26 \times 1.87$. This is a series containing ten sets of three eggs each and four sets of two.

375a. WESTERN HORNED OWL. Bubo virginianus subarcticus (Hoy.) Geog. Dist.-Western United States, from the Great Plains westward (except the northwestern coast); east casually to Illinois, Wisconsin and western portion of Canada, north to Manitoba, south to Mexican table lands.

A lighter colored form inhabiting Western United States. Its nesting, eggs and other characteristics are the same as those of B. virginianus. Four eggs in my collection from Riverside, Cal, taken in March, 1884, measure 2.16x1.78, 2.20x1.74, $2.25 \times 1.76,2.16 \times 1.78$.

375b. ARCTIC HORNED OWL. Bubo virginianus arcticus (Swains.) Geog. Dist.-Chiefly the interior of Arctic America (Fur Countries), south in winter to the Northern Rocky Mountains and Great Plains; Dakota, Montana and Wyoming.

This bird's general plumage is whitish through the fading of the ground color and restriction of the dark markings; beneath pure white, with dark markings Prof. Ridgway gives the average size of the eggs as 2.19x1.91.

375c. PACIFIC HORNED OWL. Bubo virginianus pacificus Cassin. Geog. Dist.-Southern California.

The exact range of this subspecies is not known.

- In exceptional cases four eggs have been taken from a single nest, but I. am not aware of an authentic set of five eggs or the extreme number of stx of the Eastern Horned Owl as has been reported of $B . \%$ Subarcticus in Colorado. I have in several instances received sets of four eggs of $B$. virgimians. 
376. SNOWY OWL. Nyctea nyctea (Linn.) Geog. Dist.-Northern portions of the Northern Hemisphere; in North America, migrating southward in winter to the Middle States, straggling to Virginia, South Carolina, Texas and to the Bermudas.

This large and beautiful bird inhabits the boreal regions of both continents. It is commonly called $W$ hite $O W l$, and is found with the plumage almost immacu-

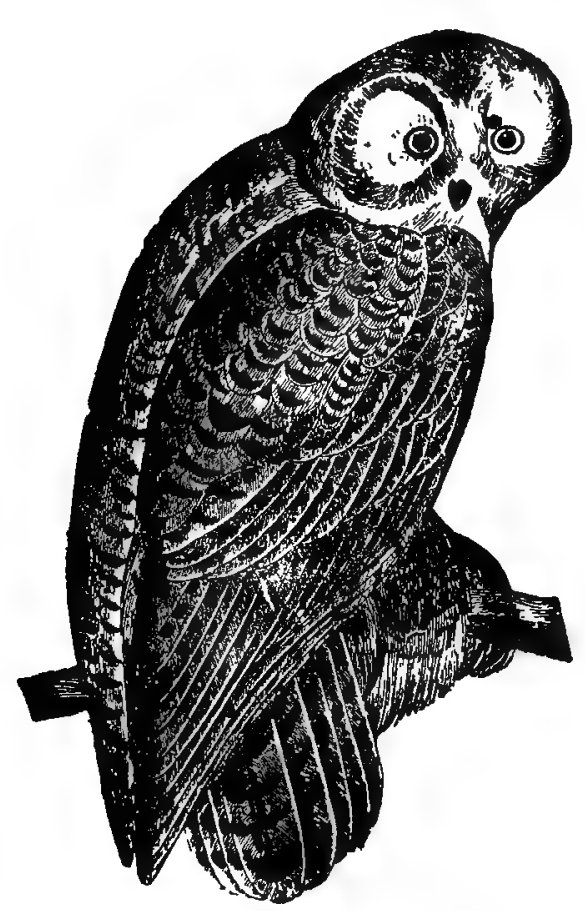

376 Snowy OwI. (After Audubon.) late, or marked with bars and spots of black and slaty-brown. It is a bird of wide range, extending its migrations as far south as the sub-tropical regions. During some winters it is very abundant in the United States, especially in the Northern, Middle and Eastern States. The food of the Snowy Owl consists of hares, squirrels, muskrats, and other small animals, and, as the bird is not exclusively nocturnal, it catches these quadrupeds in daytime as readily as any hawk. It is said probably to breed in Northern Maine, Canada, Nova Scotia and New Brunswick, as it does in Newfoundland and Labrador. Common during the summer montbs in the region of Hudson Bay and other portions of Arctic America, nesting on the ground in moss on the dry parts of marshes. I cannot quote better authority on the breeding range and nidification of this species than that of the late Major Charles E. Bendire from his "Life Histories of North American Birds." $\mathrm{He}$ says: "The breeding range of the Snowy OwI in North America extends from about latitude $53^{\circ}$ in Labrador north to the Arctic Sea, and it has been observed at the highest latitudes our Arctic explorers have as yet been able to reach., it is likewise common in Greenland during the breeding season, but much more in the northern than the southern portions." Gen. A. W. Greely, chief signal officer, U. S. army, mentions a nest of this species taken near Fort Conger, Grinnell Land, May 22, 1882, and young birds on July 8 . He says that "the Snowy Owls breed abundantly in the vicinity of Fort Conger, and as many as fifteen or twenty-five young birds were raised in 1882 and kept by us until approaching winter compelled us to release them. A nest near Fort Conger resembled that described by Maj. Feilden, which was a mere hollow scooped out of the earth and situated on the summit of an eminence which rose from the center of the valley." In this case a few feathers and a little grass were present. From three to ten eggs are laid by the Snowy Owl, usually from five to seven, white in color, sometimes apparently with a creamy tint, and oblong oval in shape. The average measurement of fifteen specimens in the $U$. S. National Museum is 2.24x1.77. 
[377.] HAWK OWL. Surnia ulula (Linn.) Geog. Dist.-Arctic portions of the Old World. Casual in Alaska (St. Michael's).

Mr. F, M. Turner obtained several specimens of this species in, the vicinity of St. Michael's, Alaska, while on duty there in connection with the U. S. Signal Service during the years 1874 to 1881 , which gives the Hawk Owl of Europe a place in our avifauna. It is a larger bird than the American Hawk Owl. Dresser in his magnificent work on "Birds of Europe" says: "The Hawk Owl is a northern species, being spread over the whole of Scandinavia and Siberia; it visits more southern countries only in winter and then very sparingly, but has not yet been found on the shores of the Mediterranean. According to Collett it is very widely distributed throughout Norway, preferring the sub-Alpine regions to the low country; it is tolerably numerous in the sub-Alpine woods of Northern Sweden and Norway, common in Lapland and Finland, occasionally visiting Denmark in winter; said to have nested in Elast Prussia." The bird nests in hollows of decayed pine trees, the lining of the nest being simply the powdered wood or rotten chips of the tree itself. The eggs are from five to nine in number, white in color, smooth and glossy; in shape like those of the Short-eared Owl. The breeding varies from the middle of April to the end of June. A set of nine eggs

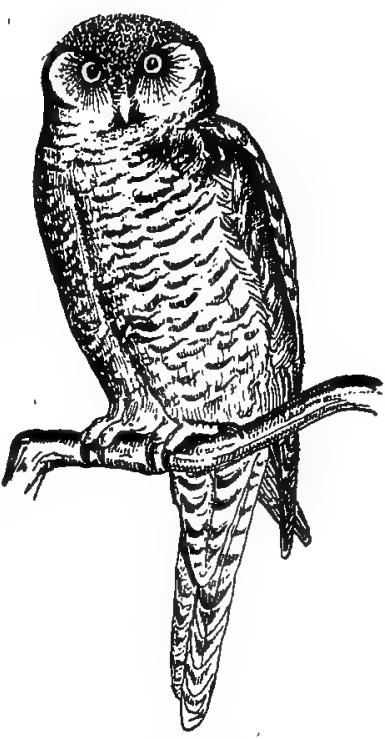

37. European Hawk OWL (From Turner). in Mr. Crandall's collection taken May 3, 1893, at Kittila, Lapland, exhibit the following measurements: $1.67 \times 1.24,1.57 \times 1.28$, $1.58 \times$ $1.23,1.63 \times 1.25,1.63 \times 1.27,1.52 \times 1.23,1.60 \times 1.23,1.58 \times 1.29,1.63 \times 1.27$.

377a. AMERICAN HAWK OWL. Surnia ulula caparoch (Mull.) Geog. Dist.-Northern North America; south in winter to Northern horder of the United States; occasional in British Islands.

A bird hawk-like in appearance, but nevertheless a true owl, and being the least nocturnal of its tribe, it is called Day Owl. Its food is chiefly field-mice and other small rodents, hawked for in broad daylight. The Hawk Owl inhabits the northern portions of North America, and is said to breed from Maine northward. Dr. Kichardson notes this species as common throughout the Fur Countries from Hudson Bay to the Pacific. It was found in considerable numbers by Mr. MacFarlane in the Anderson River Region, nesting in top branches of pine trees. Dr. Brewer describes a nest containing six eggs taken by Mr. MacFarlane on the 28th of April, which was composed of dry sticks and lined with hay and a few feathers. Another, which contained six eggs, was lined with green mosses and deer's hair. One nest contained as many as seven eggs, and all but one had as many as six. Mr. R. B. Ross found this Owl breeding in the Great Slave Lake district as early as the last of March or first of April. Dr. Merriam states that the Hawk Owl unquestionably breeds in northern Idaho. It is said that Mr. Boardman collected two of this species on the shores of the Gulf of St. Lawrence. A common species about Nualto, on the Yukon, Alaska, where Mr. W. H. Dall, on April 5th, obtained six eggs which were laid in a hollow, in the top of an old birch stump, fifteen feet from the ground. 
The eggs are said to range from two to six in number, dull white in color, roundedoval in shape, and average in their long diameter 1.53 and in their short diameter 1.35. A set of five eggs is in Mr. C. W. Crandall's collection. They were collected by Mr. Edward Arnold at Fishing Lakes, Assiniboia, British America, May 26, 1895. The nest was in a maple tree, fifteen feet from the ground; it was composed of large and small sticks, lined with grass, moss, rabblt-fur and rubbish. While taking these eggs the parent bird proved to be very pugnacious. The eggs measure as follows: $1.59 \times 1.23,1.54 \times 1.24,1.58 \times 1.24,1.53 \times 1.25,1.58 \times 1.25$.

378. BURROWING OWL. Speotyto cunicularia hypogra (Bonap.) Geog. Dist.-Western United States, from the Great Plains to the Pacilic, south to Guatemala. Accidental In New England.

The Burrowing Owl, made famous by popular stories of its Itving in burrow日 and holes of the ground with rattlesnakes, gophers and prairie dogs, inhabits the

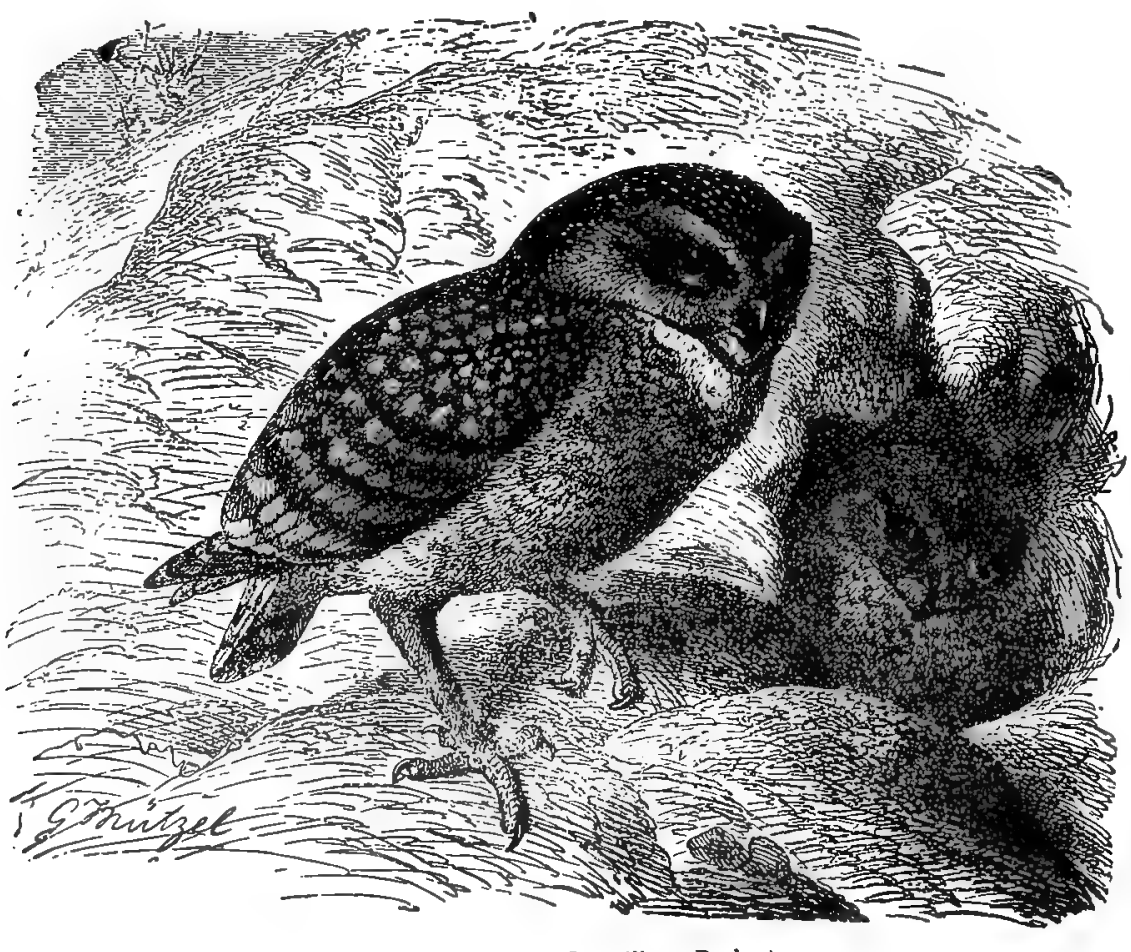

378. Burkowing OWL (From Brehm)

treeless reglons of Western North America, from the plains to the Pacific. It is tound In all suitable places in Kansas, Colorado, Utah, Nevada, Nebraska, Indlan Territory, Wyoming, Dakota, Montana, New Mexico, Arizona, Washington, Oregon and California. They are usually abundant, and congregate in large conminities, breeding in deserted burrows of quadrupeds, such as the prairle dot. badger or gopher, and there is no truth in the statements made by travelers that the 
owls, gophers and rattlesnakes dwell together in harmony. The Owls choose abandoned burrows, and if a snake or quadruped enters, it is only by accident or for the purpose of devouring the unsuspicious Owls. In Dakota and other regions'as many as twenty of these birds may be found nestling together in one hole, at which time they are well supplied with food, such as mice, shore larks, etc. In some localities the nesting place is lined with fine weed-stalks, feathers, bits of skin, etc., as Mr. Fred Corey informs me is the case in the vicinity of Santa Paula, Cal. The late Major Charles E. Bendire says he never found any other material in the cavity occupied by the nest than broken pieces of horse or cow dung, in the State of Washington. Around the outside may be found bits of skins of gophers, rats, mice, and ears of small rabbits. The eggs are pure glossy white, nearly round, although in a large series any shape may be found, from globular to pyriform. The number laid varies from four to ten, usually six or elght. Professor Evermann has a set of eleven which he collected near Santa Paula, Cal., April 14, 1881, and Major Bendire records an extraordinary set of twelve, taken by $\mathrm{Mr}$. Walter

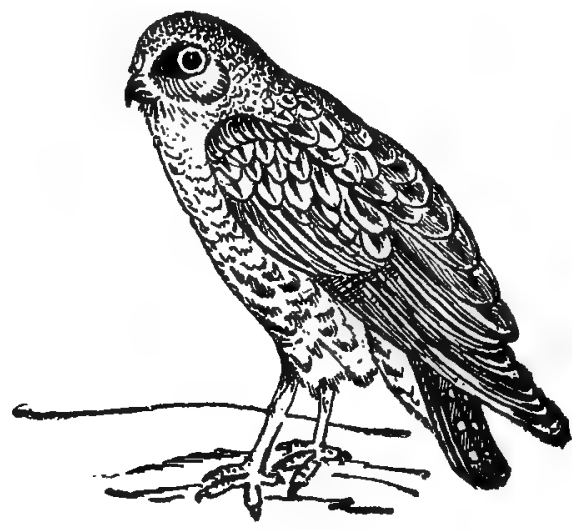

378. Burrowing OWL (After Fisher).

E. Bryant, near Carson, Nevada. The average size given by Major Bendire 1n a series of two hundred and fifty specimens is $1.24 \times 1.03$; the smallest $1.17 \times .97$, the largest $1.35 \times 1.09$.

378a. FLORIDA BURROWING OWL. Speutyto 'unicularia floridana Ridgw Geeg. Dist.-Florida and adjacent Bahama Islands.

A smaller local race of Florida, having the lower parts of its plumage nearly pure white. In some places in Florida colonies of these birds are quite common, nesting in the same manner as $S$. cunicularia hypoffel. Four eggs from Southern Manatee county, Florida, taken April 10, 1885, measure, 1.24x1.05, 1.23x1.02, 1.23x1.08, $1.25 \times 1.05$.

379. PYGMY oWL. Glauridium jnoma Wagl. Geog. Dist.-Western North America in mountainous regions from British Columbia to eastern slopes of the Rocky Mountains, and south to the tablelands of Mexico.

The breeding range of this little owl extends, as far as known, through the timbered regions of Western North America, from the Southern Rocky Mountains in Colorado, New Mexico and Arizona westward to Eastern California, Eastern Oregon and Eastern Washington; north into Eastern British Columbia, and south inte Mexico. From their very small size and unobtrusive habits they are likely to be overlooked. The Pygmy Owl feeds upon insects and the smaller rodents, which it ments by day as well as by night. Its flight is described as short, quick and jerky, Imilar to that of the Sparrow Hawk. Comparatively little has been written regarding the nesting and eggs of this bird. Thcre is no reason to believe that the babtw and eggs of this bird differ from those of the Califcrnia Pygmy Owl. 
379a. CALIFORNIA PYGMY OWL. Glaucidium gnoma californicum (Scl.) Geog. Dist.-Pacific coast region, from California to British Columbia.

A darker colored race than the preceding, is a resident of the timbered regions adjacent to the Pacific coast, where it breeds from about latitude $37^{\circ} \mathrm{N}$. in middle California, through Western Oregon, Washington and Southern British Columbia. Mr. William A. Cooper describes 'a nest of this subspecies which was found by $\mathrm{Mr}$, George H. Ready, near Santa Cruz, Cal., in a deserted woodpecker's excavation in the trunk of a tree seventy-five feet from the ground. The burrow was about nine inches deep and two inches across the mouth. The nest was found June 8; 1876; and contained three eggs, deposited upon a bed of twigs and a few feathers for a lining; three inches deep. One egg was accidentally broken. The two remaining eggs are described as dull white, with a scarcely perceptible yellowish tinge. The surface is quite smooth, and has the appearance of having been punctured with a fine point over the entire egg. They are oblong-oval in shape, more pointed at one end; sizes $1.17 \times .87,1.18 \times .90$; the larger specimen is more pointed. Incubation was far $2 d-$ vanced, and the embryos were extracted with difficulty. The eggs are three to five in number. Mr. C. Barlow has a set of four of this bird's eggs, pure white with a gloss; they measure $1.15 \times .92,1.17 \times .93,1.19 \times .97,1.18 \times .95$. An interesting paper on this bird was read before,the Cooper Ornithological Club by $\mathrm{H}$. Ward Carriger and published in the "Nidologist" for August, 1895. I quote the article in part: "The flight of this Owl is jerky and at times quite swift. It is not often one sees this bird fly for any distance, as it usually flies, if disturbed, from tree to tree. As the birds are very quick in winter they are not often seen, though you scarch carefilly for them. One rainy day in October two were met sitting side by side in the low limbs of a laurel tree, und they retained their poșition until the limb was forcibly shaken and then flew to another portion of the tree. Along in February they commence to 'toot.' This note is hard to describe, but once heard is never forgotten. It is easily imitated, and probably resembles the word 'toot' or 'who' uttered in a drawn-out; explosive manner. The Owls were observed 'tooting' as early as $6 \mathrm{a}$. m., and up to 11 a. m., but never in the afternoon. The usual time of 'tooting' is from 6 to $8: 30$ a. m., and on cloudy days later, even up to eleven o'clock. The note cannot be called loud, but nevertheless can be heard for a quarter of a mile and upward, and is deceptive. When disturbed during its time of 'tooting' the Owl will glance at the intruder for a moment, and then resume its note with apparent unconcern. During mating season they are hard to drive from their perch. Years ago Mr. Carriger remembers seeing a number of these Owls in the orchard about the house, but cf late years none have been observed within a mile or more of a residence. In 1893 a epecimen was captured and kept in a cage for over a month, when it fell a prey to a cat. Mr. Carriger has had the good fortune to discover four nests of this species during recent years. Nest No. 1 was found April 26, 1891, and contained six fresh eggs. A rap on the tree brought the bird from the cavity, and after following her for some time she returned to the nest, but left as soon as the ascent to the cavity was begun, and remained in the tree while her home was being despoiled. The cavity. was in the main body of a large white oak, fourteen feet from the ground. The entrance was a little over two inches in diameter, and four inches deep. The inside diameter of the cavity was nearly six inches. ' 1 'he nest contained a freshly. killed lizard.

379. 1. HOSKIN'S PYGMY OWL. Dist.-Lower California. 
This bird was flrst described by Mr. William Brewster. It is smaller and grayer than the California Pygmy Owl. The type specimen was taken by M. Abbott Frazar, May 10, 1887, in the Sierra de la Lagura, Lower California. Nothing is known con. cerning its hablts and eggs which doubtiess are similar or identical with those of the two preceding races.

380. FERRUGINOUS PYGMY OWI. Glaucidium phalchnides (Daud.) Geog Dist.-Southern border of the United States, from Texas to Southern Arizona, south to Southern Brazil.

The Ferruginous Pygmy Owl is a resident of the southern border of the United States, breeding in the valley of the Rio Grande in Texas, and in Southern Arizona. In Mexico its nests have been found in the hollows of trees or in those excavations made by woodpeckers. A set of four eggs was taken near Brownsville, Texas, from a nest in a woodpecker's hole in a mesquite tree, about ten feet from the ground on May 3,1890. The eggs are white, glossy and average in size 1.10x.91. Two sets of four eggs each of this species are in Mr. C. W. Crandall's collection. They were taken by Mr. Frank B. Armstrong in Tamaulipas county, Mexico, May 6 and 16th; respectively, 1895. The eggs in both cases were simply laid in the hollows in old trees, sixteen and eighteen feet from the ground. The first set taken measures as follows: $1.08 \times .90,1.10 \times .89,1.11 \times .88,1.13 \times .91$ inches; the second, $1.08 \times .88,1.10 \times .90$, $1.10 \times .90,1.11 \times .88$ inches. The average size of the eight eggs is $1.10 \times .89$ inches. They are remarkably uniform in size and are miniatures of the Screech Owl's eggs.

381. ELF OWL. Mieropallas whitweyi (Cooper.) Geog. Dist.-Southern Arizona, Southeastern California, Lower California, south to Southern Mexico.

One of the smallest of all raptorial birds, first discovered by Dr. J. G. Cooper, the type specimen being an adult male, taken near Fort Mohave, California, April 26, 1861. Others were afterwards taken by Col. Grayson on islands off the western coast of Mexico. Major Bendire took several specimens in the dense mesquite thickets, near Rillito Creek, about seven miles from Tucson, Arizona, in April, 1872. He also found one of their nests with fully fledged young in a hole of a mesquite stump. This Owl was found to be common by Mr. F. Stephens in the desert region about Tucson and Camp Lowell. Mr. W. E. D Scott states that it is decidedly the commonest Owl breeding in Southern Arizona (Pima, Pinal and Gila counties), and is very abundant during the breeding time, nesting in the woodpecker holes of the giant cactus. The eggs range from two to four in number, ordinarily three. Mr. Scott took a set of five from a nest. On one occasion, near Fuller's Ranch, about the last of May, 1883, Mr. Stephens and Mr. Scott collected a large number of the birds and their eggs in a few hours. Mr. Walter E. Bryant has a set of two eggs taken near Tucson, Arizona, May 28, 1885, by Mr. Herbert Brown. The nest was in an abandoned woodpecker's hole, in a cactus about twenty feet from the ground; the cavity was about eight or nine inches deep. The eggs measure 26.5x23.5, 26x22.5 mm.* Mr. Emerson has a set of three, taken by Mr. Stephens near Camp Lowell, May 24, 1884. They were found in a woodpecker's burrow in a giant cactus, ten feet from the ground. The sizes are $27 \times 23,26 \times 23 \mathrm{~mm} . \dagger$ A set of three eggs collected near Camp Lowell are pure white, nearly globular, and measure 1.04x.93, 1.09x.91, 1.12x.91. These were taken from a woodpecker's hole in a giant cactus twenty ieet from the ground.

* $1.04 \times .93,1.02 \times .89$.

$+1.06 \times .91,1.02 \times .91,1.06 \times .91$. 
382. CAROIINA PAROQUET. Conurus carolinchsis (Linn.) Geog. Dist.Formerly South Atlantic and Gulf States; up the Mississippt to Missouri; up the Missouri River to the Platte. Colorado; regularly to Ohio, Indiana, Illinois, Iowa, Wisconsin, Nebraska, etc. Formerly north in the Eastern United States to Pennsylvania and the Lakes.

In the first part of the present century the beautiful Carolina Paroquet was very abundant in the South Atlantic and Gulf States, and its migrations extended - Par northward. It has continued to diminish in numbers until it is now nearly exterminated, existing only in remote localities of the lower Mississippi Valley and Gulf States. It is still found in some regions of Florida. On November 1, 1889, Mr. F. M. Chapman read before a meeting of the Linnean Society of New York, a paper entitled "Notes on the Carolina Paroquet in Florida." In this paper, compiled Prom personal observation, Mr. Chapman writes as follows: "Fifteen years ago, Paroquets were more or less generally distributed throughout Florida and in many cases were extremely abundant, and even at more recent date were not uncommon in numerous localities, but today they have entirely disappeared from the more settled portions of the state, and we may look for them only beyond the bounds of

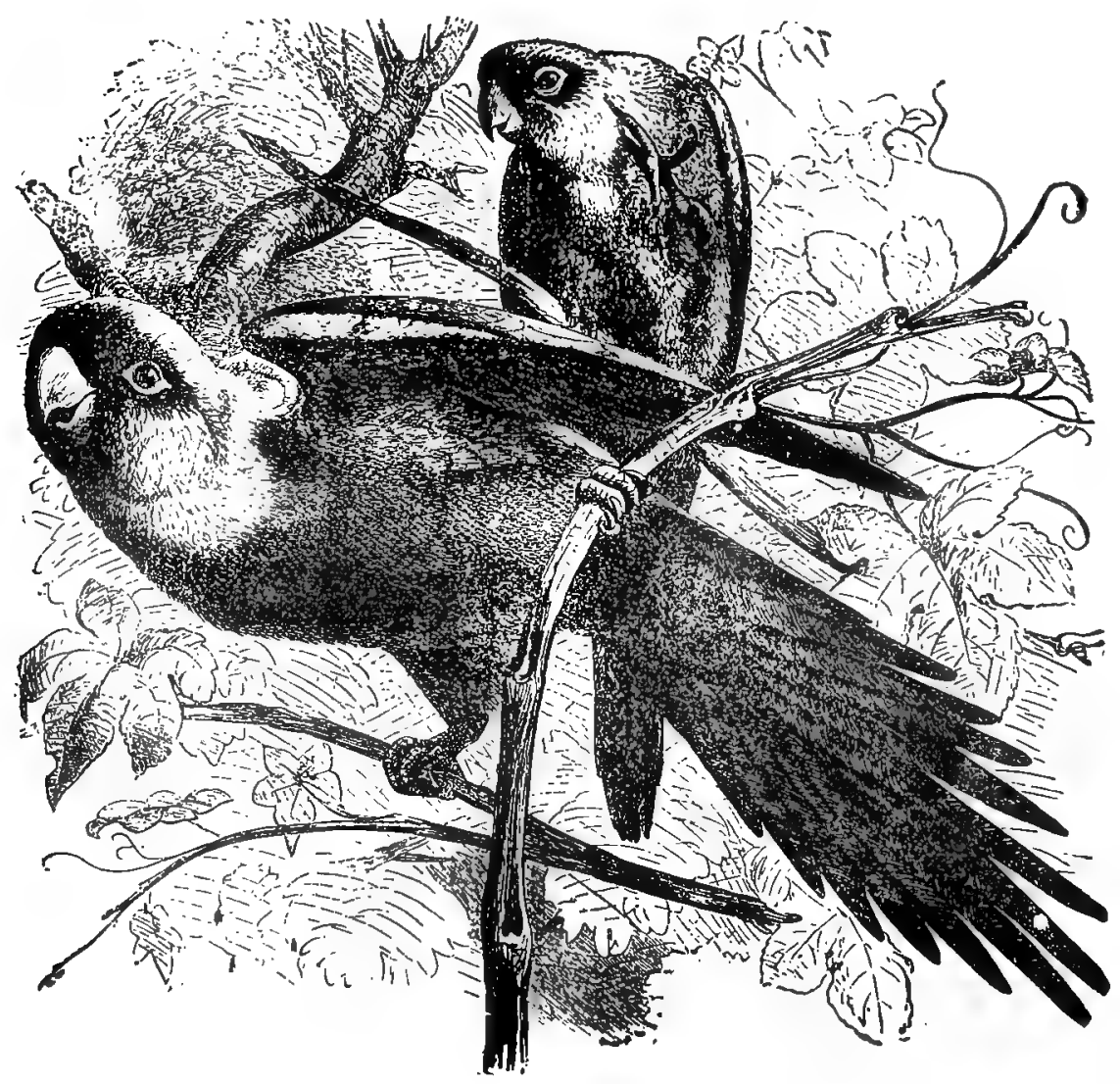

389. Carolina Paroguet (Yrokn Biebm, afler Auduboa). 
civilization, indeed in regions which are practically uninhabitable. In what numbers they still exist is impossible for us to say." Mr. William 'Brewster in "The Auk" (Vol. VI, pp. 336, 337), has probably thrown more light on the nesting habits of this species than any other writer. While in Florida during February and March, 1888 , he questioned everybody whom he met regarding the nesting of the Paroquet. Two professional hunters of alligators and plume birds, both uneducated men, stated that they had seen Paroquets' nests which they described as flimsy structures placed in the branches of cypress trees. This was so widely in variance with the state-

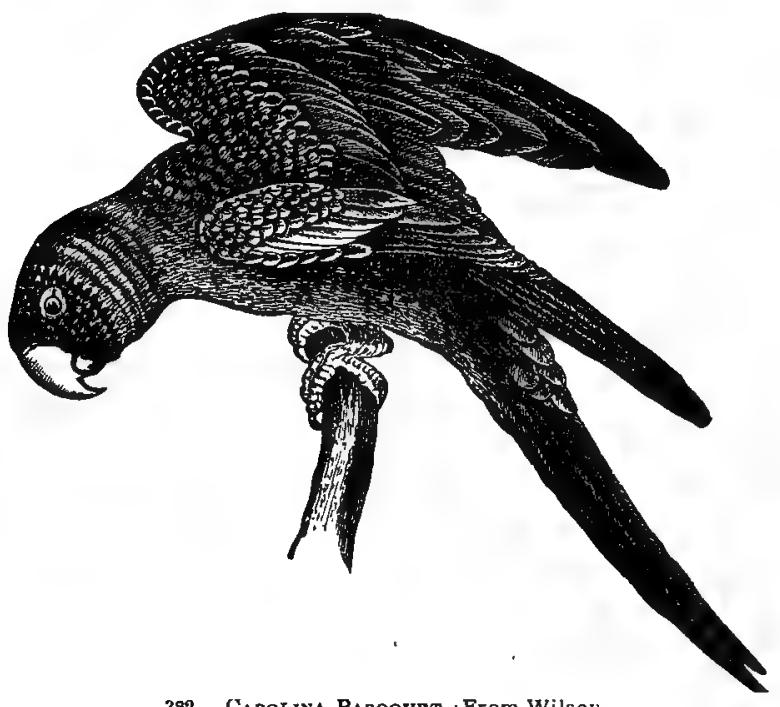

382. Carolina Paroquet (From Wilsol.

ments of Wilson, Audubon and others, that the Carolina Paroquet lays its eggs in hollow trees that the statement at the time was taken as a mere fabrication until it was strongly corroborated by Judge R. L. Long, of Tallahassee, a gentleman with a very good general knowledge of birds. He stated that formerly they nested abundantly in large colonies in the cypress swamps. Several of these colonies contained a thousand birds each, and they invariably selected a fork near the end of a slender horizontal branch for the position of the nest. Every such fork would be occupied, and he has seen as many as forty or fifty nests in one small tree. They closely resembled those of the Carolina Dove; the eggs were often visible from beneath. Mr. Long describes the eggs as being of a greenish-white color, unspotted. He thought the number laid was at least four or five. He had often taken young birds from the nest to rear or to give to his friends. He knew of a small colony of Paroquets breeding in Waukulla Swamp, about 20 miles from Tallahassee, in the summer of 1895 , and believed they still occur there in moderate numbers. There appears to be no positive information concerning the actual number of eggs laid by the Carolina Paroquet in its wild state. Dr. Karl Russ, of Berlin, Germany, mentions several instances of this bird breeding in capivity in Germany, where the egga were deposited in June and July, the number being from three to five, pure white, the grained, very round and quite glossy, like woodpeckers' eggs, and measuring about 1.50x1.42 inches. Mr. Robert Ridgway's Paroquets which he had in captivity 
would not use the nesting boxes provided for them, and both females deposited their, eggs on the floor of the cage; they were laid ir. July, August and September, respectively. None of these eggs can be called round; they vary from ovate to short ovate, and are rather pointed; they are white with the faintest yellowish tint, ivory-like nd quite glossy; the shell rather thick, close grained and deeply pitted not unlike the eggs of the African Ostrich, but the pits are not so noticeable. . These eggs meas-

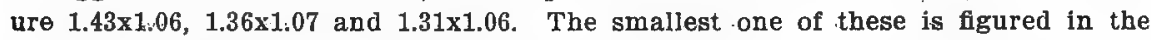
late Major Bendire's monumental work (Vol. II, Plate I). The last record we have of this bird being taken in Ohio is October 9th, 1884. A specimen was shot by Mr. A. Lee Hoskinson, near Newark, and mounted by S. G. Hamilton, taxidermist, of that city. The bird was seen about the place for several days and was heard screamIng all the night before it was killed. It is still in Mr. Hoskinson's possession.

[383.] ANI. Crotophaya ani Linn. Geog. Dist.-West Indies; eastern South America, rare or casual in Florida and Louisiana; accidental near Philadelpíáa.

The Ani, Black Witch or Savanna Blackbird; so grotesque in appearance is only of rare or accidental occurrence in the United Stateș, as in Southern Florida, and in other regions as above cited. The bird is from thirteen to fifteen inches long; tail

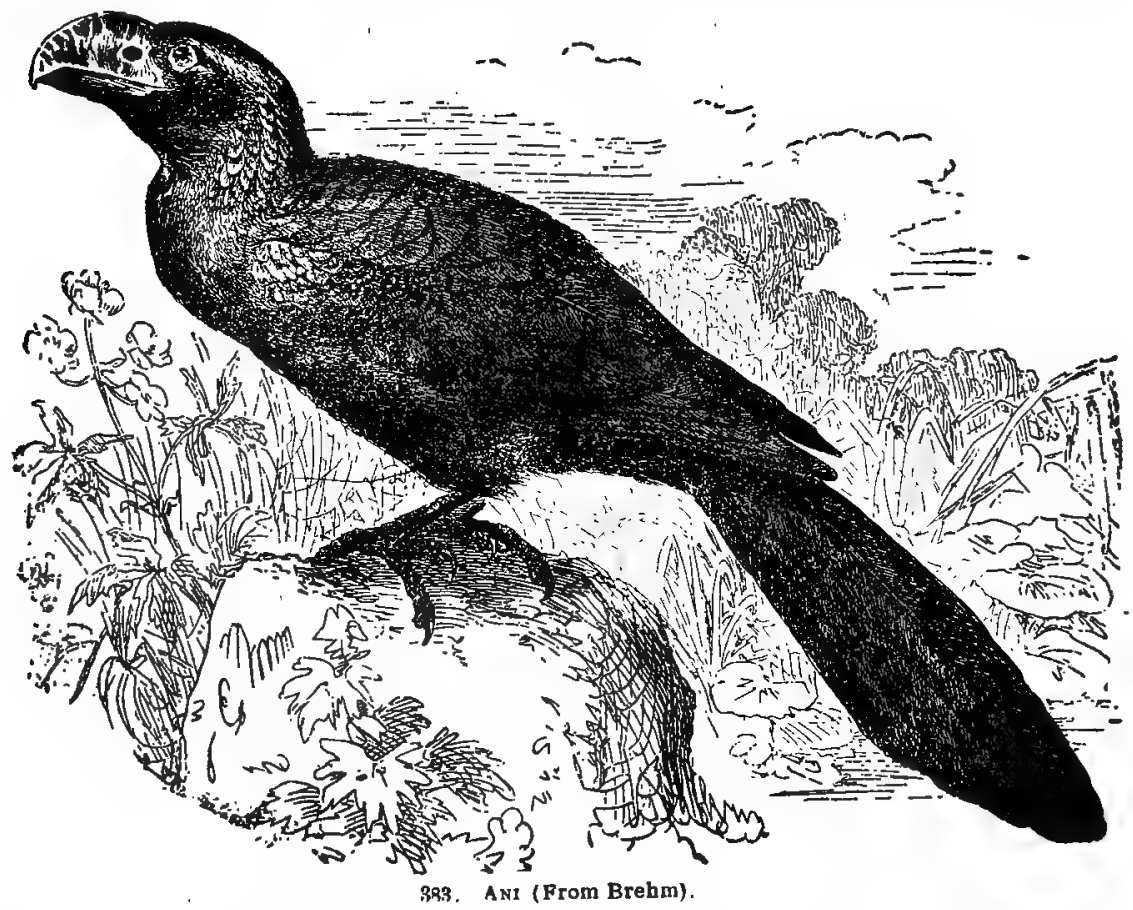

eight inches; the bill is exceedingly compressed and smooth, or with a few traverse wrinkles on the upper mandible; the color of the plumage is black, with steel-blue reflections. It is common throughout the West Indies and in Northeastern South America'. 'Observers' state that several of these birds will form sort of a community or colony to build an immense nest, which is used in common. It is a large mass of 
interwoven twigs, lined with leaves, and is built in trees or bushes, sometimes in marshes. From five to fourteen eggs, or even more, are deposited by the several birds. These are of a glaucous-blue in color, usually covered with a light chalky crust. Their average size is $1.34 \times 1.20$.

384. GROOVED-BILLED ANI. Crotophay sulcivostris Swains. Geog. Dist.Lower Rio Grande Valley in Texas and Lower California southward to Peru.

The Grooved-billed Ani was formerly only known from Yucatan, Central and South America. Between the years 1865 and 1871 it was discovered in Western Mexico, and finally added to the fauna of the United States by Mr. George B. Sennett, who shot an adult male on May 19, 1878, at Lomita Ranch, on the Rio Grande, which is seven miles above Hidalgo. It has since been found breeding in chaparral near Brownisville, Texas, and its nest and three sets of its eggs taken there are in the Ralph collection in the U. S. National Museum. The eggs of this species range from four to eight, usually five in number, and of the same color as those of the last species. No peculiarity seems to be noted in the nesting of this species; no mention is made of eggs being laid in one nest by several females, as is the case with $C$, ani, and we would naturally expect the breeding habits of both species belonging to the same genus to be very much similar. Colonel Grayson states that the nest is usually built in a thorny tree or bush, at a moderate height, and composed of thorns and dry twigs exteriorly, and lined with fibrous roots. He describes the eggs on the outside of the shell as rough and white, the inside green. The birds, he remarks, associate in small flocks of eight or ten, and are fond of picking ticks off the cattle. Mr. Charles W. Richmond states that this species is very abundant in the vicinity of Bluefields, Nicaragua. The heart of a thick thorny orange or lemon tree appears to be their favorite situation, from four to seven feet from the ground, sometimes as high up as fifteen feet. The nests like those of $C$. ani, are very bulky, conspicuous structures, composed of dead black twigs, and the cavity proper is invariably lined with green leaves. The nest is a voluminous structure, and while in its cavity may be found eggs of the original builder, other eggs, undoubtedly the product of some intruder, are often found in its framework. The eggs resemble those of the Ani so closely that the same description will answer for both. The average measurement of forty eggs in the U. S. National Museum is about 1.23x.94, the largest $1.32 \times .99$ inches, the smallest $1.09 \times .86$ inches.

385. ROAD-RUNNER. Geococcyr ralifornianus (Less.). Geog. Dist.-Texas, New Mexico, north to Western Indian Territory and Kansas; Southern Colorado, westward to California; Lower California; south into Mexico.

The Ground Cuckoo, Chaparral Cock, Snake Killer or Paisano, as it is differently called, is a curious long-tailed, chicken-like bird, noted for its swiftness of foot. It is found in Texas, New Mexico, Arizona and California southward. In Southern Calitornia, Mr. Shields states that this bird is abundant in the chaparral and sage bush regions. Its favorite food consists of small lizards and snakes. It nests in low trees, usually in the low branches of a cactus or in a thorny bush.. A nest before me, callected in Lee county, Texas, by J. A. Singley, is a coarse structure made of sticks. It was placed in a haw bush about eight feet from the ground. The structure is thick. and clumsy, with but a slight depression for the eggs. The latter are deposited at intervals of several days, and a perfectly fresh egg is often found with one on the point of hatching; or young birds of various sizes with partially incubated eggs in the same nest is of common occurrence. Mr. Shields found aggs as 
early as the last of March, and as late as the middle of June. Most of the eggs obtained by Mr. Sennett in Southern Texas were deposited in April. From two to twelve are laid, commonly five to nine; the general shape is ovate and the color white or buffy-white. Six selected specimens measure $1.56 \times 1.20,1.51 \times 1.23,1.60 \times 1.18$, $1.50 \times 1.17,1.57 \times 1.14,1.56 \times 1.23,1.58 \times 1.19,1.61 \times 1.14$.

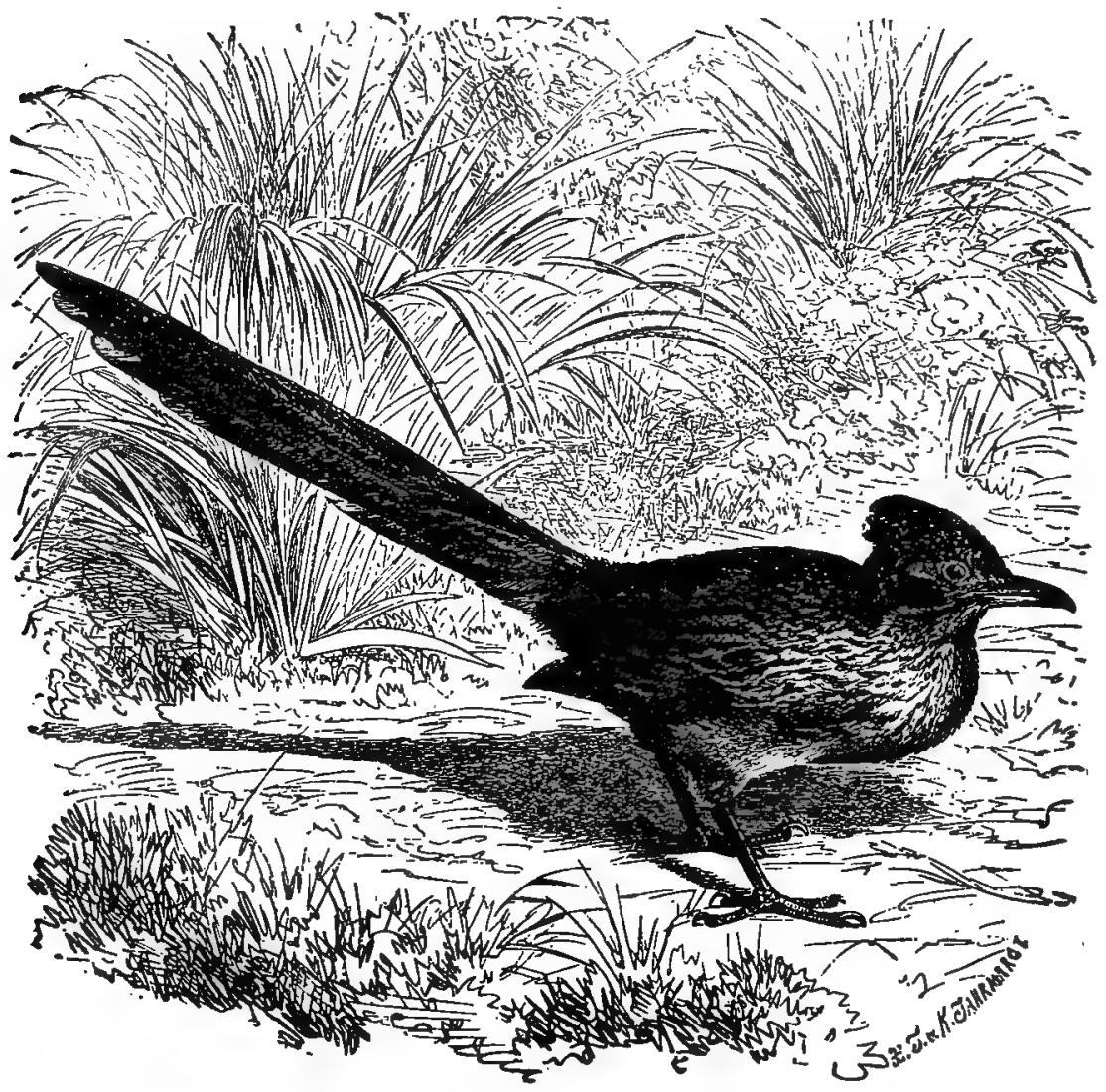

:385. ROAD-RUNAtre (From Brehm).

386. MANGROVE CUCKOO. Cuccyzus minor (Gmel.) Geog. Dist.-West Indies (except Bahamas); Florida Keys; coast of Loulslana; Central to Northern and Eastern South America.

The Mangrove Cuckoo is very much like the yellow-billed species, $C$, americanus, with the lower parts of the plumage more deeply colored-deep ochraceous, often extending to the throat; bill simllar to that of $C$. americanus. This species occurs in nearly all of the West Indian Islands, except the Bahamas, and it is'a rare summer resident of the Florida Keys. Audubon records it as a regular summer visitor to Key West and the other Keys. In the Island of Jamaica the Mangrove Cuckoo is said to breed from March to. July, building in the low branches of trees and in 
bushes. The nest is described as a loosely made structure, composed of a few dry sticks. The eggs are three, rarely four, in number, of a glaucous-green color, ovaloblong in shape, and on the whole they are of the same size and general appearance as those of $C$.americanus.

386a. MAYNARD'S CUCKOO. Coccyzus minor maynardi Ridgw. Geog. Dist.-Bahamas and Florida Keys. Cuba.(?)

A smaller and somewhat paler race than the preceding and from which it has been separated in the last decade. It has so far only been found at Key West, where it is rare, but is thought to breed there in limited numbers. The eggs are unknown, but probably are indistinguishable from those of the Yellow-billed Cuckoo.

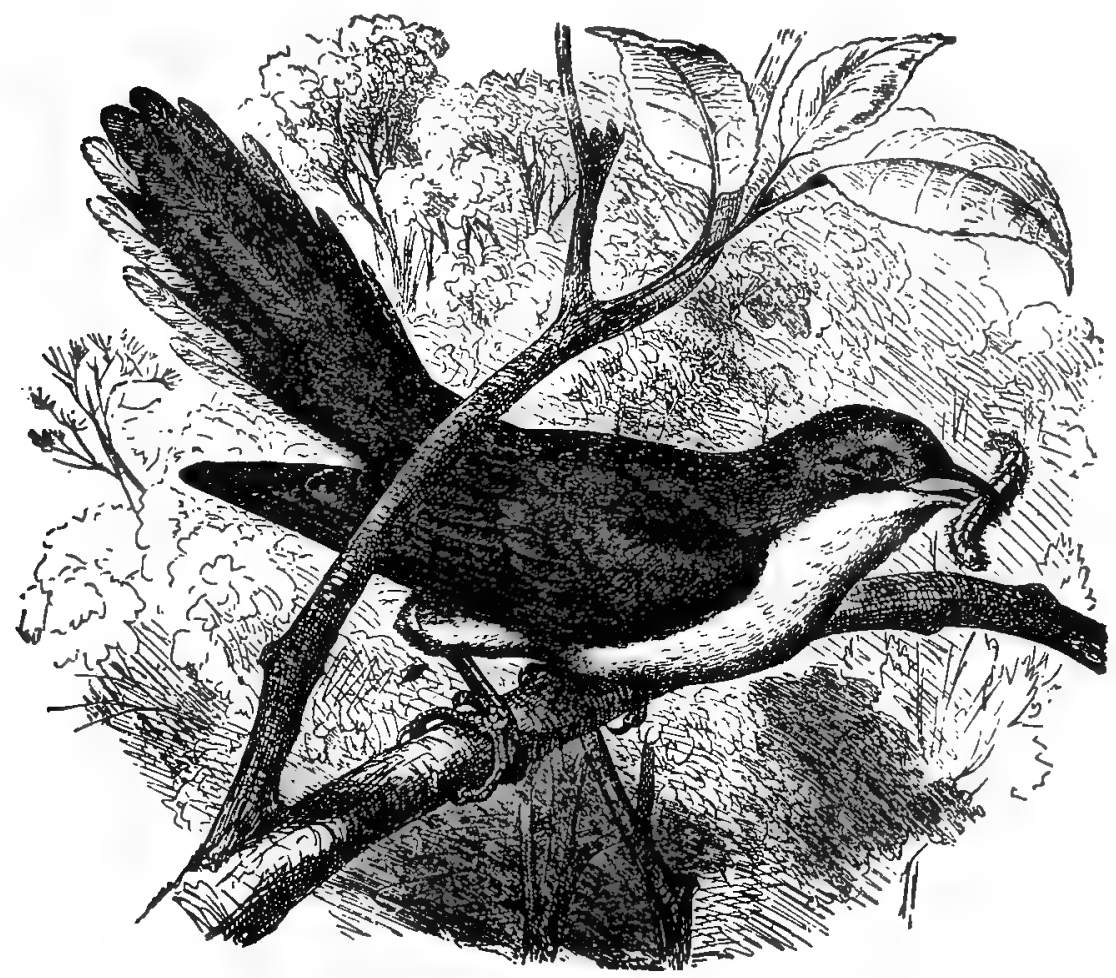

387. Yellow-Bizled Cuckoo (From Brehm).

387. TELLOW-BILLED CUCKOO. Coccyius americanus (Linn.) Geog. Dist.-Eastern North America, north to British Province, west to the edge of Great Plains, south in winter to tropical regions-West Indies, Eastern Mexico and Costa Rica. 
This bird is known by several names, such as Rain Crow, Rain Dove and Chowchow, which are likewise applied to the Black-billed species. Wherever woods and undergrovth abound in Eastern United States the Yellow-billed Cuckoo may be seen in the breeding season. Its peculiar, resounding notes resembling the syllables $k$ wok-kook-kook are probably uttered more frequently just before falling weatherhence the name, Rain Crow. Being somewhat nocturnal in their habits, the notes of both our Cuckoos are often heard at night. The nesi will usually be found in a low tree or bush, sometimes it is placed in a brier patco close to the ground. Thickets along the streams or upon islands are favorite nesting places. The usual distance of the nest from the ground is between five and ten feet. It is a slight structure of slender, dried sticks, sometimes twelve to fifteen inches long, but generally much shorter, bark-strips and catkins making up the fabric. Although near relatives of the notorious Cuckoo of Europe, which, like our Cowbird, lays its egis in the nest of other birds, our Cuckoos generally respect the marriage tie, and are not altogether deserving of the stigma of the family name of Cuckoos of the old World, although its eggs are sometimes laid in the nests of the Mourning Dove, Catbird, Gedar Waxwing, Cardinal Grosbeak, Robin and others. The eggs are deposited at intervals of two to five days, and frequently young are found in the nest with partially incubated eggs. Two to four are usually laick. Dr. Howard Jones, in "Nests and Eggs of the Birds of Ohio," says that when incubation does not begin until the complement is completed, as is commonly the case, four eggs, rarely six, make up the set. Mr. Norris has a set of six. The average size of twenty-eight specimens is $1.27 \times .89$. Fresh eggs may be found as early as the middle of May, in June, July and even. August. Not infrequently are the eggs of the Yellow-billed and Blackbilled Cuckoos found in the same nest. The color of the eggs is glaucous-green, of the same tint found in herons' eggs, which fades upon exposure to light, and when incubated, this color becomes several shades lighter than that in the fresh specimens. On June 24, 1894, a nest of this species was found by Mr. R. C. Osburn in Licking county, O., which was placed in an apple tree twenty feet from the ground. It had a lining a quarter of an inch'deep, composed wholly of the seeds of the ash tree. The seeds had been carried at least three hundred yards.

[387a.] CALIFORNIA CUCKOO. Coccyzus americanus occidentalis Ridgw. Geog. Dist.-Western United States, north to Oregon, east to New Mexıco and Colorado, south over tablelands of Mexico.

Ridgway describes this western form as larger than $C$. americanus, with proportionately larger and stouter bill.* The nesting and eggs, and the general habits of this geographic race are indistinguishable from those of the Yellow-billed Cuckoo.

388. BLACK-BILLED CUCKOO: Coccyzus erythrophthalmus (Wils.) Geog. Bist.-Eastern North America, north to Labrador and Manitoba, westward to the Rocky Mountains, south in winter to the West Indies and Tropical America.

The same names are given to this bird as are common to the Yellow-billed Cuckoo, $C$, cimericanus, and their general habits are similar. The nests of the Yellow and Black-billed Cuckoos resemble each other closely, and it is not always possible to differentiate the two. Nests of the former are often found which could not

* For Description see Manual of North American Birds, p. 273. 
be mistaken for those of the Black-billed on account of the coarseness of the nest, larger size and paler color of the eggs. However, as a rule; the nest of the Black-bill is constructed with more care, the sticks being somewhat smaller, the catkins less numerous, and the whole woven together in a firmer manner. The eggs are smaller, less elliptical, and are of a darker green-decp glaucous-green or verditer-blue. The nest complement varies from two to five, rarely six, usually four, and they are found in all stages of incubation, as is the case with the eggs of C. americanus. Ten specimens measure $1.13 \times .79,1.11 \times .86,1.15 x .84,1.13 \times .80,1.17 \times .82,1.17 x .84,1.19 x .80$, $1.12 x .86,1.13 x .82,1.18 x .89$, with an average size of $1.14 x .79$. A very interesting note concerning this species is made by Dr. Edgar A. Mearns in his "Birds of Hudson Highlands." He says: "Thc young are covered with curious-Iooking pin-feathers, which give them an appearance like that of the wire swab used in gun cleaning. The old bird is a close sitter, and when obliged to leave the nest moves off slowly upon the branches, with wings and tail outspread. Sometimes it will come quite close to the observer, and then utter for several minutes a low, mournful coo, coo, coo, coo, and then an outpouring of harsh, loud notes that quickly bring the mate to its side, all the while keeping its wings and tail expanded, and crouching low upon the branch. Its ordinary notes are quite commonly heard at night as well as during the day."

\section{[388. 1.] KAMCHATKAN CUC-} Koo. Cuculus canorus telephonus (Heine.) Geog. Dist.-Eastern Asia, casually to the Pribilof Islands, Alaska.

The Siberian Cuckoo is entitled to a place in our avifauna on the strength of a single specimen having been taken by $\mathrm{Mr}$. William Palmer at Northeast

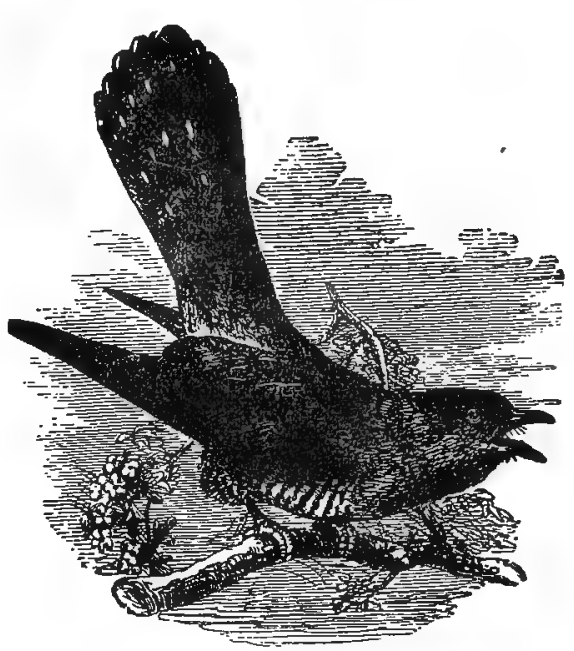

- European Cucroo. Point, St. Paul's Island, Alaska, July 4. 1890, and now in the U. S. National Museum. Nothing definite apparently is known concerning its nesting habits and eggs, but they undoubtedly correspond with those of the European Cuckoo.

389. COPPERY-TAILED TROGON. Trogon ambiguus Gould. Geog. Dist.Southern and Central Mexico, from Oaxaca and Guerrero, north to the valley of the Lower Rio Grande in Texas and Southern Arizona.

A specimen in my collection of this magnificent bird, the only representative of this family in the United States, was taken in the Huachuca Mountains,

* A List of the Birds of Hudson Highlands with Annotations. By Edgar A. Mearna: Bulletin of the Essex Institute, Vols. X-XIII, Part VIII, p. 76. 


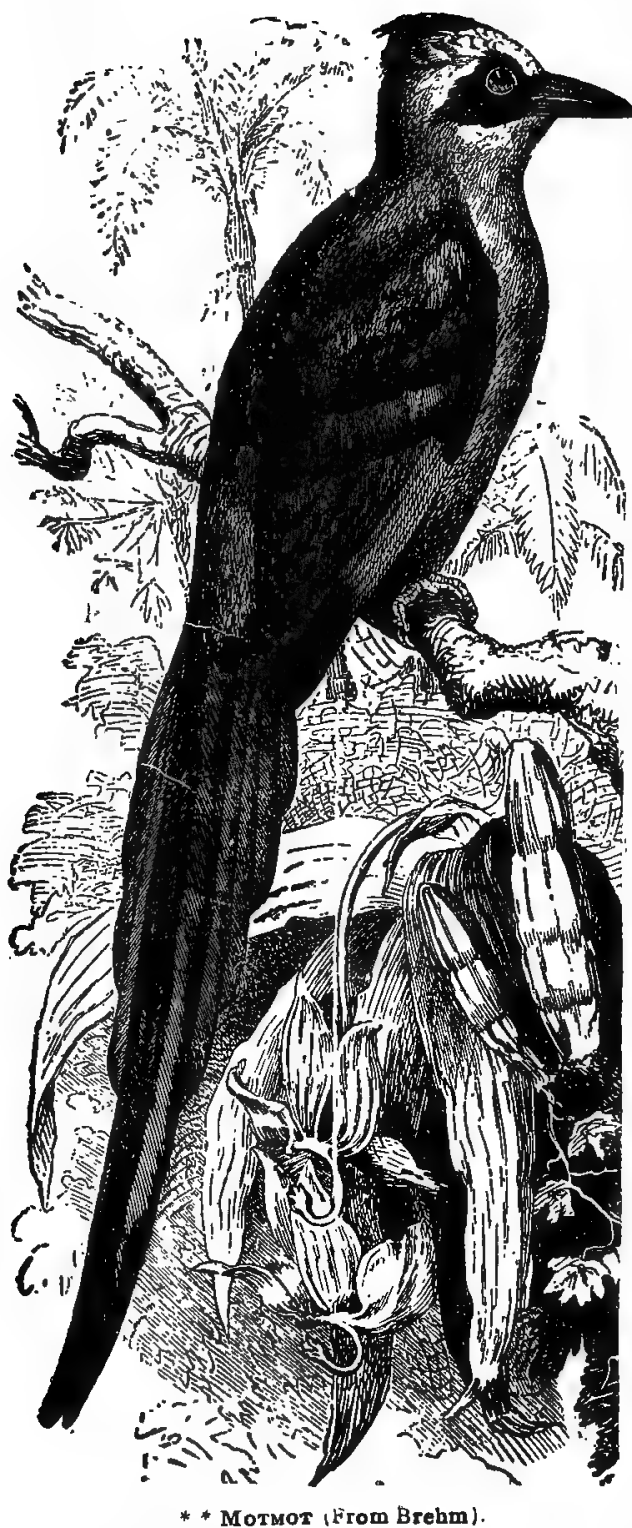

Arizona, June 16, 1894. This specimen has a copper-colored tail above, with the crown, hind-neck, back and scapulars a deep metallic green, varying to coppery bronze. The length of this species varies from elever to twelve inches, the tail ranging from 6.50 to 7.20 inches. There is no longer doubt that this beautiful species breeds in some of the mountain ranges of Southern Arizona, as it has been taken a number of times in that region from June to August. The Trogons, whose breeding habits are known, nest in the natural cavities of trees or in cavities excavated by woodpeckers, the eggs being deposited in the bottom of the holes. on the rubbish or chips which may be found in them. The eggs are said to vary from two to four in number, unspotted. The eggs of the Mexican Trogon are described as a very pale green in color, while those of Trogon surucua from Paraguay are said to be pure white. The late Maj. Charles E. Bendire, in the second volume of uis "Life Histories of North American Birds," says: "I have seen eggs purporting to belong to this species, but their large size, as well as the source erom which they came, do not warrant me in giving measurements or a description of these specimens, and as far as I know, genuine eggs of the Coppery-tailed Trogon still remain to be described." With the above facts in view I venture to describe a set of this bird's eggs in the collection of Mr. R. P. Sharples, of Springfield, Ill. The eggs, three in number, were taken June 14, 1882 , in the vicinity of Mazattan, Mexico, by Mr. A. Forrer. The nest was pläced in a hole in a bluff of a river, ten feet above the bed of the stream and two feet below the top surface of the bank, and the cavity extended in about eighteen inches. The eggs are dull white in color, nearly oval in form, and the shell has very indistinct lines, resembling water marks in writing paper. Their sizes are as follows: $1.12 \times .86,1.10 \times .87,1.03 \times .84$ inches. According to the data furnished with this set of eggs these birds nest in small colonies; six sets of eggs having been secured from the bank where this set was obtained. 
* BLUE-CROWNED MOTMOT. Momotus caruleiceps Gould. Geog. Dist.-Eastern Mexico, north to Rio Grande Valley.

The Motmots, or Sawbills, as they are called, is a family of twelve or fifteen species inhabiting tropical America, the present species coming very near our border

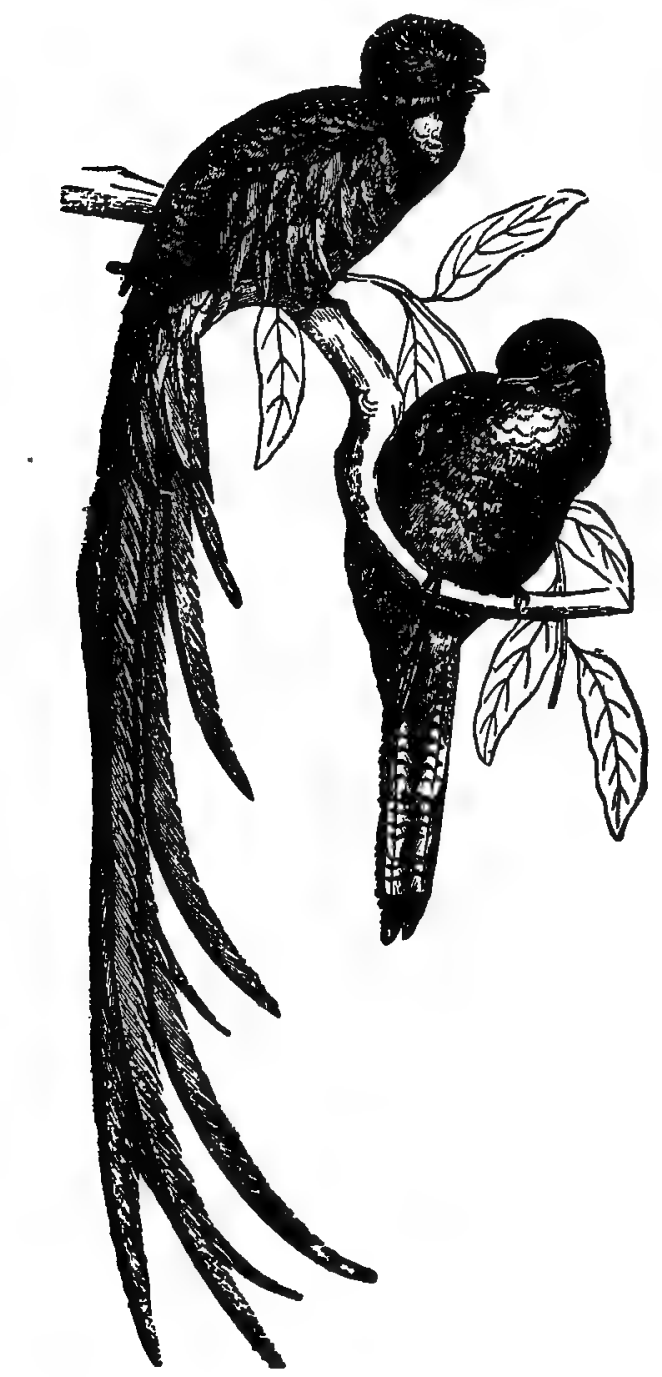

- Paradise Trogan, Pharomacrus mocinno (After Michelet).

In the Ric Grande Valley. They are birds of striking plumage, the general color being plain greenish, tinged with olive; the ear-coverets are rather lengthened and stiffened and chiefly black, but partly blue. They have lengthened and usually spatulate middle tail-feathers, blue except the tips, where they are black. The head of the 
Blue-crowned Motmot varies from bluish to greenish or, as Mr. Ridgway describes it, "verditer-blue, varying to verdigris-green, duller centrally"; length of bird about 14.20 to 15 , middle tail feathers 8.80 to 9.15 inches.

390. BELTED KINGFISHER. Ceryle alcyon (Linn.) Geog. Dist.-Entire North America, South Panama and West Indies.

This is the familiar bird whose loud, coarse, rattling notes are heard along our streams. It may be seen perched upon the lower branches of a tree overhanging the water, or on the top of a dead stump; these places furnish a favorite outlook, from

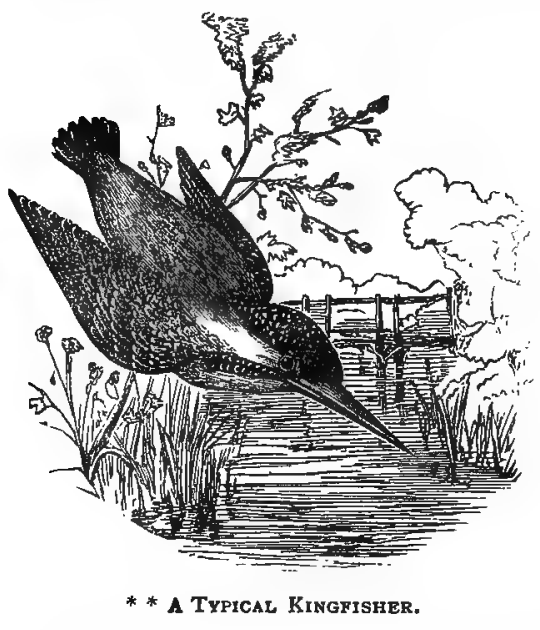
which it plunges beneath the water to secure its prey, which is chiefly fish. It is a curious fact that Mr. W. E. D. Scott frequently met with this bird in the desert region of Southern Arizona, far from water, feeding on the large insects and lizards. The nest of the Kingfisher is an excavation in the face of a perpendicular bank of a stream, or in the banks of gravel pits. The entrance is generally about two or three feet below the surface; the tunnel is usually straight, but sometimes an angle from three to six or eight feet, and is dug by the bird. The Kingfisher ejects from its mouth the bones, scales and other indigestible portions of its food, like a bird of prey. Thus are we able to account for the bones and other refuse of food found in the nesting cavities, in the midst of which the eggs are deposited. The eggs are of a clear shining white, nearly spherical in shape, usually six in number; when the full complement is laid it generally num- . bers seven or eight. Six eggs measure $1.34 \times 1.07,1.35 \times 1.08,1.37 \times 1.04,1.47 \times 1.03,1.37 \times$ $1.05,1.40 \times 1.08$.

390. 1. RINGED KINGFISHFR. Ceryle torquata (Linn.) Geog. Dist.-Mexico and southward to Southern South America; casual on the Lower Rio Grande, Texas.

This is the largest and handsomest Kingfisher found on the American continent, inhabiting suitable localities throughout the greater portion of South America, the whole of Central America, and most of Mexico. It has been added to our fauna from the fact that Mr. Geo. B. Benners shot an adult female about a mile below Laredo, Texas, on the United States side of the Rio Grande. The birds nest in holes in perpendicular hans, sometimes a long distance from water and lay white eggs which are, in all probability, similar to those of our familiar Belted Kingfisher.

391. TEXAN KINGFISHER. Ceryle americana septentrionalis Sharpe (Tschudi.) Geog. Dist.-Southern Texas to Arizona, south to Ecuador and Western Peru.

This beautiful little bird, known as Texan Green Kingfisher, is quite common in suitable places along the streams of Southern Texas-wherever the water is not too muddy for it to clearly see its prey. Like the Belted Kingfisher, this species nests in holes of banks, depositing the eggs on the bare floor of the cavity, or upon fish 
bones and other extraneous matter. Mr. Brewster describes the eggs of this species, taken in Comal county, Texas, April 25, as extremely thin-shelled, rounded-oval and nearly elliptical in shape, clear ivory-white, with a rather high pollsh; others creamy-whtte, with scarcely any polish. The sizes of five eggs are given as $1.00 \times .71$. $.94 \times .69, .99 \times .69,1.00 \times .71,1.00 \times .75$, respectively. The average size is about $.95 \times .73$ inches.

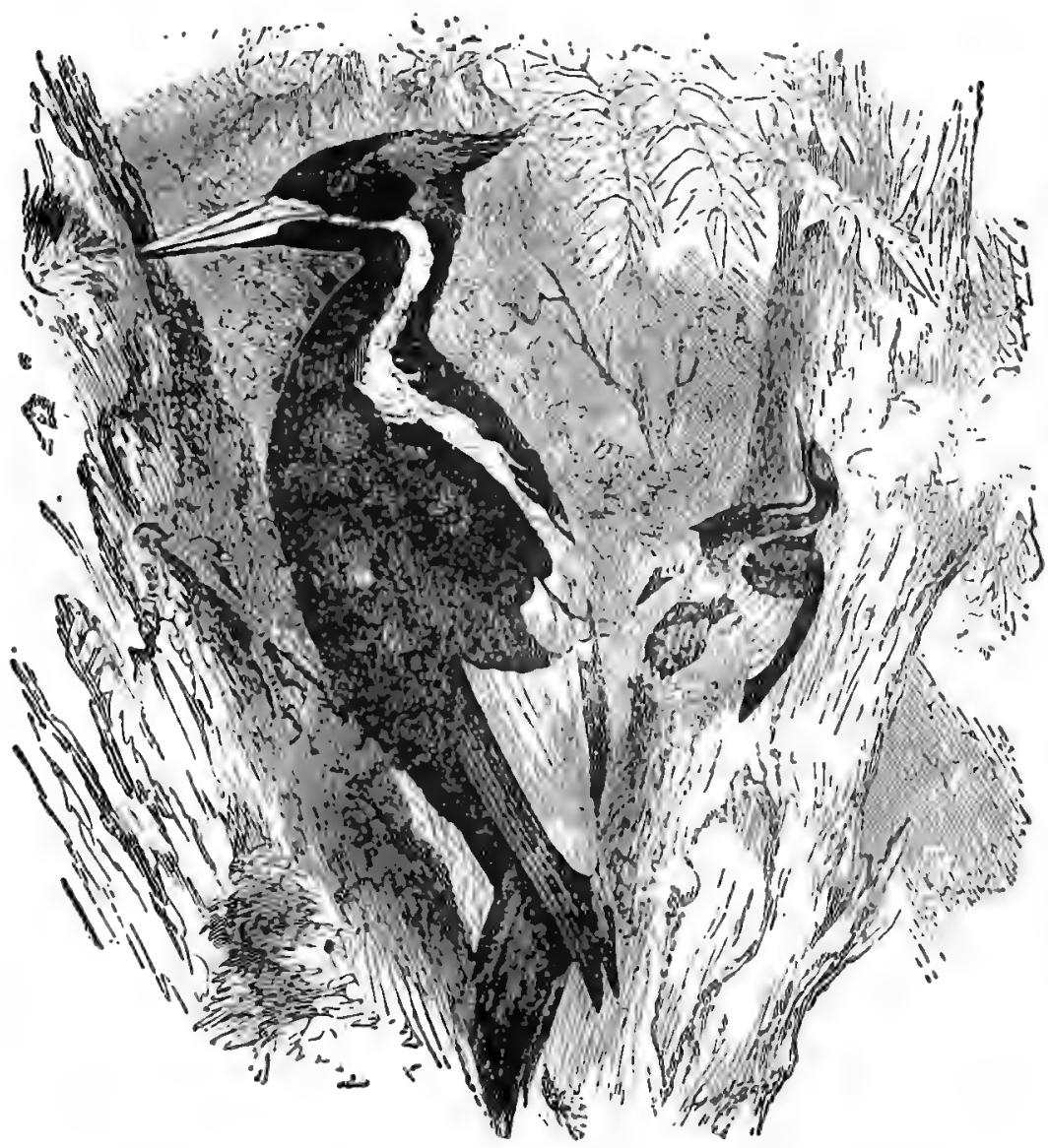

392. JVORV-BILLED WOODPECKER (From Brehm).

392. IVORY-BIILED WOODPECKER. Campephilus principalis (Linn.) Geog. Dist.-Formerly Southern Atlantic and Gulf States and Lower Mississippi Valley, north to North Carolina, Eastern Missouri, Southern Illinois and Indiana. Now restricted and only locally distributed in the Gulf States and lower Mississippi Valley where only locally. 
The largest of our North American Woodpeckers-in fact it is the prince of Woodpeckers. Its length ranges from nineteen to twenty-one inches.* The adult male has a long pointed crest of scarlet, the entire crown (with its elongated feathers) is black; the bill ivory-yellowish or whitish. This bird is now rare, and is apparently restricted to the extreme Southern States, especially those bordering the Gulf of Mexico. It is of a wild and wary disposition, making its home in the dark, swampy woodlands. The dense cypress swamps of Florida are at present one of its favorite haunts. A set of three eggs of this species is in the cabinet of Captain $B$. F. Goss. They were taken in Southern Texas in May, 1885, from a hole in a tree about forty feet from the ground; the cavity was excavated to the depth of nearly two feet, and was large enough to allow the collector to insert his arm and take out the eggs. These are pyriform in shape, and have the usual gloss of woodpeckers' eggs, and measure, respectively, $1.44 \times 1.06,1.45 \times 1.06,1.44 \times 1.07$. The average measurement of thirteen eggs in the U. S. National Museum is about $1.45 \times .99$ inches. Mr. W. E. D. Scott found a nest of this species in Hillsboro county, Florida, March 17, 1887, containing a young bird, one-third grown. The nest cavity was dug in a large cypress tree in the midst of a dense swamp, and was forty-one feet from the ground; the depth of the cavity was fourteen inches. Mr. Scott was told by old residents the bird was once very common in that region, but is now comparatively rare and shy. The day the nest was found eleven of the birds were counted in the swamp, sometimes four or five were in sight at once. $\dagger$

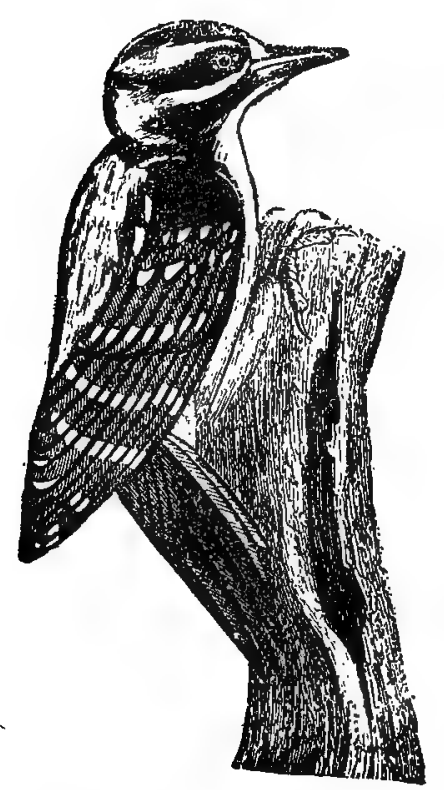

393. HAIRY WOODPECKER.

393. HAIRY WOODPECKER. Dryobates villosus (Linn.) Geog. Dist.-Northern and middle portions of the Eastern United States, from the Atlantic coast to the Great Plains.

A ragged-looking black and white species, known as the large "Sapsucker," and one of the most noisy in the woods during the breeding season, which occurs in latter part of April, through May and the early part of June. It does not accept the society of other species like its miniature, the little "Sapsucker"-Downy Woodpecker, and always maintains a more dignified manner than this species when luunting insects in the trunks of trees. The nest cavity is commonly dug in dead or partially dead treetrunks, on the outskirts of woods or those in orchards; the distance from the ground usually ranges from ten to twenty feet, and the depth of the cavity eight to fifteen inches. No material is used for a nest lining; the eggs simply rest on the fine chips made during the excavating. Four, rarely five, glossy-white eggs are deposited. Five specimens measure $.97 \times .70, .28 x$ $.70, .94 \times .69,1.00 \times .70,1.00 \times .69$.

* The Imperial Woodpecker, C. imperialis (Gould), measures twenty-three or twenty-four inches in length. This bird is found in Western Mexico, north along the Sierra Madre, and probably has not yet been observed or taken within our limits, bat is likely to occur at any time within the United States boundary.

† Auk, V. p. 186. 
393a. NORTHERN HAIRY WOODPECKER. Dryobates villosus leucometas. Bodd. Geog. Dist.-Northern North America, south to about the northern border of the United States.

The general habits, nesting and eggs are exact counterparts of those of $D$. villosus.

393b. SOUTHERN HAIRY WOODPECKER. Dryobates villosus audubonii (Swains.) Geog. Dist.-South Atlantic and Gulf States, north to North Carolina and Tennessee, west to Louisiana and Southern Texas.

The general habits, food, nesting and eggs of this geographical race are identícal with those of $D$. villosus.

393c. HARRIS'S WOODPECKER. Dryobates villosus harrisii (Aud.) Geog. Dist.-Pacific coast of North America from northern California to Southern Alaska.

Harris's Woodpecker is exactly like D.villosus, except that it has fewer wing spots; the coverts and tertials are plain black, the lower parts are usually white, frequently pure white, rarely smoky-gray. In the mountainous regions of the West coast this bird is quite common, inhabiting all kinds of forests, especially those of the pine regions. Its nesting and eggs are indistinguishable from those of $D$. villosus.

393d. CABANIS'S WOODPECKER. Dryobates villosus hyloscopus (Cab.) Geog. Dist.-Western United States, except northwest coast, and south into' Mexico.

The general habits of this race are all characteristic of those of the Hairy Woodpecker of Eastern United States. Four eggs taken in Socorro county, New Mexico, exhibit the following sizes: .95x.67, .98x.69, .96x.70, .97x.70. They are glossy-white. These were taken May 5, 1887, from a hole in an oak tree forty feet from the ground. In all respects the nesting and eggs are similar to those of $D$. villosus.

394. SOUTHERN DOWNY WOODPECKER. Dryobates pubescens (Linn.) Geog. Dist.-South Atlantic and Gulf States, from South Carolina to Florida and Texas.

A careful study of the Downy Woodpecker made by Mr. Harry C. Oberholser has resulted in separating this bird into three geographical races, the present form as the true Dryobates pubescens (Linn.), the bird of the middle region; Dryobates pubescens medianus (Swains.), and that of Alaska and northern British America, Dryobates pubescens nelsonii Oberholser. (Cf. Brewster, Auk, January, 1897, pp. 80-82.) All of these races have habits and characteristics generally alike. They are all commonly called Little or Lesser "Sapsuckers," but these are misnomers and terms which can only be applied with any propriety to woodpeckers of the genus Sphyrapicus. They are perhaps the most social of all our Woodpeckers, and the best known. They seem to enjoy the company of other birds, especially nuthatches, titmice and wrens, in whose society they are generally found, searching the branches of low trees or saplings, the hedges, the brush heaps and fences for insects and their larvæ. It is fond of drumming on the stub of a dead limb whose center is hollow, and whose shell is hard and resonant. Upon such places it will drum for an hour at a time, now and then stopping to listen for a response from its mate or of some rival. At all times unsuspicious of man, and when engaged in excavating the cavity for the nest continue the busy chiseling, unheeding his near approach. The nest is excavated in the trunk of a small dead tree, often in the dead limb of an apple tree, in a post or rail of a fence, seldom more than twenty feet from the ground, usually between ten and fifteen feet. The eggs are four or five, rarely six; they are pure 
glossy-white, and nearly elliptical in shape. There is considerable difference in the size of the eggs; a set of four measure, respectively, .75x.62, .77x.62, .73x.61, .73x.62; another set, containing four, .84x.58, .78x.59, .83x.58, .82x.56; a set of five, .80x.57, $.85 \times: 60, .84 x .60, .83 x .62, .84 x .63$.

394a. GAIRDNER'S WOODPECKER. Dryobates pubescens gairdnerii (Aud.) Geog. Dist.-Western United States, from the Rocky Mountains to the Pacific, north to British Columbia, south to New Mexico.

The western representative or counterpart of the Downy Woodpecker of the East, resembling it in size, general habits, etc. In many places of the West it is an abundant bird, but is not generally so common as the Downy is in the Eastern States. Mr. Norris has a set of five eggs of this Woodpecker, collected June 1, 1876, near Santa Cruz, California. They are glossy-white, and measure .81x.69, .80x.58, $.80 \times .59, .77 \times .58, .74 \times .56$.

394b. BATCHELDER'S WOODPECKER. Dryobates pubescens oreceus Batch. Geog. Dist.-Rocky Mountain region of the United States.

This subspecies inhabits the Rocky Mountain region of the United States, but it appears to be more common on the eastern slopes than on the western and throughout the Great Basin regions. Its habits, food, nesting and eggs are identical with those of the Downy Woodpecker of the Eastern States. A set of six eggs of this subspecies is in Mr. C. W. Crandall's oölogical collection. They were taken by Mr. D. P. Ingraham near Beulah, Pueblo county, Colorado, June 1, 1896. The bird was shot and identification made certain. The nest was in the hollow of a dead limb of an aspen tree about 14 feet from the ground, at an altitude of 8,000 feet. The eggs are pure white, very glossy and of a true ovate shape. Their sizes are as follows: $.73 \times .58, .74 \times .58, .74 x .60, .76 x .59, .76 \times .57, .74 x .59$ inches respectively.

394c. DOWNY WOODPECKER. Dryobates pubescens medianus (Swains.) Geog. Dist.-Middle and northern parts of eastern United States and northward.

Now a geographical race of the typical Dryobates pubescens of Linnæus. It is the the familiar "Downy" of the middle and northern parts of eastern United States. Its habits, nesting and eggs are described under the type No. 391.

394d. NELSON'S DOWNY WOODPECKER. Dryolates pubescens nelsoni Oberholser. Geog. Dist.-Alaska and Northern British America.

Mr. Nelson states that this Downy Woodpecker is a winter and summer resident in Alaska. Where woodland or a growth of bushes and small trees occur it is certain to be found. It has been taken along the entire course of the Yukon, as well as at various points on the coast of Bering Sea. The nesting holes were frequently found in the decaying stubs, although he did not find a nest containing eggs.

395. RED-COCKADED WOODPECKER. Dryobates borealis (Vieill.) Geog. Dist.-Southern States, north regulariy to North Carolina, irregularly to New Jersey; west to Indian Territory and Eastern Texas.

The Red-cockaded Woodpecker has a restricted distribution in the Southeastern Atlantic and Gulf States, and is found regularly as far north as the Carolinas, westward to Indian Territory and Eastern Texas, and only irregularly to New Jersey. Audubon speaks of it in his day as being found abundantly from Texas to New. Jersey, and as far inland as Tennessee, and nowhere more numerous than in the pine 


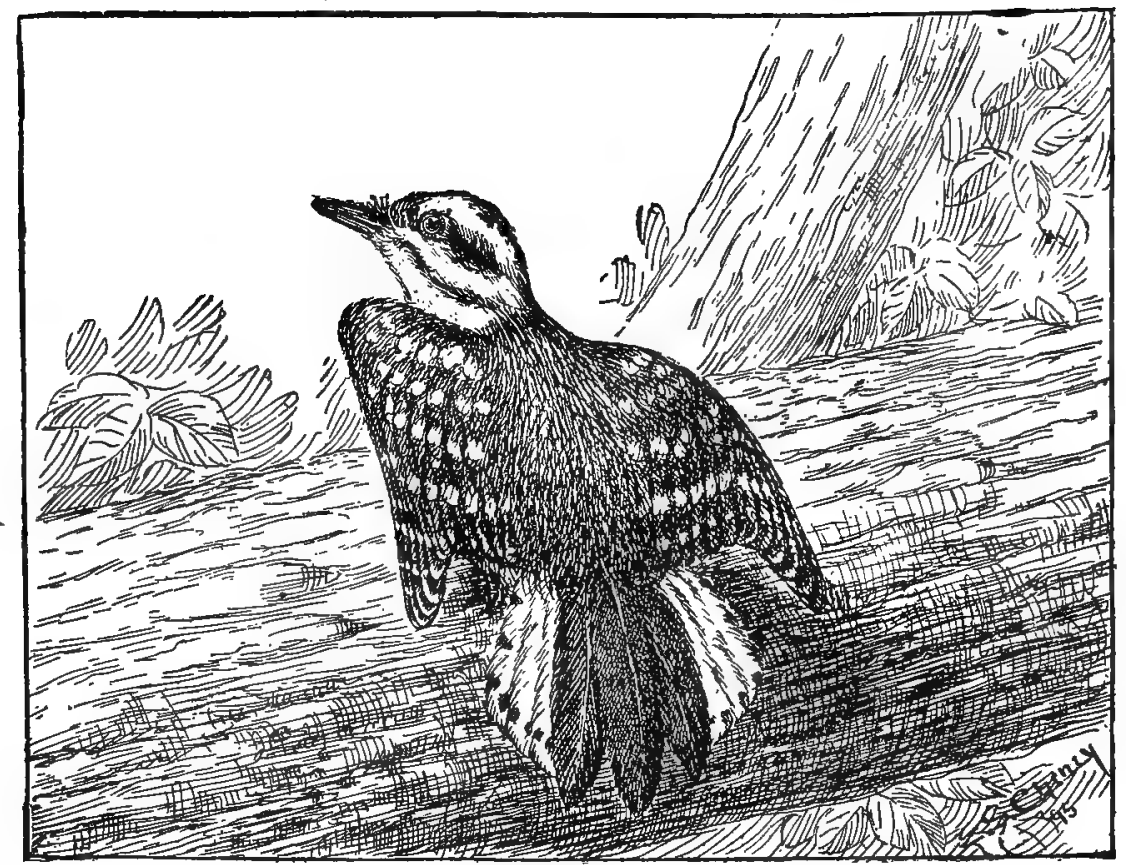

394e. Downy Woodpecker (E. S. Cheney del).

regions of Florida, Georgia and the Carolinas. He found these birds mated in Florida as early as January, and engaged in preparing a breeding place in February. The nest, he states, is not unfrequently bored in a decayed stump. In Georgia and other localities this bird excavates a nesting cavity in tall pine trees, living or dead. The eggs range from three to four in number, rarely more, glossy-white; size .91x.68.

396. TEXAN WOODPECKER. Iryovates scalaris vairdi (Malherbe). (Wagl.) Geog. Dist.-Southern border of the United States, from Texas to Arizona south into Mexico.

This bird is called the Ladder-backed Woodpecker, from the black and white cross-bars on the back. It averages larger than the Downy, $D$. pubescens. Dr. Merrill found it a common resident in Southern Texas. He states that in its habits It is so like the Downy Woodpecker that there is little to be said about it. He gives the average size of eighteen eggs as $.81 x .64$.

396 $a$. ST. LUCAS WOODPECKER. Dryobates spqaris lurasamus Xantus. Geog. Dist.-Lower California north to lat. $34^{\circ}$ in the Colorado Desert, California.

There appears to be no written account concerning the nidification of this geographical race which is found in Lower California and the Colorado Desert in California.

397. NUTTALL'S WOODPECKER. Dryobates nuttalli (Gamb.) Geog. Dist.-Southern Oregon, California and Northern Lower California.

The habitat of Nuttall's Woodpecker is restricted to the limited area of the State of California, Southern Oregon, and down into Northern Lower California. It closely resembles the Texan Woodpecker, and may be easily recognized from the 
latter by the white or dull buff nasal tufts and the markings of the tail feathers. The bird is of the same size as the Downy Woodpecker of the Eastern States, and has many of its characteristics, familiarly searching the orchards, stumps of trees and fence rails for insects and their larvæ. Mr. Walter E. Bryant found a nest of this species on Mt. Diablo, California, May 29, 1880. It was in a cavity picked between the body and the bark of an oak stump, fifteen feet from the ground. The opening was very difficult to find. The male bird was sitting, and flew from the stump as Mr. Bryant approached, and he was obliged to wait for its return before the entrance could be located. The cavity was about twelve inches deep and four inches inside diameter; diameter of the entrance was about one inch and a half. The nest contained four glistening, white eggs; their sizes being as follows: 24x17.5, 23×17,

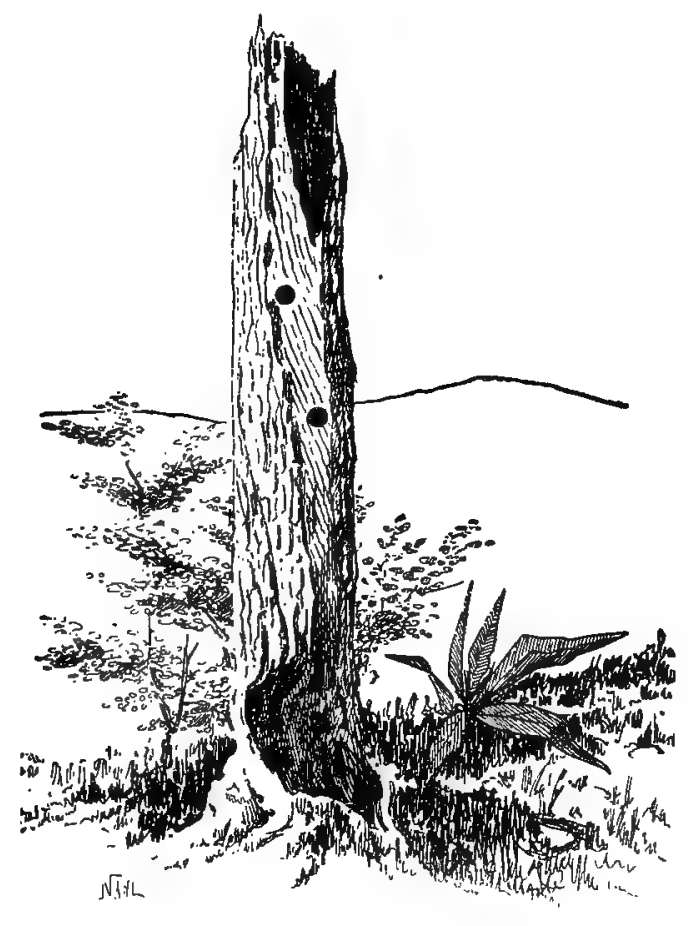

397. Home of Nuttall's Woodpecker (From The Nidologist).

23x17.5, 23.5x.17 millimeters.* Mr. B. T. Gault on April 23, 1883, obtained a set of six eggs of this species from a cavity in the main trunk of an elder bush or tree in the San Bernardino Valley. Notwithstanding various loud demonstrations-tapping on the tree trunk and chopping into the cavity with a hatchet the female bird did not leave the'nest, and when taken out appeared stupefied. The nest was about five and $a$ half feet from the ground, was very nearly a toot deep and about five inches wide;

*.94x.69, .91x.67, .91x.69, .93x.67. 
the entrance was a little larger than a silver half dollar. The eggs were pretty well advanced in incubation; their sizes are $.85 x .66, .87 x .65, .82 x .64, .85 x .66, .85 \times 66, .84 . x$ .64.* They are of a pearly white.

398. ARIZONA WOODPECKER. Dryobates arizone (Hargitt.) Geog. Dist.Southern Arizona to Northern Mexico.

Mr.F.Stephens met with this species in the Santa Rita and Chiricahua Mountains in Southern Arizona. Although the birds were not uncommon he did not succeed in obtaining the eggs. A nest was found May 16 in a sycamore tree which contained young. Mr. W. E. D. Scott found this Woodpecker in the oak region of the San Pedro slope of the Cataline Mountains where, except in midwinter, it is not uncom mon. Mr. Brown found it common on the Santa Rita Mountains. Mr. Scott rarely met with more than two in company; frequently in the fall a party was seen composed of Arizona Jays, California Woodpeckers, various Titmice and Warblers, and a pair of Strickland's Woodpeckers. They appeared mated late in January or early in February. A nest containing three young, found May 27, was in an oak about ten feet from the ground; it was much like that of the Hairy Woodpecker, but the opening was a little smaller. The eggs are three or four in number, glossy white, and average $.84 \times .64$ inches.

399. WHITE-HEADED WOODPECKER. Xenopicus albolarvatus (Cass.) Geog. Dist.-Mountains of the Pacific coast, from Southern British Columbia to Southern California (including the eastern slope of Sierra Nevada), and east to the Blue Mountains of Oregon and West Central Idaho.

This peculiarly-colored species is common in the pine regions of Washington, Oregon and California. Dr. James C. Merrill, Assistant Surgeon, U. S. Army, states that this bird was flrst observed in the vicinity of Fort Klamath, Oregon, November 9; by December it became rather abundant, and so continued until the latter part of February, but after the middle of March none were seen. Careful search during the breeding season failed to reveal its presence near the Fort, nor was it found in the higher mountains in July and August. Dr. Merrill rarely heard this Woodpecker hammer, and even tapping is rather unusual with it. The bird uses its bill as a crowbar rather than a hammer, prying off the successive scales and layers of bark in a very characteristic way, which explains the fact of its being a quiet worker. As a result of the great abundance of food which these birds obtained, the specimens killed were loaded with fat-scarcely surpassed in this respect by'some Sandpiper in autumn. $\dagger$ Capt. B. F. Goss has a set of three eggs of this species, taken May 17, 1882, near Crockers, California. The nest cavity was in a small rotten stub, thirteen feet from the ground. The eggs are pure crystalline white, exhibiting the following sizes: $.96 \times .75, .98 \times .74, .98 \times .77$. Set No. 253 (oölogical collection of Walter E. Bryant), consisting of four eggs, was taken at Blue Canon, Cal., by C. A. Allen, May 27, 1879. The nest was in an excavation of a pine stump, five feet from the ground. The eggs measure respectively $23 \times 17.5,23.5 \times 18.5,24 \times 18,24 \times 18.5 \mathrm{~mm}$. Set No. 815 in Mr. Bryant's collection was taken at Big Trees, Cal., by Chas W. Knox. This set contains five eggs; they were taken from a hole in a dead pine stump, eight feet from the ground. Their sizes are: $25 \times 19,23.5 \times 18.5,25 \times 19,24 \times 19,24 \times 19.5 \mathrm{~mm}$.

\footnotetext{
* Bull. No. 2. Ridgway Ornithological Club, April, 1887: Chicago, Ill., pp. 78-81.

† Auk, V, p. 253.

₹.91x.69,.93x.73,.94x.71, .94x.73.

$.98 \times .75, .93 \times .73, .98 \times .75, .94 x .75, .94 x .77$.
} 
400. ARCTIC THREE-TOED WOODPECKER. Picoides arcticus (Swains.) Geog. Dist.-Northern North America, from the Arctic regions south to the Northern United States (New England, New York, Michigan, Minnesota and Idaho), and in the Sierra Nevadas to Lake Tahoe.

The Black-backed Three-toed Woodpecker has an extended distribution from the Pacific to the Atlantic, and from the northern border of the United States northward to the Arctic regions. Its favorite haunts are the pine woods of mountainous country. In some portions of Northern New England it is a rare summer resident. Audubon says that it occurs in Northern Massachusetts and in all portions of Maine covered by tall trees, where it resides. It is found as far south as Northern New York, where Dr. Bachman was of the opinion that it nested. Dr. Merriam states that this bird is not an uncommon resident in those portions of Lewis county, New York, which pertain to the Canadian fauna; for they are found both in the Adirondack region and in the coniferous forests bordering Big Alder and Fish Creeks, in the Tug Hill range. Dr. J. C. Cooper found this Woodpecker quite numerous in September, in the vicinity of Lake Tahoe and the summits of the Sierra Nevada, above an altitude of 6,000 feet. Dr. Merrill mentions it as a rather common resident in the vicinity of Forth Klamath, Oregon; in summer more common in the mountains. Several nests were found early in July, but with young, fledged. The excavations were in dead young pines, not more than five or six feet from the ground, in this respect differing from those of the other Woodpeckers found there, all of which, so far as he had observed, make their holes at a greater height. The eggs range from four to six in number, pure ivory-white; average size, $.95 \times .71$.

401. AMERICAN' THREE-TOED WOODPECKER. Picoides americanus Brehm. Geog. Dist.-Northern North America east of the Rocky Mountains, south in winter to the Northern United States (Maine, Massachusetts, New York).

The Banded or Ladder-backed Three-toed Woodpecker is found in the spruce and fir regions of Northern North America. It is often found associated with the last species, $P$. arcticus, whose characteristics are similar, and whose nesting is identical. Dr. C. Hart Merriam met with a pair of these birds nesting in Northern New York, June 4, 1878. The cavity, which contained four nearly fresh eggs, was in a spruce tree about eight feet from the ground; the entrance of the hole was an inch and a half in diameter, and the cavity ten inches deep. The eggs are described as cream-white, and of a texture like those of other Woodpeckers; they are strongly ovate in outline, and measure respectively, $23.8 \times 17.2,23.6 \times 17.8,23 \times 17.9,23 \times 17.8$ millimeters.*

401a. ALASKAN THREE-TOED WOODPECKER. Picoides americanus alascensis (Nels.) Cecg. Dist.-Alaslia, south to Northern Washington.

Nothing has been published regarding this bird's nesting and eggs, but more than likely they do not differ from those of the preceding species.

401b. ALPINE THREE-TOED WOODPECKER. Picoides americanus dorsalis Baird. Geog. Dist.-Rocky Mountain region, from British Columbia and Idaho south into New Mexico.

The nesting habits, eggs and general characteristics, of this race inhabiting the Rocky Mountain region are the same as those of Picoides americanus.

$\star .94 \times .68, .93 \times .70, .94 x .71, .91 x .70$. Bull. Nutt. Club, III, 200. 


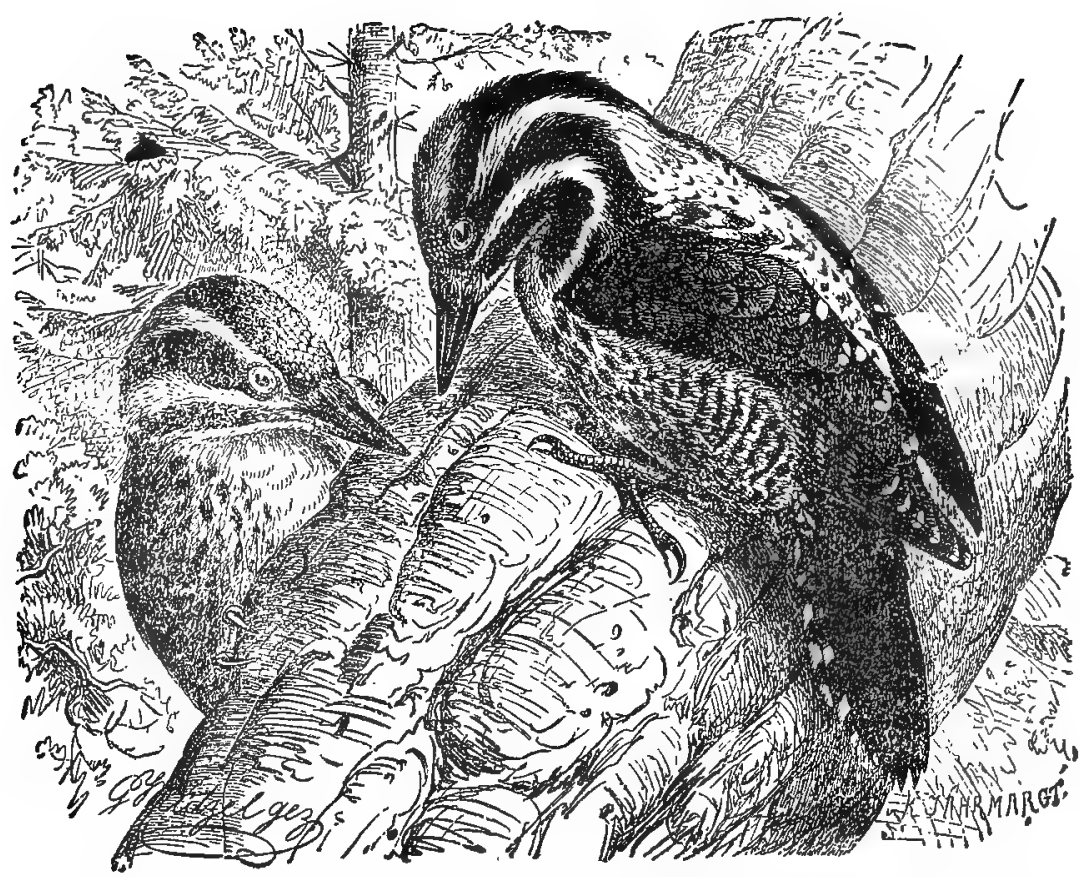

**European Three-toed Woodpecker Picoides traacrylus. Similar in cut to P, americanus (From Brehm).

402. YELLOW-BELLIED SAPSUCKER. Sphyrapicus varius (Linn.) Geog. Dist.-Eastern North America north to about $63^{\circ} 31^{\prime}$ (north of Fort Simpson), breeding from Massachusetts northward; in winter to the West Indies, Mexico and Costa Rica.

The Yellow-bellied Woodpecker is one of the most singularly marked and most attractive birds of the family. It breeds from the northern United States northward. A common bird in most of its United States range. The Woodpeckers of this genus are the only ones to which the term "Sapsucker" can with any propriety be applied. They lack the long extensile tongue which enables the other species to probe the winding galleries of wood-eating larva, and they are known to feed largely upon the green inner bark of trees. In some localities this species is said to de troy many trees by stripping off bark and girdling them with holes for the sap. The following details are from Mr. William Brewster's account of this bird's nesting habits in New England. He states that throughout the White Mountains of New Hampshire, and in most sections of Northern Maine, the Yellow-bellied Woodpeckers outnumber all the other species in the summer season. Their favorite nesting sites are large, dead birches, and a decided preference is manifested for the vicinity of water, though some nests occur in the interior woods. The average height of the excavation from the ground is about forty feet. In nearly every tree examined by $\mathrm{Mr}$. Brewster, which contained a nest, there were several newly-finished cavities, and others made in previous years, but in no case was more than one of the excavations inhabited. Many of the nests were gourd-like in shape, with the sides very smoothly 
and evenly chiseled; the average depth was about fourteen inches, by five in diameter at the widest point, while the diameter of the exterior hole varied from 1.25 to 1.60 inches. The labors of excavating the nest and those of incubation are shared alternately by both sexes. Mr. Brewster gives the eggs as numbering from.

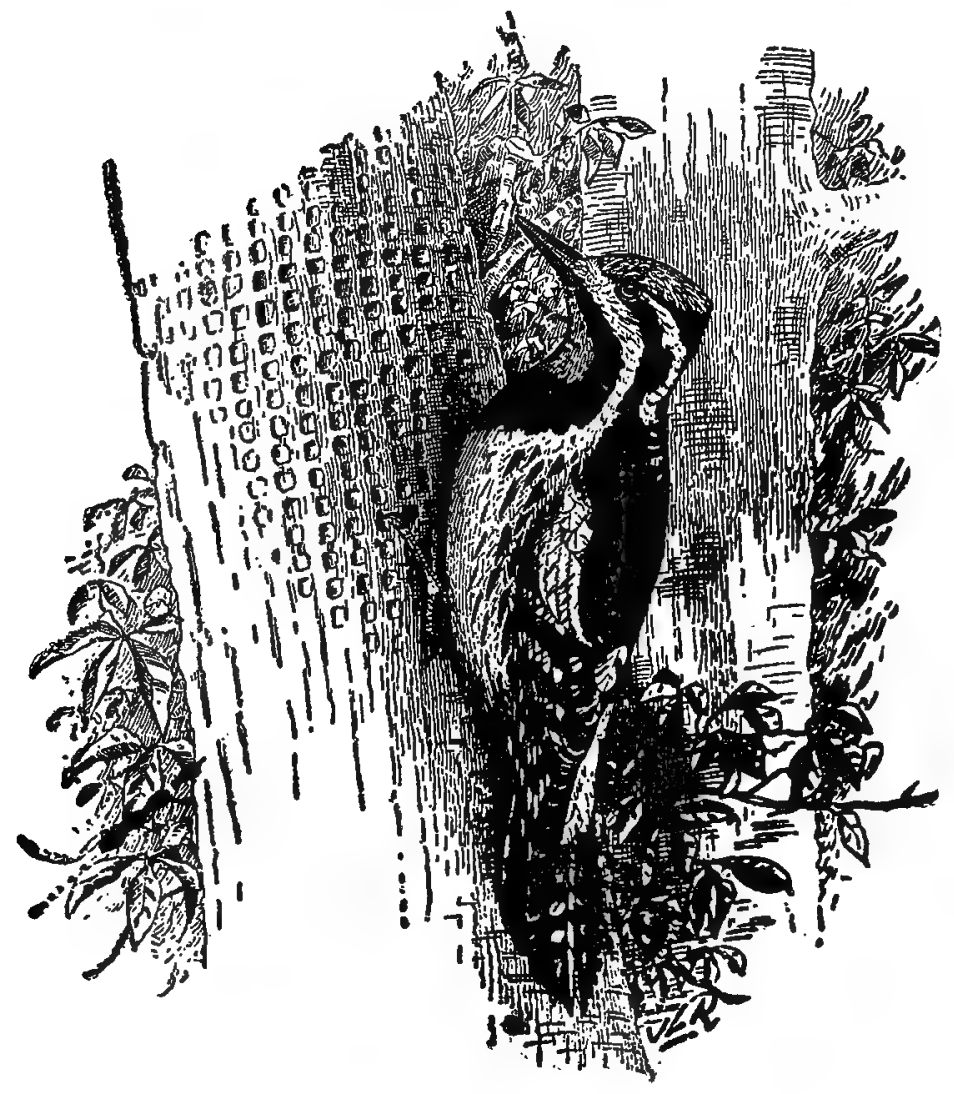

403. Yellow-bellied Sapsucker (from Beal).

five to seven in a set, and varying considerably in shape, some being oblong, others decidedly elliptical. They are pure white in color, and there is much less of that fine polish than in eggs of the other species of Woodpeckers he had examined. The size is given as $.85 \times .60 . *$

402a. RED-NAPED SAPSUCKER. Sphyrapicus varius nuchalis Baird. Geog. Dist.-Rocky Mountain region, west to the Sierra Nevada and Cascade ranges; south into Mexico.

The late Major Charles E. Bendire, U. S. A., met with this race of $\mathbf{S}$. varius sparingly distributed in various portions of the Blue Mountains of Oregon, Washington Territory and Idaho, and as far west as the eastern slope of the Cascade Range in Southern Oregon, in the Klamath Lake region, where it was replaced by Sphyrapicus ruber, the two species overlapping each other, but not intergrading, and remaining perfectly distinct.He found it breeding in June, nesting in cavities of live

- Bull. Nutt. Club, I, pp. 65-70. 
aspen trees. Dr. James C. Merrill found a nest of this bird in a cavity of a dead young cottonwood, in Montana, June 12. The height of the hole from the ground was twenty-five feet, anu near the top of the same tree were three similar holes, probably used by the same birds in previous years. Mr. Dennis Gale, an enthusiastic naturalist, has given Major Bendire the results of his observations on the nesting of this Woodpecker in the mountains of Colorado. According to him, its nesting sites are invariably in living aspen trees, along the gulches and hillsides, and the birds are seldom found above an altitude of 9000 or much below 8000 feet. In excavating the cavity the female bird does the work from beginning to end, and completes it in from six to ten days. The height of the nesting place from the ground varies from five to thirty feet. The eggs are from three to six in number, usually four or five. Fresh eggs may be found in Colorado from June 1 to 15 , and should the first set be taken, a second may generally be found in from ten to fifteen days later; and as a rule, the second nesting-site will not be a great distance from the first one. Several nests of this species may be found within a short distance of one another in the same aspen grove. The cavities are roomy and gourd-shaped. Bendire gives the measurements of two sets of four eggs each, taken by Mr. Gale. The first set, collected June, 1884, measures as follows: $.91 \times .67, .90 \times .68, .89 \times .68, .88 \times .64$; second set taken June 1 , $1887, .90 \times .69, .90 \times .69, .90 \times .68, .89 x .65$. A set of three eggs taken by himself in the Blue Mountains, Grant county, Oregon, exhibit the following sizes: $.90 x .65,90 x .64$, $.88 \times$.66. The average measurement is given as $.88 \times .66$. The eggs are pure white after blowing, moderately glossy or lustrous, and generally ovate in shape.* The set of five taken by Dr. Merrill in Montana measure .91x.72, .90x.73, .93x.71, .93x.73, $.91 x .73$, respectively.

403. RED-BREASTED SAPSUCKER. Sphyrapicus ruber (Gmel.) Geog. Dist.-Pacific coast region, from California northward into Alaska.

This species is confined to the Pacific coast region, occuring as far east as the eastern slopes of the Sierra Nevada Mountains in Central and Northern California; in the Cascade Mountains of Oregon and Washington, thence northward through British Columbia into Alaska: A handsome bird, with the whole head, neck and breast carmine-red in both sexes. Major. Bendire states that this bird is an abundant summer resident of the aspen groves on the mountains in the southwestern portion of Oregon-the region about Fort Klamath, etc. According to his observations its nesting is very similar to $S$. $v$. nuchalis-breeding in healthy live aspen trees, making a gourd-shaped nest cavity from six to ten inches deep, four or five inches wide at the bottom and three inches near the top. It is situated from fifteen to twenty-five feet from the ground, and usually excavated below the first limb of the tree. A sure sign of a nest was the chips scattered about the base of the tree. Five or six eggs are laid, and fresh eggs may be looked for in the neighborhood of Fort Klamath from May 20 to June 5. Major Bendire took the first set of eggs May 23, 1883, and he has taken nearly fresh eggs as late as June 13. When blown the eggs are a pure delicate white, the shell showing a moderate amount of lustre. There is considerable variation in their shape, running through all the different ovates to an elongate-ovate. The average measurements of sixty specimens are $.94 \times .68$; the largest egg $1.00 \times .70$; the smallest .86x.78. A set of five eggs is in Mr. Norris's collection, taken with the female bird, near Salem, Oregon, April 13, 1888, from a cavity in a cottonwood, twenty-five feet from the ground. They measure $1.00 \times .73, .91 \times .71, .94 \times .70, .90 \times 71, .90 \times 71$.

* See Notes on the Habits, Nests, and Eggs of the Genus

Charles E. Bendire: In The Auk, V, pp. 225-240.

Sphyrapicus. By Major 
404. WILLIAMSON'S SAPSUCKER. Sphyrapicus thyroideus (Cass.) Geog. Dist.-Western United States, from and inclusive of the Rocky Mountains to the Pacific.

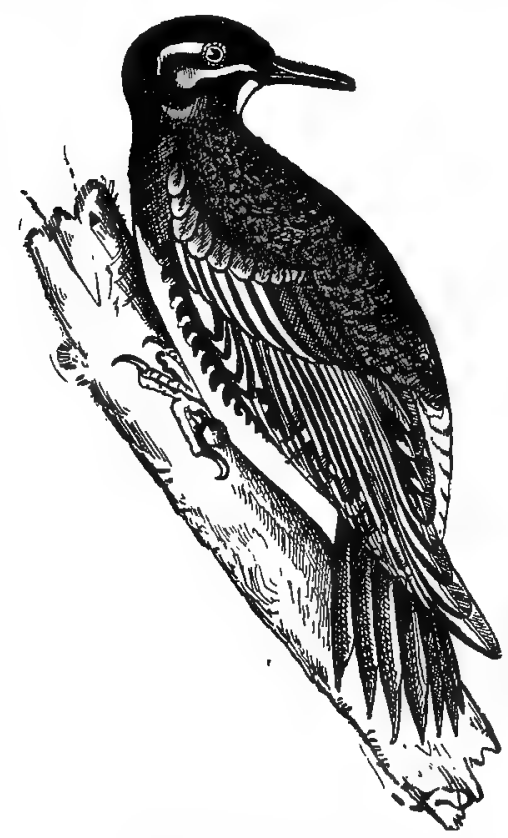

404. Williamson's Sapsucker.

This singular representative of the sphyrapicus, has a distribution extending from the eastern slopes of the Rocky Mountains to the Pacific coast in Oregon and California. The male and female of this species are so different in coloration that they were for a long time considered separate species. Regions of coniferous trees seem to be the favorite haunts of Williamson's Woodpecker. Dr. Merrill notes it as not an uncommon resident in the vicinity of Fort Klamath, Oregon, but shy and very suspicious. Two nests containing young were found June 20 in large dead pines; each were at a height of about sixty feet, and inaccessible. Mr. Dennis Gale, who has given Major Bendire his observations on the habits of this species in the mountains of Colorado, says that the birds are as often met with in moderately thick woods as in more open clearings. The nesting sites are excavated in the trunks of pine trees, at heights ranging from five to sixty feet or more. Fresh eggs may be looked for, according to altitude, from May 20 to June 15. At Fort Klamath, Major Bendire took the first set of eggs June 3, 1883. Five or six are laid. They are pure white, a trifle less lustrous than those of $S$. ruber, a little more elongated and pointed in shape, some approaching a distinct ovate-pyriform or pear shape, a characteristic not apparently found in the eggs of other species of the same genus. Major Bendire gives the average size of seventeen specimens as $.97 \times .67$; the largest, 1.02x.68; the smallest, .94x.67.

405. PILEATED WOODPECKER. Ceophlœus pileatus (Linn.) Geog. Dist.Formerly entire North America in heavily-wooded districts, south of latitude $63^{\circ}$, except in the southern Rocky Mountains; now rare or extirpated in the thickly settled part of Eastern United States.

Next in size to the Ivory-billed species is the Pileated Woodpecker, commonly called Logcock. It was formerly common to the whole wooded region of North America east of the .Rocky Mountains, but is now rare or absent in the thickly settled portions of the Eastern States. In southern districts, midst timbered swamps and heavy secluded woods it is still abundant. The nesting places are excavated usually in the main trunks of high trees, such as oaks, sycamores, elms, pines, etc. The height of the burrow from the ground ranges from twenty to eighty feet. If inhabited, and the bird is at home, a rap upon the trunk of the tree will generally bring this species to the entrance of the excavation. The eggs are from three to five in number, glossy or china-white and average in size about $1.30 \times 1.00$ inches. 


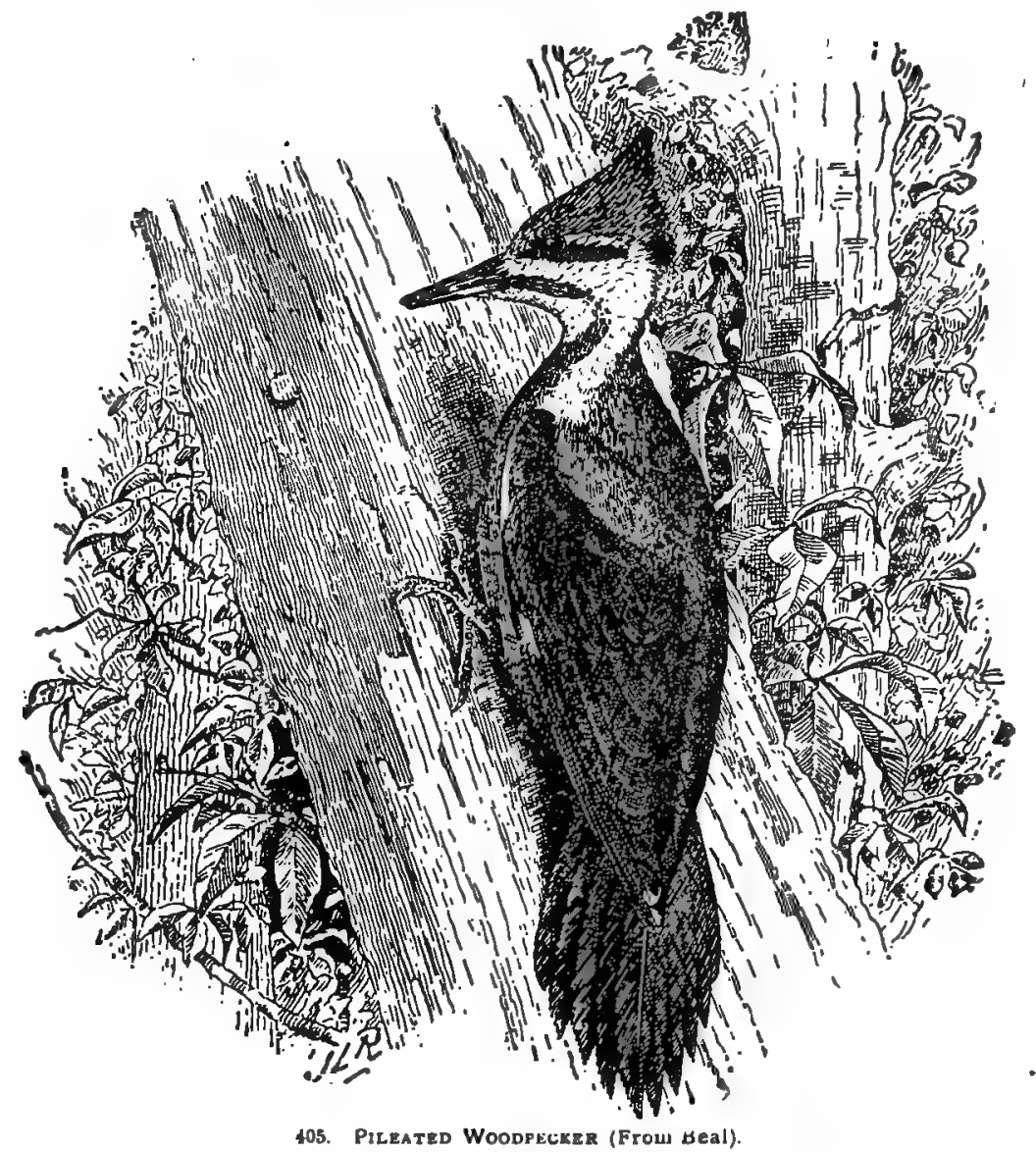

406. RED-HEADED WOODPECKER. Melanerpes erythrocephalus (Linn.) Geog. Dist.-United States and British Provinces, west to the Rocky Mountains, occasionally farther. Rare or casual east of Hudson River.

One of the most familiar birds in Eastern United States. It is found almost everywhere-in deep forests and open woods, in groves, orchards and solitary trees In fields, or along the roadside, and on the open prairies. A bird of manifold tricks and manners-some are commendable, and some are not. It is known to rob and demolish the nests of the Cliff Swallows; oftentimes whole colonies of these nests are destroyed by this Woodpecker. It seems to have considerable foresight in "looking out for a rainy day ahead" by storing grasshoppers, acorns and beech nuts in the cracks and crevices of posts, in the cavities of partially decayed trees, and under patches of raised bark. Berries and various frults are likewise a portion of Its food. A cavity for the nest is dug in the decayed trunk of any kind of a tree of sufficient thickness, and in almost any situation. Telegraph poles are often resorted to. On the open, treeless prairies it has been known to nest in the anglo formed by the shares of an upturned plow, and necessity often compels this bird to make its nest under the roofs or in any dark hole it may find on the prairie 
farms. The eggs are five or six in number; when fresh and before blowing, like those of all Woodpeckers, show the yolk through the translucent shell, which gives them a beautiful pinkish appearance. After blowing they are of a clear, glossywhite. The average size is $.99 \times .78 .^{i}$

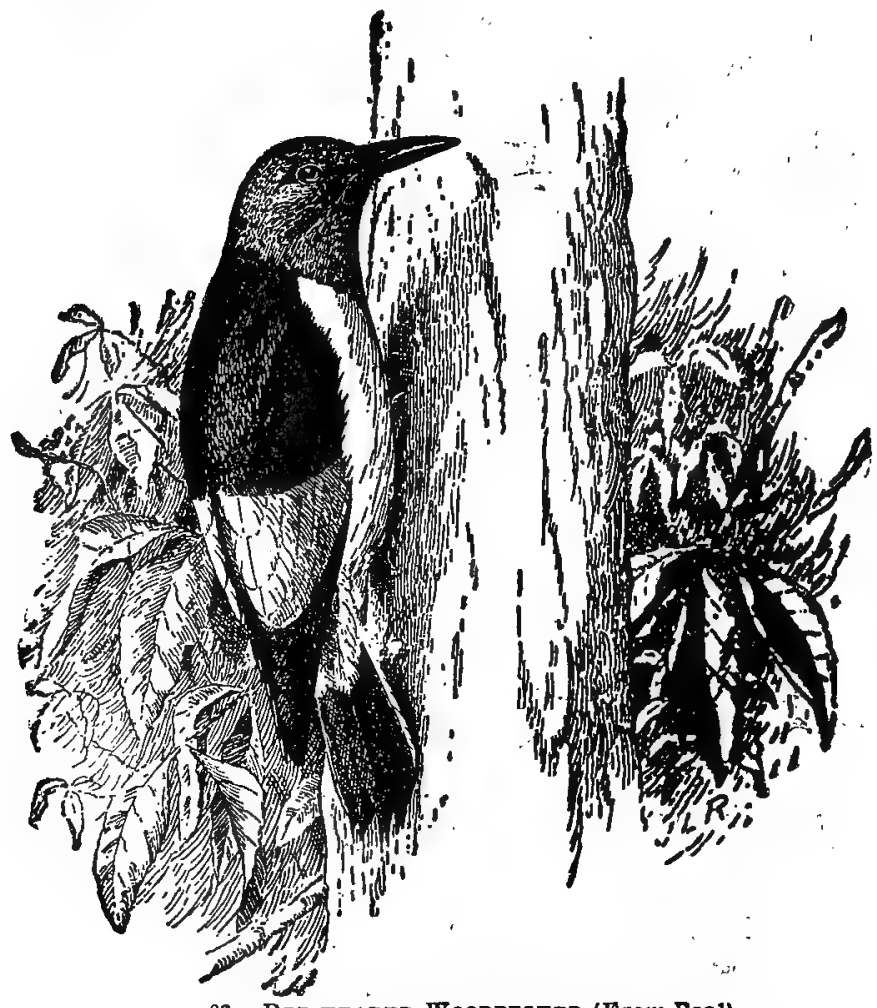

106. RED-HEADED WOODPECEER (From Beal).

407. ANT-EATING WOODPECKER. Melanerpes formicivorus (Swains.) Geog. Dist.-Western Texas, New Mexico and Arizona, thence over the tablelands of Mexico.

Mr. W. H. Henshaw met with this species in the Rocky Mountain region of New Mexico, near Santa Fe, where it frequented the small oak groves. Mr. W. E. D. Scott states that the bird is a common resident of the Pinal and the Catalina Mountains of Arizona, both in pine and oak regions as low as 4,000 feet. July 30, 1884, a nest containing three half grown young was found; it was in a natural cavity of a aycamore tree fifty feet from the ground. The number of eggs laid to a set is four or five, rarely more. They are like the eggs of all woodpeckers, pure white and glossy. The average measurement of nineteen specimens as given by Maj. Bendire is $1.00 \times .75$ inches.

407a. CALIFORNIAN WOODPECKER. Melanerpes formicirorws bairdi Ridgw. Geog. Dist.-Pacific coast region of the United States, from southern Oregon south to Northern Lower California and Mexico, east through Arizona to Southern Mexico iand Western Texas.

This subspecies of the Paclfic coast region has to same general habits as $\boldsymbol{M}$. formicivorus. 
407b. NARROW-FRONTED WOODPECKER. Melanerpes formicivorus augustifrous Baird. Geog. Dist.-Southern Lower California.

A smaller race with a brighter sulphur-yellow throat and narrow frontal band than the California Woodpecker. It is an inhabitant of the more southern portions of Lower California and was first described by Baird in 1870. Mr. L. Belding found it common at Miraflores, and abundant in the Victoria Mountains. On June 3, 1887, Mr. M. Ab sott Frazar found a nest of this species in the Sierra de la I aguna, Lower California. The eggs, four in number, are now in Mr. William Brewster's collection; these are white, with rather a dull gloss, varying in shape from blunt ovate to broad elliptical oval, measuring .95x.75, .94x.74, .89x.77, .89x.76 inches. Mur. Frazar in formed Major Bendire that as nearly as he remembered the nesting place was in a dead pine stump, not a great distance from the ground.

408. LEWIS'S WOODPECKER. Melanerpes torquatus (W1w., Geog. Dist.Western United States, from the Black Hills and the Rocky Mountains to the Pacific coast.

In most of the wooded, mountainous regions of the West, from the Rocky Mountains to the Pacific, Lewis's Woodpecker is a common bird. About Fort Klamath, Oregon, Dr. Merrill notes it as rather uncommon during the summer, nesting usually near the tops of tall dead pines, especially isolated ones, from which they can obtain a good view of passing insects, which they will often follow to a considerable distance. The general habits of this species are similar to those of the Red-headed Woodpecker. It is found in greater or less abundance in the pine and oak districts of New Mexico, Arizona, California, Colorado, etc., where the nests are burrowed, preferredly in dead trees, at all heights from the ground. The eggs are five to nine in number, six or seven being the most common number, and, like all those of the Woodpeckers, are white and glossy. The average measurement of one hundred and seventy-one specimens in the U. S. National Museum collection is about $1.03 \times .80$ inches; the largest specimen $1.18 \times .88$, the smallest $.94 x .65$ inches.

409. RED-BELIIED WOODPECKER. Melanerpes carolinus (Linn.) Geog. Dist.-Eastern United States, west to the Rocky Mountains, south to Florida and Central Texas.

This Woodpecker is regarded by some as the most beautiful of the smaller species of its tribe, and is known'to many as the "Zebra Bird," from the back and wings being closely banded with black and white; the whole crown and nape are scarlet in the male, partly so in the female. Under parts grayish, mixed with yellowishwhite, reddening on the belly. A bird generally of retired habits, seeking the deepest and most unfrequented forests to breed. When engaged in hammering fór insects it frequently emits a short, singular note, which Wilson likens to the bark of a small dog. The note is repeated twice, and resembles the hoarse utterance of the syllables chow, chom. Prof.'D. E. Lantz states that this species in the vicinity of Manhattan, Kansas, exhibits the same familiarity as shown by the Flicker, the Redheaded and Downy Woodpeckers. About a dozen nests were observed, the excavations ranging usually less than twenty feet from the ground. One nest in a burrow of a large dead limb of an elm tree was found May 12, and contained five eggs. The earliest date for a full set was May 10. . The birds were very much attached to their nests, so much so that in several, cases it was necessary to remove them with the hand before the eggs could be secured. The eggs being taken, they almost immediately begin excavating another nest cavity for the second set, always in the 
vicinity of the first nest, often in the same tree. In Ohio this bird is a common resident. Breeds in May. Four to six white eggs are laid, varying in length from .77 to 1.00 by .67 to .79 in breadth. Six cggs taken in Franklin county, Ohio, measure 1.00x.77, .98x.78, 1.00x.78, .99x.74, 1.00x.76, 1.00x.74. The average size of twentyfour specimens in the U. S. National Museum as given by the late Major Bendire is $.99 \times .73$ inches. These are mostly from Florida.

\section{GOLDEN-FRONTED WOODPECKER. Melanerpes aurifrons, (Wagl.)} Geog. Dist.-Southern Texas and Northeastern Mexico.

Dr. James C. Merrill records this species as abundant on the Lower Rio Grande in Texas, and Mr. George B. Sennett found it very common at Lomita, and as bold and noisy as the Red-headed Woodpecker of the North. Although breeding abundantly, the eggs were difficult to obtain, as the nesting cavities were often situated in the heart of large hard-wood trees, and not very accessible. From four to seven rather dull looking white eggs are laid; usually five or six. Mr. Sennett took the first set of eggs April 17, and a clutch of five fresh ones was taken May 1st. Two broods are probably reared in a season as eggs have been found in June. The lato Major Charles E. Bendire gives the average measurement of seventy-three eggs 1.02x.77 inches.

411. GILA WOODPECKER. Melanerpes uropygialis (Baird.) Geog. Dist.Southern Arizona, Southeastern nortion of California, Lower California and Western Mexico.

This species was first discovered by Dr. Kennerly in his route along the 35th parallel, and described by Professor Baird in 1854. Dr. Hermann found it abundant along the Gila river among the mesquite trees and giant cactus. He met with it in Calitornia in considerable numbers on the banks of the Colorado. Mr. G. Frean Morcom, in his valuable paper on the birds of Southern California and Southwestern Arizona,* notes this as one of the species found by Mr. F. Stephens at Yuma, Arizona, where it was not common. A nest was found May 4, excavated in a growing willow on the edge of a slough. It contained three eggs, incubation commenced. In the region about Tucson, Arizona, Mr. W. E. D. Scott states that it is a common resident, especially in the giant cactus regions, occurring in numbers up to an altitude of $\mathbf{4 5 0 0}$ feet. Though breeding in mesquite and cottonwood trees, they show a great preference tor groves of giant cactus, which afford nesting places for thousands of pairs about Tucson, Florence and Riverside. Near Tucson, Mr. Scott took fresh eggs, three to five, in number, from May 15 until the last of the month. The birds do not always excavate new nesting holes in the giant cactus, but more frequently take advantage of former excavations. The birds are very fond of the fruit of the giant and other cacti. The eggs are smooth, glossy white, and measure $.99 x .72$.

412. FLICKER. Colaptes unratus (Linn.) Geog. Dist.-Eastern North America, west to the Great Plains, north to Hudson Bay and Alaska.

This is the Golden-winged Woodpecker, Yellow-shafted Flicker, Pigeon Woodpecker, High-holder, Wake-up and Yellow-hammer of Eastern North America. Every country boy has a name for it. The bird's ordinary notes are the familiar, oft-repeated "chuck-up, chuck-up, chuck-up," the scythe-whetting note, "quit-tu, quit-tu, quit-tu," and the pecullar "wake-up" call, preluded by rapid monosyllables.

* Bulletin No. 2. The Kidgway Ornithological Club. 


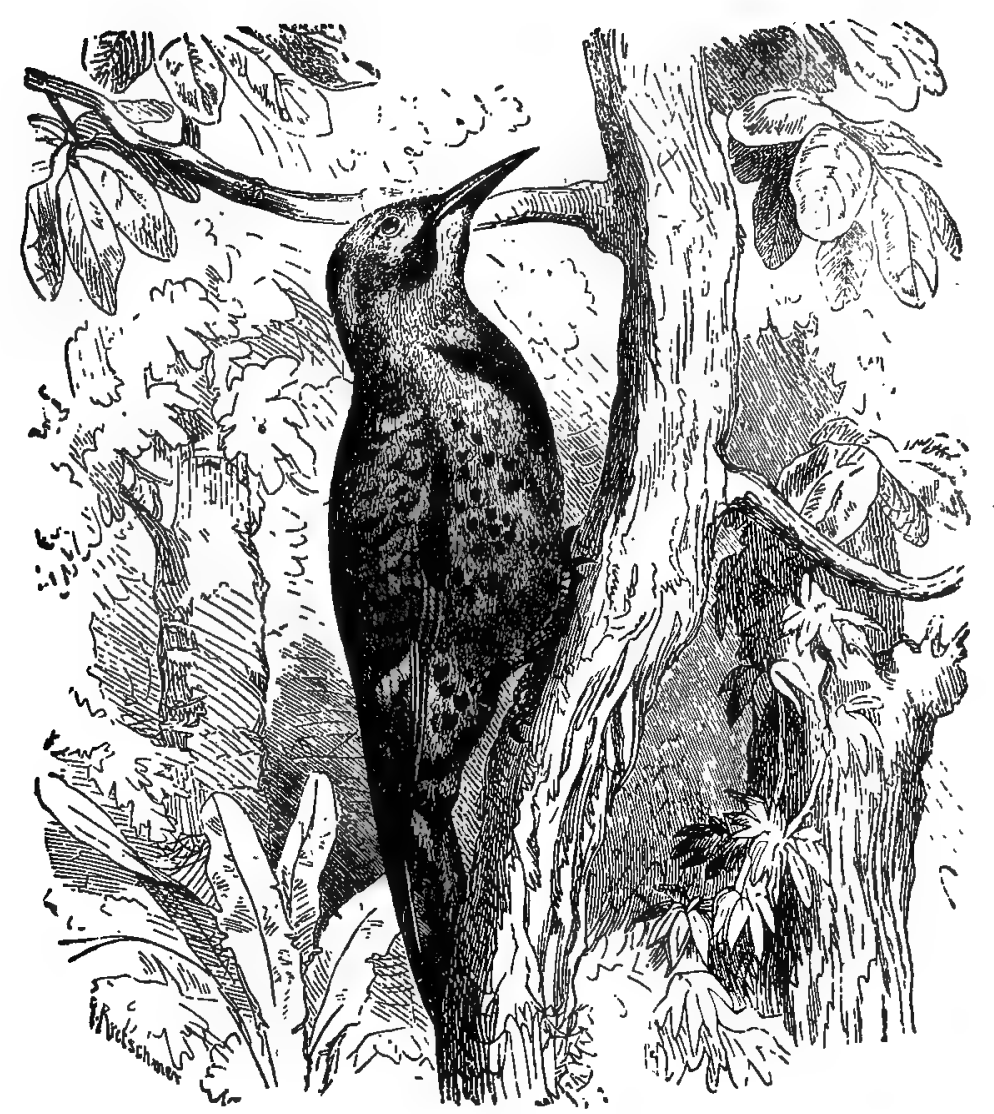

12. Flicker (From Brehm).

The Golden-winged Woodpecker is found everywhere in woodlands, nesting in the same manner as others of the family, most frequently in a dead trunk of a tree, at considerable height from the ground. The excavations are generally made by the birds, though not unfrequently the eggs are laid within a natural cavity. Curious breeding-places are sometimes selected. It has been found nesting in an old wagon hub far out on the treeless prairie; in barrels and in the crevices of deserted barns and out-houses. Mr. Raymond C. Osburn found a nest of the Flicker on May 27, 1894, in Licking county, $O$, in the natural cavity of a gate-post, only three feet from the ground. Ordinarily from six to eight or ten crystaline white eggs are deposited, but in exceptional cases this bird is known to lay a large number. Prof. Evermann took thirty-seven eggs from a single nest between May 4 and June 22, 1885. In this period of time the bird rested fourteen days. The most remarkable instance of the laylng capacity of the Flicker of which I am aware is that recorded by Charles L. Phillips, of Taunton, Mass. On May 6, 1883, he found a cavity in a large willow tree containing two eggs; he took one, leaving the other as a "nest-egg," 
and contlnued to do so day atter day until the female Flicker had lajd seventy-one eggs in seventy-three days." The average size of the eggs is 1.10x.90, and in a large serles a great variation in size and shape are noticeable. While it is hardly within the scope of the present work I herewith quote entire the "General Remarks" in Mr. F. E. L. Beal's "Food of Woodpeckers," $\dagger$ which certalnly proves their great. value to the agriculturallst. He says: "With the possibje exception of the crow, no blrds are subject to more adverse criticism than woodpeckers. Usually no attempt is made to discriminate between the numerous specles, and little account

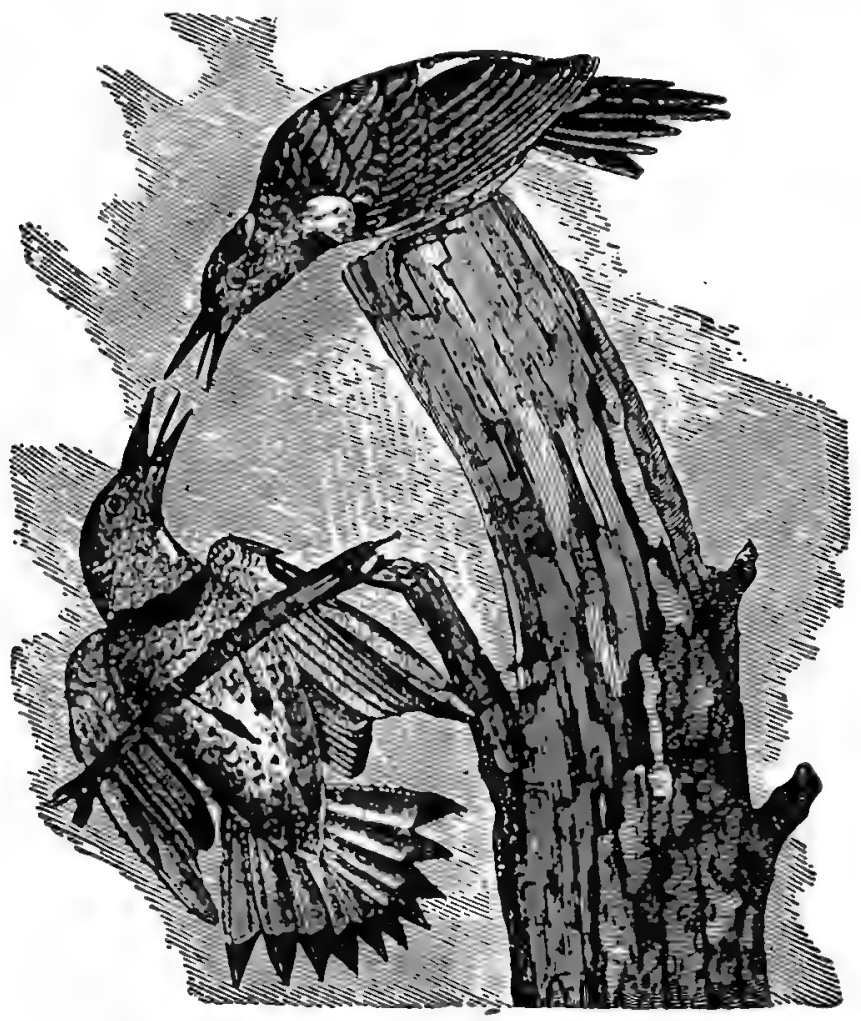

412. Flicegr (After Audubón)

Is taken of the good they do in destroying injurfous insects. The name of 'Sapsucleer' has been applied to two or three of the smaller kinds, in the bellef that they subslst to a great extent upon the juices of trees, obtained from the small holes they make In the bark. There can be little doubt that one species, the Yellow-bellied Wood-

- In the last editions of this work Mr. Phillips' record was credited to the Ornithologat and Oologist (Vol. XI, p. 16). Mention of It first appears in The Young Oologist (Vol. I. D. 26), and it has recently been recorded in The Auk, Vol. IV. p. 346.

- Bulletin No. 7, U. S. Department of Agriculture, Division of Ornithology and Mammalogy. Preliminary report on the Food of Woodpeckers, by F. F. L, Beal. Assistant Ornithologlst. The Tongues of Woodpeckers, by F. A. Lucas, Curator. Depariment Comparative Anatomy U. 8. Natlonal Museum; Washington: Government Printing Oftice, 1895. 
pecker (Sphyrapicus rarius), does live to a considerable extent upon this sap. Observation does not show that other species have the same habit, but it is a difflcult point to decide by dissection, as fluid contents disappear quickly from the stomach. Many observers have testified to the good work these birds do in destroying insects, while others have spoken of harm done to fruit or grain. Both are correct within certain limits. Field observation on the food habits of birds is attended with so many difficulties as to render it a very unreliable source from which to draw general conclusions. The most conscientious and careful person is often deceived, not only as to the quantity of a particular kind of food eaten by a bird, but as to the fact that it is eaten at all. The further dificulty of keeping a number of birds, or even a single ole, under constant observation makes an estimate of relative proportions of different kinds of food impossible. When much mischief is done the fact is apparent, but there is no way to find out how much good is done during the same time. For these reasons it often happens that reports on food habits, based on observations of wild birds, not only conflict with each other, but also disagree with the results obtained from stomach examinations. This last method must be taken as the court of final appeal, and it is evident that a collection of stomachs covering every month in the year, and as nearly as may be all points of the birds' range, becomes more and more trustworthy as it increases in size; in other words, the more stomachs examined the nearer correct will be the result as to the birds' annual diet. The present paper is merely a preliminary report, based on the examination of 679 stomachs of Woodpeckers, and representing only 7 speciesall from the eastern United States. These species are the Downy Woodpecker (Dryobates pubescens), the Hairy Woodpecker (D. villosus), the Flicker or Goldenwinged Woodpecker (Colaptes auratus), the Red-headed Woodpecker (melanerpes erythrocepahlus), the Red-bellied Woodpecker (Melanerpes carolinus), the Yellowbellied Woodpecker (Sphyrapicus rarius), and the Great Pileated Woodpecker (Ceophloeus pileatus). Examination of their stomachs shows that the percentage of animal food (consisting almost entirely of insects) is greater in the Downy, and grades down through the Hairy, Flicker, Pileated, Redhead, and Yellow-bellied to the Red-bellied, which takes the smallest quantity of insects. Prof. Samuel Aughey stated that all of these species except the Pileated (which was not present) fed upon locusts or grasshoppers during the devastating incursions of these insects in Nebraska. The vege-able matter, of course, stands in inverse order. The greatest quantity of mineral matter (sand) is taken by the Flicker, somewhat less by the Redhead, very little by the Downy and Hairy, and none at all by the Yellow-bellied and Pileated. The stomachs of all of the 7 species except the Redhead and Red-bellied contained the substance designated as 'cambium' in the accompanying list of regetable food. This is the layer of mucilaginous material lying just inside of the bark of trees, and from which both bark and wood are formed. It is supposed by many to be the.main object sought by woodpeckers. Except in the case of a single species the stomach examination does not bear out this view, since cambium, if present at all, was in such small quantities as to be of no practical importance. The Yellow-bellied Woodpecker, however, is evidently fond of this substance, for in the stomachs examined it formed 23 per cent. of the whole food of the year. It $w^{-} . s_{\text {found }}$ in 37 stomachs, most of which were taken in April and October. Of 18 stomachs collected in April, 16 contained cambium, and one of the remaining contained no vegetable food whatever. Moreover, as the true cambium is a soft and easily digested substance it is probable that what is usually found in the stomachs is only the outer and harder part, which therefore represents a much larger quantity. The extent 
of the injury done by destroying cambium must depend on the quantity taken from individual trees. It is, well known that woodpeckers sometimes do serious harm by removing the outer bark from large areas on the trunks of fruit trees. The rings of punctures often seen around the trunks of apple trees are certainly the work of the Sapsucker, though sometimes attributed to the Downy and Hairy Woodpeckers. But the bird is not sufficiently numerous in most parts of the country to do much damage. It is a difficult task to summarize the results of the investigations herein detailed, more especially if an attempt is made to decide as to the comparative merits or demerits of each particular species. The stomach examinations do not always corroborate the testimony received from observers, and many no doubt will be.inclined to think they have seen more harm done by some members of this family of birds than is shown by the data here published. If birds are seen feeding repeatedly on a certain kind of food the inference is that they are particularly fond of it, but the truth may be that they are eating it because they can find nothing they like better, and that a collection of their stomachs from many localities would show only a small percentage of this particular food. In reviewing the results of these investigations and comparing one species with another, without losing sight of the fact that comparative good is not necessarily positive good, it appears that of 7 species considered the Downy Woodpecker is the most beneficial. This is due in part to the great number of insects it eats and in part to the nature of its vegetable food, which is of little value to man. Three-fourths of its food consists of insects, and few of these are useful kinds. Of grain, it eats practically none. The greatest sin we can lay at its door is the dissemination of poison ivy. The Hairy Woodpecker probably ranks next to the Downy in point of usefulness. It eats fewer ants, but a relatively larger percentage of beetles and caterpillars. Its grain-eating record is trifling; 2 stomachs taken in September and October contained corn. For fruit, it seeks the forests and swamps, where it finds wild cherries, grapes, and the berries of dogwood and Virginia creeper. It eats fewer seeds of the poison ivy and poison sumac than the Downy. The Flicker eats a smaller percentage of insects than either the Downy or the Hairy Woodpecker, but if eating ants is to be considered a virtue, as we have endeavored to show, then surely this bird must be exalted, for threefourths of all the insects it eats, comprising nearly half of its food, are ants. It is accused of eating corn; how little its stomach yields is shown on another page. Fruit constitutes about one-fourth of its whole fare, but the bird depends on nature and not on man to furnish the supply. Judged by the results of the stomach examinations of the Downy and Hairy Woodpecker and Flicker it would be hard to find three other species of our common birds with fewer harmful qualities. Not one of the trio shows a questionable trait, and they should be protected and encouraged in every possible way. Fortunately, only one, the Flicker, is liable to destruction, and for this bird each farmer and landowner should pass a protective law of his own. The Redhead makes the best showing of the seven species in the kinds of insects eaten. It consumes fewer ants and more beetles than any of the others, in this respect standing at the head, and it has a pronounced taste for beetles of very large size. Unfortunately, however, its fondness for predaceous beetles must be reckoned against it. It also leads in the consumption of grasshoppers; these and beetles together forming 36 per cent. of its whole food. The stomachs yielded enough corn to show that it has a taste for that grain, though not enough to indicate that any material damage is done. It eats largely of wild fruit, and also partakes rather freely of cultivated varieties, showing some preference for the larger ones, such as apples. In certain localities, partlcularly in winter, it feeds extensively on beechnuts. No 
charge can be brought agalnst it on the score of injuring trees by pecking. The Red-bellied Woodpecker is more of a vegetarian than any of the others. In certain localities in Florida it does some damage to oranges, but the habit is not general. On the other hand, it eats quantities of ants and beetles. The Yellow-bellied Woodpecker seems to show only one questionable trait, that of a fondness for the sap and inner bark of trees. Both fleld observations and the contents of the stomachs prove this charge against it, but it is not probable that forest trees are extensively injured, or that they ever will be, for aside from the fact that the bark of many trees would bc unpalatable an immense number of birds would be required to do serious damage. But with fruit trees the case is different. Their number is limited, and there are no superfluous ones as in the forest. In localities where the bird is abundant consillerable harm may be done to apple trees, which appear to be pleasing to its taste. The Pileated Woodpecker is more exclusively a forest bird than any of the others, and its food consists of such elements as the woods afford, particularly the larva of wood-boring beetles, and wild fruits. The species is emphatically a conservator of the forests. In describing the stomach contents of the different woodpeckers a quantity of material is classed under the term 'rubbish:' The great bulk of this stuff is rotten wood and bark, picked up in digging for insects in decayed timber, and apparently swallowed accidentally with the food. If the six woodpeckers which had eaten rotten wood are compared with respect to the quantity of this material contained in the stomachs it is found that the Hairy Woodpecker stands at the head with 8 per cent., the Downy next with 5, the Flicker with 3 , the Redhead and Yellow-bellied with 1 per cent. each, and the Pileated with only a trace. From this it appears that the Hairy Woodpecker is preeminently a voodpecker, while the Redhead and Yellow-belly do much less of this kind of work. The difference in habit is obvious to the most casual observer. The Redhead is ordinarily seen upon a fence post or telegraph pole hunting for insects that alight on these exposed surfaces, and watching for others that fly near enough to be captured in mid-air. Unlike other woodpeckers, he is seldom seen digging at a rotten branch except in spring, when he prepares a home for the family he intends to rear."

413. RED-SHAFTED FLICKER. Colaptes cafer (Gmel.) Geog. Dist-Western United States, from the Rocky Mountains to the Pacific coast; north to Sitka; south to Southern Mexico.

This species replaces the Yellow-shafted Flicker from the Rocky Mountains to the Paciflc. In its habits, nesting and eggs it is the exact counterpart of $C$. auratus. The eggs average a trifle larger; $1.14 \mathrm{x} .86$ is the average of thirty specimens.

413 . NORTHWESTERN FIICKER. Colaptes cafer saturatior RidgW. Geog. Dist.--Northwest coast, from Northern California north to Sitka.

The general habits, nesting, etc., of this darker colored race are the same as those of $C$. auratus or C. cafer.

414. GILDED FLICKER. Colaptes chrysoides (Malh.) Geog. Dist.-Southern California, Lower California; Southern Arizona.

Mr. F. Stephens regards the distribution of this species in Arizona as coextensive with that of the giant cactus, for he never met with it except where this singular plant'grows.* Mr. Scott states that it is ommon throughout the giant cactus

* Wm. Brewster on a collection of Arizona biras. Bull. Nutt, Club, Vol. VIII, 24. 
region all about Tucson, and he occasionally saw single individuals in the mesquite timber. All that he ever met with breeding have been in giant cactus. 'The nesting time is from April 10 until the last of May. According to Mr. Scott, the number of eggs is small, varying from two to five; the latter number being the largest he ever found in a nest.* The eggs are glossy-white, and average 1.12x.84.

414a. BROWN FLICKER. Colaptes chrysoides brunnescens Anthony. Geog. Dist.-Northern Lower California.

This is a brown phase of the Gilded Woodpecker, occupying the northern portion of Lower California.

415. GUADALUPE FLICKER. Colaptes rufipileus Ridgw. Geog. Dist.Guadalupe Island, Lower California.

Mr. Walter E. Bryant gives us the first knowledge we have concerning the nesting and eggs of this bird. $\dagger$ On Guadalupe Island he found it not rare in the restricted area of a large cypress grove, but apart from this locality less than a dozen were seem during his stay on the Island. For a portion of the year the food of this species consists largely of smooth-skinned caterpillars, with numerous beetles and ants. The nesting cavities are found at heights varying from three to fifteen feet. The scarcity of decayed trees, with the exception of fallen ones, necessitates either work upon seasoned wood or the resort to dead palm stumps. A cavity was found April 7, which was dug to the depth of twenty inches, and contained six fresh eggs, upon which the female was sitting. They correspond exactly, both in color and general shape, with scores of other eggs of this genus, and offer the following measurments in millimeters: $28 \times 22,28 \times 22,28 \times 22.5,29 \times 22,29.5 \times 22,29.5 \times 22$.

416. CHUCK-WIIL'S-WIDOW. Antrostomus carolinensis (Gmel.) Geog. Dist.-South Atlantic and Gulf States, from Virginia south through Eastern Mexico to Central America; Cuba. North in the interior to Southern Illinois and Kansas. Accidental in Massachusetts.

Perhaps the two best known North American species of this family (Caprimuloide, the Goatsuckers), are the Whip-poor-will, Antrostomus vociferus, and the Nighthawk, Chordeiles virginianus. They are all more or less nocturnal, and fanciful imaginations have detected in many of their cries the syllables from which their common names are derived-such is the case with Chuck-will's-widow. It is nowhere a very abundant species, but more common in. Florida than in any other State. It is found in Georgia, South Carolina, Alabama, Mississippi and Texas. Mr. Stuart informs me that in Florida it nests in the months of May and June, depositing two eggs on the bare ground, or on leaves in the shadow of some dense thicket. According to Audubon, deep ravines, shady swamps and extensive pine groves are the retreats of this species during the day, when the birds roost in hollow trees. When in search of food, the same places are resorted to at night, and their singular notes are only uttered for a brief period in the early evening, when on the wing. If either their eggs or young are disturbed, they are carried off in the capacious mouths of the birds to some distant part of the forest, in the same manner that a cat transports her kittens. A set of two eggs in my cabinet, collected by Mr. Stuart near Tampa, Florida, May 20, 1886, measure $1.40 \times 1.02,1.42 \times 1.00$; another set, from Mana-

* The Auk, III, 429.

† Addition to the Ornithology of Guadalupe Island; Bulletin 6, California Academy of. Sciences, pD. 285-288.

$\ddagger 1.10 x .87,1.10 \times .87,1.10 x .89,1.14 \times .87,1.16 \times .87,1.16 x .87$. 
tee county, taken May 14, 1887, measure $1.39 \times 1.00,1.41 \times 1.02$. A set taken in Comal county, 'Iexas, April 22, 1888, measure 1.41x1.02, 1.42×1.04. These are beautiful eggs, with a pinkish-buff ground, variously marbled with pale buff-brown and lilac-gray. They are moderately polished. Mr. C. W. Crandall, of Woodside, N. Y., has kindly given me the measurements and description's of 56 sets of this species' eggs, all collected in Mississippi, North Carolina, Georgia and Florida, the earliest date being April 3, the latest June 24. In every instance the eggs were laid either on the bare ground or on a few dry leaves, especially in Hillsboro county, Fla., where the eggs were always laid on some dry leaves, among scrub oaks, in the hummocks. At other places the eggs were sometimes found at the foot of a tree and usually in thick woods. Concerning the coloration of this bird's eggs Mr. Crandall says: "The ground color varies from almost a pure white to a rich dark cream, pinkish buff and other creamy shades. The markings consist of about every known type of spots, specks, blotches, cloudings, marbling, lines, streaks and scratches of every conceivable pattern; sometimes all of these appear on one egg and in others the egg will only show two or three styles' of markings, the small end occasionally catches them, but the typical egg shows them generally distributed, and in the majority of specimens they form more or less of a zone around larger half of the egg." The average measurement of this series of fifty-six sets (one hundred and twelve eggs) is $1.41 \times 1.01$ inches. The largest measures $1.54 \times 1.05$, the smallest $1.29 \times .90$ inches.

417. WHIP-POOR-WILL. Antrostomus vociferus (Wils.) Geog. Dist.-Eastern United States to the Plains, and from Lat. $50^{\circ}$ south to Guatemala.

The well-known Whip-poor-will, which inhabits the Eastern United States, may be easily distinguished from $A$. carolinensis by its greatly inferior size; the colors of both birds are quite similar. In its habits the Whip-poor-will is very nearly the counterpart of the Chuck-will's-widow, keeping within the recesses of deep woods and undergrowth during the daytime, remaining perfectly silent. The name of this species is a pretty accurate rendering of its note, which is uttered when night comes on, both when the bird is on the wing in pursuit of nocturnal insects, or at rest. Rocky ravines shaded by trees, where the sun seldom penetrates the thick foliage, or beneath dense underbrush, midst fallen logs, are the favorite nesting places of the Whip-poor-will. The eggs are deposited on the ground, on decayed wood, or among fallen leaves. Two eggs constitute a set. They are elliptical, of moderate polish, with a ground colcr of white or cream color. They are handsomely marked with large and small spots of yellowish-brown distributed rather abundantly over the entire surface; occasionally a few blotches may be observed. Deep sheil marks are about as numerous as the surface marks, and are of a lilac-gray or lavender tint. A set of two eggs which I took in Franklin county, Ohio, May 28, 1887, measure 1.18x.90, 1.20x.90; a set from Delaware county, Ohio, 'collected June 2, 1888, measure $1.14 \times .87,1.16 \times .86$. Dr. Jones gives a common size as $1.12 \times .88$. Like the Chuck-will'swidow this species removes in its mouth the eggs or young to a place of safety if they have been molested or handled.

417a. STEPHENS'S WHIP-POOR-WILL. Antrostomus vociferus macromystax (Wagler.) Geog. Dist.-Arizona, New Mexico, and table lands of Mexico, south to Guatemala.

This is a larger bird than the last. Mr. F. Stephens met with it in the Chiracahua Mountains in Southern Arizona in 1880, and less numerous in the Santa Rila range in 1881 . In the Chiracahua ratige by June 1st, they were as common as he 


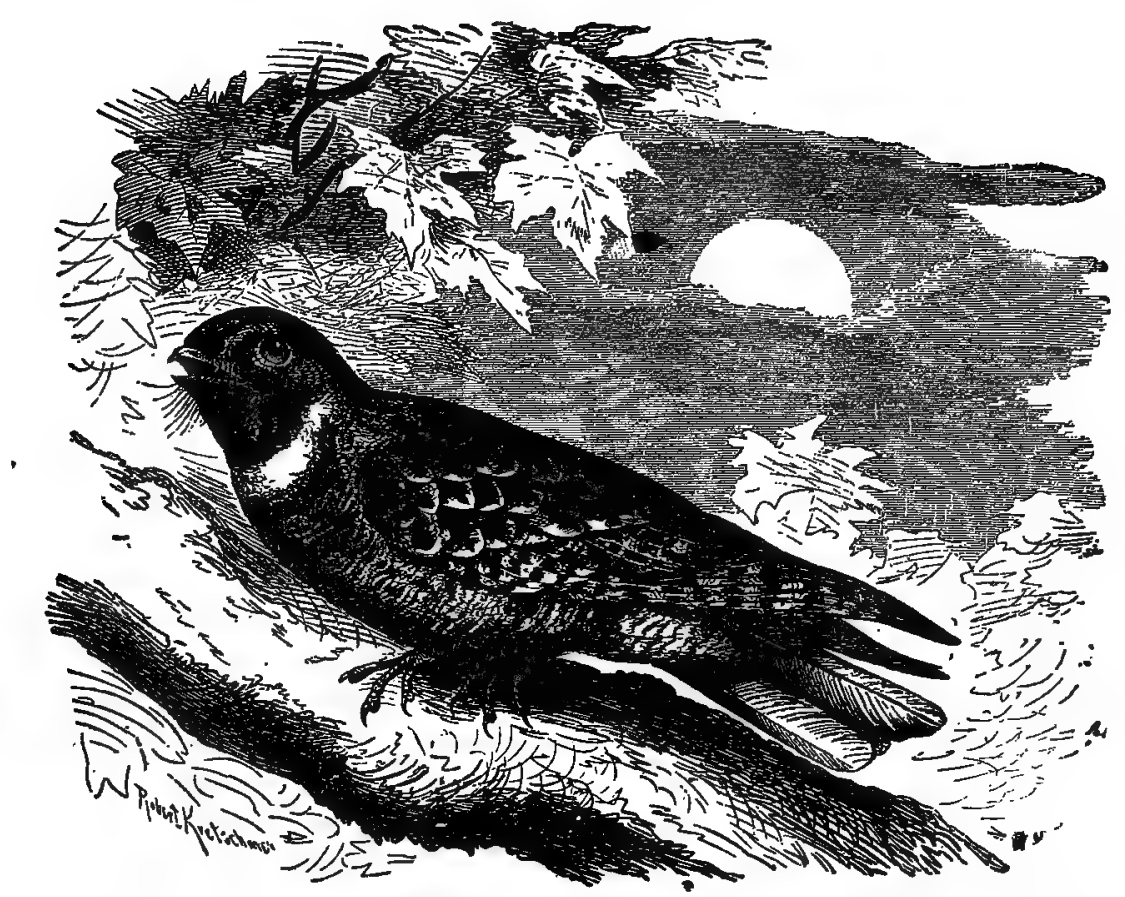

417. WhIP-POOR-WILL (From Brehm).

ever knew them to be in the East; sometimes three or four were heard whistling at once. They were restless and rather shy. July 4, a female was shot as she flew from her nest, which, as usual, was only a very slight depression in the ground, but in this case was overhung by a rock. Mr. Brewster describes the egg which this nest contained as white with a dull gloss, apparently immaculate, but upon close inspection reveals a few faint blotches of the palest purple, so faint that they might pass for superficial stains were it not for the fact that they underlie the external polish, This specimen measures $1.17 \times .87$.*

\section{POOR-WILI. Phalœnoptilus nutallii (Aud.) Geog. Dist.-Western} United States, from the Sierra Nevada eastward to Eastern Nebraska and Eastern Kansas north to Central Idaho and Montana, and south to Southern Mexico.

Nuttall's Whip-poor-will, or Poor-will, as it is called, is found to be more or less abundant throughout various States and Territories of the West-in the interior valleys and foot-hills of California, Oregon and Washington, and in Arizona, New Mexico, Texas, Colorado, etc. Colonel N. S. Goss mentions it as a common summer resident of Kansas, and may be looked for on the high prairies and rocky grounds along the banks of streams. Begins laying the last of May, depositing two white, unspotted eggs upon the bare ground, in the thick growth at the edge of timber; also at the roots of a bunch of bushes or briers upon the prairies. Mr. Emerson states

* William Brewster's Notes on Some Blrds from Arizona and New Mexico. Bull. Nutt. Club, VI, pp. 69-71; and Collection of Arizona Birds, Vol. VII, 211-212. 
that he frequently heard this bird's mournful cries, poor-uill, poor-will, in San Diego county, California, in the month of April. A set of two eggs in his collection, taken near Manhattan, Kansas, May 28, 1885, are pure glossy-white, and measure $30 \times 22,30 \times 22.5 \mathrm{~mm}$, or $1.18 \times .87$ and $1.18 \times .91$ inches.

418a. FROSTED POOR-WILL. Phalanoptilus nutallii nitidus Brewst. Geog. Dist.-Texas to Arizona and north to Western Kansas.

This lighter-colored and grayer bird than Nuttall's Poor-will was first described by William Brewster in "The Auk" (Vol. IV, 1887, p. 147), from specimens taken on the Nueces River, Texas, February, 1886. Its general habits are identical with those of $P$. nutalli. Mr. Crandall has a set of eggs of this bird which was taken by Mr. M. W. Kibbe in Franklin county, Kansas, May 10,.1891. The bird was shot and fully Identified. The eggs were laid on the bare ground on the side of a rocky hill. They measure $1.10 \mathrm{x} .81 ; 1.09 \times .80$ respectively. These eggs have the peculiar glossy polished appearance usual to eggs of Chuck-will's-widow and Whip-poor-will, and they are of a decidedly creamy white color and not a pure white, entirely unspotted and in shape like the typical egg of a Chuck-will's-widow.

418b. DUSKY POOR-WILL. Phalanoptilus nutallii californicus Ridgw. Geog. Dist.-Coast of California.

The range of this dark or dusky race is confined to the coast region of California. Its habits, nesting and eggs are the same as those of the Poor-will.

419. MERRILI'S PARAUQUE. Nyctidromus albicollis merrilli Senn. 'Geog. Dist.-Valley of the Rio Grande, north to the Nueces River, south into Northeastern Mexico.

Mr. George B. Sennett named this bird in honor of Dr. James C. Merrill, Assistant Surgeon U. S. Army. In the vicinity of Fort Brown, Texas, it was a common summer resident, arriving early in March and remaining as late as the middle of November. It frequents shady thickets and copses, and when flushed dodges rapidiy and silently among the bushes, but soon alights. In these places the eggs are deposited usually at the foot of a bush. Dr. Merrill observes that the habits and eggs of this species, in addition to its anatomical characters, show its affinity with the Whip-poor-wills rather than the Nighthawks. Their notes are among the most characteristic night sounds of the lower Rio Grande, and are constantly heard at evening during the summer months. They consist of a repeated whistle, resembling the syllables "whew, whew, whew, whew, whe-e-e-e-e-w," much stress being laid upon the last, which is prolonged. The whole is soft and mellow, yet can be heard at a great distance. Mr. Sennett, in the same region in Southern Texas, obtained a set of two eggs, April 20. He states that the birds breed in the more open places among the cactus and scattered bushes along with C. texcnsis-Texas Nighthawk. The eggs are two in number, of a rich creamy-buff, sparingly marked with a deeper shade of the same, and with lilac; average size 1.25x.92. Their size and creamy-buff color render them easy of identification. On the 15th of May, Dr. Merrill found a set of eggs of this species near camp at Hidalgo, and on returning in about fifteen minutes to secure the parent, who had disappeared among the thickets, he found that she had removed the eggs, although they had not been touched. The average of size of thirty-six sets (seventy-two eggs) of this bird in Mr. Crandall's collection is 1.24x.90; the largest 1.35x.92, the smallest in length 1.14x.92; broadest 1.33x.95 inches. These were all collected in various parts of Tamaulipa county, Texas, between April 9 and July 27. 
420. NIGHTHAWK. Chordeiles virginianus (Gmel.) Geog. Dist.-Eastern North America, north, to Hudson Bay, west to the edge of the Great Plains, south through tropical America.

The Nighthawk, Bullbat, or Goatsucker, as it is variously called, breeds throughout its range, depositing two eggs in open situations, such as fields, etc., on the cold bare ground, often among stones; scarcely a trace of a nest can be found where the eggs lay. They are frequently deposited on bare rocks, and on the flat roofs of buildings in large cities. Mr. Norris once found a set on the stump of a tree about eighteen inches from the ground; and a set in his cabinet was taken from the gravel roof of a four-story building in the center of Philadelphia. The Nighthawk and Whip-poorwill are often confounded or considered as birds of the same species. A careful com-

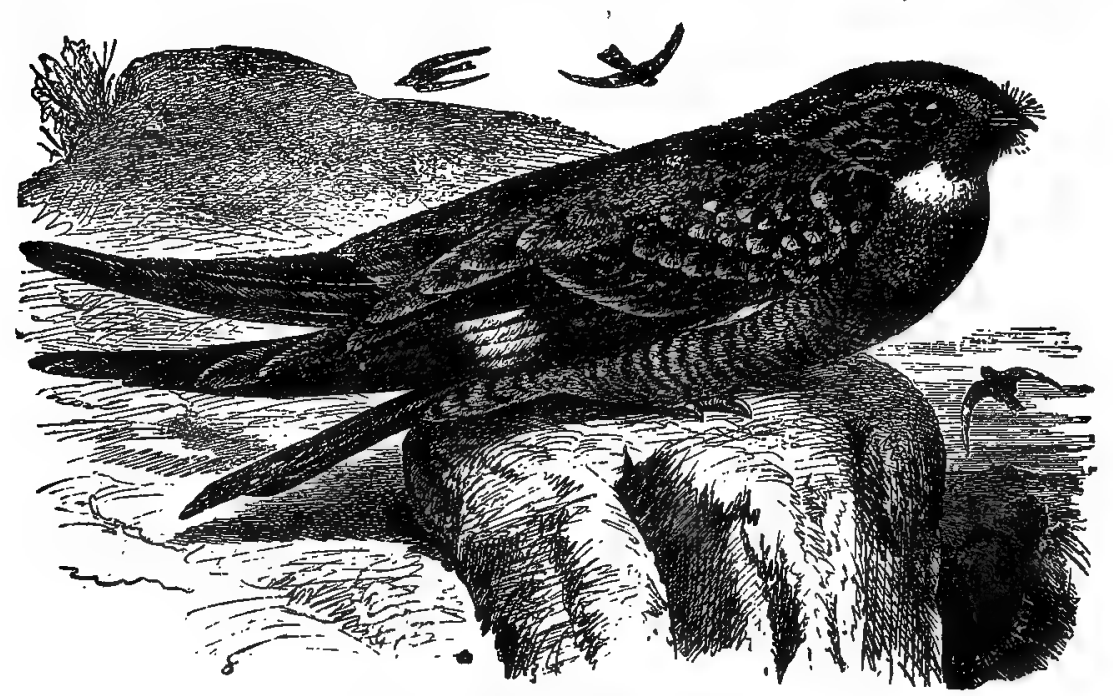

420. NightháwK (From Brebm)

parison with each other, or with the descriptions, will at once show a very decided difference. The large, white patches on the five outer primaries of the wings of the Nighthawk when flying, appear like tattered holes caused by the shot from a gun. In the evenings of summer months great troops of Nighthawks may be seen high in air over forest or town in search of insects, performing their wonderful evolutions and uttering their peevish cries, or swooping down with their strange booming or rumbling sound, they skim over the grassy meadows. Thus they continue till the gloaming merges into darkness, and their flight is seen no longer. The eggs of the Nighthawk vary from pale olive-buff to buffy and grayish-white; thickly mottled and dashed with varied tints of darker gray, slate, olive, or even blackish, mixed with a marbling and clouding of purplish-gray; the pattern and tints are very variable. The shape is elliptical, and average size 1.25x.85. Six eggs measure 1.24x.85, $1.27 \times .87,1.22 x .83,1.24 \times .86,1.21 \times .82,1.24 \times .84$.

420a. WESTERN NIGHTHAWK. Chordeiles virginianus henryi (Cass.) Geog. Dist.-Western United States from the Great Plalns to the Pacific, and from British Columbia south to Northern South America. 
A lighter-colored form of the Nighthawk, found in the unwooded portions of Western United States. Its general habits, nesting; etc., are the same as those of O. virginanus; the eggs average paler; size 1.20x.85.

420b. FLORIDA NIGHTHAWK, Ohordelles virginianus chapmani Coues. Geog. Dist.-F'lorida and the Gulf coast of Texas, south in winter to South America.

This race of the Nighthawk is dedicated by Mr. Sennett to Mr. Frank M. Chapman, the well-known ornithologist and author. It is a somewhat darker-colored bird and is smaller than the common Nighthawk. In all respects its habits, nesting and eggs do not differ from those of $C$. virginianus. $\mathrm{Mr}$. Crandall has a series of thirty-eight sets of the eggs of this geographical race, eighteen of which were taken in Manatee and Hillsboro counties, Florida, between the dates of April 27 and July 7; twenty sets on islands off the Mississippi coast of the Gulf of Mexico between the dates of May 21 and 25. The average size of the seventy-six eggs is 1.16x.84; the longest is, 1.29x.86; shortest, 1.05x.77; broadest, 1.20x.92; narrowest, $1.05 \mathrm{x} .77$ inches.

420c. SENNETT'S NIGHTHAWK. Chordeiles virginianus sennetti (Coues.) Geog. Dist.-Treeless region of the Great Plains, from the Saskatchewan south to Texas.

This geographic race is of a silvery grayish-white predominating above, the white below is greatly in excess of the narrow irregular or broken dark bars and little or no rufous anywhere.

421. TEXAN NIGHTHAWK. Chordeiles acutipennis texensis (Lawr.) Geog. Dist.-Southern border of the United States, from Texas to Southern California, north into Southern Utah; south to Cape St. Lucas ànd Veragua.

This subspecies has quite an extended range. It is known to occur as far north as San Joaquin and Stanislaus counties in California; in Southern Nevada; in the lower Santa Clara Valley, Utah; the desert regions of Arizona; southern portions of New Mexico, and it is found to be a common summer resident of the southern and western portions of Texas. The Texan Nighthawk is smaller than the foregoing subspecies, the general tone of the plumage lighter, and it differs otherwise. Mr. Sennett describes its flight as resembling that of the Whip-poor-will, but it does not indulge in the perpendicular descents accompanied by the whir of wings so characteristic of .C. viryinianus. On the Lower Rio Grande eggs were obtained as early as April 26, and fresh ones found as late as May 19. They were always laid on the bare, hot ground. Dr. Merrill states that the notes of this species are a curious mewing call difficult to describe. He found the eggs in the vicinity of Brownsville, Texas, usually deposited in exposed situations, among sparse chaparral on ground baked almost as hard as a brick by the intense heat of the sun. One set was found on a small piece of tin, near a frequented path. Mr. Rachford informs me that in Jefferson county, Texas, this species usually deposits its two eggs on the ground, in a wellbeaten cow-path; the nesting season begins from about May 10th, and eggs may be found in the latter part of June. Dr. Merrill states that the eggs vary consi ' rably; but exactly resemble the surface on which they are placed. The ground-color is usually clay; some are very sparingly dotted with brown; others mottled with light brown and onscure lilac; some are so thickly marbled with brown and lilac on a dark ground as to give them a granite-like appearance. They average 1.07x.77.

422. BLACK SWIFT. Cypseloides niger (Gmel.) Geog. Dist.-Rocky Mountain region (Colorado), west to the Pacific coast; north to British Columbia, and south to Lower California, Mexico, Costa Rica and the West Indies. 
The Black Swift has been met with sparingly in the various regions cited in the above habitat. Another common name for this bird is "Black Cloud Swift." Comparatively little has been ascertained concerning its general habits and its eggs until recently. The general habits and characteristics of this bird are well-known, wit the construction of its nest and a full description of its eggs remain unpublished. In the last two editions of this work I quoted an article which bore evidences of accuracy concerning the nesting and eggs of this species, but I am now convinced that the writer was mistaken in his identification. Mr. A. W. Anthony, in the summer of 1883, found this species abundant in Colorado, nesting in the highest inaccessible crags, and nothing but that which was provided with wings could possibly reach them. About Silverton a large colony had taken possession of a very high cliff, making their appearance about June 20. Dr. A. K. Fisher saw a number of these birds about the cliffs near Trinidad, Colorado. Mr. Ridgway met with it in Nevada. It undoubtedly occurs in suitable localities in the intervening regions, as the mountains of Utah. It is said to be abundant at Lake Samish, Washington. Mr. Rollo H. Beck, while hunting near the rocky coast of Monterey county, California, in the summer of 1894, shot a female Black Swift on June 29 , containing a nearly developed egg in the oviduct. The shell was not yet formed and he had no means of measuring it. In shape it resembled the egg of the Chimney Swift.*

423. CHIMNEY SWIFT. Chæetura pelagica (Linn.) Geog. Dist.-Eastern North America, north to Labrador and in the interior to the Fur Countries; west to the edge of the Great Plains.

The progress of civilization has brought about conditions and causes which have given rise to this bird's common and now appropriate name, Chimney Swift, or, as it is probably better known, Chimney "Swallow." When the country was first settled this species was known to breed only in the hollow trunks of forest trees, but as soon as the chimneys of dwellings erected by civilized man presented greater convenience and better security against enemies this bird forsook its primitive nesting places, and now only in remote regions or wild portions of the country, where natural facilities are still afforded, it is found breeding in the hollows of decaying trees. A chemical analysis ot this bird's nest made for me by Professor Weber, chemist of the Ohio State University, proves conclusively that the glue which these birds use is not from the'gum of any tree, but purely an animal production. This shculd set at rest the claims made by a number of writers in recent periodicals that the glue of the Swift is of a vegetable nature. The nest, as shown in our illustration, is a beautiful semi-circular basket made of small dead twigs of nearly uniform length and thickness, and when attached to the inside of a chimney is placed sufficiently below the top to be protected from the rays of the sun. The twigs are broken from trees ky the birds while on the wing. They are all strongly cemented together and fastened to the wall with the saliva of the birds. This glue-like substance dries and hardens, and becomes so firm that, when the nest is separated from the sides of chimneys, portions of the brick to which it is fastened often adhere to the structure. My friecd, Mr. Arnold Boyle, took a nest of this species from the inside of a barn in Wyandot county, Ohio; its position was similar to that of the Barn Swallow. From four to six narrowly elliptical, pure white eggs are deposited, ordinarily four. May and June are the nesting months, and usually but one brood is reared in a season. A se: of four eggs, collected in the Adirondack region, Essex county, New York, June 27 , measure $.82 x .52, .81 \times .52, .84 \times .51, .82 x .50$; a set of five taken in Franklin county,

* Seo Eerdire's Life Filstories of N. A. Birds, Vol. II, pp. 175-177. 


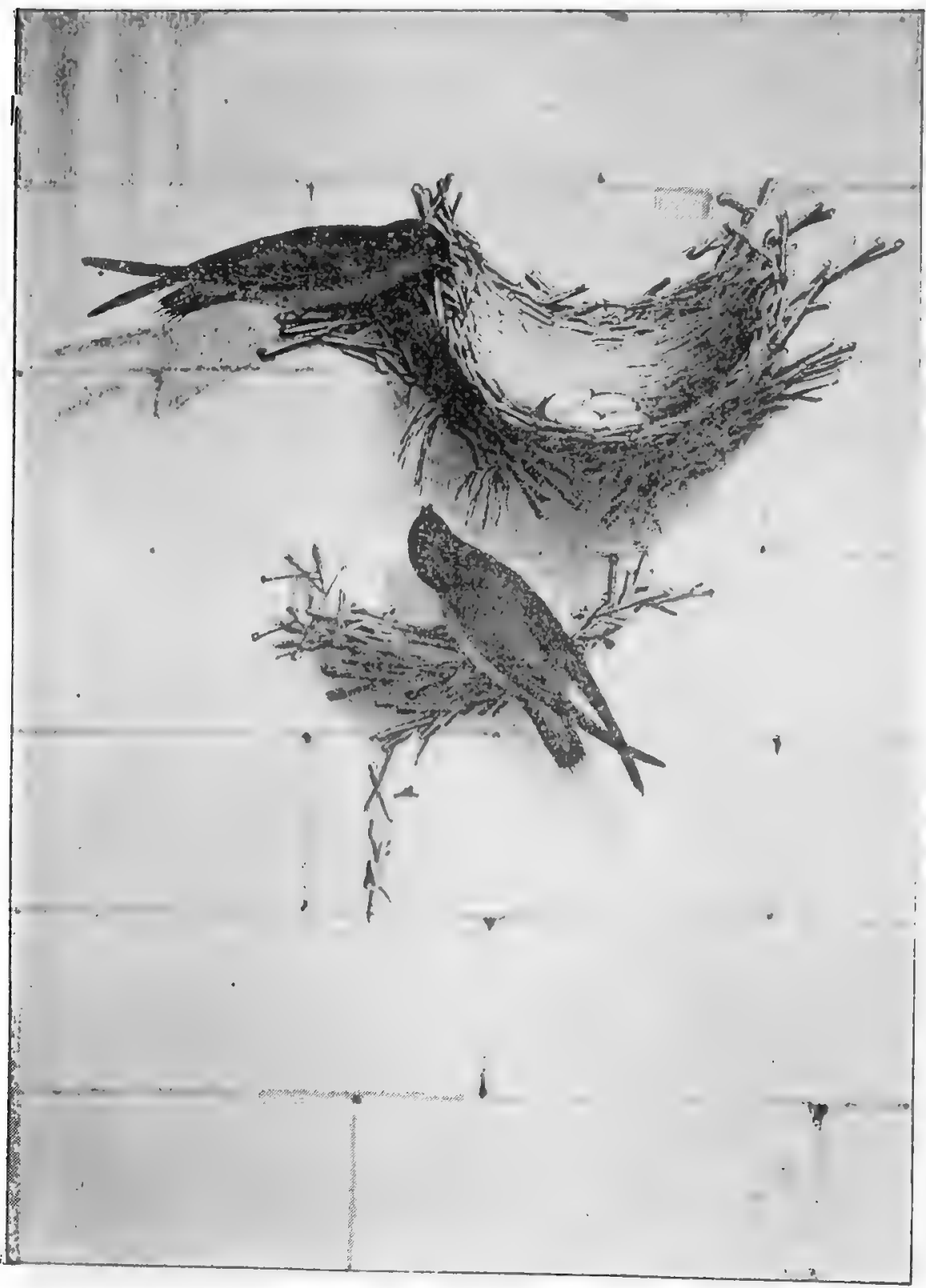

423. Chimey Swifts axp Nest. 
Ohio, exhibit the following sizes: $.79 \times .50, .80 \times .50, .80 \times .52, .77 \times .50, .79 x .53$. The eggs in a large series range from .74 to .86 in length and from .47 to .55 in breadth.

424. VAUX'S swIFT. Chatura vauxii (Towns.) Geog. Dist.-Pacific coast of the United States northward to British Columbia; south in winter to Lower California and Mexico.

This is a lighter colored and smaller species than the Chimney Swift. The habits of the two hirds, however, are similar, except that Vaux's Swift is said only to nest in hollow trees. In various regions of Oregon and in. Washington this species is a common summer resident, where it breeds in May and June, fastening to the inside walls of hollow tree trunks and stubs the half-saucer-shaped nest of twigs, which is glued together with the bird's saliva. Three to five narrow-elliptical white eggs are deposited, which have an average size of about .72x.50. Very few of this bird's eggs have found their way into collections.

425. WHITE-THROATED SWIFT. ARronautes melanoleucus (Baird.) Geog. Dist.-Western United States, from the Black Hills, Northern Wyoming and Southern Montana to the Pacific; south in winter to Guatemala.

The late Major Bendire states that the range of the "Rock" Swift, as it is commonly called, does not appear to extend nearly as far north in the mountains of the Pacific coast districts as it does in the Rocky Mountain region, where it is generally distributed throughout suitable localities, from Southern Arizona and New Mexico north ward, through Colorado and Wyoming to Montana. The latter, as far as known, marks the northern limits of its range. Here it was found breeding by Mr. R. S. Williams in small numbers in holes in a limestone cliff on Belt River, about the middle of July, 1881. It was found by Mr. Robert Ridgway to be abundant in the same situations in the Ruby Mountains and in the East Humboldt range, but less abundant in the Wasatch Mountains in Utah. The eggs of this species still remain among the special desiderata in oölogical collections and, according to Bendire (1895), there are none in the U. S. National Museum collection. Mr. Walter E. Bryant gives us the best description of the eggs I have seen. It is in the September number of the Nidologist for 1894, and is as follows: "More than a dozen years ago an imperfect set of five fresh unblown eggs of the White-throated Swift were presented to me by a young man in Contra Costa county (California). They were taken from a nest in a crevice in the back of a tunnel-shaped cave in the side of a cliff about twenty feet above the base. In color the eggs are pure white, narrowly elliptical in form, but rather smaller at one end. They measured: $.87 \times .53 ; .88 x .53$, $.88 \times .52, .86 \times .50$; the fifth was too much damaged to measure accurately. The eggs were collected on June 6, 1878."

426. RIVOII HUMMINGBIRD. Eugenes fulgens (Swaim.) Geog. Dist.Southern Arizona and tablelands of Mexico to Nicarauga.

One of the largest and one of the most handsome Hummingbirds found within the limits of the United States, and it is generally known a's the "Refulgent Hummingbird." Within our limits it is not an altogether common summer resident. It has been obtained in the mountains near the Mexican border, in Arizona, and in the extreme southwestern portion of New Mexico. It was first added to our avifauna by Henshaw, who took a specimen near Fort Grant, Arizona, in September, 187.3. The late Major Bendire describes two nests that were taken in the Huachuca Mountains, Arizona. One of these, the best preserved one, resembles the nest of the Rubythroated Hummingbird very closely, but like the bird, is considerably larger. It was found by Mr. L. Miller on June 22, 1894, at an elevation of 7000 feet, saddled on a walnut branch about ten feet from the ground and contained one young bird nearly 
able to fly. The other nest, taken June 4, 1893, contained one fresh egg which was accidentally broken.

427. BLUE-THROATED HUMMINGBIRD. Coligena clemencio Less. Geog. Dist.-Southern Arizona and the tablelands of Mexico to Guerrero and Oaxaca.

This is a slightly largor species than the Rivoli Hummingbird, and is sometimes called "Blue-throated Casique." It is only a summer resident within the southern boundary of the United States and breeds wherever found. It appears to be more common than the preceding species. It was first added to our avifauna by Mr. F. Stephens, who securtd an adult male in the Santa Catalina Mountains, Arizona, May 14, 1884. Since then it has been taken in several other mountain ranges of Arizona, and Dr. Edgar E. Mearns took it in the Luis Mountains of Southwestern New Mexico. Mr. Nelson on September 9th, 1893, found a nest containing two eggs at an altitude of 11,500 feet on the north slope of the volcano Toluca, in the State of Mexico. The nest was built in the fork of a small shrub growing out of the face of a cliff, about 30 feet above its base, on the side of a canyon in the pine and fir forest. It is a handsome and rather bulky structure, smoothly quilted together of fine mosses, and lined with the down of willow catkins. This nest was nearly inaccessible and one egg was broken in securing it. The single egg measures $.64 \times .39$

inches.

428. RUBY-THROATED HUMMINGBIRD. Trochilus colubris Linn. Geog. Dist.-Eastern United States to the Great Plains, north to Canada, south in winter to Cuba, Eastern Mexico and Central America, to Uraguay.

This is the only species of Hummingbird found east of the Mississippi, where it is common and well-known. Its small size, irridescent plumage, its marvelous swiftness of flight, and the architectural beauty of its nest are the admiration of all. The eggs of the whole family of Hummingbirds, as far as known, are white, unspotted; rather elliptical than oval, and always two in number. The only difference noticed are the relative variations in size. The nests are generally saddled upon a horizontal branch, are cup-like in shape, and are mostly made up of various kinds of soft vegetable down; in nearly all cases covered on the outside with a coating of lichens or mosses. The nest of the Ruby-throated Hummingbird is a miniature of the Blue-gray Gnatcatcher's. It is felted with a mass of exquisitely soft cottony, silky, or woolly substances, such as the down from the stem of plants, and is artistically covered on the outside with lichens. It is usually placed on a horizontal limb of a forest or orchard tree. Several specimens before me are placed on branches that were slanting, and the nests rest

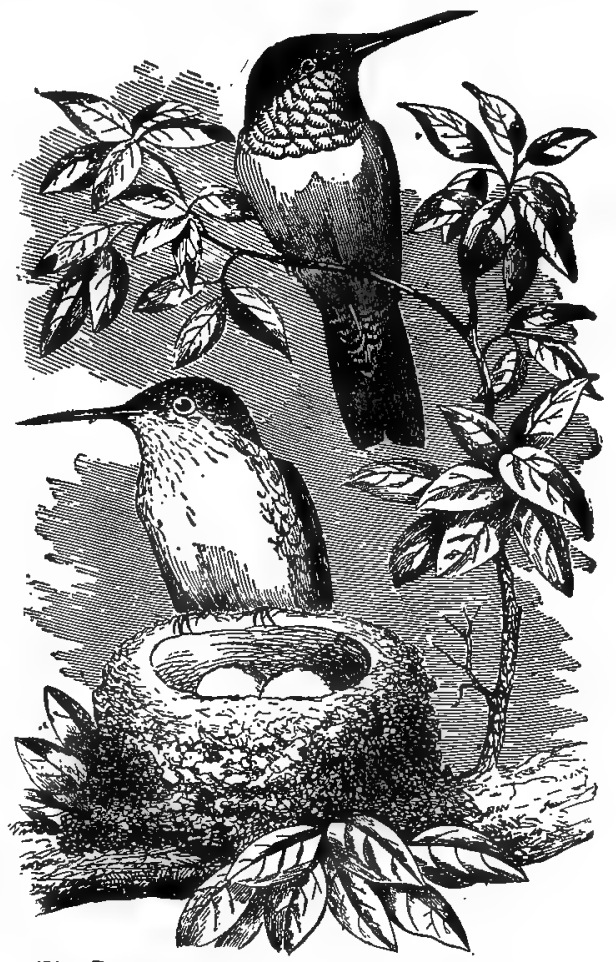

498. Ruby-Throated Hummingbirds and Net. Upper, male; lower, female. 
in small forks. A very fine one measures, outwardly, one and three-fourth inches broad by one and a half deep. Nests saddled on thick limbs are usually larger. In Ohio the Ruby-throat prefers nesting in the branches of the buckeye to all other trees. The birds are especially abundant about this tree when it is in full blossom early in May. The nesting time is from about the middle of May to the latter part of June. The average size of thirty eggs is .51x.34. The Ancients knew nothing of Hummingbirds because they belong exclusively to the Americas, and we can read nothing concerning these :gems of bird life in the mythologies and legends of the Greeks and the Romans. There are about four hundred species of Hummingbirds known to the New World.

429. BLACK-CHINNED HUMMINGBIRD. Trochilus alexandri Bourc. \& Muls. Geog. Dist.-Western United States, from the Rocky Mountains to the Pacific, south into Mexico.

This Hummingbird nests in more open ground than the Rufous or Anna's, placing the structure usually on the small branches of oaks and sycamores. Sometimes it rests lightly in the forks of a slender twig. It is composed of the web or down found on the under side of the leaves of the sycamore; the effect is that the nest looks like a small, round, yellow sponge. Eggs same as those of the Ruby-throat, with an average size of $.50 \times .30$. Mr. W. E. D. Scott states that this species is an abundant summer resident in the Catalina mountains in Southern Arizona, and by the last of May the birds are mated and begin breeding. He found fresh eggs as late as July and early in August. Mr. Stephens notes this Hummingbird as not uncommon in the San Bernardino Valley. A nest taken May 22 was built in a willow, eight feet from the ground, and contained two eggs in which incubation had commenced.

429. 1. VIOLET-THROATED HUMMINGBIRD. Trochilus violajugulum Jeffries. Geog. Dist.-Coast of California (Santa Barbara).

Known only from one specimen first described by the late J. Amory Jeffries. The specimen was a male taken April 5, 1883, near Santa Barbara, California.* Nothing is known regarding its habits or the extent of its range.

430. COSTA'S HUMmINGBIRD. Calypte costce (Bourc.) Geog. Dist.Lower California, Western Mexico, Arizona and Southern California.

Costa's Hummingbird is more or less abundant in various regions of Arizona and Southern California. It is not generally so abundant as the Black-chinned Hummingbird, in whose company it is often found breeding. Small streams in the mountain canons, fringed with alder, laurel, sycamore and other shrubbery, are their favorite resorts. Mr. Scott did not find this species very common at Riverside, Pinal county, Arizona, in 1882. On May 5 a nest was found built in a cottonwood tree thirty-five feet from the ground, almost at the extremity of the branches. Flour sets of the eggs, with the nests, of Costa's Hummer, collected in the neighborhood of Banning, California, May 12 and 13, 1884, are before me. The nests were built in shrubs, varying from six to twelve feet in height. Two of the nests rest in slender forks, while the other two are built on small twigs. The materials in these do not differ essentially from those in ten nests of Anna's Hummingbird, consisting of soft, downy, yellowish or grayish vegetable substances, with here and there bits of flower stems, the whole covered on the outside with spider webs. Each of these nests contained two eggs, and they exhibit the following sizes: .49x.31, .49x.29; $.45 \times .30, .47 \times .31 ; .48 \times .30,49 x .30 ; .45 \times .32, .46 \times .30$.

* The Auk, Vol. V,, pp. 168-169. 
431. ANNA'S HUMMINGBIRD, Calypte anna (Less.) Geog. Dist,-Valleys of California, Arizona ád Mexico

Anva s Humminguird is a common resident of California; its nest and eggs can be found almost any time in May and June. In the vicinity ol traywards, California, Mr. Emerson took a nest of this species which contained two eggs, January 20. It was built in slender forks of a pear tree, about eight feet from the ground, Over the entire outside of this nest are distributed green lichens. Mr. H. R. Taylor, of Alameda, California, records a nest containing two eggs far advanced in incubation, which he found February 13. The nest was placed about thirty feet from the ground, near the end of slender limb of a cypress tree. The birds build in trees, and are not particular what kind or where they are situated; on hillside, along: creeks, in orchards or in gardens. Ten nests collected by Mi. R. B. Herron, at San Gorgonio Pass, California, in May, do not exhibit great variation in their general make-up and style. They are composed of thistle-down and willow-cotton, with occasionally a few small feathers and bits of flower stems; on the outside, moss. well covered with spider webs, with here and there pieces of lichens. Eggs same as: those of $T$. colubris; four specimens measure as follows: $.45 x .30, .47 x .30, .49 x .32$, $.49 x .30$. Twenty-four eggs have an average size of .50x.32.

431. 1. FLORESI'S HUMMINGBIRD. Selasphorus floresii Gould. Geog. Dist.-Mexico (Bolanos, Jalisco); accidental to California.

Floresi's Hummingbird or Flame-bearer, of exquisitely gorgeous plumage, can only be considered an accidental straggler within the borders of the United States. and still is very rare in collections. It was obtained at Bolano, Oaxaca, Mexico, in 1845, and remained unique for some time; more recently it has been reported from the State of Jalisco. Mr. Walter E. Bryant found a specimen in a taxidermist's shop. in San Francisco, California, which had been mounted as a hat bird. He was assured that it had been killed near that city, which gives it a place in our avifauna. Nothing appears to be known regarding the life history of this species.

432. BROAD-TAILED HUMMINGBIRD. Selasphorus platyccrcus Swains. Geog. Dist.-Rocky Mountain plateau region of the United States, from Montana, Idaho and Wyoming southward to Guatemala.

This Hummingbird is a common species in the Rocky Mountain regions of the United States, and is particularly numerous in New Mexico, Colorado and northward. In its flight it is said to utter almost constantly a sharp screeching or chattering note. Large numbers of these birds are often found breeding in thickets of dwarf willows along streams. The nests are beautiful structures, composed of soft, vegetable down and covered externally with lichens and bark-fibre, resembling the twigs: to which they are attached, and their height from the ground ranges from three to ten feet. The nests are similar to those of the Ruby-throat, but are usually suspended on small, swaying twigs, sometimes directly over running water. In Colorado this species rears two broods in a season. Ten eggs before me are not distinguishaole from those of the Ruby-throated Hummingbird in size, color and shape.

433. RUFOUS HUMMINGBIRD. Selasphorus rufus Gmel. Geog. Dist.Western North America, from the Rocky Mountains to the Pacific coast; north to or nearly to Alaska, south over the Table Lands of Mexico.

The commonest and most extensively distributed Hummingbird of the West; from the Rocky Mountains to the Pacific, and from Mexico northward. Its favarite 
nesting site is along the borders of creeks, on the overhanging limbs and branches of trees and bushes. Mr. A. W. Anthony mentions this species as abundant in Washington county, Oregon, breeding nearly everywhere. Nests were found in ferns, in bushes, trees and vines overhanging embankments; the latter, he states, seems to be the favorite locality, six nests being found in an old railroad cut, in May and June. The materials used are willowfloss and soft plant-down. Frequently nests are found covered with light-colored lichens, which resemble the small bunches of moss in the trees where they are built. The eggs are not distinguishable from those of $T$. colubris, except that they average slightly smaller.

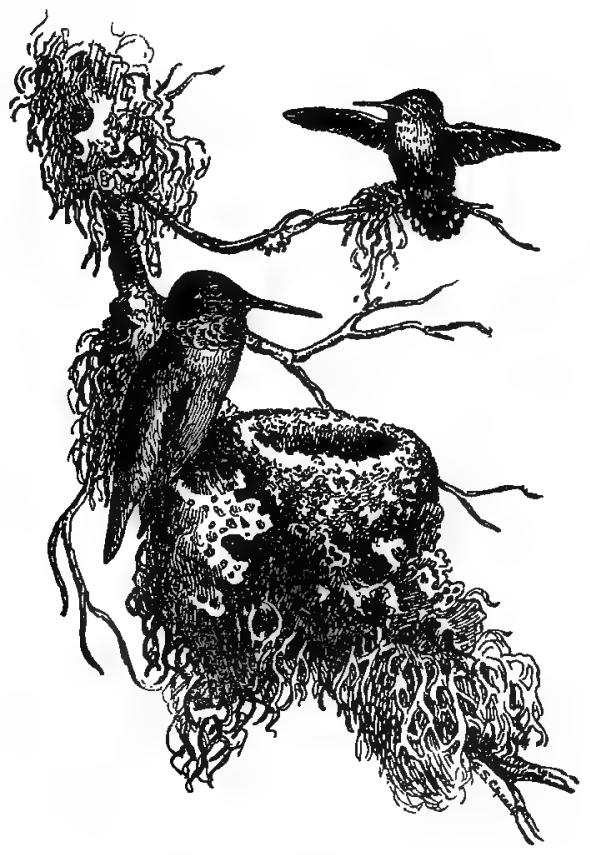

433 Rurous HOMMingairds (Cheney del).

434. ALIEN'S HUMMINGBIRD. Selasphorus alleni (Hensh.) Geog Dist.Coast district of California, north to British Columbia, south to Arizcna.

Allen's Hummingbird is found throughout the coast region of California and northward. This species is said to be very lively and active, keeping constantly in open places, and always perching upon the most prominent dead twigs. Compared to the unsuspicious nature of the Rufous Hummingbird, it is extremely shy. Nests usually in thickets and trees along creeks and canons. The outside of the nest is composed of fine moss, the lining is the delicate floss of the cottonwood. Eggs same as those of $T$. collubris. All the Hummingbirds that breed in California are said to rear two broods in a season.

436. CALLIOPE HUMMINGBIRD. Stellula calliope Gould. Geog. Dist.Western United States, north to British Columbia, south to Mexico; east to Rocky Mountains. 
One of the smallest of Hummingbirds. Common to the mountains of the Pacific slope, from British Columbia south to the tablelands of Mexico. It is abundant in some localities on the eastern slopes of the Sierra Nevada Mountains, and occurs as far east as the Rocky Mountain region, from New Mexico north to Montana. In the vicinity of Fort Klamath, Oregon, Dr. Merrill found this species abundant after May 16 about the blosoms of wild currant and gooseberry bushes. During the breedIng season the birds are generally distributed in deep pine woods as well as in more open places, the constant, sharp shrill notes of the males indicating their presence. A nest found about the middle of July which the young had just left was placed upon a dead, flattened cone of Pinus contorta. It was composed of thin strips of gray bark, with a few spiders' webs on the outside; the lining was similar, but with a few small tufts of a cottony blossom from some tree; the nest was just the color of the cone, and was admirably adapted to escape notice. Another nest containing two nearly fledged young was found at about the same time, but was quite unlike the one fust described in construction and situation, being of the common Hummingbird type, and saddled upon a dead willow twig. Near Carson, Nevada, Mr. Walter E. Bryant found a nest of this species built upon a projecting splinter of a wood pile at a height of flve feet. Another was secured to a rope within an outbuilding. The eggs of this species measures $.48 \times .32$.

437. LUCIFER HUMMINGBIRD. Calothorax lucifer (Swains.) Geog. Dist.Tablelands of Mexico, from Puebla and the Valley of Mexico north to Southern Arizona.

Mr. H. W. Henshaw added this species of Hummingbird to our fauna in 1874 when he took a specimen near Camp Bowie, Arizona. The late Major Bendire stated that so far as he was aware no other specimens have been taken within our borders since that time.

438. RIEFFER'S HUMMINGBIRD. Amazilia fuscicaudata (Fraser.) Geog. Dist.-Lower Rio Grande Valley in Texas, south through Eastern Mexico to Central America and Northern South America.

This common Central American species was given a place in our fauna by a single specimen secured alive by Dr. James C. Merrill in June, 1876. It has not been obtained in the lower Rio Grande Valley since and must be considered a straggler with these limits. It is extremely abundant in the lowlands of Eastern Nicarauga. Specimens of the nest of this species resemble some of those of the Black-chinned Hummingbird, and its eggs are similar.

439. BUFF-BELIIED HUMMINGBIRD. Amazitia rerviniventris Gould. Geog. Dist.-Lower Rio Grande Valley in Texas, south to Eastern Mexico.

Dr. James C. Merrill added this Hummingbird to the avifauna of the United States in 1876, the first specimen being taken August 17, on the Lower Rio Grande, in Texas. He found it nowhere so abundant as on the military reservation at Fort Brown, where it was perfectly at home among the dense, tangled thickets, darting rapidly among the bushes and creeping vines. A rather noisy bird, its shrill cries usually first attract one's attention to its presence. A Hummer's nest, undoubtedly made by this species, was found in September, 1877, within the fort. It was placed on the fork of a dead, drooping twig of a small tree on the edge of a path through a thicket; it was about seven feet from the ground, and contained the shriveled body of a young bird. The nest was made of downy blossoms of the tree in which it was placed, bound on the outside with cobwebs, and rather sparingly covered with lichens. The inside depth was somewhat less than 1.00; the diameter .50; external depth 1.50. Mr. C. W. Crandall's collection contains a beautiful nest and two eggs 
of this handsome Hummer secured by Mr. Armstrong, the well-known ornithological and oölogical collector, who secured them at Brownsville, Cameron county, Texas, August 3,1892 . The nest is composed principally of thistle-down, also weed stems and silky fibers of vegetable matter. It is ornamented on the outside with a few lichens held on with spider webs. The outside measurements are 1.04 in depth by 1.53 in diameter; inside diameter .97 by .73 in depth. The eggs measure .55x.36, $.51 \times 33$.

\section{XANTUS'S HUMMINGBIRD. Basilinna xantusi (Lawr.) Geog. Dist.-} Lower California.

This Hummingbird occurs in the southern portion of Lower California. It was. first taken at Cape St. Lucas by Mr. Xantus, and described by. Mr. George N. Lawrence in 1860 . I have no information regarding its specific habits; they perhaps do not differ essentially from those which characterize other Hummingbirds. Prof. Ridgway describes the nest as composed of various soft vegetable fibres (especially raw cotton, spiders' webs, etc.), and attached to small twigs. Size about 1.50 in diameter by about .80 in height, the cavity about 1.00x.55-.60. Eggs .47x.31.

440. 1. WHITE-EARED HUMMINGBIRD. Basilinna lencotis (Vieill.) Geog. Dist.-Mexico and Nicarauga, north to the Chiricahua Mountains.

A handsome Hummingbird, recently added to the avifauna of North America. by Dr. A. K. Fisher, having obtained a specimen on June 9,1894 , in the Chiricahua. Mountains of Southeastern Arizona. Early in June a camp was made at Fly Park, a well-wooded area southeast of the head of Pinery Canyon, at an altitude of about 10,000 feet. Here a boreal honeysuckle grows commonly through the woods of spruce, fir, pine and aspen. The flowers of the honeysuckle attract great numbers of Hummers. It was here that the first specimen was taken on the above date.* According to Salvin and Godman this is one of the commonest and most characteristic of the Hummingbirds of the highlands of Mexico and Guatemala. So far as I am aware there is no authentic published account of the nestis and eggs of this beautiful species.

441. BROAD-BILLED HUMMINGBIRD. Iache laterostris (Swains.) Geog. Dist.-Southern Arizona, and the South to the Valley of Mexico.

Quoting the late Major Bendire, he says: "The Broad-billed or Circe Hummingbird appears to be a moderately common summer resident in suitable localities in Southern Arizona and Southwestern New Mexico, at altitudes from 3500 to 5000 feet. It was first added to our fauna by Mr. H. W. Henshaw, who took two adult males in the Santa Rita Mountains, a few miles from old Camp Crittenden, Arizonar on August 23, 1874. Since then it has also been taken by F. Stephens in the same locality, where he secured five specimens, which are now in Mr. William Brewster's collection." He says that the birds were always found near water, and usially along the streams which flowed through canyons, high among mountains. Mr. W. E. D. Scott tcok an adult female that ccntained an egg with shell nearly formed. This was in the Catalina Mountains, June 26, 1884. So there can be no doubt that the bird breeds in that region. A nest from Mexico is described as being composed of plant fibres, and vegetable down; decorated on the outside with narrow strips of fine plant stems, bits of lichens, etc. The nest was saddled on a fork of a drooping: twig. There appears to be no published account of the eggs of this Hummer, but undoubtedly are identical with those of the other well-known smaller species of this group.

* See The Auk, Vol. XI, 1894, pp. 325-326. 
* ROSE-THROATED BECARD. Platypsaris alaio (Lafr.) Geog. Dist.Eastern Mexico, north to the Rio Grande Valley, south to Salvador.

The family Cotingidæ, or the Contingas is a very extensive group of tropical and subtropical America. They are represented by two genera on our southern border, Platypsaris and Puchyrhamphus. They are very closely allied to the family Tyrannida, the Tyrant Flycatcher, their habits and general characteristics being similar. The present species is found in Eastern Mexico and northward to the Valley of the Rio Grande. The extensive oölogical collection of Mr. C. W. Crandall contains two sets of five eggs each of this bird, which were taken by Mr. Frank B. Armstrong at Alta Mira, Mexico, May 8, 1895 . The nests in which these eggs were found were as large as a bushel basket and were composed of general rubbish, bark, straw, dry grass, etc. Each contained a small cavity where the eggs were deposited. The eggs have a ground color of a very light drab, marked with blotches, scratches and pen lines often similar to the markings found in the eggs of the Crested Flycatcher-fawn color or hair-brown inclining to form a ring around the large end. One set exhibits the following measurements: $.98 \times .71,1.04 \times .71,1.03 \times .69, .98 \times .71, .97 \times .70$; the other $1.02 \times .73,1.05 \times .73, .98 \times .73, .98 \times .73,1.02 \times .73$; the eggs in the second set are remarkable for their uniformity of breadth. The average size of the ten eggs is $1.01 \times .71$ inches.

441. 1. XANTUS BECARD. Platypsaris albiventris (Lawr.) Geog. Dist.Western and Southern Mexico, north to southern Arizona (Huachuca Mountains).

One specimen of this species taken in southern Arizona by Mr. W. W. Price gives this species a place in our fauna. A nest from Guatemala was hung from the branch of a sapling at the foot of a mountain. It was composed of strips of bark and grass so as to form a hanging nest open at the top and about 2 inches deep. The egg is white, beautifully marked with pencilings of pinkish red and spots of the same color.

[442.] FORK-TAILED FLYCATCHER. Milvulus tyromms (Linn.) Geog. Dist.-Mexico to South America. Accidental in the United States-Mississippi, Louisiana, Kentucky, New Jersey.

This handsome Flycatcher with a very deeply forked tail is found throughout tropical America. Its tail is about a foot long, and forked as much as six to eight inches. The bird's occurrence in the United States is purely accidental, and only a few specimens have thus far been taken in the regions cited above. Its habits are said not to differ essentially from those of the Scissor-tailed Flycatcher of our southern fauna. Dr. Brewer describes an egg of this species obtained by Dr. Baldamus from Cayenne, as bearing a strong resemblance to the egg of the common Kingbird. It has a clear white ground, and is spotted with deep, bold markings of reddish-brown; size $.90 \times .68$.

443. SCISSOR-TAILED FLYCATCHER. Milvulus forficatus (Gmel.) Geog. Dist.-Eastern Mexico and southwestern prairie districts of the United States, north to Indian Territory, Kansas and the southwestern portion of Missouri. Accidental in the Eastern States-Virgina, New Jersey, New England-even as far north as Hudson Bay Territory and Manitoba.

Known as the Swallow-tailed or Fork-tailed Flycatcher-an elegant, graceful bird, common in the southwestern portion of the United States, from Kansas and southwestern Missouri 'southward-especially abundant in Texas. Mr. Singley states that in Lee county, Texas, this bird nests in trees varying from six to twenty feet from the ground. He describes a typical nest as built of weeds, small stems and thistle-down, and lined with down and sometimes with a few fibrous roots. Since 
the introduction of cotton gins and sheep ranches most of the nests are built of weeds and cotton or wool, or both felted, lined with the same, but oftener with no lining. Mr. E. C. Davis informs me that the favorite nesting site of this bird in Cooke county, Texas, is in the low mesquite bushes on the prairieś. He has frequently found double nests; one now in his collection consists of three nests built on each other and made entirely of cotton, measuring fifteen inches from top to bottom. Mr. Singley says the usual number of eggs in a set is five, fully eighty per cent. being of this number; the other twenty per cent. is about equally distributed between sets of four and six. They are white, or creamy-white, marked with a few dark red spots, and occasionally of an obscure purple, chiefly at, the larger end; the eggs vary in color from pure white, unmarked specimens, which are very rare, to finely speckled with reddish-brown, and often covered with large spots and blotches of brown and lilac, and look as if whitewash had been brushed over the colors. Their average size is $.87 \times .67$. A male specimen of the Scissor-tailed Flycatcher was taken near Marietta, O., May 20, 1894, by Mr. Frank H. Welder, the skin of which is now in his collection. This, I believe, is the first record of the bird having been taken in the state.

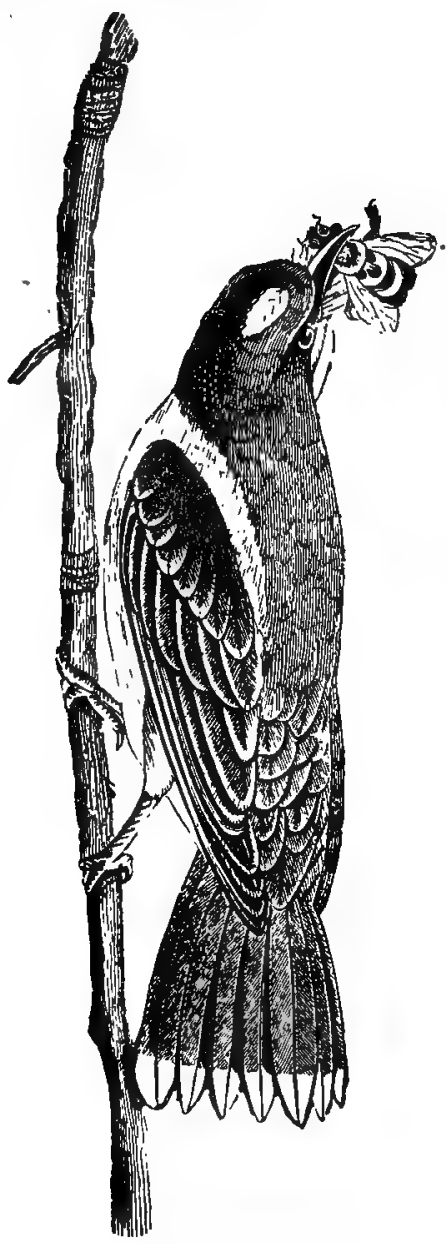

444

444. KINGBIRD. Tyrannus tyrammus (Linn.) Geog. Dist.-Eastern temperate North America, south to Central ard Western South America to Bolivia; Cuba; Bahamas. Rare west of the Rocky Mountains.

A common bird in Eastern United States, and perhaps better known by the name of Beebird or Bee-martin. It destroys thousands of noxious insects, which more thar compensates for all the bees it eats. This bird's pugnacious disposition during the breeding season, the boldness, persistent tenacity, and reckless courage with which it attacks other birds, even crows, hawks and owls, are characteristics familiar to all. The nest is placed in an orchard or garden, or by the roadside, on a horizontal bough, or in a fork at a moderate height; sometimes in the top of the tallest trees along streams. It is bulky, openly situated, and as easily found as that of the Robin. Exteriorly it is ragged and loose, but well cupped and brimmed, consisting of twigs, weedstalks, grasses, rootlets, bits of vegetable-down and wool firmly matted together. The lining is of slender grasses, chicken feathers, horse hair, fibres, rootlets and wool, used singly or combined in various proportions. The eggs range from three to five in number. A large series before me exhibit a wonderful diversity in their markings; the ground color is either white or creamy-white, and the common type is spotted with rich umber and chestnutred. The sizes vary from .80 to 1.05 in length by .69 to .75 in breadth. The average size of forty specimens is $.97 \times .70$. Sometimes sets of these eggs are found almost wholly unmarked.

445. GRAY KINGBIRD. Tyrannus dominicensis (Gmel.) Geog. Dist.-South Carolina, Georgia and Florida: West Indies, coasts of the Caribbean Sea and Gulf of Mexico. Accidental in Massachusetts.

A larger species than the common.Kingbird, but its general appearance. habits and nest- 
ing are the same. It is a common bird in the West Indies, and is found regularly in Florida and northward to Georgia, etc. Mr. Stuart states that it breeds in Florida in the months of May and June, building for its nest a frail structure of dry twigs, lined with a few roots, dead moss or fibrous plant stems; it is placed in low bushes or in trees at a considerable height. The favorite nesting localities are along streams in live oaks. Usually three, sometimes four eggs are deposited; they have a ground color of a creamy, pinkish or rosy tint, spotted, blotched or dashed with umber-brown and lilac-gray. A set of three eggs in my cabinet, taken near Tampa, Florida, May 20, 1885, measure 1.00x.75, 1.02x.76, 1.04x.75; another set of three, taken near Thomasville, Georgia, June 4, 1888, exhibit the following sizes: $.99 x .70,1.00 x$ .72, 1.00x.73. Mr. Norris has a set of four eggs, taken in Matee, Florida, May 25; these measure $.97 \times .72, .99 \times .82, .97 \times .70, .97 \times .74$.

446. COUCH'S KINGBIRD. Tyrannus melancholicus couchii (Baird.) Geog. Dist.-Northern portion of Central America, north through Mexico to southern border of the United States (Southern Texas to Arizona).

This is a common bird from Guatemala north through Mexico to the southern border of Texas, New Mexico and Arizona. It possesses the same characteristics common to birds of its family. A nest and four fresh eggs are described by $\mathrm{Mr}$. Sennett.* These, together with both parents, were taken at Lomita Ranch, on the Rio Grande, Texas, in 1881. The nest was situated some twenty feet from the ground, on a small lateral branch of a large elm, in a grove not far from houses. It was composed of small elm twigs, with a little Spanish moss, a few branchlets and leaves of the growing elm, lined with fine rootlets and black hair-like heart of the Spanish moss. The outside diameter is 6 inches and the depth 2 inches; insido diameter 3 and depth 1.25 inches. The, eggs, Mr. Sennett says, have a general resemblance to those of all our Tyrant Flycatchers, but are quite distinct in form, size and ground-color from any he had seen. The blotches are more numerous and smaller; the large end is very round, and the small end quite pointed; the groundcolor is rich buff; the blotches are similar to those of the Kingbird's eggs, but more irregularly distributed over the entire eggs; sizes $1.00 \times .76, .99 x .76, .98 \times .76, .97 \times .72$.

447. ARKANSAS KINGBIRD. Tyrannus verticalis Say. Geog. Dist.-Western North America from the Plains to the Pacific, south through Western Mexico to Guatemala. Accidental in Eastern States-Maine, New York, New Jersey and Maryland.

The Western Kingbird possesses the same general traits which are common to the Kingbird of the Eastern States. Colonel Goss mentions it as a common summer resident in middle and Western Kansas, arriving about the first of May; begins laying in the latter part of the month. Mr. A. M. Shields states that in the region about Los Angeles, California, this species is found nesting from about the first of May until late in July, building in any convenient place; in the frame-work of a windmill, the cornice of a house, on fence posts, in the forks of trees at heights ranging from five to fifty feet. The nest is built of any available material, rags, grass and twigs lined with wool or cotton. Mr. Walter E. Bryant, in his papers entitled "Unusual Nesting Sites," mentions some curious freaks concerning the nesting of the Arkansas Kingbird: An old and much flattened nest of Bullock's Oriole was found relined, and containing four Kingbird's eggs. A nest was found by Mr. A. M. Ingersoll built upon a fence post more than half a mile from the nearest tree. It was se-

- Auk, I, n 98. 
cured from observation on one side by a board nailed to the post and projecting above it. One of the most remarkable instances of persistency in nest building was met with in the case of a pair of I.ngbirds, which had attempted to construct a nest upon the outer end of a windmill fan. A horizontal blade had probably been first selected, but an occasional breath of air had slightly turned the mill, bringing, into place another and another, upon each of which had been deposited the first. material for a nest until, several nests were in different stages of construction, varying from the time tha, the windmill had remained quiet, while upon the roof below was strewn a quantity of debris that had fallen as the wheel revolved. Of course, nothing but failure could be expected from their repeated attempts. The eggs are five, sometimes four, in number. A large series before me do not differ essentially from those of $T$. tyrannus, except that they average smaller; $.94 \mathbf{x . 6 5}$.

448. CASSIN'S KINGBIRD. Tyrannus vociferans Swains. Geog. Dist.Guatemala north through Mexico and Western United States to Idaho and Southern Wyoming, and coast districts of Southern California.

Cassin's Kingbird greatly resembles T. verticalis in color; is less lively, and not so quarrelsome or pugnacious in its nature. It is a common bird in Southern California, but is nowhere so abundant as the Arkansas Flycatcher. In the Rocky Mountain region, according to Dr. Coues, it mostly replaces verticalis in the breeding season. A common bird in Arizona. Mr. W. E. D. Scott states that the position of the many nests he examined in the Catalina Mountain region shows a decided preference: for the evergreen oaks over other trees. The nest, which is commonly from twenty to twenty-five feet from the ground, is most always placed near the extremity of a branch, and is hidden by the thick leaves. Six nests and a large series of the eggs of this species before me do not differ essentially from those of $T$. tyrannus or $T$. verticalis.

449. DERBY FLYCATCHER. Pitangus derbianus (Kaup.) Geog. Dist.Northern South America, Central America, Mexico, north to the Valley of the Rio. Grande in Texas.

A large, spirited-looking Flycatcher of Mexico and southward, lately found on the Lower Rio Grande in Texas. It is said to build its nest chiefly in thorny bushes and trees; the structure is large and dome-shaped, like a Magpie's nest, with an entrance on one side. It is composed of twigs, coarse straws, dried mosses, lichens, etc. The eggs are from three to five, sometimes six in number; creamy-white, speckled, spotted and blotched, chiefly at the larger end, with umber-brown, chestnut and lilac. Average size of ten eggs is $1.20 \times .80$; an average specimen measures $1.16 \times .75$. A set of five eggs in Mr. Crandall's collection, takèn May 9, 1895, in Tamaulipas county, Mexico, measures 1.10x.82, 1.10x.83, 1.07x.87, 1.05x.81, 1.12x.85. Another set. measures $1.18 \times .84,1.18 \times .85,1.19 x .87,1.16 \times .84,1.20 \times .87$.

450. GIRAUD'S FLYCATCHER. Miviozetetés texensis (Giraud.) Geog. Dist."Texas" (Giraud), south to Central America and Northern South America.

This species is admitted to our fauna upon Giraud's record and, if it occurs at all along the Rio Grande Valley in Texas it must be considered a straggler, and it is doubtful if it breeds within our limits. Mr. Crandall has a set of four eggs of this species taken in Tamaulipas county, Mexico, April 30, 1895, by Mr. Frank B. Armstrong. The nest was placed in a bush, in open woods, was bulky and round and composed of grass, hay and moss. The eggs are creamy white, 
very sparsely marked, except at the larger end, where they form a wreath of specks and spots of brownish purple and lavender. This is a typical set in a series. The sizes are as follows: $.98 \times .67,1.02 \times .68, .96 \times .66, .96 \times .66, .99 x .68$.

451. SULPHUR-BELIIED FLYCATCHER. Myiodnastes luteiventris Scl. Geog. Dist.-Southern Arizona, south to Panama.

In $1874 \mathrm{Mr}$. W. H. Henshaw added this handsome Flycatcher to the avifauna of North America. He found it to be a summer resident in the Chiricahua Mountains of Southern Arizona, where he secured a pair of old birds, with three young, August 24. The birds frequent streams bordered with large trees, seeming always to prefer sycamores, and they are seldom seen more than 50 yards from a stream. They nest in the knot holes of trees or any suitable tree cavity, the nest being simply constructed of small twigs, stems of leaves, etc. A set of three well incubated eggs was taken August 15, 1894, in Ramsay's Canyon in the Huachuca Mountains. The ground color is a rich creamy buff, profusely blotched and lighter shades of lavender. The markings, according to the late Major Bendire, do not resemble the streaky pattern found in the eggs of the genus IIyiarchus. They measure 1.07x.75, 1.04x.74 and $.97 \times .73$ inches.

452. CRESTED FLYCATCHER. Myiarchus crinitus (Linn.) Geog. Dist.Eastern United States, west to the Plains, north to Southern Canada, south in winter through Eastern Mexico and Central America to Costa Rica.

The Great-crested Flycatcher is an abundant bird in the woodlands of Eastern United States as far north as Massachusetts. Mr. Thomas McIlwraith states that it is a regular summer resident along the southern frontier of Ontario, Canada, arriving early in May. During the summer months the loud, harsh cries of this species are familiar sounds in the woods, which, when once known, are easily recognized. The Great-crested Flycatcher breeds throughout its United States range. It builds in the hollows of trees, post-holes, and, even Bluebird and Martin boxes are sometimes occupied. The nest is made of slender twigs, grasses, fine stems and rootlets and cast-off snake skins are invariably found among the materials. The eggs are remarkable for their coloration, having a ground of buffy-brown, streaked longitudinally by lines sharp and scratchy in style, and markings of purple and darker brown; four to six in number; average size, .82x.62. The smallest egg selected from one hundred specimens measures .76x.62; the largest .93x.70. The eggs are so peculiar in their style of markings that they may be easily identified, and all the eggs of the North American species of the genus myiarchus are alike in character.

453. MEXICAN CRESTED FLYCATCHER. Myiarchus mexicanus (Kaup.) Geog. Dist.-Lower Rio Grande Valley in Texas, southward to Guatemala.

The Mexican Crested Flycatcher was found by Dr. Merrill breeding in considerable numbers on the Lower Rio Grande in Texas. In its notes and habits it appears to closely resemble $M$. crinitus. With one exception, no snake skins were used in the construction of any of the nests. They were composed of feited locks of wool and hairs, and were placed not far from the ground in old woodpeckers' holes or in natural cavities of decayed trees or stumps. Thirty-two eggs have an average size of $.93 \times .66$, the extremes being $1.03 \times .73$ and $.82 \times .65$. The eggs are similar to those of M. crinitus, except that they have a paler ground color and the markings are not so heavy. 


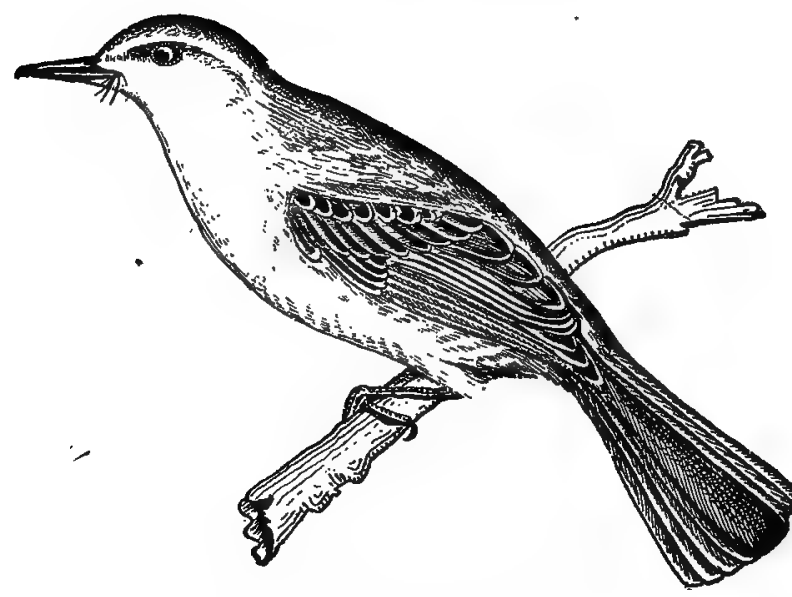

453. Mexican Crested fiycatcher.

453a. ARIZONA CRESTED FLYCATCHER. Myiarclus mexicanus magister . Ridgw. Geog. Dist.-Western Mexico, north to Southern Arizona.

Mr. W. E. D. Scott found this bird to be common in spring and summer about Tucson, Florence, Riverside, and in the foot-hills of the Catalina Mountains up to about 450 feet, in Southern Arizona. About Tucson it frequents the mesquite and giant cactus groves. In the Catalinas, at an altitude of 4000 feet, a nest was found built in a deserted Woodpecker's hole in a dead sycamore stub; it was entirely similar to that of $M$. crinitus, even to the traditional snake skins, and contained five eggs nearly ready to be hatched, very similar to those of $M$. crinitus, but a little larger. A bout Tucson the birds nest commonly in deserted Woodpecker's holes in the giant cactus. From three to five eggs are laid. An egg of this Flycatcher in my cabinet, taken in Pinal county, Arizona, March 21, 1886, measures 1.03x.70.

454. ASH-THROATED FIYCATCHER. Myiarchus cinerascens Lawr. Geog. Dist.-Western. United States from the Rocky Mountains to the Pacific, north to Oregon, Nevada, Utah and Colorado, south over the highlands of Mexico to northern Central America.

The Ash-throated Flycatcher is a common species west of the Rocky Mountains; in some places it is abundant. It is described as being shy, and of retiring habits, preferring the solitude of deep, shady forests where its insect food abounds. It is usually sole possessor of the tree in which its nest is built; all intruders are violently assailed and compelled to retreat. The nests are placed in natural cavities of trees of almost any kind, in a deserted squirrel's or Woodpeckers' hole. The clutches of eggs range from four to seven, ordinarily five or six, and the nesting season is in May and June. Old excavations of Gairdner's Woodpecker are commonly resorted to by this species in California. The eggs are colored and marked like those of $M$. mexicanus. Set No. 208 (oölogical collection of Walter E. Bryant), taken near Oakland, California, June 22, 1881, contains five eggs, which were fresh when found; their measurements are $22.5 \times 16.5,22 \times 16,23.5 \times 16.5,22 \times 16.5,23 \times 16.5 \mathrm{~mm}$.*

* . $.89 \times .65, .87 \times .63, .93 \times .65, .87 \times .65, .91 \times .65$. 
Set No. 207, five eggs, taken at Berkely, California, June 9, 1880, contained small embryos, and show the following dimensions: $21 \times 16,21.5 \times 15.5,21.5 \times 15.5,21.5 \times 16,20 \times$ $15 \mathrm{~mm} . *$

454a. NUTTING'S FLYCATCHER. Mylarchus cinerascens nuttingi (Ridgw.) Geog. Dist.-Southern Arizona, southward through Western Mexico to Costa Rica.

This is a recent addition to our avifauna. The bird with four fresh eggs was secured by Dr. A. K. Fisher at Rillito Creek, Arizona, on June 12, 1892. Other specimens of the bird have since been taken. The nest which Dr. Fisher found was in a hole formerly occupied by Woodpeckers in a giant cactus tree about four feet from the ground. The eggs are similar to those of the Ash-throated Flycatcher and measure $.96 x .67, .95 x .66, .98 \times .67$ and $.94 x .69$ inches.

[455.] LA WRENCE'S FLYCATCHER. Myiarchus lavrenceii (Giraud.) Geog. Dist.-Texas (?) and Eastern Mexico.

This species is placed in our avifauna on Giraud's record from the Iower Rio Grande in Texas, but has not since his day (1841) been observed or taken by any collector. A set of five eggs of Lawrence's Flycatcher was taken by Mr. Frank B. Armstrong near Alta Mira, Tamaulipas county, Mexico, May 20, 1895. The bird was shot and identification made certain. The nest was placed in the hole of a tree in open woods, ten feet from the ground: The composition of the nest was brownishcolored hairs, feathers, etc. I he ground color of the eggs is a rich creamy buff, very sparingly marked when compared with the eggs of other species of this genus, the same purple and dark brown colors, however, predominating, but not laid on in the same scratchy style, tending considerably more to blotches and spots, although sufficient enough to identify them as eggs belonging to birds of this genus. The set of five eggs just described are in. Mr. C. W. Crandall's collection and were sent to him by $\mathrm{Mr}$. Armstrong as being typical of the species selected from a small series taken at Alta Mira. The sizes of the eggs are as follows: $.83 x: 68, .87 x .66, .81 x .65, .88 x .67$, $.84 \times .66$; average $.85 \times .66$. inches.

455a. OLIVACEOUS FLYCATCHER. Myiarchus lawrenceii olivascens Ridgw. Geog. Dist.-Arizona and Western Mexico; casual at Fort Lyon, Colorado.

First described by Mr. William Brewster in 1881 from specimens taken by Mr. F. Stephens in the Santa Rita Mountains, Arizona, during the months of May and June. Mr. Stephens supposed that this sub-species bred in the knot holes of trees or in the excavations made by woodpeckers. Nothing possitive seems to be known concerning the eggs of this species, but in all probability they are similar to those of the Ash-throated Flycatcher.

456. PHCEB. Sayornis phœbe (Lath.) Geog. Dist.-Eastern North America; in winter south to Mexico and Cuba.

The Phøbe, Pewit, or Pewee is one of the best known birds in Eastern United States, where, with the Robin and the Bluebird, it is always one of the first spring arrivals. Shady ravines, the borders of rivers and open fields are its resorts. It is ccmmonly found perched upon a dead branch of a tree at the edge of a woods, where it sits flirting its tail and occasionally darting out after passing insects, always returning to the same twig, and frequently uttering its simple, agreeable and

$.8 € \times 63,86 \times 61, .85 \times .61, .85 \times .63, .79 \times .59$. 
emphatic note, pe-uee, pe-uit, or as some hear it, pho-bee. This species is called "Bridge-bird," from ițs habit of nesting in old wooden bridges. The original situation of the nest is the face of an upright rock, which is sometimes moss-grown and dripping with water. Wilson states that the Phœbe occasionally nests in an open well, five or six feet down, among the interstices of the side-walls; and Nuttall has known it to nest in an empty kitchen. In wild places, far from the habitation of man, hollow trees are resorted to as breeding places. Stone culverts, caves, old $\log$ houses, barns and sheds are its accustomed nesting places, and nests are often found in woods built in the roots of overturned trees. Mr. W. W. Coe records the nesting of a pair of Pewees on a ferry boat running between Portland and Middle-

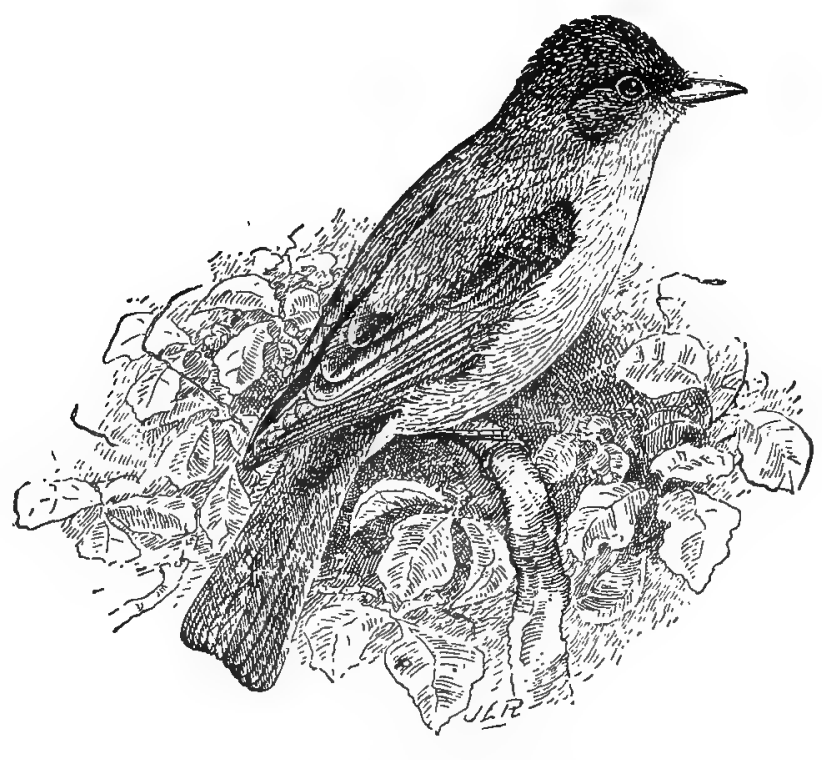

456 Phobe (From Beal)

town, Connecticut, the boat making trips every ten minutes. The birds seemed to claim Middletown as their home, and appeared to collect the material for the nest on that side of the river. My friend, Mr. Mebs, took a nest containing five eggs from the beams of a freight car, which had recently made a trip of forty-five miles. The eggs were fresh, and, except one, unbroken. Two nests which I found in culverts, over running water, were perfectly green with moss, and had evidently been occupied 'for several years. The nest, attached to a perpendicular surface, is built like that of the Barn Swallow, being compactly and neatly made of mud and various vegetable substances, with a lining of grass and feathers. This bird's attachment of a chosen locality is sometimes remarkable; its nest is known to have been torn down and rebuilt again by its owner in the same spot. The eggs may be taken, when a second and even a third set will be deposited. The eggs are ordinarily four or five in number; clutches of five are the most common; they are pure white, sometimes sparsely spotted with obscure or well-defined reddish-brown dots at the larger end. In exceptional instances the Pewee deposits six and seven eggs. Their average size is $.81 \mathrm{x} .52$. 
457. SAY'S PHCEBE. Sayornis sava (Bonap.) Geog. Dist.-Western United States from the Great Plains to the Pacific, north to the Saskatchewan, south to Mexico.

A bird of an extended distribution in Western United States, and possessing the same general traits common to the Eastern Pewee. Col. Goss records this species as a summer resident in Western Kansas, and styles it "a bird of the plains." Begins laying the last of May. Dr. Coues says that it is common in open or rocky country, where it is seen singly or in pairs; the principal flycatcher of unwooded regions, in weedy, brushy places, displaying the usual activity of its tribe, and uttering a melancholy note of one syllable, or a tremulous twitter. Like s. phrbe, it has been found nesting in hollow trees, in caves and recesses of rocks, in outbuildings or abandoned dwellings. Sometimes, with the familiarity of the Eastern species, it will build its nest on a porch of a dwelling whose inmates are almost constantly in sight. Occasionally two broods are reared in a season. Mr. Bryant mentions a nest found by Mr. Walter Bliss at Carson, Nevada, placed within and close to the entrance of a deserted Bank Swallow's burrow. The composition of the nest varies more or less according to the locality in which it is built; vegetable fibres, soft grasses, spiders' webs, etc., are the principal materials, and the shallow cavity is lined with feathers and hair. The eggs are four or five in number, white, with an average size of .75x.57. A set of four eggs, taken near Banning, California, May 19, 1884, measure .75x.61, .77x.61, .75x.61, .76x.59.

458. BLACK PHCEBE. Sayornis nigricans (Swains.) Geog. Dist.-Southwestern United States and Mexico-Texas, through Southern New Mexico and Arizona to California, northward along the coast to Oregon.

This bird's general color is like that of the "Black" Snowbird, Junco hyemalis, now called Slate-colored Junco. It is an abundant species throughout California, Southern Arizona and New Mexico, and its general habits are much the same as those of the common Phœbebird; the nests are also constructed in similar situations as those of the Eastern species-in caves, on ledges of rocks, under bridges, in deserted dwellings, etc. The bird is found more or less abundantly along streams, and is said to prefer the vicinity of human habitations. Mr. Walter E. Bryant records a pair of these birds that built for two consecutive years in a well, four feet below the surface. The first year a second nest was built after the first had been taken. Four or five eggs are laid. A set of four eggs is in my cabinet, taken April 26, by Mr. S. C. Evans, from a nest in a barn at San Jose, California. Two of them are white, unmarked, and the other two are sparsely dotted at the larger end with light reddish-brown: their sizes are $.73 \times .59, .80 \times .59, .81 \times .57, .80 \times .58$.

459. OLIVE-SIDED FLYCATCHER. Contopus borealis (Swains.) Geog. Dist.-North America at large, north even to Greenland, south in winter to Central America and Columbia.

The Olive-sided Flycatcher, apparently nowhere abundant-at least ic seems to escape the notice of observers-is very rare in the Middle and Southern States, but less so in the West. It frequents the coniferous woods of the mountain asstricts and those of the Iowlands, breeding from Northern United States northward. In some localities of New England the Olive-sided Flycatcher is rather common, where numerous instances of its nesting are recorded. It has been found breeding in New Jersey, Pennsylvania, and Northern Minnesota. Colonel Goss says it is a rare summer resident of Kansas. The nest is usually built in evergreen trees, frequently at a 
great height from the ground. It is similar in construction to that of the Wood Pewee's nest, being saddled on a horizontal limb or fixed in a fork. A nest before me, taken in Windsor county, Vt., June 10, 1884, is a shallow structure made of twigs, grasses, and bark strips, lined with soft grasses and moss; it is a very frail, clumsy structure, compared to that of Contopus rirens. This was placed in a hemlock tree, thirty feet from the ground, and contained four eggs, which is the usual number. From three to five eggs are laid by this species, and May and June are the breeding months. The eggs are creamy-white, spotted about the greater end with a distinct confiuent ring of chestnut-red and brown; there are also spois of purple and lavender, and on the whole the eggs very much resemble those of the Wood Pewee, but are larger; sizes, $.90 \times .65, .89 \times .65, .90 \times .62, .90 x .67$. These sizes are slightly larger than most of those stated by writers. The average size given is about $.82 \times .62$ inches. $\mathrm{Mr}$. C. Barlow read a paper July 10, 1897, before the Cooper Ornithological Club describing a nest and a set of eggs of the Olive-sided Flycateher taken by W. W. Price in El Dorado county, Cal. The nest was situated in a fir tree seventy-one feet from the ground.

460. COUES'S FLYCATCHER. Contopus pertinax Cab. Geog. Dist.-Mountains of Southern and Central Arizona, south through Mexico and Guatemala.

This Flycatcher was added to our avifauna by Dr. Elliott Coues, who took a specimen near Fort Whipple, Arizona, August 20;1864. It is generally distributed throughout the southern half of Arizona and southwestern New Mexico, but is nowhere common. Breeds wherever found. Like the Olive-sided Flycatcher woods on the edge of an opening or along rocky ravines. The nest and eggs of this Flycatcher were first described by Mr. Samuel B. Ladd, of Westchester, Pa., in The Auk (Vol. VIII, p. 315). They were collected June 17, 1890. It is as follows: “The nest, placed on an oak limb 20 feet from the ground, is compact, and reminds one of the nest of our Contopus virens, excepting in size. Outside diameter 5 inches by 2 inches high; inside diameter 3 inches by 1 inch deep. The body of the nest seems to consist of the web of some spider, intermingled with the exuviæ of some insect, fragments of insects and vegetable matter, such as staminate catkins, Qucrcus-cmoryi, a pod of Hosacka, and some leaves of Quercus emoryi and Quercus unulata. The interior of the nest is made up of grasses, principally of two species of $P \circ a$, also some fragments of a Bontelona and stipa. The eggs, three in number, were slightly incubated. The ground color is cream buff, spotted in a ring around the larger end with chestnut lilac-gray. Measurements: $0.63 \times 0.86,0.82 \times 0.61,0.61 \times 0.83$ inch $0.62 \times 0.84 . "$ Mr. George F. Breninger, of Phœnix, Arizona, makes note of the nesting of Coues's Flycatcher in "The Osprey" for September, 1897, page 12, as follows: "I found the Coues' Flycatcher quite a common bird in the Huachuca Mountains, but saw none in the Santa Ritas. A nest was found on June 11, by watching the female. At first both birds appeared rather indifferent about my presence, but I noticed that no time was lost in driving Jays from a large spruce tree. Patient watching revealed the nest; it was built at the confluence of two limbs, resting in part on the main limb, and so well hidden that it was located only by seeing the bird resume the duties of incubation. The nest is of the Wood Pewee type, but much larger; being composed. outwardly, of grass stems covered with lichens. The inside is lined entirely with the ripe tips of a species of grass (Stipa species?) growing in places near the nest. It was situated thirty feet from the ground, and ten feet from the trunk of the tree. In the nest were two eggs and a third one, after receiving some injury, was thrown out of the nest, lodging upon the edge, where I found it. Incubation in the two eggs 
was well advanced. Th́ey resemble eggs of the Olive-sided Flycatcher, but are somewhat smaller than that species." Mr. Crandall has in his collection a set of three eggs of this species collected by Mr. W. O. Howard in the Huachuca Mountains, Arizona, July 8, 1897. The nest was saddled on the branch of a yellow pine, near the extremity of the limb, sixty feet from the ground. The nest was composed almost entirely of dried grass of a rich straw color. On the outside it was artistically covered with bits of lichen and bark, the green tips and buds of pine. The outside depth is 1.95 by 3.80 inches, outside diameter. The eggs are of a rich cream color blotched and spotted in a confluent ring about the large end with chestnut brown and "various shades of gray. The sizes are $.86 \times .61, .81 \times .61, .83 \times .61$ inches.

461. WOOD PEWEE. Contopus virens (Linn.) Geog. Dis.-Eastern North America to the edge of the Great Plains, north to Canada, south in winter to Eastern Mexico and Guatemala.

A common and a well-known bird in Eastern United States. By those who have a superficial knowledge of birds, it is often confounded with the common Pewee, but it is considerably smaller, slenderer, and rather darker in color. The notes of both birds are very similar; those of the Pewee consist of two syllables, quickly and sharply uttered, while those of the Wood Pewee are of two, sometimes three syllables, pe-uce or pe-a-uce, repeated at all hours of the day, but especially after sunset. The notes are truly sad but sweet, less emphatic, much slower and softer than those of the Phobe and, as Mr. Thomas Milwraith says: "To human ears the notes of the male appear. to be the outpourings of settled sorrow, but to his mate the impressions conveyed may be very different."* The nest of the Wood Pewee is usually placed either on the upper surface of a limb, or in a horizontal. fork. It is generally built in a large tree in the interior or on the border of woods, or by the roadside. Very frequently the nest is placed on the horizontal branches of apple trees in orchards, and even in shade trees, in close proximity to houses, or on those along river banks. The distance from the ground ranges from six to fifty feet. The nest is a very pretty, fat, compact structure, with a thick wall and a thin floor-often the branch forms a portion of the bottom of the nest, and it is frequently so thin that the eggs can be seen from beneath. Slender or split grasses, weed-fibres, narrow strips of grapevine bark, and pieces of moss-fibres make up the nest proper. Externally it is covered with pieces of lichens, which are held in position by webs, and the structure thus ornamented is rendered indistinguishable from a natural protuberance of the branch itself. A large series of the Wood Pewees" nests which I have personally taken in the past ten years are before me. The best of them are far inferior in design to even the poorest nests built by the Blue-gray Giatcatcher and Rubythroated Hummingbird, whose structures have high walls, gracefully turned brims, deeply cupped interiors and highly artistic, lichen-covered exteriors. Some of the neșts of the Wood Pewee are scantily ornamented with lichens, are very shallow, and at once suggest a one-story, flimsy, poverty-stricken home. The nesting time is in the latter part of May or in June. The eggs are usually three, rarely four in number, with a creamy-white ground of varying intensity; the markings are formed in a wreath around the larger end, or around the center; these are spots, of reddishbrown, burnt umber and lilac-gray. In their short diameter the eggs measure from .50 to .59 ; in their long diameter from .65 to .79 ; the average size is about $.74 \times .55$.

462. WESTERN WOOD PEWEE. Contopus richardsonii (Swains,) Geog. Dist.-Western North America, from the Great Plains to the Pacific; north to British

* Birds of Ontario, p. 181. 
Columbia and interior of British America; south in winter through Mexico and Central America.

The Western Wood Pewee is common in various regions of Western United States, as in Colorado, New Mexico, Arizona, California, Oregon, etc. Colonel Goss records it as a rare summer resident in Western Kansas; begins laying the first of June. Mr. Bryant informs me that it is tolerably common near Oakland, Cal., where it nests by preference on the horizontal branches of alders, about fifteen feet from the ground. According to Mr. Emerson it is not at all common aboth Hayward, Cal. A nest taken May 22, 1881, was placed on the large horizontal limb of a sycamore, thirty feet from the ground; another, taken in Santa Cruz county, May 26, was also built in a similar position at a height of forty feet. At Fort Klamath, Oregon, Dr. Merrill found the nests usually built on a horizontal pine branch, often at a conslderable elevation; sometimes they are placed against upright twigs, and others merely saddled on the bare limb. Only one was found in an aspen tree. They averaged rather deeper than the nests of $C$. virens, and were not coated with lichens. The nests of the Western Wood Pewee do not differ widely from those of the typical virens, except that they are rarely ornamented with lichens. The eggs, too, are similar-creamy-white, marked with spots of chestnut-brown, umber and lilac-gray in wreaths about the larger end or center of the eggs; the number deposited ranges from two to four, usually three. A set of three in my cabinet collected in Douglass county, Colorado, June 10, 1887, have the following measurements: $.67 \times .57, .69 \times .57, .65 \times .57$.

462a. IARGE-BILLED WOOD PEWEE. Contopus richardsonii peninsuløe Brewst. Geog. Dist.-Sierra de la Laguna, Lower California.

This subspecies was first described by Mr. William Brewster (The Auk, Vol. VIII, p. 144). It is an inhabitant of Lower California and, while so far as I am aware there is no published account concerning its nests and eggs, it is reasonable to suppose that they differ little from those of the Western Wood Pewee, O. richardsonii.

463. YELLOW-BELLIED FLYCATCHER. Empidonax flaviventris Baird. Geog. Dist.-Eastern North America to the Great Plains, south in winter through Eastern Mexico and Central America. Breeds from Northern United Statea northward.

A common bird in Eastern United States, where it frequents thickets, swamps and woodland. It does not seem to have been met with or observed during the breedIng season so commonly, as other members of the genus Empidonax, which is doubtless due to the peculiarity of its nidiflcation, and from its limited breeding area within the United States. Its note is as much entitled to the name of song as many of the Warblers and other Oscines. A nest containing four eggs was found by $\mathrm{Mr}$. H. A. Purdy on June 18, in Aroostook county, Maine, at the edge of a wooded swamp, built in a ball of green moss in the roots of an upturned tree, two feet from the ground. It was composed of dry moss, and the outside was faced with the same in its beautiful green state. It was large for the size of the bird, and was lined mostly with fine black roots, a few pine needles and grass stems. June 10, 1878, Mr. S. D. Osborne found a nest of this species, with four eggs, on the island of Grand Manan. It was built in a good-sized hummock of moss at the edge of some low woods. The cavity extended in about two inches, and was about four inches deep, lined with a few grasses, black, hair-like roots, etc. Another nest, similar in construction, was found by Mr. Osborne in Oxford county, Maine, in a bunch of moss under the roots of a 
small tree in swampy woods, bordering a small stream. Two hests of this bird were taken at Fort Fairfield, Maine, by Mr. Chárles F. Batchelder. One found June 14 was in wet mixed woods of spruces, arbor vitæs and hemlocks; it was on the edge of a bank of a small brook, in a decayed tree trunk, and partly sunk in the surrounding moss. This nest contained four eggs. The second nest, which also contained * ur eggs, taken June 27, was deeply sunk in the soft, green moss on the side of the stump of a fallen tree.*, Mr. Frederick B. Spaulding records the finding of a nest similar to those described, near Lancaster, New Hampshire, June 14, 1886. $\dagger$ Mr. Spaulding's nest contained five fresh eggs. The eggs are usually four in number, buffy or creamy-white, speckled and spotted, chiefly around the larger end with rusty-brown or cinnamon. The average size is $.70 x .50$. The measurements of $\mathrm{Mr}$. Batchelder's two sets are as follows: .68x.52, .68x.52, .66x.51, .66x.51; .70x.54; .67x.54, $.67 \times .53, .67 \times .51$.

464. WESTERN FLYCATCHER. Empidonax difficilis Baird. Geog. Dist.Western United States, from the edge of the Great Plains to the Pacific; north to Sitka, south in winter to Western Mexico.

The Western Yellow-bellied Flycatcher is an abundant species throughout its. United States range. Its general habits, nesting and eggs are similar to those of flaviventris. Mr. Walter E. Bryant mentions a nest of this species found by Mr. A. M. Ingersoll, which was built at the bottom of a hole five inches deep, made by a Redshafted Flicker in a live oak. Mr. Emerson states that in California this bird nests in hollows in banks and along creeks, in natural cavities of trees and among the roots of fallen ones, and in some of the most out-of-the-way places; in tall Austral-. ian gum trees and in corners of rail fences. Nest composed of shreds of roots, dead leaves, cobwebs, bits of fine grass, and lined with finer grasses and a few feathers; A set of four eggs is in my collection, taken by Mr. Ingersoll, May 2, 1886. The nest was placed on rocks four feet from running water. These specimens measure as follows: .64x.50, .67x.53, .63x.49, .64x.50. The eggs are creamy-white, spotted and finely speckled with cinnamon or reddish-brown, in some quite thickly about the larger end, often forming a complete ring, again well sprinkled over the entire surface; three or four, sometimes five in number; average size .69x.51.

464. 1. ST. LUCAS FLYCATCHER. Empidonax cineritius Brewst. Geog. Dist.-Lower California.

This comparatively new species or extreme Southern variety of the Yellowbellied Flycatcher was first described by Mr. William Brewster from a specimen taken by Mr. M. Abbot Frazar at La Laguna, Lower California. I believe nothing has been published concerning its nests and eggs.

465. GREEN-CRESTED FLYCATCHER. Empidonax virescens (Vieill.) Geog. Dist.-Eastern United States, north to Southern New York and Southern Michigan, west to the Plains, south to Cuba and Costa Rica; rare or casual in New England.

A common bird in the woodlands of Eastern United States. Breeds more or less abundantly in nearly all the Mississippi Valley region, even as far south as Eastern Texas, Southern Louislana and Alabama. Colonel Goss gives it as not uncommon

* For a detailed account of these nests and eggs, see Bull. Nutt, Ornith. Club, Vol. III, pp. 166-168-187-188; Vol. IV, pp. 240-242.

f Ornithologist and Oologist, XII, pp. 133-134. 
in Eastern Kansas, where it arrives the first of May_and begins laying-early in June. Messrs. Keyes and Williams record it as a summer resident of Iowa, but not common; several nests have been taken near Des Moines during the past few years.* In New England the Acadian Flycatcher, which is its other name, is of rare occurrence. In Ohio and the bordering States it is an abundant species. Regions timbered with large trees, and overgrown with bushes, low trees, vines and weeds are its favorite resorts. The birds love to penetrate the shadowy depths of the forest, and delight to rear their young in the most quiet and gloomy spots. Rarely, if ever, is the nest built in isolated trees, but frequently in those along lonely wagon roads or at the border of woods. In these quiet retreats the observer is often startled by the bird's loud, quick and emphatic note, what-d'see, what-d'-ye-see, coming from an unseen performer, who is perched in the lower branches. The distance of the nest from the ground varies from three to twenty feet, and it is usually suspended in a horizontal fork at the extremity of a low limb. In manner of attachment it. resembles the nests of the Vireos, being fastened by the brim, while the bottom is unsupported. Sometimes, as when in vines or bushes, it is suspended between two parallel stems. On the whole, it is a loose, rustic fabric, made of grasses, catkins, weed-fibres and shreds of bark, and when just finished considerable quantities of grass hangs from the periphery of the nest, giving it a slovenly appearance. Two or three sogs are the number deposited by this species. . In only two instances, out of the large number which I have collected, have I found nests with four eggs, and in both cases one egg was badly addled. Their color is a slight yellowish-buff of varying intensity, with a decided flesh-color tint when fresh. The markings are of a light reddish or bay or rusty-brown color, and are found either in specks or spots grouped chiefly about the larger end. Ten specimens offer the following sizes: $.70 x .53, .70 x .56, .70 x .53, .72$ x.54, $.75 \times .54, .77 \times .58, .77 \times .56, .78 x .57, .77 x .56, .78 x .57$. An average egg measures .74x.54. The eggs are not distinguishable from those of trailli, except that the ground-color and markings in those of virescens are generally darker.

466. TRAIIL'S FIYCATCHER. Empidonax traillii Aud. Geog. Dist.-Western North America, from the Mississippi Valley, (Ohio, Illinois and Michigan) to the Pacific, and from the Fur Countries south into Mexico.

Common in Western woodlands, where it is generally distributed. A nest containing a set of three eggs, collected by S. C. Evans, near San Jose, California, May 26 , is in my cabinet. The nest was placed in the forks of a small bush, three feet from the ground. Its composition is chiefly vegetable fibres, loosely put together; the lining is of the same material, but of finer shreds, and horse hair. The eggs have a pale yellowish-buff ground-color, spotted and speckled at the greater end with light reddish and madder-brown; sizes, .73x.53, .74x.51, .74x.53.

466a. ALDER FLYCATCHER. Empidonax traillii alnorum Brewst. Geog. Dist.-Eastern North America, from the Maritime Provinces and New England westward at least to Northern Michigan, etc., breeding from the southern edge of the Canadian Fauna northward; in winter south to Central America.

The Alder Flycatcher breeds from the Northern United States northward, and as far south as Southern Illinois and Missouri. The locality usually selected as a nesting site by this bird is in a thick growth of alders bordering a stream, or in the deep solitude of a lonely wood, where it is associated with the Green-crested Fly-

- A Prellminary Annotated Catalogue of the Birds of Iowa: By Charles R. Keyes anu $H$. \&, Williams. M. D, Extracted from Proceedings of Davenport Academy Natural scences, Vol. V Davennort, Iowa: 1888, p. 23. 


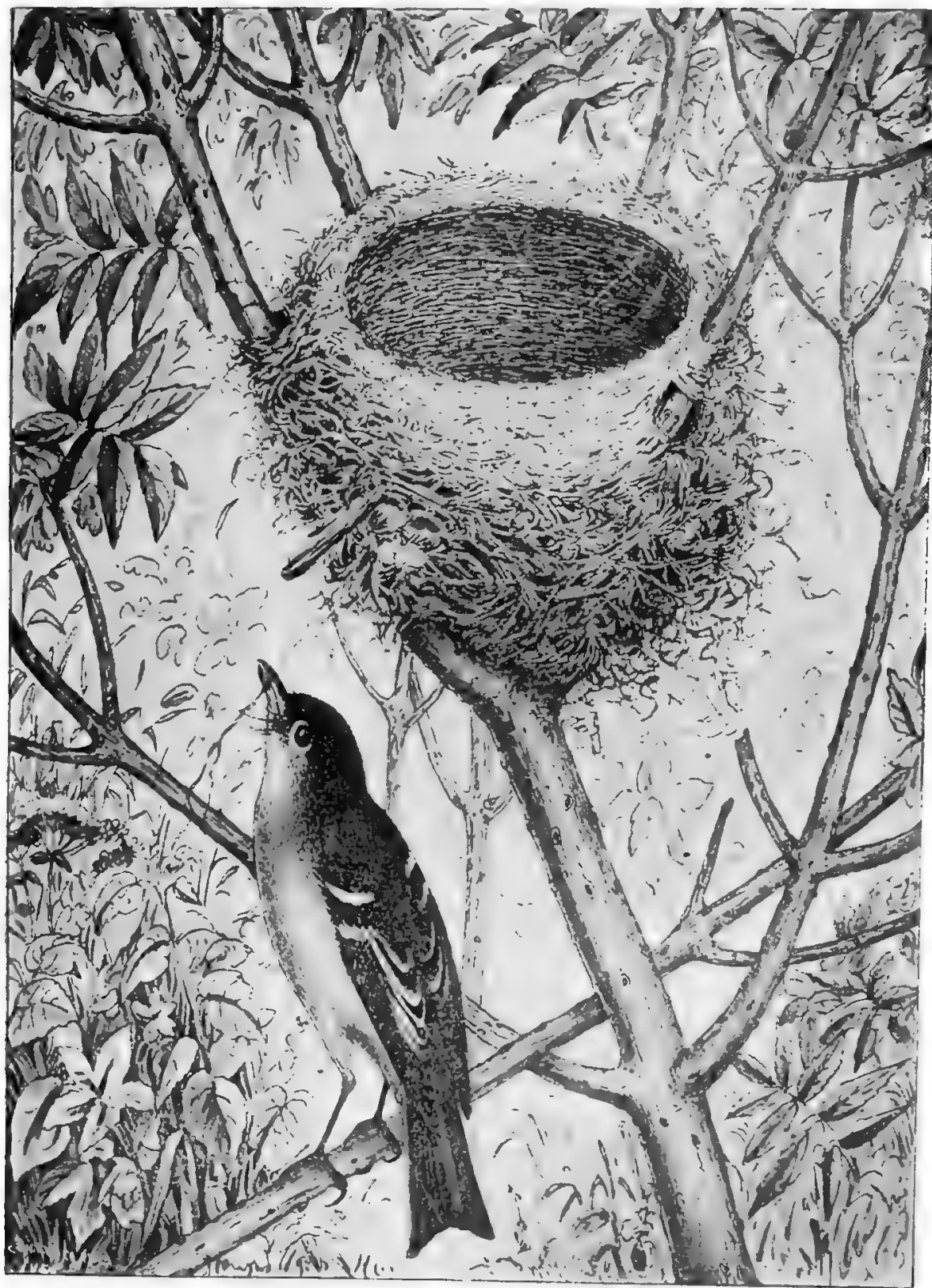

406a. Azodr Furcatches and Nest. 
catcher during the breeding season. Wherever found breeding $E$. $t$. alnorum is more: abundant than is generally supposed, but from its retiring habits is little known. Our illustration represen $\$$ s a typical nest of Alder Flycatcher, taken in June, 1885, placed in a clump of alders. They are scarcely ever placed higher than eight feet from the ground; in most cases about four. In nearly all instances they are built in an upright fork, and have a strong resemblance to the usual structure of the Yellow Warbler, but lack in compactness and neatness. The external or greater portion of the nest is composed of hempen fibres, internally lined in true Flycatcher style with fine grasses. In some, however, there is a slight lining of horse-hair and of the down from the milk-weed or thistle. A typical nest measures two and a half inches in height and three in diameter; with a cavity one inch and a half in diameter and two inches deep. Three.eggs is the usual complement, although four is not uncommon, and they are often found in varying stages of incubation. The. ground-color of the eggs is extremely variable.. In some it is of a cream, in others. approaching buff. In four sets there is a striking variation in the distribution of themarkings. They are usually marked; chiefly at the larger end, with blotches of red. and reddish-brown, and while in some the markings are simply very small"dots sparing ${ }_{1} y$ sprinkled over the surface, in others these dottings are scarcely visible, giving them the appearance of an almost unspotted surface. Six eggs exhibit the: following measurements: $.72 \times .55, .70 \times .53, .70 \times .52, .64 x .53, .69 \times .52, .70 \times .53 .4$ An average specimen measures $.73 \times .53$. The eggs of $E$. $t$. alnorum are paler in ground-color and markings than those of virescens, but the difference is so slight that no one can differentiate them with certainty.

467. LEAST FLYCATCHER. Empidonax minimus Baird. Geog. Dist.Chiefly Eastern North America west to Eastern Colorado and Central Montana, south in winter through Central America. Breeds from the Northern States northward.

In all the States between the Atlantic and the Great Plains the Least Flycatcher is an abundant species, occurring, as a migrant and breeding from about $40^{\circ}$ latitude northward. Breeds abundantly in New England and throughout all the Northern States-New York, Michigan, Wisconsin, Minnesota, etc, An abundant summer resident in Manitoba. Adult and young specimens have been taken at San Angelo, Texas, during the breeding season. It is reported as breeding commonly at Fannin. county, Texas, and sometimes in the State of Nebraska. The bird frequents the borders of woods and thickets, particularly the edges of lowland forests and the more open swamps. The nest, commonly placed in an upright fork of a small tree or sapling, sometimes on a horizontal limb, is small, compact and felted of fine, soft materials-bark-fibres, intermingled with vegetable down, lined with fine, grasses and shreds of bark, or, as is frequently the case, with a few feathers. The nest bears a strong resemblance to that of the Redstart, and the eggs canot be mistaken for those of any of our Flycatchers of the Eastern States, as they are wholly unlike any of them. They are normally pure white or buffy-white, unmarked, rarely speckled; their number is sometimes only two or three, usually four, and their average size is $.65 \times .50$. Seven eggs measure $.60 \times .50, .62 \times .50, .64 \times .51, .64 \times .52, .65 \times .53$, $.63 \mathrm{x} .50, .64 x .51$. May and June are the nesting months.

468. HAMMOND'S FLYCATCHER, Empidonax hammondi (Xantus.) Geog. Dist.-Western North America, south in winter to Southern Mexico, north to the Lesser Slave Lake. 
The Western representative of the Least Flycatcher from the Plains to the Pacific. The nesting and eggs are said to be substantially like those of $E$. minimus. On account of its general plain, soiled color it is called Dirty Little Flycatcher. A wet of four eggs was collected by Edmund Heller in San Bernardino county, California, June 16, 1897. The female was shot and identification made certain. The nest was placed on the horizontal branch of a fir tree, fifteen feet from the ground and three feet from the trunk. It was composed of strips of bark and lined with leathers; the outside diameter is 2.68 by 2.48 inches external depth. The eggs measure .70x.53, .70x.53, .70x.52, .73x.54 inches; color creamy white, unmarked. This nest and eggs are in Mr. Crandall's extensive collection.

469. WRIGHT'S FLYCATCHER. Empidonar wrightii Baird. Geog. Dist.Western United States, south to Southern Mexico, east to Rocky Mountains.

The Gray Flycatcher is common to the woodland, groves and thickets of the Western States and Territories. During the breeding season, in the region about Fort Klamath, Oregon, Dr. Merrill usually found it in groves of aspens in company $w^{\circ}$ th the Warbling Vireo; also among the pines with Cassin's Vireo and the Western Wood Pewee. The nests were most frequently built in young aspens, at an average height of about six feet. They resemble nests of the Yellow Warbler, which are found in the same localities; but all the nests of the Flycatcher were built against the main trunk, while all of the Warbler were on branches and generally higher from the ground. The nests are composed externally of strips of light gray bark of about the same colors as the bark of the aspens, and partly on this account and because of their location the.nests are liable to escape notice if careful search is not made. The lining is sometimes a smooth, felted mass of fur and horse-hairs, in others feathers are used, and the nests are generally more deeply cupped than is usual with this group. Pairs that are found among the pines usually place their nests in an upright form of a manzanita or buck-brush that grow abundantly in such localities. The eggs are dull, buffy-white; seven sets of twenty-seven specimens average .68x.53, the extremes of the sets being .65x.50 and .72x.57.*

469. 1. GRAY FLYCATCHER. Empidonax griseus Brewst. Geog. Dist.Lower California and portions of Sonora (Arizona ?).

In The Auk (Vol. VI, p. 87) Mr. William Brewster describes this new species from specimens taken by Mr. M. Abbott Frazar near La Paz, Lower California. 1t is a slightly larger and grayer bird than Wright's Flycatcher. Nothing has been published concerning its nidification.

[470.] FULVOUS FLYCATCHER. Empidonax fulvifrons (Giraud.) Geog. Dist.-“"Texas" (Giraud) and Eastern Mexico.

Giraud in his monograph, published in 1841, "Sixteen Texas Birds," first describes this species. It appears that noother specimens since that time have been taken along our southern border along the lower Rio Grande in Texas nor in Eastern Mexico, and there is nothing known concerning its nests and eggs.

470a. BUFF-BREASTED FLYCATCHER. Empidonax fulvifrons pygmows Coues. Geog. Dist.-Western New Mexico and Southern Arizona, south into Western Mexico.

* A uk, III, 258. 
This subspecies was first added to our avifauna by Dr. Elliott Coues, who obtained it near Fort Whipple, Arizona in May, 1865. Since then it has been taken several times in Western New Mexico and Southern Arizona, but is far from being a common bird. Nests and eggs unknown.

471. VERMILION FLYCATCHER. Pyrocephalus rubineus mexicanus (Scl.) Geog. Dist.-Southern border of the United States (Southern Texas to Arizona), south through Mexico to Guatemala.

Along the Rio Grande of Southern Texas and in Southern Arizona the beautiful Vermilion Flycatcher is a common species. Mr. W. E. D. Scott notes it is a common species about Riverside, Tucson, and Florence, Arizona. During the breeding season the male frequently utters a twittering song while poised in the air, in the manner of the Sparrow Hawk; during the song it snaps its bill as if catching insects. Thickets along water-courses are this bird's favorite resort. The nests are usually placed in horizontal forks of ratana trees, often in mesquites, not more than six feet from the ground; they are composed of small twigs and soft materials felted together, and the rims covered with lichens; the cavity is shallow. A few horse or cow hairs comprise the lining. Dr. Merrill states that they bear considerable resemblance to nests of the Wood Pewee in appearance and the manner in which they are saddled to the limb. Mr. Brewster describes a nest taken by Mr. F. Stephens on the 25th of April, at Tucson, Arizona, which lacks the exterior coating of lichens. Others were found by Mr. Stephens of a similar construction. The usual number of eggs is three; the ground-color is a rich creamy-white, with a ring of large brown and lilac blotches at the larger end. Dr. Merrill gives the average size of fourteen eggs as .73x.54. A set of three eggs in Mr. Norris' cabinet was taken in Cochise county, Arizona, May 21, 1888. The nest was placed in a sycamore tree near a running stream. The eggs are pale creamy-buff, with bold spots and blotches of sealbrown and lilac-gray, in a circle around the center of each egg. They measure, respectively, .71x.53, .69x.53, .80x.53. Six other sets in the same cabinet show great variation.

472. BEARDLESS FLYCATCHER. Ornithion imberbe (Scl.) Geog. Dist.Valley of the Rio Grande in Texas, south into Eastern Mexico, Guatemala and Nicaragua.

Mr. George B. Sennett took a specimen of this diminutive Flycatcher near Lomita Ranch, Texas, April 24, 1879, thus adding a new species to our avifauna.

472a. RIDGWAY'S FLYCATCHER. Ornithion imberbe ridywayi Brewst. Geog. Dist.-Southern Arizona, south in Mexico to Puebla and Jalisco.

This comparatively new addition to our avifauna was first described by $\mathrm{Mr}$. William Brewster in the Bulletin of the Nuttall Ornithological Club (Vol. VII, pp. 208, 209), from specimens secured by Mr. F. Stephens in the neighborhood of Tucson, Arizona, in the spring of 1881. On May 28 he obtained a female and a young bird which had just left the nest. In April, 1884, he also took another specimen near Tucson. Other examples have since been taken, but it is not considered by any means a common b.rd.

[473.] SKYLARK. Alauda arvensis Linn. Geog. Dist.-Europe and portions of Asia and Africa; accidental in the Bermudas and in Greenland. 
The far-famed Skylark of the Old World holds a place in the avifauna of North America from its occasional occurrence in the Bermudas, and, in Greenland. Several attempts have been made to introduce these desirable birds in Eastern United States; but so far the experiments have proved unsuccessful. The Skylark is an inhabitant of all the countries of Europe, and is said to be more plentiful in cultivated districts. The mating season is in April, and two broods are reared in a season. The nest is always placed on the ground, in meadows or open grassy places; it is often sheltered by a tuft of grass, clod of earth, or other projection. The materials used in its composition are grasses, plant stems, and a few chance leaves; the lining is of the same, but finer. The eggs are three, four or five in number, and vary considerably in form and coloration; some are grayish-white with a tinge of purple or greenish-white, thickly sprinkled and mottled with a grayish-brown or drab; others are of a deep sombre hue, and in some the markings are chiefly concentrated at the larger end. These are the variations exhibited in four sets of four eggs each in my cabinet, taken in Staffordshire, England, in the latter part of April and the first of May. The smallest set offers the following sizes: $.86 \times .57, .87 \times .60, .84 \times .58, .89 x .60$; the largest, $.93 \times .64, .95 x .64, .92 x .62, .94 x .64$, respectively.

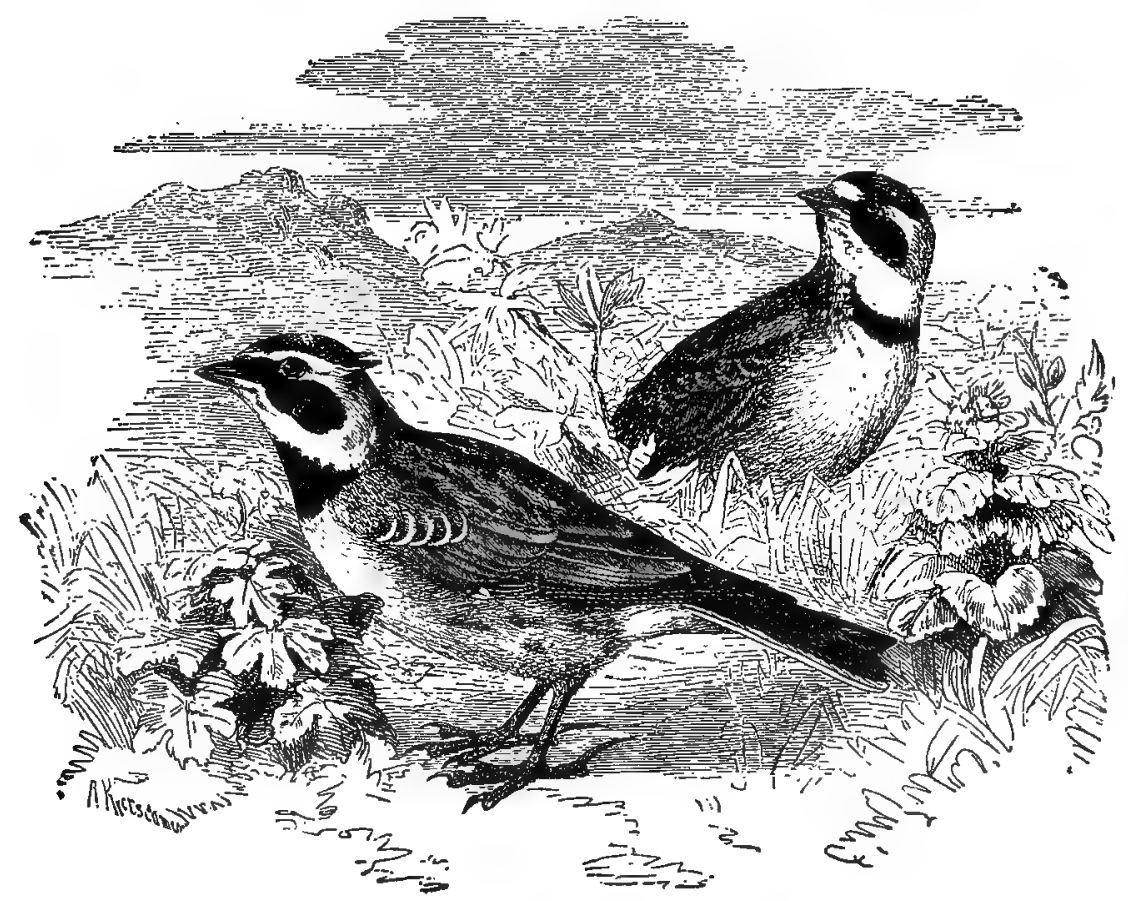

474. Horned LaRK (From Brehm).

474. HORNED IARK. Otocoris alpestris (Linn.) Geog. Dist.-Northeastern North America-Labrador, region about Hudson Bay, Greenland, and northern parts of the Old World; in winter south in Eastern United States to the Carolinas, Illinois, etc. 
The Shore Lark, the true alpestris, breeds in northeastern North Amerlca and Greenland, wintering in Eastern United States. It breeds on the coasts of Newfoundland and Labrador, in the Province of Keewatin, Dominion of Canada, and on both shores of Hudson Bay. It also inhabits northern portions of the Old World. The common name is derived from the tufts of black feathers over each ear, whtch at will the bird has the power of erecting llke the so-called "horns" of some owls. In the Eastern States, during the winter months, flocks varylng in size from a dozen to those of a hundred or more, may be seen frequenting open plains, old fields, dry shores of bays, and the banks of rivers. As there are a number of geographical varieties of the Horned Lark, the greatest uncertainty has always attended thelr identiflcation, even by experts, and the breeding and winter ranges of the various subspecies do not yet seem to be clearly deflned. This was the species found by Audubon breeding on the low, mossy and sheltered hills, along the dreary coast of Labrador. In the midst of the mosses and lichens that covered the rocks the blrd imbedded its nest, which is composed of fine grasses, arranged in a circular form and lined with the feathers of grouse and other birds. The eggs, deposited early in July, are four or five in number, and are described by Audubon as marked with bluish as well as brown spots. In his last great work the late Major Bendire describés a set of three eggs taken near Okak, Labrador, on June 21, 1892. The ground color 1s greenish-gray, somewhat darker than the rest of eggs of our Horned Larks. They are profusely blotched and spotted with dark olive, ollve-buff and lighter shades of pale lavender. They measure .98x.66, .95x.68, and .87x.64 fnches, European eggs are grayish-white, spotted with brownish-lavender or llac-gray.

474a. PALLID HORNED LARK. Otocoris alpéstris leucoloma (Coues.) Geog. Dist.-Interior of British America and Alaska, south in winter to Western United States.

This paler northwestern form of the Shore Lark breeds from Alaska southward, east of the Rocky Mountains, nearly to the United States boundary. The nest is built in a depression of the ground, and sunk a little below the surface, usually under a tuft of grass; it is well cupped and woven in a circular form of old grasses, lined with hairs. The eggs are three or four, grayish or pale olive, finely and thickly sprinkled with olive-brown. Average síze .91x.65.

474b. PRAIRIE HORNED LARK. Otocoris alpestris praticola Hensh. Geog. Dist.-Upper Mississippi Valley and region of the Great Lakes to New England, breeding eastward to Northeastern New York and Western Massachusetts, New Hampshire and Vermont, migrating south to South Carolina, Texas, etc.

The birds of this race may be distingulshed from the typical alpestris by their smaller size and paler colors. In the northern half of the Mississippl Valley it breeds abundantly, and as far south as Eastern Kansas, where Colonel Goss notes it as common and abundant. It begins laying the last of March. The Prairle Horned Lark breeds in Indiana, Illinols, Iowa, Michigan, Wisconsin and Minnesota. In Northwestern Ohio young birds have been taken in May. Mr. Ernest W. Vickers found a nest of the Prairie Horned Lark on Aprll 17, 1895. When first discovered it contained two young and one egg which was hatched the day following. Prof. E. L. Moseley informed him that this lark bred about Sandusky. Mr. James E. Gould found young birds near Blacklick, Franklin county, July 14, 1893. So far, this hinakes the breeding range of the Prafrie Horned Lark in Ohio extend from the central portion northward east and west. It doubtless breeds farther couth, but I have no 
records to that effect. Two broods are reared in a season, the first very early-usually by the last of April. Mr. L. Jones, of Grinnell, Iowa, states that as many as three broods are reared in that region; the first nest is built late in March or early In April, the second about the first of June, and the third late in July or early in August. 'The highlands of meadows' and cornfields are its resorts while breeding, the nest being placed in a hollow of the earth, compactly made of dry grasses and corn leaves, lined with a few feathers and horse hairs. Mr. Jones says that the first nest is most elaborately made, while the second and third are more slovenly put together. Three or four eggs are deposited, usually four; their ground-color varying from pale olive or light greenish to dull olive-buff, thickly speckled and sprimkled with drab. A set of four eggs in my collection, taken in Poweshick county, Iowa, by Mr. Jones, gives the following measurements: $.82 x .61, .84 x .62$, $.82 \times .63, .86 \times .62$.

474c. DESERT HORNED IARK. 'Otucoris alpestris arenicola Hensh. Geog. Dist.-Great Plains and Rocky Mounain region of the United States.

This subspecies inhabits the Rocky Mountain regions and the Great Basin of the United States, coming east to Dakota, where it breeds at least as far east as Ramsey county. Colonel N. S. Goss gives it as a common resident in Middle and Western Kansas, where it begins laying early in April. Nesting, habits and eggs similar to o. alpestris praticola. Average size of the eggs $.86 \mathrm{x} .60$.

474d. TEXAN HORNED LARK. Otocoris alpestris giraudi Hensh. Geog. Dist.- - Wastern and Southeastern Texas.

Mr. Joseph L. Hancock found this form of the Shore Lark very common on the flats north of Corpus Christi, Texas, and on May 27 a nest with four eggs was taken. The nesting and eggs of this subspecies do not differ materially from those of the others in this group that are better known. The average measurement of ten eggs before $m e$ is $.92 \times .66$ inches.

474e. MEXICAN HORNED IARK. Otocoris alpestris chrysolcona (Wagl.) Geog. Dist.-Coast district of California (north to Nicasio), Northern California, and parts of Mexico, Mirador, Vera Cruz, Valley of Mexico, etc.

This form of the Horned Lark is a constant resident of Mexico, and it occurs northward and breeds in the larger valleys of Southern California. Its nesting, eggs and general characteristics are similar to those of the preceding subspecies. The average size of twenty eggs in the National Museum collection is $.82 x .60$ inches.

474f. RUDDY HORNED LARK. Otocoris, alpestris rubea Hensh. Geog. Dist.-Sacramento and San Joaquin Valleys, California.

The breeding range of this subspecies is confined to a rather small area of the interior of the northern portion of California, the valleys of the Sacramento River and its tributaries, and probably the northern portion of the San Joaquin Valley. A 'sorrel' or rufous-colored race, abundant in California. Mr. Shields informs me that this bird may always be seen in greater of less abundance on the broad plains and prairies of Los Angeles county, California. He found their nests, containing fresh eggs, as early as April 15 and as late as the middle of June. The eggs were three or four in number, commonly four, and sometimes five. One nest was found containing six eggs. The nest is usually placed in a depression of the ground under a small bush, tuft of grass, vines, by the side of a clod of earth, small rock, etc. It is composed of fine straw and grasses lined with horse hairs. Mr. W. O. Emerson's 
collection contains a series of this Lark's eggs, collected in San Diego county, California, and in comparing them with a large number of those from the East, South and Middle States, there is really no perceptible difference in their general shape, color and markings. My cabinet contains thirty eggs of the Ruddy Horned Lark, taken in various parts of California. Their color is a pale olive-buff, finely and densely sprinkled with a rusty-drab color. Ten specimens measure: $.82 x .54, .84 x .53$, $.83 \mathrm{x} .56, .83 \times .51, .82 \times .57, .80 \times .56, .84 \times .56, .80 \times .59, .83 \times .56, .80 \times .56$.

474y. STREAKED HORNED LARK. Otocoris alpestris strigata Hensh. Geog. Dist.-Coast region of Oregon, Washington and British Columbia; islands off coast of Southern California.

This conspicuously streaked and striped Shore Lark is larger than the California bird, 0 . a. rubea, and is found breeding from Oregon northward. Its nesting and eggs are exactly the same.

474h. SCORCHED HORNED LARK. Otocoris alpestris adusta Dwight. Geog. Dist.-Southern Arizona and New Mexico; Western Texas and southward into Mexico.

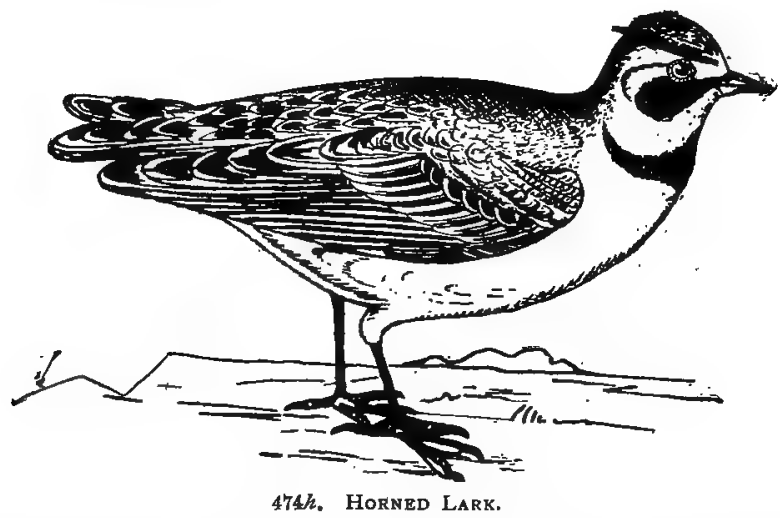

During the breeding season this subspecies is confined to the southern borders of the United States, from New Mexico and Western Texas into Northern Mexico. In its habits, nests and eggs it differs little if any from members of this family.

474i. DUSKY HORNED IARK. Otocoris alpestris merrilli Dwight. Geog. Dist.-Eastern Oregon, Washington and British Columbia, between the Cascade and Rocky Mountains; southward in winter into Nevada and California. To Dr. James C. Merrill, U. S. A., belongs the credit of having first collected the eggs of this bird. Near Fort Klamath, Oregon, May 30, 1887, he found a nest which on June 4 contained two eggs. This was the first set of these eggs known, and remained unique in collections until a second set was also found near Fort Klamath, by another collector, on June 1, 1888. The nest was sunken in the ground, and was made of grass, very loosely constructed. It contained four eggs. Two of them have an olive-buff ground-color, while the other two are of a light pea-green. All are thickly speckled with light brown. They are ovate in shape, and measure:, .83x.58, .83x.60, .85x.58, $.85 \times .60$. 
474). SONORAN HORNED IARK. Otomoris almslin millut Towns, Geog. Dist.-Lower California and Sonora.

The breeding rarge of this small pallid race is probably coextensive with its geographical range, and comparatively little is known concerning its general babtts, nests and eggs. Very likely they do not ciufer from those of other Larks of this famliy.

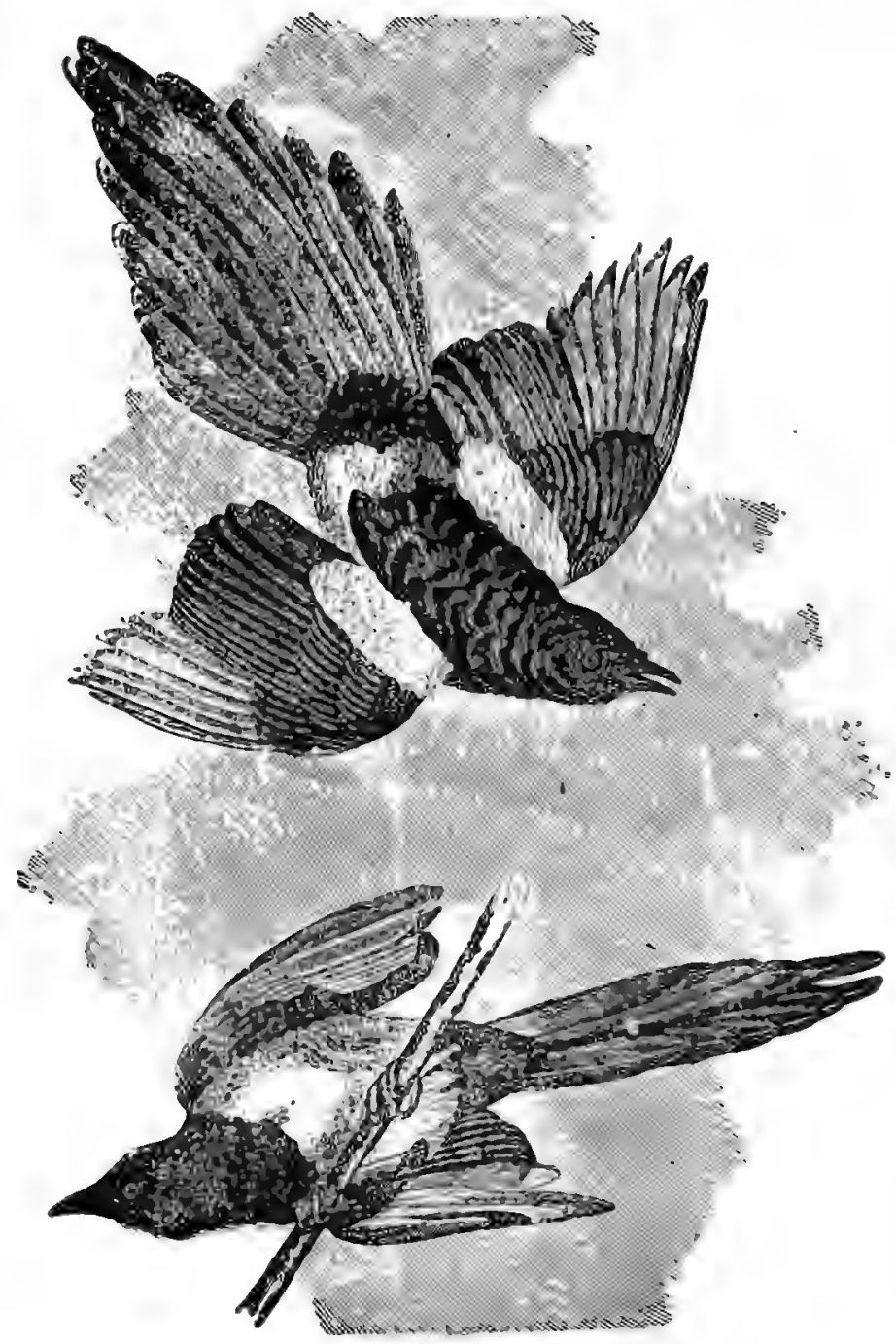

475. Amenican Magpie (After Audubon).

475. AMERICAN MAGPIE. Pirn piru hudsonica (Sab.) Geog. Dist.-Western North America (except Californla), east to the Rocky Mountains, north to Alaska, south to New Mexico and Arizona. Replaced in California, west of the Sierra Nevada by the next species. 
Known as the Black-billed Magpie. A bird of a bad reputation-a rascal, thiet, and a rogue in general, but like the Devil, is not perhaps "as black as he is painted." The camp tales of many a western traveler are interspersed with incidents illustrating the tricks and thieving propensities of the Magpie. Ls pets, their familiarity becomes a decided nuisance. A common species on the plāins, mountains and hills of Colorado, where it breeds in abundance. The height of the nest from the ground, Mr. Dille says, ranges from six to sixty feet; they are often built in the branches of a slender sapling, or in a scrubby willow. In the mountains the large black pine tree is this bird's favorite nesting site, and often as many as four nests are built in a single tree. The Lests are large and bulky-a rustic lattice-work of sticks, measuring from two to three feet high, though not more than twelve to eighteen inches in the greatest diametrr. The nest has an arched roof, with an opening on the side. Sometimes these dome-shaped roofs and doorways are not very artistically or elaborately made, and the observer is often compelled to put on the finishing touches with his imagination. The sticks are cemented together with mud, anc the lining of the nests consist usually of a few grasses or roots. The long tails of the Magpies may be observed protruding from one of the entrances of tue nest while incubating. The number of eggs varies from five to nine, commonly seven, and they are deposited in Colorado as ear'ly as the latter part of April, usually, however, in May. Dr. Merrill took a set of eggs at Modoc Pcint, Oregon, on April 8. The eggs are grayish-white, with a yellowish, occasionally with a greenish tinge, spotted, dashed and dotted with markings of $\Gamma$ rplish or violet-brown; most thickly around the larger end. Ten eggs measure: $1.32 \times .89,1.37 \times .90,1.38 \times .92,1.40 \times .94,1.34 \times .90,1.36 \times .89,1.42 \times .92,1.34 \times .89$, $1.42 \times .87,1.40 \times .93$. The average size is $1.34 \mathrm{x} .89$ inches.

476. YELLOW-BILLED MAGPIE. Pica nuttalli Aud. Geog. Dist.-California, west of the Sierra Nevada, from Sacramento Valley south to about latitude $34^{\circ}$; locally distributed.

The Yellow-billed Magpie is confined exclusively to California; where it breeds abundantly; and it begins nesting about the first of April Its general habits are like those of $P$. hudsonica, and the nest is similarly constructed. The eggs range from fiye to nine in number, usually six or seven. They are of a light drab, so thickly marked with fine cloudings of an obscure lavender color as nearly to conceal the ground, and to give the egg the appearance of an almost violet-brown. A set of six eggs, collected.in Wheeler Canon, near Santa Paula, California, exhibit the following dimensions: $1.31 \times .89,1.28 \times .89,1.31 \times .89,1.32 \times .89,1.30 x .88,1.28 x .90$. A set of six eggs in my cabinet, taken from a nest situated twenty feet from the ground in an oak tree, near Santa Barbara, California, April 10, 1887, offers the following sizes: 1.30 $\mathrm{x} .85,1.29 \mathrm{x} .84,1.29 \times .90,1.30 \mathrm{x} .82,1.28 \mathrm{x} .81,1.25 \mathrm{x} .86$.

477. BLUE JAY. Cyanocitta cristata (Linn.) Geog. Dist.-Eastern North America except Florida, west to the Plains, north to the Fur Countries.

The well-known Blue Jay is abundant in Eastern North America, where it breeds in the latter part of April, in May and June, according to locality. He is a conspicuous member of a family of questionable character and, as in the case of the Magpie, unjust prejudices have doubtless done much to brand him a profligate. His fine personal dress, and noisy, boisterous habits, only serve to make him the more prominent as a rowdy full of cunning traits. Yet no observer will dispute that the sagacity often evinced by this bird-his forethought, intelligence and sensibility, are strongly akin to reason; and according to the treatment received from a man he is justly either shy or wary, confiding or familiar. The nest of the Blue Jay is built in 


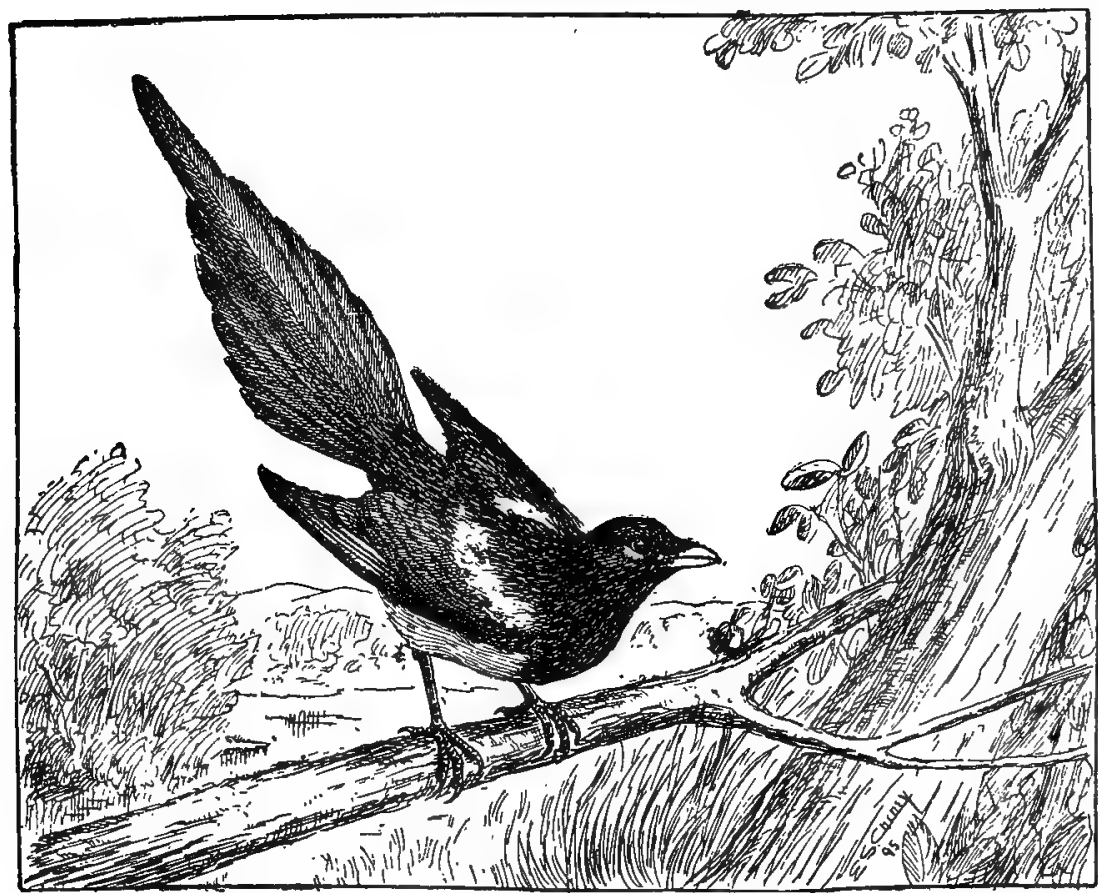

476. Yellow-Billed Magpie (Cheney del.)

the branches of a lonely forest tree, in the trees of orchards, in those bordering quiet roadways or lanes, and, where the bird is not molested it is commonly placed not far from dwelling-houses, in trees or bushes. The nest is large, and the materials used are various-twigs, leaves, roots and vegetable fibres rudely but strongly interwoven; often paper, rags, wool and yarn enter into its composition. The eggs. are four or five in number, olive-brown or olive-drab, thickly spotted with dark olive-brown. In some specimens the ground-color is light or dark green, similar to that in the eggs of the California Jay, in which the markings stand out in strong contrast. Ten eggs exhibit the following sizes: $1.02 \times .84,1.06 x .84,1.10 \times .87,1.11 \times .85$, $1.12 \times .82,1.15 x .83,1.14 x .84,1.12 x .83,1.18 x .86,1.18 x .86$; one runt egg measures $.76 x .60$. The following concerning this bird's food is from Beal's "Some Common Birds":* "The Blue Jay is a common bird of the United States east of the Great Plains, and remains throughout the year in most of its range, although its numbers are somewhat reduced in winter in the Northern States. During spring and summer the Jay is forced to become an industrious hunter for insects, and is not so conspicuous a feature of the landscape as when it roams the country at will after the cares of the nesting season are over. Ornithologists and field observers in general declare that a considerable portion of its food in spring and early summer consists of the eggs and young of small birds, and some farmers accuse it of stealing corn to an injurious extent in the fall. While there may be some truth in these accusations, they have

* U. S. Department of Agriculture. Farmers' Bulletin No. 54. Some Common Birds in Their Relation to Agriculture. By F.E. L. Beal, B. S., Assistant Ornithologist, Biologlcal Survey. May, 1897. Washington: Government Printing Office, 1897. 
almost certainly been exaggerated. No doubt many Jays have been observed robbing nests of other birds, but thousands have been seen that were not so engaged. In an investigation of the food of the Blue Jay 292 stomachs were examined, which showed that animal matter comprised 24 per cent. and vegetable matter 76 per cent. of the bird's diet. So much has been said about the nest-robbing habits of the Jay that special search was made for traces of birds or birds' eggs in the stomachs, with the result that shells of small birds' eggs were found in three and the remains of young birds in only two stomachs. Such negative evidence is not sufficient to controvert the great mass of testimony upon this point, but it shows that the habit is not so prevalent as has been believed. Besides birds and their eggs, the Jay eats mice, fish, salamanders, snails, and crustaceans, which altogether constitute but little more than 1 per cent. of its diet. The insect food is made up of beetles, grasshoppers, caterpillars, and a few species of other orders, all noxious, except from $31 / 2$ per cent. of predaceous beetles. Thus something more than 19 per cent. of the whole food consists of harmful insects. In August the Jay, like many other birds, turns its attention to grasshoppers, which constitute nearly one-fifth of its food during that month. At this time, also, most of the other noxious insects, including caterpillars, are consumed, though beetles are eaten chiefly in spring. The vegetable food is quite varied, but the item of most interest is grain. Corn was found in 7u

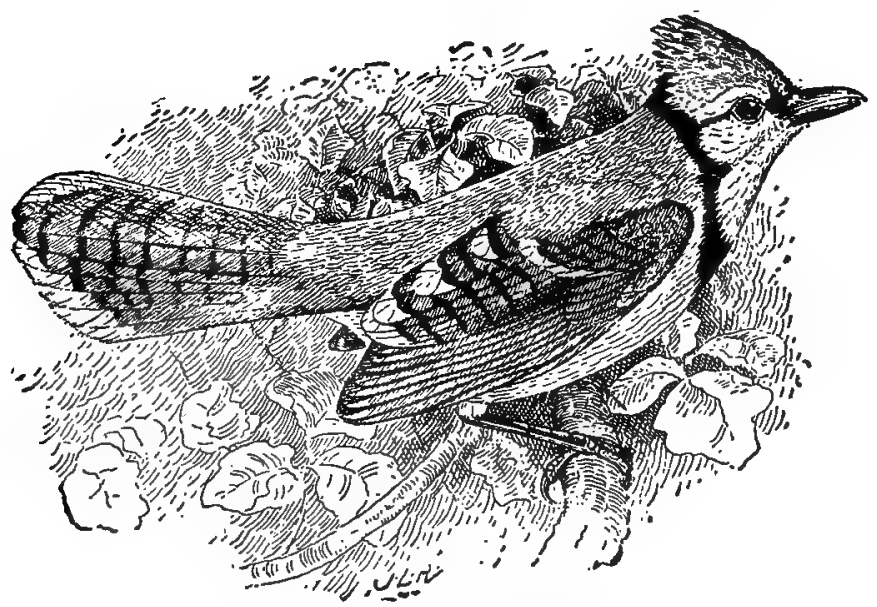

47. Brue Jay (From Beal).

stomachs, wheat in 8 , and oats in 2-all constituting 19 per cent. of the total food. Corr is evidently, the favorite grain, but a closer inspection of the record shows that the greater part was eaten during the first five months of the year, and that very little was taken after May, even in harvest time, when it is abundant. This indicates that most of the corn is gleaned from the fields after harvest, except what is stolen from cribs or gathered in May at planting time. The Jay's favorite food is rast (i. e., acorns, chestnuts, chinquapirs, etc.), which was found in 158 of the 292 stomachs and amounted to more than 42 per cent. of the whole food. In September corn formed 15 and mast 35 per cent., while in October, November and December corn dropped to an almost inappreciable quantity and mast amounted to 64,82 and 83 per cent., respectively. And yet in these months corn is abundant and everywhere easily accessible. The other elements of food consist of a few seeds and wild 
fruits, among which grapes and blackberries predominate. The results of the stomach examination show) (1) that the Jay eats many noxious insects; (2) that its habit of robbing the nests of other birds is much less common than has been asserted; and (3) that it does little harm to agriculture, since all but a small amount of corn eaten is waste grain."

477a. FLORIDA BLUE JAY. Cyanocitta cristata florincola Coues. Geog. Dist.-Florida.

This is a smaller bird than the last, with less white on the tips of the secondaries and tail-feathers. A set of four eggs in my cabinet from Florida do not differ essentially from those of $C$. cristata, having the brown type of coloration for the ground-color.

478. STELLER'S JAY. Cyanocitta stelleri (Gmel.) Geog. Dist.-Pacific coast, north to sitka, south to Northern California.

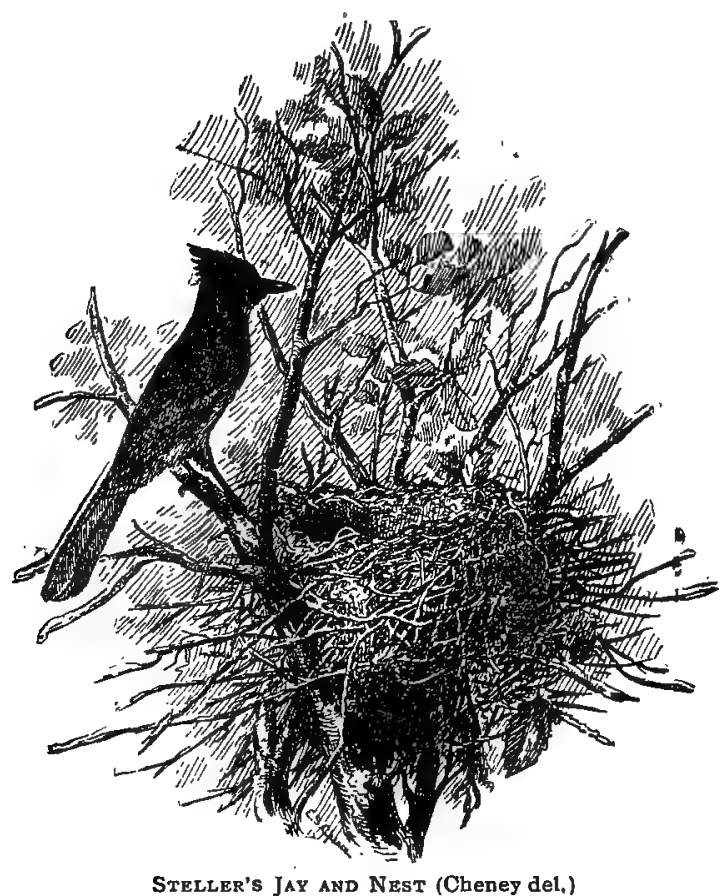

Steller's Jay is an abundant species along the Pacific coast from Northern California northward. 'In Oregon it is a very common resident. He is the same bold, noisy fellow as is his eastern cousin, the Blue Jay. The nest of this bird is built in firs and other trees, and in bushes, ranging from eight to twenty-five feet from the ground; it is very bulky, and made of large sticks and twigs, generally with a supply of mud, and a lining of fine, dry grasses and hair. The eggs, three to five in number, are usually pale green or bluish-green, speckled with olive-brown, with an average size of 1.28x.85. Mr. Norris has a set of four eggs collected near Salem, Oregon, May 4, 1888. This set was taken from a nest in a thorn bush, twelve feet from the 
ground. The eggs are light bluish-green, spotted and sprinkled with clove-brown; the markings are heavier near the larger ends, where they form indistinct circles. They offer the following dimensions: $1.25 \times .93,1.22 \times .94,1.19 x .91,1.23 \times .92$.

478a. BLUE-FRONTED JAY. Cyanocitta stelleri frontalis (Ridgw) Geog. Dist.-Southern ranges of Sierra Nevada of California and Western. Nevada, from Fort Crook south to Lower California.

A common bird in the mountains of California, inhabiting the whole length of the Sierra Nevada and also, it is said, the coast ranges. Colonel N. S. Goss found quite a number of nests of the Blue-fronted Jay in the vicinity of Julian, California, in the spring of 1883 , and "in all cases but one, in holes and trough-like cavities in trees and stubs, ranging from four to fifty feet from the ground, generally ten to twenty feet. The nest found outside was built upon a large horizontal limb of an oak close beside a gnarl, the sprout-like limbs of which thickly covered the nest overhead, and almost hid it from view below." They were quite tulky, loosely made of sticks, stems of weeds, and lined with fibrous rootlets and grasses; and as they were all built at or near the opening, the tell-tale sticks projected, and made the finding of the nest not difficult. A strange departure from the usual habits of Jays is noted of the Blue-fronted Jay by Mr. Bryant. In Placer county, California, the birds had persisted in building within the snow-sheds in spite of the noise and smoke of passing trains. "The destruction of their nests by the men employed on the water train which makes two trips a week through the sheds during the summer, sprinkling the woodwork and tearing down nests of Jays and Robins with a hook attáched to a pole, seemed not to discourage them. So accustomed do the Jays beccme to the passing of trains, that they will often remain on their nests undisturbed. In one season more than two hundred nests of Jays and Robins were destroyed, so the train men say, between Cisco and Summit, a distance of thirteen miles. Some of the nests were but partially built, others contained eggs, these latter ones having probably been overlooked on previous trips. The nesting of the Jays within the snow-sheds is, so Mr. Ingersoll supposes, to avoid the persecution of squirrels. None, he thinks, however, succeed in rearing a brood, for of more than thirty nests which he found, nearly all were uncompleted." ("Unusual Nesting -Sites," No. II.) Colonel Goss gives the color of the eggs as light blue, speckled and spotted with dark brown, rather thickest at large end, and the measurements of two sets as follows: one taken May 19, 1.20x.87, 1.20x.88, 1.21x.88; May 21, 1.21x.88, 1.15x.86, 1.19x.86, 1.16x.85. Mr. W. O. Emerson informs me that the nests in the vicinity of Haywards, California, are placed in oaks, redwood and other tall trees A nest containing a set of three eggs, collected by Mr. A. M. Ingersoll, May 19, 1888, at Julian, California, was inside of an immense oak stub, about fifteen feet from the ground, and the eggs were far advanced in incubation. They are of a light grayish-blue, speckled and spotted with burnt umber. Their sizes are: 1.26x.86, 1.30x.85, 1.21x.85.

478b. LONG-CRESTED JAY. Cyanocitta stelleri macrolopha (Baird.) Geog. Dist.-Southern Rocky Mountains, Southern Arizona and Northwestern Mexico.

A common bird in the southern Rocky Mountain region. In some portions of the pine districts of Arizona the birds are permanent residents. They are mated by the latter part of April, and nests with eggs may be found in May. It is a very numerous species in Northern New Mexico and Colorado, where it is a constant resident. Large, noisy troops of this species are to be found roving about during the winter months. Their notes at times are said to resemble those of the Blue Jay. Mr. Dille states that in Colorado the nest of the Long-crested Jay is built in trees or 
bushes, but generally artfully concealed in a bunch of rubbish at the top of a pine or spruce. It is rather large and coarse, made of small sticks, and weed-stalks, with little or no lining. Nests with eggs have been found all through June. The eggs range from three to six in number, four or five being most commonly found. They are of a light green, 'with fine markings of dark olive-brown and lighter cloudings of purplish or violet-brown, and in shape are more elongated than those of the Blue Jay. Their size ranges from 1.20 to 1.32 in length by .80 to .89 in breadth.

478c. BLACK-HEADED JAY. Cyanoeitta stelleri annectens (Baird.) Geog. Dist.-Northern Rocky Mountains, south Wasatch range, west to Eastern Oregon and Washington.

A resident of the northern Rocky Mountain region of the United States, and doubtless also in similar localities in the southern portions of British North America, in Eastern British Columbia, and in the Province of Alberta. It was found breeding in Parley's Park, Wasatch Mountains, Utah, June 25, by Mr. Robert Ridgway. The nest was placed in a small fir on the edge of a wood. It was saddled on a horizontal branch, about fifteen feet from the ground, and contained.six eggs. The base of the nest was composed of coarse, strong sticks, rudely put together. Upon this was constructed a solid, firm plastering of mud of a uniform concave shape, lined with fine wiry roots. The sizes of three eggs of the set found by Mr. Ridgway are given by the late Major Bendire as follows: $1.24 \times .84,1.26 x .86,1.26 \times .88$ inches. They resemble in every particular those of the Long-crested Jay.

\section{FLORIDA JAY. Aphelocoma floridana (Bartr.) Geog. Dist.-Florida.}

The geographical distribution of this beautiful species is confined to the limited area of Florida. In some districts it is abundant, while in others it is extremely rare. Mr. Stuart regards it as not very abundant in the region about Tampa, where it nests in March and April, usually among a thick growth of bushes. The nest is a flat, compact structure, composed of leaves, small dry sticks, lined with moss, roots, fibrous plant-stems and often with wool and feathers. The eggs of the genus Aphelocoma usually have more of a greenish ground and heavier markings than those of Cyanocitta. Mr. Stuart says that four or five eggs are generally laid by the Florida Jay, of a light blue or greenish ground, sparingly sprinkled with rufous and black, the spots being larger and more numerous towards the larger end; average size, $1.00 \times .80$.

480. WOODHOUSE'S JAY. Aphelocoma woodhouscii (Baird.) Geog. Dist.Western United States, from the desert ranges of Southern California north to Eastern Oregon, east to Montana, Wyoning, Colorado and New Mexico, and south to Northern' Mexico.

Woodhouse's Jay is more or less common throughout the States and Territories mentioned in the above habitat. It is generally not so abundant as the Longcrested Jay, and frequents the scrub-oak and other thickets on the cpen hillsides. The nest is built in bushes and thickets, or in low trees of thick foliage, and from three to six eggs are deposited. Mr. Norris has a set of five eggs of this species, taken in Weber county, Utah, April 10, 1888. The nest from which the eggs were taken was placed in a sage bush two feet from the ground, and was composed of twigs, lined with fine roots and hair. The eggs were fresh, and are of a pale bluish-green, spotted with burnt umber and lavender-gray. They measure 1.03x.80, $1.01 \times .80,1.07 \times .80,1.02 \times .82,1.05 \times .80$. The average size is $1.06 \times .80$. 
480. 1. BLUE-EARED JAY. Aphelocoma cyanotis Ridgw. Geog. Dist.Northern Mexico, ranging northward into Western Texas.

The Blue-fronted Jay is a recent addition to our fauna. It is found in the mountainous and hilly portions of. Eastern Mexico and as far north as Western Texas. Authentic eggs of this species $I$ believe remain unknown, but very likely do not differ much from other members of this genus.

481. CALIFORNIA JAY. Aphelocoma californica (Vig.) Geog. Dist.-Pacific . coast of the United States, from Southern California to Oregon, east to Western Nevada.

A common species from the southern portion of California northward to Oregon, inhabiting the trees and thickets bordering streams in the valleys. It also frequents the chapparal and sagebrush patches, and prefers the realms of solitude to the the haunts of man. It is nearly always found in company with the California Thrasher, Harporhynchus redivivus, whose tastes in regard to the general surroundings are similar. Mr. Shields says that in Los Angeles county this bird begins building about, the first of May, but fresh eggs ean be found as late as the last of June; they are usually four, sometimes five in number. The nest is large and bulky, usually placed in scrub-oak or in the thick portions of chapparal; it is composed of twigs, roots and dry grasses. The color of the eggs is a dark sea-green or bluishgreen, thickly dotted, spotted and sometimes blotched with clove-brown, chestnut, light buff, dark brown and bluish-gray. A set of five eggs measure: $1.06 \times .82,1.08$ $\times .72,1.09 \times .84,1.10 x .81,1.09 \times .80$. Ten specimens average $1.08 \times .80$.

481a. XANTUS'S JAY. Aphelocoma californica lypoleuca Ridgw. Geog. Dist.-Lower California, from Cape St. Lucas north to latitude $28^{\circ}$.

The following description of a nest and eggs is by Waiter E. Bryant:* “A single nest of this new variety was found by myself a few miles southward from San Ignacio on April 12, 1889. The nest was built about three metres high in a green acacia near the trail. The female was sitting and did not fly until preparations for climbing the tree had commenced. The nest was in quite an exposed situation amongst scant twigs on a horizontal branch. It is composed of small loosely laid dry twigs, and a shallow receptacle lined with fibre and horsehair. The eggs, three in number (set No. 899, coll. of W. E. B.), contained small embryos. They are more finely spotted than some similar Jay's eggs, with shell spots of pale lilac-gray and surface spots of pale olive-green. The ground color is dull, pale glaucous green. They measure 27.5x20.5; 27.5x21; $27 \times 21$ millimetres." $i$

481b. BELDING'S JAY. Aphelocoma californica obscura Anthony. Geog. Dist.-San Pedro Martir Mountains, Lower California.

Another subspecies of the California Jay, a darker race, described by Mr. A. W. Anthony, who named it in honor of Mr. L. Belding, the well-known ornithologist. I believe nothing is as yet known regarding its nests and eggs.

481. 1. SANTA CRUZ JAY. Aphelocoma insularis Hensh. Geog. Dist.-Santa Cruz Island, Southern California.

This species is a larger bird than the California Jay, and generally deeper colored. There appears to be little known about its llfe history.

* Proc. Cal. Acad. Scl., 2d Ser., Vol, II, June 20, 1889, p. 24.

$\dagger 1.08 \times .79,1.08 \times .83$ and $1.06 \times .83$ inches. 
482. ARIZONA JAY. Aphelocoma sieberii arizonoe Ridgw. Geog. Dist.Southern New Mexico, Arizona and Northwestern Mexico.

According to Mr. Scott the Arizona Jay is an abundant subspecies and resident wherever the live-oaks are found on the San Pedro slope of Las Sierras de Santa Catalina, in Southern Arizona, between the altitudes of 3000 and 7000 feet. It is an eminently gregarious and sociable bird; even during the breeding season a number of pairs may be found nesting in the same locality. March 16 a nest was found by Mr. Scott apparently completed, but containing no eggs; it was built in a sapling about ten feet from the ground, and was composed, of dry rootlets laid very loosely in concentric rings; there was no lining, and the walls of the structure average about three-quarters of an inch in thickness; interior diameter, five inches; greatest interior depth, an inch and three-quarters-a flat, saucer-like fabric. It was not built in a croteh, but where several small twigs leave the large branch. All other nests found resembled this one. On the 25 th the nest was visited again, and the female was sitting, but no eggs had been laid, and further out on the same branch another nest was built. Two other nests were found the same day about one hundred feet away; in one a female was sitting on two eggs, which was thought at the time to be the full set. The eggs were fresh, and so much like those of the Robin, in color and general appearance as to be almost indistinguishable from them. These two eggs measured 1.18x.88,1.13x.86. April 1 the two nests first mentioned were visited, and although the old bird was sitting on the nest earliest completed, it contained no eggs, but on April $7 \mathrm{Mr}$. Scott was rewarded by finding five fresh eggs in this nest, identical in appearance with those above described, and measure $1.25 \times .83$, $1.13 \times .85,1.23 \times .83,1.14 \times .80,1.16 x .84$. The other nest at this time did not, nor several weeks after, contain eggs. Perhaps no explanation can be offered for the preparation of the nest so long before it is used. The first nest was evidently complete on March 16, and it contained no eggs until later than April 1; the first eggs must have been deposited between that date and the 7th. Mr. Scott states that the same facts have been noted in the breeding of the Gray Vireo (Vireo vicinior). As to the circumstance of the bird sitting so constantly before laying he suggests that it is not improbable that it was in order to keep possession of their nest, for as a number of individuals of the species composed the colony a question of ownership might easily arise. He observes that the Arizona Jay is as great a robber of other birds' nests as its cousin of the East, and possibly the habit of sitting so constantly even before any eggs are laid, is to be accounted for by a strongly ingerited tendency to prevent intrusion. The building of extra nests finds a parallel in the case of the Longbilled Marsh Wrens, and is possibly to be accounted for by the nervous activity of the birds; or, the extra nest may afford night resting places for the male during the breeding season.-Auk, III, pp. 81-83.

483. GREEN JAY. Xanthoura luxuosa (Less.) Geog: Dist.-Eastern Mexico, north to the Rio Grande valley in Texas.

Dr. Merrill states that the Rio Grande Jay is a common resident about Fort Brown and higher up the river, but does not seem to pass much into the interior of Texas. Mr. George B. Sennett says: "Of all the birds on the Lower Rio Grande, this is the most mischievous, robbing and despoiling other birds' nests without mercy." Its nest, Mr. Sennett observes, is not easily found, for it is always concealed in thickets, or in the heavy undergrowth of dense woods. A large series of eggs was taken. Of those obtained early in April, few were freshly laid, while all those obtained in May were fresh, indicating that a second brood is reared, though 
no young of the first brood were seen, while numbers of adults were observed daily from April 9 until the last of May. On April 19 the first eggs were taken, two sets being found; one of four with large embryos, the other of five, nearly fresh. The latest set, consisting of four fresh eggs, was found May 17. The usual number of eggs to a clutch is four, occasionally five. The average size of the specimens collected by $\mathbf{1}$ r. Sennett in a season is $1.06 \times .81$, those taken in another season's collecting, 1.08x.81. Dr. Merrill describes the eggs as having a grayish-white groundcolor, thickly spotted with brown and pale lilac, especially at the larger end. One set, however, was found with the markings more numerous at the smaller end, and averaging 1.01x.80.

484. CANADA JAY. Perisoreus canadensis (Linn.) Geog. Dist.-Northern New England and New York, Northern Michigan and Canada, northward to Arctic America.

The Moose-Bird, Whisky Jack, or Whisky John, as it is variously called, breeds in Maine and northward. It is a resident species, and seldom seen south of its breeding range. In Manitoba it is an abundant bird. Its general habits and nesting are in nowise peculiar, being similar to those of others of the family. The nest is usually a large, bulky structure, placed on the bough of a spruce or other evergreen. It is made of twigs, pine-needles, bark-strips and grasses, lined with finer vegetable material and feathers. The nesting time in Northern Maine and New Brunswick is March and April. The eggs are light gray, with a yellowish tinge, finely marked, more abundantly at the larger end with dots and blotches of slate color and brown, and faint cloudings of an obscure lilac, exhibiting the usual variations in color and size found in the eggs of other Jays; four or five in number; average size, $1.17 \times .80$.

484a. ROCKY MOUNTAIN JAY. Perisoreus canadensis capitalis Baird. Geog. Dist.-Rocky Mountains, south to Arizona and New Mexico.

This bird is called the White-headed Jay or Rocky Mountain Whisky Jacka race of the Canada Jay, but very much different. It is peculiar to the Rocky Mountain region, and is especially common in Northern New Mexico and Colorado. In the breeding season it is found high up in the mountains in the spruce timber, from 8000 feet to timber line. He is said to be "as big a thief as ever wore feathers." White-headed, he at times appears grave and sedate, but is always possessed of a whimsical brain. Small articles around camp that strike his fancy are always found missing after one of his visits. Nest-building is begun usually in April. The site generally chosen is the horizontal branch of a pine, varying in height from fifty to sixty feet from the ground. The materials are twigs, pine-needles, lark, grasses and hempen fibres, all compactly interwoven into a rude, bulky but strong structure; it is warmly lined with the feathers and down of birds. The external height is about four inches, and the diameter seven; the cavity about two inches deep and four across. The eggs are three to five in number, grayish-white in ground-color, finely speckled with various shades of brown; in some specimens the markings are more numerous about the greater end. Size, $1.16 \times .86$.

484b. ALASKaN JAY. Perisoneus canadensis fumifrons Ridgw. Geog. Dist.Alaska, except southern coast districts.

According to Turner the Alaskan Jay rarely occurs in the vicinity of st. Michael's, but along the Yukon River it is abundant and a permanent resident. Two nests were brought Mr. Nelson from the mouth of the Tanana River by Mr. M. 
Francols Mercier, who obtained them April 1, 1880. Mr. Nelson describes them as follows: "These two nests now before me, are built of a matted mass of cottonlike down of some plant; about the upper edge and in the cavity are pieces of rabbit fur, a few Horned Owl feathers and strips of bark. The entire nest rests upon a horizontal branch nearly two inches in diameter, and a scanty number of small dead spruce twigs, six to eight inches long, loosely woven into the structure, give it consistency and prevent it from being easily damaged. This nest is four and a half inches high by six broad, with a cavity two and a half inches deep by three and three-

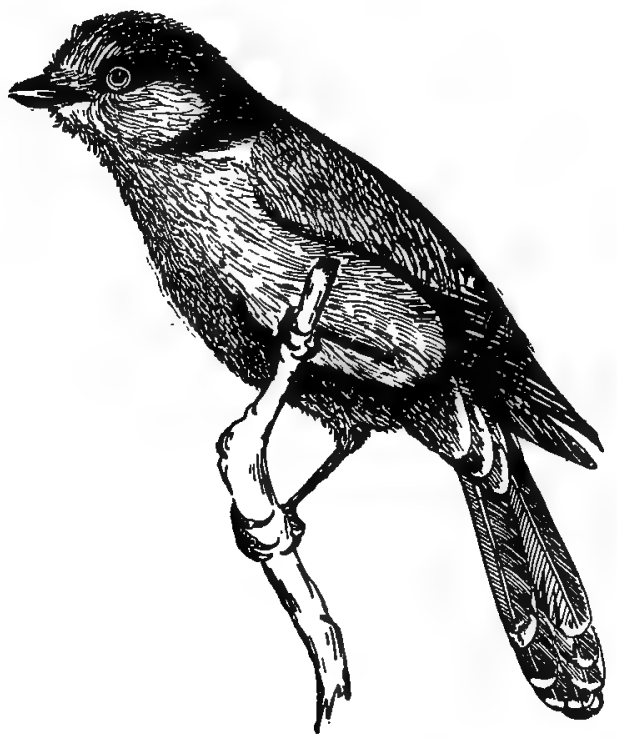

484b. Alaskan Jay (After Nelson

- fourths inches across the top. The other nest was placed in the fork of a small branch less than an inch in diameter, and rests on a rough platform of slender spruce twigs. The main part of the nest is made of the same cottony substance as is the first, and is also interwoven with twigs. Above this is a layer of flne fibrous black moss, such as occurs on spruce trees. The inside of the cavity is slightly lined with fine grass. This nest measures four inches high by six inches broad, and the cavity two inches deep by two and three-fourth inches across the top."

484c. IABRADOR JAY. Perisoreus canadensis nigricapillus Ridgw. Geog. Dist.-Coast district of .Labrador, north to Ungava Bay.

A resident and breeds wherever found. Its general habits and characteristics are similar to those of other members of this family. Major Bendire describes a set of five eggs of this bird taken in Labrador in about latitude $57^{\circ} 30^{\prime} \mathrm{N}$. They were collected by Mr. Jewell D. Sornborger in the summer of 1892 . The eggs resemble those of the Canada Jay in color and in general style of markings, but the latter are, as a rule, coarser and larger, and the eggs are more pointed. They measure $1.19 \mathrm{x}$ $.83,1.18 \times .84,1.17 \times .83$; and $1.15 \times .85$ inches, respectively. 
485. OREGON JAY. Perisoreus obscurus (Ridgw.) Geog. Dist.-Northwest coast, fram Northern California to British Columbia.

Mr. A. W. Anthony mentions this species as a common winter resident of WashIngton county, Oregon. In March they depart for the mountains to breed, although a few sometimes remain to breed in the more secluded parts of the country. He characterizes it as a bird utterly devoid of fear. While dressing deer in the thick timber he has been almost covered with these Jays; they would alight on his back, head and shoulders, and there tug and pull at each loose shred of his coat as if assisting him in all ways possible. On March 31,1884 , he took a nest with five eggs, the first, probably, ever taken. The nest was placed about eighty-five feet from the ground, in a fir, and well concealed. It was built close against the trunk, and was composed of sticks, twigs and moss, rather loosely put together, lined with cow-hair, wool, and one or two grouse feathers. The eggs were very light blue, with a grayish cast, thickly covered with spots of browti and lilac, chiefly on the larger ends. In one specimen there were a few black, hair-like lines over the larger end. Size, $1.04 \times .79$.

486. AMERICAN RAVEN. Corvus corax sinuatus (Wagl.) Geog. Dist.Western United States, from the Rocky Mountains south to Guatemala.

An inhabitant of the regions west of the Rocky Mountains, where it is common. The late Major Bendire wrote as follows: "Our ravens have recently been separated into two races; but from the information I have been able to obtain it is questionable if the alleged differences of the two forms will prove constant and marked enough to warrant this distinction. There is not at present sufficient material available for examination to determine this conclusively. I will leave this to abler ornithologists to decide, and will follow the adopted nomenclature of the American Ornithologists?

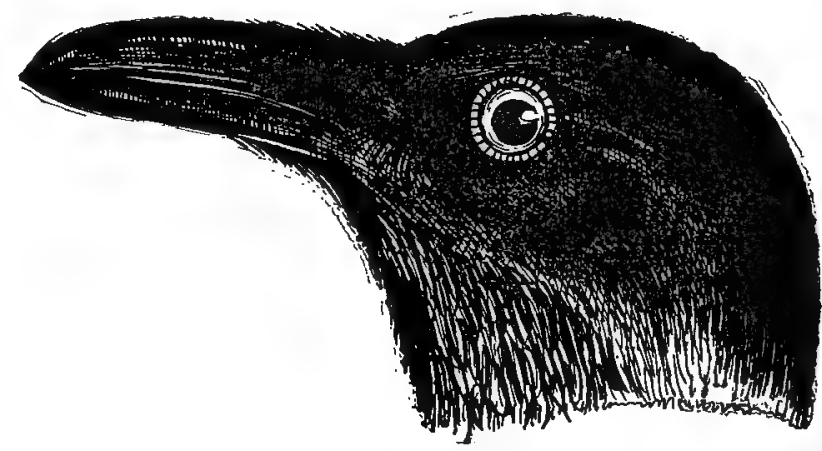

486. Head of a Raven.

Union for the present, including, however, the Ravens found in the Eastern United States in this race." He states that the Raven is found throughout the western portions of the United States more commonly than in the eastern parts of its range, where it is found only locally, chiefly in the more mountainous regions from New England and Northern New York to South Carolina, and in the thinly inhabited and heavily timbered sections of some of our Northern and Middle States. Out of twenty nests examined near Camp Harney, Oregon, only one was placed in a tree, which was in a dead willow twenty feet from the ground, on an island in Sylvies River, and contained five fresh eggs on April 13. The other nests were placed on 
cliffs and it generally took several assistants and strong ropes to reach tne nests containing the eggs. A favorite site was a cliff where the nest was completely covered from above by a projecting rock. They were constructed of sticks well interlaced, the inner cup being lined with cattle hair or quilted with the fine inner bark of the cottonwood. Mr. C. Barlow writes me (1895) that a pair of Ravens have nested on the cliffs of the Farallones for years, near what is known as the West End. No person had attempted to secure the nest and eggs until this year, when one of the lighthouse keepers, Mr. R. H. Williams, was' lowered by rope to the ledge where the nest was situated. It was placed in a niche of a cliff about one hundred feet in height, the nest being about twenty-five feet from the top. In the immediate vicinity there are numorous other niches-where solitary pairs of Baird's Cormorants breed undisturbed. On June 9th the nest contained two unfeathered young, apparently but a few days old. The nest was composed of sticks and pieces of wreckage, the cavity being lined with goat's hair, obtained from a dead animal. The number of eggs laid by the Raven ranges from five to seven; commonly five, while six is not rare. The ground color is a pale pea green or light olive green, spotted and blotched with various shades of brown, drab, and lavender. The average size is $1.92 \times .27$ inches.

486a. NORTHERN RAVEN. Corvus corax principalis Ridgw. Geog. Dist.Northern North America, from Greenland to Alaska, south to British Columbia, Canada, New Brunswick, Maine, Michigan, New Jersey, Ohio, North Carolina, etc.

If it were possible in the English language the name of Poe and Raven would doubtless become synonymous, for who can think of the Raven without associating it with the name of Edgar Allen Poe? In former years the Raven appears to have been considered not uncommon in the northern New England States, but is now considered very rare, and late records of its occurrence there are very few. It breeds occasionally on the cliffs of the island of Grand Manan, and more frequently farther east, as in New Brunswick, Nova Scotia, Newfoundland, etc. It is rather a common resident along the whole coast of Labrador. In Alaska this Raven nests about the middle of May; in. South Greenland Hagerup took eggs April 11 and May 9. MacFarlane found its eggs on the Anderson River, British America, April 30. Forestclad cliffs of great rivers, the crags of lonely islands in the ocean, wooded lakes and streams in solitary regions are the haunts of this sable-plumed, ominous bird. The Rev. J. H. Langille states that in Nova Scotia nesting begins early in March. The * site chosen for the nest is usually the most inaccessible tree or rocky cliff; sometimes, however, it is built in the flat-topped, low spruces, as is the case on Mud and Seal Islands, on the southwestern coast of Nova Scotia. The nest is made of large sticks, closely and artistically arranged, with a lining of coarse grasses, sea weed and wool. The same nest is repaired from year to year, and in course of time becomes quite bulky. The eggs are four to six in number. A set of five eggs is in my cabinet, which was collected by Mr. H. Pope, near South West Point, on the island of Anticosta, off the mouth of the St. Lawrence, April 21, 1887. The nest was built in cliffs facing the sea, and the eggs were secured only after a dangerous scramble over banks of ice and snow. Like the eggs of the crow, these are subject to great variation in markings. The ground-color is pale bluish-green or light olive-green. They are spotted, blotched, streaked or dashed with purple and greenish-brown; some specimens are so densely marked as to almost wholly obscure the ground-color, giving the surface a dull greenish-gray appearance. Four of the specimens in the set of five are of this type, while the other is of a brilliant bluish-green, sparsely marked with blackish-brown and obscure lilac. Their sizes are: $1.85 \times 1.24,1.90 \times 1.30,2.04 \mathrm{x}$ $1.32,2.07 \times 1.34$. The average size is $1.90 \times 1.27$ inches. 
Mr. Amos W. Butler, Indiana's state ornithologist, has just informed me (September 21,1897 ) that the Raven has recently been found breeding in Martin and Du Bois counties of that state. It is the only record I have of the Raven's nesting in this part of the ohio Valley. In Ohio it must be considered a rare winter visitor, and a few may breed in the northern portion. The bird was more common in former years than at present.

487. WHITE-NECKED RAVEN. Corvus cryptoleucus Couch. Geog. Dist.Southwestern United States and-table-lands, of Mexico, north to Indian. Territory, Kansas, Colorado and Southern California, south to Guatemala.

The White-necked Raven is an abundant species throughout most of its range. The bird's general appearance and its nesting habits are similar to those of the common crow, with which it is often confounded. From four to seven eggs are laid by this species, and they have, on the whole, markings of a lighter color than the eggs of other species of Corvus; and in addition they have lines running from one end of the egg to the other, somewhat after the manner of those on the genus Myiarchus, of the Flycatchers, of which the most familiar example is the Crested Flycatcher, $M$. crinitus. This peculiarity is typical of the species, and is found constant in a large series in the collection of the National Museum, at Washington. A set of five eggs in Mr. Norris' cabinet was taken May 16, 1888, in Cochise county, Arizona, from a nest in an oak tree. The eggs are of a pale bluish-green, spotted with clove-brown, and profusely streaked with longitudinal lines of olive-gray. They measure: 1.74x $1.19,1.77 \times 1.21,1.67 \times 1.18,1.76 \times 1.18,1.77 \times 1.21$.

488. AMERICAN CROW. Corvus americanus Aud. Geog. Dist.-Eastern North America except Southern Florida and Arctic regions.

An abundant bird in all the Eastern States, where it is well known. The nest is built in woods, preferably in high, thick forest, and the tree selected is one of thick foliage. In pine regions the cedar is the favorite tree. The altitude is usually so great that the nest is practically inaccessible. In quiet, solitary places, however, I have found it placed not more than ten or fifteen feet from the ground. It is built of twigs and sticks, sometimes of considerable size, firmly interlaced, while weeds and grass, often with clods of earth attached, form part of the structure. The lining is of leaves, grapevine bark and fine grasses. Mr. Frank L. Burns has probably given us the best history of the American Crow that has yet been written. In a monograph* of forty-one pages the general habits, particularly the feeding, nesting, roosting, flight, relative abundance, etc., is recorded. These facts and figures are from competent observers within the geographical range of this bird. Concerning the material of the nest, he says: "The composition of the nest varies somewhat, of course, with the local surroundings, as well as with the individual builder's experience and 'taste' as to the proper material for building. They rarely use a deserted squirrel's nest. The typical nest is composed of coarse sticks, strips of kark, clods of earth, dead leaves; lined with hog bristles, strips of grape vine bark; the inner bark of chestnut or oak, cow hair, or horse hair. Occasionally the body of the nest will contain moss, grass, rootlets, corn stalks, cloth (often from some dilapidated 'scare crow'), corn husks, weed stalks, pieces of rope, dried cow and horse manure, feathers, pieces of matting, sheep's wool, twine, or seaweed. The lining

* Bulletin No. 5: The Wilson Ornithological Chapter of the Agassiz Association. The American Crow (Corvus Amerlcanus), with special reference to its Nest and Eggs. By Frank L. Burns. Oterlin, Ohio, March 15, 1895. 
is sometimes made up of strips of cedar or juniper bark, dead leaves, sheep's wool, feathers, or skunk's hair. Quite often' in some localities, especially in the Eastern States, pine needles are used for lining; while in many other localities, where the surroundings will permit the use of this material, it is not used at all. Much binder twine is made use of in the West. Rev. P. B. Peabody, Owatonna, Minn., writes: 'It has apparently become as indispensable as nesting material to the Crow as snakeskins are to the Crested Flycatcher." 'The nesting 'season is in April and May, or June, and sometimes even in March. From four to six, and occasionally seven eggs are laid. These vary from a pale bluish to an olive-green, and from

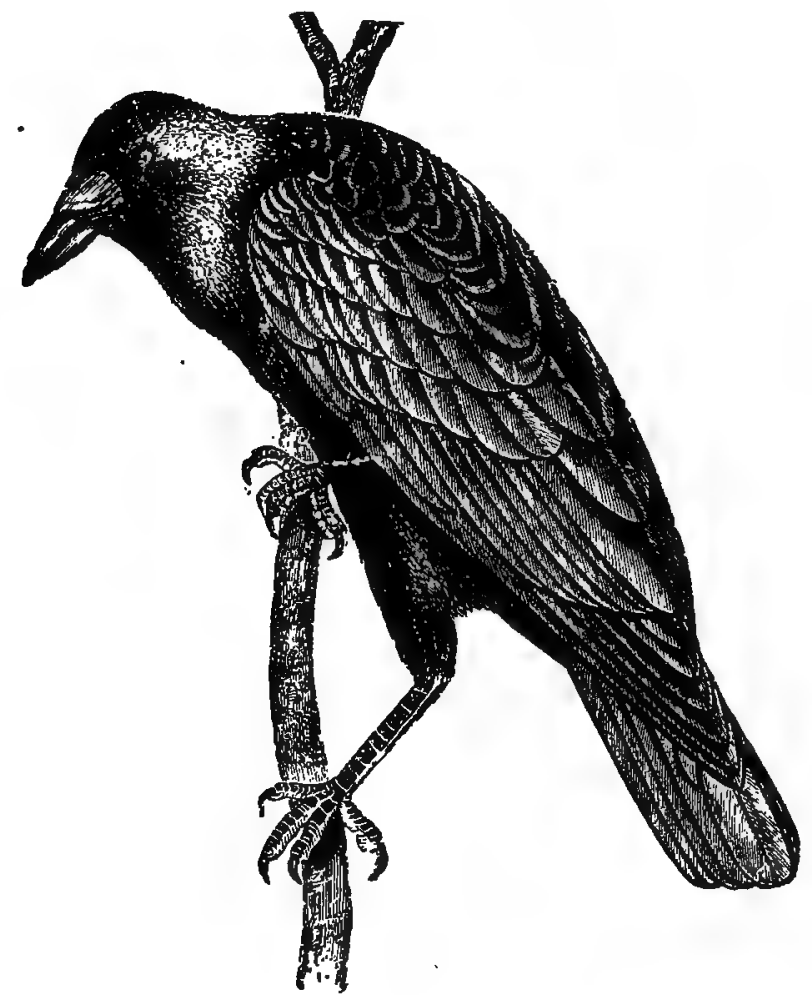

488. American Orow (After Audubon).

almost unmarked specimens to those which appear of a uniform olive-green, so dense and small are the markings. The typical egg, however, is of a light sea-green, thickly spotted and blotched with dark brown, almost black, with purplish reflections; these are chiefly about the larger end. Mr. Burns gives the measurement of three hundred and twenty, eggs from New York State as follows: Maximum, 2.03x 1.33; minimum, 1.43×1.08; average, $1.65 \times 1.15$ inches.

488a. FLORIDA CROW. Corvus americanus floridanus Baird. Geog. Dist.Southern FIorida. 
A set of four eggs from Manatee county, Florida, taken April 15, is in my cabinet, and measure $1.62 \times 1.18,1.62 \times 1.19,1.66 \times 1.18,1.62 \times 1.16$. Their color and markings are similar to those of typical eggs of $C$, americanus,

489. NORTHWEST CROW. Corvus caurinus Baird. Geog. Dist.-Northwest coast from Oregon to Kadiak, Alaska.

The Northwestern Fish Crow is a smaller bird than the common. Crow of the Eastern States. In its habits it is said to be the exact counterpart of the Fish Crow of the Atlantic coast. Its principal food is marine crabs or fish which it gathers along the banks of rivers and the shores of lakes. Like the Raven and Herring Gull, it carries clams high into the air and drops them in order to break the shell. Its nest is said to be substantially like that of Corvus ossifragus, being built in evergreens and oaks growing along ravines; and the eggs are indistinguishable. Ridgway gives their average sizes as $1.56 \times 1.08$.

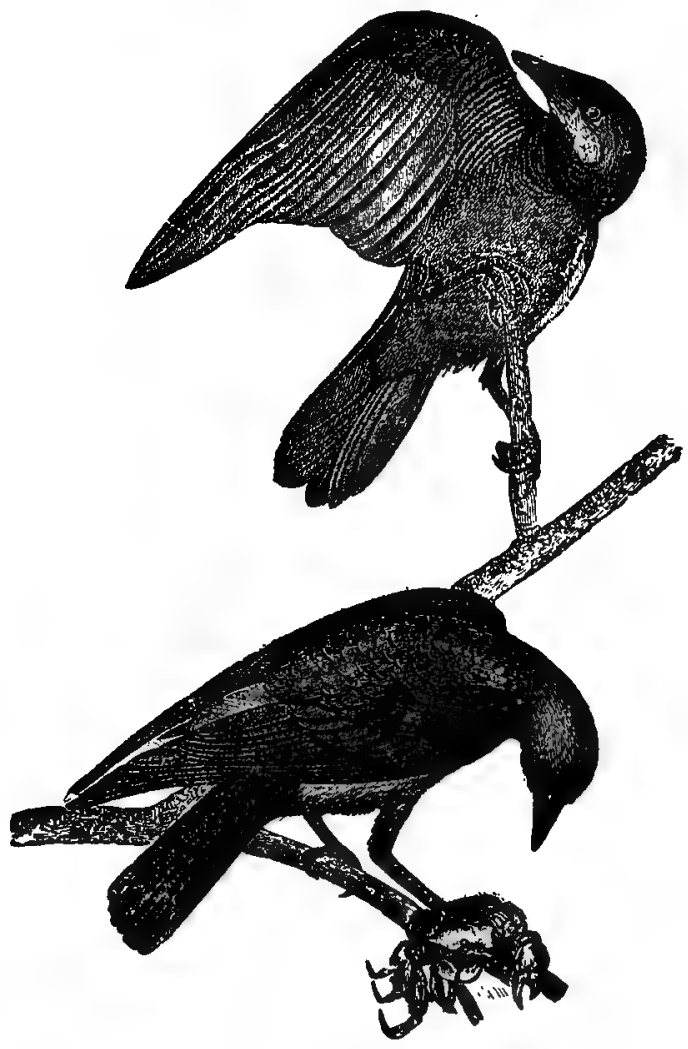

490. Fisg Crow (After Audubon).

490. FISH CROW. Corvus ossifragus Wils. Geog. Dist.-Atlantic and Gulf Coasts of the United States from Liong Island to Louisiana. 
A common species along the Atlantic coast of the United States from New Jersey to Florida, and on the Gulf coast to Louisiana. It is called the Southeastern Fish Crow. Mr. Charles S. Schick states that along the coast of Cape May county, New Jersey, he has found sets of eggs of this species as early as April 13, and on the 15th of the same month observed nests with young; the dates of laying varying with the temperature of the season. The usual number of eggs deposited is five or six, a set of seven being uncommon. In a section containing two hundred evergreen trees, there were at least sixty nests, ranging in height from twenty to sixty feet above the ground. The composition is nearly the same as in those of the Common Crow, except that the lining consists of a few dry leaves or fine bark-fibres. The bird, Mr. Shick says, feeds largely on small crabs, and devours large numbers of the eggs of the Clapper Rail. , The eggs of the Fish Crow are so nearly like those of the Crow in color and markings that one description will answer for both; those of the present species are much smaller. Five specimens measure $1.50 \times 1.08,1.50 \mathrm{x}$ $1.05,1.46 \times 1.02,1.51 \times 1.06,1.47 \times 1.02$. The average size of twelve eggs is $1.50 \times 1.09$.

491. CLARKE'S NUTCRACKER. Nucifrago columbianus (Wils.) Geog. Dist.-Western North America, north to Alaska, south to Arizona, east to and including the Rocky Mountains.

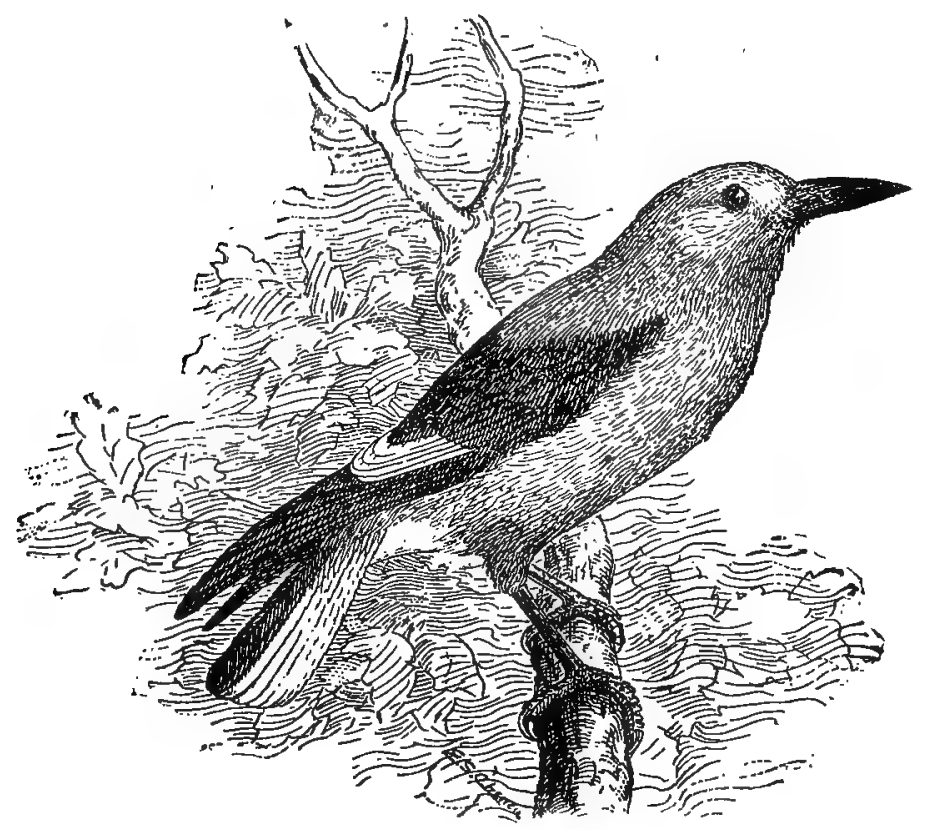

491. Ciarze's Nutcracker (Cheney del.)

Clarke's Crow, or Nutcracker, is found in considerable numbers in all suitable localities in the coniferous forests of the bigher mountain ranges within the limits of the above habitat. It is the American representative of the European Nutcracker, Nucifraga caryocatactes. A remarkable bird, embodying the peculiar habits of certain woodpeckers and those of some of the jays-wild, restless and noisy, inquisitive 
and cunning. Major Bendire found it breeding quite commonly in the mountainous regions about Fort Harney, Oregon. April 22, 1876, two nests were found, one containing a young bird, just hatched, and two eggs with the shells chipped; the other contained three young. Between April 24 and 30 about a dozen nests were observed, all containing.three young, each in different stages of development. In the spring of 1877 not a single bird was observed where they were found breeding the year before, and their absence was accounted for by the scarcity of the seeds of the pine which constitute their principal food. On April 4, 1878, a nest containing three eggs was found, and at this early date incubation was far advanced. A set of two eggs, with good-sized embryos, was taken April 8. All the nests were placed in pirie trees, generally well out on the limbs, and from sixteen to forty feet above the ground. Trees with plenty of branches seemed to be preferred, and the edges of pine timber to the interior of the forests. A nest is described as rather bulky, the base consisting of a platform of small sticks and twigs, mostly of the white sage; on this the nest. proper is placed, which is composed of dry grasses, vegetable fibres, hypnum moss and the fine inner bark of the western juniper, all compactly woven together, making a warm, comfortable structure. The sizes of four eggs, as given by Major Bendire, are as follows: $1.22 \times .95,1.20 \times .90,1.26 \times .95,1.30 \times .92$, respectively. Their color is a light grayish-green, irregularly spotted and blotched with, a deeper shade of gray, chiefly at the larger end. In the mountainous region southeast of Fort Garland, Colorado, the late Captain B. F. Goss found nests of this species under the same conditions as observed by Major Bendire. May 21 a nest was discovered containing young. The nests, at first appearance; according to both observers, looked more like squirrels' nests than anything else, and the birds were close sitters, even allowing themselves to be captured rather than leave their nests. During the breeding season they are perfectly silent.

492. PINON JAY. Cyanocephalus cyanocephalus (Wied.) Geo. Dist.-The Region-between the Rocky Mountains and Sierra Nevada Ranges, from Mexico to British America.

The region between and including the Rocky Mountains and the eastern slope of the Sierra Nevadas, wherever grows the yellow pine, the pinon and the juniper, the Blue Crow, Maximilian's or Pinon Jay makes its home. A bird combining the form of a crow and the color and habits of a jay; of a restless, roving disposition, but resident wherever found. It breeds in colonies, nesting in April, May and June, according to locality. Nests containing eggs have been found in Nevada by $\mathrm{Mr}$. H. G. Parker in the first part of May, and fully fledged young were observed in the same region by Mr. Ridgway as early as April 21. Mr. H. B. Bailey took a set of four eggs in New Mexico that were well incubated June 5. The late Captain B. F. Goss found this bird breeding in the region southeast of Fort Garland-the western base of the Sangre de Christo Mountains, at an elevation of about 9000 feet. The nests were all in small pinon pines, from five to ten feet up, out some distance from the body of the tree, and not particularly well-concealed. They are large, coarse and deeply-hollowed structures, much alike, being made mostly of grayish shreds of some fibrous plant or bark, which breaks up into a mass of hair-like fibres, these forming the lining, while some weeds and grass are worked into the general fabric. The birds were close sitters, several not leaving till the nest was shaken, and they could have been caught with the hand. One nest contained five eggs, six contained four each, and two three each; both sets of three were partly incubated. Two nests were taken May 5, five on the 10th and two on the 11th, 1879. The eggs are quite 
pointed at the small eud; the ground-color is bluish-white, splashed all over with small spots of dark brown thickest at the large end. Thirteen eggs measure respectively: $1.19 \times .88,1.21 \times .93,1.22 x .92,1.25 \times .91,1.17 \times .87,1.18 \times .84,1.17 \times .85,1.20 \times .82$, $1.17 \times .80$; average $1.19 x .87$.

[493.] STARLING. S'turnus vulgaris Linn. Geog. Dist.-Europe and Northern Asia; accidental in Greenland. Introduced in New York.

A specimen of the Starling, taken in Greenland in 1851, entitles it to a place in the avifauna of North America. It has been introduced and apparently well established in the vicinity, of New York city. Mr. Chapman in his "Birds of Eastern America," says that the Starling has bred for three successive years in the roof of the Museum of Natural History and at other points in the vicinity. It is a wellknown bird in Europe, and of a very general distribution. Its handsome plumage, sprightly, social habits, retentive memory, and pleasing, imitative voice have made it a great favorite as a caged bird. It is said to live in flocks the greater part of the year, selecting for its nest suitable pläes in holes of trees, eaves of houses, churchsteeples, old towers and ruins, in cliffs or in high rocks overhanging the sea, and in wooden boxes put up for its accommodation. The material used for the nest is twigs, straws and fine grasses. The eggs are four to six in number, of a pale greenish-blue or bluish-white. A set of five eggs collected by W. Wells Bladden, May 4, in Staffordshire, England, is in my cabinet, and exhibits the following sizes: $1.13 \times .84,1.10 x .82$, $1.11 \times .83,1.18 \times .79,1.20 \times .79$.

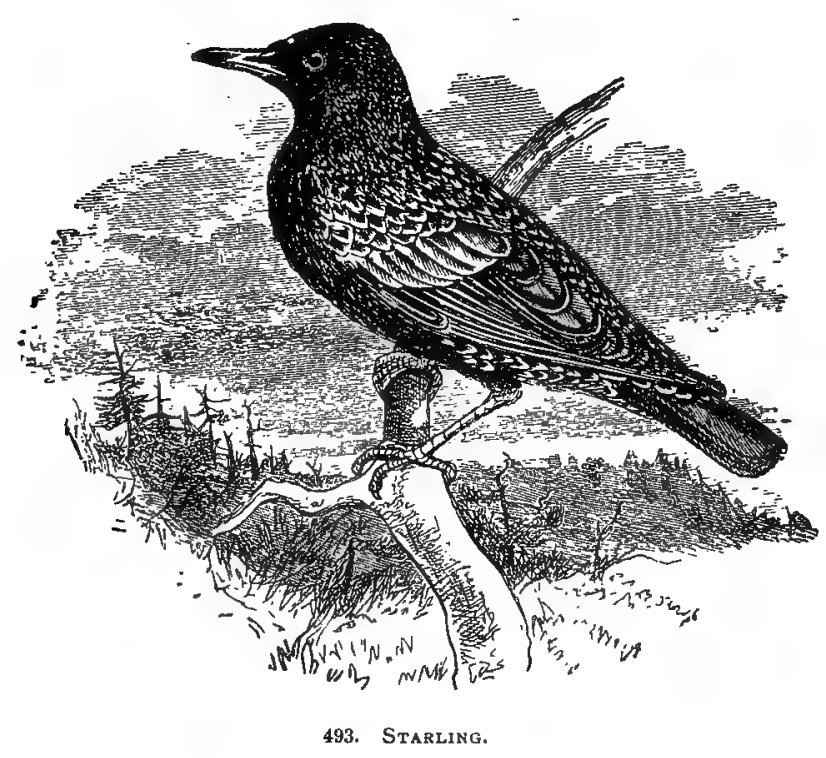

494. BовоLINK. Dolichonyx ory $\approx$ itorus (Linn.) Geog. Dist.-Eastern North America to the Plains, north to Southern Canada, south in winter to the West Indies and South America. Breeds from the Middle States northward.

A familiar bird in Eastern United States, breeding from the 38th to the 54th parallel. In some parts of the country, in suitable places, it is very abundant. of 
all our natural songsters the Bobolink is the most noted and popular. Descriptions of his song so frequently appear in literature that even those who have not heard it must form a good idea of its enchanting music:

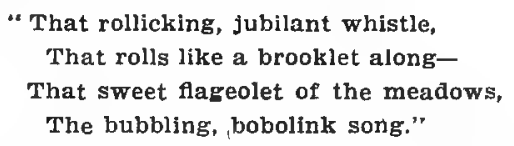

Often have I heard him sing when on the wing, or when at rest, with the broad, meadow and pasture lands spread before him, perched on the top of a wind-beaten reed, with his wings sunward spread, his head erect, his white and black back glistening in the sunlight, pouring forth his 'bubble-ing" bobolink notes to the azure windows of heaven. In the South he is known as the Rice-bird, an the Middle States as Reed-bird and Meadow-wink, and in the North as Skunk Blackbird. The nesting

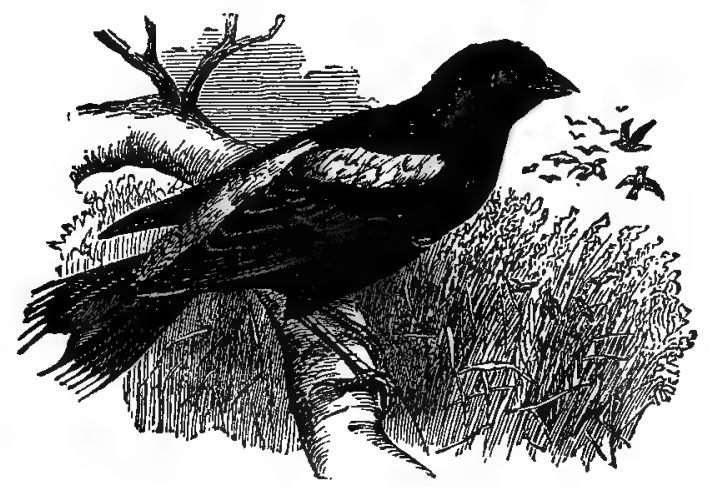

494. BовоLINK.

time is in the latter part of May or in June. The nest of the Bobolink is very hard to find; it is built in a natural cavity of the ground, amongst the tall grass of meadows; cometimes it is sunk in the depression made by a cow's or a horse's hoof. Fields of clover, with here and there a tall weed-stas $x$ or sapling, on which the birds alight, are favorite nesting resorts. In leaving the nest the female will run off through the grass quite a distance before rising, and she will repeat the same performance upon her return, so that the nest can only be found by diligent and careful search in the vicinity from which she arises. The eggs, too, resemble the color of the ground so closely that they are easily overlooked. The nest is a very slight affair, made of dry grasses and weed-stems, arranged in a circular form. The eggs are usually five, vometimes six or seven in number, and of a dull white or grayish-white, variously tinged with light drab, olive reddish and grayish-brown, intermingled with lavender; the general effect being that of a dark, heavily-colored egg. T'en specimęns measure: $.79 x .55, .80 x .55, .86 x .60, .84 x .63, .87 x .58, .87 x .61, .88 x .66, .86 x .61, .83 x .60$, $.85 x .60$. An average specimen measures $.85 x .64$.

495. CoWBIRD. Molothrus ater (Bodd.) Geog. Dist.-Whole of the United States, north into Southerm British Columbia, south in winter to Mexico.

- Known as the Cow Bunting or Cow Blackbird from its habit of alighting on the backs of cows or cattle, where it sits contentedly while they are grazing. It is a 
notorlous parasite, and does not build a nest, but like the European Cuckoo, lays its eggs in the nests of other birds, usually in those of species smaller than itself. Generally a single egg is deposited, but as many as five have been found in a nest The exact number the female lays is not known. Eggs of this bird are subject to great variation in their size and markings, and when found in the nests of such birds as the Cardinal Redbird, Towhee Bunting, Meadow Lark and Brown Thrasher,* it is sometimes 'difficult to readily distinguish which is which." Yet it should not be understood that the Cowbird's eggs look exactly like those of the species just mentioned, for they really have, on the whole, only a faint resemblance to them, and when a large series of either species is brought together and compared with those of the Cowbird the difference is at once apparent. Dr. Jones suggests that when the egg of the Cowbird resembles so closely the eggs in the nest where it has been laid, as to make identification uncertain, it is a good plan to blow all the eggs and notice if the suspected egg has a yelk of different tint from the balance of the set. If it has, it is strong evidence that it was laid by an intruder, for almost invariably eggs of the same set have the same tinted yelks. The ground-color of the Cowbird's egg is white or gray, sometimes obscured by the abundance of markings. Spots, specks and blotches are generally pretty evenly distributed over the entire surface. The markings vary from a chocolate-brown to those of a reddish and yellowish-brown. The whole surface of an egg is often quite densely marked with specks the size of a pin point, while the shell of other specimens is sparsely spotted. Ten specimens selected at random from a very large series exhibit the following sizes: $.80 x .62, .82 x .66, .84 x$ $.62, .88 x .66, .89 \times .63, .87 \times .65, .82 \times .60, .83 x .64, .89 x .64, .80 x .62$. A common size is $.88 \times .64$.

495a. DWARF COWBIRD. Molothrus ater obscurus (Gmel.) Geog. Dist.Mexico, and southern border of the United States from Texas to Arizona and Lower California.

This is a smaller form, inhabiting the southern border of the United States from 'Texas to Arizona and southward. Its habits are identical with the Cowbird of the Fast, and the eggs are colored the same, but like the bird, average smaller. Five specimens measure: $.77 \times .60, .80 \times .59, .75 \times .59, .70 \times .57, .72 \times .58$. The average size of ten specimens from Arizona is .74x.59.

496. RED-EYED COWBIRD. Callothrus robustus (Cab.) Geog. Dist.-Eastern and Southern Mexico, Yucatan, and south to Panama; north to the lower Rio Grande Valley in Texas.

A bronze-colored Blackbird with blood-red iris. Common on the Lower Rio Grande in Texas. Dr. Merrill took specimens at Hidalgo, but they were not so abundant at this point as lower down the river, where they are common throughout the year, a smaller proportion going south in winter. Those that remain gather in

* Besides those above named the following are some of the nests in which the Cowblrd's eggs have been found: Blue-gray Gnatcatcher, Black and White Warbler, Blueyellow-backed Warbler (Parula), Worm-eating Warbler, Prothonotary Warbler; Maryland Yellow-throat, Yellow Warbler, House Wren, Warbling, Yellow-throated and Redeyed Vireos, Indigo Bunting, Chipping Sparrow, American Goldfinch, Song Sparrow, Swamp Sparrow, Slate-colored Junco, Oven Bird, Pewee, Acadian and Traill's Flycatchers, Black-throated Bunting, European House Sparrow (Passer domesicus), Yellow-breasted Chat, Bluebird, Orchard, Baltimore, Bullock's and Hooded Orioles, Scarlet Tanager, Kingbird, Towhee, Prairie Horned Lark (Octocoris alpestris practicola), Wilson's Thrush,

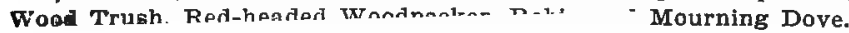


flocks with the Long-tailed Grackles, common Cowbirds, Brewer's, Red-winged and Yellow-headed Blackbirds. He found its eggs in the nests of Bullock's, Hooded and the Orchard Orioles, once in the nest of the Yellow-breasted Chat, and Red-winged Blackbird, Scissor-tailed Flycatcher and Texan Cardinal (Pyrrhuloxia sinuata). The eggs of the Red-eyed Cowbird are plain bluish-green, similar to that in the eggs as $.90 \times .70$, the extremes being $.95 \times .75$ and $.82 \times .65$.

497. YELLOW-HEADED BLACKBIRD. Xanthocephalus xanthocephatus (Bonp.) Geog. Dist.-Western North America to the Pacific, east regularly to Wis-

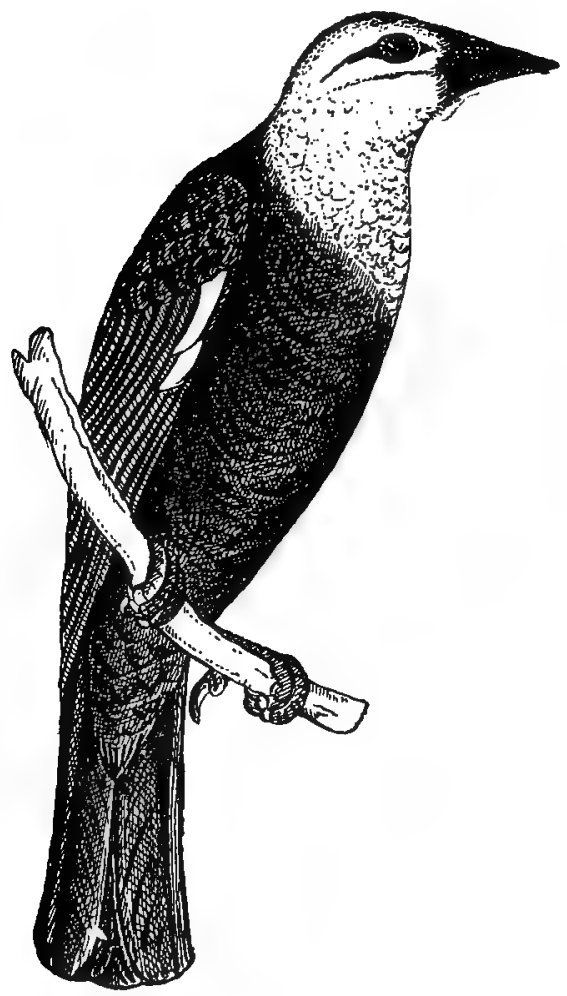

497. Yellow-heAded BlackBtrd. consin, Illinois, Kansas and Texas. Accidental in the Atlanitic States.

The handsome Yellow - headed Blackbird is found generally distributed on the prairies in all favorable localities from Texas on the south to IIlinois and Wisconsin, thence to the Pácific. A common bird in the West, nesting in May and June. It collects in colonies to breed in marshy places anywhere in its general range, often in company with the Red-winged Blackbird. The nests are usually placed in the midst of large marshes, attached to the tall flags and grasses. They are generally large, light, but thick-brimmeu, made of interwoven grasses and sedges impacted together. The eggs are stated to range from two to six in number, but the usual number is four. In the hundreds of sets that have come into my hands only three contained five eggs of each. Their ground-color is dull grayish-white, in some grayishgreen, profusely covered with small blotches and specks of drab, purplishbrown and umber. Their average size is $1.12 \times .75$.

498. RED - WINGED BLACKBIRD. Agelaius phoniceus (Linn.) Geog. Dist.-North America in general, from Great Slave Lake south to Costa Rica, excepting Western Mexico and Lower Colorado Valley, Southern Florida, the Gulf coast and the Lower Rio Grande Valley in Texas during the breeding season.

The Red-winged Starling or Swamp Blackbird is found from the Atlantic to the Pacific, and as far north as the 57th parallel, breeding more or less abundantly wherever found, from Florida and Texas to the Saskatchewan country. In its native marsheg during the breeding season, which is in May and June, a loud chorus of discord and harmony may be heard from the Red-wings, and above all the strange, reverberating kong-quer-ree, kong-quer-ree. 
bushes near the ground, often in a tussock of grass, sometimes on the ground, and once in a while at a considerable elevation in a tree. The materials are usually strips of rushes or sedges, lined with finer grass and sometimes with a few horse hairs. It is rather bulky, and not at all artistic. This bird nests in communities, and one is quite as likely to find several nests near each other as a single one, in a piece of

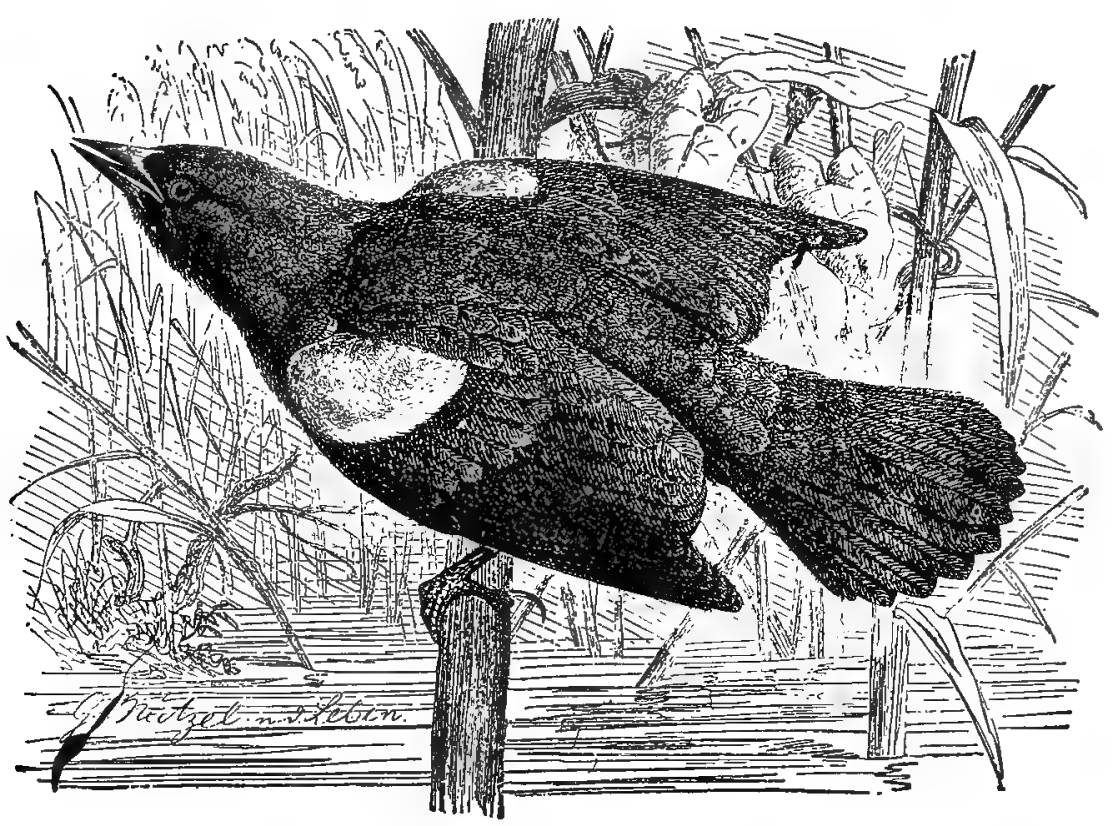

498. RED-WINGED BLACKBIRD (From Brehm).

swamp. Nests and eggs found in Texas are smaller than the average of those found in the more northern States. The eggs are light blue, marbled, lined, blotched and clouded with markings of light and dark purple and black, almost entirely about the larger end, but vary considerably in this respect; they are usually four, rarely five in number, and average 1.00x.75. Mr. I. E. Hess, of Philo, Ill., makes note of an unusual Red-wing's nest in "The Osprey"* for September, 1897. It is as follows: "On. May 25 of last season, I climbed to the top of a wild cherry tree for what I supposed to be a nest of the Kingbird. I was greatly surprised to find it a Red-winged Blackbird's nest. It was firmly fastened to a branch twenty-one feet from the ground. In construction it differed very materially from the usual Red-wing style, being composed of strings, grasses and feathers, much after the Tyrannus tyrannus mode $\mathrm{cf}$ architecture. The tree stands within fifteen feet of a large farm residence, and is fully half a mile from open water. The site is one where I should never have looked for a nest of Agelaius phoniceus."

* The Osprey, an Illustrated Monthly Magazine of Ornithology. Edited by Walter A. Johnson, associated with Dr. Elliott Coues, Washington, D. C., Vol. VII, No. 1, p. 13 . Published by the Osprey Company, Galesburg, Ill. Official Organ of the Cooper Ornithologica: Club of the Pacific Coast. 

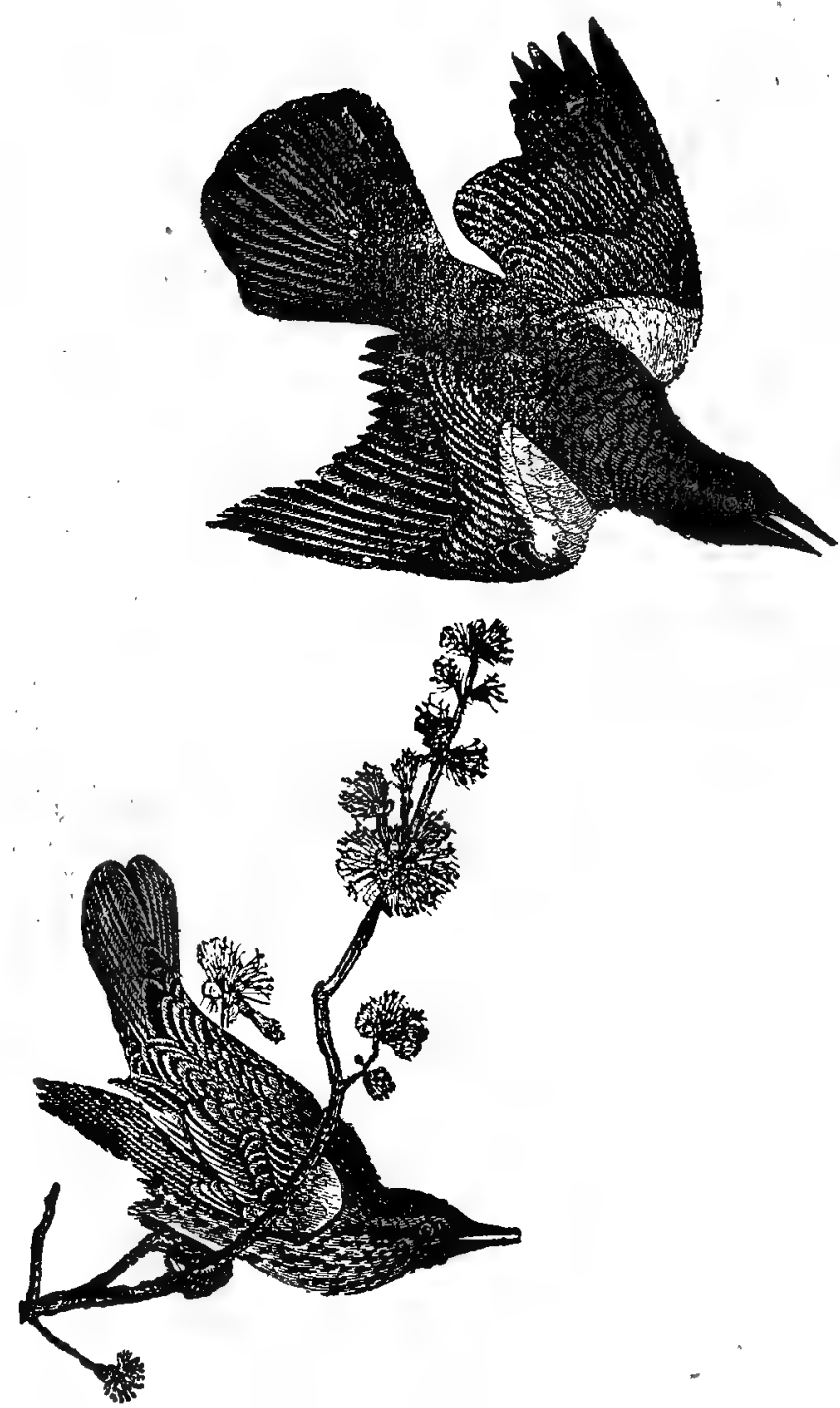

498. Red-winged Blackbird. Upper, male; lower, female (After Audubou).

498a. SONORAN RED-WING. Agelaius phæniceus sonoriensis Ridgw. Geog. Dist.-Northern Mexico and contiguous borders of the United States, from the Lower Rio Grande Valley and Southern Arizona north to the Lower Coloradn Valley, California and Chilliwack, British Columbia.

This is a larger race than the Northern Red-wing, with a smaller hill, and in the: male the upper parts are lighter colored; the female is also paler in color. The nesting habits, eggs, etc., are identical with those of Agelaius phoniceus. 
498b. BAHAMAN RED-WING. Agelaius phoniceus bryanti Rídgw. Geog. Dist.-Bahamas and Southern Florida, west to the Gulf coast of Louisiana (Lake Borgne), south to Yucatan and Nicaragua.

A smaller race with a larger bill than the preceding subspecies; the plumage of the upper parts is darker.

498c. FLORIDA RED-WING. Agelaius phoniceus floridianus Maynard. Geog. Dist.-Florida.

The Florida Red-winged Blackbird has in' all respects the general habits and characteristics of the Red-wing of the Northern States. Its nesting and eggs are identical.

499. BICOLORED BLACKBIRD. Agelaius gubernator (Wagl.) Geog. Dist.Pacific coast districts, from Western Washington, south to Lower California, west to the Cascades and the Sierra Nevadas. Casually to Western Nevada and Southeastern California.

The Red-and-black-shouldered Blackbird occurs along the Pacific coast from British Columbia south throughout California. The female is not distinguishable from the female Red-wing, and the nesting habits are exactly the same, placing the nests in watercress or rushes, along running streams, ditches and swamps. The eggs are light blue or bluish-white, marked around the larger end with waving lines of dark brown, lighter in shade than the markings on the eggs of the common Redwing; four or five in number; size from .90 to 1.05 in length by .64 to .74 in breadth.

500. TRICOLORED BLACKBIRD. Agelaius tricolor (Nutt.) Geog. Dist.Valleys of the Pacific coast, from Southern California to Western Oregon.

This species is known as the Red-and-white-shouldered Blackbird, and belongs to California and Oregon; is especially abundant in the swamps and marshes of the former State. Like the Swamp Blackbird of the Eastern States, it nests in the vicinity of water, in colonies; usually placing the nest in alder bushes, willows and flags. It is composed of mud, straw and coarse grass, lined with finer fibrous material. The eggs are of a light blue, slightly deeper than the ground-color of the Red-wing's eggs, marked around the larger end with a circle of ashy-brown, sometimes black, irregular lines and blotches; four or five in number; size 1.00x.60.

501. IIEADOWIARK. Sturnella magna (Linn.) Geog. Dist.-Fastern North America, west to the Plains, north to Canada.

The Old Field Lark is a well-known bird in the United States east of the Mississippi, breeding wherever found, from Florida and Texas northward. West of the Mississippi it is replaced by the Western form, Sturnella magna neglecta (Aud.) As its name implies, the meadows and fields are its home. In almost any stretch of pastureland may be found a pair or colony of Meadowlarks, and the sweet sound of their wild, ringing, and rather melancholy notes fill the air at short intervals from sunrise till the gloaming. The nesting time is in May, usually beginning in the middle or latter part of the month. The nest is built on the ground, in a thick tuft of grass; it is pretty compactly made of coarse, dry, wiry grasses, and lined with finer blades of the same. It is usually formed with a covered entrance in the surrounding withered grass through which a hidden and sometimes winding path is made, and generally so well concealed that the nest is anly to be found when the bird is flushed. The eggs are crystal-white, more or less tillakly spotted or dotted with reddish-brown and purplish, four to six in number, with great variation in size, averaging $1.10 x .80$. 


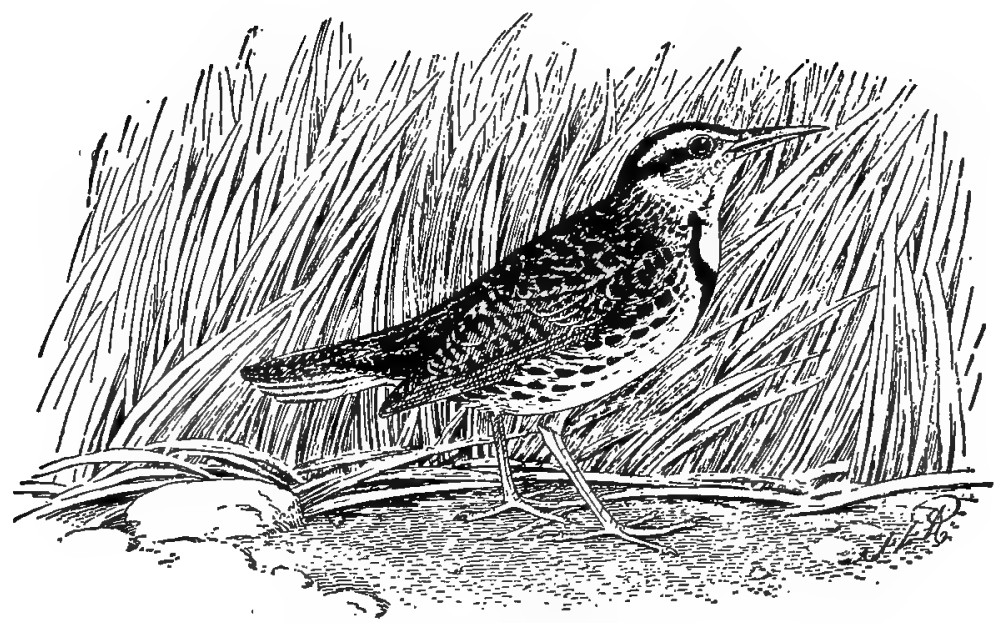

501. Meadowlark (From Brehm).

501a. MEXICAN MEADOWLARK. Sturnella magna mexicana (Scl.) Geog. Dist.-Valley of the Lower Rio Grande and Southern Arizona, and south through eastern and central Mexico to Panama.

- The general habits of this Southern race are counterparts of those of the Old Field Lark of Eastern United States. A typical set of four eggs of this variety, collected by Mr. Frank B. Armstrong in Tamaulipas county, Mexico, on May 3, 1895, is in Mr. C. W. Crandall's oölogical collection. He states that on comparing them with his series of the eggs of the Eastern and Western larks he can find no appreciable difference from the general type. The four eggs measure 1.16x.80, 1.14x.79, 1.14x.79, 1.22x.80 inches, respectively.

501b. WESTERN MEADOWLARK. Sturnella magna neglecta (Aud.) Geog. Dist.-Western United States, from Wisconsin, Illinois, Iowa, Texas, etc., west to the Pacific coast and north to British Columbia and Manitoba south through Central and Western Mexico to Guanajuato and Jalisco.

Both of our Meadowlarks, S. magna and S. neglecta, occur in portions of the Mississippi Valley, overlapping each other in their typical styles for a distance of several cundred miles, intermediate specimens being extremely rare. For this reason, and on account of the great difference of its notes and other peculiarities, $s . m$. neglecta should doubtless be considered a distinct species. Its song, according to those who have heard it, is remarkably fine, less shrill, more plaintive and richer than that of the Eastern Meadowlark.* In Los Angeles county, California, Mr. Shields states that the nesting season is from April 15 to the last of June. Colonel Goss gives it as a common bird in Western and Middle Kansas, where it begins laying about the middle of May. Nesting habits and eggs are similar to those of S. magna. The markings on a large series of the eggs of the Western Meadowlark before me are flner than on the eggs of S. magna. The average size of ten specimens is $1.08 \times .84$.

* For a description of the songs of the Western Meadowlark, see Charles N. Allen's article: Bull. Nutt. Ornith. Club. Vol. VI, pp. 145-150. 
[502.] TROUPIAL. Icterus icterus (Linn.) Geog. Dist.-Northern South America; West Indies (introduced). Accidental at Charleston, S. C. (Audubon).

This splendid Oriole is admitted as North American on the strength of a single specimen, shot in Charleston, S. C., by John W. Audubon, son of the great ornithologist. Others were seen at the same place, and Audubon was informed that small groups of four and five subsequently made their appearance in the same city and among the islands. Another specimen was shot which fell in the river, and was lost. These may have been birds that escaped from cages, but, as Dr. Brewer observes: "If his information was correct, it precludes the supposition that those which have been procured are caged birds." The Troupial is a very popular and desirable cage bird, having a loud, clear, flute-like whistle, and when kept in confinement becomes very tame. It is common to all the northern countries of South America, where it is said to associate in large flocks. The nest is described as a large, massive, pensile fabric; the eggs are four or five in number, with a groundcolor varying from reddish-drab to deep purple, blotched and streaked with reddishbrown and blackish. Size, 1.10x.90.

503. AUDUBON'S ORIOLE. Icterus audubonii Giraud. Geog. Dist.-Central and Northern Mexico, north to the Lower Rio Grande Valley in Texas.

This large and beautiful Oriole is found in the United States in the Lower Rio Grande Valley, from thence southward. Dr. Merrill found it in moderate abundance about Fort Brown, where it is the only resident species. Its usual song is a prolonged and repeated whistle of extraordinary mellowness and sweetness, each note varying in pitch from the preceding. It is shy, and remains in the deep woods during the breeding season. At Lomita, on the Rio Grande, Mr. George B. Sennett found two nests with incomplete sets of eggs early in May. At Hidalgo a set of four was taken. The three nests were found in heavy timber, some ten or twelve feet from the ground, are half-pensile, something like those of the Orchard and Bullock's Orioles, and attached to upright terminal branches. They are composed of dried grasses woven among the growing twigs and leaves so as to form a matting light and firm. They measure on the inside some three inches in depth and rather more in width. The eggs Mr. Sennett describes as being peculiar, resembling those of no other found in that region. The ground-color is white, covered with fine flecks of brown, giving the egg the appearance of being covered with dust. Over these flecks, and principally at the larger end, are irregular stains and splashes of deeper brown, sometimes mixed with lilac, on which are coarse dark brown or black hieroglyphics. Some have more and larger splashes than others, but none are free from the dark, grotesque lines peculiar to the eggs of this family. In shape they are less pointed, and in size smaller to size of bird, than those of other Orioles. The shells are very tender. Nine specimens average in size $.97 \times .71$, the largest being $1.00 \times .72$, and the smallest .96x.67.*

504. SCOTT'S ORIOLE. Icterus parisorum Bonap. Geog. Dist.-Central Mexico, north to southern border of the United States-Texas to Arizona. Lower California.

Scott's, Paris or Black-and-yellow Oriole, as it is variously called, is found more or less abundantly in all suitable localities of Southern Texas, New Mexico and Arizona. On May 4, 1885, Mr. W. E. D. Scott found a nest of this species containing

- Further Notes on the Ornithology of the Lower Rio Grande of Texas. 
two fresh eggs, in Pinal county, Arizona. During the summer of 1884 he found fve nests in the same region, between May 24 and July 1. All except one were placed in yucca plants, about four feet from the ground, and situated not far from water. Several were sewed to the edge of dead leaves, which, hanging down parallel to the trunks of the plant, entirely concealed the nest. These were semi-pensile, and composed externally of fibres of the yucca, fine grasses, cotton-waste, twine and batting, lined with fine grasses and cotton-waste throughout. A fifth nest, taken July 1, was built in a sycamore tree about eighteen feet from the ground. Pensile, being attached to the ends of the twigs very much like that of a Baltimore Oriole. The nests contained three and four eggs each. The sizes of one set of four, taken May 27, are given as follows: $.96 \times .68, .98 \times .66, .92 \times .68, .96 \times .68$; another set of four, taken May 30 , exhibit the following respective measurements: $1.01 \times .72,1.02 x .70, .97 \times .70,1.02 x$ .73. The eggs are usually four in number, of a dull white, with a bluish tint variously marked with small blotches and fine dottings of purplish-brown, approaching black; in some are found the zigzag markings common to the eggs of the Orioles.

505. HOODED ORIOLE. Icterus cucullatus Swains. Geog. Dist.-Valley of the Lower Rio Grande in Texas, south through Eastern and Southern Mexico.

According to Dr. James C. Merrill and Mr. George B. Sennett, this is the most abundant of all the Orioles on the Lower Rio Grande in. Texas. Its home is in the woods or the edges of forests and groves, where the trees are hung with pendant tresses of Spanish moss, in which the nests are built. These, Dr. Merrill says, are perfectly characteristic, being most frequently built in a bunch of the hanging moss, usually at no great distance from the ground; when so placed, the nests are formed almost entirely by hollowing out and matting together the moss with a few filaments of dark, hair-like moss as a lining. Another situation is in a bush growing to a height of about six feet, with bare stems, throwing out irregular masses of leaves at the top which conceal the nest. A few pairs build in the Spanish bayonets that grow on sand ridges in the salt prairies; here the nests are built chiefly of the dry, tough fibres of the plant, with a little wool or thistle-down as lining; they are placed among the dead and depressed leaves, two or three of which are used as supports. The eggs are three to five in number, white, with a bluish tinge, or buff, marked with hieroglyphics and pencilings common to the eggs of this family, but not so abundant. These markings are usually brown, but when profuse, black and lilac shades appear. The larger end is never free from markings, and is frequently covered with them, but more commonly displays them in the form of a band. Dr. Merrill says some sets are precisely like large Vireo's eggs. Mr. Sennett gives the average size, taken from a large series, as $.86 \times .60$.

505a. ARIZONA HOODED ORIOLE. Icterus cucullatus netsoni Ridgw. Geog. Dist.-Southern Arizona and California, south into Western Mexico and Lower Califcrnia.

This variety of the Hooded Oriole is a common breeding bird in Southern Arizona and California. Prof. B. W. Everman found it nesting quite numerously as far north as San Buenventura, California, and states that it has been found breeding at Santa Barbara, thirty miles farther up the coast, though not so commonly as in Ventura county. The first full set of eggs was taken May 1; the average number to a set in that region is five. The nests were generally suspended in sycamores, often in live-oaks, ranging from five to flfteen feet from the ground. They are composed of grass picked while yet green, so that the nest is usually of a bright straw-color. 
Mr. R. B. Herron found this bird breeding at San Gorgonia Pass, California, in the months of May and June, 1883; the nests were placed in sycamores, ranging from ten to twenty feet above the ground. In Southern Arizona it was found breeding abundantly by Mr. W. E. D. Scott, in May, June and July, rearing two, not infrequently three broods in a season; a new home is built for each brood. The nests. were built in cottonwood, ash and sycamores, from twelve to forty-five feet above the ground; they were also built in the mistletoe that grows plentifully on the mesquite trees in the region about Tucson. The nests were exceedingly variable in their appearance, composition and manner of attachment to the trees-some were truly pensile, like those of the Baltimore Oriole, others were more like those of the Orchard Oriole, and one rested on a stout twig and could hardly be regarded as a hanging nest at all. The external materials were coarse dry or green grasses and yucca fibres; the linings were the same, but finer, and in some instances horse-hairs and cotton-waste. In these nests Mr. Scott found three or four eggs. The eggs vary somewhat in shape, some being obtuse and more spherical, others more pointed and oblong. They have a beautiful white ground, sometimes tinged with bluish, marbled, blotched and dotted with large dashes and irregular zigzag lines of purple, brown and black, chiefly at the larger end. A complement of four typical eggs, collected by Professor Evermann near Santa Paula, California, April 13, 1881, measure as follows: $.94 \times .66, .94 \times .64, .92 \times .63, .89 x .63$. Four sets of four eggs each, collected by Mr. Herron', are before me. A set taken June 10, 1883, exhibit the following dimensions: $.79 x .63, .78 x .63, .80 x .62, .84 x .62$. A common size is $.84 x .64$, and the average of sixteen specimens is $.88 \mathrm{x} .62$.

506. ORCHARD ORIOLE. Icterus spurius (Linn.) Geog. Dist.-Eastern United States, west to the Great Plains, scuth in winter to Panama.

An abundant species in Eastern United States during the breeding season, which is in May and June. The male is of a chocolate and black color; the female is smaller than the male, and of a yellowish-olive. Orchards and groves are its favorite resorts, and two broods are frequently reared in a season. The nest is rarely found in a large tree or in dense woods, and the distance from the ground is from five to twenty feet, usually about ten. It is a handsome, substantial basket, or purse-like structure, woven of fresh blades of grass and lined with feathers. The grasses soon become bleached, and long retain their pea-green color, giving to the nest a beautiful appearance. Its greenness often makes it difficult to detect in the foliage. Double nests of the Orchard Oriole are occasionally met with. A specimen is in my collection, sent me from Texas by Mr. Singley. The eggs range from four to six, usually five. They have a bluish ground; the markings consist of spots, specks, a few large blotches, irregular and zigzag lines of various shades of brown, chiefly about the crown; there are also deep shell-marks of a purplish. In a large series of eggs the variation in size is considerable, measuring as they do from .70 to .86 long by .50 to. .62 broad.

507. BALTIMORE ORIOLE. Icterus galbula (Linn.) Geog. Dist.-Eastern North America, north to New England, Ontario and the Saskatchewi:- country, west nearly to the Rocky Mountains, south through Eastern Mexico and Central America to Panama.

Known as the Golden Robin, Firebird and Hangnest. A common species in Eastern United States where, on account of its handsome dress, the peculiarity of its nest and its loud and rather melancholy whistle, it is well known. Its nest is a 


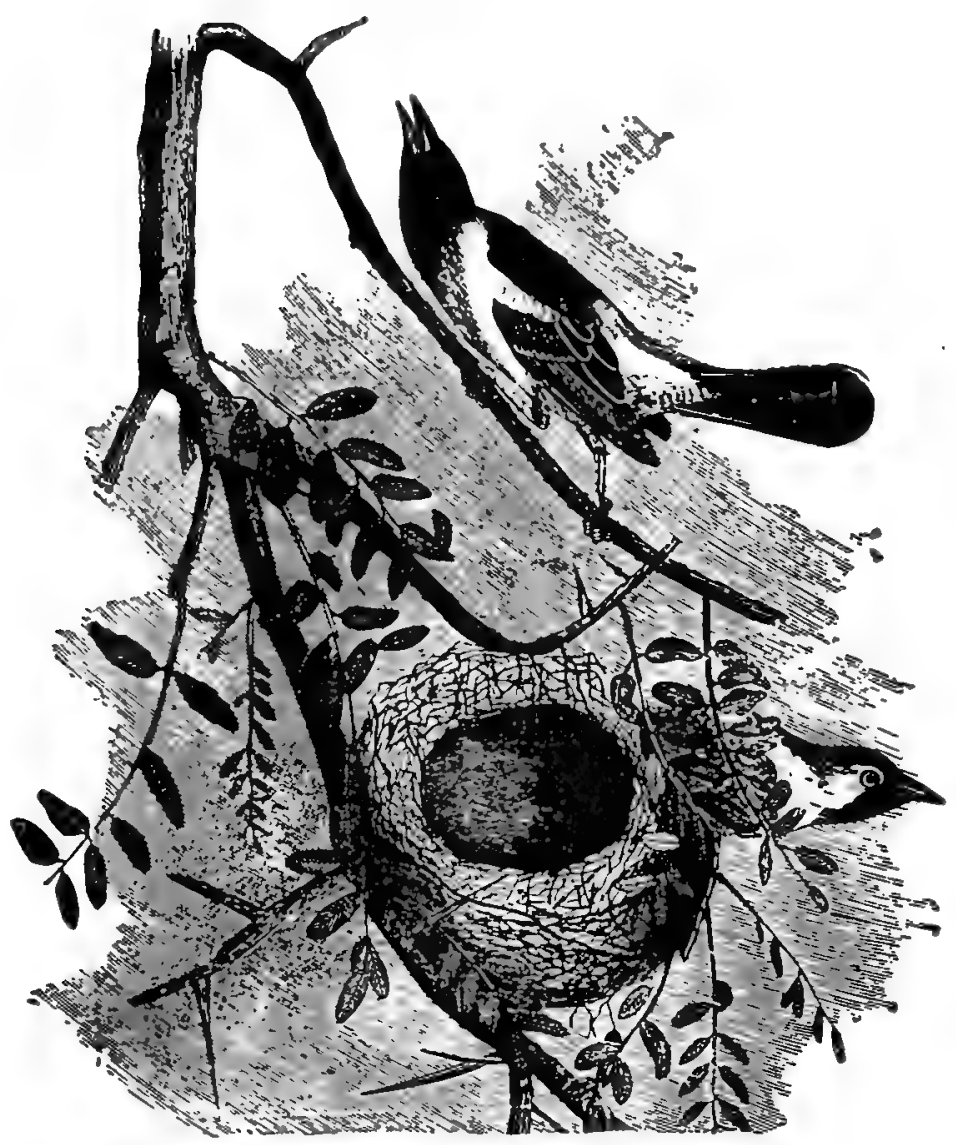

506. Orchard Oriole and Nest (Alter Audubon).

masterpiece of workmanship, which, with its bill, it weaves and suspends like a hammock from the drooping bough of an elm or sycamore, in dense foliage. The nest is pensile and nearly a cylindrical pouch, suspended from the extremity of a branch. The distance from the ground varies from four to seventy feet. Any substance combining the proper length, thickness and strength is used in the construction of its nest, consequently the materials depend to a great extent upon the locality -long grasses, strips of bark, vegetable fibres, yarns, wrapping twine, horse and cow hairs, rags, paper and other substances that are readlly accessible. The nest represented in our illustration is taken from a typical specimen which I took from the branches of a sycamore in Franklin county, Ohio, May 23, 1884; other specimens in my collection are not so elaborately made. The number of eggs laid ranges from four to six. The ground-color is white, with a slight roseate tinge when fresh, fading into a bluish tint when blown, marked with blotches, lines, scrawls, and the usual hieroglyphics common to eggs of this genus, irregularly distributed over the surface, usually thickest about the larger end, forming a wreath. A set of flve 


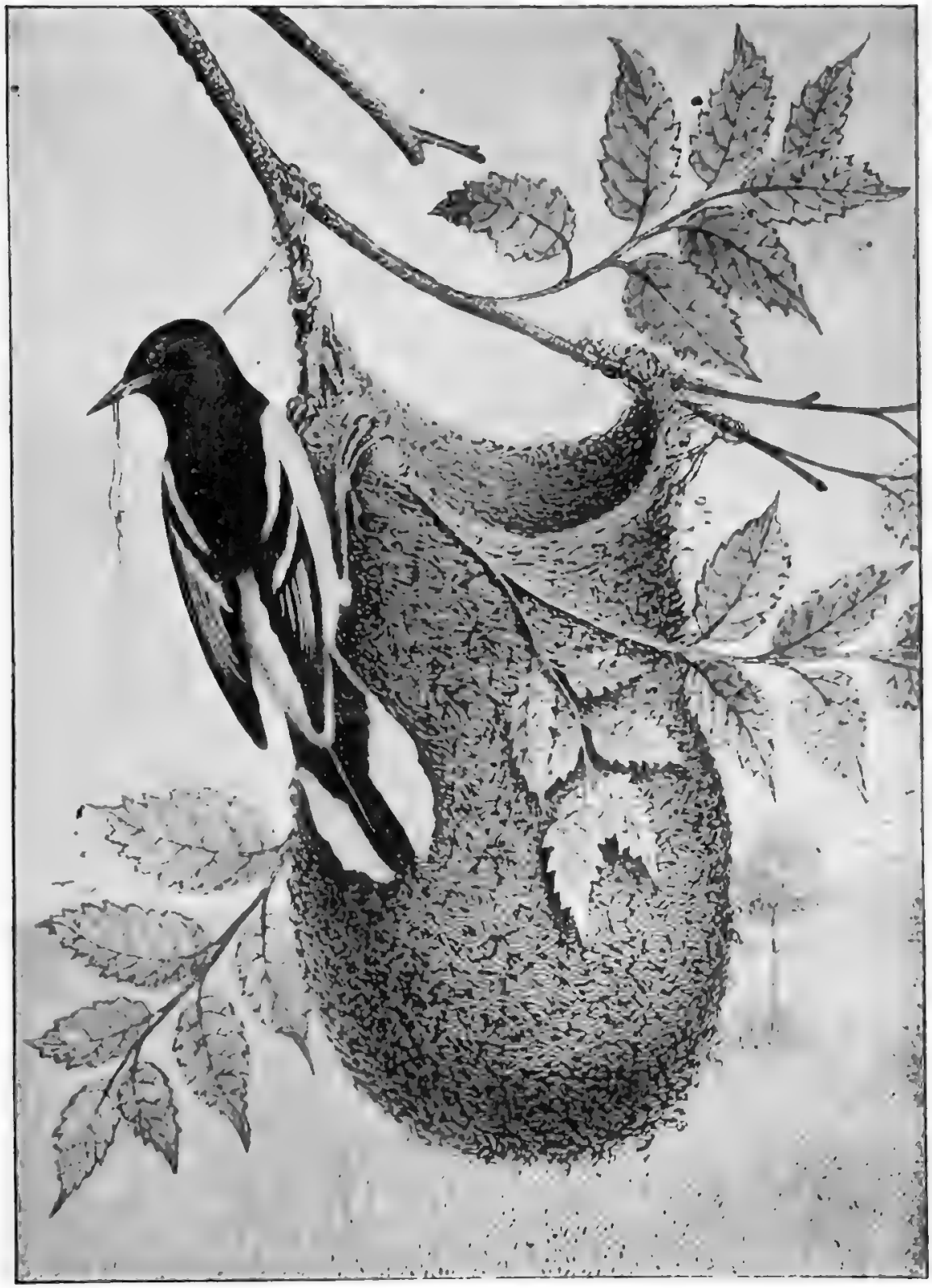

507. Baltisone ORtole and Nest (Jesper del.) 
measure, respectively, $.82 \times .62, .80 \times .62, .78 \times .60, .84 \times .64, .87 \times .63$; another set, four in number, $1.00 x .64,1.04 x .64, .98 x .64,1.08 x .67$. A common size of the Baltimore Oriole's egg is $.92 \times .62$.

508. BULLOCK'S ORIOLE. Icterus bullocki (Swains.) Geog. Dist.-Western United States east to and including the Rocky Mountains, south in winter to Mexico.

This is the western counterpart of the Baltimore from the Central Plains to the Pacific. The nests and eggs of the two species are hardly distinguishable. Mr. Shields says that Bullock's Oriole is not a common summer resident of Los Angeles county, California, and it begins building about May 1. Twenty sets, consisting of four and five eggs respectively, collected by Mr. R. B. Herron, in the latter part of May and first of June, at San Gorgonia Pass, California, are before me. In comparing them with a large series of $I$. galbula, the only difference, apparently, is that the ground-color of those of bullocki is of a paler and clearer bluish tint, upon which the markings stand out in bolder contrast.* The average size of fifteen specimens is .94x.62. The sizes of an average set of four are $.89 \times .64, .93 \times .66, .93 \times .66, .89 x .65$.

509. RUSTY BLACKBIRD. Scolecophagus carolinus (Mull.) Geog. Dist.Eastern and Northern North America, west to Alaska and the Plains. Breeds from Northern United States northward. Accidental in Lower California.

The Rusty Grackle or Thrush Blackbird is only a migratory species in most of the United States, and is only seen in small flocks in the spring and fall during its passages north and south. Breeds from the northern States northward. Mr. Ernest E. Thompson states that it is an abundant migrant in Western Manitoba, and breeds commonly about Big Plain and Winnipeg, building the nest on the ground of hair and fibres, much like that of a Savanna Sparrow on a large scale, and not necessarily near water. A nest was found June 24 near St. John, N. B., by James W. Banks; it contained two young and two eggs. The nest was placed in the upper branches of a spruce, twenty-eight feet from the ground. It was bulky and large for the size of the bird, composed chiefly of honeysuckle vines and mixed with mud, forming a solid mass. The smaller of the two eggs measured 1.09x.76. The eggs are described as varying from a grayish to a light green, very thickly covered with blotches and dottings of purplish and reddish-brown, without streaks and lines; usually four in number, varying much in the character of their markings. The variations are as great as are those in the eggs of the next species. The number laid is said to range from four to seven with an average size of 1.00x.76.

510. BREWER'S BLACKBIRD. Scolecophagus cyanocephalus (Wagl.) Geog. Dist.-Western North America, from the Great Plains to the Pacific, north to the Saskatchewan, south to the table-lands of Mexico.

The Blue-headed Grackle is an abundant species throughout the West, breeding in all suitable localities. In California it breeds in immense colonies. Mr. Shields states that in Los Angeles county it begins nesting about May 1. The usual number of eggs laid is five, sometimes six, and even eight. The nest is bullt in any suitable place-in the fork of a large bush or live-oak tree and in garden evergreens, at a

* A set of five eggs in this serles, taken June 8, seems to be unique in their groundcolor and markings. They are yellowish-buff, with a homogeneous mass of regular and itregular concentric rings about the larger ends, mingled with a few spots, blotches and bold streaks. These are of a rich reddish-brown, varying in intenslty, even approaching black. There are alse underlying circles and spots of purple. Their sizes are .87x.65, .88x.66, .2x.65, .93x.54, .95x.66. 
helght of twenty or thirty feet. It Is large and bulky and constructed externally of a rough frame of twigs, with a layer of mud, lined with fine rootlets, grasses, horse and cow hairs. As many as a dozen nests have been found in a single cypress tree. All the nests found by Mr. Bryant near Carson, Nevada, were upoz the ground, visually on the edge of a bank formed by an irrigating ditch, with the exception of one, which was bullt two feet from the ground upon dry tule and well bidden by the growing stems. In a large series of eggs extreme variations will be found in the shape, color and size. They are of a dull greenish-white or gray, with numerous streaks and blotches of dark brown; in some the markings are very large and of a liguter shade, in others smaller, but so numerous as to conceal the ground-color. Ten eggs measure: $.96 \times .71, .93 x .77,1.02 x .70,1.01 \times .76,1.03 x .68,1.00 x .73,1.05 x .75,1.06 x$ $.78,1.07 \times .73,1.09 \times .73$.

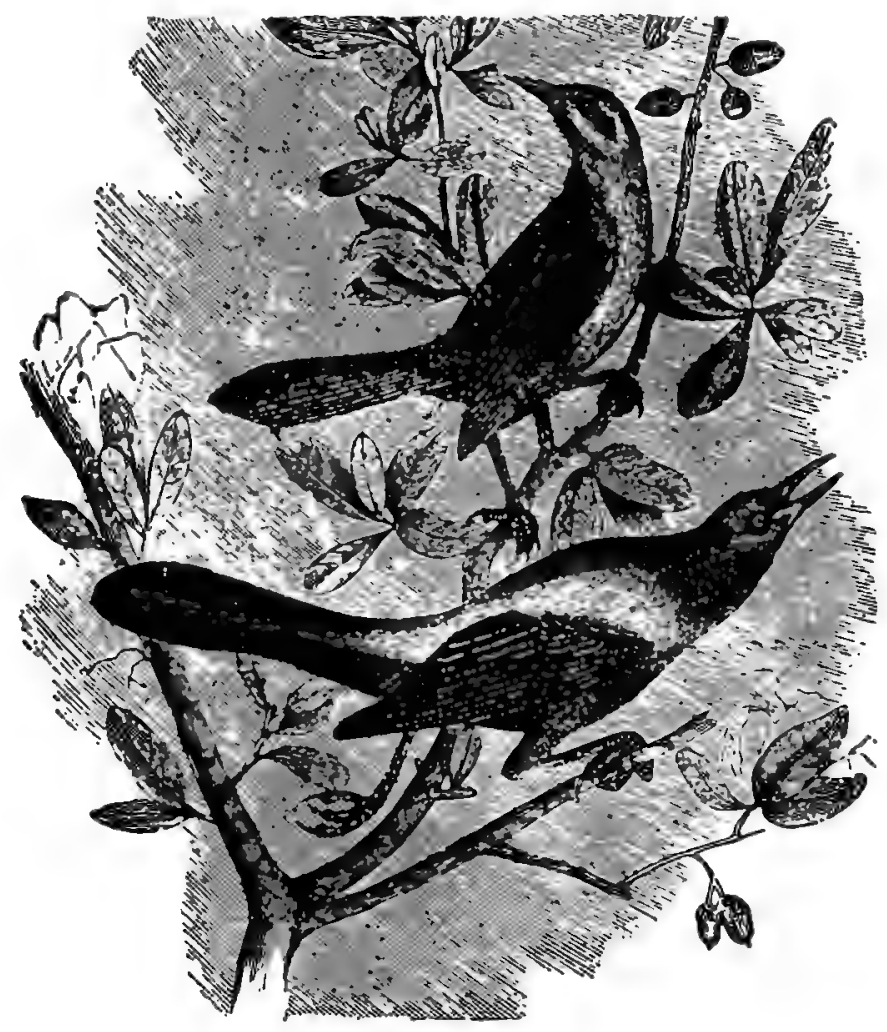

511. Purple Giackle (After Audubon).

511. PURPLE GRACKLE. Quisralus quiscula (Linn.) Geog. Dist.-Atlantic Coast of the United Statea (except Southern Florida), north to Massachusetts.

A well-known and an abundant species of the Atlantic coast, and commoaly called Crow Blackbird. Its nest is built in trees of almost any kind, usually, how- 
ever, those of thick foliage, and by preference coniferous trees. It is generally placed on the boughs, but sometimes in cavities, and quite often in hollow stubs in low trees near water. In secluded places the nest is not infrequently built in bushes. It is a loose, bulky affair of twigs, hay and grasses which are often cemented with mud. The eggs are four to six in number, and they present great variations in size and color. They are light greenish-white, with large dashes and irregular streaks of black and brown, in some chiefly at the larger end; in others the ground-color is of a rusty-brown; these are marked chiefly about the larger end with cloudy blotches of the same color. The average size is $1.18 \times .84$.

511a. FLORIDA GRACKLE. Quiscalus quiscula aglaus (Baird.) Geog. Dist.Chiefly southern portion of Florida, west along the Gulf coast to Louisiana.

This is a slightly smaller race of the Crow Blackbird than the preceding. Eggg in my cabinet collected in the vicinity of Charlotte Harbor, Florida, do not differ in size or coloration from those of quiscula oneus. The nesting season is in April, May and June.

511b. BRONZED GRACKLE. Quiscalus quiscula aneus (Ridgw.) Geog. Dist.Eastern North America, from the Alleghanies and New.England north to Hudson Bay, west to the Rocky Mountains.

The Bronzed Crow Blackbird is a very common species everywhere in its range. It begins nesting in fayorable seasons as early as the middle of March, and by the latter part of April many of the nests are finished and incubation has begun. Other nests may not be completed until sometime in May. It nests anywhere in trees or bushes, on boughs or in hollow limbs or stumps at any height. A clump of evergreen trees in a lonely spot is a favorite site; often large colonies will nest in such places; and it is also found breeding especially abundant in sycamore groves along streams and in oak woodland. A number of pairs will often find suitable nesting places in the trees of quiet orchards. The nest is a coarse, buiky structure, composed of grasses, knotty roots mixed with mud; the lining is fine, dry grass, horse hair or sheep's wool. The eggs are light greenish or smoky-blue, with irregular lines, dots, blotches and scrawls distributed over the surface; there is just as much variation in the eggs of this species as is found in those of purpureus, of the Atlantic coast. The number laid ranges from four to six, although on the 15 th of May, 1888, I found two nests containing seven each. The average size of ten specimens is $1.20 \mathrm{x} .82$.

512. GREAT-TAILED GRACKLE. Quiscalus marrourus Swains. Geog. Dist.-Southern Texas, south through Eastern Mexico to Central America.

Called the Fan-tailed Crow Blackbird or Texas Grackle. It is an abundant bird in Southern Texas. Concerning its nesting Dr. Merrill says: "Early in April, after several weeks of noisy courtship, they begin to build in irregular colonies, and by the middle of the month have eggs. The nests are perhaps most frequently placed near the top of one of the main upright branches of a young mesquite tree. "They are strongly built of straws, leaves and grasses, mud being used freely. Where Spanish moss is plentiful, the nests are sometimes composed entirely of it; and I have found them among tule-reeds, where several species of Herons were breeding. I have also found their nests either supported by the lower part of the nest of the Caracara Eagle, or in the same tree." The eggs are usually three in number, although Mr. Benners found many sets in Texas of four and five. They vary greatly in appearance; the ground color is usually a greenish-white or purplish-brown, more or 
less heavily spotted and dashed with several shades of brown. The markings are apt to be heavier at the smaller end. By this peculiarity they can usually be distinguished from those of $Q$. major. The average size of forty-five eggs is $1.26 \times .85$; largest $1.44 \times .91$; smallest $1.16 \times .82$.

513. BOAT-TAILED GRACKLE. Quiscalus major Vieill. Geog. Dist.-South Atlantic and Gulf States, north to Virginia, west to Texas.

Along the coast of the States that border on the Atlantic and the Gulf of Mexico, from the Carolinas to the Rio Grande, the Boat-tailed Crow Blackbird is an abundant. species. It is known as the Jackdaw. Breeds in colonies in reeds and rushes in the midst of swamps, or anywhere in trees, often a considerable distance from water, and the nests are also placed in bushes or upon trees at heights varying from twenty to forty feet. It is large and clumsy, made of coarse materials: sticks, dry grasses, weeds, strips of bark, lined with finer stems, fibrous roots and grasses. The nesting time is in April, May, and in June, according to locality. Three or four eggs are laid, of a brownish-drab; some tinged with olive, others with green; they are marked with irregular blotches of brown and black. Ten eggs measure: $1.20 \times .90 ; 1.21 \times .86$, $1.23 \mathrm{x} .87,1.27 \times .89,1.26 \times .89,1.27 \times .81,1.24 \times .84,1.30 \times .91,1.29 \times .84,1.28 \times .90$. The average size is $1.24 \times .81$ inches.

514. EVENING GROSBEAK. Coccothraustes respertinus (Coop.) Geog. Dist.Western British Provinces, east to Lake Superior, and casually to Michigan, Ohio, Ontario, New York, and New England.

This handsome bird is not uncommon in various portions of western North America, from the Rocky Mountains to the Pacific. It is a common resident of the forests of the States of Washington and Oregon. A specimen of this bird, a male, was killed by Mr. George Osbun in front of the Academy Hall of the Dennison University, Granville, Ohio, December 10, 1889. It was prepared by Prof. W. G. Tight, and is now in the museum collection of that institution. In Oregon Dr. Merrill observed the birds carrying building material to a huge fir tree, but was unable to locate the nest, and the tree was practically inaccessible. Mr. Walter E. Bryant was the first to record an authentic nest and eggs of the Evening Grosbeak. In a paper read before the California Academy of Sciences, June 20,1887, he describes a nest of this species containing four eggs, found by Mr. E. H. Fiske, in Yolo county, California. The nest was taken May 10, 1886, but the eggs could not be preserved, as incubation was so far advanced. In general shape, color, and markings, they were similar to. the eggs of the Black-headed Grosbeak, but in size, Mr. Fiske thinks, they were somewhat larger. The nest was built in a small live oak, at a height of ten feet, and was a more pretentious structure than is usually built by the Black-headed Grosbeak, being composed of small twigs supporting a thin layer of fibrous bark and a lining of horse hair. June 5, 1884, Mr. John Swinburne found a nest of the Evening Grosbeak in a thickly wooded canon, about fifteen miles west of Springerville, Apache county, Arizona. The nest was placed about fifteen feet from the ground, in the top of a small willow bush, on the border of a stream. It was a comparatively slight structure, rather flat, and composed of small sticks and roots, lined with finer portions of the latter. This nest contained three fresh eggs of a clear greenish-ground color, blotched with a pale brown.

514a. WESTERN EVENING GROSBEAK. Coccothraustes vespertinus montinus Ridgw. Geog. Dist.-Western North America, from the Pacific coast eastward to the Rocky Mountains; southward over the tablelands of Mexico to Orizaba. 
In general the Western Evening Grosbeak appears to be very different from that inhabiting the region of the Great Lakes and the north-central portion of North America. This has been shown from the study of quite extensive material by Dr. Edgar A. Mearns, U. S. A.* The reference made to the nests and eggs in the last species refers to this variety.

515. PINE GROSBEAK. Pinicola enucleator (Linn.) Geog. Dist.-Northern parts of the Northern Hemisphere. Breeds from Northern New England, Labrador, etc., to Alaska (except the coast south of the peninsula), and south in the higher Rocky Mountain regions to Colorado and Utah; in winter south to Northern United States.

This large, handsome, Grosbeak is resident in Northern New England, elsewhere in the Northern and Eastern States it is a winter migrant. Mr. Boardman found a nest with two eggs in it at Calais, Maine, supposed to belong to this species. Dr. Coues found it breeding in Colorado, living up near timber line, and observed young birds fully fledged in June. Mr. Mcllwraith thinks that it is hightly probable that this species may yet be found breeding in Ontario. The bird, according to Dr. Coues, inhabits chiefly coniferous woods in flocks when not breeding, feeding upon the fruit of such trees. "A fine musician, of amiable disposition and gentle manners, often caged. Nest composed of a basement of twigs and rootlets, within which is a more compact fabric of finer materials; eggs usually four, pale greenish-blue, spotted and blotched with dark brown surface markings and lilac shell-spots; 1.05x.74."

[516.] CASSIN'S BULLFINCH. Pyrrhula cassini (Baird.) Geog. Dist.Eastern Siberia. Accidental at Nulato, Alaska.

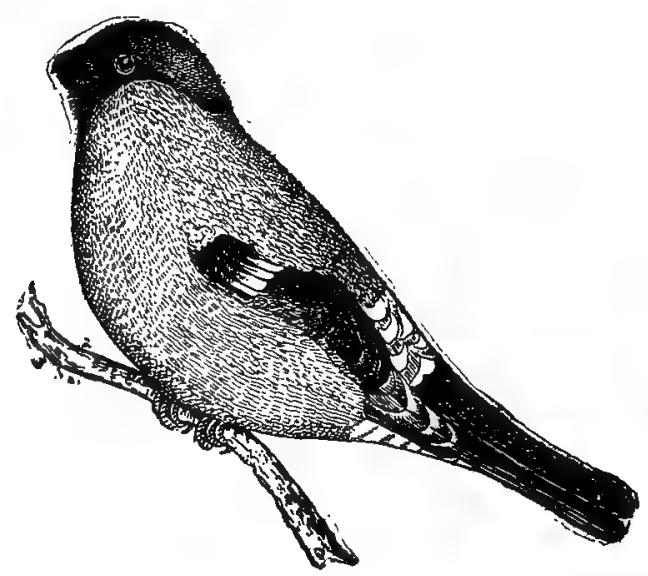

516. Cassin's Bullainch ; Adult, female (From Turner).

This bird belongs to the North American fauna solely upon the capture of a specimen at Nulato, on the Middle Yukon, June 10, 1867, by Mr. W. H. Dall. So far as I am aware its' nesting and eggs remain to be described.

*Cf. A.tk, VII, pp. 246-249. 


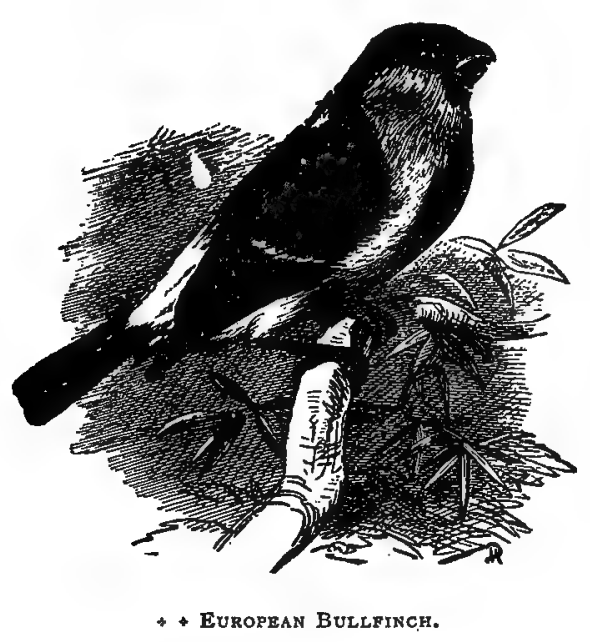

517. PURPLE FINCH. Carpodacus purpureus (Gmel.) Geog. Dist.-Eastern North America. Breeds from northern United States northward.

Called Purple Grosbeak, Crimson Finch or Linnet. It is found breeding regularly in the northern tier of States-the Dakotas, Minnesota, Wisconsin, Michigan, etc., northward, and is said to have been found nesting in northern Illinois. An abundant bird in New England, where its sweet song, bright colors and sociable disposition have made it a favorite bird. It nests in May and June. The Rev. J. H. Langille states that he has found it nowhere so abundant as in Nova Scotia. The nest is usually placed in evergreens or orchard trees, at a moderate distance from the ground. It is composed of weed-stalks, bark-strips, rootlets, grasses, all kinds of vegetable fibres, and lined with hairs. The nests and eggs remind one of the Chipping Sparrow's on a large scale. The eggs are of a dull green, spotted with a very dark brown, chiefly about the greater end; four or five in number, and measure $.85 \times .65$.

517a. CALIFORNIA PURPLE FINCH. Carpodacus purpureus. californicus Baird. Geog. Dist.-Pacific coast of the United States, from British Columbia south to Southern California.

The California Purple Finch is a common bird throughout its range. Mr. William A. Cooper notes it as abundant around Santa Cruz, California. He states that it is a most destructive bird, visiting orchards and destroying young buds, blossoms, and fruit. It retires to the wooded river bottoms and hills to breed; the favorite situations for the nest are the tops of tall willows, alders, trees covered with climbing ivy, and horizontal branches of redwoods. The nests are usually placed at a considerable distance from the ground; one was found placed in the horizontal branches of an apple tree; the composition of the nests consist of stems and vegetable fibres for the frame-work, which is generally loosely put together; the inner portions are of finer material of the same, lined with wool or a few hairs. The eggs are four or five in number; they are of a bluish-green or light emerald, marked with spots of brown and dull purple, chiefly around the larger end; in some specimens they form a confuent ring; others are spotted over the entire surface, but less abundantly 
than at the end. Mr. Cooper gives the sizes of a set of four taken May 2, as .83x.57, $.81 x .56, .81 x .56, .81 x .56, .80 x .54$; another set, taken May 3 , give the following measurements: $.75 x .55, .73 x .56, .72 \times .56, .71 \times .57^{*}$

518. CASSIN'S PURRLE FINCH: Carpodacus cassini Baird. Geog. Dist.Western United States, from the Rocky Mountains to the Pacific north to British Columbia, south over the highlands of Mexico.

A common bird in Colorado, Utah, Nevada and Eastern California. Its general habits, nesting and eggs are very similar to those of the Purple Finch of the East. The nest is found in various situations, box-alder bushes, the tops of cottonwood, aspen and pine trees. It is composed principally of roots and twigs, lined with softer material of the same, together with moss and cotton. The eggs are usually four in number, and a typical specimen is oval in shape, pointed at the smaller end. The color is light bluish-green, dotted around the larger end with slate, lilac and blackish-brown. The average size is $.84 x .62$.

519. HOUSE FINCH. Carpodacus mexicanus frontalis (Say.) Geog. Dist.Western United States, from the Rocky Mountains to Pacific coast (chiefly south of $40^{\circ}$ in the interior), and south through Western and Central Mexico to Colima and Guanajuato, Lower California. (Ridgw.)

This bird is known as the Red-headed Linnet or Burion. We also include under this head the supposed race $C$. frontalis rhodocolpus (Cab.) It is a very common bird in the interior region of the United.States, from Nevada, Utah and Colorado southward, and is also abundant on the Pacific coast. Mr. Shields mentions this as one of the best known birds of Southern California. Prof. Evermann found it to be by far the móst common bird of Ventura county, and obtained the first full complement of eggs early in April. The bird will place its nest anywhere, from the limb of any tree to the side of a haystack or a tin can on a porch. It is made of anything that the bird happens to find handy-grasses, straws, roots, etc., and the nest of an Oriole or Cliff Swallow is often occupied. Mr. Shields states that in Los Angeles county, California, this species begins nesting in the first part of April, and eggs may be found from that time into the first of July. Two, and sometimes three broods are reared in a season. The eggs are four or five, usually five in number; their color is of a pale bluish or, as some would call it, pale greenish-blue, sparsely marked with spots, specks and lines of very dark brown or black, chiefly around the larger end. Some specimens before me are unmarked. An average set of five eggs offer the following measurements: $.82 \times .57, .85 \times .54, .84 x .55, .83 \times .54, .82 \times .52$. The average of twenty specimens is $.82 x .58$.

519a. ST. LUCAS HOUSE FINCH. Carpodacus mexicanus ruberrimus Ridgw. Geog. Dist.-Lower California and probably adjacent parts of Sonora.

Mr. Walter E. Bryant found this variety of the House Finch breeding at Comondu, Lower California, where most of the nests were placed in palm trees. A nest containing two fresh eggs was collected March 31 from the under side of a veranda awning of an adove house amongst the thick vine branches. Mr. Bryant says: "The nest was like similar ones of this genus adapted to the space wherein it was built, and composed of such material as was nearest at hand. In this case rootlets, a bit of rag and considerable wild cotton, enter into the external composition, while a few shreds from plant stalks, a quantity of wild cotton, and lastly, some horse hairs com-

* Buli. Nutt. Ornith. Club, III, pp. 8-10. 
plete the Interior. 'Both birds were about while the nest was being'removed; the male was intensely bright colored. A few days later this pair began another nest under the same roof near the old site: The eggs are not distinguishable from eggs of $\boldsymbol{G}$. frontalis from California. They are sparsely marked with black in an irregular wreath about the larger end. In size they measure $18.5 \times 15$ and $19 \times 15$ millimetres."*

520. GUADALUPE HOUSE FINCH: Carpodacus 'amplus Ridgw, Geog. Dist.-Guadalupe Island, Lower California.

This darker colored House Finch was found to be quite common on Guadalupe Island, by Mr. Bryant, when he visited that place in 1885. The species did not differ in its habits or song from frontalis. February 22 two nearly completed nests weré found in cypress trees, and one with five eggs was taken March 1 . The last nest taken was on April 7, and contained five eggs with small embryos in them. Nearly all the nests were placed on the branches of cypress trees; the birds seemed to show a preference for the leeward side, where the nest would be protected from prevailing winds. One pair built in a clump of mistletoe at a height of twenty feet; others built in the tops of palms. The materials used were the finer dead stems of weeds; in one nest the foundation and sides were made of pine needles. The lining was invariably of goat's hair. The eggs, sometimes four in number, but oftener five, during the early part of the season, are colored precisely like the average specimen of $C$. $m$. frontalis, the spots being either sparingly applied or entirely wanting. They' also resemble them in general shape, but the size serves to distinguish them. Five eggs in one set measure $22 \times 15,22 \times 15.5,22.5 \times 15.5,23 \times 15.5,23 \times 16.5 \mathrm{~mm} . \dagger$ The length measurement varies from $19.5 \times 24 \mathrm{~mm}$., and the width $15 \times 16.5 \mathrm{~mm}$. The average size of thirty-two specimens is $21.3 \times 15.5 \mathrm{~mm}$.

521. AMERICAN CROSSBILL. Loxia currirostra minor (Brehm.) Geog. Dist.-Northern North America, resident sparingly south in Eastern United States to Maryland and Tennessee, and in the Alleghanies; irregularly abundant in winter. Casual at Charleston, S. C., and New Orleans, La.

A curious bird, whose home is in boreal regions; and at times, even turing the season of reproduction, straggles far southward. The American Red Crossbill is known to breed in Northern New England, and from thence northward. Breeds sporadically in mountainous regions south as

far as New York, Pennsylvania, Central Maryland, Virginia, Northern Georgia, Tennessee and Kentucky. It may be found breeding where least expected. The nesting time is usually in February and March, while the snow is yet on the ground. In the Lower Hudson Valley, Mr. Eugene P. Bicknell found a nest of this species on the 30th of April, containing three eggs. The nest was placed in a cedar of rather scanty foliage, about eighteen feet from the ground, and was without any main support, being built in a mass cf small, tangled twigs. The composition externally was of spruce twigs, loosely arranged; the main body of the structure was a mass of matted shreds of cedar bark, while

*.74x.59, .75x59 inches.

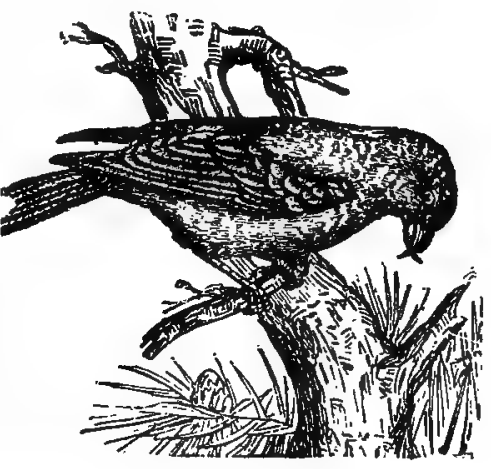

521. Crossbill.

$*+.87 \times .59, .87 \times .61, .89 \times, 61, .91 \times .61, .91 \times .65$.

₹.77 to .95 in length by .59 to .65 in breadth; average $.84 x .61$. 
the inside was felted by finer material, and lined with horse hair, fine rootlets, grass stems, pieces of string and two or three feathers. The structure also contained small pieces of moss, leaves, grass, string, cottony substances, and the green foliage of cedar.* The eggs are three or four in number, usually four. Mr. Bicknell gives the sizes of the three eggs which this nest contained as $.74 \mathrm{x} .56, .75 \times .58, .78 \times .59$ respectively. The color of the eggs is pale greenish, spotted and dotted about the larger end with various shades of brown and lavender shell-markings; average size .75x.57.

521a. MEXICAN CROSSBILL. Loxia curvirostra stricklandi Ridgw. Geog. Dist.-Mountains of Wyoming and Colorado, west to the Sierra Nevada, and south through New Mexico, Arizona and the tablelands of Mexico to Guatemala.

The nesting and eggs of this subspecies are probably indistinguishable from those of the American Crossbill.

522. WHITE-WINGED CROSSBILL. Loxia leucoptera Gmel. Geog. Dist.Northern North America, south into the United States in winter to or beyond $40^{\circ}$. Breeds from Northern New England and higher Rocky Mountains northward.

This is not so common a species as the Red Crossbill, although they are both frequently found associated in deep evergreen woods. The White-winged Crossbill is resident in Northern New England, and from the Rocky Mountain region of Colorado, Wyoming and Montana northward: It is possessed of the same uncertain and erratic disposition as $L$. c. minor, and its movements are not to be relied upon; for this reason, it is likely to be found breeding in suitable places in any of the northern tier of States. It breeds in winter or early spring, and the nesting is said to be like that of the Red Crossbill. The eggs are described as pale blue; the larger end rather thickly spattered with fine dots of black and ashy-lilac; the size .80x.56. They are said to resemble those of the Purple Finch.

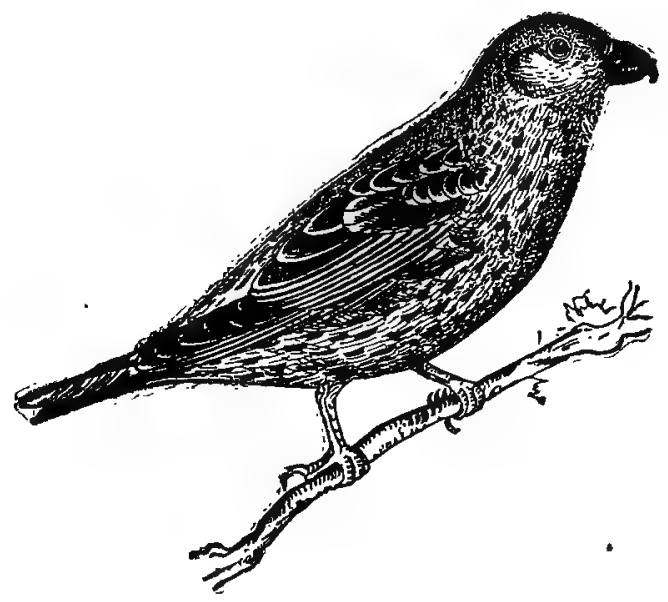

522.' White-Winged Crossbitl (From Turner).

523. ALEUTIAN LEUCOSTICTE. Leucosticte yristonucha (Brandt.) Geog. Dist.-Aleutian and Prybilof Islands, Alaska; west to Commander Islands, Kamchatka; east to Kadiak.

* For full account of this nest and the eggs see Bull. Nutt. Ornith. Club, Vol. V, pp. 7-11. 
The Aleutian Rosy Finch is the largest of the species of this genus known to in. hobit North America. It is found in abundance on the Prybilof and other Aleutian Islands. Dr. Stejneger states that on Bering Island it cannot be said to be numerous, except perhaps in a few places where the localities are favorable. Copper Island, being one mass of rugged and cracked rocks and cliffs, with steep, often quite perpendicular walls, jutting up straight out of the ocean, is the favorite haunt of these stone-loving birds, which may be said to be fairly common on that island, occurring in pairs around the whole isle during the breeding season. In the latter half of June he found parents feeding their young, and full-fledged young were taken July 7. Many pairs produce two broods in a year. Turner says: "This bird prefers the bold, ragged cliffs along the sea shore. They are constantly in motion, either on the wing, flying in sweeping, long curves, sometimes near the earth, to mount thirty or forty feet at a single effort, alighting on some projecting ledge of a bluff to search for food, and away again to alight for a moment on a weed stalk. Their nest is built on a small protected ledge of a bluff, or else in a small crevice. A nest was obtained by me from a small cleft of a rock on the side of a high bluff. It was composed of sthall pieces of wild parsnip stalks, coarse grass stems, and finer blades of grass to form the lining. The nest is not elaborate, the material being somewhat carelessly arranged. Four (sometimes five) white eggs are laid in the early part of June. The young are able to fly by the first of August." The nests and eggs of others of this genus are not certainly known, but probably resemble those of griseonucha. The eggs are described as being pure white without markings, three to six in number, usually four; size $.97 \times .67$.

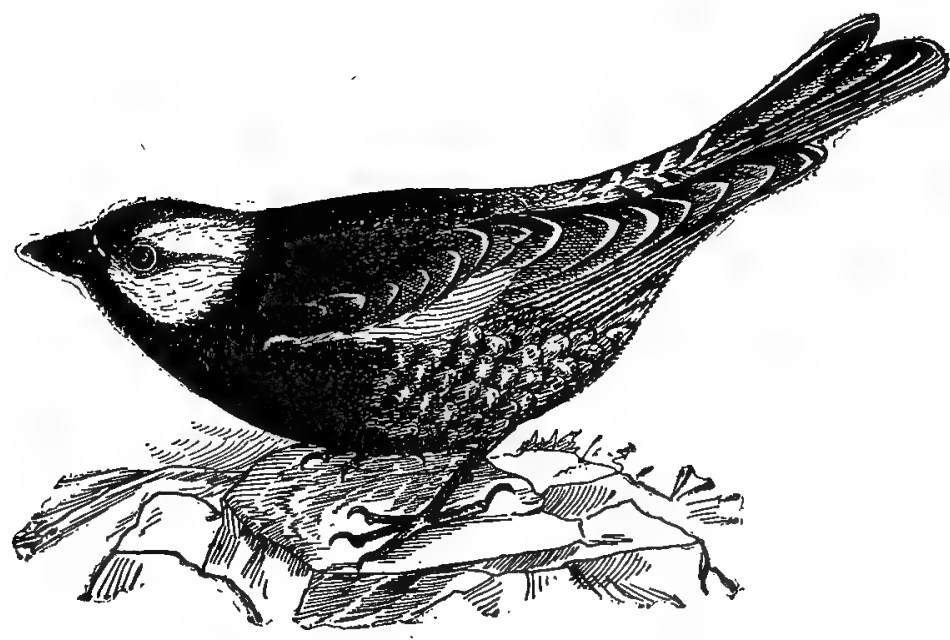

523. Aleutian Ledcosticte (From Turner).

524. GRAY-CROWNED LEUCOSTICTE. Leucosticte tephrocotis Swains. Geog. Dist.-Interior of British America, south in winter throughout the entire Rocky Mountain region of the United States; most abundant on the eastern slope.

- This is Swainson's Rosy Finch which is known to breed only in the Sierra Nevadas in California. Its general habits, nesting and eggs are identical with those of the Aleutian Leucosticte. 
524a. HEPBURN'S IEUCOSTICTE. Leucosticte tephrocotis littoralis (Baird.). Geog. Dist.-In summer, probably the interior mountainous regions of British Columbia; in winter, northwest coast, from Kadiak southward, and eastward in the Rocky Mountain region to Colorado.

Hepburn's Leucosticte is of the same size as the last, but the gray of the head is spread more or less extensively below the upper margin of the ear-coverts, sometimes covering the entire head.

525. BLACK IEUCOSTICTE. Leucosticte atrata Ridgw. Geog. Dist.-In winter, mountains of Colorado and Utah.

The male of this species is of a sooty blackish color, the female sooty slate; the head same as in the Gray-crowned Leucosticte. Breeds in the Salmon River Mountains, Idaho, and probably other northern ranges.

526. BROWN-CAPPED LEUCOSTICTE. Leucosticte australis Ridgw. Geog. Dist.-High mountains of Colorado; in winter descending into the lower valleys, New Mexico, etc.

The Brown-capped Leucosticte breeds in the mountains of Colorado, above timber line. The general color of the bird is light tawny brown.

527. GREENLAND REDPOLL. Acanthis hornemannii (Holb.) Geog. Dist.Greenland and Eastern Aretic America.

According to Hagerup this species is a resident of Greenland, breeding quite commonly north of $69^{\circ}$. The nest is placed in trees or bushes, and is composed of moss, grass, lined with vegetable down. Seebohm states that the eggs of this species are similar to those of the Mealy Redpoll, A. linaria, of Linnæus.

527a. HOARY REDPOLL. Acanthis hornemannii exilipes (Coues.) Geog. Dist.-Circumpolar continental regions; Arctic America.

The Hoary Redpoll Linnet inhabits the whole of boreal America, and it is found in abundance from Alaska to the Atlantic coast, rarely reaching the United States, and then only along the northern tier of States in winter. It breeds in high latitudes, nesting in trees and bushes. The nest is described as rather bulky, composed of small twigs, straws, etc., mixed and lined with feathers. The eggs are two to five in number, of pale bluish-green, speckled chiefly about the larger end, with reddishbrown, sometimes mixed with a few black specks and lines. Ridgway gives the average size of the eggs as $.68 \times .51$.

528. REDPOLL. Acanthis linaria (Linn.) Geog. Dist.-Northern portions of Northern Hemisphere; in North America migrating south in winter to the Middle Trnited States, Virginia, etc.

The Redpoll Linnet occurs in the United States as a winter migrant. It comes south from its breeding grounds in high latitudes, often in company with Pine Grosbeaks and Crossbills, but is so erratic in its movements that its appearance cannot be relied upon. It breeds occasionally in Northern New England; also in Nova Scotia, Newfoundland, and commonly in Labrador and all the Fur Countries. Dr. Stejneger says that this form of the Redpoll seems to be the common breeding bird on the mainland of Kamchatka, where he took a very young specimen near Petropaulski on the 4th of July. He does not think that this species breeds on the islands, as none were met with from the end of May until the beginning of November. 
The bird's general habits are very similar to those of the American Goldfinch. The neat is built in trees and bushes, is bulky, made of twigs and grasses, with generally a warm lining of feathers. A set of six eggs in Mr. Norris' cabinet were taken May 14, 1885, near Loughboro, England. Their ground-color is bluish-green, speckled chiefly at the larger ends with burnt umber; sizes $.62 \times .49, .65 \times .47, .60 \times .45, .62 \times .49$, $.64 \times .48, .64 \times .47$. The average size is $.67 \times .48$.

528a. HOLBCELL'S REDPOLL. Acanthis linaria holbœllii (Brehm.) Geog. Dist.-Northern portions of Northern Hemisphere, near sea coast, south in winter to Northern New York and Massachusetts.

An intermediate subspecies between $A$. linari and $A, l$. rostrata. It approaches the former closely and is with difficulty distinguished. A rare bird in Eastern North America.

528b. GREATER REDPOLL. Acanthis linaria rostrata (Coues.) Geog. Dist.Greenland and Northeastern North America, south irregularly in winter to New England, New York and Northern Illinois.

This is a similar bird to A. linaria, but larger, the feathers of the upper parts averaging darker, bill shorter and stouter. Hagerup states that in Greenland it is a summer visitor, but is found occasionally in small flocks or singly in winter. It is very prolific in South Greenland, but less so in the northern portion. Eggs are laid from May 20 to June 27, and their number ranges from four to seven in a set. The eggs are described as being not distinguishable from those of the Greenland Redpoll. According to Hagerup the nests are placed in willow bushes, generally in the lowest branches, about three or three and a half feet from the ground.

529. AMERICAN GOLDFINCH. Spinus tristis (Linn.) Geog. Dist.-Whole of temperate North America, resident; wintering mainly within the United States.

Thistle-bird, Yellow-bird, Lettuce-bird and "Wild Canary" are the names commonly applied to this species. It is distributed throughout North America generally, and breeds southward to the middle districts. In the United States it is a well known bird; its conspicuous bright colors, peculiar undulating flight, and its plaintive, lisping notes are familiar to even the casual observer. It nests when most other birds are through breeding-in some localities, however, as early as June 15 , but usually in July, or when the thistle-down begins to float on the breeze, in August and September. Exceptionally, nests with eggs have been found in May. The nest is a beautiful, compact, felted mass of vegetable fibres, moss, grasses, leaves, fine strips of bark, lined with plant down, and the nests that are built late enough in the season usually have a thick lining of thistle-down. It is placed in all kinds of trees and bushes, ranging from three to forty feet above the ground. Willows, maples and orchard trees seems to be favorite nesting sites, and not infrequently it is found built in the tops of thistle plants. Mr. Walter E. Bryant records the following unusual nesting place of the American Goldfinch as observed by $\mathrm{Mr}$. A. M. Ingersoll, in California: "In 1884 a grove of young willows that had been occupied the previous season by a colony of tri-colored blackbirds, was found deserted by them. Many of the blackbirds' nests still remained in forks of the willows from four to ten feet above the marsh. Six of these old nests were in possession of American Goldfinches. The present tenants had loosely filled the nests about one-half full 
of cat-tail down, and had formed only a slight hollow for the nest proper. Some were found with eggs, and in others there were 'birds in last year's nests.' " Some writers state that the eggs of the Goldfinch range from three to five in number. This is not correct, at least in Ohio. The number to a set varies from three to six. In the month of August and during the first two weeks of September, 1888, Mr. Rudolph, A. L. Baker and myself collected twenty-nine nests with eggs of the Goldfinch. Out of this number eleven contained six eggs, ten contained five, five were of four, and three were of three eggs each. Sets of five and six are common. The color of the eggs is plain, pale bluish or greenish-white, unspotted. Ten eggs measure .62x.48, .61x.49, $.61 \times .48, .62 \times .51, .63 \times .52, .65 \times .52, .67 \times .51, .67 \times .52, .66 \times .52, .67 x .52$. An average sppecimen measures .65x.52.

529a. WESTERN GOLDFINCH. Spinus tristis pallidus Mearns. Geog. Dist.-Arizona.

This appears to be a well-marked geographical race from Arizona; its general color being described by Dr. Edgar A. Mearns as being decidedly paler than that of $\boldsymbol{S}$. tristis. Other peculiarities seem to be distinctive of this local race. Its general habits, nesting and eggs are identical with those of S. tristis.

530. ARKANSAS GOLDFINCH. Spinus psaltria (Say.) Geog. Dist.-Western United States from the Great Plains to the Pacific, north on the coast to Oregon, in the interior north to Colorado and Utah, southward to Sonora.

This species is also called the Arkansaw Green-backed and Rocky Mountain Goldfinch. It is an abundant bird in the West, nesting like its Eastern cousın, the American Goldfinch, in trees and bushes. In California it breeds from the latter part of April to the middle of July; May and June being the most general breeding months. Ten nests containing four eggs each, collected by Mr. R. B. Herron, at San Gorgonia Pass, California, in May and June, are iz my cabinet. The eggs are of the same color as those of $S$. tristis, pale greenish-blue, but are much smaller. The nests are also smaller-some of the more elaborately built nests of tristts are almost double the size of those of $S$. psaltria. Ten eggs measure $.63 \times .46, .60 \times .45, .62 \times .41$, $.62 \times .42, .59 \times .46, .63 \times .44, .63 \times .47, .63 x .48, .64 x .47, .63 x .45$; comparatively little variation in size. Four eggs is the usual number laid, rarely five.

530a. ARIZONA GOLDFINCH. Spinus psaltria arizono (Coues.) Geog. Dist.-Southwestern portion of the United States, North to Arizona and Colorado, East to Texas and Mexico.

The general habits, nesting and eggs of this subspecies are exactly the same as those of the Arkansas Goldfinch.

530b. MEXICAN GOLDFINCH. Spinus psaltria mexicanus (Swains.) Geog. Dist.-Valley of the Lower Rio Grande in Texas, southward through Mexico.

The general habits, nests and eggs of this subsjecies are identical with those of the Arkansas or the Arizona Goldfinch. 
531. IAWRENCE'S GOLDFINCH. Spinus lawrencei (Cass.) Geog. Dist.Valifornia, in winter southeastward to Arizona.

Lawrence's Goldfinch is a common bird in California where it breeds in abundance, placing the nest usually near the extremity of the limb of a live oak, where it is well concealed and hard to find. They nest in April, May and June. Professor Evermann says he found the first full set of eggs in Ventura county, April 6. The nest is composed of wool, fine grasses, down and feathers, closely matted together and lined with the long hair of the larger animals. They are often made entirely of grasses. The latter is chiefly the composition of four nests before me taken by Mr. Herron in May and June. The eggs are four or five in number, and are pure white. Four typical eggs before me measure as

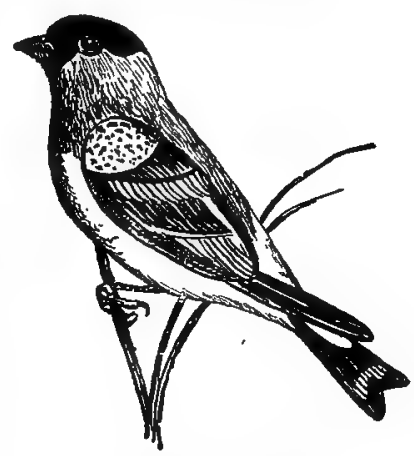

531. LAWRENCE'S GOLDFINC1! follows: $.62 x .47, .64 x .45, .62 x .44, .62 x .48$; a set of five collected at San Gorgonia Pass, by Mr. Herron, June 22, offers the following sizes: $.56 \mathrm{x} .45, .58 \mathrm{x} .45, .61 \mathrm{x} .46, .62 \mathrm{x} .46, .64 \mathrm{x} .44$.

[532.] BLACK-HEADED GOLDFINCH. Spinus notatus (Du Bus.) Geog. Dist.-Mountains of Guatemala and Southern Mexico, north at least to Central Vera Cruz; accidental in Kentucky (Audubon).

There appears to be no authentic written history concerning the nidification of this species. There is no doubt that its general habits correspond with those of others of this genus.

533. PINE SISKIN. Spinus pinus (Wils.) Geog. Dist.-Northern North America, breeding from Northern United States northward; South in winter to Mexico.

The Pine Linnet, Pine Finch, or American Siskin, breeds throughout the British Provinces, Northern Maine, New Hampshire, Vermont, New York, Michigan, thence to Oregon and Washington, in evergreen forests. Its breeding within the United States, however, is by no means of common occurrence. It has been found nesting by Dr. Merriam and others in New York and various New England States. Dr. J. A. Allen obtained a set of four eggs of this species at Cornwall-on-Hudson, Orange county, New York, May 12, 1887. The nest which contained these eggs was placed in the extremity of an upper branch of a Norway pine, about thirty-five feet from the ground.* Another nest was found by Dr. A. K. Fisher, at Sing Sing, New York, on May 25. It was situated in the top of a red cedar, about twenty-four feet from the ground and contained four nearly fresh eggs. $\dagger$ In both cases the birds were observed carrying building material to the nests. The late Captain B. F. Goss had a set of four eggs which was taken June 25, 1887, in Northern New York. The nest was placed near the top of a birch tree, and was made of dry grasses and pine needles, with a lining of feathers. The ground-color of the eggs is greenish white, spotted with various shades of brown; one of the eggs of this set is quite thickly spotted over the whole surface; on another specimen the spots are mostly confined to the larger end. The other two are faintly marked, and one of them is almost immaculate. Their sizes are: $.67 \times .45, .68 \times .48, .67 \times .48, .69 \times .47$.

* For full account of this nest and the eggs see The Auk, IV, pp. 284-286.

† Bull. Nutt Ornith. Club. VIII, pp. 180-181. 


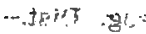

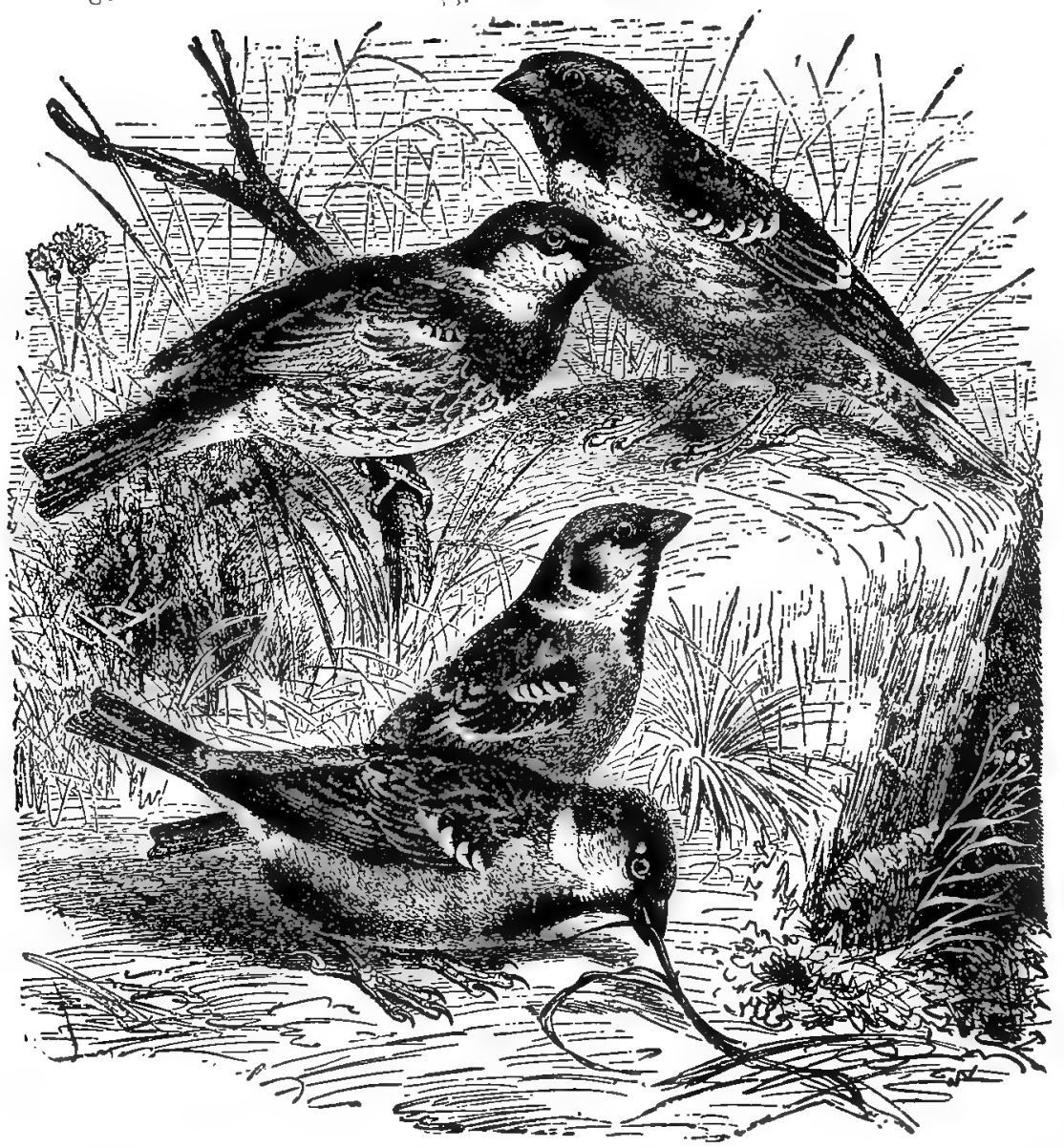

- Exotic Sparrows. Lower figure, House Sparrow; nezt, European Tree Sparrow (From Brehm).

* GOLDFINCH. . Carduelis carduelis (Linn.) Geog. Dist.-Europe and Western Asia; introduced and naturalized in portions of Eastern United-States.

The European Goldfinch has been introduced and successfully naturalized in various portions of Eastern United States, as in New York, Hoboken, New Jersey and in the vicinity of Cambridge, Mass., etc. In Central Fark, New York city, it is considered a common resident. April 20, 1886, Mr. E. T. Adney discovered two nests In Central Park, one of which contained five fresh eggs. The nests were placed in pine trees, among the tufts of long pine needles, near the end of a slender horizontal limb, about twelve feet from the ground. The nest of the European Goldfinch Is a handsome, compact, cup-shaped structure, made of fine, soft grasses, vegetable flbres and mosses. It is thick-walled and substantial, often built in bushes and 
various kinds of trees. The eggs are four to six in number of greenish-white, or light greenish-blue, dotted with reddish-brown around the larger end. Their average size is $.72 \times .50$.

* * EUROPEAN HOUSE SPARROW (ENGIISH SPARROW). Passer domesticus (Linn.) Geog. Dist.-Europe, etc.; introduced into the United States.

It is a matter of sincere regret that these rats of the air were ever introduced into America. The English Sparrow,* by which name it is so widely known, was first introduced into the United States at Brooklyn, N. Y., in 1851 and 1852; at Portland, Me., in 1854 and 1858; Boston, Mass., 1858, 1864 and 1869; in New York city 1860, 1864 and 1866; Cleveland, Ohio, and various other towns throughout the state between 1869 and 1872. As far West as Iowa it was introduced as late as 1881. It was fully. established in the city of Quebec, about the year 1866. From these and other points its numbers have spread and multiplied over vast territories east and west, north and south. In many instances the first birds introduced did not thrive, and it was frequently necessary to replenish their broken numbers with new recruits before they were acclimatized. There are chiefly two offences with which this pest is charged: The destruction of grain and fruit, and the molestation of many of our native birds whose nesting places it captures through sheer force of its numbers. Amiong the latter I may name the Bluebird, Martin, Downy Woodpecker, Crested Titmouse, White-breasted Nuthatch and others whose nesting places are in holes of trees or in boxes put up for their purpose. Had the wise men who first introduced these hoodlums into this country traveled a little farther east-to Great Britain and Germany-for the purpose of ascertaining the true character of this bird's nature, they doubtless would have been as eager to have spent their time and money in order to keep them out of this country as they were enthusiastic to introduce them. We believe, however, it has come to stay, and the problem now is, how shall we get rid of it? The nest of this Sparrow is built in all conceivable places, in the branches of trees, vines upon walls, in bushes, in open buildings, in all manner of cracks and crevices about buildings, in boxes located anywhere and in holes in trees. The nest is composed of straw, hay, grass, feathers, and any rubbish that happens to be near. A nest, which was composed of steel turnings of a lathe, was lodged on a beam in the Panhandle shops at Columbus. Two broods had been reared in this nest in one season. The House Sparrow may be said to do more or less building every month of the year, but rarely if ever raises more than six broods in a year, the majority probably not more than four. The eggs in a set range from four to seven, usually five or six in number; they are of a dull whitish color, thickly speckled and dashed with dark brown and purplish gray; size about $.87 \times$ x. 64 inches.

\section{* * EUROPEÁN TREE SPARROW. Passer montanus (Linn.) Geog. Dist.-} Europe; naturalized about St. Louis and elsewhere.

This species looks very much like the European House Sparrow, and it nests similarly-in holes of trees, nooks and corners of isolated buildings, etc. The eggs are fcur to six in number, similar to those of $P$. domesticus, but averaging "smaller and usually darker and redder." The bird is thoroughly naturalized in the vicinity of St. Louis, Mo.

"The name "English Sparrow"' is a misnomer, as the species is not confined to England, but is native to nearly the whole of Europe. Most of the birds imported into this country came from England, hence the misleading name. 
534. SNOWFLAKE. Plectrophenax nivalis (Linn.) Geog. Dist.-Circumpolar regions, except islands of Bering Sea; south in winter to Northern United States; irregular to Georgia, Southern Illinois and Kansas.

This beautiful, white bird breeds in the high Arctic regions, only visiting the Northern United States in winter in large flocks. It is known as the Snow Bunting, and is beautifully called a "warm-blooded Snowflake." Many a dreary winter landscape is made a picturesque scene when thousands are seen in their fight drifting - before a storm. The nest of this bird is placed on the ground, and is often hidden by a tussock of grass or rock; it is built of grass peculiar to the Arctic regions, mixed with moss, is very substantial, with thick walls, and a small, deep cavity, which is warmly lined with feathers. Mr. Norris has a set of four eggs of this species, which was taken in Iceland, May 30, 1882. The eggs were fresh, and are of a pale greenishwhite, speckled and spotted, most heavily near the larger ends, with russet and lilac-gray. Their sizes are $.84 x .61, .88 \times .67, .88 \times .61, .86 \times .64$. The ground-color in a large series is said to vary considerably-from whitish to dull purplish or greenish tint, and the average size is $.91 \times .64$.

534a. PRYBILOF SNOWFLAKE. Plectrophenax nivalis townsendi (Ridgw.) Geog. Dist.-Prybilof Islands, Alaska, and Commander Islands, Kamchatka.

This new subspecies is doubtless the bird found breeding by Dr. Stejneger on Bering and Copper Islands, in June and July. He states that it is resident on the islands during the whole year. If the season is open and otherwise favorable, the first eggs will be laid shortly after the middle of May; the young will be out in the beginning of June. In July he found fresh eggs of a second brood. The smallest eggs in the number taken measure $.94 x .69, .96 x .67, .93 \times .73$; the largest in long diameter, 1.06 inches.

535. McKAY'S SNOWFLAKE. Plectrophenax hyperboreus (Ridgw.) Geog. Dist.-Western Alaska.

McKay's Snowflake is known to breed on Hall's Island, and probably St. Mathew Island, Bering Sea. Nothing is known, however, concerning its nest and eggs. Mr. Charles $H$. Townsend, during the cruise of the steamer Corwin discovered the young and those in breeding plumage while the vessel was anchored off Hall's Island.

536. LAPLAND LONGSPUR. Calcarius lapponicus (Linn.) Geog. Dist.Arctic regions of both hemispheres; in North America south in winter to Northern United States, sometimes as far as South Carolina, Kentucky, Kansas, Nevada, etc.

As its name indicates, this is a boreal bird, and in North America its summer home is in the regions about Great Slave Lake, Mackenzie River, and Alaska. In these places it breeds abundantly in May, June, and July. In the United States it appears as a winter visitor, in flocks, often associating with the Horned Lark and Snow Bunting, frequenting the same fields. The nest of this species is described by Dr. Coues as placed on the ground, under tussocks, in grassy hummocks. It is built of mosses and fine, soft, dried grasses, and lined with a few large feathers from some water fowl. The eggs, four to six in number, are rather pointed at the smaller end, and are very dark colored, reminding one of the Titlark's; the color is a heavy clouding or thick mottling of chocolate-brown, through which the greenish-gray ground is apparent; average size, $.80 \times .62$ inches. 


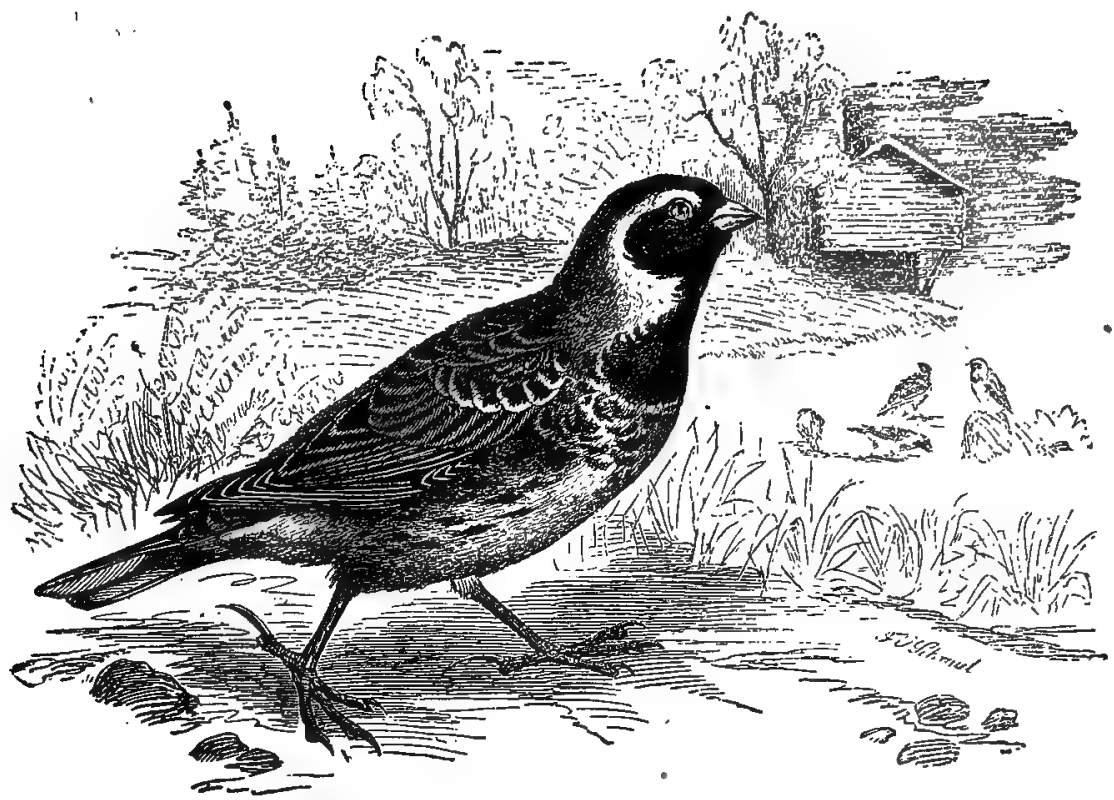

536. Iapland Longspur (From Brehm).

537. SMITH'S LONGSPUR. Calcarius pictus (Swains.) Geog. Dist.-Interior of Arctic America; south in winter over the Great Plains and prairies to Illinois and Texas.

The Painted Longspur inhabits Arctic America, chiefly the Saskatchewan and the Mackenzie River Valleys, breeding as far north as the Arctic coast and Upper Yukon Valley. It is a common bird on the prairies of Minnesota, Dakota, Montana, etc., oouthward, associating in the fall with the Chestnut-collared Longspur, but breeds mostly farther north. Its nesting is like that of C. lapponicus. The eggs, four or five in number, are light clay color, marked with obscure blotches and lines, dots an $\mathfrak{I}$ blotches of dark purplish-brown; they have the same average size as those of lapponicus, but are colored more like the eggs of the next species.

538. CHESTNUT-COLLARED LONGSPUR. Calcarius ornatus (Towns.) Geog. Dist.-Great Plains of the United States, north to the Saskatchewan; south 'n winter to Arizona, New Mexico, Texas and Mexico.

This bird is called the Black-shouldered or White-tailed Longspur. It is one of the most abundant birds of the Western plains-resident in Middle and Northwestern Kansas, breeding north through Nebraska, Dakota, Montana, etc., to high latitudes. A common but somewhat local breeder in Manitoba. In Kansas it begins laying in June. The nest is placed on the ground on the high, open prairie, and is composed wholly of mosses and fine grasses. A set of four eggs is in my cabinet, which was taken in Becker county, Minnesota, where the species is a common breedor. These eggs have a reddish-clay color, marked with dark reddish-brown spots and blotches, even approaching black, and obscure shell markings of purple; sizes $.75 x .54, .74 \times .54, .73 \times .54, .73 x .55$ inches. 
539. McCOWN'S LONGSPUR. Rhychophanes mecownii (Lawr.) Geog. Dist.Interior of North America, breeding from the northern border of Kansas, north to the Saskatchewan; south in winter to Mexico.

The Black-breasted or Bay-winged Longspur breeds in abundance throughout the prairies of Colorado, Wyoming and Montana. In the latter region and Dakota It is found associated with the Chestnut-collared Longspur, in whose general habits it is an exact counterpart. Dr. Coues says it has the same soaring, singing flight,

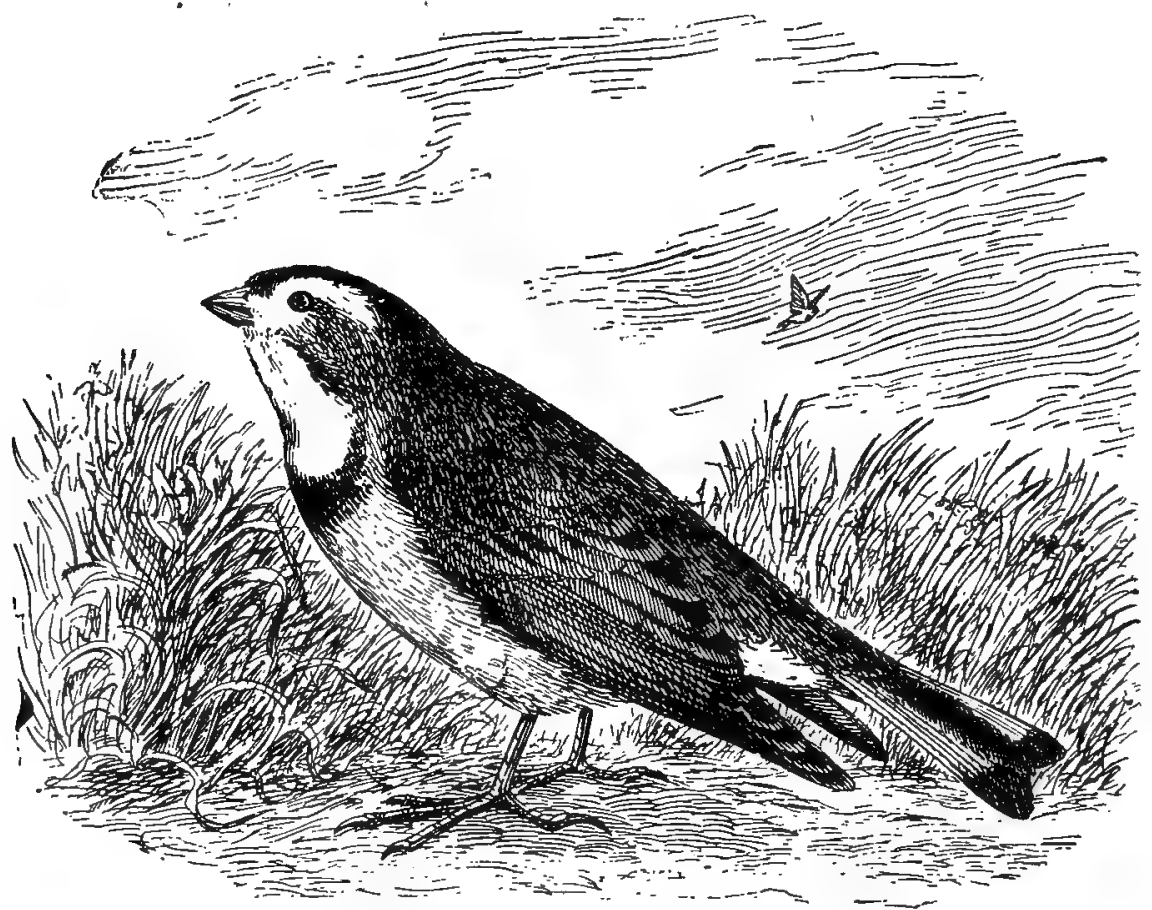

539. MCCown's Longspur (E. S. Cheney de1.)

and parachute-like descent, "sliding down on the scale of its own music." Its nestIng habits are the same as those of the last species, and the eggs, three to six in number, are similar, but their ground-color is usually more olive; average size $.82 \times .60$ inches.

540. VESPER SPARROW. Poocetes gramineus (Gmel.) Geog. Dist.-Eastern North America, west to the plains, north to Nova Scotia and Ontario, breeding southward to Virginia, Kentucky and Missouri, northward.

The Grass-Finch, Bay-winged Bunting, or "Gray Bird," as it is called, is an abundant species in Eastern United States. Its favorite resorts are weedy fields, roadsides and commons. From its habit of singing mostly in the evening and in cloudy weather, it is called Vesper Bird. The bird's song alone is suffeient to distinguish it from others of the smaller sparrows. Its song is a clear, sweet trill, finely modulated, or it is the Song Sparrow's song reversed. The breeding season is in May and June. I have found the nest with fresh eggs in July. This is placed on the 
ground, usually in an exposed position, under a thistle, small bush, or weed-stalk; it it a slight structure, composed of grasses, with a lining of hair. The eggs are four or five, usually four, in number; they are of a pale greenish-white, sometimes pinkish or grayish-white, marked with blotches, mixed with dots and lines of various shades of reddish or rusty-brown. The average size is . $80 \mathrm{x} .60$ inches.

540a. WESTERN VESPER SPARROW. Poocates gramineus confinis Baird. Geog. Dist.-Western United States, north into British America, east to Manitoba and border of the Plains, south into Mexico.

This form of the Vesper. Sparrow is common to the plains and prairies of the West. It possesses the same characteristics which are common to $P$. gramineus, nesting also in the same manner.

540b. OREGON VESPER SPARROW. Poocates gramineus afinis. Miller. Geog. Dist.-Northern California and Western Oregon.

This race of the Vesper Sparrow was first described by Mr. G. S. Miller, jr., in The Auk for October, 1888, He describes it from the type specimen taken at Salem, Oregon, as similar to that of $P . g$. confinis of Baird, but differing in being smaller and having the ground color above buffy-brown rather than grayish-brown, etc. Its general habits, nesting and eggs are the same as those of the Western Vesper Sparrow.

541. IPSWICH SPARROW. Ammodramus princeps (Mayn.) Geog. Dist.-Atlantic coast from Nova Scotia, south in winter to Virginia and coast of Texas.

It has recently been discovered that the Ipswich Sparrow breeds on Sable Island, Nova Scotia, and a series of its eggs are in the National Museum. These are similar to the eggs of the Savannah Sparrow, and, according to Ridgway, they are uniformly larger; size .81x.62. The nest is placed on the ground in meadows and other grassy places.

542. SANDWICH SPARROW. Ammodramus sandwichensis (Gmei.) Geog. Dist.-Northwest coast, from the Columbia River to Unalaska.

This Sparrow is very similar to the next subspecies. Nests and eggs indistinguishable.

542a. SAVANNAH SPARROW. Ammodranus sandwichensis sacanna (Wils.) Geog. Dist.-Eastern North America, breeding from Northern United States to Labrador, and Hudson Bay Territory.

A rather common, and in some places, an abundant bird in Eastern United States, usually breeding from about latitude $40^{\circ}$ northward. It is stated as breeding sparingly throughout Illinois and in some parts of Missouri. In Ohio it is a rare summer resident. Throughout New England the Savannah Sparrow is abundant, being found nearly all the year. Its favorite resorts are salt marshes along the coast, and wet, muddy, open ground, overgrown with grass and weeds in the interior. It is a terrestrial bird, and is known as the "Ground Sparrow." Its song is weak, squeaky and unmusical, which is at times uttered from the ground, or from the tops of bushes. The breeding season is in May and June. The nest is sunken in the ground, and generally

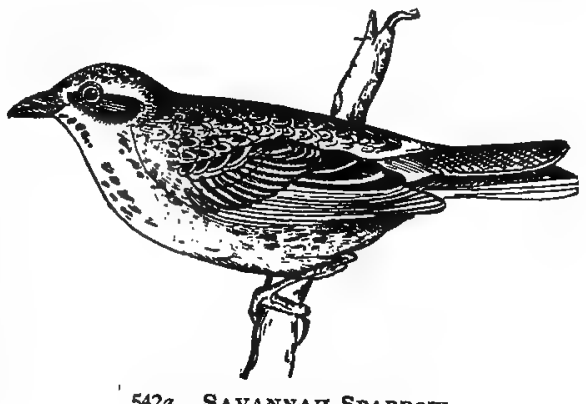

542a. SaVANMat Starrow 
well concealed among the weeds and tall grass. It is usually nothing but a slight arrangement of grasses in concentric rings, the brim being flush with the surface. The eggs are three to six in number, usually four or five, and there exists as great a variety in coloration as are to be found in the eggs of the Song Sparrow. The ground-color is greenish or grayish-white, spotted, speckled and blotched with light brown and lilac, particularly about the larger end, and the markings are often so numerous that they almost conceal the ground-color; average size $.76 \mathrm{x} .54$ inches.

542b. WESTERN SAVANNAH SPARROW. Ammodramus sandwichensis alaudinus (Bonap.) Geog. Dist.-Western North America (except in general the $\mathrm{Pa}-$ cific coast region); breeds from Rocky Mountains north to Alaska; south in winter to Mexico.

The general habits, nesting, and eggs of this Western form of the Savannah Sparrow are in no wise peculiar, but are like those of $A$. s. savanna. Average size of the eggs, $.75 x .55$ inches.

542c. BRYANT'S MARSH SPARROW. Ammodramus sandwichensis bryanti Ridgw. Geog. Dist.-Salt marshes of San Francisco Bay, and south along the coast, in winter to Southern California.

This subspecies differs from $P$. sandwichensis alaudinus in being decidedly smaller and darker in the coloration of the upper parts, which are similar to $A$. beldingi but not so heavily streaked with black, etc. It has been named by Mr. Ridgway in honor of the well-known ornithologist, Walter E. Bryant, of Oakland, Cala., who has devoted much study to the birds of San Francisco Bay and vicinity. Mr. Bryant has kindly furnished me with an account of this bird's nesting, eggs, etc. He states that it is a common resident about Oakland, particularly during the winter, when they become generally distributed over fields and along roadsides. The bird apparently prefers dry ground just away from salt marshes for nesting sites, although they also breed amongst the marsh grass in places not subject to overflow during excessively high tides. The fields selected are usually those more or less overgrown with grass and weeds, or pasture lands where considerable cattle are grazing. The nests are placed on the ground, usually in a depression. The usual number of eggs is four, rarely five. The color of a set of four taken by Mr. Bryant on May 22, 1880, is grayish-white, irregularly blotched with light brown and reddish-brown, sparingly marked with light purple, which is more noticeable about the larger end, where it appears as shell markings underlying the brown. They measure $20 \times 14.5,19.5 \times 14.5$, 19.5x14.5, 20.5x14.5 mm.* The nest from which these were taken is composed outwardly of small, dark grass-stems, and lined with fine, light-colored grasses; external diameter $115 \mathrm{~mm}$. by $50 \mathrm{~mm}$. in height; the cavity is $58 \mathrm{~mm}$. in diameter by 24 mm. deep. $\dagger$ Another set of four eggs in Mr. Bryant's collection came from San Mateo county, California, and was taken May 12, 1878. These are grayish-white, heavily blotched with yellowish and reddish-brown, and an under color of pale lavender. Their sizes are $18.5 \times 14,18.5 \times 14.5,19 \times 14.5,18.5 \times 14.5 \mathrm{~mm}$.t

543. BELDING'S MARSH SPARROW. Ammodramus beldinyi Ridgw. Geog. Dist.-Salt marshes of Southern California, from Santa Barbara south to Todos Santos Island, Lower California.

$-.79 \times .57, .77 \times .57, .77 \times .57, .81 \times .57$.

† External diameter of nest 4.53 ; helght, 1.97; dlameter of cavity, 2.28 by .94 in depth.

$\ddagger .73 \times .55, .73 \times .55, .75 \times .57, .73 \times .57$. 
Mr. B. T. Gault found this sparrow to be very abundant in the salt marshes in the vicinity of National City, San Diego county, California, in the spring of 1883. A nest containing three fresh eggs was found May 24; it was situated in a patch of marsh weed, apparently raised a little above the ground-several feet above tidewater mark, and was completely saturated with water; notwithstanding the dampness of the nest the eggs were warm to the touch, as the female had just left the nest. The structure was composed almost exclusively of weed stalks, with a little grass and a few feathers, arranged in a careless manner. The ground-color of the eggs is dirtywhite, of a brownish tinge, caused by minute specks of brown and lavender. The eggs had a pinkish tinge before they were emptied of their contents. The spots and specks are of lavender, and the blotches of amber-brown, congregating principally toward the larger end, with an occasional streak of a darker brown shade; their sizes are $.76 \times .58, .77 \times .59, .78 \times .58 .^{*}$

544. LARGE-BILLED SPARROW. Ammodramus rostratus Cass. Geog. Dist.-Coast of Southern California, south in winter to Cape St. Lucas and Northwestern Mexico.

The summer home of this species is along the coast of Southern California. The general habits of this curious bird are similar to those of Belding's Marsh Sparrow. It inhabits the marshes of the seashore, and its nesting and eggs are similar to those of $A$. beldingi.

544a. ST. EUCAS SPARROW. Ammodramus rostratus guttatus (Lawr.) Geog. Dist.-Southern Lower California.

This is a generally darker form than the last species, with characteristics and habits identical. It is found at Cape St. Lucas.

544. 1. SAN BENITO SPARROW. Ammodramus sanctorum Coues. Geog. Dist.-San Benito Island, Lower California.

This is a larger species than the last race with a differently-shaped bill, etc.

545. BAIRD'S SPARROW. Ammodramus bairdii (Aud.) Geog. Dist.--Interior portions of North America, from the Plains of Dakota and Montana to the Saskatchewan, south in winter to Texas, New Mexico and Arizona.

In the summer months this species is found on the piain's and prairies of the Dakotas and Montana, north to the Saskatchewan. The bird remained for a long time almost unknown, until Dr. Coues found it breeding in profusion on the prairies of the Dakotas in some places outnumbering all the other birds together. In general habits and appearance in life it is quite like the Savannah Sparrows. Dr. Coues states that the song of this species is peculiar, consisting. of two or three distinct syllables, of a mellow, tinkling tone, running into an indefinite trill, like zip-zip$z i p-z r-r-r-r$. The nest is a slight affair, made of grasses and weed-stalks on the ground; its diameter is about four inches. The eggs are laid in June and July, and they range from three to five in number, being similar to those of the Vesper Sparrow. They are whitish of varying tints, irregularly spotted, speckled, and blotched, with palu and dark reddish-brown; average size $.80 \times .65$ inches.

546. GRASSHOPPER SPARROW. Ammodramus savannarum passerinus (Wils.) Geog. Dist.-Eastern United States and Southern Canada to the Great Plains wintering in the Gulf States, Bahamas, Cuba and Porto Rico.

* Bulletin No. 2, pp. 58-60, Ridgway Orn. Club. 
Perhaps better known as the Yellow-winged Sparrow. Anyone will be able to identify this little bird in hand. The edge of the wing is conspicuously yellow; the lesser wing coverts and line over eye are yellowish. A common bird in the meadows and clover fields of Eastern United States, nesting in May and June. It is a bird of retiring habits, generally keeping in the tall grass, on the ground, and not usually seen only when flushed. Its flight is zig-zag. Sometimes it will mount a stump or weed-stalk, and sing at short intervals for hours at a time a peculiar, monotonous song, which has been aptly compared to that of a grasshopper-hence its common name. The nest is placed on or rather sunken in the ground, and concealed by a thick tussock of grass. The eggs are four or five in number, generally four. They. ilave no resemblance to the eggs of the Field Sparrow, Song Sparrow, Savannah Sparrow, or Grass Finch, having a clear, white ground-color, with a moderate polish, spotted more or less thickly with pale reddish-brown, chiefly and sometimes wholly at the larger end. Mr. Poling says he has found fresh eggs in Illinois as early as April 20, and as late as August 12. Two broods are often reared. A set of four eggs in my cabinet, taken by Mr. J. E. Gould, on June 14, in Franklin county, Ohio, exhibits the following respective measurements: $.77 \times .55, .77 \times .56, .79 x .56$; .81x.55; the sizes of a set of five taken May 16 by the same collector are $.80 x .59, .79 \times .59, .79 x .59$, $.78 \times 57, .77 \times .57$. A set of four from Marshall county, Kansas, taken May 30, gives.the following dimensions: $.70 \times .54, .70 \times .56, .71 \times .54, .72 x .55$. Average size $.73 \times .56$ inches.

546a. WESTERN GRASSHOPPER SPARROW. Ammodramus savannarum perpallidus Ridgw. Geog. Dist.-Western United States from the Great Plains to the Pacific, south over table-lands of Mexico.

The nesting and eggs of this paler and grayer form of the Yellow-winged Sparrow, which is found in the dry, western regions, are the same as those of the Eastern bird. Average size of the eggs, $.75 x .57$ inches.

547. HENSLOW'S SPARROW. Ammodramus henslowii (Aud.) Geog. Dist.Eastern United States, north to Ontario and Southern New England, west to the edge of the Plains, winters in the Gulf States.

Henslow's Grasshopper Sparrow or Bunting is not, on the whole, an abundant species in Eastern United States, being found common only in restricted localities. It is given as a rare sumfoer resident in portions of Southern New England. Breeds abundantly in the meadows about Washington, D. C. Mr. Shick found Henslow's Yellow-winged Sparrow breeding in the vicinity of Sea Isle City, New Jersey. Farther west it seems to be common in various sections. It may be found breeding in Southern and Western Ohio, as it is stated by Dr. Brayton to be a common summer resident on the prairies of Indiana. Breeds also on the weedy prairies of Illinois and Missouri. Messrs. Keyes and Williams record it as a common summer resident in Iowa, and Colonel Goss mentions it as a summer resident of Kansas. Mr. L. Jones informs me that in Iowa the favorite resorts of this Sparrow during the breeding season are neglected fields and pasture lands. Its nest is placed on the ground, sometimes in a slight depression, beneath a tussock of grass; the composition is of fine and coarse grasses, with a few cow hairs. The eggs, Mr. Jones says, are deposited about May 25. The bird's habits, nest, and eggs are described as being similar to those of the Yellow-winged Sparrow (A. savannarum passerinus), but the cggs are not pure white in ground-color, having a greenish or grayish-white tint, profusely dotted and blotched with several shades of brown and lilac shell markings. They. are four or five in number, and average $.75 \times .57$ inches. 
547a. WESTERN HENSLOW'S SPARROW. Ammodramus henslowii occidentalis Brewst. Geog. Dist.-South Dakota.

For a description of this comparatively newly-known race see William Brewster's article in "The Auk" for April, 1891, page 145. I have no reliable information regarding the nesting and eggs of this subspecies, but in all probability they are identical with those of 'the eastern A. henslowii.

548. IECONTE'S SPARROW. Ammodramus leconteii (Aud.) Geog. Dist.From the Plains eastward to Illinois and Indiana, and from Manitoba south in winter to South Carolina, Florida and Texas.

It is now certain that Mr. Walter Raine and Mr. G. F. Dippie, of Toronto, Ont., secured an authentic nest and eggs of this species in the vicinity of Reaburn, Manitoba. Mr. E. Arnold, of Battle Creek, Michigan, appears to have taken a nest containing four eggs in the same region. Mr. Dippie says: "Leconte's sparrows are fairly numerous in the vicinity of Reaburn, Manitoba. Their peculiar note can be heard both day and night in fine weather; the only sound I can compare it to is the note of the grasshopper. It is one of the most difficult small birds to collect that I know of. They are great skulkers; I have often followed them guided by their chirping in the grass, until I was sure the bird was not more than a few yards away, then he would suddenly "crowd on all sail" and dart away at a high rate of speed, gyrating from side to side in a manner that would test the skill of any collector. On June 18th Mr. W. Raine, then my companion at Reaburn, discovered a small nest containing five small, speckled eggs, which we felt sure were the eggs of the Leconte's Sparrow, as the birds were in the vicinity all the time. The locality was carefully noted and we visited it four or five times a day. On the morning of the 21st upon wakening we found it raining, but in a short time we were cautiously approaching the nest. When within a few yards the bird flushed and and by a lucky shot I knocked it over and in another moment I had in my hand the parent bird, Leconte's Sparrow. On the 19th, while walking over the prairie we almost tramped upon a small bird as it fluttered from under our feet and a short search revealed a nest containing four young birds and an addled egg. The egg corresponded exactly with the others, the nest also was identical and the glimpse we had of the bird made it doubtless that it was another nest of Leconte's Sparrow. The nests were composed of fine grass, cup-shaped and deep, carefully concealed in the center of a thick tuft of grass. The eggs are greenish white ground color, thickly speckled with pale ashy-brown and the average size is .65x.50 inches."

549. SHARP-TAIIED SPARROW. Ammodramus caudacutus (Gmel.) Geog. Dist.-Salt marshes of the Atlantic coast, from Prince Edward Island and Nova Scotia to North Carolina.

The Sharp-tailed Finch breeds abundantly in the salt marshes of the Atlantic coast from North Carolina northward, and it is commonly found associated in the' same places with the Seaside Finch, A. maritimus. They keep closely in the shelter of the rank salt reeds and herbage, where the nest is built. This is fastened to the sedges and composed of grasses, lined with finer material of the same. The nesting season is in May and June, and a second set of eggs may be found in July. While the nidification of this species and the Seaside Finch is essentially the same, Mr. Shick states that on the New Jersey coast, the nest of the Sharp-tail is not built so bulky as that of the former. Both species are common in the salt marshes at the mouths of creeks and rivers along the Atlantic coast. Mr. Norris has a typical set of 
four eggs of the Sharp-tailed Sparrow taken by Hon. John N. Clark, near Old Saybrook, Connecticut, at the mouth of the Connecticut river. The nest was in the salt grass of a wet meadow; the eggs were fresh, brownish-white, varying to greenishwhite, thickly sprinkled and speckled with tawny-brown, sizes: .75x.58, .76x.57, $.76 x .58, .80 x .56$. The eggs are alșo not to be readily distinguishable from some examples of the Savannah Sparrow.

549a. NELSON'S SPARROW. Ammodramus caudacutus nelsoni Allen. Geog. Dist.-Fresh marshes of the interior, from Northern Illinois northward to North Dakota and Manitoba; south in winter to Texas.

This subspecies is dedicated to Mr. E. W. Nelson, the ornithologist. It is similar to $A$. caudacutus, but smaller, with slenderer and longer bill; the colors are brighter and the markings more sharply defined. In its migrations it visits the Atlantic coast, New England and the Lower Fudson Valley. It is accidental in California. According to Mr. Walter Raine and Mr. G. F. Dippie the nests and eggs of this bird resemble those of Leconte's Sparrow very closely, the eggs being about the same in size, color and markings. The bird was found breeding by them in the marshes of Long Lake, Manitoba.

549b. ACADIAN SHARP-TAILED SPARROW. Ammodramus caudacutus subvirgatus Dwight. Geog. Dist.-Coast of Southern New Brunswick, Prince Edward Island (and probably Nova Scotia), and southward in migration to South Carolina.

A race named by $\mathrm{Mr}$. Jonathan Dwight, jr., in 1887. The bird is similar to $A$. caudacutus, but paler and much less conspicuously streaked beneath with pale greenish-gray instead of black or deep brown. It inhabits salt water marshes where grasses grow luxuriantly. According to $\mathrm{Mr}$. Dwight the male has a fine song which is repeated at all hours of the day from a tall stalk in the meadow, from a fence, or while the bird is in the grass. Occasionally toward nightfall one will mount into the air and, with set wings, float down, fairly gushing with song, a habit shared by the ordinary Sharp-tail and by the Seaside Sparrow as well.

550. SEASIDE SPARROW. Ammodramus maritimus (Wils.) Geog. Dist.Salt marshes of the Atlantic States, from Massachusetts south to those bordering Gulf of Mexico.

The Seaside Finch is a common species in the salt marshes of the Atlantic coast from Connecticut southward. Its nest and eggs are identical with those of the Sharp-tailed Sparrow, only, as already stated, in speaking of the Sharp-tailed spccies the nest is more bulky. It is carefully concealed in clumps of salt grass and quite neatly built of grasses, lined with fine material. In exceptional instances the nests have been found arched over. The largest set of eggs Mr. Shick ever found on the New Jersey coast was seven, but the usual numbers are four or five-five being the more common. Their ground-color is greenish or brownish-white, thickly speckled with umber-brown, and are not with certainty distinguishable from those of the last species. The sizes of a set of five eggs taken by Mr. Shick at Sea Isle City, New Jersey, May 21, 1887, are as follows: .70x.56, .75x.56, .74x.55, .73x.55, .71x.54.

550a. SCOTT'S SEASIDP SPARROW. Ammodramus maritimus peninsula Allen. Geog. Dist.-South Carolina to Northern Florida; Gulf coast from Florida to Texas.

This is a common southern representative of the Seaside Sparrow, A. maritimus; it is similar, but its general plumage is much darker. 
550b. TEXAS SEASIDE SPARROW. Ammodramus maritimus sennetti Allen. Geog. Dist.-Gulf coast of Texas, Corpus Christi to Galveston Bay.

In color this subspecies is similar to A. maritimus, but all the colors are lighter and paler, the nape being distinctly streaked with black. Mr. W. E. Grover in The Oölogist for November, 1893, describes a domed nest of this bird containing four eggs. He says: "April 19, 1892 found me in a larg'e salt marsh looking for Sparrow nests. After a two mile tramp one nest was found, containing four fresh eggs. The ground color is white showing the faintest tinge of green; the markings are small dots sprinkled over the entire egg, mostly, however, at the larger end, of a red-brown color. The nest was loosely made of dead grass, lined with finer, and was very neatly worked in the heart of a tussock of salt grass, eleven inches above the water, which was four inches deep. Externally the nest measured four and one-half inches in diameter by three inches high; walls one and a quarter inches thick; bottom one and three-quarter inches thick. Inside measured two inches in diameter by one and a quarter inches deep. Very often the high spring tides wash the nest away, but nothing daunted the birds build a new nest, weaving it in the tops of rank grass or rushes, and if in the latter, using the leaves to dome the nest, or rather make a rainproof roof for it. When placed in this position the nests are hard to find, as they are woven of green grass in the shape of a ball, with the entrance on one side near the top. As a general thing they prefer thick grass growing on edge of a small bayou."

550c. LOUISIANA SEASIDE SPARROW. Ammodramus maritimus macgillivrayi Aud. Geog. Dist.-Coast of Louisiana, to coast of Texas in winter.

From eggs taken on the coast of Louisiana in my collection there appears to be no distinction whatever from those of A. maritimus.

551. DUSKY SEASIDE SPARROW. Ammodramus nigrescens Ridgw, Geog. Dist.--Salt Lake and Merritt Island, Eastern Florida.

Mr. C. J. Maynard, the only collector who has ever met with this species, found a single individual, March 17, 1872, at Salt Lake, near Titusville, while in April it was "quite common on the marshes of Indian river just below Dummett's Grove" and "very abundant on the upper end of Merritt's Island." A very distinct species and can be distinguished from $A$. $m$. peninsul $x$, its nearest ally, by its much darker upper parts and conspicuously streaked under parts. Mr. Frank M. Chapman in his "Birds of Eastern North America," says that this Sparrow apparently has a more restricted range than any other North American bird. During February and March he searched for the Dusky Seaside Sparrow in the marshes of the east peninsula of Indian river, opposite Micco, but without success. The nest and eggs are unknown.

552. LARK SPARROW. Chondestes grammacus (Say.) Geog. Dist.-Mississippi Valley, west to the Plains, east to Ohio, north to Michigan and south to Eastern Texas, Louisiana, etc.; accidental near the Atlantic coast.

Throughout the Mississippi Valley the Lark Finch is found breeding more or less abundantly in all suitable places, from Eastern Texas and Louisiana on the south to Iowa and Southern Michigan on the north. Its favorite summer resorts are prairie lands, clover and stubble-fields, neglected and sparsely wooded pastures and fields bordered with low trees. Breeds in May, June and July according to locality; sometimes two and three broods are reared. It is one of the sweetest songsters among our Sparrows. Its song is uttered in a hurried manner, "in one continuous 
gush of silvery notes, and accompanied by a metallic tremolo." Several birds may be seen running in the grass with lowered heads like quails, from which manner, in some places they receive the name of "Quail-heads," and again they are given the name of "Road-birds" from their habit of running along road-sides and feeding in roads. Mr. Singley states that in Texas the Lark Finch often repairs old nests of the Mockingbird and Orchard Oriole with a lining of grass, horse hairs, etc, and Mr. Davis informs me that he has found its eggs in the nest of the Scissor-tailed Flycatcher. The nest, however, is usually placed on the ground, sometimes in trees or bushes. When on the ground it is generally sunken in a hollow, concealed by tufts of grass or clover and it is hard to find, for the bird, like the Bobolink, has the habit of running some distance from the nest before taking wing. The composition varies according to the vegetable growth of the locality in which it is built; usually grasses, clover and weed stems make up the structure. The eggs are three to five in number, commonly four; they are pure white or they have a faint bluish or brownish tinge, speckled and marked with zig-zag, straight lines, of very dark brown and black, chiefly at the larger end, like the eggs of the Baltimore Oriole, and in exceptional cases it is impossible to differentiate the eggs of the two species. The size of those of the Lark Sparrow vary from .76 to .89 in length by .59 to .68 in breadth.

552a. WESTERN LARK SPARROW. Chondestes grammacus strigatus (Swains.) Geog. Dist.-Western United States from the Great Plains and Central Texas south into Mexico.

This subspecies is common in Western United States, from the Plains and Western Texas (where it breeds abundantly) to the Pacific. In California it nests on the ground, in live oaks, sycamores, orange and lemon trees. Eggs $.80 x .60$.

553. HARRIS'S SPARROW. Zonotrichia querula (Nutt.) Geog. Dist.-Middle United States, from Illinois, Missouri and Iowa west to middle Kansas and the Dakotas, and from Texas north to Manitoba. Accidental on Vancouver Island and in British Columbia and Oregon. [Accidental in Ohio, Davie.]

The late Maj. Charles E. Bendire has given us (Auk, VI, pp. 150-152) an account of what he supposed to be a nest and eggs of Harris's Sparrow. He says: "For the purpose of drawing the attention of ornithologists located along the northern border of Montana and the Dakotas, and throughout southern British North America, to the fact that the nest of eggs of this interesting species remain still unknown, and to the probability of its breeding in these regions, instead of further north, I will state that none of the large collections of birds, nest and eggs made by the following gentlemen of the Hudson's Bay Company, Robert McFarlane, Strachan Jones, T. McDougall, Donald Gunn, C. P. Gaudet and J. Lockhart, and which were donated to the Smithsonian Institution at Washington, D. C., contained specimens of this species, although representing nearly every other bird to be found breeding throughout the vast interior of the former Hudson Bay territory. The explorations made by these gentlemen were thorough and continued through several seasons, and, chiefly through the good efforts of Mr. Robert Kennicott, all their valuable fiela notes and an immense amount of material were brought together. From the fact that no specimens of Zonotrichia querula were obtained throughout the explorations; which extended well into the Arctic Circle, and began about the 54th parallel, I necessarily believed that the summer home of Harris's Sparrow, if properly looked for, will be found along the foothills of the Bearpaw and Chief Mountains in Montana, along the Turtle Mountains in the Dakotas, and their centre of abundance probably near Duck Mountain, Manitoba, as well as in suitable localities in the territories of Al- 
berta and Assiniboia, south of Lat. $54^{\circ}$. During the summer of 1885 , while I was stationed at Fort Custer, Montana, one of my men, who was well posted about the birds of that region, and helped me to collect a good many, while out hunting one day found a nest and four eggs of some sparrow, without, unfortunately, securing the parent, and brought them in for me. I saw at a glance that these eggs were new to me, and visited the place where the nest was found next day, in the hope of possibly still finding the owners about the locality, but failed in this. The eggs in question differ materially in coloration from those of the other species of Zonotrichia, as well as from those of the genera Passerella, Melospira, and Pipilo, all of which are represented by good series in the National Museum collection. The nest was found June 24, 1885, in a dense willow thicket close to the banks of Little Horn River, about one and a half miles above the post. It was placed between several young willow twigs, about eight or ten inches from the ground, compactly built of strips of decayed willow bark, coarse grasses, etc., and lined with finer materials of the same kind. Outwardly the nest was about four and a half inches wide by three deep; the inner cavity was two and a half inches wide by two in depth. In its general make-up it resembled the average nest of a Passerella. The eggs contained small embryos. They resemble certain types of Cardinal's eggs (Cardinalis cardinalis) more than anything else, but are considerably smaller. There is no trace of green whatever noticeable in their ground color. This green tint is always found to a greater or less extent in all the eggs of the genera Zonotrichia and Passerella, and with rare exceptions in Melospina as well, while here, it is a creamy or buffy white, and the shell is also more lustrous. The eggs are thickly spotted and blotched with dark brown and burnt umber, and more or less mixed with pale heliotrope purple and purplish gray. They are ovate in shape, and measure $.89 \times .70, .88 \times .69, .86 \times .69$ and $.85 x .65$ inches. I am certain that these eggs are not those of the Cardinal, which is not found as far north as Fort Custer and would surely have been noticed by me, if it occurred there, and unless they should be sbnormally colored eggs of Pipilo maculatus arcticus, which is barely possible, although also rather small for this species, they will certainly prove to be those of Harris's'Sparrow. While I do not believe that it is a constant and common summer resident in the vicinity of Fort Custer, it probably breeds there as a straggler; I failed to meet with this species during the summer, but found it not at all uncommon during its fall migration. Specimens shot by me in the early part of October are now in the National Museum collection. I found them associated with White-crowned Sparrows and Arctic Towhees principally, scattered in small flocks through the undergrowth along the Big and Little Horn River bottoms, and it seems to confine itself to the shrubbery found along the streams. Specimens were shot by me as late as October 21, 1885." On the 28th of April, 1889, Mr. J. E. Gould shot a specimen of Harris's Sparrow two miles north of Columbus, Ohio. Four or five others were observed feeding in a thicket in company with the White-throated Sparrow, Z. albicollis. Mr. Gould generously presented me with the specimen of $Z$. querula, the skin of which is now in my collection. The identification of this specimen, previously considered by the writer to be $Z$. querula was, through the kind assistance of Mr. Chas. F. Batchelder positively determined. This, I believe is the first record of its occurrence in Ohio. The bird in this case has wandered a long way out of its ordinary habitat. Mr. Rudolph M. Anderson in his Birds of Winnebago and Hancock Counties, Iowa, says: "Harris's (or Black-hooded) Sparrow is rather a common migrant in September and October. Have seen a few specimens in the early part of May. Spring and fall plumages differ considerably."*

* An Annotated List of the Birds of Winnebago and Hancock Counties, Iowa. Being a list of birds observed in the Counties of Winnebago and Hancock, State of Iowa, with brief notes on the same. Forest City, Iowa. Printed by the Author, 1897. 
554. WHITE-CROWNED SPARROW. Zonotrichia lencophrys (Forst.) Geog. Dist.-North America at large; breeds northward; south in winter, to the Southern United States, and south to Mexico.

This is probably the most beautiful of our Sparrows. It winters in the Gulf States and southward, migrating northward in spring to its breeding grounds, which are in the higher mountain ranges of Western United States-Sierra Nevada and Rocky Mountains, and eastward north of the Great Lakes, to Newfoundland and Labrador. In Colorado this species nests in June and July, often raising two broods in a season. The bird is chiefly a ground builder, but nests are found in bushes a few feet above the ground. Mr. Elmer J. Gillette makes record of a nest of the White-crowned Sparrow which he found in Orleans county, New York. In "The Ornithologist and Botanist" he notes the following: "We sometimes think this little sparrow will spend the summer with us, for he stays until many of the small birds have built their nests and laid their eggs. In fact, on one occasion, I found a nest of this sparrow, which contained four fresh eggs. The nest was placed in a berry bush about two feet from the ground. It was composed principally of the stalks of small weeds, roots, coarse grass and other coarse material. The lining consisted almost entirely of fine grass, hair and strips of bark. The nest resembles, very closely the nest of the Song Sparrow, but somewhat smaller. The eggs also were smaller, and about the same color as the Song Sparrow's. The nest was not more than 20 rods from my house and the birds appeared to be very tame. This is the only nest of this species that I ever founu, and I never knew of another nest being found in this locality." A set of four eggs in Mr. Norris' cabinet was taken July 1, 1883, near Hancock, Col. The nest was on the ground and was composed of grasses, etc. The eggs are pale greenish-blue, speckled and spotted with bay; the markings are much heavier and thicker near the larger ends; sizes, $.87 \times .64, .89 \times .63, .91 \times .65, .93 \times .58$. The number of eggs is stated to be four or five, and are said to resemble those of the Song Sparrow, except in size, some being heavily and distinctly marked.

554a. INTERMEDIATE SPARROW. Zonotrichia leucophrys intermedia Ridgw. Geog. Dist.-Western North America from the Rocky Mountain region to the Pacific; in winter, south throughout Western United States into Mexico.

The Intermediate White-crowned Sparrow breeds in the far north-throughout Alaska (except the coast east and south of the peninsula) and eastward through the Mackenzie River region. The eggs are described as similar to those of $Z$. leucophrys, but the more cinnamon or rusty colored style predominates.

554b. GAMBEL'S SPARROW. Zonotrichía leucophrys gambelii (Nutt.) Geog. Dist:-Pacific coast region from Southern California north to British Columbia.

In California Gamble's White-crowned Sparrow breeds near the coast, building the nest in trees, bushes, and in thick clumps of weeds. It is quite bulky, and composed externally of weed stems, and fine dry grasses on the inside. Three to five eggs are laid, commonly three or four. Mr. Norris has a set of four collected by A. M. Ingersoll near Alameda, California, April 2, 1885. Their ground color 1s pale greenish-blue, spotted and splashed with liver-brown; sizes, $.88 \times .65, .88 \times .64, .88 \times .64, .94 \times .68$. A set of four taken by the same collector exhibits the following measurements: $.88 \mathrm{x}$ $.63, .90 \times .66, .94 \times .67, .88 \times .64$.

* Manual N. A. Birds, D. 415. 
557. GOLDEN-CROWNED SPARROW. Zonotrichia coronata (Pall.) Geog. Dist.-Pacific coast region, from Southern California to Alaska; migrates east irregularly to Rocky Mountains, casually to Wisconsin.

The Golden-crowned Sparrow is stated to breed in Northern California and northward to Alaska. Its nesting is similar to that of gambelii and the eggs are "colored like the more distinctly spotted of Z. leucophrys."

558. WHITE-THROATED SPARROW. Zonotrichia albicollis (Gmel.) Geog. Dist.-Eastern North America, breeding from Nortsern United States nortuward; west to the Plains; casually to Utah.

A large, handsome sparrow, very similar to the White-crowned species. Breeds in Northern Michigan, New York, and Northern New England northward; winters from the Middle States southward. In the greater portion of Eastern United States it is seen only during the migrations, or in the winter. In suitable places throughout the three Northern New England States the White-throated Sparrow is a rather common breeder, nesting in June. The nest is built on the ground, or, in exceptional cases, in bushes, and among the branches of fallen trees. It may be built in a clearing near the edge of woods, and frequently in damp places, often under a fallen branch, or at the foot of a sapling, and but slightly concealed. It is more bulky than a Song Sparrow's nest, built of weed-stems, grasses, etc. The eggs are four or five in number and, like those of the Song Sparrow, are subject to great variation in size and coloration, as are exhibited by a large series of specimens in Mr. Norris' cabinet. The ground-color is of a pale greenish-blue, spotted, sprinkled and clouded with cinnamon-rufous and bay. Some eggs are of a pale cinnamon, sprinkled and clouded with burnt umber. A set of four, containing eggs of the smallest sizes, exhibits the following dimensions: $.80 \mathrm{x} .63, .79 \mathrm{x} .61, .80 \mathrm{x} .61, .81 \mathrm{x} .62$; another containing the largest eggs gives the following measurements: $1.88 \times .64, .87 x .63, .86 \times .64, .89 \times .64$.

559. TREE SPARROW. Spizella monticola (Gmel.) Geog. Dist.-Eastern North America, west to the Plains, breeding far northward; south in winter through Eastern United States.

This bird looks very much like the Chipping Sparrow but it has a dusky spot in the center of the chest. In Eastern United States it is found only in winter-hence the name, Winter Chip-bird, by which it is known. It breeds in Labrador and the region about Hudson Bay. The nest is described as being placed in trees or bushes or on the ground, and composed of grasses, mud, fine rootlets and hair. The eggs have no similarity to those of the Chipping Sparrow. They are light green, flecked with minute markings of reddish-brown, distributed with great regularity over the surface, but so sparsely as to leave the ground distinctly visible; on the whole somewhat resembling the eggs of the Song Sparrow, with endless variations; four or five in number; size, $.80 x .60$ inches.

559a. WESTERN TREE SPARROW. Spizella monticola ochracea Brewst. Geog. Dist.-Western North America, breeding in Alaska, wintering in Western United States, south to Texas, New Mexico and Arizona.

A paler colored Tree Sparrow which breeds in Alaska and southward to an undetermined latitude. Nesting and eggs in nowise peculiar. Eggs, .78x.55.

560. CHIPPING SPARROW. Spizella socialis (Wils.) Geog. Dist.-Eastern North America, north to Great Slave Lake, west to the Plains, south into Eastern Mexico. 
Nearly everybody knows this familiar little bird as Chippy, Chip-bird, or Hairbird. The latter name is given it from the fact that its nest is for the most part, composed of horse hair, with a slight foundation of fine grass and vegetable fibres. The breeding season is usually in May and June. The nest is built anywhere in bushes, hedges, trees of any size, and almost in any situation. In exceptional cases it has been found built on the ground. The same pair of birds if unmolested will return and breed in the vicinity of their former nest year after year. Three or four eggs are laid, rarely five, bluish-green, sparsely spotted with blackish-brown and purplish, sometimes in a circle about the larger end. Ten eggs selected on account of their sizes measure: $.60 \times .50, .62 \times 52, .65 \times .52, .69 \times .50, .69 \times .53, .71 \times .54, .70 \times .50, .72 \times .51$, $.67 \times .50, .73 \times .52$. Average size .68x.51.

560a. WESTERN CHIPPING SPARROW. Spizella socialis arizonce Coues. Geog. Dist.-Western North America, east to Rocky Mountains; in summer north to beyond $60^{\circ}$; south in winter to southern Mexico.

Eggs in my collection of this paler Western subspecies do not seem to differ essentially from those of socialis. Nesting the same.

561. CLAY-COLORED SPARROW. Spizella pallida (Swains.) Geog. Dist.Interior regions of North America from Illinois, Wisconsin and Iowa, west to base of Rocky Mountains, north to the Saskatchewan, south to Texas and New Mexico; in winter to Lower California and Mexico.

The Clay-colored Sparrow breeds from Northern Illinois and Central Iowa northward. Mr. J. W. Preston found it breeding in Winnebago county, Iowa, in June, 1885, and in the summers of 1885 and 1886 in Becker county, Minnesota. The bird is an abundant breeder in Western Manitoba. The nesting season is usually in May and June. Mr. Preston found the bird frequenting the edges of brush and the borders of timber. The nests were placed on the ground; one, however, was built in the branches of a low hazel. The materials used in the construction of the nests were fine, round grasses and blades, with a lining of horse hairs. The eggs were three to five in number, commonly three or four, the latter number predominating. They are similar in color to those of the Chipping Sparrow, S. socialis, and average about the same in size, .65x.50. Mr. Norris has a set of four taken near Detroit, Minnesota, June 4, 1886; their sizes are: .64x.47, .64x.47, .62x.47, .64x.48; in these specimens the markings are fainter than are those of S. socialis. As many as six eggs are said to be laid by this species.

562. BREWER'S SPARROW. Spizella breveri Cass. Geog. Dist.-Western United States, from the Rocky Mountains to the Pacific, south in winter to Northwestern Mexico.

This bird has very much the appearance of the Clay-colored Sparrow, but is paler and duller, all the markings being indistinct. It is found from the Pacific coast to the Rocky Mountains, and from the northern portion of California to the Rio Grande and Mexico, and is especially abundant in Arizona and New Mexico. It inhabits almost exclusively open fields and bushy plains. The nests are placed in bushes, usually the sage, a few feet from the ground. It is composed of dry grasses, rootlets, and lined with hair. The eggs are generally four in number. A series of the eggs of this species in Mr. Norris' cabinet, collected near Fort Klamath, Oregon, resemble in size and coloration the eggs of the Chipping Sparrow, but as a rule the 
markings are larger, and of a more reddish tint than in those of the former species. A set of three containing the smallest eggs exhibit the following sizes: $.62 \times .48, .63 x$ $.48, .63 x .49$; one of four with larger eggs, .69x.53, .64x.52, .67x.53, .64x.52.

563. FIELD SPARROW. Spizella pusilla (Wils.) Geog. Dist.-Eastern United States and Southern Canada, west to the edge of the Great Plains.

The Field Sparrow is an abundant species in Eastern United States where it may be seen during the summer months frequenting the borders of upland woods, fields and edges of thickets. It sings during the whole day, especially at mid-day when most birds are silent, and a telegraph wire is a favorite perch while singing. The nest is placed in bushes or upon the ground in a tussock or at the root of a bush in a thicket, frequently in briers along roadsides or upon the ground in pastures, but the birds nearly always (in Ohio at least) during the breeding season, confine

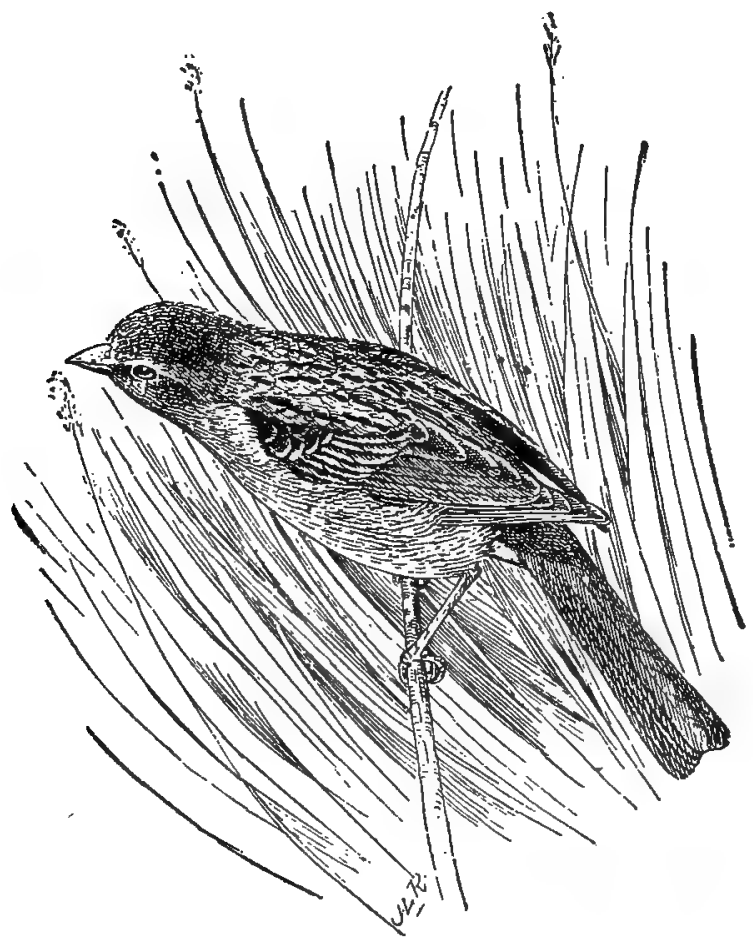

563. Field Sparkow (From Beal).

themselves to the outskirts of woods with thick undergrowth. The nest is composed of grasses on a foundation of leaves; the lining is of hair. The eggs are commonly four, sometimes three or five. The predominating ground color of the eggs is buffywhite, or clay, while others have a greenish-white ground; the markings are in the form of specks and spots of various shades of brown, which are sometimes so dense at the larger end as to almost wholly obscure the ground color. The eggs rarely measure less than .61 or more than .73 in length, and in breadth .49 or more than .55; the average is $.68 \times .52$. Two or three broods are reared in a season, the nesting time being in May, June and July. 
563a. WESTERN FIELD SPARROW. Spizella pusilla arenacea Chadb. Geog. Dist.-Great Plains, from Southern Texas north to Wyoming Territory and Nebraska.

A new subspecies inhabiting the Great Plains of Western United States. Nesting and eggs indistinguishable from S. pusilla.

564. WORTHEN'S SPARROW. Spizella wortheni Ridgw. Geog. Dist.-New Mexico (Silver City) and Chalchicomula, Puebla.

This is apparently a good species, resembling the Black-chinned Sparrow in many respects, particularly the color of the upper parts. The type specimen was taken at Silver City, New Mexico.

565. BLACK-CHINNED SPARROW. Spizella atrigularis, (Cab.) Geog. Dist.-Mexico and southern border of the United States from the Lower Rio Grande Valley to Southern California; Lower.California.

The Black-chinned Sparrow is a rather common species in all suitable places from the southern border of the United States southward. It inhabits the border of thickets, grassy fields and low shrubbery. The nest is usually placed in low bushes, and is made very similar to that of the Field Sparrow. The eggs are light greenish-blue, about the color of the eggs of the Bluebird. The average measurement of eight specimens is $.68 \times .50$ inches.

566. WHITE-WINGED JUNCO. Junco aikeni Ridgw. Geog. Dist.-Colorado, north to the Black Hills.

This species is dedicated to C. E. Aiken, of Colorado. It is like the Slate-colored Junco except that the wings are crossed with two white bars formed by the tips of the greater and middle coverets. Breeds in the Black Hills.

567. SLATE-COLORED JUNCo. Junco hyemalis (Linn.) Geog. Dist.-North America at large, breeding from the higher portions of the Alleghanies, Northern New York and Northern New England to Alaska (except the Pacific coast district, or south and east of the peninsula), south in winter to the Gulf States.

Better known as the Black Snowbird, and in most of the United States is oftener seen during the winter months. Breeds in the mountains of Northern Pennsylvania, New York, and New England; is resident throughout the year in Northeastern Ohio. and in Michigan. Mr. McIlwraith gives it as a fairly common resident of Ontario where, in the southern portion, is is known as the "White Bill." Mr. William L. Kells states that in Ontario, the Slate-colored Junco selects various places for nesting sites, such as the up-turned roots of trees, crevices in banks, under the sides of logs and stumps, a cavity under broken sod, or in the shelter of grass or other vegetation. The nest is made of dry grasses, warmly and smoothly lined with hair. Mr. Kells says the bird generally begins to nest the first week of May, and nests with eggs are found as late as August. The set of eggs is usually four or five in number, of a whitish color, varying to a greenish-white, more or less speckled with reddish-brown, with an average size of $.78 \times .57$. A set of four eggs taken by J. A. Dakin, on lMay 4, in Onondaga county, New York, measures .75x.50, .76x.56, .78x.b7, $.80 \times .58$. A nest of this species was found on the rafters of a barn in Connecticut.

567a. OREGON JUNCO. Junco hyemalis oregonus (Towns.) Geog. Dist.-Western North America. Breeds along the Pacific coast region from California northward to Sitka. 
Mr. A. W. Anthony notes this as one of the most common birds of Northwestern Oregon, rearing three and often four broods in a season. He states that the birds nest in various locations; in hollows of the ground under low bushes, the nest being built flush with the surface; also in holes among the roots of bushes and trees, and many nests are found under wood-piles. Some were found built on the shelf of a railroad cut, which was screened by a thick curtain of vines. Nesting begins about the last of March, or first of April. The materials of the nests are dry grasses rather loosely put together with a lining of cow-hair. The eggs are usually four, rarely five in number. In a large series of the eggs of this race of Junco there appears to be no distinguishable difference in coloration from those of $J$. hyemalis. The average size of ten eggs is $.77 \times .56$ inches.

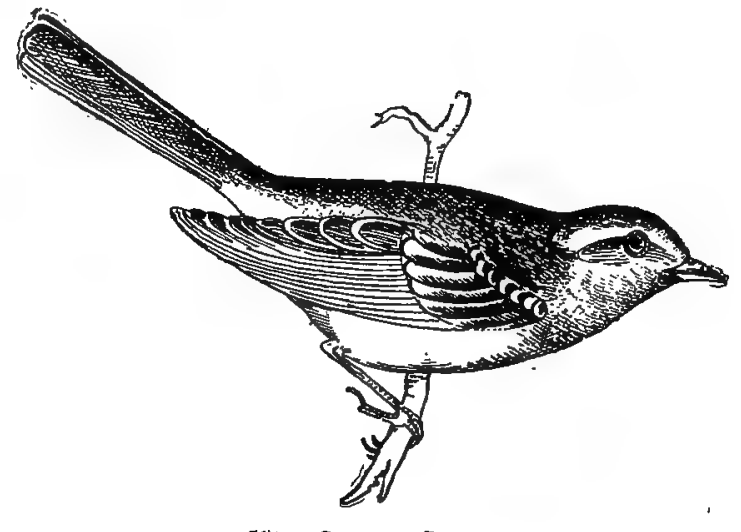

567a. OREgon Junco.

567b. SHUEELDT'S JUNCO. Junco hyemalis shufeldti Coale. Geog. Dist.Rocky Mountain region, west in the mountains of the Great Basin to California; in winter south to Arizona, New Mexico, Texas, and Northern Mexico. Accidental in Michigan, Illinois, Massachusetts, Maryland, etc.

Mr. Henry K. Coale, of Highland Park, Ill., has named this variety of Junco in honor of Dr. Robert W. Shufeldt, U. S. A., who collected the specimens from which the descriptions were made and presented them to U. S. National Museum.* The nesting habits and eggs of this bird are identical with those of the Oregon Junco.

567c. THURBER'S JUNCO. Junco hyemalis thurberi Anthony. Geog. Dist.Sierra Nevada, and deserts and southern coast rangesıof California.

The general habits, nests and eggs of this subspecies appear to be precisely the same as $J . h$. oregonus. Mr. C. W. Crandall has just added to his extensive oölogical collection an authentic set of four eggs of this bird, taken by Edmund Heller, in the San Bernardino Mountains, California, on June 8, 1897. The nest was placed on the ground in a carpet of old pine needles sunk flush with the surface, and hidden by pine brush. The nest was composed of dry grass, bits of moss and lined with finer material of the same. The outside diameter of the nest was 2.54 , inside 1.35 inches. The eggs are bluish white, handsomely ringed around the larger end with chestnut red and lavender with a few scattering spots over the major portion of the eggs. Their sizes are $.71 \times .58, .72 \times .57, .71 \times .57, .71 \times .57$ inches.

- For complete description of bird $\mathscr{C}$. Coale, Auk, IV, pp. 330-331. 
567d. POINT PINOS JUNCO. Junco hyemalis pinosus Looms. Geog. Dist.Vicinity of Monterey, California.

I know very little about this variety of the Black Snowbird, but from the quotations given by dealers on the skins and eggs, I imagine that it is a subspecies of limited abundance. Having a very restricted geographical distribution it is not probable that many skins of this bird are in private collections and far less of its eggs. For a description of the bird Cf. L. M. Loomis, Auk, X, p. 47.

567e. CAROLINA JUNCO. Junco hyemalis carolinensis Brewst. Geog. Dist.Higher portions of the Southern Alleghanies.

According to Mr. Wm. Brewster this new variety of the Black Snowbird differs from J. hyemalis in being larger, with lighter, bluer and more uniform coloration, and a horn-colored instead of pinkish-white or yellowish bill. Mr. Brewster found this bird at Highlands and on the Black Mountains of Western North Carolina. He states that it is probable that the birds represent the form which breeds on the mountains of Virginia and Pennsylvania. Two sets of eggs are،in Mr. Brewster's collection taken by Mr. Boynton, at Highlands, respectively June 30 and July 7, 1885 . "The eggs are larger than those of hyemalis but similar in color and markings." The nests are also larger and composed of coarser material, although both are neatly lined with horse-hair. The one collected July 7 was placed "in a bank by the roadside," a site often chosen by our northern birds, but the other was built in a berry bush, four feet above the ground. Both sets of eggs were perfectly fresh, a fact which proves that the bird breeds very irregularly and probably twice at least in the same season.* Mr. George B. Sennett found this subspecies breeding in the mountains of Western North Carolina. On Roan Mountain the birds were exceedingly abundant at an altitude of 6300 feet. In the latter half of April they were paired and building, and many complete nests were discovered. Fresh-laid eggs and young in all stages were found in July. The nests were found in all sorts of places-in the open fields, among the grass hummocks, along the edge of cow-paths, myrtle tussocks, under balsams or under the deciduous trees of a lower altitude. Two nests were found in balsam trees three and five feet respectively from the ground.

568. PINK-SIDED JUNCO. Junco annectens Baird. Geog. Dist.-Rocky Mountain district, from 'Arizona and New Mexico north to Idaho and Montana.

The Pink-sided Junco is found in the Rocky Mountain region, breeding from Fort Bridger northward. Dr. Merrill found it rather common in the mountains of Montana, at considerable height and among the pines. A nest taken June 13 was at the top of a ridge connecting two peaks, at an elevation of 8000 feet. The nest was under a shelving stone, in a little hollow dug out by the parents; it was rather large and compactly built, composed of coarse, dry grasses, with an inner lining of fine yellow straw and hair of the mountain sheep. The eggs, five in number, were far advanced in incubation and one was broken in blowing. The four remaining specimens measure $.81 \times .60, .80 \times .59, .84 \times .60, .83 \times .60$. They are described as dull yellowish-whitish, spotted and blotched with light reddish-brown and lavender. The spots are scattered over the entire surface of the eggs, but are largest and more numerous at the larger end.

568. 1. RIDGWAY'S JUNCO. Junco ridgwayi Mearns. Geog. Dist.-Wyoming, Colorado, Arizona and New Mexico.

According to Dr. Mearns the coloration in the upper parts of this species is similar to that of the Gray-headed Junco and the lower portions similar to that

*Auk, III, pD. 109-110: 
in the Pink-sided Junco, I have nothing authentic concerning its nests and eggs which more than likely do not differ materially from those of other Juncos.

569. GRAY-HEADED JUNCO. Junco caniceps (Woodh). Geog. Dist.-Rocky Mountain district, from the Black Hills to the Wasatch and other Mountains of Utah, south to Mexico and Arizona.

The Gray-headed Snowbird is a common breeder in the mountainous regions of Central Colorado and Utah southward, nesting in June, July and August, raising two, perhaps three broods in a season. Its nest resembles that of Junco annectens, being built on the ground in sheltered positions. The eggs have a difference in ground-color varying from white and pinkish-white to bluish or greenish-white, very faintly dotted (the markings being very minute) over the whole surface but chiefly at the larger end with reddish-brown. A set of four eggs of this Junco is in the collection of Mr. C. W. Crandall, of Woodside, N. Y. They were taken June 12, 1896, near Beulah, Pueblo county, Colorado, by Mr. D. P. Ingraham. The bird was shot and perfectly identified. The nest was placed just under the edge of a haystack. The situation was at an altitude of about 8500 feet. The eggs measure as follows: .76x.61, .77x.60, .74x.61, .76x.61, .76x.60 inches respectively.

570. ARIZONA JUNCO. Junco phoconotus palliatus Ridgw. Geog. Dist.Southern Arizona and adjacent portions of Mexico.

This is a common species at the higher altitudes in the mountains of Southern Arizona, where it dwells in the depths of the pine forests. It is generally mated in April, and nests may be found in May and June; these are placed on the ground under bushes, or otherwise sheltered. The eggs are described as being plain greenish-white, unmarked, size, .78x.60.

570a. RED-BACKED JUNCO. Junco phoconotus dorsalis Henry. Geog. Dist. Mountains of New Mexico and Eastern Arizona.

A common bird in the high mountains of New Mexico, and in the eastern portion of Arizona. July 16, Mr. F. Stephens found a nest of this bird in New Mexico, under a tuft of grass, which contained three perfectly fresh eggs. When blown, they are white, with a slight tinge of green, speckled sparsely all over, except at the smaller ends, with small brownish dots; sizes, .74x.58, .76x.62, .77x.63. Some eggs are marked in the form of a ring around the larger end.

571. BAIRD'S JUNCO. Junco bairdi Belding. Geog. Dist.-Southern Lower California.

Baird's Snow-bird was discovered in Lower California. It is described as resembling a bright colored female of $J$. $h$. oregonus, with the peculiar combination of pink sides, yellow eyes and under mandible. Its nest and eggs are unknown.

571. 1. TOWNSEND'S JUNCO. Junco townsendi Anthony. Geog. Dist.-San Pedro Martir Mountains, Lower California.

This new species from the San Pedro Mountains was described by Mr. A. W. Anthony (Proc. Cal. Acad. Sci., 2d Ser., II, Oct. 11, 1889, p. 76.) Authentic eggs of this bird are described as being indistinguishable from those of $J . h$. oregonus.

572. GUADALUPE JUNCO. Junco insularis Ridgw. Geog. Dist.-Guadalupe Islonn. Lower California. 
Mr. Bryant found this Snowbird common on Guadalupe Island, inhabiting the palm, pine and cypress groves. The birds mated early, soon after the first of the year, and were incubating by the 26th of January. A nest found March 10, contained four young, hatched but a few days before. It was placed in a depression, flush with the surface of the ground, and concealed by a covering of brush. Full fledged young were taken March 16; also a nest with three fresh eggs. This nest was placed in the cleft of a pine tree, which grew near the edge of a precipice. It was compesed of a few pieces of bark-moss, light-colored dry grass blades, and a tail feather of a petrel, lined within with goat-hair. The three eggs whioh the nest contained, Mr. Bryant says, were probably the second setting, judging from the ragged appearance of the female, indicating previous cares. Their color is a pale greenish-white, marked with fine dots of reddish-brown clustered around the larger end. They measure $19.5 \times 15,20 \times 15.5,20 \times 16$ millimeters.*

573. BLACK-THROATED SPARROW. Amphispiza bilineata (Cass.) Geog. Dist.-Southwestern United States-Texas to Lower California-south into Mexico, north in the interior to Nevada, Utah and western portions of Colorado.

The Black-throated Sparrow is an inhabitant of the southwestern portion of the United States from Western Texas to the Pacific. Mr. Wm. Lloyd.found it breeding in Western Texas, nesting in the cat-claw or chapparal bushes. Nests were found May 6 and 13, June 12, and July 13 containing fresh eggs, indicating that the bird rears at least two broods in a season. Mr. Scott notes this species as a common resident in the foothill region of the Catalinas and also about Tucson, breeding commonly at both points generally at considerable elevation. At an altitude of 4500 feet in the Catalina region tine breeding season begins early in March and continues well into the latter part of the summer. The nests he states are built near the ground in some low bush or cactus, and occasionally on the ground. The eggs are three to five, three or four being the general complement. Mr. Sennett secured several sets of eggs of this species at Lomita, on the Lower Rio Grande, in April. Mr. Davis informs me that he took two sets of the Black-throated Sparrow's eggs in Eastland county, Texas, in June; one set was far advanced in incubation, the other on the 14th was fresh. In color the eggs are plain bluish-white, and average in size, $.70 \times .51$.

574. BELL'S SPARROW. Amphispiza belli (Cass.) Geog. Dist.-California, south to Cape St. Lucas.

An abundant bird in all the thickets throughout Southern California. The nests are built in bushes and composed of grass stems and vegetable fibres, lined with hair. The nesting season is in May and.June. Eggs three or four in number to a set, pale greenish-blue, finely dotted and speckled chiefly at the larger end with cinnamon and dark reddish-brown. The average size of six specimens is $.74 \times .60$ inches.

574a. SAGE SPARROW. Amphispiza bell nevadensis (Ridgw.) Geog. Dist.Artemisia Plains of Western United States, north to Idaho, Montana and Wyoming Territories, east to Colorado and New Mexico, south to interior of Southern California, and Northern Mexico.

This bird abounds in the sage-brush deserts of Nevada, Utah, New Mexico and Arizona. Nests found near Carson City, Nevada, are described as being artfully con-

$* .77 \times .59, .79 \times .61, .79 \times .63$. 
eealed, either sunken in the ground or a few inches aivove it, in the lower branches of a bush; they are composed of sage-brush bark, dry grasses, etc. The eggs are light greenish, marked all over with very fine dots of a reddish-brown, around the larger end a ring of confluent blotches of dark purple and lines of darker brown; almost black; size $.80 \times .60$. Three or four are the usual number deposited.

574b. GIUY SAGE SPARROW. Amphispiza belli cillerca Townsend. Geog. Dist.-Lower California.

Little is known concerning the habits of this cinerous colored Sage Sparrow. They no doubt are identical with those of $A . b$. nevadensis.

\section{PINE-WOODS SPARROW. Peucca astivalis (Licht.) Geog. Dist.-} Florida and southern cortion of Georgia.

The Pine-woods Sparrow is common in some localities of Florida, where it breeds In May and June. In Alachua county, Florida, Mr. Frank M. Chapman states that it is common only in one locality, a high, open, palmetto pinery, where, May 21, 1887, a nest was found with four fresh eggs. In a letter to the late Major Bendire, Mr. Chapman states that this nest was placed beneath a scrub palmetto, and was constructed almost entirely of fine, dry grasses. It was firmly made, and held well together when lifted from the ground. It was not arched over in any way, which seems to be the peculiarity in the nests of Peucuea astivalis bachmanii. The nest was perfectly round, with the sides of rims everywhere of equal height, and was a symmetrical and well-proportioned structure. Three of the eggs taken by Mr. Chapman are in the National Museum collection, and are described by Major Bendire as pure white, slightly glossy, and rounded-oval in shape; sizes, .71x.61, .74x.61, .71x.61 inches.

575a. BACHMAN'S SPARROW. Peucra astivalis bachmanii (Aud.) Geog. Dist.-South Atlantic and Gulf States, and Lower Mississippi Valley, north to North Carolina, Eastern Tennessee, Kentucky, Southern Illinois, and west to middle Northern Texas.

Mr. Arthur T. Wayne informs me that in the region about Charleston, South Carolina, Eachman's Finch breeds in April, May, June and July, making its nest upon the ground in pine woods. He states that the birds breed in numbers seven miles north of Charleston, but the nests are difficult to find, only a single one having come under his observation. Mr. William Lloyd notes Bachman's Sparrow as a summer visitar in eastern Concho county, Texas, where nests are found from May 20 to June 1. Major Charles E. Bendire describes five nests, and several full sets of eggs of Bachman's Sparrow, which were presented to the National Museum collection by Dr. William C. Avery, of Greensboro, Alabama, in which vicinity they were taken in the months of May and June. Major Bendire says: "All the nests of this bird vary totally in structure from those of the other species of the genus Peucara, as they are known to me. They are all distinctly roofed-over or domed, a feature only found in the nest of a closely allied species, Embernagra rufivirgata, the Texas Sparrow, which constructs a somewhat similar nest. They are cylindrical in shape, about seven or eight inches long by three inches in height and four and one-half inches wide. The inner cavity is from three to four inches in length, about two inches wide, and one and three-quarters inches high. The rear wall of the nest is about one and three-quarters inches thick, the sides about an inch, and the roof a little over half an inch in thickness. These measurements vary somewhat in different specimens. The nests are all constructed out of dry grasses exclusively, and are lined with fine 
grass tops only. Some are much more artistically and compactly built than others; the roof projects somewhat over the entrance in all cases." The nest is always placed in a depression of the ground, and the entrance is invariably canted upwards at an angle of about $15^{\circ}$. The entrance to the majority of the nests faced west. The nests were found in growths of old-field pines, in patches of pine and plum bushes, on slopes of hills, in open spaces under fallen branches. The birds do not rise off the nest as other birds do when disturbed, but run some distance before taking flight." Major Bendire states that the eggs of Bachman's Sparrow in the National Museum, collected by Dr Avery, are pure white, but with less gloss than those of $P$. astivalis, more of a dead white. A set of four nearly fresh eggs taken May 8, gives the following sizes: $.72 \times .56, .75 \times .55, .72 \times .55, .71 \times .55$. A set taken June 23 , measures $.75 \times .57$, $.75 \times .60, .77 \times .61, .76 \times .61 *$ The late Captain B. F. Goss had a set of four eggs in his collection, taken by $\mathrm{Mr}$. Wayne. These measure $.79 \times .63, .75 \times .63, .75 \times .63, .75 \times .63$ inches.

576. ARIZONA SPARROW. Peucaa arizonce Ridgw. Geog. Dist.-Southern Arizona and Sonora.

The general habits, nest and eggs of the Arizona Summer Finch, as it is called, are identical with those of the next species.

577. MFXICAN SPARROW. Peucaa mexicana (Lawr.) Geog. Dist.-Valley of the Rio Grande in Texas, south into Central and Western Mexico.

Dr. James C. Merrill, met with this species on the Lower Rio Grande in Texas. He says the bird is found in some abundance on a salt prairie about nine miles from Fort Brown, and it was obtained with difficulty, as it could rarely be flushed from among the tall grass. "A nest, found June 16, 1877, was placed among the roots of a tussock of grass; it was made of blades and stems of grasses, and was rather deep, but so frail that it fell to pieces on removal. The eggs, four in number, were quite fresh. They are unspotted, white, strongly tinged with greenish-blue, and measure .82x.63." Ridgway describes the eggs as plain, pure white, size, .72x.58 inches.

578. CASSIN'S SPARROW. Peucca cassini (Woodh.) Geog. Dist.-Southwestern border of United States. Texas to Arizona, and Northern Mexico; north in summer to the Plains of Kansas.

The late Colonel N. S. Goss states that this species is a not an uncommon summer resident in Middle and Western Kansas, arriving from the first to the middle of May. Begins laying about the tenth of June. Their favorite resorts and breeding grounds are on the barren plains that are dotted over with low, stunted bushes. Dr. Merrill says Cassin's Sparrow arrives in the region of the Lower Rio Grande in Texas, about the middle of March, and frequents the open chapparal and thick bushes. Nests were found April '28, and May 4 and 22, 1877. They were placed at the foot of small bushes, and scarcely raised above the ground; were composed of dried grasses, lined with finer ones and a few hairs, but were very frail. Thirteen eggs taken from these nests are pure white, and average .74x.57. Mr. Lloyd found nests of this species in Western Texas in May, that were placed in bushes not higher than a foot from the ground, or in tufts of grasses.

579. RUFOUS-WINGED SPARROW. Peucra carpalis Coues. Geog. Dist.Arizona and Sonora.

* For Major Bendire's detalled account of the nest and eggs of "Peucæa æastivalis bachmanil see The Auk, October, 1888, pp. 351-356. 
The late Major Charles E. Bendire, U. S. A., found this species to be a common resident in the vicinity of Tucson, Arizona. The birds were especially abundant on the ridges bordering Rillitto Creek, on the dry, arid cactus-covered plains, near the present site of Camp Lowell. Here he collected many nests with eggs. The nest is usually placed in low bushes, preferably small mesquites, from six inches to five feet from the ground, most frequently about eighteen inches; and no especial attempt is made at concealment. It is firmly fixed to a fork or crotch, and is a compact structure, composed externally of coarse grasses and lined with the fine tops of the mesquite grass, and not unfrequently a few horse hairs, when such are obtainable. About one-half of the nests found contained one or more eggs of the Dwarf Cowbird. A set of three eggs collected by Major Bendire, on August 23, 1872, are in Mr. Norris' collection; they are plain bluish-white, and give the following measurements: $.75 x .57, .78 x .59, .75 x .58$. The first eggs were found by Major Bendire, June 14, but the birds were believed to commence breeding even a month earlier. The number to a set is commonly four or five.

580. RUFOUS-CROWNED SPARROW. Peucca ruficeps (Cass.) Geog. Dist.California coast from Lat. $40^{\circ}$ south to Cape St, Lucas.

The Rufous-crowned Sparrow breeds in various mountainous localities of California, where, however, it is somewhat local in its distribution. Rocky hill-sides, with a sparse growth of stunted bushes, are its favorite resorts. The breeding season is said to begin as early as April. The nest is placed on the ground in a slight hollow, and is exceedingly hard to find, as the sitting female steals silently away under cover of the surrounding vegetation, and if seen at all is likely to be mistaken for a startled mouse. A nest collected July 10, by Mr. Charles A. Allen, on Black Mountain, near Nicasio, California, and described by Mr. William Brewster, is outwardly composed of coarse grass and weed-stalks, lined somewhat scantily with horse hair, very loosely put together. The locality was an open heathy tract on the mountain-side, and the nest was placed on the ground under a bush. This nest contained three pure white eggs; size, $.89 \times .65 . *$ The eggs are described by others as plain bluish-white.

580a. BOUCARD'S SPARROW. Peucca ruficeps boucardi (Scl.) Geog. Dist.Southern New Mexico and Southern Arizona, south into Mexico and Puebla.

Mr. W. E. D. Scott found this species a resident in Southern Arizona, up to an altitude of 4000 feet in winter and nearly 10,000 feet during the warmer months, but Is much more common from the first of February until the middle of October. He states that it does not seek cover in the thick grass to the degree or in the manner so characteristic of its congeners. A nest was found June 15, 1885, well up on a hillside, at an altitude of 4500 feet, on the bare ground near a tussock of grass. The nest was bulky for so small a bird, and loosely put together. It is composed of coarse, dry grasses throughout and there is no attempt at lining with finer material. Contained in this nest were two young just hatched and one egg, apparently fresh, and plain, dead white; size, .83x.62. Three partly incubated eggs taken July 27 from a similar nest, measure $.80 \times .58, .82 \times .60, .86 x .61$. A third nest found by Mr. Scott late in July contained the same number of eggs, which were almost fresh.

580b. ROCK SPARROW. Peucaea ruficeps eremoca Brown. Geog. Dist.Southwestern Texas, south in Eastern Mexico to Orizaba.

* Bull. Nutt. Ornith. Club., II, p. 37. See also Vol. IV, pp. 47-48. 
Mr. Nathan Clifford Brown describes this subspecies from specimens taken by nim at Boerne, Texas, in 1879-80. He states that he always found the bird in rocky localities, usually in close proximity to a creek, but occasionally on barren hills a mile or more from water. It has the same shy, skulking habits which are common to other species of the genus, rarely taking wing on the approach of an intruder so long as rock, bush or weed affords a hiding place. Two sets of the eggs of this bird are in Mr. Norris' collection. One was collected June 19, 1884, in Comal county, Texas, the nest being on the ground in a bunch of grass; sizes, .81x.61, .85x.62, .81x.62, $.83 x .62$. The other set was collected April 4, 1882, in the same region, and the nest was likewise on the ground in a bunch of grass. These eggs measure, .82x.64, .78x.64, $.73 \times .63, .78 \times .64$. The eggs in both sets are plain bluish-white.

581. SONG SPARROW. Melospiza fasciata (Gmel.) Geog. Dist.-Eastern United States to the Plains, breeding from Virginia and southern portion of the Lake States northward to the Fur Countries.

The Song Sparrow in itș diverse geographical forms-varying in size, color, and in the relative size of the bill, etc., inhabits the greater part of the North American continent. The present species is one of the sweetest of songsters and is

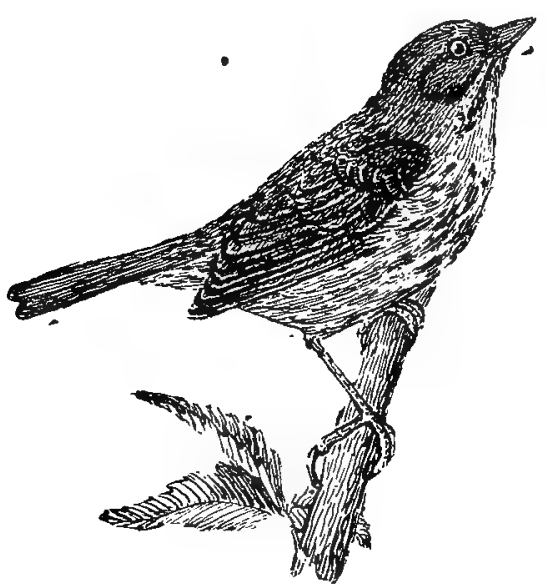

581. Song Sparrow. a familiar bird in Eastern United States, where, east of the Alleghanies, it breeds from South Carolina north into the British Provinces. West of the Alleghanies it breeds chiefly north of $40^{\circ}$ latitude, andis resident throughout the year in a large portion of the area in which it breeds. Ita nest may be found all through the summer months, two or three broods being reared; if the nest is destroyed or robbed, a fourth or fifth is frequently built, in which eggs are deposited. It is generally placed on the ground or in low bushes. The materials used in its composition are grasses, weeds and leaves, lined with fine grass stems, roots, and in some cases hair. Nests of this bird have been found built in holes of apple trees, and on the branches six or eight feet from the ground.. Again they have been placed by the side of a railroad track where the trains are continually passing. It is very frequently built in honeysuckle and other vines against the sides of houses. Curious places are often selected as nesting sites, such as a horse's skull in a grassy field, or under an old tin pan which has a hole in the top. The eggs are usually four or five, sometimes six, and rarely seven. So great is the diversity in their coloration and size that they generally serve to represent the eggs of several different species of "ground-birds" in the small boy's collection. . They vary from greenish or pinkish-white to light bluish-green, more or less thickly spotted with dark reddish-brown; the ground color and the spots have a diversity of shades; sizes range from .75 to .85 in length by .55 to .60 in breadth.

581a. DESERT SONG SPARROW. Melospira fasciata fallax (Baird.) Geog. Dist.-Parts of New Mexico, Arizona, Southern Nevada and Southwestern Utah. 
A common bird in the lower regions of Arizona, inhabiting the willow thickets and marsh grass near water. Its general habits, nesting and eggs on the whole are said to be indistinguishable from those of $M$. fasciata; three or four eggs being the usual numbers laid.

581b. MOUNTAIN SONG SPARROW. Melospiza faciata montana Hensh. Geog. Dist.-Rocky Mountain district-Colorado, Utah, Nevada, Eastern Oregon.

There is no essential difference between the nesting and eggs of this Song Sparrow and those of $M$. fasciata.

581c. HEERMANN'S SONG SPARROW. Melospiza fasciata heermanni (Baird.) Geog. Dist.-California, including the eastern slope of the Sierra Nevada Mountains.

The California Song Sparrow was named in honor of Dr. A. L. Heermann, who first obtained it in the Tejon Valley. It has been found in California as far north as San Francisco and to the south and southeast to San Diego and the Mohave River. This bird's favorite resorts are on the hillsides, canons and along the banks of streams. The nest is placed in bushes from two to six feet from the ground. Mr. Emerson states that the complement of eggs is generally four. The ground color in the eggs of heernanni is generally more bluish than in those of samurlis and the markings are heavier and of a darker brown and tend to be more confluent at the larger end than in the eggs of the latter. The egg of this species is also much larger, averaging $.87 \times .64$ inches.

581d. SAMUEL'S SONG SPARROW. Melospiza fasciata samuelis (Baird.) Geog. Dist.-Coast regions of California.

Wherever there are salt marshes along the coast of California, Samuel's Song Sparrow is sure to be found. The bird is especially abundant in the neighborhood of San Francisco. Mr. Emerson informs me that he has fourd the nest placed on the ground beneath tussocks of grass or in salt weeds and more often in a kind of low shrub that grows on the old sand drifts. Mr. Walter E. Bryant records a nest containing three eggs taken by Mr. Emerson from a round oyster can, which had lodged sideways among some driftwood, in a willow tree. A nest before me taken March 26, near Haywards, California, is composed of coarse, dry grasses and weed stems externally, the inside and lining being made of finer material of the same. Three or four eggs are deposited by this bird; their color is of a bluish-gray, spotted and blotched pretty generally over the surface with reddish-brown. A set of three eggs collected by Mr. Emerson, May 1, gives the following respective sizes: $.79 x .63$, $.75 x .59, .83 x . .59$; another, $.75 x .59, .83 \times .59, .75 x .59$ inches.

581e. RUSTY SONG SPARROW. Melospiza fasciata guttata (Nutt.) Geog. Dist.-Coast region of Washington and Oregon, south in winter to San Francisco, . Cala.

The Oregon or Rusty Song Sparrow is restricted to the Pacific coast district, breeding from Northern California northward. The eggs are described as being indistinguishable from those of $M$. fasciata, of the Eastern States, averaging the same in size.

581f. SOOTY SONG SPARRow. Melospiza fasciata rufina (Bonap.) Geog. Dist.-Coast region of British Columbia, north to Sitka. 
This is a larger and darker race of Song Sparrow inhabiting the Pacific coast region from British Columbia northward.

581g. BROWN'S SONG SPARROW. Melospizu fasciata rivularis Bryant. Geog. Dist.--Lower California, from Comondu northward.

According to Mr. Walter E. Bryant this subspecies begins nest building in the vicinity of Comondu, Lower California, about the middle of March. He found them sitting on eggs March 12. The first nest found was on March 27. It was built less than one metre above the ground in a thick growth of cat-tails, the situation being quite similar to the sites chosen by Belding's Yellowthroat, Feothlypis beldingi. The nest is composed outwardly of narrow, loosely laid leaves of cat-tails. The interior is first lined with a thin covering of fine strips of cat-tail leaves and a few fibres; over this is a thick covering of hairs. The nest is like that Duilt by the Song Sparrows. The eggs, four in number, contained large embryos. They are pale, greenish white, thickly speckled and blotched with reddish brown, forming a dense ring about the larger end. Mr. Bryant says: "On April 21, 1889, I found a set of three in a nest built amongst 'cat-tails' half a metre above a pool of water; it has the appearance of a double nest, being about twice the usual height. The eggs vary so much that they look like a composite set. Incubation was equally advanced in all. They measture $20 \times 14.5 ; 19 \times 14.5 ; 18.5 \times 14$ millimetres. Five other specimens, two from Comondu and a set of three from San Ignacio, have an average size of $19.5 \times 15$ millimetres.

581l. SANTA BARBARA SONG SPARROW. Melospiza fasciata yraminea Townsend. Geog. Dist.-Santa Barbara Island, and, in winter, adjacent mainland of California.

The habits, nesting and eggs of this variety of Song Sparrow do not differ materially from those of its allies. A set of four eggs in my collection, together with the skin of the parent bird, exhibit the same coloration as is common to the Song Sparrow of the Eastern States. The average size of the four eggs is $.76 \times .56$ inches.

581i. SAN CLEMENTE SONG SPARROW. Melospixa fasciuta clemente Townsend. Geog. Dist.--San Clemente and Santa Rosa Islands, California.

This bird of local distribution builds a nest and lays eggs which are indistinguishable from the last subspecies.

581j. DAKOTA SONG SPARROW. Melospi $\approx a$ fasciata juddi Bishop. Geog. Dist.-Turtle Mountain and vicinity, North Dakota.

For a description of this new subspecies $C f$. Bishop, Auk, XIII, Jan. 1896, p. 132.

581k. MERRILL'S SONG SPARROW. Melospiza fasciata Brewster. Geog. Dist.-Fort Sherman, Idaho.

The above is the type locality of this new subspecies. Cf. Brewster, Auk, Jan. 1896, p. 46.)

581. 1. BISCHOFF'S SONG SPARROW. Melospiza insignis Baird. Geog. Dist.-Kadiak. Island, Alaska.

I have no positive knowledge concerning the habits, nests or eggs of this species, which is known as the Cinereous or Kadiak Song Sparrow. 
582. ALEUTIAN SONG SPARROW. Melospiza cinerea (Gmel.) Geog Dist.Aleutian Islands, east to Fort Kenai, Alaska.

This is the Cinereous or Kadiak Song Sparrow of peculiar size, shape and color, and very long, slender bill. It inhabits the Aleutian Islands, where it nests among the tall grass and in the low shrubbery. Eggs similar to those of $M$. fasciata, but averaging larger, $.89 \times .65$ inches.

583. IINCOLN'S SPARROW. Melospiza lincolnii (Aud.) Geog. Dist.-Entire North America, breeding from the Northern border of the United States northward, and south in higher mountain ranges.

Lincoln's Finch is found throughout North America at large, breeding sparingly in the United States from Wisconsin and Northern New York northward, and in the west a's far south as the mountains of Southern Colorado. Breeds not uncommonly in the valleys of Oregon. From its habits of skulking through the underbrush and shrubbery of marshes, more like a mouse than a bird, it is seldom seen, and consequently it seems to be little known. Nests on the ground like the Song Sparrow. Mr. Norris has two sets of the eggs of Lincoln's Sparrow taken in Boulder county, Colorado, on June 22, and July 18, respectively. One of the nests was placed

- in a mossy bank among small swamp bushes, and composed entirely of grasses; the other was built at the base of an aspen tree: The eggs of one set, three in number, are light greenish-white heavily marked, principally at the larger end with chestnut and lavender-gray; sizes .81x.58; .81x.59, .82x.60. The nest taken June 22 is of four eggs; these are light pea-green thickly marked with chestnut and measure, $.79 \times .58$, $.76 x .57, .81 x .58, .79 x .57$ inches.

583a. FORBUSH'S SPARROW. Melospiza lincolnii striata Brewst. Geog. Dist.-British Columbia.

This subspecies is very similar to $M$. lincolnii but with the superciliary stripe and the entire upper parts more strongly olivaceous, etc. (Cf. Brewster, Auk VI, April, 1889, p. 89.)

584. SWAMP SPARROW. Melospiza georgiana (Lath.) Geog. Dist.-Eastern North America, breeding from Northern United States northward; west to the Plains, casually to Utah.

The Swamp Sparrow breeds from the Northern United States northward. On account of its secretive and retiring habits, the bird, its nest and eggs are very apt to escape notice unless perseveringly hunted and purposely looked for. The Swamp Sparrow dwells in the deep recesses of marshy thickets environed with a canopy of tangled foliage, whose treacherous quagmire abounds in a luxuriant growth of wild grasses. In these retreats the bird may exist in abundance and still be considered rare in certain localities where it has been overlooked. Its neat, trim form and tasteful colors render it one of the handsomest of our smaller sparrows. The Swamp Sparrow builds is nest on the ground in low, damp places; in construction and composition it is like that of the Song Sparrow and the eggs of the two species are somewhat similar. The eggs of $M$. georgiana, however, may generally be distinguished by the peculiarly clouded and indistinct appearance of the markings. The eggs of 1r. fasciata on the contrary, ... a rule have smaller markings and much more distinct ones, while the clouded effect of those of $M$. Deorgiana is entirely wanting. These are four or five in number and the average size is $.82 \times .56$ inches. 
585. FOX SPARROW. Passerella iiaca (Merr.) Geog. Dist.-Northern North America, breeding north of the United States; in winter south over the whole of the Eastern United States to the Gulf coast.

The Fox-colored Sparrow is one of the largest and finest of its tribe. Breeds from the Gulf of St. Lawrence and Labrador north into Alaska. It is met with in Eastern United States during the spring, fall and in winter. The Fox Sparrow in its summer home is said to be a charming songster, possessing a clear thrush-like song of exquisite melody, fairly rivaling the warblings of the ablest feathered performers in the sweetness and purity of tone and beauty of expression. Audubon met with it breeding in Labrador, and found its eggs from the middle of June to the 5th of July. It also breeds in Newfoundland. Nests of this species were, according to the reports of Mr. MacFarlane and Mr. Kennicott, found in trees and on the ground in the Arctic regions. Mr. W. H. Dall obtained the eggs on the Yukon river in Alaska, and the birds were very abundant at the mouth of this river in July and also at St. Michael's. Mr. Maynard found this species nesting on the Magdalen Islands. According to these observers the nests are, for the most part, placed on the ground, usually concealed by the drooping branches of evergreens. They are composed of grass and moss, lined with fine grass and feathers. The eggs are four or five, pale bluish-green, speckled, spotted and blotched with reddish-brown, or uniform chocolate-brown; size $.93 \times .65$ inches.

585a. TOWNSEND'S SPARROW. Passerella iliaca unalaschcensis (Gmel. Geog. Dist.-Pacific coast region, from Kadiak south in winter to Southern California.

This bird breeds north of the United States-from British Columbia north to Kadiak and coast of Alaska, west to Unalaska Islands. It has been found breeding on Vancouver Island, British Columbia, in May and June, and at St. Michael's, Alaska. In its habits it is said to be shy and retiring, frequenting the tangled thickets and brush-piles. In these its nest is built, commonly a few inches above the ground. The nest is described as being made of grasses, moss and vegetable fibres compactly woven together. The eggs, three to five in number, are described as of a greenish or dull brownish-white, spotted and blotched with reddish-brown; size $.90 \times .66$.

585b. THICK-BILLED SPARROW. Passerella iliaca megarhyncha (Baird.) Geog. Dist.--Mountain ranges of California and Oregon, including eastern slope of the Sierra Nevada.

This species is confined to the restricted area of the mountainous regions of California and Oregon. Its habits are much the sams as those of $P$. unalaschcensis, inhabiting the shrubbery of the mountain ravines, where it breeds. It is said to be an exquisite songster, its song resembling in richness and volume that of the Louisiana Water Thrush. The Thick-billed Sparrow has been found breeding in several places in California and Southeastern Oregon. 'Mr. L. Belding found it nesting in Calaveras county, California, in June. The nest is said to be built just above the ground, and sometimes at a height of five feet, and always in bushes amongst thickets. The eggs are like those of $P$. unalaschcensis, or those of schistacea, and average $.86 \times .64$ inches.

585c. SLATE-COLORED SPARROW. Passerella iliaca schistacea (Baird.) Geog. Dist.-Rocky Mountain region, west across the Great Plains into California and Oregon; east in winter to the Great Plains (Kansas). 
The Slate-colored Sparrow was met with by Prof. Ridgway in Parley's Park among the Wasatch Mountains, nesting plentifully in the willows and other shrubbery along the streams in the month of June. It was always found in company with the Mountain Song Sparrow, M. f. montana, which, in song, it greatly resembles. The nests of the two species were also much alike in manner of construction and situation and the eggs so similar that it required careful observation to identify a nest when one was found. A set containing three eggs of this species is in Mr. Norris' cabinet which was collected by Major Charles E. Bendire, at Camp Harney, Oregon, on June 21, 1875. The nest was in a rose thicket, two and a half feet from the ground, close to Rattlesnake Creek. The eggs are of a pale bluish-green, heavily spotted with burnt umber, and measure $.83 x .62, .80 x .62, .87 x .63$ inches, respectively.

585d. STEPHENS' SPARROW. Passerella iliaca stephensi Anthony. Geog. Dist.-Mountains of Southern California.

The type locality of this subspecies is the San Jacinto Mountains.

586. TEXAS SPARROW: Embernagra rufivirgata Lawr. Geog. Dist.-Valley of the Lower Rio Grande in Texas and southward.

Dr. Merrill and Mr. Sennett both note this species as a common resident on the Lower Rio Grande, in Texas, where it frequents the thickets, brush-fences and low shrubbery. Dr. Merrill says: "I have found the nests with eggs at intervals from May 9 to September 7 . These are placed in low bushes, rarely more than three feet from the ground; the nests are rather large, composed of twigs and straws, and lined with finer straws and hairs; they are practically domed, the nests being placed rather obliquely, and the part above the entrance being built out. The eggs are from two to four in number; thirty-two average $.88 x .65$, the extreme being $.97 \times .67$ and $.81 x .61$; they are pure white. Two, and probably three broods are raised in a season." Mr. Sennett obtained on April 10th young birds and a nest containing two eggB about to hatch.

587. TOWHEE. Pipilo erythrophthalmus (Linn.) Geog. Dist.-Eastern States, west to Eastern Dakota, Kansas, Texas and Gulf coast.

The Red-eyed Towhee, Chewink, Ground Robin, or Marsh Robin, as it is variously called, has an extended distribution throughout Eastern United States, from Florida and Eastern Texas on the south to the Selkirk Settlements on the northwest, and as far west as the edge of the Great Plains, where it is replaced by other closely allied races. Breeds almost wherever found. It is a spirited bird and spends a great deal of its time on the ground, hopping about among the thick underbrush, frequently uttering its peculiar notes, tohee, tohee, chevink, cheuink, in quick succession. The shady retreats of woodlands are also favorite resorts of this species. The nest is generally placed on the ground, at the foot of some bush, or under a fallen log. It is often built on the ground in the midst of deep, damp woods, well hidden In the rank grass. Occasionally, however, this Bunting places its nest in a bush or sapling. Mr. Poling states that he has taken the nest from trees as high up from the ground as seven and a half feet. It is a rude structure of grapevine bark, twigs, weed-stalks, leaves and grasses, lined with finer grasses and rootlets. The eggs of the Towhee are three or four, rarely five in number. Their ground-color is white, pinkish, or of a faint bluish-white. There is a wide variation in the shapes and and sizes of the eggs, likewise in the style and distribution of their markings. In ghape they will vary all the way from oblong oval to globular; rounded-oval however, 
being the characteristic type. They are thickly sprinkled or speckled with light reddish-brown; in some the markings are so bold and sparsely scattered that the eggs resemble very closely those of the Cowbird, Meadow-lark or Cardinal Red-bird. The markings in the eggs of the Towhee, as a general rule, have a constant pinkish cast rarely found in the eggs of the other species. We have already stated a means of distinguishing the eggs of this species from those of the Cowbird-page 272. Ten eggs measure $.89 \times .66, .89 \times .68, .89 \times .68, .90 \times .71, .88 \times .75, .90 \times .73, .94 \times .75, .96 \times .74, .93 \times .72$, $.96 \times .73$; average $.95 \times .72$ inches.

587a. WHITE-EYED TOWHEE. Pipilo erythrophthatmus alleni Coues. Geog. Dist.-Florida, Eastern Georgia and Southern South Carolina.

The Florida or White-eyed Towhee has been found breeding as far north as Beaufort county, South Carolina, by Mr. Walter Hoxie in the months of May and June. Mr. G. Noble, of Savannah, Georgia, informs me that he found the Whiteeyed in that region building chiefly in young pines from three to ten feet above the ground, and that the nest resembles that of the Yellow-breasted Chat. Mr. Hoxie found it nesting in pine trees ranging in height from four to twenty feet above the ground. The nests were made of coarse weeds, pine needles and grass, lined with finer grasses. The complement of eggs varies from two to four, and considerable variation exists in their size and markings. Mr. Norris has several sets of eggs taken near Frogmore, South Carolina. Their ground color is white, thickly speckled with pinkish-vinaceous and pearl-gray. A set of three has one egg which is covered all over with faint yellow specks, giving to the specimen a light yellow-brown appearance; the other two are bluish-white unmarked; sizes, $.90 \times .69, .85 \times .70, .82 \times .68$. Another set of two are of the same light bluish-white tint, unmarked, and offers the following sizes: $.85 x .67, .87 \times .62$. The sizes of a set of three are, $1.00 \times .74, .95 \times .72, .87 \times .70$ inches.

588. ARCTIC TOWHEE. Pipilo maculatus arcticus (Swains.) Geog. Dist.Plains of the Platte, Upper Missouri, Yellowstone and the Saskatchewan Rivers; west to the base of the Rocky Mountains; south in winter to Kansas, Colorado and Texas.

The Northern or Arctic Towhee Bunting has been found in the valley of the Saskatchewan, where it breeds, and on the high central plains of the Upper Missouri and the Yellowstone and Platte Rivers. An abundant species in the valley of the Great Slave Lake. Dr. Merrill found it in all parts of Montana wherever a stream with bordering underbrush afforded shelter. There is great diversity in the time of laying, or rather in the contents of nests found on about the same dates from the middle of May until late in July, which was attributed more to the great number of nests that must be destroyed by snakes, birds and small mammals, and to the attempt of the parents to raise another brood, than to any other cause. The nests are placed on the ground under some bush, favorite places being growths of cherry shrubbery. The rim of the nest is flush with the level of the ground, the birds scratching the hollow large enough to contain the nest, which is strongly built of bark strips, blades of dry grass, and usually lined with yellow straw. The eggs are four or five, averaging $.94 \times .69$ inches. Their ground color is white, slightly tinged with greenish and covered with dots and small spots of reddish-brown and lavender, most numerous at the large end. Some specimens are so densely covered with the markings that the ground color is harly distinguishable. 
588a. SPURRED TOWHEE. Pipilo maculatus mejalonyx (Baird.) Geog. Dist.-Rocky Mountain region westward to Southern California, north to Eastern Washington Territory, south into Northern Mexico and Lower California.

The Spurred Towhee Bunting is the prevailing form of the Rocky Mountain region-New Mexico, Arizona, etc. Its habits, nesting and eggs are substantially the same as those of $P$. erythrophthalmus. Mr. S. C. Evans found several nests of this bird near Riverside, California, all of which were placed in low bushes. Mr. Emerson says the bird is quite common in the vicinity of Haywards, California, where he has taken many of its nests. The nearest he has ever found the nest to the ground was about ten inches. In other localities, however, it is known to nest on the ground like the Eastern Towhee. The eggs have a light pinkish-white ground, thlckly sprinkled and speckled with vinaceous-cinnamon, and average $.88 \mathrm{x} .70$ inches.

588b. OREGON TOWHEE. Pinilo maculatus oregonus (Bell.) Geog. Dist.Pacific coast from British Columbia south to Santa Cruz, California.

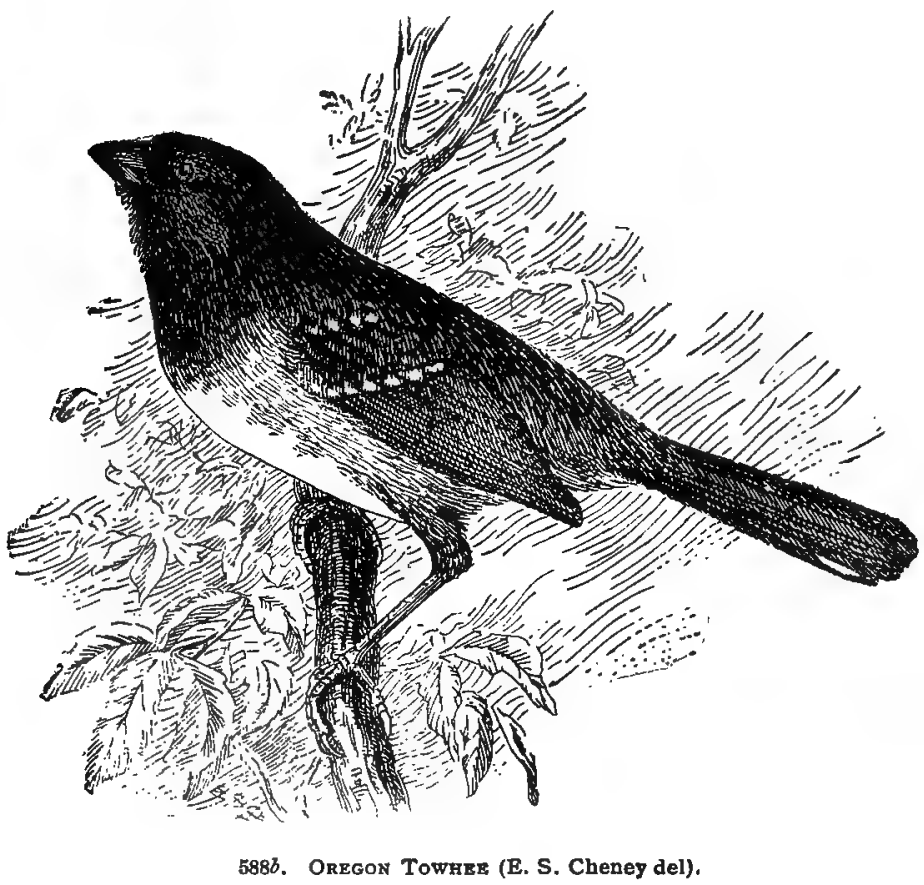

The Oregon Ground Robin is a resident in the western portion of the State of Oregon and Washington during the summer, and in the more northern portions of California. The nest is placed on the ground and sometimes in bushes, on stumps, etc., like the Eastern Towhee's. It is composed of grasses and leaves, with a lining of fine grass. Mr. Anthony mentions finding an egg of this species in the nest of the Rusty Song Sparrow. In color and general appearance the eggs resemble those of $P$. erythrophthalmus. A set of four eggs, taken May 12, are pinkish-white, thickly speckled with vinaceous and vinaceous-cinnamon; their sizes: $.94 x .70, .92 \mathrm{x}$ $.69, .91 \times .71, .95 \times .71$ inches. 
589. GAUDALUPE TOWHEE. Pipilo consobrinus Ridgw. Geog. Dist.Gaudalupe Island, Lower California.

I have no authentic description of the nesting and eggs of this species, but they can hardly differ from those of $P$. $n$. oregonus.

590. GREEN-TAILED TOWHEE. Pipilo chlorurus (Towns.) Geog. Dist.Whole of Middle Province, including the Rocky Mountains and eastern slope of the Sierra Nevada-Eastern Oregon, Idaho, Montana, etc., south into Mexico.

Called the Chestnut-crowned Towhee, Green-tailed Bunting and Blanding's Finch. It is generally distributed in all bushy places throughout the fertile tnountain portions of the interior. It is a characteristic bird of the eastern slope of the Sierra Nevada, and a summer resident arriving at.Virginia City about the middle or latter part of April. Habits, nesting, eggs and song generic. The late Mr. Snowdon Howland informed me that he collected a set of four eggs of this species in Wyoming in 1871. The nest was placed on the ground in the usual manner of that of the Eastern Towhee, and was-composed of dry grasses and shreds of bark. It was well concealed by a dense growth of low bushes. The eggs are white with a bluish tint, profusely dotted with pinkish-drab, sometimes so thickly distributed as to give the egg the appearance of a uniform color, or as an unspotted pinkish-drab, and again more sparsely diffused; their average size is, $.85 \times .65$.

591. CANON TOWHEE. Pipilo fuscus mesoleucus (Baird.) Geog. Dist.-NeW Mexico and Arizona, south into Mexico.

The Canon Bunting or Brown Towhee is abundantly distributed throughout the warmer portions of New Mexico and Arizona, from the valley of the Rio Grande to that of the Colorado. It prefers the dense bushes of the valleys, and like the Eastern Red-eye, passes the greater part of.its time on the ground, in thickets, generally in company with the Arctic Towhee. The nest is usually built in shrubs and low mesquite trees. The eggs are three or four in number and are rounded oval in shape, pale blue, spotted, dotted and lined with purplish-brown and black; sizes range from $1.00 \times .75$ to $1.05 \times .78$. The eggs of the Brown Towhee resemble those of the Redwinged Blackbirds, but are larger and more rounded oval.*

591a. ST. LUCAS TOWHEE. Pipilo fuscus albigula (Baird.) Geog. DistLower California.

The White-throated Brown Towhee is a common species at Cape St. Lucas, where it breeds abundantly, placing the nest usually in thickets, a few feet from the ground and often on the ground, in a slight hollow. It is composed of wiry grasses, a few leaves, and fine, slender roots. The eggs are usually four in number, pale greenish-white or very pale greenish-blue, with markings, dots, dashes and lines about the larger end, of a deep dark shade of purplish-brown, so dark as sometimes to be indistinguishable from black; average size $.91 \times .65$ inches.

591b. CAIIFORNIAN TOWHEE. Pipilo fuscus crissalis (Vig.) Geog. Dist.Pacific coast region west of the Cascades and Sierra Nevada, from the Umpqua Valley, Oregon, south to Northern Lower California.

An abundant bird in California and known as the California Brown Towhee, Crissal Towhee Bunting and Canon Finch. Mr. A. M. Shields states that in Southern

- Eggs of North American Birds, by C. J. Maynard, lllustrated with ten handcolored plates. Boston: DeWolfe, Fiske \& Co. 1890. 
California this species is a constant companion of the California Thrasher, frequenting the dense beds of chapparal and the scrub bushes which line the mountain cazons. The birds nest early in April, and fresh eggs may be found until the middle of May. The nest complement is generally four, often five, sometimes only three. The situation of the nest, according to Mr. Shields, is quite variable, sometimes it is placed on the ground, occasionally in crevices of vine-covered rocks, in hollow trunks of trees, etc., but the favorite nesting place is a thick, scrubby bush from three to five feet above the ground. Prof. Evermann found young birds as early as April 3 in Ventura county. The nest in that region is usually built in a sage, greasewood, or cactus, one to five feet from the ground. Occasionally, however, it is placed in live oaks, ten to fifteen feet up, and composed of twigs, bark and grass, lined with rootlets. A large series of the eggs of this species is before me. In their general appearance they resemble the eggs of the Red-winged Blackbird, being of a blue, spotted and blotched with varying shades of dark and light puirple, in some the color is not distinguishable from black, except in a strong light. The markings are chiefly or wholly at the larger ends and sometimes in the shape of scrawls and daubs. Ten eggs measure $.87 \times .72, .90 \times .73, .92 \times .71, .92 \times .73, .94 \times .74, .95 \times .70, .95 \times .73, .97 \times .73$, $.99 \times .71, .99 \times .73$ inches.

591c. ANTHONY'S TOWHEE. Pipito fuscus senicula Anthony. Geog. Dist.Southern California and Lower California, south to Lat. $29^{\circ}$.

The general habits, nesting and eggs of this subspecies are identical with those of the California Towhee. The average size of eight eggs is $.87 \times .74$ inches.

592. ABERT'S TOWHEE. Pipilo aberti Baird. Geog. Dist.-Arizona and New Mexico north into Southern Utah and Colorado.

This very large and long-tailed species, known as the Gray Towhee, is abundant in all suitable localities of Arizona and New Mexico. One of the most abundant birds throughout the valleys of the Gila and Colorado Rivers. Its favorite resorts are the dense chapparal thickets along streams. Said to be a very shy species keeping close within its retreats upon the approach of an intruder. The nest is rather loose and bulky, usually built in bushes near the ground and again in trees. Mr. Stephens found one in a bunch of mistletoe at a height of at least thirty feet. The nest is made of strips of bark, twigs and leaves, with finer lining of the same materials. The eggs are three or four in number and look exactly like those of the California Towhee-pale greenish-blue or bluish-white, speckled, spotted and splotched about the larger end, sometimes sparsely over the whole surface with dark brown. Average size 1.00x.74. A set of three eggs in my cabinet, taken by Dr. Chas. Carter, U. S. A., in Pinal county, Arizona, on April 21, 1885, exhibits the following sizes: $1.01 x .75,1.02 x .75,1.00 x .74$ inches.

593. CARDINAL. Cardinalis cardinalis (Linn.) Geog. Dist.-Eastern United States; west to Kansas, Nebraska; south to Texas and Florida; north to the Middle States; rare in New York, casual in Connecticut, accidental in Massachusetts; represented by varieties in the Southwest.

Commonly called Redbird or Cardinal Grosbeak, anđ by some Virginia Nightingale or Virginia Cardinal. It is not migratory but resident nearly wherever found, and is distributed throughout the eastern part of the United States from the latitude of Ohio southward. The nest of this species is placed in a variety of situations, usually from three to ten feet above the ground in a dense thicket, which is its favorite nesting site. I have found the nest placed on the top rail of a fence in the 
midst of a clump of brambles. The late Dr. Wheaton mentions finding it "on the top of vine-covered stumps, in wild-gooseberry bushes overhanging water, and in brush-heaps," and says: "I have found the nest ready for the reception of eggs as early as April 17." Mr. Davis states that in Cook county, Texas, the Redbird begins nesting before the trees put forth their leaves. The nest is a loose, frail structure, made of slender twigs; strips of grape-vine bark, stems, grass, and a few leaves, lined with fine rootlets and grasses, sometimes with horse hair. There is a great diversity in the coloration and general appearance in a large series of the eggs of this species. The ground-color in the various specimens runs from white through blulsh or greenish-white to that of a brownish tint. The markings are reddish-brown, lavender and gray of various shades and are pretty generally scattered over the entire surface; in other specimens they tend to cluster more thickly about or on the larger ends; some are so thickly marked as to almost conceal the ground color. The specimens generally considered handsomest are those with a greenish-white ground heavily and distinctly blotched with reddish-brown. Some of the smaller eggs and more finely dotted ones resemble very closely those of the Cowbird. Mr. Ragsdale has an egg of this species with a large chocolate blotch covering one-fourth of the shell. The eggs are three or four in number.* Eight eggs (two nests of four each) measure respectively: .98x.71, .93x.73, 1.02x.74, 1.06x.74, $.98 \times .77,1.00 \times .75,1.01 \times .76,1.03 \times .78$; average $1.00 x .73$.

593a. ARIZONA CARDINAL. Cardinalis cardinalis superbus Ridgw. Geog. Dist.-Southern and Western Mexico, south to Mazattan.

A bird very similar to $C$. cardinalis but larger, and the female more richly colored. Its general habits, nesting and eggs are not in anywise distinguishable from those of the Redbird of the Eastern States.

593b. ST. LUCAS CARDINAL. Cardinalis cardinalis igneus (Baird.) Geog. Dist.-Lower California, north to Lat. $29^{\circ}$.

A smaller bird than superbus and called Fiery-red Cardinal as its specific name implies, but is not any more so than cardinalis, and its habits, nests and eggs are the same.

593c. GRAY-TAILED CARDINAL. Cardinalis cardinalis canicaudus Chapman.-Geog. Dist.-Southwestern Texas, south into Northeastern Mexico.

Mr. Frank M. Chapman describes the male of this subspecies as being similar to Cardinalis cardinalis, but with a less black frontlet; the female averaging grayer than the female of $C$. cardinalis, and with the tail feathers broadly margined with gray instead of being narrowly edged with olivaceous brown. The type specimens, a male and female, were taken by Mr. Chapman thirty miles west of Corpus Christi, April 23, 1891 $\dagger$ Specimens of the nests and eggs of this bird in my collection, taken near Corpus Christi, appear to be identical with those of $C$. cardinalis of the North. Eight eggs average in size $.97 \times .74$ inches.

593d. FLORIDA CARDINAL. Cardinalis cardinalis floridanus Ridgw. Geog. Dist.-Florida.

* There are a number of sets of flve eggs of the Cardinal on record, but I have never geen or taken that number from a single nest myself. Sets of three are as common as those of four.

† For complete description see Bull. Am. Mus. Nat. Hist., Vol. III, v. 324. 


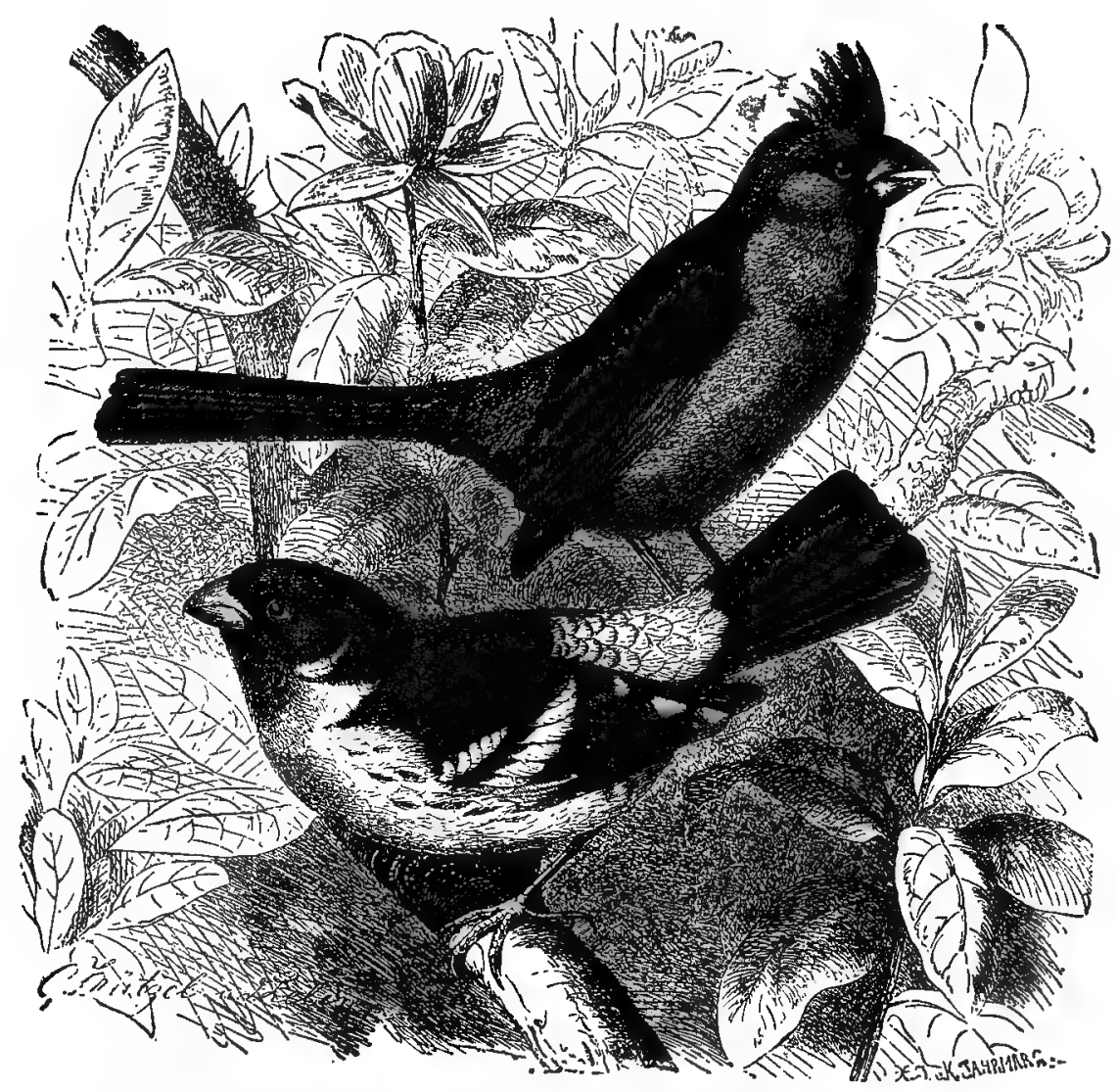

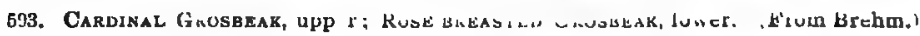

The general habits, nesting and eggs of this subspecies are precisely identical with those of the Cardinal of the North.

594. TEXAN CARDINAL. Pyrrluloxia sinuata Bonap. Geog. Dist.-Northern Mexico and Southern border of the United States-Southern Texas to Southern Arizona and Lower California.

This species inhabits the southern border of the United States. Dr. Merrill fcund it abundant at times at Fort Brown, Texas, particularly in the Spring. Mr. Sennett records it as tolerably common at Lomita and a probable resident in that region along with the Virginia Cardinal, and breeds fully as early. There is, he states, little difference between the habits of the two Cardinals, but the Texan is more confined to open and exposed situations near settlements, and is always shy and suspicious, so that he rarely came upon it unawares. The nest is built in thickets, sometimes in isolated bushes, from three to eight feet above the ground, and is said to be very much smaller than that of $C$. cardinalis. The materials are bark strips, twigs and dry grasses. The eggs are usually four in number and re- 
semble those of $C$. cardinalis except in their smaller size, averaging .92x.73. Mr. G. B. Benners gives the sizes of a set of four eggs which he obtained on the Rio Grande, April 21, as follows: .87x.69, .87x.69, .89x.69, .85x.67.

594a. ARIZONA PYRRHULOXIA. Pyrrhuloxia sinuata beckhami Ridgw. Geog. Dist.-Southern Arizona to Western Texas, and south into Northwestern Mexico.

This form, according to Mr. Ridgway differs from the Texas Cardinal, $P$. sinuata in being of a decidedly browner and somewhat lighter tone of gray and a greater extent of dark red on the tail; adult male much less (often not any) blackish

- suffusion in the lighter carmine red of the capistrum, and the red of the crest is much lighter, etc. The nest and eggs of this bird cannot be differentiated from those of the Texas Cardinal.

594b. ST. LUCAS PYRRHULOXIA. Pyrrhulonia sinuata peninsule Ridgw. Geog. Dist.-Lower California.

This race of the Cardinal is described by Mr. Ridgway as similar to $P$. s. beckhami in color, but decidedly smaller. I am informed that the eggs are similar to those of the Texas Cardinal and measure $.86 \times .67$ inches.

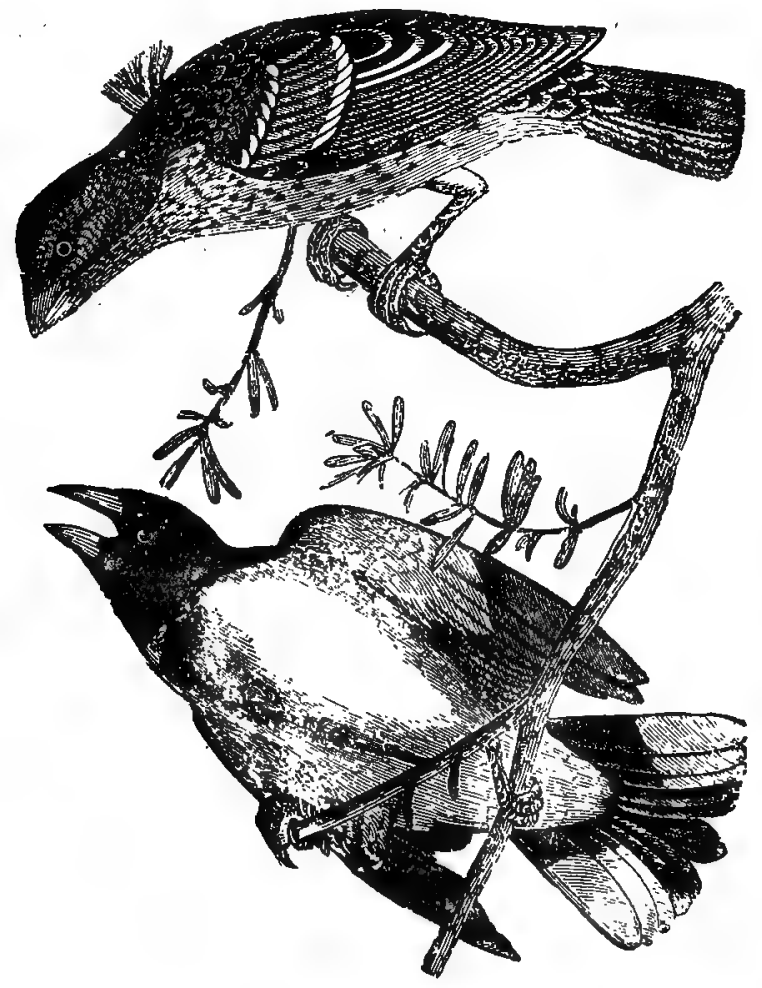

895. Rqse-breastrd Grosbeak, Upper, female; lower, male. (After Audubon.) 
595. ROSE-BREASTED GROSBEAK. Habia ludoviciana (Linn.) Geog. Dist. Eastern United States, north to Southern Canada; south in winter through Cuba, Central and into Northern South America.

The rose-bud of our North American Oscines-everywhere noted for its beauty and musical ability. Breeds from the Northern States northward, but it is nowhere an abundant bird. Trees and shrubbery along the banks of streams or the borders of dense woods are its favorite resorts. A bird with a plump, round form, the male with head and neck black, bill whitish; wings and tail white and black, the breast and under wing-coverts rosy or carmine red. The parts which in the male are black are streaked with blackish and olive-brown in the female, and the under wingcoverts saffron-yellow, and though not so striking in contrast, makes a bird of handsome appearance. The nest is placed in the thick foliage of trees at the edges of woods or on the banks of streams. It is a flat, shallow structure, composed of small twigs, vegetable fibres and grass. Breeds in May and June. The eggs are three to five in number, the latter being uncommon. They are greenish-blue or bluishgreen, more or less spotted over the entire surface with blotches of reddish-brown; the eggs resemble very closely those of the Summer Redbird or Scarlet Tanager; sizes range from .95 to 1.08 in length by .70 to .76 in breadth.

596. BLACK-HEADED GROSBEAK. Habia melanocephala (Swains.) Geog. Dist.-Western United States, east to the Great Flains, south into Mexico.

This bird occurs from the high Central Plains to the Pacific, and from the northern portions of Washington Territory to the table lands of Mexico. Breeds throughout its United States range. Colonel Goss gives it as a quite common summer resident in Middle and Western Kansas; begins laying the last of May. Quite common in California; begins nesting about the first of April-nesting abundantly in the willow and water-mootic copse near Santa Clara River and among the liveoaks along the small streams and creeks. The nests are placed from five to twenty feet from the ground, and composed of a few slender twigs, weeds, grasses and rootlets. Two to four eggs' are laid. Sets of this bird's eggs are in my cabinet ccllected at San Gorgonia Pass, California, by Mr. Herron, in May and June. These are of two and three eggs each. They are bluish-green sprinkled and blotched with reddish and rusty-brown; some heavily spotted while others are sparingly marked, the spots in all cases become more numerous towards the larger ends. Eight eggs measure $.84 \times .65, .86 \times .67, .87 \times .65, .92 x .69, .94 \times .68, .90 \times .67,1.07 \times .72,1.07 \times .73$.

597. BLUE GROSBEAK. Guiraca carulea (Linn.) Geog. Dist.-Eastern United States, from Southern New Jersey, Southern Illinois and Central Nebraska south to Cuba and Mexico. Casual northward to New England.

The Blue Grosbeak is nowhere an abundant bird, but breeds throughout its United States range, occasionally as far north as Southern Pennsylvania. In the West it is found in New Mexico, Arizona, Colorado and California. Colonel Goss gives it as a summer resident of Kansas, being quite common in the Middle and Western portion; begins laying the last of May. A common species in the South Atlantic and Gulf States. Mr. C. S. Brimley says that in the vicinity of Raleigh, North Carolina, it begins nesting about the first part of June. Mr. G. Noble, of Savannah, Georgia, has sent me a typical nest which he collected in June. In 


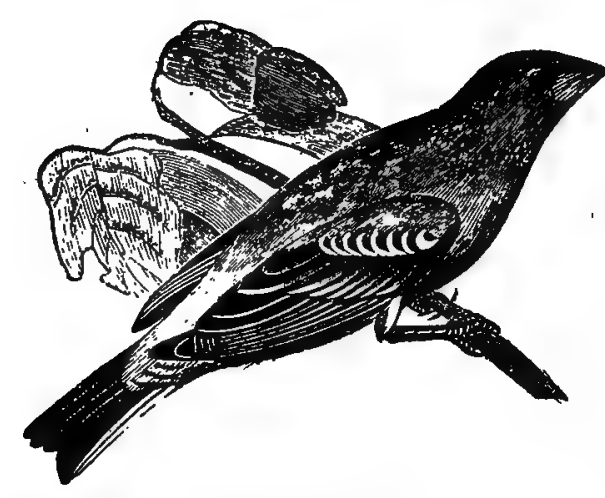

697. Blue Grosbear.

Texas, it commences to build about the first part of May. Mr. T. D. Perry has found eggs as early as May 10, slightly incubated, near Savannah, Georgia, and fresh eggs as late as July 7, indicating that at least two broods are reared in a season. The nest resembles that of the Painted Bunting, being invariably lined with fine brown rootlets, and occasionally it contains some horse hair. A characteristic of the Blue Grosbeak's nest is that it almost invariably contains pieces of snakeskin in the outer material of withered leaves and plants. It is placed in blackberry bushes along road-sides and on the border of woods.

Mr. J. A. Singley, of Giddings, Texas, says that in Lee county a favorite nesting place is in the vicinity of houses where the first growth of timber has been cut down and a growth of low thick bushes replaces it. He says he has taken the nest in peach, apple, hickory and post-oak trees, ranging from fifteen to thirty feet. Mr. E. C. Davis states that in Cooke county, Texas, this species usually nests in alder bushes in swampy places. The eggs are three or four in 'number, plain light blue, and when exposed to light a little while, fade into dull white; oval in shape and average $.84 x .66$ inches. On the 24th of May, 1887, Mr. Perry found a nest containing four spotted eggs of this species. They were distinctly marked with dots and spots of chestnut and subdued lilac. One of the eggs was accidentally broken; the remaining tbree measure $.87 \times .63, .82 \times .62, .82 \times .62$ respectively.

597a. WESTERN BLUE GROSBEAK. Guiraca carulea eurhyncha Coues. Gecg. Dist.-Southwestern United States, from South Dakota, Colorado, Southern Utah, Southern Nevada and California to Lower California and Southern Mexico.

There is absolutely no difference in the general habits, nests and eggs of this subspecies and that of $G$. carulea.

598. INDIGO BUNTING. Passerina cyanea (Linn.) Geog. Dist.-United States and Southern British Provinces; west to the Great Plains; south in winter to Veragua.

The Indigo Bluebird or Indigo Painted Bunting is quite an abundant bird in various parts of the United States from the valley of the Missouri to the Atlantic, and from Florida to New Brunswick. The male of this species is of an intense indigo-blue color, and the female plain grayish-brown. Breeds throughout its United States range. The nest is built in a bush or low shrubby tree, generally in an upright crotch; it is composed of weed stalks, twigs and coarse grass, and lined with finer material of the same. It is on the whole an inartistic nest for a bird of gay plumage. The eggs are four in number, white, with a bluish or greenish tinge, unspotted or rarely thinly dotted with brown; average size $\mathbf{. 7 5 x . 5 3}$. Sometimes the eggs of this species are pure white unmarked.

599. LAzUII BUNTING. Passerina amona (Say.) Geog. Dist.-Western United States from the Great Plains to the Pacific; south in winter to Western Mexico.

The Lazuli Painted Finch is common in Colorado, Arizona, and very abundant in California; in fact it is generally distributed throughout the west, and along the 
Pacific coast as far north as Puget Sound during the summer. It replaces the Indigo Burting from the Plains to the Pacific and is found in all suitable localities. The nest is usually built in a bush or in the lower limbs of trees, a few feet from the ground. It is composed of fine strips of bark, small twigs, grasses, and is lined with hair. The eggs are usually four in number, light bluish-green which readily fades when exposed to light; they resemble very closely the eggs of the Bluebird; some specimens are not distinguishable with certainty; average size, .75x.58. Sets of these eggs are in my cabinet collected by. Mr. R. B. Herron at San Gorgonia Pass, California, between May 4 and June 13, 1883. The sizes of two sets, four eggs each are .76x.55, $.77 x .55, .74 x .58, .74 x .56 ; .74 x .53, .75 \times .59, .78 \times .55, .79 \times .56$. A set of four taken June 10 gives the following dimensions: $.81 x .62, .83 x .64, .79 x .62, .83 x .64$,

600. VARIED BUNTING. Passerina versicolor (Bonap.) Geog. Dist.-Lower Ric Grande'Valley in Texas, southward into Eastern Mexico.

This bird is called Purple Painted Finch, Western Nonpareil, Prusiano. It inbabits the region of the Lower Rio Grande in Texas south into Eastern Mexico. Habits and nesting like those of $P$. amrena. Eggs dull bluish-white; size $.75 \times .57$ inches.

600a. BEAUTIFUL BUNTING. Passerina versicolor pulchra Ridgw. Geog. Nist.-Lower California and Northwestern Mexico.

This is a rather smaller race of the Varied Bunting. Its habits, nests and eggs remain to be described.

601. PAINTED BUNTING. Passerina ciris (Linn.) Geog. Dist.-Southern Atlantic and Gulf States, north to North Carolina and Southern Illinois, south in winter to Panama.

Called Nonpareil, Painted Finch and "Mexican Canary." In Mexico and in some of the Southern States it is a favorite cage-bird. The male is a bird of handsome variegated plumage-blue, green, vermilion-red, yellowish-green, etc., and the female plain olive-green. A common species in the South Atlantic and Gulf States, nesting in May, June and July, often rearing two broods in a season. In Georgia, Mr. Perry states that he has found nests with eggs as early as April 7 and as late as July 20. A nest before me collected by Mr. G. Noble, of Savannah, Georgia, is composed of leaves, bark strips, twigs, rootlets and fine grasses. It is on the whole a neat, compact structure. The nest is sometimes lined with horse hairs. It is built in the smallest bushes, in saplings and also in the tallest trees. Mr. Perry has found two or three nests in a single tree, and one nest built upon another, with eggs in the cavities of both. The eggs are four or five in number, dull pearly-white or bluish, speckled and blotched with reddish-brown particularly at the larger end; average size .79x.60. Four eggs measure .76x.57, .75x.55. .80x.60, .80x.57.

602. SHARPE'S SEED-EATER. Sporophila morelleti sharpei Lawr. Geog. Dist.-Lower Rio Grande Valley in Texas, and adjacent parts of Mexico.

This curious little Sparrow is found in the Rio Grande Valley in Southern Texas and adjacent portions of Mexico. Dr. Merrill states that it is not uncommon in the vicinity of Fort Brown. The birds were usually seen in patches of briers and low bushes at no great distance from water, and were very tame. During the breeding season the male has a very sprightly song much resembling that of the Indigo Bunting, but sweeter. At least two pairs built within the fort during the season 
of 1877. One of the nests, found early in May, was in a bush about three feet from the ground; it was not pensile; placed between three upright twigs, composed entirely of a peculiar yellow root. This was destroyed by a violent storm before the eggs were deposited. A second nest found May 25, placed in a young ebony-bush, four feet from the ground, was deserted immediately after completion. It was a delicate structure supported at the rim and beneath by twigs, and built of very fine, dry grass, with a few horse hairs. Mr. C. W. Crandall has a nest and four eggs of this subspecies collected by Frank B. Armstrong near Brownsville, Cameron county, Texas, May 7, 1892. The bird was shot and identification made sure. The nest was placed in a small tree, six feet above the ground in open woods. It is composed of fine fibres of wiry grass, loosely interwoven, the material for the lining being of the same kind, but finer. The eggs have a ground color of bluish green and the markings are distributed quite evenly over the entire surface; they consist of spots and blotches of brown and lavender with under shell markings of a pale shade, and numerous surface spots of a rich dark purplish brown. The sizes of the four eggs are as follows: $.67 \times .48, .63 \times .48, .64 \times .49, .68 \times .49$ inches respectively.

[603.] GRASSQUIT. Euetheia biclor (Linn.), Geog. Dist.-Cuba. Accidental in Southern Florida (Sombrero Key).

This species is a resident of the Island of Cuba and has been found on Sombrero Key, Florida. Its nests and eggs are described as being similar to those of $E$, bicolor.

[603. 1.] MELODIOUS GRASSQUIT. Euetheia canora (Gmel.) Geog. Dist.Accidental or casual in Southern Florida.

This is the Black-faced Grassquit which is common in various islands of the Bahama group. It appears to be accidental in Florida. Said to construct a large dome-shaped nest with a lateral entrance. It is built in bushes and low shrubbery. Eggs three to five, white or greenish-white, speckled with reddish-brown; average size $.65 \mathrm{x} .50$ inches.

604. DICKCISSEL. Spiza americana (Gmel.) Geog. Dist.-Eastern. United States (chiefly west of the Alleghanies) to the Rocky Mountains, north to Massachusetts, New York, Wisconsin, Minnesota, etc., south in winter to Northern South America.

Known as the Black-throated Bunting, "Little Field Lark," and "Judas-bird." In general appearance it loks like the European House Sparrow, $P$. domesticus, averaging a trifle larger. The favorite resorts of the Black-throated Bunting are pastures with a sparse growth of stunted bushes, and clover fields. In these places its unmusical, monotonous song may be heard throughout the day during the breeding season. Its song is uttered from a tall weed, stump or fence-stake and is a very pleasing ditty when its sound is heard coming far over grain fields and meadows in the blaze of the noon-day sun, when all is hushed and most other birds have retired to shadier places. The nest of the Black-throated Bunting is built on the ground, in trees and in bushes. In Central Ohio I have never found the nest in any other position than on the ground under the shelter of a tuft of grass or bush. In Western Illinois, Mr. Poling states that they are placed in the tall grass or in clover fields. Mr. L. Jones informs me that in Iowa the nest may be found almost anywhere, not above twenty feet in trees and bushes, or on the ground in prairie lands. Nesting is begun in May, and the second nests are built in July or August. The materials are leaves, grasses, rootlets, corn husks and weed stems; the lining is of fine grasses, 
and often horse hair. On the whole the nest of this species is a compact structure. The eggs are four or five in number, almost exactly like those of the Bluebird; average size $.80 \times .60$. Ten eggs measure $.76 \times .60, .76 \times .62, .77 \times .60, .79 x .62, .79 \times .59, .80 \times .62$, $.81 x .60, .80 \times .59, .75 x .56, .82 \times .59$.

605. LARK BUNTING. Calamospiza melanocorys Stejn. Geog: Dist.-Plains of Dakota and Middle Kansas west to the Rocky Mountains, northward to or beyond the United States, south in winter to Texas, New Mexico, Arizona, Lower California and Northern New Mexico; occasional west of the Rocky Mountains. Accidental in Massachusetts.

A bird of the plains - a summer resident in Middle and Western Kansas, breeding from thence northward to or beyond the United States boundary. The bird is said to utter the most delightful songs, and its warbles are described as similar to those of the Bobolink and the soft cadence of the Skylark. The nest is placed on the ground, sometimes sunken even with the surface, and beneath the shelter of a busk. or tuft of grass. It is composed of fine stems, grasses, and lined with finer grasses and vegetable down. The eggs are four or five in number, light blue, and measure $.85 \times .65$ inches.

[606.] BLUE-HEADED EUPHONIA. Euphonia elegantissima (Bonap.) Geog. Dist.-Eastern Mexico, Central America, south to Veragua, Southern Texas. (Giraud.)

This Tanager of variegated plumage is admitted to our fauna on the above authority and it doubtless does occur over the Mexican boundary. Its eggs are described as creamy-white, with a few scattered spots and blotches of two shades of brown, principally at the larger end.

607. LOUISIANA TANAGER. Piranga Iudoviclana (Wils.) Geog. Dist.Western United States, from the Plains to the Pacific, north to British Columbia, south in winter to Guatemala.

Throughout the evergreen forests from Oregon and Montana southward to Southern California and Arizona this Tanager is a common species, breeding in suitable localities, wherever found. It is caliêu crimson-headed and Western Tanager. The nesting season is in April, May, June and July, according to locality. The nest is a thin, saucer-shaped structure, made of bark strips and grass stems, placed on the horizontal branchẹs of trees, preferedly evergreens and usually in the lower branches. The eggs are three to five in number, of a clear, light bluish-green, finely and rather sparsely sprinkled chiefly at the larger end with clove-brown. The eggs are of a brighter bluish tint and the markings are more speck-like than those of the Scarlet Tanager or Summer Tanager. The average size is .95x.65 inches,

[607. 1.]. GRAY'S TANAGER. Piranga mubriceps Gray. Geog. Dist-Columbia. Accidental in California (Dos Pueblos, Santa Barbara county).

This handsome Tanager has in every respect the same general habits of the Scarlet Tanager, $P$. erythromelas. 
608. SCARLET TANAGER. Piranga erythromelas Vieill. Geog. Dist.Eastern United States north to Southern

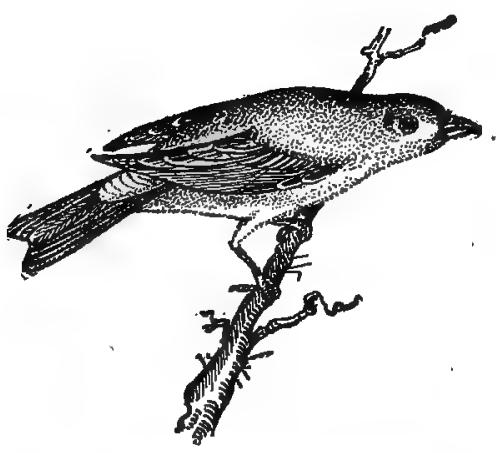
Canada, west to the Great Plains, south in winter to the West Indies, Central America. and Northern South America.

The male Scarlet Tanager is one of the most brilliant and striking of all our birds. From its black wings resembling pockets it is frequently called "Pocket-bird." The female is plain olivegreen. Breeds as far north as Southern Canada and west to Eastern Kansas, south to South Carolina and Texas. It inhabits woodlands and is particularly fond of swampy places. The breeding season begins in the latter part of May. The nest is generally found in low, thick woods, or in the skirting of tangled thickets; very often,

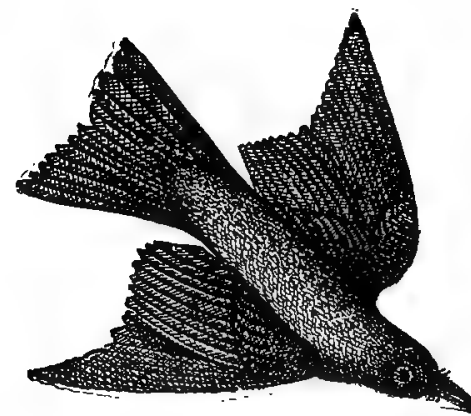
also, in an orchard, on the horizontal limb of some low tree or sapling. The nest is usually very flat, loosely constructed of twigs, fine bark strips, lined with rootlets and fine inner bark. The eggs are three to five in number, commonly four, and of a greenish-blue, speckled, spotted and blotched with rufous-brown, more or less confluent, in some chiefly at the larger end. The markings have a reddish tint while those of the Summer Redbird, P. rubra, are more of a brownish hue. Ten eggs measure respectively $.89 \times .60$, $89 \times .62, .92 x .64, .94 \times .62,1.00 \times .64, .98 \times .65,1.00 \times .65$, 608. Scarlet Tanager; upper, female; .95x.64, .94x.62, .97x.63; average size $.96 \mathrm{x} .65$ lower, male. inches.

609. HEPATIC TANAGER. Piranga hepatica Swains. Geog. Dist.-Southern Arizona and New Mexico, southward.

Mr. W. E. D. Scott gives this species as a summer resident in the oak region of the Catalina Mountains of Southern Arizona, at an altitude of 5000 feet, breeding late in the season, from May 6 to 9 . A nest found July 12 containing three young was built on the outer branch of a live oak and was entirely similar to that of the Scarlet Tanager. No reliable description of the eggs is at hand. The male of this species is of a dull red color, females and young males greenish-yellow.

610. SUMMER TANAGER. Piranga rubra (Linn.) Geog. Dist.-Eastern Tinited States west to the edge of the Plains; north regularly to about $40^{\circ}-\mathrm{New}$ Jersey, Central Ohio, Illinois, etc., casually north to Connecticut and Ontario, accidentally to Nova Scotia, wintering in Cuba, 'Central America and Northern South America.

The Summer Redbird or Rose Tanager breeds nearly throughout its United States range. The adult male is a plain vermillion red; the plumage of the female is olive. In habits this species resembles the Scarlet Tanager but is not so retiring, frequenting open groves and often visiting towns and cities. According to Colonel N. S. Goss it is a common resident in Eastern Kansas, where it begins laying about the 20th of May. The nesting season of this bird extends to the latter part of July, 
but varies with the degrees of latitude and season. The nest is composed chiefly of bark-strips and leaves interwoven with various vegetable substances. The structure is usually built on a horizontal or drooping branch, near its extremity, and situated at the edge of a grove near the roadside. All the nests of this species which I have seen collected in Ohio, are very thin and frail structures; so thin that the eggs may usually be seen from below. A nest sent me from Lee county, Texas, by Mr. J. A. Singley, is compactly built of a cottony weed, a few stems of Spanish moss, and lined with fine grass stems and a few catkins. Mr. L. O. Pindar states that nests of this species in Kentucky are compactly built but not very thickly lined. The eggs are bright, light emerald green, spotted, dotted and blotched with various shades of lilac, brownish-purple and dark brown; they cannot, with certainty, be distinguished from the eggs of the Scarlet Tanager, but the brown tint in the markings prodominate. Ten specimens offer as great variation in their sizes as do those of $P$. ervthromelas, and average about the same, $.94 \times .64$ inches.

610a. COOPER'S TANAGER. Piranga rubra cooperi Ridgw. Geog. Dist.Arizona, New Mexico, north to (Denver) Colorado, south to Western Mexico.

According to Mr. Scott this subspecies is a common migrant and summer resident about Tucson, Riverside, Florence, and, at Mineral Creek and in the San Pedro Valley of Southern Arizona. They seem to be more rare than either of the other species of the Tanager in the oak region of the Catalinas, where a few breed. The eggs are described as being not distinguishable from those of $P$. rubra.

611. PURPLe MARTIN. Progne subis (Linn.) Geog. Dist.-Temperate North America, north to Ontario and the Saskatchewan, south to the higher parts of Mexico, wintering in South America.

The Martin, conspicuous for its striking color and screaming, cracking noise, breeds throughout its United States range. It originally built in hollow trees, and some of the "old fogies" do yet, but those who find suitable nesting places in eaves and cornices of buildings or in boxes prepared for their use, are thus bred to American ideas and never return to their old log cabins in the air. This jolly fellow who puts life into the quiet streets of country towns, and large cities also, by his noise and activity, constructs a nest out of anything that is handy-leaves, twigs, straws, bits of string, rags and paper. Commonly four or five eggs are laid, rarely six. They are pure, glossy white, oval-oblong, pointed at one end, and average .98 x.73. Six specimens measure $.94 \times .69, .95 \times .70, .95 \times .69, .98 \times .75,1.00 \times .75, .99 \times .69$ inches.

611a. WESTERN MARTIN. Progne subis hesperia Brewst. Geog. Dist.California, south of Lat. $40^{\circ}$, and southern Arizona; in winter south to Nicaragua.

According to Mr. William Brewster the female of this race differs from the female of subis in having the abdominal region and under tail-coverts pure white, etc., while the male is indistinguishable from the male of subis. The nesting habits and eggs are identical with those of the Purple Martin of the Eastern States.

611. 1. CUBAN MARTIN. Progne cryptoleuca Baird. Geog. Dist.-Cuba and Southern Florida.

This is a smaller species than $P$. subis with narrower tail-feathers and relatively more deeply-forked tail. It is also characterized by a difference in the coloration of its plumage. It breeds in Cuba and in Southern Florida, nesting in holes of trees. The eggs are indistinguishable from those of Progne subis, averaging a trifle smaller. 
612. CLIFF'SWALLOW, Petrochelidon lunifrons (Say.) Geog. Dist.-North America in general; in winter south to Central and portions of South America. Not recorded from Florida or the West Indies.

The "Republicans," as they are sometimes called, or Eave swallows, are known to occur and breed throughout the whole of North America, north to the limit of trees. As the name implies, and as almost every one knows, this bird fixes its queer bottle-shaped nest to the perpendicular faces of rocks and hard embankments, also on the walls of houses and under shelter of eaves. The nests are not always retort or flask-shaped, some have no necks, and the degree of perfection in style depends upon circumstances. They are made entirely of mud, tempered by the bill of the bird and are well lined with straw, wool and feathers. The birds are always found in colonies during the breeding season, which extends all through the summer months. The eggs are white, marked with dots, blotches and points of reddishbrown, chiefly about the larger end; they are less elongated than those of the Barn Swallow, but the markings of the two are hardly distinguishable. The eggs of the Cliff Swallow average a trifle larger; they are four to five and sometimes six in number; the average size is $.82 \times .56$ inches.

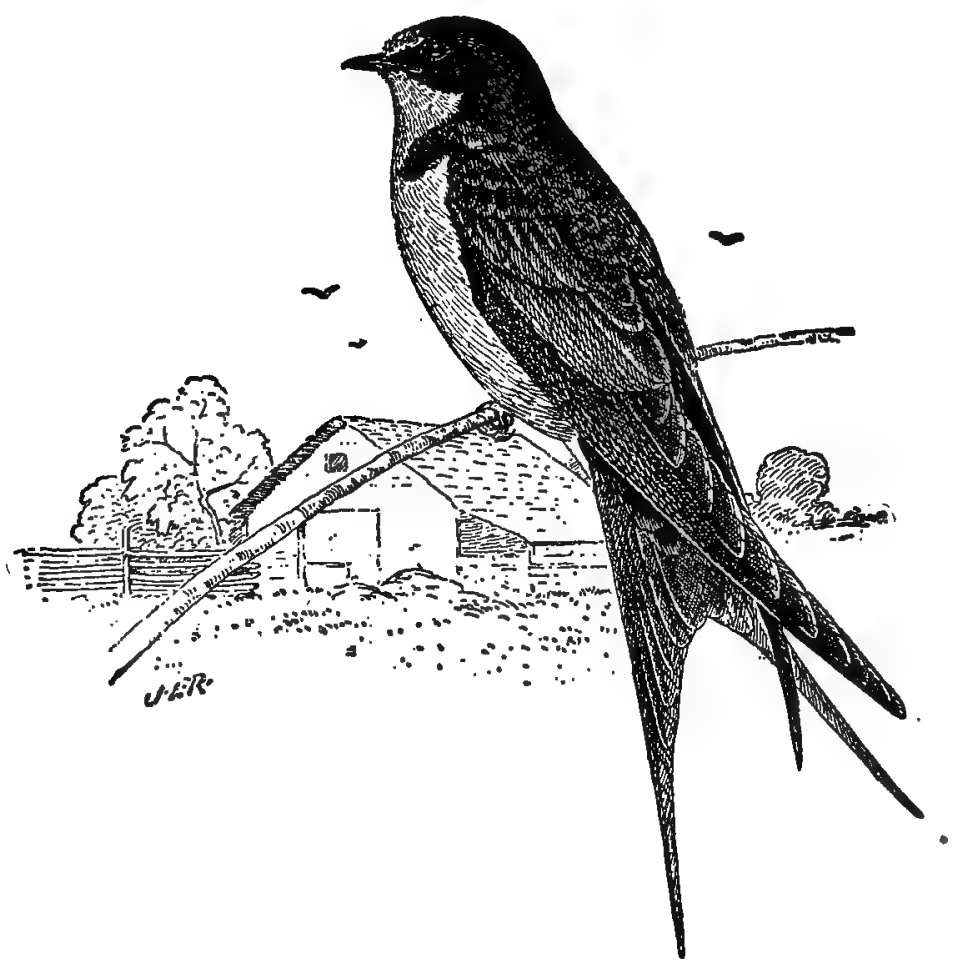

613. Barn Swallow (From Beal).

[612. 1.] CUBAN CLIFF SWALLOW. Petrochelidon fulva (Vieill.) Geog. Dist. Greater Antilles and the coast of Central America. Accidental on the dry Tortugas, Florida. 
The same general habits characterize the Cuban Cliff Swallow as are common to P. Iunifrons.

613. BARN SWALLOW. Chelidon erythrogaster (Bodd.) Geog. Dist.-Whole of North America; south in winter to Central America, West Indies, and various portions of South America.

Nearly everyone knows this beautiful, deeply forked-talled Swallow which builds its nest in barns and under the eaves of other outbuildings. The female bird of this species, however, does not possess as deeply a forked tail as is common in the male birds. The nest is a bowl-shaped structure, entirely open above, composed of

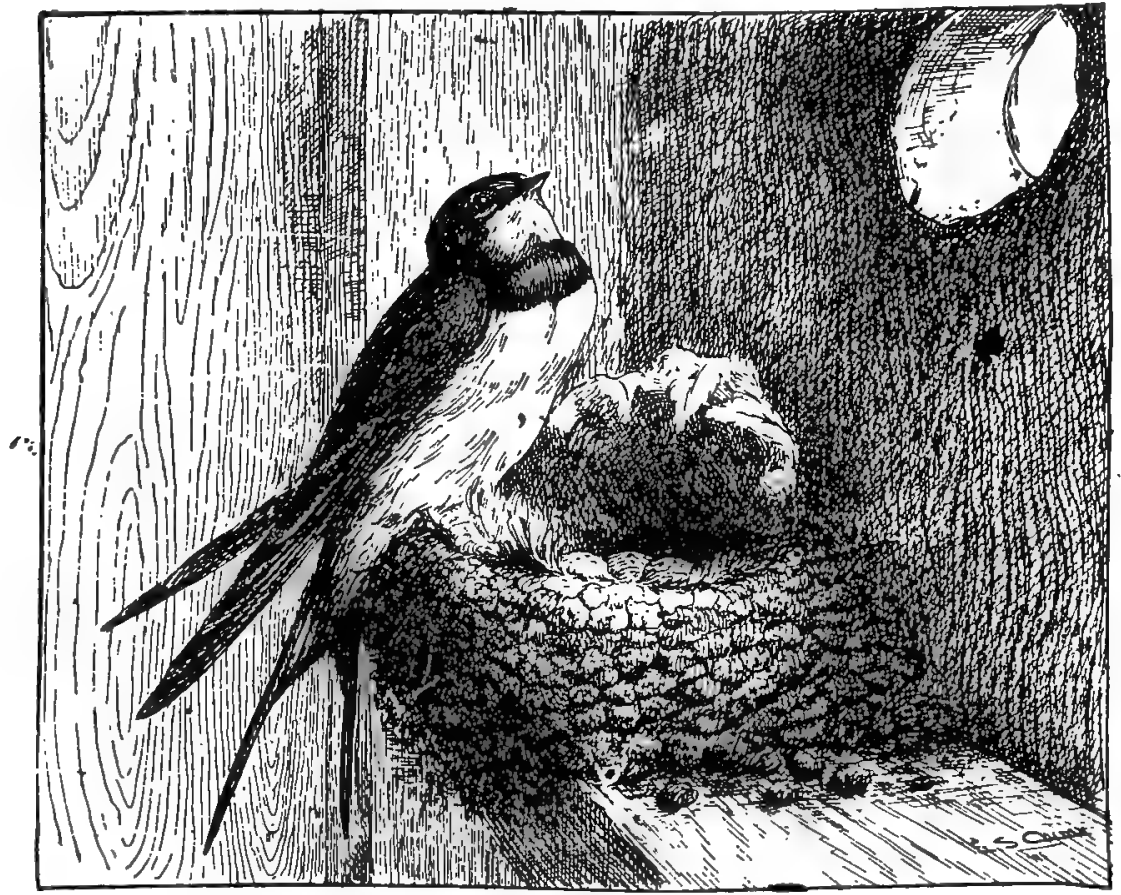

613. Bann Swallow amd Nest (E. S, Cheney del).

pellets of mud, mixed with straws, and warmly lined with soft feathers. It is attached by one side to the rafters within barns, on the sides of caves, etc. From three to five or six eggs are deposited; they are white, marked with spots and blotches of bright reddish-brown, chiefly at the larger end. The eggs appear rather narrow for their length; sizes range from .68 to .78 in length by .50 to .56 broad; average size, .75x.55 inches.

614. TREE SWALLOW. Tachycineta bicolor (Vieill.) Geog. Dist.-Whole of North America in summer; wintering from Southern Florida, Cuba and Gulf coast to Guatemala. 

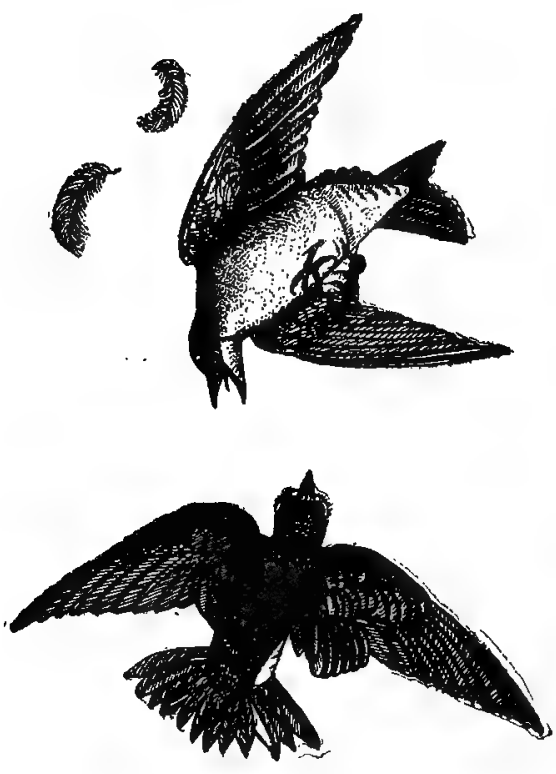

614. Tree Swaliow (From Audubon).

This is the White-bellied Swallow, which breeds in all suitable localities throughout its North American range. The nesting season is in May, June and July. Its favorite resorts are in the vicinity of ponds, marshes and rivers, and even in its migrations it is seldom seen far away from running water. In these places lofty, leafless tree-trunks are its nesting sites-in the old excavations of woodpeckers, natural cavities, etc. Sometimes it nests in cliffs or buildings. In the Eastern States this bird frequently nests in bird-boxes. M. C. S. Shick, of Sea Isle City, New Jersey, says that a pair had taken possession of a box which he had put up in his yard. The materials used in nestbuilding are grasses and straw, thickly lined with feathers. Mr. Walter E. Bryant found a nest of this bird under the projecting and decayed deck of a lumber lighter, moored at Oakland (Cal.) harbor. From four to seven, and occasionally nine, pure white eggs are laid. The average size of ten eggs is .75x.53. Mr. Edson A. McMillan informs me that he took from a single nest in regular succession no less than five sets, each containing five eggs. This was in the Adirondack Mountain region, beginning with set No. 1 the first part of June.

615. VIOLET-GREEN SWALLOW. Tachycineta thalassina (Swains.) Geog. Dist.-Western United States, from the Rocky Mountains to the Pacific; south in winter to Guatemala.

This lovely Swallow is common from tho Central Plains of the United States to the Pacific coast. It breeds abundantly in California, Oregon and Washington Territory. The most characteristic Swallow of the pine regions of Arizona, and is also found in considerable abundance in Colorado, nesting in all suitable localities, and, like the Eave Swallow, usually in colonies. It nests in knot-holes of oak and other deciduous trees and in the deserted excavations of woodpeckers, and more recently it has been found breeding under the eaves of houses, like the Cliff Swallow. The nest is made of dry grasses, lined with a thick mass of feathers. This species has also been found nesting in holes in banks. Four or five pure white eggs are laid; average size, $.74 x .52$ inches.

[615. 1.] BAHAMAN SWALLOW. Callichelidon cyaneovirdis Bryant. Geog. Dist.-Bahamas. Accidental on the dry Tortugas, Florida.

In all respects the habits, nests and eggs of this species are similar to those of tbe Violet-green Swallow. The eggs, however, are far from being common in collections. 
616. BANK SWAILOW. Clivicola riparia (Linn.) Geog. Dist.-Northern Hemisphere in general; in America, south in winter to Northern South America.

The Bank Swallow, or Sand Martin, found throughout Europe, is also equally common throughout North America, and breeds in the greater part of its range. The holes in which this bird nests are excavated by the bird in the perpendicular face of sand or gravel banks; the depth ranges from two to four feet. The termination is usually somewhat enlarged and the bottom is thinly covered with a few twigs, grasses and feathers: In suitable localities immense numbers will occupy a large bank and so perforate it with holes as to present the appearance of a huge honeycomb alive with bees. From four to six, rarely seven, pure white eggs are deposited, with an average size of .72x.50; five specimens measure .68x.52, .72x.49, .73x.51, $.72 \times .52$. Average size .71x.50 inches،

617. ROUGH-WINGED SWALLOW. Stelgidopteryx serripennis (Äud.) Geog. Dist.-United States, from Atlantic to Pacific, and adjoining British Provinces (rare). Rare in New England, except in Connecticut.

This species and the Bank Swallow are often confounded. The Rough-winged, however, is larger, has a more labored flight, lacks the pure white of under parts, and the pectoral collar is incomplete and obscured. The hooklets of the wings of the present species are only fully developed in adult birds. The Rough-winged Swallow breeds throughout most of its United States range, nesting in the crevices of stone walls and arches over bridges, sometimes in a chink in the boarding of a building; almost invariably over running water. The nesting season is in May and June. The nest is simply constructed of grasses, straws, and lined with a few feathers. The eggs are four to seven in number, pure white, and closely resemble those of the Bank Swallow, but the shells are more tender, and they average a trifle larger, $.75 \mathbf{x} .53$ inches.

618. BOHEMIAN WAX-WING. Ampelis garrulus Linn. Geog. Dist.-Northern portions of the Northern Hemisphere. In America, south regularly to the Northern tier of States, and in the Rocky Mountains to Colorado; irregularly or casually to about $35^{\circ}$ (Pennsylvania, Ohio, Indiana, Illinois, Kansas, New Mexico and Arizona).

The Bohemian Wax-wing looks like the Cedar-bird, but is much larger. It is a restless, roving species, and its visits in the Northern States are uncertain. Breeds in high latitudes, and in the West down to the United States border in the Rocky Mountains. Its nest has been found by Mr. Kennicott on the Yukon, and by Mr. McFarlane in the Anderson River region. Its nesting is substantially the same as that of the Cedar Wax-wing. Captain B. F. Goss has a set of four eggs of this species which was taken in Labrador, June 18, 1885. Their color is bluish-white, spotted with lilac, and very dark brown, being like those of the Cedar-bird, but are larger; sizes, .99x.70, .98x.70, $1.05 \times .69,1.06 \times .70$. Mr. Norris has a set of three Bohemian Wax-wing's eggs taken in Lapland, June 20, 1875. These are exactly like large eggs of $A$. cedrorum, and measure $.91 x .69, .93 x .68, .89 x .68$ inches.

619. CEDAR WAX-WING. Ampelis celrorum (Vieill,) Geog. Dist.-North America in general, from the Fur Countries southward. In winter south to Guatemala and West Indies. 


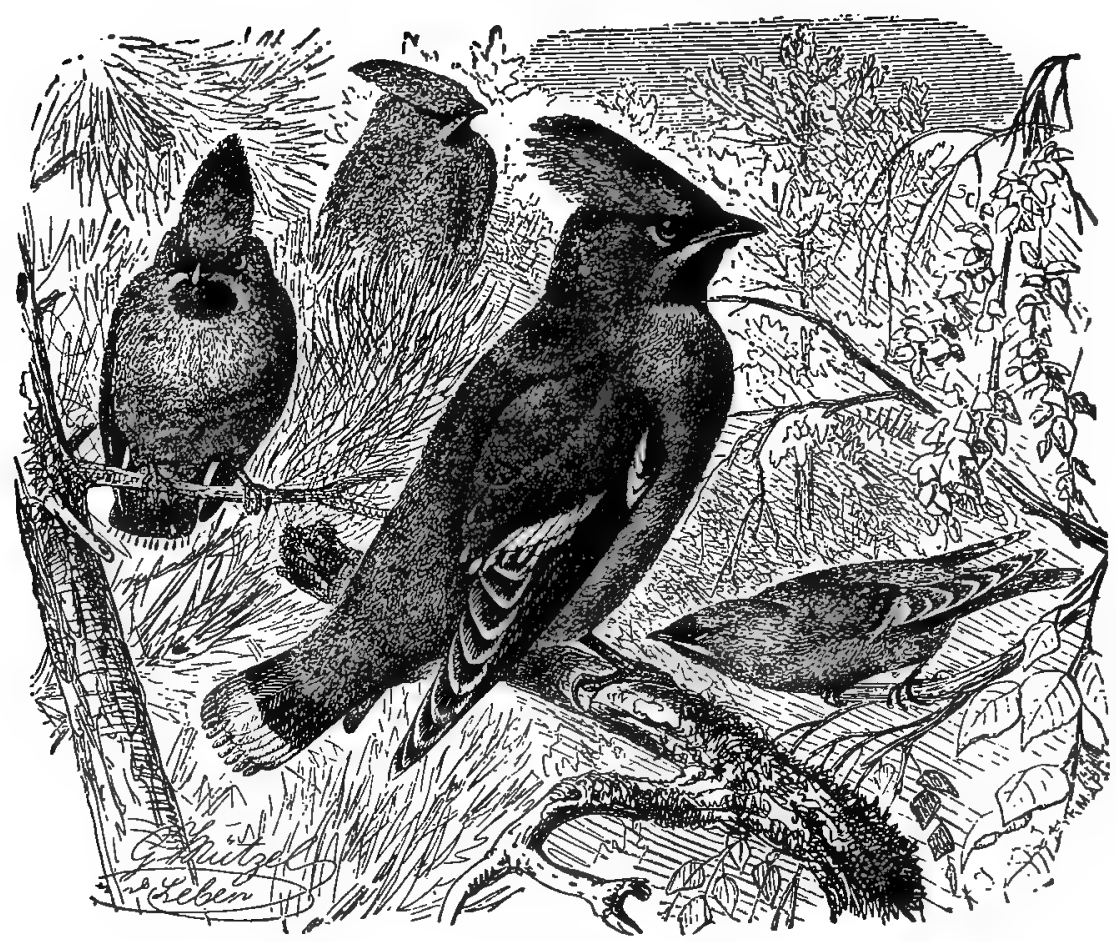

618. Bohrmian Wax-wing (From Brehm).

The Cherry-bird, Cedar-bird, Southern or Carolina Wax-wing, is found throughout North America, as far as the wooded country extends, and breeds from Florida

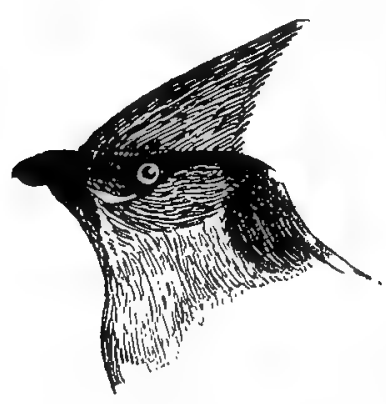

619. Cedar Wax-wing.

to the Red River country. It goes in flocks nearly the entire year. The usual position of the nest of these species is in a cedar bush or orchard tree, and it is often placed in a sycamore, the distance varying from four to eighteen feet from the ground. It is sometimes a very handsome structure, being rather bulky, and made of bark, leaves, roots, twigs, weeds, paper, rags and twine, lined with finer grasses, hair and wool. The nesting time is late-June, July and August. The eggs range from 3 to 5 in a set, average $.84 x .61$, and are from a light slate to a deep shade of stone-color, tinged with olive, marked with blotches and spots of a dark brown and purple, almost black. A set of four eggs taken by E. H. Huffman in Franklin county, Ohio, August 19, 1888, is before me. The eggs offer the following dimensions: $.93 \times .63$, $.85 \times .65, .92 \times .66, .94 \times .65$. These seem to be uncommonly large; a common size is $.85 \times .60$ inches. 
620. PHAINOPEPLA. Phainopepla nitens (Swains.) Geog. Dist.-Southwestern United States, from Southwestern Texas westward; north to Southern Utah, Nevada, Fort Crook, California and south to Cape St. Lucas and the Valley of Mexico.

A singular bird, known as the Shining Fly-snapper, or Black-crested Fly-catcher. It inhabits the southern portion of Western United States-abundant in Western Texas, Southern New Mexico, Arizona and California. Its resorts are regions of low shrubbery and wooded land in the vicinity of water. According to Mr. W. E. D. Scott, this bird has a peculiar, bell-like, whistling note that is very musical. The breeding season is in May and June. The nest is built in trees of various kinds, oftener perhaps in oaks and mesquites, ranging in height from eight to twenty-five feet above ground. It is a flat, loosely made affair, and the curious, light-colored vegetable substances-twigs, stems, mosses, and soft, downy or cottony fibres-seem to harmonize well with the odd coloration of the eggs. These are two or three in number. The majority of the nests found by Mr. Scott in Pima county, Arizona, contained three eggs, while a large series of nests, with eggs, collected at San Gorgonia Pass, California, by Mr. Herron, during the months of May and June, 1883, were of two eggs each. They are of a yellowish or light or dull gray, thickly speckled (some grotesquely marked) with a neutral tint, dark brown and blackish. Ten eggs measure, .84x.64, .87x.63, .88x.69, .89x69, .90x.70, .90x.69, .91x.70, .91x $.67, .90 \times .63, .91 \times .69$ inches.

621. NORTHERN SHRIKE. Lanius bórealis (Vieill.) Geog. Dist.-Northern North America; south in winter to the Potomac, Ohio Valley, Kansas, Colorado, Nevada, California and Arizona.

The Shrikes are birds of a cruel, reckless, quarrelsome nature-rapacious and carniverous, feeding on grasshoppers and other insects, together with lizards, small birds, and quadrupeds which they are able to overpower. They often boldly attack cage-birds, even in the presence of their owners. Their most noted trait is that of impaling small birds, mice, and other prey on thorns and sharp twigs. In the breeding season the Great Northern Shrike, or Butcher-bird, is found throughout the whole of North America, north of United States. It is said to breed in Maine and it probably does in other New England States. It inhabits woodland and thicket, and is often found in upland fields. When insect food becomes scarce this species frequently visits cities in pursuit of the European House Sparrow. This species breeds north of the United States. The nest is a rather rude, bulky affair, made of twigs, grass and stems, matted together and lined with down and feathers. It is usually built in thorny trees, bushes, or hedges, and often no attempt is made at concealment. The eggs are four to six in number, dull whitish or greenish-gray, marked and spotted with obscure purple, light brown, or olive; average size, 1.08x.79 inches.

622. LOGGERHEAD SHRIKE. Lanius ludovicianus Linn. Geog. Dist.Eastern United States, west to the Plains; north to Northern New England. Breeds from the Gulf States to Virginia and casually north, on the Atlantic coast, to Southern New Jersey; in the interior northward to the Great Lakes, and through Western Pennsylvania and New York north to New England.

This form of Shrike inhabits the more southeastern portions of Eastern United States. Dr. Coues says, in its typical manifestation it is characteristic of the South Atlantic States; but specimens more like ludovicianus than excubitorides occur north to New England and west to Ohio.* It is a common resident in Central and Southern

* Key to N. A. Birds, p. 338. 


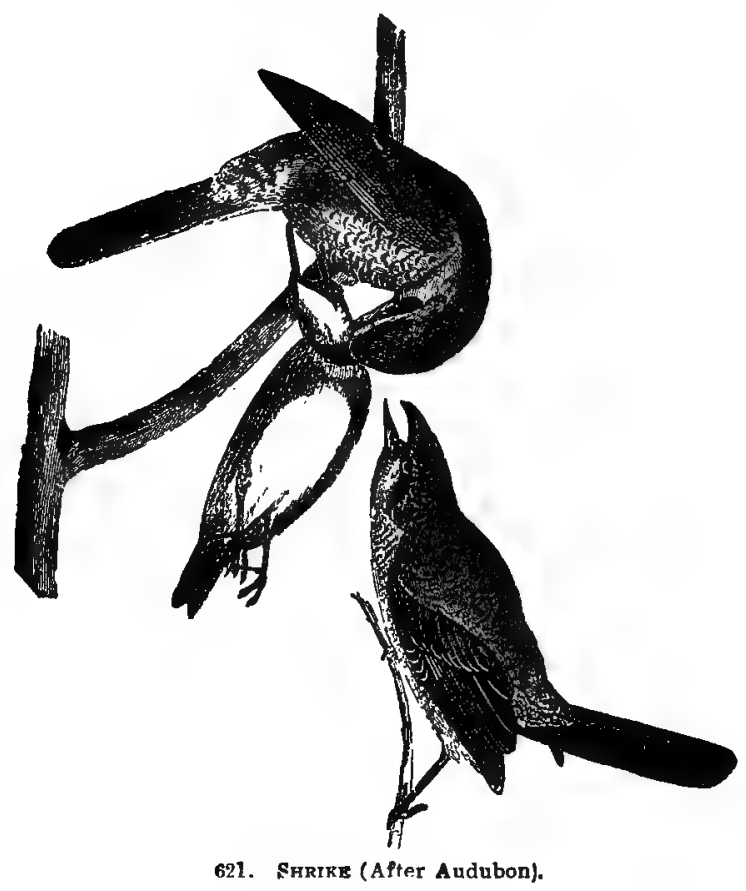

Ohio. Its habits are essentially the same as those of the Northern Shrike and are not less savage and blood-thirsty. The construction of the nest is begun in ohio as early as the middle of April, and frequently at this time the birds are sitting on the full complement of eggs. The nesting season, however, is in the month of June, and a second brood is reared some weeks later. The full complement of eggs is six. The nest is built in hedges, scrubby, isolated little trees in cultivated fields, thorn trees growing along streams or roadsides; thickets along railroads are favorite resorts, and the telegraph wire is their favorite perch. The nest is large, loose and bulky, composed of weed-stems, grasses, corn-stalks, rootlets, paper, wool, and chicken feathers (the latter being the lining; it is often very thick), the feathers concealing the eggs from view. The eggs are identical with those of borealis, but average smaller, .97x.73. Eleven eggs measure, .91x.72, .92x.70, .92x.73, .95x.76, $.98 \times .79,1.00 \times .78, .99 \times .77,1.02 \times .80,1.00 \times .82, .96 \times .79, .98 \times .72$.

622a. WHITE-RUMPED SHRIKE. Lanius ludovicianus excubitorides (Swains.) Geog. Dist.-Western North America, from the eastern border of the Plains to the Pacific, except coast of California, and from Manitoba and the Plains to the Saskatchewan south over the table lands of Mexico.

More recent investigations develop the fact that this bird, once described as a western form, has extended its range eastward, north of that of ludovicianus. It. breeds nearly throughout its entire range. In Western Manitoba, according to Mr. Thompson, it is abundant all over from May to September. The late Colonel N. $\mathbf{S}$. Goss records it as a common summer resident of Kansas; begins laying early. in 
May. Mr. Scott notes it as rather common throughout the year about Tucson, Arizona. In the Catalinas, at an altitude of 3700 feet, he found a nest of this species containing five eggs almost ready to hatch, April 1, 1885. Breeds as far north as Northern New York and Northern New England. This is the common breeding form in the northern portion of Ohio, where also occasionally well-marked individuals of ludoricianus are taken. Prof. Evermann states that until recently this bird was a very rare resident of Carroll county, Indiana, becoming more common since 1882.* This bird builds a nest and lays eggs in every particular like the Loggerhead, and its general traits are the same. A large series of eggs from Cuyahoga and Huron counties, Ohio, do not exhibit any difference whatever.

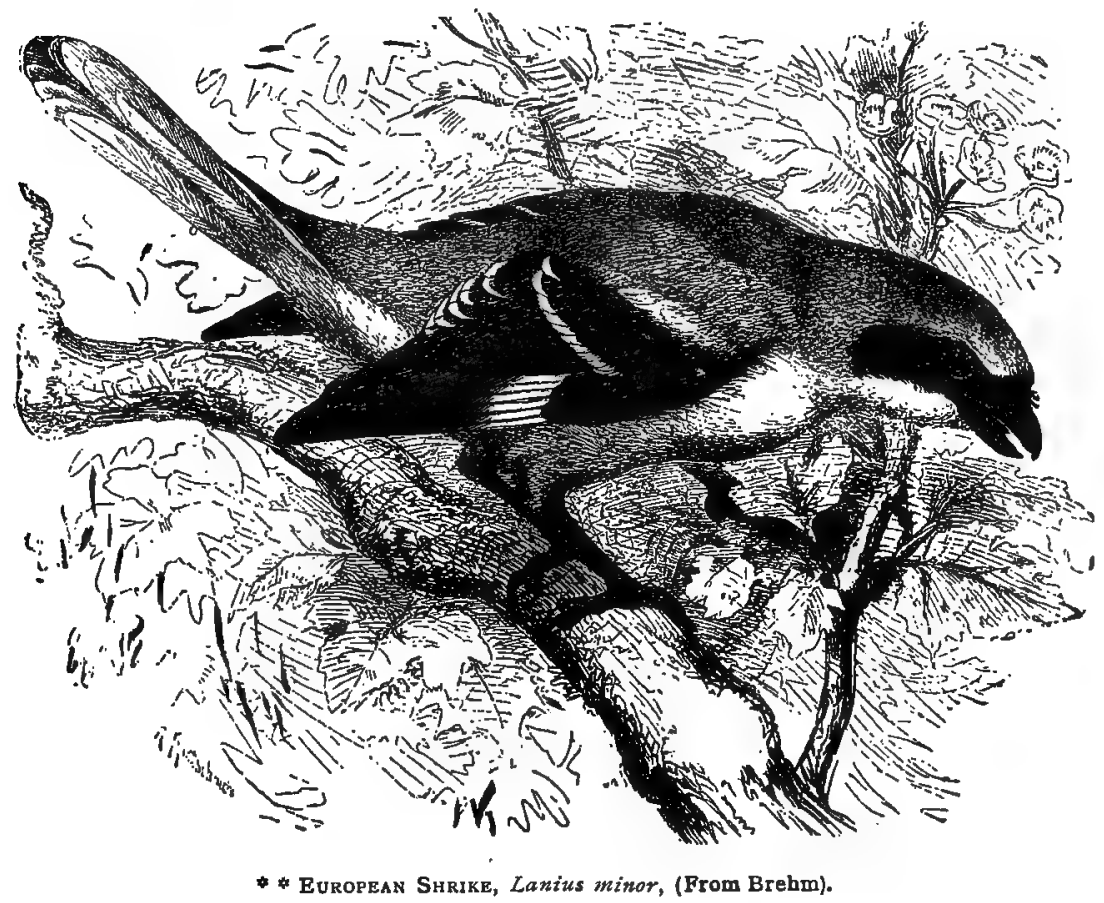

622b. CAIIFORNIA SHRIKE. Lanius ludovicianus gambeli Ridgw. Geog. Dist.-Coast of California.

Mr. A. M. Shields states that this new variety of Shrike is well known in Los Angeles county, from its frequent appearance in the orchards and gardens, and from its favorite pastime of pulling off the heads of canaries, wherever a cage is hung in the open air. My friend, Mr. Arnold Boyle, states that in the region about Banning, California, this bird feeds largely on lizards, which it often impales on thorns and leaves them sticking there. The nest is usually built in some scrubby tree-this being like the structure made by ludovicianus or excubitorides. Five sets of eggs in

* Birds of Carroll county, Indiana. By Barton W Evermann: The Auk, Vol. V. pp. 344-351; VI, pD. 22-30.

28 
my cabinet, from Banning, San Gorgonia Pass, California, do not differ at all from those of the Loggerhead and White-rumped Shrikes. They exhibit the same variations in size and coloration.

[623.] BLACK-WHISKERED VIREO. Vireo calidris barbatulus (Cab.) Geog. Dist.-Cuba, Bahamas, and casually to Southern Florida.

This bird, which is common to Cuba and the Bahamas, is entitled to a place in our avifauna on account of its occasional occurrence in Southern Florida; it has several times been taken in the region of Charlotte Harbor. From the supposed resemblance of its notes, it is called Whip-tom-kelly. The bird looks very much like the Red-eyed Vireo, but has a longer bill and other characteristics which distinguish 1t. Like other Vireos, the Long-billed Greenlet builds a beautiful, pensile, cup-like nest, which is attached by the brim and suspended from forked twigs in trees and bushes, ranging in height from five to twenty feet. The materials used in its construction are dry grasses, shreds of bark, cotton, lichens, and spider's web; the lining being soft cotton-like fibres. The walls of the structure are not only very thick, but neatly and firmly interwoven. The eggs are three or four in number, white, with a pinkish hue, speckled and spotted, chiefly at the larger end, with reddishbrown. The average size is $.78 \times .55$ inches.

624. RED-EYED VIREO. Tireo olivaceus (Linn.) Geog. Dist.-Eastern North America, as far north as Hudson Bay, etc.; west to the Rocky Mountain region; south in winter through Eastern Mexico and Central America to Northern South America.

The Red-eyed Greenlet is a common species in Eastern United States, where it breeds abundantly in the months of May aud June. It frequents woodland and is especially fond of sycamore groves along streams. A tireless, joyful songster, sing-

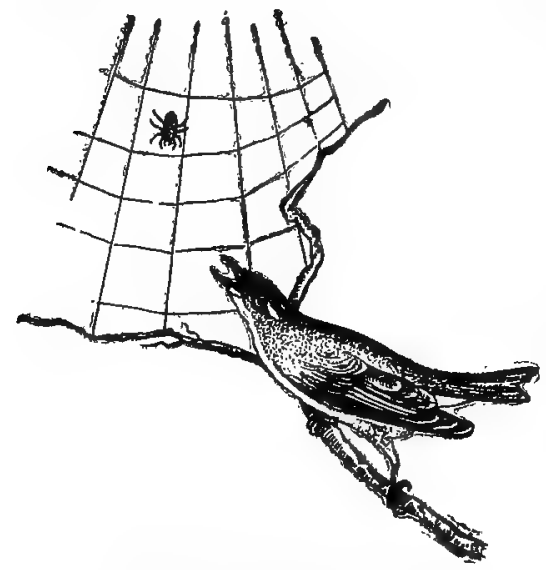

624. Red-eyed Vireo (After Audubon). ing throughout the day nearly all summer long. Its voice is often the only sound heard in the woods in sultry summer days. Compared with the song of the Warbling Vireo, it is shorter, louder, and more vigorous. The nest of this species is built in the horizontal branches of trees, usually from five to twenty-five feet above the ground, sometimes much higher. Like other nests of the birds of this family, it is pensile-a beautiful little well-woven, pendulous cup, its rim being attached to a horizontal fork of a branch in the thick foliage. It is made of vegetable fibres, strips of pliable bark, etc., lined with fine, round grasses, sometimes mingled with horse hairs and bits of newspapers. On two occasions I have found the nest containing two or three eggs before the framework was nearly completed-in fact the nests in both cases were not ready for the reception of the eggs, and were inally completed by the female with material carried by the male bird. Three or four eggs are generally laid, rarely five, pure, white, sparsely sprinkled with fine, dark reddish-brown dots, chiefly at the larger end. 
Ten eggs measure $.82 x .56, .80 x .56, .82 x .58, .84 x .59, .85 x .58, .87 \times .54, .87 x .56, .85 x .53$, $.86 x .53 .88 x .54$. ' $\mathrm{l}$ 'he average size of these ten specimens is $.85 x .56$ inches.

625. YELLOW-GREEN VIREO. Vireo flavoviridis (Cass.) Geog. Dist.Valley of the Lower Rio Grande in Texas southward to Panama, Ecuador, Peru and Upper Amazon. Accidental at Godbout, Province of Quebec, and at Riverside, California.

This Vireo is very similar to Vireo olivaceus. Its nest and eggs are described as being the same as those of the Red-eye.

626. PHILADELPHIA VIREO. Vireo philadelphicus (Cass.) Geog. Dist.Eastern portion of North America, north to Hudson Bay; south in winter to Guatemala and Costa Rica, etc.

This is apparently not a very common bird, wherever found in Eastern United States. From its close resemblance to the Warbling Vireo the bird is doubtless often confounded with that species. In portions of the Mississippi Valley it appears to be more common than in the Eastern States, occurring regularly and in considerable numbers during the spring and fall migrations. In Ohio it is not a very common spring and fall migrant in May and September. From the best information at hand, the Philadelphia or Brotherly-love Vireo breeds chiefly north of the United States. Mr. Ernest E. Thompson found a nest of this species containing four eggs near Duck Mountain, Manitoha, June 9, 1884. These were probably the first authentic eggs of this species on record. The nest was hung from a forked twig, about eight feet from the ground, in a willow which was scant of foliase, as it grew in the shade of a poplar grove. The nest was pensile, as usual with the genus, formed of grass and birch bark. The eggs presented no obvious difference from those of the Red-eyed Vireo. The eggs were accidentally destroyed before they were measured.*

627. WARBLING VIREO. Vireo gilvus (Vieill.) Geog. Dist.-North America in general, from the Fur Countries; south in to Mexico.

The Warbling Vireo, in its two forms, inhabits North Amrica in general and is abundant. The form $\nabla$. g. suainsoni, which is described as the smaller, with slenderer bill, etc., occurs in Western United States. Every collector is doubtless familiar with the incessant, mellow warblings of this Greenlet, as it rambles through the foliage of trees in open woodland, in parks, and in those along the banks of streams. In these places it dilligently searches the under sides of leaves and branches for insect life, "in that near-sighted way peculiar to the tribe." It is one of the most stoical of birds, and seems never surprised at anything; even at the loud report of a gun, with the shot rattling about it in the branches. If uninjured, it will stand for a moment unconcerned, or move along, peering on every side amongst the foliage, warbling its tender, liquid strains. The nest of this species is like that of the Red-eyed Vireo-a strong, durable, basket-like fabric, made of bark strips, and fine grasses on the inside. It is suspended by the brim in slender, horizontal forks of branches, usually at a greater height than the nest of the Red-eye. The nesting time is in May and June. The eggs are spotted, frequently blotched at the larger end with brown and reddish-brown on a clear white graund-sometimes over the surface will be found small specks of reddish-brown. The complement of eggs is three or four; size, .70 to .77 in length by about .55 in breadth. Seven eggs, taken in Ohio, measure $.70 \times .51$, .73x.50, $.74 x .53, .75 \times .52, .72 \times .55, .74 \times .55, .77 \times .53$; four from California, .72x.50 .72x.53 .70x.53 $.73 \times .51$. 
628. YELLOW-THROATED VIREO. Vireo flavifrons Vieill. Geog. Dist.Eastern United States ; west to the Great Plains; south in winter to Costa Rica.

The Yellow-throated Greenlet is common in the woodlands of Eastern United States. Mr. McIlwraith gives it as a summer resident of Southern Ontario, but is by no means common. Colonel N. S. Goss records it as a quite common summer resident of Kansas; begins laying about the 20th of May. He states that the bird inhabits the timber away from settlements. In the Eastern states it is found frequenting and nesting in the orchards and gardens, as well as in wooded country. It is a common summer resident in Ohio, especially the northern portion. It frequents secluded woods and the banks of ravines and streams, and appears to be partial to oak forests. The nest of this species is pensile, like those of other Vireos, but the architectural taste and skill displayed in its building is perhaps superior to any of the family. It is composed of strips of thin bark, grasses, etc. The outside of the structure is beautifully adorned with lichens, which are held in place by caterpillar's silk. Its size is between three and three and a half inches wide, and nearly as deep. It is bui.. in the fork of a horizontal branch, from five to fifteen and sometimes thirty feet above the ground. The eggs vary from three to five in number, four being a common set. They are easily distinguished from those of the Red-eye and Warbling Greenlets by their roseate hue, and are generally more heavily marked, having the same family resemblance, speckled and spotted with rosy and chestnutbrown, chiefly at the larger end. A set of four, taken in Franklin county, Ohio, June 2,1885 , measure $.8 \angle x .60, .80 \times .61, .83 \times .58, .79 \times .58$. The average size is $.83 \times .61$ inches.

629. BLUE-HEADED VIREO. Vireo solitarius (Wils.) Geog. Dist.-Eastern North America, north to Fort Simpson (on the Mackenzie River) and Hudson Bay; south in winter to Mexico and Guatemala.

The Blue-headed or Solitary Vireo breeds chiefly north of the United States; quite common in Manitoba. It has been found breeding in Connecticut and Massachusetts and in some of the Middle States. It is probably a summer resident in Northern Ohio. C. M. Jones found it breeding near Eastford, Connecticut, in May and June, building the nests from five to eight feet above ground, in laurel bushes and hemlock trees. Mr. F. W. Andros records a nest taken by F. T. Lincoln, in Bristol county, Massachusetts, May 30, 1887. The birds, according to the above observers, are close sitters-not easily startled from the nest, frequently permitting themselves to be taken with the hand. The nest of the Blue-headed Vireo is similar in construction to others of the family-a handsome, pendant, cup-like fabric, which is suspended by the brim from the forked twigs of a horizontal branch. The materials used are strips of fibrous bark, leaves, fine dry grass, plant-down, the outside being covered with caterpillar's silk, and sometimes ornamented with mosses and lichens. The eggs, which are three or four in number, resemble those of some of the larger Vireos. They are white, with a faint creamy tinge; pointed at the smaller ends; sometimes forming wreaths of chestnut specks around the larger portions. The average size is $.81 \mathrm{x} .62$.

629a. CASSIN'S VIREO. Vireo solitarius cassinii (Xantus.) Geog. Dist.Western United States, from the Rocky Mountains to the Pacific.

During the breeding season, which is in May, June and July, this bird is confined chiefly to the Pacific coast region. Mr. A. W. Anthony gives it as a common summer resident of Washington county, Oregon, where it frequents the coniferous 
growth, and is often found in the alders and aspens. He states that it is more common than the Warbling Vireo. Nests were found in oaks and alders. About Fort Klamath, Oregon, Dr. Merrell, says that the bird shows a marked predilection for pines and firs, and is also found, but much less frequently, in aspen groves, with Vireo gilvus sucainsoni. The nests and eggs of this species resemble those of the Warbling Vireo. The eggs measure ${ }^{8} 80 \times$.58. Mr. Norris has a set of three eggs of this species in his cabinet that was taken June 10, 1888, near Ft. Klamath, Ore. They are white, sparsely speckled with burnt umber; sizes, $.77 \times .55, .74 x .55, .83 x .60$. The last egg is abnormally large.

629b. PLUMBEOUS VIREO. Vireo solitarius plumbeus (Coues.) Geog. Dist.Rocky Mountain region of the United States; south in winter into Mexico.

This subspecies is abundant in the Rocky Mountain region of the United States, especially the southern portion, breeding in the pine districts up to an altitude of 9000 feet. In suitable localities in Colorado this Greenlet is a common summer resident; also in the mountainous regions of New Mexico and Arizona. Its nest is built very similar to that of the Solitary Vireo,. . solitarius, of the Eastern States, but is usually placed higher, and the eggs are indistinguishable.

629c. IIOUNTAIN SOLITARY VIREO. Vireo solitarius alticola Brewst. Geog. Dist.--Southern Alleghanies (Western North Carolina, etc.).

According to William Brewster, this bird differs from solitarius proper, in being larger, with a stouter bill, and duller, darker, and more uniform coloring above. Throughout the elevated plateau in the southeastern corner of Macon county, North Carolina, he found this new Vireo to be one of the most abundant forest birds, frequenting exclusively open oak and chestrut woods, mingling its wild, ringing voice with the rich music of the equally numerous Rose-breasted Grosbeaks and Scarlet Tanagers. On the Black Mountains it was very common, ranging from about 4200 feet to the lower edge of the balsams (5000 feet), and inhabiting woods similar to those just described. Mr. Brewster and Mr. R. B. McLaughlin simultaneously published accounts of the firšt nests and eggs of this bird ever taken. The nest described by Mr. Brewster contained four perfectly fresh eggs, and was found by $\mathrm{Mr}$. J. S. Cairns, May 27, 1887; on Craggy Mount,-Buncombe county, North Carolina. It was in a chestnut, ten feet out from the main trunk and about twenty feet above the ground. The nest is a substantial structure, suspended after the usual Vireo fashion in the forks of a terminal twig. In places the rim is nearly an inch in thickness. The exterior is beautifully diversified with white and purplish-brown sheep's wool, grayish lichens, small strips and fragments of decayed wood, and a few spider's cocoons, bound firmly to or hanging loosely from a frame-work proper, which is composed of coarse grass stalks and strips of bark. The interior lining is fine bleached grasses, stems, and moss. Upon comparing this nest with four New England nests of V. solitarius, Mr. Brewster states that it is much larger, with thicker walls and more elaborate external decorations. The eggs are also larger and finer spatted than any of the series of fifteen eggs of solitarius in his collection. The eggs belonging to this nest measure, respectively, $.84 x .49, .78 x .58, .78 x .58$, .80x.58. They are crate to elongate-ovate in shape; in color, pure white, with a few fine spots, and rather mumerous minute dots of brown varying in tone from vandyke to seal brown. $\mathrm{Mr}$. McLaughlin found the Mountain Solitary Vireo breeding in the vicinity of Statesville, Iredell county, North Carolina, in June, 1888. He obtained two nests containing eggs on the 11th and 15th, respectively. Mr. McLaughlin's observations indicate 
that the bird in that region confines itself to the pine woods, the summer home of the Pine Warbler, Dendroica vigorsii. Both nests found were suspended from the limbs of pines and were less than a hundred yards apart. One contained three, the other four eggs. The nests were similar in composition to that of Mr. Brewster's, except that they lack the sheep's wool on the exterior.

629d. ST. LUCAS SOLITARY VIREO. Vireo solitarius lucasanus Brewst. Geog. Dist.-Lower California.

I have no authentic record regarding the nests and eggs of this Southern variety of the Solitary Vireo, but I believe there can be very little difference, if any, In the nidification of this and that of $\nabla$. s. alticola.

630. BLACK-CAPPED VIREO. Vireo atricapillus Woodh. Geog. Dist.Mexico, and Texas north to Southwestern Kansas.

The first authentic account of the nests and eggs of this species was that given by $\mathrm{Mr}$. Brewster, from specimens collected in Comal county, Texas, in May, 1878, by Mr. W. H. Werner. Other Texas records of this species are those of Mr. Ragsdale (who considers it a rare summer visitant in Cook county, on the northern boundary,) and Mr. William Lloyd, who notes it as tolerably common in Concho county during

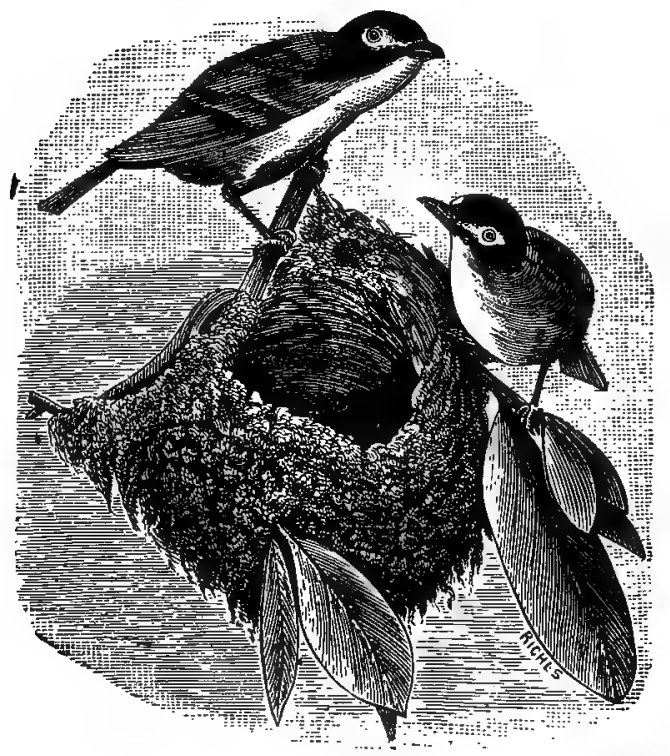

630. Black-capped Virgo and Nest (From Bull. Nutt. Ornith. Club).

the fall migrations, and breeding in two localities in Tom Green county. There he found several nests, which were always situated in some low tree at the edge of thick shrubbery, and at once distinguishable from the nests of Bell's Vireo (which breeds in the same vicinity), in that the latter is lined with wool, while the Black-cap's is not. The late Colonel N. S. Goss gives the Black-capped Vireo as a summer resident in the gypsum hills in Southwestern Kansas. He found it breeding plentifully in Comanche county. According to the observations of those who have found this 
species breeding, it generally frequents brushwood and builds the nest low down, about five feet from the ground, in elm, oak, and mesquite trees. It is suspended from a forked twig, after the usual type of Vireo architecture, is hemispherical in shape, and composed of broken fragments of bleached leaves, strips of bark, grasses, catkins, spider's or caterpillar's silk. These are all firmly interwoven and form thick walls, making a nest that belongs to the higher order of bird architecture. The eggs are usually four, pure white, and measure .72x.52. Mr. Norris has three sets of eggs of this species in his cabinet. One set, containing four eggs, was collected June 5, 1886, in Comal county, Texas. The nest was in a mesquite tree, very low down. The eggs are pure white, entirely unmarked. They measure: .69x.51, $.69 \times .51, .68 x .53, .71 x .52$. Another set, also of four eggs, was collected June 18, 1888, in the same locality, by G. B. Benners. The nest was in a Spanish oak tree, three feet from the ground. The eggs are also pure white, entirely unmarked: $.69 \times .54$, $.70 x .55, .69 \times .53, .70 x .54$. The third set was taken June 5,1888 , by Mr. Benners, in the same locality. The nest was in a Spanish oak, six feet from the ground. The set consists of three eggs and two of the Dwarf Cowbird's. The Vireo's eggs are pure white, unnmarked, and measure: $.72 \times .52, .72 \times .51, .69 \times .52$ inches.

631. WHITE-EYED VIREO. Vireo noveboracensis (Gmel.) Geog. Dist.-Eastern United States, west to the Rocky Mountains; south in winter through Eastern Mexico to Guatemala; resident in the Bermudas.

The White-eyed Greenlet is a common species in Eastern United States as far north as Maine and west to Kansas, and occasionaly to Eastern Colorado. Breeds throughout most of the Mississippi Valley south of Minnesota. Low swampy places, near the edges of woods; covered with briers, or the tangled thickets of blackberry bushes and wild vines, are its favorite nesting places. The nest is usually a purseshaped structure, swaying from a forked twig, and is rather large for the size of the bird. It is seldom placed more than three or four feet from the ground, and is composed of a mass of odd and miscellaneous materials, such as straws, bits of decayed wood, blades of grass, mosses, lichens and various vegetable substances. Wilson nicknamed this bird "Politician," because it frequently used bits of newspaper in the construction of its nest. The eggs are three to five in number, speckled with reddish-brown and dark purple on a clear white ground; the average size is $.76 \times .56$, which is smaller than those of $V$. olivaceus.

631a. KEY WEST VIREO. Direo noveboracensis maynardi Brewst. Geog. Dist.-Southern Florida.

Mr. William Brewster dedicated this bird to M. C. J. Maynard, the ornithologist and author. It is very similar to the preceding species, but the coloration is generally grayer above, and the yellow beneath paler, with other structural characteristics, described from the study and comparison of about one hundred and fifty specimens.* The bird breeds on Key West; its nesting and eggs being indistinguishable from those of the White-eyed Vireo.

632. HUTTON'S VIREO. Vireo huttoni Cass. Geog. Dist.-California, resident.

This Vireo which resembles the White-eyed Greenlet is found in various portions of California, where it is resident. Concerning its nesting and eggs $\mathrm{Mr}$. William Cooper writes as follows: “Hutton's Vireo, Vireo huttoni, breeds in the vi-

- Cf. Brewster, Auk, IV, pp. 148-149. 
cinity of Santa Cruz, though not in abundance. Retiring in habits, their nests and eggs are rarely found. April 7, 1874, I found a nest placed ten feet from the ground, suspended from a dead branch of a Negundo, containing three eggs incubated about five days. March 30, 1875, I found another nest placed eight feet from the ground, suspended from the small twigs of a Frangula. The nest-a neat, compact, structure, composed of fine vegetable fibres, bits of paper, and grasses covered on the outside with green and gray mosses, lined with fine grasses-measures 3.25 inches in diameter outside, 1.75 inside; depth 2.25 outside, 1.50 inside. The eggs, four in number, are white (a delicate blush-color before blown), marked with minute dots of reddishbrown, more numerous towards the larger end. They measure respectively, .70x.52, $.70 \times .51, .69 \times .51, .68 \times .52$. Two other nests were found, each containing four eggs. They were placed, one in a Negunda, thirty feet high, the other at the extremity of an oak limb, twenty-five feet from the ground."* Mr. Walter E. Bryant notes a pair of these Vireos (observed by C. W. Knox) which built in the outer branches of a live oak, only a few feet above the exhaust pipe from a steam pump, where at times they were compelled to suspend work, owing to the dense vapor which enveloped them. Four eggs were laid in this nest.

632a. 'STEPHENS'S VIREO. Vireo huttoni stephensi Brewst. Geog. Dist.Arizona, Western Mexico and Lower California.

This new race was first described by Mr. William Brewster, from specimens collected by Mr. F. Stephens in the Chiricahua and Santa Rita Mountains, Arizona. It is stated that he also took its nest and eggs near Fort Bayard, New Mexico, in 1876, but there appears to be no published account of them. The late Maj. Chas. E. Bendire describes a nest of this bird containing three fresh eggs, taken by Lieutenant Benson on June 21, 1887, near Fort Huachuca; Arizona, which are now in the National Museum. $\dagger$ The nest was attached to the fork of a small twig of some species of buttonwood, growing in a canon of the Huachuca Mountains, and was well concealed. It is very peculiar looking, being outwardly exclusively composed of a yellowish-buff plant down, with similarly colored grass-tops incorporated, giving the nest a uniform light color, not unlike a very fine cup-shaped sponge. It is lined with the extreme tops of grasses, also of a golden tint, and measures externally two and three-fourth inches in width by two and one-half inches in depth. The inner diameter is two inches by onę and three-fourth inches. The three eggs are ovate in shape, pure white in color, with little gloss, sparsely spotted about the larger end, with fine dots of dark umber-brown and brownish-red; sizes .72x.53, .70x.52, $.69 \times .52$ inches.

632b. ANTHONY'S VIREO. Tireo huttoni obscurus Anthony. Geog. Dist.Pacific coast, from Oregon to Southern British Columbia, south in winter to California.

This Vireo, which inhabits the Pacific coast region, is similar to $\nabla . h$. steplensi in coloration. I have nothing pertaining to its nests and eggs which $I$ can consider authentic, but more than likely they do not differ from those of Stephens's Vireo.

* Bull. Nutt. Ornith. Club, III, p. 68.

$\dagger$ Notes on a Collection of Birds' Nests and Eggs from Southern Arizona Territory. By the late Major Charles E. Bendire, U. S. A. Proceedings of the National Museum, 1887, 0D. 556-557. 
633. BELL'S VIREO. Vireo bellii Aud. Geog. Dist.-Middle districts of the United States, from Illinois and Iowa west to the eastern slope of the Rocky Mountains, south in winter to Southern Mexico.

Bell's Vireo is a common bird in the interior districts of United States, as far west as the Rocky Mountains. It breeds in a great portion of the Mississippi Valley, from Dakota and Minnesota southward. Messrs. Kejes and Williams give it as a common summer resident of Iowa, where it is perhaps the most familiar bird of its genus. Here Mr. L. Jones informs me, it frequents the brush fringing the woods or roadsides, where it attaches its nest to the twigs of the hazel bush. The height of the breeding season is about the first week of. June. The bird is an abundant summer resident from Kansas to Southeastern Texas. In Kansas it begins laying the last of May. Mr. Edwin C. Davis states that the favorite nesting places of this species in Northern Texas are well shaded orchards and the north side of osageorange hedges. The nest seems to be the favorite receptacle for the eggs of the Cowbird, and rarely is a nest found without one or more eggs of this parasite. Mr. Davis observes that he has never found a young Cowbird in the Vireo's nest, which suggests the probability that the eggs are disposed of by the parent birds in some manner. The nest is a neat, cup-shaped structure, suspended by the brim in slender, forked twigs of a bush or small tree. It is compact and smooth, made of fine bark strips and strong, flax-like fibres of different plants, lined with fine grasses, feathers and down, rootlets and hair. The usual number of eggs is four. According to $\mathrm{Mr}$. William Lloyd, this species rears two broods in a season in Western Texas, nesting from May 1 to July 3, and the average elutch of eggs is six. He.has taken sets of five, six, and two of eight eggs each. They are white, sparingly dotted wich dark umber-brown around the larger end. Six eggs measure $.69 \times .50, .70 \times .50, .70 \times .50, .72 x$ $.51, .73 \times .50, .68 \times .47$ inches.

633a. LEAST VIREO. Vireo bellii pusillus (Coues.) Geog. Dist.-Southern and Central California, Lower California and Arizona.

This bird occurs in Arizona, chiefly its lower portion, and California, from Sacramento to Cape St. Lucas. Its habits correspond closely with those of Bell's Vireo. Mr. Scott found it common in the Catalina Mountains of Arizona, arriving about the 25th of March, and apparently mated at that time, as they proceed to build nests and lay eggs, the latter commonly three in number. Nests from Arizona are described as substantially like those of the former species. The eggs measure about $.69 \times, 48$, and are of crystalline whiteness, speckled with red and reddish-brown, the markings being very minute and scarcely discernible in some cases, in others larger and more distinct.

634. GRAY VIREO. Tireo vicinior Coues. Geog. Dist.-Northwestern Mexico, Western Texas, New Mexico, Arizona and Southern California.

A very limited number of specimens of the Arizona or Gray Vireo had been procured since its discovery and description by Dr. Coues in 1866, and the species was considered rare until Mr. W. E. D. Scott, in 1884, found it to be fairly abundant on the mesas and foothills of the San Pedro slope of the Santa Catalina Mountains, in Pinal county, Arizona. The limits' of its distribution while breeding, were between the altitudes of 2800 and 4000 feet, and the locality' where it was found most abundant is where the mesquites terminate and the oaks begin. The smooth, flat mesas, and the broad, open bottoms of the wilder canon are quite as much frequented by it as the rough and broken hillsides. The bird is exceedingly active, rapidly 
searching the limbs of trees and bushes for food, constantly uttering its clear liquid song. It is rarely found higher up than fifteen feet in trees and bushes. Two young males which had just left the nest were taken by Mr. Scott on May 26, and a nest was discovered the same day and others were found at different dates till June 11. They were built in mesquites and thorn bushes ranging from four to seven feet from the ground. One was attached at the rim for almost the entire circumference, very much like a Red-eyed Vireo's nest, but here the resemblance ceases, for it is not fastened to the many small twigs, on which it nests, that pass diagonally downward, so that it is not even a semi-pensile structure. Others were found situated in upright V-shaped forks, with the rims partially attached to small twigs and the botton resting in the crotch-a Vireo's nest resting in a crotch and in no degree pensile. The materials used in the composition were coarse dry grasses and shreds of bark externally, while the inner portion is composed of fine, dry grasses arranged in concentric layers. The nests found by Mr. Scott contained three and four eggs each respectively. The one discovered on May 26 did not contain any eggs until the 30th. This habit of sitting on a finished nest for a considerable time before any eggs are laid he found to be characteristic of the Arizona Jay, Aphelocoma sieberii arizonk, (see pages 262-263 of this work.) The eggs are rather rounded in their general shape, rosy when fresh, dead white when blown, and rather sparsely spotted with reddish and umber-brown spots, some chiefly at the larger end. Mr. Scott gives the sizes of three eggs from a set of four as .77x.59, .78x.58, .75x.57, respectively; another of three, .72x.53, .70x.55, .68x.53 inches.*

\section{BAFAMA HONEY CREDPER. Coereba bahamensis Reich. Geog.} Dist.-Bahamas, Florida Keys and adjacent coast of Southern Florida.

This littlo bird as its name indicates belongs to the Bahamas. It occurs in the Florida Keys and strays to the adjacent portions of the southern coast of Florida as far north as Charlotte Harbor. In the Bahamas it nest's in April, May and June. It builds in small trees or bushes, constructing a globular shaped nest with an entrance in one side. The structure is very large for so small a bird. Exteriorally it is built of weed stems, dry grasses, and lined with finer and softer vegetable fibres. The eggs are two to four in number, commonly four, are white, finely speckled with reddish-brown, chiefly at the larger end; average 'size $.60 \times .50$ inches.

636. BLACK AND WHITE WARBLER. Mniotilta varia (Linn.) Geog. Dist.-Eastern North America, north to Fort Simpson, west to the Great Plains; in winter Gulf States, West Indies, Central America and Northern South America.

The little Black-and-white Creeping Warbler, which climbs around the trunks of trees and among their branches in the manner of a true Creeper, breeds throughout its range, and winters from the southern border of the United States southward. Nests usually in the latter part of May and in June, constructing a neat, compact domicile of leaves, bark-strips, grasses, with a lining of hairs and hair-like roots. The nest is built on the ground in woods, usually embedded in a depression, and built on a foundation of decayed wood or leaves. It is generally placed under the shelter of weeds, by the side of a stump, fallen log, or under a projecting stone on a hulside. The eggs are usually five in number, and exhibit considerable variation in size and markings, yet on the whole the eggs have an individuality of their own which enables one to distinguish them from the eggs of any other Warbler. The typical egg

* For a detalled account of the habits, nests and eggs of this species see Mr. Scott's article: Breeding Habits of some Arizona Birds, in The Auk, II, pp. 321-326. 


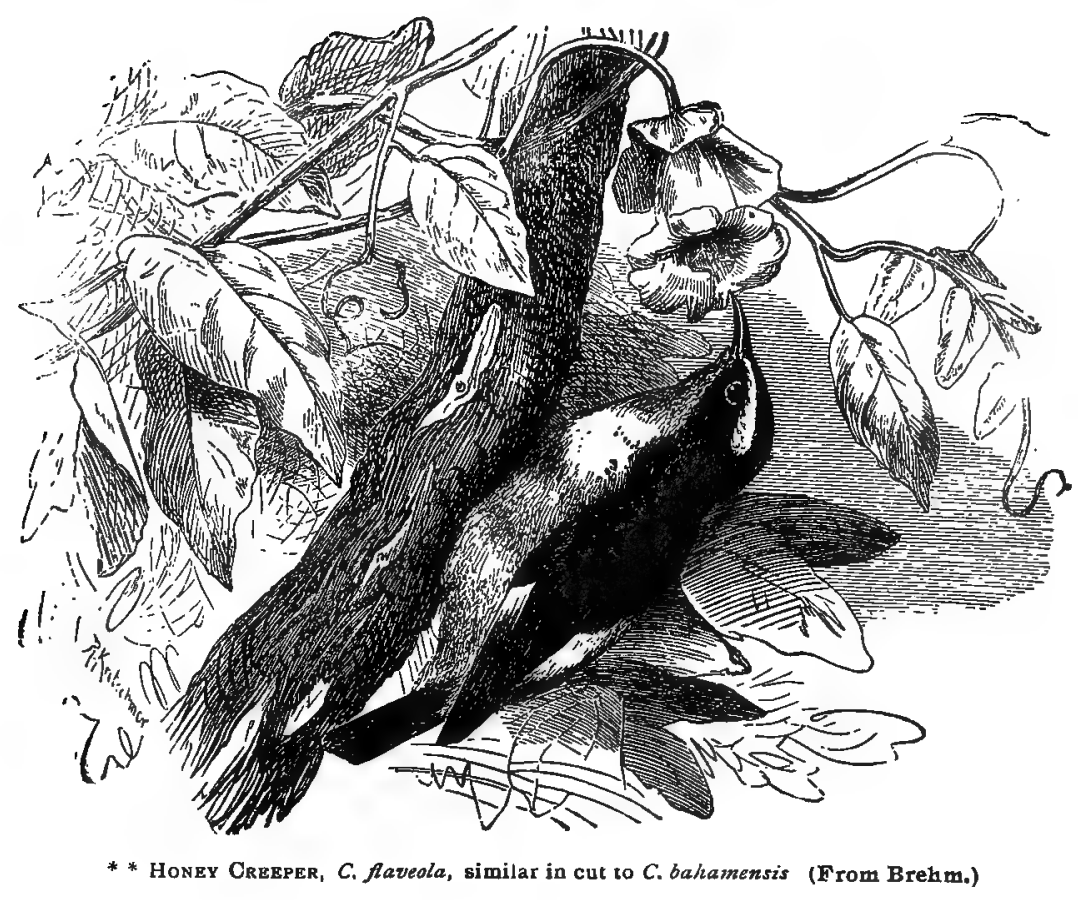

of this species is white or creamy-white, speckled and spotted with chestnut and hazel, generally in the form of a wreath around the larger end, although the rest of the surface is not unspotted. A typical set measures $.65 x .51, .63 \times .51, .60 \times .50, .65 x .49$, $.64 \times .50$; the average is $.65 \times .55$ inches.

637. PRothonotary WARBLER. Protonotaria citrea (Bođd.) Geog. Dist.-Mississipp1 Valley and Gulf States north regularly as far as Iowa, Illinois, Indiana, etc., casually to Wisconsin; rare or casual on the Atlantic Coast, north of Georgia, south in winter to Cuba, Central America and Northern South America.

The vicinity. of willow swamps, the borders of ponds and streams in the bottom lands of the Mississippi Valley and Gulf States is the summer home of the Golden Swamp Warbler. Messrs. Keyes and Williams record it as a summer resident of Iowa and not uncommon, summer resident of Kansas; common in the eastern portion. It is abundant in portions of Indian Territory and Texas. Prof. Evermann notes the Prothonotary Warbler as a rare summer resident of Carroll county, Indiana. It is a summer resident in Western Ohio, where it has been observed breeding. Mr. William Brewster found this species to be one of the most abundant and characteristic birds of Southern Illinois and Southwestern Indiana. In his charming account* of its life-history he describes its song as resembling the note of the Solitary Saudpiper, and its alarm note that of the Water Thrush. The typical nesting site, he states, was the deserted hole of the Downy Woodpecker or Carolina Chickadee. The height varied from two to fifteen feet, though the usual elevation was about

- Bull. Nutt. Ornith. Club, III, pp. 153-162. 
four. If the cavity was old and broken out, or otherwise enlarged, it was far more likely to be chosen than a neater and newer one close at hand. The stump selected almost invariably stood in or projected over. water. When the hole was deep it was usually filled up to within four or five inches of the entrance-the material being moss, leaves and cypress twigs. Mr. O. C. Poling found this Warbler breeding in abundance in the latter half of May, 1887; in Western Illinois, about twenty miles above Quincy, and obtained a large series of the eggs. These are four to seven in number, usually six, sometimes five, rarely seven. Their shape is usually roundedoval of nearly equal size at both ends, some being nearly spherical, others much elongated. The ground color is glossy creamy-white or buff, spotted, blotched and dotted with rich chestnut red, in some the ground being almost obscured by the markings. The sizes of a typical set taken by Mr. Poling are, $.73 \times .55, .73 \times .52, .73 \times 52$, $.73 x .52, .72 x .50$; another set of six, taken May 21, .72x.57, .71x.56, .70x.58, .71x.54, .70x.59, $.72 \times .58$.

638. SWAINSON'S WARBLER. Helinaia swainsonii Aud. Geog. Dist.Southeastern portion of the United States-from South Carolina to Florida and Eastern Texas-northward in the Mississippi Valley to Southern Indiana (Knox county), Jamaica in winter.

Until recently this was one of our rarest North American birds. Its nests and eggs were first described by Mr. William Brewster from specimens collected by Arthur T. Wayne, near Charleston, South Carolina, June 5 and :6, 1885.* Since that date many nests, eggs and skins of the bird have been taken by various collectors, chiefly, however, by Mr. Wayne, T. D. Perry and George Noble, in the vicinity of Charleston, South Carolina, and Savannah, Georgia. From these collectors I gather that the birds nests in wild shrubbery of swamps or pools of stagnant water, along running streams, and on high, dry land at a considerable distance from water. The nests are built in bushes, canes, palmettos, and clumps of vines from three to ten feet above the ground or surface of the water. Mr. Perry observes that the birds breed in small colonies; two or more pairs are usually found nesting near one another. He describes their song as being exactly like that of the Hooded Warbler-a low, sweet call, consisting of a few notes. The nests are all essentially the same, being made outwardly of leaves, placed in layers, and lined with pine ncedles and fine, fibrous roots. Three, rarely four, eggs are laid, and their color is a plain white, with a faint, bluish tinge-the only eggs among our North American Warbler which are unmarked. The eggs are deposited in May and June. Mr. Perry has found nests containing eggs slightly incubated as late as July 13. Two eggs taken May 15, 1885, measure .80x.60; two taken by Mr. Noble, May 16, 1887, .78x.57, $.77 \times .58$.

639. WORM-EATING WARBLER. Helmitherus vermivorus (Gmel.) Eastern United States, north to Connecticut Valley, casually to Maine; west to Missouri, Kansas, and Indian Territory; scuth in winter to Florida, Cuba, Jamaica, Mexico, Central America.

The Worm-eating Warbler breeds throughout its United States range, which extends as far west as Kansas and Nebraska. In some sections, however, it is only an occasional or a rare summer visitor, while in others it breeds abundantly. It has been found breeding frequently in Southern Connecticut and various parts of . Southern New England, in New York and Pennsylvania. This bird may be seen scratch-

*In "Forest and Stream," July 9, 1885. 
ing the leaves on the ground, or rustling in the leaves of a fallen tree in search of worms and spiders. Sometimes while in the higher branches its actions are much like those of a Vireo. In Ohio the Worm-eating Warbler is a rare summer resident. It has been found breeding abundantly in Chester county, Pennsylvania, by Mr. Thomas H. Jackson and Samuel.B. Ladd, in the months of May, June and July. The nest is usually built in a depression of the ground on a hillside, beneath a bush, beside a fallen log, at the foot of a sapling or tree. It is, according to the observations of Mr. Ladd and Mr. Jackson, likewise built on level ground in rather open places, with little sheiter from the sun. It is composed outwardly of leaves, and lined with hairlike moss; sometimes fine grass and horse hair is part of the lining. The eggs are four to six in number, usually five, and exhibit a great variation in size, shape and aarkings, some being faintly marked with light reddish spots, chiefly about the larger end, while others are heavily blotched with lavender and rich chestnut. The shape varies from equal ended to those that are quite pointed. A set containing the smallest normal specimen, collected June 30, in a large series of eggs described by $\mathrm{Mr}$. Ladd, offers the following dimensions: $.64 \times .49, .64 \times .50, .65 \times .48, .64 x .49$; a set of five taken June 6, measure .71x.57, .72x.58, .71x.58, .76x.57, .77x.55.

640. BACHMAN'S WARBLER. Helminthophila bachmanii (Aud.) Geog. Dist.-Coast of South Atlantic and Gulf States, from South Carolina ro Louisiana. Cuba in winter.

- An extremely rare bird. Said to nest in low trees. Eggs four. One of a set of four, taken April 30, and found in the collection made between the years 1853 and 1865 by the late Dr. S. W. Wilson in Georgia, is described by Mr. H. B. Bailey as dull white; around the larger end is a wreath of dark brown, covering nearly onethird of the egg; while a few obscure spots of lilac are scattered over the rest of the surface. It has no resemblance to any Warbler's egg, and especially none of any of this genus.* Size about .74x.60: Ridgw.

641. BLUE-WINGED WARBLER. Helminthophila pinus (Linn.) Geog. Dist.-Eastern United States north to Connecticut and Southern New York, the Great Lakes and Minnesota; south in winter to Eastern Mexico, Guatemala.

The Blue-winged Yellow Warbler breeds throughout its United States range, chiefly, however, north of $40^{\circ}$ latitude. Apparently it is not found in great abundance wherever observed during the breeding season. Records'are at hand of its breeding in Southern Connecticut, New York, Southeastern Pennsylvania, Central Ohio, Indiana and Southeastern Illinois. Colonel Goss.gives it as a rare summer resident of Kansas. It has probably been found breeding most abundantly in Southeastern Pennsylvania by Isaac $\mathbf{S}$. Reiff. The site generally selected for a breeding place in that locality is a clump of blackberry bushes on the edge of a wood, and high ground a short distance from water seems to be preferable. Nest building begins as early as May 10, and nests were found containing young as early as June 3 . The nest is built on the ground in thickets; sometimes it is raised two or three inches above the ground and hidden by tall grass or a cluster of small oak sprouts or vines. The materials used in the construction of the nests were dry leaves, strips of wild grape bark, becoming finer towards the inner part; the lining is of very fine grass. The eggs are four or five in number, white, faintly and sparsely speckled with burnt umber and seal brown. The average size is $.64 x .51$.

* Bull. Nutt. Ornith. Club, VIII, p. 38. 
642. GOLDEN-WINGED WARBLER. Helminthophila chrysoptera (Linn.) Geog. Dist.-Eastern United States and British Provinces; in winter south to Cuba, Eastern Mexico and Central America.

The breeding range of this handsome Warbler is about the same as that of the last, but it seems not to extend its range so far west in the summer months. It has been found nesting in Georgia, North and South Carolina, and as far north as Southern New England. Breeds in Minnesota, Wisconsin and Michigan and is a rather common summer resident of Ohio. Mr. O. C. Poling found the Blue Goldenwinged Warbler breeding in limited numbers in the bottom lands of Western Illinois, along the Mississippi River. The birds seem to prefer low land covered with long grass with here and there a bush or grove of trees. Swampy lands that skirt small woods are its favorite resorts in Central Ohio. The nest is built on or near the ground under tussocks of grass or bushes. All the nests found by Mr. Poling were placed above the ground. The composition consists of leaves, vegetable roots, sedges, and fine strips of bark, lined with fine grasses-on the whole the situation and style of the nest is like that of the Maryland Yellow-throat. The eggs, four to six in number, are white, speckled with burnt umber, chestnut and lilac-gray. The average size is $.62 \times .48$ inches.

643. LUCY'S WARBLER. Helminthophila lucioe (Cooper.) Geog. Dist.-Valleys of the Colorado and Gila Rivers in Arizona and Southern California, south into Sonora.

Major Bendire discovered the nest and eggs of this species near Tucson, Arizona, May 19, 1872. The nest was built between the loose bark and the trunk of a dead tree, a few feet from the ground, similar to that of the Brown Creeper. Mr. F. Stephens found it abundant in the vicinity of Tucson in 1882. The birds frequented the willows along the banks of streams, and like the Kinglets, spent much of their time in searching for insects in the outer branches. Many nests and eggs were examined after May 8 . These were variable, the characteristic place being like that found by Major Bendire, but the nests were also built in deserted woodpecker's excavations, knot-holes and all sorts of crevices. A brood of young was actually taken from the deserted domicile of a Yellow-headed Titmouse. The eggs are three or four in number, white, usually sparsely speckled with brown and black, chiefly at the larger end. A set of four taken by Mr. Stephens is described by Mr. Brewster as being handsomely wreathed about the larger ends with reddish-brown and umber spots, a few of which are scattered over the general surface. Their sizes are .58x.46, $.58 \times .46, .62 \times .46, .60 x .47$ * $^{*}$

644. VIRGINIA'S WARBLER. Helminthophila virginioe (Baird.) Geog. Dist.-Chiefly the Rocky Mountain districts, north to Wyoming, Colorado, Utah and Nevada; south into Central Mexico.

In some portions of the Rocky Mountain region this is an abundant species, as in Colorado, Wyoming and Utah. It frequents the shrubbery along creeks, where it breeds. A nest with eggs obtained by Prof. Ridgway, near Salt Lake, Utah, is described as being embedded in the deposits of dead or decaying leaves, on ground covered by dense oak-brush. Its rim was just even with the surface. It was built on the side of a narrow ravine, at the bottom of which was a small stream. It consists of a loose but intricate interweaving of fine strips of the inner bark of the mountain mahogany, fine stems of grasses, roots, and mosses, and is lined with the same with

* Bull. Nutt. Ornith. Club, VII, pp. 83-84. 
the addition of the fur and hair of the smaller animals. The eggs were four in number, and measured $.64 x .47$ of an inch. They are of a rounded-ovold shape, have a white ground with a slightly roseate tinge; and are profusely spotted with numerous small blotches and dots of purplish-brown and lilac, forming a crown around the larger end.

645. NASHVILLE WARBLER. Helminthophila ruficapilla (Wils.) Geog. Dist.-Eastern North America to the Plains, north to the Fur Countries, south in winter to Eastern Mexico and Guatemala.

The Nashville Warbler breeds from the Northern United States northward to Hudson Bay and interior British America. Throughout New England it is a common summer resident, breeding in any suitable locality in the latter part of May and in June. At this season it may also be found in Michigan. Wisconsin, Northern Illinois, etc. The nest is placed on the ground and is composed of leaves, bark strips, sometimes almost entirely of pine needles, the lining being finer materlal of the same with grasses and hair. Often the nest is embedded in the ground fiush with the surface, and it is usually hidden under \& tussock of grass. The ground color of the eggs varies from white to creamy-white, and are speckled with minute dots over the surface, but chiefly at the larger end with reddish-brown, hazel and lilac. They are three or four in number and have an average size of .64x.45 inches.

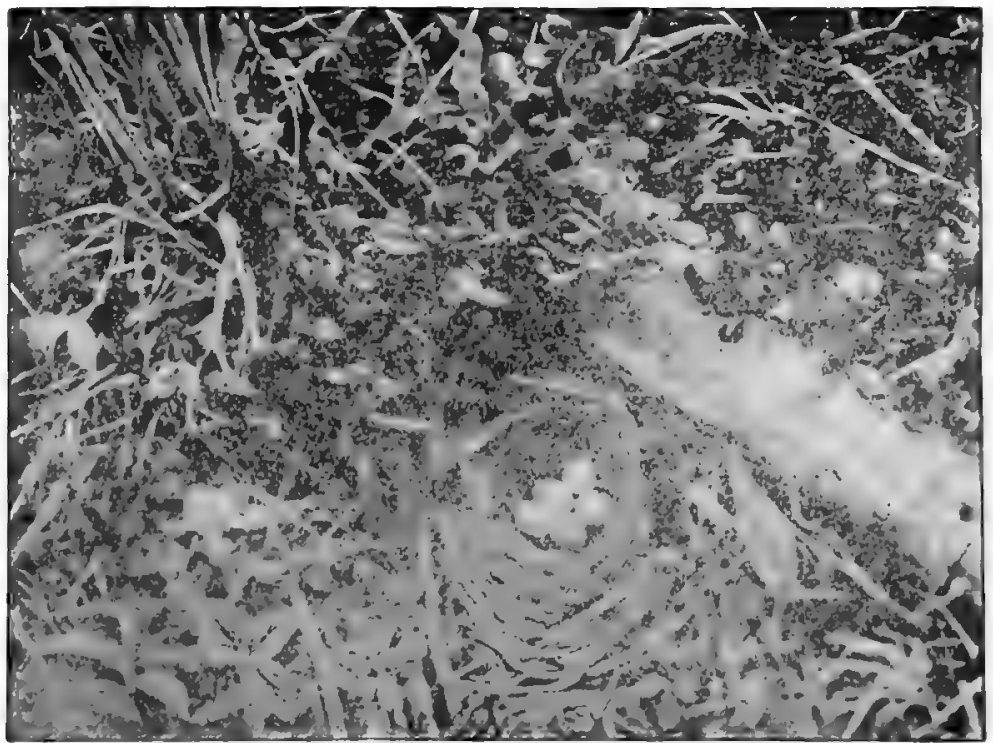

646. Nrgt of Orange-crowned Wareler. Photo by Walter Raine.

645a. CALAVERA'S WARBLER. Helminthophila ruficapilla gutturalis Ridgw, Geog. Dist.-Pacific coast of North America, eastward during migrations to the Rocky Mountains, northward to Kadiak, Alaska, and southward to Lower California and Western Mexico.

This bird is very similar to the Nashville Warbler and its nests and eggs are probably identical. 
646. ORANGE-CROWNED WARBLER. Helminthophila celata (Say.) Geog. Dist.-Northern North America, breeding in high latitudes, as in the Yukon and Mackenzie River-regions, southward into the Rocky Mountains. Winters in the South Atlantic and Gulf States and Eastern Mexico, rare in the Northeastern States.

As mentioned in the above habitat the Orange-crowned Warbler breeds north of the United States. Its nests and eggs were found by Mr. Kennicott, in the middle of June, in the vicinity of Great Slave Lake. They were generally built on the ground among clumps of bushes, often in the side of a bank, and usually hidden by the dry leaves among which they were placed. They were large for the size of the bird, and were composed almost entirely of long, coarse strips of bark, loosely interwoven with a few dry grasses and plant stems. They were warmly lined with hair and fur of small animals. The birds was found breeding near Fort Resolution on the Yukon, at Fort Rae, and at Fort Anderson. The eggs are white or creamywhite, finely speckled, chiefly on the larger end, with reddish or chestnut-brown; average size $.64 x .46$.

646a. LUTESCENT WARBLER. Helminthophila celata lutescens (Ridgw.) Geog. Dist.-Pacific coast region north to Kadiak, Alaska, south in winter to Lower California and Western Mexico and eastward during the migrations to Colorado, Arizona, etc.

The Lutescent Warbler breeds in the coast ranges of Southern California and northward to Kadiak Island, Alaska. Mr. W. O. Emerson states that it may be seen during the entire year in the vicinity of Haywards, California, where Dr. J. G. Cooper took the first known nest. Mr. Emerson also informs me that Mr. A. M. Ingersoll has collected large numbers of the nests and eggs of this bird in Alameda county, California. The nest is built on the ground, often concealed by tall grass or bushes. It is composed of dry grass, rootlets, moss and lined with a few horse hairs and fine vegetable fibres. The eggs range from three to five in number, and vary from white to dull creamy-white, finely speckled with lilac-gray and cinnamon-rufous, chiefly at the larger ends. They are indistinguishable from those of the Orange-crowned Warbler with an average size of .65x.46.

646b. DUSKY WARBLER. Helminthophila celata sordida Townsend. Geog. Dist.-San Clemente, Santa Cruz and Santa Rosa Islands, California.

Very much similar to the preceding species. Its nest and eggs are no doubt identical.

647. TENNESSEE WARBLER. Helminthophila peregrina (Wils.) Geog. Dist.-Eastern North America, breeding from Northern New England, Northern New York and Minnesota northward into the Fur Countries; migrating through Eastern United States, chiefly west of the Alleghanies, as far west as the Rocky Mountains; south through Mexico and Central America.

A nest of this bird was taken by Prof. Horsford, near Springfield, Massachusetts. It is described by Dr. Brewer as being built in a low clump of bushes, just above the ground, and made of fine, vegetable fibres, grasses, mosses, etc., lined with hair. The eggs were pearly white, wreathed about the larger end with brown and purplish markings, size $.60 \times .50$.

648. PARULA WARBLER. Compsothlypis americana (Linn.) Geog. Dist.二 Eastern United States and Canada; in winter Southern Florida, more Northern West Indies, Eastern Mexico and Northern Central America (Guatemala). 
Better known as the Blue-yellow-backed Warbler. Breeds in suitable localities throughout its United States range. It has been observed rearing its young in various parts of Nebraska and Illinois, and its nest and eggs have been taken in Missouri. Mr. Nehrling saw old birds feeding their young in July and August in Southern Texas, and Colonel Goss makes note of the same fact occurring near Neosha Falls, Kansas, in July, 1879. This species is a summer resident in Northern Ohio, but not common. It seems to be more abundant during the breeding season in the States bordering the Atlantic coast, especially from New Jersey northward. The Parula Warbler loves to make its summer home midst swampy groves, whose trees and bushes are draped in festoons of a long, light green moss, with fine, hairlike filaments-the pendulous tree moss-the usnea of the botanists. In the bunches of this thread-like lichen the Parula usually makes its nest with an entrance at one side. "J. M. W..," (Mr. C. L. Rawson), who is well acquainted with the habits of this species in. New London county, Connecticut, says that the bird simply gathers together the lower strands of the usnea, felting it with the same material, and the nest is done. This very accurate naturalist and charming writer also observes that at first sight the riest might indicate a greater degree of skill than the little architect possesses. Such is doubtless the case with the one represented in our illustration, which is a faithful picture of a specimen selected from five beautiful nests, furnished by Mr. W. W. Worthington, of Shelter Island, New York; where the birds breed abundantly. The nests are situated in low trees and bushes at heights ranging from three to forty feet, usually from six to twelve feet. Mr: Worthington and Mr. Griffing both found nests in the moss attached to the sides of the trunks of large trees. Sometimes one or two horse hairs are woven into the nest, and occasionally a piece of fine grass. In regions destitute of tree moss, in which this species can make its nest, it frequently adapts itself to circumstances by nesting in the bunches of dead leaves, caught on branches during freshets. Dr. C. Hart Merriam records a nest of this kind taken near St. Louis; Missouri, June 8, 1885. Mr. William Brewster makes note of an unusual nest of the Parula Warbler, which was made by the birds and suspended by the upper edges to the drooping boughs of a live hemlock. In.general style of construction it closely resembles a wide-mouthed nest of the Baltimore Oriole open at the top. It is composed entirely. of isnea, closely woven or felted with a scanty lining of fine grasses and pine needles. The breeding season is in May, June and July. The usual number of eggs laid by this species is four, sometimes five. Mr. Rawson and Mr. Worthington have both taken sets containing seven, and one of that number taken by the former collector is in $\mathrm{Mr}$. Norris' cabinet, which contains thirty-nine sets of the eggs of this species. The ground-color of the eggs is white or creamy-white, more or less glossy, and speckled with reddish-brown, cinnamon-rufous, chestnut and in some gray tintings. Many eggs are wreathed near the larger ends. Ten selected specimens before me offer the following sizes: $.62 x .42, .67 \times .46, .64 x .46, .65 \times .47, .65 \times .45, .69 x .48, .67 \times .47, .69 x .43, .70 x$ $.45, .66 \times .46$.

648a. NORTHERN PARULA WARBLER. Compsothlypis americana usnew Brewster. Geog. Dist.-New England New York and:westward along the northern tier of States, and northward into the Maritime Provinees and Ontario, migrating southward beyond the United States.

- So far as the nesting, eggs and general habits of this subspecies are concerned they are substantially the same as those described under $C$. americana; many of the references in the text refer to the present bird. 


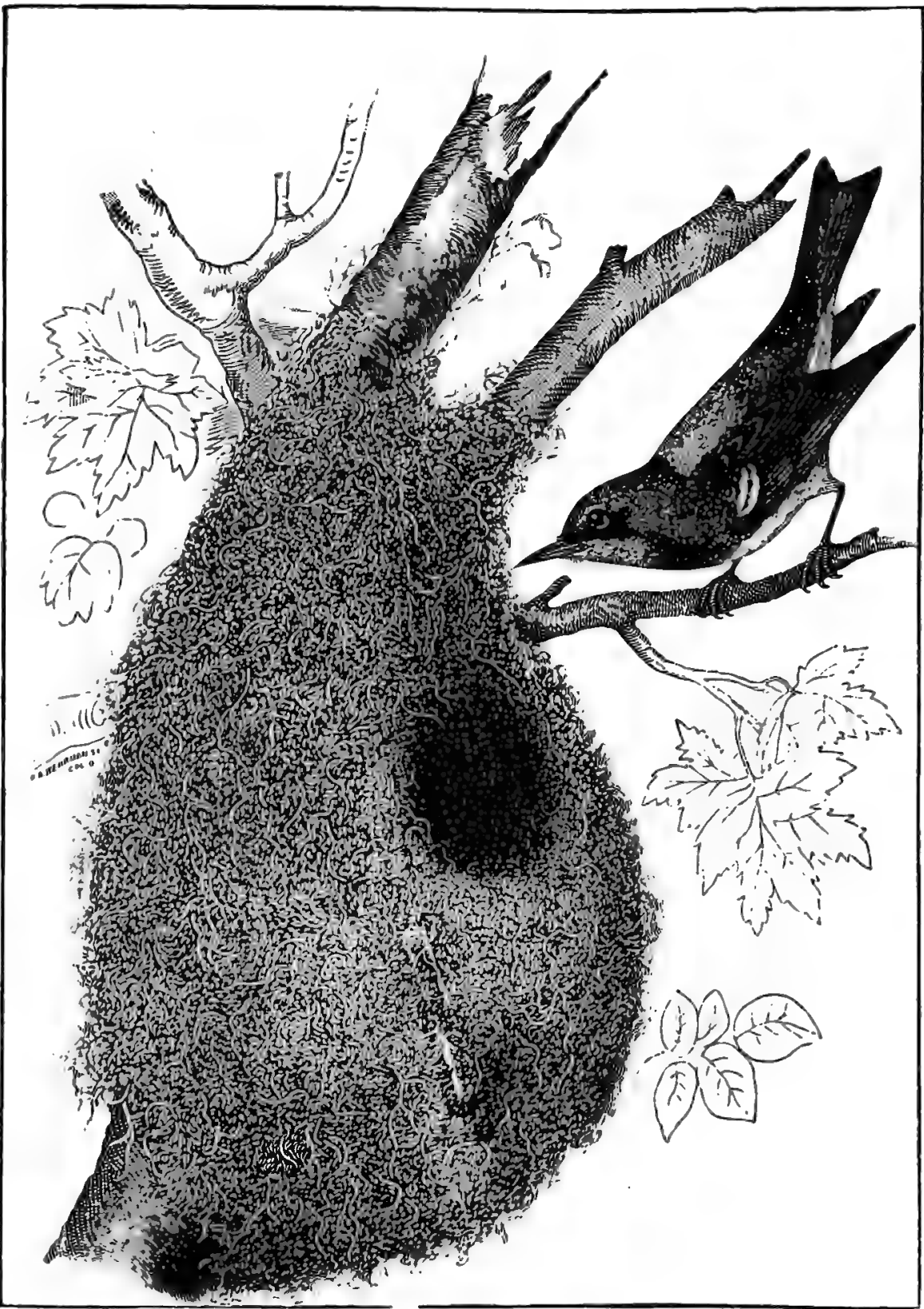

6480. Notrtherk Parula or Blug-Ygllow-baczed Warblef and Nest. 
649. SENNETT'S WARBLER. C'ompsothlypis nigrilora (Coues.) Geog. Dist.Valley of the Lower Rio Grande in Texas.

This is a common species at various localities on the Lower Rio Grande in Texas. It was observed by Dr. Merrill to be quite common at Brownsville, and also by Mr. George B. Sennett at Lomita. Mr. Sennett states that it is truly a bird of the forest, where it delights to flit about in the upper branches of the tallest trees continuously warbling its clear song, which is readily distinguished from that of all other birds. On May 17 a nest containing one egg was found; it was made in a gray mistletoe-like orchid, an air-plant very common on the Rio Grande, which establishes itself on the small branches of trees and varies in size up to eight or ten inches in diameter. This one is six inches long by four and one-half inches wide, quite firm in texture, and was fastened some ten feet from the ground, to the end of a drooping branch of a brazil tree in open woodland. The nest is constructed by simply parting the gray leaves of the orchid, and digging into its center from the side, a cavity some two inches in diameter being made with an opening one and one-quarter inches. The birds evidently build also in the hanging trusses of Spanish moss so abundant everywhere, as a nest was found by Dr. Merrill, July 5, 1877, in a small bunch of moss about eight feet from the ground. The single egg is described by Mr. Sennett as similar to that of $C$. americana; its spots of lilac and brown forming a broad incompact band near the larger end, and the entire surface is sparingly marked with the same colors on a dull white ground; size .67x.46 inches.

650. CAPE MAY WARBLER. Dendroica tigrina (Gmel.) Geog. Dist.-Eastern North America, north to Hudson Bay, Lake Winnipeg, etc. Breeds from Northern New England northward, also in Jamaica; winters in Greater Antilles.

Not a common bird wherever found in Eastern North America, except in restricted areas during the migrations, when great numbers are seen in a day. Some years, in certain localities it is more frequently observed than at other times. Forests of evergreens are its favorite resorts. It is known to breed in Northern New England and northward. A nest with eggs taken by James W. Banks near St. John, N. B., is described by Mr. Montague Chamberlain. The nest was hidden in a cluster of low cedars, growing in an exposed position on a rather open hillside; it was placed less than three feet from the ground, and within six inches of the tips of the branches amidst the densest part of the foliage, and well screened from observation. June

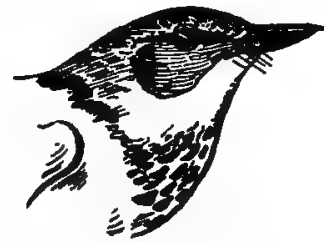

650. Cape May Warbler 13 the nest was completed and contained two eggs, and on the 16th four eggs. The nest somewhat resembles that of the Magnolia Warbler, $D$. maculosa, being composed of minute twigs of dry spruce, grasses, with spider's webs interwoven. The lining is composed entirely of horse hair laid with precision, and shaped into a prettily formed cup, the brim being turned with exquisite grace. The eggs of this species are described as dull or buffy-white, or grayish, speckled or spotted round the larger end with dark brown or reddish-brown and lilac-gray, sometimes a few specks of blackish are scattered over the greater part of the surface. The ground-color of the eggs belonging to the nest just described, is dull white like that of the Magnolia's; their sizes $.69 \times .49, .65 \times .49, .66 \times .49, .66 \times .48$. The average is $.68 \times .49$ inches. 


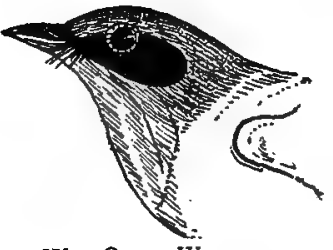

651. Olive Warbler.

651. OLIVE WARBLER. Dendroica olivacea (Giraud.) Geog. Dist.-Highlands of Guatemala and Mexico, north to Southern New Mexico and Mt. Graham, Arizona.

A curious Mexican Warbler known to inhabit Arizona and as far north as southern New Mexico, chiefly in the mountainous portions. Its habits are described as being similar to those of the Pine Warbler, $D$. vigorosi. Its nests and eggs remain undescribed.

652. YELLOW WARBLER. Dendroica astiva (Gmel.) Geog. Dist.-North America at large, except the southwestern part.

Known by several names, such as Summer Warbler, Summer Yellow-bird, Blueeyed Yellow Warbler and Golden Warbler. An abundant bird everywhere throughout its range, in woodland, orchards, parks and gardens. Nests in fruit or shade trees, low shrubbery and brushwood. Sometimes the nest is built at heights ranging from ten to forty feet in large trees, but their favorite nesting places are hedges and low bushes. The nest is usually skillfully fastened to several small twigs, and is a neat, compaot, cup-shaped structure, made of grayish, hempen fibres, slender stems of plants and leaves, lined with soft plant down and feathers. The Cowbird makes the nest of this Warbler a favorite receptacle for depositing her eggs. In United States the Yellow Warbler begins nest building about the first of May: The eggs are four or five in number. They have a greenish-white or even a decided green ground-color, spotted, usually. in a wreath around the larger end, witদ umberbrown, blackish and lilac-gray. They vary in size from .62 to .70 long by .48 to .53 broad. A common size is $.67 \times .47$ inches.

652a. SONORA YELLOW WARBLER. Dendroica estiva. sonorana Brewster. Geog. Dist.-Southern Arizona to Western Texas and Northwestern Mexico.

Very similar to $D$. astiva, but with the underparts of the male more faintly and sparsely streaked, etc.* Nests and eggs identical with those of the preceding.

652b. ALASKAN YELLOW WARBLER. Dendroica astiva rubiginosa (Pall.) Geog. Dist.-Alaska and British Columbia, southward through western United States in migration.

From a careful examination of a series of Yellow Warblers in the U. S. National Museum by Harry C. Oberholser, the existence of a well-defined geographical race has been discovered. Its nesting and eggs no doubt, and its general habits are similar to those of the typical $D$. cestiva.

653. MANGROVE WARBLER. Dendroica bryanti castaneiceps Ridgw. Geog. Dist.-Western Mexico and southern part of Lower California.

This race breeds in Western Mexico and on Cape St. Lucas, Lower California, but the eggs are unknown. They are probably very similar to those of $D$. astiva.

654. BLACK-THROATED BLUE WARBLER. Dendroica carulescens (Gmel.) Dist.-Eastern North America to the Great Plains; breeding from the northern and more elevated portions of Eastern United States northward; in winter, Florida and West Indies.

* Cf. Brewster, Auk, V, p. 137. 
In most of the Eastern United States this beautiful Warbler is known only as a spring and fall migrant. It has been observed breeding in Northern New England, New York and in Ontario. The Rev. C. M. Jones found it breeding at Eastford, Connecticut, in deep, swampy woods, which the birds seem to make their favorite resorts. Four nests were discovered piaced in laurel bushes, from five to about eighteen inches above the ground. They were composed of dry grape vine bark, twigs and roots, and partially covered on the outside with the woolly substance of cocoons; the lining was of fine black roots and hair, and they contained four eggs respectively. These nests were found in the first half of June. Mr. William L. Kells found the Black-throated Blue Warbler breeding in the thick underbrush of the high timber land, near Listowel, Ontario, in June, and on the 5th of that month, 1886, discovered a compactly built

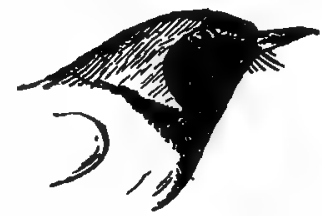

654. BLACK-THROATED BLUE WARBLER. nest of this species in a small maple. On the 9th it contained three eggs of the Warbler and one of the Cowbird. Another nest found placed in a small leafy shrub at the edge of a thicket contained three young of $D$. corulescens and one young Cowbird. Mr. Egbert Bagg and Dr. William M. Ralph found this Warbler nesting in swampy and heavily timbered woods, thickly ovérgrown with brush, near Holland Patent, New York. Four nests were taken between May 29 and June 14, 1886; they were built in the upright "orks of little maple bushes, from nine inches to two feet above the ground. The sizes of two sets of four eggs each are given as follows: $.66 \times .50, .66 \times .51, .64 \times .51, .64 x .51 ; .75 \times .54, .72 \times .55, .76 \times .54, .72 \times .52$. The eggs are buffy-white or greenish-white, more or less heavily blotched with pinkish-brown, reddish-brown, of varying shades; some specimens in general shape and appearance resemble the eggs of the American Redstart, being marked with chestnut and hazel, chiefly at the larger ends.

654a. CAIRN'S WARBLER. Dendroica carulescens cairnsi Coues. Geog. Dist.--Higher parts of the Alleghanies, from Virginia to Georgia.

The general habits, nesting and eggs of this subspecies are identical with those of the preceding species.

655. MYRTLE WARBLER. Dendroica coronata (Linn.) Geog. Dist.-Entire of North America, rare west of the Rocky Mountains, except on the Pacific coast, where more or less common. Breeds from Northern United States northward. Winters from the Middle States and Ohio Valley $\left(40^{\circ}\right)$ southward to West Indies and Panama. Breeds also in Jamaica.

The Yellow-crowned or Yellow-rumped Warbler is a common and well-known species in Eastern United States, breeding from the northern portions northward in . May, June and July. Breeds abundantly in the coniferous forests of Maine, New Hampshire and Vermont. In Central and Northern Ohio it is a rather common breeder. Dr. Howard E. Jones has several times found it nesting in Pickaway county, and has observed it in the extreme southern portions of the State in July. In the vicinity of Listowel, Ontario, Mr. W. L. Kells met with this species breeding in swampy woodland, in company with the American Redstart, Black-and-white Warbler, Chestnut-sided and Bay-breasted Warblers. The Myrtle Warbler spends most of its time in the higher branches of trees searching for food, but builds its nest down on the lower branches, preferedly in pine, hemlock, spruce and other coniferous trees; the height of the nest from the ground is seldom more than eight 


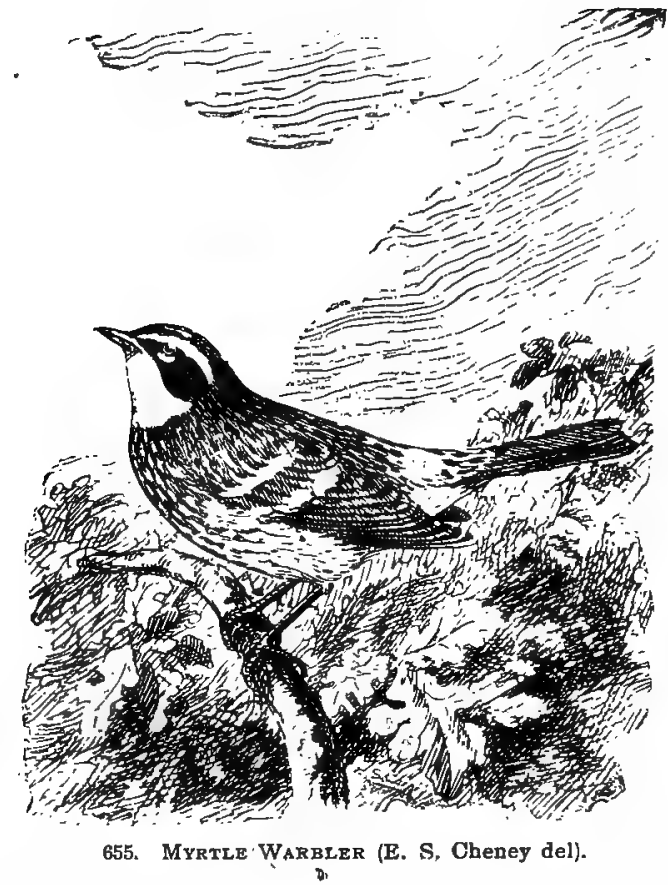

or ten feet, usually four or five. The locality in which Mr. Kells found this species breeding was woods of black ash, intermingled with balsams and cedars. The nest is composed of soft vegetable fibres, with a few grass stems for a lining; in some there is a lining of feathers when they are obtainable. The eggs are four or five, usually four, in number, and vary from creamy-white to dull white, speckled and spotted, and frequently blotched, generally in wreaths near the larger ends, with various shades of reddish-brown and lilac gray. The sizes of a set containing the largest eggs in a series in Mr. Norris' collection are .70x.54, .69x.54, .72x.55; these were taken at Grand Manan, New Brunswick, June 24, 1878. A set of four exhibiting the smallest sizes was taken by Mr. William Brewster at Lake Umbagog, Maine, June 11, 1876. These measure .64x.51, .64x.49, .66x.50, .66x.50, respectively.

656. AUDUBON'S WARBLER. Dendroica auduboni (Towns.) Geog. Dist.Western North America, east to the eastern slope of the Rocky Mountains, north to British Columbia; south in winter to Guatemala. Accidental in Massachusetts.

Audubon's Warbler looks like the last species except that its throat is yellow instead of white. An abundant species in all suitable places throughout the west. Mr. Scott found it nesting at Twin Lakes, Colorado, and Mr. D. H. Minot notes it as

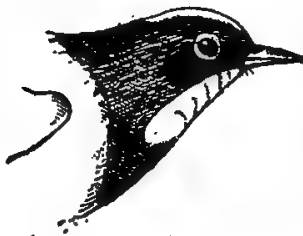

6:6. 'AUDUBON'S WARBLER a summer resident in the region about Boulder, where the bird prefers high willow swamps and spruce timber. $\mathrm{He}$ found nests June 24; at Seven Lakes. Mr. Frank M. Drew gives it as an abundant resident in San Juan county, Colorado. Dr. Merrill states that it breeds rather abundantly in the Big Horn Mountains, Montana. Mr. H. W. Henshaw states that Audubon's Warbler breeds abundantly throughout the pine woods of the mountains about Santa Fe, New Mexico. Mr. A. W. Anthony says that a few breed in the 
more elevated parts of Washington county, Oregon. The nests of this species are situated at various heights, ranging all the way from three to thirty feet, and usually on the outer branches of pine or spruce trees. Their composition is fine strips of bark, grass, small stems of the sage bush, pine needles, etc., lined with fine roots, hairs and feathers. The eggs are usually four in number, sometimes five. Some specimens are somewhat like the common type of the Yellow Warbler's, being greenish-white, marked chiefly about the crown with olive-brown. The ground color, however, varies from dull olivaceous-white to pale green or even pale blue, and the markings are usually blackish-brown and lilac-gray; average size .67x.52.

657. MAGNOLIA WARBLER. Dendroica maculosa (Gmel.) Geog. Dist.Eastern North America as far west as base of Rocky Mountains. Breeds from northern parts of New England, New York, and Michigan northward to about Hudson Bay. In winter, Bahamas, Cuba and Central America.

An elegant little bird, and perhaps better known as the Black-and-yellow Warbler. Breeds commonly in Northern New England, New York, Michigan and northward. Not an abundant summer resident in Northeastern Ohio. Accounts of this species nesting in New Hampshire and Maine have been given by Mr. William Brewster, Ruthven Deane, C. J. Maynard and others. It was found breeding quite abundantly on Grand Manan by Mr. Charles H. Andros. The time of laying for this species is usually in the first half of June. According to Mr. Brewster it is found everywhere common throughout the White Mountains of New Hampshire.* Its favorite resorts are little clumps of fir and spruce shrubs, also willow thickets near streams and "ponds and damp places. Its gay colors and sprightly song will at once attract the attention of even the casual observer. The nest is usually placed in the

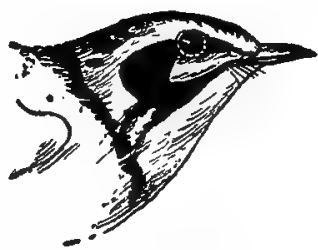

657. Magnolia Warbeer. horizontal twigs of a fir or spruce at heights ranging from five to six feet, four being the average elevation, and the favorite localities are the edges or wood-paths, clearings or roads bordered by woods. Sometimes the nests are built in the tops of young hemlocks ten to fifteen feet up, or in the heart of the forest, thirty-five feet above the ground. The nest Mr. Brewster states is loosely put together, of fine twigs, preferedly hemlock, coarse grasses, dry weed stalks; the lining is fine black roots, closely resembling horse hair. In general style it approaches more nearly the nest of the Chestnut-sided Warbler. The eggs are four in number, very rarely five. A series of forty-three sets of the eggs of this species is in Mr. Norris' cabinet. The ground color of the specimens is usually creamy-white, spotted and blotched with various shades of reddish-brown, hazel and chestnut. The markings are generally large and well defined and often form wreaths about the larger ends; again the ground-color of the eggs will be almost wholly obscured by innumerable fine specks. The sizes of two sets containing the smallest and largest eggs are as follows: $.56 \times .48, .59 \times .48, .59 \times .45, .56 \times .47 ; .70 \times .49, .68 \times .47, .70 \times .49, .68 \times .49$.

658. CERULEAN WARBLER. Dendroica carulea (Wils.) Geog. Dist.-Eastern United States (west of the Alleghanies) and Southern Canada, east to Central New York; south in winter to Cuba and northern portions of South America.

A beautiful little sky-blue feathered creature, and well named Azure Warbler. Its home is in the top branches of trees in sylvan groves, where it may be seen

* Bull. Nutt. Ornith Club, II, pp. 1-7. 
sometimes in numbers, flitting about in search of insect food, and uttering its peculiar syllables which sound like zee, zee, zee, $\approx c-c c-c \ell p$. It is not strange that the nest of this species has been so seldom discovered, even where the bird is very abundant during the breeding season. The nest is built in the higher horizontal branches of forest trees, always at some distance from the trunk, and ranging from twenty to fifty feet above the ground. The Blue or Cerulean Warbler is an abundant summer resident in Central Ohio, where it prefers damp woods for nesting. Mr. J. A. Allen describes a nest and lour eggs which were taken in Monroe county, New York, June 7, 1878. The nest was placed in the forks of a small ash, about twenty-five feet from the ground. One taken near Drummondsville, Ontario, near Niagara Falls, and described by Dr. Brewer, was built in a large oak tree, fifty feet from the ground. This and another nest containing four eggs taken by Mr. Wm. Bryant at Mount Carmel, Illinois, May 16, 1878, are in the Museum of Comparative Zoology. Mr. Allen states that the Mount Carmel nest was also placed at an elevation of twenty-five feet." Prof. Evermann gives the Cerulean Warbler as a common summer resident of Carroll county, Indiana. Mr. J. L. Davidson secured two nests of this species with eggs: in Niagara county, New York, on June 8 and 23, 1888. They were built in small basswood trees, about twenty feet above the ground. On June 30 another nest was discovered, but was too high and inaccessible. Two broods were observed in July in the same woods. The nests are compactly made of fine, dry grasses, bound together with spiders' silk to which are attached pieces of whitish lichen; the lining iś strips of bark and fine grass. The eggs are bluish-white or greenish-white, speckled with reddish-brown and lilac, chiefly at the larger end, and often in the form of a wreath. Mr. Davidson gives the measurements of two specimens that were saved out of the first nest, as .70x.52, .71x.52. The second nest contained three eggs of the Warbler and one of the Cowbird; sizes, .64x.50, .63x.49, .64x.50.

659. CHESTNUT-SIDED WARBLER. Dendroica pensylvanica (Linn.) Geog. Dist.-Eastern United States and Canada. Breeds north of $40^{\circ}$ except in higher mountain ranges. In winter, south to Bahamas, Eastern Mexico, and Central Amcrica to Panama.

This well-known Warbler breeds abundantly in the Middle and Northern States within its range. Mr. McIlwraith gives it as a common resident of Ontario, breeding in suitable places near Hamilton and throughout the country, raising two broods in

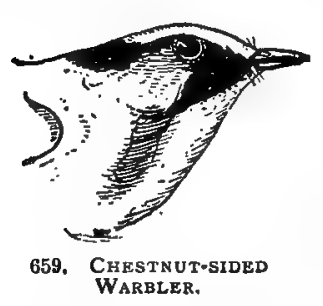
a season. Breeds, but not commonly, in Central Ohio, more abundant in the northern portion. Nests in the latter part of May and in June. The nest is commonly built in a low bush, shrub or sapling from two to eight feet above the ground. The situations chosen are the "scrub-lands" or open woods in low grounds, with a growth of bushes, vines, etc. The nest is generally coarser than the Yellow Warbler's, and contains fewer woolly materials. It is composed of narrow strips of thin bark or dried grasses, mixed with plant-down, fine bleached grasses, and lined with hair. The eggs are four, rarely five, in number, and vary from clear-white to creamy-white in grcund-color, speckled with rusty-brown and chestnut, often tinged with lilacgray, chiefly at the larger end, where they frequently form wreaths. A set of four offers the following sizes: $.68 x .50, .65 x .47, .67 x .49, .68 x .49$; average $.68 x .50$. Eggs of the Cowbird are commonly found in nests of this speeies.

* Bull. Nutt. Ornith. Club, IV, pp. 25-27. 
660. BAY-BREASTED WARBLER: Dendroica castanca (Wils.) Ġeog. Dist.-Eastern North America. Breeds from Northern New England and Northern Michigan northward to Hudson Bay; south in winter through Eastern Mexico and Central America.

The Bay-Breasted Warbler is known to breed from Northern New England and Northern Michigan northward. Mr. William L. Kells found it breeding in the vicinity of Listowel, Ontario, in low, swampy woods, where there is a mixture of evergreens, ash, birch, elm and other trees. The nests are compact, cup-shaped structures, usually placed in coniferous trees from five to fifteen or even twenty feet above the ground. Mr. Kells found a nest placed between a slender limb and the trunk of a small cedar about five feet up; another was found in a hemlock at an elevation of fourteen feet. The nest is composed of fine shreds of bark, small twigs, fibrous roots and pine hair; the interior is a little more than two inches in diameter by one in depth. The eggs are deposited in the latter half of May or first half of June. Four is the usual number laid; they are white, with a bluish tinge, finely speckled on or round the larger end with reddish-brown; average size $.70 x .50$ inches.

661. BLACK-POLL WARBLER. Dendroica striata (Forst.) Geog. Dist.Eastern and Northern North America, breeding from Northern New England, Labrador, etc., to coast of Alaska (north of the Alaskan Peninsula) and to the Arctic Ocean; accidental in Greenland. In winter, south to Bahamas, Cuba and Northern South America.

In the United States the Black-poll Warbler is known as a spring and fall migrant, except in Northern New England, where a few pair remain to breed. Its breeding grounds are from thence northward into the Arctic regions. The nests are usually built in the month of June, and are placed in low, thick spruce trees about eight feet from the ground. They are made of small $t$ igs, lichens, slender rootlets, sedges, and lined with feathers. The eggs are four or five in number and have an average size of $.74 \times .52$ inches. In shape they vary from ovate to elongate-ovate, and the ground-color varies from white to creamy and buff, and occasionally a light

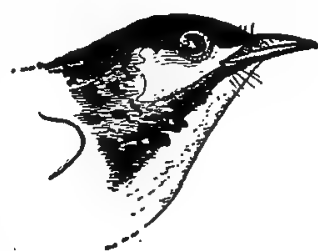

661. BLACK-POLL Warbler. shade of greenish-white is found. They are speckled, spotted and blotched with various shades of reddish-brown and frequently lilac-gray. Occasionally a set shows such small specks all over the surface as to almost obscure the ground-color. The markings are always much heavier at the larger ends, but they rarely form wreaths,

662. BLACKBURNIAN WARBLER. Dendroica blackburnia (Gmel.) Geog. Dist.-Eastern North America to the Great Plains, casually to Utah and New Mrexico. Breeds from Northern United States northward. South in winter to the Bahamas, Central America and Northern South America.

A lovely Warbler, with throat and chest of intense orange yellow. Breeds from the northern States northward, occurring as it does in most of the United States as a spring and fall migrant. Its nests and eggs have been taken in Massachusetts and other more northern New England States. Dr. C. Hart Merriam found a pair of these birds breeding in a grove of large white pines in Lewis county, New York. In the latter part of May the female was observed building, and on June 2 the nest contained four fresh eggs of the Warbler and one of the Cowbird. The nest 
was saddled on the horizontal limb about eight feet from the ground and about ten feet from the trunk. Blackburn's Warbler has been found breeding in Southern Michigan, "where nests have been taken in pine trees at an elevation of forty feet. In all cases the nests are placed high in hemlocks or pines, which are the bird's favorite resorts. Mr. J. W. Preston met with the Blackburnian Warbler breeding in the hemlock and spruce regions of Northern Minnesota. One nest was found placed against the trunk and upon a small branch which grew from the tree at a height of twenty feet; another was built in the fork of a horizontal branch near the end, five feet from the trunk and thirty feet from the ground. One nest contained two, the other three eggs, and in each was a Cowbird's egg. From all accounts the nests of this species are elegantly and compactly made, consisting of a densely woven mass of spruce twigs, soft vegetable down, rootlets and fine shreds of bark; the lining is often intermixed with horse hairs and feathers. The full complement of eggs is four, and they are described as greenish-white or very pale bluish-green, speckled or spotted, chiefly around the larger end, with brown or reddish-brown and lilacgray; average size .69x.50. The sizes of the set taken by Dr. Merriam are $.69 \times .50$, $.70 \times .45, .71 \times .49, .69 \times .50$, respectively.

663. YELLOW-THROATED WARBLER. Dendroica dominica (Linn.) Geog. Dist.-South Atlantic States north along the sea coast regularly to Maryland; casually to New York, Massachusetts, etc., south to the West Indies.

The Yellow-throated Warbler breeds commonly in the South Atlantic States, in some portions of which it is resident throughout the year. The nest is placed on branches of pine trees, usually at a considerable elevation. It is also not infrequently

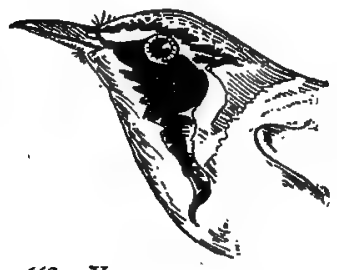

663. YELLOW-THROATED WARBLER. built in the pendulons tufts of Spanish moss, which grows abundantly on the live oaks and other trees. Mr. William Brewster found a nest of this species in Camden county, Georgia, May 2, which was placed at a height of thirty-five feet from the ground, on the stout, horizontal branch of a Southern pine, in a thinly scattered grove. The nest was set flatly on the limb-not saddled to it-nearly midway between the juncture with the main trunk and the extremity of the twigs, and was attached to the rough bark by silky fibres. It is composed of short twigs, strips of bark, bound together with Spanish móss and silky down; the lining is soft, hair-like vegetable down. Mr. Arthur T. Wayne obtained nests and eggs of this Warbler in the mixed woods near Charleston, South Carolina. The nests were found built in the tufts of tree moss, and lined with feathers. The heights range from thirty to about forty feet above the ground. Mr. R. B. McLaughlin found, on June 4, a nest of this species built close to the main body of a small pine tree, in woods near Statesville, North Carolina. The nest rested on a short, dead twig, nineteen feet from the ground. It contained three young birds and one egg. The eggs are three or four in number, rarely five. They are of a dull greenish or grayishwhite, spotted with various shades of brown and lavender-gray almost entirely near the larger ends; in some specimens they form wreaths about the crown. This bird deposits its eggs early, usually in the first part of April. The average size of ten eggs is $.74 \times .53$.

663a. SYCAMORE WARBLER. Dendroica dominica albalora Ridgw. Geog. Dist.-Mississippi Valley, west to the Plains, north to Lake Erie and Southern Michigan, and east to Western North Carolina; in winter south to southern Mexico, Honduras, Guatemala and Nicaragua. 
This is precisely like the last species, but the superciliary stripe is entirely white and the chin cut off from the bill by white. This subspecies breeds in Ohio. It is, I believe, well named, for the majority of specimens I have taken were in sycamore trees. A nest containing four eggs was found by $\mathrm{Mr}$. L. C. Horton near Mt. Vernon, Knox county, Ohio, June 28, 1897. The female was shot and it, with the nest and eggs are in Mr. Horton's collection. The nest was placed on a horizontal branch in an elm tree twenty feet from the ground, a short distance from water. It is composed of fine shreds of vegetable material, intermingled with short, slender twigs as the base. The eggs measure respectively as follows: $.63 \times .52, .63 x .50, .69 \times .53$, $.71 x .53$ inches. They have the same coloration as the eggs of the Yellow-throated species, $D$. dominica.

664. GRACE'S WARBLER. Dendroica gracice Baird. Geog. Dist.-Southern New Mexico and Arizona, and southward into Sonora.

This Warbler was dedicated by the late Prof. Spenser F. Baird in honor of Miss Grace D. Coues, sister of the eminent naturalist and scientist, Dr. Elliott Coues. The nesting and eggs of this species are identical with those of $D$. dominica, but its eggs will not be found numerous in collections.

665. BLACK-THROATED GRAY WARBLER. Dendroica nigrescens (Towns.) Geog. Dist.-Western United States, north to Colorado and Oregon, and British Columbia, west to the Cascades; south in winter into Mexico, etc.

Mr. A. W. Anthony gives this species as a summer resident of Washington county, Oregon, where it frequents the thick firs. In the breeding season it is quite shy and retired, inhabiting the younger growth of firs and dense thickets of alder and willows. The eggs are four in number. The extensive cabinet of $\mathrm{Mr}$. J. Parker Norris contains a set of four eggs of this Warbler, which was taken in Polk county, Oregon. The nest was situated in a fir tree twenty feet from the ground, and is composed of fine grasses, profusely lined with feathers. The eggs are pinkish-white, spotted with cinnamon-rufous and lilac-gray. The markings are nearly all at the larger ends. They

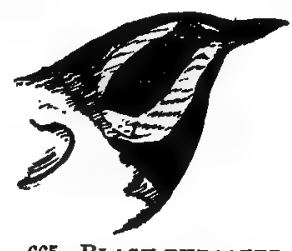

665. BLACK-THRoATED GRAY WARBLER. measure $.67 x .51, .71 x .54, .71 x .54, .68 x .53$ inches. Mr. C. Barlow has kindly sent me for inspection a nest containing four eggs of this Warbler which were taken near Lakeport, Lake county, California, by Corydon Chamberlain, an account of which was read in a paper before the Cooper Ornithological Club. A description was published in "The Nidologist" for September, 1895. On the 5th of May the nest was found compactly put together, symmetrically lined with fine hair of quadrupeds; external width three and one-third inches, external depth two inches. The nest was found in a small clump of manzanitas, about four feet from the ground. The eggs are white, dotted with reddish-brown and purple, chiefly about the larger end, where the dots are frequently confluent, and also form small blotches. Their sizes are as follows: $.65 \times .52, .66 \times .52, .65 \times .51, .66 \times .51$ inches.

666. GOLDEN-CHEEKED WARBLER. Dendroica chrysoparia Scl. \& Salv. Geog. Dist.-Central Texas and southward to Guatemala.

So far as I am aware all the nests and eggs of this rare Warbler that are in various cabinets have been collected in Comal county, Texas. Mr. Wm. Brewster describes specimens of its nests and eggs taken by Mr. W. H. Werner in that region 
in the month of May, 1878. The birds were found invariably in cedar timber. Four nests were discovered, all of which were similar in construction, being built in the forks of perpendicular limbs of the Juniperus virginiana, from ten to eighteen feet from the ground. They were composed of the inner bark of this tree interwoven with spider webs, in color resembling the bark of the tree in which they were built, making them difficult to detect. The interior is lined with hair and feathers: The nest resembles the average nest of the Black-throated Green Warbler, but is larger. Mr. G. B. Benners met with this species breeding in Comal county, Texas, in April, 1884. The nests were placed in cedars from five to ten feet above the ground and similar in materials and construction to those found by $\mathrm{Mr}$. Werner, being neatly. and compactly built. The cavity of a typical nest measures about 1.50 to 1.60 across by 1.50 to 2.00 inches deep. The eggs are four, rarely five in number. The eggs have a ground-color of creamy-white, with a slight gloss, speckled and spotted with shades of red and brown that vary from a cinnamon-rufous to burnt umber. Some eggs have specks of lilac-gray. The measurements of three eggs taken by Mr. Werner are given as $.75 \times .57, .77 \times .56, .76 \times .58$ inches.

667. BLACK-THROATED GREEN WARBLER. Dendroica virens (Gmel.) Geog. Dist.-Eastern North America, west to the Great Plains, breeding from Northern United States northward. In winter, south through Eastern Mexico and Central America to Panama; also to the West Indies. Casual in Greenland.

The Black-throated Green Warbler breeds from the Northern United States northward-wherever there are tracts of coniferous trees the bird is almost sure to be found during the breeding season, which is generally in the latter part of May or in June. Throughout the pine regions of New England it is an abundant species. Breeds in New York, Michigan and it is also stated to breed in Northern Illinois. A few pairs are said to remain during the summer months in Northern Ohio. The nest of this Warbler is placed in the fork of a horizontal bough of a coniferous tree, usually at a considerable height-thirty to fifty feet, but frequently as low down as fifteen or even five feet above the ground. Mr. L. C. Holmes, of Standish, Maine, states that all the nests he has found were in low, scrubby firs. The typical nest is a compact, well-woven fabric made of thin bark strips, twigs, dry grasses, wool and feathers, lined with hair and vegetable down. The eggs are four in number, and have a ground-color which ranges from white to buffy or creamy-white. The markings are specks and spots of cinnamon-rufous, chestnut, and lilac-gray, forming indistinct wreaths about the large ends. The average measurement of four single eggs is $.61 x .50$ inches.

668. TOWNSEND'S WARBLER. Dendroica townsendi (Towns.) Geog. Dist.-Western North America (but chiefly near the Pacific coast), north to Sitka, east during the migrations to the Rocky Mountain region; south in winter to Northern Central America.

Townsend's Warbler is well known as a Pacific coast species. It inhabits the pine regions, nesting similar to $D$. virens in coniferous trees. The eggs are described as buffy-white, speckled and spotted with reddish-brown, blackish and lilac-gray; average size, $.64 \times .53$ inches.

669. HERMIT WARBLER. Dendroica occidentalis (Towns.) Geog. Dist.Western United States chiefly near the Pacific coast, east during migrations to the Rocky Mountains; south in winter to Northern Central America. 


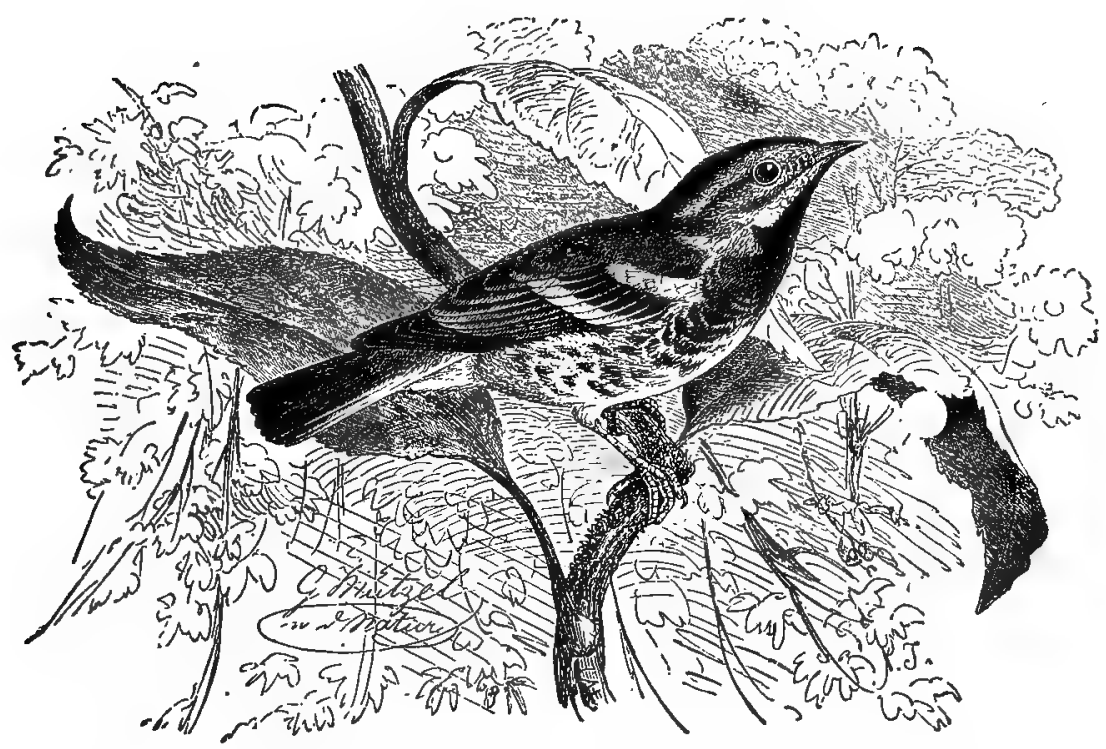

667. BLACK-throated GReEN WARBLER (From Brehm.)

Two nests of the Western Warbler were found by C. A. Allen during the season of 1886, in Blue Canon, California. The first contained two eggs June 4, and was left for a full set. Three days after it was found in a dilapidated condition and the eggs destroyed, evidently the work of squirrels. The eggs, however, are described as resembling those of the Yellow Warbler, D. astiva, but were more heavily marked. Another nest was found June 7, containing three young birds and one was found seven or eight years previous also containing three young. These nests were all simila 1 y placed and well concealed in "pitch pines" from twenty-five to forty feet above the ground on thick, scraggy limbs, and very difficult to find. The cavity of the nest taken June 7, 1886, measures 1.25 deep by 2.50 across; external diameter 4.50 by 2.00 in depth. It was composed of fibrous stalks of plants, fine dead twigs, lichens, a little cotton twine, and is lined with soft inner bark and hair. Major Bendire had what he believed to be a set of the eggs of this Warbler taken at Big Meadows, Oregon, on the banks of the Des Chutes River near its head waters, June 12, 1882. The nest was placed in the crotch of a willow overhanging the water, and the parent was shot but fell into the water and was carried away. The eggs are described as being about the size of those of $D$. astiva, and resemble the eggs of $D$. blackburnia, with the exception of the ground-color, the green of which is not as perceptible as in the eggs of blackburnice. They have a faint grayish-green ground, two of them heavily spotted with lilac and dark umber-brown.*

670. KIRTLAND's WARBLER. Dendroica kirtlandi Baird. Geog. Dist.Eastern United States, South Carolina, Virginia, Ohio, Indiana, Illinois, Missouri, Michigan, Wisconsin, Minnesota, and the Bahamas in winter.

Outside of the description of the plumage here is about all we know concerning

* $C f$. Brewster, The Auk, IV, pp. 166-167. 
Kirtland's Warbler: Mr. H. A. Purdie (Bull. Nutt. Orn. Club, IV, 1879, p. 185), records the last capture of a specimen, and enumerates the examples previously known, as follows: Mr. Adolphe B. Covert, of Ann Arbor, Michigan, shot a female of this much desired warbler, his second capture of the species. This recent specimen I make to be the ninth known to science, viz.: 1. Male, caught on a vessel at sea off Abaco, Bahamas, by Dr. Samuel Cabot, of Boston, the second week in October, 1841. Not identified until several years after the typo specimen was described. 2. Male, taken by Dr. J. P. Kirtland near Cleveland, Ohio, May 13, 1851. Type of the species. 3. Male, obtained by R. K. Winslow near Cleveland, Ohio, in June (May?), 1860. 4. Male, shot by Charles Dury at Cincinnati, Ohio, the first week in May, 1872. 5. Female, collected by A. B. Covert, at Ann Arbor, Michigan, May 15, 1875. 6 and 7. Male and female, taken by Messrs. William and John Hall, at Rockport, Cuyahoga county, Ohio, May, 1878. 8. Female, collected by Charles B. Corey, on Andros Island, Bahamas, January 9, 1879. Several others have been taken; about a dozen in all, but its summer residence is unknown, and its nest and eggs have never been described.

671. PINE WARBLER. Dendroica vigorsii (Aud.) Geog. Dist.-Eastern United States, north to Ontario and New Brunswick; wintering in more Southern States and Bahamas; Bermudas.

The Pine-creeping Warbler breeds in various localities throughout its United States range and apparently only in regions where there are tracts of coniferoug trees. Its nest is always placed on the horizontal boughs in pines or cedars, ranging all the way from eight to eighty feet above the ground, usually at an elevation of from thirty to forty feet. In the pine districts of the States along the Atlantic coast from the Carolinas northward the bird is a common breeder, nesting in March. Mr. R. R. McLaughlin took nests containing eggs in Iredell county, North Carolina, March 25. Mr. C. S. Brimley found the birds building nests in Wake county, of the same State, in the latter part of March. The nest, according to these observers, is hard to discover, and in most cases it is found by watching the birds carry building material which consists of bark-strips, bits of weed and oak leaves, caterpillar's silk. and vegetable sedges. It is compactly built and warmly lined with horse hair and feathers. The eggs are four, rarely five in number. The ground-color varies from a dull whitish to gray or purplish-white, and the markings are in the form of spots and specks of lilac-gray and burnt umber, more dense near the larger ends, and generally form wreaths.

672. PALM WARBLER. Dendroica palmarum (Gmel.) Geog. Dist.-Northern interior to Great Slave Lake; in winter South Atlantic and Gulf States, the West Indies and, Mexico. Of rare but regular occurrence in the Atlantic States in migrations.

This Vrarbler breeds in the northern interior, to the Great Slave Lake, nesting in June. Its nests and eggs are not common in collections. Its nest is placed on the ground, is very compactly built of fine grasses, shreds of bark and moss; it is usually hidden in a tuft of grass or under the shelter of some plant. No more than four eggs have, I believe, ever been found in a nest. They are creamy white, spotted and blotched, usually about the larger end with purple, lilac and reddish-brown. The reddish and purplish markings are permanent characteristics. The average size is $.70 x .52$ inches. This average size is taken from eight authentic eggs. 
672a. YELLOW PALM WARBLER. Dendroica palmarum hypochrysea RidgW. Geog. Dist.-Atlantic coast of North America. Breeds from New Brunswick and Nova Scotia to Hudson Bay. Winters in the South Atlantic and Gulf States.

There are two forms of the Palm Warbler, D. palmarum (Gmel.) being the form of the interior region north in summer to Great Slave Lake, migrating south through the Mississippi Valley to the Gulf States, Florida, Bahamas, etc., and casually during migrations east of the Alleghanies. The present form, hypochrysea, breeds from Nova Scotia and New Brunswick northward. Its nest is placed on the ground in open situations, usually on the edge of a swampy thicket and it is composed of weed-stalks, grasses, rootlets and pine leaves, lined with fine grasses and hair. The eggs, usually four in number, are yellowish or buffy-white, with a roseate tinge, speckled with brown and lilac. Average size .65x.51 inches.

673. PRAIRIE WARBLER. Dendroica discolor (Vieill.) Geog. Dist.-Eastern United States, north to Michigan and Southern New England; south in winter to Florida, Bahamas and West Indies.

The Prairie Warbler is a rather common breeding bird in many localities east of the Alleghanies from the latitude of Massachusetts southward; west of this region it appears to be rare during the summer months. It is known, however, to breed in Michigan and regularly (?) in Northern Ohio, but I have no late authentic records to that effect from the latter region. Mr. H. K. Jamison found the Prairie Warbler breeding abundantly on the 13 th of May, in a scrubby oak thicket in Fairfax county, Virginia. The nests were placed from two to seven feet above the ground. Dr. Coues found it nesting in astonishing numbers within a small area, near Washington, D. C., in the latter part of May. The nests were only a few feet from the ground, and were placed preferably in hickory and dogwood bushes. Mr. Worthington found it

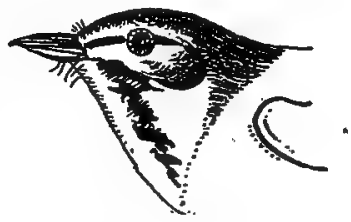

673. Pratrit Warblek. nesting in low bushes and also in small birch and oak saplings on Shelter Island, New York, in the latter part of May and first half of June. The nest is a very pretty, deeply cup-shaped fabric, composed of vegetable fibres and fine grasses, closely felted and lined with hair. Four, rarely five, eggs are laid. Twelve sets of these eggs are in Mr. Norris' cabinet, many of which were taken by C. L. Rawson, in New London county, Connecticut. Their ground-color apears white until they are com: pared with pure white eggs, when'a very faint tinge of greenish is perceptible. The markings are specks of chestnut and burnt-umber, and usually in the form of wreaths about the large end. Two sets taken, respectively, May 31, 1880, and June 14, 1888, near Norwich, Connecticut, exhibit the following sizes: .59x.47, .64x.48, $.60 \times .45, .63 \times .47 ; .68 \times .50, .66 \times .50, .67 \times .47, .67 \times .47$ inches.

674. OVEN-BIRD. Seiurus aurocapillus (Linn.) Geog. Dist.-Eastern North America, breeding from about $38^{\circ}$ northward, west to eastern base of Rocky Mountains. In winter, south to Southern Florida, West Indies and Central America.

Called Oven-bird on account of the remarkable nest which it usually builds. This, in its typical form, is roofed over, arched or domed, with an entrance more or less to one side like the mouth of an oven. It is placed on the ground, or rather embedded in a depression in the earth amongst leaves, at the foot of a tree or bush near a fallen log, or under the shelter of tall grass in woods. On the whole, it is loosely constructed of skeleton leaves, grasses, strips of wild grape vine bark, slender weed stalks, with a lining of finer grasses and often horse hair. The bird is known 


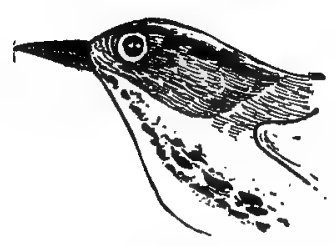

674. OVEn-Bird.

py other names, such as Golden-crowned Thrush, Goldencrowned Wag-tail Warbler, and Golden-crowned Accentor. An abundant species in the woods of Eastern North America, where it is found breeding from Kansas, the Ohio Valley and Virginia northward into the Arctic regions in the months of May, June and July, according to latitude and season. In the United States the nesting time is chiefly in the latter half of May and June. The birds inhabit dry and wet leafy woods, and seem to be partial to those through which a small stream flows, and where wild vines climb to the upper branches of trees whose foliage throws darkened shadows beneath. In these retreats, during the mating season, the bird's incessant, emphatic crescendo chant may be heard. It is repeated with such vehemence that it is really startling in solitary woods. The eggs of the Oven-bird are four or five in number, rarely six. Their color is white or creamywhite, more or less glossy, and the markings are in the form of specks and spots, often sparsely scattered over the entire surface, but usually more heavily marked at the larger ends, and frequently wreathed. The color of the markings is reddishbrown of various shades and lilac-gray. Ten specimens measure .70x.59, .74x.57, $.72 \times .59, .76 \times .58, .79 \times .60, .79 \times .63, .80 \times .62, .82 \times .62, .84 \times .63, .82 \times .61$. A common size in a large series is $.78 \times .58$. Though well concealed and hard to find by the collector, the nest of this species often contains the eggs of the notorious Cowbird. Mr. Lynds Jones found "a nest near Grininell, Iowa, containing no less than five eggs of the Cowbird.

675. WATER-THRUSH. Seiurus noveboracensis (Gmel.) Geog. Dist.-Eastern North America as far west as the Mississippi Valley. Breeds from the Northern United States northward; south in winter to the Gulf States, West Indies, Northern South America.

The small-billed Water-thrush, New.York Accentor, or Wag-tail Warbler breeds from Northern United States northward. It frequents swampy woods and open, wet places, nesting on the ground or in the roots of overturned trees at the border of swamps. It is more or less abundant in all suitable places in the New England States and New York. It has been found breeding in Northern Illinois and in Iowa, near Des Moines, according to Messrs. Keyes and Williams, a female was seen feeding its young in June, 1884. A common summer resident in Manitoba. Mr. M. K. Barnum, of Syracuse, New York, found a nest of this species in the roots of a tree at the edge of a swamp, on May 30. It was well concealed by the overhanging roots, and the cavity was nearly filled with moss, leaves and fine rootlets. The nest at this date contained three young and one egg. The eggs of this species are four or five in number. Two sets are in Mr. Norris' cabinet; one taken near Listowel, Ontario, from a nest under a stump in a swamp, on June 7, 1888; the other set is from New Canada, Nova Scotia, and was taken July 30,1886 . The nest was built in moss on the side of a fallen tree. They are creamy-white, speckled and spotted, most heavily at the larger ends, with hazel and lilac, and cinnamon-rufous; in the last mentioned set forming wreaths near the larger ends: Their sizes are .78x.54, .78x.56, $.77 \times, 55, .77 \times .54 ; .78 \times: 61, .78 \times .63, .77 \times .60, .77 \times .59$ inches.

675a. GRINNELL'S WATER-THRUSH. Seiurus noveboracensis notabilis Ridgw. Geog. Dist.-Western United States; from Indiana and-Illinois westward to California, and north into British America. Casual in migrations eastward to the 
Atlantic coast. Winters from the southern border of the United States southward to Lower California, Mexico and Northern South America.

This bird is like the last species in coloration, but it is larger and its general habits are identical. A set of four eggs of this bird are in the collection of Mr. James B. Forniff, of St. Louis. They were taken near Denver, Colorado June 15, 1897. The nest was placed in the exposed roots of a tree growing on the bank of a small stream. The eggs are the same in color as those of $S$. noveboracensis and measure as follows: $.75 x .55, .78 \times .56, .74 x .59, .76 x .59$ inches. The well-known oölogist, Mr. Wm. L. Kells, of Listowel, Ontario, states that the nesting period of Grinnell's Water-Thrush in that region is from the middle of May to that of July. He found the nests more frequently in the under side of an up-turned root over a pool of water and states that the usual set of eggs is more frequently four than five eggs.

676. LOUISIANA WATER-THRUSH. Seiurus motacilla (Vieill.) Geog. Dist.-Eastern United States, north to the Great Lakes and Southern New England, west to the plains. In winter, Gulf States, West Indies, Eastern Mexico and Middle America.

The Large-billed Water-Thrush or large-billed Wag-tail Warbler breeds more. or less commonly in suitable places throughout its United States range south of about latitude $42^{\circ}$. It is found during the summer months as far west as Kansas, where Colonel Goss notes it as a common summer resident, and begins laying about the 8 th of May. It is rare in Nebraska, and a few remain to breed in Iowa, but it does not appear to occur in Minnesota. It is a common summer resident in Ohio, but of irregular distribution. Mr. William Brewster found this species breeding in Knox county, Indiana, and gives an excellent account of its nest and eggs.* Hon. J. N. Clark met with it breeding quite commonly in Middlesex county, Connecticut, where he took complete sets of eggs as early as May 7. $\dagger$ In the northwestern portion of North Carolina (Iredell county), Mr. R. B. McLaughlin took eggs of this species in April and May. The nest, according to all observers, is built and carefully hidden in the cavities among the roots of fallen trees, old logs, stumps, or mossy banksalways in swampy places. They are usually bulky, and made of partially decayed leaves, which the female extracts from the bog with mud adhering to them. These are laid together, and when dry make a solid and compact structure. The inner nest is formed of grape-grass, and sometimes hair. The great similarity of the materials in the nest to the external surroundings makes it difficult to detect. Mr. McLaughlin says that this bird in North Carolina prefers the smaller streams as breeding placesnesting in the exposed roots of trees along the banks. The eggs are four or five, sometimes six in number, the usual number being five. The ground color of the eggs varies from a pure white to a deep creamy-white, thickly speckled with cinnamon-rufous or chestnut (more heavily near the larger ends) and lilac-gray. Some specimens have very bold spots of chestnut, and the specks are entirely wanting. Mr. Brewster gives the size of six eggs as follows: $.75 \times .63, .78 \times .64, .75 x .63, .76 x .62$, $.76 \mathrm{x} .62, .75 \times .61$.

67\%. KENTUCKY WARBLER. Geothlypis formosa (Wils.) Geog. Dist.Eastern United States, chiefly west of the Alleghanies to the Plains, north to the Great Lakes and,Southern New England; in winter, south through Eastern Mexico

- and Central America to Panama; Cuba.

* Bull. Nutt. Ornith. Club, III, pp. 138-135.

† For Mr. Clark's extended account, see Ornithologist and Oologist, VII, pp. 145-147. 30 
The Kentucky Warbler is particularly an abundant species in the Lower Mississippi Valley-Southern Indiana and Illinois, and southward to Texas. Colonel Goss gives it as a common summer resident of Kansas; begins laying about May 20 . Its nests and eggs have been taken in Southern Illinois and Indiana in the middle of May. It is a rare summer resident in particular localities in Ohio; more common in the southwestern portion. Mr. Frank W. Langdon found a nest containing four eggs of the Warbler and one of the Cow-bird near Madisonville, Hamilton county, Ohio, on May 28. The eggs were far advanced in incubation. In Jones' magnificent work, "Nests and Eggs of Birds of Ohio," there is a beautiful illustration of a nest which was found on the 20th of May, 1880, in Kentucky, near the Ohio line. The bird has been discovered nesting near Sing Sing, New York, in June; at Fort Lee, New Jersey. Its nests have also been taken in the District of Columbia in May. John S. Cairns found a nest of the Kentucky Warbler in Buncombe county, North Carolina, June 15, 1886. Mr. C. J. Fennock in "Birds of Chester county, Pennsylvania"* gives it as a rather common summer resident. It has been found nesting in that region by Mr. Pennock, Mr. Ladd, Thomas H. Jackson and others. The nest of this species is placed on the ground in woods; it is usually very bulky, composed of leaves, grasses, and lined with rootlets or horse hair. It is generally situated at the foot of a bush or weed stalk. Mr. Pennock informs me that he found-the nest deeply imbedded in leaves with weeds growing around them; others were discovered among leaves at a considerable distance from grass or weeds. The eggs are four or five, rarely six, in number. They are white, variously speckled or spotted with burnt umber, cinnamonrufous and lilac-gray, chiefly and more heavily at the larger ends. The average size of the eggs is $.73 \times .57$ inches.

\section{CONNECTICUT WARBLER. Geothlypis agilis (Wils.) Geog. Dist-} Eastern North America, breeding north of the United States

This is one of the rarest of North American Warblers, seen in the United States only during the spring and fall migrations; in the latter season abundant in some localities. The first authentic nest and eggs of this species known were those taken by Mr. Ernest E. Thompson, who found a nest June 21, 1883, on a moss mound in a tamarack swamp near Carberry, Manitoba. It was composed entirely of dry grass, sunken level with the surface. The eggs were four in number and measured .75x .56 inches. Before blown they were of a delicate creamy-white, with a few spots of lilac, brown, and black, inclining to form a ring at the large end. The nest with eggs and parent birds is now in the National Museum. Another set of these eggs has, I believe, been taken, but I have no record of it. Mr. C. W. Crandall, of Woodside, N. Y., has what is undoubtedly the second or third authentic set of the Connecticut Warbler's eggs known to science. They were taken by the veteran collector and ornithological writer, Wm. L. Kells, on Wildwood Farm, Listowel, Ontario, June 7,1895. The nest was placed in a cluster of raspberry vines, in hardwoor itimber. The nest is composed of shreds of leaves, fibres of bark, grass, rootlets and hair. The eggs, four in number, measure as follows: $.79 x .56, .81 x .57, .81 x .56, .80 x .57$ inches, respectively. Mr. Crandall writes me: "Your description of the coloration of $\mathrm{Mr}$. Thompson's set of this species fits my eggs exactly with the exception that the markings are not all confined to the large ends, but are also, especially in two of the specimens, sparingly distributed over the entire egg, and in one specimen the fine specks are pretty evenly distributed over the entire surface. The surface markings are very few, the majority being shell spots." 
679. MOURNING WARBLER. Geothlypis philadelphia (Wils.) Geog. Dist.Eastern North America, breeding from the Northern United States northward; in winter, south to Central and Northern South America.

The Mourning Warbler is known to breed in the mountainous portions of Pennsylvania, New England, New York, Michigan, Minnesota and Eastern Nebraska northward. It has been found nesting in Illinois, south of latitude $39^{\circ}$. Its nest is built on or near the ground in woods. One discovered by Mr. John Burroughs in the State of New York was built in ferns about a foot from the ground, on the edge of a hemlock wood. It contained three eggs. Mr. Wm. L. Kells found what doubtless was the nest of this species in a swampy woods near Listowel, Ontario, early in June, 1877. The nest was placed in the horizontal branch of a small cedar a little more than a foot above the ground. It was composed of fine strips of bark and other fibrous material, lined with fine hair. This nest contained four eggs which are white with a sprinkling of redđish dots near the larger ends. The eggs are described as being colored like those of $G$. formosa or $G$. agilis; size .71x.54 inches.

680. MACGILLIVRAY'S WARBLER. Geothlypis macyillivrayi (Aud.) Geog. Dist.-Western United States, north to British Columbia; in winter, south through Mexico, and Central America to Panama.

Macgillivray's Warbler breeds.throughout its United States range-in Colorado, Utah, Montana, Idaho, Washington Territory, Oregon, and in the mountains of California. Mr. A. W. Anthony gives it as a common summer resident of Washington county, Oregon, where it frequents the low, tangled shrubbery, and is found much of the time on the ground. A nest was discovered placed in a hazel at an elevation of one foot. Mr. H. D. Minot obtained a nest at Manitou, Colorado, June 21, which was placed in a scrub-oak five feet above the ground and three feet from a traveled road. Mr. Charles F. Morrison states that this species is one of the most common birds of La Plata county, Colorado, where it nests in juniper bushes, four to six feet un. A set of three eggs in 'Mr. Norris' cabinet was taken May 18, 1884, near Riverside, California. The nest was situated in a small bush near the ground, and was made of dry tules, lined with horse hair. Incubation had begun. The eggs are creamy-white, marked near the larger ends with spots and pen lines (somewhat like an Oriole's egg) of clove brown. Their sizes are .74x.54, .73x.53, .71x.51. The eggs of this species are three to five in number, usually four, and average $.72 x .52$ inches.

681. MARYLAND YELLOW-THROAT. Geothlypis trichas (Linn.) Geog. Dist.-Eastern United States, north to Canada and Nova Scotia; in winter, South Atlantic and Gulf States and the West Indies.

This active little Warbler breeds throughout its United States range. Beging building about the middle of May. The nest is not an easy one to find, being built on the ground, snugly tucked under the foot of bush or tussock of rank grass, and sometimes partly roofed over like the Oven-bird's. The favorite resorts of this Warbler are in low, swampy places or in the shadowy undergrowth of woodland. It resembles a wren in its fondness for bush and brier. On approaching such places early in spring one is almost sure to be saluted with its sprightly song, full of energy. My friend, Mr. Thomas M. Earl, has given me the best description of this bird's song that I know of. One evening in May, 1884, he was returning from a day's hunt, and after a rest on an old log, he was about to start on his journey homeward. At this instant a little Yellow-throat mounted a small bush, and in quick succession said, tackle me! tackle me! tackle me! The eggs of this gpecies are four 
or five, rarely six in number, clear crystalline white but often creamy-white speckled, chiefly at the larger end with reddish-brown, dark umber and black; in some, occasional lines or scrawls appear. Two sets of four eggs each measure, respectively, $.71 \times .53, .71 \times .50, .69 \times .50, .69 \times .51 ; .67 \times .48, .69 \times .50, .66 \times .48, .68 \times .49 ;$ the average is $.69 \times .52$ inches.

681a. WESTERN YELLOW-THROAT. Geothlypis trichas occidentalis Brewst. Geog. Dist.-United States west of the Mississippi Valley. In winter, the more southern portion of the United States chiefly west of the Mississippi, and south through Western and Central Mexico.

The same general habits which are common to the Eastern Yellow-throat are also characteristic of this subspecies in the West. Dr. Merrill states that its favorite haunt, and one in which it is very common in the region of Fort Klamath, Oregon, is among the tules in company with Marsh Wrens and Yellow-headed Blackbirds. The eggs average a trifle smaller than those of $G$. trichas; and are less heavily marked; $.67 \times .50$ inches.

681b. FLORIDA YELLOW-THROAT. Geothlypis trichas ignota Chapman. Geog. Dist.-Florida, north to southern Georgia.

This is called Palmetto bird, very similar to the Maryland Yellow-throat, but with longer tarsus, tail and bill, etc.* Nesting and eggs identical with $G$. trichas.

682. BELDING'S YELLOW-THROAT. Geothlypis beldingi Ridgw. Geog. Dist.-Southern portion of Lower California, north to San Ignacio (Lat. $27^{\circ}$ ).

Mr. Walter E. Bryant writes as follows on Belding's Yellow-Throat: "This Warbler was first known from specimens taken at San Jose del Cabo in April, 1882, by Mr. L. Belding, but the eggs have since remained unknown so far as the obtaining of an authentic n'est is concerned. In the Proceedings of the U. S. National Museum (Vol. V, p. 546), Mr. Belding says: "Their habits are quite like those of G. trichas, and the eggs not materially different, if a nest found by my guide on the Miraflores and Todos Santos trail May 6, belonged to this species, as I supposed it did, having seen a fine male near the spot from which it was taken.' As these eggs were not preserved, the eleven herein described are presumably the first and only ones known. In March and April, 1888, I found this species breeding at Comondu, Lower California, the only locality in which I found it that year, and the most northern point (at that time) from which it had been obtained. No nests were found during March, 1888, and by April the young were flying. I was fortunate in visiting Comondu during the latter part of March of this year, and made a special effort to collect the eggs of this species, and by offering a cash reward interested some Mexican boys in the search. This resulted in five nests being found, from four of which eggs were taken, eleven specimens in all. To Mr. T. S. Brandegee, the well known botanist, who accompanied me, is due the credit of finding the first nest, March 25, 1889 (set No. 881, coll. W. E. B.). This was discreetly left undisturbed until I could be shown to the spot a few hours later. The nest was loosely woven in a clump of 'cat-tails' ( $($ y h ha) onie metre above running water. It is composed outwardly entirely of dry leaves of the 'cat-tail,' and thinly lined with fine fibre and a few horse hairs. It measures, nearly as can be determined, not less than $150 \mathrm{~mm}$, in height by about 115 $\mathrm{mm}$. in diameter. The receptacle is about $55 \mathrm{~mm}$. in depth, with a diameter at the

* Cf. Chapman, "Birds of Eastern North America," p. 37. 
top of $50 \mathrm{~mm}$. The general appearance is almost identical with some song sparrows' nests. When taken the eggs were cold and the birds absent, although the female was seen when it was first iound. In size the eggs are larger than any other North

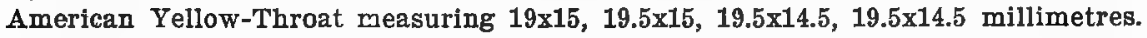
They are white, with shell spots and dots of lilac-gray and a few surface spots and pencillings of black. There is but little variation from this pattern in the markings of the other sets mentioned later. The Mexican boys were emphatically instructed that whatever nests were found they were to be left until I could be shown to the place. The same day that Mr. Brandegee found the set of four, a bright little fellow came to camp with the information that be had found a nest containing three eggs. This was in quite similar situation to the other, but placed not more than half a metre high. On March 27 the nest and eggs were taken, incubation having commenced. The nest is of the same material as used in the other, but is smaller exteriorly. This set (No. 880 , coll. W. E. B.) measures $19.5 \times 15.5 \mathrm{~mm}$. with each egg. On March 28 I found a third nest in a heavy growth of 'cat-tails' near the outer edge of the clump, and placed one and one-half metres high. This nest, like the others, is composed of 'cat-tail' leaves, but is lined almost exclusively with black horsehairs, so few being used that they do not even hide the structural material. The two eggs which were in the nest found were not taken until March 31, when they contained small embryos. Although these two eggs constituted a set, I do not consider it a normal one, but lacking in number from some cause unknown. The diameter of each specimen is $19.5 \times 15 \mathrm{~mm}$. The female was sitting at the time I went to take the nest, but quietly retreated amongst the rushes and made no demonstration, further than a coarse 'tchep' note. Two other nests, one containing two fresh eggs and the other new, were shown to me by Mexican boys April 3; my departure from Comondu on that day prevented me from securing more than these two additional eggs, which measure $19.5 \times 14.5$ and $19.5 \times 15$ millimetres."

682. 1. RIO GRANDE YELLOW-THROAT. Geothlypis poliocephala ralphi Ridgw. Geog. Dist.-Lower Rio Grande Valley.

I have no knowledge concerning the habits, nests or eggs of this race of the Yellow-throat. They are, in all probability similar to G. trichas.

683. YELLOW-BREASTED CHAT. Icteria virens (Linn.) Geog. Dist.-Eastern United States to the Great Plains, north to Ontario and Southern New England; south in winter through Eastern Mexico to Northern Central America.

The Yellow Breasted Chat may be found breeding in all suitable places throughout its range. It inhabits the thickets and brambles of low undergrowth, preferredly in the vicinity of a marsh, and the bird is oftener heard than seen. In the mating season it is the noisiest bird in the woods, at which time it may be observed in its wonderful aerial evolutions, uttering its medley of sputtering, cackling, whispering and scolding notes, interluded with loud whistles. The nest is built in brier thickets from two to five feet above the ground, and is composed of withered leaves, dry grasses, strips of 'bark and lined with finer grasses. Large colonies of these birds are often found nesting in a single locality. A strange nesting place of a pair of Chats is recorded by Mr. Charles F. Batchelder as observed by Mr. C. W. Beckham in Howard county, Maryland, where a pair built in a Wren box attached to one of the pillars of a piazza which partially fronts a small ravine. The birds seemed little disturbed by the occasional visits of members of the family. The eggs of the Chat are three or four fn number, usually four. They are white with a glossy 
surface; some specimens have a pinkish tinge, others greenish. The markings are light reddish, cinnamon-rufous, or chestnut, in the shape of specks and spots, which are heavier and bolder at the larger ends; again specimens are found with the markings evenly distributed over the entire surface or in a well defined wreath around the larger end, with the rest of the egg unmarked. They vary from .84 to 1.02 in length by .62 to .70 in breadth. The average size of ten specimens is $.92 \times .71$.

683a. LONG-TAILED CHAT. Icteria virens longicauda (Lawr.) Geog. Dist.Western United States from the Great Plains to the Pacific; south into Mexico.

The general habits, nests and eggs of this Western subspecies are the same as those of Icteria virens. Colonel Goss says it is not an uncommon summer resident. of Western Kansas and Mr. Lloyd gives it as an abundant breeder in Tom Green and Concho counties, Texas.

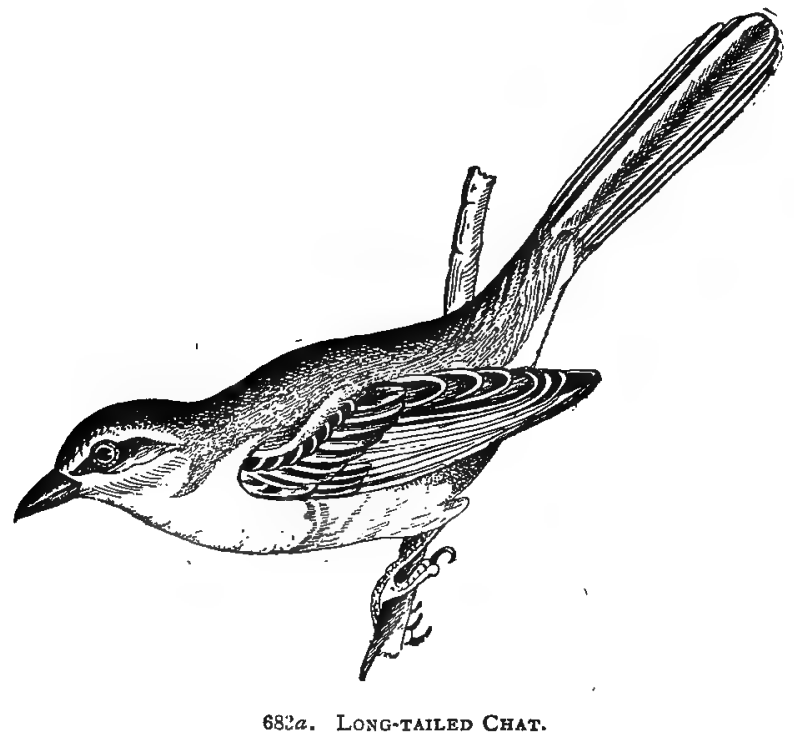

684. HOODED WARBLER. Syltania mitrata (Gmel.) Geog. Dist.-Eastern United States, west to the edge of the Great Plains, north to Southern portions of Micnigan, New York and New England; south in winter to Cuba, Jamaica; through Eastern Mexico and Central America.

The Hooded Flycatching Warbler breeds throughout its United States range. Colonel Goss mentions it as a rare summer resident of Eastern Kansas where it begins laying the last of May. It is a common resident in the cane-brakes and low shrubbery along the Lower Wabash in Southern Illinois. In Georgia the Hooded

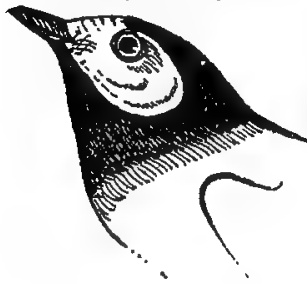

684. HOODED WARELER. Warbler deposits its eggs about the middle of May. Mr. Arthur T. Wayne has taken fresh eggs near Charleston, South Carolina, in the first week of June. The bird is a rare summer resident of Ohio: Dr. Kirtland notices its breeding in the vicinity of Cleveland. Mr. Gould found it nesting near Sugar Grove, May 29, 1889. A nest was found contairing four young. Many of the birds were observed, and some secured. For a number of years the Hon. John N. Clark has observed this Warbler breeding in Middlesex county, Connecticut, usually in the latter part of May or first half of June. The bird is one of the liveliest of its tribe and is very 
active in catching insects on the wing in the manner of the true Flycatchers. It frcquents thickets and undergrowth of high and iow lands, where it skillfully conceals itself when pursued. It has a peculiarly graceful manner of closing and spreading its broad tail, like the Redstart. The nest of the Hooded Warbler is built in the low bushes of undergrowth usually within a few inches or foot of the ground. It is composed of leaves, shreds of bark, and scales of beech buds, all compactly woven and secured together with spider webs; the lining in some nests is entirely horse or cattle hair, others are found lined with fibres of grape-vine bark, or mixed with both. The eggs are four in number, rarely five. The usual ground-color is white, or creamy-white, and the markings are generally specks and spots of chestnut or burnt umber and lilac-gray, principally near the larger end, and often forming wreaths. The average size of twenty specimens is $.71 x .52$ inches.

685. WILSON'S WARBLER. Sylvania pusilla (Wils.) Geog. Dist.-Eastern North America, west to and including the Rocky Mountains, and to the coast of Bering Sea. Breeds from northern border of United States and higher Rocky Mountains northward. South in winter through Eastern Mexico and Central America.

The Green Black-capped Flycatching Warbler, or Wilson's Black-capped Warbler, breeds from the northern border of the United States northward, chiefly, however, in the higher latitudes. Mr. H. D. Minot found a nest of this bird containing five fresh eggs, on June 22, at Seven Lakes, on Pike's Peak, Colorado. The nest was found on the ground, under a low, spreading branch of a dwarf willow, at the edge of a swamp.* The eggs of this species are four or five, sometimes six in number. 1 set of five in Mr. Norris' cabinet was taken June 15, 1887, in Boulder county, Colorado. The nest was well imbedded in the ground among some willow twigs, and was composed of leaves and swamp grass externally, lined with fine grasses and a few aairs. The eggs are white, speckled with cinnamon-rufous and lavender-gray. Nearly all the markings are near the larger ends, where they form wreaths. Their respective measurements are $.59 x .49, .60 x .49, .60 x .48, .58 x .48, .60 \times .48$.

685a. PILEOLATED WARBLER. Sylvania pusilla pileolata (Pall.) Geog. Dist.-Western North America chiefly along or near Pacific coast, north to Kadiak Island, Alaska, south in winter through Western Mexico to Costa Rica.

The Western Black-capped Flycatching Warbler is a common breeding bird in various sections on the Pacific coast from Southern California northward. Mr. W. Otto Emerson states that in the vicinity of Haywards, California, he has taken eggs as early as April 22, and full-fledged young were observed by May 17. The birds nest in the thickets along water courses, and rear at least two broods in a season. Prof. Evermann found a nest near San Buenaventura, California, on May 23, 1881, placed about a foot from the ground, in a clump of blackberry bushes. Dr. Merrill notes that the bird breeds in considerable numbers in the swampy willow thickets along Wood River and Fort Creek, in the regiorf of Fort Klamath, Oregon. The nest is composed of leaves, bark strips, weed stems, vegetable fibres, rootlets, lined with finer grasses. Often it is made entirely of leaves and lined with fibrous roots. It is placed in bushes from one to four feet above the ground. The eggs are four in number, white or creamy-wnite, speckled with reddish-brown and lilac-gray; in some specimens these markings are in the form of a wreath near the larger ends. .

* See foot note in New England Bird Life, Vol. I, pp. 172-173. 
A set in Mr. Norris' collection, taken at Waterville, California, May 6, 1875, gives the following measurements: $.6<x .48, .60 \times .49, .60 \times .48, .60 \times .48$; another, collected at Alameda, California, April 11, 1885: .57x.49, .58x.49, .58x.50. Average size, .60x.48 Inches.

686. CANADIAN WARBLER.' Sylvania canadensis (Linn.) Geog. Dist.Eastern North America, west to the Great Plains, north to Newfoundland, Southern Labrador and Lake Winnipeg, south in winter through Eastern Mexico and Central America to Ecuador.

The Canada Flycatching Warbler breeds occasionally from the Middle States, and regularly from New England northward. In other Northern States it breeds sparingly. Mr. Robert B. Lawrence found a nest of the Canadian Warbler in the mountains of Pike county, Pennsylvania, on June 9, 1887. The nest was placed in the roots of an old stump, and contained four young birds and one unhatched egg. It has been known to nest in Northern Illinois. In some portions of Canada it is a common breeder. Thomas McIlwraith says that a few remain to spend the summer in Southern Ontario, while the majority go farther north. Mr. William L. Kells found it nesting in the low, swampy woodlands near Listowel, and obtained sets of its eggs in the latter part of May and first week of June. The nests were found in the cavities of upturned roots of trees, and in the depressions in banks near pools of water. They are generally well hidden by weeds or grass, and are commonly placed on the ground, in underbrush, by the side of a log or at the foot of a bush. Their composition is dry weeds, fine roots, with a lining of hair. The eggs are four or five, white or buffy, speckled or spotted, chiefly round the larger end, with reddish-brown and lilac-gray. Their average size is .68x.51 inches.

687. AMERICAN REDSTART. Setophaga ruticilla (Linn.) Geog. Dist.Eastern North America, north to Fort Simpson, west to and including the Rocky Mountains. In winter, West Indies, Eastern Mexico, Central America and south to Northern South America.

The richly-colored Redstart breeds in most of its United States range and whereever found in British America. It is an abundant breeding species from the Northern States northward. Nests in May and June. In Ohio I have invariably found it in the woods which are the favorite haunts of the Oven-bird, Senirus aurocapillus. About four miles east of Columbus, in a thick damp woods of about fifteen acres in extent, I counted no less than twenty-seven nests in a single day. In many sections the birds are really more common than the Yellow Warbler, D. astiva. The nest built by the Redstart is a beautiful, compact, cup-shaped structure, made of shreds of plants and hempen fibres, held together with spiders' 'webs; the lining is of fine grasses and hair. It is either saddled on a branch or placed in the forked twigs of a small tree or sapling, usually from six to twelve feet above the ground, but often as high as thirty. A curious habit of the Redstart is that of opening and closing its fan-like tail while flitting about in the trees and bushes. The eggs are four, rarely five, in number and they are subject to a remarkable variation in size and color. In a large series the ground color will vary from white to greenish-white or grayishwhite. The markings are specks or spots of cinnamon-brown and lilac-gray, chiefly round the larger end. Ten specimens selected on account of their sizes give the following measurements: $.57 \times .47, .60 x .45, .61 \times .47, .62 \times .48, .64 x .52, .66 \times .51, .67 \times .48$, $.68 \times .49$, . $69 \times .48, .70 \times .50$ inches. 
688. PAINTED REDSTART. Setophaya picta Swains. Geog. Dist.-Southern Arizona and New Mexico, south to highlands of Mexico.

This is the Painted Flycatching Warbler of so striking colors. It is found in Southern Arizona and New Mexico southward into Mexico. It frequents shrubbery near water and in some localities is abundant. Mr. Walter E. Bryant gives the first description of the nest and eggs of this species from specimens obtained by $\mathrm{Mr}$. Herbert Brown in the Santa Rita Mountains, Arizona, June 6, 1880.* The nests and eggs do not resemble those of $S$. ruticilla. The nesting site is within cavities in banks or under projecting stones. A nest as taken by Mr. Brown from a hole in a road bank in the mountains; this Mr. Bryant describes as being loosely constructed of dry gray grasses and fine shreds of vegetable bark, and lined with black and white horse hairs. It contained four incubated eggs of a light pearl-white thickly dotted with brownish-red and traces of lilac on the larger end. They measure $.57 \times .48$, $.60 \times .50, .64 x .50, .58 \times 49$. Another set of four was taken from a similar nest beneath a small bush. The eggs are somewhat larger and spotted over the entire egg, the markings clustering about the larger end. The sizes of three of them are .69x.52, $.65 \times .51, .66 \times .50$; the fourth was broken. Mr. William Brewster describes a nest and eggs of the Painted Redstart obtained by Mr. F. Stephens in the Santa Rita Mountains. The nest was under a projecting stone in a bank near a small stream. The three eggs which this nest contained were clear, dead white, delicately spotted with light reddish-brown, the markings being sparsely distributed over the surface and handsomely wreathed about the larger end. They measure .64x.51, .64x.50, $.66 \times .49$. The average size is $.65 \times .48$ inches.

\section{[689.] RED-BELLIED REDSTART. Setophaga miniata Swains. Geog.} Dist.-Highlands of Mexico. Texas (Giraud).

The white of the tail feathers of this species is more restricted, reduced to a narrow terminal spot (sometimes wanting altogether) on the third feather and never found on the fourth. Breast and belly usually more orange-red. Nests and eggs undescribed. The bird breeds in Mexico.

690. RED-FACED WARBLER. Cardellina rubrifrons (Giraud.) Geog. Dist.Highlands of Northern Central America (Guatemala) and Mexico, north to Southern Arizona.

The first knowledge we have concerning the nests and eggs of this handsome Warbler is from specimens taken by Mr. W. W. Price on May 31; 1888, in the pine regions of Southern Arizona-the Huachuca Mountains. The nest was placed on sloping ground, in. a slight hollow, and contained four fresh eggs, and dissection of the female showed that the full clutch had been laid. The nest was so well hidden by a few sprays of columbine that it would have been overlooked had the bird not been started directly from it. It was so loosely built that it crumbled to fragments on being removed. The chief substance was fine, fibrous weed stalks, while the lining consisted of fine grass, rootlets, plant fibres and a few hairs. Skeleton leaves and bits of fine bark were intermingled throughout the nest, and the ground on which it was placed was so damp that the bottom part was badly decayed. The eggs from this nest were presented by Mr. Price to the National Museum Collection, at Washington, D. C., and are described by the late Maj. Chas. E. Bendire as ovate in shape; their ground color, "a delicate creamy-white, spotted with small blotches of

* Bull. Nutt. Ornith. Club, VI, pp. 176-177.

+ Bull. Nutt, Ornith. Club, VII, pp. 140-141. 
cinnamon-rufous and a few dots of heliotrope-purple and pale lavender. These form a wreath around the larger end. They resemble the eggs of Helminthophila lucia and $H$. virginio to a certain extent."*

691. RED WARBLER. Ergaticus ruber (Swains.) Geog. Dist.-Highlands of Mexico. Texas (Giraud).

This dusky red warbler is an inhabitant of Mexico and is recorded as far north as southern Texas by Giraud. Its nests and eggs are unknown.

[692.] BRASHER'S WARBLER. Basileuterus culicivorus (Licht.) Geog. Dist.-Central America, from Panama north to Eastern Mexico. Texas (Giraud).

This is a Central American species recorded by Giraud as occurring as fár north as Southern Texas. Its nesting and eggs remain to be described.

[693.] BELL'S WARBLER. Basileuterus belli (Giraud.)' Geog. Dist.-Guatemala and Mexico, north to the temperate regions of Vera Cruz. Texas (Giraud).

There appears to be little known concerning the general habits of this warbler, which are recorded with a colored illustration by Giraud in his work entitled "Sixteen Species of Texas Birds," in 1841.

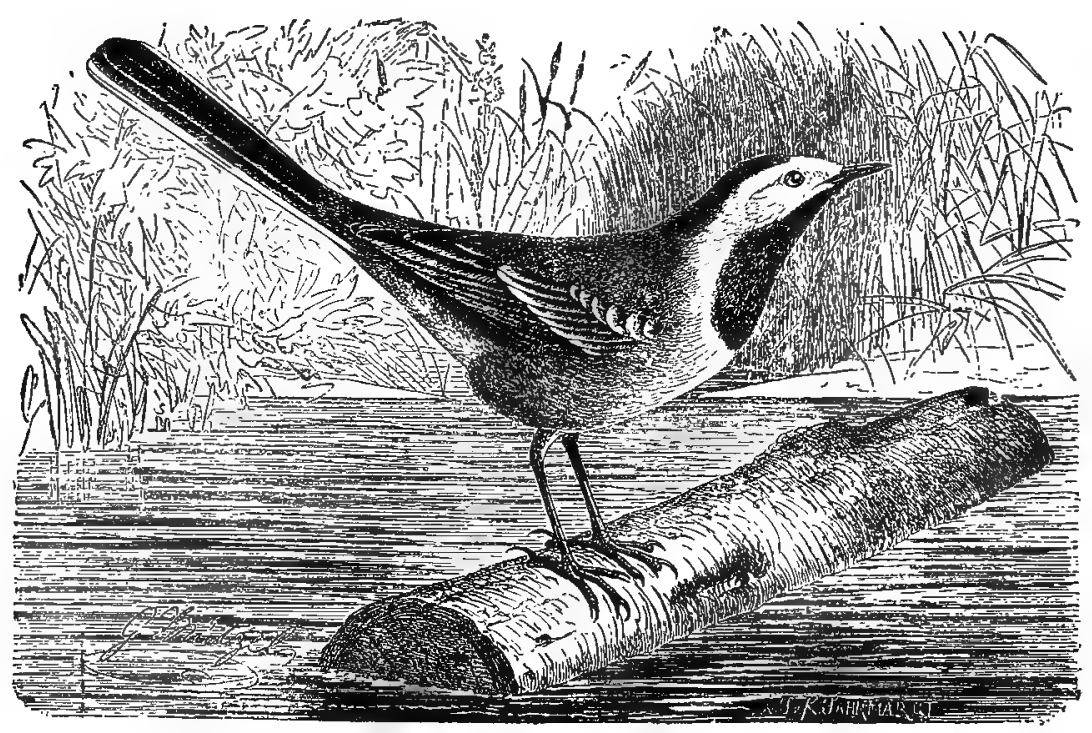

494. White Wagtail (rroin Brehuh.,

[694.] WHITE WAGTAIL. Motacilla alba Linn. Geog. Dist.-Europe and Northern Asia; in winter, Northeastern and Southern Asia. Accidental in Greenland.

The common White Wagtail of Europe claims a place in the North American avifauna as an accidental visitant of Greenland. It is found in all portions of Europe,

* The Auk, V, pp. 385-386. 
and its favorite haunts are meadows in the vicinity of water, villages and old houses. It nests on the ground among the grass of the meadows, in crevices of rocks or old buildings; in the roots of trees along the banks of streams; under bridges. The nests are constructed of small stems, twigs, grass, straws, leaves and rootlets, the lining being of wool and hair. The eggs are four, five, six or even seven in number. A set of six eggs in my cabinet, taken May 10, 1880, in Staffordshire, England, have a grayish-white ground-color, and are speckled all over the surface with minute ashgray specks. Several single specimens have markings that are of a decided dark brown color. The set of six measure: $.77 \times .58, .79 \times .56, .76 \times .55, .79 \times .59, .78 \times .56$, $.77 \times .57$. The average size is $.75 \times .55$ inches.

[695.] SWINHOE'S WAGTAIL. Montacilla ocularis Swinh. Geog. Dist.Eastern Asia. Accidental in Lower California and Aleutian Islands.

Mr. Nelson says: "Although this bird has been taken repeatedly at Plover Bay, Siberia, and thence throughout a large portion of Northeastern Asia, including China and Formosa, to the Lake Baikal region, it appears to be almost unknown in Alaska. In fact its claim as a bird of the territory rests upon the capture of a single specimen, a young bird in summer plumage, by Captain Kellett and Lieutenant Wood in "Northwest America," as recorded in the Brit. Mus. Cat. Birds, X, 473. The Wagtail seen by Mr. Turner on Attu Island, on the western extreme of the Aleutian chain, may possibly have been of this species, but it is far more probable that it was the $M$. lugens which Dr. Stejneger found common upon the Commander Islands. A single specimen of ocularis was taken by Mr. Belding at La Paz, Lower California, during the winter of 1881-82. It is scarcely necessary to add that its occurrence at this point, so far from its home, is entirely accidental. The western limit of this

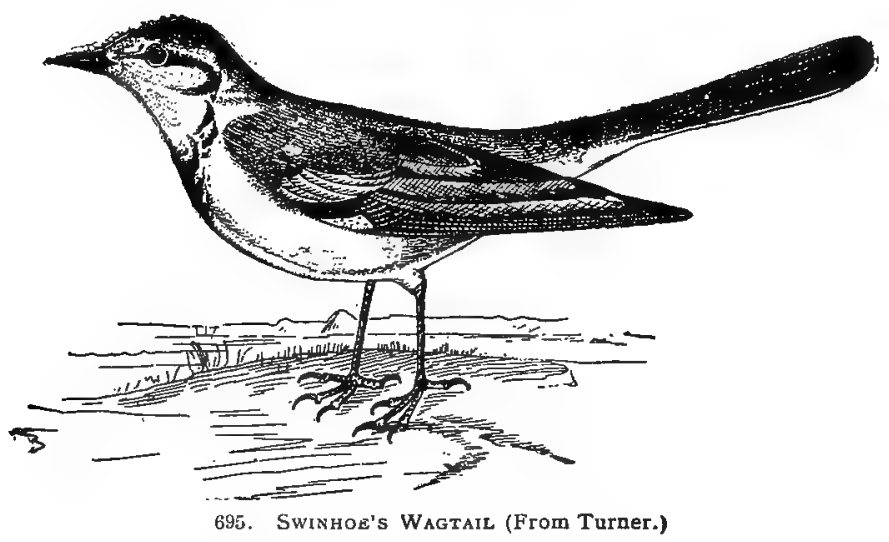

bird in Siberia is given by Seebohm as the water-shed between the Yenesei and the Lena Rivers; thence east it has been taken in many portions of the continent, including Mongolia, Chukchi land, and the localities previously mentioned."

696. SIBERIAN YELLOW WAGTAIL. Budytes flavus leucostriatus (Hom.) Geog. Dist.-Alaska, north of the Peninsula; Eastern Siberia and Kamchatka, wintering in Eastern China. 
This Wagtall occurs abundantly in Alaska. Dr. Stejneger states that $\boldsymbol{B}$. leucostriatus is a common breeding bird in the environs of Petropaulski, Kamchatka, being found during the months of June and July everywhere on the low marshy grounds surrounding the lakes, fresh-water ponds and brackish lagoons of the vicinity. On Bering Island single individual were seen until June 10 . The nest of this bird is placed on the ground and usually concealed by a tussock of grass, projecting stone, etc. The eggs are dull white, yellowish or brownish-white, profusely covered with fine dots of reddish-gray, dark brown or black; average size, $.76 x .55$.

697. AMERICAN PIPIT. Anthus pensilvanicus (Lath.) Geog. Dist.-Whole of North america, breeding from the high mountains of Colorado and from Labrador northward to the Arctic coast. Winters in the Gulf States, Mexico and Central America.

Known as the American Titlark, Brown Lark, Louisiana Lark and Wagtail. An abundant and a well-known bird everywhere in fields and plains throughout North America. In the United States it is seen chiefly in flocks in fall, winter and spring. Breeds in the mountains of Colorado (above timber line), and from Labrador northward to the Arctic regions. The nest is placed on the ground, and is large and bulky, made of coarse, dry grasses and moss loosely put together. From four to six dark chocolate-colored eggs are laid, the surface of which is marked or overlaid with numerous specks and streaks of grayish-brown. The average size of the eggs in five sets in Mr. C. H. Cole's collection is .76x.56 inches.

[698.] MEADOW PIPIT. Anthus pratensis (Linn.) Geog. Dist.-Europe; northern portions of Africa in winter; occasional in Southern Greenland.

The European Titlark very closely resembles the American bird, A. pensilvanicus, in appearance and all its general characteristics. An occasional visitant in Southern Greenland. It inhabits the whole continent of Europe, where it is the most common and best known of its tribe. In Great Britain the Titlark is found throughout the year. It frequents all kinds of localities-hill or valley, marsh or moorland, shady woods and flowery meadows, the neighborhood of busy towns, or the sandy sea-shore. The nest is built on the ground, and is composed of dried grasses, lined with finer grass, moss and a few hairs. The eggs are four to six in number, and scarcely any two sets are exactly alike in color; the ground tint may be blue-gray, reddish-brown or yellow-brown; in all cases the eggs are spotted and mottled with darker brown or mouse-gray, giving to the surface a uniform dark appearance. A set of five eggs collected by Mr. W. Wells Bladen, June 2, 1879, in Staffordshire, England, exhibits the following sizes: $.79 \times .59, .80 \times .59, .83 \times .58, .84 x .59, .85 \times .60$. A set of four from Suffolk measure respectively, .78x.58, .75x.54, .74x.57, 77x.56. The average size is $.78 \times .57$ inches.

[699.] RED-THROATED PIPIT. Anthus corvinus (Pallas.) Geog. Dist.Northern parts of the Old World. Accidental in Lower California, St. Michael and Aleutian Islands, Alaska.

Seebohm states that in Northern Europe the Red-throated Pipit breeds on the tundra above the limit of forest growth, from the Atlantic to the Pacific, but becomes rarer west of the Ural Mountains. The nest is made entirely of dry grass, the foundation being made of the coarser pleces. It is generally placed on the ground under.the sheiter of vegetation. The eggs vary from 


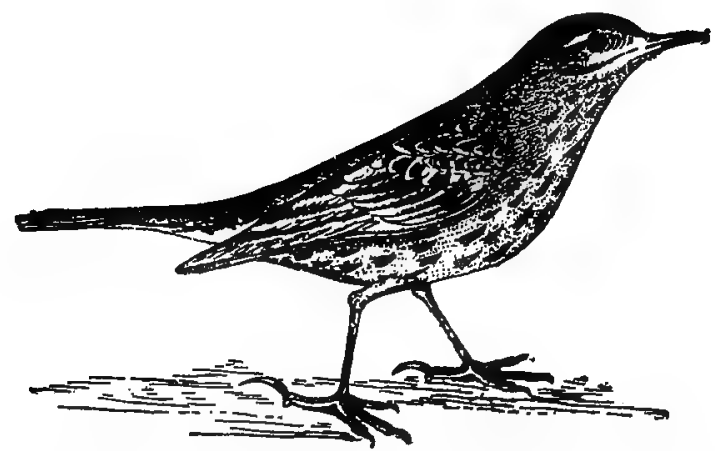

699. Red-thronted Pipit. Adult, winter plumage.

four to six in number and are usually of a pale grayish color with a faint tinge of purple, dotted with purplish brown or red, but the markings vary greatly as do the eggs in size. In length they vary from .68 to .82 and in breadth from .55 to .62 inches. A specimen of this bird was taken in Greenland in 1845, and since then Dall has taken it at St. Michael's, Alaska.

700. SPRAGUE'S PIPIT. Anthus spragueii (Aud.) Geog. Dist.-Interior plains of North America. Breeds from Central Dakota northward to the Saskatchewan country; south in winter over southern plains to Southern Mexico.

The Missouri Skylark has the same general habits common to the Titlark, but soaring like the European Skylark when singing, and according to those who have heard it, its vocal powers are not less inferior than those of that celebrated bird. It breeds abundantly in Dakota and Montana northward to the Saskatchewan districts, where Captain Blakiston found them common on the prairies during the breeding season. Sprague's Pipit can also be found in summer in Western Minnesota and in Nebraska. Its nest is built on the ground in a depression, and is made of fine grasses, interwoven in a circular form and without lining. The surrounding grasses are sometimes formed into an arch like the arch-way of the Meadow Lark's nest. The eggs are four or five, of grayish-white, minutely speckled with purplish-gray; size $.87 \times$ x.67 inches.

701. AMERICAN DIPPER. Cinclus mexicanus Swains. Geog. Dist.-Mountainous portions of Western North America, from the Yukon Valley south to Northern Central America (Guatemala).

The American Water Ouzel, a grayish-colored bird, which has the aquatic habits of a duck and the tilting movements of a sandpiper, inhabits exclusively the mountainous portions of Western North America. It is resident as far north as the valley of the Yukon River. It is never found near still water, frequenting only wild, forcible mountain streams, cascades, eddies and swift currents. Mr. Frank M. Drew beautifully says that the birds "are the very embodiment of a mountain torrent-bustling and energetic; and their song is like crystallized spray. Sweet, sparkling and vivacious, taken with its surroundings, I do not know of any bird-song which surpasses it." The nest is variously situated, but always near water in a nook or crevice, on shelving rocks, among roots of trees, often where the water sprays keep the outside damp. It is a beautiful ball of soft green moss, measuring about seven inches 
by ten, and is usually dome-shaped, with a small, round hole in one side for an entrance; within it is strongly arched over with leaves and grasses and supported by twigs, and all cemented with mud. The eggs are three to five in number, plain, pure white, and average 1.00x.70. The eggs are usually deposited in the latter part of May or in June. A set of four eggs in my cabinet taken June 10, 1880, in San Juan county, Colorado, offers the following measurements: $1.01 \times .73, .99 x .72,1.00 x .70$, $1.01 \times .72$.

702. SAGE THRASHER. Oroscoptes montanus (Towns.) Geog. Dist.-Sagebrush regions of Western United States, from the western part of the Great Plains to the Pacific; in winter south into Mexico.

Erroneously called Mountain Mocking Bird, for it is exclusively an inhabitant of the sage-brush region of the West, and is partial to the lower portions of the country, though not infrequently met with in the open mountains. It nests in low bushes, especially the sage and cactus, from ten inches to three feet above the ground. The nest is a loose, bulky structure, made of bark-strips, small twigs, coarse grasses lined with fine stems and rootlets. The eggs are three or four, rarely five, in number, and they are deposited variously in the latter half of May, in June, and as late as the first or second week in July. Their ground-color is of a rich greenishblue, spotted with bright reddish-brown, and a few plumbeous markings. In shape they vary from an ovate to a short ovate. Average size .95x.70.

703. MOCKINGBIRD. Mimus polyglottos (Linn.) Geog. Dist.-United States, south into Mexico; rare or local north of $38^{\circ}$.

The true home of this inimitable vocalist is in the Southern States, where it is very abundant. It has occasionally been detected breeding in the more northern States and above latitude $38^{\circ}$-as, near Springfield and Arlington, Massachusetts, and in the Connecticut Valley. There are records of the bird's residing in summer in Central and Southern Iowa. We must consider the Mockingbird as a rather irregular breeding bird in suitable localities of Ohio, being a more common summer resident in the southern portions than elsewhere. It may be looked for along the beautiful valley of the Muskingum and other streams in that neighborhood. Mr. C. H. Morris and Mr. E. G. Arrick, of McConnelsville, Morgan county, found the Mockingbird breeding in that region in the summer of 1896. Along Meig's Creek, about eight miles north of McConnelsville several nests were found. One was discovered June 26 , situated on a rail fence along a roadway; it contained three young and one unhatched egg. One of the young is now in captivity. Four days afterward the birds built another nest a short distance from the first, in the same position. About the middle of July a nest containing four young ready to fly was found. The same pair of birds again built in a small sycamore tree about five feet from the ground, an illustration of which we herewith copy from a photograph. About twenty birds were gathered together when they left Morgan county for their winter home. The birds again returned this Spring (1897), but owing to the extremely cold weather in May and June, they disappeared. I have several times taken them in June, and my friend, J. E. Gould, observed a pair that lingered about the grounds in the vicinity of the Ohio State University during the summer months of 1887, but was unable to discover their nest, which was doubtless in the neighborhood. A pair built their nest and reared their young for several years near the residence of Dr. Kirtland, at Rockport, and the bird has been found breeding frequently in Southern Ohio. Goss gives the Mockingbird as a summer resident of Kansas; begins laying 


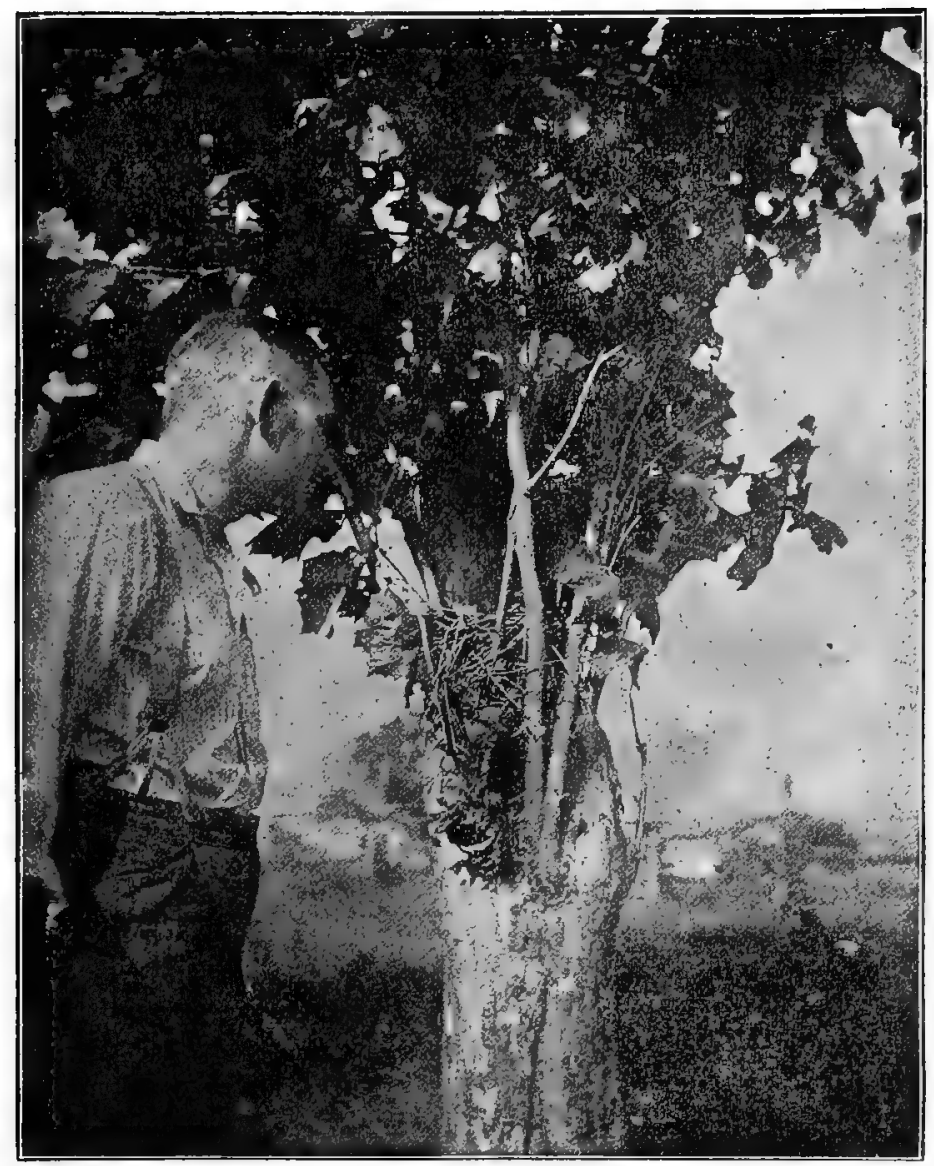

703. A Mockingbird's nest in Morgan County, Ohio. (From photo) (See page 462)

about the 20th of May. Mr. Shields informs me that in Los Angeles county, California, where it is an abundant resident, nest-building is begun early in May, and fresh eggs may be found as late as the last of June. He states that when deprived of the first set of eggs, a second nest is invariably built and another set deposited. The nest is composed of small twigs and weeds, lined with roots and sometimes with horse hair and cotton. Various situations are selected for the nest; an almost impenetrable thicket of brambles, a hedge, an orange tree or holly bush seem to be favorite localities. Often the nest is built in a bush a few feet from a door or window of a dwelling. Generally two or three broods are reared in a season. Mr. J. A. Singley, of Giddings, Lee county, Texas, informs me that he finds the nests in that locality built mostly in clumps of live oaks scattered over the prairies, also in brush-piles, corners of rail fences, and in fact everywhere except on the ground. He has found them as low as six inches from the ground in a low bush, and as high 
as fifty feet in trees. A set of five eggs was taken from the hollow of a live oak in May, 1886. The eggs are usually four or five, seldom six. The ground-color varies from pale greenish-blue to dull buffy, marked with spots and blotches of yellowishbrown, russet or chestnut. A great variation exists in the sizes. Specimens in a

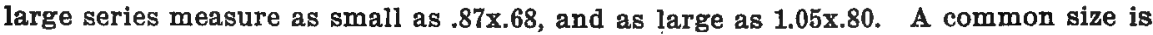
$.94 \times .71$ inches.

704. CATBIRD. Galeoscoptes carolinensis (Linn.) Geog. Dist.-Eastern United States and British Provinces, north to about $54^{\circ}$ in the interior; west to and including the Rocky Mountains. Winters in the Southern States, Cuba and Central America to Panama.

This well-known bird breeds throughout its range, nesting in bushes, low trees, or clusters of vines, generally in retired places. It is seldom placed more than ten feet above the ground. Thickets or orchards are its favorite haunts. The nest is bulky and inartistic, made of dry leaves, twigs, dry grass, and lined with black fibrous roots and grass. The eggs are usually four, frequently five, and rarely six. They are plain, deep bluish-green; average size $.95 \times .71$.

705. BROWN THRASHER. Barporhynchus rufus (Linn.) Geog. Dist.-Eastern United States, west to the base of the.Rocky Mountains; north to Southern

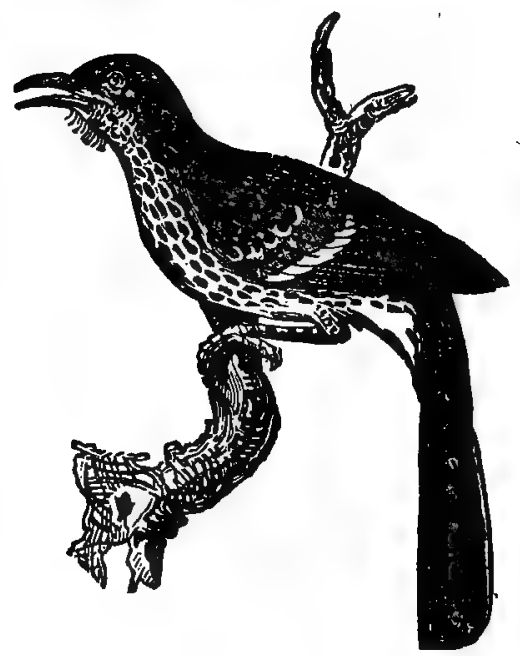

755. Brown Thrasher (After Wilson) Maine, Ontario and Manitoba. Winters in more Southern States, north to about $37^{\circ}$.

The Brown Thrasher breeds in all suitable localities throughout its range, building its nest in low bushes, or on stumps, in clusters of wild vines and briers, in heaps of brush-wood, and often on the ground. It may be frequently found nesting in the fruit trees of quiet orchards, and in trees situated in unfrequented places. When the nest is placed on the ground where the soil is wet and clayey the eggs become addled; three instances of this kind have come under my notice, and the eggs have failed to hatch. The same observations have been made by a number of my correspondents. The nests are rather flat, loosely and rudely constructed of twigs, strips of bark, withered leaves, and black, fibrous roots, lined with horse hair and a few feathers. In some sections the Brown Thrasher begins to build in the latter part of April, but more generally in the first half of May. The eggs are three or four, sometimes five in number. Their ground color varies from white through pale-buff to pale-greenish, and, very rarely, quite a distinct green; the markings are minute specks of reddish-brown, thickly sprinkled over the entire surface, frequently forming distinct wreaths near the larger ends. The average size is $1.08 \times .80$, with considerable variation.

706. SENNETT'S THRASHER. Harporhynchus longirostris sennetti (Ridgw.) Geog. Dist.-Lower Rio Grande Valley. 
Mr. Sennett says that the Texas Thrasher is a very abundant species throughout the whole Lower Rio Grande country. It frequents shady thickets, and is rarely seen in the open plains. Dr. Merrill pronounces it a fine songster, and states that in habits it scarcely differs from the Eastern bird, rufus. The eggs, as Mr. Sennett found them, are usually four in the first clutch in April, while second sets, late in May, contain generally three. They are hardly distinguishable from those of $H$. rufus. Dr. Merrill gives the average size of fifty-two eggs as 1.08x.82, the extremes being $1.13 \times .86$ and $.97 \times .75$.

707. CURVE-BILLED THRASHER. Harporhynchus curvirostris (Swains.) Geog. Dist.-Mexico, north to Southern Texas and New Mexico (east of the Rocky Mountains).

According to Dr. J. C. Merrill and Mr. George B. Sennett, this species is about as common as the Mockingbird or $\boldsymbol{H}$. longirostris sennetti on the Lower Rio Grande. It inhabits tangled thickets as well as prickly-pear cactuses and mesquite trees, which afford breeding resorts. In two instances Mr. Sennett found nests in ebony trees near much frequented pathways, and the birds were as tame as Robins. The usual height of nests from the ground is about four feet. Mr. G. B. Benners found a nest of this bird in a Woodpecker's hole in a live oak on the banks of the Rio Grande. It contained four eggs. Dr. Merrill says: "They are, as a rule, readily distinguishable from those of the Texas Thrasher and Mockingbird by the almost invariable lining of yellow straws, giving a peculiar appearance to the nest. They are also more compactly built, are well cupped, and often have the edges well guarded by thorny twigs." Mr. Sennett states that the bird commences to breed in March on the Rio Grande, and rears several broods. The first eggs are laid in April, and generally number four; by the middle or latter part of May the second sets consist nearly always of three. A few sets of four were found of the second laying. Five sets of these eggs are in my cabinet, taken near Camargo, Mexico, in March, April and May. They vary from oval-oblong to almost pyriform in shape, and their ground-color is almost invariably light bluish-green, minutely speckled with reddishbrown. The sizes of two sets as as follows: $1.01 \times .73,1.00 \times .75,1.02 \times .79,1.10 \times .75 ; 1.10$ $\mathrm{x} .79,1.10 \times .81,1.15 x .83,1.13 \times .81$. The average size is $1.08 \times .78$.

707a. PALMER'S THRASHER. Harporhynchus curvirostris palmeri Ridgw. Geog. Dist.-Southern Arizona, southward into Sonora (Guaymas).

One of the most common birds on the cactus-covered plains of Arizona. The breeding season in some sections begins in February, in other localities early in March, and generally two broods are reared in a season. The nests are usually built in the cholla, a kind of prickly cactus, at a height of about three to six feet. It is composed of twigs and lined with dry grass; sometimes the lining is mixed with hair or feathers when procurable. According to the observations of Mr. W. E. D. Scott and Mr. Herbert Brown, the usual number of eggs laid by Palmer's Thrasher is three, sometimes four, not infrequently two and rarely one. The eggs cannot with certainty be distinguished from those of the Curve-billed Thrasher. The sizes of a set of eggs containing the smallest specimens in a series of twenty-one sets in $\mathrm{Mr}$. Norris' collection are, 1.10x.78, 1.09x.78, 1.13x.78; the largest 1.24x.81, 1.20x.79, 1.16x.79.

708. BENDIRE'S THRASHER. Harporhynchus bendirei Coues. Geog. Dist.Southern Arizena, south into Sonora (Guaymas), casually northeastward to Colorado. 
The late Major Charles E. Bendire, U. S. A., discovered this species in the vicinity of Tueson, Arizona, in 1872. The bird inhabits the same regions frequented by $H$. palmeri and crissalis, with whom it associates. Mr. Scott states that the song of the male of this species is particularly beautiful, and is to be compared with the best efforts of the Mockingbird. The nests are placed in mesquites and cactuses, usually at a height of three or four feet above the ground. The colla cactus is their favorite nesting-site. The breeding season begins early in March; and two broods are generally reared in a season. The eggs are three or four, rarely two, in number. The eggs are greenish-white, spotted with lavender-gray and drab. The average size is. $1.02 \times .74$ inches.

709. ST. LUCAS THRASHER. Harporhynchus cinereus Xantus. Geog. Dist.Lower California.

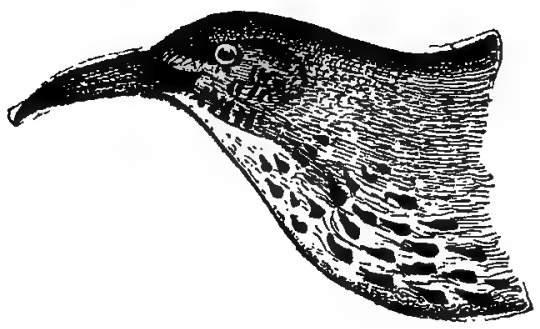

709. ST. Lucas ThraghrR.

This Thrasher is confined to the peninsula of Lower California. Its general habits are described as being similar to those of $H$. palmeri or crissalis. Its nest is a flat structure, with a slight hollow, and usually built in low trees, shrubs and cactus plants about four feet from the ground. The eggs are two or three in number, and are described as greenishwhite, spotted with pale reddish-brown. Average size 1.06x.75.

709a. MEARN'S THRASHET. Harporhynchus cinereus mearnsi Anthony. Geog. Dist.-Northern Lower California.

Mr. Anthony has named this bird in honor of the well-known ornithologist and scientist, Dr. Edgar A. Mearns. For a description of the bird see Auk, Vol. XII, January, 1895, page 53. The price of the egg of this Thrasher is quoted at $\$ 4.00$, but I have never seen one.

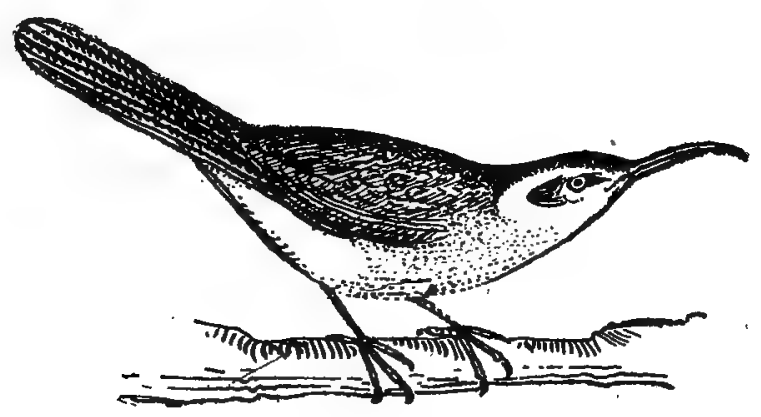

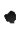

710. California Thrasher.

710. CAIIFORNIA THRASHER. Harporhynchus redivivus (Gamb̈.) Geog. Dist.-Coast region of California, southward along the Pacific coast to Lower California.

This Thrasher is an abundant resident of the coast region of California. "Mr. A. M. Shields informs me that its favorite haunts in Los Angeles county are the 
scrub oaks and grease-wood brush that fringe deep mountain gorges. It begins to build toward the last of April, and by the last of May it is difficult to procure a perfectly fresh set of eggs. The bird, he says, is a close sitter, often allowing one's hand to touch it before leaving the nest. The general character of the nest is a coarse, rudely constructed platform of sticky, coarse grass and mosses, with but a very slight depression. Occasionally, however, nests of this bird are more carefully and elaborately made. It is.always well hid in the low scrub bushes. The usual complement of eggs is three, sometimes four and occasionally only two. They are light greenishblue, with russet-brown and chestnut spots; average size 1.18x.85. Ten specimens measure $1.05 x .80,1.05 \times .82,1.02 x .79,1.04 x .77,1.08 \times .80,1.22 x .84,1.21 \times .85,1.27 \times .82,1.28 x$ $.79,1.30 \times .84$ inches.

711. LECON'TE'S THRASHER. Harporhynchus lecontei (Lawr.) Geog. Dist.Valleys of the Gila and Lower Colorado Rivers, south into Sonora.

This is the least common of all the Thrashers in the region which it inhabits; and from all accounts it is a very shy and difficult bird to obtain. Comparatively few of its eggs have yet appeared in collections. Mr. E. Holterhoff, Jr., discovered its nest and eggs at Flowing Wells, a station in the middle of the Colorado Desert, in California.* In the same region a number of the nests and eggs have been taken by Mr. F. Stephens and R. B. Herron. Dr. Edgar A. Mearns, U. S. A., met with this bird in the desert country, between Phcenix and Casa Grande, Arizona. $\dagger$ He states that the song of this species is remarkable for its loud, rich tone, and is at least as fine as any of the genus. Deserts of sand, "covered in places with patches of sage-brush and groves of cholla cactuses, with a few mesquites and shrubs scattered along the dry arroyos," are the favorite haunts of Leconte's Thrasher. A glance at these bushes will usually suffice to detect the nest, as it is large and conspicuous, except when the shrub is bushy. The nest is usually built near the center of a cholla cactus, from one to seven feet above the ground; it is likewise fre-

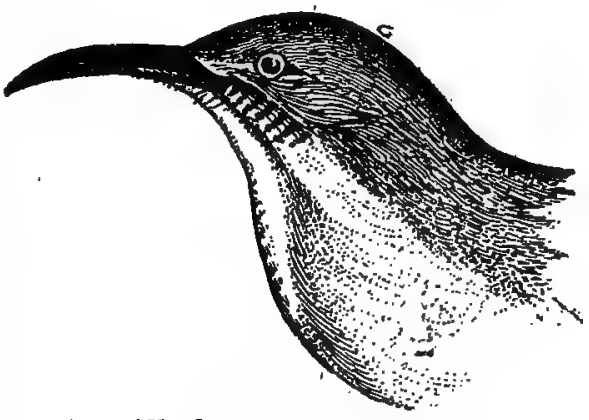

TI1. LeCONTE'S THRASHER. quently placed in mesquites. The birds are close sitters and one can approach within a few yards before they slip off-which they usually do on the opposite side of the bush-dropping to the ground they run briskly and seek the cover of the surrounding vegetation, and so adroitly conceal themselves that it is almost impossible to detect them. The nest is composed of twigs, grasses and weeds and is lined with feathers. The breeding season begins in March, and, according to Mr. Herron's observations, some at least very likely begin laying in February: The eggs are three or four in number, greenish-blue, faintly speckled, chiefly at: the larger end, with cinnamonrufous or yellowish-brown. Some specimens have large blotches on the surface. The general shape of the eggs is elongated-oval. The sizes of a set containing four

* Described in the American Naturalist, XV, March, 1881; for fuller account Cf. Bul1, Nutt. Ornith. Club, VIII, 48-49.

$\dagger$ For an extended historical account, together with full detalls of 'the habits of " $H$ tecontei and crissalis," see Dr. Mearns' article, "Some Arizona Blrds," in The Auk, III, pp. 289-307. 
eggs collected on May 24, 1883, in San Gorgonia Pass, California, by Mr. Herron, are $1.13 \times .75,1.07 \times .77,1.08 \times .77,1.14 \times .75$. The average is $1.07 \times .76$ inches.

712. CRISSAL THRASEER. Harporhynchus crissalis (Henry.) Geog. Dist.New Mexico, Arizona, Southern Utah; Southeastern California and northern portion of Lower California.

This is a common species in suitable localities throughout New Mexico, Arizona and Southeastern California. Dr. Mearns states that it is abundant all over the Verde River bottom lands, preferring mesquite thickets and the vicinity of streams. He says it is one of the few birds that truly sing; and it shares, in Arizona, this rare gift with its congeners-Bendire's, Palmer's and Leconte's Thrashers. It: song is remarkable for its scope and sweetness, having all the power of the Mockingbird, singing from the tops of the tallest bushes in' the same attitude as the Brown Thrasher of the East. Like the rest of the Thrashers it is highly terrestrial, and runs swiftly on the ground from bush to bush, often jetting its long tail upward, more or less above the horizontal. They breed about the same time as Bendire's Thrashers. Mr. Scott found eggs in the Catalina Mountains of Arizona during the first week in April that were about ready to be hatched, and young birds fully fledged were obcerved as early as May 1 . Dr. Mearns saw young birds that were strong on the wing by the end of April. Two broods are reared, and the number of eggs laid, so far as I am able to ascertain, is usually three, sometimes four. Dr. Mearns discovered, on

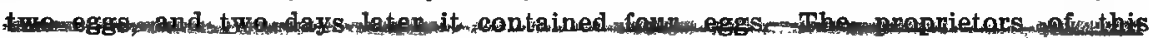
two eggs, and in two days later it contained four eggs. The proprietors of this nest divided their, attention between the care of their nest and a family of young not yet able to shift for themselves. The nests, placed in bushes, are large conspicuous objects, rudely constructed of coarse twigs; the inner nest is made of finer vegetable materials. The eggs are pale greenish-blue, unmarked. The average size is $1.08 x$ .75 inches.

713. CACTUS WREN. Heleodytes brunneicapillus (Lafr.) Geog. Dist.-Southwestern border of the United States, from Southern Texas to the coast of Southern California; south into Northern and Central Mexico.

A common bird in the cactus'and chaparral regions of Texas, New Mexico, Arizona, Southern Utah, Nevada, and Southern California. As its name implies, cactus groves are its favorite haunts. In these, and other thorny shrubs, its nest is placed, which is a very large and purse-shaped affair with an entrance at one end. It is composed of little thorns and grasses, and lined with feathers. Mr. Shields states that in Los Angeles county, California, there is no grove of cactus along the foothills without these Wrens: He has often found from four to ten nests in a bed of cacti not more than a dozen yards square. Three broods are probably reared, as fresh eggs may be found from the middle of April to the last of July. The eggs are generally five, sometimes four, and occasionally only three. They are white or creamy In ground-color, which is thickly covered with rich, reddish-brown spots or specks, giving to the entire egg a beautiful rich salmon-colored hue. Ten eggs selected out of fifteen sets give the following measurements: $.86 x .62, .89 x .62, .93 \times .63, .90 x .60, .94 x$ $.67, .96 \times .67, .95 \times .66, .94 \times .69, .95 \times .67, .98 x .69$. The average size is $.97 \times .65$. Their general shape is oblong-oval.

713a. BRYANT'S CACTUS WREN. Heleodytes brunneicapillus bryanti Anthony. Geog. Dist.-Northern Lower California, north into Southern California. 
The nesting and eggs of this bird, which is named in honor of Mr. Walter $\mathbf{E}$. Bryant. are in every respect the same as those of the Cactus Wren, H, brunneicapillus.

7130. ST. LUCAS CACTUS WREN. Heieodyles brunneicapillus affinis Xantus. Geog, Dist.-Southern Lower California.

The habits, nesting and eggs of this species are identical with those of the last.

715. ROCK WriEN. Sulpinctes obsoletus (Say.) Geog. Dist.-Arid regions of Western United States from the Great Plains to the Pacific, south through Mexico to Northern Central America.

This is a more or less common species in the dry, rocky regions of Western United' States. Mr. Scott says that in the Catalina Mountains of Arizona they begin to breed about the middle of March; six or eight young are the common inmates of the nest, and two broods are reared. Mr. Emerson found this species to be quite common on the Farallone Islands, and it is the only land bird which is resident. They were found all over the South Farallone, building in suitable crevices a nest of Farallone weed, lining it with chicken feathers and hair shed from the island mule. The nest is usually built in a rift of rocks, or on the ground beneath some shelving rock. It is composed of a mass of material, very miscellaneous in character, sometimes a single substance, but a variety of materials are more generally used, such as sticks, bark-strips, weeds, grasses, moss, hair, wool, etc. A curious habit of the Rock Wren is that of paving the ground about the entrance of the nest with pebbles, or bits of rock and glass. On the Farallones small pieces of coal, mussel shells, and small bones of sea-birds and rabbits are used for this purpose. Mr. Fred Corey, of Santa Paula, California, informs me that he found a nest with four eggs of this bird under the rafters of a house. Five and six eggs constitute an average set, and seven, eight, or nine are sometimes deposited. Mr. Emerson found one nest with ten eggs, two of which were fresh and the others in various stages of incubation. The eggs are pure glossy white, finely and sparsely speckled with reddish-brown, chiefly at the larger end. The average size is .72x.54 inches.

716. GUADALUPE ROCK WREN. Salpinctes guadeloupensis Ridgw. Geog. Dist.-Guadalupe Island, Lower California.

Mr. Walter E. Bryant states that this is undoubtedly the most common of the birds on Guadalupe Island, distributed from the beach to the summit, but found most numerous on the upper and central portions. They are first to begin nesting. A few birds began the construction of their nests in December, and one had her work nearly completed on the 25th of December, 1885. Four fresh eggs were found in it on January 17. The breeding season, strictly speaking, Mr. Bryant says, extends from the middle of January through the month of March. "Nests were found in cavities of immense boulders, under rocks, in fallen and decayed trunks of cypress trees, tho latter location being apparently a favorite one. But wherever the nests were located the passages leading to them were, with one or two exceptions, paved with flat pebbles ranging in size from a Lima bean to a half dollar. Fully a quart of these pebbles were removed from the entrance to a nest built in a boulder at a height of four feet, where, at some previous time, other birds had evidently built and accumulated their share of the pavement. As a rule, scarcely an ordinary handful of stones is used." The nest is built to conform to the size and shape of the cavity which it occupies; it is made of fine dry grasses and lined with goat hair. The eggs are usually four, though sometimes five ịn number, and resemble, both in color and shape, those 


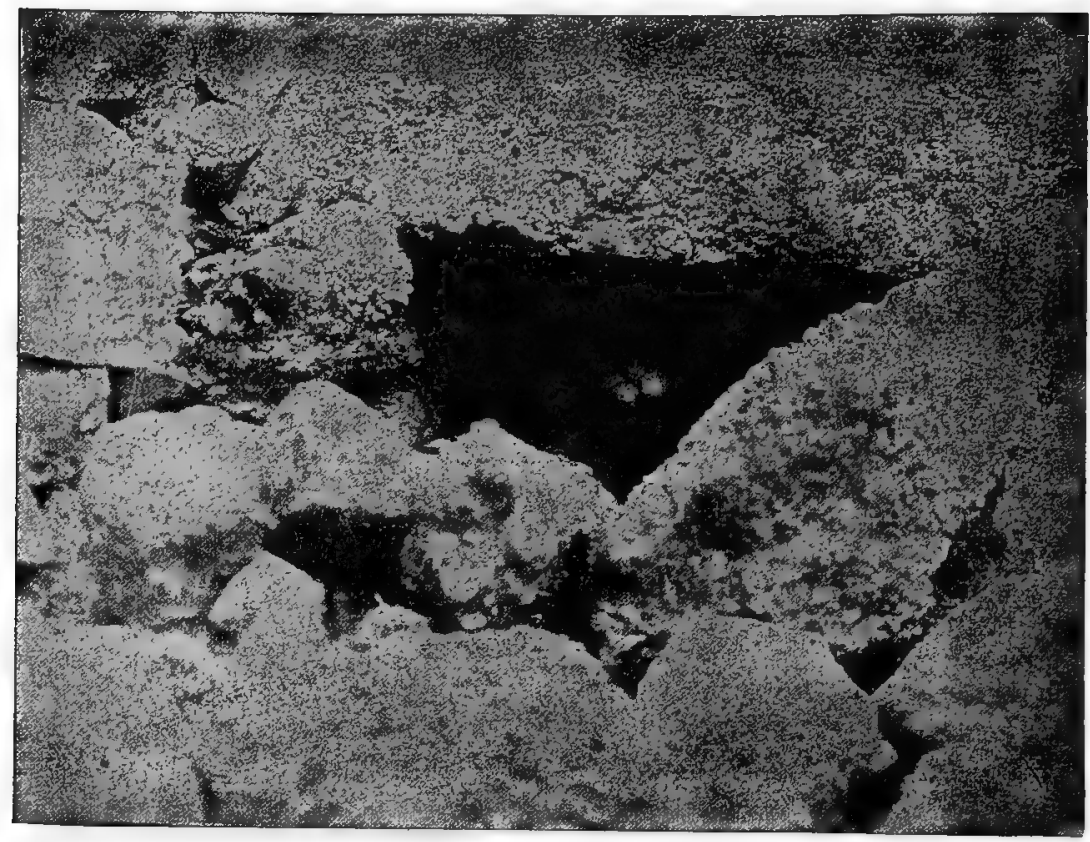

715. Nest and EgGs of the Rock Wren. (From The Nidologist.)

of the common Rock Wren, S. obsoletus. Set No. 781 in Mr. Bryant's collection measures $17 \times 14,17 \times 14.5,18 \times 14.5,18.5 \times 14.5$ millimeters.* Set No. 782 measures in millimeters, $19 \times 14,19 \times 14,19.5 \times 14.5,19.5 \times 14.5,19.5 \times 15 . \dagger$ The two largest eggs in a series of fifty-two specimens measure $21 \times 15 \mathrm{~mm}$. and $20 \times 16 \mathrm{~mm}$. respectively; the two smallest $17 \times 14 \mathrm{~mm}$.; average $19 \times 14 \mathrm{~mm}$.

[717.] WHITE-THROATED WREN. Caterpes mexicanus (Swains.) Geog. Dist.-Mexico, from Oaxaca and Orizaba northward on the tablelands. Texas (Giraud).

This bird is similar to the next form, but is darker colored above and below, with a sharper contrast of the white throat; the white speckling mostly confined to the back and wings. It is common to Mexico and its range extends to the Texan border. In all respects its habits, nests and eggs are indistinguishable from those of $C . m$. conspersus.

717a. CANON WREN. Catherpes mexicanus conspersus Ridgw. Geog. Dist.Great Basin and Rocky Mountain region, from the Sierra Nevada and Cascades eastward to Southern Idaho, Wyoming, Colorado and Western Texas; south on the tablelands of Mexico to Aguas Calientes. Breeds nearly throughout its range; resident in southern parts of its range in U. $S$.

2. The rocky canons of the mountain regions throughout its range are the home of this species. It is easily recognized by its white throat and rich yellowish-brown .... is tail, and by its notes, ${ }_{2}$, peculiar insect-like chirp, and a delightful clear whistling

$* .67 \times .55, .67 \times .5 i, .71 \times .57, .73 \times .57$.

$\dagger .75 \times .55, .75 \times .55, .77 \times .57, .77 \times .65, .77 \times .59$.

$\$$ Largest $.83 \times .59$ and $.79 \times .63$; smallest .67x.55; average .75x.55. 
song. The nest of the Canon Wren is generally built in some deserted tunnel or cave, in holes in bluffs, and at times in unused buildings. It is frequently placed on some projecting ledge or shelf. Mr. H. D. Minot found a nest of this bird containing five fresh eggs near Manitou, Colorado, on June 8, 1880. It was placed in the roof of a cave, about ten feet from the ground in a niche or pocket with a narrow vertical opening. The stones being broken away revealed the nest which rested on the bottom slab. In appearance the structure resembled that of the Eastern Wood Pewee, being composed of twigs, stalks, bits of leaves, thickly felted with down silk and feathers. Mr. Scott says that in Southern Arizona three broods are generally reared each season. The eggs are from four to six in number. Mr. C. B. Benners found this species nesting on the rocky side of a dry river bed in Comal county, Texas, and on April 10 took a set of five eggs. The eggs are white, speckled with lavender-gray and vinaceous-rufous; in some specimens the markings are chiefly at the larger ends, where they often form indistinct wreaths. The average size is $.72 \times .53$ inches.

717l. DOTTED CANON WREN. Catherpes mexicanus punctulatus Ridgw. Geog. Dist.-Oregon and California, west of the Cascades and Sierra Nevada, and Lower California.

The Dotted Canon Wren is resident from middle California southward. Its. nests and eggs and general habits are the same as those of $C . m$. conspersus.

718. CAROLINA WREN. Thryothorus ludoticianus (Lath.) Geog. Dist.--Eastern United States except Southeastern Florida (rare toward the northern border), west to the edge of the Great Plains; south to gulf coast, including Northeastern Mexico. Rare in Southern New England.

A common and well known bird in the more southern portion of its range, being rare or local north of latitude $40^{\circ}$ It may be found almost everywhere, but shady ravines, wooded and rocky banks of streams, piles of logs and brush-heaps are its. favorite haunts. The Carolina Wren has a loud, rich song, which it pours forth while mounted on the end of a fence rail, top of a stump, or the topmost branch of a tree. The song is repeated most frequently, and with more vehemence during the mating. season, which is early in spring. Breeding begins in the latter part of March or early in April, and two, sometimes three, broods are reared in a season. The typical nest of this bird in Central Ohio, where it is a common resident, is a massive, coarse structure, made of strips of corn-stalks, grasses, hay and leaves, with an intermixture of the silk of corn; the lining is of chicken feathers, fine, dry grasses and horse hatr. The bird is not particular as to the situation of its nest. It is found in holes of trees, In wood-piles, and in low bushes; sometimes in the nook or corner of a barn; occasionally in a box, placed in the verandas of dwellings in retired places; often under an accumulation of brush-wood. Sometimes the nests are arched over or dome-shaped, the opening being only large enough to admit the bird. The number of eggs laid ranges from four to six, and the average size of twenty specimens is .74x.61; a common size is .72x.56. - The ground-color of the eggs varies from a whitish to creamy-white or salmon-buff; this is thickly sprinkled with a brownish-pink, and so heavily laid on in some specimens that the surface has this sume appearance. Some, however, are marked more heavily at the larger end.

718a. FLORIDA WREN. Thryothorus ludovicianus miamensis Ridgw. Geog. Dist.-Southern Florida.

This race of the Carolina Wren belongs to Southern Florida. It is a larger bird and generally more deeply colored than T. ludovicianus. Nesting and eggs indistinguishable. 
718b. LOMTTA WREN. Thryothorus ludovicianus lomitensis Senn. Geog. Dist.-Southeastern Texas.

This is a lighter colored subspecies than the typical ludovicianus. It inhabits the chickly timbered regions along the Rio Grande in Texas. Mr. C. W. Crandall has a set of flve eggs of this bird collected by Mr. Frank B. Armstrong near Brownsville, Cameron county, April 16, 1893. The nest was placed in the hole of a tree about ten feet from the ground. It was composed of dry leaves, hay and feathers. The groundcolor of the eggs is similar to that of the eggs of T. ludovicianus; one of the eggs being whitish, sprinkled with brownish-pink and lavender, forming a distinct ring around the large end. Their sizes are $.68 x .55, .74 x .57, .66 x .55, .72 x .57, .73 x .55$ inches respectively.

719. BEWICK'S WREN. Thryothorus bewickii (Aud.) Geog. Dist.-Eastern United States, rare or local east of the Alleghanies and north of $40^{\circ}$; west to the border of the Great Plains. Winters in the more Southern States.

Bewick's or the Long-tailed House Wren is a common species in Eastern United States, particularly southerly; breeding from latitude $40^{\circ}$ southward. In some placcs in the interior it replaces the common House Wren. It is not common on the Atlantic coast. Nests of this bird are placed anywhere - in boxes, holes, fence-posts, brushheaps, stumps, hollow trees, barns, sheds, etc. Dr. Howard E. Jones, who obtained the first specimens of nests and eggs of this species ever taken in Ohio, has the following in his text of the magnificent work, "Illustrations of the Nests and Eggs of the Birds of Ohio": "The nest and eggs of Bewick's Wren resemble very closely some specimens of the House Wren's in size and shape, and, except in size, approach even closer to those of the Great Carolina Wren. The nest alone would be difficult to distinguish from uncovered nests of $T$. adon, but the eggs are not nearly so thickly marked. Normal specimens of each can be always differentiated. The House Wren, however, sometimes lays eggs very similar to typical eggs of Bewick's Wren. The complement of eggs varies from four to six or seven. They measure in long diameter from .60 to .68, and in short diameter from .48 to .54. A common size is .49x.64. They are spotted and speckled with reddish-brown, sparingly about the point, but plentiful toward the crown, where the marks are often confluent, forming a wreath. The deep shell-marks are purplish."

719a. VIGORS's WREN. Thryothorus bewickii spilurus'(Vig.) Geog. Dist.Pacific coast region of North America, southward to Lower California and Western Mexico. Breeds nearly throughout its range.

The general habits and nests of this subspecies are identical with those of Bewick's Wren. The eggs are white, finely speckled with chestnut and lavendergray. In remote regions it frequently nests in crevices of rocks. The eggs average in size $.64 \times .50$ inches.

719b. BAIRD'S WREN. Thryothorus beuickii bairdi (Salv. \& Godm.) Geog. Dist.-Southern Texas, New Mexico, Arizona, south to Southern Utah, Colorado and Middle Kansas, south into Mexico. Breeds throughout its range. Resident from Arizona and Kansas southward.

This is a common bird in various parts of Southwestern United States, as in Western and Southern Texas, New Mexico, Arizona, etc. According to the late Col. Goss, it is not uncommon in Southwestern Kansas. It was found common on the Lower Rlo Grande by Dr. Merrill and Mr. Sennett. Mr. Scott met with it in Southern Arizona. The only nests he found were built in natural hollows, or deserted Woodpeckers' holes in live oak trees. Dr. Merrill states that this bird has a great 
variety of notes, the principal song being much like that of the Song Sparrow, but sweeter. The nest of this Wren, besides being built in Woodpeckers' excavations and natural cavities of trees, is likewise placed in hollow logs, under brush-heaps, or in any nook or corner about a deserted building, and, when in a cavity, the space which it occupies is generally well flled with roots, straws and grasses, lined with fur or feathers. The nest is also frequently built among the twigs of dense thorny bushes. Two or three broods are reared in a season. The eggs are usually five to seven in number, white, speckled with chestnut or reddish-brown and lavender-gray, heavier at the larger ends, and massed there in distinct, broad bands. Three sets of these eggs from Comal county, Texas, are in Mr. Norris' cabinet; two of seven eggs each were taken April 4 and 25, respectively; the third, containing five eggs, was collected June 21. The sizes by sets in their order are as follows: $.65 \times .50, .64 \times .49, .64 \times .49, .68 \times .50, .65 \times .49, .63 \times .48, .65 \times .50 ; .71 \times .51, .71 \times .50$, $.69 \times .51, .71 \times .51, .70 \times .52, .72 \times .52, .71 \times .52 ; .65 \times .50, .66 \times .51, .64 \times .52, .66 \times .53, .67 \times .52$; average $.64 \times .46$ inches.

719. 1. SAN CLEMENTE WREN. Thryothorus leucophrys Anthony. Geog. Dist.-San Clemente Island, California.

This species is found on San Clemente Island, California. In its habits it is simllar to Baird's Wren, and its eggs, I am informed, are also "very much the same in color and size." For a, description of the bird Cf. Anthony, Auk, January, 1895. p. 52.

720. GUADALUPE WREN. Thryothorus brevicauda Ridgw. Geog. Dist.Guadalupe Island, 'Lower California.

I believe the nests and eggs of this bird remain undescribed.

721. HOUSE WREN. Troglodytes adon Vieill. Geog. Dist.-Eastern United States and Southern Canada, west to the Mississippi Valley (Michigan to Louisiana); winters in southern portions.

A common and well-known bird in Eastern United States. It builds its nest under the eaves of houses, in corners of the barn, martin-boxes, hollows in trees, and, in fact, they are found nesting in every conceivable cavity or crevice. The nest is composed of a mass of miscellaneous rubbish, sticks, grasses, hay and other convenient materials. If a box or cavity holds a peck the little birds will fill it full. The nesting season begins early in May, and two or three broods are generally reared. Mr. L. O. Pindar, of Hickman, Kentucky, informs me that he saw a pair of these birds nesting on the ground under the floor of a barn, which was elevated four or five inches, and another pair had their nest in a paper bag full of hops, hanging in a neighbor's porch. It has been found nesting in the skulls of horses and oxen lying in grassy fields. Mr. George B. Sennett and Dr. B. H. Warren found a pair breeding in a Kingfisher's hole in a sand-bank, near Erie, Pennsylvania. August 1, 1888. The eggs are white, with a light tinge of purple, so thickly dotted with reddish-brown as to nearly conceal the ground-color; they are nearly spherical to oblong-oval in shape. The eggs are usually seven, sometimes nine, measuring $.64 \mathrm{x} .52$, with great variations in this respect.

721a. PARKMAN'S WREN. Troglodytes adon parkmanii (Aud.) Geog. Dist.Pacific coast region of British Columbia, Washington, Oregon and Northern California. 


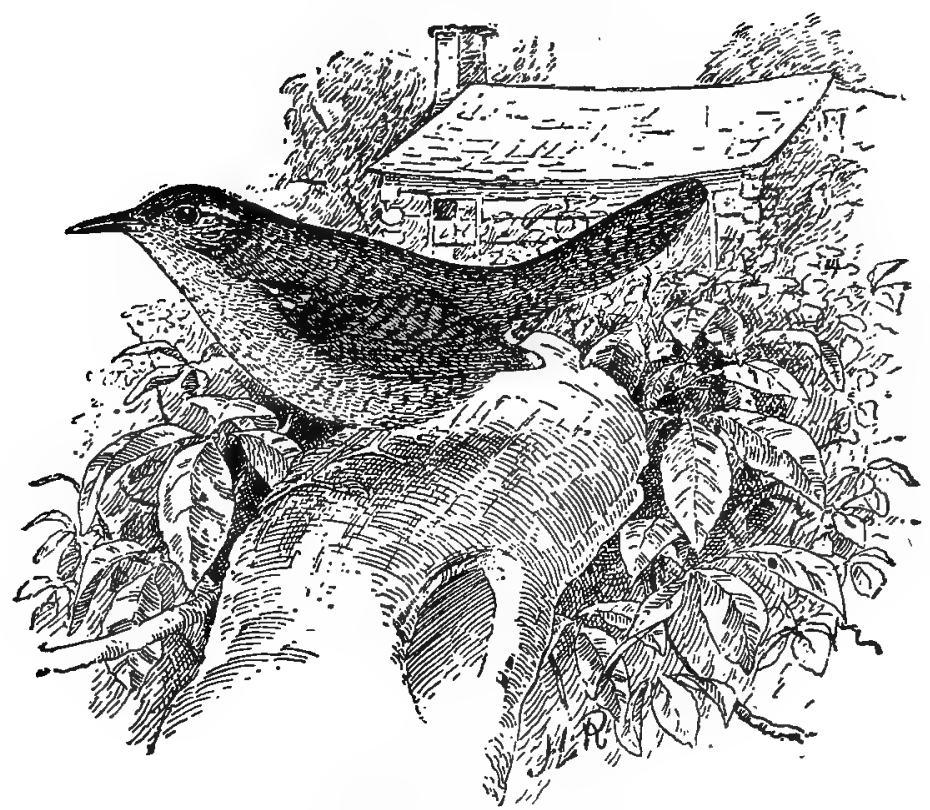

T21. House WREN (From Beal.)

The nesting, eggs and entire general habits of $T$. o. parkmanii correspond exactly with those of the House Wren of the East. Mr. Walter E. Bryant states that Parkman's Wren has been known to build in the skull of a horse, which had been placed in a fruit tree, in the nests of Cliff Swallows, and within an old shoe lodged in a tree.

721b. WESTERN HOUSE WREN. Troglodytes adon a teand Baird. Geog. Dist.-Western United States, except the Pacific coast, east to Manitoba, south into Mexico.

A smaller and paler form than the last; habits and eggs indistinguishable.

722. WINTER WREN. Troglodytes hiemalis Vieill. Geog. Dist.-Eastern North America, breeding from northern border of the United States northward; wintering from its southern breeding limit southward.

The Winter Wren breeds from Northern United States northward. A number of records are, at hand of its breeding in Southern New York, in Maine, New Hampshire and Vermont. The late Dr. Wheaton took young birds of this species in Central Ohio whose plumage indicated they had shortly left the nest. He was of the opinion that the bird breeds in Northern Ohio. Mr. McIlwraith states that a few remain to breed in suitable places throughout Ontario. Mr. Wm. L. Kells found it breeding in wet woods of Central Ontario, nesting in cavities in the roots of upturned trees. While the general habits of this bird are much like those of the House Wren, its song, from all accounts, during the breeding season, is entirely different-"a soul vibrating, gushing melody, which calls forth the sweetest woodland echoes." The nest of this diminutive Wren is placed in hollows of low stumps in wet places, in crevices of unoccupled buildings, in the tangled piles of fallen trees and branches. It is composed of small twigs with moss and leaves interwoven, and warmly lined with feathers of hawks, crows, grouse, or any that are at hand. The eggs are laid as early as the middle of May or in June, and two broods are reared. Mr. Kells says that the birds will at once forsake a nest that has been touched by human hand. The eggs are four, five, or six in number, clear white in ground color, spotted with reddishbrown and purple, chiefly at the larger ends. Average size .69x.49. 
722a. WESTERN WINTER WREN. Troglodytes hiemalis pacificus Baird. Geog. Dist.-Pacific coast region from Sitka to Southern California; south in winter to Western Mexico; east to Eastern Oregon, Nevada, etc.

This subspecies breeds from the southern coast ranges of California north to Sitka. Habits, nesting and eggs like those of T. hiemalis of the East. Eggs .60x.48.

723. ALASKAN WREN. Troglodytes alascensis Baird. Geog. Dist.-Aleutian and Pribilof Islands, Alaska.

'In a small collection of birds' skins, nests and eggs recently acquired by the Museum of Comparative Zoology, collected at the Pribilof Islands, Alaska, is the nest and two eggs of the Alaskan Wren (Troglodytes parvulus var. alascensis), which are believed to be the first ever seen by Naturalists. . The nest is quite large and very compactly built, being composed externally of fine moss of a bright green color, inter woven with fine roots, and lined heavily with hair and feathers. Conspicuous among the latter are the rosytipped feathers of the Leucosticte griseinucha. The hairs are rather coarse and white, three to four inches in length, and appear to be hairs. of the Polar bear. The nest was obtained in June, 1876, on St. Georgo

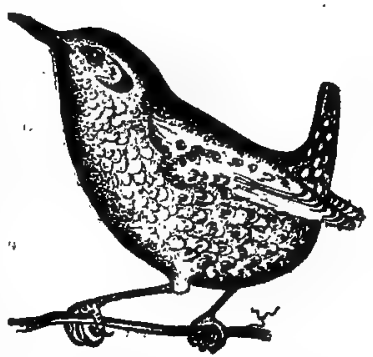
Island, by Mr. W. J. McIntyre, to whom it was brought 723. Alaskan Wrex; (From Turner.) by a native. It is said to have been placed deep down in the crevices of large rocks, and to have originally contained twelve eggs, all but two of which were broken before they came into Mr. McIntyre's possession. These measure, respectively, .68 by .51 and .60 by .50 . Their general color is dull white, with a very few minute dots of reddish, so few and small as to be easily overlooked."-J. A. Allen, Bull. Nutt. Orn. Club, July, 1877, p. 82.

724. SHORT-BILIED MARSH WREN. Cistothorus stellaris (Licht.) Geog. Dist.-Eastern United States and Southern British. Provinces, west to the Great Plains. Winters in the Gulf States and southward.

The reedy swamps, fresh water marshes and meadows of Eastern United States are the summer home of the Short-billed Marsh Wren. Breeds abundantly in Western Manitoba, and occasionally in the southern portions of its range, but chiefly north of latitude 10․ The late Colonel Goss states that t possibly breeds in Kansas and Messrs. Keyes and Williams give it as a rather common summer resident of Iowa. Dr. Agersborg has recorded it as a rare breeder in Southeastern Dakota. The Short-billed Marsh Wren is a summer .esident of Ohio, but here, as is the case elsewhere, it is not so abundant as the Long-billed species. The nest coresponds to that of the Long-billed, but no mud is used in its construction. It is built in the midst of a tussock of soarse, high grass, the tops of which are ingeniously interwoven into a coarse and strong covering, spherical in shape, and closed on every side, except one small aperture left for entrance. The strong, wiry grass of the tussock is also

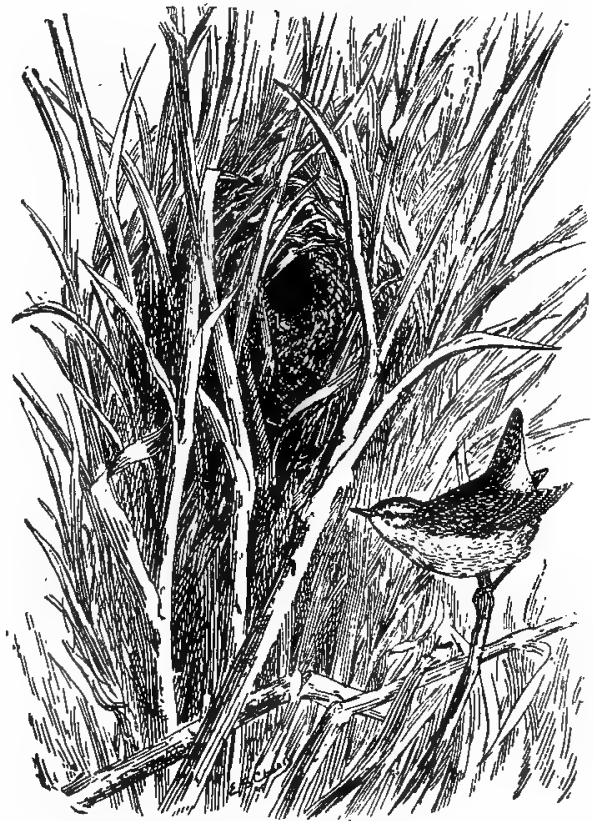

724. Short-billed Marsh Wren and Nest (Oheney del:; 
interwoven with flner materials, making the whole impervious to the weather. The inner nest is composed cf grasses and fine sedges, lined with soft vegetable down. Several nests are frequenily built by a single pair of birds, but not more than one is used. The eggs are six to eight in number, are pure white, unmarked and average $.64 \times .50$.

725. LONG-BILLED MARSH WREN. Cistothorus palustris (Wils.) Geog. Dist.-Eastern United States and British Provinces, wintering in the Gulf States.

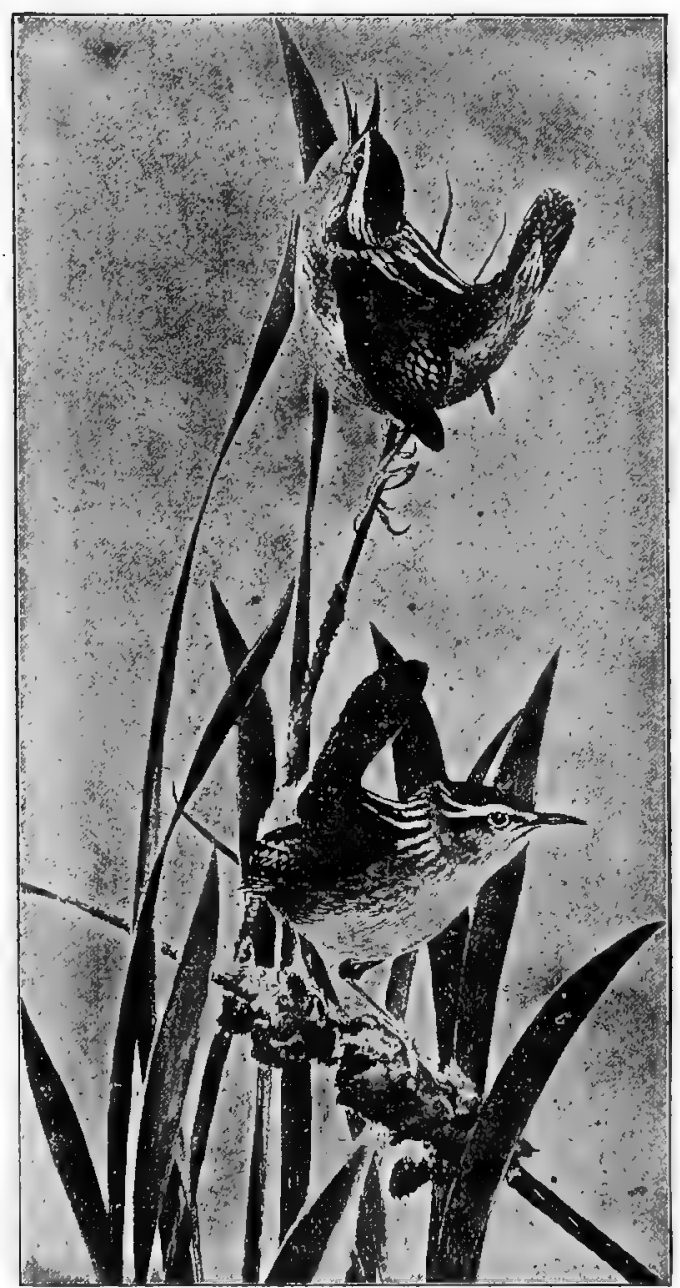

725. Long-BiLled Maksh WREi (From The Osprey.)

The Long-billed Marsh Wren is a common species in swampy places and salt marshes throughout Eastern United States, where it breeds in colonies of greater or less extent. The nest is globular, or somewhat the shape of a cocoanut, very conspicuous by its bulk and its exposed position. It is built of grasses and reeds closely interwoven and often plastered with mud, securely fastened to the upright swayingreeds or cat-tails; it is lined with fine grasses, has a hole on one side, sometimes nearer the bottom than the top. A single pair of these birds will often build several nests, only one of which is ever used. The eggs range from five to nine in number, usually five or six; they are very dark colored, being so thickly marked with brown as to appear of a uniform chocolate color; average size $.64 \times .45$, with considerable variation.

725a. TULE WREN. Cistothorus palustris paludicola Baird. Geog. Dist. - Western United States, east to the Rocky Mountains, south to Northern Central America (Guatemala).

The nesting and eggs of this Western form of the Long-billed Marsh Wren are the same as those of $C$. palustris of the Eastern States. It nests more generally among the tules, more rarely among the flags. Mr. Bryant makes note of a nest found in California which contained eggs and was woven among the almost leafless branches of a young willow, five feet above a fresh water marsh. The false nests were built as usual, but in the coarse grass near by.

725. WORTHINGTON'S MARSH WREN. Cistothorus palustris grisqus Brewst. Geog. Dist.-Coast region of South Carolina and Georgia. 
I have no positive knowledge concerning the nests and eggs of this new varlety of Marsh Wren, but they probably not differ essentially from those of $C$. palustris.

725. 1. MARIAN'S MARSH WREN. Cistothorus mariance Scott. Geog. Dist.-Western Florida.

This species is named in honor of Mrs. Marian J. Scott, wife of the eminent ornithologist and naturalist, Dr. W. E. D. Scott, so frequently quoted in this work. A series of fourteen specimens from which the types were selected were taken at Tarpon Springs, Florida, in 1888.* These are now in the American Museum of Natural History, New York City.

726. BROWN CREEPFR. Certhia familiaris americana (Bonap.) Geog. Dist.Eastern North America, breeding from northern border of United States northward, and in higher mountain districts.

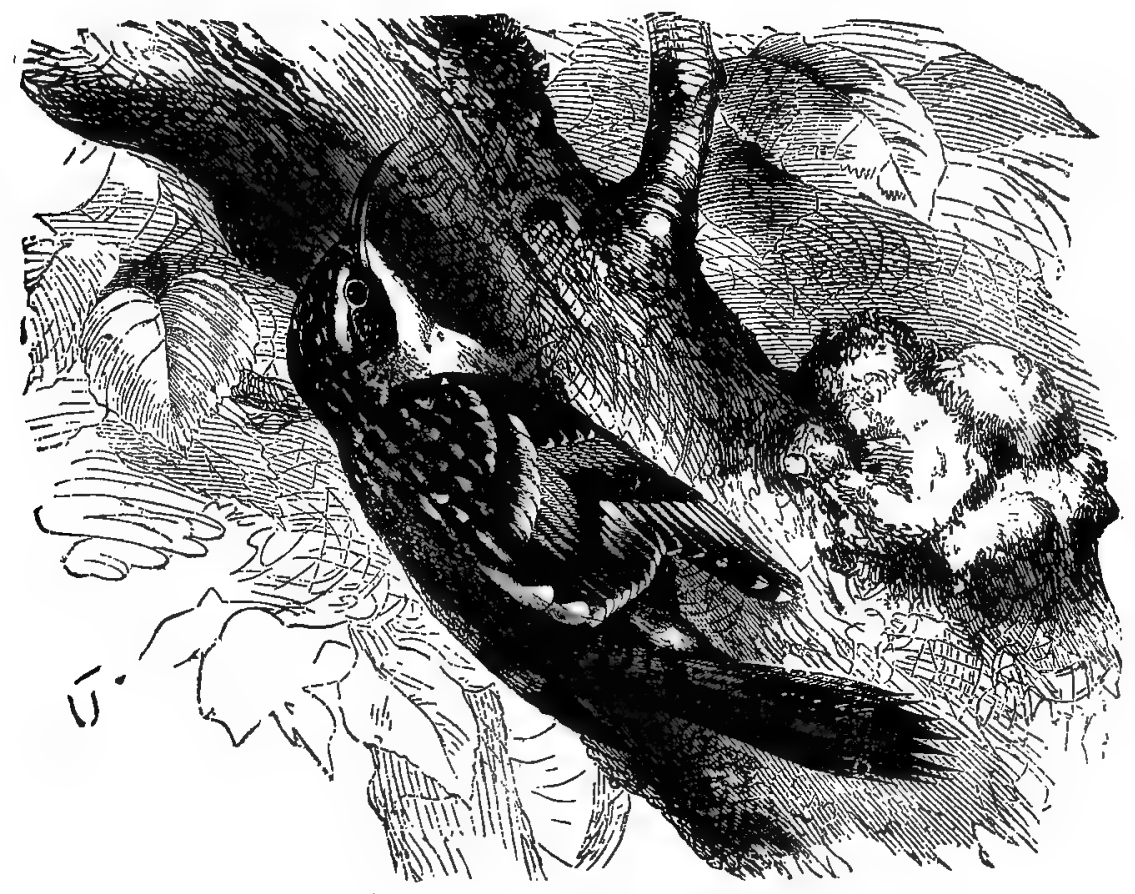

726. Brown Creeper (From Brehm)

The Little Brown Creeper breeds from the northern border of the United States northward, and is seen in most of its United States range during the fall, winter, and early spring. A resident throughout New England, but more abundant in the northern portion. Mr. Wm. Brewster has given us the best account of the breeding habits of this bird in the heavy timbered region bordering on Lake Umbagog, Western Maine.t The nest of the Brown Creeper is built behind loose bark of dead treetrunks or stumps. All of the nests examined by Mr. Brewster were similar in con-

- For a description of this bird C. Auk, V, April, 1888, p. 188.

+ Cf. BuIl. Nutt. Ornith. Club, IV, pp. 199-209. 
struction, and the sites chosen were of a uniform character. In every instance the nest was placed in a balsam fir, though spruce birch, or elm stubs were more numerous. Within the loose scale of bark was crammed a mass of twigs and other rubbish; upon this was the finer bark of various trees, with an intermixture of a little usnea moss and a number of spiders' cocoons. Mr. Brewster obtained eggs from the 31st of May to June 23. The eggs are five to elght in number, white or creamywhite, speckled or spotted with hazel or reddish-brown, chiefly at or around the larger end, often in the form of wreaths. A set of six eggs in Mr. Norris' cabinet collected by Mr. Brewster in Oxford county, Maine, June 5, 1879, exhibits the following sizes: $.58 x .46, .58 x .45, .57 x .45, .57 \times .45, .58 x .46, .57 x .46$. A set of six taken in Buncombecounty, North Carolina, May 2, 1888, measures .59x.45, .58x.46, .57x.44, .56x.45, .58x.45. Several other sets in the same cabinet show great variation. The average size is $.59 \times .47$.

726a. MEXICAN CREEPER. Certhia familiaris mexicana (Glog.) Geog. Dist.-Northern Central America (Guatemala); Mexico, and Southern Arizona.

No reliable information is at hand regarding the nidification of this Mexican form of the Creeper which is, doubtless, similar to that of $C$. $f$. americana.

726b. ROCKY MOUNTAIN CREEPER. Certhia familiaris montana Ridgw. Geog. Dist.-Rocky Mountain district, north to Alaska; west to Nevada, etc. Ridgw.

The nesting and eggs of this. form are litke those of the Brown Creeper of the Eastern States. Prof. Rịtgway gives the average "size of the eggs as .59x.46.

726c. CAIIFORNIA CREEPER. Certhia familiaris occidentalis Ridgw. Geog. Dist.-Pacific caast region of North America from California to Southern Alaska.'

This race of the Creeper is confined to the Pacific coast region. Dr. Merrill met with it in the vicinity of Fort. Klamath, Oregon; and states that in no part of the West did he find it so abundant as there. "Several pairs bred in the immediate vicicinity of the Fort, and during the winter several of their characteristic nests were found hidden by loosened scales of bark, usualiy on pines, but once or twice on aspens. The eggs, according to $\mathrm{Mr}$. Ridgway, average $.61 x .48$ inches.

727. WHITE-BREASTED NUTHATCH. Sitta carolinensis Lath. Geog. Dist.-Fastern United States and British Provinces.

The White-ibreasted Nuthatch" is often improperly called "Sapsucker," a name commonily applied to the Downy Woodpecker and others. Nearly every person readlly recognizes this black-capped species as it runs up and down and around the branches and trunks of trees in search of insect food, now and then uttering its curious quank, quank, quank." It is a common breeding bird throughout its range and usually begins nesting early in Aprill. Two broods are not infrequently reared in a season. This species usually selects for its nesting place the decayed trunk of a tree or stub, ranging all the way from two to sixty feet above the ground. The entrance may be $a^{r}$ lnot-hole, a small opening, or a round perforation is constructed and a cavity within in which the nest is made. Often the old excavation of the Downy Woodpecker is made use of. The nest is composed of chicken feathers, hair, and a few dry leaves loosely thrown together. The eggs are five to eight in number, rarely nine and ten; their usual shape is somewhat long and pointed. They are white with a roseate tingè, speckled or spotted with reddish-brown and a slight tinge of purple. The markings as a rule are thickest near the larger ends.; The average size of ten specimens is $.77 \times .56$. 
727a. SLENDER-BILIED NUTHATCH. Sitta carolinensis aculeata (Cags.) Geog. Dist.-Western United States east to and including the Rocky Mountains, south into Mexico.

This bird is similar to the lasst, but has a longer and slenderer bill. It is abundant in the. wooded and mountainous regions of the West, replacing S. carolinensis. It possesses the same characterisțic habits of the White-breasted Nuthatch of the Eastern States, nesting, also in a like manner. 'Mr. W. O. Emerson states that' it breeds in, all the coast range valleys of California, wherever there is plenty of white and black oak timber, and also, high up in the Sierras. The nests are built in cavities or knot-holes of trees and stumps, composed of feathers and sometimes mostly of rabbit's fur. Six or seven eggs are usually laid; they are creamy-white speckled with reddish brown and hazel. Tha late Col. B. F. Goss had a set of seven eggs in 'his extensive collection which he took from' a hole in a tree seven feet from the ground, in .Southern California, May 7, 1884," "These measure respectively, .75x.57, $.75 \times .53, .74 \times .53, .74 \times .53, .73 \times .57, .78 \times .54, .71 \times .57, .72 \times .56$.

727b. FLORIDA WHITE-BREASTED NUTHATCH. Sitta carolinensis atkinsi Scott. Geog. Dist.-Florida, and northward,along the coast to South Carolina.

The habits, nests and eggs of this race are identical with"those of S. carotinensis.

728. RED-BREASTED NUTHATCH. Silla cáadensis Linn. Geog. Dist.Whole of North America, breeding chiefly north of the United States, except in western mountainous regions; Eastern United States chiefly in winter.

This is a common bird throughout North America, breeding from Northern United States northward. Its habits are essentially the same as those of $S$. carolincnsis. Mr. Manly Hardy has written a good account of this bird's breeding habits in Maine.*" He 'found them 'nesting in white-birch and poplar stubs, usually from ten to fifteen feet, and sometimes as low down as four feet above the ground. In making the entrance to the nest cavity proper, the birds perforate the bark in a circle with smaller holes, and then take out the center piece. A strange fact concerning the nests found by Mr. Hardy and others, is that the bark at their entrance is coated with fir balsam or pitch from an inch to three or four inches around the hole. In one instance the pitch extended down for twenty-one inches, and was stiuck full of the red breast-feathers of the Nuthatches. The cavities are about four inches deep, in which the nest is made of fine grass. The eggs, four to six in number, are very thickly spotted with reddish-brown. Average size .60x.50.

729. BROWN-HEADED NUTHATCH. Sitta pusilla Lath. Geog. Dist.South Atlantic"and Gulf States, north regularly to Southern Maryland and Virginia, casually to Ohio, Michigan, Missouri, etc.

The home of the Brown-headed Nuthatch is in the South Atlantic and Gulf States, where it is a common breeder. Its habits are generic. Mr. Arthur T. Wayne states that in South Carolina the Brown-headed Nuthatch pairs in the latter part of January", and the bird's begin to excavate a hole in a dead stump or limb of a tree, usually not more than a few feet or inches from the ground, and, again, as high as ' Porty ơ fifty feet. Eggs may be obtained in March as four or five weeks are required to complete the excavation. Mr. George Noble informs me that he found a nest of

* Bull. Nutt. Ornith. Club. III, p. 196. 


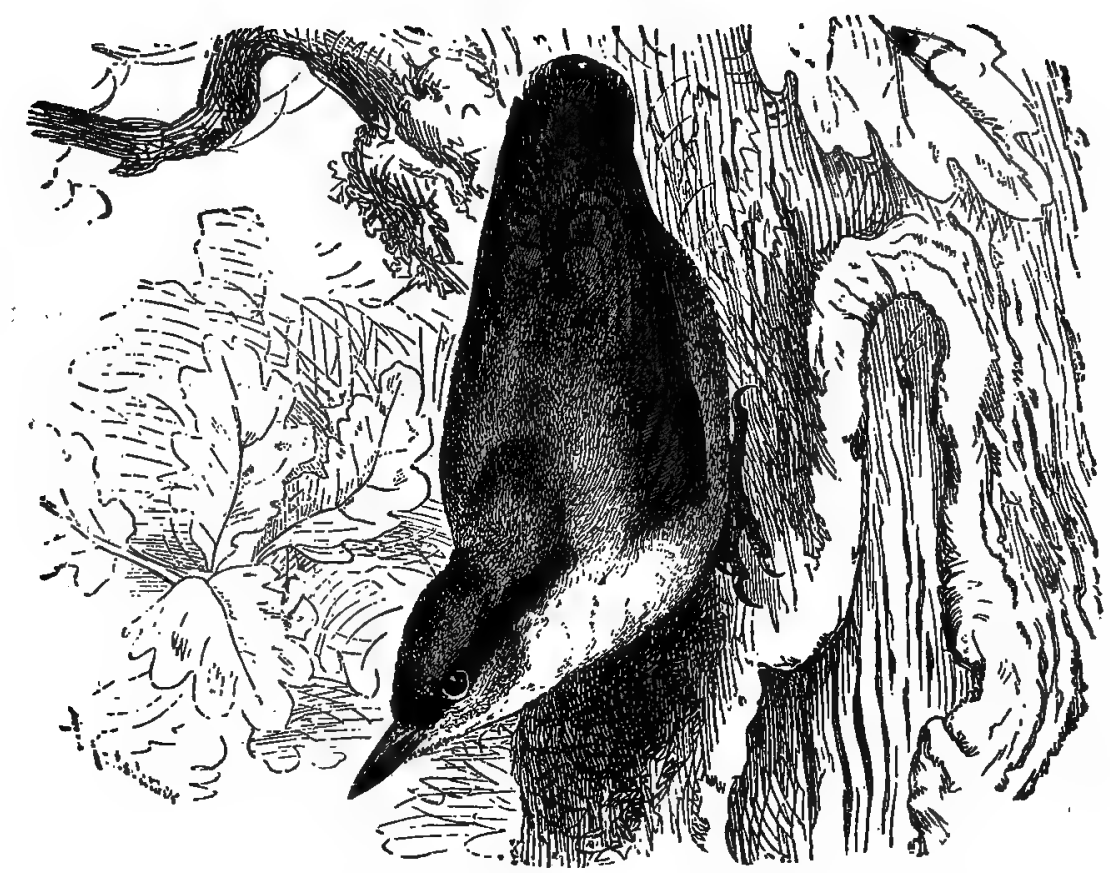

+ European Nuthatce, Sitta caia; in cut resembling our Brown-headed Nutiatch. (From Brehm.)

this species in the cavity of a stump in a pond. It was two feet from the surface of the water. Mr. C. S. Brimley found eggs of this species near Raleigh, North Carolina, in the month of April. Mr. Wayne says that the birds dig several holes before a satisfactory one is completed for the nest. The cavity extends downward from eight to twelve inches, and is filled with short pieces of grass, bits of cotton, wool, feathers, and the leaf-like substance of "pine seed leaves." The eggs are five or six in number. The ground-color varies from white through creamy-white, to a dull white, and the markings are several shades of reddish-brown and lavender-gray. The average gize is $.62 \times .49$.

730. PYGMY NUTHATCH. Sitta pygmaa Vig. Geog. Dist.-Western United States east to and including the Rocky Mountains; from the northern boundary south into mountainous districts of Mexico.

This diminutive Nuthatch is found throughout Western United States from the Rocky Mountains to the Pacific. It is abundant, chiefly in pine woods in mountainous districts, nesting like the rest of the genus in holes of trees. Mr. Charles F. Morrison gives it as a common species of La Plata county, Colorado, and is resident up to 10,000 feet; breeds abundantly, but the nest is hard to flnd. The eggs are from six to nine in number. They are crystalline white, speckled more or less thickly with brick-red, varying in intensity in different specimens. The average size of elghteen specimens is $.54 \times .44$ inches. 
730a. WHITE-NAPED NUTHATCH. Sitta pygmoea leuconucha Anthony. Geog. Dist.-San Pedro Mountains, Lower California.

The nesting habits and eggs of this race are the same as those of the last species.

731. TUFTED TITMOUSE. Parus bicolor Linn. Geog. Dist.-Eastern United States to the Plains, north to Northern New Jersey and Southern Iowa; casual in Southern New England. Resident throughout its breeding range.

The Tufted Titmouse is an abundant resident in Eastern United States, as far west as Eastern Kansas, and, chiefly, however, south of $40^{\circ}$. Its clear, loud whistling song may occasionally be heard in sunny days through the winter months, but particularly in the early spring-in March, the mating season, for nesting usually begins early in April. Deserted Woodpecker excavations, natural cavities of trees, or

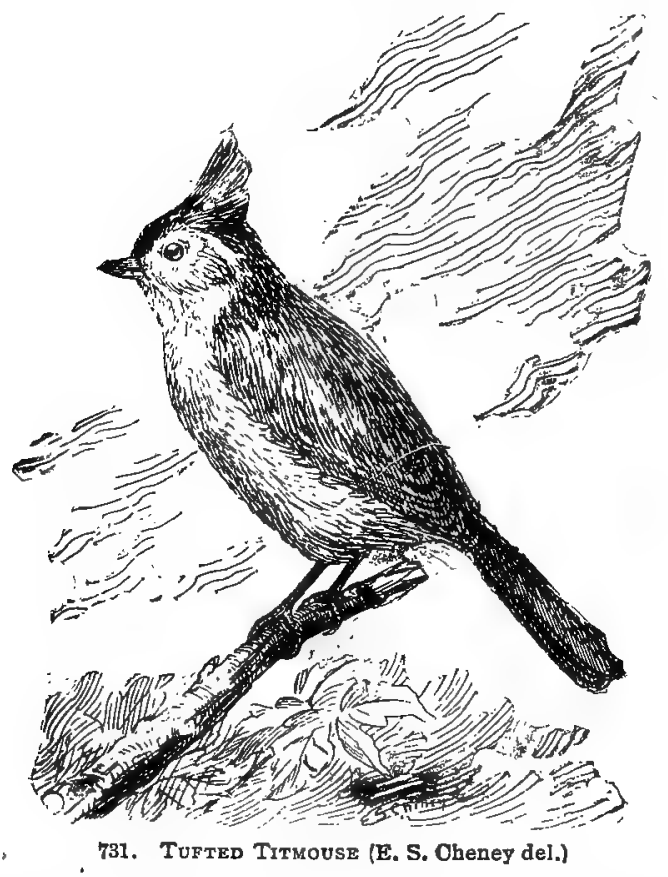

those in stubs in deep or open woods are the farorite nesting sites of the Tufted Titmouse. In these cavities the nest is formed of a mass of leaves, moss, cornstalks, soft, fibrous bark-strips, and the hair of cattle; this is all carried to the nesting place in great mouthsful by the female bird. She has often been accused of picking to pieces and carrying away the moss from hanging baskets suspended on porches. Mr. O. C. Poling found a nest of this bird containing five eggs in a box near a ruined building, in the vicinity of Quincy, Illinois. From five to eight eggs are deposited, five or six being the usual numbers. I have taken three sets in Central Ohio, all containing six eggs. They are of a pure white or light cream ground-color, which is profusely speckled and spotted with different shades of reddish-brown. Eight specimens, selected on account of their sizes, measure $.67 x .52, .67 \times .51, .69 \times .52, .71 \times .51$, 
$.74 \times .53, .76 x .54, .78 \times .54, .80 \times .56$; a common size is $.74 \times .52$ inches. The Tufted Titmouse will frequently nest in boxes that are put up in the woods for that purpose. The birds are close sitters, and often have to be lifted from the nest before the eggs san be secured.

731a. TEXAN TUFTED TITMOUSE. Parus bicolor texensis Senn. Geog. Dist.-Southeastern Texas (Bee and Cameron counties).

This race of the Tufted Titmouse was first described by Mr. George B. Sennett from specimens taken in Bee county, Texas. Its general color is paler than that of $P$. bicolor. Its nesting and eggs are indistinguishable from those of the northern bird.

732. BLACK-CRESTED TITMOUSE. Parus atricristatus Cass. Geog. Dist.Eastern Mexico, north into Southern Texas.

An inhabitant of Southern Texas and southward into Eastern Mexico. Mr. William Lloyd states that this species is a tolerably common resident in Concho and Tom Green counties, Texas, and from thence to El Paso is the prevailing species. Nests were found in old Woodpecker holes April 15, 18 and 20. On the Lower Rio Grande the Black-crested Titmouse was found to be common by Dr. James C. Merrill and Mr. George B. Sennett, where nests containing eggs were found in April. Besides old Woodpeckers' excavations, the nesting sites chosen are hollows or deep cracks in tree trunks. The nest is composed of grasses, inner bark, feathers, moss and wool, and, like the nest of the Blue Grosbeak, it almost invariably contains pieces of snakeskin. The eggs are usually five or six in number, with a clear, white ground-color, and small spots of chestnut sparsely scattered over the surface; in other specimens the markings are larger and more closely disposed over the shell. They can be distinguished at a glance from those of $L$. bicolor. The spots on the eggs of $L$. atricristatus are fewer and more scattered than on those of bicolor. The average size of a set of six eggs is $.67 x .54$ inches.

733. PLAIN TITMOUSE. Parus inornatus Gamb. Geog. Dist.-Pacific coast of Salifornia to Oregon.

The Plain or Western Tufted Titmouse is resident along the coast of California. In some localities it is common, and in others, apparently as well suited to its mode of living, it is scarce or wanting. The nesting sites are the hollows of limbs, usually in oaks. Mr. Walter E. Bryant, of Oakland, California, found a nest of this species placed, in the ventilator of an outbuilding. The shape of the nest conforms to the character of the cavity in which it is built; this is filled with fine grasses, feathers, cow's hair, rabbit's fur, moss, and almost any soft substance that is available. Mr. H. R. Taylor, of Alameda, California, observes that the birds begin to construct their nests as early as March 7, and the selection of a hole well sheltered from the rain is a very necessary precaution. From all accounts the bird is a close sitter; e):en when a stick is thrust into the nest cavity it is met with a vigorous resistance; and the bird, if taken from the nest and tossed into the air, will often return immediately and settle down on the eggs in presence of the collector. Under these circumstances one or more of the eggs are frequently broken or injured by the bird's claws as she is being removed from the nest. The eggs are five or eight in number, and may be plain white or spotted. Mr. Frank B. Webster has kindly sent me six 
eggs of this species, showing their extreme variations. Three of these are pure white, unmarked; the fourth is very obscurely marked with reddish specks at the larger end, while the fifth is distinctly speckled over the entire surface with vinaceous cinnamon, but chiefly at the larger end; the sixth is marked generally over the entire shell. These variations may exist in the eggs of a single set, but usually the specimens in sets are of one type or the other-plain white or speckled. The sizes of the six eggs just described are $.68 \times .49, .69 x .53, .71 x .51, .72 x .54, .73 \times .53, .74 \times .53$.

733a. GRAY TITMOUSE. Parus inornatus griseus Ridgw. Geog. Dist.-New Mexico and Colorado to Arizona, Nevada and California east of the Sierra Nevada.

I have no information regarding the nidification of this variety of Parus inornatus. Their nesting habits, however, can differ but little if any.

733b. ASHY TITMOUSE. Parus inornatus cineraceus Ridgw. Geog. Dist.Lower California.

There appears to be nothing published regarding the nidification of this Titmouse of Lower California.

734. BRIDLED TITMOUSE. Parus wollweberi (Bonap.) Geog. Dist.-Western Texas, Southern New Mexico and Southern Arizona, south into Mexico.

Mr. W. E. D. Scott found this Titmouse to be a rather common resident in the evergreen oak region of both the Pinal and Santa Catalina Mountains of Arizona. It is gregarious, except during the breeding season, going about in small companies. It was frequently found, especially in the fall and winter months, associated with flocks of the Plumbeous Bush-tit (Psaltriparus plumbeus) and a pair or more of Arizona Woodpeckers (Dryobates Arizonæ) are generally found in the band. He observes that the Bridlea Titmouse is as unsuspicious and as fond of the society of man as the Black-capped Titmouse (Parus atricapillus). On two occasions he discovered it breeding, the nests being located in natural cavities of live oaks, close to his house. The first was found May 9, 1884, which was in a cavity tormed by decay, in an oak stump; the opening, which was a small knot hole where the branch had been broken off, was about three and a half feet from the ground. The hollow was lined with cottonwood down, the fronds of some small rock-ferns, and bits of cotton-waste that had been used to clean the machinery of a mill near by. The nest contained three pure white, unspotted eggs, with a pinkish tinge before being blown. Two of these were accidentally broken; the unbroken one measures .63x.48. Another nest was found May 9, 1885, in a similar location, some six feet from the ground. In addition to the material of the nest already mentioned, there were decayed grasses and rabbit's fur. This nect contained four young just hatched and two eggs, similar to the last in color-plain, dead white, and measure .65x.51, .67x.53. The eggs are said to range from five to seven in number.

735. CHICKADEE. Parus atricapillus Linn. Geog. Dist.-Eastern North America, chiefly north of $40^{\circ}$, west to the Plains.

The little Black-capped Chickadee or Titmouse is an abundant species in Eastern United States, north of the Potomac and Ohio Valleys. The usual nesting time is about the middle of April. The late Colonel Goss gives it as a common resident 
of Kansas, begins laying early in April. The nest is constructed in deserted Woodpecker holes, natural cavities in trees, decayed stumps; hollow fence posts, etc. These places are filled with a mass of leaves, moss, dry grasses and warmly lined with downy feathers, hair from cattle, and often of the fur of the smaller.quadrupeds. The eggs are five to eight in number, white, speckled all over, but most thickly at or around the larger ends with light reddish-brown. The average size is $\mathbf{. 5 7 \times . 4 7 . ~ O f ~}$ this species Wilson says: "They traverse the woods in regular progression from tree to tree, tumbling, chattering and hanging from the extremities of the branches, examining about the roots of the leaves, buds, and crevices of the bark for insects and their larvæ. They also frequently visit the orchards, particularly in fall, the sides of the barn and barn-yard in the same pursuit, trees in such situations being generally much infested with insects. We, therefore, with pleasure, rank this little bird among the farmers' friends, and trust our rural citizens will always recognize him as such."*

735a. LONG-TAILED CHICKADEE. Parus atricapillus septentrionalis (Harris.) Geog. Dist.-Rocky Mountain district (New Mexico to Alaska), west to the edge of the Great Basin, east nearly across the Plains.

This is the Western form of $P$. atricapillus, and identical with it in general habits. It is found as far east as Missouri, Eastern Nebraska and Western' Minnesota along the Red River, thus slightly overlapping the home of $P$. atricapillus proper. Dr. Agersborg states that it is the only Chickadee found in Southeastern Dakota, and the late Colonel Goss said it was common in Western Kansas. In the South it has been found in Texas, where it was found mixed with the Southern Chickadee. Prof. Lantz took a fine set of the eggs of the Eastern form. $\dagger$ The eggs of the Long-tailed Chickadee are dull white, and very uniformly speckled with reddish-brown; their average size is .60x.47.

735b. OREGON CHICKADEE. Parus atricapillus occidentalis (Baird.) Geog. Dist.-Northwestern coast district of United States, from Northern California northward (to Southern Alaska?).

A common bird along the coast region of Northern California, Oregon and Washington, possessing all the habits of the Eastern atricapillus, and nesting in a like manner. The eggs of the two birds are indistinguishable. The average size of the eggs in a series of ten sets is $.60 \times .48$ inches.

736. CAROLINA CHICKADEE. Parus carolinensis Aud. Geog. Dist.--Eastern United States, chiefly south of $40^{\circ}$, west to Missouri, Indian Territory and Eastern Texas.

The Carolina or Southern Chickadee is a common bird in Eastern United States, chiefly south of $40^{\circ}$. It is supposed to be resident throughout its range, and is particularly abundant in the Southern States. This bird, like the Black-capped Chickadee, nests in old Woodpeckers' excavations, natural cavities of trees, hollow fence rails, etc., not at a great elevation. The material used in these cavities consists of

* American Ornithology, or the Natural History of the Birds of the United States. Illustrated with Plates engraved from drawings from Nature. By Alexander Wilson and Charles Lucien Bonaparte. Popular edition. Four volumes in one. Philadelphla: Porter \& Coates. Vol. II, D. 214.

$+C f$. Report on Bird Migration in the Mississlppi Valley in the years 1884 and 1885, by W. W. Cooke. Edited and revised by Dr. C. Hart Merriam, Washington. Government printing. Office. 1888. P. 278. 
fine dry grasses, shreds of fibrous bark, with a warm lining of feathers, cattle hair and fur of the smaller quadrupeds. The eggs are five to eight in number, white, sprinkled with specks and small blotches of reddish-brown. In a large series, however, there is considerable variation, both in color and size. Ten specimens average .60x.50. The eggs are not distinguishable from those of Parus atricapillus.

736a. PLUMBEOUS CHICKADEE. Parus carolinensis agilis Senn. Geog. Dist.-Eastern and Central Texas (Bee, Victoria, Cook and Concho counties, etc.).

Mr. George B. Sennett, who describes this new Chickadee* says that it can be distinguished from its nearest ally, $P$. carolinensis, by its whiter underparts; by its being almost entirely free from buff washings on sides, and from olive and brown washings on upper parts; and its very pale lead color on back. Mr. J. A. Singley has sent me five eggs of this bird which he collected in Lee county, Texas, with full details of the bird's nidification. The nest is usually excavated in an oak stub at elevations ranging from two to fifteen feet. Deserted Woodpecker holes, natural cavities in trees are commonly chosen, and occasionally Martin bozes are used. The breeding season is from the last of February to the first of May. The foundation of the nest is mado of short, green moss, mixed with animal hair, and the lining, as a rule, is of rabbit fur. The bird sits so closely that it usually has to be lifted from the nest. The eggs are five to eight in number, white, variously speckled, spotted and blotched with cinnamon-rufous. Thes cannot be distinguished from the eggs of $P$. atricapillus or carolimensis, and vary in as great a degree, both in size and coloration, as eggs of the same species are found to differ. The sizes of fire eggs just mentioned are $.56 x .43, .61 x .47, .62 \times .50, .63 \times .47, .63 \times .50$. This plumbeous colored Chickadee is very likely the prevailing form of Texas.

737. MEXICAN CHICKADEE. Parus meridionalis Scl. Geog. Dist.-Mountains of Mexico, from Orizaba north to Southern Arizona.

The Mexican Chickadee differs from $P$. atricapillus in having the under parts of a paler shade of the ashy of the upper, instead of white. Nesting and eggs indistinguishable from atricapillus.

738. MOUNTAIN CHICKADEE. Parus gambeli Ridgw. Geog. Dist.-Moun-2 tainous regions of Western United States.

The Mountain Chickadee inhabits the mountainons regions of Western . United States, chiefly the alpine districts. It nests in old Woodpeckers' excavations and natural cavities of trees and stumps, from two to twenty feet above the ground. Fibrous roots, grasses, sheep's wool, cattle's hair, or fur of the smaller qaudrupeds constitute the materials of the nest; these will rary with the locality. A nest of this bird was found in a rotten stump, two feet from the ground, by $\mathrm{Mr}$. L. Belding, near Marysville, California, containing seven white eggs. $f$ Dr. Brewer describes a nest which was discovered by Mr. Charles A. Allen, June 11, 1879, in the mountains of Placer county, California. It was constructed in an ald hole of the White-headed Woodpecker, Yenopicus albolartatus, and contained seven eggs, six of which were pure white, unspotted, and the seventh marked over the entire surface with dots of reddish-brown. $\neq$ Dr. James C. Merrill found a nest of this species in Montana, on June 18. It was in a carity of a pine, about sixteen feet above the

* The Auk, r. D. 46.

† Cf. Bull. Nutt. Ornith. Club, III, pp. 102-103.

$\neq$ Ib. $T$. .4. 
ground, and contained five or six young and one addled egg, which was dull, unspotted, chalky-white. Dr. Elliott Coues makes note of two white unmarked eggs of this species, taken by William G. Smith, in Colorado. Dr. Merrill says that this species is perhaps the most common resident species at Ft. Klamath, Ore., and in winter is seldom out of sight or hearing. Between May 25 and July 4, five nests containing eggs were discovered in Woodpeckers' holes in aspen or pine stubs. The eggs were five to eight in number, and of the five sets two are entirely unspotted; in two, one or two eggs are pure white, the others having faint, light brown spots, mostly at

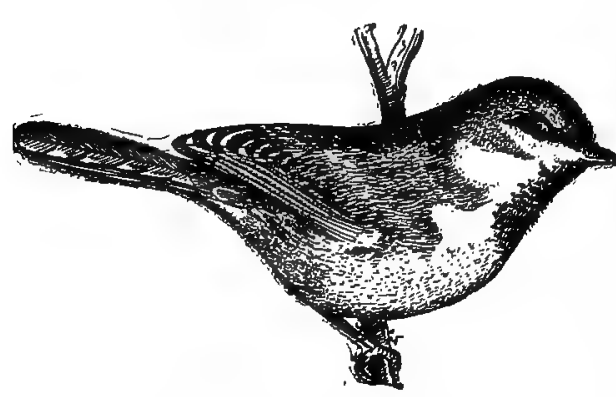
the larger end; in the other set two of the eggs are quite unmarked, but the others have distinct reddish spots. $\mathrm{He}$ states that the female birds sit very close, and when disturbed keep up a constant hissing, so much like that of some snakes that no prudent squirrel would venture to enter the hole. The eggs have an average size of .60x.41 inches.

739, SIBERIAN CHICKADEF. Parus cinctus obtectus (Cab.) Geog. 739. Sibertan Chrckadee (From Turner.) Dist.-Eastern Siberia and Northern Alaska.

An inhabitant of Eastern Siberia and northern portions of Alaska. Its habits, nesting and eggs are similar to those of P. gambeli. Eggs, .65x.50.

740. HUDSONIAN CHICKADEE. Parus hudsonicus Forst. Geog. Dist.Northern North America east of the Rocky Mountains, south to the more elevated portions of the United States-New England, New York, Northern Michigan, etc.

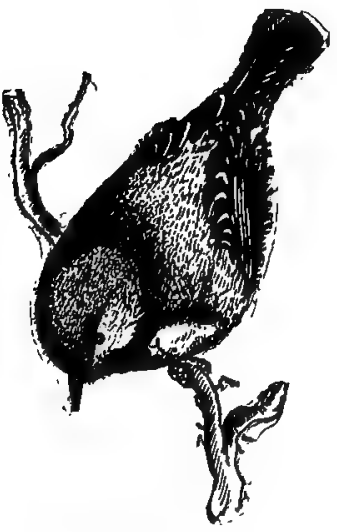

746. Hudsonian Chickadee (From Turner.)

The Hudscnian Chickadee is resident in Labrador and the Hudson Bay region. It is given as a resident of Northern New England, and breeds on the Island of Grand Manan, New Brunswick. Audubon found a nest of this Chickadee in Labrador, built in a decayed stump. about three feet from the ground and composed entirely of the finest of fur of various quadrupeds, chiefly of the northern hare, and all so thickly and ingeniously matted throughout as to seem as if felted by the hand of man. Mr. Montague Chamberlain mentions several nests that were found in New Brunswick, one of which was built in a cavity of a telegraph pole and others built in decayed stumps. He says that when this species is excavating for its nest it sometimes enters from the side of a tree and not invariably from the top of a stump. Mr. James W. Banks, during the seasons of 1885 and 1886, discovered three nests, the entrances of which were at the side of a decayed stump. One of these nests is about two inches deep and is set on a cushion of dried moss, and besides the felted fur there is congiderable dry moss mixed throughout. The entrance was about six inches from the top of the nest. The eggs are usually six or seven in number. The ground-color 
of the eggs is of a creamy-white tint, sprinkled with hazel and blackish; average size, $.60 \times .46$ inches.

740a. KOWAK CHICKADEE, Parus luudsonicus stoneyi (Ridgw.) Geog. Dist.-Valley of the Kowak River, Northwestern Alaska.

According to $\mathrm{Mr}$. Ridgway this variety ${ }^{\circ}$ of Chickadee is similar to P. Iudsonicus, but in color much grayer above, sides of neck purer ash gray, etc. Its nesting and eggs are doubtless similar to hudsonicus.

7400. COLUMBIAN CHICKADEE. Parus hudsonicus columbianus Rhoads. Geog. Dist.-Rocky Mountains, from Liard River south into Montana.

The nesting and general habits of this Chickadee are not known, but are probably similar to those of $P$. hudsonicus.

741. CHESTNUT-BACKED CHICKADEE. Parus rufescens Towns. Geog. Dist.-Northwestern coast-Oregon, Washington, British Columbia and Southern Alaska.

The Chestnut-backed Chickadee is an inhabitant of the Northwest coast where, in some regions, it is rather common. Mr. A. W. Anthony gives it as a common winter resident of Washington county, Oregon. It was first seen by him in December, 1884, in company with the Oregon Chickadee, Parus atricapillus occidentalis. A few lingered to breed, but disappeared as soon as the first brood was raised. A nest was found April 28, in a large fir stub three feet four inches in diameter, running horizontally three inches then turning downward for six inches before opening into the nest, which was of cow hair and rabbit fur. It contained seven eggs with large embryos. The eggs of this species are five to seven in number; their ground color is white, sprinkled over with distinct spots of redish, especially at the large end where, in most specimen's, they tend to form a ring. Their average size is .64x.47 inches. The eggs of this species and those of the next form are not distinguishable.

741a. CAIIFORNIA CHICKADEE. Parus rufescens neglectus Ridgw. Geog. Dist.-Coast district of California.

This bird is confined to the coast regions of California where Mr. W. O. Emerson informs me it can always be found in the redwood belts. He has only seen two birds of this species in the vicinity of Haywards, which is doubtless on account of there being no redwood timber. It nests in cavities of trees and stumps, and in old Woodpeckers' excavations, making the nest of quadrupeds' hair. Six or seven eggs are usually deposited. A set of six eggs in Mr. Emerson's collection was taken by Mr. George H. Ready, April 13, 1885, in Santa Cruz county, California. They were take. from an old cavity of a Gairdner's Woodpecker in a maple stub, eight feet from th ground. The eggs are similar to some specimens of the Black-capped Chickade Parus atricapillus, being white, sparsely marked over the entire surface with red spots, and tending to form a ring at the larger end; average size is .63x.47.

742. WREN-TIT. Chamaa fasciata Gamb. Geog. Dist.-Coast region of California, from Monterey county northward.

The Ground-Tit or Wren-Tit, which partakes of the features of a wren and a titmouse, may not be considered a common species in the Pacific Coast region of 
California. On account of its retired habits it is seldom seen. It frequents the shrubbery of out-of-the-way ravines and solitary canons, often where there is no water. The nest is built in low bushes from two to four feet above the ground, is cup-shape in form, with thick walls, and compactly made of bark-strips, grasses, flbrous roots, lined with cattle hair. The cavity measures about three inches in width and three-fourths deep. The breeding season begins in May, and two broods are usually reared in a season. From three to five eggs are laid, four being the usual complement; they are of a plain pale blue, a shade darker than those of the Black-throated Bunting or Dickcissel, Spisa americana. Seven eggs of this species, collected by Mr. R. B. Herron in San Gorgonia Pass give the following respective measurements: $.68 \times .54, .66 \times .54, .69 \times .58, .77 \times .56, .75 \times .55, .76 \times .56, .75 \times .55$. The average size is .73x.56. Mr. Emerson informs me that the birds sit very close on the nest, and when flushed immediately set up a hissing or cricket-like sound.

742a. PAIID WREN-TIT. Chamaa fasciata henshaui Ridgw. Geog. Dist.Interior of California, including the western slope of the Sierra Nevada, from the head of the Sacramento Valley south to Northern Lower California.

The habits, nesting, etc., of this paler subspecies are the same as those that are characteristic of the last species; the eggs are indistinguishable.

743. BUSH-TIT. Psaltriparus minimus (Towns.) Geog. Dist.-Northwestern coast, from Northern California to Washington.

This is a darker-colored species than the California Bush-Tit. It is a common resident of Oregon and northward into Washington. Breeds preferredly in thickets of ash and willow, building a beautiful pensile nest like that represented in our illustration of $P$. m. californicus. The eggs of the two birds are likewise indlstinguishable.

743a. CALIFORNIA BUSH-TIT. Psaltriparus minimus californicus Ridgw. Geog. Dist.-- California, except northern coast district.

This lighter colored Bush-Tit is a common bird in California. It frequents bushes and low shrubbery, and very actively hops among the branches, hanging from them in the manner of other Titmice. The beautiful and bulky purse-shaped nest built by this species seems out of all proportions to the diminutive size of the bird. The one shown in our illustration is drawn from a typical specimen collected near Santa Paula, California, by Dr. S. P. Guiberson, April 11, 1885 . It was suspended from a small, forked twig, eight feet from the ground. It is six inches long. Prof. Evermann says that the nests vary all the way from four to twenty-two inches in length. From five to nine pure white, unmarked eggs are laid, commonly six or seven. Ten eggs out of a number collected by Mr. R. B. Herron in San Gorgonia Pass in May, measure .51x.40, .53x.40, .51x.39, .54x.40, .55x.41, .56x.41, .54x.41, .55x.43, $.54 \times .44, .54 \times .42$.

7436. GRINDA'S BUSH-TIT. Psaltriparus minimus grinda (Belding.) Geog. Dist.-Lower California.

There is, apparently at the present time, no description concerning the nidification of the variety of Bush-Tit inhabiting Lower California. Its breeding habits, however, can differ but little, if any, from P. minimus or californicus.

744. LEAD-COLORED BUSH-TIT. Psaltriparus plumbeus Baird. Geog. Dist.--Rocky Mountain district, from Western Colorado and Wyoming to Eastern Oregon and Western Nevada, south to Southern New Mexico and Arizona. 


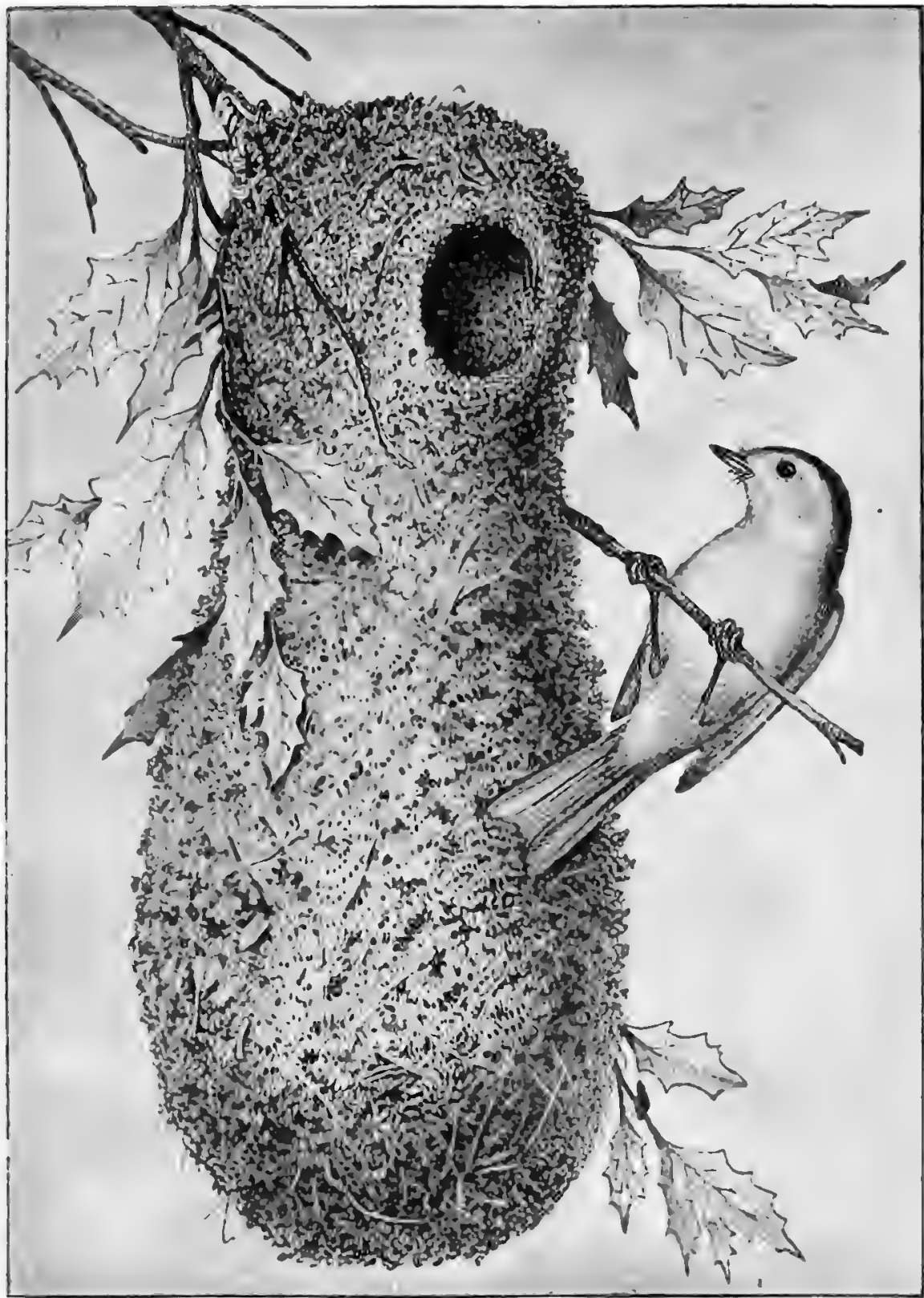

743a. Nest of Califoriga Bush-tit. 
The following is Maj. Charles E. Bendire's account of the nesting and eggs of this species: "Although this "little Bush-Tit is a widely distributed species throughout the West, and has been known to naturalists for more than thirty years, nothing whatever has been placed on record respecting its nesting habits. The credit for the discovery of their nests and eggs belongs to Lieutenant Benson; who found them breeding abundantly in the vicinity of Fort Huachuca during the month of April, 1887. Their favorite abiding places seemed to be along dry water-courses, up narrow ravines, running into the mountains and on flats, covered with scruboak, between the hill-sides; he says that they are exceedingly tame, perfectly unconscious of danger, and will work on their nests with a person not ten feet away from them. They are one of the first birds to arrive in the spring, but are not resident throughout the year. The nests, of which a number are before me, are all more or less gourd-like in form; that is, considerably narrower near the top than around the bottom. They are not strictly pensile, but are woven into and supported by small twigs and branches of the oak bushes (Quercus undulata?) in which they are built. Several nests were placed in bunches of a species of mistletoe (probably Phoredendron flavescens), and in these cases the nests are suported and placed directly in the forks of this plant: They vary in length from seven to nine and a half inches. and from four to five inches in diameter. The entrance to the nest is on the side, near the top of the structure, about three-quarters of an inch in diameter. The inner cavity is from four to five inches deep, and about one and a half inches in diameter. The nests are outwardly composed of the dried, curled-up leaves of the white sage, plant-down of a pinkish tint, spider webs, small bits of mosses and lichens, and are thickly lined inside with soft, small feathers. The walls of the nest increase in thickness from top to bottom, so that while near the top they are not over threeeights of an inch through, near the bottom they are fully one and a half inches thick. The nests are placed in about equal proportions in low oak bushes, from five to seven feet from the ground, generally well concealed by the foliage, or in bunches of mistletoe in oak or mesquite trees, from fifteen to twenty feet high. Some of these hirds commenced building in the first week of March, but no eggs were discovered in any of the nests till fully a month later, the first ones being taken April 8, 1887. The number of eggs to a set varies from four to six, five being the most common number found. Probably two or more broods are raised during the season. The eggs are pure white in color, ovate in shape, and measure $.56 \times .42$ inches for the largest to $.49 \times .40$ for the smallest. Their average size is $.53 \times .40$ inches."* The late Captain B. F. Goss had a set of four eggs of the Lead-colored Bush-Tit, taken near Fort Huachuca, Arizona, April 10, 1887. These measure .55x.45, .55x.44, .56x.45, .58x .44 inches,

744. 1. SANTA RITA BUSH-TIT. Psaltriparus santa rito Ridgw. Geog. Dist.--Santa Rita Mountains, Southern Arizona.

This Bush-Tit, inhabiting the Santa rita Mountains, has, in all probability, the same general habits which characterize $P$. plumbeus.

745. LLOYD'S BUSH-TIT. Psaltriparus lloydi Sennett. Geog. Dist.-Western Texas (mountains between Pecos River and Rio Grande), and west to Sonora.

- Notes on a collection of Birds' Nests and Eggs from Southern Arizona Territory. By the late Major Chas. E. Bendire, U. S. A. Proceedings of U. S. National Museum, 1887, pp. 557-558. 
Mr. George B. Sennett describes a nest of this species as being pensile, purse-like, composed of mosses, flower stems and lichens, having a lining of feathers. Eggs pure white. Breeds in pineries of high altitudes. An egg in the collection of Mr. Sennett measures .58 inches in length by .42 in breadth. The nest with this egg was taken in Limpia, Cameron county, June 21, 1887, at an altitude of 6200 feet. It was fastened to twigs of a cedar seven feet from the ground. The tree was twenty-five feet in height, situated on a divide between two ravines.

746. VERDIN. Auriparus flaviceps (Sund.) Geog. Dist.-Northern regions of Mexico and contiguous portions of the United States, from Southern Texes to Arizona and Lower California.

The little Yellow-headed Bush-Tit or Verdin is a common bird in suitable 10calities throughout the arid regions of Northern Mexico, the southern portions of Texas, Arizona, New Mexico, and in Lower California. It is smaller than the largest North American Hummingbird, Eugenes fulgens, which inhabits Southern Arizona and southward. This species measures about 5.00 in length, while the length of the Verdin varies from 4.00 to 4.60 inches. Notwithstanding the diminutive size of the bird, it builds a remarkable structure for a nest-large, and bulky, and a marvel of bird architecture. It is comparatively easy to find, being built near the ends of the branches of some low, thorny tree or shrub-in the numerous varieties of cacti and thorny bushes which grow in the regions of its home. The nest is globular, flaskshape in form, the outside being one mass of thorny twigs and stems interwoven, while the middle is composed of flower stems and the lining of feathers. The entrance is a small circular opening. Mr. Sennett took a number of the birds, nests and eggs at Lomita, on the Lower Rio Grande. Dr. Merrill did not observe this species in the immediate vicinity of Fort Brown, Texas, but it was rather common at Edinburgh in April and May, frequenting mostly amargosa chapparal. $\mathrm{Mr}$. $\mathrm{H}$. P. Atwater found it a resident and quite common at San Antonio, Bexar county, Texas, where a number of skins, nests and eggs were taken in 1884; the first nest was found March 31, and contained four fresh eggs. Mr. Atwater says that the birds occupy the nest during the winter months, and the inside is made much warmer by the addition of feathers. The birds are generally found nesting in the high, dry parts of the country, away from tall timber, where the thorns are the thickest. From three to six eggs are deposited, of a bluish or greenish-white or pale blue, speckled, chiefly round the larger end, with reddish-brown. Their average size is $.59 \times .43$ inches.

\section{KENNICOTT'S WILLOW WARBLER. Phyllopseustes borealis (Blas.)} Geog. Dist.-Northeastern Asia and Alaska.

The first American record of the capture of this bird was a single specimen taken at St. Michael's, Alaska, August 16, 1866, and later another was taken. During the summer of 1877, in July, Nelson secured two specimens at St. Michael's, and others have been taken since. The bird is known to be a great wanderer, migrating through Japan, China and Formosa, and reaching the Malayan Peninsula and Archipelago. In summer it seeks the high latitudes of Asia, to northern Russia, and thence even to Alaska. We must depend upon those who have visited its haunts in Northern Europe and Asia for an account of its nesting and eggs. Seebohm's account (Ibis, Vol. III, p. 9, 1879), is as follows: "When I left the Arctic Circle it had probably not commenced to breed; but on the 6th of July I had the good fortune to shoot a bird from its nest at Egaska, in latitude $67^{\circ}$. The eggs are larger than those 
of our Willow Warblers, pure white, and profusely spotted all over with very small and very pale pink spots. They. were five in number. The nest was built on the ground in a wood thinly scattered with trees, and was placed in a recess on the side of a tussock or little mound of grass and other plants. It was semi-domed, the outside being composed of moss, and the inside of fine dry grass. There was neither feather nor hair used in the construction. I did not see this bird farther north than latitude $69^{\circ} . "$

748. GOLDEN-CROWNED KINGLET. Regulus satrapa Licht. Geog. Dist.North America generally, breeding in the northern and elevated parts of the United States and northward, migrating south in winter to Guatemala.

Although a dainty little creature, the Golden-crowned Kinglet appears to be of a hardy nature, being found during the winter months nearly throughout the Eastern States. Breeds from the northern portions of the United States northward, moving south in the fall, returning northward in spring, and retiring to its breeding grounds. It is resident in Northern New England. Mr. H. D. Minot found a nest of this species containing young, in the White Mountains of New Hampshire, July 16, 1876.* The late Dr. T. M. Brewer describes a nest which doubtless belonged to this bird, and which was found in the neighborhood of Bangor, Maine. It contained ten eggs and was built in a fir tree, at an altitude of six feet. It consisted of a large ball of green moss, about four and a half inches in diameter. A nest was found by Dr. North up at Caribou, Maine, containing an incomplete set (five eggs). It was placed partly pendant from a horizontal branch of a small hemlock at the edge of a forest. Mr. Chas. H. Andros records a nest containing ten eggs, taken "on or about June 1," at Grand Manan, New Brunswick. This nest was saddled on a spruce limb and was similar in shape to the nest of the Blue-Gray Gnatcatcher, but much larger and deeper, and was externally covered with green moss, cobwebs and lichens, internally lined with soft down and sheep's wool. $\dagger \quad B y$ far the best account we have of the nidification of the Golden-crested Kinglet is that recently given by Mr. William Brewster, who found it nesting in a dense woods of mixed pines and spruce, on low, rather swampy ground, in the neighborhood of Winchendon, Worcester county, Mass.t With the assistance of Messrs. C. E. Bailey, S. W. Denton and H. M. Spelman, three nests were secured, two.with sets of nine eggs each. They were found June 13, 16 and 17 (1888), respectively, and were all taken on the 29 th. The first was placed in a tall, slender spruce, within about two feet of the top of the tree, and at least sixty feet above the ground; suspended among the fine pendant twigs, about two inches below a short horizontal branch, some twelve inches ont from the main stem; the second was in a heavily-limbed spruce, about fifty feet above the ground, twenty feet below the top of the tree, six feet out from the branch, in a dense cluster of' stiff radiating twigs; the third was also in a spruce; thirty feet from the ground, twelve feet out from the main stem and five feet from the end of the branch. This nest on the 29 th contained no eggs, and was evidently deserted; it was found in a dilapidated condition. In position the first nest resembles that of the Baltimore Oriole, being near the ends of long, drooping twigs. The second is built more like a Vireo's, but with this difference, that instead of being suspended by its upper edges only, and between the forks of a single stem, it is suported on every side, and from the top nearly to the bottom, by numerous stiff, radiating twigs. It is nevertheless a

* Minot's Land and Game Birds of New England, p. 56.

† Ornithologist and Oologist, YY. pp. 908-204.

¥ The Auk, V, pp. 337-344. 
distinctly pensile nest. The third is different from either of the others in position. Placed nearly midway between two stout branches, which in reality are forks of the same branch, one above the other, and attached by the sides and upper edges to the twigs which depend from the branch above, while its bottom rests firmly on a bristling platform of stems which rise from the branch below. Thus it is at once pensile and non-pensile. The material used in the construction of these nests on the exterior is chiefly green mosses, diversified with grayish lichens and usnea, the whole resembling the general color of the surrounding foliage. The interior at the bottom is lined with delicate strips of soft inner bark and fine black rootlets. Near the top are rather numerous feathers of the Ruffed Grouse, Red Crossbill, Hermit Thrush, and Ovenbird, arranged with the points of the quills down, the tips rising to or slightly above the rim, and arching inward over the cavity, forming a screen that partially concealed the eggs. In both nests, the space being too. small for the accommodation of the numerous eggs, they were piled in two layers, one above, the other. In the first nest the number in each layer was equal, but in the second five eggs were in the lower layer and four in the upper. All of these nests were found by watching the birds building; and, taking into consideration the dim light of dense spruce woods, the torture one must endure from mosquitoes while watching the erratic and puzzling movements of the birds flying from branch to branch with their bills filled with material, the rapidity and unaccountable way in which the substance was often deposited in the clusters of dense foliage, made it a very difficult and tedious task to locate the nest in the many similar dark clusters in the spruces.* The eggs vary from creamy-white to exceedingly deep, often somewhat muddy, cream color, sprinkled with numerous markings of pale wood-brown, varying from small dots to blotches. Three specimens are described by Mr. Brewster as having spots and blotches of faint lavender. The markings of most of the specimens are distributed pretty thickly over the entire shell, but in nearly all they are most numerous about the larger ends; where they form a more or less distinct wreath. The sizes of Set A, nine eggs, are $.56 \times .44, .57 \times .44, .55 \times .42, .57 \times .43, .57 x .44, .56 x .45, .57 x .44, .57 x .44$.

748a. WESTERN GOLDEN-CROWNED KINGLET. Regulus satrapa olivaceus Baird. Geog. Dist.-Pacific coast region from California to Sitka.

The nesting and eggs of this Pacific coast form of Golden-crowned Kinglet are similar to those of $R$. satrapa.

749. RUBY-CROWNED KINGLET. Regulus calendula (Linn.) Geog. Dist.Entire North America, breeding from the northern border and higher mountains of the United States northward. Winters in more Southern United States and southward to Northern Central America.

The:Ruby-crowned Kinglet breeds from the extreme northern border and higher mountains of the United States northward. Mr. W. E. D. Scott took a nest containing five eggs on June 25, at Twin Lakes, Colorado. The nest. was suspended to the leaves of the uttermost twigs of a pine tree, much like a Vireo's nest, and about twelve feet from the ground. Mr. Frank M. Drew states that in San Juan county,

* Mr. Brewster says that in her flights after building material the female went a distance of a hundred yards or more, but oftener she confined her quest to the trees within a radius of fifty yards or less of the one which concealed the nest. She was invariably followed closely by the male, who, however, did not assist her in any way other than. by, singing almost incessantly in an undertone. In the case of the nests discovered, the males' singing was the characteristic performance which attracted attention to the spot where the female was at work. 
Colorado, this bird breeds from 7000 to 10,000 feet altitude. A nest taken July 5 was placed in the uppermost branches of a spruce thirty feet from the ground-in one of those dark masses where the cones grow thickest. It contained four fresh and one addled egg. Dr. Merrill found a nest of this species containing eight eggs, in Montana, on the 18th of June, at an elevation of 7700 feet. It was in a fir tree about eighteen feet from the ground, and placed directly against the trunk, supported by a single branch beneath, and by several twigs to which the sides were firmly attached. Dr. Merrill also found these birds common about Fort Klamath, Oregon, apparently placing their nests in dense firs. Mr. Montague Chamberlain records a nest which was taken at Lennoxville, Quebec, May 15, 1882. This was pensile, and was attached to a branch of a small tree. It contained nine eggs, one of them a Cowbird's. The nests of the Ruby-crown vary somewhat in their general style of structure and in composition. They are usually semi-pensile, neatly and well made with soft, thick walls, composed of moss, fine strips of bark, and well lined with feathers of various birds, which are woven into the sides and bottom of the structure. The eggs are five to nine in number, and are dull whitish or pale buffy, faintly speckled or spotted with light brown, chiefly at the larger ends. Their average size is .55x.43. Occasionally some of the eggs of this bird are very nearly plain in color.

750. DUSKY KINGLET. Regulus obscurus Ridgw. Geog. Dist.-Guadalupe Island, Lower California.

Mr. Walter E. Bryant found the Dusky Kinglet frequenting more numerously the large cypress grove on Guadalupe Island; they were also found in the smaller groves and among the pines. As early as the middle of February, nest-building was in order, the birds selecting the topmost foliage of a cypress, and sometimes the very outer extremity of a horizontal branch. After many days' diligent search, three nests were observed, and these were detected by watching the birds collect building material, or by tracing to its source a peculiar, low song which the male sometimes sings when close to the nest. These nests were all found over twenty feet high, and only one could be seen from the ground, and that merely during the intervals when the wind parted the branches. They were placed in the midst of a thick bunch of foliage and but lightly secured to the twigs. Compact, though not very smooth in structure, they were composed of soft bark-strips intermingled with feathers, bits of moss, fine grass and cocoons. Additional warmth is secured by a quantity either of goat's hair or feathers, and, lastly, a thin lining of goat's hair. Their external measurement is about $70 \mathrm{~mm}$. in height by $90 \mathrm{~mm}$. in diameter, while the internal depth is about $45 \mathrm{~mm}$., and diameter 35 to $45 \mathrm{~mm}$.* A nest containing two fresh eggs was found March 24, in the top of a slender cypress twenty-five feet high. It could not be seen from the ground, but was located by the subdued song of the male bird. In color the eggs are white, with a dense wreath of pale yellowish-brown spots encircling the larger end. In some places these spots appear to be laid over a pale lavender washing, and in one specimen, these fine, almost indistinct dots extend sparingly over the entire surface. They measure in millimeters, $14 \times 11$ and $15 \times 11 . \dagger$

751. BLUE-GRAY GNATCATCHER. Polioptila corulea (Linn.) Geog. Dist.-Middle and southern portions of the Eastern United States; south, in winter to Guatemala, Cuba, and the Bahamas; rare north toward the Great Lakes, Southern

* External height about 2.76, diameter 3.54; Internal depth 1.77, and dlameter 1.38 to 1.77 inches.

$\uparrow .55 \times 43, .59 \times 43$ Inches. 


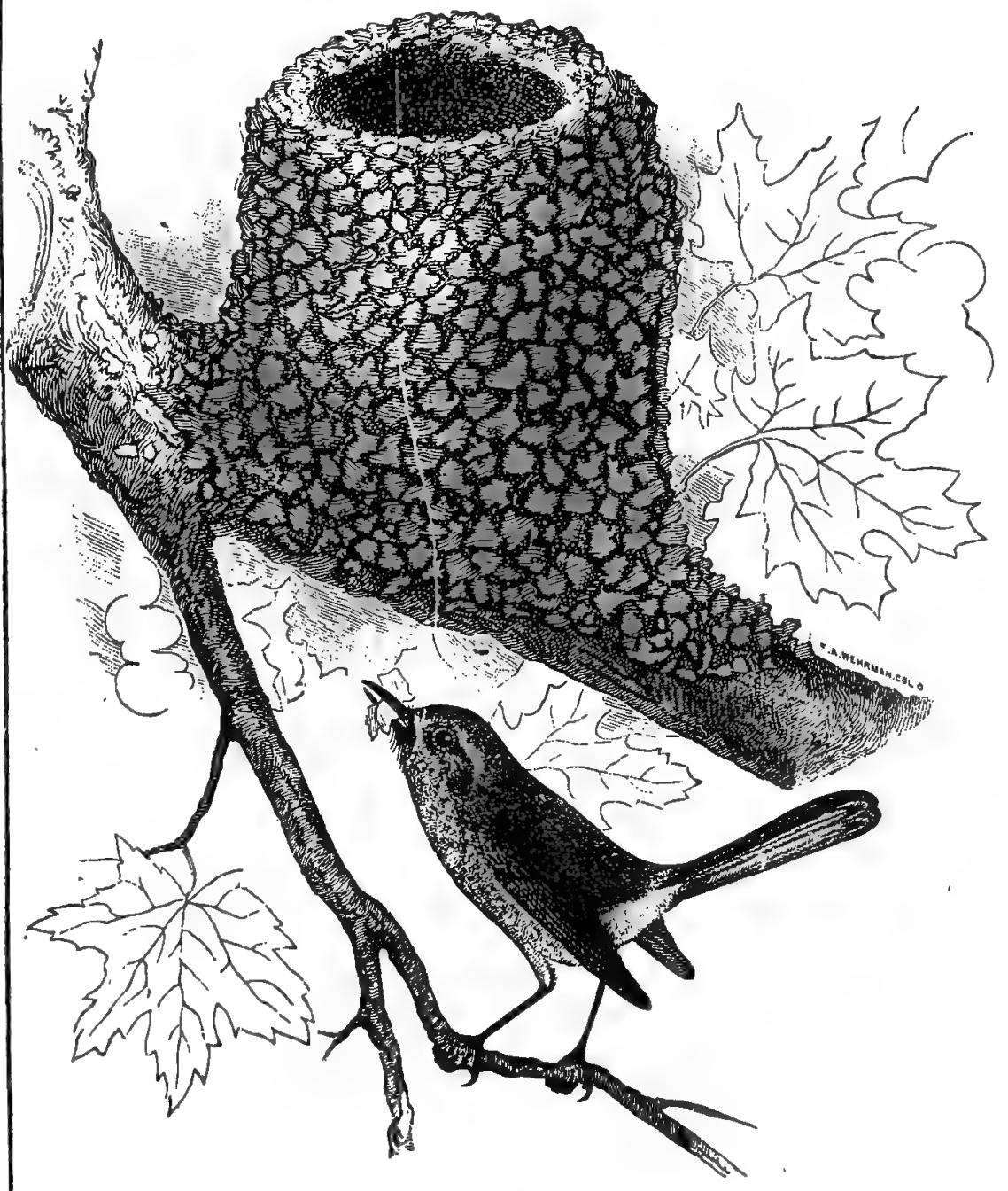

751. BLUE-GRay GatcatcagR AND Nest (Jasper del.) 
New York and Southern New England; accidental north to Massachusetts and Maine. Breeds throughout its United States range, and winters from South Atlantic and Gulf States southwarc.

The Blue-Gray Gnatcatcher is an abundant bird throughout most of the wooded districts of the United States, breeding in suitable places, south of $42^{\circ}$. As a work of beauty and ingenious'architectural design the nest of this bird has few equals in this country. On the whole it is a rather frail structure, usually built in the small upright twigs or saddled on the horizontal limbs of trees at heights ranging from ten to fifty feet, but gencrally at an elevation of about fifteen or twenty feet. The typical nest has high, compact walls, contracted at the brim and gracefully turned; the interior is deeply cupped, and the exterior is beautifully ornamented with lichens. The nest shown in our illustration is selected from eight specimens which I took on a little island in the Scioto river, Franklin county, Ohio, May 27, 1885. Ten nests of this species collected by Mr. R. B. Herron in San Gorgonia Pass, California, are entirely deficient of the lichens which characterize the Ohio nests. The interior is composed of soft downy materials-cotton-like substances of withered blossoms and the silky down of the milkweed-fine wiry grasses, stems of old leaves, horse hair and an occasional feather from the breast of the bird is intermingled. The cavity measures from one to one and a half inches deep, and about the same in diameter. At a short distance the nest often looks like a round knot protruding from the limb. The eggs are four or five in number; their ground-color is greenish or bluish-white, speckled with chestnut, and in some the markings are of a darker brownish tinge. Ten specimens measure, .55x.42, .56x.43, .57x.45, .58x.45, .57x.42, .56x.41, .58x.47, $.59 x .44, .58 \times .44, .59 \times .45$ inches.

751a. WESTERN GNATCATCHER. Polioptila carulea obscura Ridgw. Geog. Dist.-Arizona, California, Lower California and Western Mexico.

The general habits, nesting and eggs of this western form are identical with those of $P$ carulea. The nests of this variety, as will be seen in the description of the eastern species, lack the abundance of artistically arranged lichens on the outside.

752. PLUMBEOUS GNATCATCHER. Polioptila plumbea Baird. Geog. 'Dist.-Southwestern border of the United States-Southern Texas to Lower Rio Grande Valley; Northern Mexico and Lower California to Cape St. Lucas.

A nest of the Plumbeous Gnatcatcher was taken at Yuma, Arizona, by Mr. F. Stephens, July 15, 1881. It was placed in a bunch of mistletoe, at a height of about eight feet from the ground, and contained one egg of its owner and one of the Dwarf Cowbird. Mr. William Brewster says that although a delicate structure the nest will not compare with that of the Blue-gray Gnatcatcher, entirely lacking the exterior coating of lichens, but in its general appearance closely resembles the Redstart's, being felted with soft bark-strips and hemp-like vegetable fibres. It was lined with plant down, a few feathers and the hair of some small quadruped. Mr. Brewster describes the eggs as pale greenish-blue, coarsely and very evenly spotted with reddish-brown; size .53x.42.* Mr. Stephens found two nests of the Black-capped Gnatcatcher at Yuma, Arizona, in May, 1886, containing four esgs each; one of these containing an egg of Molothrus ater obscurus. $t$

753. BLACK-TAILED GNATCATCHER. Polioptila californica Brewst. Geog. Dist.-Southern California and Pacific coast of Lower California.

* Bull. Nutt. Ornith. Club, VII, p. 77.

$\dagger$ Bull. No. 2, Ridgway Ornithological Club; April, 1887, pp. 56-57. 
"This Gnatcatcher was first described by Mr. William Brewster, from specimens collected by Mr. F. Stephens, near Riverside, San Bernardino county, California, March 28, 1878. "A nest and four eggs of this species have recently been obtained from Mr. Stephens, to whom the credit belongs for the discovery of the first specimens. These were taken near the town of San Bernardino, California, on May 2, 1887, and are now in the National Museum collection (Catalogue No. 23,294). The nest of $P$. californica, like that of $P$. plumbea Baird, from Arizona Territory, differs radically in its structure from that of its Eastern relative, $P$ carulea (Linn.), which is too well known to ornithologists to require description. It lacks entirely the artistic finish of the lichen-covered structure of the former, and resembles more in shape certain forms of the nest of the Summer Yellow Warbler, Dendroica astiva (Gml.), and the American Redstart, Setophaga ruticilla (Linn.). The nest is cone-. shaped, built in the forks of a small shrub, a species of mahogany, Coleogyne ramosessima (Torr.), I think, only two feet from the ground, and it is securely fastened to several of the twigs among which it is placed. Its walls are about half an inch in thickness. The material of which the nest is composed, is well quilted together and makes a compact and solid structure. Externally the nest is composed principally of hemp-like vegetable fiber mixed with small curled-up leaves of the white sage, Eurotia lanata, plant-down, and fragments of spiders' webs. Inside the nest is lined with the same hemp-like fiber, only much finer, and a few feathers: The cavity of the nest is cup-shaped and rather deep. Externally the nest measures two and a half inches in diameter by three and one-fourth inches in depth. Compared with a nest of Polioptila plumbea Baird, now before me, from Arizona Territory, it seems much better constructed and also somewhat larger. I took three nests of the latter species near Tucson, Arizona, during the months of May and June, 1872. Two of these were placed in bunches of mistletoe, probably Phoredendron flavescens, growing on mesquite trees from twelve to twenty feet from the ground; and one of them is described in the 'History of North American Birds,' by Baird, Brewer and Ridgway, Volume III, page 502. The third nest was placed in a crotch of a cholla cactus. The ground-color of the eggs of the Polioptila californica Brewster is bright light green, much more pronounced than in the eggs of either $P$. carulea and $P$. plumbea, now before me. They are covered with minute spots of a brownish-red color distributed irregularly over the entire surface of the egg, but nowhere so thick as to hide the ground-color. These eggs measure $.50 \times .45, .58 \times .45, .57 \times .45$ and $.57 \times .44$ inches."*

754. TOWNSEND'S SOLITAIRE. Myadestes townsendii (Aud.) Geog. Dist.Western United States, from the Plains to the Pacific.

So far as I am aware, Mr. Wilbur F. Lamb took the first known eggs of Townsend's Fly-catching Thrush. This was in Summit county, Colorado, July, 1876, at an altitude of about ten thousand feet. The nest was placed in the upper bank of a miner's ditch near Blue River; it was partly concealed by overhanging roots; yet rendered conspicuous by the loose, swaying material of which it was composed. $\mathrm{Mr}$. T. M. Trippe found a nest of this species in San Juan county, Colorado, July 9, at an altitude of 10,500 feet; it was built in a little cranny in a bank, and contained four eggs in which incubation had just begun. Dr. Coues describes a nest taken by Mr. G. Smith, of Buffalo Creek, Jefferson county, Colorado. This was found June 18, 1883 , and was built in the end of a hollow $\log$; it was about three feet off the ground

* Major Chas, E. Bendire, U. S. A. Proc. U. S. Nat. Mus., 1887, pp. 549-550. 
and about one foot from the end of the log. The foundation of the nest was a great quantity of trash, bits of sticks, etc., the nest proper being constructed chiefly of pine needles, grasses, and disintegrated weed-stalks-the whole, loose and slovenly, could hardly be handled without coming apart. Mr. Walter E. Bryant describes tho location of three nests taken by Mr. L. Belding, at Big Trees, California, in various years, in June. They were placed on the ground in a slight depression, and concealment was attempted by the aid of weeds, a stone, or a large piece of bark. One nest was built on the ground, within the semi-circular cavily of a standing tree. The nests were composed mostly of pine needles. Mr. Lamb describes the eggs which he obtained as resembling those of the Shrikes, and gives the sizes of three specimens preserved out of the set of four as $1.01 \times .66, .94 \times .68, .88 \times .66$. The usual number laid is four, with an average size of $.93 \times .67$.

755. WOOD THRUSH. Turdus mustelinus Gmel. Geog. Dist.—Eastern United States, in summer north to Southern Michigan, Ontario, Massachusetts, etc.; south in winter to Northern Central America and Cuba.

A common bird in the woodland of Eastern United States and as far West as Eastern Kansas, where Colonel Goss gives it as an abundant summer resident. Its favorite resorts are low, damp woods and thickets, where it spends much of its time on the ground scratching among the leaves. The bird has a sweet song, which it sings from the higher branches of trees, generally towards the close of summer afternoons. The nest is usually saddled upon the horizontal limbs of saplings and low trees, six to ten feet from the ground; on the outside it is composed of leaves, grasses and stems of weeds, which are gathered when wet, and become solid and firm; and between these are tracings of mud; the lining is of small fibrous roots. The breeding season is in May. Usually four eggs are laid, often only three. Their color is a plain greenish-blue, and their average size is $1.02 x .74$, with considerable variation.

756. WILSON'S THRUSH. Turdus fusccscens. Steph. Geog. Dist.-Eastern United States and British Provinces to the Plains, north to Manitoba, Ontario, Anticosti and Newfoundland.

Wilson's, the Tawny Thrush, or Veery, is an abundant species in the wooded regions of Eastern United States. It is rather partial to low, wet woods. Breeds from about latitude $40^{\circ}$ north to Manitoba, Ontario, Anticosti and Newfoundland. It has been considered a doubtful breeding bird in Central Ohio; has lately proven to be quite common during the summer months. I took a nest May 27, 1885, in the characteristic position-at the base of a sapling in swampy woods. The nest is of the usual type, composed of leaves, strips of grapevine bark, weed stems, and lined with black rootlets. This nest contained three eggs of its owner and one of the Cowbird. An illustration of a Wilson's Thrush's nest appears in Jones' magnificent work, "Nests and Eggs of Birds of Ohio," which was taken May 21, 1884. Dr. Jones took another nest which was placed at the base of the leaf of the skunk-cabbage plant, eighteen inches from the ground, at the odge of swampy woods. Nests of this bird alave been found in hollow trunks of trees, fifteen feet from the ground, and in old tin cans lying on the ground in the woods. The eggs are four or five in number, and are plain, pale greenish-blue; average size, .87x.64.

756\%. WILLOW THRUSH. Turdus fusccscens salicicola (Ridgw.) Geog. Dist.-Rocky Mountain region of the United States, east casually during the migraticn to Dakota, Minnesota, Illinois, etc. 
The Willow Tawny Thrush inhabits the lower willowy portions of the Rocky Mountain region in United States. Habits, nests and eggs are similar to those of Wilson's Thrush. Eggs, .85x.66.

757. GRAY-CHEEKED THRUSH. Turdus alicia Baird. Geog. Dist.-Eastern North America, west to the Great Plains, Alaska, Eastern Siberia north to the Arctic coast. In winter south to Costa Rica.

The Gray-cheeked Thrush breeds from Labrador and Hudson Bay north to the Arctic coast and the coast of Bering Sea. It has been found breeding abundantly in the Mackenzie River region and on the Anderson River. The nests were found, with all but few exceptions, on the branches of low trees, from two to seven feet from the ground. In a few exceptional cases they were built on the ground. They are usually compact, and composed of an elaborate interweaving of fine sedges, leaves, stems, dry grasses, strips of fine bark and lined with fine grasses. Occasionally nests are found constructed with mud, like those of the common Robin. The eggs are usually four in number, and are greenish-blue, marked with spots of russet and yellowish-brown. Captain B. F. Goss has two eggs of this species, taken by Mr. R. R. MacFarlane, at Fort Anderson, Arctic America. The nest from which these were taken was placed in a low tree. The eggs are greenish-blue, faintly marked over the entire surface with reddish-brown. Their sizes are .91x.71, .91x.72.

757a. BICKNELI'S THRUSH. Turdus alicia bicknelli (Ridgw.) Geog. Dist.In summer, higher mountains of Northeastern United States (Catskills, White Mountains, etc.), and Nova Scotia. Winter home unknown.

This Thrush, recently identified in the Catskill and White Mountains, and named in honor of its discoverer, Mr. Eugene P. Bicknell, was found breeding by the Rev. J. H. Langille, on Mud and Seal Islands, out at sea off the coast of Nova Scotia and westward from the city of Yarmouth. These are almost entirely covered with a low growth of evergreens-black spruce and balsam fir. Except the Robin, Song Sparrow, Snowbird, a few Redstarts and Winter Wrens, almost the only small land-birds breeding here are the Black-poll Warbler and Bicknell's 'Thrush-the last two being very abundant. Mr. Langille says that its song is similar in tone to that of Wilson's Thrush, but more slender and wiry, and therefore not nearly so grand and musical. The birds were found nesting in almost impenetrable evergreen thickets, beneath which there is a dense carpet of moss. The nests were all nearly alike in location, structure and materials; placed a few feet from the ground, against the trunk of an evergreen tree. They were composed of various kinds of mosses, a few fine sticks, weed-stems and rootlets, and were lined with fine bleached grasses. The nest on the outside was as green as a bunch of fresh moss. The eggs were of a light bluishgreen speckled with brown; size, $.87 \times .63 . *$

758. RUSSET-BACKED THRUSH. Turdus ustulatus (Nutt.) Geog. Dist.Pacific coast region, north to Sitka; south, in winter, through Western Mexico, to Northern Central America.

The Russet-backed Thrush is a common species in suitable localities along the Pacific coast of California and northward .Mr. A. W. Anthony states that it is not an uncommon summer resident of Washington county, Oregon. The bird frequents

* Our Birds in Their Haunts: A Popular Treatise on the Birds of Eastern North America. By Rev, Hibbert Langille, M. A. Boston: S. E. Cassino \& Co. 1884. Pp. 511-513. 


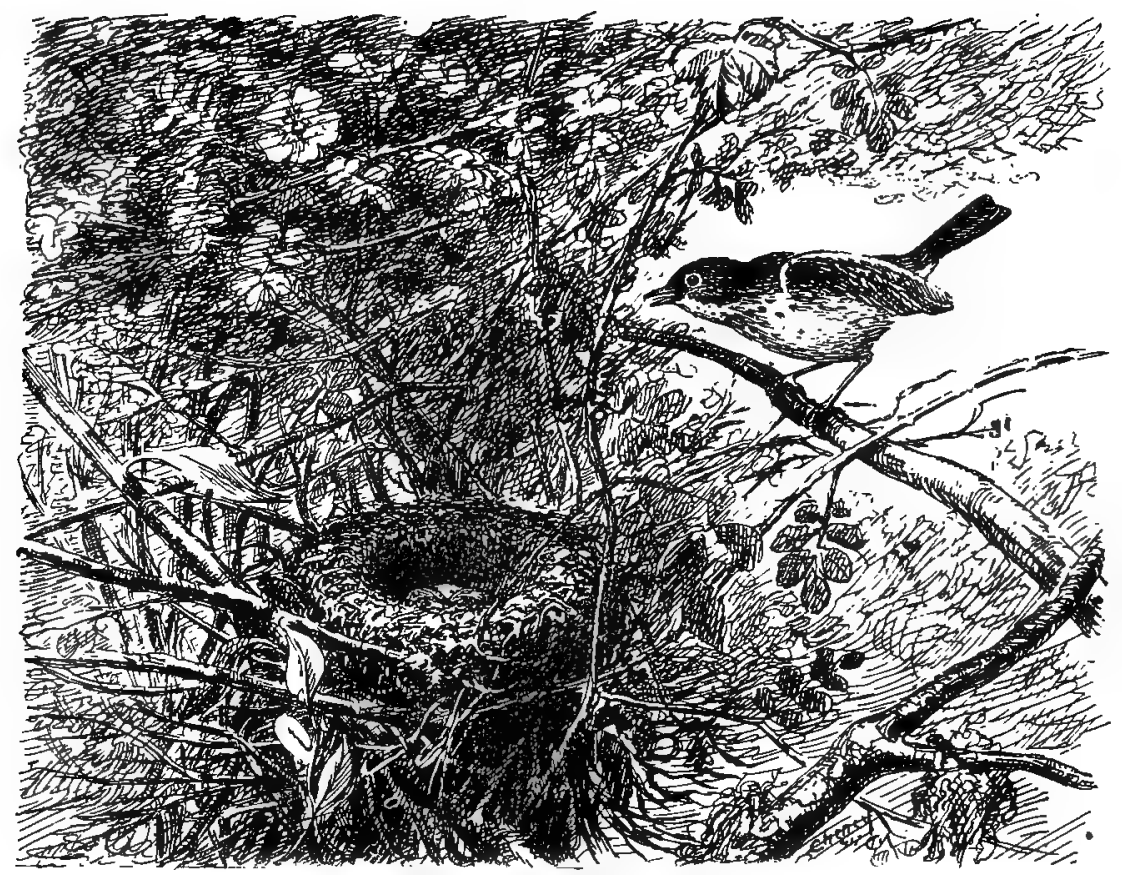

758. Russet-backed Throsh and Nest (E. S. Cheney de1.)

the deepest thickets, and when disturbed utters an alarm note like that of the Brown Thrasher, chuck, chuck. It is also a fine songster, and may be heard at dusk and early morning. The nest is built in thickets or bushes, a few feet above the ground. It is composed of twigs, grasses, roots and leaves, and in some cases mosses are used. A set of four eggs taken near San Jose, California, May 18, 1885, gives the following dimensions: $.92 x .65, .95 \times .66, .97 \times .68$. They are greenish-blue spotted with yellowishbrown, chiefly about the larger end. The average size of ten specimens is $.94 \times .65$.

758a. OLIVE-BACKED THRUSH. Turdus ustulatus swainsonii (Cab.) Geog. Dist.-Eastern North America, west to and including Rocky Mountains, and as far as East Humboldt ranges and the Upper Columbia. Breeds chiefly north of the United States, rintering from the Gulf States and Mississippi Valley southward to Northern South America.

The Olive-backed Thrush breeds chiefly north of the United States. It is given as a common breeding bird in the Wasatch Mountains, Utah. Mr. Kennicot found it nesting in the Arctic regions, frequently placing the nest not more than two feet from the ground. In his Catalogue of the Birds of New Brunswick,* Mr. M. Chamberlain gives it as a summer resident, breeding in abundance. Breeds abundantly in Nova Scotia. In some parts of Maine and New Hampshire it is the commonest Thrush, except the Robin, during the breeding season. $\dagger$ Mr. Frank H. Lattin has for two

* Birds of New Brunswick. Bulletin of the Natural History Society of Néw Bruswick. No. 1. Published by the Society. St. John, N. B., 1882. Pp. 29-68.

$\dagger$ New England Bird Life, Part I, p. 58. 
successive years found nests and eggs of the Olive-backed Thrush at Gaines, Orleans county, New York, within a short distance of his residence. Dr. Morris Gibbs has taken its nests and eggs in Kalamazoo county, Michigan. It may be found breeding in Northern Ohio. This species, like the Hermit Thrush, frequents retired woodland, but its mode of nesting (except the structure of the nest), as well as its eggs, are quite different. The nest is built in a bush or small forest tree, a few feet from the ground-usually from five to eight feet. It is composed of a mass of leaves, twigs, shreds of bark, and, in the Arctic regions, moss is one of the principal substances which enter into its composition. The nests average about four inches in diameter by two in height, the cavity being three wide by one and a half deep. The eggs are usually deposited in the first part of June, these being three or four in number, of greenish-blue (some much duller than others), speckled with reddish-brown and other tints. Their average size is $.92 \times .66$.

759. DWARF HERMIT THRUSH. Turdus aonalaschka Gmel. Geog. Dist.Pacific coast region, breeding from Californja northward; south in winter to Lower California and Western Mexico; during the migrations east to Nevada and Arizona.

The Dwarf Hermit Thrush breeds from the mountains of California northward as far as Kadiak. Very few of the eggs of this species appear in the numerous collections, and from the meagre accounts we have concerning them, they must be considered rare. Mr. Chas. N. Comstock, of Oakland, California, found a nest of this species containing two eggs, in June, 1883, while on a collecting trip to the Calaveras group of big trees. The nest was placed in a bush about two feet from the ground. The eggs are described by Mr. Comstock as being a little lighter than a Robin's, and all one color.* The sizes of these two specimens are $21 \times 16 \mathrm{~mm}$., $21.5 \times 16.5 \mathrm{~mm} . \dagger$

759a. AUDUBON'S HERMIT THRUSH. Turdus aonalaschka auduloni (Baird.) Geog. Dist.-Rocky Mountain region of the United States, south to Northern Central America.

Known as the Rocky Mountain Hermit Thrush from the region which it inhabits. In some parts of Colorado it is very common. Mr. Frank M. Drew states that it is common and breeds in San Juan county, Colorado. Its clear, sweet notes can be heard from nearly every dark glen or secluded part of the woods. A nest was found in the latter part of June, placed in a spruce bush, about three feet from the ground. It contained three eggs. Mr. Chas. F. Morrison records this bird as tolerably common in La Plata county, Colorado. The nest he says is generally, if not always, placed in bushes where the undergrowth is thick and heavy. The bird prefers hillsides near sluggish water, as old beaver dams and swamps, nesting in their vicinity, and breeding before the last of May or first of June, and later at a higher altitude. The nest is composed of twigs, straws, rootlets, coarse grass and moss; it is often compact, with thick walls. The average diameter is about five inches, with a cavity two and a half by two deep. The eggs are usually four, and of a plain greenish-blue. A set of four in my cabinet, taken at Canon City, Colorado, July 4, 1885 , offers the following sizes: $.85 x .65, .84 x .66, .88 \times .66, .86 \times .64$.

759b. HERMIT THRUSH. Turdus aonalaschka pallasii (Cab.) Geog. Dist.Eastern North America, breeding from the Northern United States northward, wintering from about latitude $40^{\circ}$ to the Gulf coast.

* Young Oologist, I, p. 149.

$\dagger .83 x .63, .85 x .65$ inches. 
'The Hermit Thrush or "Ground Swamp Robin," breeds from the Northern United States northward. It is common in the northern portions of New England in summer, and in Maine, where it is abundant, it begins to breed during the last week of May. It is common in Nova Scotia and in New Brunswick, and begins to build about the middle of May. Dr. Frank W. Langdon states on the authority oi Mr. Chas. Dury, that the nest and eggs of the Hermit Thrush have been taken near Cincinnati, Ohio, May 10, 1877. The bird probably breeds in Northern Ohio and other parts of the State. It has been observed nesting in Michigan, a nest being recorded by Dr. Morris Gibbs as taken by. W. A. Gunn in Montcalm county, May 15, 1879. Nuttall says that the song of the Hermit Thrush "seems to be unusually lively and varied, warbling almost like the Yellow Bird, and then chanting like the Robin." This charming writer, in speaking of the marshy places which this bird inhabits, beautifully says: "In these almost Stygian regions which, besides being cool, abound probably with its favorite insect food, we are nearly sure to meet our sweetly vocal hermit flitting through the settled gloom, which the brightest rays of noon scarcely illumine with more than twilight. The nest, like that of Wilson's Thrush, is built on the ground or very near it, in some low, secluded spot, generally. bencath the shelter of dense shrubbery. It is rather bulky, and loosely made of leaves, shreds of bark, grasses, mosses, and lined with similar but finer material. The eggs are usually four, often only three, of greentsh-blue, unspotted, and average $.86 \times .65$.

[760.] RED-WINGED THRUSH. Turdus iliacus Linn. Geog. Dist.-Northern portions of Europe and Asia; accidental in Greenland.

The Red-winged Thrush of Europe claims a place in the avifauna of North America from its accidental occurrence in Greenland. During the breeding season it is found in the more northern portions of Europe, only occasionally breeding as far south as England. Breeds in the wooded districts of Norway and Sweden. It has been found nesting in the Faroe Islands, Iceland and Northern Russia. In the winter the Redwing extends its migrations to the more southern portions of Europe-Sicily, Malta, and even Smyrna. The nest of this species is usually placed in the center of a thorn bush or small tree, and is made of moss, roots, and dry grasses outwardly, cemented together with clay, and lined inwardly with finer grass. The external diameter averages about five inches by three deep; the cavity is three in diameter by about two deep. The eggs range from four to six in number, pale bluish-green or olive-greenish, speckled and spotted with reddish-brown. Their average size is $1.04 \times .75$.

761. AMERICAN ROBIN. Merula migratoria (Linn.) Geog. Dist.-Eastern and Northern North America (Hudson Bay region to Alaska); west to the Great Plains, of occasional occurrence in Eastern Mexico.

During the summer months this familiar bird has an extensive range, breeding as it does from near the southern border of the United States northward to the Arctic coast. The nest is saddled on a horizontal branch or built in the crotch of trees of almost any kind, and it is commonly placed on the top rail of a fence, often on stumps, and, in fact, in all sorts of curious places, even in bird boxes. Orchards and the shade trees along streets are favorite nesting sites. The nest is a large, coarse structure, made of twigs, roots, stems, grasses, dry leaves, hair and wool. It is strengthened by a neatly-made cup of clay or mud, which is surrounded by these materials. The typical set of eggs is four, rarely five. They are greenish-blue, unspotted. Very rarely, however, speckled with brown. Average size, 1.16x.80. 


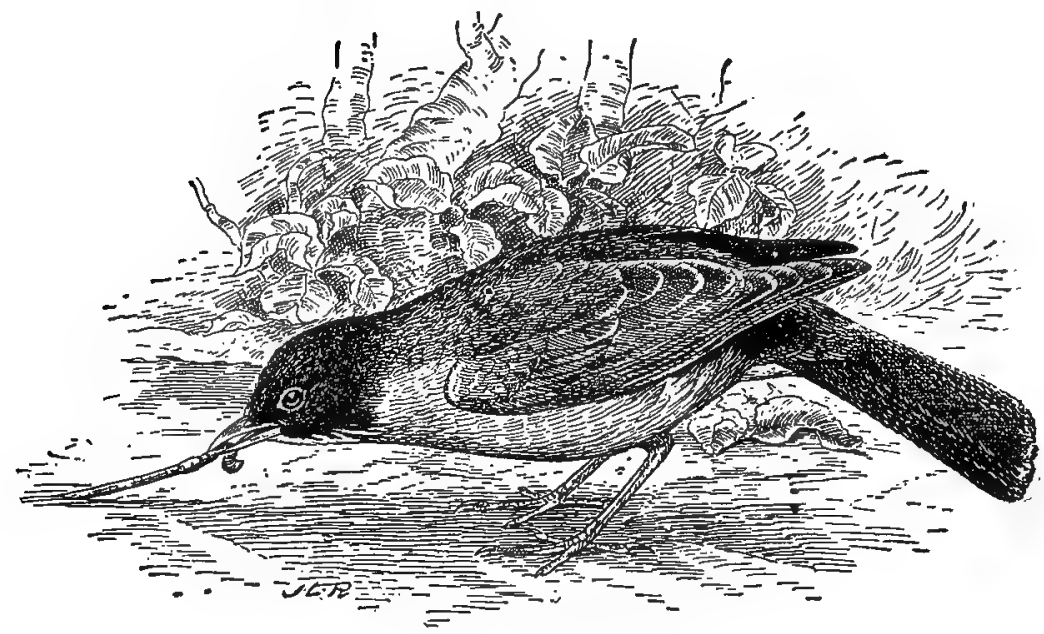

761. RoBIN (From Beal.)

761a. WESTERN ROBIN. Merula migratoria propinqua Ridgw. Geog. Dist.- Western United States east to and including Rocky Mountains, south into Mexico.

The general habits, nesting and eggs of this Western form of the Robin are like those of the Eastern species. Mr. Walter E. Bryant notes a pair of these birds that nested and reared a brood in a hanging basket suspended from the edge of a veranda. at the residence of $\mathrm{Mr}$. H. G. Parker at Carson, Nevada.

762. ST. LUCAS ROBIN. Merula confinis Baird. Geog. Dist.-Cape region of Lower California; accidental at Hayward, California.

This is a distinct species inhabiting the cape region of Lower California. The adult bird resembles a young robin. The eggs are unknown.

763. VARIED THRUSH. Hesperocichla ncvia (Gmel.) Geog. Dist.-Western: North America, chiefly near the Pacific coast, from California to Bering Strait. Breeds chiefly north of the United States; east casually to New Jersey, Long Island. and Massachusetts.

In various parts of Alaska this is a common breeding bird. A few are known to breed in the spruce forests of Washington, but their breeding grounds are chiefly north of the United States. According to Dr. Brewer, Mr. W. H. Dall furnished the: first authentic knowledge concerning the nest and eggs of the Varied Robin as he: found them in Alaska. The nest found by him was built in a willow bush, about two feet from the ground, and upon the top of a large mass of rubbish lodged there by some previous inundation. It measures six inches in diameter with a depth of two, and one-half inches. It has but a very slight depression, apparently not more than half an inch in depth. The original shape of the nest had, however, been somewhat flattened in transportation. The materials of which it was composed were fine dry mosses and lichens impacted together, intermingled with fragments of dry stems of grasses. Other nests of the same species were met with in several places between Fort Yukon and Nulato, always on or near a river bank and in low secluded localities. 


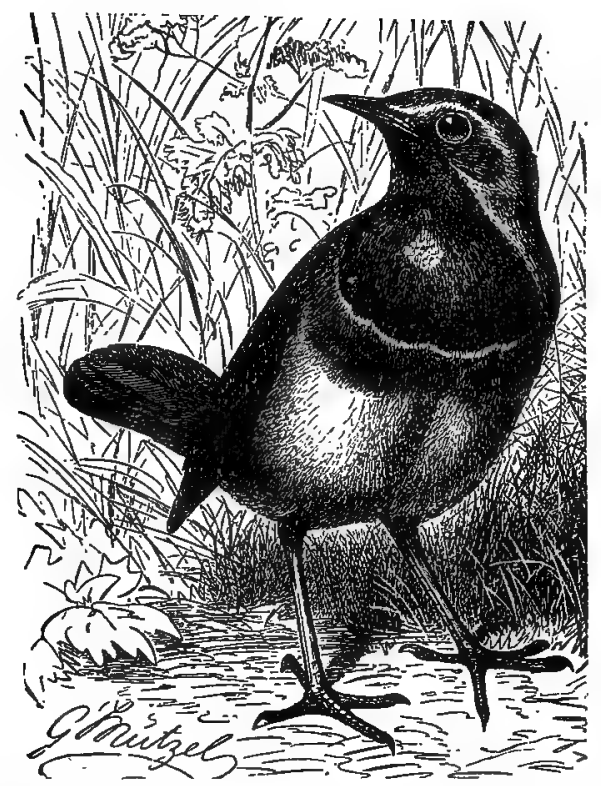

764. RED-SPOTtED BLdethroat (From Brehm.)

A nest of this thrush obtained by Dr. Minor, in Alaska, is a much more finished structure. Its base and periphery are composed of an elaborate basketwork of slender twigs. Within these is an inner nest consisting of an interweaving of fine dry grasses and long gray lichens. The eggs are described as pale greenish-blue, sparingly but distinctly sprinkled and spotted with dark umber-brown, size 1.13x.80.

[764.] RED - SPOTTED BLUETHROAT. Cyanecula suecica (Lynn.) Geog. Dist.-Northern Europe and Asia; casual in Alaska.

This beautiful and interesting bird, known as the Blue-throated Redstart, is widely distributed in the Old World, breeding in the more northern portions -Norway, Sweden, Russia and Siberia. In June, 1851, Dr. Adams found a flock of these birds feeding about some willows in the vicinity of St. Michael's, Alaska. The nest is placed on the ground, midst the larger herbage, in the cavities of banks and under low brushwood, usually well concealed. It is composed of dry grass, moss, withered leaves, roots, and is lined with finer mosses, hair and the down of cotton-grass. The eggs are four to 'six in number, generally a greenish-blue, but varying to grayish-green or olive; they are spotted with reddishorown, which is usually thickest and deeper at the larger end. The average size is

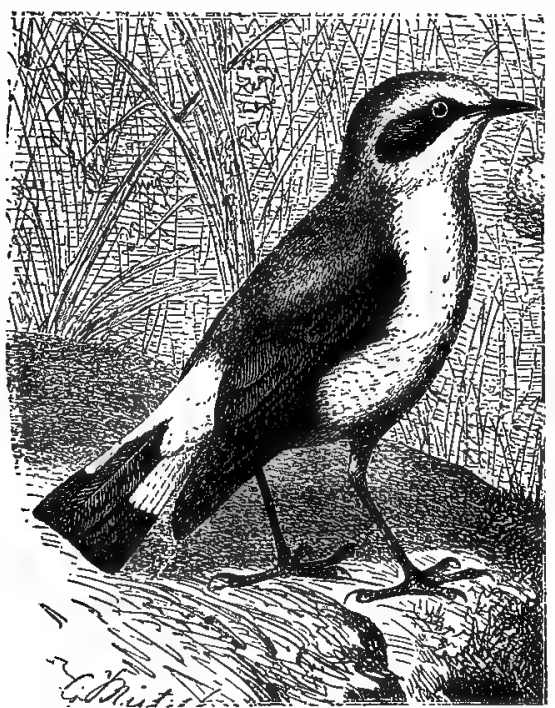

765. WHEATEAR (From Brehm.) $.75 \times .53$ inches.

765 WHEATEAR. Saxicola onanthe (Linn.) Geog. Dist.-Europe, Northern Africa, Asia, Greenland and Labrador, straggling south to Nova Scotia, Maine, Long Island and the Bermudas.

The well-known Wheatear of the old World is common in Greenland and probably also breeds in Labrador. Dr. C. Hart Merriam makes note of its probable breeding on the north shore of the Gulf of St. Lawrence-at Godbout. A female was shot by .Mr. Napoleon A. Comeau, June 9, 1885, in which the eggs were pretty well developed. Its mate was also seen and it is presumed that the birds would, in all probability, have bred in the vicinity. The Wheatear breeds throughout the British Lslands, and in all of Northern Europe and Asia. In the British Islands it begins to make its nest in May. This is usually well hidden in the innermost recess of some crevice among rocks, in an old wall, stonequarry, gravel-pit, and frequently in a deserted rabbit burrow. Mr. Hewiston has known a pair to make their nest in the de- 
serted hole of a Sand Martin in a river bank. The nest is rudely constructed of grass, moss, hair, wool, rabbits' fur, or any rubbish obtainable. The eggs usually range from four to six in number and are of a pale, plain greenish-blue. A set of four eggs collected ŕear Larne, Ireland, May 30, 1882, is in my collection. Their sizes are $.88 \times .60, .88 \times .59, .94 \times .60, .99 \times, 61$ inches.

766. BLUEBIRD. Sialia sialis (Linn.) Geog. Dist.-Eastern United States, north to Nova Scotia, Ontario, Manitoba, etc., west to the Rocky Mountains. Resident in the Bermudas.

In its several forms the Bluebird is an inhabitant of the entire temperate North America, and especially the eastern bird and aIso the western variety, occidentalis, are familiar to all who study bird life in the regions in which they are to be found. Dr. J. G. Cooper has aptly said that the Bluebird always bears the national colors, red, white and blue, and that it is one of the most strikingly peculiar of American singing birds, and in its habits a model of civilized bird life. Its natural nesting places are in the deserted excavations of Woodpeckers, hollows of trees, and even in the crevices of rocky cliffs. With the progress of civilization the Bluebird has taken advantage of modern surroundings, adopting the boxes that are put up for its use, nesting also in every conceivable nook and corner in houses and barns. Very frequently letter boxes upon fences are taken possession of. I found a Bluebird's nest in the interior of a wheel of a railroad car during the strike a few years since, and on another occasion, in Morrow county, Ohio, I discovered a brood of young Bluebirds in a Cliff Swallow's nest under the eaves of an old barn. The normal color of the eggs of the Bluebird is uniform pale blue, unspotted. They are four, five, and sometimes six in number, and their average size is $.84 x .62$. The eggs of this bird are frequently very light bluish-white, and rarely pure white. All found in one nest are of one tint; that is to say, a white egg is never found in a set with the blue ones.

766a. AZURE BLUFBIRD. Sialia sialis azurea (Swains.) Geog. Dist.Southern Arizona and Eastern Mexico.

This bird has the same habits of $\mathbb{S}$. sialis and the eggs are indistinguishable. Breeds in Southern Arizona and southward.

767. WESTERN BLUEBIRD. Sialia mexicani occidentalis Swains. Geog. Dist.-Western United States, from the Rocky Mountains to the Pacific, south to . Southern Mexico.

An inhabitant of Western United States north to British Columbia. Its habits are exactly similar to those of the Eastern Bluebird. It nests in holes and cavities of decayed trees, between their trunks and the loose bark, making the nest of sticks, grasses, straws, and almost any rubbish procurable. Mr. Walter E. Bryant states that Dr. Cooper informs him that he has known a Bluebird to build in a Cliff Swallow's nest. The eggs of this species are four or five in number, uniform pale blue, of a slightly deeper shade than those of the preceding species, and average $.81 x .62$ inches.

767a. CHESTNUT-BACKED BLUEBIRD. Sialia mexicana bairdi Ridgw. Geog. Dist.-Rocky Mountain district, south to Northern Mexico.

The habits and characteristics of this subspecies are identical with those of $\mathbb{S}$. siatis. 
767b. SAN PEDRO BLUEBIRD. Sialia mexicana anabele Anthony. Geog. Dist.-San Pedro Martir Mountains, Lower California.

I have no positive information regarding the nidification or habits of this subspecies, but they probably do not differ materially from those of the next species.

768. MOUNTAIN BLUEBIRD. Sialia arctica (Swains.) Geog. Dist.-Rocky Mountain region, north to Great Slave Lake, south to Mexico, west to the higher mountain ranges along the Pacific.

Known as the Rocky Mountain and Arctic Bluebird. It is very common in the Rocky Mountain region and is also abundant as far west as the mountain ranges. along the Pacific. Breeds in deserted Woodpecker holes, natural cavities of trees, etc. In settled portions of the West it nests in the cornice of buildings, under the eaves of porches, in the nooks and corners of barns and out-houses, and in boxes provided for its accommodation. Mr. Walter E. Bryant says that three incubated eggs of this species were taken from the nest of a Barn Swallow, at Lake Tahoe, California, by Walter Bliss. Prof. Ridgway found the Rocky Mountain Bluebird breeding in Virginia City, Nevada, in June. Its nests were built about old buildings and occasionally in the unused excavations about mines. Mr. Wilbur F. Lamb informs me that in Summit county, Colorado, he found this species nesting generally in old Woodpeckers' excavations. One nest was found placed under the projecting roofpales of a miner's cabin. The nests were composed almost entirely of dry grass. In some sections, however, the inner bark of the cedar enters largely into their composition. In most cases Mr. Lamb found the nests to contain five eggs, though seven perfectly fresh eggs were taken from one nest, while another contained only three in an advanced stage of incubation. So that taking the reports of other collectors into consideration with Mr. Lamb's experience, the bird lays from three to seven eggs, rarely the latter number, and more commonly five. They are pale, plain greenish-blue and average $.85 \times .63$ inches.

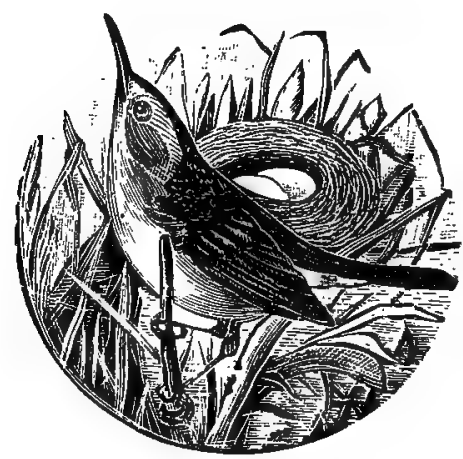




\section{APPENDIX.}

Since the foregoing pages have been put into metal I have received notes on the nesting habits of the following species. In some cases their nidification has hitherto been unknown, and is not mentioned under their respective titles in the body of this work:

\section{XANTUS'S MURRELET. Brachyramphus hypoleucus Xantus.}

Here is probably the frst knowledge we have regarding the nesting and eggs of Xantus's Murrelet. Two sets of two eggs each are in the extensive oological collection of Mr. C.. W. Crandall, Woodside, N. Y., and to this collection I shall have occasion to refer several times in this Appendix on account of the new material recently acquired of especial interest to ornithologists and oölogists. The eggs of this species were collected by the well-known ornithologist, A. W. Anthony, on San Benito Island, Lower California, March 28th, 1897. The nests were in clefts of rocks and the birds had to be lifted from the nest before the eggs could be secured. The ground color is almost an exact raw umber, over which are spots and blotches of walnut brown and umber with under shell markings of a much lighter shade. These are sparingly distributed at the large end, where they form somewhat of a wreath, though not massed together so as to lose their distinctness. Set No. 1 measures $2.10 \times 1.39,2.13 \times 1.39$; No. $2,2.12 \times 1.47$, $\times 2.06 \times 1.43$ inches respectively.

\section{9a. RIDGWAY'S TERN. Anous stolidus ridgroayi.}

This new species of Tern was found breeding on Socorro Island, Mexico, about the middle of May, 1897, depositing its single egg on the bare rocks. The eggs are hardly distinguishable from those of the Noddy Tern. Five eggs in Mr. Crandall's collection measure respectively as follows: $2.00 \times 1.43,2.00 \times 1.46,1.96 \times 1.36,1.99 \times 1.40$, 2.15 $\times 1.47$ inches.

93. BLACK-VENTED SHEARWATER. Puffinus gavia (Forst.)

A. W. Anthony collected eggs of this species on Nativadad Island in April, 1897. The nests were in burrows in the sand five or six feet deep, and the birds were taken on their nests. A single egg is laid; it is of a clear, pure white texture, elongate ovate in shape and quite pointed. Three sets of one egg each are in Mr. Crandall's collection and measure as follows: $2.36 \times 1.57 ; 2.33 \times 1.59 ; 2.54 \times 1.69$ inches, respectively.

206. SANDHILL CRANE. Grus mexicana (Mull.)

W. C. Mills, of Chicago Junction, Huron Co., O., took near that place on May 15, 1897, two sets of two eggs each of the Sandhill Crane, and on the 18th another set of two. This establishes the fact that the bird very likely breeds regularly in Northern. 
Ohio. A few years ago I mounted a specimen which was killed out of a flock of eight or ten near Springfield, Ohio. In 1882 the late Dr. Wheaton wrote as follows concerning this bird: "Rare migrant; probably occasional summer resident. Mr. Winslow includes it in his list of birds of Northern Ohio, and it has been reported to me as breeding within a few years in the vicinity of Toledo. Mr. Langdon mentions two specimens taken in the vicinity of Cincinnati. I have never seen the bird in this vicinity, and though I have frequently heard of its occurrence, the identification has never been unquestionable. Both this bird and the Blue Heron are sometimes confounded under the common name of Blue Crane."

\section{* REDSHANK. Totanus totanus (Linn.)}

The European Redshank has been recorded as North American on the ground that a specimen was taken in the Hudson Bay region and was formerly in British Museum (Cf. Faun. Bor.-Am. II, 1831, p. 391). The bird breeds nearly throughout the whole of Europe, placing its nest in a mere hollow of the ground. A set of four eggs taken in North Britain May 7, 1891, exhibit the following dimensions: 1.71x $1.22,1.75 \times 1.27,1.72 \times 1.24,1.76 \times 1.26$ inches. They are pyriform in shape; the groundcolor being of a pale buff; this is spotted and blotched with a rich seal brown, mingled with under shell markings of gray and lavender, these tending to form a ring about the large ends.

\section{1. FRAZAR'S OYSTER-CATCHER. Homatopus frazari Brewst.}

This species was found breeding by A. W. Anthony on San Roque Island in. June, 1897. Mr. Crandall has a set of two eggs, taken by Mr. Anthony June 21. The nest from which these were taken was a simple hollow on top of a bluff; it was lined with pebbles. The color of one egg is creamy buff, the other more of an olive buff. Both specimens are spotted and blotched with brownish-black and purplish-gray shell markings. Their sizes are $2.33 \times 1.52,2.35 \times 1.52$ inches, respectively. Mr. Crandall says: "In comparing these eggs with sets of the American and European Oyster-catchers in my collection, I find the shade of ground-color is exactly midway between the two species, darker than the American and lighter than the European. In shape they are elongate ovate."

\section{2a. ALASKAN BALD EAGLE. Halicetus leucocephalalus alascanus.}

Mr. C. H. Townsend says of this new subspecies as follows: (Proc. Biological Society, Wash., Vol. XI, pp. 145-146, June.9, 1897.) "In forty specimens examined from localities between Florida and Alaska there is a regular increase in size northward. Eagles from Northern States are larger than those from Florida and Louisiana. In addition to the other differences in size, the bill of the Alaskan bird is wider, while the edging to the feathers, especially on the wing coverts, is both lighter and broader. The egg of the northern bird is distinctly larger, the average of sixteen specimens being $73.5 \times 57.5 \mathrm{~mm}$, while that of forty-five Florida specimens is $69 \times 53.5 \mathrm{~mm}$." Mr. Crandall has a set of two eggs of this variety, taken by Mr. Geo. G. Cantwell at Houcan, Alaska, May 19, 1897. The nest was placed in a dead spruce seventy feet from the ground. It was made of coarse sticks and lined with moss. The eggs measure $2.94 \times 2.37 ; 2.88 \times 2.35$ inches, respectively. In shape and color they are the same as those of the Bald Eagle of the South, but the shell appears to be thicker. 
365. AMERICAN BARN OWL. Strix pratincola Bonap.

The Monkey-faced Owl, as it is commonly called, was formerly considered a rare visitor in Ohio. It is now a very common resident ańd breeds. Dr. Howard Jones informs me that in May, 1897, he found a set of eight eggs in the hollow of a sycamore tree near Circleville, Ohio, and also secured the parent bird. I know a farmer not far from Columbus who raises these birds in confinement and they thrive well. As a taxidermist I mounted no less than twenty specimens in 1897, from various localities in Ohio.

373g. AIKEN'S SCREECH OWL. Megascops asio aikeni Brewst.

Mr. D. P. Ingraham found a nest containing three eggs of this subspecies in Pueblo county, Colorado, April 28, 1896. The parent bird was captured and was identified by Dr. J. A. Allen. The nest was in an old hole in a cedar tree about eight feet from the ground. The eggs in shape and color are like others of the genus and measure $1.45 \times 1.23,1.44 \times 1.24,1.44 \times 1.23$ inches. These eggs are in $\mathrm{Mr}$. Crandall's collection and are probably the first authentic specimens that have been taken

374. FLAMULATED SCREECH OWL. Megascops flammeola (Kaup.)

Two sets of this species were taken in Pueblo county, Colorado, in May, 1897, by D. P. Ingraham. One of three nests taken on the 29 th contained three eggs. The nest was in an old excavation of a woodpecker, about twenty feet from the ground in a quaking aspen tree. The altitude was 7800 feet. The three eggs measure $1.25 \times 1.03,1.22 \times 1.01,1.21 \times 1.02$ inches $A$ nest was found on the 27 th in a pine stub, about eighteen feet from the ground in an old woodpecker's excavation, at an altitude of 7200 feet This nest contained two eggs and measure as follows: $1.28 \times 1.03,1.25 \times 1.05$ inches. The eggs are white with a faint cream color, oval in shape, shell finely granulated and only slightly glossy.

401b. ALPINE THREE-TOED WOODPECKER. Picoides americana dorsalis Baird.

In Custer county, Colorado, Mr. Ingraham took a set of three eggs of this bird June 9, 1897. The nest was in an aspen tree about sixteen feet from the ground, at an altitude of 8000 feet. The eggs are pure shining white in color, almost ovate in shape and offer the following dimensions: $1.03 \times .72,1.00 \times .71$ and $1.00 \times .71$ inches. These are in Mr. Crandall's oölogical collection, and are doubtless the first genuine eggs of this bird known to science. 



\section{PART II.}

\section{ORNITHOLOGICAL ^No OÖLOGICAL}

COLLECTING. 



\section{CHAPTER I.}

\section{OOLOGICAL COLLECTING.}

An egg collected without being authentically identified is worth absolutely nothing. My younger readers should pay particular attention to this remark. When a nest containing eggs which are unknown is discovered, the bird should be shot, skinned and preserved. Its identification should be determined by a competent. judge. I shall treat of the skinning and preparation of skins in the following chapter. The novice, of course, will destroy more animal life than the experienced. He will probably kill a Song Sparrow for a Swamp Sparrow-a Crow for a Raven, etc. Therefore I shall not urge the new beginner to kill a bird of which he is ignorant in order to identify the oölogical specimens belonging to its nest. The old student will take as few lives as possible, for he is better acquainted ornithologically with the avifauna which he is studying. In order to study oölogy we must take care of these objects existing around us, and if the naturalist does not call a halt on their extermination, who will? Animal life must be protected by the naturalist for, if it is exterminated, where has his delightful study gone? Experienced taxidermists, ornithologists and oölogists will make better game wardens than politicians! Why? Because we cannot afford to kill the goose which lays the golden egg! She may lay another.

Who on earth could be more desirous of preserving animal life than we? Nobody, not a single person. These side remarks are intended for no other purpose than to show who are the best able and capable to take care of those things which they love the most.

These directions for collecting and preserving birds, nests and eggs, and the whole contents of this work are intended to assist the true naturalist in the delightful subject herein treated. For those who idly roam the woodlands and pebbly shores, collecting everything in reach with aimless intent, this book was never calculated.

To every person who loves to study in the great fleld of Nature; to those especially who are deeply interested in the habits of the feathered tribe, the protection of bird life is of the utmost importance.

Surely none of the readers of the foregoing pages are engaged in the wholesale collecting of eggs for purely mercenary purposes, sacrificing and depopulating our birds, and screening their fiendish acts under the gauzy lace of science!

Empty the contents of an egg through one smoothly drilled hole in the side, and drill it as small as can be got along with. Force the contents out by blowing into the hole with a blow-pipe. Do not make holes at the ends of an egg for the purpose of blowing the contents out. If the embryo is partially developed, the hole must necessarily be made larger, and the embryo should be extracted a little at a time with an embryo hook or forceps, and cut in pieces with a fine, narrow-bladed scissors. By soaking the egg in water over night the embryo will often become very tender and can be taken out with ease. 
After the egg is blown it should be thoroughly rinsed by taking water into the mouth and spirting it through the blow-pipe.

Eggs, as a rule, should be kept in sets; a "set" being those taken from any one nest; and each one of a set should bear a number referring to a corresponding one in a note-book where full particulars of the nest and eggs should be given. A printed label or data blank similar to the following diagram is also necessary:

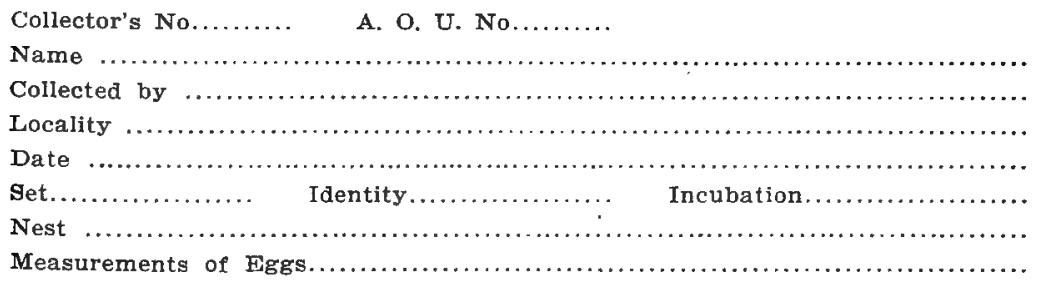

For illustration, the blank lines of the label should be filled in the following manner: Collector's No. 126. A. O. U. No. 447. Name, Arkansas Flycatcher. Collected by J. L. Clemmons. Locality, San Diego, California. Dated, June 2, 1881. Set, 1/4 (indicating that the number of eggs in this set is four). Identity, bird shot. Incubation, begun. Nest, made of coarse sticks and twigs, lined with hair and cotton, placed in an "Australian Gum Tree," twenty feet from the ground. All these data should be carefully written, and the label placed in the cabinet with the eggs. If there are several sets of the same species, the collector should have his own number to distinguish the sets. The label with full data should alvays accompany the set in making exchanges. Besides the above particulars the note-book should be filled with memoranda devoted to the records of nests found and examined; the general nature of the surroundings; the precise color and condition of the eggs when found, as all these fade quickly from the memory.

Nests that can be collected require a wrapping of thread for their safe keeping, as shown in Fig. 10, Plate 1.

In climbing high trees, climbing irons are often used. A wooden or tin box, filled with cotton, should be taken up with you; in this, securely place the eggs before descending the tree.

When eggs are to be shipped by mail or express they should never be packed in anything but wooden or tin boxes. Each egg should be wrapped in cotton and bound tightly with thread and then wrapped in tissue paper. Place them in layers in the box with bits of cotton between each egg The bottom, sides and end of the boxes are often lined with sheet cotton which is still better protection.

In all ordinary cases collections of eggs are preserved in the drawers of a cabinet. These, are divided by partitions, and each section partly filled with grated cork or box-wood sawdust, in which the eggs are placed. The choice of a rabinet must depend largely upon the collector's means, if not also upon his individua: preference.

The very best trays or boxes ever designed for keeping eggs in the drawers of a cabinet or for exhibition purposes are those manufactured by E. J. Schaefer, No. 338 Second street, New Orleans, Louislana. They are neatly made of paste-board, the sides and bottom are ingeniously cushioned with strips of sheet cotton. Each box has a lid on which the label can be pasted. These boxes are made to suit all sizes of eggs, and range in price from $\$ 2.50$ to $\$ 8.00$ per hundred, according to size. 
PLATE I,

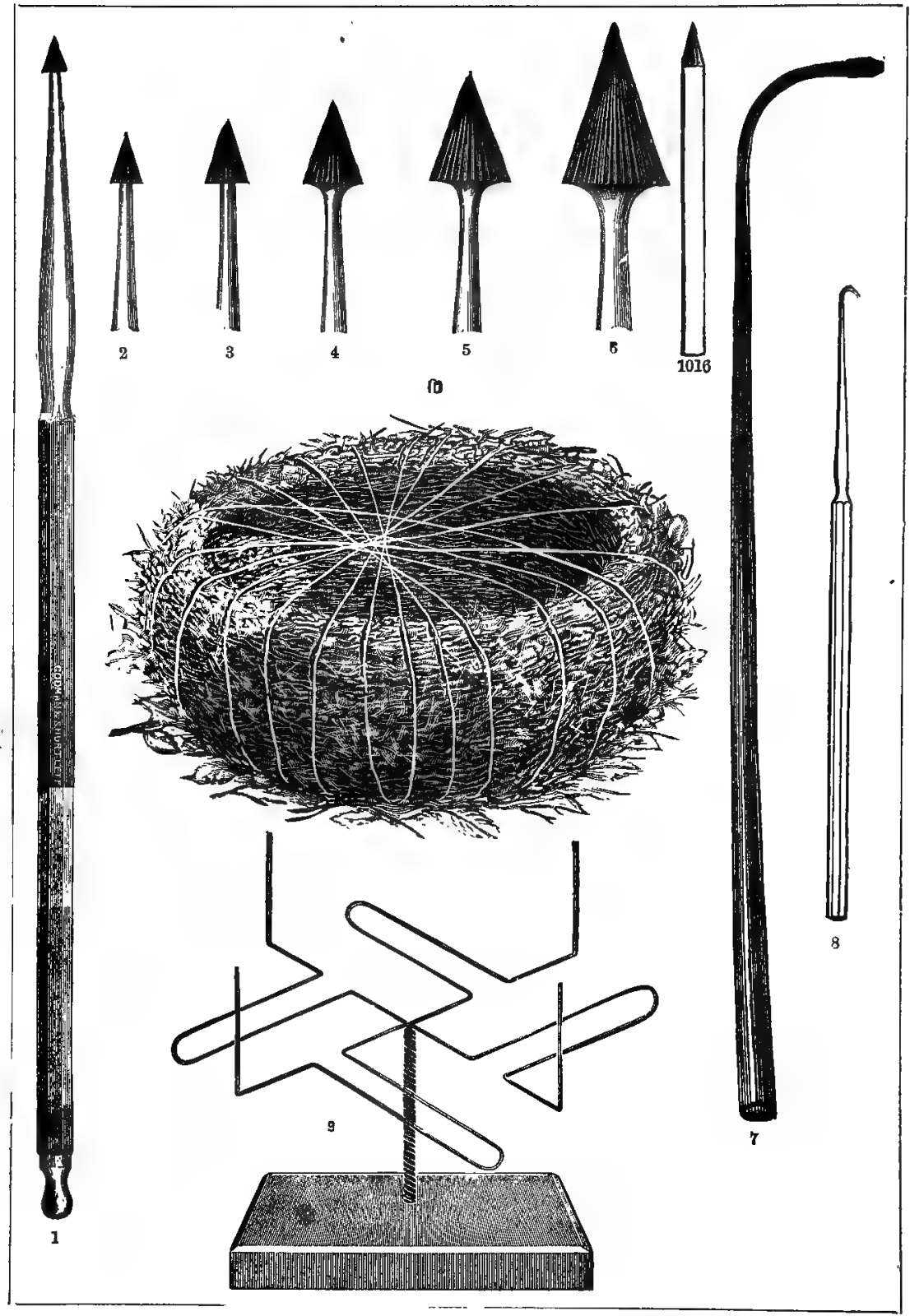

OOLOGICAL, INSTRUMENTS. 
In our Plate are figured the various instruments used in the collecting and preparation of birds' eggs. The egg drills are made with octagon handles six inches long, as represented by Fig. 1, in Plate 1. The sizes of the burrs, as will be seen in Figs. 1 to 6 , range from 3-32 inch to $16-32$ inch. The following is a list of the essential oölogical instruments, with their prices:

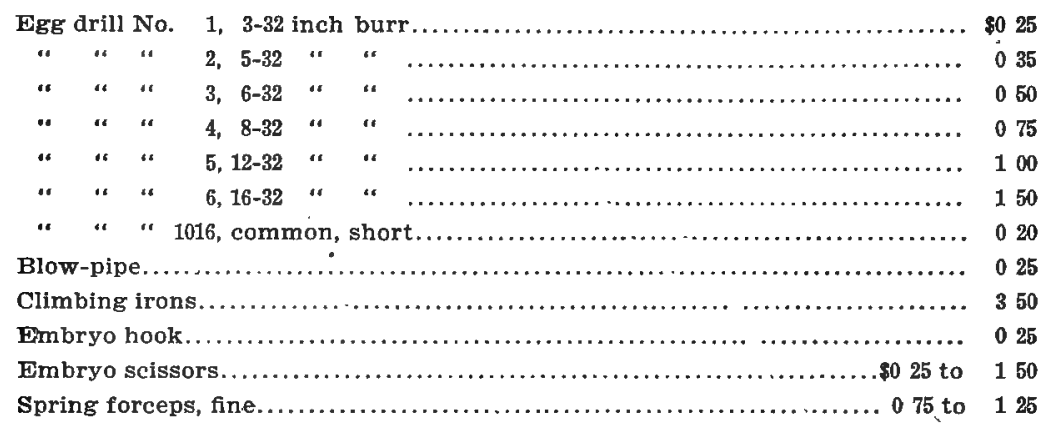

If you are just beginning to make a collection of eggs, two or three drills are all that are necessary for ordinary purposes, Nos, 1, 3 and 5 being the most desirable sizes. If you are to make an extensive collecting trip to remote regions, the entire outfit enumerated above should be taken with you.

The style of arrangement for mounting birds' nests by the late Maj. Bendire is illustrated in Fig. 9 of our Plate.

\section{CHAPTER II.}

\section{THE SKINNING AND MAKING UP OF BIRD SKINS.}

The following is taken almost entirely from the writer's "Methods in the Art of Taxidermy."

In this chapter. I propose to tell you how to skin birds and to make them into a shapely form. With the assistance of the illustrations each procedure will be so clearly depicted that the student will, I believe, about as readily understand the system of work as though he were to see the actual operations performed on the bench. For our first attempt we shall try the American Robin Merula migratoria (Linn.), and I care not if it be Mr. Ridgway's Western representative, Merula mipropinqua-it's a robin just the same. All the principles of skinning the robin will be given, while all the variations and exceptions in the skinning of other birds form the size of a hummingbird and upwards will be found chiefly in foot-notes. It will, therefore, make very little difference what kind of a bird you may have in hand to work upon.

Before we begin operations however, you will doubtless want to know how to "cure" or preserve the skin of a bird-the materials used. They are, in fact, very 
simple. Some taxidermists use nothing but the common pulverized arsenic, whtch they sprinkle over the inside of the skin. Others prefer the old-time arsenical soap, which is very good and can be bought from any dealer in natural history materials, or you can make it yourself, and I herewith give the formula:

ARSENICAL SOAP.

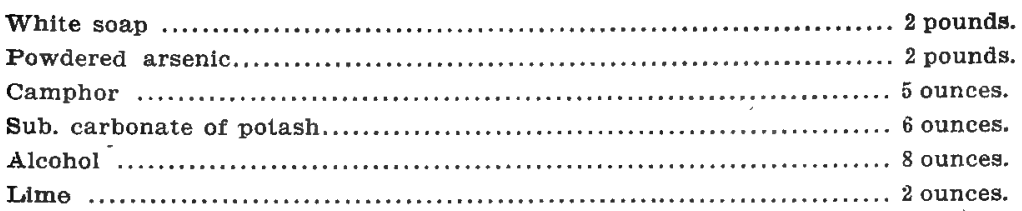

Directions.-Slice the soap and melt it in a small quantity of water over a slow tire, stirring it sufficiently to prevent its burning. When melted, add the potash and lime, and boil until it becomes quite thick. Now stir in the powdered arsenic, after which add the camphor, previously dissolved in the alcohol. When the mass has been boiled down to the consistency of thick molasses, pour it into an earthen jar to cool and harden. Stir it frequently while cooling to prevent the arsenic settling to the bottom. When cold it should be like lard or butter. For use, mix a small quantity with water until it resembles buttermilk, and apply with a common paint brush.

The preservative which I have always used is the following:

-

ARSENICAL SOLUTION AND ARSENICAL PASTE.

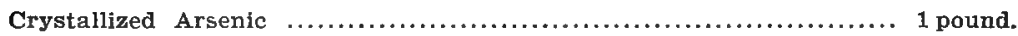

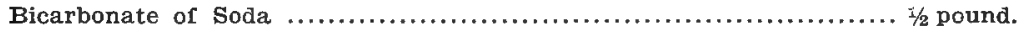

Place these two ingredients in a vessel containing five pints of water and boil the whole down to three pints, or until the arsenic and soda have disappeared, stirring frequently to keep them from settling to the bottom. Crush the large pieces of arsenic in order that they may more quickly dissolve. When cold it is ready for use. Put the liquid in a large bottle, properly labeled, "Poison." When a quantity of this solution is mixed with common whiting to the consistency of cream it is ready to be applied to the inside of skins with a brush, and is called Arsenical Paste. For the purpose of mixing the solution and whiting take a wide-mouthed bottle or a shallow dish and keep a large and a small brush in it for use on the various sizes of skins. The beauties of the Arsenical paste are, that it is quickly and easily made, is cheap, makes a most substantial coating and its poisonous effect on skins is equal to anything of the kind made, not excepting the time-tried Arsenical Soap.

\section{INSTRUMENTS.}

i dissecting case which can be purchased for $\$ 3.50$ will be found serviceable at home and in the field. It contains:

1 cartilage knife.

1 scalpel.

1 pair of scissors.

1 dissecting point.

1 pair of forceps.

1 hooks and chain.

1 blow-pipe and drill. 


\section{GUNS AND AMUNITION.}

The choice of a gun for the purpose of shooting sepcimens must depend largely upon individual preference or the means of the collector. The most improved double-barreled, hammerless shotgun is of course desirable; Nos. 10 or 12 gauges being at the present time preferred. A No. 16 or 20 gauge will be found to serve about as well in most cases for ornithological collecting purposes. Auxiliary barrels, No. 32 gauge, are now made to fit in the 10 or 12 gauge guns; these are very handy, and the brass shells made for them can be loaded at a trifling cost.

A five-shot No. 38 taxidermist's gun with brass shells is also manufactured and sold by dealers in naturalists' supplies. This makes an excellent collecting gun for small birds, from the size of warblers and upwards to that of a blackbird. In this gun and in the shells for the auxiliary barrels the smallest size shot are used, called "mustard seed." In shooting birds with the larger guns the size of the shot and weight of charge must be duly considered. For any North American bird Nos. 8 or 5 shot will usually prove effective, even upon the largest species within gun range.

The chief object in shooting a bird is to shoot to kill, not to mangle. A bird well shot for the ornithologist is as good as a "stitch in time." The minute a dead birds falls into your hands plug the mouth, nose-holes, vent and shot-holes with cotton in order to prevent the blood or liquids from further soiling the plumage. Put the dead bird in a paper cone, head first, and place it in your collecting satchel. The large birds you must treat in the same manner and carry them home the best way to suit your convenience.

With the above knowledge of what is necessary for the preservation of the skins of birds and the instruments required for the work we shall proceed to skin the robin. Perhaps you have carried the bird wrapped in a paper cone in your satchel or collecting box for a half day or more and the rigor mortis has passed off. The cotton in all the shot-holes, mouth, nose-holes, ear cavities and rent should be taken out and carefully renewed, as this will prevent the blood and liquids from soiling the feathers during the process of skinning. ${ }^{1}$ A strict observance of this rule in all cases will often save a great amount of labor in cleaning the feathers after the bird is skinned. Have a box of corn meal or plaster of Paris at hand; this should be frequently and profusely sprinkled on the carcass, if very fat, to absorb any blood or grease which is liable to soil the feathers. ${ }^{2}$ The first thing to do before you proceed to skin the bird is to take full measurements of the specimen and record them in

1. FILLING EAR CAVITIES_-As a rule it is not necessary to fill the ear cavities with cotton, except in the case of owls and other birds which have very large ear orifices.

2. FASTENING THE BFAKS OF BIRDS TOGETHER WHILE SKINNING.-In

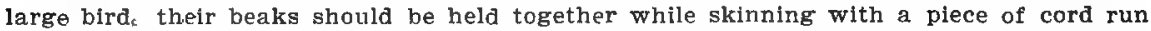
through tice nose-hole, and under the lower mandible and tied fast. A small piece of bee's wax will hold together the beaks of the majority of small birds. To the beginner this precaution may seem superfluous after having plugged the mouth, nose-holes, vent, etc., with cotton; but It frequently will save him a vast amount of labor in cleaning blood and liquids from specimens that mfght otherwise come through and stain the feathers. 
your note-book.' You may now brcak the humerus or upper arm bone of each wing with your fingers in order that the wings will hang down out of the way. ${ }^{2}$ Lay the bird on its back and separate the feathers along the breast, and with a scalpel or sharp pen-knife make an incision, beginning high up on the breastbone and down

1. DIRECTIONS FOR MEASUREMENT OF BIRDS.-I cannot recummend any other system of measurement than that given by Dr, Elliott Coues in his matchless work: Key to North American Birds. His directions are as follows:

For large birds, a tape-line showing fourths will do; for smaller ones, a foot-rule graduated for inches and eighths, or better, decimals to hundredths, must be used; and for all nice measurements the dividers are indispensable.

Length.-Distance between the tip of the bill and end of the longest tail-feather. Lay the bird on its back on the ruler on a table; take hold of the bill with one hand and of both"legs with the other; pull with reasonable force to get the curve all out of the neck; hold the bird thus with the tip of the bill flush with one end of the ruler and see where the end of the tail points.

Put the tape-line in place of the ruler, in the same way for larger birds.

Extent.-Distance between the tips of the outspread wings.

They must be fully outstretched, with the bird on its back, crosswise on the ruler, Its bill pointing to your breast.

Take hold of right and left metacarpus with the thumb and forefinger of your left and right hand, respectively, stretch with reasonable force, getting one wing-tip flush with one end of the ruler, and see how much the other wing-tip reaches. With large birds pull away as hard as you please, and use the table, floor or side of the room; mark the points and apply tape-line.

Length of Wing.-Distance from the carpal angle formed. at the bend of the wing to the end of the longest primary.

Get it with compasses for small birds. In birds with a convex wing, do not lay the tape-line over the curve, but under the wing in. a straight line. This measurement is the one called for short "the wing."

Length of Tall.-Distance from the roots of the rectrices to the end of the longest one. Feel for the pope's nose; in either a fresh or dried specimen there is more or less of a palpable lump into which the tall feathers stick. Guess as near as you can to the middle of this lump; place the end of the ruler opposite thist point, and see where the tip of the longest tail-feather comes.

Length of Bill.-Some take the curve. of the upper mandible; others the side of the upper mandible from the feathers; others the gape, etc. I take the chord of the culmen. Place one foot of the dividers on the culmen just where the feathers end; no matter whether the culmen runs up on the forehead, or the frontal feathers run out on the culmen, and no matter whether the culmen is straight or curved. Then with me the length of the bill is the shortest distance from the point just indicated to the tip of the upper mandible; measure it with the dividers. In a straight bill of course it is the length of the. culmen itself; in a curved bill, however, it is quite another thing.

Length of Tarsus.-Distance between the joint of the tarsus with the leg above, and that with the first phalanx of the middle toe below. Measure it always with dividers, and in front of the leg.

Length of Toes.-Distance in a straight line alnng the upper surface of a toe from the point last indicated to the root of the claw on top. Length of toe is taken without the claw, unless otherwise specified.

Length of the Claws.-Distance is a straight line from the point last indicated to the tip of the claw.

Length of Head.-Is often a convenient dimension for comparison with the bill. Set one foot of the dividers over the base of the culmen (determined as above) and allow the other to slip snugly down over the arch of the occiput.

2. BREAKING THE HUMERUS IN BIRDS' WINGS.--This is of little importance and entirely a matter of habit. As for myself I prefer never to break the upper arm bone of any bird, even if the wings do come constantly in the way during the process of skinning. It is easler to skin a bird after the rigor mortis has passeu off than while it remains in its death stlffi_css. This comes on more or less speedily according to temperature and climate, and a freshly killed bird at all times bleeds too freely to skin. It should be given time for the blood to coagulate and the muscles to relax. (Continued on next page.) 
to the vent ${ }^{1}$ (Plate 2, Fig. $1 a$ to $b$ ). Do not cut through the wall of the abdomen, for the intestines, blood, etc., will come out and give you trouble. Now raise the skin carefully along the cut until the muscles of the leg are visible; push gently, but with sufficient force until the knee-joint protrudes, and cut it off here (Plate 2, Fig. $2 d$ ), leaving the thigh attached to the body. ${ }^{2}$ Most of the cutting from this point until the bird is flnished may be done with the scissors. Skin the leg down to the heel, strip the flesh off perfectly clean (Plate 2, Fig. 3 f) and poison thoroughly with arsenical paste or arsenical soap (see formulas, page 7). ${ }^{3}$ Proceed in the same manner with the other leg, then loosen the skin down on the back as far as possible, stand the bird on its breast, bend the tail and cut carefully through the tail joint or pope's nose (Plate 2, Fig. $4 \mathrm{~g}$ ). In doing this you will find it necessary to work slowly and carefully in order to avoid cutting the skin. You may now hang the specimen up on one of the hooks suspended from the ceiling. Be sure, however, to leave enough of the pope's nose to hold the feathers fast. Skin down the body, cut off one of the wings at the shoulder joint, as indicated by the dotted lines in Fig. $5 h$, Plate 2. Strip off the flesh from the humerus or upper arm bone and also the forearm (ulna and radius) or double bones, detaching the secondaries of the wing down to the carpus or wrist joint (Fig. $6 l$, Plate 2). In the smaller birds, like the robin for example, you may cut the wing-bones off at the dotted lines in Fig. 6, Plate 2,

With a little care and gentle force, after hanging the bird on the hook you can peel the skin down to the shoulder joint and there disjoint it without disturbing the feathers to any great extent.

The best bird artist I ever knew never broke the humerus in an $y$ wing in order to facilitate the skinning of the bird. He skinned down the body complexely as represented in Fig. 5, Plate 2, and exposed both upper arm bones; these were cu* off, skinned and cleaned as seen in FIg. 6, Plate 2, leaving the other wing attached to thu body, skinning it down with the assistance, of a second hook.

In the smaller birds it is well enough to cut the wing off at the end of the humerus, where the dotted lines show in the upper portion of Fig. 6, Plate 2. In dil of the larger birds, however, the humerus should be allowed to remain attached to the ulna and radius as seen in Fig. 6, Plate 2.

In all of the larger birds, the eagles, the hawks, owls, herons, pelicans, ducks, etc., be sure and leave all the wing-bones remain attached to one another and skin the wing from the outside leaving the secondary feathers attached to the ulna of the forearm as illustrated in Plate 4, Fig. 7. The reason of this will he further discussed when we are ready to skin the wing of the subject we have on hand.

1. OPENING CUT IN THE BACKS OF BIRDS.-In the grebes, loons, gulls and many of the ducks I shall recommend making the opening cut along the back, as this will enable you to preserve with more certainty the beauty of the underparts.

2. SKINNING THE LEGS OF BIRDS.-In skinning the legs of birds the rule is to skin down as far as feathers grow or in all cases to the heel.The legs of many of the owls should be skinned down as far as the base of the toes which is as far as we can reach from the inside. The legs in all hawks and eagles should be skinned to below the heel.

3. REMOVING TENDONS FROM LEGS. OF BIRDS.-The tendons in the legs of eagles, large hawks, pelicans, flamingoes and large herons, down to the size of the American Bittern Botaurus lentiginosus (Montag.), should be taken out. To do this make a cut in the ball of the foot and draw the tendons out by means of a hook turned on the end of a plece of hard wire. If you choose to do so you may put a wooden handle on the wire and make it a permanent tool for your outfit. After making the sllt in the ball of the foot $I$ sometimes cut the tendons where they branch to the toes, take hold of them with pliers and draw them out. It requires much longer time to remove the tendons from a dry $Y$ :in which you have relaxed than from a fresh bird.

In making up large birds in the form of skins the tendons should, by all means be laken out and the legs thoroughly poisoned, both to cure them and protect them against the attacks of insects. (Contined on page 12.) 
PLATE 2.

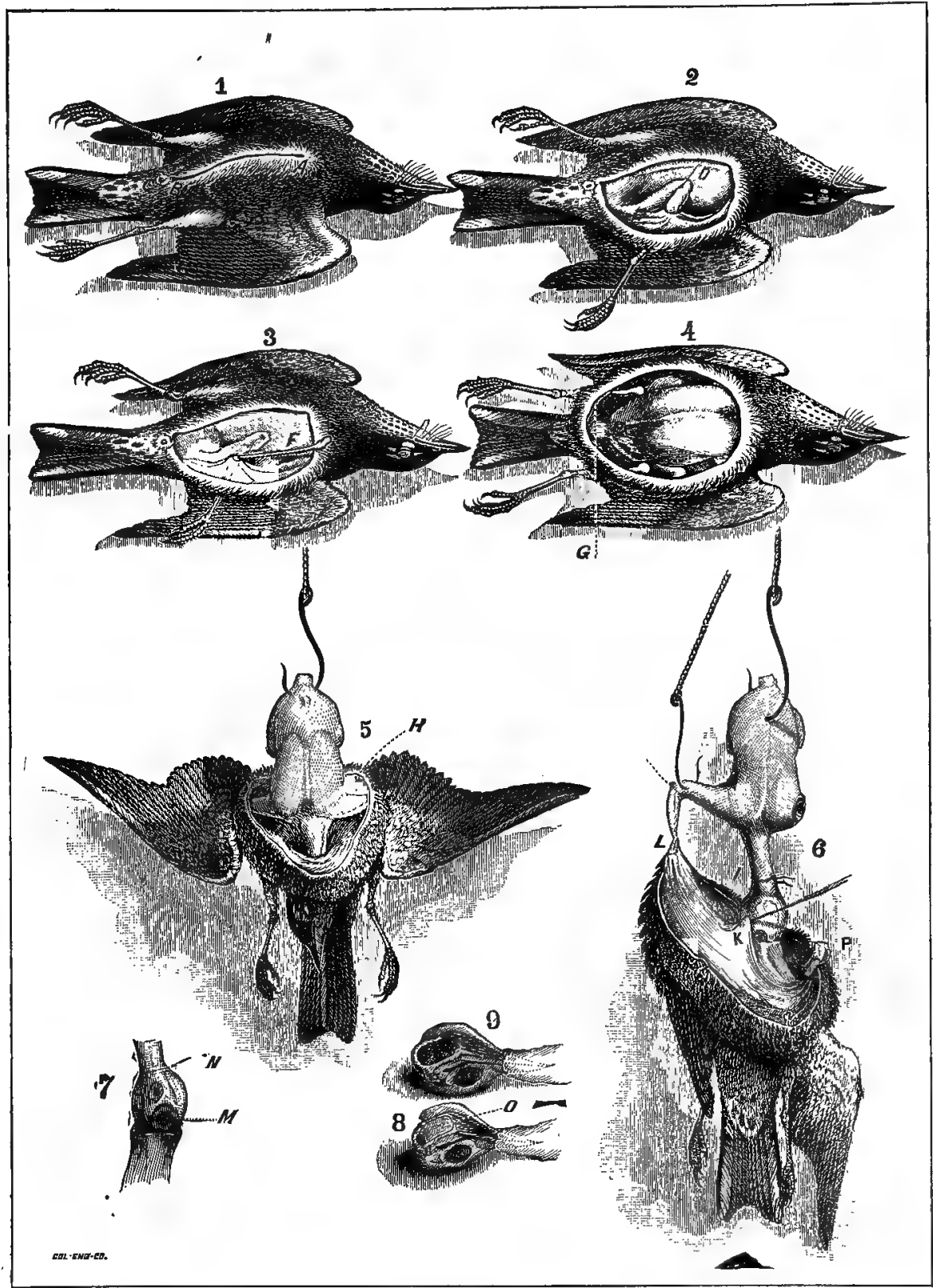

From Methods in the Art if Taxidermy.

THE PROCEDURES IN SKINNING A BIRD. 
and leave the double bones of the wing remain intact. ${ }^{1}$ Skin thoroughly; anoint them with poison and let them drop back in their place. Both wings being detached and skinned we now proceed down the neck until the base of the skull is reached. ${ }^{2}$ For good reasons do not pull or stretch the neck skin in this operation. In order to keep back any blood or liquid which is often ready to flow, before severing the head from the neck tie a cord firmly about the neck just above the skull, as shown in Plate 2, Fig. $6 i$. Before severing the head from the body we will carefully detach the membrane of the ear by inserting an awl or other pointed instrument under it, and by pulling upward and outward quickly the membrane will come out (Plate 2, Fig. $6 \mathrm{k}$ ). The eyes come next and can be observed through the thin membrane; cut very slowly through this until the eye is exposed, and be careful not to cut through the eye-lids (Fig. $7 \mathrm{~m}$, Plate 2). ${ }^{3}$ Now loosen the skin from the skull until you come down to the base of the mandibles. Scoop out the eye-balls, sever

After the tendon has been removed run a sharp-pointed wire in at the sole all the way up and through the heel as seen in our illustration. On this wire, at the sole and at the heel place with a brush, all the arsenical paste or arsenical soap that the wire will hold, and then draw the wire up and down until the tarsi has been thoroughly poisoned. 1 have frequently repeated this operation two and three times, and then coated the outside of the tarsi and toes with the clear arsenical solution.

1. LEAVING ALL THE BONES IN WINGS OF BIRDS.-Never take any of the wing-bones out of any of the larger birds, such as eagles, hawks, owls, Ioons, pelicans, geese, ducks, large gulls, herons etc. You can hardly estimate the value there is in leaving all the wing-bones in the larger birds and I may say, even in the smaller ones. Skin down to the double bones of the wing (ulna and radius) or elbow, clean the flesh thoroughly from the single bone (humerus) and stop there; if it has been done properly the humerus will be seen as it is in Plate 4. Fig. 7. After treating both wings allke, and, after you have skinned the bird completely as directed, and it is lying before you, separate the feathers along the under side of the wing, make an incision, take out all the flesh, but leave the secondaries of the wing attached to the ulna. This is elearly illustrated in Plate 4, Fig. 7. In order to thoroughly clean the entire wing of the flesh an opening between the metacarpal bones should be made. This is also seen in the Fig. just referred to. While it is of great importance to make this cut in order to take out all the flesh and poison the skin and bones thoroughly to the end of the wing, many taxidermists overlook this important point. In order to skin the wing in this manner, make the incision along the under side of the wing as indicated in our drawing, and after having the skin lifted up along both sides of the cut drive pins along its edge into your bench to hold the skin back out of the way while you are removing the flesh. Poison the bones and skin" thoroughly, take the pins out and the wings are completely prepared. If the wings are to be spread you should sew this opening up very nicely. In mounting a bird with the wings spread never detach the feathers from the ulna of the wing, for you cannot replace them as nature has done; nor can you spread them so regularly if you detach them. In skinning the wings as I have described there are many advantages to be gained. The wings fold up or spread out perfectly; you can also always depend upon getting the proper length of them. There is another point in the philosophy of leaving all the wing-bones in birds. They assist materially in obtaining the proper shape of the back, and it is absólutely impossible to find any artificial structure which will fill their place' in this regard, while their solidity is beyond question.

2. EXCEPTIONS IN SKINNING THE HEADS OF CERTAIN BIRDS.-The heads of some birds are too large to pass through the neck-skin, and thry must be skinned and treated differently. To skin the heads of woodpeckers, ducks, geese, swans, flamingoes, cranes, ostriches, peacocks, etc, an opening cut must be made from the outside as seen in Fig. 5, Plate 4. Skin down to the base of the bill as usual, cut away the flesh, take out the eyes and brain, poison thoroughly, fill the eye-sockets with cotton and sew up the slit as seen in Fig. 6 of the $s$ me plate. This is done, of course, after skinning down as far as possible on the inside. Make a hole in your bench to fit the shape of 'your bird's bill and rest it in there while si inning the head (Plate 4, Fig. 5).

3. OWLS' EYES.-Never remove the buny eye-sup in owls. If you take these out your owls will lose their characteristic expression. Dig the eye-ball out with your scalpel 
PLATE 3 .

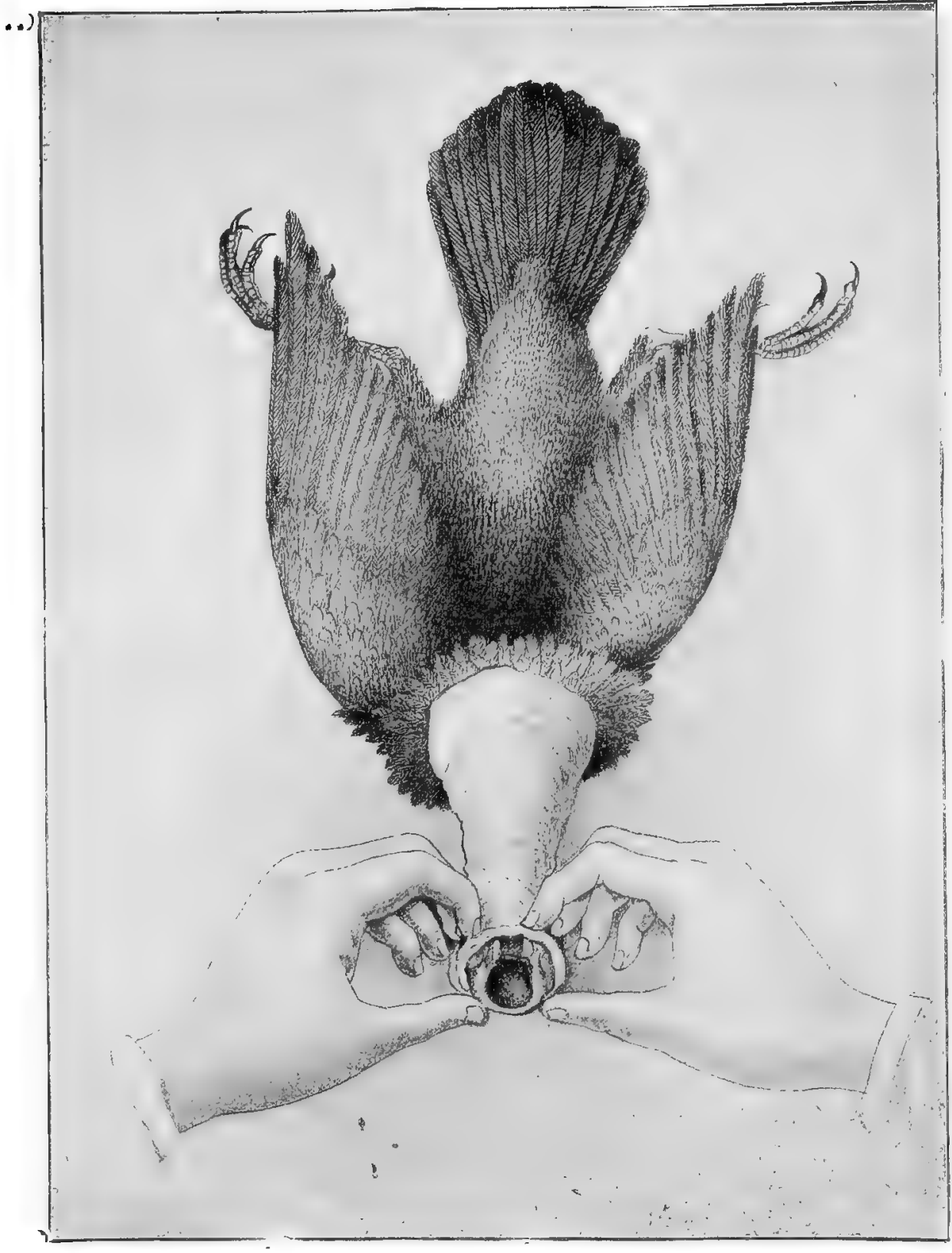

From Methods in the Art of Taxidermy. RETURNING THE NECK SKIN OVER THE SKULL. 
the head'from the neck at the base of the skull, as in Flg. $7 n$, Plate 2, taking out with the neck the tongue. The muscles of the lower mandible and around the skull must be cut away. Now take out the brain. Do not cut the whole back of the skull off in order to get at the brain, as I have seen some taxidermists do; but make an opening at the base of tie skull extending over into the roof of the mouth, exactly as we have it pictured in Figs. 8 and 9, Plate 2. Scoop out the brain with your brain-spoon or knife, and clean the head all over in a thorough and general manner. Give it a heavy coat all over with arsenical paste or arsenical soap; fill the eye-sockets loosely with balls of clean, white cotton, and the skin is ready to be returned. Before you do this, however, while the skin is lying before you, wrong side out, clean all particles of flesh and fat from it and poison the skin all over in the most thorough manner. The returning of the skin back over the skull is well illustrated in Plate 3 . Let me caution the beginner that he will find some difficulty in performing this operation the first two or three times, especially if he is in haste to do it. Take your time by all means with the first birds, and you will soon learn the knack of returning the skin over the skull. Do not imagine that you can poke the skull straight through the neck-skin without some careful manipulation. Work the skin over gradually, and whenever it becomes rolled up on top of the skull or elsewhere work on the opposite side until the folded portion will clear itself, and suddenly it will pass through and the skin will once more be right side out. The arsenical paste or soap will here be of great assistance in aiding the skin to slip easily over the skull. The skin now being turned right side out, the feathers may be very much disarranged. Take hold of the bill, adjust the feathers with your fingers and spring forceps, and assist them to fall back in their natural position. Insert the blunt end of a darning needle in the eye-hole and rub it along under the skin above the skull and the skin and feathers will fall back to their natural places. This little procedure is of the greatest importance in adjusting the skin and feathers of a bird's head. You must now with a needle point pluck out the cotton in the eye-sockets to the natural fullness of the eyes, but do not make them bulge out. Make the circle of the eyelids perfectly round, adjust the feathers of the neck carefully, and if all has been done according to directions our robin skin is ready to be filled with tow or cotton to the natural fullness, which $I$ shall describe in the next chapter.

\section{CHAPTER III.}

THE MAKING UP OF BIRDS' SKINS.

What is technically known to ornithologists and taxidermists as a "bird skin" is one constructed more or less artificially to conform to the general shape of the actual dead bird. It is intended for scientific study, because a mounted bird is not so easily handled, and a collection of them ordinarily occupies too much space. The shapes into which these skins are made all depend upon the structural peculiarities of the specimens.

and scissors. If you desire to do so you can take the eye-cup out and clean it of its contents, but you must put it back in its place. It is far better to leave the eye-cups in place and clean the contents out without disturbing them. 
PLATE 4.

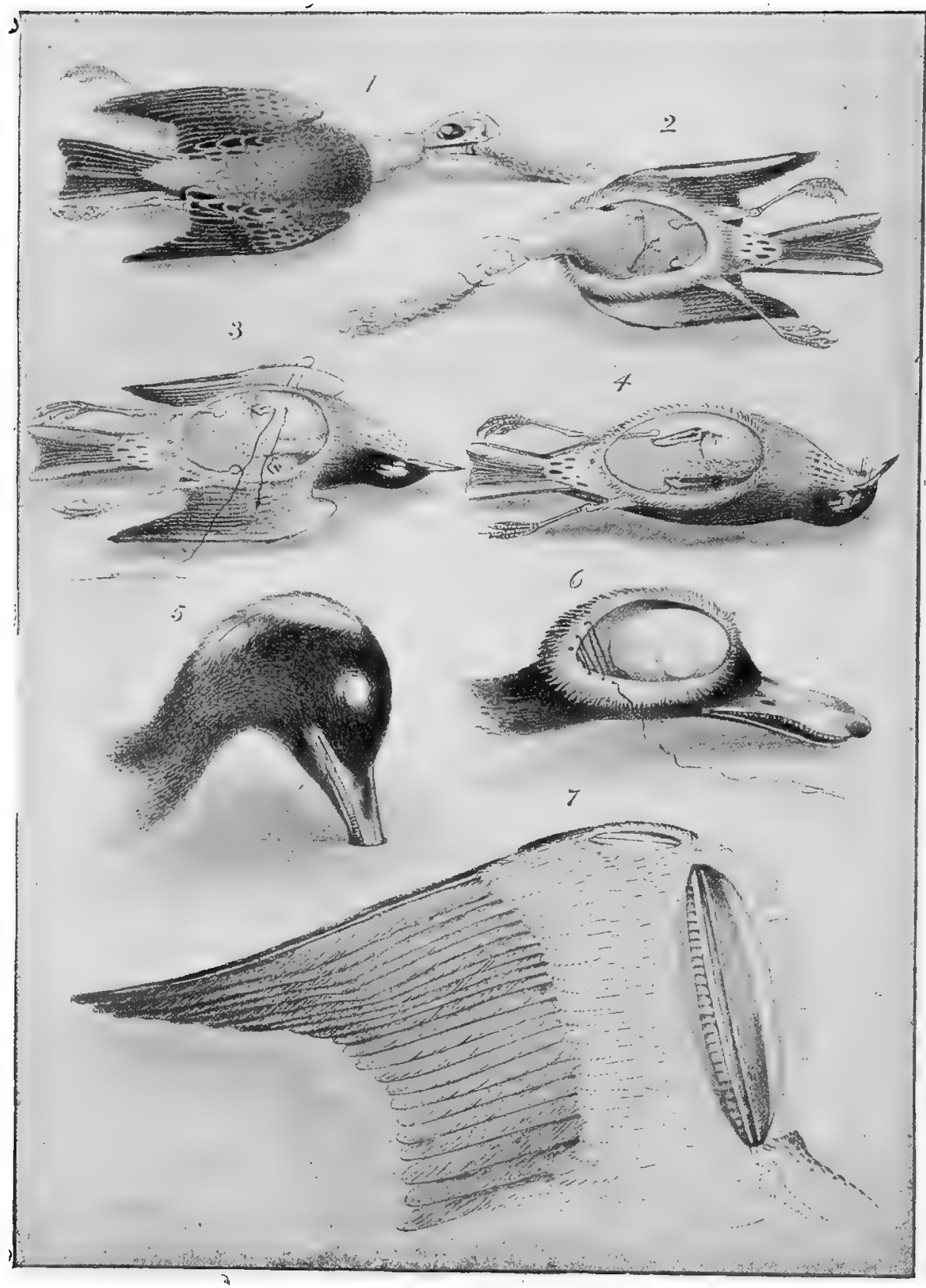

From Methods in the Art of Taxidermv.

LIIITRATTING EXCEPIIONS TO THE GENERAL RULE IN SKINNING BIRDS. 
To make up a clean, shapely, well-prepared bird skin requires considerable experience and practice. Facility and speed will come with both. I have already described in detail the manner in which a bird should be skinned.

In these directions we shall again take up the robin as our example and skin it exactly as I have directed in Chapter II, and, if it be any other species much larger, you will, as before, refer to the foot-notes in case there be any variations or exceptions to the general rule, as for instance, skinning the heads of woodpeckers, ducks, skinning the wing by an opening cut along the underside of the wing in large birds, etc. Do not fail to take full measurements, ascertain the sex, etc., before beginning as before recommended.

Having skinned the specimen it lies before you exactly as you see it in Plate 4, Fig. 4, ready for the filling. Some taxidermists fill the neck-skin with tow (Plate 4, Figs. 1 and 2) before turning the skin back. I prefer always to fill the neck after the skin has been returned over the skull. Poison the entire skin thoroughly. Make a roll of fine tow the thickness of the natural neck and longer than the entire neck and body; insert one end of this into the cavity of the skull and let the other extend as far as the tail. Many do not allow the neck roll to extend farther down than shown in Figs. 3 and 4, Plate 4. The wing-bones in very small birds need not be wrapped with cotton. In all cases the leg-bones should have a wrapping of cotton or fine tow; for the small ones cotton will do; but tow should be used in the large ones. Cotton will answer for the body-filling in the small birds, but tow is the thing to use in the larger ones. This should be made in one mass, rather firmly moulded into something like the shape of the bird's body or trunk, but rather less in bulk. Insert this into the skin until it fits nicely, bring the edges of the incision together and the skin is about completed. In some cases the opening is held together by taking one or two stitches with a needle and thread:

The usual fault of beginners is in using too much stuffing, thus making the skin to "bulge out" in the wrong places, especially between the shoulders and along the neck. Never make the neck of a skin too long. The specimen is usually meant to lie on its back with tne head drawn down near the body, the neck being of natural length. It only remains to "set" the specimen in a shapely manner by folding the wings neatly, adjusting the head and neck, bringing the legs together and crossing them. The throat of the bird should be filled with cotton and the skin can now be labeled and placed in a drying-board.

These are found very useful in forming or moulding the shape of the skin. They are made by gluing or tacking pieces of thin wood of the same size on a board, equal distances apart. Pieces of heary paper are fitted between the cross-boards and glued or tacked in position, so as to form semi-cylindrical grooves. Tin or zine can be used for making drying-boards for large birds. The old-fashioned paper cone, in which you thrust the bird head foremost, pinning the cone on the wall while the bird is drying, is an excellent method in some cases. All birds with crests should have the head turned slightly to one side and their crests raised. This is illustrated in Plate 5, Figs. 1 and 2.

Ducks, herons. geese and all other long-necked birds should, when placed to dry, rest upon the breast with the head and neck resting upon the back. The feet of the long-legged waders should be placed underneath the breast. This is beautifully illustrated in Plate 5, Figs. 3,5 and 6, in skins of the Great Blue Heron, Avocet and Marbled Godwit. In Fig. 4 of the same plate we have an illustration of the skin of the Hooded Merganser, which has as long a neck as some of the ducks. When preparing a long-necked skin in this manner always wrap tow to the natural thickness 
PLATE 5.

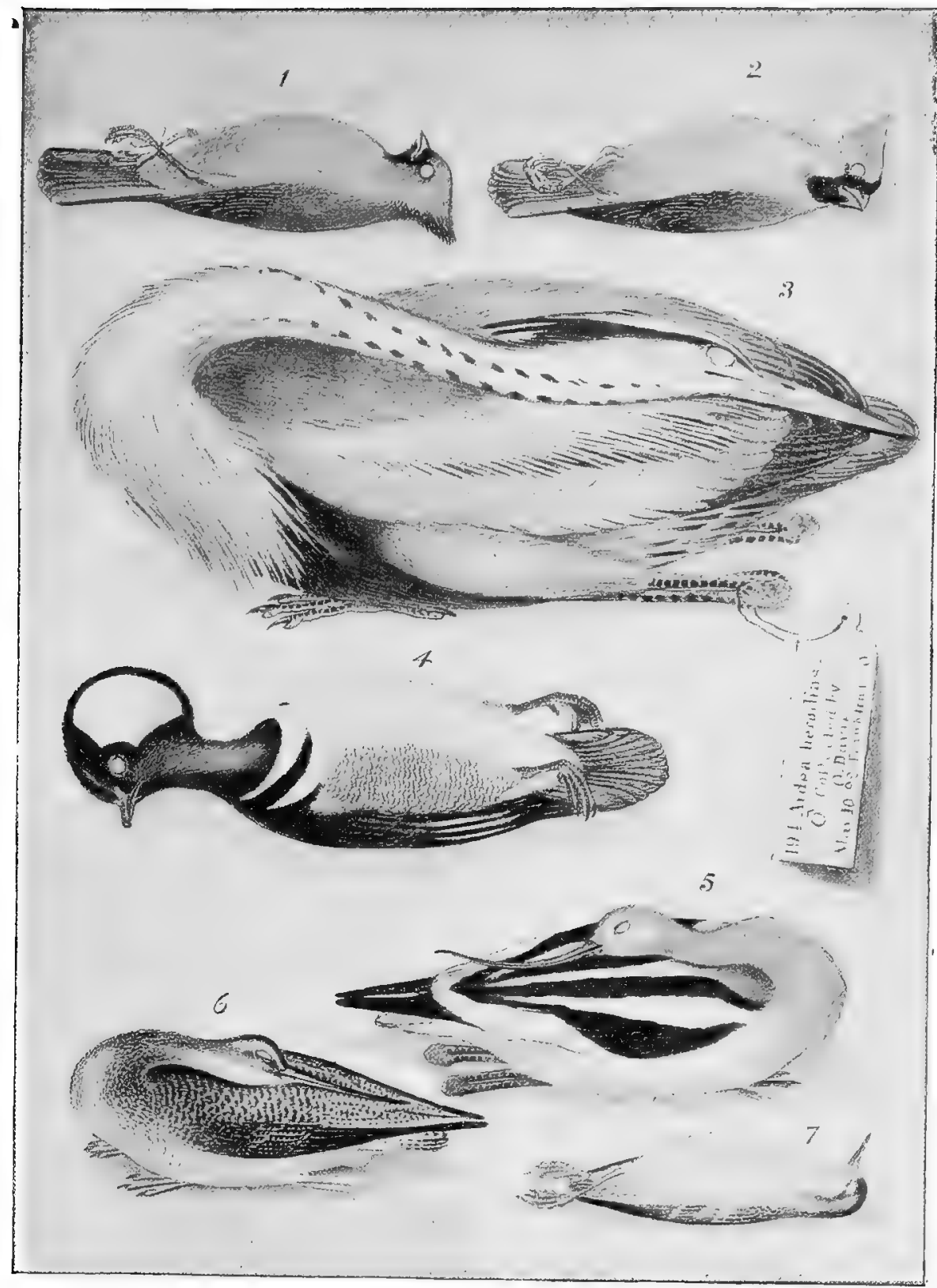

From Methods in the Art of Taxidermy. 
of the neck around a piece of wire, anchor it in the skull cavity and form the bodyfilling around it. All long-necked birds should be treated in this manner, no matter how you place the neck. It will often prevent them from becoming broken off. The opening in all large skins should be neatly sewn up. All skins prepared for the cabinet and all specimens mounted should have a label attached to the legs giving the species, sex, locality, date of collection, etc. In many adult birds the sex can be determined by the color of the plumage. In most cases the body should be examined. to make sure of the sex of the specimen. The testes of the male and the ovaries of the female lie in the same position in the small of the back, close to the kidneys, and may easily be reached by cutting through the wall of the abdomen on one side and pushing the intestines out of the way. The testes of the male are a pair of yellowish bodies lying close together. The ovary is a mass of small spheres. In the breeding season both these organs are subject to such enlargement that they become very conspicuous, and differ so much in appearance that they cannot be mistaken. At other seasons of the year they can only be recognized upon close examination. The male is denoted by the sign of Mars, the female by the sign of Venus, or the right leg is crossed over the left to indicate the male, and the left over the right to denote the female.

The best method in the world for laying skins away in the cabinet is to wrap them in sheet cotton batting, allowing the label to be seen when placed in the cabinet drawer. When collecting in the field in remote regions you may fill the body of the gkin with leaves, dry grass or paper, when tow or cotton cannot be obtained, but never with wool or hair.

It is essential for the preservation of skins to use nothing for the filling that can be attacked by insects.

Some years ago I very nearly ruined my reputation as a taxidermist by attempting to mount five hundred bird skins, from the Holy Land, which were filled with old woolen clothing of the Arabs and the hair of quadrupeds. Upon these the moths had feasted and become fat and robust. The skins and feathers had next received their attention. The havoc they wrought is indescribable.

One evening after a desperate struggle. with the hundredth specimen of these bunches of hides and feathers I was indulging in reveries of stern realities-how patience will sometimes pause-how ingenuity will stagger when invention failshow time as well as love's labor is sometimes lost.

I sat in my study till the last slanting sunbeams were gilding the walls-till the objects before me became indistinct in the twilight, and in fancy saw Job in one corner of my workshop smiling at $m y$ impatience, and heard Shakespeare by his side whispering, "What fools these mortals be!" 


\section{INDEX.}

\section{ACANTHIS.}

hornemannit, 360 .

hornemannii exilipes, 360 .

linaria, 360.

linaria holbœlli, 361.

linaria rostrata, 361.

Accipiter.

atricapillus, 205.

atricapillus striatulus, 205.

cooperi, 204.

velox, 202.

Actitis.

macularia, 150.

Aschmophorus. occidentalis, 1.

\section{Fgialitis,}

dubia, 156.

hiaticula, 155.

meloda, 156.

meloda circumcincta, 157 .

mongola, 157.

montana, 158.

nivosa, 157.

semipalmata, 155.

vocifera, 155.

wilsonia, 157.

Aeronautes.

melanoleucus, 290.

Astrelata.

fisheri, 53.

hasitata, 53.

scalaris, 53.

Agelaius.

gubernator, 343.

phœeniceus, 340 .

phœniceus bryanti, 343 .

phceniceus floridanus, 343 .

phœniceus sonoriensis, 342.

tricolor, 343.

Alx sponsa, 84 .

Ajaja.

ajaja, 107.

Alauda.

arvensis, 314.

Albatross, Black-footed, 46.

Short-tailed, 47.

Sooty, 47.

Wandering, 45.

Yellow-nosed, 47.

Alca.

torda, 21.

Alle.

alle, 24.
Amazilia.

cerviniventris, 295.

fuscicaudata, 295.

Ammodramus.

bairdii, 371 .

beldingi, 370 .

caudacutus, 373 .

caudacutus nelsoni, 374.

caudacutus subvirgatus, 374.

henslowii, 372 .

henslowii occidentalis, 373.

leconteii, 373.

maritimus, 374 .

maritimus macgillivrayi, 375.

maritimus peninsulæ, 374 .

maritimus sennetti, 375 .

nigrescens, 375.

princeps, 369.

rostratus, 371.

rostratus guttatus, 371 .

sanetorum, 371 .

sandwichensis, 369 .

sandwichensis alaudinus, 370 .

sandwichensis bryanti, 370 .

sandwichensis savanna, 369.

savannarum passerinus, 371

savannarum perpallidus, 372 .

Ampelis.

cedrorum, 413.

garrulus, 413.

Amphispiza.

belli, 386.

belli cinerea, 387.

belli nevadensis, 386 .

bilineata, 386 .

Anas.

americana, 80.

boschas, 78 .

carolinensis, 81.

crecca, 80.

cyanoptera, 81.

discors, 81.

fulvigula, 79 .

fulvigula maculosa, 79.

obscura, 79.

penelope, 80.

strepera, 79.

Anhinga, 63.

anhinga, 63.

Ani, 252.

Groove-billed, 253.

Anous.

stolídus, 44. 
Anser.

albifrons, 97.

alblfrons gambell, 97.

fabalis, 97.

Anthus.

cervinus, 460.

pensilvanicus, 460 .

pratensis, 460 .

spragueli, 461.

Antrostomus.

carolinensis, 282.

vociferus, 283.

vociferus macromystax, 283.

Aphelocoma callfornica, 326.

californica hypoleuca, 326.

californica obscura, 326 .

cyanotis, 326.

floridana, 196.

insularis, 326.

sieberii arizonæ, 327 .

woodhousel, 325.

Aphriza.

Aquila.

virgata, 158.

Aramus.

chrysaetos, 216.

giganteus, $\cdot 122$

Archibuteo.

ferrugineus, 216.

lagopus, 215.

lagopus sancti-Johannis, 216.

Arctonetta.

Ardea.

fischeri, 91.

candidissima, 115.

cinerea, 114.

cærulea, 118.

egretta, 115.

herodias, 114.

occidentalis, 113.

rufescens, 117.

tricolor ruficollis, 118.

virescens anthonyi, 119 .

virescens, 118.

virescens frazarl, 119.

wardi, 113.

Ardetta.

exillis, 112.

neoxena, 113.

Arenaria.

interpres, 158.

melanocephala, 159.

Asto.

acclpitrinus, 235.

wilsonianus, 234.

Asturina.

plagiata, 214.

Auk, Great, 21.

Razor-billed, 21.

Auklet, Cassin's, 13.

Crested, 14.

Least, 16.

Paroquet, 13.

Rhinoceros, 13.

Whiskered, 15 .
Auriparus.

flaviceps, 491.

Avocet, American, 132.

Aythya.

affinis, 87.

americana, 86.

collaris, 87.

marila nearctica, 87 .

vallisneria, 86 .

BALDPATE, 80.

Bartramia. longicauda, 149.

Basileuterus. belll, 458 . culicivorus, 458.

Basilinna. leucotis, 296. xantusi, 296.

Becard, Rose-throated, 297. Xantus's, 297.

Bird, Man-of-War, 74.

Red-billed Tropic, 59.

Surf, 158.

Yellow-billed Tropic, 59.

Bittern, American, 111. Cory's Least, 113.

Least, 112.

Blackbird, Bicolored, 343.

Brewer's, 350.

Red-winged, 340.

Rusty, 350.

Tricolored, 343.

Yellow-headed, 340.

Bluebird, 505.

Azure, 505 .

Chestnut-backed, 505.

Mountain, 506.

San Pedro, 506.

Western, 505.

Bluethroat, Red-spotted, 504.

Bobolink, 337.

Bob-white, 163.

Cuban, 164.

Florida, 164.

Masked, 164.

Texan, 164.

Bonasa.

umbellus, 169.

umbellus sabini, 170 .

umbellus togata, 170 .

umbellus umbelloides, 170.

Booby, 61.

Blue-faced, 60 .

Blue-footed, 61.

Brewster's, 61.

Red-footed, 62.

Botaurus.

lentiginosus, 111.

Brachyramphus.

craveri, 17.

hypoleucus, 17.

kittlitzil, 17.

marmoratus, 16. 
Brant, 101.

Branta.

Black, 101.

bernicla, 101.

canadensis, 98.

canadensis hutchinsil, 100.

canadensis minima, 100.

canadensis occidentalis, 100 .

leucopsis, 101.

nifrtcans, 101.

Bubo.

virginianus, 241.

virginianus arcticus, 243.

virginianus pacificus, 243.

virginianus subarctlcus, 243.

Budytes.

flavus leucostriatus, 459.

Buffle-head, 88.

Bullfinch, Cassin's, 354.

Bulweria.

bulweri, 58.

Bunting, Beautiful, 405.

Indigo, 404.

Lark, 407.

Lazuli, 404.

Painted, 405.

Varled, 405.

Bush-TIt, 488.

Californian, 488.

Grinda's, 488.

Lead-colored, 488.

Lloyd's, 490.

Buteo.

Santa Rita, 490.

abbreviatus, 210.

albicaudatus sennetti, 210.

borealis, 206.

borealis calurus, 208 .

borealis harlani, 208.

borealis krideril, 208.

boregalis lucasanus, 208.

brachyurus, 213.

buteo, 206.

latissimus, 212.

lineatus, 209.

lineatus alleni, 210.

lineatus elegans, 210.

swainsoni, 211.

Buzzard, European, 206.

CALAMOSPIZA.

melanocorys, 407.

Calcarius.

lapponicus, 366 .

ornatus, 367.

pictus, 367 .

Calidris.

arenaria, 142.

Callichelidon. cyaneoviridis, 412.

Callipepla.

californica, 166.

californica vallicola, 167.

gambelii, 167.

gquamata, 165.

- squamata castanogastris, 166.
Callothrus.

robuetus, 339.

Calothorax. lucifer, 295.

Calypte. anna, 293. costae, 292.

Campephilus. principalis, 261.

Camptolaimus. labredorius, 91.

Canvas back, 86 .

Caracara, Audubon's, 230. Guadalupe, 231.

Cardellina rubrifrons, 457.

Cardinal, 399. Arizona, 100.

Florida, 400.

Gray-tailed, 400 .

Saint Lucas, 400. Texas, 401.

Cardinalis. cardinalis, 399. cardinalls canjcaudus, 400 . cardinalis floridanus, 400 . cardinalis Igneus, 400. cardinalis superbus, 400 .

Carduelis carduells, 364.

Carpodacus. amplus, 357.

cassinl, 356.

mexicanus frontalis, 356.

mexicanus ruberrimus, 356 .

purpureus, $\mathbf{3 5 5}$.

purpureus callfornicus, 355 .

Casearca cascarca, 82.

Catbird, 464.

Catharista. atrata, 195.

Cathartes. aura, 194.

Catherpes. mexicanus, 470. mexicanus conspersus, 470. mexicanus punctulatus, 471.

Centrocercus. urophasianus, 178.

Ceophlous. pileatus, 272.

Cepphus, 10. columba, 18. grylle, 17. mandtij, 18.

Cerorhinca. monocerata, 13.

Certhia. famlliaris alticola, 478 . familiaris americana, 477 . famillaris montana, 478. Ceryle. familiaris occidentalis, 478 .

alcyon, 260.

americana septentrionalis, 260. torquata, 260. 
Chachalaca, 183.

Chætura. pelagica, 288. vauxii, 288 .

Chamæa. fasciata, 487. fasciata henshawi, 488 .

Charadrius. apricarius, 154. dominicus, 154. dominicus fulvus, 155. squatarola, 154.

Charitonetta. albeola, 88.

Chat, Long-tailed, 454. Yellow-breasted, 453.

Chelidon. erythrogaster, 411.

Chen.

cærulescens, 96.

hyperborea, 96 .

hyperborea nivalis, 96. rossii, 97.

- Chickadee, 483.

California, 487.

Carolina, 484.

Chestnut-backed, 487 .

Columbian, 487.

Hudsonian, 486.

Kowak, 487.

Long-tailed, 484.

Mexican, 485.

Mountain, 485.

Oregon, 484.

Plumbeous, 485.

Siberian, 486.

Chondestes.

grammacus, 375 .

grammacus strigatus, 376.

Chordeiles.

acutipennis texensis, 287 .

virginianus, 286.

virginianus chapmani, 287.

virginianus henryi, 286.

virginianus sennetti, 287.

Chuck-will's-widow, 282.

Cinclus.

mexicanus, 461.

Circus hudsonius, 201.

Cistothorus.

marianæ, 477.

palustris, 476.

palustris griseus, 476.

palustris paludicola, 476.

stellaris, 475 .

Clangula. hyemalis, 89 .

Clivicola. riparia, 413 .

Coccothraustes. vespertinus, 353 .

vespertinus montanus, 353 .
Coceyzus.

americanus, $\mathbf{2} 55$.

americanus occidentalis, 256.

erythropthalmus, 256.

minor, 254.

minor maynardi. 255.

Coligena.

clemenciæe, 291.

Ccereba.

bahamensis, 426 .

Colaptes.

auratus, 276 .

cafer, 281.

cafer saturatior, 281.

chrysoides, 281.

chrysoides brunnescens, 282

rufipileus, 282.

Colinus.

ridgwayi, 164.

virginianus, 163.

virginianus cubanensis, 164.

virginianus floridanus, 164.

virginianus texanus, 164.

Columba.

fasciata, 184.

fasciata vioscæ, 184

flavirostris, 184.

leucocephala, 185.

Columbigallina.

passerina pallescens, 189.

passerina terrestris, 189.

Colymbus.

auritus, 3.

dominicus, 4.

holbnllii, 2.

Colymbus nigricollis californicus, 3

Compsothlypis.

americana, 432.

americana usnex, 433.

nigrilora, 435 .

Contopus.

borealis, 305 .

pertinax, 307.

richardsonii, 307.

richardsonii peninsulæ, 308

virens, 306.

Conurus.

carolinensis, 250.

Coot, American, 129.

European, 128.

Cormorant, 64 .

Baird's, 69.

Brandt's, 68.

Double-crested, 65.

Farallone, 67.

Florida, 66.

Mexican, 68.

Pelagic, 69.

Red-faced, 70.

Violet-green, 69.

White-crested, 66

Corvus.

americanus, 332.

americanus floridanus, 333. 
Corvus caurinus, 334. corax principalis, 331. corax sinuatus, 330 . cryptoleucus, 332. ossifragus, 334.

Coturnix coturnix, 163.

Cowbird, 338.

Dwarf, 339.

Red-eyed, 339.

Crake, Corn, 127. Spotted, 125.

Crane, Little Brown, 121.

Sandhill, 122.

Whooping, 120.

Creeper, Bahama Honey, 426.

Brown, 477.

California, 478.

Mexican, 478.

Rocky Mountain, 478.

Crex.

crex, 127 .

Crossbill, American, 357. Mexican, 358.

White-winged, 358.

Crotophaga.

ani, 252.

sulcirostris, 253.

Crow, American, 332.

Fish, 334.

Florida, 333.

Northwest, 334.

Crymophilus.

filicarius, 130.

Cuckoo, Black-billed, 256.

California, 256.

Kamchatkan, 257.

Mangrove, 254.

Mlaynard's, 255.

Yellow-billed, 255 .

Cuculus.

canorus telephonus. 257.

Curlew, Bristle-thighed, 152.

Eskimo, 151.

Hudsonian, 151.

Long-billed, 150.

Cyanecula. suecica. 504

Cyanocephalus. cyanocephalus, 336.

Cyanocitta. cristata, 320 .

cristata florincola, 323.

stelleri, 323.

stelleri annectens, 325 .

stelleri frontalis, 324.

stelleri macrolopha, 324.

Cyclorrhynchus. psittaculus, 13.

Cymodroma. grallaria, 68.

Cypşeloides.

niger, 287.
Cyrtonyx.

montezumæ. 167.

DAFILA.

acuta. 83.

Daption.

capensis, 53.

Dendragapus.

canadensis, 169.

franklinji, 169.

obseurus, 168.

obscurus fuliginosus, 168.

obscurus richardsonil, 169.

Dendrocygna.

autumnalis, 103.

fulva, 103.

Dendroica.

æstiva, 436.

æstiva rubiginosa, 436 .

æstiva sonorana, 436.

auduboni, 438.

blackburniæ, 441.

bryanti castaneiceps, 436 .

cærulea, 439.

cærulescens, 436 .

cærulescens cairnsi, 437.

castanea, 441.

chrysoparia, 443.

coronata, 437.

discolor, 447.

dominica, 442.

dominica albilora, 442.

graciæ, 443.

kirtlandi, 445.

maculosa, 439.

nigrescens, 443.

occidentalis, 444.

olivacea, 436.

palmarum, 446.

palmarum hypochrysea, 447.

pensylvanica, 440 .

striata, 441.

tigrina, 435 .

- townsendi, 444.

vigorsii, 446 .

virens, 444.

Dickcissel, 406.

Diomedea.

albatrus, 47.

exulans, 45 .

nigripes, 46 .

Dipper, American, 461.

Dolichonyx.

oryzivorus, 337.

Dove, Ground, 189.

Inca, 190.

Mexican Ground, 189.

Mourning, 187.

White-fronted, 188.

White-winged, 189.

Zenaida, 188.

Dovekie, 24. 
Dowitcher, 136.

Long-billed, 136.

Dryobates arizonæ, 267.

borealis, 264.

nuttalli, 265.

pubescens, 263.

pubescens galranerii, 264.

pubescens medianus, 264.

pubescens nelsoni, 264.

pubescens oreceus, 264.

scalaris bairdi, 265.

scalaris lucasanus, 265.

villosus, 262.

villosus audubonil, 263.

villosus harrisli, 263.

villosus hyloscopus, 263.

villosus leucomelas, 263.

Duck, American Scaup, 87.

Black, 79.

Elorida, 79.

Harlequin, 90.

Labrador, 91.

Lesser Scaup, 87.

Masked, 95.

Mottled, 79.

Ring-necked, 87.

Ruddy, 95.

Rufous-crested, 85.

Steller's, 91.

Wood, 84 .

Dunlin, 140.

EAGLE, Bald, 218.

Golden, 216.

Gray Sea, 218.

Harpy, 218.

Ectopistes.

migratorius, 185.

Egret, American, 115.

Reddish, 117.

Elder, American, 92.

King, 98.

Northern, 91.

Pacific, 93.

Spectacled, 91.

Elanoldes.

forflcatus, 196.

Elanus.

leucurus, 198.

Embernagra.

rufivirgata, 395.

Empldonax.

cineritius, 309.

dificills, 309 .

flaviventrig, 308.

fulvifrons, 313.

fulvifrons pygmæus, 313.

eriseus, 313.

hammondl, 312.

minlmus, 312.

traillil, 310 .

trallli alnorum, 310.

virescens, 300.

wrightil, 313.
Eniconetta.

stelleri, 91.

Ereunetes. occldentalis, 142. pusillus. 141.

Ergaticus. ruber, 458.

Erismatura.

Euetheia. rubida, 95.

bicolor, 406. canora, 406.

Eugenes. fulgens, 290.

Euphonla. elegantissima, 407.

Euphonia, Blue-headed, 407.

Eurynorhynchus. pygmæus, 141.

FALCO.

columbarius, 224.

columbarius suckleyi, 225.

dominicensis, 230.

fusco-coerulescens, 226.

Ișlandus, 220.

mexicanus, 222.

peregrinus anatum, 223.

peregrinus pealei, 223.

regulus, 225.

richardsonil, 225.

rusticolus, 221.

rusticolus gyrfalco, 221.

rusticolus obsoletus, 221.

sparverius, 228.

sparverius deserticolus, 230.

sparvertus peninsularis, 230.

tinnunculus, 227.

Falcon, Aplomado, 226.

Peale's, 223.

Pralrie, 222.

Finch, Callfornia Purple, 355.

Cassin's Purple, 356.

Gaudalupe House, 357.

House, 356.

Purple, 355.

St. Lucas House, 356.

Flamingo, American, 105.

Flicker, 276.

Brown, 282.

Gllded, 281.

Guadalupe, 282.

Northwestern, 281.

Red-shafted, 281.

Flycatcher, Alder, 310.

Arizona Crested, 302.

Ash-throated, 302.

Beardless, 314.

Buff-breasted, 313.

Coues's, 306.

Crested, 301.

Derby, 300.

Fork-talled, 297. 
Flycatcher, Fulvous, 313.

Giraud's, 300 .

Gray, 313.

Green-crested, 309 .

Hammond's, 312.

Lawrence's, 303.

Least, 312.

Mexican Crested, 301.

Nutting's, $\cdot 303$.

Olivaceous, 303.

Olive-slded, 305.

Ridgway's, 314 .

St. Lucas, 303.

Scissor-tailed, 297.

Sulphur-bellied, 301.

Traill's, 310.

Vermilion, 314.

Western, 309.

Wright's, 313.

Yellow-bellied, 308.

Fratercula:

arctica, 11.

arctica glacialis, 11. corniculata, 11.

Fregata. aquila, 74.

Fulica.

americana, 129.

atra, 128.

Fulmar, 48.

Giant, 48.

Lesser, 49.

Pacific, 50.

Rodgers's, 50 .

Slender-billed, 51.

Fulmarus.

glacialis, 48.

glacialis glupischa, 50 .

glacialis minor, 49.

glacialis rodgersil, 50.

glacialoldes, 51.

GADWALL, 79.

Galeascoptes. carolinensis, 464.

Gallinago.

* delicata, 135.

gallinago, 135.

Gallinula.

galeata, 128.

Gallinule, Florida, 128. Purple, 128.

Gannet, 62.

Gavia.

alba, 27.

Gelochelidon.

nilotica, 38.

Geococcyx. callfornianus, 253.

Geothlypis.

agilis, 450.

belding1, 452 .

formosa, 449.

macgllivrayl, 451.
Geothlypis, phlladelphia, 451. trichas, 451.

trichas ignota, 452.

trichas occldentalls, 452. poliocephala ralphi, 453.

Geotrygon.

martinica, 190.

montana, 190.

Glaucidium.

gnoma, 247.

gnoma californicum, 243.

hoskinsii, 243.

phalænoides, 249.

Glaucionetta.

clangula americana, 88.

islandica, 88.

Gnatcatcher, Black-tailed, 496.

Blue-gray, 494.

Plumbeous, 496.

Western, 496.

Godwit, Black-tailed, 14.

Hudsonian, 143.

Marbled, 143.

Pacific, 143.

Golden-eye, American, 88.

Barrow's, 88.

Goldfinch, 364 .

American, 361.

Arizona, 362.

Arkansas, 362.

Black-headed, 363.

Lawrence's, 363.

Mexican, 362.

Western, 362.

Goose, American White-fronted, 97. Barnacle, 101.

Bean, 97.

Blue, 96.

Cackling, 100.

Canada, 98.

Emperor, 102.

Greater Snow, 96.

Hutchins's, 100.

Lesser Snow, 96.

Ross's Snow, 97.

White-cheeked, 100.

White-fronted, 97.

Goshawk, American, 205.

Mexican, 214.

Western, 205.

Grackle, Boat-talled, 353.

Bronzed, 352.

Florida, 352.

Great-tailed, 352.

Purple, 351.

Grassquit, 406.

Melodius, 406.

Grebe, American Eared, 3.

Holbcell's, 2.

Horned, 3.

Pled-billed, 4.

St. Domingo, 4.

Western, 1. 
Green-shank, 144.

Grosbeak, Black-heaaed, 403.

Blue, 408.

Evening, 353.

Pine, 254.

Rose-breasted, 403 .

Western Blue, 404.

iv estern Evening, 353.

Grouse, Canada, 169.

Canadian Ruffed, 170.

Columbian Sharp-tailed, 177.

Dusky, 168.

Franklin's, 169.

Gray Ruffed, 170.

Oregon Rufied, 170.

Prairie Sharp-tailed, 178.

Richardson's, 169.

Ruffed, 169.

Sage, 178.

Sharp-tailed, 177.

Sooty, 168.

Grus.

americana, 120.

canadensis, 121.

mexicana, 122.

Guara.

alba, 107.

rubra, 108.

Guillemot, Black, 17.

Mand,t's, 18.

Pigeon, 18.

Guiraca.

cærulea, 403.

cærulea euryncha, 404.

Gull, American Herring, 32.

Bonaparte's, 36.

California,' 33.

Franklin's, 35.

Glaucous, 28.

Glaucous-winged, 29.

Great Black-backed, 30.

Herring, 32.

Heermann's, 35.

Iceland, 29.

Ivory, 27.

Kunalien's, 30.

Laughing, 35 .

Little, 36.

Mew, 34.

Nelson's, 30.

Point Barrow, 29.

Ring-billed, 34.

Ross's, 36.

Sabine's, 37.

Short-billed, 34.

Siberian, 31.

Slaty-backed, 31.

Vega, 33.

Western, 31.

Gyrfalcon, 221.

Black, 221.

Gray, 221.

White, 220 .
HABIA.

ludoviciana, 403.

melanocephala, 403.

Hæmatopus.

bachmani, 161.

frazari, 161.

ostralegus, 159.

palliatus, 160 .

Halocyptena.

microsoma, 54 .

Haliæetus. albicilla, 218.

leucocephalus, 218.

Harporhynchus.

bendirei, 465 .

cinereus, 466.

cinereus mearnsi, 466.

crissalis, 468.

curvirostris, 465.

curvirostris palmeri, 465.

lecontei, $\mathbf{4 6 7 .}$

longirostris sennetti, 464 .

redivivus, 466.

rufus, 464.

Hawk, American Rough-legged, 216.

American Sparrow, 228.

Desert Sparrow, 230.

Broad-winged, 212.

Cooper's, 204.

Cuban Sparrow, 230.

Duck, 223.

Florida Red-shouldered, 210

Harlan's, 208.

Harris's, 206.

Krider's, 208.

Marsh, 201.

Mexican Black, 213.

Pigeon, 224.

Red-bellied, 210.

Red-shouldered, 209.

Red-tailed, 206.

Rough-legged, 215.

Sennett's White-talled, 210.

Sharp-shinned, 202.

Short-tailed, 213.

St. Lucas Sparrow, 230.

Swainson's, 211.

Zone-tailed, 210.

Heleodytes brunneicapillus, 468. brunneicapillus affinis, 469 . brunneicapillus bryanti, 468 .

Helinaia. swainsonii, 428.

Helminthophila. bachmani, 429 . celata, 432. celata lutescens, 432. celata sordida, 432. chrysoptera, 430 . lucize, 430. peregrina, 432. pinus, 429. ruficapilla, 431. 
Helminthophila, ruficapilla gutturalis, 431. virginiæ, 430.

Helmitherus. vermivorus, 428.

Hen, Attwater's Prairie, 175. Heath, 175.

Lesser Prairie, 177.

Prairie, 175.

Heron, Anthony's Green, 119. Black-crowned Night, 119. European Blue, 114. Frazar's Green, 119. Great Blue, 114.

Great White, 113.

Green, 118.

Little Blue, 118.

Louisiana, 118.

Snowy, 115.

Ward's, 113.

Yellow-crowned' Night, 120.

Hesperocichla. nævia, 503.

Heteractitis. incana, 147.

Himantopus. mexịcanus, 132.

Histrionicus. histrionicus, 90.

Hummingbird, Allen's, 294. Anna's, 293. Black-chinned, 292. Blue-throated, 291. Broad-billed; 296. Broad-tailed, 293. Buff-bellied, 295.

Calliope, 294.

Costa's, 292.

Floresi's, 293.

Rieffer's, 295.

Rivoli, 290.

Ruby-throated, 291.

Rufous, 293.

Violet-throated, 292.

White-eared, 296.

Xantus's, 296.

Hydrochelidon.

leucoptera, 44.

nigra surinamensis, 43.

\section{TACHE.}

latirostris, 296.

Ibis, Glossy, 109.

Scarlet, 108.

White, 107.

White-faced Glossy, 110

Wood, 110.

Icteria.

virens, 453.

virens longicauda, 454.
Icterus.

audubonif, 345 .

bullock1, 350 .

cucullatus, 346.

cucullatus nelsoni, 346.

galbula, 347 .

icterus, 345.

parisorum, 345.

spurius, 347 .

Ictinia,

mississippiensis, 199.

Ionornis.

martinica, 128.

JABIRU, 110.

Jacana.

spinosa, 161.

Jacana, 'Mexican, 161.

Jaeger, Parasitic, 25.

Pomarine, 25.

Long-tailed, 26.

Jay, Alaskan, 328.

Arizona, 327.

Belding's, 326.

Black-headed, 325.

Blue, 320.

Blue-eared, 326.

Blue-fronted, 324.

California, 326.

Canada, 328.

Florida, 325.

Florida Blue, 323.

Green, 327.

Labrador, 329.

Long-crested, 324.

Oregon, 330.

Pinon, 336.

Rocky Mountain, 328.

Santa Cruz, 326.

Steller's, 323.

Woodhouse's, 325.

Xantus's, 326.

Junco.

aikeni, 382.

annectens, 384 .

bairdi, 385 .

caniceps, 385.

phæonotus dorsalis, 385 .

phæonotus palliatus, 385 .

hyemalis, 382.

hyemalis carolinensis, 384 .

hyemalis oregonus, 382.

hyemalis pinosus, 384 .

hyemalis shufeldti, 383 .

hyemalis thurberi, 383 .

insularis, 385.

ridgwayi, 384.

townsendi, 385 .

Junco, Arizona, 385.

Baird's, 385.

Carolina, 384 
Junco, gray-headed, $\mathbf{3 8 5}$.

Guadalupe, 385.

Oregon, 382.

Pink-sided, 384.

Point Plnos, 384,

Red-backed, 385.

Ridgway's, 384.

Slate-colored, 38\%.

Shufeldt's, 383.

Thurber's, 383.

Townsend's, 385.

White-winged, 382 .

KESTREL, 227.

Killdeer, 155.

Kingbird, 298.

Arkansas, 299.

Cassin's, 300.

Couch's, 299.

Gray, 298.

Kingfisher, Belted, 260.

Ringed, 260.

Texan, 260.

Kinglet.

Dusky, 494.

Golden-crowned, 492.

Ruby-crowned, 493.

Western Golden-crowned, 493.

Kite, Everglade, 201.

Mississippi, 199.

Swallow-talled, 196.

White-tailed, 198.

Kittlwake, 27.

Pacific, 28.

Red-legged, 28.

Knot, 136.

\section{LAGOPUS.}

evermanni, 174.

lagopus, 171.

lagopus allent, 172.

leucurus, 174.

rupestris, 173.

rupestris atkhensis, 173.

rupestris nelsoni, 173.

rupestris reinhardi, 173.

rupestris townsendi, 174.

welchi, 174.

Lanius.

borealis, 415 .

ludovicianus, 415 .

ludovicianus gambeli, 417.

ludovicianus excubitorides, 416.

Lapwing, 152.

Lark, Desert Horned, 317.

Dusky Horned, 318.

Horned, 315.

Mexican Horned, 317.

Pallid Horned, 316.

Pralrle Horned, 316.

Ruddy Horned, 317.

Scorched Forned, 318 .

Sonoran Horned, 319.

Streaked Horned, 318.

Texan Horned, 317.
Larus.

affinis, 31.

argentatus, 32.

argentatus smithsonlanus, 32 .

atricilla, 35.

barrovianus, 29.

brachyrhynchus, 34 .

cachinnans, 33.

californicus, 33.

canus, 34.

delawarensis, 34.

franklinit, 35 .

glaucescens, 29.

glaucus, 28.

heermanni, 35.

Larus philadelphia, 36. kumlient, 30.

leucopterus, 80

marinus, 30 .

minutus, 36 .

nelsoni, 30.

occidentalis, 31 .

philadelphia, 36.

schistisagus, 31.

vegæ, 33.

Leptotila.

fulviventris brachyptera, 188.

Leucosticte.

atrata, 360 .

australls, 360.

griseonucha, 358.

tephrocotis, 359.

tephrocotis littoralls, $\mathbf{3 6 0}$.

Leucosticte, Aleutian, 358.

Black, 360.

Brown-capped, 360 .

Gray-crowned, 359.

Hepburn's, 360.

Limosa.

fedoa, 143.

hæmastica, 143.

lapponica bauert, 143.

limosa, 144.

Limpkin, 122.

Longspur, Chestnut-collared, 367.

Lapland, 366.

McCown's, 369.

Smith's, 367.

Loon, 6 .

Black-throated, 7.

Pacific, 8.

Red-throated, 8 .

Yellow-bllled, 7 .

Lophodytes.

Loxia

cucullatus, 77.

curvirostra minor, 357 .

curvirostra, stricklandi, 358. leucoptera, 358.

Lunda.

clrrhata., 9.

MACRORAAMPHUS.

griseus, 136.

scolopaceus, 136. 
Magpie, American, 319. Yellow-billed, 320 .

Mallard, 78.

Man-o'-War Bird, 74.

Mareca, 49.

Martín, Cuban, 409. Purple, 409. Western, 409.

Meadowlark, 343. Mexican, 344. Western, 344.

Megalestris. skua, 24.

Megascops. asio, 239. aslo atkenI, 241.

Megascops asio maxwelliæ, 240. asio cineraceus, 240. asio floridanus, 240 . asio kennicottil, 240 asio macfarlanei, 241. asio maxwelliæ, 240 . asio trichopsis, 240 . flammeola, 241 . flammeola idahoensis, 241 .

Melanerpes, 164. aurifrons, 276. carolinus, 275. erythrocephalus, 273. formicivorus, 274. formicivorus angustifrons, 275. formicivorus bairdi, 274. torquatus, 275.

Meleagris. uropyglalis, 276.

gallopavo, 180. gallopavo ellioti, 183. gallopavo mexicana, 182 Eallopavo osceola, 183.

Melopelia. leucoptera, 189.

Melospiza. cinerea, 393. rasciata, 390. fasclata clementæ, 392. fasclata fallax, 390 . fasciata graminea, 392. fasciata guttata, 391. fasciata heermanni, 391. fasciata juddi, 392. fasciata montana, 391. fasciata rivularis, 392. fasciata rufina, 391. fasclata samuelis, 391. georgiana, 393. insignis, 392. Iincolni, 393. lincolni striata, 393.

Merganser. americanus, 76. serrator, 77 .

Merganser, American, 76. Hooded, 77.

Red-breasted, 77.
Merginæ.

Mergus albellus, 78.

Merlin, 225. Black, 225.

Merula. Richardson's. 205.

confinis, 503. migratorla, 502. migratoria propinqua, 603.

Micropalama. himantopus, 136.

Micropallas.

Milvulus. whitneyf, 249.

forficatus, 297. tyrannus, 297.

Mimus. polyglottos, 462.

Mnlotilta. varia, 426.

Mockingbird, 462.

Molothrus. ater, 338. ater obscurus, 339.

Motacilla. alba, 458 . ocularis, 459 .

Motmot, blue-crowned, 259.

Momotus coruliceps, 259.

Murre, 18.

Brunnich's, 20.

California, 19.

Pallas's, 20.

Murrelet, Anclent, 16. Craveri's, 17. Kittlitz's, 17. Marbled, 16. Temmick's, 16. Xantus's, 17.

Myadestes. townsendil, 497 .

Mycteria. americana, 110.

Mylarchus. cinerascens, 302. cinerascens nuttingl, 303. crinitus, 301. lawrenceii, 303. lawrencell olivascens, 303. mexicanus, 301. mexicanus magister, 302.

Myiozetetes. texensis, 300 .

Mylodynastes. luteiventris, $\$ 01$.

NETTA. rufina, 86.

Nighthawk, 286. Florida, 287.

Sennett's, 287. Texan, 287. Western, 286. 
Noddy, 44.

Nomonyx. dominicus, 95.

Numenius arquatus. borealis, 151. hudsonicus, 151. longirostris, 150. phreopus, 152. tahitiensis, 152.

Nutcracker, Clarke's, 335.

Nuthatch, Brown-headed, 479. Florida White-breasted, 479. Pygmy, 480.

Red-breasted, 479.

Slender-billed, 479.

White-breasted, 478 .

White-naped, 481.

Nyctala.

acadica, 238.

tengmalmi richardsoni, 238.

Nyctea. nyctea, 244

Nycticorax. nycticorax nævius, 119. violaceus, 120.

Nyctidromus. albicollis merrilli, 285.

OCEANITES. oceanicus, 58.

Oceanodroma. furcata, 55. homochroa, 57. leucorhoa, 56 . macrodactyla, 56. melania, 56. socorroensis, 58 .

Oidemia. americana, 93. deglandi, 94. fusca, 94. perspicillata, 95.

Old-squaw, 89.

Olor.

buccinator, 105.

columbianus, 104. cyngus, 104.

Oreortyx.

pictus, 164.

pictus confinis, 165 . pictus plumiferus, 165.

Oriole, Arizona Hooded, 346. Audubon's, 345 .

Baltimore, 347 .

Bullock's, 350 .

Hooded, 346.

Orchard, 347.

Scott's, 345 .

Ornithion.

imberbe, 314.

imberbe ridgwayi, 314.

Oroscoptes. montanus, 462.
Ortalis.

vetula maccali, 183.

Osprey, American, 231.

Ossifraga. gigantea, 48 .

Otocoris.

alpestris, 315 .

alpestris adusta, 318.

alpestris arenicola, 317.

alpestris chrysolæma, 317 .

alpestris giraudi, 317.

alpestris Ieucolæma, 316.

alpestris merrilli, 318.

alpestris pallida, 319 .

alpestris praticola, 316 .

alpestris rubea, 317.

alpestris strigata, 318 .

Oven-bird, 447.

Owl, American Barn 233.

Aiken's Screech, 241.

American Hawk, 245.

American Long-eared, 234.

Arctic Horned, 243.

Barred, 235.

Jurrowing, 246.

California Pygmy, 243.

California screech, 240.

Dwarf Screech, 241.

Elf, 249.

Ferruginous Pygmy, 249.

Flammulated Screech, 241.

Florida Barred, 236.

Florida Burrowing, 247.

Florida Sereech, 240.

Great Gray, 237.

Great Horned, 241.

Hawk, 245.

Hoskins' Pygmy, 243.

Kennicott's Screech, 240 .

I sapp, 237.

MacFarlane's Screech, 241.

Mexican Screech, 240.

Pacific Horned, 243.

Pygmy, 247.

Richardson's, 238.

Rocky Mountain Screech, 240.

Saw-whet, 238.

Screech, 239.

Short-eared, 235.

Snowy, 214.

Spotted, 236.

Texas Screech, 240.

Western Horned. 243.

Oyster-catcher, 159.

American, 160.

Black. 161 .

Frazar's, 161.

PANDION.

haliaetus carolinensis, 231.

Parabuteo.

unicinctus harrisi, 206.

Parauque, Merrill's, 285.

Paroquet, Carolina, 250. 
Partridge, Callfornia, 166.

Chestnut-bellied Scaled, 166.

Gambel's, 167.

Massena, 167.

Mountain, 164 .

Plumed, 165.

San Pedro, 165.

Scaled, 165.

Parus.

Valley, 167.

atricapillus, 483.

atricapillus occidentalis, 484.

atricapilius septentrionalis, 484

atricristatus, 482.

bicolor, 481.

bicolor texensis, 482 .

carolinensis, 484.

carolinensis agilis, 485 .

cinctus obtectus, 486.

gambeli, 485 .

hudsonicus, 486.

hudsonicus columbianus, 487.

hudsonicus stoneyi, 487.

inornatus, 482.

inornatus cineraceus, 483.

inornatus griseus, 483.

meridionalis, 485.

rufescens, 487.

rufescens neglectus, 487 .

wollweberi, 483.

Passer domesticus, 365.

montanus, 365 .

Passerella.

iliaca, 394.

iliaca mergarhyncha, 394.

iliaca schistacea, 394 .

iliaca stephensi, 395 .

iliaca unalaschensis, 394 .

Passerina.

amoena, 404.

ciris, 405.

cyanea, 404.

versicolor, 405 .

versicolor pulchra, 405 .

Pavoncella.

pugnax, 148.

Pediocætes.

phasianellus, 177.

phasianellus campestris, 178.

phasianellus columbianus, 177.

Pelagodroma.

marina, 59.

Pelecanus.

californicus, 73.

erythrorhynchos, 70 .

fuscus, 73.

Pelican, American White, 70.

Brown, 73.

California Brown, 73 .

Perisoreus.

canadensis; 328.

canadensis capitalis, 328.

canadensis fumifrons, 328 .

canadensis nigricapillus, 329 .

obscurus, 330 .
Petrel, Ashy, 57.

Black, 56 .

Black-capped, 63.

Bulwer's, 58.

Figher's, 53.

Fork-tailed, 55.

Guadalupe, 56.

Leach's, 56.

Least, 54.

Pintado, 63.

Scaled, 53.

Socorro, 58.

Stormy, 54.

White-bellied, 58.

White-faced, 59.

Wilson's, 58.

Petrochelidon.

Iulva, 410 .

lunifrons, 410.

Peucæa.

æstivalis, 387.

æstivalis bachmanil, 387 .

arizonæe, 388.

carpalis, 388.

cassini, 388.

mexicana, 388 .

ruficeps, 389 .

ruficeps boucardi, 389 .

ruficeps eremcea, 389 .

Peucedramus, 274.

Pewee, Large-billed Wood, 308. Western Wood, 307.

Wood, 307.

Phaethon. æthereus, 59.

flavirostris, 59 .

Phainopepla, 415. nitens, 415.

Phalacrocorax. carbo, 64 .

dilophus, 65 .

dilophus albociliatus, 67 .

dilophus cincinatus, 66.

dilophus floridanus, 66 .

mexicanus, 68.

pelagicus, 69 .

pelagicus resplendens, 69.

pelagicus robustus, 69 .

penicillatus, 68 .

urile, 70.

Phalænoptilus.

nuttallii, 284.

nuttallii californicus, 285.

nuttallii nitidus, 285 .

Phalarope, Northern, 131.

Red, 130.

Wilson's, 131.

Phalaropus.

lobatus, 131.

tricolor, 131.

Phasianus colchicus, 179. torquatus, 179 .

Pheasant, 179.

Ring-necked, 179. 
Philacte. canagica, 102.

Philohela. minor, 134.

Phobe, 303. Black, 305. Say's, 305.

Phøbetria. fuliginosa, 47.

Phœicopterus. ruber, 105.

Phyllopseustes. borealis, 491.

Plea.

nuttalli, 320.

pica hudsonica, 319 .

Picoldes.

americanus, 268.

americanus alascensis, 268 . americanus dorsalis, 268. arctícus, 268.

Picicorvus.

columblanus, 335.

Pigeon, Band-talled, 184.

Passenger, 185.

Red-billed, 184

Vlosca's, 184.

White-crowned, 185.

Pinicola.

enucleator, 354.

Pintall, 83.

Pipilo.

alberti, 399.

chlorurus, 398.

consobrinus, 398.

erythrophthalmus, 395.

erythrophthalmus alleni, 396.

fuscus albigula, 398.

fuscus crissalis, 398.

fuscus mesoleucus, 398.

fuscus senfcula, 399 .

maculatus arcticus, 396 .

maculatus megalonyx, 397.

maculatus oregonus, 397.

Piplt, American, 460 .

Meadow, 460.

Red-throated, 460.

Sprague's, 461.

Piranga.

erythromelas, 408.

hepatica, 408.

ludoviciana, 407 .

rubra, 408.

rubra cooperi, 409.

rubriceps, 407.

Pitangus.

derblanus, 300 .

Platypsaris.

alafæ, 297.

albiventris, 297

Plautus.

impennis, 21.
Plectrophenax.

hyperboreus, 366.

nivalis, 366 .

nivalis townsend1, 366 .

Plegadis.

autumnalis, 109.

guarauna, 110.

Plover, American Golden, 154.

Belted Pfping, 157.

Black-bellied, 154.

Golden, 154.

Little Ring, 156.

Mongolian, 157.

Mountain, 158.

Pacific Golden, 155.

Piping, 156.

Ring, 155 .

Semipalmated, 155.

Snowy, 157.

Snowy, 157.

Wilson's, 157.

Podilymbus.

podiceps, 4.

Polloptila.

cærulea, 494.

cærulea obscura, 496.

callfornica, 496.

plumbea, 496.

Polyborus.

cheriway, 230.

lutosus, 231.

Poocætes.

gramineus, 369.

gramineus affinis, 369 .

gramineus confinis, 369 .

Poor-will, 284.

Dusky, 285.

Frosted, 285.

Porzana.

carolina, 125.

coturnicułus, 127.

jamaicensis, 127.

noveboracensis, 126.

porzana, 125.

Procellarla. pelagica, 54.

Progne.

cryptoleuca, 409.

subis, 409.

subis hesperia, 409 .

Protonotaria. citrea, 427.

Psaltriparus. lloydl, 490. minimus, 488.

minimus californicus, 488. minlmus grindæ, 488. plumbeus, 488. sanitaritæ, 490 .

Pseudogryphus. californtanus, 191.

Ptarmigan, Allen's, 172. Everman's, 174.

Nelson's, 173. 
Ptarmigan, Reinhardt's, 173.

Rock, 173.

Townsend's, 174.

Turner's, 174.

Welch's, 174 .

White-tailed, 174.

Willow, 171.

Ptychoramphus.

aleuticus, 13.

Puffin, 11.

Horned, 11.

Large-billed, 11.

Tufted, 9.

Puffinus.

auduboni, 51.

borealis, 51.

cinereus, $\mathbf{5 2}$.

creatopus, 61.

gavla, 52.

griseus, 58.

kuhlii, 52.

major, 51 .

puffinus, 51.

strickland, 52.

tenuirostris, 52.

Pyrocephalus.

rubineus mexicanus, 314.

Pyrrhula.

cassinl, 354 .

Pyrrhuloxia. sinuata, 401. sinuata beckhami, 402 . sinuata peninsulæ, 402.

Pyrrhuloxia, Arizona, 402. Saint Lucas, 402.

QUAIL, European, 163.

Quail-Dove, Blue-headed, 191. Key West, 190. Ruddy, 190.

Quiscalus.

macrourus, 352.

major, 353.

quiscula, 351.

quiscula æneus, 352 .

quiscula aglæus, 352 .

RAIL, Belding's, 123.

Black, 127.

California Clàpper, 124.

Caribbean Clapper, 125.

Clapper, 124.

Farallone, 127.

Florida Clapper, 125.

King, 123.

Louislana Clapper, 12 .

Virginia, 125.

Rallus, Yellow, 126.

belding1, 123.

elegans, 123.

crepitans, 124.

crepitans saturatus, 124.

longlrostris caribæus, 125.
Rallus, obsoletus, 124. scottil, 125.

virginianus, 125.

Raven, American, 330.

Northern, 331.

White-necked, 332.

Recurvirostra. americana, 132.

Redhead, 86.

Ređpoll, 360.

Greenland, 360 .

Greater, 361.

Hoary, 360.

Holbcell's, 361.

Redstart, american, 456.

Painted, 457.

Red-bellled, 457.

Red-tafl, St. Lucas, 208. Western, 208.

Red-winf Bahama, 343. Florida, 343.

Sonoran, 342.

Regulus.

çalendula, 498.

obscurus, 494.

satrapa, 492.

satrapa olivaceus, 493.

Rhodostethia. rosea; 36 .

Rynchophanes. mecownli, 369.

Rissa.

brevirostris, 28.

tridactyla, 27.

tridactyla pollicaris, 28.

Road-runner, 253.

Robin, American, 502.

St. Lucas, 603.

Western, 503.

Rastrhamus. sociabilis, 201.

Rough-leg, Ferruginous, 216.

Ruff, 148.

Rynchops.

nigra, 44.

SALPINCTES.

guadeloupensis, 469. obsoletus, 469.

Sanderling, 142.

Sandpiper, Aleutian, 137. .

Baird's, 139.

Bartramian, 149.

Buff-breasted, 149.

Curlew, 141.

Green, 146.

Least, 139.

Pectoral, 138.

Pribllof, 137.

Purple, 137.

Red-backed, 140.

Semipalmated, 141 .

Sharp-tailed, 138. 
Sandpiper, Solitary, 145.

Spoon-bill, 141.

Spotted, 150.

Stilt, 136.

Western, 142.

Western Solitary, 146.

White-rumped, 139.

Sapsucker, Red-breasted, 271.

Red-naped, 270.

Williamson's, 272.

Yellow-bellied, 269.

Saxicola.

cenanthe, 504 .

Sayornis.

nigricans, 305.

phœbe, 303.

saya, 305.

Scardafella. inca, 190.

Scolecophagus. carolinus, 350.

cyanocephalus, 350 .

Scolopax. rusticola, 133.

Scoter, American, 98. Surf, 95.

Velvet, 94.

'White-winged, 94.

Scotiaptex.

clnerea, 237.

cinerea lapponica, 237.

Seed-eater, Sharpe's, 405.

Seiurus.

aurocapillus, 447 .

motacilla, 449.

noveboracensis, 448 .

noveboracensis notabllis, 448.

Selasphorus.

alleni, 294.

floresii, 293.

platycercus, 293.

rufus, 293.

Setophaga.

miniata, 457.

picta, 457.

ruticilla, 456.

Shearwater, Audubon's, 51.

Black-talled, 62.

Black-vented, 62.

Cinereous, 62.

Cory's, 51.

Dark-bodied, 62.

Greater, 51.

Manx, 51.

Pink-footed, 51.

Slender-billed, 62.

Sooty, 62.

Sheldrake, Ruddy, 82.

Shoveller, 82.

Shrike, Californla, 417.

Loggerhead, 415.

Northern, 415.

White-rumped, 416.
Slalia.

arctica, 506.

mexicana anabelæ, 506 .

mexicana bairdi, 505 .

mexicana, occidentalis, 505 .

sialis, 505.

sialis azurea, 505.

Simorhynchus.

cristatellus, 14.

pusillus, 16.

pygmæus, 15.

Siskin, Pine, 363.

Sitta.

canadensis, 479.

carolinensis, 478.

carolinensis aculeata, 479.

carolinensis atkinsi, 479.

pusilla, 479 .

pygmæa, 480.

pygmoa leuconucha, 481.

Skimmer, Black 44.

Skua, 24.

Skylark, 314.

Smew, 78.

Snipe, European, 135.

Wilson's, 135.

Snowflake, 366.

McKay's, 366.

Pribilof, 366 .

Solitaire, Townsend's, 497.

Somateria.

dresseri, 92.

mollissima borealis, 91 .

spectabilis, 93.

v-nigra, 93 .

Sora, 125.

Sparrow, Acadian Sharp-tailed, 374. Aleutian Song, 393.

Arizona, 388.

Bachman's, 387.

Baird's, 371.

Belding's Marsh, 370.

Bell's, 386.

Bischoff's Song, 392.

Black-chinned, 382.

Black-throated, 386.

Boucard's, 389.

Brewer's, 380.

Brown's Song, 392.

Bryant's Marsh, 370.

Cassin's, 388.

Chlpping, 379.

Clay-colored, 380.

Dakota Song, 392.

Desert Song, 390.

Dusky Seaside, 375.

European House, 365.

European Tree, 365.

Field, 381.

Forbush's, 393.

Fnx, 394.

Gambel's, 378.

Golden-crowned, 379.

Grasshopper, 371. 
Bparrow, Gray Sage, 887.

Harris's, 376.

Heermann's, 391.

Henslow's, 372.

Intermediate, 378.

Ipswich, 369.

Large-billed, 371.

Lark, 375.

Leconte's, 373.

Lincoln's, 393.

Louisiana Seaside, 375.

Mexican, 388.

Merrill's Song, 392.

Mountain Song, 391.

Nelson's, 374.

Oregon Vesper, 369.

Pine-woods, 387.

Bock, 389.

Rufous-crowned, 389.

Rufous-winged, 388 .

Rusty Song, 391.

Sage, 386.

Samuels's Song, 391.

San Benito, 371 .

San Clemente Song, 392.

Sandwich, 369.

Santa Barbara Song, 392.

Savanna, 369.

Scott's Seaside, 37t.

Seaside, 374 .

Sharp-tailed, 373.

Slate-colored, 394 .

Song, 390.

Sooty Song, 391.

Stephens's, 395.

St. Lucas, 371.

Swamp, 393.

Texas, 395.

Texas Seaside, 375.

Thick-billed, 394.

Townsend's, 394.

Tree, 379.

Vesper, 369.

Western Chipping, 380.

Western Field, 382.

Western Grasshopper, 372.

Western Henslow's, 373.

Western Lark, 3i6.

Western Savanna, 370.

Western Tree, 379.

- Western Vesper, 369.

White-crowned, 378.

White-throated, 379.

Worthen's, 382.

Spatula.

clypeata, 82

Speotyto.

cunicularia floridana, 247.

cunicularia hypogzea, 246.

Sphyrapicus.

ruber, 271.

thyroideus, 272.

varius, 269 .

varius nuchalis, 270.
Spinus.

lawrencei, 363 .

notatus, 363

pinus, .363.

psaltria, 362.

psaltria arizonæe, 362.

psaltria mexicanus, 362.

tristis, 361.

tristis pallidus, 362.

monticola ochracea, 379.

Spiza.

- americana, 406.

Spizella.

atrigularis, 382.

breweri, 380.

monticola, 379 .

pallida, 380 .

pusilla, 381.

pusilla arenacea, 382 ,

socialis, 379 .

socialis arizonæ, 380 .

wortheni, 382.

Spoonbill, Roseate, 107.

Sporophila.

morelleti sharpel, 405.

Starling, 337.

Starncenas. cyanocephala, 191.

Stelgidopteryx. serripennis, 413.

Stellula. calliope, 294.

Stercorarius. longicaudus, 26. parasiticus, 25. pomarinus, 25.

Sterna.

aleutica, 42.

anæthetus, 43.

antillarum, 42.

dougalli, 41.

elegans, 40.

forsteri, 40 .

fuliginosa, 42.

hirundo, 41.

maxima, 39.

paradisæa, 41.

sandvicensis acuflavida; 40 .

trudeaui, 40.

tschegrava, 38.

Stilt, Black-necked, 132.

Stint, Long-toed, 140.

Strix.

pratincola, 233.

Eturnella.

magna, 343 .

magna mexicane, 344 .

magna neglecta, 344.

Sturnus.

vulgaris, 337 . 
Sula.

bassana, 62 .

brewsteri, 61.

cyanops, 60.

gossi, 61.

piscator, 62.

sula, 61.

Surnia.

viula, 245.

ulula caparoch, 245.

Swallow, Bahaman, 412.

Bank, 413.

Barn, 411.

Cliff, 410.

Cuban Cliff, 110.

Rough-winged, 418.

Tree, 411.

Violet-green, $\mathbf{1 1 2}$.

Swan, Trumpeter, 105.

Whistling, 104.

Whooping, 104 .

Swift, Black, 287.

Chimney, 288.

Vaux's, 290.

White-throated, 290.

Sylvania.

canadensis, 456.

mitrata, 454

pustlla, 455 .

pusilla pileolata, 455 .

Symphemia.

semipalmata, 147.

semipalmata inornata, 14 .

Synthliboramphus.

antiquus, 16.

wumizusume, 16.

Syrnium.

nebulosum, 235.

nebulosum alleni, 236.

occidentale, 236.

\section{TACHYCINETA.}

bicolor, 411.

thalassina, 412.

Tanager, Cooper's, 409.

Gray's, 407.

Hepatic, 408.

Louisiana, 407.

Scarlet, 408.

Summer, 408.

Tantalus

loculator, 110.

Tatler, Waindering, 147.

Teal, Blue-winged, 81.

Cínnamon, 81.

European, 80.

Green-winged, 81.

Tern, Aleutian, 42.

Arctic, 41.

Black, 43.

Bridled, 48.
Tern, Cabot's, 40.

Caspian, 38.

Common, 41.

Elegant, 40.

Forster's, 40.

Gull-billed, 38.

Least, 42.

Roseate, ㄴt.

Royal, 39.

Sooty, 42.

Trudeau's, 40.

White-winged Black, 44.

Thalassogeron.

culminatus, 47.

Thrasaetos.

harpyia, 218.

Thrasher, Bendire's, 465.

Brown, 464.

California, 466.

Crissal, 468.

Curve-billed, 465.

Leconte's, 467.

Mearns's, 466.

Palmer's, 465.

Sage, 462.

St. Lucas, 466 .

Sennett's, 464.

Thrush, Audubon's Hermit, 501.

Bicknell's, 499.

Dwarf Hermit, 501 .

Gray-cheeked, 499.

Hermit, 501.

Olive-backed, 500 .

Red-winged, 502.

Russet-backed, 499.

Varied, 503.

Willow, 498.

Wilson's, 498.

Wood. 498 .

Thryothorus.

bewickii, 472 .

bewickii bairdl, 472 .

bewickii spllurus, 472.

brevicauda, 473.

leucophrys, 473.

ludovicianus, 471.

ludovicianus lomitensis, 472.

ludovicianus miamensis, 471.

Titmouse, Ashy, 483.

Black-crested, 482.

Bridled, 483 .

Gray, 483.

Plain, 482.

Texas Tufted, 482.

Tufted, 481.

Totanus.

flavipes, 145 .

melanoleucus, 144.

nebularius, 144.

ochropus, 146.

solitarius, 145.

solitarius cinnamomeus, 146. 
Towhee, 395.

Abert's, 399.

Anthony's, 399.

Arctic, 396.

Callfornla, 398.

Canon, 398.

Green-talled, 398.

Guadalupe, 398.

Oregon, 397.

Saint Lucas, 398.

Spurred, 397.

White-eyed, 396.

Treo-duck, Black-bellied, 103. Fulvous, 103.

\section{Tringa.}

acuminata, 138.

alpina, 140.

alpina pacifica, 140.

bairdii, 139.

canutus, 136.

couesI, 137.

damacensis, 140.

ferruginea, 141.

fuscicollis, 139.

maculata, 138.

maritima, 137.

minutilla, 139.

ptilocnemis, 137.

Trochilus.

alexandri, 292.

colubris, 291.

violajugulum, 292.

Troglodytes.

aedon, 473.

aedon aztecus, 474 .

aedon parkmanis, 473.

alascensis, 475 .

hiemalis, 474.

hiemalis pacificus, 475 .

Trogon.

amblguus, 257.

Coppery-tailed, 257.

Troupial, 345.

Tryngites.

subruficollis, 149.

Turdus.

aliciæ, 499.

aliciæ bicknelli, 499 .

a.onalaschkæ, 501.

aonalaschkæ audubon1, 501.

aonalaschkæ pallasi, 501.

fuscescens, 498.

fuscescens sallcicolus, 498.

1liacus, 602.

mustelinus, 498.

ustulatus, 499.

ustulatus swainsont, 500 .

Turkey, Florida Wild, 183.

Mexícan, 182.

Rio Grande Wild, 183.

Wild, 180.
Turnstone.

Black, 159.

Tympanuchus.

americanus, 175.

americanus attwatert, 175.

cupido, 175.

pallidicinctus, 177.

Tyrannus.

dominicensis, 298.

melancholicus couchli, 299.

tyrannus, 298.

verticalis, 299.

voclferans, 300 .

URIA.

lomvia, 20.

lomvia arra, 20.

troile, 18.

trolle callfornlca, 19.

Urinator.

adamsil, 7 .

arcticus, 7.

lmber, 6.

lumme, 8.

pacificus, 8.

Urubitínga.

anthracina, 213.

\section{VANELLUS.}

vanellus, 152.

Verdin, 491.

Vireo.

atricapillus, 422.

bellii, 425 .

bellil pusillus, 425.

calidris barbatulus, 418.

flavifrons, 120.

flavoviridis, 419.

gilvus, 419.

huttoni, 423.

huttoni ohscurus, 424.

huttond stephensi, 424.

noveboracensis, 423.

noveboracensis maynard1, 423.

ollvaceus, 418.

phlladelphicus, 419.

solitarius alticola, 421 .

solitarius cassinil, 120.

solitarius lucasanus, 422 .

solitarius plumbeus, 421.

vicinior. 425.

Vireo, Anthony's, 424.

Bell's, 425.

Black-capped, 422.

Black-whiskered, 418.

Blue-headed, 420.

Cassin's, 4200.

Gray, 425.

Hutton's, 423.

Key West, 423.

Least, 425.

Mountain Solitary, 421.

Philadelphla, 419.

Plumbeous, 421. 
Vireo, Red-eyed, 418.

St. Lucas Solitary, 422.

Stephens's, 424

Warbling, 419.

White-eyed, 423.

Yellow-green, 419.

Yellow-throated, 420.

Vulture, Black, 195.

California, 191.

Turkey, 194.

WAGTAIL, Siberian Yellow, 459.

Swinhoe's, 459.

White, 458.

Warbler, Alaskan Yellow, 436.

Audubon's, 438.

Bachman's, 429.

Bay-breasted, 441.

Bell's, 458.

Black and White, 426.

Blackburnian, 441.

Black-throated Blue, 436.

Black-throated Gray, 443.

Black-throated Green, 444.

Blue-winged, 429.

Brasher's, 458.

Cairn's, 431 .

Calaveras, 431.

Canadian, 456.

Cape May, 435.

Cerulean, 439.

Chestnut-sided, 440.

Connecticut, 450 .

Dusky, 432.

Golden-cheeked, 443.

Golden-winged, 430.

Grace's, 443.

Hermit, 444.

Hooded, 454.

Kennicott's Willow, 491.

Kentucky, 449.

Kirtland's, 445.

Lucy's, 430.

Lutescent, 432.

Macglllivray's, 451.

Magnolia, 439.

Mangrove, 436.

Mourning, 451.

Myrtle, 437.

Nashville, 431.

Northern Parula, 423.

Ollve, 436 .

Orange-crowned, 432.

Palm, 446.

Parula, 432.

Pileolated, 455.

Pine, 446.

Prairie, 447.

Prothonotary, 427.

Red, 458.

Red-faced, 457 .

Sennett's, 435.

Sonora Yellow, 436.
Warbler, Swainson's, 428.

Sycamore, 442.

Tenneswee, 432.

Townsind's, 444.

Virginia's, 430.

Wilson's, 455.

Worm-eating, 428 .

Yellow, 436.

Yellow Palm, 447.

Yellow-throated, 442.

Water-Thrush, 448.

Grinnell's, 448.

Louisiana, 449.

Waxwing, Bohemian, 413. Cedar, 413.

Wheatear, 504.

Whimbrel, 152.

Whip-poor-will, 283. Stephens's, 283.

Widgeon, 80 .

Willet, 147. Western, 147.

Woodcock, American, 134. European, 133.

Woodpecker, Alaskan Three-toed, 268. Alpine Three-toed, 268.

American Three-toed, 268.

Ant-eating, 274.

Arctic Three-toed, 268.

Arizona, 267.

Batchelder's, 264.

Cabanis's, 263.

Californian, 274.

Downy, 264.

Gairdner's, 264.

Gila, 276.

Golden-fronted, 276.

Hairy, 262.

Harris's, 263.

Ivory-billed, 261.

Lewis's, 275.

Narrow-fronted, 275.

Nelson's Downy, 264.

Northern Hairy, 263.

Nuttall's, 265.

Pileated, 272.

Red-bellied, 275.

Red-cockaded, 264.

Red-headed, 273.

Saint Lucas, 265.

Southern Hairy, 263.

Downy, 263.

Texan, 265.

White-headed, 267.

Wren, Alaskan, 475.

Baird's, 472.

Bewick's, 472.

Bryant's Cactus, 468.

Cactus, 468.

Canon, 470.

Caralina, 471.

Dotted Canon, 471.

Florida, 471. 
Wren, Guadalupe, 473.

Guadalupe Rock, 469.

House, 473.

Lomita, 472.

Long-billed Marsh, 476.

Marian's Marsh, 477.

Parkman's, 473.

Rock, 469.

St. Lucas Cactus, 469.

San Clemente, 473.

Short-billed Marsh, 475 .

Tule, 476.

Vigors's, 472.

Western House, 474.

Western Winter, 475.

White-throated, 470.

Winter, 474.

Worthington's Marsh, 476.

Wren-Tit, 487.

Pallid, 488.

\section{XANTHOCEPHALUS.}

xanthocephalus, 340 .

Xanthoura.

luxuosa, 327.
Xema.

sabinii, 37.

Xenopicus.

albolarvatus, 267.

YELLOW-LEGS, 145. Greater, 144.

Yellow-throat, Beldfing's, 452.

Florida, 452.

Maryland, 451.

Rio Grande, 453.

Western, 452.

ZENAIDA.

zenaida, 188.

Zenaidura. macroura, 187.

Zonotrichia.

albicollis, 379 .

coronata, 379.

leucophrys, 378.

leucophrys gambeli, 378.

leucophrys intermedia, 378.

querula, 376. 



CONSERVATION

REVIEW: 7-. 19-91

No futher acticn 


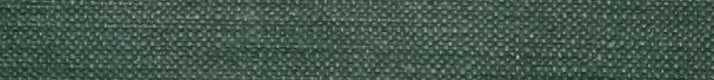
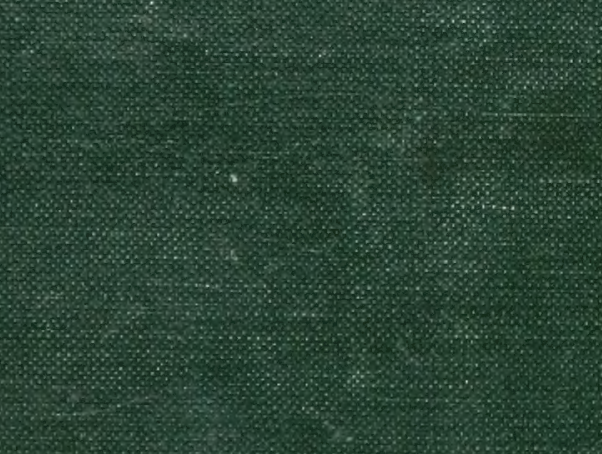

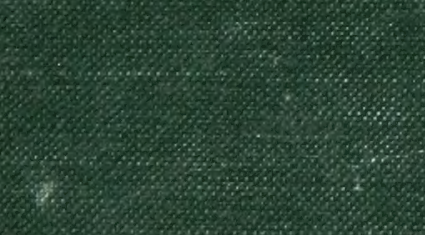

